

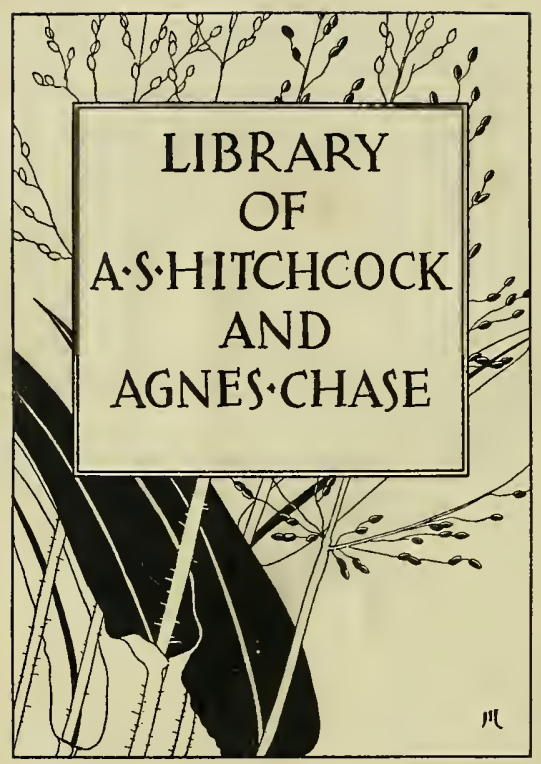



ora col.

ations as

ends the 1

Hinghan.

ON JUNI

recently

notici

ren. 
1910] Knowlton,- Pinus resinosa in Norwood, Massachusetts 217

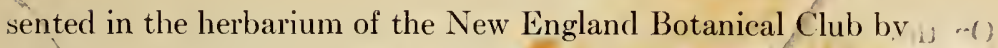
mens from Cranston (Collins) and from a salt meadow, $\mathrm{M}_{\mathrm{ir}}$

(B. L. Robinson).

Cerastium semidecandrum L. Abundant in sanc: Buttonwoods Beach. Previously recorded in New from East Lyme, Connecticut (Graves, RHodora, ii sented in the Gray Herbarium by characteristic by Judge J. R. Churchill at "Asyllum," Nantuckt

$\times$ Fragaria GRANdiflora Ehrh. The commonl berry is abundantly established on the railroad 19 Buttonwoods station. It was found by $\mathrm{J} . \mathrm{F}$. Col ous ne writer in a similar habitat at Elmwood; May $18,1898$.

$\times$ Lysimachia PRoducta (Gray) Fernald. At olt int in a boggy meadow, Warwick. The only member of the genu stoticed.

Apocynum Cannabinum L., var. pubescens (R. Br.) DC. Sandy thicket back of Buttonwoods Beach. Represented in the Gray Herbarium by a specimen collected by Olney at Smithfield, July 23, 1845 .

Scrophularia leporella Bicknell. Gravelly banks near Buttonwoods station.

Galium Claytoni Michx. Boggy meadow, Warwick.

Carduus aCANThoides L. Abundant in gravel along the electric railway from Warwick station to Buttonwoods, and presumably beyond in each direction. Collecterl by J. F. Collins in 1895 on "cove lands," Providence.

Hypochaeris radicata L. Sandy grassland, Warwick, a few plants only. Already established near New Bedford and at other scattered points on the Atlantic coast and likely to become a troublesome weed.

Gray Herbaricm.

Pinus resinosa in Norwood, Massachusetts.- Two or three years ago while riding on the Midland Division of the N. Y. N. H. \& H. Railroad, I noticed from the car window a pine tree which seemed to be Pinus resinosa Ait. It stands apart from the other pines in a pasture between Ellis Station and Norwood, on the eastern side of the track. Although I saw the tree several times from the train, I was ynable to identify it absolutely until this year, May 14, 1910. 
On that date I went to the tree and secured specimens. The local fora committee received reports of this species from several scattered stations as far south as Chestnut Hill, Brookline, so this new station extends the range sereral miles southward-C Carence H. Knowlтox, Hinghan, Massachusetts.

Note oN JUNiperus horizontalis and J. virginiana. - While engaged recently in the preparation of a key to the New England junipers, I noticed that besides the differences between Juniperus horizontalis Moench and J. virginiana L. emphasized in Gray's Manual, other characters of some value in the separation of these species are afforded by the fruit. In the Gray Herbarium material, which I examined with Prof. Fernald, it was found that the fruits of $J$. horizontalis contained generally four seeds, rarely three or five, when mature chestnut-brown and roughened. J. virginiana, on the other hand, had fruits with one or (usually) two seeds, very rarely three, rather pale ashy-brown and smooth at maturity. The representation of mature-fruited $J$. virginiana at hand being rather scanty, I dissected 66 of the berries, collected in Stoughton, finding 52 with but one well-developed seed each, and only 14 with two, reversing the proportions we had been led to expect from the study of the Herbarium material. This latter, however, coming as it does from widely separated localities, probably more truly represents the normal numerical tendencies of the J. virginiana fruits.- SIDNEY F. BLAKE, Stoughton, Iassachusetts.

The North American Species of Panicum.- Possibly no monograph of similar scope in American taxonomic literature represents a more intensive and critical study than Hitchcock and Chase's treatment of Panicum, ${ }^{1}$ which has just appeared from the Government Printing Office. By extensive field-work, continued through several seasons, both authors have obtained first-hand knowledge of nearly every species which reaches the United States, and of many Mexican and West Indian species. Their field-work has been supplemented by green-house cultures, in order to establish beyond doubt the identity of the vernal and autumnal phases of many species, and by a thorough study of most of the Panicum material in European

1 The North American Species of Panicum, by A. S. Hitchcock and Agnes Chase. Contributions from the United States National Herbarium, XV, Washington, 22 Oct. 1910. 
and American herbaria. In the extent to which Hitchcock and Chase have borrowed and determined the collections belonging to smaller institutions and to individuals, they have set an example which other monographers may well follow. Few professional botanists have any idea of the stimulus which can thus be given to botanical collecting and exploration.

The monograph covers all America north of Panama, including the West Indies. In this area the authors recognize 205 species and subspecies, although they exclude from Panicum a number of outlying groups, which are better treated as generically distinct. It gives one faith in the serviceability of the authors' species-concept to know that they have been able to place, definitely, with no evasion and no sidetracking, a mass of material numbering many thousands of sheets. Yet the work contains only 16 new species and subspecies. To most botanists the treatment might have been made a trifle more satisfactory if certain varieties and forms, which are informally defined, with citation of specimens, had been named instead of treated as "exceptional specimens."

A feature which deserves the highest praise is the full discussion, under each species, of the synonyms which are referred to it. Prof. Hitchcock has studied practically every extant specimen of American Panicum, which has ever been designated as a type, or can be construed as a type. The result is a surprisingly short list of "Doubtful Species" and a critical commentary on the synonymy which will be of great use to future students. In this connection it may be noted that misapplied names ( $i . e$., published errors in determination) are given no nomenclatorial standing.

The description of each species is accompanied by two text-figures, an enlarged spikelet and a map showing, roughly, the geographic range in the United States. In nearly every case the spikelets have been drawn from type or authentic material, and are thus of permanent value as standards for comparison, regardless of what difference of opinion may ever arise in regard to the delimitation of groups or the identity of particular specimens. It is unfortunate that the presswork at the Government Printing Office was not of a high enough order to make the most of Mrs. Chase's beautiful figures. The maps are not as useful as they would have been if the dots had always been placed so as to indicate precise localities. A dot placed in the center of a state is used frequently to indicate a general distribution of the species in that state.

In the citation of specimens the authors have been unusually liberal. They have not only cited specimens under each species, to show the geographic range, but they have also prepared an index to numbered specimens which will prove one of the best features of the book.

The treatment of the dichotomous Panica (under the newly named subgenus Dichanthelium Hitchcock \& Chase) is painstaking in the ex- 
treme. There is a key to the 17 sections of the subgenus with page references to sectional keys, which are introduced at the appropriate places in the text. In addition, there is an artificial key to the whole subgenus, in which the species are not retained in taxonomic sequence.

The authors have followed the "American" code of nomenclature.

In a few cases specific names are used which would not be authorized by the Vienna Code. An interesting example is that of Panicum polyanthes, a name justified by the "American" rules but not by the Vienna rules (although it has crept into Gray's Mannal, ed. 7!) The valid name is Panicum multiflorum Ell. 1816. Panicum multiflorum Poir. 1816 is $P$. dichotomiflorum $\mathrm{Mx}$.

Hitchcock and Chase have given us a book of enduring worth,a book which it is a pleasure to own and which it will be a greater pleasure to use.-H. H. Bartlett, Bureau of Plant Industry, Washington, D. C.

Vol. 12, no. 142, including pages 193 to 208, was issued 1 November, 1910. 


H 675 SMITHSONIAN INSTITUTION

UNited States National MUSEUm 2

CONTRIBUTIONS

FROM THE

United States National Herbarium

VOLUME 15

THE NORTH AMERICAN SPECIES

OF PANICUM

By A. S. HITCHCOCK and AGNES CHASE

WASHINGTON

GOVERNMENT PRINTING OFFICE

1910 
BULLETIN OF THE UNITED STATES NATIONAL MUSEUM. IsSUed ОстоBer 22, 1910.

II 


\section{PREFACE.}

The accompanying paper, entitled The North American species of Panicum, by A. S. Hitchcock, Systematic Agrostologist of the United States Department of Agriculture, and Agnes Chase, Assistant in Systematic Agrostology, is the result of an exhaustive study of the material of this genus in the United States National Herbarium and in the other large herbaria of the United States. All the more important herbaria of Europe were visited by Mr. Hitchcock for the purpose of examining the type specimens of American species described by European authors. This opportunity is taken to acknowledge the many courtesies extended by the curators of the herbaria visited. In addition to the knowledge of the genus gained through an examination of many thousand herbarium specimens, the authors have had opportunity to collect material throughout the United States and have observed nearly all the species of that region in their native habitats. Because of the lack of material and of the necessary field studies, it has been impossible to present the species of tropical America with the same degree of detail as the species of the United States, but it has seemed advisable to include these tropical species in order to bring together in one paper our present knowledge of the genus in North America.

The authors describe 197 species and 8 subspecies, each of which is accompanied by a text figure illustrating the spikelet and fruit. The descriptions of species occurring within the limits of the United States are also accompanied by an outline map graphically representing the geographical distribution.

Frederick V. Coville, Curator of the United States National Herbarium. 



\section{CONTENTS.}

Introdhetion Page.

Basis and methods of the work............................... 1

American herbaria examined............................. 1

European herbaria examined............................ 2

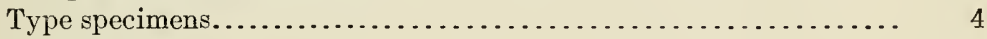

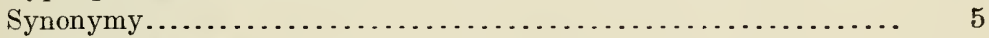

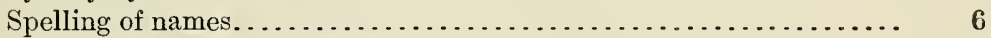

Species, subspecies, and forms............................ 7

Geographical distribution............................. 8

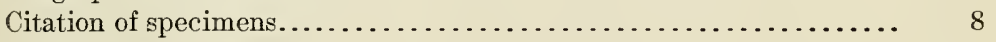

Text figures of spikelets .............................. 10

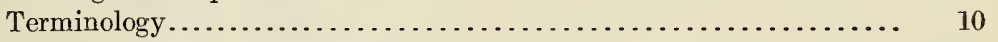

History and limitation of the genus....................... 11

Pre-Linnæan use of the name......................... 11

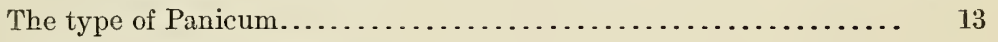

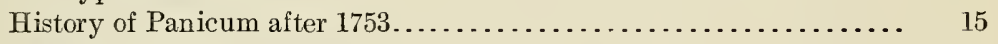

Genera here excluded............................... 16

Grouping of the species...................................... 17

Description of the genus and species.............................. 18

Doubtful species............................................ 329

List of new subgenera and species and new names................. 332

Index to numbered specimens............................... 333

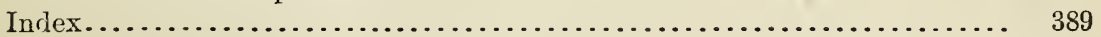





\section{ILLUSTRATIONS.}

TEXT FIGURES.

Fic. 1. Panicum distantiflorum

2. $P$. utowanaeum

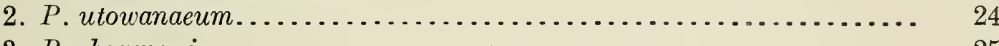

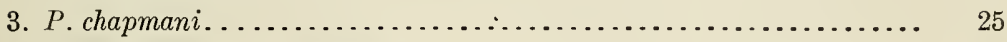

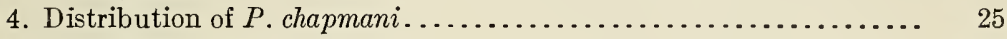

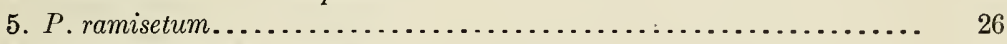

6. Distribution of $P$. ramisetum........................... 26

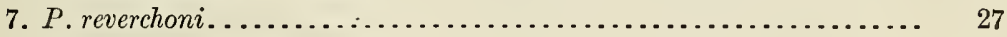

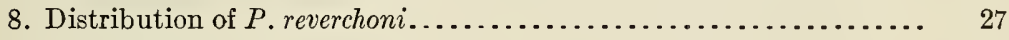

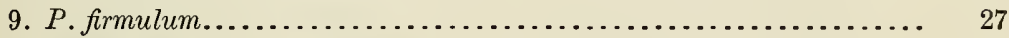

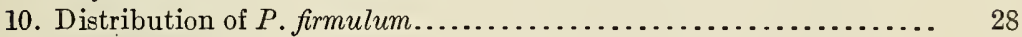

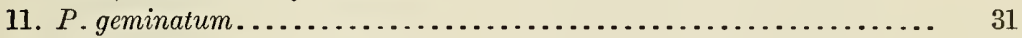

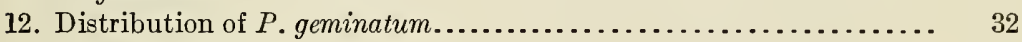

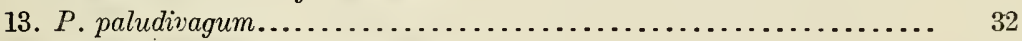

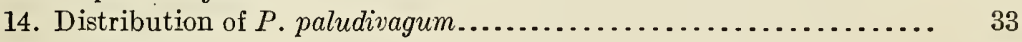

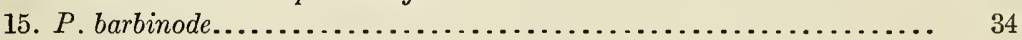

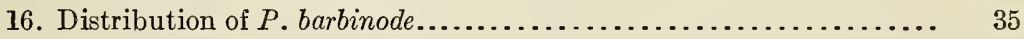

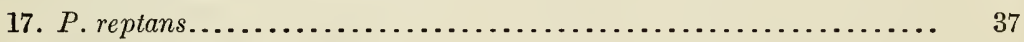

18. Distribution of $P$. reptans............................... 37

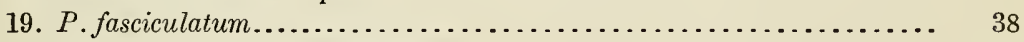

20. Distribution of $P$. fasciculatum . . . . . . . . . . . . . . . . . 40

21. P. fasciculatum chartaginense.......................... 41

22. Distribution of $P$. fasciculatum chartaginense................ 41

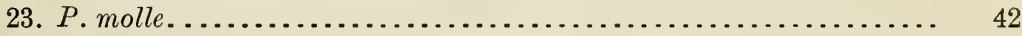

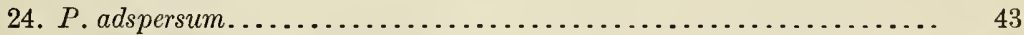

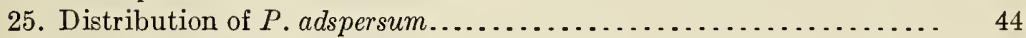

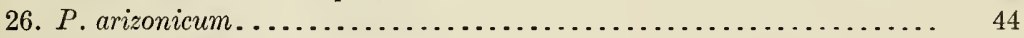

27. Distribution of $P$. arizonicum........................... 46

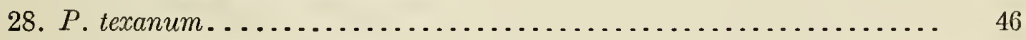

29. Distribution of $P$. texanum .......................... 47

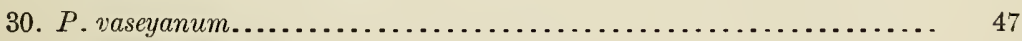

31. P. dichotomiflorum................................ 50

32. Distribution of $P$. dichotomiflorum ..................... 51

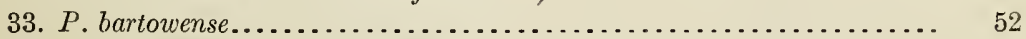

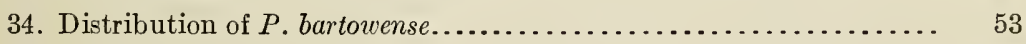

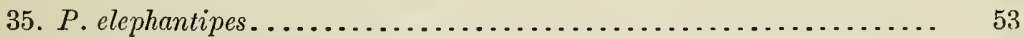

36. P. flexile.............................................. 56

37. Distribution of $P$. flexile ............................. 56

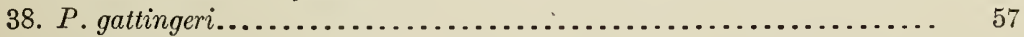

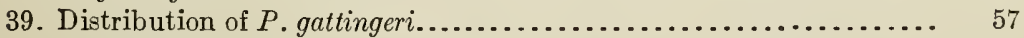

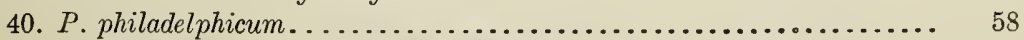

41. Distribution of $P$. philadelphicum...................... 59 


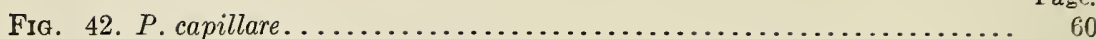

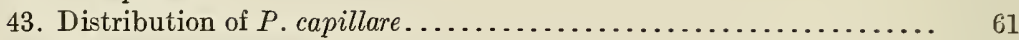

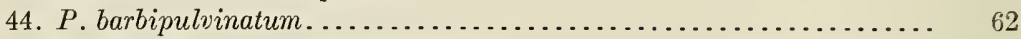

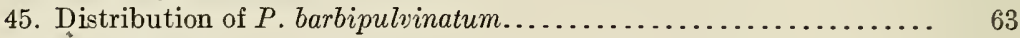

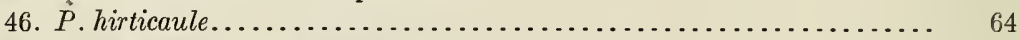

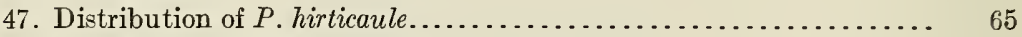

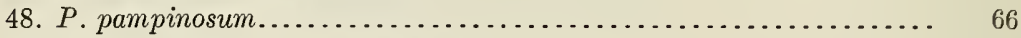

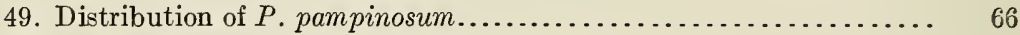

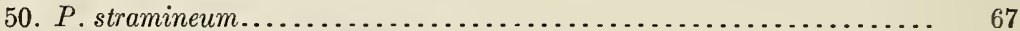

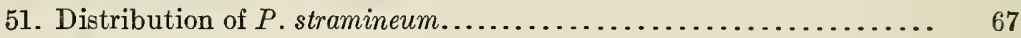

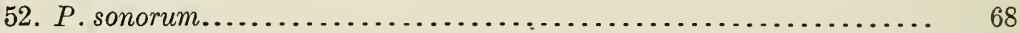

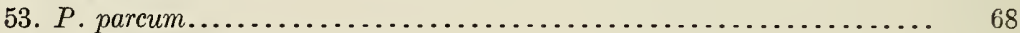

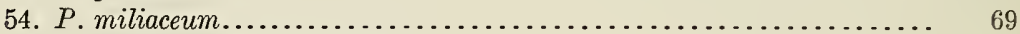

55. Distribution of $P$. miliaceum................................... 70

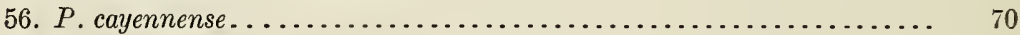

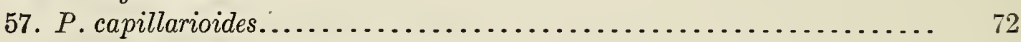

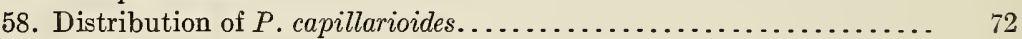

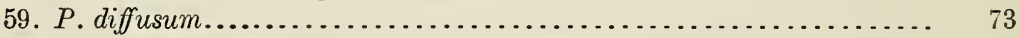

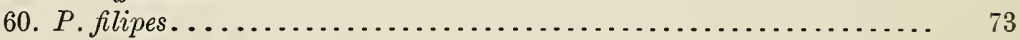

61. Distribution of $P$. flipes.............................. 74

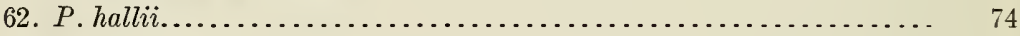

63. Distribution of $P$. hallii................................. 75

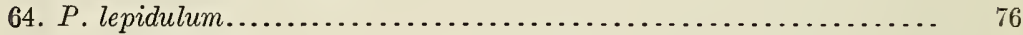

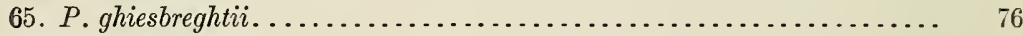

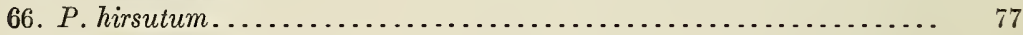

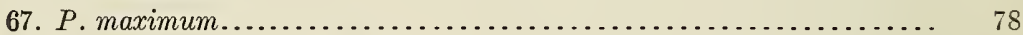

68. Distribution of $P$. maximum . . . . . . . . . . . . . . . . . . . 79

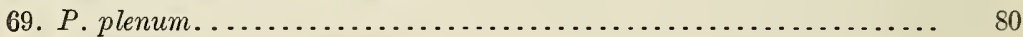

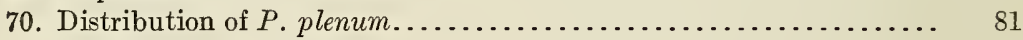

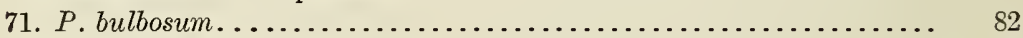

72. Distribution of $P$. bulbosum.......................... 83

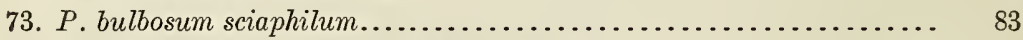

74. Distribution of $P$. bulbosum sciaphilum.................. 84

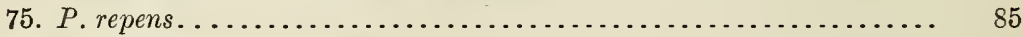

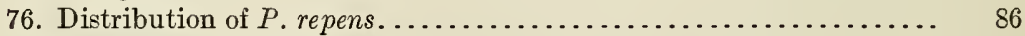

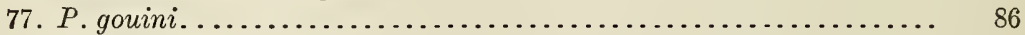

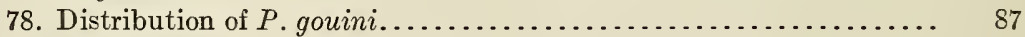

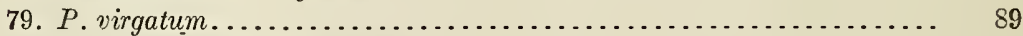

80. Distribution of $P$. virgatum............................. 90

81. P. virgatum cubense.................................... 92

82. Distribution of $P$. virgatum cubense....................... 92

83. P. havardii............................................. 93

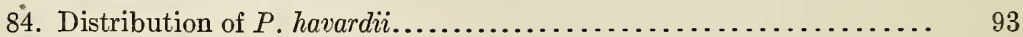

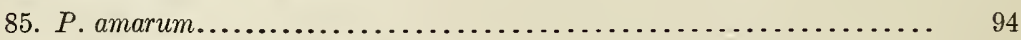

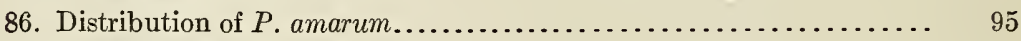

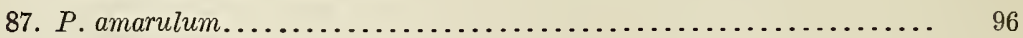

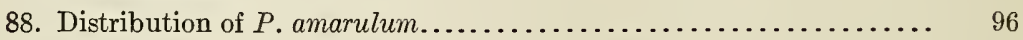

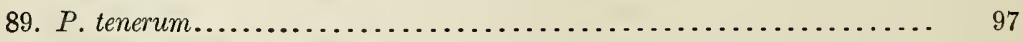

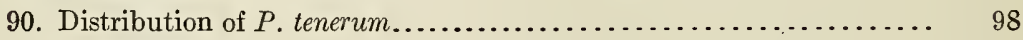

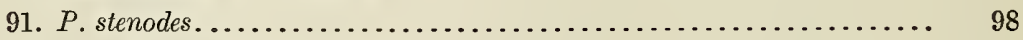

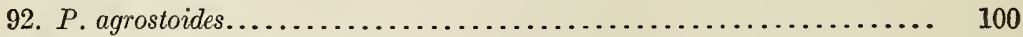

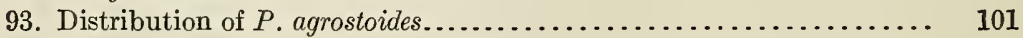

94. P. condensum..................................... 102 


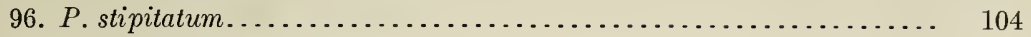

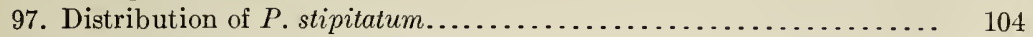

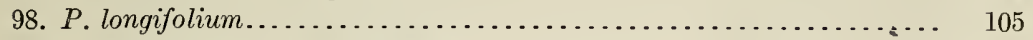

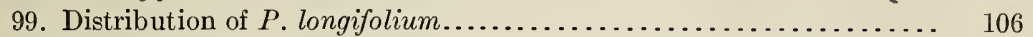

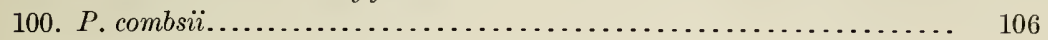

101. Distribution of $P$. combsii............................. 107

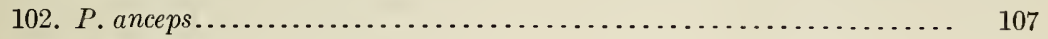

103. Distribution of $P$. anceps ............................ 108

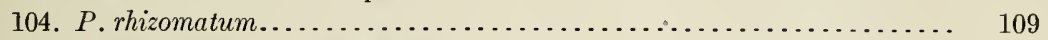

105. Distribution of $P$. rhizomatum......................... 110

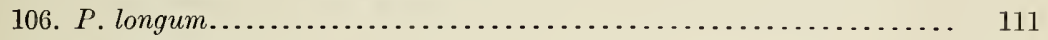

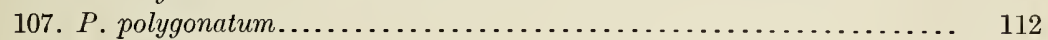

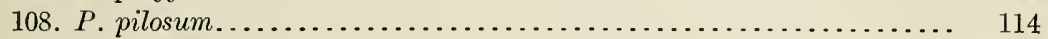

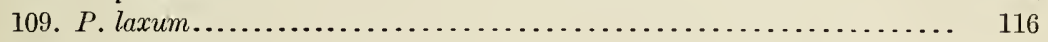

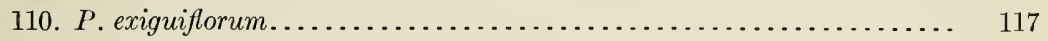

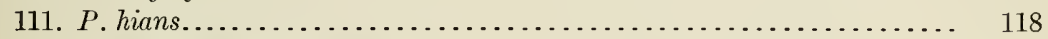

112. Distribution of $P$. hians............................. 119

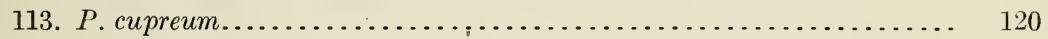

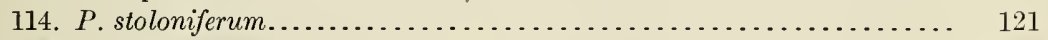

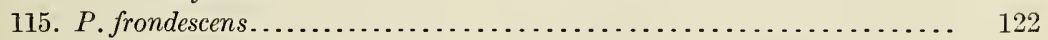

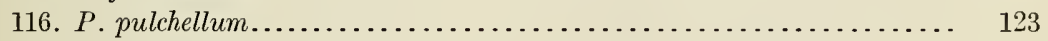

117. P. biglandulare ....................................... 124

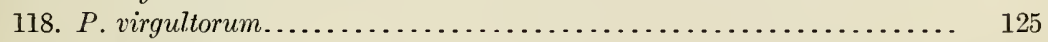

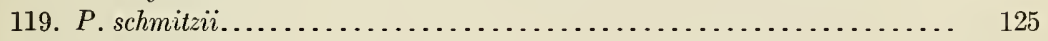

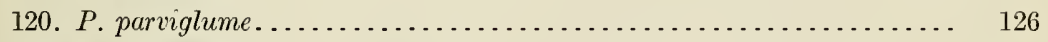

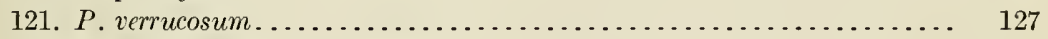

122. Distribution of $P$. verrucosum........................ 127

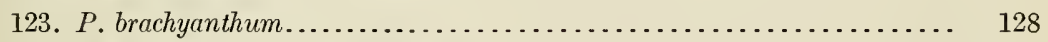

124. Distribution of $P$. brachyanthum .............................. 129

125. P. trichoides...................................... 130

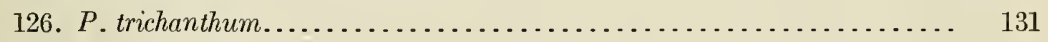

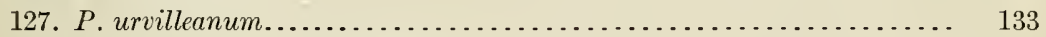

128. Distribution of $P$. urvilleanum........................ 133

129. P. costaricense....................................... 134

130. P. parvifolium.......................................... 135

131. P. millegrana.................................... 137

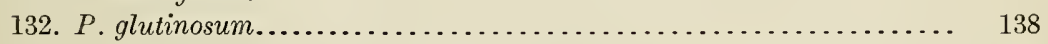

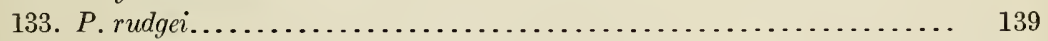

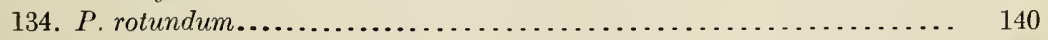

135. P. megiston ............................................... 141

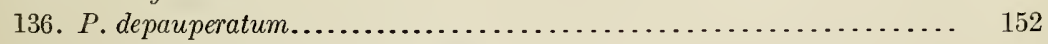

137. Distribution of $P$. depauperatum ....................... 153

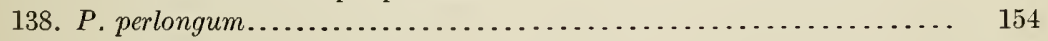

139. Distribution of $P$. perlongum......................... 154

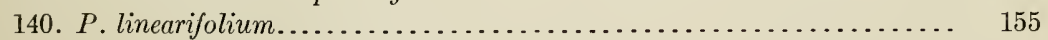

141. Distribution of $P$. linearifolium......................... 156

142. P. werneri........................................... 157

143. Distribution of $P$. werneri................................. 157

144. P. laxiflorum....................................... 158

145. Distribution of $P$. laxiflorum............................ 159

146. P. xalapense....................................... 160

147. Distribution of $P$. xalapense.......................... 160 
FIG. 148. P. xalapense strictirameum............................ 161

149. Distribution of $P$. xalapense strictirameum .................. 161

150. P. ciliatum........................................... 162

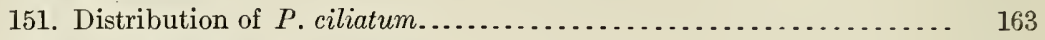

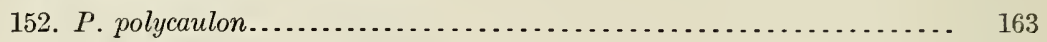

153. Distribution of $P$. polycaulon................................ 164

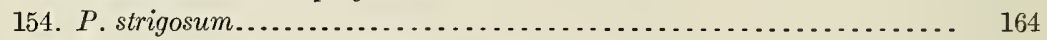

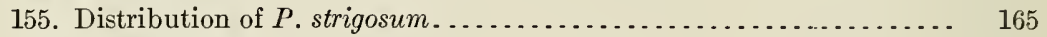

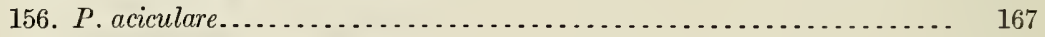

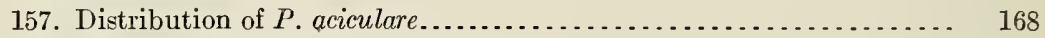

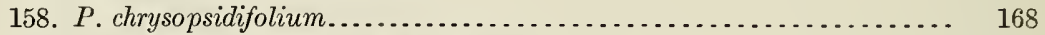

159. Distribution of $P$. chrysopsidifolium ...................... 169

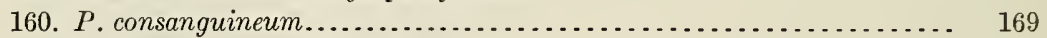

161. Distribution of $P$. consanguineum...................... 170

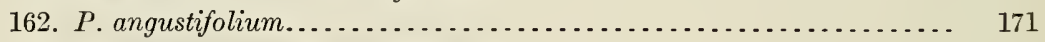

163. Distribution of $P$. angustifolium............................ 171

164. P. fusiforme............................................ 172

165. Distribution of $P$. fusiforme.................................. 173

166. P. arenicoloides......................................... 173

167. Distribution of $P$. arenicoloides.......................... 174

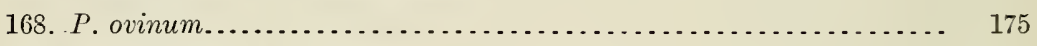

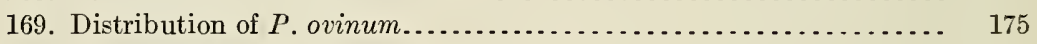

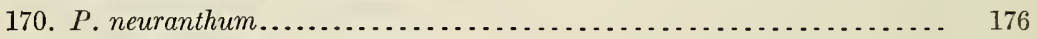

171. Distribution of $P$. neuranthum............................... 176

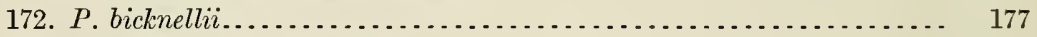

173. Distribution of $P$. bicknellii............................. 177

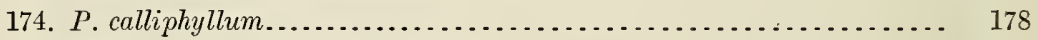

175. Distribution of $P$. calliphyllum.......................... 178

176. P. nudicaule............................................ 179

177. Distribution of $P$. nudicaule ....................................... 179

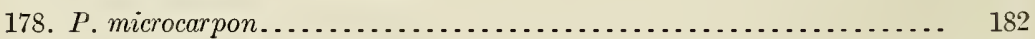

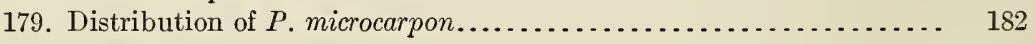

180. P. nitidum............................................... 184

181. Distribution of $P$. nitidum............................... 184

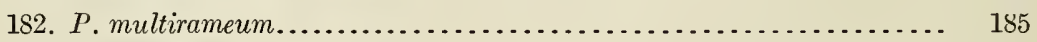

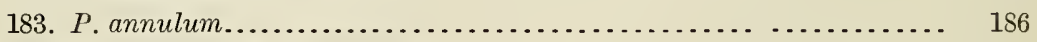

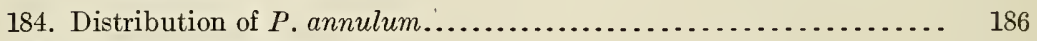

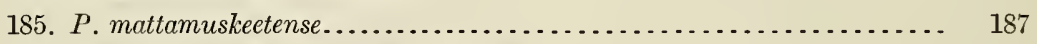

186. Distribution of $P$. mattamuskeetense.................... 187

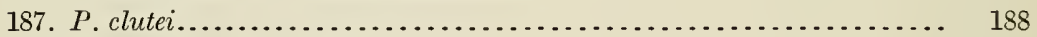

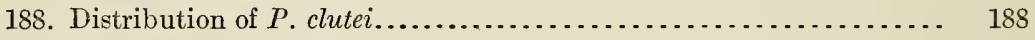

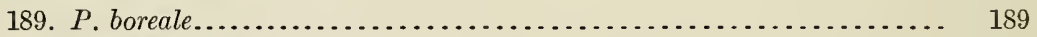

190. Distribution of $P$. boreale.............................. 190

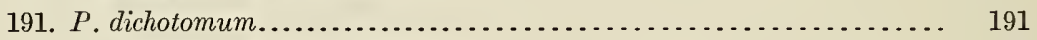

192. Distribution of $P$. dichotomum.......................... 192

193. P. barbulatum........................................ 193

194. Distribution of $P$. barbulatum.............................. 194

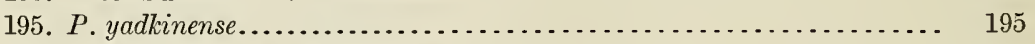

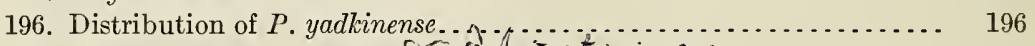

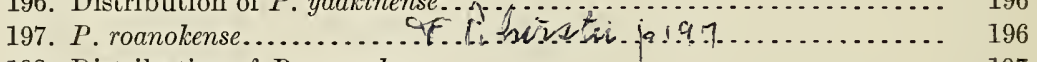

198. Distribution of $P$, roanokense............................. 197

199. P. caerulescens....................................... 197

200. Distribution of $P$. caerulescens......................... 198 
Fig. 201. P. lucidum........................................ 198

202. Distribution of $P$. lucidum............................. 199

203. P. sphagnicola..................................... 200

204. Distribution of $P$. sphagnicola........................... 200

205. P. spretum............................................ 202

206. Distribution of $P$. spretum............................ 202

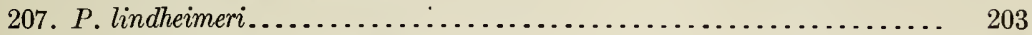

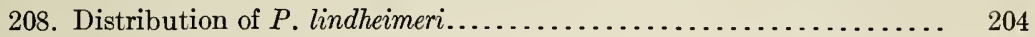

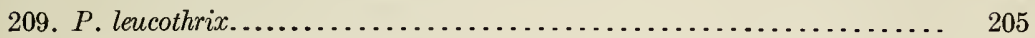

210. Distribution of $P$. leucothrix............................ 206

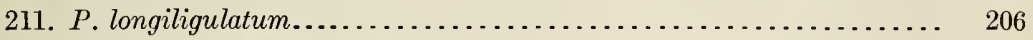

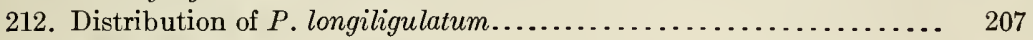

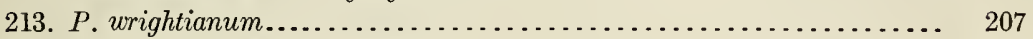

214. Distribution of $P$. wrightianum....................... 208

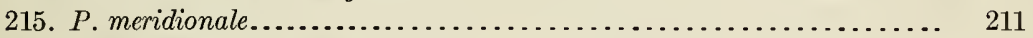

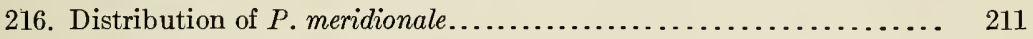

217. P. albemarlense..................................... 212

218. Distribution of $P$. albemarlense......................... 213

219. P. implicatum........................................ 213

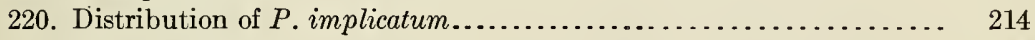

221. P. huachucae..................................... 215

222. Distribution of $P$. huachucae............................. 216

223. P. huachucae silvicola.................................. 217

224. Distribution of $P$. huachucae silvicola..................... 218

225. P. tennesseense.................................... 219

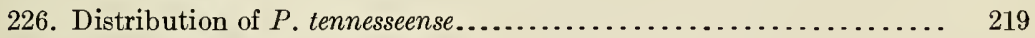

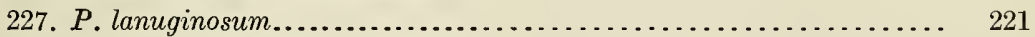

228. Distribution of $P$. lanuginosum........................ 222

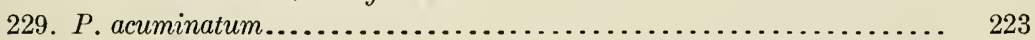

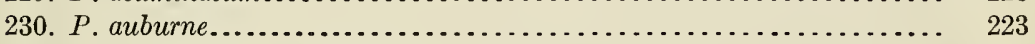

231. Distribution of $P$. auburne............................... 224

232. P. thurowii............................................. 224

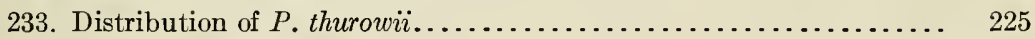

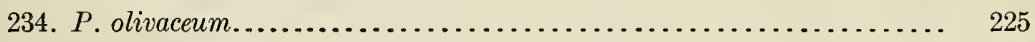

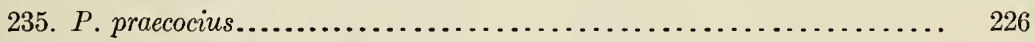

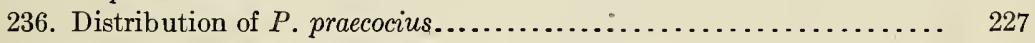

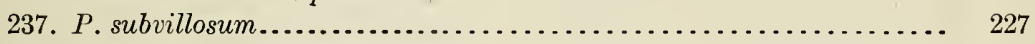

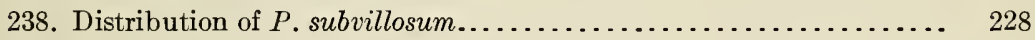

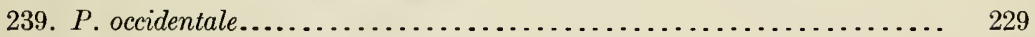

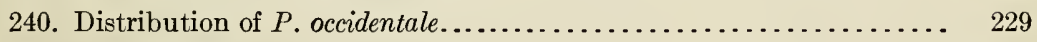

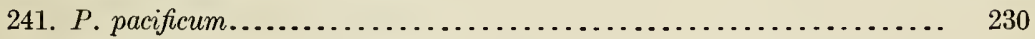

242. Distribution of $P$. pacificum.......................... 230

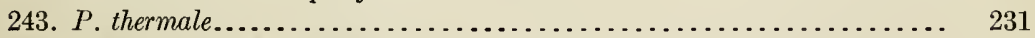

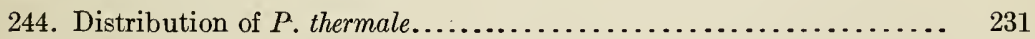

245. P. languidum...................................... 232

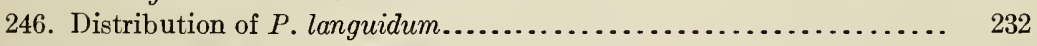

247. P. villosissimum..................................... 234

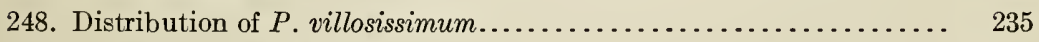

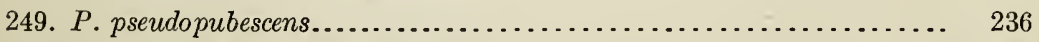

250. Distribution of $P$. pseudopubescens ...................... 236

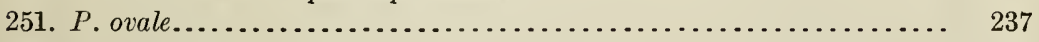

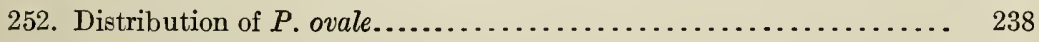

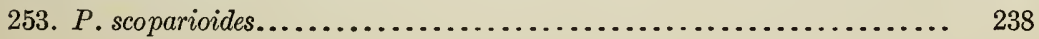


Frg. 254. Distribution of $P$. scoparioides......................... 239

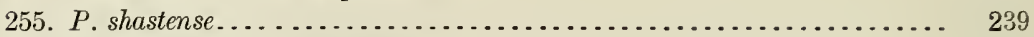

256. Distribution of $P$. shastense............................ 240

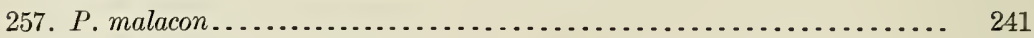

258. Distribution of $P$. malacon ............................. 241

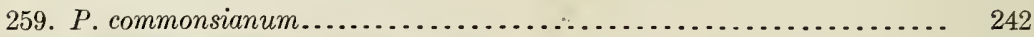

260. Distribution of $P$. commonsianum....................... 242

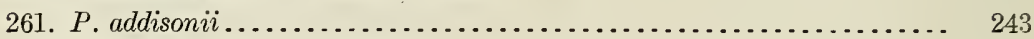

262. Distribution of $P$. addisonii............................. 244

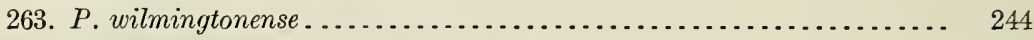

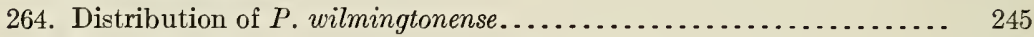

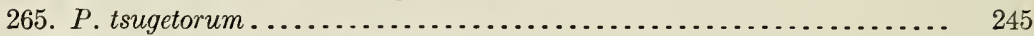

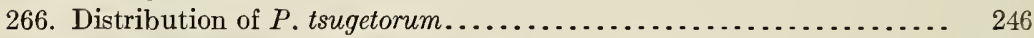

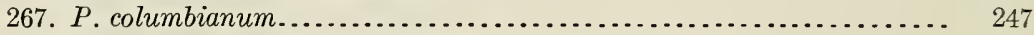

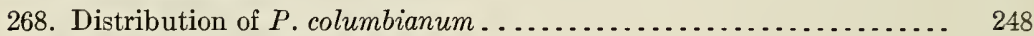

269. P. columbianum thinium................................ 248

270. Distribution of $P$. columbianum thinium..................... 249

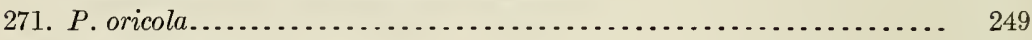

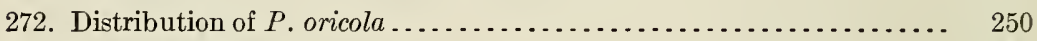

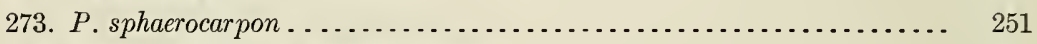

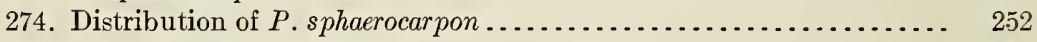

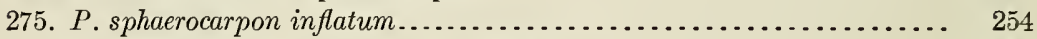

276. Distribution of $P$. sphaerocarpon inflatum................... 254

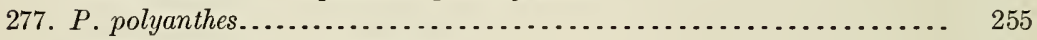

278. Distribution of $P$. polyanthes .......................... 256

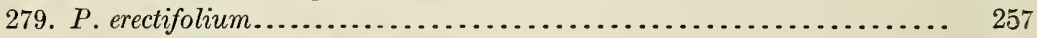

280. Distribution of $P$. erectifolium ........................ 257

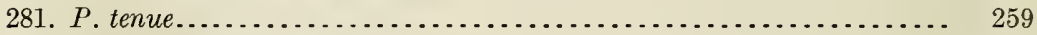

282. Distribution of $P$. tenue................................ 260

283. P. albomarginatum..................................... 260

284. Distribution of $P$. albomarginatum ......................... 261

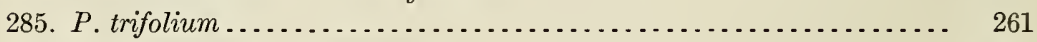

286. Distribution of $P$. trifolium............................. 262

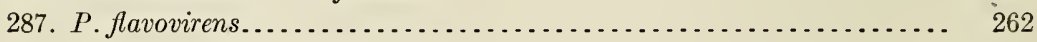

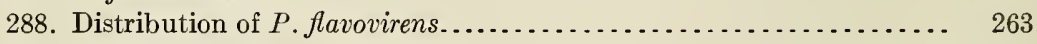

289. P. concinnius.......................................... 263

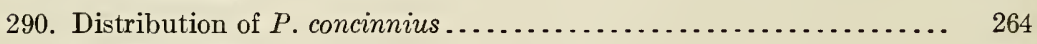

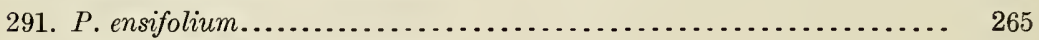

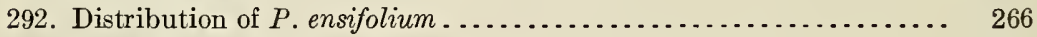

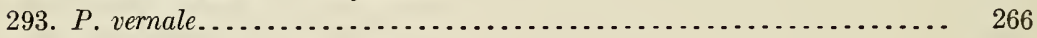

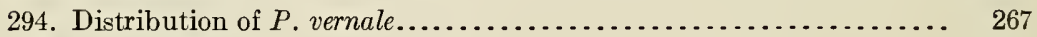

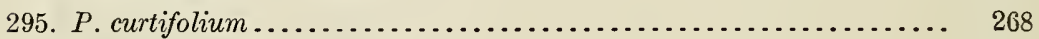

296. Distribution of $P$. curtifolium........................... 268

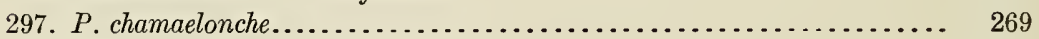

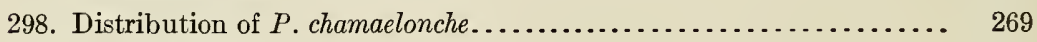

299. P. glabrifolium ...................................... 270

300. Distribution of $P$. glabrifolium......................... 270

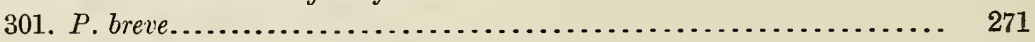

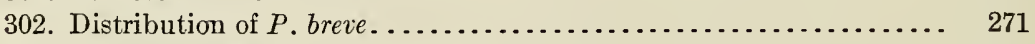

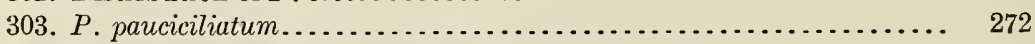

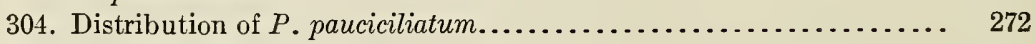

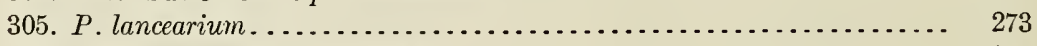

306. Distribution of $P$. lancearium............................... 274 
Fig. 307. $P$ patuluma ............

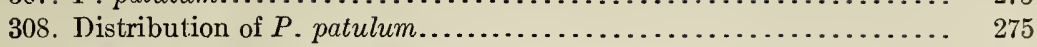

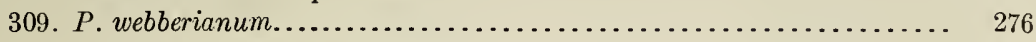

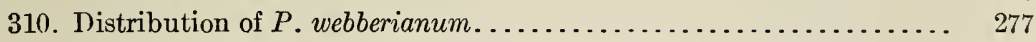

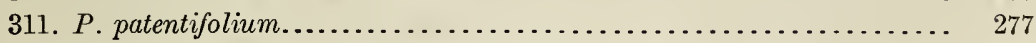

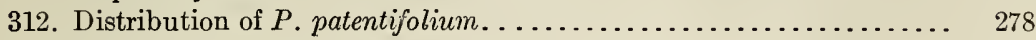

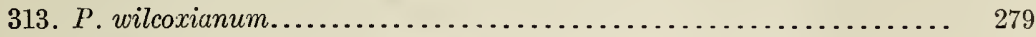

314. Distribution of $P$. wilcoxianum.......................... 279

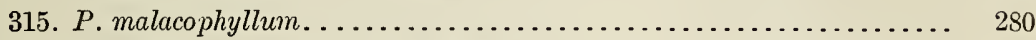

316. Distribution of $P$. malacophyllum ..................... 281

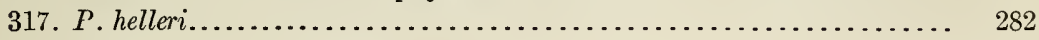

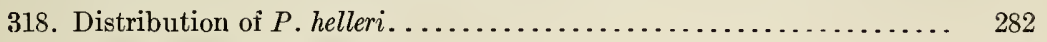

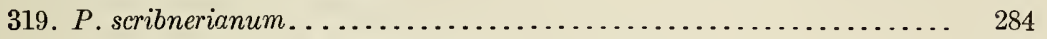

320. Distribution of $P$. seribnerianum....................... 285

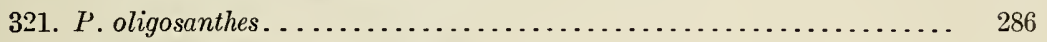

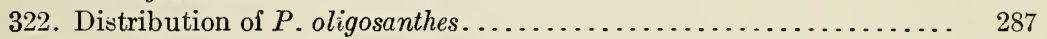

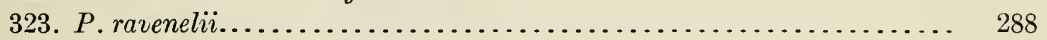

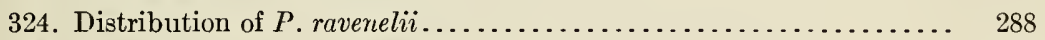

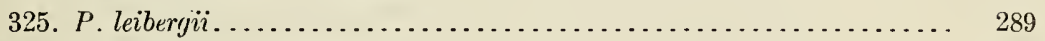

326. Distribution of $P$. leibergii.......................... 290

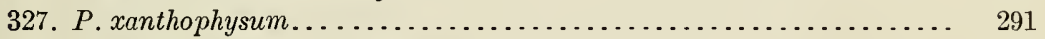

328. Distribution of $P$. xanthophysum ...................... 292

329. P. pedicellatum................................... 292

330. Distribution of $P$. pedicellatum........................ 293

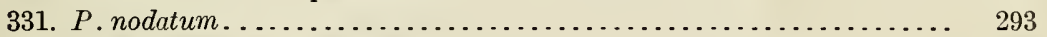

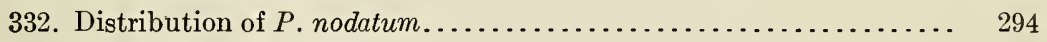

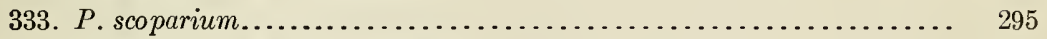

334. Distribution of P. scoparium......................... 296

335. P. viscidellum........................................ 296

336. P. aculeatum...................................... 297

337. Distribution of $P$. aculeatum........................ 298

338. P. scabriusculum..................................... 299

339. Distribution of $P$. scabriusculum....................... 299

340. P. cryptanthum................................. 300

341. Distribution of $P$. cryptanthum........................ 300

342. P. ashei............................................. 302

343. Distribution of $P$. ashei............................ 302

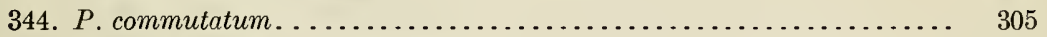

345. Distribution of $P$. commutatum........................... 306

346. P. mutabile....................................... 307

347. Distribution of $P$. mutabile.......................... 308

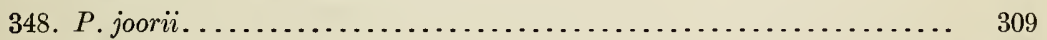

349. Distribution of $P$. joorii................................. 309

350. P. equilaterale.................................. $\quad 310$

351. Distribution of $P$. equilaterale........................ 311

352. P. albomaculatum................................ 311

353. P. clandestinum.................................. 313

354. Distribution of $P$. clandestinum....................... 313

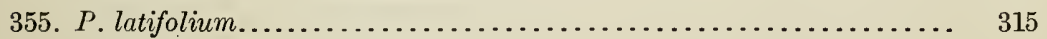

356. Distribution of $P$. latifolium.......................... 316

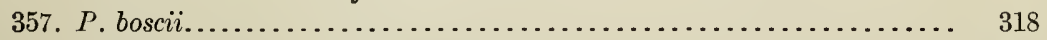

358. Distribution of $P$. boscii................................. 319

359. P. boscii molle...................................... 320 


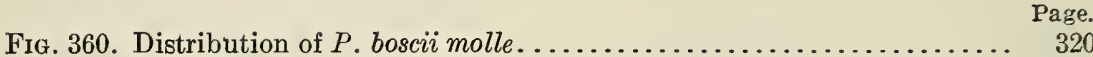

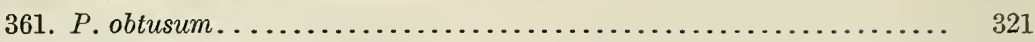

362. Distribution of $P$. obtusum ........................... 322

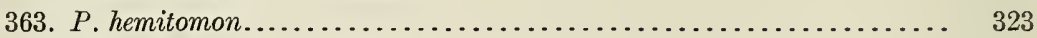

364. Distribution of $P$. hemitomon ........................... 324

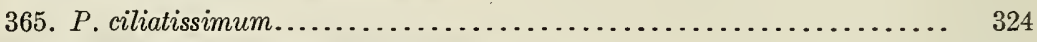

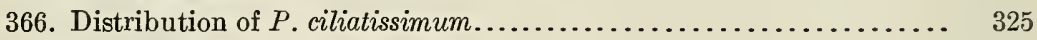

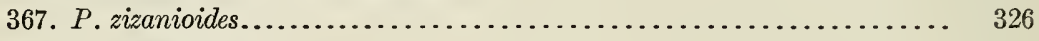

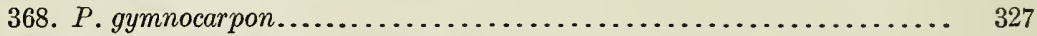

369. Distribution of $P$.gymnocarpon.......................... 328

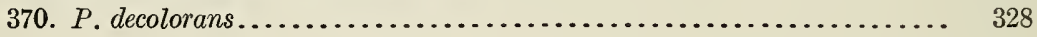




\title{
THE NORTH AMERICAN SPECIES OF PANICUM.
}

\author{
By A. S. Hitchoock and Agnes Chase.
}

\section{INTRODUCTION.}

\section{BASIS AND METHODS OF THE WORK.}

The present paper discusses the species of Panicum known to occur in North America north of Panama, including the West Indies. The results presented are based primarily upon the collections in the United States National Herbarium. The collections of Panicum in all the large herbaria in this country and in Europe have also been examined. In addition to the work done on this large amount of herbarium material both authors have carried on for several years extensive field studies in all parts of the United States, as is indicated by the specimens cited under "Distribution." A number of species / of the section Dichanthelium have been grown for several seasons in the greenhouse in order to determine the relation between ther vernal and autumnal forms.

\section{AMERICAN HERBARIA EXAMINED.}

Biltmore, North Carolina. The Biltmore Herbarium, containing the types of most of the grasses published by Chapman in his Flora of the Southern States.

CAMBRIDGE. The Gray Herbarium of Harvard University.

Chicago. The herbarium of the Field Museum of Natural History.

New York Citr. The herbarium of the New York Botanical Garden, at Bronx Park. The herbarium of Columbia University, which is kept apart from the general herbarium of the Botanical Garden, contains the Torrey Herbarium, each sheet of which is appropriately stamped. The private herbarium of Mr. George V. Nash is also located at the Botarical Garden, purchased by Garden in 1910. fide

Philadelphia. The herbarium of the Academy of Natural Sciences of Philadelphia, containing the plants of Nuttall and Buckley 
incorporated in the general herbarium, and the. Muhlenberg Herbarium and the Short Herbarium segregated.

ST. Louis. The herbarium of the Missouri Botanical Garden. This contains the Bernhardi Herbarium and the Engelmann Herbarium incorporated in the general herbarium.

Wasmington. The United States National Herbarium in the National Museum.

Besides the above many smaller collections were examined, about 45 in all, from the herbaria of educational institutions and from private individuals, among which may be mentioned the following:

The Elliott Herbarium at the Charleston Museum, Charleston, South Carolina, containing the types of species described in Elliott's Sketch of the Botany of South Carolina and Georgia. See Rhodora 44:

The Parry Herbarium, at the Iowa State College, Ames, Iowa.

The Gattinger Herbarium, at the University of Tennessee, Knoxville, Tennessee.

The private herbarium of Mr. W. W. Ashe, Forest Service, Washington, D. C., containing the types of many species described by him in the Journal of the Elisha Mitchell Society. For several years this herbarium has been in storage and not easily accessible. Mr. Ashe kindly loaned a portion of the collection of Panicum in December, 1905. A second portion was sent in February, 1908. Certain of Mr. Ashe's type specimens were not included in either of those loans, but they may become accessible at some future time. These are mentioned under the appropriate species.

The private herbarium of Prof. F. Lamson-Scribner, which was partially destroyed by fire in 1894 . The remaining portion, consisting of the Paniceae, Poa, and a part of the Agrostideae, together with subsequent additions, was purchased by A. S. Hitchcock in 1905 and is now at the United States Department of Agriculture. - L.SN Hab 1413

The Mohr Herbarium, now at the United States National Herbarium.

We have been unable to locate the types of Rafinesque or of Alphonso Wood.

*

EUROPEAN HERBARIA EXAMINEDly zletchcock

ANTwERP. The herbarium of the late Doctor Van Huerck contains a good set of the plants collected by Salzmann in Bahia, Brazil.

ATTERSEE. Here is the large and important private herbarium of the eminent Austrian agrostologist, Dr. Eduard Hackel, formerly of St. Pölten, later of Graz.

BERLIN. The herbarium is at the Königlicher Botanischer Garten, which is located at Dahlem-Steglitz, a suburb. The Willdenow Herbarium is kept apart. ASH. A C. 
Brussels. The herbarium of the Jardin Botanique de l'Ettat contains some of Fournier's types, especially those based on the collection of Galeotti from Mexico.

Copenhagen. The herbarium is at the Universitets Botaniska Have, or Botanical Garden of the University. Of especial importance is the large collection of Liebmann plants from Mexico.

Florence. At the herbarium of the Orto Botanico are many types of Poiret in the Desfontaines Herbarium. There are also many duplicate types of Desvaux and Lamarck and a good collection of Bosc's Carolina plants.

Geneva. There are three large herbaria here. The Conservatoire et Jardin Botaniques contain the Delessert Herbarium. The De Candolle Herbarium, in the city of Geneva, and the herbarium of William Barbey, known as the Boissier Herbarium, at Chambésy, a suburb, are both private. There is also a smaller herbarium at the Institut de Botanique de l'Université.

Göttingen. Of chief interest to American botanists is the Grisebach Herbarium, at the Botanischer Garten der Universität.

Halle. Prof. Carl Mez has been engaged for several years upon a revision of the Paniceae for Engler's Pflanzenreich. He has borrowed the grasses of this group from several of the larger European herbaria. These collections were examined at Halle through the courtesy of Doctor Mez.

London. The rich collections of this city are grouped at three places. The largest collection is at the Royal Botanic Gardens at Kew, a suburb of London. This contains many types of species described by Pursh. The herbarium of the British Museum of Natural History, at South Kensington, contains, aside from the general collection in which is the Gronovius Herbarium and many authentic specimens from Raddi, Rudge, and others, certain segregated herbaria, two of which are the Sloane Herbarium and a small collection of Walter's plants. The Linnæan Herbarium is at the rooms of the Linnæan Society of London.

MADRID. 'The herbarium at the Jardin Botanico contains the types

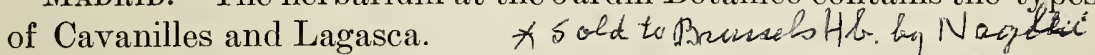

Munıch. The herbarium at the Königliches Botanisches Museum contains the collections of Martius from Brazilf the grasses of which were described by Nees von Esenbeck in his Agrostographia Brasiliensis and by Doell in Martius's Flora Brasiliensis. There are also duplicates from Swartz and Lagasca.

PadUa. At the Orto Botanico is an important collection made by Bosc in Carolina. These plants were obtained mostly in the vicinity of Charleston, South Carolina, and Wilmington, North Carolina. ${ }^{a}$

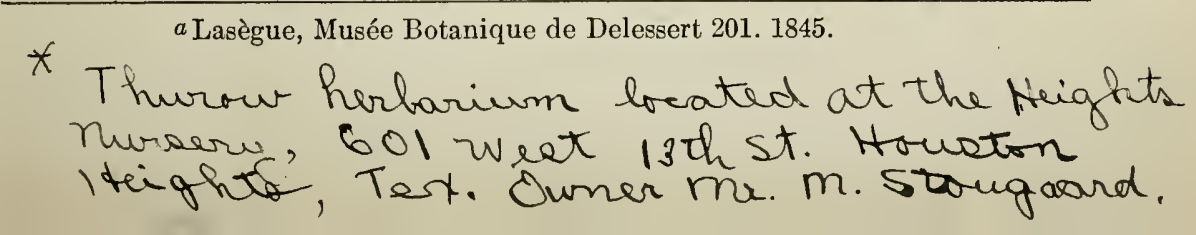


Ls PARIs. From an agrostological standpoint the collections at Paris are of great importance. The herbarium is at the Muséum
d'Histoire Naturelle in the Jardin des Plantes. The general her$11^{2} 9$ barium contains the types of Bonpland, Desvaux, Fournier, Richard, and Steudel. The Michaux Herbarium, the Jussieu Herbarium, and the Lamarck Herbarium are severally segregated. The Cosson Herbarium recently acquired by the Muséum contains many Poiret types. The private herbarium of Drake de Castillo, now located at Rue de Balzac 2, and containing the Franqueville Herbarium, has come under the control of the Muséum. Here are many duplicate types of Michaux and Richard, and a set of Schaffner's Mexican plants.

Prague. To Americans the most important plants here are those collected by Haenke and described by C. B. and J. S. Presl in Reliquiae Haenkeanae. A part of the grasses are at the Museum des Königreichs Böhmen and a part at the Botanischer Garten of the German University.

At the St. Petersibug. The herbarium of the Botanical Garden conbeginming tains the Mexican collections of Karwinsky and F. Mueller, among of Revolu which are several of Fournier's types. To agrostologists a very narred important herbarium is that of Trinius at the Académie Impériale "The Prim-des Sciences de St. Pétersbourg. This is kept apart from the general ical gardenherbarium.

Ane herbarium of the Naturhistoriska Riksmuseum (nature, noucontains the types of Fries and Lindman from South America and, 28,19252 segregated, the Swartz Herbarium of West Indian plants.

VIEnNA. The most important herbarium is that of the Kaiserliches und Königliches Naturhistorisches Hofmuseum. AS H.

TYPE SPECIMENS.

As indicated in a previous paper ${ }^{a}$ the type specimen of a species is that specimen or one of the specimens from which the author drew up the description, or the specimen which the author had chiefly in mind when writing the description. Not infrequently the description is based upon a single specimen, in which case there is no doubt as to what specimen is the type. Sometimes the author had several specimens at hand, in which case it becomes necessary to determine, if possible, which specimen represented to the author his ideal of the species. This may be shown, in case the author has designated no type, by the specific name, which may indicate a collector or locality, or by a careful comparison of the description, and especially of notes, with the specimens," or by some note upon the sheets of specimens which the author is known to have had before him at the time of

$a$ Hitchcock, Types of American Grasses, Contr. Nat. Herb. 12: 113. 1908. 
describing the species. In the absence of any indication that will point toward a particular specimen, the first one mentioned or the one from the locality first mentioned with the original description, or at least the first one among those equally eligible, is chosen as the type.

Immediately following the citation of the name and its place of publication, is, quoted verbatim, when practicable, the "type locality," or that portion of the author's statement which indicates the origin of his specimen. Where there is doubt as to what specimen is the type, the reasons are given for choosing any particular specimen. All the types mentioned have been examined by one or both of the authors unless otherwise stated. After quoting from the original publication the portion relating to the type, we have indicated the location of the type specimen and have recorded any information concerning the specimen, or any data of significance upon the label.

SYNONYMY.

The name of each species accepted in this work is the earliest valid name, as governed by the recent American Code of Botanical Nomenclature. $^{a}$ Under the accepted name the synonyms have been placed in chronological sequence.

Nomina nuda have been mentioned only when they have found their way into botanical literature, especially the Index Kewensis. If such nomina nuda can be identified by type specimens they are placed as synonyms of the species to which the type belongs. If they were originally mentioned as synonyms but can not be identified, they are placed under those species to which they were assigned as synonyms.

Typonyms are different names based upon the same type. When an author definitely changes a name, or substitutes one name for another, the old name and the new are typonyms of each other. This is the case even when the author making such change describes a different species, or cites incorrect synonyms or specimens that belong to a different species. As an example of a simple change of name we have, "Panicum ramisetum Scribn. nom. nov. Panicum subspicatum Vasey, U. S. Dept. Agr. Div. Bot. Bul. 8: 25, 1889, not Desvaux, Opuscules 84, 1831." The evidence here is complete that Panicum ramisetum Scribn. and $P$. subspicatum Vasey are typonyms. As an example of change of name accompanied by a description of a different species may be given, Panicum polyneuron Steud. ${ }^{c}$ The author had evidently seen no specimen of this himself, but translates 
the description of $P$. nervosum Muhl. given by Torrey ${ }^{a}$ and cites as synonym, "P. nervosum Mühlbrg. Gram. p. 116," and also cites "Torr. Fl. N. Am. I. 143." Steudel apparently changes the name on account of $P$. nervosum Lam., which he described on the same page. The grass described by Steudel, that is, the one described by Torrey, is $P$. latifolium L., but since Steudel intended to change Muhlenberg's name, $P$. polyneuron Steud. is a typonym of $P$. nervosum Muhl., which is $P$. commutatum Schult. Hence $P$. polyneuron is placed as a synonym under $P$. commutatum Schult.

A change of rank of misapplied names has not infrequently been made by authors. Such names are typonyms of the original regardless of the plant described. For example, Panicum nitidum barbulatum Chapm. ${ }^{b}$ is based on $P$. barbulatum Michx., but the species described by Chapman is $P$. microcarpon Muhl. Nevertheless P. nitidum barbulatum Chapm. is a typonym of $P$. barbulatum Michx. In the same way all subspecific names based on $P$. barbulatum Michx., to whatever species applied, are typonyms of P. barbulatum Michx. and are listed under that species in this paper, though the species described, or the one the particular author supposed he was transferring, was usually P. microcarpon Muhl.

The cases are not infrequent where one author has misapplied the name of a preceding author-that is, under a given name has described a different species. Pursh ${ }^{c}$ uses the name Panicum diffusum Swartz, but describes a different species, $P$. flexile (Gattinger) Scribn. The Index Kewensis lists the former as "Panicum diffusum Pursh." This is misleading, as Pursh did not intend to describe a new species with the name $P$. diffusum. It is a case of misapplication of a name, or an error of determination. Names of this kind are not listed as synonyms, but, where the importance warrants it, they are mentioned as misapplications in a note at the end of the synonymy.

\section{SPELLING OF NAMES.}

The original spelling of names has been followed, except that typographical errors and wrong gender endings have been corrected. It is not always easy to determine how far it is proper to carry such corrections. In the case of Panicum sphagnicolum Nash, we have adopted the change to "sphagnicola," already made by its author in Britton's Manual, but it has not seemed wise to make such changes as "oligosanthes" to "oliganthum." Occasionally the original spelling of names has been inadvertently altered by later authors. As an example of this may be mentioned "barbatum" and "barbatulum" instead of the original "barbulatum." Such mis- 
spellings are not given formal standing as synonyms, but are listed under the proper paragraph-that is, in this case, under Panicum barbulatum.

\section{SPECIES, SUBSPECIES, AND FORMS.}

The determination of the relation of taxonomic groups rests, in the last analysis, upon judgment and experience. Such judgment is greatly influenced by the amount of material that has been examined, both in the herbarium and in the field. Our judgment concerning the taxonomic rank of many of the less known groups may be altered after an examination of more specimens. The herbarium may show only 1 per cent of specimens intermediate between two groups, while a study of the same groups in the field may show a much larger proportion of intergrades. Or, field work may show, on the other hand, that the peculiar or intermediate specimens are rare and that the two groups are easily distinguished. The line is not sharp between forms and subspecies nor between subspecies and species. If a group of specimens presents constant characters of what we consider major importance, it is recognized as representing a species. If the characters are of minor importance, but constant and well marked, and the specimens tend to show a distinct geographical range, the group may still be given the rank of a species. If two groups present fairly well marked characters, but there is a considerable proportion of intermediate specimens - that is, the characters are not constant for the two groups - they stand in the relation of species and subspecies. The names species and subspecies are a taxonomic convenience and are entirely arbitrary. They may not represent a biological relation in the sense that one is an offshoot or development from the other, but signify only that the form to which the name species was applied was recognized and given taxonomic or nomenclatorial standing before the other. The species may be the less common or a product of local conditions. Panicum huachucae is the name applied originally to a specimen from the Huachuca Mountains, Arizona, but represents an outlying form of a widespread species. The commoner form has been designated a subspecies, P. huachucae silvicola, because the name was applied to this at a later date.

On the other hand, the fact that there are occasional intermediate specimens does not, of itself, invalidate the standing of two related groups as species. It becomes then both a question of fact and a question of judgment. If the two groups as a whole show well-marked and fairly constant characters, and an examination of a large number of specimens indicates that as a matter of fact the number of intergrades is comparatively few, we have accepted the two groups as species and have mentioned intermediate herbarium specimens. 
The geographical range of a form is to be taken into consideration along with the morphological characters, in determining the taxonomic standing of a given group. A group distinguished by small differences in morphological characters may be assigned subspecific or even specific rank when the differences are supported by a distinct or at least a different geographical range. Groups that are not sufficiently distinct to be assigned subspecific rank are mentioned after the general description of the species and specimens are cited as illustrations. In a few cases these citations are given in a formal manner to emphasize the distinctness of the group, in which cases the same specimens do not occur among those cited in the general distribution. Usually the specimens mentioned as illustrating a particular departure from the typical form are cited by collector and number or date only, and are repeated under "Distribution." The locality is given in such cases only when the geographical range is of significance.

\section{GEOGRAPHICAL DISTRIBUTION.}

The species of the genus Panicum, numbering probably about five hundred, are found in the Tropies and warm temperate regions of both hemispheres. In North America the genus extends throughout the West Indies, Central America, Mexico, and the United States and into the southern part of the Dominion of Canada. The subgenus Dichanthelium, which includes over one-half the species of the entire genus as represented in North America, is confined to the Western Hemisphere and almost to North America. The center of distribution of this group is the Atlantic Coastal Plain of the Southeastern States, whence it extends north to the eastern Canadian Provinces, west to the Pacific coast and British Columbia and south through Mexico and the West Indies to northern South America. A few species of true Panicum, such as $P$. virgatum and species of Capillaria, also extend over a wide range. The latter group is represented from Maine to British Columbia and southward into South America. The genus is poorly represented in the mountainous regions of the United States and not at all at high altitudes. Panicum thermale is found around hot springs in the Rocky Mountains at an altitude of 2,000 meters, but this is an exceptional case. The genus is poorly represented on the Great Plains and especially in the arid regions of the Great Basin. As to habitat, the species are found growing under a variety of conditions, but rarely in shady, hard-wood forests.

\section{CITATION OF SPECIMENS.}

The general range of all species is given, so far as indicated by specimens, even when this range extends beyond the limits of North America. The detailed citation of specimens is given by 
States or countries, the States being in the sequence followed by the Century Atlas, the other countries and provinces being interpolated or added with the intention of preserving the general sequence from north to south. Mexico and Central America precede the West Indies. The islands of Tobago and Trinidad are considered as belonging geographically to South America and are listed after Venezuela. All specimens cited in the distribution or mentioned in the notes are in the United States National Herbarium unless otherwise stated. Specimens from other herbaria are cited from States or countries when such specimens add to the known range or fill in gaps in the listed distribution. In such cases only one specimen is mentioned from each additional State, unless the species is rare or of peculiar distribution. These additions are taken from other herbaria in the following order: Hitchcock's herbarium, Gray Herbarium, herbarium of the Academy of Philadelphia, herbarium of the Missouri Botanical Garden, Biltmore Herbarium, herbarium of the Field Museum, the herbarium of the New England Botanical Club, and other local herbaria in no particular sequence.

In order to save space, specimens are cited by collector and number only, or, if the collector's number is not given, the year is stated. ${ }^{a}$ This method makes clear in most cases the identity of the specimens listed. It must be borne in mind that when a specimen is cited by the collector's number it refers to the particular sheet in the National Herbarium or other herbarium mentioned. It not infrequently occurs that two or more species, collected at the same time and place, or collected at different times and places but supposed by the collector to be the same species, are distributed under the same number to different herbaria. Collectors have in some cases sent to the National Herbarium a set of grasses for identification, and later distributed other sets in which the species under certain numbers were different from those submitted for names. This is especially misleading if the labels state that the sets have been determined at the National Herbarium or the Department of Agriculture or by a specialist whose name appears upon the label. The numbered sets collected by Charles Wright in Cuba, which contain many examples of more than one species distributed under one number, have been discussed in an earlier publication. ${ }^{b}$

The locality cited in the distribution does not always exactly agree with that given on the label. Occasionally, for convenience, several specimens from the same general locality are listed under one heading; for instance, "Vicinity of Cape Henry" may include specimens labeled "Virginia Beach" or "Lynn Haven." This has not often

a Smith 1900 indicates that the specimen is Smith's number 1900; Smith in 1900 indicates that the specimen was collected by Smith in the year 1900 .

$b$ Hitchcock, Contr. Nat. Herb. 12: 185. 1909. 
been done and only when the number identifies the sheet. Specimens are listed under the names of the States as they are at present recognized and limited. Those labeled as from Indian Territory are listed under Oklahoma.

The maps illustrating distribution are intended to present graphically the general range of each species within the United States. Usually a single dot is placed upon the map in each State in which the species is known to grow, as indicated by herbarium specimens. In the larger States a dot may be placed in each of the general divisions in which the species occurs. If the species is found throughout a State the dot representing this may be placed in the center, but if the species is confined to a particular portion of a State, such as the coastal plain of South Carolina, or subtropical Florida, the dot is placed in that portion.

TEXT FIGURES OF SPIKELETS.

Each species is illustrated by a text figure showing usually two views of the spikelet and one view of the fruit. The spikelet is usually shown as seen from the front and from the back, but in a few species the side view is shown, when this is more characteristic. The fruit is placed by the side of the spikelet, and on a line with its position within the spikelet, so that its relation to the other parts is readily apparent. These figures are all magnified ten diameters.

The spikelets from which the drawings are made were usually from the type specimens of the species. In most cases where the type specimen was not accessible the drawings were made from the type or duplicate type specimens of one of the synonyms. In a very few cases the drawings were made from specimens which were not types or duplicate types. The identity of the specimen from which the drawing was made is indicated in each case.

\section{TERMINOLOGY.}

No new terms are used in the present paper, but it may be well to call attention to the term "lemma," and to certain other terms used in a somewhat restricted or modified sense. The lemmas, or the flowering glumes of some authors, are the bracts of the spikelet above the empty glumes. A lenma is said to be fertile when it bears a perfect flower in its axil, and sterile when its flower is staminate or suppressed. The term "fruit" is used to include the caryopsis and its inclosing lemma and palea. In the subgenus Dichanthelium the terms "vernal form" and "autumnal form " are used for the two successive seasonal conditions of the individuals. The vernal form appears early in the season, in spring or early summer, and is followed sooner or later by the branched stage called the "autumnal form." 


\section{HISTORY AND LIMITATION OF THE GENUS.}

PRE-LINN AAN USE OF THE NAME.

The name Panicum, as used by the ancient Latin authors, referred to Chaetochloa italica (L.) Scribn. (Panicum italicum L.), and the genus Panicum of the medieval botanists was based mainly upon this species, which was commonly cultivated as a cereal. Tournefort ${ }^{a}$ gave the genus a more formal standing and described fifteen species, one of which he figured. By him the genus is characterized as having the flowers aggregated in a spike and is made to include species now referred to Chaetochloa italica (L.) Scribn., C. viridis (L.) Scribn., C. verticillata (L.) Scribn., Pennisetum americanum (L.) Schum., Echinochloa crusgalli (L.) Beauv., Polypogon monspeliensis (L.) Desf., and Gastridium lendrgerum (L.) Gaud. The species figured, however, is a form of Chaetochloa italica, which is, therefore, the type of Panicum as limited by Tournefort.

On the other hand the ancient name Milium referred to Panicum miliaceum L., the common millet of Europe. Tournefort followed his predecessors in including under the genus Milium the millets $(P a-$ nicum miliaceum L.) and the sorghums (Holcus sorghum L. ), but figures the former.

Linnæus ${ }^{b}$ at first recognized the two genera Panicum and Milium, basing the former on "Panicea Scheuch. 2:2," and the latter on "Tournef. 298." The Scheuchzer ${ }^{c}$ figures cited by Linnæus are those of the spikelets of Chaetochloa viridis and Echinochloa crusgalli. Linnæus's description states that the involucre is many-leaved and capillary ("Involucrum uniflorum, polyphyllum: foliolis capillaribus, inaequalis insertionis"), which refers to the genus Chaetochloa Scribn. (Setaria Beauv.). This description, together with his reference to Scheuchzer, would indicate Chaetochloa viridis (L.) Scribn. as the species considered by Linnæus as typical of his genus Panicum. He also adds a note that in some species the valve of the corolla terminates in an awn, which statement refers to Echinochloa crusgalli. Linnæus here uses the name Milium in the same sense as does Tournefort. The two genera are treated in the same manner in the succeeding editions of the Genera Plantarum; up to and including the fourth, published in 1752 , except that a statement is added to the effect that an involucre is wanting in some species. In the fifth edition of this work ${ }^{d}$ the reference to Scheuchzer is omitted, as is also that portion of the diagnosis which refers to the involucre, and the above-mentioned note is replaced by one to the effect that species are included in which there is a many-leaved, capillary involucre. That is, in the first edition of this work that was published after the Species Plantarum the genus Panicum was based upon species hav-

$a$ Inst. Rei Herb. 1: 515. pl. 298. f. M. 1700.

$b$ Gen. Pl. 17. 1737. c Agrost. 45. pl. 2.f. 2. 1719.

$d$ Gen. Pl. 29. 1754 . 
ing a 3-valved calyx and lacking awns and involucre. But it is clear from the note that Linnæus here also referred to the genus Panicum those species in which the spikelet is awned and those with an involucre. It is true he refers to the corolla valves as being awned, but this is apparently an error, and originated from a misinterpretation of Scheuchzer's figure ${ }^{a}$ of Echinochloa crusgalli.

As stated above the genus Milium, as described in the first edition of Linnæus's Genera Plantarum, is based on the species now called Panicum mitiaceum L. and is taken directly from Tournefort's work. The calyx is described as 3-valved. In the next three editions of the Genera Plantarum, Linnæus still cites Tournefort as the author of Milium and refers to his plate 298, but he changes the diagnosis to read, calyx 2-valved, and adds the note that Milium with a 2-valved calyx differs from Panicum with a 3 -valved calyx. The genus appears in the fifth and sixth editions as in the preceding three editions, except that the last-mentioned note is omitted.

The treatment of the two genera in the Species Plantarum ${ }^{b}$ is in accord with that in the fifth edition of the Genera Plantarum. Under Panicum twenty species are described, divided into two groups, Spicata and Paniculata. The species are as follows:

\section{SPICATA.}

1. P. alopecuroid[esj=Pennisetum caffrum (Bory) Leeke.

Munro ${ }^{c}$ states that the specimen in the Linnæan Herbarium is Gymnothrix thouarii. Beauv., which species is referred by Leeke ${ }^{d}$ as above. This is a different species from Pennisetum alopecuroides Desv. ${ }^{e}$ or Pennisetum alopecuroides Spreng., ${ }^{f}$ which is based on Cenchrus alopecuroides Thunb.

2. P. glaucum =Chaetochloa glauca (L.) Scribn.

$P$. glaucum $\beta=$ Chaetochloa viridis (L.) Scribn.

P. glaucum $\gamma=$ Chaetochloa glauca (L.) Scribn. $g$

3. P. americanum =Pennisetum americanum (L.) Schum.

4. P. italicum = Chaetochloa italica (L.) Scribn.

5. P. crusgalli = Echinochloa crusgalli (L.) Beauv.

P. crusgalli $\beta=$ Echinochloa crusgalli (L.) Beauv. The long-awned form.

6. $P$. dissectum $=$ Paspalum dissectum $\mathrm{L}$.

7. P. dimidiatum $=$ Sienotaphrum dimidiatum (L.) Brongn.

8. P. sanguinale =Syntherisma sanguinalis (L.) Dulac.

9. P. filiforme =Syntherisma filiformis (L.) Nash.

10. P. compositum=Oplismenus compositus (L.) Beauv.

a Agrost. pl. 2.f. 2. F. 1719.

b L. Sp. PI. 55.1753.

$c$ Proc. Linn. Soc. Bot. 6: 37. 1862.

$d$ Zeitschr. Naturwiss. 79: 39. 1907 .

$e$ Hamilt. Prodr. Pl. Ind. Occ. 11. 1825.

$f$ Syst. Veg. 1: 303. 1825.

$g$ For a further discussion of the Linnæan species based upon American plants, see Hitchcock, Contr. Nat. Herb. 12: 114. 1908. 

11. P. dichotomum.
12. P. clandestinum.
13. P. capillare.
14. P. patens.
15. P. dactylon = Capriola dactylon (L.) Kuntze.
16. P. miliaceum.
17. P. latifolium.
18. P. brevifolium.
19. $P$. arborescens $a=P$. brevifolium $\mathrm{L}$.
20. P. virgatum.

PANICULATA.

THE TYPE OF PANICUM.

As stated above, the historic type species of Panicum is Chaetochloa italica, the common foxtail millet. This is the plant to which the name Panicum was universally applied by Latin writers as far back as our record extends. As the idea of genera developed, botanists, until the time of Tournefort, included under the general name Panicum other species with a sinilar inflorescence. This author included several rather diverse species, but the one which he chose for his illustration and which we may consider his type was the same wellknown plant, the Panicum of the ancients (Chaetochloa italica).

Another ancient name, Milium, was applied to a widely cultivated cereal (Panicum miliaceum), and later, as the idea of genera grew, the name was made to include the sorghums, and was thus used by Tournefort, ${ }^{b}$ who, however, figured $P$. miliaceum as his type species.

Linnæus at first accepted these two genera in the historic sense, and the type of his Panicum, since he referred to Scheuchzer, was the plant now called Chaetochloa viridis. Later, however, his ideas underwent a change, until finally in 1753 he had united under the generic name Panicum the twenty species mentioned above, including, as will be seen, not only the historic type of Panicum and its allies, and another common species (Echinochloa crusgalli) referred to Panicum by Tournefort ${ }^{b}$ and other pre-Linnæan botanists, but also several new species, and, most noteworthy of all, Panicum miliaceum, the type of the old genus Milium. He, however, still retained the name Milium for another genus (including $M$. effusum and $M$. confertum). Since no generic descriptions are given in the Species Plantarum, it is necessary to consult the first succeeding edition of the Genera Plantarum, namely the fifth, published in 1754. In this place Linnæus still credits the genus Milium to "Tournef. 298," though he has

a Trimen (Journ. Linn. Soc. Bot. 24: 155. 1888.) states that this species, as described in Linnæus's Flora Zeylanica, upon which is based $P$. arborescens L., is $P$. ovalifolium Poir. ( $P$. brevifolium L.), and that the specimen in the Linnæan Herbarium belongs to the same species. Mixed with the above-mentioned herbarium specimen is a fragment of an Arundinaria, which probably accounts for the specific name and the reference to its lofty stature.

$b$ Inst. Rei Herb. 54. pl. 298. f. L. 1700. 
placed the species represented by the plate 298 under Panicum, and the other Tournefortian species of Milium under Holcus. But he has made one important alteration in the description, a comparison of which with the first edition shows the two to be identical except as to the statement concerning the calyx or glumes. In the first edition the diagnosis reads, "Gluma uniflora, trivalvis: Valvulis ovatis, acuminatis, duabus interioribus oppositis, tertia a tergo alterius posita;" in the fifth, "Gluma uniflora, bivalvis: Valvulis ovatis, acuminatis." By the change of trivalvis to bivalvis he has transferred the generic idea of Milium from Panicum miliaceum to Milium effusum.

It is now necessary to decide upon the type species of Panicum as presented in the Species Plantarum. There is nothing in this work to indicate which species Linnæus considered the type of the genus, but by taking into consideration the description of Panicum as given in the fifth edition of the Genera Plantarum we arrive at a partial interpretation of his ideas. In the latter work he describes the calyx (glumes and sterile lemma) and corolla (fertile lemma and palea) as follows: "Cal. Gluma uniflora, trivalvis: Valvulis ovato-acuminatis: tertia minima a tergo alterius posita. Cor. bivalvis: Valvulae ovatoacuminatae: altera minor planior." The description of the other parts has no significance, but at the end is a note which throws much light on the question under consideration. It reads: "Obs. Aristae terminant in quibusdam corollae valvulam planiorem. Species datur involucro polyphyllo capillari instructa." It is evident from this note that Linnæus did not consider as typical those species with awns or with an involucre, though he admitted them as exceptional. As awned species he had in mind particularly Panicum crusgalli, an old and well-known species illustrated by Scheuchzer; and as involucrate species he referred especially to his Panicum glaucum and P. italicum.

In accordance with the recent American Code of Botanical Nomenclature ${ }^{a}$ the type is chosen, in the absence of other indications, by an application of Canon 15, section d, which reads: "Where economic or indigenous species are included in the same genus with foreign species, the type is to be selected from (1) the economic species or (2) those indigenous from the standpoint of the author of the genus." The only important economic species described by Linnæus are Panicum americanum, $P$. italicum, and $P$. miliaceum, to which might be added, as of much less importance, $P$. dactylon. It seems evident then, that, since Linnæus did not consider as typical those species having an involucre, the type is the remaining important economic species, namely, Panicum miliaceum.

It is unfortunate that Linnæus and succeeding botanists did not retain Panicum and Milium for the groups containing the historic types; and especially unfortunate that Beauvois did not retain the 
name Panicum for the group which he segregated as Setaria, and restore the name Milium for the group which he called Panicum. But since botanists have for one hundred and fifty years almost unanimously accepted the nomenclatorial idea of retaining the name Panicum for the group containing $P$. miliaceum, it would be unwise to alter the application of the names Panicum and Milium unless it becomes the consensus of botanical opinion that all generic names shall be based upon historic types. Aside from the nomenclatorial confusion arising from such a series of changes, we fear that the difficulties and uncertainties encountered in an attempt to establish a stable nomenclature on such a basis would be much greater than those that have arisen in applying the generic names in accordance with the American Code of Botanical Nomenclature, which arbitrarily fixes 1753 as the date from which priority shall be reckoned and allows the type of Linnæan genera to be selected from economic species.

HISTORY OF PANICUM AFTER 1753.

The second edition of Linnæus's Species Plantarum contains twenty-eight species of Panicum, including all except two of the original twenty. Panicum dissectum was removed to Paspalum, established by Linnæus in 1759 , and P anicum americanum was transferred to Holcus as H. spicatus. In 1772 Panicum sanguinale was separated by Scopoli as Digitaria sanguinalis, and in the course of a few years other species of the first group, Spicata, were separated from Panicum and assigned to the genera Setaria, Echinochloa, Oplismenus, and others. Panicum dactylon was included by Linnæus in his second group, Paniculata, though the inflorescence is spicate as he himself describes, "Panicum spicis digitatis patentibus." This species was soon made the type of a new genus, Capriola Adans., and, later, of Cynodon Rich. Later authors have almost universally retained the name Panicum for the paniculate species, and often have included as sections Echinochloa and Digitaria.

Miller ${ }^{a}$ reverts to the original use of the generic names Milium and Panicum, the former including, among other species, $M$. panicum (Panicum mitiaceum L.) and M. effusum L., and the latter including $P$. germanicum, $P$. italicum, and three kinds of pearl millet (Pennisetum). Moench ${ }^{b}$ and Adanson ${ }^{c}$ also use Milium and Panicum in the pre-Linnæan sense, the former being credited to Tournefort (based on Panicum miliaceum L.) and the latter by Moench to Gaertner (who figures Chaetochloa glauca), and by Adanson to Plinius (who describes Chaetochloa italica).

$a$ Gard. Dict. 1768.

$b$ Meth. PI. 1794.

c Fam. Pl. 1763. 
GENERA HERE EXCLUDED.

The genus Panicum as accepted by Dalla Torre and Harms ${ }^{a}$ includes a number of groups which in our treatment have been excluded. Of the twelve sections into which Panicum is there divided, the first eleven belong to allied genera, as do Streptostachys and Otachyrium of the twelfth section. Coleataenia Griseb. from South America, included in the twelf th section, is a true Panicum.

In addition to the groups mentioned above, several species referred by many authors to Eupanicum have been excluded.

Sacciolepis $\operatorname{Nash}^{b}$ has been discussed by Chase. ${ }^{c}$ This genus has been confused with Hymenachne Beauv. on account of the similarity in the form of the inflorescence, which is usually a spike-like panicle. The genus is chiefly distinguished by the saccate second glume and stipitate fruit.

Lasiacis (Griseb.) Hitchc. (Panicum, section Lasiacis Griseb.), ${ }^{d}$ includes the woody, bamboo-like species with globose spikelets having a bony-indurated fruit, with a downy tuft at the apex, the palea gibbous above and concave toward the base. The type of this genus is Lasiacis divaricata (L.) Hitchc., based on Panicum divaricatum L., the type of Grisebach's section.

Panicum uncinatum Raddi $e$ is here excluded from Panicum because of the distinctly different spikelets placed with the back of the fruit turned from the rachis, the narrow, aristate first glume as long as the spikelet, the large boat-shaped second glume beset with divergent, uncinate spines, the sterile floret large and having a subindurated lemma and palea, the fertile floret about two-thirds as large as the sterile one, the margin of the lemma not inrolled-a combination of characters showing a closer approach to Echinolaena than to Panicum.

Panicum aturense H. B. K. ${ }^{f}$ is also here excluded, differing from Panicum as here limited in having equal glumes exceeding the subhyaline sterile lemma and a scarcely indurated fruit, the margins of the lemma thin and flat.

Panicum tuerckheimii Hack., of which we have seen but a single specimen (Tuerckheim's no. 8618, a duplicate type), is an anomalous species with spikelets in which the first glume is wholly wanting, and in which no rudiment of a palea is found in the sterile lemma.

The genus Lasiacis and the other species here excluded from Panicum will be separately considered in a subsequent paper.

a Gen. Siphonog. 13. 1900.

$b$ Britton, Man. 89. 1901.

$c$ Proc. Biol. Soc. Washington 21: 6. 1908.

d Fl. Brit. W. Ind. 551. 1864. $e$ Agrost. Bras. 41. 1823.

$f$ Nov. Gen. \& Sp. 1:103. pl.33.181

$g$ Allg. Bot. Zeitschr. 12: 60. 1906.

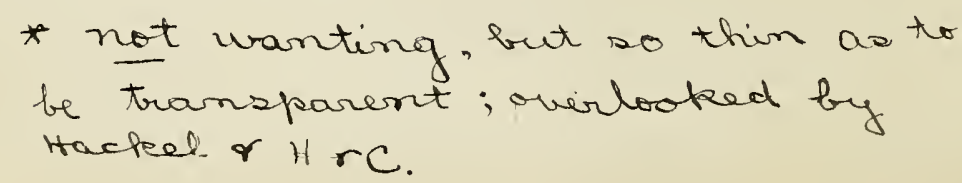


GROUPING OF THE SPECIES.

The genus Panicum, as here limited, contains two groups sufficiently well marked to warrant their segregation as subgenera, namely, Paurochaetium and Dichanthelium. Nearly all the remaining species group themselves around the central idea of the genus as typified by $P$. miliaceum. In order to avoid assigning to the main portion of the genus a name of formal nomenclatorial significance, such as Eupanicum, this group is called true Panicum. There are five outlying species which show no close relationships with the others, but are not sufficiently distinct to be assigned generic rank. These are placed in a final group under "Miscellaneous Species." It is probable that a further study of the species in other parts of the world will indicate that at least some of these species may, together with extra North American allies, be placed in definite subgenera.

The group true Panicum and the subgenus Dichanthelium are susceptible of further division into minor groups, the names of which are the plurals of the characteristic species of each group. These names are not intended to be formal and should have no nomenclatorial standing. The term Angustifolia is used as if we were to say, $P$. angustifolium and its allies. A few tropical species of true Panicum remain ungrouped, as they have no near allies in North America, and there is no advantage in making a group for each species.

The groups of these two main divisions are arranged to represent our judgment as to their relationship, so far as this can be done in a lineal sequence. In true Panicum the first group, the Geminata, is furthest removed from the typical species, the inflorescence resembling that of Paspalum. The Capillaria, Diffusa, and Virgata, typical groups, are near the center of the series. In the same way, the Depauperata are an outlying group of Dichanthelium, the typical groups being the Dichotoma and Lanuginosa.

The species of each group are also arranged to represent their affinities, but it is impossible to indicate the difference in the degree of relationship. Some of the groups are manifestly more homogeneous than others. The group Geminata, for example, includes two closely allied species, $P$. geminatum and $P$. paludivagum, and one, $P$. barbinode, in which the affinity is less evident. The latter species is placed in the same group as the other two partly as a matter of convenience. If there were several other species more closely allied to this than to $P$. geminatum it would have been more convenient to segregate these as a separate group. One more example will suffice to illustrate the unequal value of the groups. Panicum reptans is placed in the group Fasciculata because it is more closely allied to the other species of that group than to those of any other group, yet the

$41616^{\circ}-$ vor $15-10-2$ 
degree of difference between this and any other species of the group is much greater than that between such species as $P$. fasciculatum, $P$. arizonicum, and $P$. adspersum. But other groups, such as the Lanuginosa, are made up of closely allied species, connected with one another by intergrades, to form a composite taxonomic network whose component parts cannot be definitely distinguished by clean-cut lines of demarcation.

\section{DESCRIPTION OF THE GENUS AND SPECIES.}

\section{PANICUM L.}

Eatonia Panicum L. Sp. P1. 55. 1753.

Streppostachys, Steinchisma Raf. Bull. Bot. Seringe 220. 1830.a

Monachue Phanopyrum (Raf.) Nash in Small, Fl. Southeast. U. S. 104. 1903.b

Spikelets articulated below the glumes, falling entire, more or less compressed dorsoventrally, arranged in panicles, rarely in racemes; glumes two, herbaceous, nerved, usually very unequal, the first often minute, the second typically equaling the sterile lemma, the latter of the same texture and simulating a third glume, bearing in its axil a membranaceous or hyaline palea and sometimes a staminate flower, the palea rarely wanting; fertile lemma chartaceous-indurated, typically obtuse, the nerves obsolete, the margins inrolled over an inclosed palea of the same texture, a lunate line of thinner texture at the back just above the base, the radicle protruding through this at germination; stamens three, styles two, stigmas plumose; grain dorsoventrally compressed, with a punctiform hilum, free within the firmly closed lemma and palea.

Annual or perennial herbaceous grasses, of various habit, confined to the warmer regions of both hemispheres.

A number of species here included in the genus Panicum depart in some measure from these generic characters. The subgenus Paurochaetium approaches Chaetochloa Scribn. and the group hitherto referred to Panicum section Ptychophyllum A. Br., in that the uppermost spikelet of each branchlet is subtended by a bristle-like prolongation of the axis. Panicum geminatum Forsk. and P. paludivagum Hitchc. \& Chase have a racemose inflorescence as in Brachiaria Griseb., but the spikelets are placed with the back of the fruit turned toward the rachis as in true Panicum, not in the reverse position as in Brachiaria. In P. barbinode Trin., P . arizonicum Scribn. \& Merr., and $P$. texanum Buckl. spikelets toward the ends of the branches are often placed in the reverse position characteristic of Brachiaria, while others on the same branch are placed with the back of the fruit toward the axis, showing that in an inflorescence not strictly racemose this character of the position of the spikelets in relation to the axis is not of taxonomic significance, since it depends on whether one or the other of a pair of spikelets on a one-flowered branchlet has been developed. Hence this character, while distinguishing between Paspalum L. on the one hand and Axonopus Beauv. and Brachiaria Griseb. on the other, does not alone clearly separate the latter from Panicum, but must be taken in connection with the strictly racemose inflorescence. In Panicum elephantipes Nees the thin but not hyaline margins of the acuminate lemma are not inrolled above the middle, the fruit thus suggesting an approach to Valota Adans., but in texture it is not cartilaginous and papillose as in that genus nor does $P$. elephantipes approach Xalota in habit or inflorescence. In the Verrucosa and the related Trichoidia the firm-margined lemmas are not inrolled except at the base.

$a$ See discussion under P. hians, p. 118.

$b$ See discussion under $P$. gymnocarpon, p. 327 . 
The first glume in this genus is typically not more than half the length of the spikelet, and is commonly much shorter than this, but in a few species, as in P. glutinosum Swartz, P. urvilleanum Kunth, and in most of those included under "Miscellaneous Species " the first glume is nearly as long as the second. All the outlying species at the end, nos. 192 to 196, depart in some particular from typical Panicum, such departure being discussed under each species.

\section{KEY TO SPECIES AND GROUPS.}

Axis of branchlets extending beyond the base of the uppermost spikelet as a point or bristle 1 to $6 \mathrm{~mm}$.

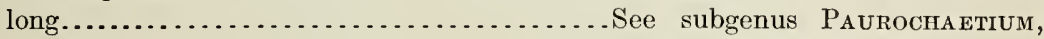

Axis of branchlets not extending into a bristle. (In P. gemip. 22. natum and $P$. paludivagum the somewhat flattened axis pointed but not bristle-form.)

Plants annual.

Inflorescence consisting of several more or less secund spike-like racemes.

Fruit smooth and shining; spikelets about $1.5 \mathrm{~mm}$. long.

Rachis bearing slender bristles (these wanting in exceptional specimens); nodes usually villous. . 59. P. pilosum.

Rachis without bristles; nodes glabrous.........6. 60. P. laxum.

Fruit transversely rugose; spikelets $2 \mathrm{~mm}$. or more long See Fasciculata, p. 35 .

Inflorescence a more or less diffuse panicle.

Spikelets tuberculate. See

VERRUCOSA, p. 126.

Spikelets not tuberculate.

Spikelets 1.2 to $1.4 \mathrm{~mm}$. long; tropical species...... See

TRICH OIDIA, p. 129.

Spikelets $1.7 \mathrm{~mm}$. or more long.

Glumes and sterile lemma hispid along the margins.............................. 76. P. costaricense.

Glumes and sterile lemma glabrous.

First glume not over one-fourth the length of the spikelet, truncate or triangular-tipped..... See

DichotomifloRA,

First glume usually as much as one-half the length of the spikelet, acute or acuminate..See p. 47.

C A P I L L A R I A, p. 54 .

Plants perennial.

Spikelets short-pediceled along one side of the rachises, forming spike-like racemes.

First glume nearly equaling the sterile lemma.

Racemes spreading; fruit not over one-third the length of the spikelet....................196. $P$. gymnocarpon. 
Racemes appressed; fruit nearly as long as the spikelet.

Spikelets silky-villous, pointed..................194. P. ciliatissimum.

Spikelets glabrous, obtuse....................192. P. obtusum.

First glume much shorter than the sterile lemma.

Spikelets hispid and with two crateriform glands on the sterile lemma.

Spikelets not over $2 \mathrm{~mm}$. long; blades not over $4 \mathrm{~cm}$. long........................... 66. Pulchellum.

Spikelets $3.6 \mathrm{~mm}$. long; blades 4 to $10 \mathrm{~cm}$. long.. 67. P. biglandulare. Spikelets glabrous.

Blades . lanceolate to ovate-lanceolate; glumes strongly carinate; spikelets 2.3 to $2.8 \mathrm{~mm}$. long; tropical species.

Blades not over $5 \mathrm{~cm}$., usually 2 to $3 \mathrm{~cm}$. long; second glume rather blunt and shorter than the sterile lemma..................64. P. stoloniferum.

Blades 5 to $11 \mathrm{~cm}$. long; second glume acute, but slightly shorter than the sterile lemma.... 65. P. frondescens.

Blades linear, often elongated; glumes not carinate or but slightly so.

Spikelets not over $1.5 \mathrm{~mm}$. long.

Spikelets pointed, not expanded at maturity by an enlarged sterile palea........... 58. P. polygonatum. Spikelets blunt, expanded at maturity by the enlarged sterile palea.

Rachis bearing slender bristles (these wanting in exceptional specimens); nodes usually villous ................... 59. P. pilosum.

Rachis without bristles; nodes glabrous. . . 60. P. laxum.

Spikelets $2.5 \mathrm{~mm}$. or more long.

Axis pilose 57. P. longum.

Axis not pilose.

Fruit transversely rugose.............. See Geminata, p.30.

Fruit not rugose . . . . . . . . . . . . . . . . . 193. P. hemitomon.

Spikelets in open or sometimes in contracted or congested panicles, but not in spike-like racemes.

Basal leaves usually distinctly different from those of the culm, forming a winter rosette; culms at first simple, the spikelets of the primary panicle not perfecting seed, later usually becoming much branched, the small secondary panicles with cleistogamous, fruitful spikelets.......... See subgenus D r с н A LIUM, p. 142.

Basal leavès similar to culm leaves, not forming a winter rosette; spikelets all fertile.

Fruit transversely rugose.................... See Maxima, p. 78.

Fruit not transversely rugose (minutely papilloseroughened in $P$. millegrana). 
First glume very small, not over one-fourth the length of the small, obovate, blunt spikelet; tropical species. (See also $P$. repens with pointed spikelets) ...................... See

First glume as much as one-third the length of the PARVIGLUMIA, p. 124.

spikelet (shorter in $P$. repens).

Spikelets pubescent.

Fruit silky-villous; spikelets 6 to $7 \mathrm{~mm}$. long, densely villous................... 75. P. urvilleanum.

Fruit smooth and shining; spikelets not over $3.5 \mathrm{~mm}$. long.

Culms and sheaths glabrous or softly pubescent; blades ovate-lanceolate......... .

Culms and sheaths densely harshly villous; blades linear

78. P. millegrana.

Spikelets glabrous.

Sterile palea enlarged and indurated at maturity, expanding the spikelet; blades scarcely wider than their sheaths.

Spikelets $3 \mathrm{~mm}$. long, congested; panicles dark purple....................63. P. cupreum.

Spikelets not over $2.4 \mathrm{~mm}$. long; panicles green or pale.

Panicle branches spikelet or branchletbearing along the upper half or toward

the ends only....................

throughout their length or nearly so. 61. P. exiguiflorum.

Sterile palea, if present, not enlarged and indurated.

Plants forming conspicuous creeping, scaly rootstocks.

Spikelets long-pediceled, not secund,. arranged in open or contracted panicles ....................... See Virgata, p. 84 .

Spikelets short-pediceled, more or less secund along the nearly simple panicle branches.

Panicles open; spikelets 3.4 to 3.8 $\mathrm{mm}$. long (shorter in exceptional specimens) ....................

Panicles more or less contracted; spikelets not over $2.8 \mathrm{~mm}$. long........ $56 . \therefore$. rhizomatum...

Plants not forming creeping, scaly rootstocks. 80. P. rudgei.

62. P. hians.

Fruit crested at the apex; spikelets 5.5 to $6 \mathrm{nim}$. long; tropical species......... 195. P. zizanioides.

Fruit not crested. 
Panicles narrow and few-flowered; culms erect and wiry; blades drying involute ........................ See Tenera, p. 97.

Panicles open or contracted, manyflowered.

Panicles 40 to $60 \mathrm{~cm}$. long, the numerous elongated branches in verticils;

tropical species.............. 81. P. megiston.

Panicles mostly much less than $40 \mathrm{~cm}$. long; branches not verticillate.

Spikelets short-pediceled along the nearly simple panicle branches. See

Spikelets long - pediceled; panicle

AGROSTOIDIA, p. 99. open (dense in $P$. hirsutum). Spikelets viscid; first glume about as long as the second; tropical species.................. 79. P.glutinosum.

Spikelets not viscid; first glume much shorter than the second. Culms erect or rarely spreading; blades linear, usually elongated; spikelets pointed..See' Difrusa, p. 71. Culms decumbent at base; blades ovate to oblong-lanceolate; spikelets blunt; tropical species.

Panicles mostly less than 5 cm.long; plantsglaucous. 77. P. parvifolium. Panicles 10 to $20 \mathrm{~cm}$. long; plants not glaucous..... 78. P. millegrana.

\section{Subgenus PAUROCHAETIUM subgen. nov.}

Perennials; culms tufted, erect, blades not over $7 \mathrm{~mm}$. wide; inflorescence narrow, more or less interrupted, the branches short and appressed, the ultimate branchlets bearing 1 to several spikelets, produced beyond the uppermost spikelet as a bristle 1 to. $6 \mathrm{~mm}$. long; spikelets 1.5 to $3.5 \mathrm{~mm}$. long, much swollen on the face, glabrous; fruit transversely rugose, apiculate.

The type species is $P$. distantiflorum

This group approaches Chaetochloa in having branchlets produced into bristles, and in the shape of the spikelets and rugose fruits.

Blades elongated, usually more than $15 \mathrm{~cm}$. long, narrowed toward the base.

Spikelets about $3.5 \mathrm{~mm}$. long.................. 5. P. reverchoni.

Spikelets about $2 \mathrm{~mm}$. long, or less.

First glume rounded or truncate; second glume about as long as fruit. 3. P. chapmani. 
First glume acute, second glume about two-thirds as

long as fruit.

Spikelets $1.5 \mathrm{~mm}$. long; blades involute....... 1. $P$. distantiflorum.

Spikelets $2 \mathrm{~mm}$. long; blades scarcely involute.. 2. P. utowanaeum.

Blades usually less than $10 \mathrm{~cm}$. long, not narrowed toward the

base; spikelets 2.5 to $3 \mathrm{~mm}$. Iong.

Blades of mid-culm long-acuminate, usually 2 to $3 \mathrm{~mm}$.

wide............................ 4. P. ramisetum.

Blades of mid-culm abruptly acute, usually 4 to $6 \mathrm{~mm}$. wide............................. 6. firmulum.

\section{Panicum distantiflorum Rich.}

Panicum distantiflorum Rich. in Sagra, Hist. Cuba 11: 304. 1850. "Crescit in graminosis montosis insulae" Cubae." The type in the Paris Herbarium is labeled "in montosis ins. Cubae," and was received from Sagra. In the same herbarium is a specimen of Panicum megiston Schult., from Cayenne, which bears a slip with the name "Panicum distantiflorum," accompanied by a diagnosis and drawings of spikelets. The diagnosis and drawings apply to the Cuban specimen and not to the very different Cayenne specimen. It would appear that the drawings had been attached to the wrong sheet.

\section{DESCRIPTION.}

Plants cespitose, glabrous; culms 60 to $80 \mathrm{~cm}$. high, slender, wiry, compressed, producing slender, sometimes fascicled branches from all the nodes; sheaths longer than the internodes, but narrow and sheathing the joints only at the base, flattened, a minute tuft of hairs on the auricles; ligule a ring of very short hairs; blades erect, firm, narrower than the summit of the sheath, linear to almost capillary, as much as $30 \mathrm{~cm}$. long, 1 to $2 \mathrm{~mm}$. wide, mostly strongly involute, at least the lower commonly more or less curled, usually with a few hairs at the base; panicles numerous, 2 to $7 \mathrm{~cm}$. long, very narrow, the branches appressed, scarcely overlapping, the lower 8 to $15 \mathrm{~mm}$. long, the branchlets bearing 1 to 3 subsessile spikelets, the setiform prolongation of the axis

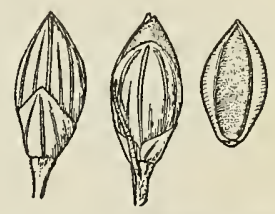

FIg. 1. $-P$. distantiflorum. From type specimen.

rarely equaling the spikelet, usually not more than $1 \mathrm{~mm}$. long; spikelets $1.5 \mathrm{~mm}$. long, $0.7 \mathrm{~mm}$. wide, ellipsoid, acute, glabrous; first glume about half as long as the spikelet, acute, strongly 5-nerved; second glume obtuse, two-thirds to three-fourths as long as the fruit and the strongly 7 -nerved, acute, sterile lemma; fruit $1.3 \mathrm{~mm}$. long, $0.6 \mathrm{~mm}$. wide, elliptic, pointed, finely rugose.

\section{DISTRIBUTION.}

Open rocky soil, Bahamas and Cuba; apparently rare.

BaHAmas: Inagua, Hitchcock in 1890, Nash \& Taylor 893 (both in Field Mus. Herb.).

CubA: Playa de Cojimar, near Habana, Hitcheock 144; Colombia near Habana, León 305b, 567; Santiago de Cuba, León 912, 917; Playa de Marianao, León in 1909.

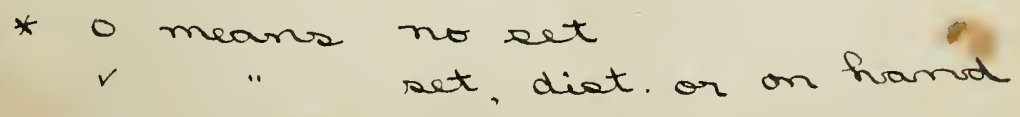




\section{$\checkmark$ 2. Panicum utowanaeum Scribn.}

Panicum utowanaeum Scribn. in Millsp. Field Columb. Mus. Bot. 2: 25. 1900. "No. 702 [Millspaugh Plant. Utowan.], from a dry hillside near Guanica, Porto Rico, Jan. 22, 1899. Type in Field Col. Mus. Herb. No. 60702." In this specimen the rootstock is scarcely visible, but in the duplicate in the National Herbarium the slender rootstock is shown.

Panicum sintenisii Nash, Bull. Torrey Club 30:382. 1903. "In woods, Guanica, Sintenis 3463." The type, in the herbarium of the New York Botanical Garden, is labeled "Guanica, in sylva ad Cerro de la Ensenada, Porto Rico. Sintenis 3463, Jan. 28, 1886." The specimen shows only a trace of the slender rootstock.

\section{DESCRIPTION.}

Plants tufted from the joints of short, slender rootstocks, glabrous; culms ascending or somewhat spreading, 25 to $60 \mathrm{~cm}$. high, slender, compressed, sparingly branching; sheaths shorter than the internodes, compressed, especially the lowermost, ciliate at the auriculate summit; ligule a minute ring of stiff hairs; blades erect or spreading above, 10 to $20 \mathrm{~cm}$. long, 1 to $4 \mathrm{~mm}$. wide, slightly scabrous on the margin

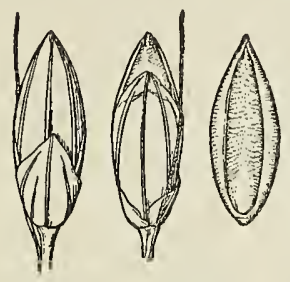

Fig. 2.-P. utowanaeum. From type specimen. (sometimes sparsely pilose on the upper surface at the base), narrowed and more or less involute at the base and much narrower than the sheath; panicles 3 to $10 \mathrm{~cm}$. long, very slender, the scattered, erect branches 1 to $3 \mathrm{~cm}$. long, the bristle usually equaling or exceeding the spikelet; spikelets subsessile, 2 to $2.1 \mathrm{~mm}$. long, 0.6 to $0.7 \mathrm{~mm}$ : wide, elliptic, somewhat beaked at the summit, glabrous, pale with green nerves; first glume half as long as the spikelet, acute, 3-nerved; second glume two-thirds to three-fourths as long as the fruit, 3 to 5 nerved, sterile lemma 5-nerved, abruptly pointed; fruit 1.9 $\mathrm{mm}$. long, $0.6 \mathrm{~mm}$. wide, elliptic, minutely rugose; slightly beaked at the acute apex.

This species is closely allied to $P$. distantiflorum, but may be distinguished from it by the wider, flat or scarcely involute blades and larger, pale, less strongly nerved spikelets. The rootstock is very slender and so easily broken off in collecting that only about half the specimens cited below show it.

\section{DISTRIBUTION.}

Open rocky soil, mostly near the coast, Cuba, Porto Rico, and Guadeloupe.

CuBA: Triscornia, near Habana, Hitchcock 141, Tracy 9089; without locality, Wright 3452 (Gray Herb.).

Porto Rico: Guanica, Millspaugh Pl. Utow. 702, Sintenis 3365, 3416, 3463 (N. Y. Bot. Gard. Herb.).

Leeward Islands: Guadeloupe, Duss 3177.

\section{- 3. Panicum chapmani Vasey.}

Panicum chapmani Vasey, Bull. Torrey Club 11:61. 1884. No locality nor specimen is cited, but the author says: "This is the Panicum tenuiculmum of Chapman's Flora, but is not the P. tenuiculmum of Meyer." A specimen in the National Herbarium from the Chapman Herbarium labeled "Panicum tenuiculmum S. Fl. S. Florida" in Chapman's hand, and "Panicum Chapmani Vasey," in Vasey's hand, is chosen as the type. 


\section{DESCRIPTION.}

Plants cespitose, glabrous; culms ascending or spreading, $40 \mathrm{~cm}$. to 1 meter high, slender, compressed, wiry, sparingly branching; sheaths about as long as the inter-
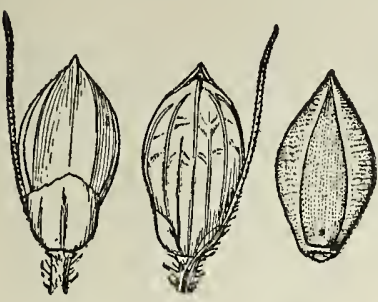

FIG. 3.-P, chapmani. From type specimen. nodes, compressed, pubescent at the scarcely auriculate summit, sometimes ciliate on the margin; ligule a ring of very short hairs; blades erect, rather firm, linear, 15 to $40 \mathrm{~cm}$. long, 2 to $5 \mathrm{~mm}$. wide, acuminate, narrowed to the base, more or less involute when dry, scabrous on the margin and upper surface, the latter usually sparsely pilose toward the base; panicles elongated, sometimes as much as $30 \mathrm{~cm}$. long, of remote, appressed, raceme-like branches bearing few to several subsessile, somewhat crowded spikelets, the setiform prolongation of the axis 3 to $6 \mathrm{~mm}$. long; spikelets

2 to $2.2 \mathrm{~mm}$. long, 1 to $1.2 \mathrm{~mm}$. wide, obovate, abruptly pointed, turgid, pale green or yellowish; first glume about one-third the length of the spikelet, obtuse or truncate, 3-nerved; second glume slightly shorter than the fruit and sterile lemma, strongly 5 to 7 -nerved, obscurely reticulated; fruit $1.8 \mathrm{~mm}$. long, 1 to $1.1 \mathrm{~mm}$. wide, elliptic, abruptly acute, minutely rugose, the margins of the lemma inrolled only at base.

As observed on Key Largo the blades in this species are flat on plants growing in shadef situations and involute on plants in the sun. The

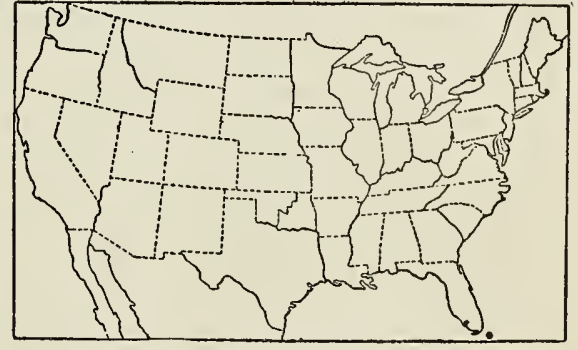

FIG. 4.-Distribution of $P$. chapmani. flat blades become more or less involute in drying.

\section{DISTRIBUTION.}

Coral sand and shell mounds, southern Florida and the Bahamas.

Florida: Marco, Hitchcock Lee Co. Pl. 487; Cape Sable, Simpson 157; Key Largo, Chase 3926, Curtiss 5457; Little Pine Key, Curtiss 3607; Key West, Garber in 1877; "Shores of Manettee River," a Rugel 394; without locality, Blodgett, Chapman.

Baнamas: New Providence, Britton \& Brace 401; Rose Island, Britton \& Millspaugh 2137; Great Exuma, Britton \& Millspaugh 3076 (all in Field Mus. Herb.).

\section{$\checkmark$ 4. Panicum ramisetum Scribn.}

Panicum subspicatum Vasey, U. S. Dept. Agr. Div. Bot. Bull. 8 : 25. 1889, not Desv. 1831. "Texas (Buckley, Nealley)." Both specimens cited by Vasey are in the National Herbarium. The second of these has been chosen as the type for the following reasons: The first specimen cited, S. B. Buckley in 1881, does not bear the specific name in Vasey's hand, and furthermore is a mixture of $P$. ramisetum and $P$. reverchoni; the second specimen, collected in Texas by G. C. Nealley in 1887, bears the specific name, "subspicatum V." in Vasey's hand. Another Nealley specimen bears the name in Vasey's hand, but was collected in 1892, after the publication of the species.

Panicum ramisetum Scribn. U. S. Dept. Agr. Div. Agrost. Circ. 27:9. 1900. Based on Panicum subspicatum Vasey, not Desv. 


\section{DESCRIPTION.}

Plants pale green, tufted, from short horizontal rootstocks; culms erect or ascending, 25 to $60 \mathrm{~cm}$. high, commonly branching at the base and lower nodes, scabrous at least

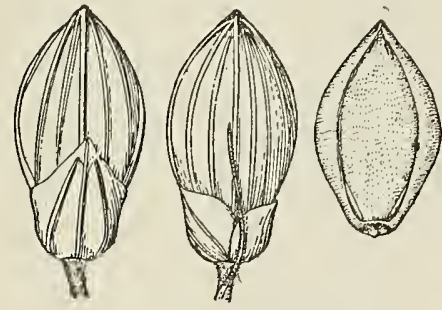

Fig. 5.-P. ramisetum. From type specimen. below the nodes; sheaths nearly as long as the internodes or the lower overlapping, not compressed, sparingly papillose-pilose, especially along the margins and at the summit; ligule about $1 \mathrm{~mm}$. long, with longer hairs at the sides; blades rather firm, erect or ascending, 5 to $12 \mathrm{~cm}$. long, the lower shorter and more spreading, 2 to $4 \mathrm{~mm}$. wide, tapering to an involute tip, not narrowed at base, but about as broad as the sheath, sparsely papillose-pilose on both surfaces, at least toward the base, sometimes sparsely ciliate; panicles very slender, 5 to 20 $\mathrm{cm}$. long, not conspicuously interrupted, their branches erect, the ultimate branchlets of 1 to 4 subsessile spikelets, the setiform prolongation of the axis usually not exceeding the short-pediceled spikelet; spikelets 2.4 to $2.6 \mathrm{~mm}$. long, 1.4 to $1.5 \mathrm{~mm}$. wide, obovate, subacute, turgid, plano-convex; first glume clasping, about half the length of the spikelet, subacute or acute, 5-nerved; second glume and sterile lemma subequal, scarcely covering the fruit at maturity, strongly 7 to 9 -nerved; fruit 2.2 to $2.3 \mathrm{~mm}$. long, $1.4 \mathrm{~mm}$. wide, elliptic, acute.

\section{DISTRIBUTION.}

Sandy plains and prairies, southern Texas and northern Mexico.

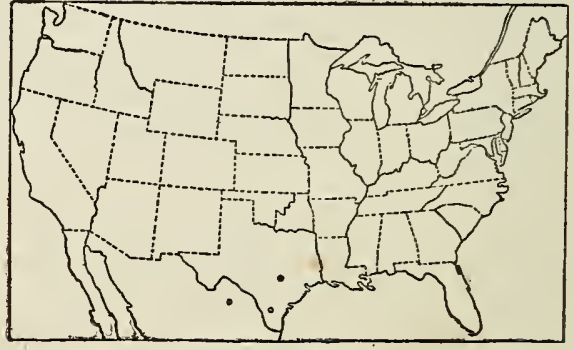

FIG. 6.-Distribution of $P$. ramisetum.

Texas: Big Springs, Tracy 7958, 8229; Kingsville, Tracy 8879; Encinal, Griffiths 6380; Laredo, Nealley in 1891, Pringle 2377, Sauvignet in 1891; Eagle Pass, Havard 98; San Diego, Nealley 62, Smith in 1897; without locality, Buckley in 1881, Nealley in 1887, 1888, 1889, and 1892.

Mexico: State of Coahuila, near Diaz, Pringle 8323.

\section{Panicum reverchoni Vasey.}

Panicum reverchoni Vasey, U. S. Dept. Agr. Div. Bot. Bull. 8: 25. 1889. "Texas (Reverchon)." The type, in the National Herbarium, was collected by J. Reverchon, near Dallas, Texas, and distributed in "Curtiss, North American Plants No. I," as Setaria uniseta Fourn.

\section{DESCRIPTION.}

Plants tufted from short rootstocks, branching at the base; culms stiffly erect, 30 to $70 \mathrm{~cm}$. high, simple or occasionally bearing one or two sterile branches, slender, subcompressed, glabrous or the lower internodes strigose, the nodes appressed-pubescent; sheaths mostly longer than the internodes, ciliate on the margin toward the summit, otherwise glabrous, often slightly scabrous, or the lowermost sometimes sparsely strigose; ligule about $0.3 \mathrm{~mm}$. long; blades erect, stiff, 5 to $20 \mathrm{~cm}$. long, 2 to $3 \mathrm{~mm}$. wide, flat or involute toward the apex and base (the blades of the basal shoots commonly involute-setaceous), scabrous on both surfaces, especially the upper, at the base narrower than the sheath, the lower commonly disarticulating at this point; panicles 
long-exserted, very slender, 5 to $20 \mathrm{~cm}$. long, the branches scattered, short, erect, the

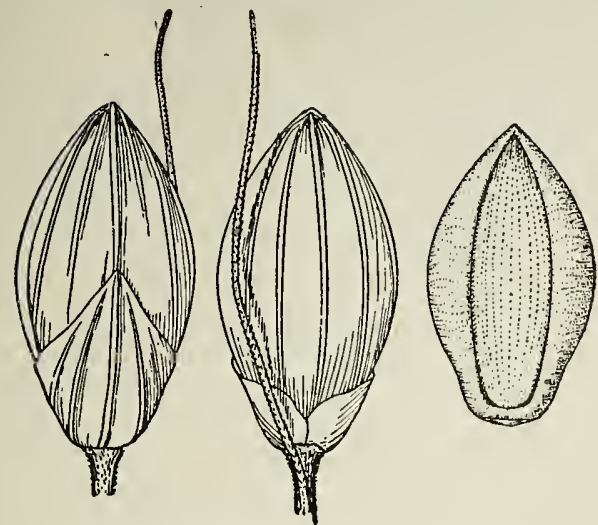

Fig. 7.-P.reverchoni. From type specimen. branchlets bearing 1 or 2 subsessile spikelets, the setiform prolongation of the axis mostly equaling or exceeding the spikelet; spikelets 3.5 to $3.8 \mathrm{~mm}$. long, 1.8 to $2 \mathrm{~mm}$. wide, elliptic, turgid, abruptly pointed; first glume about half the length of the spikelet, subacute, strongly 5 to 7-nerved; second glume and sterile lemma scarcely equaling the fruit, strongly 5 to 7 -nerved; fruit 3.1 to $3.3 \mathrm{~mm}$. long, 1.8 to $1.9 \mathrm{~mm}$. wide, elliptic, minutely pointed, obscurely transversely rugose.

This species differs from P. ramisetum in having longer, narrower blades, narrower at the base than the summit of the sheath, and larger spikelets, commonly but one to a branchlet, hence most of the spikelets subtended by a bristle.

\section{DISTRIBUTION.}

Rocky or sandy prairies and limestone hills, Texas.

Texas: Dallas, Bebb 1321, Bush 674, Reverchon 1096, in Curtiss N. Amer. Pl. 3618*, L; Abilene, Tracy 7940; Colorado, Tracy 7939 ; Weatherford, Tracy 7948; Kerrville, Heller 1603; Gillespie County, Jermy 39; Bexar County, Jermy 233, 234; San Antonio,

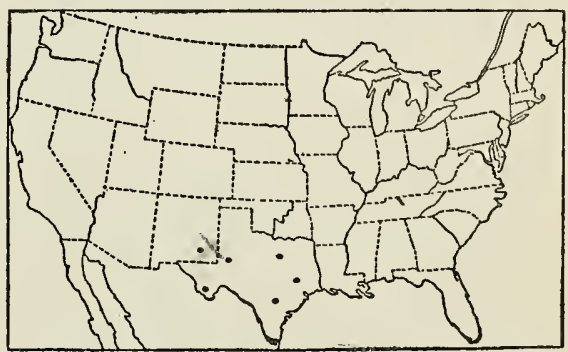

FIG. 8,-Distribution of $P$. reverchoni.

Jermy; southwest Texas, Nealley in 1890; without locality, Wright 792.

\section{$\checkmark \quad 6$. Panicum firmulum sp. nov.}

\section{DESCRIPTION.}

Plants light olive green, rather loosely tufted, ascending or decumbent at base,
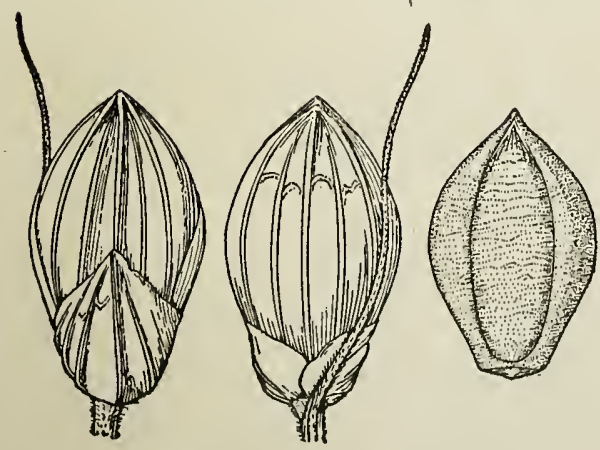

Fra. 9.-P. firmulum. From type specimen. from creeping knotted rootstocks as much as $5 \mathrm{~cm}$. long; culms 30 to $40 \mathrm{~cm}$. high, simple or with a few appressed branches, glabrous, the nodes glabrous or strigose; sheaths overlapping, striate, papillose-pubescent, papillose only, or nearly glabrous, a tuft of stiff hairs $3 \mathrm{~mm}$. long on the sides at the summit; ligule dense, about $1.5 \mathrm{~mm}$. long; blades ascending or spreading, firm, 4 to 10 $\mathrm{cm}$. long, the lower shorter and more spreading, 4 to $7 \mathrm{~mm}$. wide, abruptlyacuminate, rounded at the base and wider than the sheath, sparsely papillose-ciliate, at least toward the base, scabrous on the upper surface; panicles slender, interrupted, their branches erect,

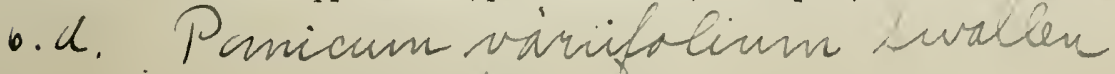
Mucatan 
the branchlets bearing 1 to 3 short-pediceled spikelets, the setiform prolongation of the axis usually about as long as the spikelets, sometimes twice as long; spikelets 3 to 3.2 $\mathrm{mm}$. long, 1.7 to $1.8 \mathrm{~mm}$. wide, obovate, subacute, turgid, strongly nerved; first glume clasping, half the length of the spikelet, pointed, 5 to 7nerved; second glume and sterile lemma subequal, scarcely covering the fruit, 5 to 7 -nerved, the glume obscurely reticulated toward the summit; fruit 2.7 to $2.8 \mathrm{~mm}$. long, 1.6 to $1.7 \mathrm{~mm}$. wide, obovate-elliptic, abruptly acute, very turgid.

Type U. S. National Herbarium no.

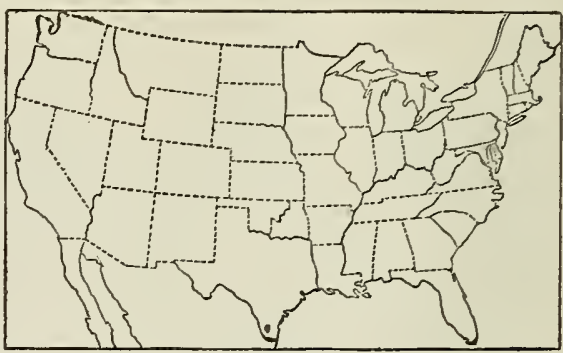

FIG.10.-Distribution of $P$. firmulum.

592755 , collected May 27, 1904, Elsordo, Zapata County, Texas, by David Griffiths (no. 6446).

This species resembles $P$. ramisetum, from which it differs in the larger spikelets, usually longer setæ, broader, more or less ciliate blades, and markedly knotty rootstock.

\section{DISTRIBUTION.}

Sandy prairies, southern Texas.

Texas: Elsordo, Griffiths 6446; Sarita, Hitchcock 3866; without locality, Nealley.

\section{TRUE PANICUM.}

\section{SYNOPSIS OF GROUPS.}

Inflorescence consisting of several spike-like racemes along a main axis; fruit transversely rugose.

Perennials; culms spreading or creeping; spikelets glabrous ...............................................

Annuals; spikelets pubescent or glabrous................ Fasciculata (p. 35).

Inflorescence an open or contracted panicle, or if with racemose branches fruit not transversely rugose.

Annuals; panicles open, usually diffuse. (See also Laxa and $P$. costaricense no. 76.)

Spikelets glabrous, not warty nor rugulose; fruit polished.

First glume less than one-fourth the length of the spikelet, obtuse or truncate; sheaths glabrous except in $P$. bartowense............ D I C H O T O M IFL O A

First glume nearly half the length of the spikelet (p. 47). or more; sheaths hispid (sometimes glabrous in $P$. decolorans and $P$. stramineum). . Capillaria (p. 54).

Spikelets warty, rugulose, or hispid; fruit not polished, margins of lemma not inrolled.

Spikelets $2 \mathrm{~mm}$. or more long; not tropical species. VERRUCOSA (p. 126).

Spikelets not over $1.4 \mathrm{~mm}$. long; tropical species. TrichoIdia (p. 129).

Perennials (two species in Laxa annuals).

Fruit transversely rugose (very faintly so in $P$. plenum); spikelets ellipsoid, glabrous; plants robust.................................

Fruit not transversely rugose.

Spikelets densely silky-villous, 6 to $7 \mathrm{~mm}$. long; lemma silky on the margins............. Urvilleana (p. 132). 
Spikelets not silky-villous.

Panicles more or less diffuse (somewhat contracted in P.hirsutum and $P$. gouini); the spikelets not short-pediceled along raceme-like branches.

Spikelets pointed, glabrous; culms terete.

Rootstocks wanting; sheaths usually hirsute............... Diffusa (p. 71).

Rootstocks present; sheaths glabrous................... Virgata (p. 84).

Spikelets obtuse and glabrous or pointed and sparsely hispid............. See ungrouped tropical species, nos. 76 to 81 .

Panicles more or lcss contracted, or the spikelets short-pediceled along the main branches.

First glume usually about one-fifth the length of the roundcd-obtuse spıkelets; tropical species......... ParvigLumia (p. 124).

First glume usually more than one-third the length of the acute spikelets (subobtuse in P. stenodes and certain species of Laxa).

Culms erect or stiffly ascending, not geniculate; sterile palea not enlarged at maturity; panicle branches not conspicuously raceme-like; blades linear.

Panicles few-flowered; contracted; sterile palea not enlarged at maturity ... TEnera (p. 97).

Panicles many-flowered, open or contracted; the shortpediceled, pointed spikelets often secund.........AGrostoidia (p. 99).

Culms often decumbent or more or lcss geniculate, if stiff and crect the sterile palea enlarged at maturity; panicle branches raceme-like (except in $P$. hians and $P$. exiguiflorum).

Second glume and sterile lemma boat-shaped or the latter bearing two crateriform glands; spikelets glabrous or pubescent............ STolonifera (p. 120).

Second glume and sterile lemma not boat-shaped (or the glume but slightly so) nor gland-bearing; spikelets glabrous or scabrous at the apex only............ 
Geminata.-Perennials; culms tall, spreading or creeping; inflorescence consisting of several erect, spike-like racemes distributed along an elongated axis; spikelets secund, glabrous, fruit more or less transversely rugose or roughened. Growing in water or wet places.

Nodes bearded................................ 9. P. barbinode. Nodes glabrous.

Spikelets $3 \mathrm{~mm}$. long; glumes and sterile lemma papery.... 8. P. paludivagum. Spikelets not over $2.4 \mathrm{~mm}$. long; glumes and sterile lemma not papery............................. 7. P.geminatum.

\section{$\checkmark$ 7. Panicum geminatum Forsk.}

Panicum geminatum Forsk. Fl. Aegypt. Arab. 18. 1775. "Rosettae in pratis ad littora Nili." We have not seen the type of this, but the description applies to the American plant which appears to be the same as the Old World species. We are informed by Mr. A. B. Rendle that the type is not in the herbarium of the British Museum.

Paspalum appressum Lam. Tabl. Encycl. 1: 176. 1791. "Ex America merid. Com. D. Richard." We have not seen the type specimen.

Digitaria appressa Pers. Syn. 1: 85. 1805. Based on Paspalum appressum Lam.

? Digitaria affinis Roem. \& Schult. Syst. Veg. 2:470. 1817. "In Santa Fé de Bogota. Ab amiciss. Zea nobiscum communicata." This specimen has not been examined, but the form to which Nees $a$ and Trinius refer Roemer and Schultes's name, as shown by a specimen from Bahia in the Trinius Herbarium sent by Nees, is the one here described. Roemer and Schultes's description leaves the species in doubt, however, since it would only apply to an unusually small specimen and may possibly refer to a different species from that to which Nees and Trinius applied the name.

Panicum beckmanniaeforme Mikan; Trin. in Spreng. Neu. Entd. 2: 83. 1821. "Hab. in Brasilia." A portion of the type is in the Trinius Herbarium. It is from Brazil sent by Mikan.

Panicum truncatum Trin. Gram. Pan. 130. 1826. The author states he has seen specimens from "Ind. or., Egypt (Lindley. Sieber in hb. Maur. I. I. no. 28.) e Brasil.-s. nom. Panic. affine Schult.-N. Aв Esenb." The specimen figured in the Icones $b$ is from Egypt. The specimen has not been examined, but the plate shows the species to be the same as the above-mentioned specimen sent by Nees under the name of $P$. affine Schult.

- Panicum affine Nees, Agrost. Bras. 113. 1829. Among several other names "Digitaria affinis P. \& Sch." is cited as a synonym. Since this specific name is retained, this is considered as based on Digitaria affnis Roem. \& Schult., though Nees's description is evidently based on the specimen first cited, one collected by Martius in Bahia, Brazil, and preserved in the Munich Herbarium, and belonging to the species here described.

Panicum brizaeforme Presl, Rel. Haenk. 1: 302. 1830. "Hab. in Luzonia." The type, in the herbarium of the German University at Prague, is labeled "Acapulco. Haenke." The specimen in the Bernhardi Herbarium at the Missouri Botanical Garden, which is the same species, is from Luzon.c

Panicum carnosum Salzm.; Steud. Syn. Pl. Glum. 1:60. 1854. This is mentioned as a synonym under $P$. paspaloides, with the citation "Hrbr. Bahia." There is a specimen of this collection in the Trinius Herbarium and another in the United States National Herbarium.

a Panioum affine Nees, Agrost. Bras. 113. 1829.

$b$ Trin. Gram. Icon. $2:$ pl. 168. 1829.

$c$ Scribner, Rep. Mo. Bot. Gard, 10:46. 1899.

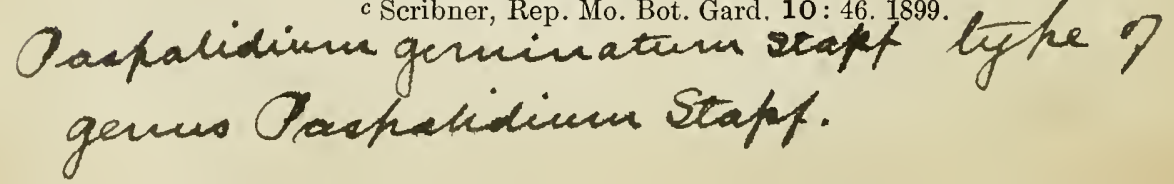


Panicum glomeratum Buckl. Prel. Rep. Geol. Agr. Surv. Tex. App. 3. 1866, not Moench, 1794. "Western Texas." The type, in the herbarium of the Philadelphia Academy, is a single culm; the turgid spikelets are $2.3 \mathrm{~mm}$. long.

Panicum appressum Lam.; Doell in Mart. Fl. Bras. $2^{2}$ : 184. 1877, not Forsk. 1775. Based on Paspalum appressum Lam.

This species has usually been called $P$. paspalodes Pers. $a$ The latter, however, is based on $P$. brizoides Lam., $b$ not L. ${ }^{c}$ The published locality for Panicum brizoides Lam. is "India." The type, in the Paris Herbarium, is labeled "herb. certo i. de France [Mauritius] Commerson." It belongs to the species described by Hooker $d$ as $P$. punctatum Burm., ${ }^{\circ}$ to which, however, Burmann's description does not well apply.

\section{DESCRIPTION.}

Plants glahrous throughout; culms cespitose, usually numerous, 25 to $80 \mathrm{~cm}$. high, spreading from a more or less decumbent base, scarcely succulent; sheaths usually

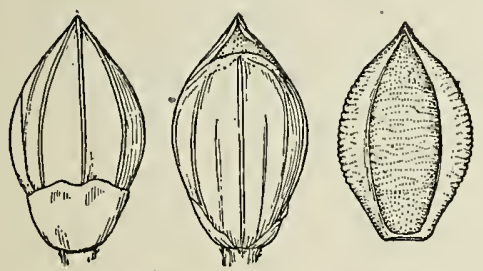

FIG.11.-P.geminatum. From type specimen of P. brizaeforme Presl. overlapping, rather close; ligule ciliate, $1 \mathrm{~mm}$. long; blades 10 to $20 \mathrm{~cm}$. long, 3 to $6 \mathrm{~mm}$. wide, rather stiflly spreading or erect, flat, or involute toward apex, somewhat scabrous on the upper surface; panicle short-exserted or included at the base, 12 to $30 \mathrm{~cm}$. long; axis angled, smooth except toward the summit; racemes 12 to 18 , erect or narrowly ascending, the lower rarely distant more than their own length, gradually approximate, the lower 2.5 to $3 \mathrm{~cm}$. long, gradually shorter upward, the axis usually ending in a more or less well-marked, pointed prolongation; spikelets subsessile, 2.2 to $2.4 \mathrm{~mm}$. long, $1.4 \mathrm{~mm}$. wide, turgid, abruptly and minutely pointed; first glume about one-third the length of the spikelet, truncate or obtuse; second glume nearly as long as fruit (exceeded only by the point of latter) 5 -nerved; sterile lemma 5-nerved, abruptly pointed, equaling the fruit and like the second glume very faintly reticulate toward the summit, inclosing a hyaline palea and usually an abortive staminate flower; fruit $2.2 \mathrm{~mm}$. long, $1.2 \mathrm{~mm}$. wide, elliptic, abruptly pointed, strongly transversely rugose.

In many of the specimens cited below the base is lacking. Other specimens show a cespitose base with fibrous roots, and a single specimen from Cuba (Hitchcock 142) shows in addition to the cespitose base long slender stolons. The specimen grew in moist soil and the stolons extended over the mud, rooting at the nodes and sending up vertical shoots. These stolons appear very different from the succulent submerged bases of $P$. paludivagum.

\section{DISTRIBUTION.}

Moist ground, mostly near the coast, southern Florida and Texas, south through Mexico and the West Indies to Brazil and Peru; also in warmer parts of the Old World.

Florida: Manatee, Tracy 7381; Key Largo, Curtiss 3601*; Key West, Blodgell, Hitchcock 613; Rugel 123.

$a$ Syn. Pl. 1: 81. 1805.

$b$ Tabl. Encycl. 1 : 170. 1791. Persoon quotes Lamarck's description.

c Mant. Pl. 2: 184. 1771. This is Echinochloa colona (L.) Link.

$d$ Fl. Brit. Ind. 7: 29. 1896.

$\leftarrow$ Fl. Ind. 26. 1768. 
Texas: Dallas, Reverchon 1078; Giddings, Hall 823; Houston, Thurow in 1898; Pierce, Tracy 7392; Spofford, Griffiths 6306; without locality Nealley in 1884.

Mexico: Lower California, El Taste, Brandegee in 1893; San José del Cabo, Brandegee 14, 36; Guaymas, Palmer 690 in 1887; Yaqui Piver, Palmer 15 in 1869; Acapulco, Palmer 289 in 1894; Yucatan, Izamal, Gaumer 1027 (Hitchcock Herb.).

Guatemala: San José, Kellerman 6250.

Baнamas: Nassau, Curtiss 175.

CubA: Santiago de las Vegas, Hitchcock 143; Habana, León 918; Batabano, Hitchcock 142; Hanabana, Wright 761; Guanabacoa, León 920; Guantánamo, Britton 2281.

JAMA1CA: Gordon Town, Hart 806.

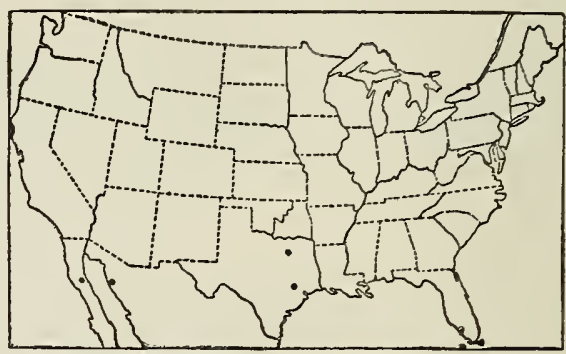

FIG. 12.-Distribution of $P$. geminatum.

Porto Rico: Guanica, Sintenis 3367.

DANISH West IND1Es: St. Croix, Ricksecker 212; St. Thomas, Eggers in 1882.

Leeward Islands: Guadeloupe, Duss 2690, 3584, L' Herminier.

WindWard Islands: Martinique, Duss 1293.

Colomb1a: Santa Marta, Smith 151.

British Guiana: Jenman 3969, 4438, 6022.

Dutch Guiana: "Surinam" Hering (Acad. Phil. Herb.).

BrAzIL: Bahia, Salzmann.

Peru: Lima, Wilkes Expl. Exped.

GaláPagos Islands: Snodgrass \& Heller 557, 746 (Gray Herb.).

\section{O 8. Panicum paludivagum sp. nov.}

\section{DESCRIPTION.}

Plants apparently perennial, glabrous throughout; culms elongated, from a long, creeping base, rooting at the nodes, rather soft and succulent, as much as 2 meters long,
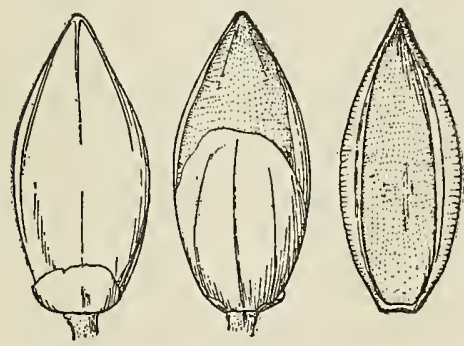

Frg. 13. $-P$. paludivagum. From type specimen. the lower submerged portion loosely branching, the internodes, except the uppermost, somewhat swollen, the nodes constricted and often dark colored; sheaths papery and more or less inflated, especially the lower, mostly deciduous from the submerged portion; ligule ciliate, about $1 \mathrm{~mm}$. long; blades 15 to $40 \mathrm{~cm}$. long, conduplicate at base, flat above, long-acuminate, rather lax, very scabrous on the upper surface, smooth below, the lower much reduced or rudimentary; panicle usually overtopped or equaled by the leaves, 25 to $35 \mathrm{~cm}$. long; axis angled, smooth; racemes 12 to 15, erect, the lower distant, $3 \mathrm{~cm}$. long, the upper gradually approximate and shorter, the axis ending in a rudimentary spikelet or sometimes in a short, slender-pointed prolongation; spikelets appressed to the angled rachis, 2.8 to $3 \mathrm{~mm}$. long, 1.4 to $1.6 \mathrm{~mm}$. wide, narrowly ovate, not turgid, subacute; first glume about one-fifth the length of the spikelet, nerveless, erose-truncate; second glume half to two-thirds the length of the spikelet, faintly 3-nerved; sterile lemma as long as the fruit, very faintly nerved toward the summit, inclosing a palea of equal length and a staminate flower; fruit 2.8 to $3 \mathrm{~mm}$. long, 1.2 to $1.3 \mathrm{~mm}$. wide, narrowly ovate, acute, very obscurely rugose, the margins scarcely inrolled. 
Type U. S. National Herbarium no. 207685, collected May 16 to 31, 1894, "in water," in the vicinity of Eustis, Lake County, Florida, by George V. Nash (no. 746).

This species differs from $P$. geminatum in the succulent stems, the lower part submerged, branching and rooting at the nodes, the loose papery sheaths, the lower nearly bladeless, the elongated aerial blades, and the longer, not turgid spikelets, scarcely nerved glumes, shorter second glume, and nearly smooth fruit.

This species has usually been distributed as Panicum paspalodes Pers. It is closely related to the species described by Hooker as $P$. punctatum Burm. ${ }^{a}$ but differs especially in the papery, nearly nerveless glumes and sterile lemma and the nearly smooth fruit.

The preceding species, $P$. geminatum, grows along the seacoast, while this species appears to be an inhabitant of fresh-water lakes and rivers. Lake Amatitlan, the cited locality for the Guatemala specimens, lies at an altitude of 1,200 meters. Pringle's no. 9556 is labeled "In water, Valley of Zamora, $5000 \mathrm{ft} ., "$ and his no. 3336, "Shallows of Lake Patzcuaro."

\section{DISTRIBUTION.}

Growing more or less submerged in fresh-water rivers and lakes of the interior at least up to 1,600 meters altitude, in Florida, Texas, Mexico, and Central America; also in Uruguay.

FloRIDA: Grasmere, Combs 760, 1052; Eustis, Nash 746; Manatee, Tracy 7412; Braidentown, Combs 1253; Little River, Garber in 1877.

Texas: Without locality, Nealley in 1888 .

Mexico: Guadalajara, Palmer 429 in 1886; State of Michoacan, Valley of Zamora, Pringle 9556; Lake Patzcuaro, Pringle 3336 .

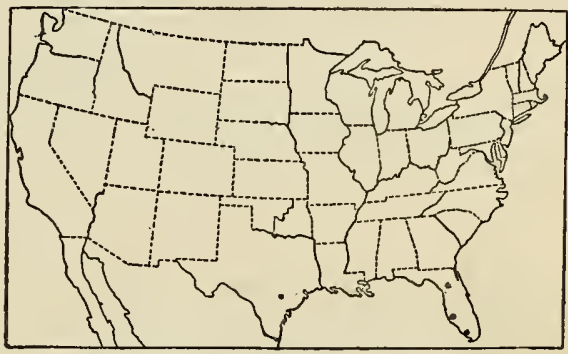

FIG. 14.-Distribution of $P$. paludivagum.

Guatemala: Amatitlan, Tuerckheim 8790; Lake Amatitlan, Kellerman 6253, 6254, Pittier 101.

Uruguay: Montevideo, Arechavaleta.

\section{Panicum barbinode Trin.}

Panicum purpurascens Raddi, Agrost. Bras. 47. 1823, not H. B. K. 1815. Raddi states that this species is cultivated "in Provincia Rio janeiro," and also grows spontaneously. We have ret seen the type, but Raddi's description applies well to $P$. barbinode.

Panicum barbinode Trin. Mém. Acad. St. Pétersb. VI. Sci. Nat. 1:256. 1834. Trinius cites "Panicum barbinode Trin. ic. gr. XXVII. tab. 318," then unpublished, and states that his specimen is from Brazil. In the Icones $b$ the habitat is given as Bahia. This specimen, in the Trinius Herbarium, which is the type, is labeled "Bahia, Riedel 1831."

Panicum guadaloupense Steud. Syn. Pl. Glum. 1: 61. 1854. "Ins. Guadaloupe." We have not seen the type, but the description applies well to $P$. barbinode Trin.

Panicum equinum Salzm.; Steud. Syn. Pl. Glum. 1: 67. 1854. "Salzmann in Bahia" is the first specimen cited. The specimen in the De Candolle Herbarium labeled "P. equinum Salz., Bahia, Salzm." is probably the type.

$a$ See footnote $d$, page $31,[P$. geminatum $]$ and the paragraph to which it is appended. $b$ Gram. Icon. 3: pl. 318.1836.

$41616^{\circ}$ - vou $15-10-3$ 
Panicum pictigluma Steud. Syn. PI. Glum. 1: 73. 1854. "Brasil." We have not seen the type of this, but Steudel cites $P$. purpurascens Raddi as a synonym and his description applies well to $P$. barbinode.

Panicum paraguayense Steud.; Doell in Mart. Fl. Bras. $2^{2}: 189.1877$. This is given as a synonym under $P$. numidianum Lam., and credited to "Steudel in plantarum Renggeri schedulis." We have not seen the type.

The name $P$. numidianum Lam. was taken up as the earliest one for this species by Nees, ${ }^{a}$ Doell, ${ }^{b}$ Hitchcock, ${ }^{c}$ and others, but the type specimen of $P$. numidianum,

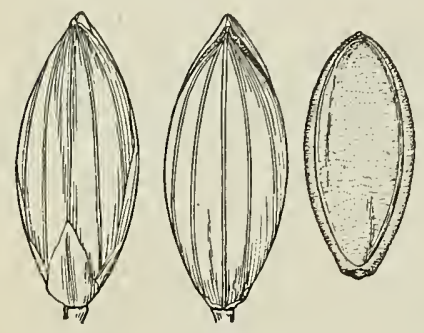

Fig. 15.-P. barbinode. From type specimen.

"Ex numidia," in the Lamarck Herbarium, does not agree in all respects with the type of $P$. barbinode. The lower glume is longer and is 3-nerved instead of 1-nerved, the pedicels of the stalked spikelets are longer, and the rachis lacks the long hairs of $P$. barbinode.

Panicum muticum Forsk.d is accepted for this species by Hooker $e$ and others, but the identity of Forskal's species is uncertain, as we have not seen the type and the description is insufficient to identify it. Forskål's plant was collected at Rosetta and is said to be allied to Panicum colonum. Te are informed by Mr. A. B. Rendle that the type is not in the herbarium of the British Museum.

$$
\text { sex } 13 x \text { is } 1969
$$

Recent American authors $f$ have applied the name $P$. molle Swartz to this species, but an examination of Swartz's type $g$ shows it to belong to a very different species.

\section{DESCRIPTION.}

Plants perennial, sending out widely creeping stolons; culms decumbent at base, rooting at the lower nodes, 2 to 5 or 6 meters high, or higher in cultivation, robust, simple, or producing leafy shoots only, glabrous, the nodes densely villous; sheaths softly or harshly villous to merely papillose or even glabrous toward the summit, densely pubescent at the juncture with the blades; ligules membranaceous, densely ciliate, about $1 \mathrm{~mm}$. long; blades ascending or spreading, 10 to $30 \mathrm{~cm}$. long, 10 to 15 $\mathrm{mm}$. wide, rounded at the base, glabrous on both surfaces, the margin scabrous; panicle 12 to $20 \mathrm{~cm}$. long, about half as wide, the rather distant, subracemose, densely flowered branches ascending or spreading, the main axis and the somewhat flattened branches scabrous on the edges, densely pubescent in the axils, a few stiff hairs on the very short pedicels; spikelets $3 \mathrm{~mm}$. long, $1.3 \mathrm{~mm}$. wide, elliptic; first glume about one-fourth the length of the spikelet, 1-nerved, acute; second glume and sterile lemma subequal, both exceeded by the sterile palea; fruit about $2.5 \mathrm{~mm}$. long, $1.1 \mathrm{~mm}$. wide, obtuse, minutely transversely rugose.

This species, commercially known as "Para grass," is cultivated in South America, the West Indies, and Mexico, and has been introduced into the Gulf States.

a Agrost. Bras. 122. 1829 .

$b$ Mart. Fl. Bras. $2^{2}$ : 188. 1877.

$c$ Contr. Nat. Herb. 12: 224. 1909.

dFl. Aegypt. Arab. 20. 1775.

e Fl. Brit. Ind. 7 : 34.1896.

$f$ Scribner, U. S. Dept. Agr. Div. Agrost. Bull. 14: 54. 1900; Nash in Small, Fl. Southeast. U. S. 90. 1903.

$g$ See $P$. molle Swartz, page 42 ; and for a full discussion of Swartz's types, see Hitchcock, Contr. Nat. Herb. 12: 135-143. 1908. 


\section{DISTRIBUTION .}

Cultivated and waste ground, escaped from cultivation, Florida to Texas, and throughout subtropical and tropical America; native of Brazil.

Florida: Merrimack, Baker 48; Braidentown, Combs 1265, 1311, Tracy 7763.

Alabama: Mobile, Mohr. in 1880.

Texas: Without locality, Nealley.

Mexico: Cuantla, Holway 3045; Manzanillo, Palmer 1078 in 1890; Colima, Emrick 8; Lower California, Brandegee 46.

Guatemala: Alta Vera Paz, Tuerckheim 7799, 8617; Mazatenango, Maxon\& Hay 3476.

Salvador: Without locality, Renson 214.

Nicaragua: Chinandega, Baker 2053.

Costa Rica: Térraba, Pittier 412; border of Rio Tuís, Tonduz 11393.

Bahamas: Nassau, Curtiss W. Ind. Pl. 115.

Cuba: Puentes Grandes, León 283; near Cienfuegos, Pringle 26, Habana, León 568; Romelie, Eggers 4870.

Porto Rico: Bayamon, Heller 100, Millspaugh 324; Guanica, Millspaugh 727; Yauco, Heller 6293; Los Mameges, Eggers 1328.

Danish West Indies: St. Croix, Ricksecker 300.

Leeward Islands: Guadeloupe, Duss 2689, L'Herminier in part.

Windward Islands: Martinique, Duss 539; Granada, Broadway in 1904 and 1905.

Colombia: Santa Marta, Smith 211.

British Guiana: Jenman 5998.

Brazil: Bahia, Salzmann; Campinas, Novaes 1242; São Sebastião, Löfgren 3142; without locality, Riedel.

\section{Paraguay: Morong 779a.}

EcUador: Lehmann 5744.

This species occurs in the warmer parts of the Old World, where it was probably introduced from South America. Hooker $a$ states that it is "cultivated or naturalized" in Bengal and Ceylon. Trimen ${ }^{b}$ makes the following statement concerning it: "A well-known fodder-grass in Ceylon, but there is no record of its introduction into the island. According to Roxburgh seeds were received at the Calcutta Botanical Garden from Sumatra in 1804, through Dr. Charles Campbell. As it is a native of tropical America, the Dutch, who then held ports in Sumatra, may have imported it from Surinam." Durand and Schinz $c$ state concerning $P$. barbinode, which is re-

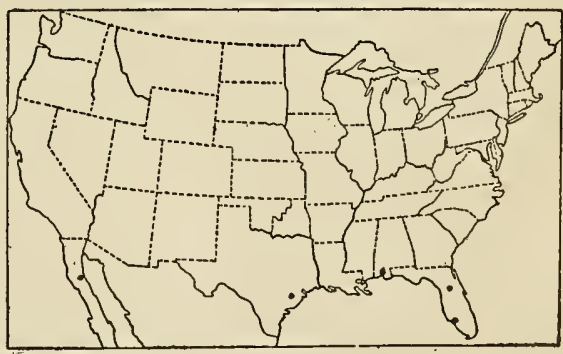

FIG. 16.-Distribution of $P$. barbinode. ferred to P. molle Swartz, "Maurice, Seychelles.-Distrib.: Originaire des Indes ocid. et abondamment répandu maintenant dans l'ancien monde (Baker)."

Fasciculata.-Annuals with flat, usually rather wide blades; ligules ciliate or membranaceous-ciliate, not over $1 \mathrm{~mm}$. long; inflorescence of several narrow or spike-like racemes along a main axis; second glume and sterile lemma usually more or less reticulate-veined, at least toward the apex, the lemma, excepting in occasional specimens of $P$. molle, inclosing a palea of nearly equal length and often a staminate flower; fruit transversely rugose.

a Fl. Brit. Ind. 7 : 35. 1896. Hooker gives here several synonyms based upon Asiatic specimens, which we have not examined.

$b$ Fl. Ceylon $5: 140.1900$.

$c$ Consp. Fl. Afr. 5 : 755. 1895. 
Spikelets 5 to $6 \mathrm{~mm}$. long 15. P. texanum.

Spikelets 2 to $4 \mathrm{~mm}$. long.

Spikelets strongly reticulate-veined, 2 to $3 \mathrm{~mm}$. long; glabrous.

Panicle branches long and spreading; blades pubescent or glabrous.

11. P. fasciculatum.

Panicle branches short, appressed; blades narrow, pubescent

11a. P. fasciculatum chartaginense.

Spikelets scarcely reticulate-veined or only near apex.

Spikelets not over $2 \mathrm{~mm}$. long, glabrous . ......... 10. P. reptans.

Spikelets over $3 \mathrm{~mm}$. long, pubescent.

Rachis scabrous but not bristly .............. 13. P. adspersum.

Rachis pilose with bristly hairs.

Plant more or less velvety, sheaths not papillose.................... 12. P. molle.

Plant not velvety; sheaths papillose....... 14. P. arizonicum.

\section{$\checkmark$ 10. Panicum reptans L.}

Panicum reptans L. Syst. Nat. ed. 10. 2: 870. 1759. No locality is here given, but the same specimen is described more fully by Linnæus, under the name Panicum grossarium, later in his list of Jamaica plants. ${ }^{a}$ The type specimen, in the Linnæan Herbarium, is marked "Br" [for Browne who sent the plant] and on the sheet the word "reptans" was written and then crossed out. A full discussion of the type of this and $P$. grossarium is given in another place. $b$

Panicum grossarium L. Syst. Nat. ed. 10. 2: 871. 1759. The type specimen is the same as that of $P$. reptans.

Panicum prostratum Lam. Tabl. Encycl. 1: 171. 1791. "Ex Insulis Caribæis." The type, in the Lamarck Herbarium, is from Santo Domingo.

Panicum caespitosum Swartz, Fl. Ind. Occ. 1: 146. 1797. "Habitat in pascuis siccioribus Jamaicae." The type, $c$ in the Swartz Herbarium, is from "Jamaica, Swartz."

Panicum insularum Steud. Syn. Pl. Glum. 1: 61. 1854. "Ins. Antillae minores." The type, in the Steudel Herbarium, is labeled "Panicum insularum Steud. Antillae minores. Hohenacker."

Brachiaria prostrata Griseb. Abh. Ges. Wiss. Göttingen 7:263. 1857. Based on Panicum prostratum Lam.

Panicum aurelianum Hale in Wood, Class-book ed. 3. 787. 1861. "Damp soils, about N. Orleans (Hale)." We have not been able to locate the type of this, but in the herbarium of the Missouri Botanical Garden there is a specimen of $P$. reptans bearing a ticket reading "Panicum aurelianum New Orleans Dr. Hale." This agrees perfectly with Hale's description.

Panicum prostratum pilosa[um] Eggers, Fl. St. Croix \& Virgin Isl. 104. 1879. "St. Croix (La Grange)." We have not seen the type. The description applies to the common form of $P$. reptans with pilose rachises.

a Amoen. Acad. 5 : 392.1759.

$b$ Hitchcock, Contr. Nat. Herb. 12: 119. 1908.

$c$ For an account of Swartz's American grasses, which are preserved in the Natural History Museum at Stockholm, see Hitchcock, Contr. Nat. Herb. 12 : 138.1908.

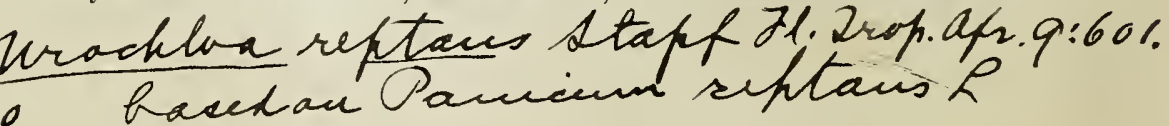




\section{DESCRIPTION.}

Plants spreading, usually prostrate, or with a decumbent base, rooting at the lower nodes; culms slender, usually freely branching, ascending 10 to $30 \mathrm{~cm}$. above the decumbent or creeping base, glabrous, the nodes usually puberulent; sheaths
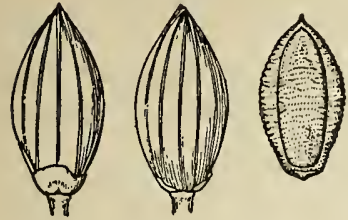

Fig. 17.-P. reptans. From type specimen of $P$. prostratum Lam. loose, glabrous, densely ciliate, shorter than the internodes; ligule a dense ring of hairs $1 \mathrm{~mm}$. long or less; blades lanceolate or ovate-lanceolate, 1.5 to $6 \mathrm{~cm}$. long, 4 to $12 \mathrm{~mm}$. wide, cordate, glabrous or puberulent on both surfaces, the white, undulate margin hispidscabrous, ciliate at base with long, stiff hairs; inflorescence finally long-exserted, 2 to $6 \mathrm{~cm}$. long, consisting of 3 to 12 spike-like, ascending or spreading racemes arranged along a main axis; racemes solitary or sometimes somewhat fascicled, the upper approximate and shorter, the lower rather distant and 2 or $3 \mathrm{~cm}$. long; rachises and pedicels scabrous and usually sparsely pilose with long, weak hairs; spikelets borne on one side of the rachis, irregularly and rather densely clustered, on pubescent pedicels $1 \mathrm{~mm}$. or less in length, elliptic, 1.9 to $2 \mathrm{~mm}$. long, 0.9 to $1 \mathrm{~mm}$. wide; acute, glabrous; first glume about one-sixth the length of the spikelet, rounded or truncate; second glume and sterile lemma slightly exceeding the fruit, strongly 5 to 7 -nerved; fruit $1.7 \mathrm{~mm}$. long, $0.8 \mathrm{~mm}$. wide, elliptic, apiculate.

As a whole this species is very uniform, but the long hairs on the secondary rachises and pedicels are sometimes wanting.

\section{DISTRIB UTION.}

Moist open ground and a frequent weed in waste places and cultivated soil, Florida to Texas, Mexico, and the West Indies, south to northern South America; also in the tropical regions of the Eastern Hemisphere.

Florida: Apalachicola, Biltmore Distr. Chapman Herb. 4276 (Gray Herb.).

Alabama: Mobile, Mohr in 1884.

Louisiana: Pointe a la Hache, Langlois 45 in 1882, 154 in 1883; Burnside, Combs 1431; New Orleans, Ridell in 1840; Algiers, Tracy 1837.

Texas: Columbia, Bush 266, 1296; Industry, Wurzlow 6; Houston,

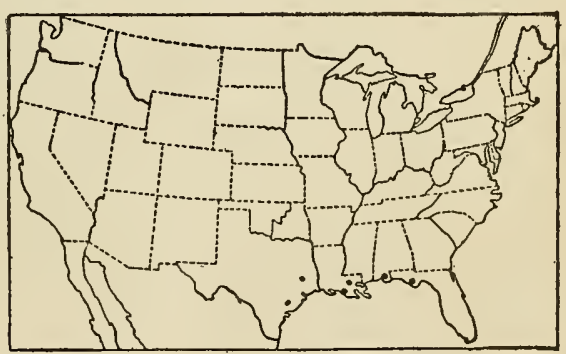

FIG. 18.-Distribution of $P$. reptans. Thurow 21 in 1903; Pierce, Tracy 7387; Lynchburg, Joor 39 in 1884; without locality, Nealley in 1884 and 1888.

MeXico: Cuicatlan, Nelson 1622.

Cuba: Habana, Curtiss 691, Hitchcock 146, León 276, 292, 297, 566, 576, 906, 910c; Madruga, Curtiss 536; San Antonio, Hitchcock 145; Herradura, Tracy 9103; Cienfuegos, Pringle 73; Baracoa, Pollard, Palmer \& Palmer 19; La Magdalena, Earle \& Baker 2455; Santiago, León 910; Guayabal, León 910b; without locality, Wright 3857.

Jamaica: Hope, Harris 6845; Gordon Town, IIart 838.

Porto Rico: Guanica, Millspaugh PI. Utow. 726, Sintenis 3368; Salinas de Cabo, Sintenis 847; Coamo Springs, Goll 662; Ponce, Heller 497.

Danisu West Indies: St. Croix, Ricksecker 77; St. Thomas, Eggers 293 (Hitchcock Herb.). 
Leeward Islands: Guadeloupe, Duss 3529.

Windward Islands: Martinique, Duss 1290.

Colombia: Santa Marta, Smith 173.

Venezuela: Island of Margarita, Miller \& Johnston 171.

British Guiana: Jenman 6024.

\section{$\checkmark$ 11. Panicum fasciculatum Swartz.}

Panicum fasciculatum Swartz, Prodr. Veg. Ind. Occ. 22. 1788. "Jamaica." The type, in the Swartz Herbarium, has sparsely papillose-hispid sheaths and spikelets 2.1 to $2.2 \mathrm{~mm}$. long.

Panicum fuscum Swartz, Prodr. Veg. Ind. Occ. 23. 1788. "Jamaica." The type, in the Swartz Herbarium, consists of two smaller, more branching plants, with somewhat more hispid sheaths and more contracted panicles than in the type of $P$. fasciculatum; the spikelets are 2.1 to $2.3 \mathrm{~mm}$. long.

Panicum flavescens Swartz, Prodr. Veg. Ind. Occ. 23.1788. "Jamaica." The type, in the Swartz Herbarium, consists of the upper portion of two culms with panicles somewhat more open than those of the type of $P$. fasciculatum, but otherwise very like that; the spikelets are 2.2 to $2.3 \mathrm{~mm}$. long. This is not the species described under this name by Grisebach $a$ and by Hooker, $b$ which is a species of the section Ptychophyllum.

Panicum fusco-rubens Lam. Tabl. Encycl. 1: 171. 1791. "Ex Ins. Carbiaeis."
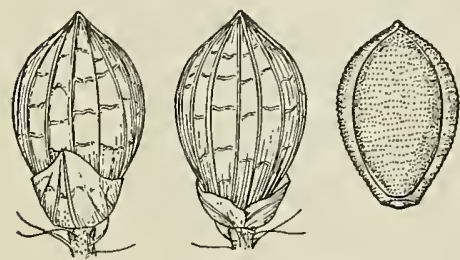

Fig. 19.-P. fasciculatum. From type specimen. The type, in the Paris Herbarium, is a portion of a large plant with a rather open panicle and spikelets $2.5 \mathrm{~mm}$. long.

Panicum fastigiatum Poir. in Lam. Encycl. Suppl. 4:277. 1816. Based on Panicum fasciculatum Swartz, the name changed because of P. fasciculatum Lam. 1798.

Panicum nigricans Willd.; Spreng. Syst. Veg. 1: 310.1825 . This is given as a synonym under O P.fasciculatum. The type, in the Willdenow Herbarium, is from "Amer. Merid." collected by Humboldt. The spikelets are 2.1 to $2.2 \mathrm{~mm}$. long.

- Panicum fuscatum Presl; Nees, Agrost. Bras. 152. 1829. This is given as a synonym under $P$. fasciculatum $r$. We have not seen Presl's specimen.

Panirum spithamaeum Willd.; Nees, Agrost. Bras. 152. 1829. This name is mentioned in a note under $P$. fasciculatum. The type, in the Willdenow Herbarium, from Humboldt, is labeled, "Amer. Merid." This name is mispelled "spithamineum" by Steudel.c

Panicum illinoniense Desv. Opusc. 91. 1831. "Habitat in America boreali." The type, in the Desvaux Herbarium, bears a slip with the name "Panicum illinoniense DesV. Op. p. 91," and "Hab. Carol." The locality, if meant for Carolina, is clearly an error, but there are many errors in the data on the labels of Desvaux's plants. The specimen is much like the type of $P$.fuscum.

Panicum reticulatum Griseb. Abh. Ges. Wiss. Göttingen $7: 264$. 1857, not Torrey, 1852. Grisebach states that his specimen was collected by Duchaissing either in the Caribbees or in the Isthmus of Panama. We have not seen the type, but Grisebach later $a$ refers this species to P. fuscum Swartz.

Panicum fuscum fasciculatum Griseb. Fl. Brit. IT. Ind. 547. 1864. Based on P. fasciculatum Swartz. 
Panicum fasciculatum genuinum Doell in Mart. Fl. Bras. $2^{2}: 204.1877$. Based on P. fasciculatum Swartz.

Panicum fasciculatum flavescens Doell in Mart. Fl. Bras. $2^{2}: 205.1877$. Based on $P$. flavescens Swartz.

Panicum fasciculatum fuscum Doell in Mart. Fl. Bras. $2^{2}: 205.1877$. Based on $P$. fuscum Swartz.

Panicum fasciculatum was described under a phrase name and figured by Sloane, ${ }^{a}$ whose type is at the British Museum of Natural History. $b$ Kuntze misapplies the name Panicum paniculatum (L.) Kuntze, ${ }^{c}$ based on Paspalum paniculatum L., to this species, owing to the fact that Linnæus erroneously cites Sloane's plate of Panicum fasciculatum after his description of Paspalum paniculatum, the type of which is in the Linnæan Herbarium. $d$ Nashe also later made the combination Panicum paniculatum on the same grounds.

\section{DESCRIPTION.}

Plants erect or spreading from a decumbent base, the more robust becoming much branched from the lower nodes; culms 30 to $100 \mathrm{~cm}$. or more high, glabrous or scabrous, or sometimes pubescent below the panicle or hispid below the appressed-pubescent nodes; sheaths sometimes shorter, sometimes longer than the internodes, glabrous or more or less papillose-hispid, densely ciliate, pubescent at the juncture with the blades; ligule a dense ring of hairs about $1 \mathrm{~mm}$. long; blades flat, 4 to $30 \mathrm{~cm}$. long, 6 to $20 \mathrm{~mm}$. wide, glabrous, usually scabrous above, sometimes sparsely hispid on one or both surfaces, the nerves in the larger blades conspicuous, sometimes appearing somewhat plicate; inflorescence short-exserted or included at base until maturity, consisting of a series of spike-like racemes arranged along a scabrous, sometimes pilose, main axis, 5 to $15 \mathrm{~cm}$. long, the racemes 5 to $10 \mathrm{~cm}$. long, solitary or fascicled, narrowly ascending to somewhat spreading, spikelet-bearing from the base, or naked below, the short-pediceled spikelets approximate or somewhat crowded, borne singly, or two or three together on short branchlets, along the under side of the axis; spikelets bronze to mahogany colored, 2.1 to $2.5 \mathrm{~mm}$. long, in occasional specimens as much as $3 \mathrm{~mm}$. long, obovate, turgid, abruptly short-pointed, glabrous; first glume clasping, about one-third the length of the spikelet, subacute, 5 to 7 -nerved; second glume and sterile lemma slightly exceeding the fruit, 9-nerved, faintly to strongly transversely wrinkled between the nerves; fruit 1.9 to $2.3 \mathrm{~mm}$. long, obovate, obscurely apiculate.

This species is variable in the amount of pubescence and in the size of the spikelets. Almost all the West Indian specimens cited below have spikelets not over $2.3 \mathrm{~mm}$ : long. The greater number of specimens from Mexico and the United States have spikelets 2.5 to $2.8 \mathrm{~mm}$. long, while about half the Central American specimens have the larger spikelets. This difference in size can not be correlated with any other character.

\section{DISTRIBUTION.}

Moist open ground, often a weed in fields and along roadsides, southern Florida and Texas, southward through Mexico and the West Indies to Brazil and Ecuador.

Florida: Cape Canaveral, Curtiss 3589; Lastero Bay, Garber 36; Sneeds Island, Tracy 6455; Caxambas Island, Simpson 275; Marco, Hitchcock Lee Co. Pl. 484; Key West, Rugel; without locality, Blodgctt.

$a$ Voy. Jam. 1 : 115. pl. 79.f. 2. 1707.

$b$ See Hitchcock, Contr. Nat. Herb. $12: 131.1908$, for an account of Sloane's Jamaica grạsses.

c Rev. Ge11. Pl. 3 : 363. 1898.

$d$ See Hitchcock, Contr. Nat. Herb. 12 : 116. 1908.

$e$ Bull. Torrey Club $30: 381.1903$. 
Texas: Robbstown, Griffiths 6508.

Mexico: Santa Ana, Griffiths 6857; Guaymas, Palmer 158 and 207 in 1887, Alamos, Palmer 694 in 1890; Hermosillo, Hitchcock 3598; Chihuahua, Palmer la in 1885; Colima, Palmer 19 in 1897; Topolobampo, Palmer 241 in 1897; Culiacán, Palmer 1557 in 1891; Teotalcingo, Liebmann 277; Santa Maria Tlatella, Liebmann 279; Córdoba, Finck in 1893; State of Chiapas, Nelson 2874, 2958; Merida, Schott 384; Rosario, Rose 1834, 1884.

Guatemala: Alta Vera Paz, Goll 81; Chicacao, Heyde \& Lux 6404; Esquintla, J. D. Smith

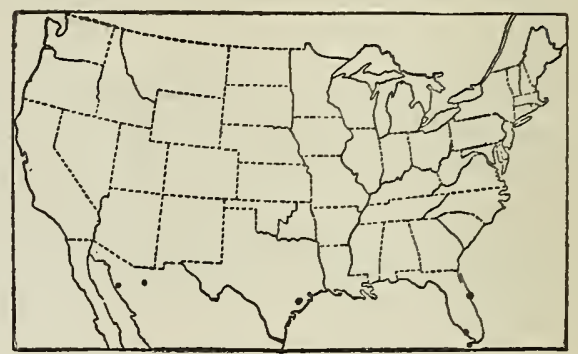

FIG.20.-Distribution of $P$. fasciculatum. 2233; Dept. Huehuetenango, Seler 2704; Gualán, Deam 6267.

Honduras: San Pedro Sulá, Thieme 195, 5584.

NiCARAgua: Flint in 1868.

Costa Rica: Puerto Viejo, Biolley 7471; Matina, Pittier 9727; Nicoya, Tonduz 13749; near the Rio Grande, Pittier 2035.

Panama: Bocas del Toro, Hart 78.

BaHAMas: Turks Island, Madiana (Gray Herb.).

CuBA: San Antonio, Eggers 4875; Cienfuegos, Pringle 74, 124; Santiago de las Vegas, Wilson 593; Habana, León 573; Herradura, Tracy 9091; Sancti Spiritus, León 916; Santiago, León \& Boillot 813.

JAmaICA: Bath, Maxon 2361; Hope Gardens, Maxon 1659; Gordon Town, Hart 785,840 .

HaItr: Jacquemont (Gray Herb.).

Porto Rico: Rio Piedras, Barrett 63, Heller \& Heller 135; Culebra, Britton \& Wheeler 137; Caguas, Goll 385, 588; Ponce, Heller 6226, 6302; Guinaca, Sintenis 3647; "Monte Goyo," Sintenis 1901; Aguadilla, Heller 4528; Aibonito, Underwood \& Griggs 462; without locality, Underwood \& Griggs 824.

Danish West Indies: St. Croix, Ricksecker 317; St. Thomas, Eggers in 1882.

LeEWard Islands: Guadeloupe, Duss 2691, L'Herminier.

Windward Islands: Martinique, Duss 537, 538; Hahn in 1867-1870; Granada, Broadway in 1905.

Colombia: Santa Marta, H. H. Smith 208; Santa Ana, Pittier 1610.

Venezuela: Island of Margarita, Miller \& Johnston 180.

Trinidad: Botanic Gardens Herb. 2283, 3192.

French Guiana: Without data (Gray Herb.).

Brazil: Piauhy, Gardner 2357.

ECUADOR: El Recreo, Eggers 15418, 15834.

Galápagos Islands: Agassiz in 1891.

\section{1a. Panicum fasciculatum reticulatum (Swartz) Doell.}

Panicum chartaginense Swartz, Prodr. Veg. Ind. Occ. 22. 1788. "America meridionalis, Chartagena." The type, in the Swartz Herbarium, is a more or less prostratespreading plant, with short, crowded leaves and narrow, compact panicles somewhat included at base. The blades, and especially the sheaths, are hispid; the spikelets are 2.6 to $2.8 \mathrm{~mm}$. long.

Panicum reticulatum Torr. in Marcy, Expl. Red Riv. 299. 1852. "Main fork of Red River, [Texas] July." The type, in the Torrey Herbarium, consists of three slender 
plants with papillose-hispid sheaths and blades and contracted panicles; the spikelets are $2.8 \mathrm{~mm}$. long.

Panieum-fasciculatumc[h]arthaginense Doell in Mart. Fl. Bras. $2^{2}: 205.1877$. Based on P. chartaginense Swartz.

Panicum fasciculatum reticulatum Beal, Grasses N. Amer. 2 : 117. 1896. Based on P. reticulatum Torr.

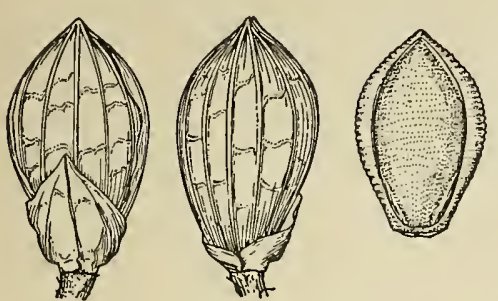

FIG. 21.- P. fasciculatum chartaginense. From type specimen.

Panicum fuscum reticulatum Scribn. \& Merr. U.S. Dept. Agr. Div. Agrost. Circ. 32: 4.1901. Based on $P$. reticulatum Torr. The specimen here referred to $P$. chartaginense is $P$. ramosum L. $a$ of Asia.

\section{DESCRIPTION .}

Differing from $P$. fasciculatum in having smaller, more compact panicles, the branches ascending or appressed, narrower blades, usually pubescent on both surfaces, and spikelets 2.6 to $3 \mathrm{~mm}$. long.

There are many intermediate specimens. The well-marked form is usually smaller, with appressed branches and blades. It occurs in the drier regions of the Mexican Plateau. Some specimens, such as Griffiths 1545 and 1616, cited under P. fuscum reticulatum by Scribner and Merrill, $b$ are nearly glabrous.

The following specimens from Texas seem to be intermediate between the species and subspecies. They are mostly large plants with rather open panicles and spikelets about $3 \mathrm{~mm}$. long: Fort Worth, Tracy 8171; Dona, Tracy 8890; College Station, Price in 1895; Abilene, Bentley in 1899; Victoria, Plank 74; San Antonio, Havard, Heller 1698, Jermy 202; Dallas, Reverchon 94; Houston, Thurow 16.

A closely allied species, $P$. multiculmum Anders., $c$ from the Galápagos Islands, has been referred to $P$. chartaginense Swartz by Grisebach. $d$

\section{DISTRIBUTION.}

Prairies, fields, and waste ground, Texas and Arizona to Mexico; also in Venezuela (Swartz).

Texas: Uvalde, Reverchon 1086; Dallas, Bush 1157; Taylor, Ball in 1901; Abilene, Bentley in 1899; Waco, Plank 11; Big Springs, Tracy 8289; Columbia, Bush 270; Manor, Hall 825; San Antonio, Havard in 1882, Hitchcock 162, Jermy 203, Plank 47; Bexar County, Jermy 22; Laredo, Sauvignet in 1892; without locality, Nealley in 1887, Wright 797.

New Mexico: Socorro, Plank 38.

Arizona: Tucson, Griffiths -1545 , -1616,3362, Hitchcock 3495; Pringle in 1881; Papayo-Reservation, Griffiths 1654; Santa Rita Mountains, Griffiths 7297, 7299.

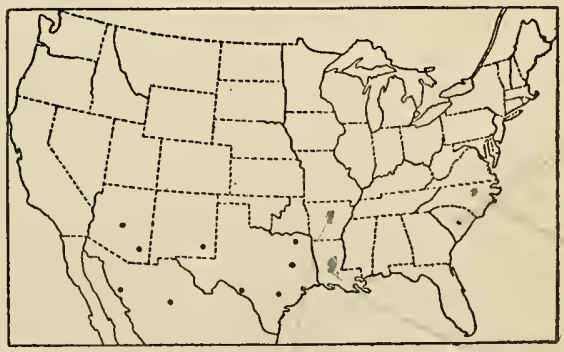

Fig. 22.-Distribution of $P$. fasciculatum chartaginense. - preacelia 40

MeXIco: Chihuahua, Pringle 379, 380; San Dieguito, Palmer 152 in 1904; Victoria, Palmer 412 in 1907; Guaymas, IItchcock 3561, Palmer 159 in 1887 in part.

a See page 44.

$b$ Loc. cit. $c$ Vet. A kad. Handl. Stockh. $1853: 133.1855$.

$d$ Fl. Brit. W. Ind. 546. 1864. 


\section{Panicum molle Swartz.}

Panicum molle Swartz, Prodr. Veg. Ind. Occ. 22. 1788. "India occidentalis." The type, in the Swartz Herbarium, has already been discussed. $a$ The sterile lemma bears in its axis a well-developed palea. There is some uncertainty as to the original locality of the type specimen of $P$. molle. It is said by Swartz to come from the West Indies, but we have seen no other specimens of this species from that region.

Panicum velutinosum Nees; Trin. Gram. Pan. 144. 1826. This is given as a synonym of Panicum petiverii Trin. $\beta$. Trinius's specimen was from "Brasil," communicated by "N. Aв Esenb." This is in the Trinius Herbarium and is the original of the plate ${ }^{b}$ of $P$. velutinosum in the Icones. The spikelets differ from those of the type of $P$. molle in that the palea of the sterile lemma is wanting. Neesc later described $P$. velutinosum, giving the locality as follows: "Habitat in sylvaticis prope Villa da Cachoeira, provinciae Bahiensis." [Brazil]. His specimen, of which Trinius's is evidently a duplicate, is in the Munich Herbarium. There are six plants on the sheet, all much smaller than Swartz's plant, and having shorter, broader blades. The Argentine specimens, which have been referred to $P$. velutinosum, have a welldeveloped palea in the sterile floret. Doell $d$ recognized the two species as distinct chiefly because of this character. More material is needed definitely to determine whether or not these two forms should be segregated.

In Kunth's Enumeratio $e$ the name is misprinted P. velutinum Nees.

\section{DESCRIPTION:}

Plants ascending or spreading from a decumbent base, usually branching; culms 30 to $70 \mathrm{~cm}$. high, softly pubescent, at least below the pubescent nodes; sheaths usu-
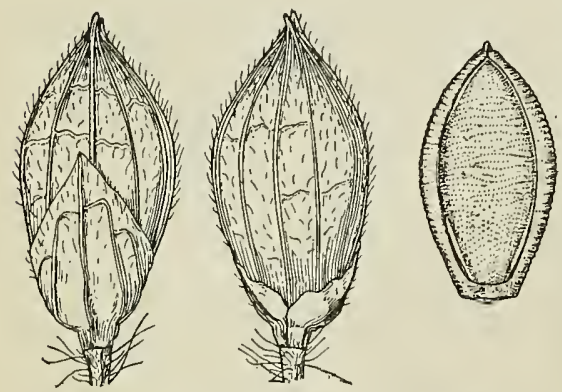

FIG. 23.-P. molle. From type specimen. ally shorter than the internodes, loose, softly pubescent between the nerves, sometimes obscurely so, densely ciliate; ligule a dense ring of hairs about $1 \mathrm{~mm}$. long; blades ascending or spreading, 4 to $15 \mathrm{~cm}$. long, rarely longer, 7 to $15 \mathrm{~mm}$. wide, rounded at the base, finely and softly pubescent on both surfaces or nearly glabrous on the upper; panicles short-exserted or, especially those of the branches, included at base, 6 to $15 \mathrm{~cm}$. long, the several to many subracemose branches ascending, rarely widely spreading at maturity, the main axis and those of the branches densely softly pubescent and also beset with stiff, spreading hairs about $1 \mathrm{~mm}$. long, the short pedicels of the somewhat crowded spikelets similarly hirsute; spikelets 3.4 to $3.8 \mathrm{~mm}$. long, 1.5 to $1.7 \mathrm{~mm}$. wide, obovate, turgid, abruptly pointed, short-attenuate at base, a distinct internode of the rachilla between the first and second glumes; first glume clasping, half as long as the spikelet or more, acute, 5-nerved, the nerves usually anastomosing toward the apex, pilose; second glume and sterile lemma pointed beyond the fruit, 5 -nerved, obscurely reticulated between the nerves, pilose, often densely so; fruit 2.6 to $3 \mathrm{~mm}$. long, 1.5 to $1.6 \mathrm{~mm}$. wide, elliptic, apiculate.

The Argentine specimens are less velvety and approach in appearance the large forms of $P$. arizonicum, but these as well as the Mexican specimens lack the papillae commonly present on the sheaths of $P$. arizonicum.

$a$ See footnote $c$, p. 36 .

b Trin. Gram. Icon. 2 : pl. 180. 1829. c Agrost. Bras. 121. 1829.

d Mart. Fl. Bras. $2^{2}$ : 187. 1877.

e Enum. Pl. 1: 92. 1833. 


\section{DISTRIBUTION.}

River banks and moist places, Mexico to Argentina.

Mexico: Colima, Palmer 149 in 1897; Lodiego near Culiacán, Palmer 1660 in 1891; Saltillo, Brandegee 17 in 1893 (Univ. Cal. Herb.); Yucatan, Schott 592 (Field Mus. Herb.).

Guatemala: Agua Caliente, Deam 6143.

Brazil: Piauhy, Gardner 2353, 2361; Prov. Ceará, Gardner 1876 (all in Gray Herb.).

Argentina: Córdoba, Stuckert 11719, 56 in Kneucker Gram. Exs. 366.

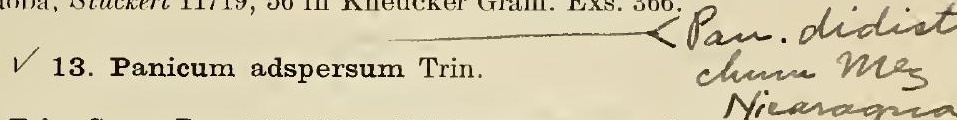

Panicum adspersum Trin. Gram. Pan. 146. 1826. Trinius states as to the origin of

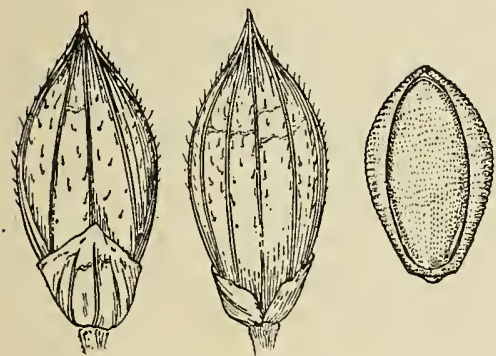

Fig. 24.- $P$. adspersum. From type specimen. his specimen, "V.sp. Doming. (SPrengel, sub nomine Pan. caespitosi.)" The type, in the Trinius Herbarium, is labeled, "Panicum adspersum m. St. Domingense s.[ub] n.[omine] P. caespitosum Lam. (!) mis. cl. Sprengel." This specimen was afterwards figured by Trinius. $a$ The spikelets are 3.2 $\mathrm{mm}$. long.

Panicum thomasianum Steud.; Doell in Mart. Fl. Bras. $2^{2}: 188.1877$. This is mentioned as a synonym under $P$. adspersum Trin. The type, collected by Duchaissing in St. Thomas, is in the Steudel Herbarium.

This species has been referred by many authors to $P$. grossarium $L$., but that name is a synonym of $P$. reptans.

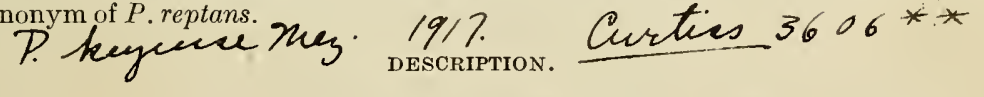

Plants light green, glabrous except as noted, ascending or spreading from a decumbent base, rooting at the lower nodes, commonly rather freely branching; culms 30 to $100 \mathrm{~cm}$. high, compressed; sheaths shorter than the internodes, rather loose, densely ciliate at least toward the summit; ligule a ciliate-membranaceous ring scarcely $1 \mathrm{~mm}$. long; blades ascending or spreading, 5 to $15 \mathrm{~cm}$., rarely as much as $20 \mathrm{~cm}$. long, 8 to 20 $\mathrm{mm}$. wide, abruptly acuminate, sometimes ciliate at the rounded base, scabrous on the margin; panicles rather short-exserted, 6 to $15 \mathrm{~cm}$. long, composed of few to many ascending spike-like racemes, 3 to $10 \mathrm{~cm}$. long, the slender axes angled, scabrous, usually pubescent in the axils, bearing approximate, short-pediceled spikelets singly or two or three together on short branchlets along the under side; spikelets 3.2 to $4 \mathrm{~mm}$. long, 1.5 to $1.8 \mathrm{~mm}$. wide, fusiform, turgid, abruptly acuminate; first glume clasping, about one-third the length of the spikelet, subacute, 5-nerved, glabrous; second glume and sterile lemma exceeding the fruit and pointed beyond it, 5 to 7-nerved, hispid at least toward the summit, or sometimes hispidulous only, rarely glabrous, sometimes obscurely reticulate; fruit 2.2 to $3 \mathrm{~mm}$. long, obovate, obtuse.

This species varies much in size and habit. The Florida specimens are more robust than many of those from the West Indies, including the type specimen. There ap-

$Q$ pear $\%$, however, to be no characters by which these can be separated. Some of the Cuban specimens, such as Curtiss 748 , are equally robust. In a specimen from St. Croix, Eggers in 1876, the spikelets are strongly papillose-hispid. 
DISTRIBUTION.

Moist open ground, Florida and the West Indies, often a weed in pastures and cultivated fields. It has been collected as a ballast plant by Mohr at Mobile, Alabama, by Scribner at Philadelphia, Pennsylvania, and by Martindale at Camden, New Jersey.

Florida: St. Augustine, Curtiss 6705, Kearney 176, Ricker 952; Sanibal Island, Simpson 292; Marco, Hitchcock Lee Co. Pl. 485; Miami, Chase 3851, Hitchcock 650; Sand Key, Curtiss 3606*; Key West, Curtiss 5431, Hitchcock $611,618,620$; without locality Chapman.

Alabama: Mobile, on ballast, Mohr in 1891.

Bahamas: Nassau, Curtiss 113.

Cuba: Habana, Curtiss 748, León 291, 570; Santiago de las Vegas, Baker \& Wilson 512, Hitchcock 147, 148, Tracy 9109; Triscornia, Hitchcock 159; Cabanas, Palmer \& Riley 746, 771; Her-

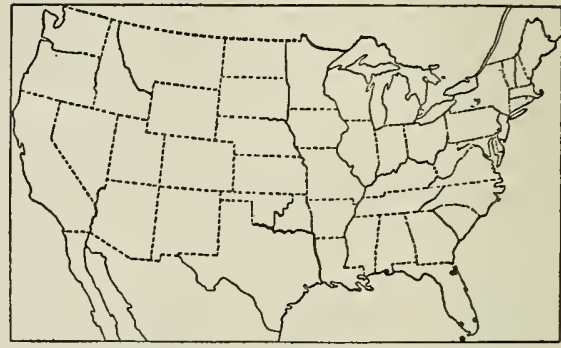

FIG. 25.-Distribution of $P$. adspersum. radura, Tracy 9102; Sancti Spiritus, León 925; Guines, León 924; without locality, Wright 3869 ;

JAMAICA: Without locality, March (Gray Herb.).

Porto Rico: Between Coamo and Aibonito, Sintenis 1957.

Danish West Indies: St. Croix, Eggers in 1876, Ricksecker 66, 384.

Leeward Islands: Guadeloupe, Duss 3180.

Panicum Ramosum L. Mant. Pl. 1: 29. 1767, an Asiatic species of this group and somewhat resembling $P$. adspersum, but with smaller spikelets, having a finely transversely rugose sterile lemma, in appearance much like the fertile lemma, was collected on ballast, at Mobile, Ala., Sept. 16, 1891, by Dr. Charles Mohr. This is the specimen referred by Scribner $a$ to $P$. chartaginense.

\section{Panicum arizonicum Scribn. \& Merr.}

Panicum dissitiflorum Vasey in S. Wats. Proc. Amer. Acad. 24: 80. 1889. This is listed without description, Palmer's numbers 159 and 190, Guaymas, Mexico, being cited. Two species were distributed under Palmer 159, $P$. arizonicum and $P$.
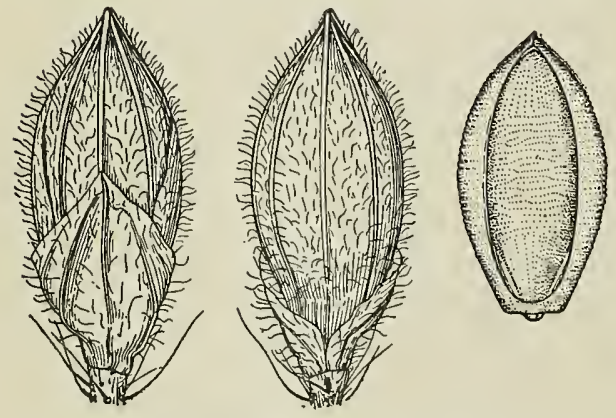

Fig. 26.-P. arizonicum. From type specimen of $P$. dissitiflorum Vasey.

fasciculatum chartaginense, a specimen of each of which is on the sheet of no. 159 which was in the National Herbarium in the time of Doctor Vasey. The plant of $P$. arizonicum is taken as the type, since other specimens of this species are named $P$. dissitiflorum in Vasey's writing.

Panicum fuscum major[us] Vasey, U. S. Dept. Agr. Div. Bot. Bull. 8: 26. 1889. "Mexico (Dr. E. Palmer)." The type, in the $\mathrm{Na}$ tional Herbarium, is from southwestern Chihuahua, collected August to November, 1885, no. 1 b. It is a robust specimen, $60 \mathrm{~cm}$. high, lacking the base, the blades as much as $15 \mathrm{~cm}$. long and $15 \mathrm{~mm}$. wide, the large panicle $15 \mathrm{~cm}$. long, the sheaths and under surface of the blades papillose-hispid. 
Panicum arizonicum Scribn. \& Merr. U. S. Dept. Agr. Div. Agrost. Circ. 32 : 2. 1901. Based on "(Panicum (sine nomine) Scribn. Bul. Torr. Bot. Club, 9: 76. 1882; $P$. fasciculatum dissitiflorum Vasey, in herb. Not $P$. dissitiflorum Steud. 1841)." The authors also cite, "Type specimen collected on mesas near Camp Lowell, Santa Cruz Valley, Arizona, 465 C. G. Pringle, 1881." As indicated above this species was first mentioned as "Panicum (Virgaria) sp." where the specimen referred to is Pringle 465. The same specimen, which is in the National Herbarium, was marked by Doctor Vasey, "Panicum fasciculatum var. dissitiflorum, "and later by Scribnerand Merrill as the type of $P$. arizonicum. It is about $60 \mathrm{~cm}$. high, but more slender than Palmer's specimen mentioned above; the sheaths and blades bear only a few scattered papillæ, mostly without hairs.

Panicum fasciculatum dissitiflorum Vasey; Scribn. \& Merr. U. S. Dept. Agr. Div. Agrost. Circ. $32: 2$. 1901. This herbarium name is given as a synonym of $P$. arizonicum of which it is a typonym.

Panicum arizonicum tenue Scribn. \& Merr. U. S. Dept. Agr. Div. Agrost. Circ. 32 : 3. 1901. "Type specimen collected at Fort Huachuca, Arizona, by T. E. Wilcox in 1894." The type, in the National Herbarium, is the small form common in sterile soil. The largest specimen is $17 \mathrm{~cm}$. high. Some of the sheaths are sparsely papillosehispid, some glabrous.

Panicum arizonicum laeviglume Scribn. \& Merr. U. S. Dept. Agr. Div. Agrost. Circ. 32 : 3. 1901. "Type specimen collected at Mescal, Arizona, 1810 David Griffiths, October, 1900." The type, in the National Herbarium, is a plant about $20 \mathrm{~cm}$. high, with glabrous spikelets and glabrous to sparsely papillose-hispid sheaths.

Panicum arizonicum major[us] Scribn. \& Merr. U. S. Dept. Agr. Div. Agrost. Circ. 32 : 3. 1901. Based on P. fuscum majus Vasey.

\section{DESCRIPTION}

Plants erect or ascending, sometimes decumbent at base and rooting at the lower nodes, branching at the base and lower nodes; culms 20 to $60 \mathrm{~cm}$. high, glabrous except below the panicle, the nodes sometimes slightly pubescent; sheaths shorter than the internodes or the upper often overlapping, rather loose, glabrous to strongly papillosehispid; ligule a ring of hairs about $1 \mathrm{~mm}$. long; blades rather thin, ascending or spreading, 5 to $15 \mathrm{~cm}$. long, 6 to $12 \mathrm{~mm}$. wide, rounded at base, glabrous on both surfaces, or scabrous to papillose-hispid beneath, the scabrous, thin, cartilaginous margin usually papillose-ciliate at base; panicles usually long-exserted, 7 to $20 \mathrm{~cm}$. long, the solitary, ascending, slender branches loosely flowered, the spikelets borne on very short, appressed branchlets, the pedicels and axes of branchlets, branches, and the entire panicle finely pubescent and also copiously papillose-hirsute; spikelets 3.5 to $3.8 \mathrm{~mm}$. long, obovate-elliptic, abruptly pointed, attenuate at base as in $P$. molle, densely hirsute to glabrous; first glume clasping, half the length of the spikelet, acute, 5 -nerved; second glume and sterile lemma pointed beyond the fruit, 5 -nerved, the nerves sometimes anastomosing as in $P$. molle; fruit 2.9 to $3 \mathrm{~mm}$. long, 1.5 to 1.6 $\mathrm{mm}$. wide, obovate-elliptic, apiculate.

This species is variable in size and in the amount of pubescence. In cultivated or moist soil it is robust as in the type of the species or of Scribner and Merrill's subspecies majus. The commoner form is smaller, more like the type of Scribner and Merrill's subspecies tenue. The form separated by Scribner and Merrill as subspecies laeviglume, because of the glabrous spikelets, appears to have no other distinguishing characters. The following specimens are this form, though in some cases the spikelets are sparsely pubescent or some of the spikelets are glabrous and some are pubescent: Canby 8, Griffiths 1913, 6152, 6168, 6929, 6938, 6939, 6990, Griffiths \& Thornber 75, 230, 239, Merton 1694, Metcalfe 768, Pringle 487, Smith in 1896, Wilcox in 1894. 


\section{DISTRIBUTION.}

Open sandy or stony ground, western Texas to southern California and northern Mexico.

Texas: El Paso, Jones in 1884; Presidio County, Nealley in 1892.

New Mexico: Mangas, Smith in 1896, Metcalfe in 1897; Las Cruces, Griffiths 7399 in part; Mogollon Mountains, Metcalfe 768; Sierra County, Metcalfe 1294.

Arizona: Tucson Mountains, Griffiths 6152, 6938, 6939; Tucson, Griffiths 1596, 3356, 6168, 6737, 7017, Hitcheock 3482; Santa Rita Mountains, Griffiths 5981, 6894, 6990, Griffiths \& Thornber 75, 230, 239; Santa Catalina

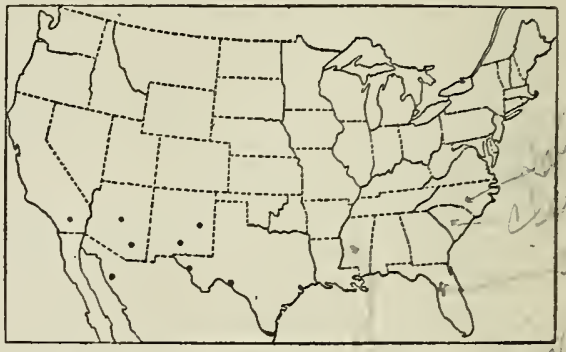

FIG. 27.-Distribution of $P$. arizonicum. (i.t.

Mountains, Griffiths 7143, 7148, Lemmon 3062; Sasabe, Griffiths 6929; Bowie, Toumey in 1896; Lowell, Pringle 465; Mescal, Griffiths 1810; Fort Huachuca, Wilcox in 1894; Patagonia, Hitchcock 3695; Bisbee, Mearns 1072; San Pedro River, Merton 1694; Cochise, Griffiths 1913; without locality, Lemmon 353.

California: Jamacha, Canby 8 in 1894.

Mexico: San José del Cabo, Brandegee 18 in 1890; south of Nogales, Hitchcock 3637; Arroyo San Lazaro, Brandegee in 1902; Guaymas, Hitchcock 3562, Palmer 159 in 1887 in part; Hermosillo, Hitchcock 3542; Nogales, Griffiths 6747, 6759; Loquka, [Lacuca?] Sonora, Griffiths 6891; Topolobampo, Palmer 250 in 1897; State of Chihuahua, Palmer $1 \mathrm{~b}$ in 1885, Pringle 487; State of Durango, Rose 2280.

\section{$\checkmark$ 15. Panicum texanum Buckl.}

Panicum texanum Buckl. Prel. Rep. Geol. Agr. Surv. Tex. App. 3. 1866. " Austin, Texas." The type specimen, in the herbarium of the Philadelphia Academy, consists of two overmature plants lacking the base.

\section{DESCRIPTION.}

Plants erect or ascending, often decumbent and rooting at the lower nodes, branching
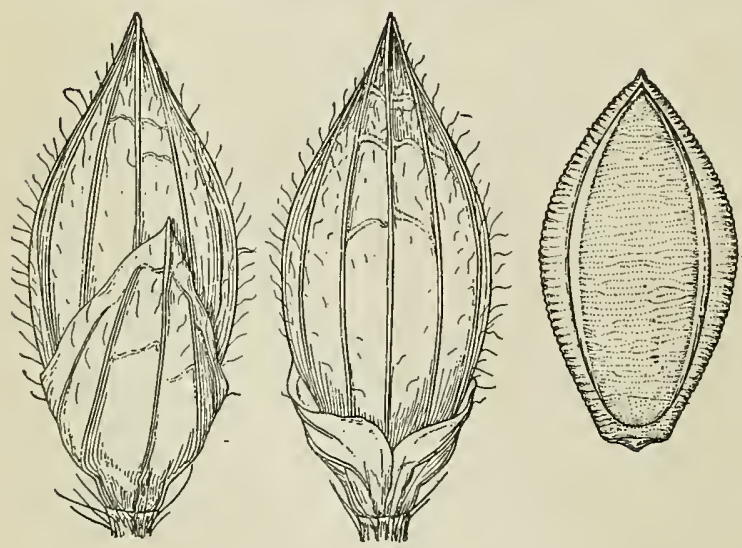

FIG. 28.-P. texanum. From type specimen. from the base and commonly from the lower and middle nodes; culms stout, 50 to $150 \mathrm{~cm}$. high, or in robust specimens as much as 3 meters high, softly pubescent at least below the nodes and below the panicles; sheaths softly pubescent, often papillose; densely ciliate, the lower shorter than the internodes, the upper usually overlapping; ligules about $1 \mathrm{~mm}$. long; blades ascending or spreading, 8 to $20 \mathrm{~cm}$. long, 7 to $15 \mathrm{~mm}$. wide, rounded at the base, softly pubescent on both surfaces, often finely papillosespanicles finally exserted, 8 to $20 \mathrm{~cm}$. long, 1 to $3 \mathrm{~cm}$. 
wide, the main axis much exceeding the erect branches, the axes densely clothed with short pubescence having long, stiff hairs intermixed, the short-pediceled spikelets somewhat crowded; spikelets 5 to $6 \mathrm{~mm}$. long, about $2 \mathrm{~mm}$. wide, fusiform, pointed, short-attenuate at base, pilose; first glume clasping, more than half the length of the spikelet, acute, 3 to 5nerved; second glume and sterile lemma exceeding the fruit, 5-nerved, often obscurely reticulate; fruit 3.7 to 3.8 $\mathrm{mm}$. long, about $2 \mathrm{~mm}$. wide, elliptic, apiculate.

\section{DISTRIBUTION.}

Prairies and open ground, especially on low land along streams, often a weed in waste ground and cultivated fields, Texas and northern Mexico.

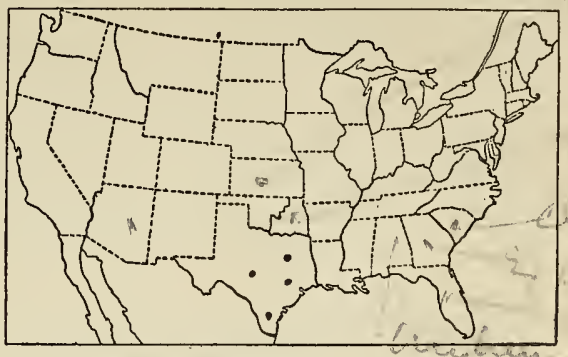

Fig. 29.-Distribution of P. texanum.

This is sparingly cultivated under the name of Colorado grass.

Texas: Dallas, Reverchon 1226 in Curtiss N. Amer. Pl. 3607A; Corsicana, Reverchon 2228; Pierce, Tracy 7748; Victoria, Plank 73; Austin, Plank 31; Harvester, Thurow in 1898; Wallisville, Wallis in 1880; Goliad County, Lea in 1874; San Antonio, Bush 1198, Havard in 1882; Corpus Christi, Hitchcock 163.

Mexico: Monterey, Hitchcock 5540.

Dichotomiflora.-Annual plants with smooth culms, mostly large, spreading panicles, the branchlets short and appressed along the ascending or rarely spreading main branches; ligule membranaceous below, densely ciliate above, 1 to $3 \mathrm{~mm}$. long; spikelets glabrous, narrow, acute or acuminate, 2 to $5 \mathrm{~mm}$. long, the first glume one-fifth to one-fourth as long, truncate or with a broadly triangular tip; fruit smooth and shining.

Panicles narrow, less than $1 \mathrm{~cm}$. wide................... 16. P. vaseyanum.

Panicles open, the branches usually ascending.

Fruit acuminate; culms with a long, rooting base....... 19. P. elephantipes.

Fruit not acuminate.

Sheaths papillose-hispid..................... 18. P. bartowense.

Sheaths glabrous........................... 17. P. dichotomiflorum.

\section{$\checkmark$ 16. Panicum vaseyanum Scribn.}

Panicum vaseyanum Scribn.; Beal, Grasses N. Amer. 2:140. 1896. The only specimen cited is "Mexico, Pringle 1415." The type specimen, in the National Herba-

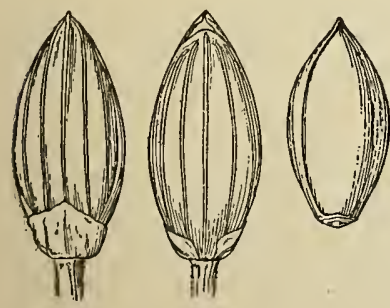

Fig. 30.-P. vaseyanum. From type specimen. rium, was collected in the State of Chihuahua, in "Wet places, pine plains, base of Sierra Madre," September 30, 1887, by C. G. Pringle.

\section{DESCRIPTION.}

Plants spreading, branching at base and at the lower and middle nodes, glabrous throughout; culms 50 to $70 \mathrm{~cm}$. long, somewhat compressed; sheaths shorter than the elongated internodes; ligules 1 to $2 \mathrm{~mm}$. long; blades 5 to $20 \mathrm{~cm}$. long, 3 to $7 \mathrm{~mm}$. wide, linear, scarcely narrowed at the folded or enveloping base; panicles terminal and from the axils of the upper leaves of the main culms and large branches, narrow, 4 to $7 \mathrm{~cm}$. long, less than $1 \mathrm{~cm}$. wide, partially included, equaled or exceeded by the erect uppermost blade; spikelets short-pediceled, narrowly ovate, $2.5 \mathrm{~mm}$. long, 1.1 to $1.2 \mathrm{~mm}$. wide, subacute; first glume about one- 
fifth the length of the spikelet, truncate or obtuse; second glume slightly shorter than the sterile lemma, both 7-nerved, palea of the sterile floret obsolete; fruit 2.1 $\mathrm{mm}$. long, $1 \mathrm{~mm}$. wide, elliptic, apiculate.

This very distinct species is known from a single collection only, that distributed by Pringle, mentioned above.

\section{Panicum dichotomiflorum Michx.}

Panicum miliaceum Walt. Fl. Carol. 72. 1788, not L. 1753. Since Walter does not give Linnæus as authority nor use his diagnosis, this is evidently intended as a new species. No specimen of this is found in Walter's herbarium, $a$ but the description indicates $P$. dichotomiflorum, which, together with Walter's name, Elliott $b$ refers to $P$. geniculatum Muhl.

Panicum dichotomiflorum Michx. Fl. Bor. Amer. 1: 48. 1803. "НАв. in occidentalibus montium Alleghanis." The type is in the herbarium of Drake de Castillo. It was sent by Richard, having been collected by Michaux "ad occidentum montium Alleghanis." The specimen of this in the Michaux Herbarium is labeled "in regione Illinoensium." Both of these specimens are the common glabrous form of the United States as represented by Chase in Kneucker, Gram. Exs. no. 546.

Panicum geniculatum Muhl. Cat. Pl. 9. 1813. Based on P. dichotomiflorum Michx. The specimen in the Muhlenberg Herbarium is in folio 181, marked "Panicum geniculatum (dichotomiflorum) M. 114."

Panicum aquaticum Poir. in Lam. Encycl. Suppl. 4: 281. 1816. "Cette plante croît à Porto-Ricco; elle m'a été communiquée par M. Ledru." The type, in the Cosson Herbarium, is from Porto Rico. In the description the species is compared to $P$. melicarium Michx., and the label of the type bears the abbreviated statement, "aff. P. melicario Mich." In the Desvaux Herbarium there is a similar specimen from the Antilles, labeled "P. aquaticum Desv. in Poir. Enc. Suppl." In both specimens the spikelets are nearly $3 \mathrm{~mm}$. long as in Wright 3861 . In the original publication there is no indication that Desvaux is the author of the species. This name was erroneously referred by Hitchcock $c$ to $P$. elephantipes. The fruit is not acuminate as in that species

Panicum multiflorum Poir. in Lam. Encycl. Suppl. 4: 282. 1816. "Cette plante croît à la Caroline; elle m'a été communiquée par M. Bosc." We take the specimen labeled "bosc. caroline," in the Cosson Herbarium, to be the type. Another specimen of the same collection is in the Desfontaines Herbarium. It is labeled, "Am. Sept. Bosc," and also "Panicum brachiatum Bosc." These are the typical form.

Panicum brachiatum Bosc; Spreng. Syst. Veg. 1:321. 1825, not Poir. 1816. The locality given by Sprengel is "Ins. Bermud." As indicated above, the specimen of $P$. multiflorum from Bose is labeled P. brachiatum Bosc. There is also in the Delessert Herbarium a specimen so labeled, collected in South Carolina by Bosc. We have seen no specimen of Bosc's from the Bermudas, the published locality, and we find no, record that Bosc visited the Bermudas. The meager description applies to $P$. dichotomiflorum.

Panicum chloroticum Nees; Trin. Gram. Pan. 236. 1826. Trinius describes a variety " $\alpha$ (agreste N. ab Es.)" which is the equivalent of the species, and " $\beta$ (sylvestre N. $a b$ Es.)," both from Brazil, "V. utriusque spp. Brasil (N. A B Esenb. LangsDORFF)." The latter differs in having a more open panicle, larger spikelets, and narrower leaves. Nees $d$ described the same species later, with three varieties,

$a$ For an account of Walter's grasses see Hitchcock, Rep. Mo. Bot. Gard. 16: 31-56. 1905.

$b$ Bot. S. C. \& Ga. 1 : 117. 1816.

$c$ Contr. Nat. Herb. 12: 218. 1909.

d Agrost. Bras. 164. 1829. 
$\alpha$ agreste, the equivalent of the species, "Habitat in graminosis cultis prope Soteropolin et Oeiras provinciae Bahiensis et Piauhiensis;" $\beta$ sylvestre, "Habitat in sylvis ad Almada, Ferradas et in via Felisbertia districtus Insulanorum prov. Bahiensis, (Martius et Maximil. Princ. Neovid.);" r pingue, "Habitat in cultis ad Soteropolin, provinciae Bahiensis." Specimens of none of these could be found in the Trinius Herbarium, and therefore the specimens described by Nees, which are in the Munich Herbarium, may be considered the types. These are all labeled with the published data as given above. The types of agreste and pingue are similar, having broad blades and rather dense panicles of small spikelets 2.2 to $2.3 \mathrm{~mm}$. long as in Chase 4234 from Florida and Morong 543 from Paraguay. The type of variety sylvestre differs in having narrow and shorter blades, smaller, more open panicle, and larger spikelets about $3 \mathrm{~mm}$. long as in Riedel 959 from Brazil. This form may prove to be a distinct species. None of the specimens shows the base of the plant. Kunth $a$ erroneously refers variety sylvestre to Panicum brachiatum Poir., which is a species of Chaetochloa.

Panicum elliottii Trin.; Nees, Agrost. Bras. 170. 1829. This is mentioned as a synonym under $P$. proliferum Lam. which latter name Nees applies to $P$. dichotomiflorum Michx. The type was not found in the Trinius Herbarium nor at Munich.

Panicum retrofractum Delile; Desv. Opusc. 96. 1831. Desvaux gives no locality other than "America borealis." The type, in the Jussieu Herbarium, is from "Caroline," and is the typical form.

Panicum hygrophilum Salzm.; Steud. Syn. Pl. Glum. 1:71. 1854. "Bahia." In the National Herbarium is a specimen labeled $P$. hygrophilum Salzm. from Bahia, which agrees with Nees's variety sylvestre. There is a specimen of the same in Van Heurck's herbarium, where is located the original set of Salzmann, and duplicates in Hackel's and other European herbaria, but we do not know which specimen was seen by Steudel.

Panicum proliferum pilosum Griseb. Cat. Pl. Cub. 232. 1866. "Wr[ight] a. 1865, ad lagunas." The type, in the Grisebach Herbarium, is labeled, "Around lagunas in wet or damp ground, Hanabana," no. 186. This is a small plant with spreading or decumbent culms, papillose-hispid sheaths and blades villous above. Nash's no. 567 from Eustis, Florida, is similar to this but has somewhat larger spikelets.

Panicum proliferum strictum Griseb. Cat. Pl. Cub. 232. 1866. "Wr[ight] 3456." The type, Wright's no. 3456 from Cuba, is in the Grisebach Herbarium. The spikelets are about $3 \mathrm{~mm}$. long, the sheaths smooth, the blades villous above.

Panicum proliferum geniculatum Wood, Bot. \& Flor. 392. 1874. This is probably based on $P$. geniculatum Eil., though that name is not mentioned; no locality nor specimen is cited. Vasey $b$ makes the same combination, basing it upon $P$. geniculatum Ell.

Panicum amplectans Chapm. Bot. Gaz. 3:20. 1878. "South Florida." The type, in the Chapman Herbarium at Biltmore, was collected by Blodgett.

Panicum francavillanum Fourn. Mex. Pl. 2: 25. 1886.c "Tacabaya (Schaffn[ER]

a Enum. Pl. 1 : 155.1833.

$b$ Grasses U. S. 12. 1883.

$c$ The date given on the title-page of this work is 1886. A set of proof sheets was supplied to Bentham in 1880 and is referred to by the latter author in his paper, Notes on Gramineae, read November 3, 1881, and published in the Journal of the Linnaean Society (Botany 19: 14-134. 1881). Fournier's names are also cited by Hemsley (Biol. Centr. Amer. 3 : 1885), to which work they are referred by the Index Kewensis, but the names are there usually nomina nuda. The proof sheets mentioned above are in the library at Kew, marked, "Proof sheets of Mr. Fournier Gramineae, 1881. From Mr. Bentham." They are stamped, "1re Epreuve 18 Mai 1880." Bentham says of these (Notes on Gramineae, p. 20), "Eugène Fournier's 'Enumeration of

$41616^{\circ}-$ vor $15-10-4$

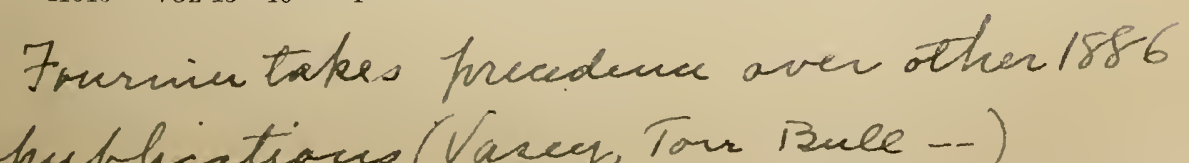


n. 301)." The type is in the herbarium of Drake de Castillo. The name was earlie mentioned by Hemsley. $a$

Panicum proliferum chloroticum Hack. in Repert. Nov. Sp. Fedde 7 : 343. 1909. Based on P. chloroticum Nees.

This species was referred by Pursh, $b$ as it has been by most later authors, to $P$. proliferum Lam. The latter is, however, the same as P. miliare Lam., an Old World species.

$$
\begin{aligned}
& \text { Description. "antiototale Rets. Bas, Fedele } \\
& \text { Rop. } 1960:-331,1960
\end{aligned}
$$

Plants usually freely branching, ascending or spreading from a geniculate base, or sometimes erect, usually smooth throughout, or, in tropical forms, more or less pubescent; culms somewhat compressed, often thick and succulent, drying furrowed, usually 50 to $100 \mathrm{~cm}$. long, in robust specimens as much as 2 meters long, the nodes

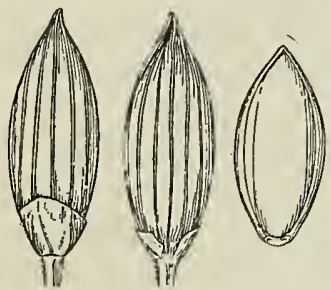

Fig. 31.-P. dichotomiflorum. From specimen of $P$. geniculatum Muhl. in Elliott Herbarium. smooth, at least the lower swollen; sheaths often compressed, usually longer than the internodes, ciliate on the margin toward the summit; ligules 1 to $2 \mathrm{~mm}$. long; blades flat or in small specimens sometimes folded, glabrous or sparsely pilose above, 10 to $50 \mathrm{~cm}$. long, 3 to $20 \mathrm{~mm}$. wide, at base about as wide as sheath, the white midnerve usually prominent; panicles terminal and axillary, included at base or tardily short-exserted, many-flowered, 10 to 40 $\mathrm{cm}$. long or more, the main branches ascending, or finally spreading or even reflexed, the short branchlets appressed, bearing short-pediceled, often rather crowded spikelets, the axes angled and scabrous; spikelets narrowly oblongovate, 2 to $3.2 \mathrm{~mm}$., usually about $2.5 \mathrm{~mm}$. long, about 0.9 $\mathrm{mm}$. wide, acute, often greenish purple; first glume onefifth to one-fourth the length of the spikelet, truncate or broadly triangular; second glume and sterile lemma more or less pointed beyond the fruit, rather faintly 7 -nerved, the palea of the sterile floret present or wanting; fruit 1.8 to $2 \mathrm{~mm}$. long, about $0.8 \mathrm{~mm}$. wide, elliptic.

This species as it occurs in the United States is usually glabrous throughout but varies much in the size of the blades and of the spikelets, the latter varying from 2 to $3.2 \mathrm{~mm}$. in length. Not uncommonly specimens occur with the upper surface of some or all of the blades sparsely or even densely pilose, such as: CoNNECTICUT, Wilson 1248; New York, Young in 1872; Pennsyluania, Heller in 1900; Delaware, Commons 230; Kansas, Carleton in 1892; Florida, Chase 4294, Combs 94, 1251. One series of specimens from Florida, Nash $567, c$ is low, 20 to $30 \mathrm{~cm}$. high, with narrow blades pubescent above, and papillose-hispid sheaths. Nash's no. 372 from the same locality is glabrous throughout, except the ciliate margin of the sheaths, but otherwise is the same as his no. 567. Two Cuban specimens, Hitchcock 149 and Wright 3860, are like Nash's no. 567. Many of the West Indian specimens have blades pilose above, some of which have spikelets about $2 \mathrm{~mm}$. long and others about $3 \mathrm{~mm}$. long. Such are: Brace 3742, Britton \& Cowell 432, Curtiss 177, Duss 3178, Eggers 4405, 4512, Geogr. Soc. Baltimore 489, Hitchcock 150, Wright 3861. The South American specimens cited are glabrous. Those from Arechavaleta and Morong 543 have small spikelets as in the

Mexican Gramineae' is not yet published; but being already printed off and M. Fournier having obligingly supplied me with a copy, I feel bound in so far as I am concerned, to treat it as having already taken date." The Kew copy ends with page 150 and lacks index, title-page, and plates.

$a$ Biol. Centr. Amer. Bot. 3 : 489. 1885.

b Fl. Amer. Sept. 1: 68. 1814.

$c$ This number was distributed under an unpublished varietal name. 
type of $P$. chloroticum, while Morong 1002 and Riedel 959 have spikelets $3 \mathrm{~mm}$. long, as in the type of $P$. chloroticum $\beta$ sylvestre.

These different variations in pubescence, size of spikelet, and habit can not be in any way correlated and each is connected by intergrading specimens with the typical form. Nor has any variation a separate geographical range, though specimens with pilose blades are commoner in the West Indies than elsewhere.

The specimens cited below from Brazil have larger spikelets. They belong to the form mentioned above under $P$. chloroticum as variety sylvestre.

\section{DISTRIBUTION .}

Moist ground, along streams, and a weed in waste places and cultivated soil, Maine to Nebraska, south to Florida and Texas; also in California, Mexico, the West Indies, and South America to Uruguay.

MaIne: North Berwick, Parlin in 1891 (Gray Herb.).

Massachusetts: Cambridge, Morong in 1876; Newburyport, Leavitt \& Eaton in 1902; Plymouth, Oakes.

Connecticut: Stamford, Driggs 8; South Glastonbury, Wilson 1248; Bridgeport, Eames.in 1895.

New York: Northville, Young in 1872 (Hitchcock Herb.).

New Jersey: Clifton, Nash in 1891; Weehauken, Van Sickle in 1895; Freehold, Pearce in 1884.

Pennsylvania: Easton, Porter in 1895; Chambersburg, Porter in 1898; Westmoreland County, Pierron in 1877; Lancaster County, Heller in 1900.

Онго: Niles, Ingraham in 1891; Sheffield, Ricksecker in 1894.

Indiana: Wells County, Deam in 1903; Lafayette, Dorner 23, 86.

IllinoIs: Chicago, Moffatt 374, Umbach in 1896; Pine Rock, Waite in 1885; Peoria, Brendel, McDonald 71; St. Clair County, Eggert 110.

Iowa: Mount Pleasant, Mills in 1894; Jefferson, Wilcox 27; Manchester, Ball 39; Murray, Morris A 287; Fayette County, Fink 409.

Nebraska: Talmage, Elmore 71; without locality, Holmes in 1889.

MissourI: Courtney, Bush 10 in 1892.

Kansas: Topeka, Smyth 331; Riley County, Hitchcock 3838, Norton 567, Carleton in 1892.

Dela WARE: Wilmington, Commons 229, 230, Canby in 1896.

Maryland: Garrett County, Smith in 1879 .

District of Columbia: Chase in Kneucker Gram. Exs. 546, Mc Carthy in 1886, Pollard 682, Steele in 1896, Vasey in 1887, Ward in 1876, Williams in 1896.

Virginia: Virginia Beach, Hitchcock 217; Gravelly Run, Ward in 1886.

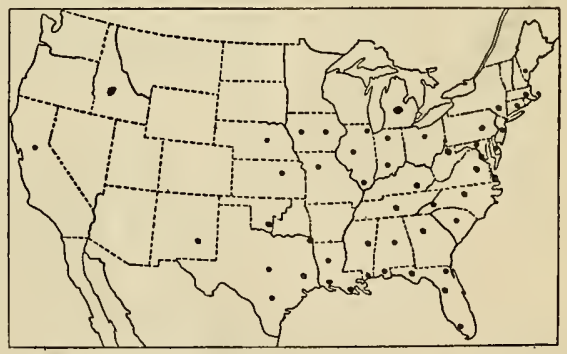

FIG. 32.-Distribution of P. dichotomiflorum.

Wést Virginia: Aurora, Steele in 1898; Tygarts Valley, Smith in 1879.

North Carolina: Chapel Hill, Ashe; West Raleigh, Stanton 1280; Biltmore, Biltmore Herb. 702a; Magnetic City, Wetherby 19.

South Carolina: Lexington, Corley in 1879; St. Helena Island, Cuthbert in 1904.

Georgia: Dalton, Harper 382; Augusta, Kearney 208.

Florida: Duval County, Fredholm 395; Lake City, Chase 4234, Combs 94; Eustis, Nash 372, 567, 874; Crystal, Combs 990; Manatee, Chapman, Combs 1251.

KenTuCKy: Bell County, Kearney 374.

Tennessee: Knoxville, Ruth 71; Cocke County, Kearney 966; Nashville, Gattinger in 1879 . 
Alabama: Mobile, Mohr in 1878; Deatsville, Pollard \& Maxon 307.

Mrssissippr: Starkville, Kearney 9, 18; Nicholson, Kearney 372 in part; Biloxi, Tracy 4618, 6507; Mississippi City, Tracy 77.

Loursiana: Calhoun, Ball 67; McCall, Combs 1436; Burnside, Combs 1419; Coushatta, Ball 135; Natchitoches, Ball 139, 164; Rayville, Ball 31, 24; Oberlin, Ball 215, 229; South Pass, Tracy \& Lloyd 471; Baton Rouge, Joor 25; Lake Charles, Chase 4392; without locality, Langlois 29.

Texas: Houston, Hall 817; Waller County, Thurow in 1898 and 1903; Texarkana, Heller 4210, 4246; Clarksville, Plank 8; Llano, Plank 18 in part; Kerrville, Heller 1883 in part; Santa Maria, Nealley in 1889; without locality, Joor, Nealley in 1886.

Oкцанома: False Washita, Palmer 375 in 1868.

NEw MExico: Las Cruces Plank 29.

Fdano: so ither Biotett 140 . Shattuck in 1910.

Mexico: Head of Mazatlan River, Wright 1317 (Gray Herb.).

Bermudas: Hamilton, Millspaugh Pl. Utow. 126.

Bahamas: Hog Island, Eggers 4405, 4512; Nassau, Curtiss 177; Cat Cay, Brace 3742; Watlings, Geogr. Soc. Baltimore 489.

CubA: Herradura, Tracy 9055, 9342; Santiago de las Vegas, Hitchcock 151; Batabano, Hitchcock 150; Guanabacoa, León 919; without locality, Wright 3456, 3860 in part, 3861.

Porto Rrco: Utuado, Britton \& Cowell 432.

LeEWARD Islands: Guadeloupe, Duss 3178.

Brazrl: Bahia, Salzmann; without locality, Riedel 959.

Paraguay: Morong 543, 1002 in part.

Uruguay: Montevideo, Arechavaleta.

\section{Panicum bartowense Scribn. \& Merr.}

Panicum bartowense Scribn. \& Merr. U. S. Dept. Agr. Div. Agrost. Circ. 35: 3. 1901. "Type specimen collected in wet, reclaimed swamps at Bartow, Polk County,

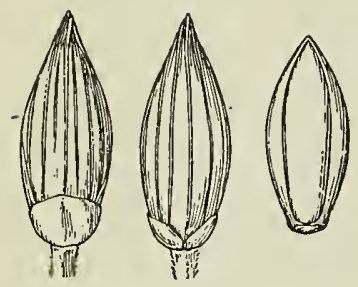

FIG. 33.-P. bartowense. From type specimen. Fla. No. 1220, Robert Combs, September 29, 1898." The type, in the National Herbarium, is an erect, simple plant about 1.75 meters high, with conspicuously hispid sheaths and nearly glabrous blades, the spikelets about $2.5 \mathrm{~mm}$. long.

\section{DESCRIPTION.}

Plants simple or sparingly branching, as much as 2 meters high, erect; culms glabrous, the larger as much as $7 \mathrm{~mm}$. thick; sheaths mostly longer than the internodes, papillose-hispid; ligules 2 to $3 \mathrm{~mm}$. long, the ciliæ more or less segregated in tufts; blades 15 to $40 \mathrm{~cm}$. long, 5 to $13 \mathrm{~mm}$. wide, glabrous or more or less pilose above, rarely sparsely hispid beneath, rather prominently papillose on the margin near the round but scarcely cordate base; panicles large and finally loosely spreading, 15 to $60 \mathrm{~cm}$. long, the branches at first ascending, finally spreading, the short branchlets and short-pediceled spikelets appressed as in $P$. dichotomiflorum; spikelets 2.2 to $2.7 \mathrm{~mm}$. long, the glumes and fruit as in $P$. dichotomiflorum.

This species is closely allied to $P$. dichotomiflomu, and may be only an extreme form of that species. As limited here, it differs in having tall, erect, simple, or nearly simple culms and papillose-hispid sheaths. The blades are usually pilose above, though the type specimen has nearly glabrous blades, but this is the case 
with some of the specimens referred to $P$. dichotomiflorum. A few specimens mentioned under the latter species have papillose-hispid sheaths, but are low branching plants with the habit of that species rather than of $P$.bartowense. Although most of the specimens cited below are erect and simple, one, Chase 3850 , is much branched and spreading at the base like $P$. dichotomiflorum, and it is possible that the erect, simple habit has no special significance as a specific character.

\section{DISTRIBUTION.}

Low ground, often growing in shallow

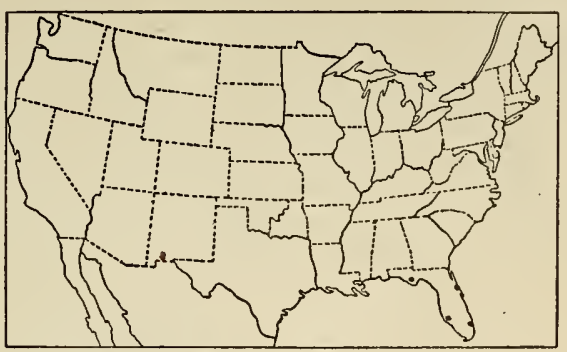

FIG. 34.-Distribution of $P$. bartowense. water, Florida and the Bahamas.

Florida: Homosassa, Combs 971; Titusville, Chase 4007; Manatee, Tracy 6691; Braidentown, Tracy 7738; Palma Sola, Tracy 7740; Bartow, Combs 1220; Myers, Hitchcock Lee Co. Pl. 483; Palm Beach, Curtiss 5386; Little River, Eaton 467; Miami, Chase 3850, Eaton 164 in part, Hitchcock 648, 658, 697; without locality, Simpson in 1889.

BaHAmas: Great Bahama, Britton \& Millspaugh 2706; North Bimini, Brace 3467 (all in Field Mus. Herb.).

\section{$\checkmark$ 19. Panicum elephantipes Nees.}

Panicum elephantipes Nees, Agrost. Bras. 165. 1829. "Habitat in sylvis udis archipelagi Paraënsis." The type, in the Munich Herbarium, labeled as above, consists of a large detached panicle, a leaf, and a few inches of a culm.

Paricum fistulosum Hochst.; Steud. Syn. Pl. Glum. 1: 71. 1854. The locality

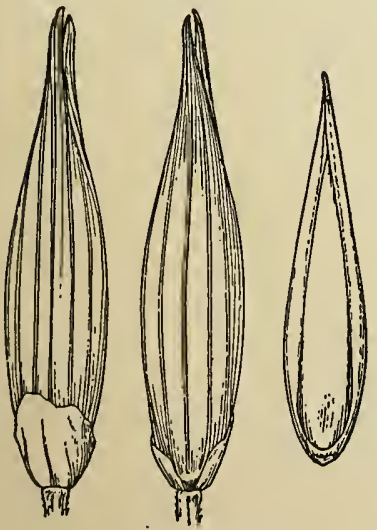

Fig. 35.-P. elephantipes, From type specimen. mentioned is, "Surinam" and the specimen cited is "Hrbr. Kappler nr. 1434." A specimen of Kappler 1434 was examined at the Florence Herbarium and another at Stockholm. As no specimen of this number was found among the Steudel plants at Paris, we are unable to locate the type.

In India is found a similar species, described in Hooker's Flora of India $a$ as $P$. proliferum ( $P$. paludosum Roxb.) which, judging from the specimens in the U. S. National Herbarium, is a smaller plant, with small, tardily exserted panicles 10 to $15 \mathrm{~cm}$. long.

\section{DESCRIPTION.}

Culms ascending from a decumbent, often widely creeping base, rooting at the nodes, succulent, as much as $2 \mathrm{~cm}$. thick, apparently a meter or more high, glabrous, the nodes glabrous, usually conspicuously dark colored; sheaths glabrous, longer than the internodes, loose, the lower often tesselated by cross partitions between the nerves; ligules about $3 \mathrm{~mm}$. long; blades 15 to $50 \mathrm{~cm}$. long, 7 to $20 \mathrm{~mm}$. wide, glabrous beneath, pilose above, at least near the base; panicles large and open, as much as $40 \mathrm{~cm}$. long, 
the short branchlets appressed along the ascending branches; spikelets 4 to $5 \mathrm{~mm}$. long, lanceolate, acuminate; first glume one-fifth to one-fourth the length of the spikelet, subacute or obtuse, rarely pointed and one-third the length of the spikelet; second glume and sterile lemma subequal, 7 to 9-nerved, the palea of the sterile floret wanting; fruit 3 to $4 \mathrm{~mm}$. long, about $0.8 \mathrm{~mm}$. wide, lanceolate, acuminate, the margins of the lemma above the middle thin and not inrolled.

This large, succulent, semi-aquatic, apparently annual species, often producing dense masses of roots at the submerged nodes, is readily distinguished from $P$. dichotomiflorum by the acuminate fruit. The Mexican specimens cited below have narrower blades than the others and none show the basal portion, but the floral characters agree with the type, except that the fruit is more turgid and less acuminate.

\section{DISTRIB UTION.}

In ponds and shallow water, West Indies and southern Mexico, south to Argentina. An introduced specimen was collected in North Carolina, "Eastern part of state along seacoast," by McCarthy in 1898.

Mexico: Near Mexico City, Bourgeau 529, Pringle 6322,a 9577.a

Guatemala: Alta Vera Paz, Goll 35A.

CubA: San Antonio, Hitchcock 152; Habana, León 335.

Porto Rico: Fajardo, Sintenis 938.

Paraguay: Morong 1002 in part.

UrUGUAY: Montevideo, Arechavaleta in 1876, without locality, Arechavaleta in 1892.

Argentina: Lagos de la Darsesso, Buenos Aires in 1892, name of collector not given.

* Capillaria.-Annuals; papillose-hispid at least on the sheaths, or rarely glabrous, ligules membranaceous, ciliate, 1 to $3 \mathrm{~mm}$. long; panicles many-flowered; more or less diffuse, often breaking away at maturity and rolling before the wind; spikelets pointed, glabrous, the first glume large and clasping, the fruit often falling from the spikelet before the disarticulation of the latter, smooth and shining, usually olive brown at maturity, the nerves showing as faint pale lines.

Panicles more or less drooping.

Spikelets not over $3.5 \mathrm{~mm}$. long; Mexican species..... 28. P. sonorum.

Spikelets 4.5 to $5 \mathrm{~mm}$. long; introduced from Old World. 30. P. miliaceum.

Panicles erect.

Inflorescence elongated, composed of several approximate, implicate panicles......................... 31. P. cayennense.

Inflorescence not composed of approximate nor implicate panicles.

Panicles more than half the length of the entire plant.

Panicles narrow, usually less than half as broad as long........................... 20. Plexile.

Panicle as broad as long.

Spikelets 2 to 2.2 , rarely $2.5 \mathrm{~mm}$. long; blades not crowded toward the base. 23. P. capillare.

Spikelets 3 to 3.3 , rarely only $2.5 \mathrm{~mm}$. long; blades usually crowded toward the base....................... 24. P. barbipulvinatum.

$a$ These numbers were distributed as a variety of $P$. proliferum Lam., the varietal name being unpublished. 
Panicles not more than one-third the entire height of the plant.

Spikelets not over $2 \mathrm{~mm}$. long, acute but not longacuminate.

Culms stout; blades about $1 \mathrm{~cm}$. wide; spikelets turgid................ 21. P. gattingeri.

Culms slender; blades not over $6 \mathrm{~mm}$. wide; spikelets not turgid............... 22. P. philadelphicum.

Spikelets 2.7 to $6 \mathrm{~mm}$. long, acuminate.

First glume about one-third the length of the spikelet, subacute or blunt......... 27. P. stramineum.

First glume usually more than half the length of the spikelet, acuminate.

Spikelets 4.5 to $6 \mathrm{~mm}$. long.

Spikelets $6 \mathrm{~mm}$. long, scattered.. 29. P. parcum.

Spikelets scarcely over $5 \mathrm{~mm}$.

long, approximate.......26A. P. decolorans.

Spikelets not over $4 \mathrm{~mm}$. long.

First glume more than three-fourths the length of the spikelet; spikelets $4 \mathrm{~mm}$. long....... 26. P. pampinosum.

First glume half to two-thirds the length of the spikelet; spikelets not over $3.3 \mathrm{~mm}$. long... 25. P. hirticaule.

\section{Panicum flexile (Gattinger) Scribn.}

Panicum capillare flexile Gattinger, Tenn. Fl. 94. 1887. "Characteristic of the cedar glades." In the Gattinger Herbarium are two specimens labeled "Panicum capillare L. var. Alexile Gattinger" in Gattinger's hand. The larger specimen is chosen as the type. This is labeled "Cedar glade near Nashville, Sept. '88. A. Gattinger."

Panicum flexile Scribn. in Kearney, Bull. Torrey Club 20: 476. 1893. Based on $P$. capillare flexile Gattinger.

Panicum minus Nash, Bull. Torrey Club 22: 421. 1895. Based on "Panicum capillare var. minus Muhl.," though Nash's description applies to P. philadelphicum.

Scribner and Merrill $a$ applied to this species the name P. philadelphicum Bernh., but this name belongs to a different species. Muhlenberg $b$ describes $P$. flexile as a variety of $P$. capillare, but without giving a varietal name, saying, "Varietas minor occurrit ubique in cultis magis aridis," and following this by a description. This specimen in the Muhlenberg Herbarium is labeled, "183 Panicum capillare var. minor."

Pursh $c$ describes $P$. flexile under the name of $P$. diffusum Swartz. It was also described by Trinius $d$ as $P$. capillare $\beta$ Panicula depauperata.

\section{DESCRIPTION.}

Plants erect, much branched from the base, 20 to $70 \mathrm{~cm}$. high; culms slender, glabrous, or somewhat hispid below, nodes pubescent; sheaths papillose-hispid, the hairs shorter than in P. capillare; blades erect but not stiff, glabrous or sparsely hispid,

$a$ U. S. Dept. Agr. Div. Agrost. Circ. 27: 3. 1900. A discussion of "The grasses in the Herbarium of Dr. H. Muhlenberg."

$b$ Descr. Gram. 124. 1817.

$c$ Fl. Amer. Sept. 1: 68. 1814.

$d$ Gram. Pan. 215. 1826. See note under P. philadelphicum, p. 58. 
as much as $30 \mathrm{~cm}$. long, 2 to $6 \mathrm{~mm}$. wide, rarely narrower; panicles rather few-flowered,

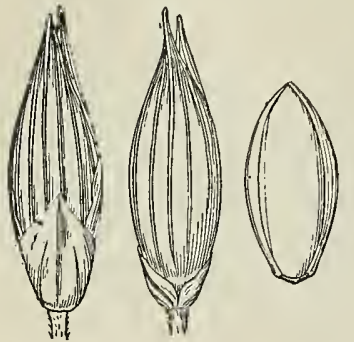

FIG. 36.-P. flexile. From type specimen. oblong, narrow, 10 to $20 \mathrm{~cm}$., rarely $30 \mathrm{~cm}$. long, about one-third as wide, the branches at first narrowly ascending, somewhat spreading at maturity, the peduncle of the panicle not brittle and readily breaking as in $P$. capillare; spikelets long-pediceled, 3.1 to $3.5 \mathrm{~mm}$. long, 0.9 to $1 \mathrm{~mm}$. wide, lanceolate, acuminate; first glume about one-third the length of the spikelet; second glume slightly longer than the sterile lemma, both 7 to 9 -nerved, much exceeding the fruit, the palea of the sterile floret wanting; fruit $2 \mathrm{~mm}$. long, $0.9 \mathrm{~mm}$. wide, elliptic.

This species is distinguished from $P$. capillare by the more slender culms, less dense pubescence, narrower blades, the narrow, less diffuse panicles and the longer, acuminate spikelets; and from $P$. philadelphicum by the narrow panicle and larger, acuminate spikelets.

\section{DISTRIBUTION.}

Sandy, mostly damp soil, meadows and open woods, Ontario to South Dakota, south to Florida and Texas.

Ontario: Sarnia, Dodge 128, 130, Macoun 26332; St. Clair River, Dodge 124; Birch Island, Macoun 26331; Point Edward, Macoun 26330.

Pennsylvania: Lancaster County, Heller 701, 4777, 4786, Porter in 1862, Small in 1890 and 1892.

Oнiо: Erie County, Moseley in 1895; Columbus, Werner 6777.

INDIANA: Clarke, Umbach in 1898.

Ildinors: Chicago, Bebb 2928, Chase 1474, 1479, 1729, 2006, Hill in 1901; Ingraham in 1893; Beach, Umbach 2543; St. Clair County, Eggert 241.

Michigan: Port Huron, Dodge in 1909; Orion, Farwell 893; Jackson County, Wheeler in 1892.

South Daкота: Stearns, Wallace 46.

Iowa: Cedar Rapids, Pammel in 1889 (Mo. Bot. Gard. Herb.).

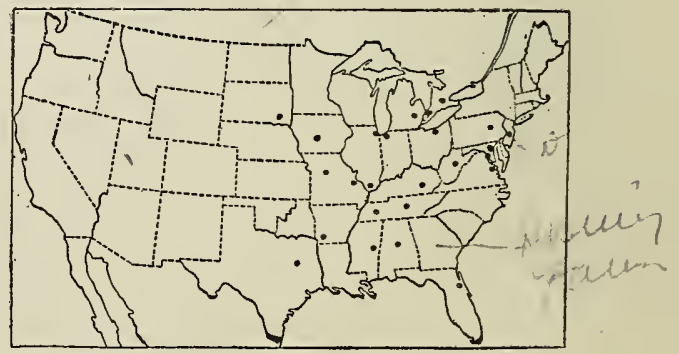

FIG. 37.-Distribution of $P$. flexile.

Missouri: Glenwood, Bush 3295; St. Louis, Eggert in 1875; Dodson, Bush 848; Eagle Rock, Bush 384; Noel, Bush 5259.

Balt; more District of Columbia: Steele in 1896 and 1898.

chill in Virginia: Four-Mile Run, Chase 5444.

West Virginia: Peters Mountain, Steele 281.

FlORIDA: Without locality, Curtiss in 1886.

Kentucky: Bell County, Kearney 312.

Tennessee: Knoxville, Kearney in 1893, Ruth 66; Johnson City, Canby 221; Cocke County, Kearney 960; Nashville, Gattinger in Curtiss N. Amer. Pl. $3581 \mathrm{~J}, 3582 \mathrm{a}$, and J.

Alabama: Monte Sano, Baker in 1897; Jackson County, Chase 4492.

Mississippi: Starkville, Chase 4453, Kearney 72,88 in part.

Arkansas: Benton County, Plank 12, 107; Fulton, Bush 906.

Texas: Clarksville, Plank 6, 10 in part. 


\section{Panicum gattingeri Nash.}

Panicum capillare campestre Gattinger, Tenn. Fl. 94. 1887, not P. campestre Nees, 1826. No definite locality in Tennessee is given. In the Gattinger Herbarium are
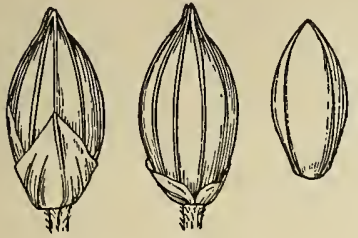

FIG. 38.-P. gattingeri. From type specimen. four specimens very much alike labeled "Panicum capillare L. var. campestre Gattinger" in Gattinger's hand. The specimen with the following data is chosen as the type: "Cedar glades near Nashville, Sept. A Gattinger."

Panicum capillare geniculatum Scribn. in Kearney, Bull. 'Torrey Club 20: 447. 1893, not P. geniculatum Lam. 1798. "In the neighborhood of Wasiota," [Bell County, Kentucky]. No type is indicated. Kearney (on page 479) lists numbers $317,335,378,497$ as $P$. capillare geniculatum. A sheet of Kearney's no. 378, collected near Wasiota, Bell County, Kentucky, in 1893, in the National Herbarium, and evidently the only one of the cited series examined by Scribner, is taken as the type.

Panicum capillare gattingeri Nash in Britt. \& Brown, Illust. Fl. 1: 123. 1896. Based on $P$. capillare campestre Gattinger.

Panicum gattingeri Nash in Small, Fl. Southeast U. S. 92 and 1327. 1903. Based on $P$. capillare campestre Gattinger.

\section{DESCRIPTION .}

Plants at first erect, but soon decumbent-spreading and rooting at the lower nodes, freely branching from the lower and middle nodes; culms papillose-hispid, in robust specimens as much as 1 meter in length; sheaths hispid like the culms; blades 10 to 20 $\mathrm{cm}$. long, 6 to $10 \mathrm{~mm}$. wide, narrow to a rounded base, more or less hispid on both surfaces or nearly glabrous; panicles numerous, terminating the culms and main branches and auxillary at most of the nodes, short-exserted or, especially the axillary, included at base, oval or elliptic in outline, the terminal 10 to $15 \mathrm{~cm}$. long, two-thirds as wide, the lateral smaller, rather densely flowered, the branches ascending or tardily spreading; spikelets shorter-pediceled than in $P$. capillare and more turgid, $2 \mathrm{~mm}$. long, 0.9 to $1 \mathrm{~mm}$. wide, elliptic; first glume about two-fifths as long as the spikelet, acute or blunt; second glume and sterile lenma equal, 5-nerved, but slightly exceeding the fruit, the palea of the sterile floret wanting; fruit $1.6 \mathrm{~mm}$. long, $0.8 \mathrm{~mm}$. wide, elliptic.

This species differs from $P$. capillare in the branching, spreading habit, and the numerous panicles, oval in outline and less diffuse, produced from all the nodes. The spikelets in $P$. gattingeri are not so variable in length as in the other species in this group.

\section{DISTRIBUTION :}

Open ground and waste places, often a weed in cultivated soil, Pennsylvania to Iowa and Missouri, south to North Carolina and Tennessee.

This is the form introduced into South $\Lambda$ frica and described by Stapf

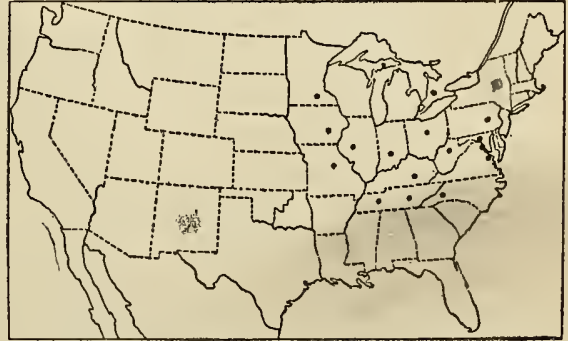

FIG. 39.-Distribution of $P$. gattingeri. as $P$. capillare. ${ }^{a}$

Ontario: Kingston, Fowler in 1897 (Field Mus. Herb.).

Pennsylvania: Lancaster County, Heller in 1901. 
Oнго: Sheffield, Ricksecker in 1894; Cincinnati, Lloyd in 1883.

In Liana: Lafayette, Dorner 87.

Iluinois: Peoria, Brendel; Wady Petra, V. H. Chase 124 in 1897, 783; Canton, Wolf in 1882 .

Minnesota: Hennepin County, Sandberg in 1890 (Univ. Cal. Herb.).

Iowa: Emmett County, Pammel \& Crutty 850.

Missour1: Sugar Creek, Bush 4824; Monteer, Bush 5116.

Marylanid: Bethesda, Steeie in 1899; Plummers Island, Steele in 1897; Cabin John, Chase 2628.

District of Columbia: Hitchcock 167, Williams in 1900.

Virginia: Arlington, Chase 5443.

West Virginia: Aurora, Steele in 1898.

North Carolina: Magnetic City, Wetherby 21.

Kentucky: Bell County, Kearney 378.

Tennessee: Cocke County, Kearney 962, 963; Knoxville, Ruth 59 in part; Nashville, Gattinger.

\section{Panicum philadelphicum Bernh.}

Panicum capillare sylvaticum Torr. Fl. North. \& Mid. U. S. 149. 1824, not P. sylvaticum Lam. 1798. "In dry woods near New York." The type is in Columbia University Herbarium.

Panicum philadelphicum Bernh.; Trin. Gram. Pan. 216. 1826. This is mentioned by Trinius as a variety of $P$. capillare, similar to his $\beta[P$. flexile], but with spikelets

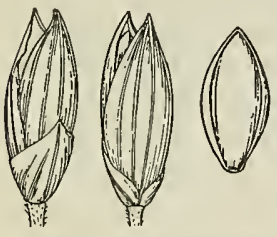

FIG.40.-P.philadelphicum. From duplicate typespecimen in Stockholm Herbarium. only acute [not acuminate as in the others], "misit s. $\mathrm{n}$. Pan. philadelphici sibi cl. Bernhardi." Enough description is given to technically constitute publication. Nees later $a$ describes the species more fully. The type, in the Trinius Herbarium, is from Philadelphia, sent by Bernhardi. On the same sheet is a specimen of $P$. flexile from the same source, but a drawing by Trinius with the name of $P$. philadelphicum indicates which specimen is the type.

Panicum porphyrium Trin.; Nees, Agrost. Bras. 198. 1829. This is given as a synonym under $P$. philadelphicum Bernh. We have not seen the type.

Panicum torreyi Fourn. in Hemsl. Biol. Centr. Amer. Bot. 3: 497. 1885. Based on P. capillare sylvaticum Torr. Fournier's description $b$ does not apply to this species and a specimen in the Fournier Herbarium, cited by him under this name, is $P$. bulbosum.

Panicum capillare minimum Engelm.; Gattinger, Tenn. Fl. 94. 1887. No definite locality in Tennessee is mentioned. The type in the Gattinger Herbarium bears the name in Gattinger's writing and the data "Greenbriar, Sept. '78. A. Gattinger." This name is initialed "F. L. S." by Scribner, hence the same name publishedc later by him is also based on this specimen.

Panicum minimum Scribn. \& Merr. U. S. Dept. Agr. Div. Agrost. Circ. 27: 4. 1900. Based on $P$. capillare minimum Engelm.

Panicum soboliferum Tuckerm.; Scribn. \& Merr. Rhodora 3: 106. 1901. This is given as a synonym under $P$. minimum. Tuckerman's specimen, in the Gray Herbarium, is from "Head of Lake Memphremagog, Vt., Sept. 1859." 


\section{DESCRIPTION.}

Plants light yellowish green, in small tufts, freely branching, erect or rarely decumbent at base, 15 to $50 \mathrm{~cm}$. high, depauperate, northern specimens sometimes forming small mats; culms slender, papillose-hispid to nearly glabrous, more or less zigzig at base, the lower internodes much shortened; sheaths mostly longer than the internodes, papillose-hispid; blades erect or ascending, 4 to $15 \mathrm{~cm}$. long, 2 to $6 \mathrm{~mm}$. wide, rather sparsely hirsute, rarely nearly glabrous; panicles exserted, diffuse, ovoid, 10 to $20 \mathrm{~cm}$. long, forming one-third the entire height of the plant or more, few-flowered, the capillary, scabrous branchlets solitary, bearing rather short-pediceled spikelets, usually in twos, at the ends; spikelets 1.7 to $2 \mathrm{~mm}$. long, $0.7 \mathrm{~mm}$. wide, elliptic; first glume about two-fifths the length of the spikelet, 5 -nerved, acute; second glume and sterile lemma equal, only slightly exceeding the fruit, the palea of the sterile floret wanting; fruit $1.5 \mathrm{~mm}$. long, $0.6 \mathrm{~mm}$. wide, elliptic.

This species differs from $P$. capillare in its narrow, erect blades, more slender culms, and smaller, fewer-flowered panicles, with more divergent branches and spikelets mostly in twos. The spikelets are usually slightly smaller, but the spikelets of the type of $P$. philadelphicum and of several other specimens are $2 \mathrm{~mm}$. long.

Two specimens from Stone Mountain, Georgia, Harper 184 and Hitchcock 439, have spikelets $2.2 \mathrm{~mm}$. long, and are erect, narrow-leaved plants with somewhat the aspect of $P$. flexile.

\section{DISTRIBUTION .}

Dry open or sandy ground, Maine to Wisconsin and Oklahoma, south to Georgia and Mississippi.

Quebec: Chandiere River, Macoun 7444 (Herb. Geol. Survey Can.).

Marne: Holden, Knight in 1893; Mattawamkeag, Fernald 2802; Henderson, Parlin 1776.

New Hampshire: Alstead, Fernald 361.

Vermont: Lake Memphremagog, Tuckerman in 1859 (Gray Herb.).

Connecticut: Hadlyme Ferry, Graves 167.

Rhode Island: Lincoln, Fernald in 1906 (Gray Herb.).

New YoRk: Kinderhook Iake, Peck; Verona, Haberer in 1900.

New Jersey: Lakehurst, Macken1 zie 2366.

3 Pennsylvania: LancasterCounty, Heller 4789.

Oнго: Ottawa, Kellerman in 1900 (Univ. Ohio Herb.).

Wisconsin: Sauk City, Luders in 1885; Granite Heights, Cheney 2911.

Missouri: Monteer, Bush 5119, 5120 ; Readings Mill, Bush 5203.

Delaware: Collins Beach, Commons in 1879.

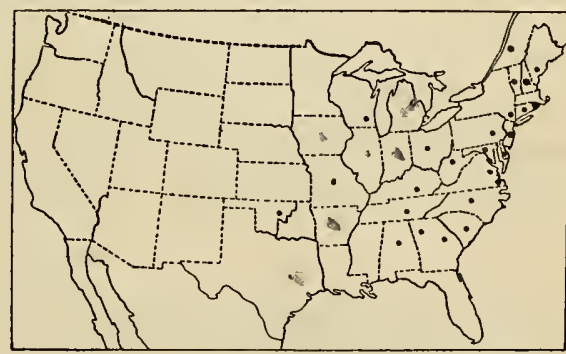

FIG. 41.-Distribution of $P$. philadelphicum.

MarYland: Glen Echo, Kearney in 1897; Chevy Chase, Chase 2599.

District of Columbia: Chase 5441, Kearney in 1897, Steele in 1899, Vasey in 1882, Williams 10 in part, 12.

Vrrainia: Four-Mile Run, Hitchcock 166; Alexandria, House 413; Portsmouth, Chase 3687; Craigs, Steele 16.

West Virginia: Aurora, Steele in 1898; Baileysville, Morris 1283.

North Carolina: Chapel Hill, Ashe.

South Carolina: Orangeburg, Hitchcock 7.

Georgia: Thomson, Bartlett 1024; Stone Mountain, Harper 184, Hitchcock 439. 
Kentucky: Harlan County, Kearney 151.

Tennessee: Bluff City, Hitchcock 165; Cocke County, Kearney 961; Chester County, Bain in 1892.

Alabama: Cullman County, Eggert 58 .

Окцанома: Sapulpa, Bush 722 in 1894.

Texas: Dallas County, Reverchon 1842 (Mo. Bot. Gard. Herb.).

23. Panicum capillare L.

Panicum capillare L. Sp. Pl. 58. 1753. Linnæus gives no description of his own but bases his name upon a phrase name of Gronovius $a$ which he quotes. Hence the type of $P$. capillare is the same as the type of Gronovius's species, namely, Clayton no. 454, cited by Gronovius. This specimen, in the herbarium of the British Museum, is the common form of this species with broad blades and ample panicle; the spikelets are $2 \mathrm{~mm}$. long. Linnæus also cites a phrase name and a figure from Sloane $b$ as a synonym, the Sloane plant, also in the British Museum, being Panicum trichoides Swartz. On the strength of these two citations, Linnæus gives the habitat as "Virginia, Jamaica." In the Linnæan Herbarium there is a specimen of $P$. capillare from "H. U." [Hortus Upsalensis] upon which Linnæus has written the name.

Milium capillare Moench, Meth. Pl. 203. 1794. Based on Panicum capillare L.

Panicum bobarti Lam. Encycl. 4: 748. 1798. Lamarck cites the following: "Gramen paniculatum virginianum, locustis minimis Bobarti. Moris. hist. 3. p. 202.

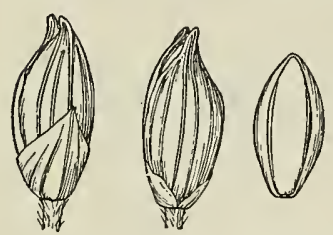

FIG. 42.-P. capillare. From type specimen in Gronovius Herbarium. no. 33. Ex herb. Vaill." It would seem that Lamarck is quoting the data on a specimen and not direct from Morison's History, since the name Bobart nowhere occurs in Morison's description or plate, ${ }^{c}$ which applies to some species of Panicularia. In the Lamarck Herbarium is a fragmentary specimen of $P$. capillare bearing in Lamarck's writing the data he quotes and in addition, also in his writing, the name "panicum Bobarti, Lam. dict." Since Lamarck's description applies to this it is taken as the type. Panicum capillare agreste Gattinger, Tenn. Fl. 94. 1887. No definite locality in Tennessee is mentioned. The type specimen, in the Gattinger Herbarium, is labeled in Gattinger's hand "Panicum capillare L. var. agreste. Fields, Ridgetop, Sumner Co., 14. IX. '82." Collected by Dr. A. Gattinger. It is a medium-sized specimen of $P$. capillare.

Panicum capillare vulgaris[e] Scribn. Tenn. Agr. Exp. Sta. Bull. 7:44. 1894. No specimen is cited and no definite locality in Tennessee is given, but Scribner states that this variety is the same as "the variety agreste of Dr. Gattinger."

\section{DESCRIPTION.}

Plants erect or ascending, simple or sparingly branched at the base or sometimes above, 20 to $80 \mathrm{~cm}$. high; culms papillose-hispid to nearly glabrous, the pubescence dense at the nodes; shea ths usually longer than the internodes, densely papillose-hispid; blades 10 to $25 \mathrm{~cm}$. long, 5 to $15 \mathrm{~mm}$. wide, scarcely narrowed toward the rounded base, hispid on both surfaces, the midrib prominent; panicle densely flowered, large and very diffuse, often half the length of the entire plant, included at the base until maturity, the solitary or fascicled branches at first ascending, at maturity divaricately spreading, the whole panicle breaking away and rolling before the wind, the main

$a$ Fl. Virg. 1: 13. 1739. See Hitchcock, Contr. Nat. Herb. 12: 118. 1908.

$b$ Voy. Jam. 1: 115. pl. 72.f. 3. 1707.

$c$ Moris. Pl. Hist. 3: 202. sect. 8. pl. 6.f. 33. 1715. 
axis and branches sparsely pilose, the numerous capillary, scabrous branchlets bearing long-pediceled spikelets toward their ends; spikelets 2 to $2.5 \mathrm{~mm}$. long, 0.8 to 0.9 $\mathrm{mm}$. wide, elliptic; first glume about half the length of the spikelet, acute, 5 to 7 -nerved; second glume and sterile lemma equal, more or less acuminate beyond the fruit, the palea of the sterile floret wanting; fruit about $1.5 \mathrm{~mm}$. long, 0.7 to $0.8 \mathrm{~mm}$. wide, elliptic.

This common and widely distributed species is variable, occasional specimens approaching or intergrading with each of its closely allied species. Thus Bush 3318, Chase 2008, and V. H. Chase 183 are intermediate between this and $P$. philadelphicum; Bush 4138, Gattinger, Nashville, Tenn., in 1882 , and Steele 243 , between this and $P$. gattingeri; Bebb 2917 and Chase 1480 approach $P$. flexile, and Blankinship, Huntsville, Oklahoma in 1896, and Griffiths 15 and 120 approach P. barbipulvinatum. Besides these there is a group of rather low, freely branching specimens with fewerflowered, divaricately branched panicles forming as much as two-thirds the

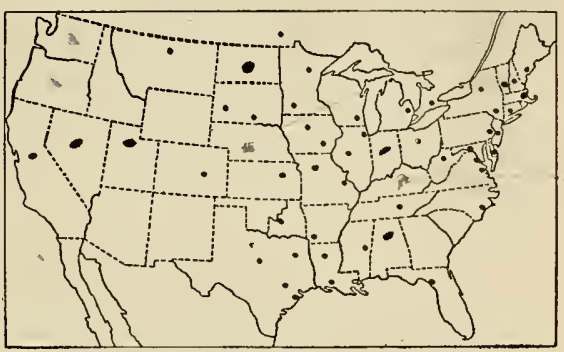

FIG. 43. Distribution of $P$. capillare. entire height of the plant, and acuminate spikelets 2.4 to $2.6 \mathrm{~mm}$. long, tending to be in twos as in $P$. philadelphicum. These are the following and are not cited in the general distribution. MaIne: Westbrook, Ricker 975; Massachusetts: South Hadley, Cook in 1887; Pennsylvania: Williamsport, Small \& Heller in 1890; New York: Verona, Haberer in 1900; Illinois: Chicago, Nelson 3000.

A Florida specimen, Combs 665 , has exceptionally turgid spikelets $2.5 \mathrm{~mm}$. long.

\section{DISTRIBUTION.}

Open ground, fields and waste places, Maine to Dakota and Colorado, south to Florida and Texas; also introduced in the Bermudas.

MaIne: Bangor, Knight 65.

New Hampshire: Jaffrey, Robinson 396.

Vermont: Manchester, Day in 1898.

Massachusetts: Boston, Hitchcock in 1903 (Hitchcock Herb.).

Connecticut: South Glastonbury, Wilson 1249.

New York: New Hannibal, Pearce in 1883; Oxford, Coville in 1884.

Ontario: Galt, Herriot 69; Kingston, Fowler in 1897; Wilmot Center, Umbach in 1899; Windsor, Macoun 26317; Sarnia, Morris A 171; Belleville, Macoun in 1864.

New Jersey: Stockholm, Van Sickle in 1895.

Pennsylvania: Philadelphia, Scribner 48; Smith 110; Easton, Porter in 1894.

OHIo: Berea, Watson in 1897; St. Marys, Wetzstein in Kneucker Gram. Exs. 189; Columbus, Kellerman 6765.

Illinors: Chicago, Bebb 2917, Chase 1480; Naperville, Umbach in 1898; Roberts, Wilcox 109; Mokena, Chase 2008; Wady Petra, V. H. Chase 125 in 1897, 183, 774.

Michigan: Port Austin, Morris A 226.

Wrsconsin: Sauk City, Luders in 1885; Ashland, Hitchcock 5099, 5111.

Manitoba: Killarney, Macoun 13225.

Minnesota: Spicer, Frost in 1892; Fort Snelling, Mearns 756; Montevideo, Moyer 43. 
South Dakota: Yankton, Bruce 10; Aurora, Wilcox in 1892; Redfield, Griffiths 207; Huron, Griffiths 15; Aberdeen, Griffiths 120.

IowA: Thayer, Morris A 252; Decatur County, Fitzpatrick 31; Ames, Ball 120; Dudgeon in Pammel Amer. Weeds 20; Manchester, Ball 720; Ledyard, Pammel 767.

Missouri: Creve Cœur Lake, Kellogg 20; Courtney, Bush 3318.

Kansas: Manhattan, Hitchcock 2380, 3842, 3851, Norton 568.

Delaware: Greenbank, Commons 30; Townsend, Canby in 1896.

MarYland: Garrett County, Smith in 1879.

District of Columbia: Steele in 1896; Blanchard in 1891.

Virginta: Arlington, Chase 5442.

West Virginia: Sweetsprings, Steele 243.

North Carolina: Wilmington, McCarthy in 1885.

Florida: Bay Head, Combs 665.

Tennessee: Knoxville, Ruth 59 in part; Nashville, Gattinger in 1882.

Ala Bama: Scottsboro, Chase 4495.

Mississippi: Starkville, Chase 4461, Kearney 80.

Arkansas: Benton County, Plank 84, 159.

Louisiana: Natchitoches, Ball 149; McCall, Combs 1435.

Texas: Seguin, Plank 99; Ennis, Smith in 1897; Texarkana, Plank 82; Dallas, Bebb 1299; Waller, Thurow in 1898; Galveston Island, Tracy 7409; Chillicothe, Ball 966.

Oкцанома: Huntsville, Blankinship in 1896.

Montana: Columbia Falls, Hitchcock 4932.

Colorado: Above Manitou, Williams 2184.

California: Pinegrove, Hansen 599.

Bermudas: Brown \& Britton 21.

\section{Panicum barbipulvinatum Nash.}

Par calecilai r.accendected Repdi / fys".

Panicum capillare brevifolium Vasey; Rydb. \& Shear, U. S. Dept. Agr. Div. Agrost. Bull. 5 : 21. 1897, not P. brevifolium L. 1753. "Montana: Manhattan, on a shaded sandbar in the Gallatin River; July 19, [Shear] 436." The type, collected by C. L. Shear, is in the National Herbarium.

Panicum barbipulvinatum Nash in Rydb. Mem. N. Y. Bot. Gard. 1: 21. 1900. "Panicum capillare brevifolium Vasey * * * not Panicum brevifolium L." is cited, but as a
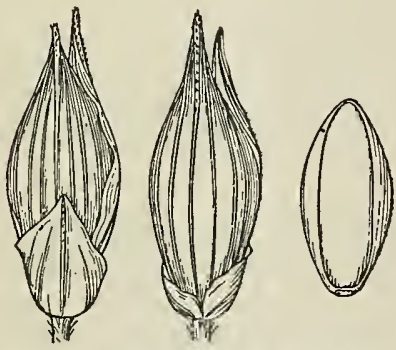

Fig.44.-P. barbipulvinatum. From type specimen. description follows and a new type is indicated, "Yellowstone Park: Lower Geyser Basin, August 4, 1897, Rydberg \& Bessey, 3544 (type)," this should not be considered as primarily a change of name. The specimen, in the herbarium of the New York Botanical Garden, agrees with Shear's no. 436, mentioned above.

\section{DESCRIPTION .}

Plants erect, 15 to $50 \mathrm{~cm}$. high, freely branching at the base, the branches often much shorter than the main culm and spreading; culms rather slender, glabrous or hispid below the nodes, the lower internodes much shortened, the nodes often somewhat geniculate; sheaths usually longer than the internodes, papillose-hispid; blades erect or erect-recurving, 3 to $15 \mathrm{~cm}$. long, 3 to $12 \mathrm{~mm}$. wide, longer or wider in exceptional specimens, hispid on both surfaces or sometimes nearly glabrous; panicles soon exserted, about half the length of the entire plant, rather few-flowered, the branches early divaricate, the pulvini often. 
prominent, hispid, the axis and branches scabrous only or sometimes sparsely pilose; spikelets 2.5 to $3.3 \mathrm{~mm}$. long (usually about $3 \mathrm{~mm}$. long), $1 \mathrm{~mm}$. wide, turgid, lanceolate-elliptic, acuminate; first glume about two-fifths the length of the spikelet, pointed, the midnerve scabrous toward the apex; second glume slightly longer than the sterile lemma, both much exceeding the fruit, 9-nerved, the nerves scabrous toward the apex, the palea of the sterile lemma wanting; fruit 1.7 to $1.8 \mathrm{~mm}$. long, $0.9 \mathrm{~mm}$. wide, elliptic.

This species differs from $P$. capillare in being on the average lower, in having shorter, less pubescent blades crowded toward the base of the plant, shorter, exserted panicles with divaricate branches, and larger spikelets.

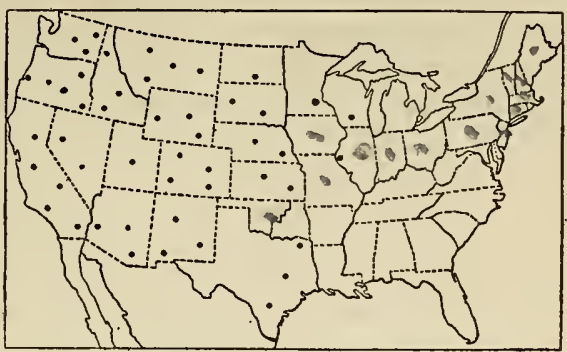

FIG. 45.-Distribution of $P$. barbipulvinatum. The plants are often depauperate and tufted and the blades sometimes whitemargined.

Occasional specimens, as Mearns 743, Parish 1081 and Rydberg 1538, scarcely branching at the base and with longer blades, approach $P$. capillare.

\section{DISTRIBUTION.}

Open ground, waste piaces and cultivated fields, Wisconsin, Minnesota to British Columbia, south to Texas and southern California.

Illinors: Oquawka, Patterson.

Wisconsin: Madison, Agr. Exp. Sta. (probably transient adventive).

Minnesota: Fort Snelling, Mearns 755; Hennepin County, Sandberg in 1889; Duluth, Hitchcock 5083 .

North DA котA: Medora, Brannon 134, Bismarck, Field 1867; Devils Lake, Hitchcock 5050 .

South Daкотa: Hot Springs, Rydberg 1096; White Horse Camp, Griffths 278; Cheyenne River, Wallace 2; Bellefourche, Griffiths 399; Huron, Griffiths 7.

Nebraska: Simeon, Bates 1114; North Platte, Plank 38; Central City, Rydberg 2011, Shear 264; Niobrara, Clements 2705; Hooker County, Rydberg 1538; Grant County, Rydberg 1788.

Kansas: Bucklin, Hitchcock in 1892; Ulysses, Thompson 56; Syracuse, Thompson 134; Tribune, Reed in 1892; Osborne City, Shear 152.

Texas: Abilene, Tracy 8295; Paloduro, Gardner 24; without locality, Nealley in 1889.

Montana: Great Falls, R. S. Williams 843; Silesia, Griffiths \& Lange 15; Upper Big Horn River, Blankinship 179; Missoula River, Scribner 328; Glendive, Ward in 1883; Billings, Williams \& Griffths 246; Manhattan, Shear 436.

Wroming: No Wood Creek, Williams 2847; Sand Creek, E. Nelson 4984; Sybille Creek, E. Nelson 481; Badger, A. Nelson 8346; Cheyenne River, Geyer in 1839; Buffalo Fork, Tweedy 93, 95; Newcastle, Griffiths 684; Yellowstone National Park, Chase 5251, 5253, Hitchcock 2114, Rydberg \& Bessey 3544.

I daho: St. Anthony, Merrill \& Wilcox 152; Merrill 43; Shoshone, Evermann in 1893; Rathdrum, Sandberg, Heller \& MacDougal 713; Caldwell, Chase 4746.

Washington: Kittitas County, Sandberg \& Leiberg 431; Waitsburg, Horner 526; Streptoe, Vasey 3065; Prosser, Cotton 625, 891; Spokane, Chase 4986; Lake Chelan, Elmer 484, 848.

British Columbia: Sicamous, Macoun 6 in 1889.

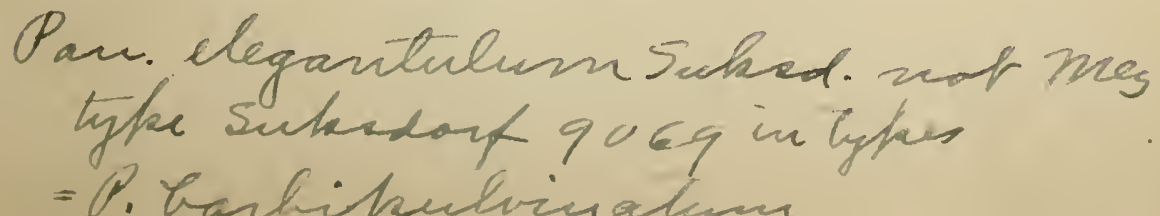




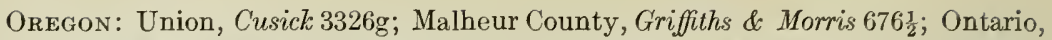
Griffiths \& Morris 935; Harney County, Griffiths \& Morris 891, 900; Malheur Lake, Griffiths \& Morris 738; Manns Lake, Griffiths \& Morris 696; Beulah, Griffiths \& Morris 864; Princeville, Leiberg 834; Milton, Brown 34; Upper Klamath Lake, Leiberg 714; Sauvies Island, Howell in 1882; Corvallis, Hitchcock in 1901; Roseburg, Hitchcock 2789, 2798.

Colorado: Denver, Eastwood 17a, Letterman in 1884; Manitou, Chase 5292, 5307; Rocky Ford, Griffiths 3313; Fort Collins, Agr. College 3368, Cowen 549; Golden, Rydberg 2505, Shear 755; Canyon City, Shear 965; Piedra, Baker in 1899; Durango, Tweedy 386; Black Canyon, Baker 676; Steamboat Springs, Eastwood 14; Grand Junction, Hitchcock 2204; Montrose, Hitchcock 2205; above Manitou, Hitchcock 2374; Ouray, Hitchcock 2275; Trinidad, Chase 5345.

Uтан: Cottonwood Canyon, Watson 1349; Logan, Rydberg 2351; Gunnison, Ward 679; Elk Ranch, Jones 6035; Ephraim, Tidestrom 2482.

Nevada: Leonard Creek, Griffiths \& Morris 270; Big Creek, Griffiths \& Morris 188; Ruby Valley, Watson 1349; Reno, Tracy 192; Virginia City, Bloomer 2265 .

New Mexico: Tierra Amarilla, Wooton 2948; Cliff, Smith in 1897; White Mountains, Wooton 303; Albuquerque, Harward 21a; Las Cruces, Plank 2; Mogollon Mountains, Metcalfe 434; Pecos, Standley 4948; Cimarron Canyon, Griffiths 5551; Organ Mountains, Wooton 1071; Deming, Hitchcock 3760; Las Vegas Hot Springs, Grant 5536; Mesilla Park, Hitchcock 3819; Dona Ana County, Wooton \& Standley 3184 .

Arizona: San Francisco Mountains, Leiberg 5783; Canyon de Chelly, Griffiths 5852; Big Valley Mountains, Baker \& Nutting in 1894; San Bernardino Ranch, Mearns 743, 788.

California: Castle Crag, Hitchcock 3069; Mt. Shasta, Palmer 2649 in 1892; Yreka, Butler 871; on the Sacramento, Wilkes Expl. Exp.; Tulare County, Michener \& Bioletti 115, Palmer 2709 in 1892; Modoc County, Baker \& Nutting in 1894; Riverside, Hall in 1901, Reed 1137; Colorado River, Cooper 2228; San Bernardino, Parish 1081.

\section{Panicum hirticaule Presl.}

Panicum hirticaulum[e] Presl, Rel. Haenk. 1: 308. 1830. The locality as given by Presl is "ad Acapulco, Mexico." The type, in the herbarium of the National
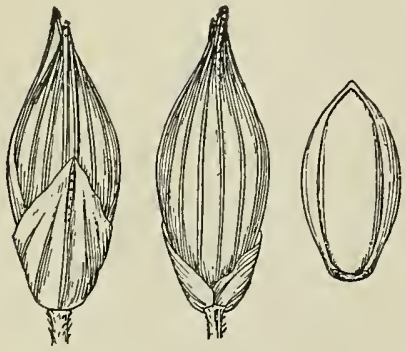

FIG. 46.-P. hirticaule. From type Especimen. Museum at Prague, is labeled "Mexico." It represents the medium form "of the species, with nearly simple culms, narrowly ascending lower panicle branches and reddish brown spikelets, 3 $\mathrm{mm}$. long.

Panicum flabellatum Fourn. Bull. Soc. Bot. France II. 27:293. 1880, not Steud. 1854. This is published in a list of plants collected in Nicaragua by Paul Lévy, "Omotepe (n. 1166)" being cited. The type, Lévy no. 1166 in the Paris Herbarium, was collected October, 1869, on "Prairies, Ile d'Omotepe."

Panicum polygamum hirticaulum $[e]$ Fourn. Mex. Pl. 2: 28. 1886. Based on "P. hirticaulum Presl," but the specimens here cited are referable to $P$. maximum.

This species was listed by Brandegee $a$ as Panicum capillare var. glabrum Vasey, without description, having been so named by Vasey. The specimen in the National Herbarium consists of several small plants of $P$. hirticaule. 
DESCRIPTION.

Plants erect, simple or nearly so, or sometimes branching and decumbent at base, 15 to $70 \mathrm{~cm}$. high; culms papillose-hispid to glabrous, nodes spreading-hispid; sheaths papillose-hispid, but sometimes sparsely so; blades 5 to $15 \mathrm{~cm}$. long, 4 to $13 \mathrm{~mm}$. wide, often cordate at base, sparsely hispid or nearly glabrous, ciliate toward the base; panicles exserted, 5 to $15 \mathrm{~cm}$. long, scarcely one-third the entire height of the plant, rather many-flowered, the branches ascending, the lower usually narrowly so, scabrous but not pilose, bearing rather short and appressed-pediceled spikeletsalong half to two-thirds their length, the glabrous pulvini inconspicuous; spikelets 2.7 to $3.3 \mathrm{~mm}$. long, 1 to $1.1 \mathrm{~mm}$. wide (smaller in occasional specimens), lanceolate-fusiform, acuminate, typically reddish brown; first glume half to three-fourths the length of the spikelet, acuminate, the midnerve scabrous toward the apex; second glume slightly longer than the sterile lemma, both much exceeding the fruit, strongly

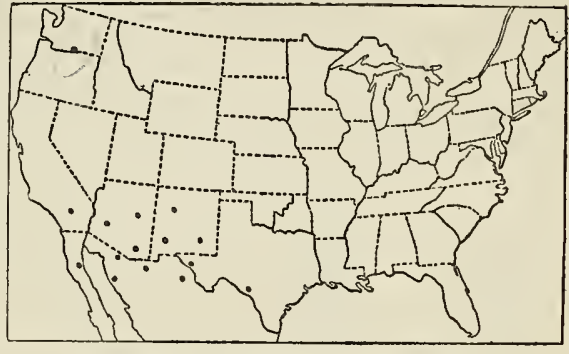

FIG. 47.-Distribution of P. hirticaule. many-nerved, the midnerves scabrous toward the summit, the palea of the sterile floret small, nerveless; fruit $2 \mathrm{~mm}$. long, $1 \mathrm{~mm}$. wide, elliptic, a scar sometimes showing on either side at base.

This species is variable; the Mexican specimens are mostly fairly typical, but the more northern ones are often rather freely branched or the panicles are less strict or the spikelets not reddish.

In the following Mexican and Central American specimens the spikelets, though reddish brown and borne on strict branches, are only 2.2 to $2.5 \mathrm{~mm}$. long. Mexico: Colima, Palmer 14, 143, and 145 in 1897; Alamos, Palmer 690 in 1890; Territorio de Tepic, Rose 3351. Nicaragua: Without locality, Flint in 1868.

\section{DISTRIBUTION。}

Rocky or sandy soil, Texas to southern California and south through Mexico; also in the Galápagos Islands.

Texas: El Paso, Jones 4212; without locality, Nealley in 1887.

Washington: Bottomland near Bingen, Suksdorf 2330. This is probably introduced, as it is far out of its range.

New Mexico: Organ Mountains, Wooton in 1907, Standley in 1906; Florida Mountains, Mulford 1012, 1078; Mangas, Metcalfe in 1897, Smith in 1898; Rio Gila, Greene 258; Hillsboro, Metcalfe 1442; San Luis Mountains, Mearns 2093.

Arizons: Tucson, Griffiths 1520, 3358, Hitchcock 3481, 3494, 3509, Pringle in 1881; Santa Rita Mountains, Griffiths 7005, 7194, Griffiths \& Thornber 4, 28, 256; Salero Mountains, Griffiths 6123; Santa Catalina Mountains, Griffiths 7146; Huachuca Mountains, Holzner 1659; Fort Huachuca, Wilcox in 1894; Pearce, Griffiths 1938; Cochise, Griffiths 1918; Phoenix, Griffiths 7317; Patagonia, Hitchcock 3658, 3675; Benson, Hitchcock 3730; near monument 82, Mearns 1905; near Mexican boundary, Mearns 738, 767.

California: Sierra Nevada Mountains, Lemmon in 1875; Jamacha, Canby 6 in 1894.

$41616^{\circ}-$ VOL $15-10-5$ 
Mexico: Near International Boundary, Mearns 2294, Merton 1705; northern Sonora, Griffiths 6758, 6799, 6892; Nogales, Hitchcock 3631; Llano, Hitchcock 3526; Hermosillo, Hitchcock 3541, 3573, 3604; Guaymas, Hitchcock 3547, 3553, Palmer 208 and 346 in 1887; Alamos, Palmer 695 and 750 in 1890; Purisima, Lower California, Brandegee 8 in 1889, 42 in 1899; State of Chihuahua, Nelson 6297, 6355, Palmer 1 b in 1885 in part; Topolobampo, Palmer 249 and 251 in 1897; Culiacán, Palmer 1544, 1545, and 1554 in part in 1891.

Galápagos Islands: Agassiz in 1891.

26. Panicum pampinosum sp. nov.

\section{DESCRIPTION.}

eight? Plants freely branching from the base; culms ascending from a decumbent base, branching at the lower and middle nodes, compressed, glabrous, or sparsely pilose

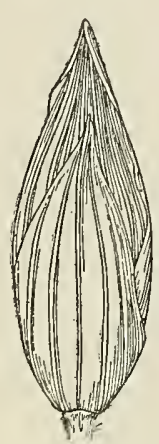

Fig. 48.-P. pampinosum. From type specimen.

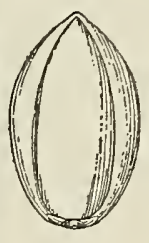

below the panicle, the nodes pubescent; sheaths loose, papillose-hispid, ciliate; ligules of very stiff hairs 2 to $3 \mathrm{~mm}$. long; blades 5 to $12 \mathrm{~cm}$. long, 5 to $10 \mathrm{~mm}$. wide, flat, scarcely narrowed at the rounded or subcordate base, sparsely pilose above, sparsely hispid beneath, the margin pilose and more or less undulate; panicles long-exserted, 6 to $15 \mathrm{~cm}$. long, half to two-thirds as wide, the branches solitary, the lower as much as 5 to $8 \mathrm{~cm}$. long, often bearing a branchlet at base, stiffly ascending, bearing several, mostly short, appressed branchlets with rather crowded, sbort-pediceled spikelets; spikelets about $4 \mathrm{~mm}$. long, $1.4 \mathrm{~mm}$. wide, very turgid, pointed; first glume more than three-fourths the length of the

spikelet, pointed; second glume and sterile lemma subequal, exceeding the fruit and pointed beyond it, the sterile palea short; fruit $2.2 \mathrm{~mm}$. long, $1.3 \mathrm{~mm}$. wide, oval, an indistinct scar at the base.

Type U. S. National Herbarium no. 592754, collected August 25, 1903, on range reserve, altitude $2,6 \mathrm{C} 0$ feet, Wilmot, Arizona, by Prof. J.J.Thornber (no. 193).

\section{DISTRIBUTION}

On mesas, New Mexico and Arizona.

New Mexico: Organ Mountains, Wooton 2014; Grant County, Rusby 444; without locality, Wright 2084.

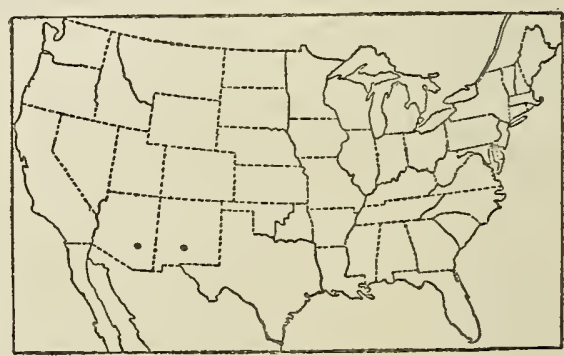

FIG. 49.-Distribution of $P$. pampinosum.

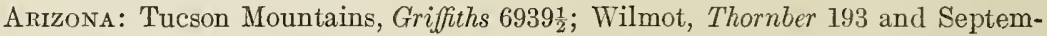
ber 3, 1903 (the latter in Univ. Ariz. Herb.).

$\checkmark$ 26A. Panicum decolorans H. B. K. $a$

$a$ While this revision was in press this species was collected by A. S. Hitchcock at its type locality, Querétaro, Mexico. It has therefore been removed from the list of doubtful species. The description and illustration will be found on page 328 . 
- 27. Panicum stramineum sp. nov.

DESCRIPTION.

Plants ascending or widely spreading, sparingly branching at the base and lower nodes, or simple, 20 to $50 \mathrm{~cm}$. high; culms glabrous, the nodes appressed-villous;
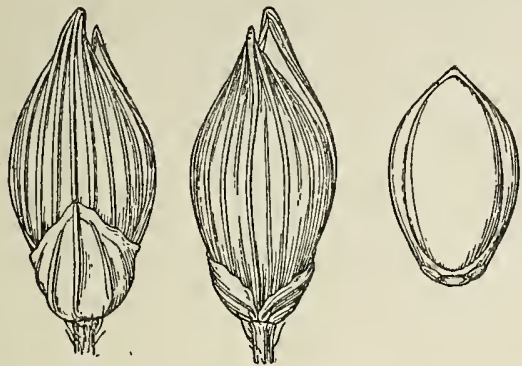

FIG. 50.-P. stramineum. From type specimen. sheaths glabrous, sparsely papillose or papillose-hispid; blades erect or ascending, 10 to $30 \mathrm{~cm}$. long, 4 to $15 \mathrm{~mm}$. wide, rounded or somewhat cordate at base, glabrous, scabrous on the margin and sometimes on the upper surface, sometimes ciliate at base; panicles finally exserted, one-fourth to one-third the entire height of the plant, ovoid in outline, rather many-flowered, the pedicels scarcely as appressed as in $P$. hirticaule; spikelets 3.2 to $3.7 \mathrm{~mm}$. long, $1.5 \mathrm{~mm}$. wide, elliptic, abruptly acuminate, turgid, pale stramineous; first glume one-third the length of the spikelet, blunt or subacute, the nerves usually anastomosing; second glume and sterile lemma equal, or the glume slightly shorter, not much exceeding the fruit, the palea of the sterile floret as long as the fruit, 2-nerved; fruit $2.2 \mathrm{~mm}$. long, $1.3 \mathrm{~mm}$. wide, obovate-elliptic, turgid, a rather prominent scar on either side at base.

Type U.S. National Herbarium no. 592753, collected 1887, Guaymas, Sonora, Mexico, by Dr. Edward Palmer (no. 206).

This species differs from $P$. hirticaule in being nearly glabrous throughout, in the longer blades, more turgid, less long-pointed spikelets with shorter, scarcely acute first glume.

\section{DISTRIB UTION.}

Rich bottom lands and damp soil, southern Arizona and northwestern Mexico.

Arizona: Near the Mexican boun-

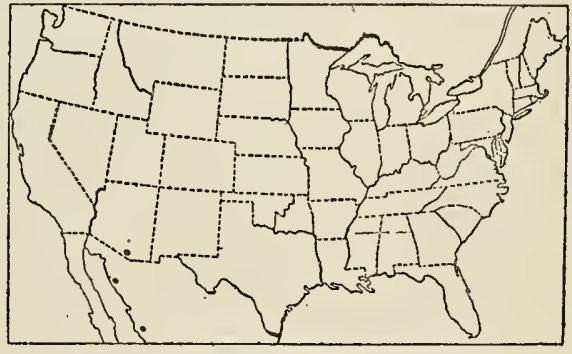

Fig. 51.-Distribution of P. stramineum.

dary, Pringle in 1884; Tucson, Thornber in 1901, and 219 (the latter in N. M. Agr. Col. Herb.).

Mexico: Guaymas, Palmer 168a and 206 in 1887; Culiacán, Palmer 1538 in 1891; State of Sinaloa, Rose 1878, 1883; Acaponeta, Rose 1889, 3281.

\section{- 28. Panicum sonorum Beal.}

Panicum capillare miliaceum Vasey, Contr. Nat. Herb. 1: 28 1890, not $P$. miliaceum L. 1753. Collected at Lerdo, Mexico, at the head of the Gulf of California, in 1889, Palmer 947. This is not based on P. miliaccum L. The type is in the National Herbarium.

Panicum sonorum Beal, Grasses N. Amer. 2: 130. 1896. Based on P.capillare miliaccum Vasey. 


\section{DESCRIPTION.}

Plants robust, erect or spreading, $60 \mathrm{~cm}$. to over 1 meter high; culms glabrous or sparsely papillose-hispid, the nodes pubescent; sheaths papillose-hispid or nearly glabrous; blades 15 to $40 \mathrm{~cm}$. long, 15 to $30 \mathrm{~mm}$. wide, cordate-clasping at base, rather
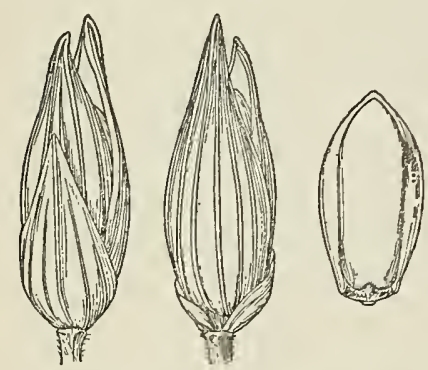

FiG. 52.- $P$. sonorum. From type specimen. prominently nerved, glabrous or sparsely papillosehispid; panicles large and more or less drooping, 20 to $30 \mathrm{~cm}$. long, densely flowered, the numerous branches narrowly ascending; spikelets 3 to 3.3 $\mathrm{mm}$. long, $1.1 \mathrm{~mm}$. wide, lanceolate, strongly nerved, brownish; first glume half to two-thirds the length of the spikelet, acuminate; second glume slightly exceeding the sterile lemma, the palea of the sterile floret wanting; fruit $2.1 \mathrm{~mm}$. long, $1 \mathrm{~mm}$. wide, oblong-obovate, subacute.

This species may be a cultivated form of $P$. hirticaule. It is large in all its vegetative parts. Palmer states that it is used as food by the Cocopa Indians, the seed being sown in spring on wet ground. A specimen from the State of Chiapas in southern Mexico, Nelson 2959, is intermediate between this and P. hirticaule but is more robust than the latter species, the blades being $15 \mathrm{~cm}$. long and $18 \mathrm{~mm}$. wide.

DISTRIBUTION.

Rich bottom land, northwestern Mexico.

Mexico: Lerdo, Palmer 947 in 1889; southwestern Chihuahua, Palmer $1 \mathrm{c}$ in 1885; Culiacán, Palmer 1539 and 1554 in part in 1891.

$\checkmark$ 29. Panicum parcum sp. nov.

DESCRIPTION .

Plants sparingly branching from the middle or upper nodes; culms 30 to $50 \mathrm{~cm}$. high, slender, erect or somewhat geniculate at base, glabrous; sheaths rather sparingly papillose-hispid, glabrate toward the base; ligules 1 to $2 \mathrm{~mm}$. long; blades ascending, rather thin, linear, elongated, 10 to $30 \mathrm{~cm}$. long, 2 to $6 \mathrm{~mm}$. wide, slightly narrowed to the base, acuminate, sparsely pilose on both surfaces or glabrate, more or less ciliate; panicles short-exserted, the terminal 10 to $20 \mathrm{~cm}$. long, half to two-thirds as wide (the axillary smaller), few-flowered, the few, slender, but not capillary, flexuous branches solitary, remote, ascending, bearing ascending or appressed branchlets with scattered, rather long-pediceled spikelets; spikelets about $6 \mathrm{~mm}$. long, 1.8 $\mathrm{mm}$. wide, turgid, acuminate-pointed; first glume about half the length of the spikelet, pointed; second glume longer than the sterile lemma, both exceeding the fruit and pointed beyond it, the sterile palea about half as long as its lemma; fruit $3.3 \mathrm{~mm}$. long, $1.4 \mathrm{~mm}$. wide.

Type U. 'S. National Herbarium no. 471378, collected October 9 to 15,1891 , on

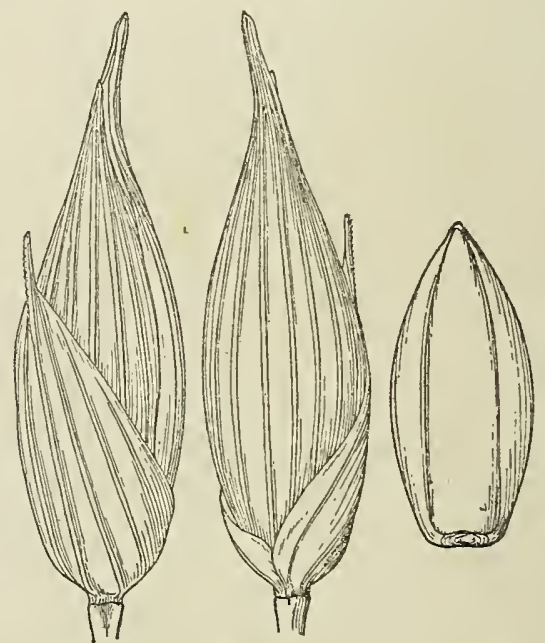

Fig. 53.-P. parcum. From type specimen. "mountain side, not very common," Lodiego, on the Culiacán River, Sinaloa, Mexico, by Edward Palmer (no. 1657). 
The only other specimen examined is also from the vicinity of Culiacán, Sinaloa; Copradia, Brandegee 4 in 1904.

\section{- 30. Panicum miliaceum L.}

Panicum miliaceum L. Sp. Pl. 58. 1753. "Habitat in India" is the only citation given. We have not seen the type, which may not be in existence.

Milium panicum Mill. Gard. Dict. no. 1. 1759. Based on Panicum miliaceum L.

Milium esculentum Moench, Meth. Pl. 203. 1794. Based on Panicum miliaceum L.

Panicum milium Pers. Syn. Pl. 1:83. 1805. Based on P. miliaceum L. the original description of which is copied but very slightly augmented.

Panicum asperrimum Fisch.; Jacq. Eclog. Gram. 46. pl. 31. 1815-1820. The description is based on a specimen grown in the garden of the University at Vienna from seed received from Count Razoumovsky of Gorenki [near Moscow]. This name was earlier listed by Fischer $a$ without description. We have not seen the type, but Jacquin's description and plate identify the species.

\section{DESCRIPTION.}

Plants erect or decumbent at base, usually branching from the basal nodes, $20 \mathrm{~cm}$. to as much as 1 meter high; culms stout, hispid below the pubescent nodes or glabrous; sheaths loose, sometimes longer than the internodes, papillose-hispid; blades drying yellowish green, more or less pilose on both surfaces, or glabrate, as much as $30 \mathrm{~cm}$. long and $2 \mathrm{~cm}$. wide, rounded at base, gradually narrowed to the apex; panicles usually more or less included at base, 10 to $30 \mathrm{~cm}$. long, more or less nodding, usually rather compact, the numerous branches narrowly ascending, very scabrous, spikelet-bearing toward the summit; spikelets 4.5 to $5 \mathrm{~mm}$. long, ovate, acuminate, strongly many-nerved;
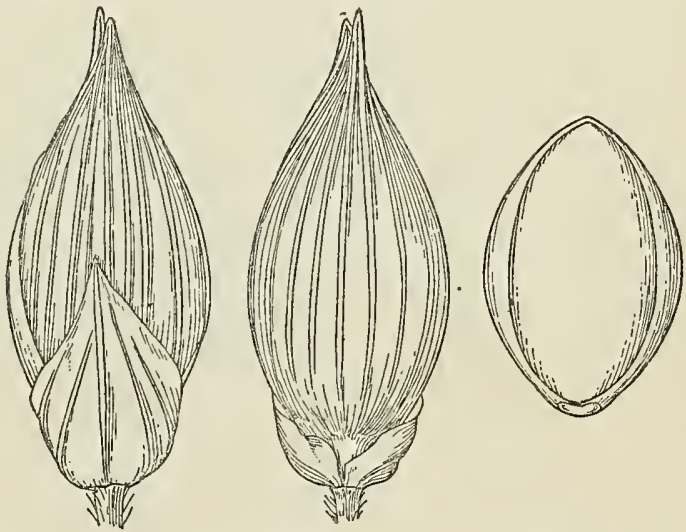

FIG. 54.-P. miliaceum. From Griffith's no.6490, East Himalaya.

first glume half the length of the spikelet or more, acuminate; second glume and sterile lemma subequal, a small palea in the sterile floret; fruit $3 \mathrm{~mm}$. long, $2 \mathrm{~mm}$. wide, elliptic, stramineous to reddish brown.

\section{DISTRIBUTION.}

Waste places, introduced from the Old World. Cultivated under the name of broomcorn millet or hog millet. Scattered specimens, introduced or escaped from cultivation, are found in all the cooler parts of the United States, especially eastward. Cultivated specimens may be larger than indicated in the above description, while in dry soil depauperate specimens occur.

Maine: Orono, Harvey in 1897.

VERMONT: Burlington, Brainerd in 1895 (Gray Herb.).

Massachusetts: Essex County, Conant in 1880. 
Connecticut: Bridgeport, Eames in 1895.

NEW York: Ontario Beach, Britton in 1892.

New Jersey: Califon, Fisher in 1899; Landisville, Gross in 1883.

Pennsylvania: Luzerne County, Small \& Heller in 1890.

Orio: Cleveland, Claasen in 1891 (Gray Herb.).

InDIANA: Miller, Umbach 2363.

IluinoIs: Chicago, Chase 1633 (Hitchcock Herb.).

Michigan: Without locality, Farwell 1414.

Delaware: Wilmington, Commons 57.

District of Columbia: Steele in 1899.

Florida: Pensacola, Curtiss 6867.

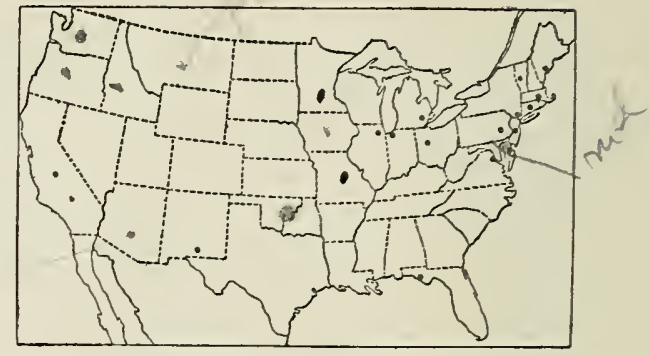

FJG. 55.-Distribution of $P$. miliaceum.

New Mexico: Lincoln County, Wooton \& Standley 3528.

Calimornia: Kenwood, Smith in 1898; Sacramento, Williams in 1906.

\section{$\checkmark$ 31. Panicum cayennense Lam.}

Panicum cayennense Lam. Tabl. Encycl. 1:173.'1791. "Cayenna. D. Stoupy." The type, in the Lamarck Herbarium, is labeled "Panicum cayennense Lam. ill. gen.
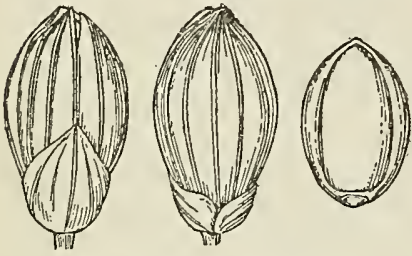

Fig. 56.-P.cayennense. From type specimen. aff. Panico capillare." Lamarck states in the original description that this species is near $P$. capillare. In the general herbarium at Paris is a specimen of $P$. rudgei from Cayenne collected by Le Blond, which is labeled in Lamarck's hand "Panicum cayennense lam. illustr. et dict." This specimen does not correspond to Lamarck's descriptions, especially the later one, ${ }^{a}$ so well as does the preceding specimen, which is therefore taken as the type.

Panicum floribundum Rich.; Lam. Encycl. 4:742.

1798. This is given as a synonym under P. cayennense, and credited to "Rich. herb." The type, in the Richard Herbarium, is from Cayenne. This specimen agrees with the first of those mentioned above.

Panicum pedunculare Willd.; Steud. Syn. Pl. Glum. 1: 77. 1854. "Brasil." This is credited to "Willd. hrbr." The name occurs earlierb as a nomen nudum. The type, in the Willdenow Herbarium, was collected by Humboldt in "Amer. meridion."

Panicum cayennense patulum Doell in Mart. Fl. Bras. $2^{2}: 220.1877$. Based on $P$. cayennense Lam.

\section{DESCRIPTION.}

Plants, erect, or, when much-branched at the base, spreading; culms 20 to $50 \mathrm{~cm}$. high, often zigzag, glabrous or more or less papillose-pilose below the pilose nodes; sheaths papillose-pilose, ciliate; blades linear, 10 to $20 \mathrm{~cm}$. long, 4 to $10 \mathrm{~mm}$. wide, rather stiffly ascending, rounded at the scarcely narrowed base, rather sparsely papillose-pilose on both surfaces or sometimes nearly glabrous; panicles terminal and

a Lam. Encycl. 4: 742. 1798.

b Steud. Nom. ed. 2. 2: 261. 1841. 
axillary from the upper 2 or 3 sheaths, rarely fascicled, approximate and forming an elongated inflorescence from two-thirds to almost the entire height of the plant, the individual panicles included at the base, 8 to $20 \mathrm{~cm}$. long, half to two-thirds as wide, the slender, scabrous branches and branchlets and the long, flexuous pedicels divaricate; spikelets 2.2 to $2.3 \mathrm{~mm}$. long, $1.2 \mathrm{~mm}$. wide, obovoid, turgid; first glume about half the length of the spikelet, acute; second glume and sterile lemma equal, slightly exceeding the fruit, abruptly short-pointed, strongly 5 to 7 -nerved, the sterile palea about half the length of its lemma; fruit $1.7 \mathrm{~mm}$. long, $1.1 \mathrm{~mm}$. wide, oval, turgid.

In its elongated inflorescence composed of several approximate panicles this species resembles $P$. rudgei Roem. \& Schult., with which it has commonly been confused.

\section{DISTRIBUTION.}

Pine woods, Costa Rica, Cuba, and South America.

Costa Rica: Buenos Aires, Tonduz 3685.

Cuba: Pinar del Rio, Wright 3865; Herradura, Tracy 9073; Isle of Pines, Curtiss 267, Palmer \& Riley 1086, Taylor 34.

French Guiana: Cayenne (Paris Herb.).

BrAzIL: Burchell 8350 .

Diffusa.--Perennials; culms stiff, somewhat tufted, sheaths mostly hirsute, ligules membranaceous, ciliate, 1 to $3 \mathrm{~mm}$. long; blades long and narrow; spikelets mostly narrowly ovate, acuminate, glabrous; first glume clasping, the equal second glume and sterile lemma exceeding the fruit and pointed beyond it, the palea of the sterile floret about half as long as its Iemma; fruit smooth and shining. The species of this group often resemble those of Capillaria, especially in their spikelets, but the latter are all annual.

Second glume and sterile lemma elongated, at least three

times as long as the fruit.................... 32. P. capillarioides.

Second glume and sterile lemma not elongated.

no Panicles narrow, compact; blades $2 \mathrm{~cm}$. or more wide... 38. P. hirsutum.

Panicles diffuse, at least at maturity; blades not over 1

$\mathrm{cm}$. wide.

Blades 1.to $3 \mathrm{~mm}$. wide, plants spreading or ascending 33. P. diffusum.

Blades mostly over $5 \mathrm{~mm}$. wide, plants erect.

Spikelets 4 to $4.2 \mathrm{~mm}$. long, the midnerves of glumes and sterile lemma scabrous toward the apex........................ 36. P. lepidulum.

Spikelets usually less than $3.5 \mathrm{~mm}$. long.

Blades hirsute on both surfaces (sometimes glabrescent), not at all glaucous..... 37. P. ghiesbreghtii.

Blades glabrous on both surfaces or with a few hairs on either surface, glaucous above.

Panicles much exceeding the leaves; spikelets 3 to $3.5 \mathrm{~mm}$. (rarely 3.7 $\mathrm{mm}$.) long.................... 35. P. hallii.

Panicles usually equaled or exceeded by the uppermost blades; spikelets 2 to $2.6 \mathrm{~mm}$. long.............. 34. P. filipes. 


\section{Panicum capillarioides Vasey.}

Panicum capillarioides Vasey in Coulter, Contr. Nat. Herb. 1:54. 1890. "Point Isabel," collected by "G. C. Nealley, in the region of the Rio Grande, in Texas."

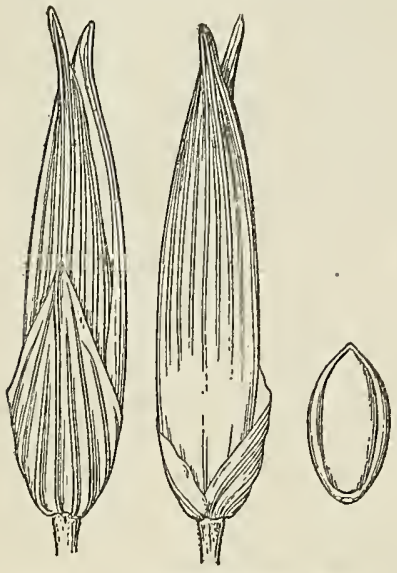

Fig. 57.-P. capillarioides. From type specimen. The type specimen, in the National Herbarium, bears the name in Vasey's writing and the serial number 634 as in the list in which the species is published.

\section{DESCRIPTION.}

Plants in tufts of few to several culms from a knotted crown, erect or ascending, 30 to $55 \mathrm{~cm}$. high; culms stiff, simple or sparingly branching, appressed-pubescent or sometimes glabrate, the nodes densely ascending-pubescent; sheaths mostly equaling or exceeding the rather short internodes, papillose-pubescent; ligules about $1.5 \mathrm{~mm}$. long; blades rather stiff, ascending, 10 to $30 \mathrm{~cm}$. long, 2 to $10 \mathrm{~mm}$. wide, scarcely narrowed to the rounded base, flat or drying somewhat involute, harshly papillose-pubescent on both surfaces, usually sparsely so beneath; panicles short-exserted, usually nearly equaled by the upper blades, diffuse, few-flowered, 10 to $20 \mathrm{~cm}$.

long, as wide or wider, the capillary branches stiffly spreading at maturity, bearing rather short-pediceled spikelets toward the ends, the axis and branches scabrous, the rather conspicuous pulvini pubescent; spikelets 5 to $6 \mathrm{~mm}$. long, 1 to $1.2 \mathrm{~mm}$. wide, lanceolate, long-acuminate; first glume one-third to half the length of the spikelet, acute, 7-nerved; second glume and sterile lemma, subequal, many-nerved, at least three times as long as the fruit, usually more or less inflated above it; fruit 1.6 to $1.8 \mathrm{~mm}$. long, 0.8 to $0.9 \mathrm{~mm}$. wide, elliptic.

This species is readily distinguished

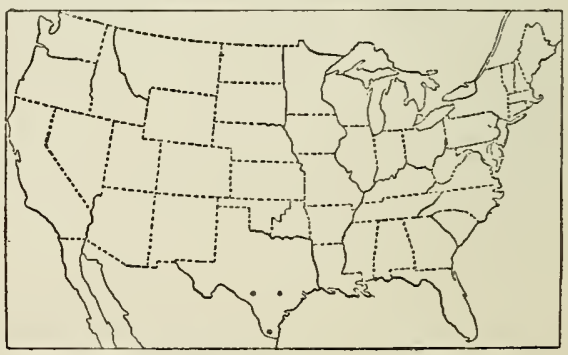

FIG. 58.-Distribution of $P$. capillarioides.

from all others by the elongated second glume and sterile lemma, greatly exceeding the small fruit.

DISTRIBUTION.

Prairie, southern Texas and northern Mexico.

Texas: San Diego, Croft 240, Nealley 69 in 1892; Pena, Nealley 30 in 1891; Kingsville, Piper in 1906; Corpus Christi to Brownsville, Hitchcock 218; without locality or date, Buckley (Hitchcock Herb.).

Mexico: Monterey, Hitchcock 5547.

\section{Panicum diffusum Swartz.}

Panicum diffusum Swartz, Prodr. Veg. Ind. Occ. 23. 1788. "Jamaica, Hispaniola." The type, $a$ in the Swartz Herbarium, is labeled "diffusum fl. ind. occ."

Panicum caespititium Lam. Tabl. Encycl. 1: 173. 1791. "Ex Amer. merid. communic. D. Richard." The type specimen, in the Lamarck Herbarium, is marked "Ex D. Richard." 


\section{DESCRIPTION.}

Plants in small, dense tufts, spreading, or ascending from a decumbent base, simple or sparingly branching, rarely repeatedly branching, 25 to $50 \mathrm{~cm}$. high; culms slender, wiry, glabrous, the nodes appressed-pubescent; sheath $_{\mathrm{s}}$ shorter than the internodes, striate, glabrous, or pubes cent along the margin toward the summit or the lower sparsely so throughout; ligules about $1 \mathrm{~mm}$. long; blades erect from the sheath but often spreading at the ends, 5 to $20 \mathrm{~cm}$. long, 1 to $3 \mathrm{~mm}$. wide, flat or drying subinvolute, sparsely pilose on the upper surface, glabrous or sparingly pubescent beneath; panicles exserted, 5 to 10 $\mathrm{cm}$. long, nearly as wide, the few capillary branches at first ascending, stiffly spreading at maturity, bearing a few short-pediceled spikelets toward the ends; spike-

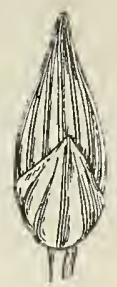

FIG. 59.-P. diffusum. Fromtype specimen.

lets 2.1 to $2.5 \mathrm{~mm}$. long, about $1 \mathrm{~mm}$. wide; first glume about half the length of the spikelet, acute, 5-nerved; second glume and sterile lemma 7 to 9 -nerved; fruit 1.5 to $1.6 \mathrm{~mm}$. long, $0.9 \mathrm{~mm}$. wide, elliptic.

A collection from Santo Domingo, Wright, Parry \& Brummel 627, is doubtfully referred here. It consists of tall plants, 60 to $70 \mathrm{~cm}$. high, with spikelets 2.8 to $3 \mathrm{~mm}$. long. The blades are narrow as in $P$. diffusum, but hirsute on both surfaces as in P. ghiesbreghtii.

\section{DISTRIBUTION.}

Savannas and borders of open woods, West Indies.

Bahamas: New Providence, Britton \& Brace 424.

Cuba: Habana, León 190, 305 in part, 923, 923b; Santiago de las Vegas, Baker \& Wilson 511, Tracy 9111, Van Hermann 1444, Wilson 1405; Triscornia, Tracy 9082; Guanajay, Palmer \& Riley 802; Prov. of Santa Clara, León 923c; without locality, Wright 3852, 3860 in part, 3877; Isle of Pines, Nueva Gerona, Curliss 384, 494.

Danish West Indies: St. Thomas, Eggers in 1882.

Windward Islands: Martinique, Duss 536.

\section{$\checkmark$ 34. Panicum filipes Scribn.}

Panicum filipes Scribn. in Heller, Contr. Herb. Frankl. Marsh. Coll. 1: 13, 1895. "Growing in rich shaded ground in the upper part of the 'Arroyo,' at Corpus Christi,"

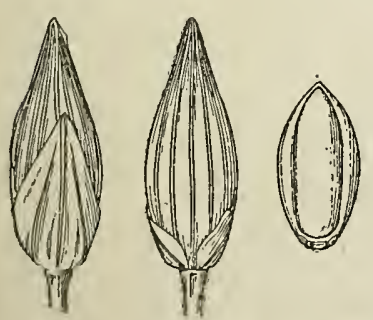

FiG. 60.-P. filipes. From type specimen.

Texas. The type, in Hitchcock's herbarium, was collected May 31, 1894, by A. A. Heller, no. 1809. The panicle is rather more lax and has longer, more delicate branchlets than usual in the species, and spikelets 2.5 to $2.6 \mathrm{~mm}$. long.

\section{DESCRIPTION.}

Plants pale green, in small dense tufts, erect or ascending, 30 to $80 \mathrm{~cm}$. high; culms simple or sparingly branching, stiff, glabrous except the appressedpubescent nodes; sheaths shorter than the internodes, glabrous or sparsely appressed-hispid toward the summit; ligules about $1.5 \mathrm{~mm}$. long; blades thin, ascending or laxly spreading, 10 to $25 \mathrm{~cm}$. long, 3 to $8 \mathrm{~mm}$. wide, flat, glaucous and glabrous on the upper surface, glabrous beneath or very sparsely papillose-hirsute; panicles exserted, usually equaled or exceeded by the uppermost blades, 7 to $25 \mathrm{~cm}$. long, about as wide, the distant branches spreading, the branchlets rather more numerous and the spikelets usually longer-pediceled than in $P$. diffusum; spikelets 2 to $2.6 \mathrm{~mm}$. 
long, about $1 \mathrm{~mm}$. wide; first glume about two-thirds the length of the spikelet, acuminate, 3 to 5-nerved, second glume and sterile lemma 5 to 7 -nerved; fruit 1.5 to $1.7 \mathrm{~mm}$. long, about $0.8 \mathrm{~mm}$. wide, elliptic.

This species has been confused with both $P$. diffusum and $P$. hallii, to both of which it is closely related. From the first it is distinguished by the taller, erect or nearly erect culms, and wider blades glabrous and glaucous on the upper surface. The typical form has a much more loosely-flowered panicle than has $P$. diffusum, but most of the specimens are less well marked. From $P$. hallii it is distinguished by the looser panicles of usually longer pediceled, smaller spikelets, by the usually taller culms and longer blades, often equaling or exceeding the panicle.

The following specimens have spikelets 2.8 to $3 \mathrm{~mm}$. long and appear to be

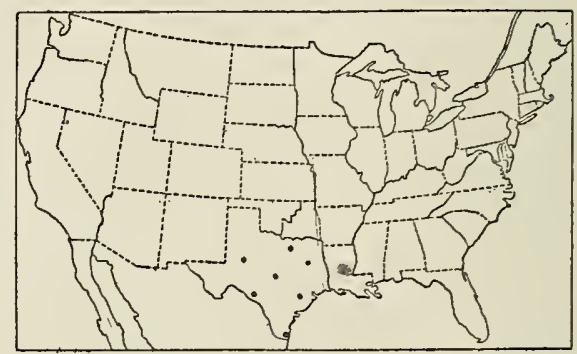

FIG. 61.-Distribution of $P$. filipes. intermediate between $P$. filipes and $P$. hallii. Texas: Abilene, Bentlcy in 1899; Daffan, Bodin 310; Dallas, Bush 1156; Spofford, Griffiths 6323; Olmito, Tracy 8908; Corpus Christi, Heller 1490. Mexico: Guerrero, Lagunillas, Langlassé 263.

A specimen from "Overflow land along Colorado River," southern California, Schellenger 3, is doubtfully referred here. It appears to be an annual but is probably $P$. filipes fruiting the first year from seed.

\section{DISTRIBUTION.}

Low open ground or among chaparral, southern Texas.

Texas: Arlington, Reverchon 3526; Terrell, Warburton in 1904; Burnet, Plank 38; Llano, Plank 2; Kingsville, Piper in 1906; Houston, Nealley in 18s6; Hempstead, Thurow in 1906; Kerrville, Heller 1883 in part; Seguin, Plank 97; Abilene, Bentley in 1899; Del Rio, Plank 85; San Diego, Nealley in 1894; Encinal, Griffiths 6387; Corpus Christi, Nealley 28 in 1891, in 1893 and 1894; Santa Maria, Nealley in 1889; Brownsville, Hitchcock 220, without locality, Buckley in 1881 and 1883, Drummond 286, 384, 394, Nealley in 1888.

\section{- 35. Panicum hallii Vasey.}

Panicum hallii Vasey, Bull. Torrey Club 11: 64. 1884. "This is number 816 of E. Hall's Texas collection, distributed as P. giganteum, Scheele." The type, in the

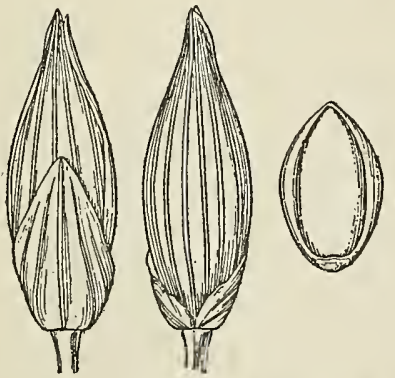

Fig. 62.-P. hallii. From type specimen. National Herbarium, was collected on "Dry hills, Austin, Eastern Texas, May 18, 1872, by Elihu Hall:" Two species were distributed by Hall under 816 , the other being $P$. filipes.

\section{DESCRIPTION.}

Plants rather glaucous green, in small tufts, erect, 15 to $60 \mathrm{~cm}$. high; culms simple or sparingly branching from the lower nodes, glabrous except the appressed-pubescent nodes; leaves commonly more or less crowded toward the base, the blades becoming curled or twisted, the lower sheaths overlapping on theshortinternodes; sheathssparsely papillose-hispid to glabrous; ligules about $1.5 \mathrm{~mm}$. long; blades erect or nearly so, 4 to $15 \mathrm{~cm}$. long, 2 to $6 \mathrm{~mm}$. wide, flat, usually sparsely papillose-ciliate toward the base, otherwise glabrous or with a few long, delicate hairs on the upper 
curling like showings with age;

surface or sparingly papillose-hispid beneath, often with a thin, cartilaginous, white margin; panicles usually long-exserted and much exceeding the leaves, 6 to $20 \mathrm{~cm}$. long, rather narrowly flabellate in outline, the few branches stiffly ascending, bearing short, appressed branchlets with approximate spikelets on short, appressed pedicels; spikelets 3 to $3.7 \mathrm{~mm}$. long, 1.1 to $1.5 \mathrm{~mm}$. wide, turgid; first glume half to two-thirds the length of the spikelet, acuminate, 3 to 5-nerved; second glume and sterile lemma strongly 5 to 7 -nerved; fruit 1.7 to $2 \mathrm{~mm}$. long, 1 to $1.3 \mathrm{~mm}$. wide, oval, obtuse, dark olive brown at maturity.

The following specimens have looser panicles than typical and spikelets only 2.8 to $3.2 \mathrm{~mm}$. lung, the two Plank specimens having also laxer blades. These appear to be intermediate between $P$. filipes and $P$. hallii but rather nearer the latter. Texas: Abilene, Tracy 7941, Del Rio, Plank 44, 57.

Leiberg's no. 5916, collected on cinder cones, is a depauperate form, scarcely $10 \mathrm{~cm}$. high.

DISTRIBUTION.

Dry prairie, rocky and gravelly hills and canyons and in bottomlands, and irrigated fields, Texas to Arizona and south to central Mexico.

Texas: Texline, Griffiths 5600; Baird, Letterman in 1882; Austin, Hall 816, Stiles in 1884; Abilene, Bentley in 1899, Tracy 7950; Colorado, Tracy 7945; Big Springs, Tracy 7953; Kimble County, Reverchon 1682; Kerrville, Smith in 1897; San Antonio, Hitchcock 219, Plank 46, 53; Corpus Christi, Hitchcock 221; Olmito, Tracy 9338; Spofford, Griffiths 6288; Del Rio, Plank 72 in part; Midland, Tracy 7952, 7954; Guadalupe Mountains, Bailey 719; Fort Davis, Nealley in 1893, Marfa, Havard 23; Sierra Blanca, Nealley in 1893; El Paso, Vasey in 1881; without locality, Nealley in 1887.

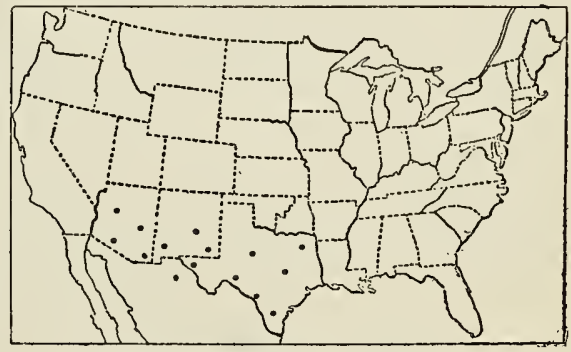

FIg. 63,-Distribution of $P$. hallii.

New Mexico: Cimarron Canyon, Griffiths 5504; Roswell, Earle 302; Carlsbad, Tracy 8200; Organ Mountains, Hitchcock 3783; Las Cruces, Griffiths 7408; Dona Ana County, Wooton \& Standley 3983; Deming, Hitchcock 3762; Grant County, Metcalfe 807, Smith in 1896 and 1897.

Arizona: San Francisco Peaks, Leiberg 5916; Ash Fork, Griffiths 7357; Prescott, Toumey in 1894; Clifton, Davidson 31a, 414a; Mescal, Griffiths 1813; Santa Rita Mountains, Griffiths 3388, Griffiths \& Thornber 238, 309; Patagonia, Hitchcock 3706; Paradise, Blumer 1683; Huachuca Mountains, Holzner Internat. Bound. Comm. 1566; without locality, Lemmon in 1883.

Mexico: Tamaulipas, Palmer 554 in 1907; Coahuila, Palmer 1338 in 1880; Chihuahua, Pringle 376.

36. Panicum lepidulum sp. nov.

DESCRIPTION.

Plants solitary or in small tufts, erect, 25 to $70 \mathrm{~cm}$. high; culms usually producing one or two erect branches from the lower nodes, sparsely papillose-pilose to merely scabrous toward the summit; sheaths longer than the short lower internodes, shorter than the middle and upper ones, papillose-hispid, the hairs ascending; ligules about $2 \mathrm{~mm}$. long; blades erect, or spreading at the apex, 7 to $30 \mathrm{~cm}$. long, 5 to $10 \mathrm{~mm}$. wide, scarcely narrowed to the more or less infolding base, flat or folded, sparsely papillosepilose to nearly glabrous on both surfaces, glaucous on the upper surface; terminal 
panicles rather long-exserted, those of the branches short-exserted or slightly included at base, 7 to $20 \mathrm{~cm}$. long, usually scarcely half as wide, the flexuous branches ascending, bearing short, rather spreading branchlets with 1 to 3 spikelets toward their ends, the whole forming a more evenly flowered panicle than in $P$. hallii; spikelets 4 to $4.2 \mathrm{~mm}$.

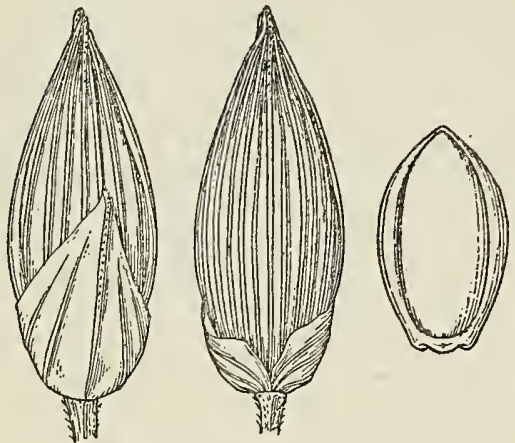

FIG.64.-P.lepidulum. From type specimen. long, about $1.5 \mathrm{~mm}$. wide, narrowly ovate, turgid, acuminate; first glume about half the length of the spikelet, acuminate, 5nerved, the midnerve scabrous toward the apex; second glume and sterile lemma strongly 7 to 9 -nerved, the midnerves scabrous toward the apex; fruit 2.3 to $2.5 \mathrm{~mm}$. long, 1.3 to $1.5 \mathrm{~mm}$. wide, oval, turgid, obtuse.

Type U. S. National Herbarium no. 155163, collected September 22, 1885, by streams, rocky hilis near Chihuahua, State of Chihuahua, Mexico, by C. G. Pringle (no. 497), and distributed as $P$. diffusum Swartz.

This species is distinguished from $P$. hallii by the more evenly flowered, narrower panicle of larger spikelets, and by the greater amount of pubescence. The plants average taller than $P$. hallii, though $P a l$ mer 533 is a depauperate specimen only $15 \mathrm{~cm}$. high.

A specimen from Santa Catalina Mountains, Arizona, Griffiths 7063, with spikelets only $3.8 \mathrm{~mm}$. long, is doubtfully referred here.

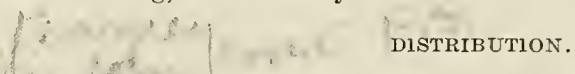

Moist places in the mountains, Chihuahua to the City of Mexico.

Mexico: Chihuahua, Pringle 497; Durango, Palmer 525 in 1896, 533 in 1906; City of Mexico, Hitchcock 5958.

\section{Panicum ghiesbreghtii Fourn.}

Panicum ghiesbreghtii Fourn. Mex. Pl. 2: 29. 1886. This name was earlier listed by Hemsley ${ }^{a}$ without description. Fournier cites three specimens, the first being "Absque loco (GHIESBREGHT)," which, since the species is named for this collector, is taken as the type. This is in the Paris Herbarium. It was collected in Mexico in 1845. A specimen collected by Ghiesbreght in Mexico and labeled $P$. ghiesbreghtii in the herbarium of the Botanical Garden in St. Petersturg, is P. flipes.

Panicum hirtivaginum Hitchc. Contr. Nat. Herb. 12: 223. 1909. "Type specimen Wright 75s, Cuba, U. S. National Herbarium no. 559958." The label on this specimen gives no locality in Cuba.

\section{DESCRIPTION.}

Plants in small tufts, rather robust; culms erect, papillose, ascending-hirsute, 60 to $80 \mathrm{~cm}$. high, the nodes densely hirsute; sheaths mostly longer than the internodes, hirsute like the culms; ligules about $2 \mathrm{~mm}$. long; blades erect or ascending, as much as $60 \mathrm{~cm}$.

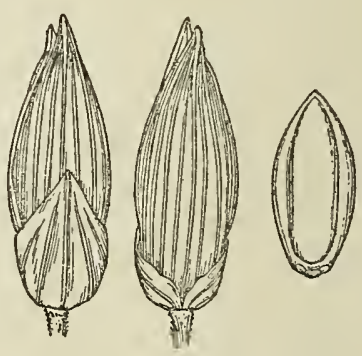

Fig. 65.-P. ghiesbreghtii. From type specimen. long and 12 mm. wide, flat, not narrowed to the rounded base, papillose-hirsute on both suricices or glabrescent; panicle short-exserted, nearly equaled by the 
upper blades, 20 to $30 \mathrm{~cm}$. long, usually less than half as wide, the branches ascending, naked at the base, the branchlets more or less appressed, bearing short-pediceled, approximate, but not crowded spikelets $3 \mathrm{~mm}$. long, $1 \mathrm{~mm}$. wide; first glume half to two-thirds the length of the spikelet, acute, 3 to 5-nerved; second glume and sterile lemma strongly 7 to 9 -nerved; fruit 1.9 to $2 \mathrm{~mm}$. long, $0.9 \mathrm{~mm}$. wide, elliptic.

This species differs from $P$. diffusum in its robust habit, wider, flat blades, hirsute on both surfaces, and in its larger spikelets.

\section{DISTR1BUTION.}

Low moist ground, Mexico, Central America, and the West Indies; also in Ecuador. Mexico: Borrego près Orizaba, Bourgeau 2751; Yucatan, Izamal, Gaumer 2477. Costa Rica: Salinas Bay, Pittier \& Durand 2633.

CubA: Santiago de las Vegas, Tracy 9116; Herradura, Tracy 9068; La Soledad, Eggers 5406; Calvario, León 922; Guayabal, León 922b; without locality, Wright 758. Bahamas: Crooked IsI., Brace 4812

Porto Rico: Tabucoa, Sintenis 4983.

LEEWARD Islands: Guadeloupe, Duss 3184 and a specimen without number or date.

Ecuador: Manabi, Eggers 15419.

\section{$\checkmark$ 38. Panicum hirsutum Swartz.}

Panicum hirsusum Swartz, Fl. Ind. Occ. 1: 173. 1797. "Habitat in Jamaicae et Hispaniolae graminosis." The type, in the Swartz Herbarium, is from "Jamaica, Swartz."

\section{DESCRIPTION.}

Plants robust, culms as much as $1 \mathrm{~cm}$. thick and 1.5 meters or more high, simple or sparingly branching, glabrous or with a few scattered hairs, the nodes appressedpubescent; sheaths mostly overlapping, appressed papillose hirsute, the hairs sometimes dense at the summit; ligules dense, about $3 \mathrm{~mm}$. long; blades flat, 20 to $50 \mathrm{~cm}$. long, 20 to $35 \mathrm{~mm}$. wide, scarcely narrowed to the rounded base, glabrous or with a few hairs toward the base, the margin serrulate; panicles short-exserted or included at base, 20 to $35 \mathrm{~cm}$. long, 3 to 12 mide, compact, densely flowered, the long lower branches erect, naked at base; spikelets 2 to $2.2 \mathrm{~mm}$. long, about $0.9 \mathrm{~mm}$. wide, rather turgid, abruptly pointed; first glume scarcely half the length of the spikelet, acute, 3 to 5 -nerved; second

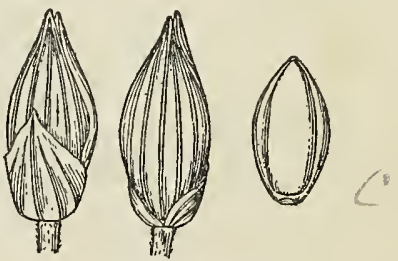

FIG.66.-P.hirsutum. From type specimen. glume and sterile lemma 5 to 7 -nerved; fruit $1.5 \mathrm{~mm}$. long, $0.7 \mathrm{~mm}$. wide, elliptic.

This species is much more robust than any other in this group, to which, because of its compact panicle, it is not very closely allied.

\section{DISTRIBUTION.}

Gravelly river banks and wet places, Mexico, Central $\Lambda$ merica, and the West Indies.

' Leeward Islands: Guadeloupe, Duss 3917.

Mexico: Oaxaca, Pringle 5573.

Costa Rica: Confluence of Puerto Viejo and Sarapiquí, Biolley 7467; Port Limon, Pittier in 1904.

Trinidad: Botanic Gardens Herb. 2295, Broadway 2629.
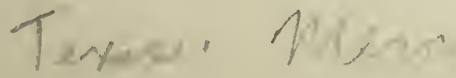
Panicum Bergil Arechav. $a$ a South American species with numerous leaves clustered at the base, hispid sheaths, involute blades, and very diffuse panicles, a third or more the entire height of the plant, with verticillate lower branches, conspicuously pilose in the axils, and short-pointed spikelets 2.2 to $2.6 \mathrm{~mm}$. long, was collected on ballast at Mobile, Alabama, in July and August, 1891, by Mohr and at Galveston, Texas, in 1903, by Hitchcock (the latter in Hitchcock Herb.).

Maxima.-Perennials; culms mostly robust and more than 1 meter high, simple or branching at the base only, or with small sterile shoots from the lower nodes; ligules membranaceous, ciliate; blades linear, flat; panicles large, manyflowered; spikelets ellipsoid, glabrous, mostly faintly nerved, the sterile floret with a well-developed palea and in P. maximum a staminate flower; fruit strongly to very obscurely transversely rugose, puberulent at the apex.

Culms with a corm-like base.

Blades mostly over $5 \mathrm{~mm}$. wide; culms more than 1 meter high........................... 41. P. bulbosum.

Blades less than $5 \mathrm{~mm}$. wide; culms rarely as much as 1 meter high.

Culms from a creeping rootstock, not corm-like at base.

$$
\begin{aligned}
& \text { 41a. P. bulbosum sci- } \\
& \text { aphilum. }
\end{aligned}
$$

Nodes hirsute; ligules 4 to $6 \mathrm{~mm}$. long; fruit strongly rugose.............................. 39. P. maximum.

Nodes glabrous; ligules $2 \mathrm{~mm}$. long; fruit very obscurely rugose............................. 40. P. plenum.

\section{$\checkmark$ 39. Panicum maximum Jacq.}

Panicum maximum Jacq. Coll. Bot. 1: 76. 1786. "In insula Guadeloupe sponte crescit." In the Vienna Herbarium is a specimen from "Hb. Jacq. fil." $b$ This is

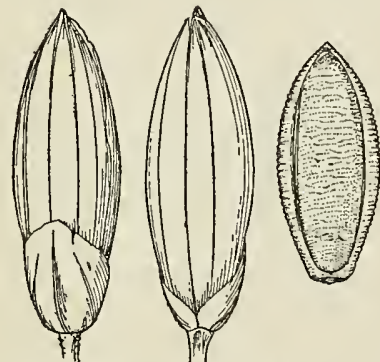

FIG. 67.-P. maximum. From type specimen of $P$. polygamum Swartz. probably the most authentic specimen to be obtained. The plate in Jacquin's Icones $c$ is an excellent illustration of the species as commonly understood.

Panicum polygamum Swartz, Prodr. Veg. Ind. Occ. 24. 1788. "India occidentalis" is the only locality cited. The type specimen, marked "Jamaica. Swartz. P. polygamum prodr.," is in the Swartz Herbarium.

Panicum laeve Lam. Tabl. Encycl. 1: 172. 1791. "E Domingo, ins. Franc." is the only citation given. The type specimen, in the Lamarck Herbarium, is marked "Panicum laeve n. Lam. ill. gen. * * * Ste. Dominique."

Panicum jumentorum Pers. Syn. PI. 1: 83. 1805. Based on $P$. polygamum Swartz, the description of which Persoon copies.

Panicum scaberrimum Lag. Gen. \& Sp. Nov. 2. 1816. "Habitat in Nova Hispania. Introd. ann. 1804 ex seminibus per. D. Sessé missis." The type specimen, in the Madrid Herbarium, bears a label reading "Panicum scaberrimum sp. n. Ex h. r. m.d an 1804. Habitat in N. Hispania."

a Anal. Mus. Nac. Montevideo 1: 147. 1894. "Campos del Departmento de Montevideo, San José, Florida, Mercedes, etc."

$b$ Nicolas Joseph Jacquin the author of the Collectiones.

c Icon. Pl. Rar. 1: 2. pl. 13. 1781-1786. This work is dated 1781-1786, but "Jacq. coll. vol. 1 " is cited, which would indicate that the Collectiones appeared the earlier.

$d$ Hortus regius Matritensis. 
Panicum trichocondylum Steud. Syn. Pl. Glum. 2: 74. 1854. "Duchaising legit in Ins. Guadaloup." The type specimen, in the Steudel Herbarium, bears a label with the data as published.

Panicum praticola Salzm.; Doell in Mart. Fl. Bras. $2^{2}: 203.1877$. This is given as a synonym of $P$. maximum Jacq. Doell cites "Salzmann Herb. Bahiense N. 683," which specimen we have seen.

\section{DESCRIPTION.}

Plants light green, 1 to 2.5 meters high, or taller in cultivation, in tufts of few to many culms, from creeping rootstocks; culms robust, erect or sometimes geniculate and rooting at the lower nodes, glabrous, the nodes usually densely hirsute; sheaths shorter than the internodes, papillose-hirsute to glabrous, ciliate, usually a dense ring of pubescence at the juncture with the blade; ligules 4 to $6 \mathrm{~mm}$. long, stifly and densely ciliate from a membranaceous base; blades erect or ascending, flat, 30 to $75 \mathrm{~cm}$. long, 1 to $3.5 \mathrm{~cm}$. wide, very scabrous on the margin, otherwise glabrous, or hirsute on the upper surface at the base; panicles finally long-exserted, 20 to $50 \mathrm{~cm}$. long, usually about one-third as wide, densely flowered, the long, rather stiff branches ascending, naked at the base, the lower in whorls, the axils pilose, the branchlets short, appressed, bearing more or less clustered, short-pediceled spikelets; spikelets 3 to $3.3 \mathrm{~mm}$. long, 1 to $1.1 \mathrm{~mm}$. wide, and about as

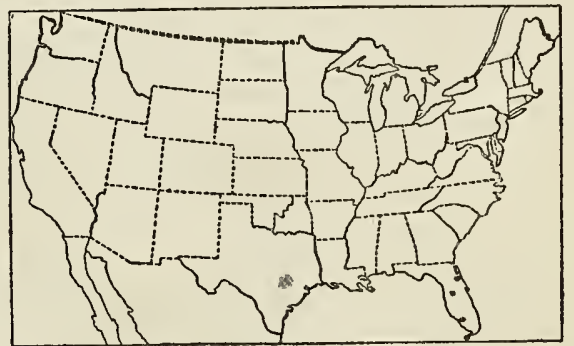

FIG. 68.-Distribution of $P$. maximum. thick, oblong-ellipsoid, glabrous, somewhat shining, faintly nerved; first glume about one-third the length of the spikelet, obtuse; second glume and sterile lemma subequal, slightly exceeding the fruit, thin in texture, the lemma inclosing a staminate flower; fruit 2.3 to $2.5 \mathrm{~mm}$. long, about $1 \mathrm{~mm}$. wide, elliptic, transversely rugose, minutely puberulent at the apex.

\section{DIS'TRIBUTION.}

Cultivated for forage under the name of Guinea grass in the Gulf States, especially in Florida, and southward through tropical South America, whence it has escaped into fields and waste places; $a$ also in the tropical parts of the Old World.

Flonida: Duval County, Fredholm 373; Indian River, Curtiss 3597***; Eustis, Nash 1730; Grasmere, Combs 1170; Orange County, Baker in 1897; Braidentown, Combs 1310; Caximbas Island, Simpson 580; Key West, Blodgett; without locality, Simpson.

Mexico: State of Vera Cruz, Finck 8 and in 1893, Smith 1409; Córdoba, Kerber 48; State of Colima, Emrick 3; Huitamalco, Liebmann 425 in part; Zacualpan, Purpus 3774 .

a Trimen (Hand. Fl. Ceyl. $5: 154$. 1900) states the following concerning this grass: "The well-known Guinea Grass was introduced from W. Trop. Africa into Jamaica about 1774 , by Mr. John Ellis, as food for some birds which he had imported. The birds died, and the seed, being thrown away as useless, yielded a magnificent grass greedily eaten by cattle and horses. It was introduced into India in 1802 by Sir John Sinclair, and must have been rapidly disseminated, for I find a specimen in Rottler's Herbarium (named $P$. meneri, miliacea, var. (?) $P$. nodosum, nob.) received from Heyne, with the date, June 3, 1808. There is no record of its introduction into Ceylon, but it is included in Moon's Catalogue, published in 1824." 
Guatemala: Escuintla, J. D. Smith 2705, 2706; Morales, Kellerman 6267; Alta Vera Paz, Cook \& Griggs 579; Gualán, Deam 6268.

Honduras: Cortez, Kellerman 4725.

Salvador: Izalco, Pittier 1960; San Salvador, Velasco in 1906; without locality, Renson 293.

Costa Rica: San José, Pittier 9050; Alajuelita, Pittier 2995, Tonduz 2995; a Boca Banana, Tonduz 9114; Zent Farm, Pittier in 1904.

Bermudas: Brown \& Britton 20.

Bahamas: Nassau, Curtiss W. I. P1. 124; Eleuthra, Geogr. Soc. Baltimore 338.

CubA. Pinar del Rio, Palmer \& Riley 377; El Guama, Palmer \& Riley 178; San Diego de los Baños Palmer \& Riley 542, 545; Guanajay, Palmer \& Riley 816; Santiago de las Vegas, Hitchcock 157, Wilson 438; Santiago, León \& Voisard 915, Pollard, Palmer \& Palmer 283; Guines, León 427, Liebmann 445 in part; Herradura, Hitchcock 156; Guayabal, León 921; Marianao, León 957.

Jamaica: Gordon Town, Hart 797; Port Antonio, Fredholm 3319.

Ponto Rico: Cayey, Sintenis 2468; Mayaguez, Sintenis 51; El Sobrante, Eggers 1226; Guanica, Sintensis 3366; Martin Pena, Heller \& Heller 377.

Danish West Indies: St. Croix, Ricksecker 200, 413; St. Thomas, Eggers in 1887, Millspaugh 454.

Leeward Islands: Guadeloupe, Duss 3186.

Windward Islands: Martinique, Duss 1288; Barbados, Dash 259; Granada, Broadway in 1905.

Colombia: Santa Marta, Smith 2153; Magdalena, Pittier 1617.

Venezuela: Island of Margarita, Miller \& Johnston 177.

BraziL: Province of Ceará, Gardner in 1838; Rio, Glaziou 18627; without locality, Glaziou 16612, Riedel 53.

\section{- 40. Panicum plenum sp. nov.}

DESCRIPTION.

Plants mostly in large clumps, 1 to 2 meters high, erect, from a stout rootstock, mostly glaucous; culms robust, compressed, glabrous, usually decumbent at base,

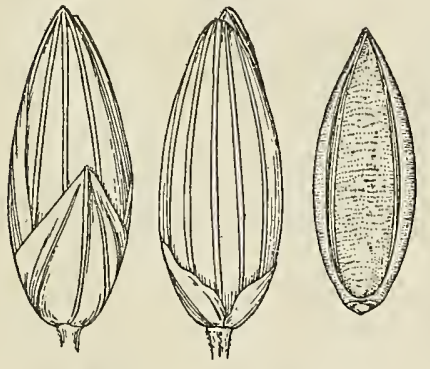

FIG. 69.-P. plenum. From type specimen. sometimes branching at the lower nodes; sheaths overlapping on the short lower internodes, shorter than the upper, glabrous, or the lower sometimes pubescent toward the summit, more or less keeled; ligules densely ciliate, about $2 \mathrm{~mm}$. long; blades erect or ascending, or the lower spreading, flat, 20 to $35 \mathrm{~cm}$. long, 7 to $17 \mathrm{~mm}$. wide, glabrous on both surfaces or rarely sparsely pilose on either surface toward the base, the upper surface scarcely scabrous; panicles 20 to $50 \mathrm{~cm}$. long, about two-thirds as wide, the slender branches somewhat spreading, the general appearance much like that of $P$. bulbosum but proportionately wider, the main axis nearly smooth; spikelets 3 to $3.4 \mathrm{~mm}$. long, $1.2 \mathrm{~mm}$. wide, oblong-elliptic, glabrous, rather strongly nerved; first glume scarcely half the length of the spikelet or less, subacute, 3-nerved; second glume and sterile lemma subequal, scarcely exceeding the fruit, the palea

$a$ Some of the Pittier collections were distributed with the name of Tonduz as collector. The numbers are in one series, some of the plants having been collected by Pittier, some by Tonduz, and a few by Biolley. The labels may be marked, "Herb. Instit. physico-geogr, nat, costaricensis," or, "Plantae costaricenses exsiccatae." 
of the sterile floret about as long as its lemma; fruit 2.9 to $3 \mathrm{~mm}$. long, $1 \mathrm{~mm}$. wide, elliptic, acute, only very obscurely rugose, minutely puberulent at the apex.

Type U. S. National Herbarium no. 495701, collected September 18, 1903, "at Mangas Springs, 18 miles northwest of Silver City, Grant County, New Mexico, by O. B. Metcalfe (no. 739), altitude 4,770 feet."

This species is related to $P$. bulbosum from which it is distinguished chiefly by the creeping rootstock and decumbent, not corm-like, base of the culms. Specimens lacking the base may be recognized by the compressed culm, scarcely scabrous blades, shorter first glume, and only very obscurely rugose fruit, appearing smooth except under

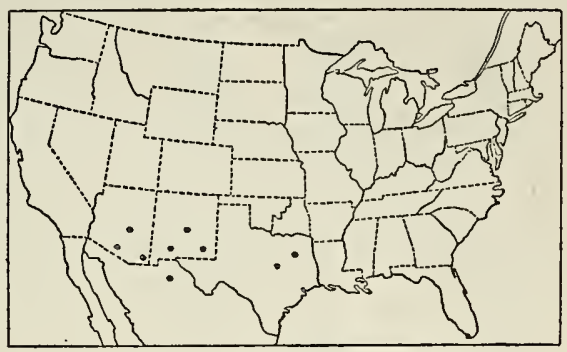

F IG. 70.-Distribution of $P$. plenum. a high power lens. Many specimens of this species have been distributed as $P$. avenaceum but an examination of the type specimen of the latter, together with the statement in the original description that the base is bulbous, shows it to be the same as $P$. bulbosum.

\section{DISTRIBUTION.}

Moist places in rocky hills and canyons, Texas to Arizona, south to southern Mexico.

Texas: Kerrville, Heller 1898; Colorado, Tracy 8224; without locality, Nealley in 1887.

New Mexico: Organ Mountains, Vasey in 1881; Wooton 2017; Mangas Canyon, Smith in 1896; Mangas Springs, Metcalfe 738, 739; Mangas, Metcalfe 6, 80 in part, J. K. Metcalfe in 1897, Smith in 1896; Greenwood Canyon, Smith in 1896; Las Cruces, Griffiths 7400, 7401; "from Western Texas to El Paso," N. M., Wright 786 .

Arizona: Santa Rita Forest Reserve, Griffiths 3427; Fort Huachuca, Wilcox in 1894; Patagonia, Hitchcock 3649; Dos Cabezas, MacDougal 789; Mustang Mountains, Pringle 7 in 1884 (Hitchcock Herb.); without locality, Emersley in 1890 .

Mexico: Chihuahua, Wilkinson in 1885; Durango, Palmer 741 in 1896; Faral, Schumann 1733; Orizaba, Botteri 160; Las Cuevas, Hartman 170.

\section{Panicum bulbosum H. B. K.}

Panicum bulbosum H. B. K. Nov. Gen. \& Sp. 1: 99. 181". "Crescit in Novæ Hispanix scopulosis et frigidis juxta Santa Rosa, Los Joares et Guanaxuato, inter 1070 et 1360 hexap. altitudinem." The type specimen, from the Bonpland Herbarium in the Paris Herbarium, has a well developed corm. The accompanying label reads, "Panicum bulbosum Kunth Synops. 175. in scopulosis \& frigidis. Nova Hisp. alt. 10701360 hex. No. 4250." The spikelets are $3.7 \mathrm{~mm}$. long.

Panicum avenaceum H. B. K. Nov. Gen. \& Sp. 1: 99. 181\$. "Crescit in regno Quitensi, in valle amoena Chilloensi et planitie Cachapamba, regione subtemperata, alt. 1340 hexap." The type specimen, from the Bonpland Herbarium in the Paris Herbarium, bears a label with the following data: "Panicum avenaceum Kunth, Synops. 175. (P. bulbosum proximum) in valle amoena Chilla. alt. 1340 h. regn. Quitensis. No. 3016." The base of the specimen is wanting, though the description states that it is bulbous. The spikelets are $4 \mathrm{~mm}$. long. These slightly larger spikelets and the few hairs on the

$$
41616^{\circ}-\text { vol } 15-10-6
$$


sheaths are the only characters not agreeing with those of the type of $P$. bulbosum. The author states it is closely allied to that species and scarcely different from it.

Panicum gongylodes Jacq. Eclog. Gram. 30. pl. 21. 1815-1820. The description is based on a plant grown in the University garden at Vienna in 1807 from seed received
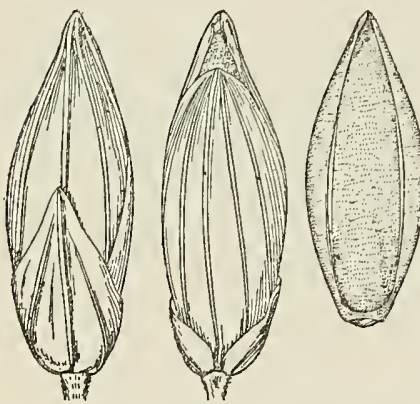

FIG. 71.-P. bulbosum. From type specimen. from the Botanical Garden at Montpellier under the name Panicum altissimum Brouss. ${ }^{a}$ A specimen labeled "Panicum gongylodes Jacq." cultivated in the garden at Vienna and preserved in the Vienna Herbarium is taken as authentic if not the type. Plate 21 of the Eclogae represents $P$. bulbosum. The date on the title-page of the fascicle in which this species appears, containing numbers 21 to 40 , is $1815-1820$.

Panicum confusum Trin.; Nees, Agrost. Bras. - 174.1829. This name, credited to "Herb. Trin." is given as a synonym of $P$. gongylodes Jacq. No specimen so named was found in the Trinius Herbarium.

Panicum nodosum Willd.; Steud. Nom. Bot. ed. 2. 2:260. 1841. This is given as a synonym of Panicum bulbosum and credited to "Willd. hrb." The type, in the Willdenow Herbarium, is P. bulbosum.

Panicum maximum gongylodes Doell in Mart. F1. Bras. $2^{2}: 203$. 1877. Based on $P$. gongylodes Jacq.

Panicum maximum bulbosum Vasey in Wheeler, Rep. U. S. Surv. 100th Merid. 6: 295. 1878. Presumably based on P. bulbosum H, B. K. "Jacq." is erroneously given as authority for the combination.

Panicum polygamum gongylodes Fourn. Mex. P1. 2:28. 1886. Based on "P. gongylodes Jacq.'

Panicum bulbosum avenaceum Beal, Grasses N. Amer. 2: 132. 1896. Based on $P$. avenaceum H. B. K.

Fournier $b$ gives a "S. -var. violaceum" under P. bulbosum H. B. K., citing "Chinantla, in pratis (LIEBM[ANN]n. 451)" but giving no description. A specimen of this number was examined at Halle. There is also a specimen of the same in the United States National Herbarium bearing the name in Fournier's writing.

\section{DESCRTPTION.}

Plants in tufts of few to several culms, 1 to 2 meters high; cuims robust, erect, glabrous, the lowest internode thickened into a hard, corm-like base, 1 to $2 \mathrm{~cm}$. thick, budding at the base, sometimes one or more corms of previous years attached; sheaths shorter than the internodes, glabrous or scabrous to pilose toward the summit, the lower often appressed-pubescent at base; ligules scarcely $1 \mathrm{~mm}$. long; blades erect or ascending, flat, 25 to $60 \mathrm{~cm}$. long, 3 to $12 \mathrm{~mm}$. wide, scabrous on the upper surface, often pilose toward the base, glabrous beneath; panicles long-exserted, 20 to $50 \mathrm{~cm}$. long, usually about half as wide, rather many-flowered, the slender, flexuous branches ascending or somewhat spreading, solitary or fascicled, naked at the base, the branchlets 1 to several $\mathrm{cm}$. long, bearing scarcely clustered, rather shortpediceled spikelets, the ares and pedicels very scabrous; spikelets 3.5 to $4.2 \mathrm{~mm}$. long, 1.2 to $1.4 \mathrm{~mm}$. wide, slightly pointed, more strongly nerved than in $P$. maximum, glabrous, commonly purplish; first glume half to two-thirds the length of the spikelet, bluntly pointed, 3-nerved; second glume shorter than the fruit and sterile lemma, the latter rarely inclosing a staminate flower; fruit 3.2 to $4 \mathrm{~mm}$. long, nar-

$a$ This name was listed without description in Brouss. Elench. Hort. Monsp. 42. 1805. We have not been able to verify this reference.

$b \mathrm{Mex}, \mathrm{Pl}, 2: 27,1886$. 
rowly ovate, more finely transversely rugose than in $P$. maximum, the bluntly pointed apex puberulent.

The type specimen of $P$. bulbosum represents the medium form of this species, which varies much in height, width of blades, and size of spikelets. Numerous specimens intermediate between this and the subspecies sciaphilum occur; that is, with the larger spikelets and narrower blades or smaller spikelets and wider blades.

\section{DISTRIBUTION.}

Moist places in canyons and valleys of the Rocky and Sierra Madre mountains, New Mexico and Arizona to southern Mexico.

New Mexico: Animas Valley, Mearns 2501; Black Range, Metcalfe 1422; Mangas, Metcalfe 80 in part; Burro Mountains, Rusby 445b; Las Vegas, Tasey in 1881; White Mounains, Wooton 368; Organ Mountains, Standley in 1906.

Arizona: Chiricahui Mountains, Toumey in 1896; Rincon Mountains, Nealley in 1891; Huachuca Mountains, Holzner 1966 , 2079, 2163, Lemmon 2912, 2914, 2916; Santa Catalina Mountains, Griffiths 7083; Walnut Canyon, MacDougal 336; Barfoot Park, Blumer 1341; without locality, Rusby in 1883.

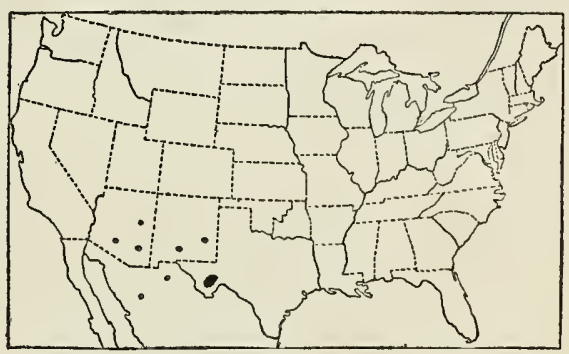

FIG. 72.-Distribution of $P$. bulbosum.

Mexico: Chihuahua, Hartman 790, Pringle 377, Nelson 6187, 6301; Sierra Madres, Townsend \& Barber 221; San Luis Potosi, Parry \& Palmer 958; Durango, Palmer 525a in 1896; Otinapa, Palmer 340 in 1906; Tejamen, Palmer 469 in 1906 in part; Rio Blanco, Palmer 207 in part and 207a in 1886; Puebla, Purpus 2908; Eslava, Holway 12, Pringle 9575; Valley of Toluca, Pringle 5207 (Hitchcock Herb.); State of Jalisco, Rose 2609; Valley of Mexico, Bourgeau 235, Pringle 6418; Territorio de Tepic, Rose 1999, 3361; Chinantla, Liebmann 441, 442; Mount Orizaba, Bourgeau 2794, Seaton 317; Oaxaca, Conzatti \& Gonzales 243, Nelson 1374.

- 41a. Panicum bulbosum sciaphilum (Rupr.).

Panicum sciaphilum Rupr.; Fourn. Mex. PI. 2: 19. 1886. This name was listed with-
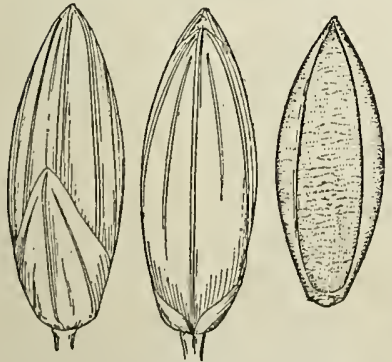

FIG. 73.-P. bulbosum sciaphilum. From type specimen. out description by Ruprecht, $a$ "Col. H. Gal[eotti] no. $5759 * * *$ Yavezia" being cited, and also by Hemsley. $b$ Fournier cites "Sierra de Yavesia, 7,000' (GAL[EotTi] n. 5759 in herb. Brux. et Mus. Par.)" The type specimen is in the Brussels Herbarium.

Panicum bulbosum minor[us] Vasey, U. S. Dept. Agr. Div. Bot. Bull. 8: 38. 1889. "(P. maximum, var. bulbosum, Munro)" is cited and range is given as "Texas, New Mexico, and Arizona." Wright's no 2086 of the Mexican Boundary-Survey in the Nationat marium marked "Panicum maximum Jacq. var. bulbosturr trin. (fide Munro)" is taken as the type, since this is doubttess the basis of Vasey's understanding of Munro's use of the name cited. This combination was earlierc listed without description by Vasey. 


\section{DESCRIPTION.}

Plants less than 1 meter, sometimes only 30 to $40 \mathrm{~cm}$. high; culms slender, few to many in loose clusters, the corms smaller, not over $8 \mathrm{~mm}$. in diameter, commonly many together attached at the base to a rootstock; blades 10 to $40 \mathrm{~cm}$., usually less than $25 \mathrm{~cm}$. long, 2 to $4 \mathrm{~mm}$. wide; spikelets 2.8 to $3.2 \mathrm{~mm}$. long.

As limited here this subspecies includes only those specimens having both the smaller spikelets and narrower blades. Many intergrading forms are included in the species.

\section{DISTRIBUTION.}

Gravelly river banks, ravines of mesas and similar situations in the Rocky and Sierra Madre mountains from New Mexico and Arizona to central Mexico.

New Mexico: Mangas, Smith in 1897; Las Vegas, Vasey in 1881; Mogollon Mountains, Metcalfe 357; Gray, Earle \& Earle 180; Organ Mountains, Hitchcock 3784; Niggerhead Mountains near Monument no. 82, Mearns 1932; without locality, Wright 2086.

Arizona: Chiricahui Mountains, Toumey 12; Santa Rita Mountains, Pringle in 1884; San Francisco Mountains Forest Reserve, Leiberg 5816; Burro Mountains, Rusby 445c in part; Yavapai County, Rusby in 1883; Flagstaff, Jones 4019; Patagonia, Hitcheock 3716;

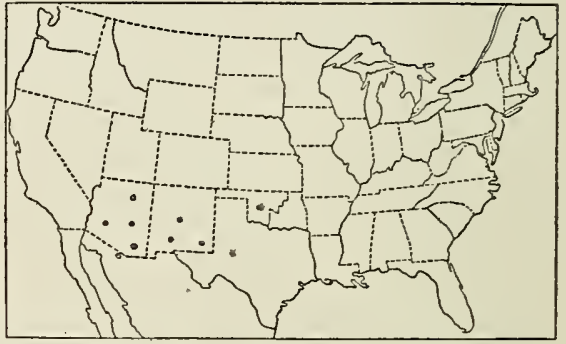

FIG. 74.-Distribution of P. bulbosum sciaphilum.

Huachuca Mountains, Griffiths 4811, Holzner 1729, 1742, Lemmon 2908, 2922; Fort Huachuca, Wilcox in 1891; Bill Williams Mountain, Lemmon 3152; Beaver Creek, Rusby 866; without locality, Rothrock 296.

Mexico: Nogales, Griffiths 67851 ; Chihuahua, Nelson 6298; Cusihuiriachic, Pringle 1406; Otinapa, Palmer 348, 349, and 554 in 1906; Tejamen, Palmer 469 in 1906 in part; Papasquiaro, Palmer 467 in 1896; Territorio de Tepic, Rose 2053.

Virgata.-Perennials from stout rootstocks; mostly maritime species, with stout simple culms and firm foliage; ligules membranaceous, ciliate; panicles open or contracted; spikelets glabrous, mostly large, terete or thicker than wide, usually gaping, owing to the well-developed staminate floret and its palea in addition to the perfect one, the glumes and sterile lemma firm in texture, the fruit relatively rather small, smooth and shining, in some species the margins of the lemma scarcely inrolled.

Spikelets not over $2.5 \mathrm{~mm}$. long, first glume less than half the length of the spikelet.

Panicles loosely flowered; first glume truncate, about one-fifth the length of the spikelet........... 42. P.repens.

Panicles rather densely flowered; first glume triangular, about one-third the length of the spikelet........ 43. P.gouini.

Spikelets 3 to $7 \mathrm{~mm}$. long (sometimes less than $3 \mathrm{~mm}$. in $P$. virgatum cubense); first glume more than half the length of the spikelet.

Panicles elongated, strongly contracted; seacoast plants.

Culms rarely 1 meter high, solitary from the nodes of the horizontal rootstock ................. 46. P. amarum. Culms 1 to 2 meters high, in dense tufts......... 47. $P$. amarulum. 
Panicles diffuse, or only slightly contracted; plants sometimes of salt marshes but not littoral.

Spikelets 6 to $8 \mathrm{~mm}$. long; culms solitary, with a creeping base.......................... 45. P. havardii.

Spikelets less than $5 \mathrm{~mm}$. long (in exceptional specimens $6 \mathrm{~mm}$. long); culms erect, producing numerous scaly rootstocks.

Panicles open, loosely-flowered; spikelets 3.5 to $5 \mathrm{~mm}$. long, beaked; first glume two-thirds the length of the spikelet or more, acuminate-pointed ......................... 44. P. virgatum.

Panicles somewhat contracted; spikelets not over
$3.2 \mathrm{~mm}$. long, not beaked; first glume about half the length of the spikelet, not acuminate ...........................
44a. P. virgatum cub- ense.

\title{
42. Panicum repens $\mathrm{L}$.
}

\author{
1:
}

Panicum repens L. Sp. PI. ed. 2.'87. 1762. "Habitat in Hispania? inde missum a Claud. Alstraemer." The type specimen is in the Linnæan Herbarium.

Parioum notum Rotz Obs. Bat 4:18. 1786. "In Sumatra * * * D: Wennerbera." The specimen from Sumatra in the Willdenaw Herbarium labeled Panicum notatum, though probably not the type, agrees with the description and may be regarded as an authentic specimen. Be Ror. Fedde Ref. 63:329.1960.

Panicum arenarium Brot. Fl. Lusit. 1:82. 1804. "Hab. in arenosis subhumidis; occurrit in Algarbiis." We have not seen the type specimen, but the ample description and the plate given later by Brotero $a$ clearly identify this species with P. repens $\mathrm{L}$.

Panicum littorale Mohr; Vasey, Bot. Gaz. 4: 106. 1879. "Mobile, Alabama," sent by "Mr. Chas. Mohr." The type specimen, in the National Herbarium, was collected by Dr. Mohr, July 4, 1877.

A few other names based on Old World plants, the type specimens of which we have not seen, are referred to $P$. repens as synonyms by various authors.

\section{DESCRIPTION.}

Culms rigid, 30 to $80 \mathrm{~cm}$. high, erect or ascending from the nodes of strong, horizontal, often extensively creeping rootstocks, simple, clothed at the base with bladeless, overlapping sheaths; upper leaves numerous, the sheaths usually oyerlapping, rather loose, more or less pilose, especially along the margin, or sometimes glabrous; ligules about $1 \mathrm{~mm}$. long; blades 4 to $15 \mathrm{~cm}$. long, 2 to $5 \mathrm{~mm}$. wide, or those of sterile

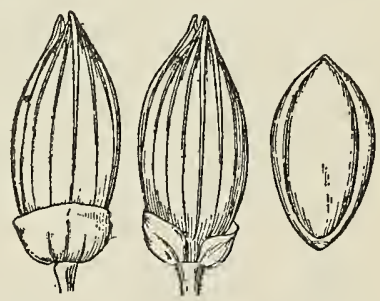

FIG. 75.-P. repens. From type specimens of $P$. littorale Mohr.

shoots sometimes longer and wider, firm, stiffly ascending or spreading, often conspicuously distichous, flat or folded, long-pilose at the base on the upper surface, otherwise sparsely pilose to glabrous on both surfaces; panicles rather short-exserted, stramineous, 7 to $12 \mathrm{~cm}$. long, one-third to two-thirds as wide, the somewhat distant branches stiffly ascending, rarely spreading, usually naked at the base, bearing short, appressed branchlets with short-pediceled, approximate spikelets toward the ends; spikelets 2.2 to $2.5 \mathrm{~mm}$. long, 1 to $1.1 \mathrm{~mm}$. wide, ovate, abruptly pointed; first glume 
about one-fifth as long as the spikelet, broad, loose and truncate, obscurely nerved; second glume and sterile lemma equal, 5 to 7 -nerved; fruit 1.8 to $1.9 \mathrm{~mm}$. long, about $1 \mathrm{~mm}$. wide, obovate-elliptic.

\section{DISTRIBUTION,}

Sea beaches, extensively creeping and acting as a sandbinder, along the Gulf Coast, Alabama to Louisiana, native to tropical and subtropical coasts of both hemispheres.

Alabama: Mobile, Curtiss 6513, Kearney 17, Mohr in 1876, 1877, and 1882.

Mıssissipp1: Biloxi, Chase 4377, Kearney 342, Pollard 1152; Horn Island, Tracy 3861; Ocean Springs, Tracy 38; Deer Island, Tracy in 1898.

Louisiana: Cameron, Cocks 2186, Baton Rouge (in rice fields

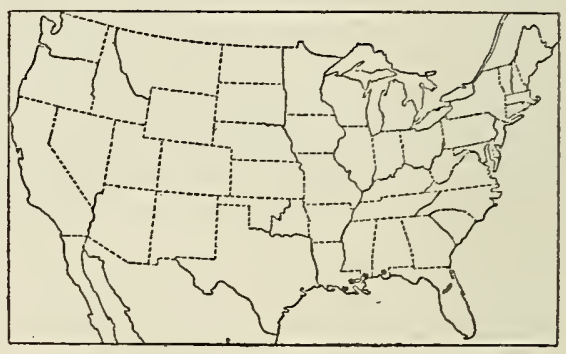

FIG. 76.-Distribution of $P$. repens. along the Mississippi River), Fulton in 1907; Plaquemines County, Langlois in 1882; Pointe a la Hache, Langlois in 1884.

Nicaragua: Flint in 1868.

Cuba: Habana, León 296, 563.

BrAzIL: Itajahy, Ule 567.

\section{$\sqrt{ }$ 43. Panicum gouini Fourn.}

Panicum gouini Fourn. Mex. PI. 2: 28. 1886. This name was earlier listed without description by Hemsley.a Fournier cites "Vera Cruz (Gourn n. 4, julio)." The type specimen is in the Paris Herbarium.

Panicum gouini pumilum Fourn. Mex. P1.2: 28. 1886. This name was earlier listed without description by Hemsley. ${ }^{a}$ Fournier cites two specimens as follows: "Vera Cruz (VirL[et] n. 1300); Antigua in pratis humidis (Liebu[ann] n. 450)." The first could not be found; the second, in the Copenhagen Herbarium, is labeled "Panicum Gouini Fourn." in Fournier's writing. It consists of six small plants of this species. A specimen of this number in the United States National Herbarium, also labeled in Fournier's hand, is also this species.

Panicum repens confertum Vasey, Bull. Torrey Club 13:25. 1886. "Collected in
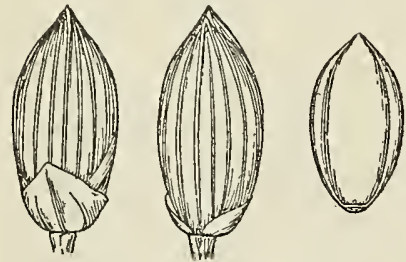

FIG. 77.-P. gouini. From type specimen. Louisiana by A. B. Langlois." The type, in the National Herbarium, was collected "In sandy beach of Gulf, B[ay] St. Louis, Miss., 13 Sept., 1883," the published locality being an error, doubtless due to the fact that the printed label bears Langlois's home address, "Pointe-a-la-Hache, La.," the written locality being overlooked.

Panicum halophilum Nash in Lloyd \& Tracy, Bull. Torrey Club 28: 86. 1901. Based on " $P$. repens $\mathrm{L}$. var. confertum Vasey, not $P$. confertum Desv. 1816." A description is given and one specimen cited, Petit Bois Island, Miss., Tracy 4566. 


\section{DESCRIPTION.}

Plants like $P$. repens in habit; culms on the average lower, rarely over $30 \mathrm{~cm}$. high; sheaths and blades usually glabrous, more crowded than common in P. repens; panicle smaller, narrower, more densely flowered, commonly purple; spikelets 2 to $2.4 \mathrm{~mm}$. long, about $1 \mathrm{~mm}$. wide; first giume broadly triangular, one-third to nearly half the length of the spikelet; second glume slightly shorter than the sterile lemma.

This species is closely allied to $P$. repens and approached by occasional specimens of that species, which varies more than does this.

\section{DISTRIBUTION.}

Sea beaches, along the Gulf Coast from Alabama to Louisiana and south to Vera Cruz; also on the coast of Uruguay. We have seen no specimens of this species from the Old World.

Alabama: Mobile, Mohr in 1881.

Mississıppi: Mississippi Sound, Smith in 1885; Horn Island, Tracy 7753; Deer Island, Seymour in Seymour \& Earle Mex. Gulf Fl. 91825; Ship Island, Tracy in 1898; Petit Bois Island, Tracy 4566; Bay St. Louis, Langlois in 1883.

Mexıco: Vera Cruz, Müller 2177,

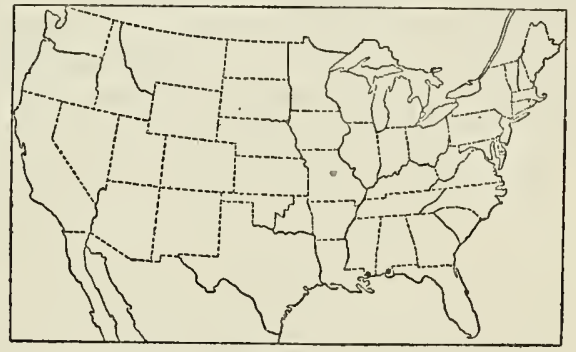

FIG. 78.-Distribution of P.gouini.

Pringle 5569 (IIitchcock Herb.); Antigua, Liebmann 450; Coatzacoalcos, C. L. Smith 913.

Uruguay: Maldonado, Baldwin (Hitchcock Herb.). = repens ?

\section{$\checkmark \quad$ 44. Panicum virgatum L.}

Panicum virgatum L. Sp. Pl. 59. 1753. Linnæus gives a short diagnosis of his own, also quotes a diagnosis from Gronovius, and gives as habitat "Virginia." The type specimen, in the Linnæan Herbarium, appears to have been received from Gronovius as the sheet bears Gronovius's phrase name and the number 578, which is the Clayton number referred to by Gronovius. ${ }^{a}$ Gronovius's specimen of Clayton's no. 578, in the herbarium of the British Museum agrees with the Linnæan specimen. These represent the medium form of the species with open panicle and spikelets 4.1 to $4.2 \mathrm{~mm}$. long. Clayton's no. 606 is the same.

Panicum coloratum Walt. Fl. Carol. 73. 1788, not L. 1767. There is no specimen of this in Walter's herbarium. The brief description applies well to P. virgatum, to which Pursh ${ }^{b}$ referred Walter's species.

Eatonia purpurascens Raf. Journ. de Phys. 89 : 104. 1819. For locality the author gives "Dans les marais maritimes de New-York, etc." In the De Candolle Herbariuri is a specimen from Rafinesque so named by him. It bears the data "Long Island, Rafinesque 1819." This consists of a leaf and a narrow panicle of $P$. virgatum, with spikelets $3.5 \mathrm{~mm}$. long. Rafinesque's description well agrees with this species but his comparisons of it with other genera and especially the names he gives as synonymous are misleading.c

Panicum pruinosum Bernh.; Trin. Gram. Pan. 191. 1826. This is given as a synonym of $P$. virgatum $\beta$ glaucum. Trinius states "V.spp. Am. bor. (Bern Hard sub 
nom. Panici pruinosi.)" The type, in the Berlin Herbarium, is labeled by Bernhardi "Panicum pruinosum mihi, Delaware, affine $P$. virgato." The spikelets are $4.5 \mathrm{~mm}$. long.

Panicum giganteum Scheele, Linnaea 22: 340. 1849. "Im trockenen felsigen Flussbett des Cibolo zwischen San Antonio und Neubraunfels: Lindheimer. August." We have not seen the type, but in the Engelmann Herbarium is a specimen of $P$. virgatum collected by Lindheimer, which appears to be a duplicate type. It is labeled "Auf felsigen Boden im Bett der Cibolo. Sept."

Panicum glaberrimum Steud. Syn. Pl. Glum. 1: 94. 1854. "Cultum ex H. Berol. sem. 1840. sub Ichnanthus glaber. Link. Am. sptr." The type, in the Steudel Herbarium, is labeled "Panicum glaberrimum Steud. Cultum in H. Berol. comun. Hohenacker."

Ichnanthus glaber Link; Steud. Syn. Pl. Glum. 1: 94. 1854. This name is mentioned under Panicum glaberrimum.

Panicum kunthii Fourn.; Hemsl. Biol. Centr. Amer. Bot. 3 : 490. 1885, not Steud. 1841. Based on "Panicum coloratum Kunth, Enum. *** not L." Kunth refers " $P$. virgatum Muhl." to $P$. coloratum $L$. as a synonym, probably basing this reference upon a note which Muhlenberg $a$ appends to his description of $P$. virgatum, " "Non virgatum sed coloratum L.' Smith." The species described by Muhlenberg under this name is true P. virgatum L., and the specimen so labeled in the Muhlenberg Herbarium must be taken as the type of $P$. kunthii Fourn. Fournier intended to change the name of P.coloratum Kunth, not L., which must refer to the Muhlenberg species, as the other references are to $P$. coloratum L. Fournier's later description $b$ of $P$. kunthii and the specimens cited refer to $P$. elephantipes. A synonym cited, $P$. arenarium [Brot. misapplied by] Schlecht., is $P$. gouini.

Panicum ichnanthoides Fourn. Mex. Pl. 2:30. 1886. This name was earlier listed without description by Hemsley.c Fournier cites "Orizaba (F. MÜLL[ER] n. 2082 in herb. Petrop.)" The specimen in the herbarium of the Botanical Garden in St. Petersburg labeled as above is Müller 2002, the number as printed being an error. The panicle is narrow, the spikelets 3.5 to $3.8 \mathrm{~mm}$. long.

Panicum virgatum confertum Vasey, Bull. Torrey Club 13:26. 1886. Vasey gives no definite locality, merely stating that the variety grows, "particularly on the sea coast." The type, in the National Herbarium, is labeled "Seashore at Atlantic City, N. J., Geo. Vasey, 1884." The panicles are narrow and compact, about $20 \mathrm{~cm}$. long and $5 \mathrm{~cm}$. wide. The spikelets are about $3.5 \mathrm{~mm}$. long.

Panicum virgatum elongatum Vasey, Bull. Torrey Club 13: 26. 1886. No definite locality is given. The type, in the National Herbarium, was collected at White River, South Dakota, August, 1892, by E. N. Wilcox, no. 13. This is an immature specimen, the long narrow panicle and slender spikelets, as described, being due to immaturity. This name is not based on P. elongatum Pursh, since Vasey says, "perhaps this is the Panicum elongatum of Pursh."

Panicum virgatum diffusum Vasey, Bull. Torrey Club 13:26. 1886. "Sandy prairies, Kansas, Colorado, etc." No specimen bearing this name can be found in the National Herbarium nor any from Kansas or Colorado collected before 1886. Palmer's no. 376 from Indian Territory in 1868, with a very large and diffuse panicle and marked "P. virgatum?" by Vasey well answers his brief description.

\section{DESCRIPTION.}

Plants erect, usually 1 to 2 meters high, producing numerous scaly, creeping rootstocks, glabrous throughout except as noted, commonly purple tinged, often glaucous, especially on the internodes and upper surface of the blades; culms in large to small clumps or even solitary, simple, robust, tough and hard; sheaths longer than the rather short lower internodes, usually shorter than the upper ones, often ciliate, sometimes 
villous at the throat; ligules dense, 2 to $4 \mathrm{~mm}$. long; blades ascending, 10 to $60 \mathrm{~cm}$. long, 3 to $15 \mathrm{~mm}$. wide, slightly narrowed toward the base, and gradually long-acu-
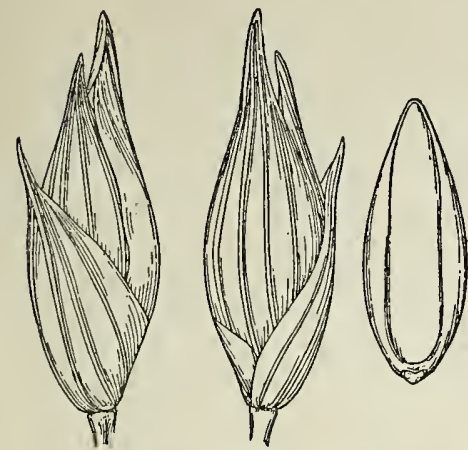

FrG. 79.- $P$. virgatum. From type specimen in Gronovius Herbarium. minate, flat, sometimes pilose on the upper surface toward the base, rarely to the apex, margins scabrous; panicles long-exserted, 15 to $50 \mathrm{~cm}$. long, mostly one-third to half as wide, but sometimes contracted, or very loose and nearly as wide as long, usually many-flowered, the slender, scabrous, usually fascicled branches ascending or spreading, naked at base, repeatedly branching along the upper half or twothirds; spikelets rather short-pediceled, 3.5 to $5 \mathrm{~mm}$., rarely but 3 or as much as $6 \mathrm{~mm}$. long, 1.2 to $1.5 \mathrm{~mm}$. wide, elliptic-ovate, acuminate, strongly nerved; first glume clasping, two-thirds to tliree-fourths the length of the spikelet, rarely equaling the sterile lemma, acuminate to cuspidate, 5-nerved; second glume longer than the sterile lemma, both much exceeding the fruit, 5 to 7 -nerved; fruit narrowly ovate, the margins of the lemma inrolled only at base.

This species is well marked but variable. The blades are usually glabrous or pilose above near the base only. Sometimes, however, the entire upper surface or even both surfaces are pilose. Examples of this are: Minnesota: Mearns 743; South Dakota: Thornber; Nebraska: Rydberg 1561; Kansas: Smyth 92; Georgia: Tracy 3604, Harper 631; Flonida: Combs 597; Alabama: Carver 72; Mississipp1: Chase 4459.

The form named by Vasey $P$. virgatum confertum, with more or less compact panicles, is represented by: NEw JeRsey: Scribner in 1895, Vasey in 1884, Ward in 1884; V1RGinia: Knowlton in 1897; North Carolina: Mc Carthy in 1885; Florida: Kearney 158.

The size of the panicle is variable, in northern specimens being often much dwarfed. The branches may be stiffly ascending or laxly spreading or drooping, these characters not being coördinate with others. The glaucous character also appears to be without significance in separating forms, glaucous and green individuals growing under the same conditions. All these variations are connected by all shades of intergradation with the typical form.

Throughout the western portion of the range of the species there is found, chiefly on sandy soil, a form with mostly single or loosely cespitose culms, often decumbent at base, pale green or glaucous foliage, and small panicles with ascending branches. We have been unable to separate this form as a subspecies because of the numerous intergrading specimens. The following, which are not cited under the distribution of the species, are representative of this form: South Dakota: Huron, Williams in 1892; Bellefourche, Griffiths 395; White River, Wallace 3, 4, 5; Iowa: Cherokee County, Crozier in 1888; Nebraska: Sidney, Plank 13; Mullen, Rydberg 1597; KanSAs: Morton County, Hitchcock Pl. Kans. 570a; Texas: Tascora, Reverchon 2844; Channing, Williams 3061; Colorado: Raton Mountains, Griffiths 5463; Arizona: Flagstaff, MacDougal 265; without locality, Lemmon 3154.

The spikelets are frequently affected by a smut, this sometimes resulting in abnormal forms with spikelets in glomerules or with two to several staminate or abortive florets to a spikelet, as in Sandberg from Minnesota in 1891 and Brandegee from Colorado in 1878.

\section{DISTRIBUTION.}

Prairies, moist open ground, open woods and salt marshes, Maine to Wyoming and south to Florida and Arizona, southwest through Mexico to Costa Rica; also in the Bermudas and Trinidad.

MAINE: Scarboro, Chamberlain 552.

New Uampshire: Walpole, Fernald 271 (N. E. Bot. Club Herb.). 
Vermont: Brattleboro, Grout in 1895.

Massachusetts: South Hadley, Cook in 1887.

Rhode Island: Newport, Hitchcock 170.

Connecticut: Fairfield, Eames in 1896; South Glastonbury, Wilson 1251.

New York: Cayuga Lake, Dudley in 1884.

Ontario: Toronto, Macoun 26324.

New Jersey: Stockton, Fisher in 1897; Camden, Scribner 104; Atlantic City, Scribner in 1895, Vasey in 1884, Ward in 1884.

Pennsylvania: Easton, Porter in 1895; Sayre, Barbour in Kneucker Gram. Exs. 302; Safe Harbor, Heller in 1893;

Harrisburg, Small in 1888.

Oнiо: Sandusky, Morris 53, 124; Columbus, Fischer 6801; Cedar Point, Wilkinson 6805.

InDIANA: Dune Park, Umbach1922; Indiana Harbor, Deam 2638; Pine, Umbach in 1898; Clarke, Umbach in 1896; Lafayette, Dorner 12,85 .

ILLinoIs: Lake County, Gleason \& Shobe 326; Chicago, Chase 1178, 1636 ; Joliet, Skeels 470; Oregon,

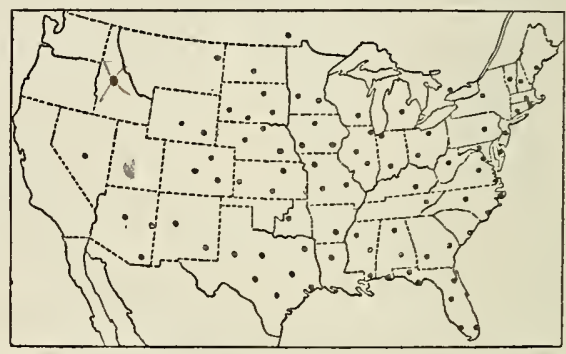

FIG. 80.-Distribution of $P$. virgatum.

Waite in 1885; Thawville, Wilcox 100 ; Wady Petra, V. H.Chase 73 in 1897; Princeville, V.H. Chase 818; Peoria, Brendel, McDonald 59; Athens, Hall in 1870.

Michigan: Lansing, Beal in 1881 (Hitchcock Herb.).

Wisconsin: Witches Gulch, Cheney 3868; without locality, Wood in 1889.

Minnesota: Pipestone City, Sheldon in 1891; Chippewa County, Moyer 42; St. Paul, Blanchard in 1890; Fort Snelling, Mearns 743 in part, 758, 769, 793.

Manitoba: Brandon, Macoun 13231; Assiniboine River, Macoun 29303; Red Deer River, Macoun 29304.

SASKATCHEWAN: Saskatoon, Macoun 73003.

North Dakota: Minot, Waldron 1813; Davenport, Wright 1866; Dunseith, Brannon 99.

South Dакота: Aberdeen, Griffths 82, 132; Black Hills, Rydberg 1097; Frankfort, Griffiths 53; Huron, Griffiths 22; Aurora, Wilcox 54; Brookings, Wilcox 15; Jamesville, Bruce 16; Grindstone, Griffiths 751; Bellefourche, Griffiths 371; Redfield, Griffiths 206; White Eorse Camp, Griftths 295; Zell, Griffiths 242; Dell Rapids, Thornber in 1892; White River, Wilcox 13.

IowA: Armstrong, Shimek 63; Spirit Lake, Geyer in1839; Fayette County, Fink 459; Mount Pleasant, Mills 770; Iowa City, Somes 189, 219; Murray, Morris A 294.

Nebraska: North Platte, Rydberg 2516, Shear 767; Talmage, Elmore 6, 126; Pishelville, Clements 2742; Broken Bow, Plank 57; Mullen, Rydberg 1561.

Missouri: Courtney, Bush 705 in part, 4038; Allenton, Letterman in 1892; Jefferson County, Eggert in 1896; Monteer, Bush 5105.

Kansas: Manhattan, Hitchcock 3840; Riley County, Norton 570; Hutchinson, Smyth 9; Osborne City, Shear 223; Wichita, Smyth 230, 257; Florence, Grif-

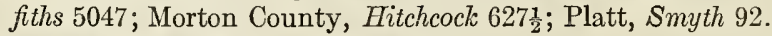

Delaware: Kimensi, Commons in 1897.

Maryland: Cumberland, Shriver 610; River View, Blanchard in 1891; Bay Ridge, Scribner in 1897; Chesapeake Beach, Chase 2528, Hitchcock 442, 2391, House 358; Anne Arundel County, Smith in 1879; High Island, Dewey 134, Steele in 1896, Scribner in 1894; Great Falls, Steele.

District of Columbia: Kearney in 1897, Pollard 595, Steele in 1896, Ward in 1871.

Virginia: Chain Bridge, Chase 3623; Rosslyn, Topping in 1895; Hampton, McCarthy in 1883; Virginia Beach, Hitchcock 171, Kearney 2018; Dismal Swamp, Chase 3676; Walnut Point, Knowlton in 1897. 
West Virginia: Tucker County, Greenman 47 (Gray Herb.).

North Carolina: Wilmington, Kcarney 267a; Tarboro, McCarthy in 1883 and 1885; Swanquarter, Ashe in 1898; West Raleigh, Stanton 1283; Biltmore, Biltmore Herb. 700c.

South Carolina: Charleston, Donaldson in 1888; Isle of Palms, Hitchcoch 226; St. Helena Island, Cuthbert in 1905.

GeoRgia: Early County, Harper 1220; Sumter County, Harper 429, 631, 1037; Albany, Tracy 3604.

Florida: Jacksonville, Curtiss 3609, 5084, Combs 8, 14, Kearney 158; Baldwin, Combs 63, 66; Lake City, Combs 119; Madison, Combs 235, 267; Monticello, Combs 348; Apalachicola, Biltmore Herb. 700b; De Funiak Springs, Combs 437, 458, 473, 475; Bay Head, Combs 645, 646, 647, 654; Chipley, Combs 537. 579, 597; Old Town, Combs 887; Gainesville, Combs 722; Waldo, Combs 695. 703; Eustis, Nash 1761; Manatee, Combs 1297; Arcadia, Combs 1249, 1280; Myers, Hitchcock Lee Co. Pl. 491; Miami, Chase 3900, Hitchcock 728; without locality, Rugel 595.

Kentucky: Clays Ferry, Peter in 1834 (Ky. State Univ. Herb.).

Tennessee: Hollow Rock, Biltmore Herb. 700a.

Alabama: Valley Head, Ruth 76; Auburn, Earle \& Bakcr in 1897, Tracy in 1897; Birmingham, McCarthy in 1888; Tuskegee, Carver 72; Mobile, Kearney 20 in part.

Mississippr: Starkville, Chase 4459, 4460, Kearney 82; Waynesboro, Kearney 168; Jackson, Smith in 1885; Batesville, Eggert 126; Biloxi, Tracy 3660, 3762 in part, 3763; Ocean Springs, Kearney 298, Tracy in 1889; Point St. Martin, Tracy 4565; Bay St. Louis, Langlois 34.

Arkansas: Batesville, Coville in 1887; Benton County, Plank 68; without locality, Harvey in 1882.

Louisiana: Oberlin, Ball 192.

Texas: Dallas, Reverchon 1622; Gill County, Jermy 219; Jacksonville, Plank 18; Clarksville, Plank 4; Trinity Bay, Joor in 1884; Wallisville, Wallis in 1880; Gillespie County, Jermy 787; Luling, Plank 21; Lampasas, Joor 23; Harris County, Joor 34; Paloduro, Gardner 18; Texline, Griffiths 5664; Waller County, Thurow in 1898; Eagle Pass, Havard 84; Fort Concho, Havard in 1881; Moore County, Carleton 422; without locality, Lindheimer 733, Reverchon 22, 32.

Окцанома: Verdigris River, Blankinship in 1895; False Washita, Palmer 376 in 1868; without locality, Sheldon in 1891.

Montana: Glendive, Ward in 1883.

Wroming: Laramie County, A. Nelson 3626, E. Nelson 330, 476; Glen Rock, A. Nelson 8386 .

Colorado: Fort Collins, Crandall \& Cowen 550; Denver, Tracy 912; Millers Ranch, Fry 3371; Golden, Rydberg 2508, Shear 756; Meadow Park, Shear 606; La Veta, Shear 819; Canyon City, Shear 980; Trimble Springs, Baker, Earle \& Tracy 962, Selig 1264; La Salle, Rydberg 2512.

Nevada: Ash Meadows, Purpus in 1898.

New Mexico: Tesuque, Wooton 2936; Grant County, Rusby 445; Pecos, Standley 5289.

Arizona: San Francisco Mountains, Leiberg 5732; Tuscon, Toumey 7811 Creek, MacDougal 474; Yavapai County, Rusby in 1883; Beaver Creek, Rusby in 1883; Flagstaff, Toumey in 1894; Turkey Tanks, Wooton 2001.

Mexico: State of Jalisco, Palmer 207 and 510 in 1886; Chiapas, Nelson 2975; Orizaba, Botteri 648.

Honduras: San Pedro Sula, Thieme 532.

Costa Rica: Buenos Aires, Tonduz 3619.

Bermudas: Brown \& Britton 358, Moore 2850 (both in Field Mus. Herb.).

TrinidaD: Without data (Gray Herb.). 


\section{4a. Panicum virgatum cubense Griseb.}

Panicum virgatum cubense Griseb. Cat. Pl. Cub. 233. 1866. The only specimen mentioned by Grisebach is, "Wr. a. 1865," that is, collected in Cuba by Wright in

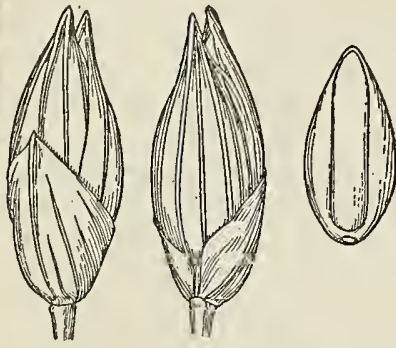

FIg. 81.- $P$. virgatum cubense. From type specimen.

1865. The type, in the Grisebach Herbarium, bears the number 183 and is labeled "Low savannas, Hanabana, May 19."

Panicum virgatum obtusum Wood, Bot. \& Flor. 392. 1874. "N. J." [New Jersey]. The whereabouts of the type, if it be in existence, is not known. The diagnosis "Panicle contracted; spikelets smaller, not pointed, obtusish," seems sufficiently to indicate this subspecies.

Panicum virgatum breviramosum Nash, Bull. Torrey Club 23: 150. 1896. "Collected by Dr. Small in clay soil in the pine lands about Augusta, Georgia, where it was common, June 27-July 1, 1895." The type, in Columbia University Herbarium, is a slender plant with narrow panicles about $12 \mathrm{~cm}$. long and 3 to $4 \mathrm{~cm}$. wide, rather compactly flowered, and as a whole very like Wright's no. 183 mentioned above. P. virgatumv. Thyraiforme Linder.

Differs from $P$. virgatum in having culms more slender than usual in the species, solitary or few in a clump, usually narrow panicles with ascending branches, and smaller spikelets, 2.8 to $3.2 \mathrm{~mm}$. long, the first glume usually about half the length of the spikelet, acute but usually not acuminate-pointed, the second glume and sterile lemma about equal and but slightly exceeding the fruit, the latter about $2 \mathrm{~mm}$. long.

This combination of characters fails to hold throughout. A few of the specimens cited below have open panicles, but the small, obtuse spikelets with shorter first glume; others have the panicle characteristic of the sub-

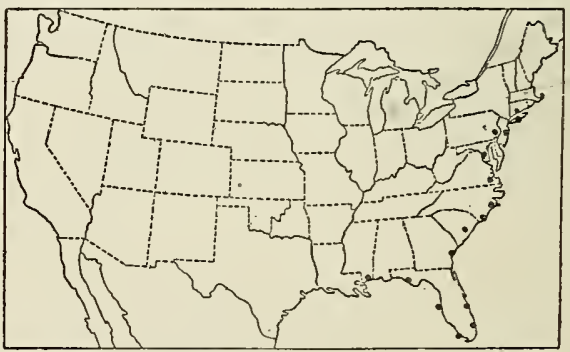

Fig. 82.-Distribution of $P$. virgatum cubense. species but an acuminate-pointed first glume to the small spikelets. The following represent these intermediate specimens: Connecticut: Graves 244; New Jersey: Pearce in 1884; North Carolina: McCarthy in 1885; Florida: Chase 3859, 3860, Hitchcock 743, Hume 37.

\section{DISTRIBUTION.}

Pine woods, the Atlantic Coastal Plain from Connecticut to Florida; also in the Bermudas and Cuba.

ConNecticut: Groton, Graves 244.

New York: Aquebogue, Scribner in 1872 (Hitchcock Herb.).

New Jersey: Atsion, Chase 3573; New Durham, Van Sickle in 1895; without locality, Pearce in 1884.

Pennsylvania: Philadelphia, Smith 109.

Maryland: College Park, Novik in 1907.

Virginia: Ashland, DeChalmot; Portsmouth, Noyes 87.

North Carolina: Edenton, Kearney 1899; Tarboro, McCarthy in 1885; Wilmington, Chase 3144, Coville 104, Kearney 267b; Hendersonville, Biltimore Herb. $700 \mathrm{e}$. 
South Carolina: Elgin, House 2575; Camden, House 2668.

Georgia: Camp Cornelia, Ricker 936; Augusta, Cuthbert 1015, Small in 1895.

Florida: Homosassa, Combs 930; Cedar Key, Combs 774; Jensen, Hitchcock 743; Sanibel Island, Hume 37; Miami, Chase 3859, 3860; Big Pine Key, Simpson 335.

Missrssippi: Scranton, Pollard 1201; Biloxi, Tracy 3762 in part.

Bermudas: Stone in 1888 (Acad. Phil. Herb.).

ó Cuba: Batábano, Hitchcock 153; Palmer \& Riley 1134; without locality, Wright 3873 .

O 45. Panicum havardii Vasey.

Panicum virgatum macranthum Vasey, Bull. Torrey Club 13: 26. 1886, not Panicum
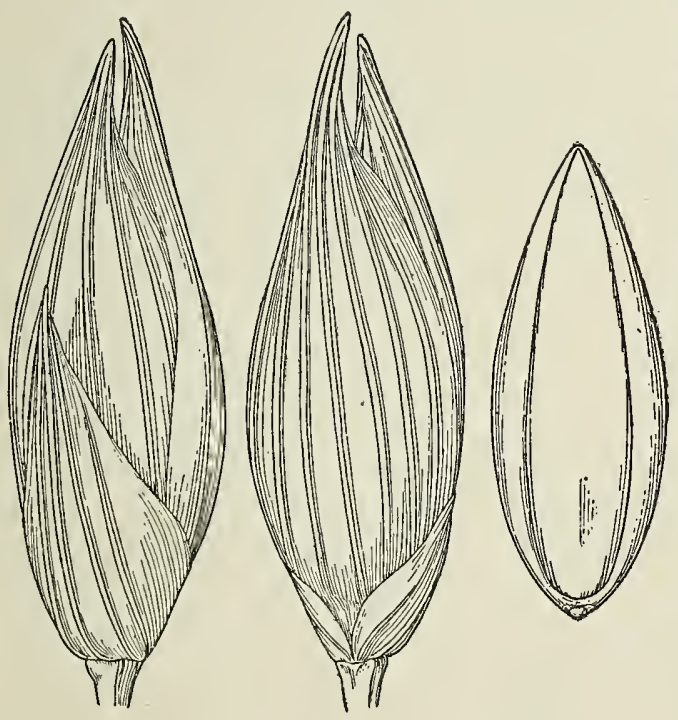

Frg. 83.-P. havardii. From type specimen. macranthum Trin. 1826. "Collected by Dr. Havard, in the Guadalupe Mountains, Texas." The type, in the $\mathrm{Na}$ tional Herbarium, collected in 1881, is labeled in Vasey's hand with the data as published. It consists of the upper portion of a robust culm, the large and open panicle measuring $40 \mathrm{~cm}$. long and 30 $\mathrm{cm}$. wide, the spikelets nearly $7 \mathrm{~mm}$. long.

Panicum havardii Vasey, Bull. Torrey Club 14: 95. 1887. Based upon the type of Panicum virgatum macranthum Vasey.

\section{DESCRIPTION.}

Plants 1 meter or more tall, pale green, glaucous, glabrous throughout; culms robust, sol-

itary, erect from creeping rootstocks, simple; sheaths longer than the internodes; ligules dense, about $3 \mathrm{~mm}$. long; blades erect or ascending, 25 to $40 \mathrm{~cm}$. long, 5 to 10 $\mathrm{mm}$. wide, broadest at the base, tapering into long, involute-setaceous tips, sometimes pilose on the upper surface at the base; panicles short-exserted, as much as $40 \mathrm{~cm}$. long, half to three-fourths as wide, loosely flowered, the mostly verticillate branches ascending or finally spreading; spikelets 6 to $8 \mathrm{~mm}$. long, about $2 \mathrm{~mm}$. wide, ovate, acuminate, strongly nerved; first glume clasping, half to two-thirds the length of the spikelet, acuminate; second glume sligh tly shorter than the sterile lemma, both exceeding the fruit, 7 to 9-nerved; fruit 4.5 to $5 \mathrm{~mm}$. long, about $1.8 \mathrm{~mm}$. wide, narrowly ovate, the margin of the lemma inrolled only at base.

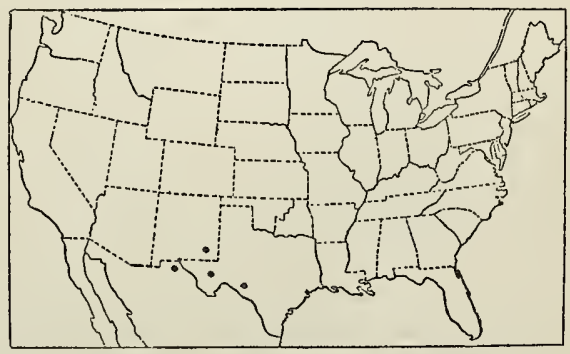

FIG. 84.-Distribution of $P$. havardii.

This apparently rare species resembles $P$. virgatum from which it differs in the decumbent base of the solitary culms and in the larger spikelets. 
DISTRIBUTION.

Arroyos and sandhills, western Texas, New Mexico, and northern Mexico.

Texas: Guadalupe Mountains, Havard in 1881; without locality, Nealley in 1887. New Mexico: Las Vegas, Vasey in 1880; Roswell, Griffiths 5735.

Mexico: Paso del Norte, Pringle 1124 (Hitchcock Herb.).

\section{Panicum amarum Ell.}

Panicum amarum Ell. Bot. S. C. \& Ga. 1: 121. 1816. "Grows among the sandhills on the seashore," presumably of South Carolina and Georgia. No specimen of this could be found in the Elliott Herbarium. $a$ The description is as follows: "Plant very glabrous; leaves thick, glaucous; panicle appressed; glumes acuminate. Root perennial? Stem 2-3 feet high, columnar, thick, nearly an half inch in diameter. Leaves nearly flat, almost coriaceous, the margins very entire; sheaths shorter than the joints, tinged with yellow; the throat contracted, purple; stipules villous. Panicle large, branches all appressed. Flowers very large. Peduncles, which in every other species are very scabrous, and generally hairy, are glabrous and nearly smooth. Calyx 2-flowered, hermaphrodite and male; valves glabrous and tinged with purple.
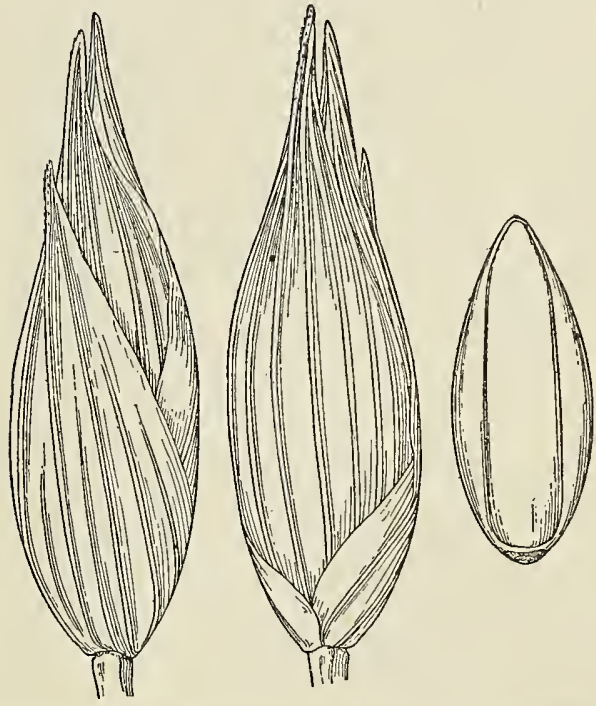

FIG. 85.-P.amarum. From type specimen of $P$. amarum minus Vasey. Corolla, valve of the male floret as large as those of the hermaphrodite. * * Grows among the sandhills on the seashore. Leaves excessively bitter." The greater part of this description will be seen to apply equally well to the cespitose species to which the name $P$. amarum has been applied and to $P$. amaroides Scribn. \& Merr. Scribner and Merrill $b$ accepted the cespitose form as the true $P$. amarum, but the fact that $P$. amaroides and not the cespitose species grows on the coast of North and South Carolina, and especially that it is abundant on the Isle of Palms in Charleston Harbor, Elliott's own locality, casts doubt on the correctness of this identification of Elliott's species. In the description quoted above "Panicle appressed" seems to indicate $P$. amaroides, as does the query after "root perennial." There could be no doubt about the cespitose species (unless one had only a specimen without the base), while in $P$. amaroides the horizontal rootstock is deep in the sand and the solitary culms are readily detached from it. "Stem 2-3 feet high" applies much better to $P$. amaroides, since the allied species is rarely as low as 3 feet. "Leaves excessively bitter" is true of $P$. amaroides while those of the cespitose species are but slightly or not at all bitter. On the whole the evidence is so strongly in favor of $P$. amaroides as

$a$ Scribner and Merrill (U. S. Dept. Agr. Div. Agrost. Circ. 29: 5. 1901) state that "The specimen in the Herbarium of Elliott under this name is a robust form of Panicum virgatum Linn." This name, however, was added later, since it is initialed "H. W. R." [Ravenel.] The original label bears an unpublished name.

$b$ U. S. Dept. Agr. Div. Agrost. Circ. 29: 5.1901. 
the plant described by Elliott as $P$. amarum that we are forced to apply his name to the species named $P$. amaroides. In the herbarium of the Philadelphia Academy is a specimen of this species bearing two tickets reading respectively "Panicum amarum" and "Elliott S. C.," the former being in the handwriting found in the Elliott Herbarium. While this may not be the type, it would seem to be an authentic specimen. A second specimen of this species in the same herbarium bears a ticket reading "Georg. Baldw."

Panicum amarum minor[us] Vasey \& Scribn. U. S. Dept. Agr. Div. Bot. Bull. 8 : 38. 1889. "Fortress Monroe, Va., and north ward, near the coast." The type specimen, in the National Herbarium, was collected by Dr. Vasey at Fort Monroe, Va., in 1879.

Panicum amaroides Scribn. \& Merr. U. S. Dept. Agr. Div. Agrost. Circ. 29: 5. f. 1. 1901. Based on P. amarum minus Vasey \& Scribn.

\section{DESCRIPTION.}

Plants glaucous and glabrous throughout; culms solitary from the nodes of extensively creeping, horizontal rootstocks, simple or occasionally branching from the lower nodes, $30 \mathrm{~cm}$. to 1 meter high; sheaths overlapping but commonly narrow and partially exposing the short, very glaucous internodes; ligules dense and silky, about $3 \mathrm{~mm}$. long; blades ascending or spreading, thick, 10 to $30 \mathrm{~cm}$. long, 5 to $12 \mathrm{~mm}$. wide, broadest at the base, flat below, involute toward the tip, margins smooth; panicles short-exserted or included at base, one-fourth to one-third the height of the plant, or sometimes more, not over $3 \mathrm{~cm}$. wide, mostly few-flowered, the distant, appressed branches bearing scattered, short, appressed branchlets with approximate, shortpediceled spikelets; spikelets 5 to $6.5 \mathrm{~mm}$. long, about $2 \mathrm{~mm}$. wide and as much as 3 $\mathrm{mm}$. thick, narrowly ovate, acuminate, strongly nerved; first glume clasping, twothirds to three-fourths the length of the spikelet, acuminate, 7 to 9-nerved, the midnerve usually scabrous toward the apex; second glume slightly longer than the sterile lemma, both much exceeding the fruit, 9-nerved, the midnerves scabrous toward the apex; fruit $3.5 \mathrm{~mm}$. long, about $1.5 \mathrm{~mm}$. wide, narrowly ovate.

\section{DISTRIBUTION.}

Sandy seashores and coast dunes, Connecticut to Georgia; also on islands off the coast of Mississippi. An important sand binder.

Connecticut: New Haven, Winton in 1887.

New York: Long Island, Miller, Young in 1872; Staten Island, Tyler in 1895.

New Jersey: Cape May, Burk in 1881 (Hitchcock Herb.).

Delaware: Cedar Neck, Commons '28 in 1875; Lewes, Hitchcock 227; without locality, Canby

Marylani: Bay Ridge, Scribner in 1897.

Virg1nia: Fort Monroe, McCarthy in 1883, Vasey in 1879; Portsmouth, Noyes 66 in 1895 ; Ocean View, Vasey in 1890 ; Virginia Beach, Hitchcock

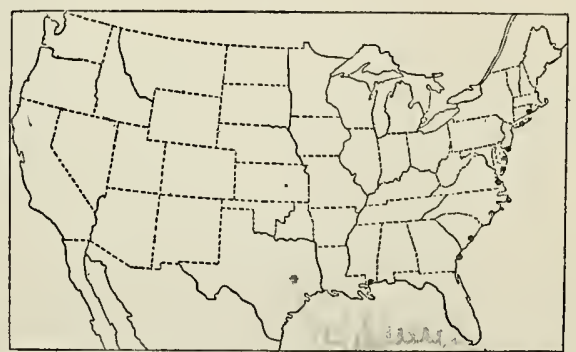

FIG. 86.-Distribution of $P$. amarum. 169, Kearncy 2064, Mackenzie 1736, Williams 3089.

Norti Carolina: Ocracoke Island, Kearney 2317; Brunswick County, McCarthy; Wilmington, Hitchcock 441; without locality, McCarthy in 1885.

South Carolina: Isle of Palms, Chase 4555.

Georg:A: Tybee Island, IIarper 742 .

MIssisiIPPI: Horn Island, Tracy 2854 and in 1897. 


\section{$\checkmark$ 47. Panicum amarulum sp. nov.}

DESCRIPTION.

Plants glaucous but less so than in $P$. amarum, glabrous throughout, cespitose in large bunches sometimes as much as a meter across, 1 to 2 meters high; culms
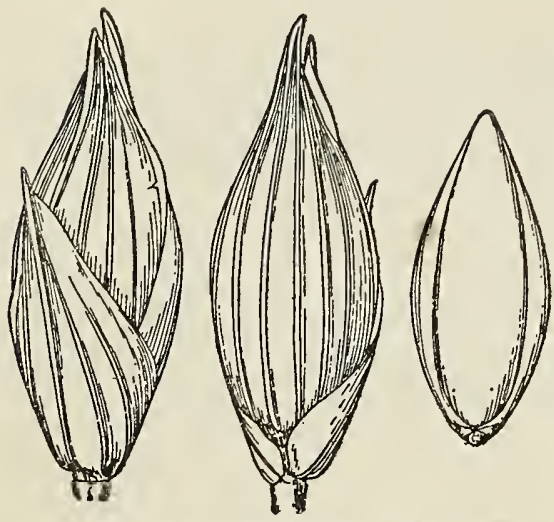

FIG. 87.-P. amarulum. From type specimen. simple above the base, stout, sometimes $1 \mathrm{~cm}$. thick; sheaths mostly overlapping; ligules dense, about 3 $\mathrm{mm}$. long; blades erect or ascending, 20 to $50 \mathrm{~cm}$. long, 5 to $12 \mathrm{~mm}$. wide, broadest at the base, more or less involute, pilose at the base on the upper surface; panicles finally exserted, one-third the height of the plant or more, 5 to $10 \mathrm{~cm}$. wide, slightly nodding, compact, densely flowered, the long, fascicled branches erect but more or less spreading at their tips, spikelet-bearing from the base; spikelets short-pediceled, 4.3 to $5.5 \mathrm{~mm}$. long, 1.7 to $2 \mathrm{~mm}$. wide, narrowly ovate, acuminate, strongly nerved; first glume half to two-thirds as long as the spikelet, acuminate, 5 to 7-nerved; second glume slightly longer than the sterile lemma, both 7 to 9 -nerved, pointed beyond the fruit; fruit 3 to $3.5 \mathrm{~mm}$. long, about $1.4 \mathrm{~mm}$. wide, narrowly ovate, bluntly pointed.

Type U. S. National Herbarium no. 592748, collected September 24, 1900, Virginia Beach, Va., by T. A. Williams (no. 3090).

This is the species to which the name $P$. amarum was restricted by Scribner and Merrill, $a$ Nash, $b$ and Hitchcock, $c$ when this species and the preceding $d$ came to be regarded as distinct.

The name here proposed is an attempt to associate this species with the name it has so long borne, and also refers to the slightly bitter taste of the foliage.

\section{DISTRIBUTION.}

Sandy seashores and coast dunes, Virginia to Florida and west to Louisiana; also in the Bahamas.

Virginia: Norfolk, Kearney 292; Ocean View, Kearney 1775, Vasey in 1890; Lynn Haven, Hitchcock 440; Virginia Beach, Hitchock 168, Kearney 2021, 2063, Mackenzie 1725, Williams 3090.

Florida: Indian River, Curtiss 3578; Cape Malabar, Curtiss in 1879; Lake Worth Inlet, Curtiss 5527; Sea Breeze, Webber 465; Miami, Chase 3899; Cape Florida,

$a$ U. S. Dept. Agr. Div. Agrost. Circ. 29 : 5.1901.

$b$ Britton, Man. ed. 2. 1048. 1905.

$c$ Gray, Man. ed. 7. 104. 1908.

$d$ See note under $P$. amarum Ell. p. 94. tr Wertgate, Miami, sla. in 1904 ve a
teretologiscral specimern with multiplierd
glumes. 
Chase 3953; Key Largo, Chase 3935, Curtiss in 1884; Upper Metacumbe Key, Chase 3915; Santa Rosa Island, Tracy 6508; without locality, Chapman, Rugel 444.

Louisiana: Battledore Island, Tracy \& Lloyd 464.

Baнamas: Great Bahama, Britton \& Millspaugh 2739; New Providence, Britton \& Brace 307, 493 (all in Field Mus. Herb.).

Cuba: Camaquex, Shafer 2735 .

Tenera.-Perennials; culms slightly compressed, wiry, the internodes much elongated; ligules membranaceous, about $0.5 \mathrm{~mm}$. long; blades linear, at the base narrower than their sheaths; panicles small, narrow, nearly simple; splkelets short-pediceled, glabrous or nearly so; palea of sterile floret a small nerveless scale; fruit elliptic, smooth and shining.

Panicles 3 to $8 \mathrm{~cm}$. long; spikelets 2.2 to $2.8 \mathrm{~mm}$. long, pointed...... 48. P. tenerum. Panicles not over $2 \mathrm{~cm}$. long; spikelets not over $1.6 \mathrm{~mm}$. long, blunt. 49. P. stenodes.

\section{Panicum tenerum Beyr.}

Panicum tenerum Beyr. in Trin. Mém. Acad. St. Pétersb. VI. Sci. Nat. 1: 341. 1834. The citation given is "Georg. Amer. (in paludibus nemorum cresc.) BeYRICH ms." The label accompanying the type specimen in the Trinius Herbarium reads

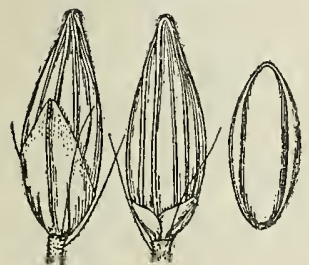

FIG. 89.-P. tenerum. From type specimen.

"Panicum tenerum n. sp. Georgia, in paludibus nemorum," and "mis. Beyrich 1834" added in Trinius's writing. A second ticket bears the name "Pan. tenerum Beyr."

Panicum anceps strictum Chapm. Fl. South. U. S. 573. 1860. "Damp sterile soil, Florida." In the Chapman. Herbarium at Biltmore is a specimen labeled "P. anceps strictum from the original locality Apa[lachicola] 1887" and in the Chapman Herbarium in that of Columbia University is a similar specimen labeled "Panicum anceps $\mathrm{L}$. var. strictum, Southern Flora. Florida," with nothing to indicate whether or not it was collected before the date of publication. In the National Herbarium are two more specimens from Chapman also without date. All the specimens belong to $P$. tenerum, hence there is no doubt as to the identity of Chapman's variety, though whether or not the type be in existence can not be determined.

This species was described under the name of $P$. stenodés Griseb. by Vasey, a Chapman, $b$ Scribner, $c$ and Nash. $d$

DESCRIPTION .

Plants in small tufts from a knotted crown, 40 to $90 \mathrm{~cm}$. high, olivaceous; culms erect, stiff and wiry, producing small, solitary panicles from the upper nodes or remaining simple, glabrous; sheaths much shorter than the internodes, the upper glabrous, the lower sparsely to copiously papillose-pubescent toward the summit with soft, spreading or reflexed hairs; blades 4 to $15 \mathrm{~cm}$. long, 2 to $4 \mathrm{~mm}$. wide, (the uppermost much reduced), erect, firm, drying involute at least toward the summit, pilose on the upper surface toward the base, or the lower sometimes on both surfaces; terminal panicles rather short-exserted, 3 to $8 \mathrm{~cm}$. long, rarely over $5 \mathrm{~mm}$. wide, the short, appressed, subracemose branches bearing rather crowded spikelets throughout their length, the

$a$ U. S. Dept. Agr. Div. Bot. Bull. 8 : 25. 1889.

$b$ Fl. South. U. S. ed. 3. 583. 1897.

$c$ U. S. Dept. Agr. Div. Agrost. Bull. 7 : 64.f. 46. 1897; op. cit. (ed. 2) 52.f. 46. 1900.

$d$ Small, Fl. Southeast. U. S. 92.1903.

$$
41616^{\circ}-\text { Vol } 15-10 \longrightarrow 7
$$


pedicels usually with a few long hairs at the summit; spikelets 2.2 to $2.8 \mathrm{~mm}$. long, 0.8 to $1 \mathrm{~mm}$. wide, narrowly ovate, pointed; first glume clasping, half as long as the spikelet or more, I-nerved, glabrous or obscurely strigose toward the summit; second glume and sterile lemma equal, exceeding the fruit, 5 to 7 -nerved, glabrous; fruit 1.7 to $1.8 \mathrm{~mm}$. long, about $0.8 \mathrm{~mm}$. wide.

\section{DISTRIBUTION.}

Margins of swamps and wet places in flatwoods and pine barrens near the coast, Georgia to Florida and west to Texas; also in the Bahamas and Cuba.

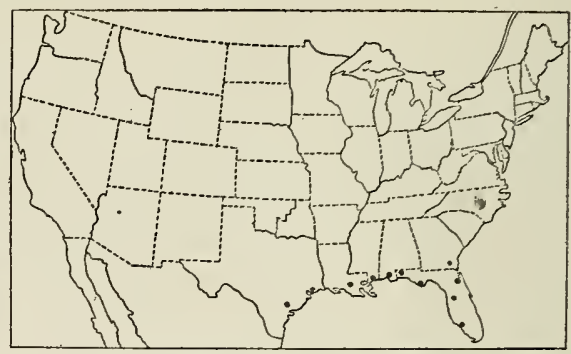

FIG. 90.-Distribution of P. tenerum.

r.C. A.S. HGeong1A: Cobb, Harper 1045; Ruskin, Ricker 908.

- Florida: Jacksonville, Curtiss 3579 in part, 4035, 5083; Kearney 139; Baldwin, Combs61, Nash 2249; De Funiak Springs, Combs 476; A palachicola, Chapman; Pensacola, Combs 530; Avondale, Comus 487; Jupiter, Curtiss 5576C; Chipley, Combs 574, 619; Grasmere, Combs 1112; Tampa, Garber in 1877; Braidentown, Combs 1266; Myers, Chase 4187, Hitchcock Lee Co. Pl. 492; without locality, Chapman, Garber in 1878, Simpson in 1889.

Alabama: Mobile, Kearney 50 in part, Mohr in 1884, 1893, and 1894.

Mississippr: Ocean Springs, Kearney 293, Tracy 26; Horn Island, Tracy in 1898. Louisiana: Without locality, Hale (Gray Herb.).

Texas: Nona, Nealley in 1892; without locality, Nealley in 1884.

Bahamas: Andros, Brace 7019, 7132 (both in Field Mus. Herb.).

Cuba : Pinar del Rio, Wright 3870 in part; Herradura, Hitchcock 154, Tracy 9080.

\section{$\checkmark$ 49. Panicum stenodes Griseb.}

Panicum stenodes Griseb. Fl. Brit. W. Ind. 547. 1864. "HA R. Jamaica!, Pd. [Purdie], in savannahs, Manchester." The type specimen, bearing data as published, is in the Kew Herbarium.

Panicum hians Spruce; Griseb. Fl. Brit. W. Ind. 548. 1864, not Ell. 1816. This name is given as a synonym of $P$. stenodes and credited to " $P l$. Spruce." We have

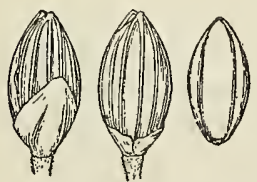

FIG. $91,-P$. stenodes. From Wright's no. 192 in Grisebach Herbarium. not seen Spruce's specimen and the name is here referred to $P$. stenodes on the authority of Grisebach.

\section{DESCRIPTION}

Plants in small tufts, 25 to $50 \mathrm{~cm}$. high, glabrous throughout; culms erect or reclining, very slender and wiry, producing from the middle nodes slender branches about equaling the main culm, both this and the branches bearing small, solitary or fascicled panicles from the upper nodes; sheaths very short, about 1 to $2 \mathrm{~cm}$. long; blades 1 to $4 \mathrm{~cm}$. long, 1 to $2 \mathrm{~mm}$. wide, the upper often reduced to mere points, erect, firm, involute; panicles short-exserted, the lateral often partly included, 1 to $2 \mathrm{~cm}$. long, 1 to $2 \mathrm{~mm}$. wide, subracemose; spikelets 1.4 to $1.6 \mathrm{~mm}$. long, about $0.7 \mathrm{~mm}$. wide, elliptic, rather turgid; first glume about half the length of the spikelet, blunt, nerveless or 1-nerved; second glume and sterile lemma equal, scarcely exceeding the fruit, 5-nerved; fruit $1.3 \mathrm{~mm}$. long, $0.6 \mathrm{~mm}$. wide.

This species is distinguished from $P$. tenerum by its more slender culms, numerous branches, and smaller panicles of smaller spikelets. 
Panicum caricoides Nees, ${ }^{a}$ the type specimen of which, in the Munich Herbarium, was collected by Martius in the province of Para, Brazil, is an allied species. The Martius specimen differs from the West Indian plants in having larger spikelets, 1.8 to $1.9 \mathrm{~mm}$. long, and numerous long, stiff, erect hairs on the pedicels.

\section{DISTRIBUTION.}

Borders of ponds and wet savannas, Costa Rica and the West Indies; also in Brazil.

Costa Rica: Buenos Aires, Pittier 10589.

CubA: Herradura, Baker \& Dimmock 4837 (Hitchcock Herb.), Hitchcock 155; without locality, Wright 3871; Hanabana, Wright 192 (Grisebach Herb.).

Santo Domingo: Wright, Parry, \& Brummel 624.

Brazil: Prov. of St. Paul, St. Hilaire 758 (Paris Herb.); Barra, Spruce 1289 (Gray Herb.).

Agrostoidia.-Tufted perennials; culms erect, compressed, sheaths more or less keeled; ligules membranaceous, short, sometimes ciliate; blades long and narrow; spikelets lanceolate, glabrous; first glume keeled, scabrous on the keel toward the apex, the second glume and sterile lemma pointed beyond the fruit, more or less keeled, the spikelet thus often appearing laterally compressed, the palea of the sterile floret about half as long as its lemma; fruit elliptic, smooth and shining, a minute tuft of thickish hairs at the apex.

The first three species of this group have much the appearance of certain species of Agrostis.

Rootstocks present; culms but little compressed; spikelets set obliquely on their appressed pedicels.

Panicles open; spikelets 3.4 to $3.8 \mathrm{~mm}$. long (shorier in exceptional specimens).................... 55. P. anceps.

Panicles more or less contracted; spikelets not over 2.8

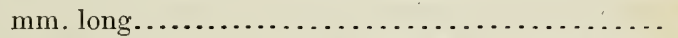

Rootstocks absent; culms strongly compressed with keeled sheaths; spikelets not obliquely disposed.

Ligules ciliate; basal leaves half as long as the culm or more; panicle much exceeding the upper leaves.

Spikelets not over $2.7 \mathrm{~mm}$., usually $2.5 \mathrm{~mm}$. long, the first glume less than half that length; ligules 2 to $3 \mathrm{~mm}$. long....................... P. Pongifolium.

Spikelets 3 to $3.5 \mathrm{~mm}$. long; first glume two-thirds to three-fourths that length; ligule less than 1 mm. long........................... 54. P. combsii.

Ligules erose or lacerate, not ciliate; basal leaves in short tufts, the upper usually nearly equaling the terminal panicle.

Fruit stipitate; spikelets 2.5 to $2.8 \mathrm{~mm}$. long, conspicuously secund.................. 52. P. stipitatum.

Fruit not stipitate; spikelets not conspicuously secund.

Spikelets 1.8 to $2 \mathrm{~mm}$, in occasional specimens $2.2 \mathrm{~mm}$. long; panicle branches ascending or spreading..................... $50 . \quad P$. ugrostoides.

Spikelets about $2.5 \mathrm{~mm}$. long; panicle branches erect or nearly so................. 51. P. condensum. 


\section{Panicum agrostoides Spreng.}

Panicum agrostoides Spreng. Pl. Pugill. 2:4. 1815. Sprengel first gives an original diagnosis, then cites "P. agrostidiforme Lam. ill. n. 895. encycl. 4. 738. Habitare videtur in Cayenna. Misit etiam Mühlenbergius e Pensylvania." Then follows an ample description which applies to the plant bearing the name Panicum agrostoides and marked as sent by Muhlenberg which is found in the Willdenow Herbarium. Sprengel's herbarium is not segregated from the general herbarium at Berlin, as is Willdenow's, and no specimen marked Panicum agrostoides from Mfuhlenberg was found in the general herbarium. Sprengel's description was doubtless based on the specimen in the Willdenow Herbarium, which is therefore taken as the type, the citation of Lamarck's name $a$ as a synonym being erroneous. It would seem that the name $P$.agrostoides was given by Muhlenberg on the specimen sent to Willdenow, since Muhlenberg shortly after $b$ published this as a new species of his own. ${ }^{c}$ In the Muhlenberg Herbarium specimens of both this species and of $P$. stipitatum are found in the cover marked "Panicum agrostoides M."

Panicum rigidulum Bosc; Spreng. Syst. Veg. 1:320. 1825. 'This is given as a synonym of $P$. anceps Michx. and is based on P. "rigidulum Bosc. (II. herb.)." The

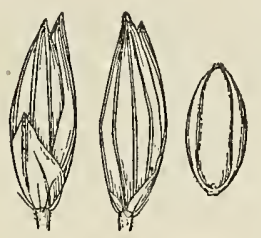

FIG. 92.-P. agrostoides. From type specimen in Willdenow Herbarium. specimen in the Willdenow Herbarium is $P$. agrostoides. Panicum rigidulum was described by Nees $d$ as a new species with Bosc as the author, and based on the specimen in the Willdenow Herbarium.

Agrostis polystachya Bosc; Steud. Nom. Bot. ed. 2. 1: 40. 1840. This is given as a synonym of $A$. composita Poir. No locality is cited. A specimen in the De Candolle Herbarium, collected in Carolina by Bosc, is referable to P. agrostoides. In the Delessert Herbarium are two specimens labeled by Bose as Agrostis polystachya; one is Panicum anceps and the other is $P$. virgatum.

Panicum elongatum ramosior[ius] Mohr, Contr. Nat. Herb. 6:

357. 1901. "Alabama: Damp cultivated ground. Mobile County, Pierce's Landing." The type specimen, in the Mohr Herbarium, collected by "C. Mohr, Oct. $1885, "$ is a portion of a plant with an unusually large and open panicle.

This species was described by Nash $e$ under the name of $P$. agrostidiforme Lam.

\section{DESCRIPTION.}

Plants in dense clumps, from a short caudex, with numerous shoots of short leaves at the base, erect, glabrous throughout except as noted, $50 \mathrm{~cm}$. to 1 meter or more high; culms rather stout, compressed; sheaths longer than the internodes, keeled, occasionally pilose on the sides at the juncture with the blade; ligules erose, about $1 \mathrm{~mm}$. long; blades erect, conduplicate at the base, but flat above or sometimes drying involute, 20 to $50 \mathrm{~cm}$. long, rarely longer, 5 to $12 \mathrm{~mm}$. wide; panicles terminal and axillary, finally long-exserted, 10 to $30 \mathrm{~cm}$. long, rarely longer, usually half to two-thirds as wide but occasionally diffuse and nearly as wide as long, the stiff branches ascending or sometimes spreading at maturity, with more or less divergent, densely flowered branchlets, commonly from the lower side, the ultimate branchlets and short pedicles

a Panicum agrostidiforme Lam., the type of which is in the Lamarck Herbarium, is P. laxum Swartz.

${ }^{b}$ Descr. Gram. 119. 1817.

$c$ Sprengel does not include his $P$. agrostoides in the Systema [Syst. Veg. 1: 319 . 1825 ] but gives $P$. agrostoides Muhl. as a synonym of $P$. proliferum.

$d$ Agrost. Bras. 163. 1829.

e Britt. \& Brown, Illust. F1. 1 : 115. f. 249. 1896. 
appressed, scabrous, the latter usually bearing at the summit one to several delicate white hairs, these often one-fourth to one-third as long as the spikelet; spikelets 1.8 to $2 \mathrm{~mm}$. long, in occasional specimens $2.2 \mathrm{~mm}$. long, 0.7 to $0.8 \mathrm{~mm}$. wide; first glume hardly half the length of the spikelet; second glume and sterile lemma subequal, 5-nerved, the midnerves scabrous at the summit; fruit $1.3 \mathrm{~mm}$. long, $0.6 \mathrm{~mm}$. wide.

This widely distributed species is variable in the form of the panicle, occasional specimens approaching $P$. condensum and others $P$. stipitatum. The Muhlenberg specimens in the Willdenow and Muhlenberg herbaria are the characteristic form described above.

The following specimens have rather turgid spikelets 2 to $2.2 \mathrm{~mm}$. long, more or less crowded on the ascending but not appressed branches and appear to be intermediate between $P$. agrostoides and $P$. condensum. These are not cited in the distribution given below. Marne: North Berwick, Parlin 751; Massachusetrs: Newburyport, Conant; New York: Erastina, Pollard in 1894; Virginia: Boettcher 462; Georgia: Leslie, Harper 1730; Florida: Jacksonville, Curtiss 5302; Bartow, Combs 1207; Louisiana: Lake Charles, Chase 4410; Texas: Dallas, Reverchon 1083A; Hempstead, IIall 819; without locality, Reverchon 103 in 1879.

In the following specimens the spikelets are more or less secund on the branchlets, giving the panicles much the aspect of those of $P$. stipitatum, but the spikelets are 2 $\mathrm{mm}$. long or scarcely more: Bartlett 1066, Chase 4397, Curtiss 6890, Harper 1239, Plank 24, Riggs, Marshall, Texas.

Unusually loosely flowered, open-panicled specimens, such as that named $P$. clongatum var. ramosius, are the following: Chapman, Georgia, Curtiss 6888, Mohr in 1885, Plank 75, Winchell, Alabama.

\section{- distribution.}

Wet meadows and shores, Maine to Illinois and Kansas, south to Florida and Texas; also on Vancouver Island and in California.

MaIne: Orono, Harvey 1240; North Berwick, Parlin in 1896 (Gray Herb.).

MassachUSETTS: Without locality, Conant; Middlesex Fells, Knowlton 910 (Hitchcock Herb.).

Connecticut: South Manchester, Hitchcock 129; Huntington, Eames in 1895; Southington, Bissell 5529.

Rhode Island: Cumberland, Greenman 1804 (Gray Herb.).

New York: Cleveland, Rowlee in 1906.

New Jersey: Mount Arlington,

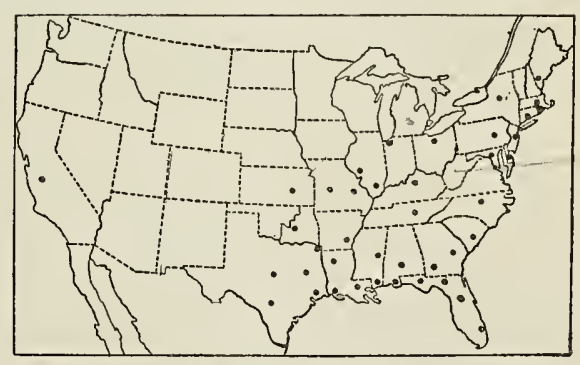

FIG. 93.-Distribution of $P$. agrostoides. Mackenzie 2355; Stockholm, Van Sickle in 1895; Atsion, Chase 3529; Moninouth Junction, Pearce in 1884.

Pennsylvania: Chambersburg, Porter in 1897; Tinicum, Smith 158; Westchester, Darlington; without locality, Mc Minn.

OHio: Sandusky, Kellerman in 1902 (Univ. Ohio Herb.).

Indiana: Miller, Umbach in 1896 (Field Mus. Herb.).

Illinors: Madison, Eggert 227; St. Clair County, Brendel in 1850; southern Illinois, Vasey in 1860 .

Missouri: Lake City, Mackenzie 301; Sibley, Bush 302; Monteer, Bush 5115 in part; Lees Summit, Bush 5234; Dunklin County, Bush 9. 
Kansas: Cherokee County, Hitchcock Pl. Kan. 877; Kingman County, Carleton 548 .

Delaware: Townsend, Canby in 1891; Talleyville, Commons in 1897.

Maryland: Lanham, Chase 3469, Hitchcock 2398; Glen Echo, Kearney in 1895; Great Falls, Ball 83.

North Carolina: Chapel Hill, Coker in 1908.

South Carolina: Aiken, Ravenel in 1869; Orangeburg, Hitcheoch 445.

Georgra: Thomson, Bartlett 1066; Leesburg, Curtiss 6888, 6890; Arlington, Harper 1239; Augusta, Cuthbert 1128; without locality, Chapman.

Florida: Old Town, Combs 879; Dunnellon, Combs 915; Lake City, Chase 4286, 4287; Eustis, Nash 1694; Grasmere, Combs 1120; Clarcona, Meislahn 100, 159a; Orange County, Baker 131; Crystal, Combs 1012; Homosassa, Combs 961; Bartow, Combs 1198, 1204; Ellzey, Combs 804; Jenkins, Eaton 242; Miami, Eaton 164 in part, 165; without locality, Rugel in 1842.

Kentuchy: Lexington, Short in 1835 (Gray Herb.).

Tennessee: Knoxville, Ruth 65.

Alabama: Eufaula, McCarthy in 1888; Cullman County, Eggert in 1897; Mobile County, Mohr in 1885; without locality, Chapman, Winchell.

Mississippr: Starkville, Chase 4445, Kearney 74; Nicholson, Kearney 372 in part; Panola County, Eggert in 1896; Horn Island, Tracy 2036.

Arkansas: Fulton, Bush 1023; Texarkana, Heller 4235.

Louisiana: Coushatta County, Ball 124; Alexandria, Ball 169; Rayville, Ball 20 in part; Natchitoches, Ball 156; Oberlin, Ball 225; Chalmette, Tracy 7651; Shreveport, Ball 111; Pointe a la Hache, Langlois in 1880; Lake Charles, Chase 4397.

Texas: Texarkana, Plank 24; Beaumont, Plank 24; Jacksonville, Joor in 1884; Rusk, Plank 75; Marshall County, Riggs 18; Columbia, Bush 1398; Harvester, Thurow in 1898; Hockley, Thurow in 1859; Tyler, Reverchon 2222; Luling, Plank 22; "60 miles south of Fort Scott," Palmer in 1863.

OкLAномa: Poteau, Hitchcock in 1903 (Hitchcock Herb.); without locality, Sheldon in 1891.

British Columbia: Sproat Lake, Vancouver Island, Macoun 135, 29348. a

California: On the Sacramento, Wilkes Expl. Exped. $b$

\section{Panicum condensum Nash.}

Agrostis purpurascens Bert.; Steud. Nom. Bot. ed. 2. 1:42. 1840, not Swartz, 1788. "Domingo" is cited, but no description is given. Bertero's specimen, labeled "Agros-

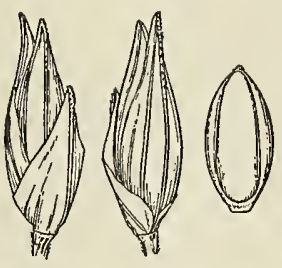

Fig. 94.-P. condensum. From type specimen. tis purpurascens loc. aquosis. S. Domingue Bertero. M. Balbis 1821," in the Berlin Herbarium, is P. condensum.

Panicum contractum Trin.; Steud. Nom. Bot. ed. 2. 2: 254. 1841. "Trin. mpt. Guadal. Domingo" is cited, but no description is given. The specimen in the Berlin Herbarium, bearing this name in Trinius's writing and labeled "S. Domingo, locis aquosis. Balbis misit 1824 ," is $P$. condensum.

Panicum condensum Nash in Small, Fl. Southeast. U. S. 93. 1903. On page 1327 in the list of new genera and species the following citation is given: "Type, Curtiss, Second Distr. Pl. So. U. S., no. 5576, in Herb. C. U." The type, in Columbia University Herbarium, is a single plant lacking the base. Curtiss's no. 5576 was collected October 16, 1895, near Jacksonville, Fla.

$a$ These were collected on the same date, but have been distributed under two numbers.

$b$ Thurber [Torr. Bot. Wilkes Expl. Exped. 1:480. 1874] calls attention to the fact that this collection was far out of the known range of $P$. agrostoides. 
DESCRIPTION.

Plants like $P$. agrostoides in habit, culms on the average rather taller, sometimes geniculate at base; sheaths appressed-pubescent along the sides toward the summit or glabrous; blades often sparsely pilose on the upper surface at the conduplicate base; panicles terminal and axillary, 10 to $25 \mathrm{~cm}$. long, rarely over $5 \mathrm{~cm}$. wide, the long, solitary or fascicled branches erect, naked at the base, with appressed branchlets bearing crowded spikelets on short, scabrous, but not pilose pedicels, or these occasionally with one or two erect hairs; spikelets 2.2 to $2.5 \mathrm{~mm}$. long, about $0.8 \mathrm{~mm}$. wide, turgid; first glume slightly more than half the length of the spikelet, acuminate; second glume slightly longer than the sterile lemma, both

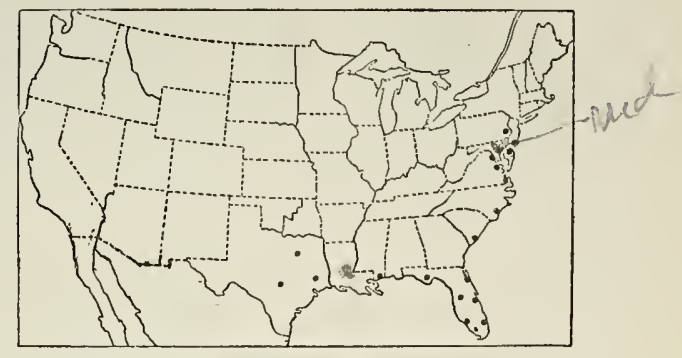

FIG. 95.-Distribution of $P$. condensum. acuminate, the tips slightly spreading, scabrous on the midnerves toward the apex; fruit 1.4 to $1.5 \mathrm{~mm}$. long, about $0.7 \mathrm{~mm}$. wide.

This species is closely related to $P$. agrostoides, from which it is distinguished by the condensed panicle of slightly larger spikelets. In occasional specimens, as Combs 9641 $\frac{1}{2}, 973$, Hitchcock 174, and Meislahn 159, the panicle branches are ascending, the panicle not contracted, thus approaching $P$. agrostoides.

\section{DISTRIBUTION.}

Borders of streams and ponds and in wet places, Pennsylvania to Florida and west to Texas, mostly near the coast; also in the West Indies.

New Jersey: Cape May County, Van Pelt in 1909 (Acad. Phil. Herb.).

Pennsyluania: Chambersburg, Porter in 1897.

Delaware: Sinyrna, Long in 1908 (Acad. Phil. Herb.).

District of Columbia: Steele in 1896.

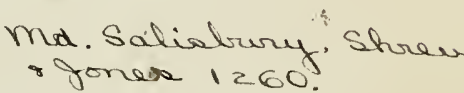

Virginia: Brick Haven, Steele in 1896; Four-Mile Run, Chase 2673; Virginia

Beach, Hitchcock 174.

North Carolina: Wilmington, Hitchcock 444.

South Carolina: Isle of Palms, Chase 4527.

Florida: Jacksonville, Curtiss 5298, 5576, 5576A; Titusville, Chase 4014; Orange

County, Baker 18, Combs 1144; Clarcona, Meislahn 159; Homosassa, Combs

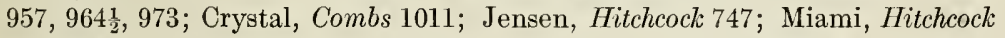
172, 695, 699; Braidentown, Simpson 7093; St. Vincents Island, Chapman, Tracy 6444.

Mississippi: Horn Island, Tracy in 1893 (Hitchcock Herb.).

Texas: Dallas County, Reverchon 2368; Waller County, Thurow in 1898; without locality, Lindheimer 728.

Bahamas: Nassau, Curtiss W. Ind. Pl. 174.

Cuва: Without locality, Wright 3862 in part.

Grand Cayman: Hitchcock in 1891 (Mo. Bot. Gard. Herb.).

Leeward Islands: Guadeloupe, Duss 3919. 


\section{$\checkmark$ 52. Panicum stipitatum Nash.}

Panicum elongatum Pursh, Fl. Amer. Sept. 1: 69. 1814, not Salisb. 1796. "New Jersey to Virginia." Among the Pursh plants in Kew Herbarium are two sheets

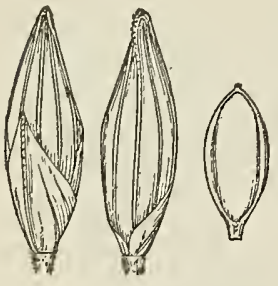

FIG. $96 .-P$. stipitatum. From Common's no. 305. labeled "Panicum elongatum Pursh. Fl: Amer.," on one of which is a robust specimen and a ticket bearing an unpublished herbarium name, and also the name "elongatum" and the word "Delaware." This is taken as the type. On the second sheet are two slender specimens, one of this species and the other of $P$. agrostoides.

Panicum agrostoides elongatum Scribn. Tenn. Agr. Exp. Sta. Bull. 7 : 42. pl. 9.f. 34. 1894. Based on P. elongatum Pursh. Panicum stipitatum Nash in Scribn. U. S. Dept. Agr. Div. Agrost. Bull. 17 (ed. 2):56.f.352. May 22, 1901. Based on P. elongatum Pursh, 1814, not Salisb. 1796. "Nash, in Britt. Manual, 83, 1901," is here cited as the place of publication, but this must have been taken from proof sheets, since the Manual was not published until after August 24, 1901, that being the date given after the preface.

\section{DESCRIPTION.}

Plants like $P$. agrostoides in habit, often purple-tinged throughout; culms on the average stouter, strongly conpressed; sheaths much overlapping, blades usually equaling or exceeding the terminal panicles, often scabrous on the lower surface; panicles usually several to a culm, sometimes as many as five axillary panicles, commonly dark purple, short-exserted, 10 to $20 \mathrm{~cm}$. long, one-third to half as wide, densely flowered, the numerous stiff branches ascending, with numerous divaricate branchlets mostly from the lower side and beginning at the base, bearing crowded, subsecund spikelets, the short, scabrous pedicels only rarely with one or two erect hairs; spikelets 2.5 to $2.8 \mathrm{~mm}$. long, about $0.7 \mathrm{~mm}$. wide, often curved at the point; first glume about half the length of the spikelet; second glume and sterile lemma subequal, scabrous on the midnerve at the acuminate apex; fruit about $1.5 \mathrm{~mm}$. long, about $0.6 \mathrm{~mm}$. wide, short-stipitate.

Typical specimens of this species are characteristic and readily distinguished from $P$. agrostoides, but less densely panicled forms, with smaller spikelets approach that species. Such are the following: Bush 3658, Chase 4497, Cocks 3008. In these specimens the fruit is stipitate, for which reason they are referred to this species.

\section{DISTRIBUTION.}

Moist soil, Connecticut to South Carolina, west to Kentucky, Missouri, and Texas.

Connecticut: Lyme, Graves 236.

New Jersey: Camden, Scribner 39 in part; Oradell, Mackenzie 1893.

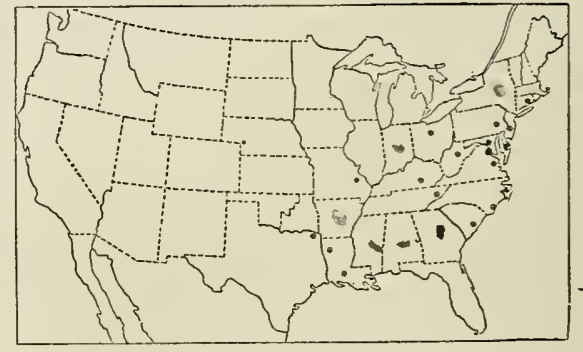

FIG. 97.-Distribution of $P$. stipitatum.

Pennsylvania: Chambersburg, Porter in 1897; Westchester, Darlington in 1827. Онго: Lancaster, Kellerman 6800.

Missouri: Williamsville, Bush 3658.

DELA WARE: Greenbank, Commons 25 and 305 in 1884.

Maryland: Hyattsville, House 1443.

Indiana: 5 miles east of Norris. Deam. $1=090$. 
District of Columbia: Greene in 1908, Steele, Vasey.

Virginia: Four-Mile Run, Chase 2679; Goshen, Steele in 1904.

West Virginia: Grafton, Guttenberg in 1879, Smith in 1879.

North Carolina: Newbern, Kearney 2249; eastern North Carolina, McCarthy in 1885; Henderson County, Smith in 1881.

South Carguina: Aiken Ravenel in 1869: Isle of Palms, Hitchcock 225.

KENTUCKY: Bell County, Kearney 380; ${ }^{\text {G Hallan County, Kearney } 380 . a}$

Tennessee: Hollow Rock, Biltmore Herb. 808a, Eggert in 1897; Cocke County, Kearney 969; Madison County, Bain in 1892.

Alabama: Scottsboro, Chase 4497.

Louisiana: Calhoun, Ball 70; Calcasieu, Cocks 3008.

Texas: Texarkana, Plank 77.

\section{$\checkmark$ 53. Panicum longifolium Torr.}

Panicum longifolium Torr. Fl. North. \& Mid. U. S. 149. 1824. "In the pine barrens of New Jersey. * * * For specimens * * I am indebted to $\mathrm{Mr}$.

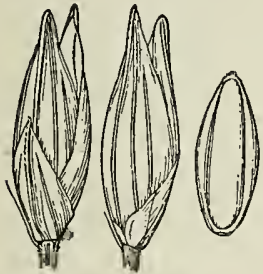

Fig. 98.-P. longifolium From type specimen. James Goldy." The type, in the Columbia University Herbarium, is a small specimen $35 \mathrm{~cm}$. high, with an open, fewflowered panicle.

Panicum anceps pubescens Vasey, U. S. Dept. Agr. Div. Bot. Bull. 8 :37. 1889 . "Mobile, Ala. (Dr. Mohr)." There is no specimen in the National Herbarium marked with this name in Vasey's writing, but there are two duplicate specimens of $P$. longifolium with pubescent sheaths and blades, collected by Dr. Charles Mohr, Mobile, Alabama, both labeled Panicum anceps and bearing an unpublished varietal name in Vasey's writing. These agree with Vasey's brief description and are doubtless the basis of this name. Vasey applied this unpublished varietal name also to specimens of $P$. anceps and to one of $P$. rhizomatum, but Dr. Mohr's, being the only specimen cited, is taken as the type.

Panicum pseudanceps Nash, Bull. Torrey Club 25: 85. 1898. "Collected by Mr. J. H. Simpson in Florida in 1889." The type, in Nash's herbarium, consists of two plants 58 and $60 \mathrm{~cm}$. high, the panicles less open than those of the Goldy specimen mentioned above.

DESCRIPTION.

Plants in dense tufts, 35 to $80 \mathrm{~cm}$. high, usually surrounded by basal leaves nearly half as long as the culm; culms rather slender, much compressed, stiff, glabrous; sheaths mostly shorter than the internodes except at the base, keeled, usually hairy on the sides at the juncture with the blade, otherwise glabrous or villous toward the summit, sometimes densely so; ligules fimbriate-ciliate, 2 to $3 \mathrm{~mm}$. long, the ciline usually at the sides only, not meeting at the back; blades erect or sometimes recurved or truos, conduplicate at base, flat above or somewhat involute, 8 to $40 \mathrm{~cm}$. long, 2 to $5 \mathrm{~mm}$. wide, pilose on the upper surface toward the base, sometimes also on the lower surface; lateral panicles few or none; terminal panicles finally long-exserted, much exceeding the leaves, 10 to $25 \mathrm{~cm}$. long, usually half to two-thirds as wide, but sometimes rather contracted, the distant, slender branches solitary or fascicled, ascending, usually nak $d$ at base, bearing short, appressed, rather closely flowered branchlets, these and the pedicels scabrous, the latter sometimes with a few hairs at the summit; spikelets 2.4 to $2.7 \mathrm{~mm}$. long, about $0.7 \mathrm{~mm}$. wide; first glume two-fifths to scarcely half the length of the spikelet, acute; second glume slightly longer than the sterile lemma, both keeled, usually spreading at the tip, scabrous on the midnerve at the apex; fruit $1.6 \mathrm{~mm}$. long, $0.6 \mathrm{~mm}$. wide.

a These two collections were distributed under the same number. 
A specimen from Nicholson, Mississippi; Kearney 380, with spreading panicle branches and spikelets only $2 \mathrm{~mm}$. long is doubtfully referred here.

\section{DISTRIBUTION.}

Moist sandy ground, Rhode Island and Connecticut to Florida and west to Texas, mostly near the coast.

Connecticut: Groton, Bissell 11596, Graves 248, 256.

Rhode Island: Shannock, Moore in 1896.

New York: New York, Biclnell in 1896; Long Island, Miller in 1873 (both in Hitchcock Herb.).

New Jersey: Atsion, Chase 3530; without locality, Holmes in 1890.

Pennsylvania: Philadelphia, Saunders in 1898, Smith.

Dela ware: Ellendale, Commons 224, 343, 344.

Maryland: Berlin, Novik 421.

District of Columbia: Kearney in 1897, Steele in 1897 and 1898.

Virginia: Cape Henry, Hitcheock 446; Dismal Swamp, Chase 3662; Virginia Beach, Kearney 2025.

North Carolina: N ew ber n, Kearney 2242; Wilmington, Biltmore Herb. 3627, Chase 4564, Hitchcock 447; eastern North Carolina, Ashe; West Raleigh, Stanton 1270; middle

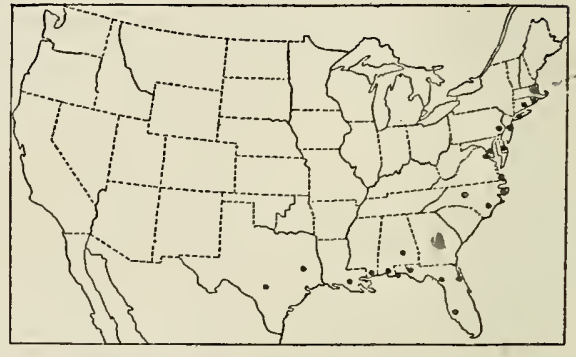

FIG. 99.-Distribution of $P$. longifolium. North Carolina, Ashe.

Florida: Jacksonville, Curtiss 5576B; Milton, Chase 4318; Bayhead, Combs 644; Chipley, Combs 571; Gainesville, Chase 4225; Crystal, Combs 1010; Grasmere, Combs 1154, 1168; Bartow, Combs 11801 1235.

Alabama: Tuskegee, Carver 100, Cullman, Eggert in 1897, Mohr in 1886; Mobile, Mohr.

Mississippi: Biloxi, Chase 4346, Kearney 220, Tracy 3627, 3860, 6507a; Fontainbleau, Tracy 3858, 3859; Ship Island, Tracy 4563; Waynesboro, Kearney 116. Louisiana: Without locality, Hale (Gray Herb.).

Texas: Jefferson, Plank 31; without locality, Nealley in 1885, Wright.

\section{- 54. Panicum combsii Scribn. \& Ball.}

Panicum combsii Scribn. \& Ball, U. S. Dept. Agr. Div. Agrost. Bull. 24 : $42 . f .16$.

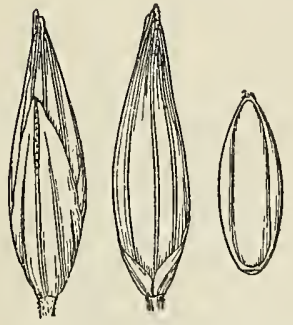

FIG. 100.-P. combsii. From type specimen. 1901. "Type collected by Robert Combs, No. 583, for whom the species is named, in damp, fertile flat woods at Chipley, Washington County, Florida, August 20, 1898." The type specimen, in the National Horbarium, is a tuft of several culms with mature panicles.

\section{DESCRIPTION ,}

Plants like P. longifolium in habit; leaves somewhat more clustered at base; sheaths glabrous or pubescent along the margin toward the summit; ligules less than $1 \mathrm{~mm}$. long, sometimes a few longer hairs at the margin; blades averaging shorter, rarely $25 \mathrm{~cm}$. long, glabrous or pilose on the upper surface at the base, usually sparsely so; lateral panicles wanting or but one or two, terminal panicles 12 to $20 \mathrm{~cm}$. long, two-thirds to three-fourths as wide, few-flowered, the slender, scattered branches ascending; 
spikelets 3 to $3.5 \mathrm{~mm}$. long, 0.7 to $0.8 \mathrm{~mm}$. wide, acuminate; first glume two-thirds to three-fourths the length of the spikelet; second glume and sterile lemma subequal, usually scabrous on the midnerve, much exceeding the fruit; fruit 1.8 to 2 $\mathrm{mm}$. long, 0.6 to $0.8 \mathrm{~mm}$. wide.

This species is closely related to $P$. longifolium from which it may be distinguished by its shorter blarles, longer spikelets, and usually by the lack of pubescence.

\section{DISTRIBUTION.}

Margins of ponds and wetwoods, Georgia to Florida, and west to Louisiana.

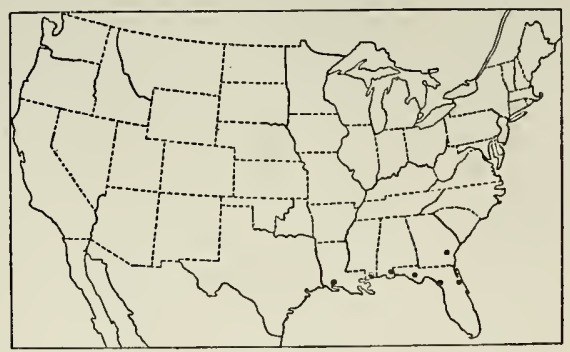

FIG. 101.-Distribution of $P$. combsii.

Georgia: Tifton, Harper 1679; Douglas, Harper 2014, Huntington, Harper 1081.

Florida: Pensacola, Cuxtiss 6919; Argyle, Curliss 6925A; Chipley, Combs 583; witlout locality, Chapman.

Alabama: Gateswood, Tracy 8408.

Mrssissippr: Biloxi, Tracy 4568 in part.

Louisiana: Lake Charles, Chase 4434.

\section{Panicum anceps Michx.}

Panicum anceps Michx. Fl. Bor. Amer. 1: 48. 1803. "НАB. in Carolinae herbosis humidis sylvaticis." The type specimen, labeled "Panicum anceps, Hab. in herbosis humidis Carolinae, Virginiae, Georgiae," is in the Michaux Herbarium.

Panicum rostratum Muhl.; Willd. Enum. Pl. 1032. 1809. "Habitat in sylvaticis humidis Pensylvaniae, Carolinae." The type specimen, in the Willdenow Herbarium,

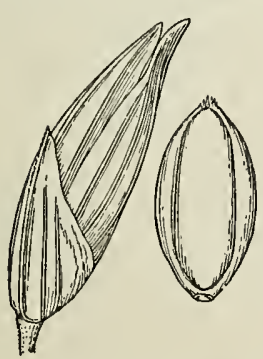

FIG. 102.-P. anceps. From type specimen. is marked "P. rostratum Am. Boreal. Muhlenberg." Muhlenberg later ${ }^{a}$ published $P$. rostratum as a new species. The specimen in the Muhlenberg Herbarium is the same species as the one sent to Willdenow.

Agrostis nutans Poir. in Lam. Encycl. Suppl. 1: 255. 1810. "Cette plante a été recueillie dans la Caroline, par M. Bosc." We have not seen this specimen, but the description applies well to $P$. anceps, to which species Poiret later $b$ refers his $A$. nutans.

Panicum nutans Desv. Opusc.93.1831. Based on "Agrostis nutans Poir. Enc. suppl."

Panicum anceps angusta[um] Vasey, U. S. Dept. Ágr. Div. Bot. Bull. 8: 37. 1889. "Texas (G. C. Nealley)." The type specimen, in the National Herbarium, is a tall plant with an immature panicle, the long blades involute.

Panicum anceps densiflorum Vasey, U. S. Dept: Agr. Div. Bot. Bull. 8:37. 1889. "Texas (J. F. Riggs)." The type specimen, in the National Herbarium, was collected November, 1884, Marshall, Texas, by J. F. Riggs, no. 91. It consists of the upper portions of two robust plants, the panicle branches densely flowered.

\section{DESCRIPTION.}

Plants in tufts of few to many culms, $50 \mathrm{~cm}$. to 1 meter or more high, with numerous stout, scaly rootstocks; culms usually robust, not strongly compressed, glabrous; sheaths usually shorter than the internodes, glabrous to densely papillose-pilose, 
especially at the summit; ligules membranaceous, less than $1 \mathrm{~mm}$. long; blades erect, flat or but slightly conduplicate at base, 20 to $50 \mathrm{~cm}$. long, 4 to $12 \mathrm{~mm}$. wide, pilose and usually ciliate on the upper surface toward the base, otherwise glabrous, scabrous or more or less pubescent on the upper and occasionally on the under surface; panicles terminal only, or narrow, long-peduncled panicles produced from the upper sheaths, the terminal ones finally long-exserted but often nearly equaled by the long blades, 15 to $40 \mathrm{~cm}$. long, usually half to twothirds as wide (or occasionally narrow), the long, slender, remote, branches somewhat spreading, bearing short, mostly appressed, distant or approximate branchlets with rather crowded, somewhat curved, subsecund spikelets set obliquely on their short, appressed, scabrous pedicels, the first glume toward the main axis, the axes and branches scabrous, usually a few hairs in the axils; spikelets 3.4 to $3.8 \mathrm{~mm}$. long, 1 to $1.2 \mathrm{~mm}$. wide (occasional

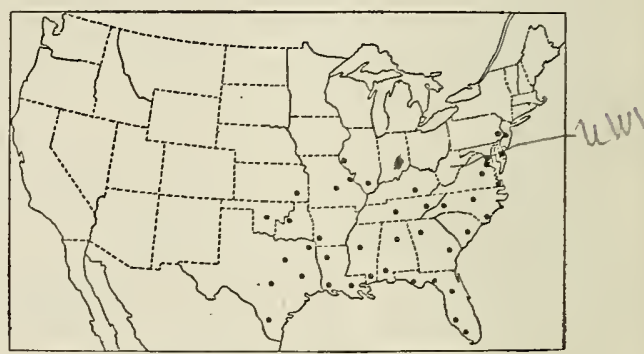

FIG. 103.-Distribution of $P$. anceps. specimens with smaller spikelets); first glume one-third to half the length of the spikelet, acute; second glume and sterile lemma subequal, forming a beak beyond the fruit, the tips open at maturity; fruit 2 to $2.2 \mathrm{~mm}$. long, about $1 \mathrm{~mm}$. wide.

This species is variable in the pubescence on sheaths and blades and somewhat so in the panicle. The short secondary branchlets may be distant, giving the long branches the appearance of interrupted racemes, or approximate, producing densely flowered branches as in Vasey's variety densiflorum.

A comparatively few specimens occur with spikelets only 3 to $3.2 \mathrm{~mm}$. long. Such are the following, which, being nearly glabrous plants with open panicles, are referred here, though in the smaller spikelets they approach the next species: Ball 228, Chase 4201, 4393, 4554, Cocks 3001, Combs 717, 878, 1398, Kearney 376, Mohr in 1885, Tracy $4620,8414$.

\section{DISTRIBUTION.}

Moist sandy soil, New Jersey to Florida and west to Kansas and Texas.

New Jersey: Stockton, Fisher in 1897.

Pennsylvania: Philadelphia, Smith; Lancaster, Porter in 1861.

IllinoIs: Oquawka, Patterson; Mount Carmel, Waite in 1887.

Missouri: Monteer, Bush 5114; St. Louis, Eggert in 1886.

Kansas: Cherokee County, Hitchcock Pl. Kan. 876.

Delaware: Carpenter Station, Commons 225; Greenbank, Commons 303.

Maryland: West Chevy Chase, Chase 2585; Cabin John, Steele in 1896.

District of Columbia: Blanchard in 1891, Chase 2996, House 257, Kearney 16, Vasey in 1874, Ward in 1878.

Virginia: Fairfax County, Chase 3631; Arlington, Dewey 53; Norfolk, Kearney 1748; Virginia Beach, Britton in 1895, Hitchcock 228.

North Carolina: Madison County, Biltmore Herb. 5839b; West Raleigh, Coit 1301, Stanton 1282; Dunns Mountain, Small in 1894; eastern North Carolina, McCarthy in 1885; Wilmington, Kearney 274.

South Carolina: Aiken, Ravenel in 1869; Orangeburg, Hitchcock 448, 449; Isle of Palms, Chase 4554.

Georgia: Thomson, Bartlett 903; Whitfield County, Harper 369; Stone Mountain, Hitchcock 230; Leesburg, Curtiss 6887; Augusta, Cuthbert in 1904.

Florida: Madison, Combs 282; Quincy, Combs 415; Tallahassee, Combs 381, Kearney 87, Nash 2529; De Funiak Springs, Combs 470; Chattahoochee, Cur- 
tiss 5936; Apalachicola, Biltmore Herb. Dist. Dupl. Chapman 696b; Monticello, Combs 320; Homosassa, Combs 935, 972; Lake City, Chase 4284; Crystal, Combs 1021; Gainesville, Chase 4201, Combs 717; Old Town, Combs 878; Chipley, Combs 560, 586; Grasmere, Combs 1073; Orange Bend, Chase 4095; Bartow, Combs 1206; Tampa, Combs 1398; Fort. Lauderdale, Eaton 341; without locality, Chapman.

KentuCky: Bell County, Kearney 372 in part.

Tennessee: Bristol, Hitchcock 229; Lavergne, Biltmore Herb. 696a; Knoxville, Ruth in 1895 and 1898; Cocke County, Kearney 965; Grainger County, Smith in 1880 .

Alabama: Auburn, Tracy in 1897; Birmingham, McCarthy in 1888; Gadsden, McCarthy in 1888; Nesheka, Carver 7; Cullman, Mohr in 1885.

Mississippr: Nicholson, Kearney 376; Taylorville, Tracy 8414; Waynesboro, Pollard 1228; Tupelo, Tracy 1535; Starkville, Chase 4464, Kearney 20 in part; Biloxi, Tracy 4620 and in 1893; Bay St. Louis, Langlois in 1883; Pass Christian, Langlois in 1882.

Arkansas: Benton County, Plank 65; Miller County, Eggert in 1896; Harvey in 1880, Louisiana: Natchitoches, Ball 166; Rayville, Ball 8; Coushatta County, Ball 125; Calhoun, Ball 46; Oberlin, Ball 228; West Carroll Parish, Moseley in 1903; Lake Charles, Chase 4393; Calcasieu, Cocks 3001.

Texas: Texarkana, Heller 4082, Plank 80; Columbia, Bush 1298; Rusk, Plank 76; Beaumont, Plank 25; Marshall, Riggs 91; Waller, Thurow in 1898; Ennis, Smith in 1897; Industry, Wurzlow in 1894; without locality, Nealley in 1887; Reverchon 106.

Oklahoma: On the False Washita, Palmer 380 in 1868; Kingfisher County, Carleton in 1891; Choctaw Agency, Bigelow in 1853-4.

\section{Panicum rhizomatum sp. nov.}

\section{DESCRIPTION.}

Plants like $P$. anceps in habit; the culms less robust, the scaly rhizomes slender and more numerous; leaves more or less clustered toward the base, the sheaths, except the

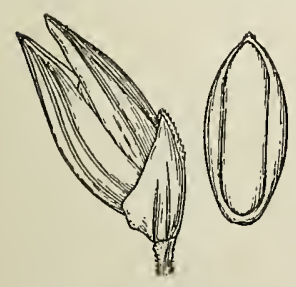

FIG. 104.-P. rhizomatum. From type specimen. lowermost, shorter than the internodes, densely to sparsely villous along the margin and toward the summit, a dense ring of pubescence at the juncture with the blade; ligules nearly obsolete; blades erect or the lower commonly spreading, 10 to $40 \mathrm{~cm}$. long (usually not over $30 \mathrm{~cm}$.), 5 to $10 \mathrm{~mm}$. wide, pubescent on both surfaces or sometimes glabrous except on the upper surface toward the base; terminal panicles long-exserted, the usually numerous smaller axillary ones short-peduncled or partially included, 10 to 25 $\mathrm{cm}$. long, usually less than one-third as wide, more or less contracted and densely flowered, rather more compound than in $P$. anceps, the distant primary branches ascending, bearing numerous branchlets 1 to $3 \mathrm{~cm}$. long, these with appressed, short, approximate branchlets, with crowded spikelets set obliquely on their short, appressed pedicles as in $P$. anceps, but hardly at all secund; spikelets 2.4 to $2.8 \mathrm{~mm}$. long, about $1 \mathrm{~mm}$. wide; first glume one-third to scarcely half as long as the spikelet, acute; second glume and sterile lemma subequal, beaked as in $P$. anceps but less strongly so, but little exceeding the fruit; fruit $1.9 \mathrm{~mm}$. long, $0.9 \mathrm{~mm}$. wide.

Type U. S. National Herbarium no. 592752, collected August 18, 1905, Orangeburg, S. C., by A. S. Hitcheock (no. 450).

This species was referred by Scribner in the herbarium to $P$. anceps pubescens Vasey and was distributed under this name by Nash and others. It is distinguished from $P$. anceps by the somewhat contracted, more densely flowered panicles of smaller 
spikelets and by the shorter leaves more or less crowded at the base. In occasional specimens the panicle is rather open but less so than in $P$. anceps; but the following three specimens, having all the other characters of $P$. rhizomatum, have panicles as open as those of $P$. anceps, the small spikelets secund as in that species, and appear to be intermediate. Florida: Bay Head, Combs 648; Orange County, Baker 40; MississipPi: Starkville, Kearney 61; Waynesboro, Kearney 108.

\section{DISTRIBUTION .}

Moist sandy woods and savannas, Virginia to Forida and west to Texas.

Virginia: Lynn Haven, Hitchcock 175 ; Portsmouth, Noyes 67 in part.

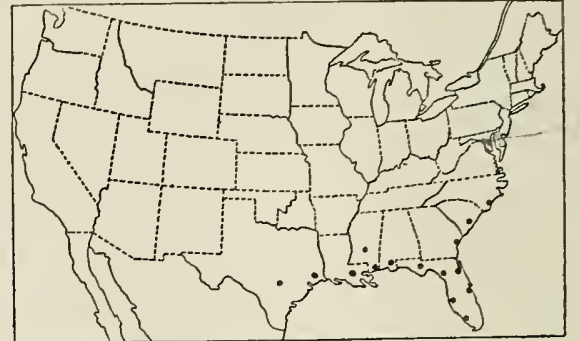

Fig. 105.-Distribution of P. rhizomatum.

North Carolina: Wilmington, Chase 4560, Hitchcock 310.

South Carolina: Orangeburg, Hitchcock 450; Isle of Palms, Hitchcock 104; without locality, Curtiss in 1875.

Georgia: Savannah, Kearney 181; Dock Junction, Ricker 962; Camp Cornelia, Ricker 933.

Florida: Jacksonville, Curtiss 5289, 5747, Kearney 138; Duval County, Curtiss 3579 in part; Madison, Combs 259; Old Town, Combs 884; Lake City, Combs \&

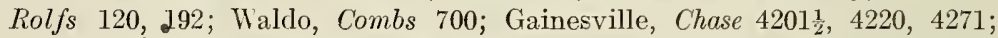
Citrus, Bystra in 1906; Titusville, Chase 3984; Sanford, Nash 2258; Grasmere, Combs 1051, 1125; Eustis, Nash 1713; Ellzey, Combs 820; Dunnellon, Combs 919; Bay Head, Combs 633, 648; Tampa, Combs 1395; Avondale, Combs 496; Bartow, Combs 1192, 1217a; Braidentown, Combs 1252, 1264, 1303, Tracy 7093, 7105; Myers, Chase 4191, Hitchcock Lee Co. Pl. 490.

Alabama: Without locality, Mohr in 1878.

Mississippr: Centerville, Tracy 4564; Nicholson, Kearney 358; Biloxi, Kearney 235, Tracy 3603, 3626, 4619, 4621, and in 1889; Ocean Springs, Forkert 33, Pollard 1106; Bay St. Louis, Langlois in 1883; Pass Christian, Langlois in 1880 and 1882 .

Louisiana: Natchitoches, Ball 137.

Texas: Pierce, Tracy 7405; without locality, Nealle $y$.

Laxa.-Plants mostly perennial, apparently annual in P. laxum and P. pilosum; more or less decumbent at base and rooting at the lower nodes, creeping in $P$. polygonatum, commonly not decumbent in $P$. hians and P.cupreum; culms compressed, glabrous; ligules membranaceous, very short or wanting; spikelets short-pediceled, more or less clustered, not over $3 \mathrm{~mm}$. long, glabrous, the palea of the sterile floret, except in $P$. polygonatum and $P$. longum, becoming more or less enlarged and indurated, expanding the spikelet at maturity; fruit mostly elliptic, minutely papillose-roughened, rather thin in texture.

Spikelets pointed, not expanded at maturity by an enlarged sterile palea.

Nodes densely pubescent; spikelets not over $1.5 \mathrm{~mm}$.

long..................................... 58. P. polygonatum.

Nodes glabrous; spikelets $2.5 \mathrm{~mm}$. long............... 57. P. longum.

Spikelets blunt, expanded at maturity by the enlarged sterile palea.

Panicle branches subracemose, the spikelets secund; blades at least $5 \mathrm{~mm}$. wide; the enlarged sterile palea not conspicuous. 
Rachises bearing slender bristles (these wanting in exceptional specimens); blades broadest near the cordate or truncate base; nodes usually villous............................. 59. P. pilosum.

Rachises without bristles; blades narrowed toward the base; nodes glabrous................6. 60. P. laxum.

Panicle branches not racemose; blades scarcely wider than their sheaths; the sterile palea conspicuously enlarged.

Spikelets $3 \mathrm{~mm}$. long, congested; panicles dark purple............................. 63. P. cupreum.

Spikelets not over $2.4 \mathrm{~mm}$. long; panicles green or pale.

Panicle branches spikelet or branchlet-bearing along the upper half or toward the ends only ............................ 62. Pians.

Panicle branches branchlet-bearing throughout their length or nearly so............ 61. P. exiguiflorum.

- 57. Panicum longum nom. noy.

Panicum munitum Trin.; Steud. Nom. Bot. ed. 2. 2: 260. 1841. This nomen nudum is credited to "Trin. mpt. Mexico." A specimen of $P$. longum collected near Jalapa by Schiede and Deppe, no. 674, and listed by Schlechtendahl $a$ as number 898 "Panicum proximum piloso Sw.," was examined at Halle. The sheet is marked "Panicum munitum" by Trinius, and may be the type of this name, but since the species was not described by Trinius $P$. longum is here based on Scribner's type, Pringle 8195.

Panicum pilosum macranthum Scribn. U. S. Dept. Agr. Div. Agrost. Circ. 19: 1. 1900, not P. macranthum Trin. 1826. "Swamps near Jalapa, State of Vera Cruz, altitude 1,230 m., May 21. C. G. Pringle, No. 8195. 1899." The type, in the National Herbarium, is a slender plant $150 \mathrm{~cm}$. high.

DESCRIPTION.

Plants perennial, ascending or spreading from a more or less geniculate base; culms rather robust, 1.2 to 2 meters long, simple or sparingly branching from the lower nodes,

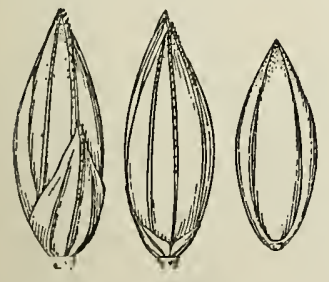

Fig. 106.-P. longum. From type specimen of $P$. pilosum macranthum Scribn. glabrous, the nodes glabrous; sheaths nearly as long as the internodes or overlapping, papillose or papillose-hirsute (the greater number of papillæ without hairs); ligule about $0.5 \mathrm{~mm}$. long; blades ascending or spreading, 10 to $25 \mathrm{~cm}$. long, 6 to $12 \mathrm{~mm}$. wide, linear, scarcely narrowed to the rounded base, very sparsely papillose-pilose on the upper surface, glabrous beneath or with a few papillæ; panicles short-exserted or included at the base, 20 to $25 \mathrm{~cm}$. long, 2 to $5 \mathrm{~cm}$. wide, the branches raceme-like, the lower solitary, distant, the middleand upper opposite or verticillate, the rachises and upper part of the main axis with stiff hairs slightly exceeding the short-pediceled, secund, approximate, but scarcely crowded spikelets; spikelets mostly in pairs, $2.5 \mathrm{~mm}$. long, 0.9 $\mathrm{mm}$. wide, pointed, strongly nerved, the nerves minutely scabrous toward the summit; first glume about half the length of the spikelet, pointed; second glume shorter than the sterile lemma, both slightly exceeding the fruit, the sterile palea

a Linnaea $6: 35.1831$. 
obsolete; fruit $2.1 \mathrm{~mm}$. long, $0.8 \mathrm{~mm}$. wide, acute, thin in texture, scabrous toward the summit.

This species seems to be more nearly related to $P$. polygonatum than to any other, for which reason it is placed, though somewhat doubtfully, in this group.

Swamps, Mexico.

DISTRIBUTION.

Mexıco: Jalapa, Pringle 8195, Schiede \& Deppe 674 (Halle Herb.).

\section{Panicum polygonatum Schrad.}

Panicum polygonatum Schrad. in Schult. Mant. 2 : 256. 1824. "In Brasilia, ad ripas fluvii Ilhéos. Princeps Sereniss. Maxim. Neowidens." The type, in the herbarium of the Botanical Garden in St. Petersburg, has a large panicle, pubescent nodes, and a few bristles on the rachis.

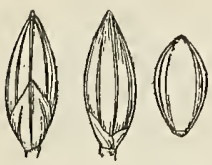

FIG. 107. $-P$. polygonatum. From type specimen.

Panicum potamium Trin. Gram. Pan. 239. 1826. "Brasil. (LANGSDorfF)." The type, in the Trinius Herbarium, is from near Mandioca, Brazil, collected by Langsdorff "in udis aquosis puris." This name is spelled " $P$. potamicum" by Steudel. $a$

Panicum hydrophilum Trin.; Nees, Agrost. Bras. 208. 1829. This is given as a synonym under $P$. dubium Lam., the specimen referred to as "(Langsdorff. - V. in Herb. Trin.)," doubtless being the basis of this name. We have not seen this specimen, but Trinius $b$ refers to this name in a note under $P$. potamium as "olim $P$. hydrophilum mihi dictam."

Setaria polygonata Kunth, Rév. Gram. 1: 47. 1829. Based on Panicum polygonatum Schrad.

Panicum trichogonum Willd.; Steud. Nom. Bot. ed. 2. 2: 261. 1841. This is given as a synonym under $P$. polygonatum Schrad. with the following citation: "Willd. hrb. (Sec. Trin. mpt.)." The type, in the Willdenow Herbarium, is labeled "Amer. merid. Humboldt."

Panicum pilosum polygonatum Doell in Mart. Fl. Bras. $2^{2}: 211.1877$. Based on $P$. polygonatum Schrad.

Panicum bourgaei Fourn. Mex. Pl. 2: 25. 1886. This name was earlier listed by Hemsley ${ }^{c}$ without description. Fournier cites a single specimen, "In valle Cordovensi, januario (Bourg[EAU] n. 1662 part.)." The specimen of this number seen at Halle is $P$. polygonatum, while the one in the Gray Herbarium is $P$. laxum. The original description calls for a plant with pubescent nodes, which would indicate $P$. polygonatum.

\section{DESCRIPTION.}

Plants rather freely branching from the lower nodes, widely spreading from a decumbent or creeping base, rooting at the nodes; culms 20 to $100 \mathrm{~cm}$. long, the nodes densely pubescent; sheaths shorter than the internodes or sometimes nearly equal, densely ciliate, otherwise glabrous or hirsute toward the summit; ligules less than $0.5 \mathrm{~mm}$. long; blades ascending or spreading, oblong-lanceolate, 3 to $13 \mathrm{~cm}$. long, 8 to $15 \mathrm{~mm}$. wide, usually ciliate at the cordate base, otherwise glabrous or occasionally sparsely hirsute; panicles 7 to $20 \mathrm{~cm}$. long, about half as wide, the lower branches solitary, distant, spreading, the upper sometimes in pairs, the numerous raceme-like branchlets secund from the lower side of the branches, the somewhat clustered, short-pedicled spikelets also secund on the branchlets, the rachises sparsely pilose with long, weak hairs, or

$a$ Syn. Pl. Glum. 1:71. 1854.

$b$ Mém. Acad. St. Pétersb. VI. Sci. Nat. 1: 266. 1834.

$c$ Biol. Centr. Amer. Bot. 3: 486. 1885. 
sometimes glabrous; spikelets 1.4 to $1.5 \mathrm{~mm}$. long, $0.5 \mathrm{~mm}$. wide, not thickened, pointed; first glume about half the length of the spikelet, 3-nerved, acute; second glume and sterile lemma equal, 3 to 5 -nerved, exceeding the fruit, the sterile palea only about half the length of its lemma; fruit $1 \mathrm{~mm}$. long, $0.5 \mathrm{~mm}$. wide, obovate.

This species differs from $P$. laxum and $P$. pilosum in the pointed spikelets which are not expanded by an enlarged sterile palea, and in the compound lower branches of the panicle.

\section{DISTRIBUTION.}

Swamps and moist soil along roads and in open woods, Mexico to Brazil and Paraguay.

Mexico: Córdoba, Bourgeau 1662 in part.

Guatemala: Dept. Alta Vera Paz, Collins \& Goll 08, Cook \& Griggs 530, Tuerckheim 7797, 8795; Puerto Barrios, Kellerman 5114.

Honduras: San Pedro Sulá, Thieme 781, 5578, 5587 in part.

Costa Rica: Buenos Aires, Tonduz 4042; Turrialba, Tonduz 4092; Tuís, Tonduz 11396; Talamanca, Tonduz 8557; Carrilj6, Biolley 3107; Echeverría, Pittier \& Tonduz 2479; San José, Pittier 1183.

Panama: Hart 73.

Colombia: Santa Marta, Smith 206, 2190.

Trinidad: Fendler 946 (Kew Herb.).

Brazil: Madeira, Rusby 199 in part.

Paraguay: Morong 441.

\section{$\checkmark$ 59. Panicum pilosum Swartz.}

Panicum pilosum Swartz, Prodr. Veg. Ind. Occ. 22. 1788. "Jamaica." The type, in the Swartz Herbarium, labeled "Jamaica, Swartz. P. pilosum fl. ind. occ.," consists of two branching plants.

Panicum distichum Lam. Encycl. 4 : 731. 1798. " Cette plante crôit à la Jamaique." The type, in the Lamarck Herbarium, consists of a panicle only. No locality is given upon the label.

Panicum pilisparsum Geyer, Prim. Fl. Esseq. 57. 1818. "In graminosis humidis plantitionis Hamburg," Essequibo [British Guiana]. The type is in the Göttingen Herbarium, but a portion of this is in the Trinius Herbarium and was examined there.

Panicum trichophorum Schrad. in Schult. Mant. 2:247.1824. "In Brasilia. Princeps Sereniss. Maximil. Neowidensis." The type is in the Schrader Herbarium at the Botanical Garden in St. Petersburg. HBK yew. Sen $\$ 5 \% 1 / 1 / 2.18 / 6$.

Setaria disticha Humb.; Spreng. Syst. Veg. 1:305. 1825. Based on "Panicum distichon Lam."

Panicum distans Willd.; Spreng. Syst. Veg. 1:305. 1825. This herbarium name of Willdenow is given as a synonym under Setaria disticha Humb. The type, in the Willdenow Herbarium, was collected by Humboldt in "America meridionale."

Panicum densiflorum Willd.; Spreng. Syst. Veg. 1:320. 1825. The name is credited to "W. herb.," and the locality is given as "Ad Orinoc." The type collected by Humboldt, in the Willdenow Herbarium, is labeled "Amer. Merid."

Setaria pilosa Kunth, Rév. Gram. 1:47.1829. Based on Panicum pilosum Swartz.

Setaria meyeri Kunth, Rév. Gram. 1: 47. 1829. Based on Panicum pilisparsum Meyer.

Setaria schraderi Kunth, Rév. Gram. 1: 47. 1829. Based on Panicum trichophorum Schrad.

Panicum apiculatum Salzm.; Steud. Syn. Pl. Glum. 1:65. 1854. This is given as a synonym under $P$. pilosum Swartz. In the Trinius Herbarium and in the United States National Herbarium are specimens bearing this name collected by Salzmann in Bahia, Brazil, which belong to P. pilosum.

$$
41616^{\circ}-\operatorname{voL} 15-10-8
$$


Panicum distichum lancifolium Griseb. F1. Brit. IV. Ind. 548. 1864. Grisebach bases this upon a specimen from Trinidad collected by Crueger. The type, Crutger 81, in the Grisebach Herbarium, is an exceptionally robust plant, with numerous racemes and villous nodes. Grisebach states that the rachis of the branches is glabrous, but the type has slender bristles thinly interspersed. It resembles Hart's no. 732 from Jamaica.

\section{DESCRIPTION.}

Plants annual, usually decumbent or creeping at base, rooting at the nodes and sending up erect branches, smaller plants sometimes erect; culms usually branching, 25 to $100 \mathrm{~cm}$. high, the nodes villous or sometimes glabrous or nearly so; sheaths elongated, but usually less so than the internodes, keeled, separating more or less from the culm, exposing the long prophyllum, and inrolled at the summit, somewhat simulating a

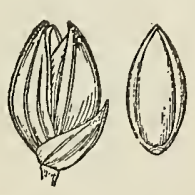

FIG. 108.-P. pilo sum. From type specimen. petiole to the blade, glabrous or sometimes ciliate or sparsely hirsute; ligules wanting; blades ascending or spreading, narrowly lanceolate, 4 to $20 \mathrm{~cm}$. long, 7 to $15 \mathrm{~mm}$. wide, broadest near the cordate or truncate base, puberulent at the very base, otherwise glabrous or sometimes sparsely pubescent; panicles consisting of 10 to 40 spike-like, densely-flowered, somewhat spreading racemes along an axis 5 to $15 \mathrm{~cm}$. long, the lower distant; racemes 1 to $3 \mathrm{~cm}$. long, straight or curved, bearing numerous spikelets in clusters of 1 to 3 secund on the lower side, the rachises copiously to sparsely papillose-hispid, the hairs 1 to $3 \mathrm{~mm}$. long, wanting in occasional specimens; spikelets about $1.5 \mathrm{~mm}$. long, $0.6 \mathrm{~mm}$. wide, and nearly $1 \mathrm{~mm}$. thick; first glume about half the length of the spikelet; second glume and sterile lemma equal, the former 5, the latter 3-nerved, both scabrous on the midnerve at the apex, the sterile palea as long as its lemma, becoming subrigid and forcing open the spikelet; fruit $1.3 \mathrm{~mm}$. long, $0.6 \mathrm{~mm}$. wide.

This species differs from $P$. laxum in the more freely branching habit, comparatively shorter and uniformly cordate or truncate blades, and smaller panicles of shorter, denser racemes, usually conspicuously bristly. In the following specimens the bristles are wanting: Curtiss 305, Rovirosa 599, Rusby \& Squires 79. The latter is also exceptional in having pubescent spikelets. In this species an occasional internode is much shortened, thus giving a few leaves the appearance of being nearly in pairs. Most of the specimens from North America have villous nodes, but those from South America are commonly glabrous on the nodes.

\section{DISTRIBUTION.}

Fields and open woods, Mexico, West Indies, and south to Brazil.

Mexico: Mirador, Liebmann 411; Chiapas, Nelson 3056; San Juan Bautista, Rovirosa 599.

Guatemala: Los Andes, Kellerman 5119; Dept. Alta Vera Paz, Goll 11, Tuerckheim 8797.

Honduras: San Pedro Sulá, Thieme 5587 in part; Bonacco Island, Gaumer. Nicaragua: Wright.

Costa Rica: Rio Hondo, Cook \& Doyle 499; Talamanca, Tonduz 9495; Puerto Viejo, Biolley 7463.

Panama: Fendler 368.

CubA: Herradura, Tracy 9063, Van Hermann 763; Dayaniguas, Wright 3451 in part; Sancti Spiritus, León 908; Isle of Pines, Curtiss 305, Taylor 36.

Jamaica: Gordon Town, Hart 732; Navy Island, Millspaugh 1859 (Hitchcock Herb.), Port Morant, Hitchcock in 1890 (Hitchcock Herb.).

LeEWard Islands: Guadeloupe, Duss 4154.

Windward Islands: Granada, Broadway in 1904.

Colombia: Santa Marta, Smith 203.

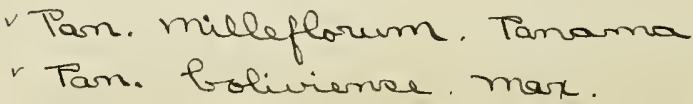


Venezuela: Sacupana, Rusby \& Squires 79, 347.

TRINIDAD: Hart 3293.

Toвago: Eggers 5534 .

British Guiana: Jenman 5969.

Dutch Guiana: Hostmann 641 (Gray Herb.).

French Guiana: Rotherey 14.

BraziL: Falls of Madeira, Rusby 210 in part; Campinas, Novaes 1288; Bahia, Salzmann; Rio Janeiro, Widgren, Wilkes Expl. Exped. in part; without locality, Riedel; Piauhy, Gardner.

Bolivia: Mapirí, Rusby 212.

PARAgUAY: Hassler 8192 (Gray Herb.).

\section{Panicum laxum Swartz.}

Panicum laxum Swartz, Prod. Veg. Ind. Occ. 23. 1788. "Jamaica." The type, in the Swartz Herbarium, is the upper part of a culm. The spikelets are 2.2 to $2.3 \mathrm{~mm}$. long. A specimen in the Munich Herbarium sent by Swartz as P. laxum is a species of Leptochloa.

Panicum agrostidiforme Lam. Tabl. Encycl. 1: 172. 1791. Lamarck cites "Ex Amer. merid. Communic. A. D. Richard." The type, in the Lamarck Herbarium, is the upper part of a culm.

Panicum tenuiculmum[e] Meyer, Prim. Fl. Esseq. 58. 1818. Meyer gives no particular locality. The type is in the Göttingen Herbarium, but the portion examined is in the Trinius Herbarium, having been sent by Meyer to Trinius.

Panicum diandrum Kunth, Rév. Gram. 2: 393. pl. 110. 183d. "Crescit in insula Guadelupæ inque Brasilia." The type, in the Berlin Herbarium, being the plant figured, was collected in Guadeloupe by Balbis in 1844.

Panicum leptomerum Presl, Rel. Haenk. 1: 311. 1830. The locality was unknown to Presl, who gives "Hab........." The type, collected by Haenke, in the Bohemian Museum, bears the name but no locality.

Panicum ramuliftorum Hochst.; Steud. Syn. Pl. Glum. 1: 65. 1854. This is based on "Pl. Kappler surin. nr. 1523." Specimens of this number have been examined at Munich and Leipzig, but none was found in the Steudel Herbarium.

Agrostis nigrescens Salzm.; Steud. Syn. Pl. Glum. 1: 65. 1854. "Bahia." This name is mentioned under Panicum ramuliforum Hochst. as applying to a variety "ramulis paniculae densiflorus." Steudel gives the name earlier, $a$ but as a nomen nudum. Salzmann specimens from Bahia, bearing this name, in the Trinius Herbarium and in the United States National Herbarium, are densely flowered forms of $P$. laxum.

Panicum nigrescens Salzm.; Steud. Syn. Pl. Glum. 1: 66. 1854. This is given as a synonym under $P$. laxum Swartz. Doell $b$ also gives this name in the same way. It is doubtless the same as Agrostis nigrescens, but we have seen no Salzmann specimen labeled Panicum nigrescens.

Panicum agrostis Nees; Doell in Mart. Fl. Bras. $2^{2}: 213.1877$. This is given as a synonym under $P$. laxum Swartz, and is credited to "Nees in herb. schedulis." The type, in the Berlin Herbarium, was collected in Brazil by Sello.

Panicum laxum pubescens Doell in Mart. Fl. Bras. $2^{2}: 213.1877$. The first specimen cited by Doell is "Prope Santarem (Spruce 'Panicum. n. 26')." The type, in the Munich Herbarium, has pubescent spikelets. = he L Leecend

Panicum pilosum epilosum Fourn. Mex. Pl. 2: 24. 1886. This appears to be founded on $P$. agrostidiforme Lam., as this is the first synonym given. The specimens cited by Fournier belong to $P$. laxum Swartz. 
DESCRIPTION.

Plants more or less spreading, often rooting at the nodes of the decumbent base; culms simple or sparingly branching, 40 to $100 \mathrm{~cm}$. or more high; sheaths shorter than the elongated internodes, ciliate and hirsute at the juncture with the blade, otherwise glabrous or papillose-hirsute toward the summit; ligules fimbriate, about $0.5 \mathrm{~mm}$. long; blades erect or ascending, conduplicate or flat, 10 to $25 \mathrm{~cm}$.

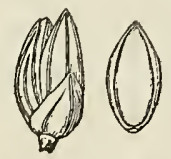

Fig. 109.-P. $\operatorname{lax}$ $u m$. From type specimen. long, 5 to $15 \mathrm{~mm}$. wide, rarely wider, narrowed to the rounded or subcordate base, glabrous or with a few scattered hairs on the upper surface; panicles oblong in outline, 5 to $30 \mathrm{~cm}$. long, composed of many slender, raceme-like branches, the lower distant, spreading, sometimes as much as $10 \mathrm{~cm}$. long, the upper ascending; branchlets very short, mostly secund on the lower side of the branches, bearing 2 or 3 spikelets, or a few toward the base of the lower branches 5 to $10 \mathrm{~mm}$. long; spikelets 1.1 to $1.5 \mathrm{~mm}$. long, about $0.7 \mathrm{~mm}$. wide and as thick or thicker; first glume one-third to half the length of the spikelet, subacute, 1 to 3-nerved; second glume slightly shorter than the sterile lemma, the latter subtending a palea of nearly equal length, this becoming subrigid at maturity forcing open the spikelet; fruit 1 to $1.1 \mathrm{~mm}$. long, about $0.5 \mathrm{~mm}$. wide.

This widely distributed species is variable in appearance. The following exceptionally robust specimens from Mexico and Guatemala have comparatively short, cordate blades 1.5 to $1.8 \mathrm{~cm}$. wide, and very turgid spikelets $1.5 \mathrm{~mm}$. long, a few stiff hairs on the branchlets: Finck 3, Liebmann 419, Purpus 2159, 2160, a Tuerckheim 1254 .

Tonduz's no. 3071 and his no. 4868, in the Costa Rica Herbarium, have pubescent spikelets as in the Spruce specimen upon which Doell bases his variety pubescens. These appear to be merely exceptional specimens.

DISTRIBUTION.

Savannas and open woods, Mexico, West Indies, and south to Paraguay.

Mexico: Culiacán, Palmer 1558 in 1891; Mirador, Liebmann 412, 419; Córdoba, Finck 3; Mayito, Rovirosa 427; Zacualpan, Purpus 2159, 2160 in part; Orizaba, Botteri 688 .

Guatemala: Dept. Alta Vera Paz, Tuerckheim 1254, 8803; Santa Rosa, Heyde \& Lux 3900; Puerto Barrios, Pittier 361.

Honduras: San Pedro Sulá, Thieme 5587 in part.

Costa Rica: Buenos Aires, Tonduz 4864, 4871; Rio Tilirí, Tonduz 3071; Turrialba, Pittier 16123; Las Mesas, Pittier 3117.

BaHamas: Turk Island, Madiana (Gray Herb.).

CuBA: Herradura, Calduell \& Baker 7136, Hitchcock 177, Tracy 9054, 9062, 9072, 9099; Wajay, Earle \& Wilson 343; Santiago de las Vegas, Hitchcock 178, Tracy 9114; Retiro, Wright 759; Guanabacoa, León 914; Sancti Spiritus, León 907, 909; without locality, Wright 3751 in part, 3863 in part; Isle of Pines, Curtiss 464, Palmer \& Riley 1069, Taylor 37.

Porto Rico: Utuado, Britton \& Cowell 394; Cayey, Heller \& Heller 522; Cataño, Heller \& Heller 1378; Ponce, Heller in 1902; Mayaguez, Sintenis 360; Fajardo, Sintenis 1254; Mount Morales, Britton \& Marble 1068; without locality, Eggers 1329.

Danish West Indies: St. Thomas, Eggers 165 (Gray Herb.).

Leeward Islands: Guadeloupe, Duss 3179.

Windward Islands: St. Lucia, U. S. Fish Com. in 1887; Barbadoes, Dash 450; Granada, Broadway in 1905.

a Panicum viscidellum Scribn. was also distributed under this number. 
Colombia: Santa Marta, Smith 202, 204; Córdoba, Pittier 521, 553; Cali, Pittier 665.

Trinidad: Hart 2177, 2289.

British Guiana: Jenman 6008, 6009.

French Guiana: Sagot 692 (Gray Herb.).

Brazil: Bahia, Salzmann; Madeira, Rusby 210; Prov. Goyaz, Gardner 3517; Campinas, Novaes 1246; Rio Janeiro, Wilkes Expl. Exped. 10; without locality, Gardner 1183, Riedel 52, Sello.

Paraguay: Hassler 8465, Morong 534, 537, 977, 1574.

Uruguay: Arechavaleta 31 in 1888, 2 in 1893.

Ecuador: Balao, Eggers 14585.

Bolivia: Mapirí, Rusby 228, 236; Unduavi, Rusby 22; Yungas, Bang 266, in part, 30sa; Chaco, Fries 1537.

\section{Panicum exiguiflorum Griseb.}

Panicum minutiflorum Rich. in Sagra, Hist. Cuba 11:305. 1850, not Rasp. 1825. "Crescit in pratis et locis herbosis insulae Cubae." The type, in the Paris Herbarium, is labeled "Insula Cuba. Legit Ramon de la Sagra."

Panicum laxum variegatum Griseb. Cat. Pl. Cub. 233. 1866. The only specimen cited is Wright 3450 . The type, in the Grisebach Herbarium, is from western Cuba, 1863 , and is numbered " $909=3450$."

Panicum exiguiflorum Griseb. Cat. Pl. Cub. 234. 1866. Based on "P. minutiflorum Rich. ex descr., non Hochst."

Panicum tricolor Hack. Oesterr. Bot. Zeitschr. 51:370. 1901. "In insulis Bahama;

Fortune Island, inter frutices, Eggers nr. 3978." The type is in Hackel's herbarium.

Digitaria mimitiflasa stapt, traced ow Pardicin

Plants perennial, cespitose, sometimes sending out prostrate, stolon-like shoots; culms simple or sparingly branching from the upper nodes, erect from a decumbent

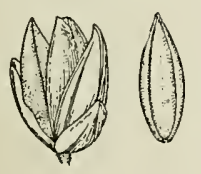

Fig. 110.-P. exiguiflorum. From type specimen of P. laxum variegatum Griseb. or ascending base, slender, wiry, 15 to $50 \mathrm{~cm}$. high, the lower nodes geniculate; sheaths much shorter than the elongated internodes, ciliate, otherwise glabrous; ligules membranaceous, delicate, fimbriate; blades appressed or ascending, 2 to $6 \mathrm{~cm}$. long, 0.5 to 1.5 $\mathrm{mm}$. wide, glabrous; panicles 3 to $10 \mathrm{~cm}$. long, one-third to half as wide, the slender branches few, spreading or reflexed at maturity, bearing short, divergent branchlets with clustered, short-pediceled spikelets; spikelets 1.4 to $1.5 \mathrm{~mm}$. long, about $0.5 \mathrm{~mm}$. wide, and twice as thick; first glume about one-third the length of the spikelet, 3-nerved; second glume about two-thirds the length of the subequal sterile and fertile florets, the sterile palea very large and firm at maturity, much expanding the spikelet; fruit $1.3 \mathrm{~mm}$. long, $0.5 \mathrm{~mm}$. wide, acute.

The immature spikelets are dorsally compressed, as characteristic in this genus, but as they mature the sterile palea becomes greatly enlarged, with broad firm wings, and forces the spikelet open. In this character and in habit this species is most closely related to $P$. hians Ell.

\section{DISTRIBUTION.}

Low savannas and moist sandy woods, Bahamas and Cuba.

Baнamas: Fortune Island, Eggers 3978 (Hackel Herb.), Hitchcock in 1890; Inagua, Nash \& Taylor 1450; Long Cay, Brace 4158, 4164; Acklins Island, Brace 4380 (all in Field Mus. Herb.).

CuBA: Chirigote, Wright 3450; Herradura, Hitchcock 179, Tracy 9075; Prov. of Santa Clara, León 902; Guanabacoa, León 911, 913; Isle of Pines, Taylor 35.

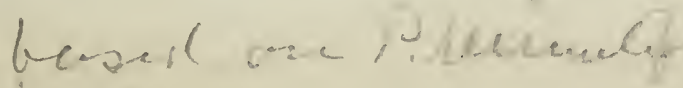




\section{Panicum hians Eli.}

Panicum hians Ell. Bot. S. C. \& Ga. 1: 118. 1816. Elliott gives no particular locality, but he states that the species is "Very abundant near Michaux's old farm, 10 miles from Charieston." The type, in the Elliott Herbarium, is labeled "Panicum Hians mihi. Hab: in pinetis humidis," but without particular locality.

Panicum oblongiflorum Desv. Opusc. 89. 1831. "Habitat in Carolina * * * à Bosc." The type is in the Desvaux Herbarium.

Panicum jejunum Trin. Mém. Acad. St. Pétersb. VI. Sci. Nat. 2 : 103. 1836. "Louisiana." The type specimen, in the Trinius Herbarium, is marked "Louisiana. mis. Hooker. 1835."

Aira incompleta Bose; Steud. Nom. Bot. ed. 2. 1: 45. 1840. This is a nomen nudum mentioned as a synonym of Panicum debile [no author cited], but there is no cross reference under Panicum debile. We have seen specimens of this collected by Bosc,

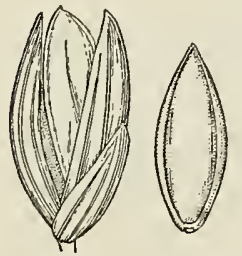

FIG. 111.-P. hians. From typespecimen. in the Trinius Herbarium, in the Padua Herbarium, and in the Delessert Herbarium. All are Panicum hians. In the absence of any evidence as to which is the type specimen we take as the type the one in the Padua Herbarium, which appears to contain Bosc's own herbarium. The locality of this is given as "Caroline."

Steinchisma hians Raf.; Ind. Kew. 2: 982. 1895. Based on Panicum hians Ell. Nash ${ }^{a}$ segregated the genus Steinchisma and was followed by Hitchcock. $b$ Steinchisma was first mentioned by Rafinesque $c$ in a letter to De Candolle in which he proposes several new genera, this genus appearing as follows: "Steinchisma= Panicum divaricatum, hians." This probably refers to Panicum hians Ell. and to $P$. divaricatum Michx. which is given by Elliott as a queried synonym under P. hians. Panicum divaricatum Michx. is, however, Festuca obtusa Spreng.d Rafinesque's name is given by Steudel $e$ as "Steinschisma Rafin. Panicum debile." Panicum debile Ell. is P. verrucosum Muhl.

Nash separated the genus Steinchisma on the character of the enlarged palea of the sterile floret. This character is shared by Panicum exiguiflorum, $P$. cupreum, the South American $P$. decipiens Nees, and, in less pronounced form, by $P$. laxum and $P$ pilosum, while $P$. polygonatum, which is evidently allied to $P$. laxum, has a very small palea. This character, since it proves not to be correlated with any other, does not seem to us sufficient for the segregation as a genus of those species showing it, especially since such segregation would place closely allied species in separate genera.

Beal $f$ and Scribner $g$ misapply the name Panicum melicarium Michx. to $P$. hians Ell. Panicum melicarium Michx. is Panicularia elongata (Torr.) Kuntze, P. melicaria (Michx.) Hitchc. $h$

\section{DESCRIPTION.}

Plants perennial, cespitose; culms simple or sparingly branching, 20 to $60 \mathrm{~cm}$. high, erect or a few of the outer ones geniculate and rooting at the lower nodes, sometimes prostrate and sending up erect branches; sheaths usually much shorter than the internodes, keeled, glabrous; ligules about $0.5 \mathrm{~mm}$. long; blades 5 to $15 \mathrm{~cm}$. long, 1

$a$ Small, Fl. Southeast. U. S. 105. 1903.

b A. Gray, Man. ed. 7. 117. 1908.

$c$ Bull. Bot. Seringe 220. 1830.

$d$ See Hitchcock, Contr. Nat. Herb. $12:$ 149. 1908.

$e$ Nom. Bot. ed. 2. 2:635. 1841.

$f$ Grasses N. Amer. $2: 127.1896$.

$g$ U. S. Dept. Agr. Div. Agrost. Bull. 7 : 66. f. 48.1897.

$h$ See Hitchcock, Contr. Nat. Herb. 12: 149. 1908. 
to $5 \mathrm{~mm}$. wide, usually scarcely wider than the sheaths, erect, flat or folded, pilose on the upper surface near the base, otherwise glabrous; panicles 5 to $20 \mathrm{~cm}$. long, usually loose and open, the primary branches few, slender, distant, spreading or drooping, sometimes rather narrow and compact, with ascending branches, the branchlets borne along the upper half or toward the ends only, the short-pediceled spikelets in more or less secund clusters; spikelets 2.2 to $2.4 \mathrm{~mm}$. long, about $0.8 \mathrm{~mm}$. wide and twice as thick at maturity, rather strongly nerved; first glume about half the length of the spikelet, acute; second glume and sterile lemma subequal, slightly exceeded by the enlarged, indurated sterile palea; fruit 1.8 to $1.9 \mathrm{~mm}$. long, $0.7 \mathrm{~mm}$. wide, the margins of the lemma scarcely inrolled.

The immature spikelets are dorsally compressed; it is only as they mature that the characteristic induration of the sterile palea takes place.

\section{DISTR1BUTION.}

Damp soil along ponds and streams, North Carolina to Florida, west to New Mexico and north through Arkansas to southern Missouri and Oklahoma.

Missour1: Campbell, Bush 120.

North Carolina: Rowan County, Small \& Heller 205; Wilsons Mills, Chase 3098.

South Carolina: Columbia, Curtiss 3594; Orangeburg, Hitchcock 451.

Georg1A: Savannah, Kearney 187; Bulloch County, Harper 838; Oliver, Curtiss 6836.

Flor1da: Jacksonville, Combs 26, Kearney 173; Lake City, Combs 117, 125, 172, 187; Madison, Combs 262; River Junction, Combs 434; Pensacola, Combs 526; Quincy, Combs 427; Chipley, Combs 587; Waldo, Combs 712; Ellzey, Combs 831; Arcadia, Combs 1246; Eustis, Nash 213; Jupiter, Curtiss 5534; Manatee, Rugel 231; Braidentown, Combs 1261, 1325, Tracy 7038; Pease Creek, Curtiss 3594; Myers, Hitchcock 872, Lee Co. Pl. 488, 489; Miami, Chase 3889.

Alabama: Tuskegee, Carver 47; Mobile, Kearney 30, Mohr in 1883.

Mississippi: Nicholson, Kearney 363; Starkville, Tracy in Pollard Distr. 1418; Waynesboro, Kearney 121; Ocean Springs, Seymour 25.

Arkansas: Central Arkansas, Harvey; Malvern, Eggert 117.

Louisiana: Rayville, Ball 26; Calhoun, Ball 60, Hitchcock 1282;

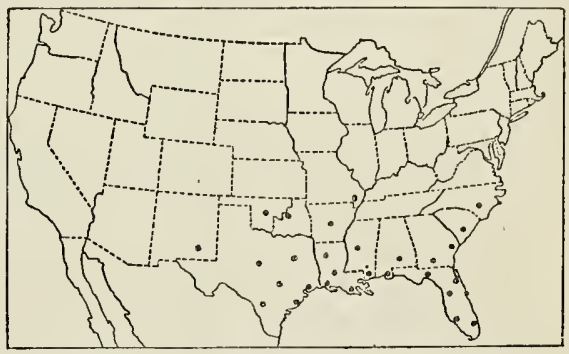

FIG. 112.-Distribution of P. hians. Alexandria, Ball 535; Oberlin, Ball 190; Red River Parish, Ball 123; Abbeville, Langlois in 1884; Lake Charles, Hítchcock 1133, Tracy in 1897.

Texas: Jacksonville, Plank 63; Luling, Plank 18; Texarkana, Heller \& Heller 4103, 4145; Huntsville, Plank 65; Orange, Plank 46; Pierce, Tracy 7745; Terrell, Warburton in 1904; Hempstead, Hall 815; Indianola, Ravenel in 1869; Ennis, Smith in 1898; Harvester, Hitchcock 1184, Thurow in 1898; Galveston, Plank 35, 83; Kingsville, Piper in 1906; Cold Creek, Bigelow. in 1853; without locality, Reverchon 99 in 1879.

Orlahoma: Sapulpa, Bush 707, 708, 709; on the Washita, Palmer 381 in 1868.

New Mexico: Las Cruces, Plank 6. 


\section{Panicum cupreum nom. nov.}

Panicum hians purpurascens Scribn. Proc. Acad. Phila. 1891: 296. 1891, nat $P$. purpraseens H. B. K. 1815. "(3449) [Pringle] * * * Wet hollows in prairies of Flor de Maria, State of Mexico. September 4." The type is in Hitchcock's herbarium. It was collected in 1890 .

\section{DESCRIPTION.}

Plants perennial, in small tufts; culms simple, erect, 40 to $60 \mathrm{~cm}$. high, slender, wiry, glabrous; leaves somewhat clustered at the base, the sheaths keeled, glabrous,

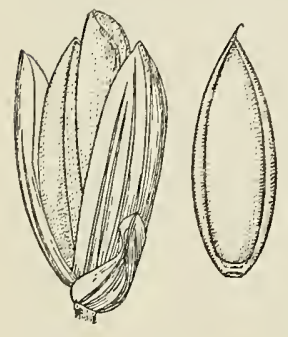

FIG. 113.-P. cupreum. From type specimen of $P$. hians purpurascens Scribn. the lower overlapping, the upper shorter than the internodes; ligules fimbriate, scarcely $0.5 \mathrm{~mm}$. long; blades 5 to 15 $\mathrm{cm}$. long, 2 to $4 \mathrm{~mm}$. wide, at the base scarcely as wide as the sheaths, erect or ascenaing, folded and more or less twisted, glabrous or with a few long hairs on the upper surface at the base; panicles very long-exserted, 3 to $11 \mathrm{~cm}$. long, dark purple, composed of a few distant, slender, appressed or ascending branches, naked about half their length, bearing short, crowded branchlets with densely clustered spikelets along the upper half or toward the ends; spikelets $3 \mathrm{~mm}$. long, about $1.2 \mathrm{~mm}$. wide, and at maturity nearly twice as thick, rather strongly nerved; first glume one-third the length of the spikelet or less, obtuse, concave along the midnerve; second glume and sterile lemma equal, exceeded by the enlarged sterile palea, the lemma strongly concave along the midnerve below; fruit $2.4 \mathrm{~mm}$. long, $0.8 \mathrm{~mm}$. wide, the margins of the lemma more inrolled than in $P$. hians, the apex tipped with a minute bit of hyaline membrane.

This species is allied to $P$. hians, from which it is chiefly distinguished by the larger, more congested spikelets, with shorter, concave first glume and concave sterile lemma.

The type collection, Pringle's no. 3449, two specimens of which we have seen, is the only one known of this species.

Stolonifera.-Plants perennial, decumbent at base or widely creeping and rooting at the nodes; culms branching, pubescent in lines or glabrate; sheaths (except in $P$. biglandrilare) with a dense line of pubescence at the summit; ligules membranaceous, nearly obsolete; blades lanceolate or ovate-lanceolate, acuminate and with a pubescent, petiole-like base; panicles composed of few to several short, densely-flowered racemes along a main axis, a tuft of pubescence at the bases of the rachises; spikelets short-pediceled, mostly in 2's, secund along the lower side of the rachis, strongly nerved, the second glume and sterile lemma scabrous on the midnerves toward the summit, exceeding the smooth and shining fruit.

Spikelets hispid and with 2 crateriform glands on the sterile lemma; second glume and sterile lemma not boat-shaped.

Spikelets not over $2 \mathrm{~mm}$. long; blades not over $4 \mathrm{~cm}$. long. 66. P. pulchellum. Spikelets $3.6 \mathrm{~mm}$. long; blades 4 to $10 \mathrm{~cm}$. long........ 67. P. biglandulare.

Spikelets glabrous, glandless; second glume and sterile lemma boat-shaped.

Blades not over $5 \mathrm{~cm}$., usually 2 or $3 \mathrm{~cm}$. long; second glume rather blunt and shorter than the sterile

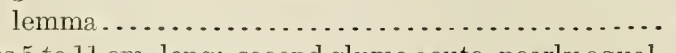

Blades 5 to $11 \mathrm{~cm}$. long; second glume acute, nearly equal64. P. stoloniferum. ing the sterile lemma.....................6. 65. P. frondescens. 
64. Panicum stoloniferum Poir.

Panicum stoloniferum Poir. in Lam. Encycl. Suppl. 4: 274. 1816. "Cette plante crôit à l'ile de Cayenne." The type is in the Cosson Herbarium.

Panicum ctenodes Trin. Gram. Icon. 2: pl. 171. 1829. Trinius cites no specimen nor particular locality, but states that the figure is "ad specimen Brasiliense." There is apparently no specimen in the Trinius Herbarium bearing this name, but in the Berlin Herbarium is a specimen from Trinius which is probably a part of the type, and which bears the name in Trinius's handwriting. It was collected in Brazil by Beyrich.

Panicum leprieurii Steud. Syn. Pl. Glum. 1: 65. 1854. Two specimens are cited, "P. stoloniferum Hochst. Hrbr. Kappler nr. 1500. Surinam et Leprieur in Cayenne."

On account of the specific name Leprieur's specimen is taken as the

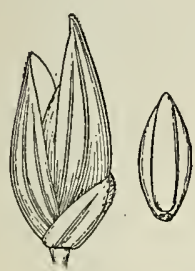

Fig. 114.-P.stoloniferum. From type specimen. type. This is in the Steudel Herbarium at Paris. It is a somewhat undersized specimen labeled, "Cayenne, Leprieur 1835."

\section{DESCRIPTION.}

Plants creeping, freely branching; culms 10 to $50 \mathrm{~cm}$. long, with two opposite lines of minute crisp pubescence, rarely pubescent all over or glabrate, the nodes pubescent or glabrous; sheaths shorter than the internodes or overlapping on the branches, ciliate, otherwise glabrate, or crisp-pubescent; ligules fimbriate, about $0.2 \mathrm{~mm}$. long; blades 1 to $5 \mathrm{~cm}$. long, 3 to $15 \mathrm{~mm}$. wide, the margins undulate, glabrous or sparsely pilose on the upper surface, minutely softpubescent beneath; panicles 1 to $5 \mathrm{~cm}$. long, about one-third as wide, racemes 5 to 10 $\mathrm{mm}$. long, ascending or spreading, the main axis more or less pubescent; spikelets 2.3 to $2.5 \mathrm{~mm}$. long, about $0.6 \mathrm{~mm}$. wide and $1 \mathrm{~mm}$. thick, glabrous; first glume about one-third the length of the spikelet, 3-nerved, blunt; second glume blunt, shorter than the acute sterile lemma, both somewhat boat-shaped, 5-nerved, the sterile palea about half as long as its lemma; fruit $1.3 \mathrm{~mm}$. long, $0.5 \mathrm{~mm}$. wide, acute.

\section{DISTRIBUTION}

Woods and low grounds, Guatemala to Brazil and Ecuador.

Guatemala: Puerto Barrios, Pittier 364.

Trininad: Broadway 2370; Crueger 79, Bot. Gard. Herb. 2293.

British Guiána: Jenman 4081.

Dutch Guiana: "Surinam" Hering (Acad. Phil. Herb.).

French Guiana: Sagot 667.

Brazil: Beyrich (Trinius Herb.).

Ecuador: Balao, Eggers 14149.

\section{Panicum frondescens Meyer.}

Panicum frondescens Meyer, Prim. Fl. Esseq. 56. 1818. "In graminosis umbrosis insulae Arouabisch" [British Guiana]. We have not examined the type, which is at Göttingen, but we have seen in the Trinius Herbarium a portion of it which was sent by Meyer.

Panicum olyraefolium Raddi, Agrost. Bras. 43. pl. 1.f.6. 1823. Raddi states $a$ that this occurs "in sepibus prope fossas udas in viciniis Rio-Janeiro." We have not seen the type of this, but the description and figure agree with $P$. frondescens. 
Panicum ctenodes majus Trin. Gram. Icon. 2: pl. 171. f. A. 1829. In the description of $P$. ctenodes a larger variety is referred to and figure $A$ of the plate represents this form. It does not appear certain that Trinius intended to name this in this way, but in the explanation of the figure "ad specimen Brasiliense" he uses the term "Var. major," and Kunth a cites the name as "Panicum ctenodes var. major." The type is in the Trinius Herbarium. It is a shoot without a label, lying on a sheet of specimens of $P$. stoloniferum from Brazil and appears to be the basis of figure A. One of the loose labels may belong to this specimen.

Panicum stoloniferum major[us] Kunth, Rév. Gram. 2: 389. 1831. Based on Panicum ctenodes majus Trin.

Panicum brachyclados Reichenb.; Trin. Mém. Acad. St. Pétersb. VI. Sci. Nat. 1: 251. 1834. This is given as a synonym under $P$. frondescens Meyer, the authorship being given as "Rchbch, in Weig. hb. Surin." The type, in the Trinius Herbarium, is labeled "Panicum (Echinochloa) brachyclados. Surinam. ex herb. Reichenb."

Panicum kegelii Steud. Syn. Pl. Glum. 1: 65. 1854. "Guatemala." There is a specimen in the Berlin Herbarium bearing this name, collected in Guatemala by Kegel (no. 12716), which may be the type. No specimen of this

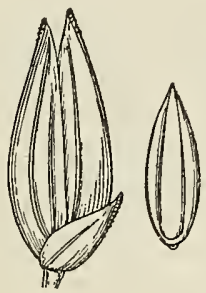

FiG. 115.-P. frondescens. From type specimen. was seen in the Steudel Herbarium.

Panicum umbrosum Salzm.; Steud. Syn. Pl. Glum. 1: 65. 1854, not Retz. 1786. This is given as a synonym under $P$. stoloniferum Poir. The type, in the Paris Herbarium, is from Bahia, Brazil.

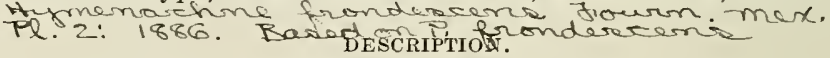

Culms ascending from a decumbent or creeping base, less freely branching than in $P$. stoloniferum, 30 to $50 \mathrm{~cm}$. high, compressed, glabrous except below the panicle or sometimes with two lines of pubescence toward the summit of the internodes; nodes black; sheaths shorter than the internodes, densely ciliate, otherwise glabrous; ligules nearly obsolete; blades 5 to $11 \mathrm{~cm}$. long, 12 to $20 \mathrm{~mm}$. wide, acuminate, narrowed- toward the base, glabrous; panicles 5 to $11 \mathrm{~cm}$. long, usually less than one-third as wide, rather compact, the numerous, approximate racemes ascending or somewhat spreading, the lower 10 to $25 \mathrm{~mm}$. long; spikelets 2.6 to $2.8 \mathrm{~mm}$. long, about $0.6 \mathrm{~mm}$. wide and $1 \mathrm{~mm}$. thick, glabrous; first glume scarcely one-third the length of the spikelet, acute, scabrous on the midnerve; second glume and sterile lemma subequal, somewhat boat-shaped, acute, the sterile palea about two-thirds as long as its lemma; fruit $1.6 \mathrm{~mm}$. long, $0.5 \mathrm{~mm}$. wide, pointed, short-stipitate.

This species resembles $P$. stoloniferum, but is larger in all its parts, while the numerous racemes are usually aggregated into a rather compact panicle.

The spikelets of this species and of $P$. stoloniferum, with their somewhat boat-shaped second glume and sterile lemma, suggest species of Sacciolepis. In this species the stipitate fruit also shows an approach to that genus, but the habit is wholly different.

\section{DISTRIBUTION}

Moist woods, Mexico to Brazil and Peru.

Mexico: Papantla, Liebmann 405; St. Sebastian, Rovirosa 497.

Guatemala: Dept. Peten, Walker 1138.

Trinidad: Broadway 2371.

British Guiana: Meyer (Trinius Herb.).

Dutch Guiana: Weigelt (Trinius Herb.); Hering (Acad. Phil. Herb.).

French Guiana: Sagot 689 (Gray Herb.). 
HITCHCOCK AND CHASE-NORTH AMERICAN PANICUM.

123

BraziL: Bahia, Salzmann; Rio Janeiro, Wilkes Expl. Exped. 11; São Paulo, Löfgre \& Edwall 2803; Porto Alegre, Reineck \& Czermak 241.

Peru: Pöppig (Trinius Herb.).

Bolivia: Mapirí, Busby 229.

66. Panicum pulchellum Radii.

Panicum pulchellum Kadi, Agrost. Bras. 42. 1823. "In sylvaticis pope Catumby, non procul ab Urbe Rio de janeiro." There is a specimen in the herbarium of the British Museum marked "Panicum pulchellum Rad. Rio janeiro. Radii" which appears to be authentic, but probably is not the type.

Eriochloa? pulchella Kunth, Rev. Gram. 1: 30. 1829. Based on Panicum pulchellum Radii.

Panicum leptostachyum Press, Rel. Hank. 1: 311. 1830. "Hab. in Mexico." The type, in the herbarium of the Bohemian Museum, is labeled "Mexico."

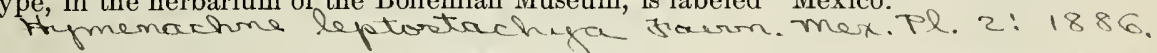

Pancium bipuatulatimm Schlecht. Verey. Wagenenss.

Plants apparently perennial, decumbent or creeping at base; culms slender, rather freely branching, ascending, pubescent in lines or glabrate, the nodes bearded;

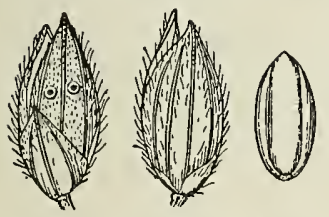

FIG. $116 .-P$. pulchellum. From Radii's specimen in British Museum. sheaths short, softly pubescent or glabrate; ligule ciliate, about $0.3 \mathrm{~mm}$. long; blades thin, spreading, 1.5 to $4 \mathrm{~cm}$. long, 4 to $15 \mathrm{~mm}$. wide, rather abruptly acuminate, unsymmetrically subcordate; panicles oblong, 2 to $12 \mathrm{~cm}$. long, rarely over $2 \mathrm{~cm}$. wide, the racemes 5 to $15 \mathrm{~mm}$. long, all about the same length, ascending or finally spreading, distant or approximate toward the summit; spikelets 1.8 to $2 \mathrm{~mm}$. long, about $0.8 \mathrm{~mm}$. wide, turgid but not thicker than wide, hispid, the hairs longer toward the margin; first glume one-third to half the length of the spikelet, acute, 3-nerved; second glume and sterile lemma subequal, acute, the latter bearing at either side of the midnerve a crateriform gland, the sterile pale about three-fourths as long as its lemma; fruit $1.3 \mathrm{~mm}$. long, $0.6 \mathrm{~mm}$. wide, rather blunt.

DISTRIBUTION .

Woods and savannas, Mexico to Brazil and Bolivia.

Mexico: Córdoba, Bourgeau 1455; Minatitlan, Smith 589 (Hitchcock Herb.).

Guatemala: Dept. Alta Vera Pay, Cook \& Gigs 284, Mason \& Hay 3153, Tuerckheim 7702, 8794; El Palmar, Kellerman 6246.

Costa Rice: Boruca, Pettier 4459, Tonduz 4460 in part; Cannas Gordas, Pettier 7360; Bueno Aires, Tonduz 4881.

Brazil: Rio Janeiro, Radii (British Mus. Herb.).

Bolivia: Guanaí, Rushy 217.

67. Panicum biglandulare Scribn. \& Smith:

Panicum biglandulare Scribn. \& Smith, U. S. Dept. Agr. Div. Agrost. Bull. 4: 13. pl. 4. 1897. "Near Pinabete, Chiapas, February 8, 1896, at an altitude of 6,500 to 8,000 feet; No. 3781," collected by E. W. Nelson. The type, in the National Herbsrum, is a culm $120 \mathrm{~cm}$. long, bearing two ascending branches about the middle, the lower portion being naked.

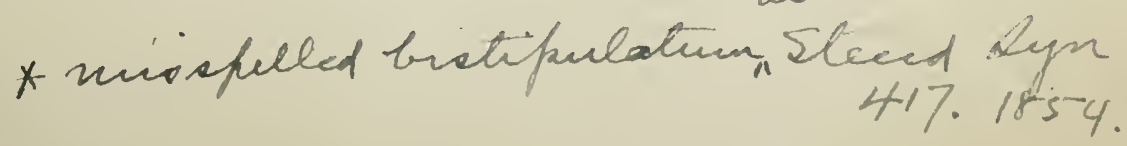


DESCRIPTION.

Culms ascending from a decumbent base, becoming spreading and much-branched, somewhat compressed, the line of pubescence sparse or wanting; sheaths densely

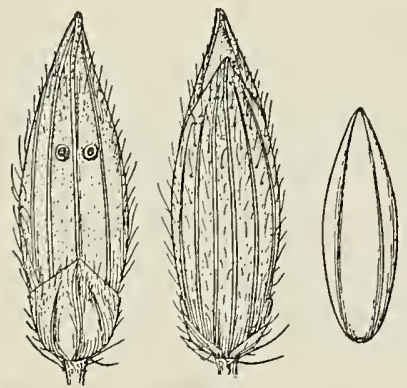

FIG. 117.-P. biglandulare. From type specimen. papillose-ciliate, otherwise glabrous; blades 4 to $10 \mathrm{~cm}$. long, 10 to $18 \mathrm{~mm}$. wide, lanceolate, acuminate, narrowed to the rounded base, more or less pilose on both surfaces; panicles 5 to $12 \mathrm{~cm}$. long, the few, distant, racemes 0.8 to $2 \mathrm{~cm}$. long, ascending or finally spreading; spikelets $3.6 \mathrm{~mm}$. long, about $1 \mathrm{~mm}$. wide, pointed; first glume scarcely one-third the length of the spikelet, hispid along the midnerve and margin; second glume shorter than the sterile lemma, 7-nerved, hispid, the hairs longer toward the summit and margin, the sterile lemma 5-nerved, hispidulous and along the margins hispid, bearing at either side of the midnerve a crateriform gland, these more prominent than in $P$. pulchellum, the sterile palea nearly as long as its lemma, hispidulous; fruit $2.4 \mathrm{~mm}$. long, $0.7 \mathrm{~mm}$. wide, elliptic, minutely stipitate.

In the original description of $P$. biglandulare the margins of the sheaths are described as "clothed with glands bearing branching hairs." The hairs are found to be simple and arising from papillæ.

\section{DISTRIBUTION.}

Among bushes, mountains of Mexico and Guatemala.

Mexico: Near Pinabete, Nelson 3781.

Guatemala: Coban, Tuerckheim II 1956.

Parviglumia.-Plants erect or ascending, usually from à decumbent base; culms slender; sheaths densely ciliate and with a dense ring of pubescence at the summit; ligules less than $0.5 \mathrm{~mm}$. long; blades firm, lanceolate, constricted into a very short petiole-like base, and having a thin, white, cartilaginous margin; panicles light green, with few, compactly flowered branches; spikelets not over $2 \mathrm{~mm}$. long, obovate, obtuse, glabrous, the first glume usually about one-fifth the length of the spikelet; fruit, except in $P$. parviglume, with scattered, appressed, silky hairs.

Besides the three here given two Brazilian species belong in this group: $P$. trichidiachne Doell $a$ and $P$. schiffneri Hack., $b$ and also $P$. conchatum Fourn. ${ }^{c}$ described from a Mexican specimen. $d$

Blades 12 to $16 \mathrm{~cm}$. long, 2 to $3 \mathrm{~cm}$. wide; fruit glabrous.... 70. P. parviglume.

Blades not over $10 \mathrm{~cm}$. long nor $1.8 \mathrm{~cm}$. wide; fruit with scattered silky hairs.

Blades scabrous on the upper surface, not falcate...... 68. P. virgultorum.

Blades sparsely hispid on the upper surface, falcate..... 69. P. schmitzii.

$a$ In Mart. Fl. Bras. $2^{2}$ : 339. pl. 49. 1877.

$b$ Denkschr. Math.-Naturw. Akad. Wiss. Wien 79: 11. 1906

c Mex. Pl. $2: 25.1886$.

$d$ See $P$. conchatum Fourn. page 329 .

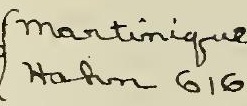




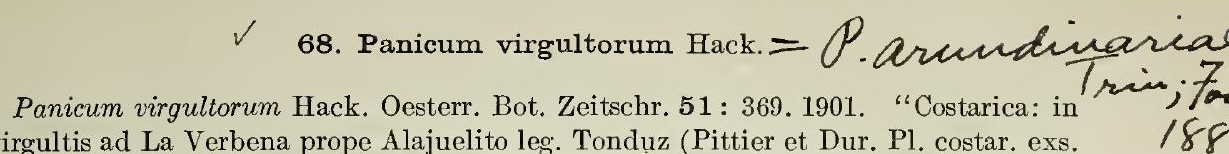
nr. 8829) et ad rivulos prope tres Rios (Pittier ibid. nr. 4326)." The type, Tonduz 8829 , is in Hackel's herbarium.

Tonduz $a$ listed this species under the name "Panicum oblongum Hack." This was a herbarium name at first applied by Hackel to Tonduz's no. 8829, as shown by specimens in Hackel's herbarium and others distributed by Tonduz.

DESCRIPTION.

Plants perennial, ascending from a decumbent or sometimes a widely creeping base, branching and rooting at the lower, geniculate nodes; culms slender, wiry, 0.4 to 1 meter or more long, compressed, glabrous or pubescent below the nodes; nodes pubescent or glabrous; sheaths often as long as the internodes, usually shortciliate, otherwise glabrous or the lowermost pubescent; ligules membranaceous; blades 5 to $10 \mathrm{~cm}$. long, 5 to 10 mm. wide, narrowly lanceolate, acuminate, narrowed to the base, scabrous on the upper surface, smooth and glossy beneath; panicles mostly long-exserted, 2.5 to 7 $\mathrm{cm}$. long, half to two-thirds as wide, the 2 to 4 branches
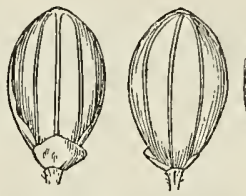

Fig.118.-P.virgultorum. From type specimen. ascending, compactly flowered except at the base, or the lower sometimes naked one-third its length, the short branchlets and pedicels pubescent; spikelets $1.6 \mathrm{~mm}$. long, $0.9 \mathrm{~mm}$. wide; first glume less than one-fourth the length of the spikelet; second glume and sterile lemma equal, 5-nerved; fruit $1.5 \mathrm{~mm}$. long, $0.8 \mathrm{~mm}$. wide, oval, smooth and shining but with sparse, long, appressed, silky hairs.

\section{DISTRIBUTION.}

Hedgerows and cultivated fields, Guatemala and Costa Rica.

Guatemala: Dept. Huehuetenango, Seler 2708.

Costa Rica: Alajuelita, Tonduz 8818, 8829.

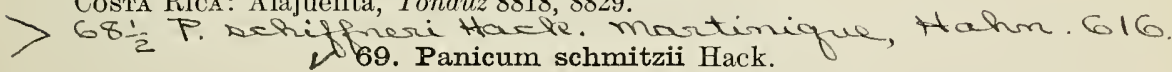

Panicum schmitzii Hack. Ann. Naturhist. Hofm. Wien 17: 254. 1902. No specimen nor locality is cited. The author states that the specimen was from Mexico and was sent him by Dr. Zahibruckner for identification, having been communicated to the

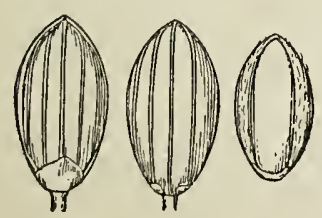

FIG. 119.-P. schmitzii. From type specimen. Hofmuseum by Schmitz, but that neither the name of the collector nor the date of collection was given. The type is in Hackel's herbarium.

\section{DESCRIPTION.}

Plants apparently perennial ascending, or erect from a long-jointed, creeping base, rooting and branching from the nodes of the decumbent portion, the suberect branches 20 to $45 \mathrm{~cm}$. high, simple or nearly so; culms puberulent at least below the puberulent nodes; sheaths short, puberulent, at least toward the summit; ligules ciliate; blades 6 to $10 \mathrm{~cm}$. long, 10 to 18 $\mathrm{mm}$. wide, lanceolate, more or less falcate, narrowed to the rounded base, sparsely papillose-hispid on the upper surface, glabrous or with a few scattered papillæ or hairs beneath; panicles rather short-exserted, 4 to $8 \mathrm{~cm}$. long, the few subracemose 
branches finally somewhat spreading, pubescent at the base, bearing short, appressed, approximate branchlets of crowded spikelets along the upper two-thirds to threefourths of their length; spikelets $1.8 \mathrm{~mm}$. long, $0.9 \mathrm{~mm}$. wide; first glume scarcely one-fifth the length of the spikelet; second glume slightly longer than the sterile lemma, both 5-nerved; fruit $1.5 \mathrm{~mm}$. long, $0.8 \mathrm{~mm}$. wide, oval, the lemma sparsely clothed with appressed, silky hairs, the palea glabrous.

\section{DISTRIBUTION.}

Shaded rocky slopes, southern Mexico.

Mexico: Las Canoas, San Luis Potosí, Pringle 3817.

\section{Panicum parviglume Hack.}

Panicum parviglume Hack. Oesterr. Bot. Zeitschr. 51: 429. 1901. "Costarica: in ripis fl. Rio Torres prope S. José (Pittier 9080), prope S. Francisco de Guadalupe (Tonduz, 2448)." The type, Pittier 9080, is in Hackel's herbarium.

\section{DESCRIPTION.}

Culms slender, erect, from an ascending base, $100 \mathrm{~cm}$. high, striate, sparsely papillose-pilose; sheaths exceeding the internodes, ciliate, sparsely papillose-pilose, striate,

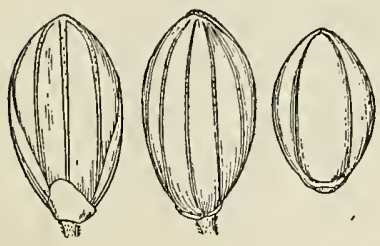

FIG. 120.-P. parviglume. From type specimen. more densely pubescent at the juncture with the blade; ligules very short, ciliate; blades lanceolate or linear-lanceolate, 8 to $16 \mathrm{~cm}$. long, 12 to $25 \mathrm{~mm}$. wide, flat, firm, rounded at base, acuminate, sparsely hispidulous, especially above, the margin very' ${ }^{-}$scabrous; panicles ovate, 15 to $25 \mathrm{~cm}$. long, the branches spreading or ascending, the lower distant, solitary, 10 to $12 \mathrm{~cm}$. long, the lower fourth naked, bearded at base; branchlets appressed, the longer 1 to $2 \mathrm{~cm}$. long, bearing 3 to 8 subcontiguous spikelets on slender, flexuous, scabrous pedicels 0.5 to $2 \mathrm{~mm}$. long; spikelets oval, $2 \mathrm{~mm}$. long, $1.2 \mathrm{~mm}$. wide; first glume about one-fifth the length of the spikelet; second glume and sterile lemma equal, slightly exceeding the fruit, faintly 5-nerved, minutely apiculate; fruit smooth.

\section{DISTRIBUTION.}

Thickets along streams, southern Mexico and Costa Rica. The only complete specimen in the National Herbarium is Tonduz's no. 8448 from which the above description is drawn. This was collected by Tonduz and Pittier at San Francisco de Guadalupe, Costa Rica, "Buissons sur les bords du Rio Torres."

In the National Herbarium there is a panicle, with upper leaf, of a.plant of this species, with the specimen of Botteri's no. 150, collected in Mexico. A similar fragmentary specimen is mixed with the same collection in the Gray Herbarium.

Verrucosa.-Glabrous annuals with weak, divaricately branching culms, decumbent at base and usually provided with aerial brace-roots at the lower nodes, the lower internodes much shorter than the middle and upper; ligules ciliate, not over $0.5 \mathrm{~mm}$. long; panicles with divaricate, capillary branches, spikeletbearing toward the ends; spikelets tuberculate; fruit minutely papillose, the margin of the lemma flat, inrolled only at base.

Spikelets about $2 \mathrm{~mm}$. long, glabrous................... 71. P. verrucosum.

Spikelets over $3 \mathrm{~mm}$. long, hispid................ 72. P. brachyanthum. 


\section{$\checkmark$ 71. Panicum verrucosum Muhl.}

Panicum debile Ell. Bot. S. C. \& Ga. 1: 129. 1816, not Desf. 1798. No specimen nor locality is cited. The type was not found in the Elliott Herbarium but the description clearly identifies the species.

Panicum verrucosum Muhl. Descr. Gram. 113.1817. "Habitat in N. Cæsarea, Delaware, et Georgia." The type is in the Muhlenberg Herbarium. On the sheet is written "verrucosum" but there is nothing to indicate from which of the three States cited the specimen came.

Panicum umbraculum Bosc; Spreng. Syst. Veg. 1:314. 1825. This and the following are names found in the Willdenow Herbarium, on specimens collected by Bosc, and published as synonyms of $P$. verrucosum Muhl. Both belong to this species.

Panicum rugosum Bosc; Spreng. loc. cit.

\section{DESCRIPTION.}

Plants bright green, solitary or few together, lax, at first erect but soon decumbent at base, and ascending or widely spreading; culms slender, $20 \mathrm{~cm}$. to 1.5 meters high;
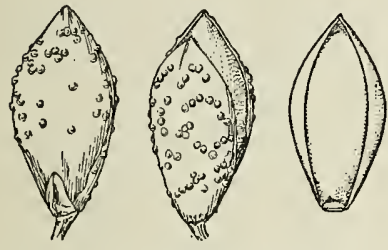

FIg. 121.-P.verrucosum. From type specimen. sheaths shorter than the internodes, ciliate; blades thin, lax, flat, 5 to $20 \mathrm{~cm}$. long, 4 to $10 \mathrm{~mm}$. wide, somewhat narrowed toward the base, gradually narrowed to the acuminate apex, glabrous; panicles finally exserted, 5 to $30 \mathrm{~cm}$. long, about as wide, diffuse, small panicles often produced at the lower nodes, at least the ultimate branchlets scabrous, the branches mostly solitary, the branchlets bearing a few short-pediceled spikelets, mostly in twos, toward the ends; spikelets 1.8 to $2.1 \mathrm{~mm}$. long, about $1 \mathrm{~mm}$. wide, elliptic-obovate, subacute; first glume onefourth the length of the spikelet or less; second glume and sterile lemma warty, glabrous, the glume shorter than the fruit at maturity; fruit 1.8 to $2 \mathrm{~mm}$. long, $1 \mathrm{~mm}$. wide, elliptic, acute.

\section{DISTRIBUTION.}

Wet, mostly shady soil, Atlantic Coastal Plain, Massachusetts to Florida and Texas; also in Indiana and Tennessee.

Massachusetrs: Springfield, Andrews 23; Plymouth, Oakes.

New York: Staten Island, Tyler in 1898 .

New Jersey: Atsion, Chase 3546; Egg Harbor, Scribner in 1886, Vasey in 1884; Englishtown, Pearce in 1884 .

Pennsylvania: Tinicum, Diffenbaugh in 1868, Smith 99.

Indiana: Dune Park, Chase 918, Hill 177 in 1898.

Delaware: Ellendale, Commons 231.

MARYLAND: Eastern Shore, Canby.

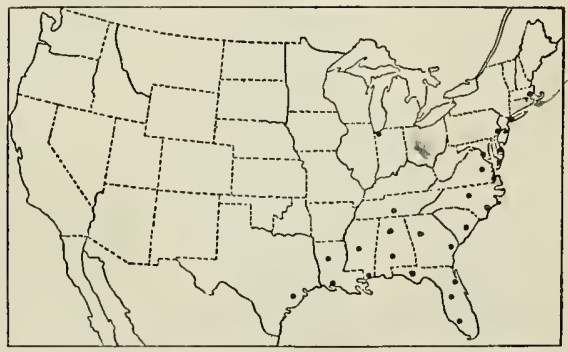

FIG. 122.-Distribution of $P$. verrucosum.

District of Columbia: Chase 5440, Dewey 408, Kearney in 1895; Steele in 1896, Ward in 1878 and 1879.

Virginia: Parksley, Warburton in 1903; Munden, Mackenzie 1671; Portsmouth, Noyes 84; Virginia Beach, Britton in 1895, IIitchcock 164, Kearney 2053; Suffolk, Boottcher 471; Dismal Swamp, Chase 3660. 
North Carolina: West Raleigh, Stanton 1271; Swain County, Beardslee \& Kofoid in 1891; Wilmington, Ashe in 1897.

South Carolina: Santee Canal, Ravenel (Gray Herb.).

Georgia: Sumter County, Harper 638; Thomson, Bartlett 1103; Stone Mountain, Hitchcock 216; Augusta, Cuthbert in 1903; without locality, Latimer in 1885.

Florida: Jacksonville, Curtiss 3608, 4036, 5252, 5808; Milton, Chase 4314; Orange County, Baker 31, Combs 1049, 1116, Meislahn 22a; Titusville, Chase 3986; Eustis, Chase 4066, Nash 780; Gainesville, Chase 4202; Braidentown, Combs 1269, 1294; Bartow, Combs 1234; without locality, Rugel 598.

Tennessee: Nashville, Gattinger in 1882.

Alabama: Cullman County, Eggert 59; Auburn, Earle \& Baker in 1897.

Mississippi: Nicholson, Kearney 379; Waynesboro, Kearney 120; Biloxi, Kearney 336 in part, Tracy 4562; Pass Christian, Langlois 35 in 1882.

Louisiana: Oberlin, Ball 204; Lake Charles, Chase 4424.

Texas: Jefferson, Plank 30 (Hitchcock Herb.).

\section{$\checkmark$ 72. Panicum brachyanthum Steud.}

Panicum brachyanthum Steud. Syn. Pl. Glum. 1: 67. 1854. The only specimen cited is, "Vinzent Coll. nr. 124. Texas." The type, in the Paris Herbarium, is labeled "In sabulosis sylvaticis, Texas, prope coloniam Rusk County, Vincent coll. 124."

Panicum sparsiflorum Vasey, U. S. Dept. Agr. Div. Bot. Bull. 8: 36. 1889, not Doell, 1877. Vasey cites "(P. angustifolium, Chap. non Ell.)," gives a description, and follows with the range "South Carolina to Texas." As this is not primarily a change of name, the type is one of the specimens which Vasey had before him when he wrote the description. From among those in the National Herbarium upon which Dr. Vasey has written the name, we have chosen as the type one collected in dry soil at San Bernardino, Texas, -October, 1839, by Dr. Ridell, no. 20. This was first named by Dr. Vasəy, P. angustifolium Ell. The authority, "Ell.," was changed to "Chap. non Ell." No specimens from South Carolina can be found named $P$. sparsiflorum by Vasey nor is the species known from that State.

\section{DESCRIPTION.}

Plants weakly ascending or spreading from a decumbent base, freely branching from

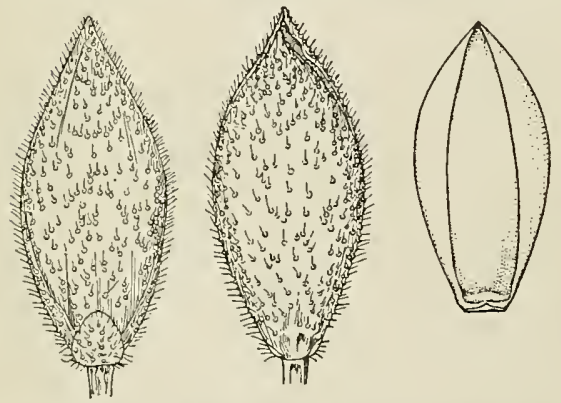

FIG. 123.-P. brachyanthum. From type specimen. the lower nodes; culms slender, $30 \mathrm{~cm}$. to 1 meter high; sheaths shorter than the internodes, minutely ciliate; blades 5 to $15 \mathrm{~cm}$. long, 2 to $3 \mathrm{~mm}$. wide, narrowed toward the base, often involute and scabrous toward the apex, the uppermost usually reduced; panicles dinally exserted, 5 to $15 \mathrm{~cm}$. long "about as wide, the branches few, scabrous, 4 ise lower sometimes as much as $10 \mathrm{cn}$ long, bearing a few short-pediceled spikelets, mostly in twos, toward the ends; spikelets 3.2 to $3.6 \mathrm{~mm}$. long, $1.5 \mathrm{~mm}$. wide, elliptic-obovate, abruptly pointed; first glume minute; second glume and sterile lemma subequal, the tubercles bearing stiff, spreading hairs; fruit 2.9 to $3 \mathrm{~mm}$. long, $1.4 \mathrm{~mm}$. wide, obovate-elliptic, subacute. 


\section{DISTRIBUTION.}

Sandy soil, Louisiana, Texas, and Oklahoma.

Louisiana: Oberlin, Ball 220; Lake Charles, Chase 4389; without locality, Hale (Hitchcock Herb.).

Texas: Jacksonville, Joor in 1884, Plank 22, 60; Grand Saline, Reverchon 2223; Paris, Heller 4221; College Station, Nealley in 1882; Galveston, Joor 3648; Industry, Wurzlow 9; Marshall, Bush 979; Tyler, Reverchon 2224; Harvester, Thurow in 1898; without locality, Nealley in 1885.

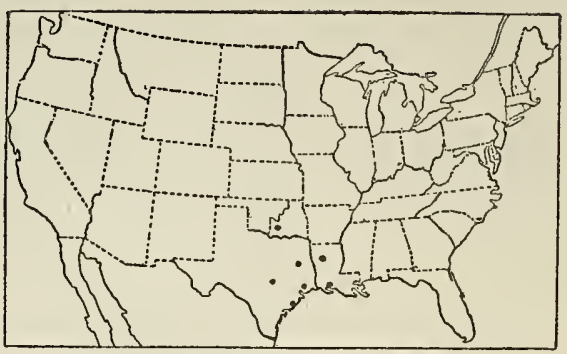

FIG. 124.-Distribution of $P$. brachyanthum.

OкLAномa: Sapulpa, Bush 738 (Gray Herb.).

Trichoidia.-Annuals, decumbent at base and rooting at the lower nodes, rather freely branching; blades oblong-lanceolate to ovate; panicles short-exserted or included at base until maturity, very diffuse, the numerous branches, branchlets and long pedicels capillary; spikelets minute, not over $1.4 \mathrm{~mm}$. long; fruit minutely papillose, the margin of the lemma flat.

Blades more than one-fourth as wide as long; spikelets pubescent.............................. 73. P. trichoides.

Blades less than one-eighth as wide as long; spikelets minutely bullate-rugose....................... 74. P. trichanthum.

\section{$\checkmark$ 73. Panicum trichoides Swartz.}

Panicum trichoides Swartz, Prodr. Veg. Ind. Occ. 24. 1788. "Jamaica, Hispaniola." Swartz cites Sloane's plate 72, figure 3, but does not quote his diagnosis, hence the type $a$ is not the Sloane plant, which belongs to the same species, but the plant in the Swartz Herbarium labeled "trichoides fl. ind. occ." from "Jamaica, Swartz."

Panicum capillaceum Lam. Tabl. Encycl. 1: 173. 1791. Lamarck gives for the locality "Amer. merid." and cites Sloane's plate 72, figure 3. The type, in the Lamarck Herbarium, was collected in Porto Rico by Le Dru. Persoon, $b$ while quoting Lamarck's diagnosis, gives the name as "Capillaceum (filamentosum)." The second word does not seem to be meant either as a change of name or as a variety. What the author intended is not apparent.

Panicum acutifolium Willd.; Spreng. Syst. Veg. 1: 320. 1825. This is given as a synonym under $P$. capillare and is credited to "W. herb." The type, in the Willdenow Herbarium, was collected by Humboldt at Cumanacoa.

Panicum capillaceum strictius Doell in Mart. Fl. Bras. $2^{2}: 249$. 1877. "In Prov. Piauhyensi (Gardner n. 3509)." This specimen we have not seen.

This species has usually been referred by authors of American floras to $P$. brevifolium L., which is from India, and is the same as $P$. ovalifolium Poir. as described by Hooker, $c$ and a very different species.

$a$ See Hitchcock, Contr. Nat. Herb. 12: 140. 1908.

$b$ Syn. Pl. 1: 83. 1805.

$c$ Fl. Brit. Ind. $7: 44.1896$.

$41616^{\circ}$ - vou $15-10-9$ 
DESCRIPTION.

Plants often widely spreading; culms ascending from a decumbent base, the ascending portion 20 to $40 \mathrm{~cm}$. high, rather slender, leafy, pubescent; sheaths short, but sometimes overlapping toward the summit and on the branches, ciliate and papillosehirsute, at least toward the summit; ligules membranaceous-ciliate, scarcely $0.5 \mathrm{~mm}$. long; blades spreading, thin, 2 to $6 \mathrm{~cm}$. long, 1 to $2 \mathrm{~cm}$. wide,

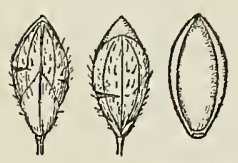

FIG. 125.-P. trichoides. From type specimen. ovate or ovate-lanceolate, somewhat unsymmetrical, acuminate, cordate and somewhat clasping at the ciliate base, glabrous or sparsely hirsute on both surfaces; panicles oval or ovate in outline, 5 to $20 \mathrm{~cm}$. long, nearly as wide, the axis sparsely pilose, the numerous branches and branchlets and the long pedicels capillary; spikelets 1.2 to $1.3 \mathrm{~mm}$. long, about $0.5 \mathrm{~mm}$. wide, obovate-elliptic, sparsely hirsute; first glume about half the length of the spikelet, acute, 1-nerved; second glume shorter than the sterile lemma, both 3-nerved, and at maturity sometimes ruptured by the expanding fruit, often only the lower part of each remaining; fruit at maturity 1.3 $\mathrm{mm}$. long, $0.6 \mathrm{~mm}$. wide, elliptic, minutely papillose while immature, becoming smooth but not polished.

\section{DISTRIBUTION.}

Woods and open ground, often a weed in cultivated soil, Mexico and the West Indies, south to Ecuador and Brazil.

Mexico: Imala, Palmer 1758 in 1891; Manzanillo, Palmer 1083 in 1890; Acapulco, Palmer 287 in 1895; Guadalajara, Pringle 3828; Guatulco, Liebmann 317; Zacualpan, Purpus 2902; Córdoba, Finck in 1893; La Correa, Langlassé 380; Coahuayutla, Emrick 53; Tabasco, Rovirosa 434; San Juan Bautista, Rovirosa 598; Yucatan, Gaumer 522; Tres Marias Islands, Nelson 4257.

Guatemala: Santo Thomas, Deam 6041; Dept. Santa Rosa, Heyde \& Lux 4299; El Palmar, Kellerman 6263; Alta Vera Paz, Tuerckheim 7801.

Honduras: Wilson 188 (Field Mus. Herb.).

Salvador: San Salvador, Velasco in 1906.

Costa Rica: Nicoya, Cooper 10379; Matina, Pittier 9754; Buenos Aires, Pittier 3651, Tonduz 4865; San José, Tonduz 3123; without locality, Pittier 4458, 16081.

Cuba: Habana, Curtiss 714 .

Jamaica: Port Antonio, Fredholm 3282.

Ponto Rico: Mayaguez, Cowell 522, 583, Sintenis 160; Ponce, Heller 6094; Luquillo Mountains, Wilson 283; Martin Peña, Heller \& Heller 387; Cayey, Heller \& Heller 531; Mount Morales, Britton \& Cowell 444; Rio Piedras, Barrett 61; Santurce, Heller \& Heller 157.

Leeward Islands: St. Christopher, Britton \& Cowell 295; Dominica, Eggers in 18ș1; Guadeloupe, Duss 2681.

Windward Istands: Martinique, Duss 1321, Hahn 1047; Granada, Broadway in 1905, Eggers 5987.

Colour1a: State of Magdelena, Pittier 1621; Calí, Pittier 971; Santa Marta, Smith 167.

Venezuela: Tovar, Fendler 2499.

Trinidad: "Ex herb. W. Mitten," collector not given.

British Gulana: Demerara, Jenman 4403.

Brazil: Para, Spruce 466 (Panicum 13); without locality, Burchell 8706.

EcUador: Balao, Eggers 14481; El Recreo, Eggers 15417. 


\section{Panicum trichanthum Nees.}

? Milium microspermum Lag. Gen. \& Sp. Nov. 2. 1816. "Habitat in Nova Hispania. Semina communicavit perill. D. Sessé." We have not seen the type specimen and the short description applies equally well to $P$.trichoides. Fournier ${ }^{a}$ gives this as equivalent to $P$. trichanthum Nees.

Panicum trichanthum Nees, Agrost. Bras. 210. 1829. "Habitat in Brasilia aequatoriali (Siber.-Vidi in Herb. Reg. Berol.) In regno Mexicano (ab Irumboldt, Haenke.) (Vide in Herb. Willd. et Haenk.)" Nees's first citation, however, following the diagnosis and preceding his discussion of this and P. trichoides is as follows: "Panicum tricho[i]des, Humb. et $K$. * * * (fide Herb. Willd.)" While Nees's description distinguishes carefully between this species and $P$. trichoides, there is some confusion as to the specimens mentioned, since some are referable to $P$. trichanthum and some to $P$. trichoides. The specimen in the Willdenow Herbarium marked "P. trichanthum" in Nees's writing, which appears to be the specimen referred to as that of "Humb. et $\mathrm{K}$. ," is accepted as the type.

Panicum guayaquilense Steud. Syn. Pl. Glum. 1: 85. 1854. "Jameson Hrbr. nr. 560 , Guayaquil." The type, in the Steudel Herbarium, is labeled "Savannis Guayaquilensibus."

Panicum microspermum Fourn.; Hemsley, Biol. Centr. Amer. Bot. 3: 492.1885. "Panicum trichoides [Swartz, misapplied by] Ch. et Schl. in Linnæa, VI. p. 33" and "Panicum trichanthum Nees Agrostol. Bras. p. 210," are cited as synonyms, no description being given. Schlechtendal and Chamisso $b$ give without description $P$. trichoides Swartz as the name of Schiede \& Deppe's no. 894, the specimen of which, in the Berlin Herbarium, is referable to $P$. trichanthum. Panicum microspermum as used by Hemsley, then, must be considered as based on $P$. trichanthum Nees. Fournier $a$ later describes the species under the name $P$. microspermum Fourn., citing as synonyms the names given by Hemsley and also "Milium microspermum Lag.," which, since Fournier takes up Lagasca's specific name, would be the basis of Fournier's name as published by himself. While the identity of $M$. microspermum is doubtful all the specimens cited by Fournier are referable to $P$. trichanthum.

DESCRIPTION.

Plants often in large bunches; culms ascending from a decumbent base, as much as 1 to 2 meters long, rather stout, glabrous; sheaths shorter than the internodes, ciliate, and usually with a villous ring at the juncture with the blade, otherwise glabrous or rarely pubescent toward the summit;

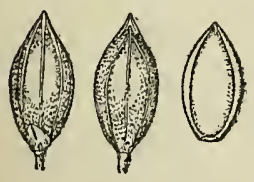

FiG. 126.-P. trichanthum. From Fendler's no. 1643 . ligules membranaceous, less than $0.5 \mathrm{~mm}$. long; blades oblonglanceolate, usually 10 to $15 \mathrm{~cm}$. long, 10 to 15 or rarely $25 \mathrm{~mm}$. wide, cordate, rather strongly nerved, glabrous or puberulent, often pilose above the ligule; panicles 10 to $30 \mathrm{~cm}$. long, the axis glabrous, the numerous branches and branchlets and the long pedicels capillary, flexuous; spikelets 1.2 to $1.4 \mathrm{~mm}$. long, $0.6 \mathrm{~mm}$. wide, obovate-fusiform, acute; first glume less than onefifth the length of the spikelet; second glume shorter than the sterile lemma, both 3-nerved and under a lens minutely bullate-rugose, often ruptured and breaking off as the fruit matures, as in P. trichoides; fruit $1.2 \mathrm{~mm}$. long, $0.6 \mathrm{~mm}$. wide.

$a$ Mex. Pl. 2 : 22.1886.

$b$ Linnaea 6 : 33.1831.

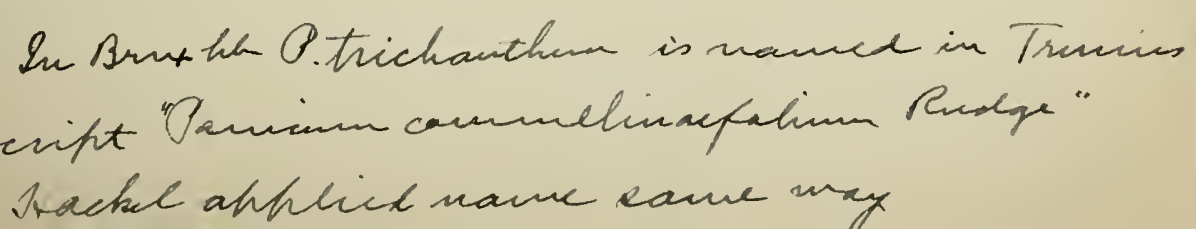




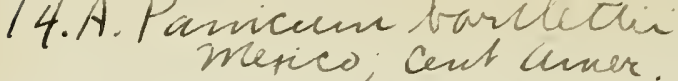
CONTRIBUTIONS FROM THE NATIONAL HERBARIUM.

DISTRIBUTION.

Thickets, river banks and rocky slopes, Mexico, the West Indies, and south to Paraguay.

Mexico: Colima, Palmer 1257 in 1891; Colipa, Liebmann 432; Jicaltepec, Liebmann 320; Vera Cruz, Müller 2172 in part; San Luis Potosí to Tampico, Palmer 1151 in 1879.

Guatemala: Alta Vera Paz, Lewton 377, Tuerckheim 7798; Gualan, Deam 424; Morales, Kellerman 6272.

Honduras: San Pedro Sulá, Thieme 5587 in part.

Costa Rica: Talamanca, Tonduz 8600, 8670.

Panama: Bocas del Toro, Hart 87.

Cuba: Trinidad, Wright 753; Romelie, Eggers 5350; Vento, Curtiss 598, León 557. Jamaica: Purdie (Gray Herb.).

Porto Rico: Cayey, Sintenis 2471.

Colombia: Santa Marta, Smith 2151.

Venezuela: Tovar, Fendler 1643.

BrazIL: Without locality, Burchell 7062, 8791, Riedel 1360.

Paraguay: Morong 317, 1571.

Urvilleana.-Perennials with large, densely villous spikelets, the fertile lemma clothed with long hairs on the margin. A South American group of two or three species, of which one extends into the desert region of the southwestern United States.

\section{Panicum urvilleanum Kunth.}

Panicum megastachyum Presl, Rel. Haenk. 1: 305. 1830, not Nees 1826. "Hab. in montanis Peruviae huanoccensibus." The type specimen, labeled "Panicum megastachyum Presl. Peruana montano guanoccensis. Haenke," is in the herbarium of the Bohemian Museum.

Panicum urvilleanum Kunth, Rév. Gram. 2: 403. pl. 115. 1830. Kunth gives no definite locality other than "Crescit in regno Chilensi." The name is listed with the citation "Chili: Legit amiciss. Dumont D'Urville," but without description, in an earlier part of the same work. $a$ The type specimen, in the Berlin Herbarium, is labeled "Conception de Chili, D'Urville ded 1815."

Panicum preslei Kunth, Enum. P1. 1: 121. 1833. Based on "P. megastachyum Presl," the name is presumably changed because of P. megastachyum Nees. Presl's description is copied, Kunth evidently not having seen the plant.

Panicum urvilleanum longiglumis[e] Scribn. U. S. Dept. Agr. Div. Agrost. Bull. 17: (ed. 2). 49. 1901. "San Jacinto, Southern Calif. No. 887. S. B. \& W. F. Parish, June, 1882." The type specimen, in the National Herbarium, has spikelets about 7 $\mathrm{mm}$. long.

\section{DESCRIPTION.}

Plants robust, erect from a creeping rootstock, 0.5 to 1 meter high, culms solitary or few in a tuft, simple or branching at the base only, the nodes densely bearded, rarely visible; sheaths overlapping, loose, densely, retrorsely, harshly villous; ligules densely ciliate, about $2 \mathrm{~mm}$. long; blades 30 to $60 \mathrm{~cm}$. long, 4 to $7 \mathrm{~mm}$. wide, tapering from a flat base to a long involute-setaceous point, retrorsely strigose to nearly glabrous on both surfaces; panicles short-exserted, equaled or exceeded by the upper blades, 25 to $30 \mathrm{~cm}$. long, about half as wide, rather many-flowered, the glabrous to pilose, slender, flexuous branches ascending, producing spikelet-bearing branchlets along the upper half to two-thirds of their length; spikelets short-pediceled, 6 to $7 \mathrm{~mm}$. long, about 2

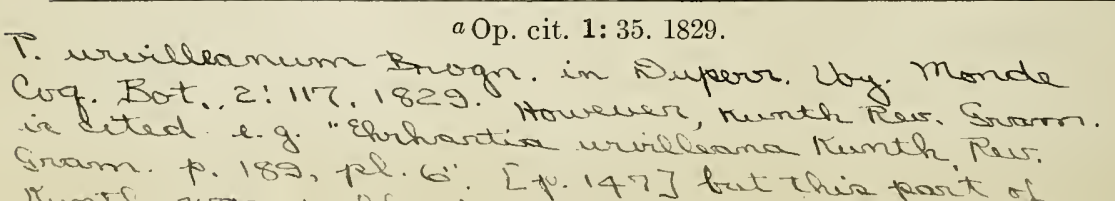


$\mathrm{mm}$. wide, and as much as $4 \mathrm{~mm}$. thick, ovate, densely silvery to tawny villous, strongly nerved but the nerves obscured by the pubescence; first glume clasping, twothirds to nearly as long as the spikelet, sparsely villous or glabrescent toward the
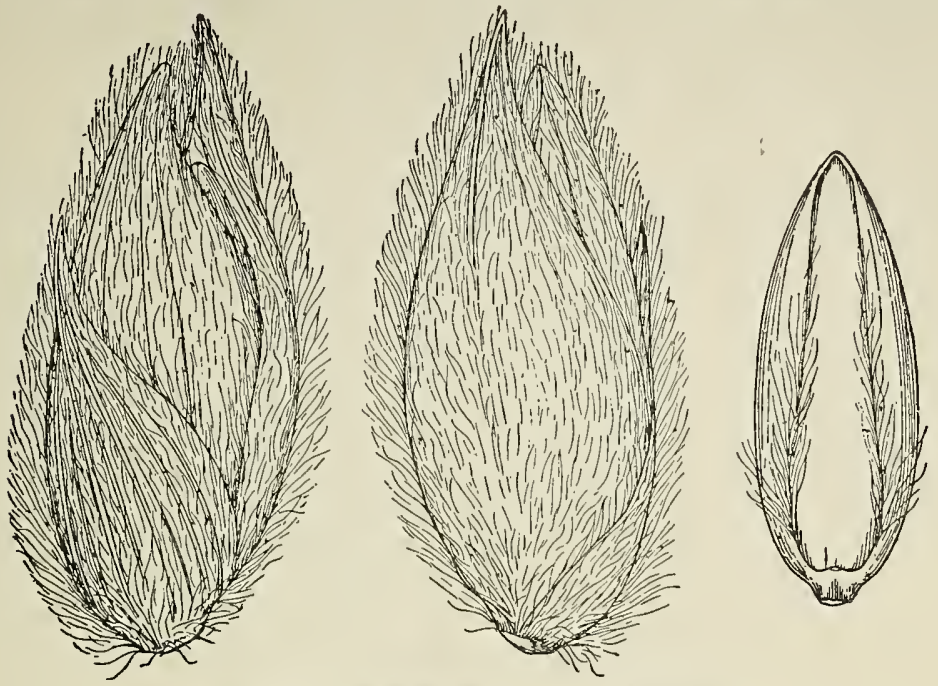

FIG. 127.-P. urvilleanum. From type specimen.

acuminate apex; second glume slightly longer and more pointed than the sterile lemma, both exceeding the fruit, the lemma inclosing a villous palea of equal length and a staminate flower; fruit 4.2 to $4.5 \mathrm{~mm}$. long, about $1.6 \mathrm{~mm}$. wide, the margins of the lemma clothed with long white hairs, otherwise smooth and shining.

DISTRIBUTION.

Sandy deserts, Arizona and southern California south to Argentina.

Arizona: Without locality, Lemmon in 1884.

California: San Jacinto, S. B. \&

W. F. Parish 887 in 1882; Agua

Caliente, S. B.\& W. F. Parish

887 in 1881; Barstow, Chase

5766, Tracy 434; Hesperia, Abrams 2164; Colorado Desert, Chase 5519, Parry \& Lemmon 400 (Hitchcock Herb.), Wilder 1082.

Argentina: Rio Negro, Wilkes S.

Pac. Expl. Exped. in 18381842.

Chrle: Gillies (Gray Herb.).

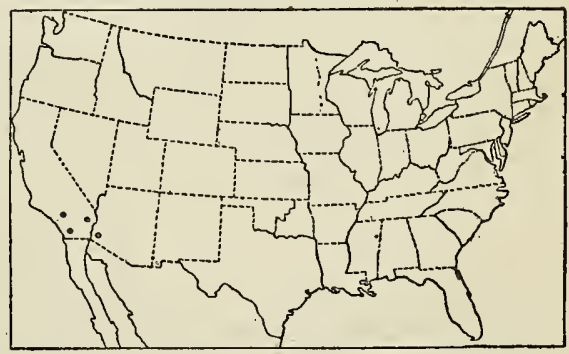

FIG. 128.-Distribution of $P$. urvilleanum.

\section{UNGROUPED SPECIES OF TRUE PANICUM.}

The following tropical species do not fall into any of the foregoing natural groups nor, with the exception of Panicum rudgei and $P$. rotundum, which are allied species, do they form such groups among themselves. The Mexican and Central American species are as yet not so well understood as those of the United States, and further study is necessary before our knowledge of the species of the former regions shall be as detailed as that of the species occurring north of the Mexican boundary. This study awaits additional material and extended field work in Mexico and Central America. 
$\checkmark$ 76. Panicu hanfiearnum Preal!

Panicum costaricense Hack. Oesterr. Bot. Zeitschr. 51:428. 1901. "Costarica: Inter Buenos Aires et Térraba (Pittier 3636); in silva prope Térraba (3673), in virgultis ad Rio Ceibo (4860)." The first specimen cited, which is taken as the type, is in the Brussels Herbarium, and was examined by Hackel, but is not in his own herbarium. The two other specimens are in Hackel's herbarium.

\section{DESCRIPTION.}

Plants apparently annual; culms slender, erect, 0.5 to 1 meter high, sparingly branched, striate, glabrous or minutely pubescent; sheaths much shorter than the

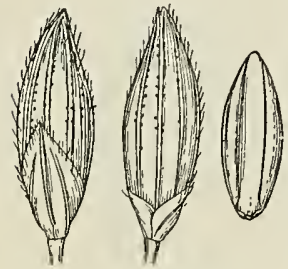

FIG. 129.-P. costaricense. 3 From type specimen. elongated internodes, papillose-pilose to glabrate, ciliate at least toward the summit; ligules membranaceous, ciliate, about $0.5 \mathrm{~mm}$. long; blades 5 to $10 \mathrm{~cm}$. long, 6 to $12 \mathrm{~mm}$. wide, narrowed toward the base, long-acuminate, very sparsely pilose on both surfaces or glabrate; panicles ovoid in outline, 10 to $15 \mathrm{~cm}$. long, about two-thirds as wide, loosely flowered, the slender, flexuous branches ascending or spreading, bearing delicate branchlets throughout, the scattered spikelets on capillary, flexuous pedicels; spikelets $2.4 \mathrm{~mm}$. long, 0.7 $\mathrm{mm}$. wide, elliptic, acute, rather strongly nerved; first glume nearly half the length of the spikelet, acute, hirsute toward the margin; second glume and sterile lemma sub qual, pointed beyond the fruit, hirsute toward the margin and with very minute papillæ bordering the nerves; fruit $1.7 \mathrm{~mm}$. long, $0.6 \mathrm{~mm}$. wide, elliptic, smooth and shining, the margins of the lemma near the base each bowed out into a little angle, giving a somewhat auricled appearance.

The somewhat auricled base of the fruit in this species suggests an approach to species of Ichnanthus.

Forests, Costa Rica. -

Costa Rica: Buenos Aires, Pittier 3661, Tonduz 4860; Cordoncillal, Pittier 3640; Boruca, Pittier 4626; Térraba, Tonduz 3673.

condovemsePanicum expansum Fourn., ${ }^{a}$ the type specimen of which, Liebmann's no. 426 from Huitamalco, Mexico, in the Copenhagen Herbarium, was examined at Halle, is apparently closely related to $P$. costaricense. The fruit has the same auricled or angled base, but the spikelets are slightly larger and glabrous, and the blades are glabrous. Liebmann's no. 427 in the same herbarium is the only other specimen of this species we have seen. For the satisfactory placing of this species more material is needed.

\section{ᄂ 77. Panicum parvifolium Lam.}

Panicum parvifolium Lam. Tabl. Encycl. 1: 173. 1791. The only specimen mentioned is "Ex Amer. merid. Communic. D. Richard." The type, in the Lamarck Herbarium, labeled, "ill. gen. ex D. Richard," is a single slender culm.

Panicum brasiliense Spreng. Syst. Veg. 1: 321. 1825. "Brasil. (P. ascendens W. herb.)" In the Willdenow Herbarium is a specimen of $P$. parvifolium labeled, "Panicum adscendens. Brasil. Hoffmansegg," which is evidently the specimen referred to by Sprengel, and is the type of $P$. brasiliense.

Panicum ascendens Willd.; Spreng. Syst. Veg. 1: 321. 1825. This is given as a synonym of $P$. brasiliense of which it is a typonym.

Panicum adscendens Hoffmgg.; Ind. Kew. 2: 410.1894. This is listed with the reference "ex Schult. Mant. 2: 592," but this is evidently an error, since-the Mantissa"

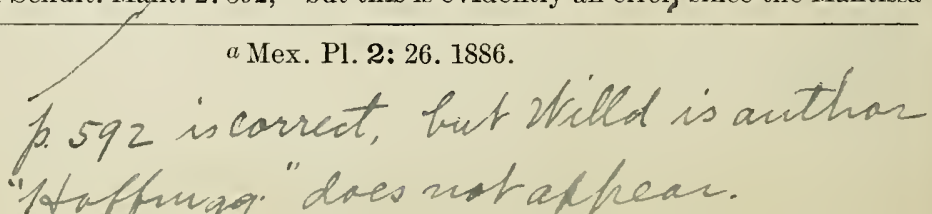


volume 2 contains but 522 -pages in all the copies we have seen. The type is undoubtedly the Hoffmansegg specimen mentioned above.

Panicum oplismenoides Nash, Bull. Torrey Club $30: 381.1903$, not Hack. 1888. "Collected on the edge of a ditch at Vega Baja, May 9, 1899, by Heller, no. 1316." The type is in the herbarium of the New York Botanical Garden.

\section{DESCRIPTION.}

Plants perennial, cespitose, decumbent or creeping, rooting at the lower nodes, glaucous and glabrous throughout, except as noted; culms slender, branching, 20 to $80 \mathrm{~cm}$. long, leafy, with numerous short internodes, the nodes sometimes sparsely

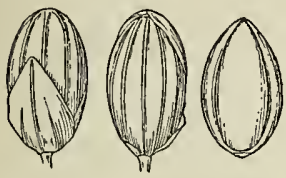

FIG. 130.-P. parvifolium. From type specimen. pilose; sheaths rarely over $1 \mathrm{~cm}$. long, ciliate, and sometimes, especially on young shoots, sparsely pilose; ligules nearly obsolete; blades 1 to $3 \mathrm{~cm}$. long, 2 to $6 \mathrm{~mm}$. wide, oblong-lanceolate, rounded or subcordate at base, spreading or reflexed, or the upper and often those of young shoots appressed, sometimes sparsely pilose at the base; panicles short-exserted, 2 to $4 \mathrm{~cm}$., rarely $6 \mathrm{~cm}$. long, about as wide, loosely flowered, the slender, flexuous branches spreading, the branchlets and pedicels divergent; spikelets about 1.5 $\mathrm{mm}$. long, $0.8 \mathrm{~mm}$. wide, turgid, blunt, glabrous; first glume slightly more than half the length of the spikelet, subacute, 3-nerved; second glume and sterile lemma subequal, 5-nerved, the sterile palea nearly as long as its lemma; fruit $1.4 \mathrm{~mm}$. long, $0.8 \mathrm{~mm}$. wide, ovate, smooth and shining.

\section{DISTRIBUTION .}

Damp shady places, Costa Rica and the West Indies, south to Brazil and Paraguay. Costa Rica: Buenos Aires, Pittier 10594, Tonduz 3631.

Cuba: Los Almacigos, Wright 3458; Herradura, Baker 2078, Hitchcock 181, Tracy $9060,9079$.

Porto Rico: Sintenis 5719, 1216 (Krug \& Urban Herb.); Vega Baja, Heller \& Heller 1316.

TRINIDAD: Broadway 2372.

British Guiana: Schomburgk 407.

Dutch Guiana: Surinam, no collector given (Gray Herb.).

French Guiana: No data (Gray Herb.).

BrazIL: Falls of St. Gabriel, Spruce 2207; Santarem, Spruce 632; São Paulo, Löfgren 1124; Campinas, Novaes 1245; without locality, Riedel 958.

Paraguay: Morong 519.

\section{$\checkmark$ 78. Panicum millegrana Poir.}

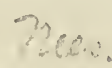

Panicum hirsutum Lam. Encycl. 4:741. 1798, not Swartz, 1797. "Cette plante croît à Cayenne, d'ou elle a été envoyée par le citoyen Leblond." The type, in the Paris Herbarium, labeled "Cayenne, Le Blond," has glabrous spikelets.

Panicum millegrana Poir. in Lam. Encycl. Suppl. 4:278. 1816. "Cette plante croît dans l'A mérique méridionale ( $V . s$. in herb. Desfont)." This specimen was not found in the Desfontaine Herbarium at Florence. In the Paris Herbarium is a specimen from "Cayenne, Martin," labeled "Panicum millegrana Poir.," which appears to be authentic and may be the type. Poiret's description applies well to this plant and to the species known as $P$. rugulosum Trin. The spikelets are glabrous as in the type of that species.

Panicum rugulosum Trin. Gram. Pan. 195. 1826. "Brasil (LANGSdorff.)" The type, in the Trinius Herbarium, has glabrous spikelets. 
Panicum sellowii Nees, Agrost. Bras. 153. 1829. "Habitat in Brasilia meridionali. (Sellow)." The type, in the Berlin Herbarium, has spikelets densely papillosepubescent with short, stiff hairs.

Panicum beyrichii Kunth, Rév. Gram. 2: 231. pl. 27. 1830. "Crescit in nemoribus prope novum Triburgum Brasiliæ." Kunth states that he received the plant under the name $P$. sellowii Nees from Beyrich who collected it. The type, in the Berlin Herbarium, has glabrous spikelets as in the type of $P$. millegrana. $\Lambda$

Panicum lasianthum Trin. Gram. Icon. 3:pl.245. 1830. Trinius states that the figure is "ad specimen Brasilianum." The type, in the Trinius Herbarium, collected in Brazil by Langsdorf, has papillose-hispid spikelets.

Panicum puberulum Trin. Mém. Acad. St. Pétersb. VI. Sci. Nat. 1: 277. 1834, not Kunth, 1829. Trinius states that his specimen is from Brazil. The type, in the Trinius Herbarium, collected in Brazil by Sello, has papillose-hispid spikelets as in the type of $P$. sellowii.

Panicum dispersum Trin. Mém. Acad. St. Pétersb. VI. Sci. Nat. 1: 282. 1834. Trinius gives the locality as "Bahiens." The type, in the Trinius Herbarium, collected in Bahia, Brazil, by Riedel in 1831, is a prostrate or decumbent plant with glabrous spikelets.

Panicum expansum Trin.; Stetd. Nom. Bot. ed. 2. 2:256. 1841. This is a nomen nudum credited to "Trin. mpt. Mexico." The type, in the Trinius Herbarium, labeled "Mexico, Hacienda Laguna, Schiede," has glabrous spikelets. This is not the $P$. expansum of Fourn: or $a$ who cites Trinius's name as a synonym under P. rugulosum. ${ }^{b}$

Panicum pilosum leiogonum Rupr. Bull. Acad. Roy. Belg. 9²: 239. 1842. This name is listed without description. The only specimen mentioned is Galeotti 5728 from Xalapa, Mexico. The type is in the Brussels Herbarium. This name is given by Fournier ${ }^{a}$ as a synonym under $P$. rugulosum, but Galeotti's no. 5728 he cites $c$ also under $P$. pilosum genuinum.

Panicum sellowii longevaginatum Rupr. Bull. Acad. Roy. Belg. 9²: 239. 1842. Under this name, which is listed without description, Ruprecht cites two specimens, Galeotti 5726 and 5699. The first has glabrous, the second hispid spikelets. This name is given by Hemsley $d$ and Fournier $e$ as a synonym under P. rugulosum.

Panicum valenzuelanum Rich. in Sagra, Hist. Cuba 11: 304. 1850. "Grescit in locis montosis partis occidentalis insulae Cubae Vuelta de abajo dictae * * * (Don José María Valenzuela)." The type, in the Richard Herbarium, labeled "Vuelta de Abajo (Valenzuelana)," has papillose-hispid spikelets.

Panicum probandum Steud. Syn. Pl. Glum. 1: 76. 1854. Based on "P. puberulum Trin. non Kunth."

Panicum rugulosum hirtiglume Griseb. Cat. Pl. Cub. 233. 1866. The only specimen cited is Wright 3455 . The type, in the Grisebach Herbarium, has hispidulous spikelets.

Panicum rugulosum glabrescens Doell in Mart. Fl. Bras. $2^{2}: 259$. 1877. As no specimen is mentioned, $P$. beyrichii Kunth, the first synonym cited, is taken as determining the type.

Panicum rugulosum pubescens Doell in Mart. Fl. Bras. $2^{2}: 259.1877$. No specimen is mentioned. The type of the first synonym cited, P. rugulosum Trin., has glabrous spikelets, while Doell describes his variety as having puberulent glumes, hence the type of the second synonym cited, P. sellowii Nees, which has hispid spikelets, is taken as the type.

$a$ Mex. Pl. 2: 26. 1886.

$b$ Op. eit. 21.

cOp. cit. 24. $d$ Biol. Centr. Amer. Bot. 3: 495. 1885.

$e$ Mex. Pl, 2: 21. 1886. 
Panicum rugulosum subvelutinum Doell in Mart. Fl. Bras. 22: 259. 1877. " $A \mathrm{cl}$. Wullschlaegel (n. 1612) in Surinamiae districtu Paraënsi lecta." We have not seen this specimen but the description, "foliorum lamina utrinque subvelutina," would indicate the form with velvety blades.

\section{DESCRIPTION.}

Plants perennial, spreading; culms sparingly branching, 0.5 to 1 meter high, ascending from a decumbent base, softly pubescent to glabrous; sheaths ciliate and with a dense ring of pubescence at the summit, otherwise papillose-pilose to glabrous; ligules membranaceous, scarcely $0.3 \mathrm{~mm}$. long; blades ascending or spreading, thin, ovate-lanceolate, 4 to $15 \mathrm{~cm}$. long, 10 to $30 \mathrm{~mm}$. wide, somewhat unsymmetrical at

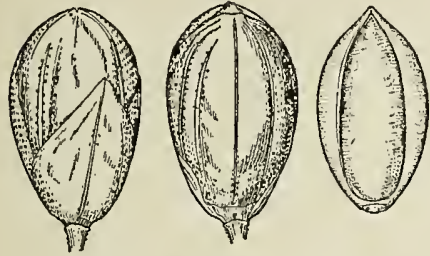

Fig. 131.-P. millegrana. From type specimen of $P$. rugulosum Trin. the rounded or slightly cordate, sometimes ciliate, base, softly pubescent, or sometimes velvety, on both surfaces to glabrate except near the margin and at the base; panicles short-exserted, finally loose and rather few-flowered, 10 to $20 \mathrm{~cm}$. long, about two-thirds as wide when expanded, the rather few, slender, branches stifly ascending or spreading, bearing toward the ends short, appressed branchlets with 1 to 3 rather short-pediceled spikelets; spikelets 2 to $2.3 \mathrm{~mm}$. long, 1 to $1.2 \mathrm{~mm}$. wide, obovate, obtuse, turgid, at maturity olivaceous or brown, glabrous or more commonly papillose-hispidulous; first glume about two-thirds as long as the spikelet, acute; second glume slightly shorter than the sterile lemma, exposing the summit of the fruit at maturity, both 5 -nerved, in glabrous spikelets the nerves bordered by interrupted rows of minute papillæ; fruit 1.9 to $2.1 \mathrm{~mm}$. long, about $1 \mathrm{~mm}$. wide, elliptic, obscurely pointed, papillose-roughened, becoming dark brown at maturity.

This species as here defined is very variable. The examination of a greater number of specimens and field study may show $P$. sellowii to be distinct from $P$. millegrana. From the material at hand they can not be satisfactorily separated, for while most of the specimens have either glabrous or papillose-hispidulous spikelets a few have both sorts in the same panicle, and the pubescence of the sheaths and blades can not be correlated with that of the spikelets.

The following specimens have glabrous spikelets: Fendler 1641, Heyde \& Lux 3927, Holway 3083, Liebmann Pl. Mex. 275, Löfgren 1228, Regnell III 1359**, Riedel, Rusby 233, Smith 2146, Widgren in 1844.

In Spruce 603 and Tuerckheim 657 most of the spikelets are glabrous but some in the same panicle are hispidulous, while in Wright 3455 the greater number of the spikelets are hispidulous but glabrous ones are found in the same panicle.

\section{DISTRIBUTION.}

Damp woods, Mexico and Cuba, south to Brazil.

Mexico: Mirador, Liebmann 275; Jalapa, Holway 3083; State of Chiapas, Heyde \& Lux 3927.

Guatemala: Dept. Alta Vera Paz, Tuerckheim 657, 8783, 8784.

Costa Rica: El General, Pittier 10615.

CubA: Habana, Wright 3462 in part; La Catalina, Wright 3455; Pinar del Rio, Wright 3855; Herradura, Hitchcock 180, Tracy 9098.

Colombia: Santa Marta, Smith 2146.

Venezuela: Tovar, Fendler 1641.

Brazil: Campinas, Novaes 1249; São Paulo, Löfgren 1228; Rio Janeiro, Widgren in 1844; Prov. Minas Geraes, Regnell III 1359**; Santarem, Spruce 603; Madeira, Rusby 233; without locality, Burchell 4146, 4315-2, 4653, Riedel.

Paraguay: Laguna Ipacarary, Fiebrig 561 (Field Mus. Herb.). 


\section{$\checkmark$ 79. Panicum glutinosum Swartz.}

Panicum glutinosum Swartz, Prodr. Veg. Ind. Occ. 24. 1788. "Jamaica." The type is in the Swartz Herbarium.

Panicum obtusiflorum Rich. in Sagra, Hist. Cuba 11:305. 1850. "Crescit ad marginem rivuli Cauta in provincia Santiago de Cuba. (Linden, n.2143.)" The type, in the Richard Herbarium, is labeled "St. Yago de Cuba. Linden 2143."

Panicum lindenii Griseb. Cat. Pl. Cub. 233. 1866. Based on "P. obtusiflorum Rich. Cub. non Hochst. [1851]; Lind[en]. 2143."

\section{DESCRIPTION.}

Plants perennial, somewhat glaucous; culms erect from a geniculate or decumbent base, often rooting at the lower nodes, 1 to 2 meters high, robust, compressed, glabrous; sheaths often longer than the internodes, somewhat keeled, especially the lower,
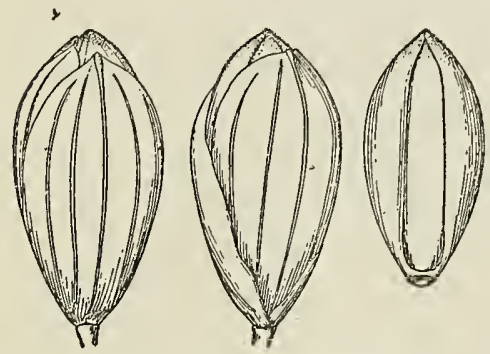

FIG. 132.-P. glutinosum. . From type specimen. glabrous or sometimes pilose, densely bearded at the juncture with the blade; ligules obsolete; blades elongated-lanceolate, acuminate, 15 to $50 \mathrm{~cm}$. long, 15 to $25 \mathrm{~mm}$. wide (the uppermost reduced), abruptly or gradually narrowed at the base, more or less ciliate along the lower portion, glabrous or sometimes very sparsely pilose; panicles rhomboid in outline, 15 to $30 \mathrm{~cm}$. long, about as wide, the lower branches verticillate, nearly as long as the main axis, stiffly ascending, the axis and branches glabrous, sometimes viscid, bearded in the axils, bearing slender, flexuous, scabrous branchlets, with rather long-pediceled spikelets, mostly along the upper half; spikelets $3 \mathrm{~mm}$. long, 1.5 to $2 \mathrm{~mm}$. wide, turgid, obovoid, obtuse, olivaceous to brown, the faintly nerved, very viscid glumes whitish on the margin; first and second glumes about equal, slightly shorter than the fruit, the sterile lemma thinner in texture, mostly entirely concealed beneath the first glume, sterile palea wanting; fruit $2.6 \mathrm{~mm}$. long, -1.2 to $1.5 \mathrm{~mm}$. wide, obovoidelliptic, olive-brown, densely minutely puberulent at the summit, otherwise smooth and shining, the margins of the lemma toward the summit scarcely inrolled.

\section{DISTRIBUTION .}

Mountain woods, Mexico and the West Indies, south to Paraguay and Bolivia.

Mexico: Zacualpan, Purpus 2156, 2903; Mirador, Liebmann 428; San Cristobal, Bourgeau 3192; Orizaba, Botteri; State of Chiapas, Nelson 3357.

Costa Rica: Cañas Gordas, Pittier 11017; Diquís Valley, Pittier 12002.

Cuba: Loma Pelada, Wright 757.

Jamaica: Gordon Town, Hart 792; Troy, Maxon 2816.

Ponto Rico: Mayaguez, Sintenis 357; Sierra de Yabucos, Sintenis 2609.

Brazil: Prov. Minas Geraes, Widgren in 1845, Regnell III 1370; São Paulo, Löfgren 2291, Löfgren \& Edwall 2383; Campinas, Novaes 1247.

Paraguay: Central Paraguay, Morong 405 A.

Bolrvia: Mapirí, Rusby 244. 
80. Panicum rudgei Roem. \& Schult. $a$

Panicum scoparium Rudge, Pl. Guian. 1:21. pl. 29. 1805, not Lam. 1798. Noparticular locality in Guiana is mentioned by Rudge. In the Berlin Herbarium is a specimen from Rudge which is authentic though it probably is not the type. The original description and the plate leave no doubt as to the identity of the species.

Panicum rudgei Roem. \& Schult. Syst. Veg. 2: 444. 1817. Based on "Pan. scoparium Rudge."

Panicum rudgei brasiliense Raddi, Agrost. Bras. 48. 1823. "Species rarissima observata tantum in viciniis fluminis Inhumirim." We have not seen the type of this, but the description applies to the type of $P$. rudgei.

Panicum dasytrichum Spreng. Syst. Veg. 1: 317. 1825. "Brasil." The type, in the Sprengel Herbarium, was collected by Hoffmansegg.

Panicum hirsutum Willd.; Spreng. Syst. Veg. 1: 317. 1825, not Swartz, 1797. This is given as a synonym under $P$. dasytrichum and is credited to "W. herb." The type, in the Willdenow Herbarium, was collected by Hoffmansegg in Brazil.

Panicum rhigiophyllum Steud. Syn. Pl.
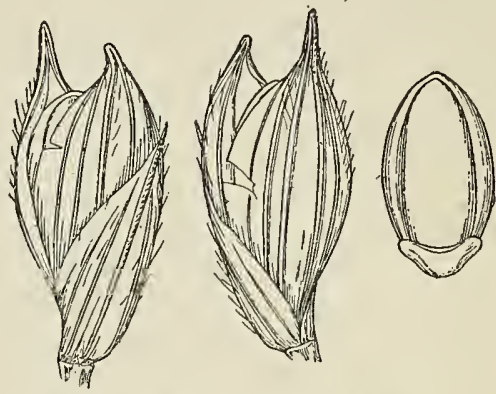

FIG. 133.-P. rudgei. From Salzmann's specimen of $P$. rigens.

Glum. 1: 76.1854. "P.rigens. Salzm. Hrbr. Bahia." This specimen was not found in the Steudel Herbarium, but a Salzmann specimen bearing this name was examined at Halle.

a The following species, though not North American, may here be described on account of its relationship to Panicum rudgei:

\section{Panicum rotundum sp. nov. $=$ P. carirtion 205}

Plants perennial, in small tufts; culms 30 to $50 \mathrm{~cm}$. high, rather stout, stiff, erect or somewhat geniculate at base, densely ascending-hirsute, the nodes densely bearded; sheaths, except the upper, mostly shorter than the internodes, hirsute like the culms; ligules membranaceous, ciliate, the hairs mingling with those of the blade; blades thick, erect or appressed, linear, 5 to $20 \mathrm{~cm}$. long, 2 to $5 \mathrm{~mm}$. wide, more or less involute, at least toward the long-acuminate apex, only as wide as the sheath at base, the juncture
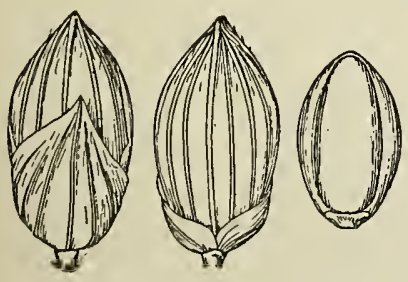

FIG. 134. $-P$. rotundum. From type specimen. obscure, densely hirsute on the upper surface, harshly velvety beneath; panicles terminal and in the axils of the upper 1 to 3 leaves, forming an oblong inflorescence as in P. rudgei, about one-third the height of the plant, the main axis pilose, the slender, angled, scabrous, stiff but flexuous branchlets ascending or spreading, pilose in the axils, the long pedicels divergent; spikelets 2.3 to $2.5 \mathrm{~mm}$. long, 1 to $1.2 \mathrm{~mm}$. wide, very turgid, abruptly pointed, strongly nerved, a few stiff, appressed hairs here and there between the nerves; first glume over half the length of the spikelet, abruptly pointed; second glume and sterile lemma subequal, exceeding the fruit, the lemma subtending a palea and staminate flower; fruit $1.8 \mathrm{~mm}$. long, $1 \mathrm{~mm}$. wide, ellipsoid, smooth and shining, a broad scar at the base. 
Panicum rigens Salzm.; Steud. Syn. Pl. Glum. 1:76. 1854, not Swartz, 1788. This is given as a synonym under $P$. rhigiophyllum Steud. Salzmann specimens from Bahia, bearing this name have been examined in the herbaria at Munich and Halle and in the United States National Herbarium.

Panicum cayennense divaricatum Doell in Mart. Fl. Bras. $2^{2}: 220$. 1877. Based on "Panicum scoparium Rudge * * * non Lam. * * * nec Michaux."

\section{DESCRIPTION.}

Plants perennial, yellow-green or tawny; culms robust, 30 to $100 \mathrm{~cm}$. high, erect or somewhat geniculate at base, often zigzag, especially above, densely and harshly villous; sheaths nearly equaling the internodes or overlapping, densely papillosevillous or hirsute; ligules membranaceous, ciliate, about $1 \mathrm{~mm}$. long, the hairs of the ligule blending with the hairs of the upper surface of the blade: blades thick, linear, 15 to $40 \mathrm{~cm}$. long, 5 to $10 \mathrm{~mm}$. wide, rather rigidly ascending, flat or folded, slightly narrowed toward the base, gradually long-acuminate, densely short-hirsute on both surfaces or glabrate; panicles terminal and in the axils of the approximate upper 2 to 6 leaves, forming an oblong inflorescence one-third the height of the plant, or more, each more or less included at base in the subtending sheath; branches pilose in the axils, branching freely from the base, the branches and branchlets angled, scabrous, the lower branchlets stiffly ascending, the upper and the long pedicels divaricate, somewhat flexuous; spikelets about $3.5 \mathrm{~mm}$. long, $1.5 \mathrm{~mm}$. wide, turgid, somewhat attenuate at base, strongly nerved, sparsely hirsute, the stiff hairs irregularly distributed; first glume about two-thirds the length of the spikelets, acuminate; second glume and sterile lemma subequal, exceeding the fruit, abruptly pointed, the latter subtending a palea and staminate flower; fruit $2.1 \mathrm{~mm}$. long, $1.1 \mathrm{~mm}$. wide, elliptic, smooth and shining, a eartilaginous flap-like appendage at the base.

All the cited specimens from Costa Rica have pubescent blades, while several of those from South America have glabrate blades, e. g., Rusby \& Squires 362, Spruce 93. These specimens with glabrate blades, though apparently less common than those with pubescent blades, are the typical form described by Meyer.

\section{DISTRIBUTION.}

Savannas, Costa Rica to Brazil.

Costa Rica: Buenos Aires, Pittier 10576, Tonduz 3679, 4875; Los Palmares, Fittier 10588; Helechales del General, Pittier 12064.

Venezuela: Santa Catalina, Rusby \& Squires 362.

British Guiana: Jenman 5978.

Dutch Gulana: Surinam, Mostmann 642.

Brazil: Para, Spruce 93; Bahia, Salzmann; Organ Mountains, Wilkes Expl. Exped. 9; without locality, Gardner 1178.

Type U. S. National Herbarium no. 824039 , collected in 1845 , in the Province of Minas Geraes, Brazil, by Widgren, "Ex herb. Brasil. Regnellian. Musei bot. Stockholm," and distributed as "Panicum cayennense Lam."

This species is related to $P$. rudgei with which and $P$. cayennense it has been confused.

DISTRIBUTION.

Brazil. The data on the labels of the specimens examined do not include habitat.

BraziL: Prov. Minas Geraes, Henschen \& Regnall III 1367, Widgren in 1845; without locality, Burchell A 101-2 (Gray Herb.), Riedel. 


\section{HITCHCOCK AND CHASE-NORTH AMERICAN PANICUM. 81. Panicum megiston Schult.) Reth,}

Panicum altissimum Meyer, Prim. Fl. Esseq. 63. 1818, not DC. 1817.a "In sylvis humidis plantationis Hof van Holland," Essequebo or British Guiana. We have seen a portion of the type in the Trinius Herbarium. The type is in the Göttingen Herbarium.

Panicum megiston Schult. Mant. 2: 248. 1824. Based on P. altissimum Meyer.

Panicum tuberculatum Presl, Rel. Haenk. 1:307. 1830. The locality given by Presl is, "Hab. in Luzonia." The type, in the herbarium of the German University at Prague, is labeled "Luzonia," but it probably came from Mexico.

Panicum elatior[us] Kunth, Rév. Gram. 1:38.1829. Based on P. altissimum Meyer.

Panicum equisetum Nees; Doell in Mart. Fl. Bras. $2^{2}: 206.1877$. This is given as a synonym under $P$. megiston Schult., and is credited to "Nees ab Esenbeck in herb. Reg. Berolinensis schedula." The type, in the Berlin Herbarium, was collected by Sello in Bahia, Brazil.

\section{DESCRIPTION.}

Plants perennial; culms tall and robust, glabrous; sheaths papillose-hispid or papillose only; ligules fimbriate, about $1.5 \mathrm{~mm}$. long; blades firm, ascending, 15 to $40 \mathrm{~cm}$. or more long, 1.5 to $3 \mathrm{~cm}$. wide, linear-lanceolate, slightly narrowed to the rounded base, glabrous; panicles finally exserted, 40 to $60 \mathrm{~cm}$. long, the stiff main axis striate-angled, smooth or scabrous, the branches in distant verticils, often as many

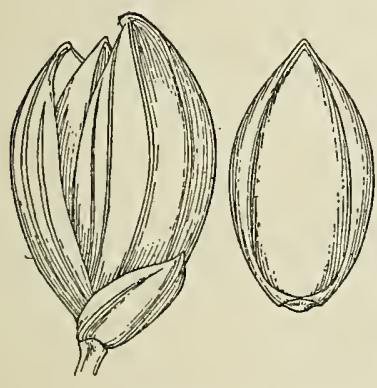

FIG. 135. $-P$. megiston. From type specimen of $P$.altissimum Meyer. as 20 to 30 in a verticil, 10 to $20 \mathrm{~cm}$. long, slender, stiffly or sinuously ascending, very scabrous, nearly simple, bearing the scattered, short-pediceled spikelets along the upper half or third; spikelets usually purplish at maturity, about $3.4 \mathrm{~mm}$. long, $1.5 \mathrm{~mm}$. wide, globular-obovoid, glabrous; first glume scarcely one-third the length of the spikelet, pointed; second glume slightly shorter than the sterile lemma, both abruptly apiculate, 7 to 9 -nerved, the glume about equaling the fruit, the sterile palea rather firm, about as long as the fruit; fruit $2.8 \mathrm{~mm}$. long, $1.4 \mathrm{~mm}$. wide, abruptly pointed, smooth and shining.

Meyer states that the culms ascend to a height of 20 or 30 feet and that they are much branched. Our specimens are all, with the exception of Wright 3872 , the simple upper part of the culm only. Eggers, on the label accompanying his no. 14345, gives the height as 6 to 8 feet. The Wright specimen, except for the underground portion, is entire. This is simple and measures but 1.2 meters in height.

This species somewhat resembles $P$. oaxacense and $P$. procerrimum of the genus Lasiacis, but the fruit has not the form and texture characteristic of that genus.

\section{DISTRIBUTION.}

In moist woods, Mexico and Cuba to Paraguay.

Mexico: San Juan Bautista, Rovirosa 532.

Cuba: St. Cruz de los Pinos, Wright 3872.

Venezuela: Santa Catalina, Rusby \& Squires 355.

Brazil: Without locality, Riedel 1239, Gardner 1179.

Paraguay: Morong 813, 1072.

Ecuador: Balao, Eggers 14345.

a Roem. \& Schult. Syst. Veg. 2: 457. 1817. The diagnosis is here referred to De Candolle "Hornem. Hort. Hafn. I. p. 84." The latter work we have not seen, nor that cited by the Index Kewensis, "Elench. Hort. Monsp. 42. 1805," for P. "altissimum Brouss., *** nomen." In any case the name $P$. altissimum is preoccupied. 


\section{Subgenus DICHANTHELIUM subgen. nov.}

Perennial, from a crown, rarely from short, matted rootstocks, surrounded by a more or less well-marked rosette of usually short winter leaves, in spring producing simple culms with mostly narrowly lanceolate blades and terminal panicles with numerous spikelets, these rarely perfecting seed; the early culms branching at some or all of the nodes (in a few species from the base only) after the maturity of the primary panicles or sometimes before; the branches often repeatedly branching, the short branchlets more or less fascicled and bearing usually much reduced leaves; the terminal one or two joints of the primary culms often finally falling, the whole producing an autumnal form usually strikingly different from the vernal form; the secondary panicles reduced, the latest more or less included in the sheaths, cleistogamous and perfecting their grains.

The type species is $P$. dichotomum $\mathrm{L}$.

In this group there is an intermediate stage of branching, in which the plants do not show the characteristic vernal nor autumnal habit. Vernal culms are sometimes produced on plants during the branched condition, because of renewal of activity, due to increased moisture, excess of nutriment, injury, or other causes.

\section{SYNOPSIS OF GROUPS.}

Blades elongated, not over $5 \mathrm{~mm}$. wide, 20 times as long as wide; autumnal form branching from the base only (from the lower nodes in P. werneri)...................... Depauperata (p. 151).

Blades not elongated, (or if so, more than $5 \mathrm{~mm}$. wide and autumnal form not branching from base).

Plants branching from the base, finally forming rosettes or cushions, foliage soft and lax; blades prominently ciliate except in $P$. laxiflorum.......................... L LAXIFLORA (p. 158).

Plants branching from the culm nodes or rarely remaining simple.

Blades long, stiff; autumnal form bushy-branched above. Spikelets turgid, attenuate at base; mostly pustulosepubescent; blades conspicuously striate, tapering from base to apex......................... ANGUstifolia (p. 165). Spikelets scarcely turgid, not attenuate at base; blades tapering to both ends........................ Bickneldiana (p. 176).

Blades not long and stiff (somewhat so in $P$. oligosanthes, $P$. malacon, $P$. commonsianum, and $P$. equilaterale); not bushy-branched.

Plants not forming a distinct winter rosette; spikelets attenuate at base, papillose.................... Pedicellata (p. 292).

Plants forming a distinct winter rosette; spikelets not attenuate at base.

Spikelets turgid, blunt, strongly nerved (not strongly turgid in $P$. oligosanthes); blades rarely as much as $1.5 \mathrm{~cm}$. wide (sometimes $2 \mathrm{~cm}$. in $P$. ravenellii and $P$. xanthophysum).

Sheaths, or some of them, papillose-hispid (sometimes all glabrous in $P$. helleri); spikelets 3 to 4 mm. long (2.7 to $3 \mathrm{~mm}$. in P. wilcoxianum) I2. Oligosanthia (p. 278). Sheaths glabrous or minutely puberulent; spikelets 1.5 to $2.5 \mathrm{~mm}$. long, unsymmetrically pyriform; culms wiry......................L. LANCEARIA (p. 271). 
Spikelets not turgid, blunt, nor strongly nerved (see, however, $P$. roanokense and $P$. caerulescens.)

Ligule of conspicuous hairs, usually 3 to $5 \mathrm{~mm}$. long.

Sheaths glabrous or only the lowermost somewhat pubescent..................... Spreta (p. 200).

Sheaths strongly pubescent............... ?. LANUGinosa (p. 208).

Ligule obsolete or nearly so (manifest in $P$. viscidellum, $P$. oricola, $P$. tsugetorum and $P$. curtifolium.)

Spikelets spherical at maturity; blades glabrous, firm, cordate; plants sparingly branching.9. SPHAERocarPa (p.250). Spikelets usually obovate or elliptic.

Blades of mid-culm elongated, less than $1.5 \mathrm{~cm}$. wide; culms usually tall; spikelets pointed, abruptly so in the velvety $P$. scoparium and P. viscidellum......................Scoparia (p. 294).

Blades of mid-culm not elongated (somewhat so in $P$. equilaterale).

Blades cordate, 1 to $3 \mathrm{~cm}$. wide (5 to $12 \mathrm{~mm}$. in $P$. ashei); spikelets pubescent.

Spikelets 2.5 to $3 \mathrm{~mm}$. long; sheaths glabrous or minutely puberulent. L.5. СоммuтAтA (p. 300).

Spikelets 3 to $5 \mathrm{~mm}$. long (sometimes but

$2.7 \mathrm{~mm}$. long in the hispid-sheathed

P.clandestinum ................... . Latifolia p. (312).

Blades not cordate less than $1 \mathrm{~cm}$. wide.

Sheaths crisp or appressed-pubescent; blades firm; spikelets pubescent. .8. . Columbiana (p. 240).

Sheaths glabrous (sparsely pilose in $P$. curtifolium and the lower, velvety in P. mattamuskeetense).

Vernal culms delicate (sometimes scarcely oftan veluetes so in $P$. albomarginatum and $P$. tenue); spikelets $1.5 \mathrm{~mm}$. or less long (1.6 to $1.7 \mathrm{~mm}$. in P. tenue) 1 o Ensifolia (p. 258).

Vernal culms slender but not delicate, rarely less than $40 \mathrm{~cm}$. high; spikelets 2 to $2.9 \mathrm{~mm}$. long $(1.5 \mathrm{~mm}$. in $P$. microcarpon and $P$. caerulescens).

Lower internodes shortened, upper elongated, producing a nearly naked culm, leafy at base; spikelets narrowly ovate, 2.7 to 2.9 mm. long..................... Nudicaulia (p. 179).

Lower internodes not shortened; vernal culms about evenly leafy throughout, spikelets elliptic or obovate, not over 2.5 mm. long..................... Diснотома (p. 179). 
Spikelets glabrous.

Spikelets $3 \mathrm{~mm}$. or more long, strongly nerved.

Spikelets pointed, blades elongated................ 82. P. depauperatum.

Spikelets blunt, blades not elongated.

Spikelets 3.2 to $3.3 \mathrm{~mm}$. long; blades firm; sheaths, or

some of them, hispid .......................171. P. scribnerianum.

Spikelets not over $3 \mathrm{~mm}$. long; blades rather thin;

sheaths glabrous or sparsely hispid.............170. P. helleri.

Spikelets less than $3 \mathrm{~mm}$. long.

Second glume and sterile lemma exceeding the fruit and pointed beyond it; spikelets 2.2 to $2.9 \mathrm{~mm}$. long.

Blades clustered toward the base................ 101. P. nudicaule.

Blades not clustered toward the base.

Sheaths, at least the secondary, hispid ........... 181. P. scabriusculum.

Sheaths glabrous.

Blades firm; fruit $1.5 \mathrm{~mm}$. long................ 182. P. cryptanthum.

Blades thin; fruit nearly $2 \mathrm{~mm}$. long.............111. P. yadkinense.

Second glume and sterile lemma not pointed beyond the

fruit.

Ligule manifest, 1 to $3 \mathrm{~mm}$. long.

Gulms rather stout; ligule 2 to $3 \mathrm{~mm}$. long; sheaths glabrous...............................116. P. spretum.

Culms slender; ligule $1 \mathrm{~mm}$. long; sheaths sparsely pilose .159. P. curtifolium.

Ligule obsolete.

Spikelets $1.5 \mathrm{~mm}$. or less long.

Nodes bearded. 102. P. microcarpon.

Nodes not bearded.

Culms and blades pilose.

90. P. strigosum.

Culms glabrous.

Blades conspicuously ciliate; plants branching at base only..................... 89. P. polycaulon.

Blades not ciliate; plants branching from middle or upper nodes.

Vernal culm $50 \mathrm{~cm}$. or more high; spikelets turgid, strongly nerved; autumnal form erect, with fascicled branches shorter than the primary internodes..........113. P.caerulescens.

Vernal culms usually much less than $50 \mathrm{~cm}$. high; autumnal form spreading or reclining.

Spikelets 1.1 to $1.2 \mathrm{~mm}$. long; blades rarely as much as $5 \mathrm{~cm}$. long........160. P. chamaelonche. Spikelets 1.2 to $1.4 \mathrm{~mm}$. long.

Blades elongated, at least some of them 8 to $10 \mathrm{~cm}$. long.................. Plabrifolium.

Blades not over $3 \mathrm{~cm}$. long............157. P. ensifolium.

Spikelets $2 \mathrm{~mm}$. or more long.

Blades elongated, some of them 20 times as long as wide; spikelets 2.2 to $2.8 \mathrm{~mm}$. long.

Blades erect; branches, when present, from the lower nodes only ..................... 85. P. werneri.

Blades spreading; branches from upper nodes... 99. P. bicknellii. 
Blades not elongated, about 10 times as long as wide.

Culms soon prostrate, vine-like; branches divaricate.

Plants bright green; culms lax; spikelets not over $2.1 \mathrm{~mm}$. long.................... 114. P. lucidum.

Plants grayish green; culms stiff; spikelets 2.5 $\mathrm{mm}$. long........................ 115. P. sphagnicola.

Culms not vine-like; branches not divaricate.

Spikelets 2.3 to $2.6 \mathrm{~mm}$. long.

Blades, or some of them, at least $8 \mathrm{~mm}$. wide; fruit papillose-roughened.............. 166. P. webberianum.

Blades not over $6 \mathrm{~mm}$. wide; fruit smooth and shining..................... 167. Patentifolium.

Spikelets $2 \mathrm{~mm}$. long.

Culms wiry, crisp-puberulent; blades ciliate at base....................... 164. P. lancearium.

Culms glabrous; blades not ciliate.

Blades erect, firm; spikelets turgid, strongly nerved; plants grayish olive. 112. P. roanokense. Blades spreading; spikelets not turgid. Nodes glabrous; autumnal form erect, branched like a little tree........ 109. P. dichotomum.

Nodes, at least the lowest, usually bearded; autumnal form topheavyreclining....................... 110. P. barbulatum.

Spikelets pubescent.

Spikelets $3 \mathrm{~mm}$. or more long.

Blades elongated, those of the mid-culm at least 15 timesas

long as wide.

Secondary panicles from basal sheaths only.

Spikelets pointed, about $3.5 \mathrm{~mm}$. long.............

Spikelets blunt, $3 \mathrm{~mm}$. or less long..............

Secondary panicles from upper branches.

Spikelets attenuate at base, pustulose-pubescent; lowermost sheaths softly villous..............

Spikelets not attenuate at base, not pustulose; lowermost sheaths glabrous or hispid.

Upper leaves approximate; sheaths glabrous..... 187. P. equilaterale.

Upper leaves distant; at least lower sheaths hispid. 180. P. aculeatum.

Blades not elongated, usually less than 10 times as long as wide.

Blades velvety-pubescent beneath.

Spikelets $3 \mathrm{~mm}$. long; plants velvety-villous throughout 3 mm. longi plants velvety-villous through- 100

Spikelets $4 \mathrm{~mm}$. or more long.

82. P. depauperatum.

83. P. perlongum.

95. P. fusiforme.

169. P. malcophyllum. $a$

Sheaths ascending-hirsute; ligule 3 to $4 \mathrm{~mm}$. long.. 173. P. ravenelii.

Sheaths downy-pubescent; ligule obsolete..........191a. P. boscii molle.

Blades not velvety-pubescent beneath.

Sheaths glabrous or minutely puberulent only.

Nodes bearded; spikelets $4 \mathrm{~mm}$. or more long

Nodes not bearded; spikelets not over $3.8 \mathrm{~mm}$. long.

Spikelets 3.5 to $3.8 \mathrm{~mm}$. long; blades $2 \mathrm{~cm}$. or more wide. 191. P. boscii.

$41616^{\circ}$ - vol $15-10-10$ 
Spikelets scarcely more than $3 \mathrm{~mm}$. long.

Spikelets turgid, blunt; blades mostly less

than $1 \mathrm{~cm}$. wide ..................... P. helleri.

Spikelets not turgid; blades more than $1 \mathrm{~cm}$. wide.

Panicle narrow, branches ascending; spike-

lets on long stiff pedicels.............100. P. calliphyllum.

Panicle as broad as long, branches spreading.

Plants glaucous; basal blades conspicuously ciliate..................... 185. P. mutabile.

Plants not glaucous; basal blades not ciliate, or at the base only.

Culms erect, or autumnal form leaning; blades symmetrical, broadly cordate......................184. P. commutatum.

Culms decumbent; blades usually unsymmetrical and falcate; narrowed

Sheaths pubescent. to the scarcely cordate base.........186. P. joorii.

Pubescence ascending or appressed.

Spikelets 3 to $3.2 \mathrm{~mm}$. long; first glume conspicuously remote..........................142. P. malacon.

Spikelets 3.5 to $4 \mathrm{~mm}$. long; first glume not remote...........................172. P. oligosanthes.

Pubescence spreading, sometimes sparse.

Plants robust, about 1 meter high; blades usually $2 \mathrm{~cm}$. or more wide...................189. P. clandestinum.

Plants rarely more than $50 \mathrm{~cm}$. high; blades rarely over $1.5 \mathrm{~cm}$. wide.

Panicles about as wide as long; blades ascending or spreading.

Spikelets attenuate at base, 3.5 to $4 \mathrm{~mm}$. long

Spikelets not attenuate at base, not over 3.3 $\mathrm{mm}$. long.

Spikelets 3.2 to $3.3 \mathrm{~mm}$. long, blades firm; sheaths, or some of them, more or less hispid...........................171. P. scribnerianum.

Spikelets not over $3 \mathrm{~mm}$. long; blades rather thin; sheaths, or some of them, glabrous or sparsely hispid..........170. P. helleri.

Panicles narrow, branches erect (sometimes ascending in $P$. wilcoxianum), or spreading at anthesis only; blades erect.

Spikelets not over $3 \mathrm{~mm}$. long; blades not over $6 \mathrm{~mm}$. wide..................168. P. wilcoxianum.

Spikelets 3.7 to $4 \mathrm{~mm}$. long; blades 8 to 20 $\mathrm{mm}$. wide.

Blades papillose-hispid..................174. P. leibergii.

Blades glabrous on both surfaces.........175. P. xanthophysum.

Spikelets less than $3 \mathrm{~mm}$. long.

Blades elongated, not over $5 \mathrm{~mm}$. wide; secondary panicles at the base only or wanting. 
Culms single or few in a tuft; spikelets turgid, 2.7 to 3 $\mathrm{mm}$. long............................... 83. P. perlongum.

Culms in large tufts; spikelets not turgid, not over 2.7 $\mathrm{mm}$. long.

Sheaths pilose... 84. P. linearifolium.

Sheaths glabrous. 85. P. werneri.

Blades usually not elongated; secondary panicles not at the base.

Spikelets attenuate at base, mostly prominently pustulose; blades narrow, stiff, strongly nerved, tapering from base to apex.

Nodes bearded; plants grayish-villous; autumnal blades flat.

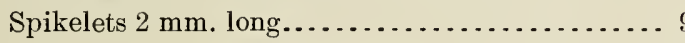

\section{P. chrysopsidifo- lium.}

93. P. consanguineum.

Spikelets 2.5 to $2.8 \mathrm{~mm}$. long

Nodes not bearded; plants villous only at the base, or nearly glabrous.

Autumnal blades flat; lower panicle branches spreading or deflexed...................

Autumnal blades involute; lower panicle branches more or less ascending.

Plants glabrous or nearly so; autumnal culms erect.

Spikelets subsecund along the suberect panicle branches.......................... 98. P. neuranthum. Spikelets not subsecund; panicle loose and open............................ 97. P. ovinum.

Plants pubescent, at least on the lower half.

Spikelets about $2.4 \mathrm{~mm}$. long; vernal blades 7

to $12 \mathrm{~cm}$. long, autumnal blades not falcate. 96. P. arenicoloidcs.

Spikelets not over $2 \mathrm{~mm}$. long; vernal blades

4 to $6 \mathrm{~cm}$. long, autumnal blades falcate.. 91. P. aciculare.

Spikelets not attenuate at base.

Sheaths retrorsely pilose; blades soft and lax.

Panicle branches ascending, forming a compact

panicle; spikelets $1.6 \mathrm{~mm}$. long.............. 87 a. $P$. xalapense sirictirameum.

Panicle branches loosely spreading.

Blades ciliate and more or less pilose on the sur-

face; spikelets $2 \mathrm{~mm}$. long.............. 87. P.xalapensc.

Blades glabrous or nearly so on the surface and margin; spikelets $2.2 \mathrm{~mm}$. long ......... 86. P. laxiflorum.

Sheaths not retrorsely pilose.

Ligule manifest, mostly 2 to $5 \mathrm{~mm}$. long.

Sheaths, or all but the lowest glabrous; spike-

lets not over $1.6 \mathrm{~mm}$. long.

Panicle narrow, one-fourth to one-third as wide as long...........................116. P. spretum.

Panicle open, nearly as wide as long.

Spikelets $1.5 \mathrm{~mm}$. long.................117. P. lindheimeri.

Spikelets $1.1 \mathrm{~mm}$. long..................119. P. longiligulatum.

Sheaths pubescent. 
Spikelets abruptly pointed; blades cordate;

Mexican .........................179. P. viscidellum.

Spikelets not pointed at maturity; blades not

cordate.

Ligule $1 \mathrm{~mm}$. long; sheaths sparsely pilose;

spikelets $1.4 \mathrm{~mm}$. long...............159. P. curtifolium.

Ligule usually more than $1 \mathrm{~mm}$. long.

Ligule $\mathrm{I}$ to $1.5 \mathrm{~mm}$. long; culms and sheaths appressed-pubescent; spikelets 1.5 to $1.9 \mathrm{~mm}$. long.

Spikelets 1.8 to $1.9 \mathrm{~mm}$. long; plants bluish green.....................146. P. tsugetorum.

Spikelets $1.5 \mathrm{~mm}$. long, nearly globular; plants olivaceous................148. P. oricola.

Ligule 2 to $5 \mathrm{~mm}$. long.

Spikelets 1 to $1.3 \mathrm{~mm}$. long; culms and sheaths soitly appressed-pubescent.

Spikelets 1.2 to $1.3 \mathrm{~mm}$. long.........118. P. leucothrix. Spikelets not over $1 \mathrm{~mm}$. long........120. P. wrightianum. Spikelets mostly more than $1.5 \mathrm{~mm}$.

long, if less, pubescence spreading. See L A N U G 1 N O S A

Ligule obsolete or less than $1 \mathrm{~mm}$. long.

(p. 208).

Nodes bearded ( $P$. scoparium may appear to be bearded).

Spikelets nearly $3 \mathrm{~mm}$. long; plants velvety-

villous throughout................... 169. P. malacophyllum.

Spikelets rarely as much as $2.5 \mathrm{~mm}$. long;

plants not pubescent throughout.

Spikelets 1.5 to $1.6 \mathrm{~mm}$. long

102. P. microcarpon.

Spikelets $2 \mathrm{~mm}$. or more long.

Blades all velvety; autumnal form sparingly branched...................105. P. annulum.

Blades glabrous, or only the lower pubescent or velvety.

Spikelets $2 \mathrm{~mm}$. long; autumnal form profusely branching.

Fruits slightly exposed at maturity; upper sheaths viscid-spotted......103. P. nitidum.

Fruits covered at maturity; sheaths not viscid-spotted; Mexican.....104. P. multirameum.

Spikelets $2.2 \mathrm{~mm}$. or more long; autumnal form less profusely branching.

Sheaths and upper nodes glabrous....107. P. clutei.

Lower sheaths and all nodes pubescent ........................106. P. mattamuskee-

Nodes not bearded. tense.

Plants densely gray-velvety throughout, a

viscid, glabrous ring below the nodes.....178. P. scoparium.

Plants not gray-velvety.

Sheaths or some of them pilose or hispid.

Pubescence papillose-hispid.

Spikelets ovate, pointed, 2.3 to $2.6 \mathrm{~mm}$. long. 181. P. scabriusculum. 
Spikelets obovate, obtuse, nearly $3 \mathrm{~mm}$.

long."

Blades about $2 \mathrm{~cm}$. wide.......... 189. P. clandestinum.

Blades not over $6 \mathrm{~mm}$. wide........ 168. P. wilcoxianum.

Pubescence ascending-pilose.

Spikelets 2 to $2.5 \mathrm{~mm}$. long.

Winter blades elongated, 5 to $10 \mathrm{~cm}$. long; plants bluish green; spikelets $2 \mathrm{~mm}$. long ............... 145. P.wilmingtonense.

Winter blades 1 to $3 \mathrm{~cm}$. long; plants olivaceous.

Spikelets about $2.4 \mathrm{~mm}$. long; panicle open, branches stiffly spreading................. 143. P.commonsianum.

Spikelets 2 to $2.1 \mathrm{~mm}$. long; panicle rather dense, branches ascending ................... 144. P. addisonii.

Spikelets not over $1.7 \mathrm{~mm}$. long.

Blades white-margined; spikelets 1.6 to $1.7 \mathrm{~mm}$. long, elliptic........ 152. P. tenue.

Blades not white-margined; spikelets 1.3 to $1.4 \mathrm{~mm}$. long, nearly globular....................147a.P. columbianum thinium.

Sheaths glabrous or puberulent only.

Spikelets spherieal, not over $1.8 \mathrm{~mm}$. long;

blades cordate, ciliate at base........ See Sphatrocarpa

Spikelets not spherical. (p. 250).

Culms soon prostrate, vine-like; branches divaricate.

Plants bright green; culms lax; spikelets not over $2.1 \mathrm{~mm}$. long........ 114. P. lucidum.

Plants grayish green; culms stiff; spikelets $2.5 \mathrm{~mm}$. long ........ 115. P. sphagnicola.

Culms not vine-like; branches not divaricate.

Spikelets unsymmetrically pyriform, strongly nerved; culms wiry..... See LANCEARIa (p. 271).

Spikelets not pyriform.

Blades elongated, especially the upper, about 20 times as long as wide; spikelets about $2.5 \mathrm{~mm}$. long, on long pedicels..........

(Continuation.)

Blades not elongated. (See con99. P. bicknellii.

Spikelets $2 \mathrm{~mm}$. or more long.

Spikelets 2.5 to $3 \mathrm{~mm}$. long; blades cordate, usually 1 $\mathrm{cm}$. or more wide.

Plants glaucous; basal blades conspicuously ciliate.. 185. P. mutabile. Plants not glaucous; basal blades ciliate at base only.

Blades nearly linear, that is, with parallel margins; first glume about half as long as the spikelet; Mexican................ 188. P.albomaculatum. 
Blades lanceolate; first glume not more than onethird as long as the spikelet.

Culms crisp-puberulent; blades rarely over $1 \mathrm{~cm}$. wide; spikelets about $2.5 \mathrm{~mm}$.

long ........................... P.

Culms glabrous or obscurely puberulent;

blades usually $1.5 \mathrm{~cm}$. or more wide;

spikelets 2.7 to $3 \mathrm{~mm}$. long........184. P. commutatum.

Spikelets not over $2.3 \mathrm{~mm}$. long; blades not cordate, usually less than $1 \mathrm{~cm}$. wide.

Blades conspicuously ciliate, soft and lax, crowded

at the base . . . . . . . . . . . . ciliatum.

Blades not ciliate or so only at base, not crowded

at the base of the culm.

Blades not over $6 \mathrm{~mm}$. wide; plants not branching or rarely branching from near the base .............................. 85. P. werneri.

Blades $7 \mathrm{~mm}$. or more wide; plants branching from middle and upper nodes.

Primary blades spreading; panicle purplish; fruit exposed at summit........... 107. P. clutei.

Primary blades erect; panicle green; fruit covered .......................108. P. boreale.

Spikelets not over $1.7 \mathrm{~mm}$. long.

Culms crisp-puberulent; spikelets turgid............147. P. columbianum. Culms glabrous.

Blades white-margined, firm.

Blades puberulent beneath, often above.......152. P. tenue.

Blades glabrous.

Uppermost blades much reduced; culms branching from lower nodes only, the branches repeatedly branching......153. P. albomargina-

Uppermost blades about as long as the others; tum. culms bearing short branches from middle and upper nodes............154. P. trifolium.

Blades not white-margined or very obscurely so (or if white margin is evident, spikelets only 1.1 $\mathrm{mm}$. long).

Culms branching only at base; plants soft, light green......................... 158. P. vernale.

Culms branching at the nodes.

Spikelets $1.1 \mathrm{~mm}$. long; winter blades bluish green, not glossy ............... 156. P. concinnius.

Spikelets 1.3 to $1.5 \mathrm{~mm}$. long.

Blades involute, falcate, with long stiff hairs on margin near base; plants stiff and wiry ...............162. P. breve.

Blades not involute or at tip only, not falcate.

Plants bright green; winter blades conspicuous, glossy green...155. P. flavovirens.

Plants olive; winter blades not conspicuous nor glossy.........157. P. ensifolium. 
Depauperata.-Culms simple, mostly 10 to $40 \mathrm{~cm}$. high; ligules less than $1 \mathrm{~mm}$. long; blades much elongated, 5 to $35 \mathrm{~cm}$. long, 2 to $5 \mathrm{~mm}$. wide, narrowed at the base, long-acuminate at apex, basal blades shorter, but not forming a distinct. rosette in the autumn; spikelets 2.2 to $3.8 \mathrm{~mm}$. long, strougly 7 to 9 -nerved. Autumnal form bearing simple branches from the basal or lower nodes, the reduced panicles more or less concealed in the foliage at the base of the plants.

Spikelets about $3.5 \mathrm{~mm}$. long, beaked.................. 82. P. depauperatum.

Spikelets $3 \mathrm{~mm}$. long or less, (sometimes $3.2 \mathrm{~mm}$. long in $P$. per-

longum) not beaked.

Culms single or few in a tuft; spikelets turgid, blunt, 2.7

to $3.2 \mathrm{~mm}$. long; prairie plants.............. 83. P. perlongum.

Culms in large tufts; spikelets not turgid, 2.2 to $2.7 \mathrm{~mm}$.

long; plants of dry woods.

Sheaths pilose; spikelets 2.2 to $2.7 \mathrm{~mm}$. long, pilose.. 84. P. linearifolium.

Sheaths glabrous; spikelets 2.2 to $2.3 \mathrm{~mm}$. long; glab-

rous or sparingly pilose.............. 85. P. werneri.

\section{Panicum depauperatum Muhl.}

Panicum strictum Pursh, Fl. Amer. Sept. 1: 69. 1814, not R. Br. 1810. "On the banks of the Delaware, Pennsylvania." The type, in Kew Herbarium, has pilose sheaths.

Panicum depauperatum Muhl. Descr. Gram. 112. 1817. "Habitat in glareosis, floret Maio, Junio, Penns. Carolina." The type is in the Muhlenberg Herbarium. Muhlenberg described the species as having glabrous or pubescent leaves, pilose sheaths, glabrous spikelets, and fertile floret a little shorter than the second glume and sterile lemma. This description applies to the plant that has generally been referred to $P$. depauperatum rather than to the one with smaller spikelets later distinguished as $P$. linearifolium, although in Muhlenberg's herbarium specimens of both species are included in the same cover. Furthermore, some specimens with large spikelets have pilose and others glabrous sheaths. Of these, a specimen with pilose sheaths and spikelets $3.5 \mathrm{~mm}$. long has been chosen as the type and has been so indicated by attaching a note to the specimen.

Panicum rectum Roem. \& Schult. Syst. Veg. 2: 457. 1817. Based on P. strictum Pursh, the original description of which is copied.

Panicum involutum Torr. Fl. North. \& Mid. U. S. 144. 1823. "Near Deerfield, Massachusetts. Cooley." The type, in the Torrey Herbarium, is a small clump with culms 20 to $30 \mathrm{~cm}$. high, sparsely pilose sheaths, involute blades with a few hairs on under surface, overmature primary panicles 4 to $5 \mathrm{~cm}$. long, and spikelets $3.8 \mathrm{~mm}$. long, the second glume and sterile lemma with a few hairs; secondary panicles with nearly mature spikelets are present at base. The sheet bears two labels, one, "From Dr. Cooley, Mass.," the other in Torrey's handwriting bears the name "Panicun involutum, ** [Torrey used an asterisk to indicate his own species] followed by a diagnosis.

Panicum muhlenbergii Spreng. Syst. Veg. 1: 314. 1825. Sprengel states nothing as to the source of his specimen other than "Amer. bor. (P. acuminatum Muhl.)." Since this name immediately follows $P$. acuminatum Swartz it seems evident that Sprengel meant to name the species which Muhlenberg described $a$ as Panicum acuminatum Swartz. There is no specimen bearing this name in the Muhlenberg Herbarium. In the Sprengel Herbarium the specimen labeled "Panicum Muhlenbergii," and which must be taken as the type, is P. depauperatum Muhl. This is from "Pine barrens, N. Jers., from Dr. Torrey."

Panicum junceum Trin. Gram. Pan. 220. 1826. Trinius states that his specimen is from North America and called $P$. acuminatum by Sprengel. Such a specimen 
could not be found in the Trinius Herbarium. Since Sprengel cites "P. acuminatum Muhl." under his $P$. muhlenbergii his specimen or a part of it is doubtless the specimen referred to by Trinius. The description well applies to an involute-leaved plant of $P$. depauperatum.

Panicum sprengelii Kunth, Rév. Gram. 1: 39. 1829. Based on P. muhlenbergii Spreng., without explanation as to change of name.

Panicum depauperatum involutum Wood, Class-book 786. 1861. Based on $P$. involutum Torr.

? Panicum depauperatum laxa[um] Vasey, U. S. Dept. Agr. Div. Bot. Bull. 8: 29. 1889. "Virginia, Florida, Texas, Arkansas, Missouri." Described as "weaker stemmed, panicle with longer and more spreading branches, ** * spikelets smaller." No type is indicated and there is no specimen in the National Herbarium so marked by Doctor Vasey. The description would seem to apply to $P$. linearifolium, but the range given is south of that in which that species is common, and no specimens of it from any of the States mentioned, except one each from Missouri, Arkansas, and Texas which are labeled "Panicum depauperatum Muhl." in Vasey's writing, were in the National Herbarium in the time of Doctor Vasey. Hitchcock's no. 1354, Stone Mountain, Georgia, with spikelets 3.1 to $3.2 \mathrm{~mm}$. long, and rather loose panicles may represent Vasey's variety.

\section{DESCRIPTION.}

Vernal form with culms several to many in a tuft, 20 to $40 \mathrm{~cm}$. high, slender but rather stiff, erect or spreading at the summit, glabrous, puberulent or sometimes pilose; nodes ascending-pubescent; sheaths, except the lowest, shorter than the internodes, glabrous to papillose-pilose; blades linear, 6 to $15 \mathrm{~cm}$. long, 2 to $5 \mathrm{~mm}$. wide (the lower shorter), often involute in drying, scabrous on both surfaces, sometimes pubescent beneath; panicles exserted, usually not much exceeding the leaves, 4 to $8 \mathrm{~cm}$. long, rarely longer, few-flowered, the rather strict, remote branches narrowly ascending at maturity; spikelets 3.2 to $3.8 \mathrm{~mm}$. long, rarely only $3 \mathrm{~mm}$. or as much as $4 \mathrm{~mm}$. long, 1.5 to $1.7 \mathrm{~mm}$. wide, elliptical, pointed, glabrous or sparsely pubescent; first glume one-third to half the length of the spikelet, subacute; second glume and sterile lemma
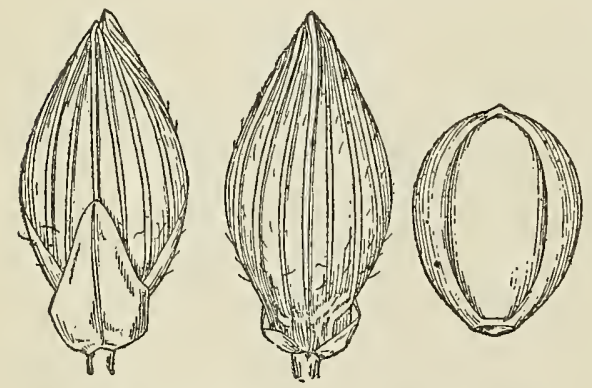

Frg. 136.-P. depauperatum. From type specimen. equal, extending beyond the fruit, forming a beak, strongly 7 to 9 -nerved; fruit 2.1 to $2.3 \mathrm{~mm}$. long, 1.4 to $1.5 \mathrm{~mm}$. wide, oval, minutely umbonate at the apex.

Autumnal form similar to the vernal, the reduced secondary panícles produced on branches from the basal or lower nodes, more or less concealed in the tuft of basal leaves.

This species is variable as to pubescence and size of spikelets. The spikelets of the type specimen are 3.5 $\mathrm{mm}$. long, those of the glabrous plants on the same sheet in the Muhlenberg Herbarium are $3.9 \mathrm{~mm}$. long. Many New England specimens and occasional specimens from elsowhere have spikelets only $3 \mathrm{~mm}$. long. This form is represented by Chamberlain 298, Chase 3379, and Parlin 1957 from Maine; Burgess in 1893 from Massachusetts; Pierron in 1876 from Pennsylvania, and Lansing 2743 from Indiana. The difference in length is often due to the inrolling of the summit of the second glume and sterile lemma, but the glumes show greater proportion of variation than usual in this genus. As a rule the spikelets do not vary on the same plant, but Chase 2402, has spikelets $3 \mathrm{~mm}$. long on the terminal panicle and 3.5 to $4 \mathrm{~mm}$. long on the basal panicles. The fruit shows little variation in size. 


\section{DISTRIBUTION.}

Open sterile woods, Maine to Minnesota, south to Georgia and Texas.

Marne: Canton, Parlin 1957; Chesterville, Chase 3283, 3316; Fayette, Chase 3379;

Cumberland, Chamberlain 298.

New Hampshire: Sanbornton, Carter 100 (Hitchcock Herb.).

Vermont: Burlington, Flynn in 1902.

Massachusetts: Ipswich, Boott.

Connecticut: Hartford, Wilson 1257; Montville, Graves in 1897; Southington, Andrews 58, Bissell 5533.

Rhode Island: Gloucester, Collins in 1908.

New York: Bronx, Bicknell in 1896; Woodmere, Bicknell in 1905; Rockville Center, Bicknell in 1906; Norwood, Bicknell in 1903; Long Island, Bicknell in 1905 .

Ontario: Sarnia, Macoun 26322; Toronto, Biltmore Herb. 797c.

New Jersey: Atco, Painter 699; Eagle Rock, Mackenzie 1452.

Pennsylvania: Lancaster County, Heller 4775; Easton, Porter in 1897; Penryn, Small in 1889; Broad Mountain, Pretz 1959.

INDIANA: Clark, Bebb 513; Miller, Chase 1540, Lansing 2743, Umbach 1657.

Iluinors: Lansing, Chase 867; Makanda, Gleason 1022.

Michigan: Port Huron, Dodge 78.

Wisconsin: Clear Lake, Cheney 1216.

Minnesota: Hennepin County, Sandberg in 1890; Nicollet, Ballard in 1892.

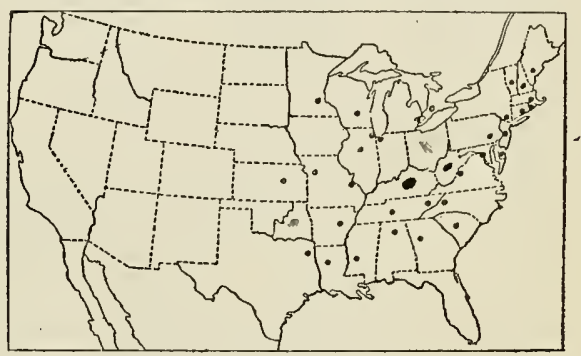

FIG. 137.-Distribution of $P$. depauperatum.

Missouri: St. Louis, Eggert 233; Monteer, Bush 4654; Lees Summit, Bush 3936.

Kansas: Lindsborg, Plank 18.

Delathare: Mount Cuba, Commons 29.

Maryland: Chesapeake Junction, Hitchcock 2414; West Chevy Chase, Hitchcock 341; Great Falls, Chase 2864, in Kreucker Gram. Exs. 548.

District of Columbia: Chase 2284, 2402, Hitchcock 340, House 947, Pollard 338, Ward in 1876.

Virginia: Luray, Steele 229.

North Carolina: Biltmore, Biltmore Herb. 797; Watauga County, Small \& Heller 279; Chapel Hill, Chase 3053; Henderson County, Biltmore Herb. 797a.

South Carolina: Clemson College, House 2161.

Georgia : Stone Mountain, Eggert 39, Hitchcock 1354, 1360; Augusta, Cuthbert 388.

Tennessee: Knoxville, Ruth 63; Ducktown, Chambliss 89.

Alabama: Auburn, Earle \& Baker in 1897.

MississipPI: Jackson, Hitchcock 1303.

Arkansas: Fulton, Bush 2350 (Gray Herb.).

Louisiana: Shreveport, Hitchcock 1249.

Texas: Denison, Bebb 2663.

Che. 15.

83. Panicum perlongum Nash.

Panicum perlongum Nash, Bull. Torrey Club 26: 575. 1899. "On prairies and dry soil, Illinois to North Dakota, south to Indian Territory. Type collected in Indian Territory at Creek Nation, by M. A. Carl[e]ton, April 25, 1891, No. 98." The type, 
in Nash's herbarium, consists of five clumps of several culms each, 7 to $40 \mathrm{~cm}$. high, with mature primary and immature secondary panicles, and spikelets 3 to $3.2 \mathrm{~mm}$. long.

Panicum pammeli Ashe, N. C. Agr. Exp. Sta. Bull. 175: 116. 1900. "Prairies of Iowa, June." The type, in Ashe's herbarium, collected by R. I. Cratty, June 12, 1881, has spikelets 3.1 to $3.2 \mathrm{~mm}$. long.

\section{DESCRIPTION.}

Vernal form similar to that of $P$. depauperatum, more strict in habit, and in smaller tufts, more constantly pilose and usually papillose, the blades on the average longer

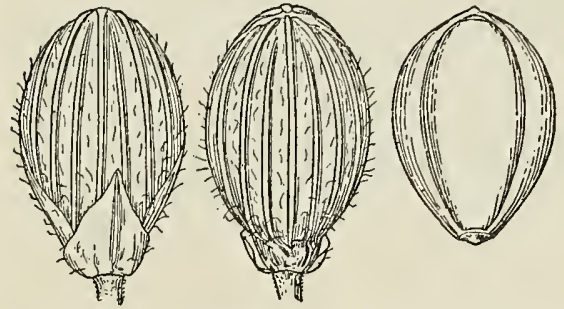

FIG. 138.-P. perlongum. From type specimen. and narrower, sometimes $25 \mathrm{~cm}$. long, pubescent on the lower surface; panicles smallerand narrower, the branches erect, hence appearing more densely flowered; spikelets 2.7 to $3.2 \mathrm{~mm}$. long, 1.6 to 1.7 $\mathrm{mm}$. wide, oval, blunt, sparingly pilose; first glume one-fourth to one-third the length of the spikelet, acute or obtuse; second glume and sterile lemma equal, obtuse, not extended beyond the fruit, strongly 7 to 9 -nerved; fruit $2.4 \mathrm{~mm}$. long, 1.5 to $1.6 \mathrm{~mm}$. wide, obovateoval, rounded and minutely umbonate at the summit.

Autumnal form with secondary panicles usually more numerous than in $P$. depauperatum and sometimes produced from the second node.

\section{DISTRIBUTION.}

Prairies and dry soil, Michigan and Manitoba to Texas.

Indiana: Elkhart County, Deam $6753 .{ }^{a}$

Illinois: Hanover, Gleason \& Gates 2530; Naperville, Umbach 1670; Wady Petra, V. H. Chase 460, 1158, 1731, in Kneucker Gram. Exs. 547; Peoria, Brendel, McDonald 18.

Michigan: Keweenaw County, Farwell 755.

Wisconsin: Racine, Wadmond in 1901.

Mrnnesota: Lake City, Manning in 1883 (Gray Herb.).

Man ттова: Lake Winnipeg Valley, Bourgeau in 1837 (Gray Herb.).

South Dakota: Custer, Rydberg 1100; Clark, Griffiths 863.

IowA: Ames, Ball 30, 145; Clinton, Vasey; Iowa City, Somes 245.

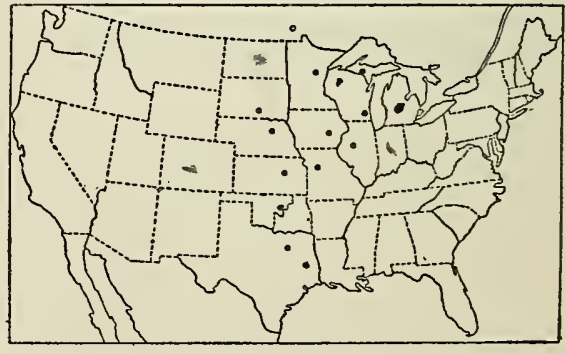

FIG. 139.-Distribution of $P$. perlongum.

Nebraska: Ewing, Bates 1120.

Missouri: Lees Summit, Bush 3089.

Kansas: Manhattan, Hitchcock 2501, 2509.

Texas: Llano County, Nealley 79; Wallisville, Wallis 38.

OкLанома: Creek Nation, Carleton 98.

$a$ This specimen and those of $P$.xalapense, $P$. ashei, and $P$. commutatum from Indiana were received too late for representation in the maps. 


\section{Panicum linearifolium Scribn.}

Panicum linearifolium Scribn. in Britt. \& Brown, Illust. Fl. 3: 500. f. 268a. June, 1898. "Dry soil, especially hillsides, New York and New Jersey to Missouri." This was again published $a$ as "n. sp." a few days later. "New England, southward to Virginia and westward to Texas." Both descriptions state that the sheaths are glabrous or pilose, both illustrations indicate pilose sheaths. The type, in the National Herbarium, is marked "P. linearifolium Scribn. Type." in Scribner's handwriting, and is labeled "Washington, D. C., Vasey, 1882," but was probably collected in Maryland, along the Potomac northwest of Washington, where this species is frequent in rocky woods. The specimen is a tuft of culms 30 to $40 \mathrm{~cm}$. high, with pilose sheaths, mature primary panicles, and much reduced, nearly hidden secondary ones. The spikelets are 2.2 to $2.4 \mathrm{~mm}$. long.

DESCRIPTION.

Vernal form light green, in dense tufts, often surrounded by the withered, persistent, more or less curled leaves of the previous year, the culms readily separating, 20 to 45 $\mathrm{cm}$. high, very slender, erect, spreading or almost drooping at the summit, glabrous, minutely puberulent or rarely pilose; sheaths usually equaling or exceeding the internodes, sparsely to densely papillose-pilose, the papillæ often obscure; blades elongated and erect, usually overtopping the panicles until maturity, 10 to $35 \mathrm{~cm}$. long (the lower shorter), 2 to $4 \mathrm{~mm}$. wide, scabrous on both surfaces or often pubescent on the lower, rarely on the upper surface, usually ciliate near the base with long hairs; panicles finally long-exserted, 5 to $10 \mathrm{~cm}$. long, half to two-thirds as wide, rather fewflowered, the scabrous, flexuous branches remote, ascending; spikelets 2.2 to $2.7 \mathrm{~mm}$. long, 1.3 to $1.5 \mathrm{~mm}$. wide, oblong-elliptic, obtuse, sparsely pilose with weak, spreading hairs; first glume one-fourth to one-third the length of the spikelet, obtuse, or pointed by the inrolling of the margins; second glume and sterile lemma equal and equaling the fruit at maturity; fruit 2 to $2.1 \mathrm{~mm}$. long, $1.2 \mathrm{~mm}$. wide, oval, obscurely umbonate at the summit.

Autumnal form similar, the reduced secondary panicles produced on short basal
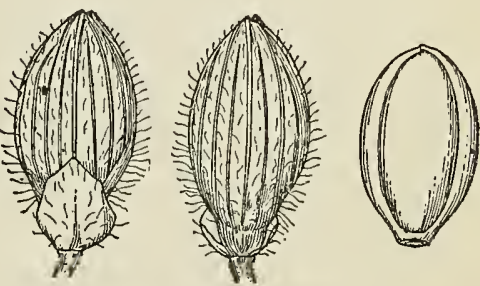

Fig. 140.-P. linearifolium. From type specimen. branches mostly concealed in the tuft of basal leaves.

While the typical form of this species is quite distinct from $P$. depauperatum, occasional specimens, such as the following, seem to be intermediate between the two: Burnham 24, Bush 1555, 4734; Hitchcock Pl. Kans. 880; Plank 40. In these the spikelets are about $3 \mathrm{~mm}$. long and sometinies obscurely short-pointed.

The following specimens have the sheaths glabrous or nearly so and approach the closely allied P. werneri: Bissell 5541, Bush 4411A, Deam, Wells County, Indiana, in 1901, Hitchcock 598, Pollard, Washington, D. C., in 1897, Rose \& Painter 8153.

\section{DISTRIBUTION.}

Dry woods, Maine to Kansas, south to Georgia and Texas.

Maine: Chesterville, Chase 3326; Fayette, Chase 3393; Canton, Parlin 1971.

Vermont: Barnet, Blanchard in 1888; Burlington, Hitchcock 598.

MassachuSETTS: Williamstown, Churchill in 1901.

Connecticut: Southington, Andrews 49, Bissell 5541, 5542; Fairfield, Eames in 1895.

$a$ Scribn. U. S. Dept. Agr. Div. Agrost. Bull. 11: 42. pl. 1. July 20, 1898. 
New York: Thousand Islands, Robinson \& Maxon 20; Oxford, Coville in 1884; Washington County, Burnham 24; Hempstead, Bicknell in 1903; Jamaica, Bicknell in 1905.

Ontario: Galt, Herriot 34.

New Jersey: Wildwood, Pollard in 1897; Morris County, Mackenzie 1339, 1398; Springdale, Pretz 1882.

Pennsylvania: Newtown, Smith 156; York County, Rose \& Painter 8153.

Онго: Barnesville, Laughlin 6906.

Indiana: Wells County, Deam in 1901; Kosciusko County, Deam 3218.

ILLinois: Wheaton, Moffatt 255 in 1893; Makanda, Gleason in 1903; Cobden, Waite in 1885.

Michigan: Keweenaw County, Farwell 597; Agricultural College, Lake in 1888.

Minnesota: Lake Kilpatrick, Ballard in 1893 (Univ. Minn. Herb.).

Missouri: Monteer, Bush 731 in part, 742, 2881a, 4734; Eagle Rock, Bush 153; Pleasant Grove, Bush 320; Carthage, Bush 1555; Swan, Bush 4533, 4549; Chadwick, Bush 4411, 4411A; Pilot Knob, Ward in 1878.

Kansas: Manhattan, Hitchcock 2506, Pl. Kans. 880.

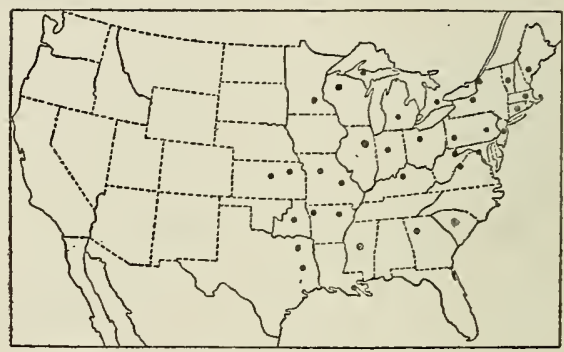

FIG. 141.-Distribution of P. linearifolium.

Maryland: Cabin John, Chase 5411; Plummers Island, Hitchcock 597; Great Falls, Chase 2303.

District of Columbia: Pollard in 1897, Vasey in 1882.

West Virginia: Harpers Ferry, Hitchcock in 1905.

Georgia: Silver Creek, Biltmore Herb. 7079 a (Biltmore Herb.).

Kentucky: Lexington, Short 8 (Gray Herb.).

MississipPI: Without locality, Johnson in 1886.

Arkansas: Benton County, Plank 45, 55, 96, 100, 143, 157; northwest Arkansas, Harvey 7.

Louisiana: New Orleans, Ridell (Gray Herb.).

Texas: Palestine, Plank 40; Jacksonville, Plank in 1894; without locality, Nealley in 1890, Wright (Gray Herb.).

OKLaнoma: Sapulpa, Bush 1107 in 1895 (Mo. Bot. Gard. Herb.).

\section{O 85. Panicum werneri Scribn.}

Panicum werneri Scribn. in Britt. \& Brown, Illust. Fl. 3: 501.f. 268b. 1898. "Dry knolls in swamps, New York and Ohio." The type, in Hitchcock's herbarium, is a specimen collected by William C. Werner, near Painesville, Ohio, 1889, no. 60. It consists of eight simple culms, mostly lacking the base, glabrous except for the sparsely bearded nodes, with over-mature panicles; spikelets almost glabrous, the sparse hairs obscure.

Panicum delawarense Ashe, N. C. Agr. Exp. Sta. Bull. 175: 116. 1900. "Dry soil near Centreville, Del. Collected by A. Commons, July 6, 1878." The type, in Ashe's herbarium, consists of four solitary culms with long-exserted, over-mature panicles, and sparsely pubescent spikelets.

\section{DESCRIPTION.}

Vernal form similar to that of $P$. linearifolium, typical specimens differing as follows: Culms stiffer, nodes usually sparingly pilose, sheaths glabrous, often shorter than the internodes; blades firmer, shorter and wider, $15 \mathrm{~cm}$. long or less, the lower culm blades 
3.5 to $6 \mathrm{~cm}$. long, 3 to $6 \mathrm{~mm}$. wide, a few long hairs at the rounded base, scabrous on both surfaces, not pubescent; spikelets 2.1 to $2.4 \mathrm{~mm}$. long, 1.2 to $1.3 \mathrm{~mm}$. wide, nearly or quite glabrous.

Autumnal form similar to the vernal, remaining simple or late in the season bearing simple branches from the lower, rarely from the basal, nodes.

The above-mentioned types are both of this form, but material examined shows a much less clear distinction from $P$. linearifolium, with which this species seems to
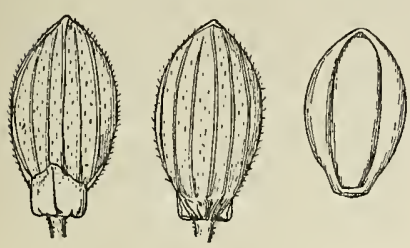

Fig. 142.-P. werneri. From type specimen. intergrade. The division is here based on a combination of stiffer habit, glabrous sheaths, shorter, broader, and firmer blades, and less pubescent spikelets. In many specimens, however, having the other characters enumerated the blades are as long as in many specimens of $P$. linearifolium. The following represent these intergrading specimens: Biltmore Herb.8342, Chase 3299, 3382, Jones, Burlington, Vermont, in 1892, Knight 55, 57, Parlin 1190, Porter, Easton, Pennsylvania, in 1895, 1897, and 1898.

In habit, especially as seen in the field, $P$. werneri often suggests $P$. depauperatum. The following specimens, with slightly pointed spikelets 2.5 to $2.8 \mathrm{~mm}$. long, approach that species: Briggs 1248, Graves 7, Eggleston 1757, H. W. Merrill 44.

\section{DISTRIBUTION.}

Sterile woods and knolls, Maine to Minnesota, south to Ohio and Texas.

Manne: Penobscot County, Fernald 506, Knight 55, 57; Chesterville, Chase 3299; Fayette, Chase 3382; North Berwick, Parlin 1190, 1502, 1806; Hiram, $H$. $W$. Merrill 44, 47; Orono, Briggs 1248.

New Hampshire: Laconia, Carter 101, 242 (Hitchcock Herb.).

Vermont: Burlington, Jones in 1892; Eggleston 1757.

Massachusetts: Sheffield, Hoffmann in 1901.

Connecticut: Ledyard, Graves 16; Volunteer, Graves 17; Franklin, Woodward in 1906; Southington, Chamberlain \& Bissell in 1903; Waterford, Graves 7.

New YoRk: Tripoli, Burnham in 1897; Ithaca, Ashe, Rowlee in 1892; New York, Bicknell in 1895 .

Ontario: Toronto, Biltmore Herb. 8342 ; Kingston, Fowler in 1898; Kingston Mills, Klugh in 1907; Algonquin Park, Macoun 21957.

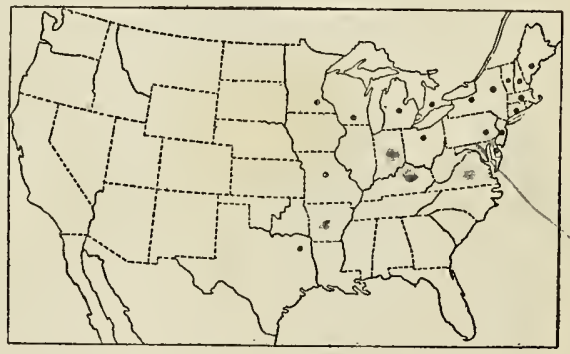

FIG. 143.-Distribution of $P$. werneri.

New Jersey: Berkeley Heights, Mackenzie 2251.

Pennsylvania: Easton, Porter in 1895, 1897, and 1898.

Oн1о: Painesville, Werner 60, 65 (both in Hitchcock Herb.).

Mrchigan: Flint, Clark (Field Mus. Herb.).

Wrsconsin: Rainbow Rapids, Cheney 1345.

Mrnnesota: Chisago County, Sandberg in 1886.

Missouri: Swan, Bush 2913, 2926.

Delaware: Centerville, Commons 358.

Texas: Dallas, Reverchon in 1876 (Gray Herb.). 
Laxiflora.-Plants light green, vernal culms 10 to $40 \mathrm{~cm}$. high, numerous in tufts; blades flat, soft, mostly ciliate, basal blades shorter, but not forming true rosettesin the autumn; ligules nearly obsolete; primary panicles long-exserted; spikelets 1.3 to $2.3 \mathrm{~mm}$. long, obovate, obtuse, turgid, 5 to 7 -nerved. Autumnal form freely branching near the base, forming close, flat, soft tufts, the reduced panicles often exceeded by the leaves.

Sheaths retrorsely pilose; spikelets papillose-pilose.

Panicle branches ascending, forming a rather compact

panicle; spikelets $1.6 \mathrm{~mm}$. long.............. 87a. P.xalapense stric-

Panicle branches loosely spreading.

tirameum.

Blades ciliate and more or less pilose on the surface;

spikelets $2 \mathrm{~mm}$. long................... 87. P. xalapense.

Blades glabrous or nearly so on the surface and margin; spikelets $2.2 \mathrm{~mm}$. long.............. 86. P. laxiflorum.

Sheaths not retrorsely pilose; spikelets pubescent or glabrous.

Spikelets pubescent, about $2 \mathrm{~mm}$. long.............. 88. P. ciliatum.

Spikelets glabrous.

Blades glabrous on the surface.............. 89. P. polycaulon.

Blades pilose on the surface................ 90. P. strigosum.

\section{○ 86. Panicum laxiflorum Lam.}

Panicum laxiflorum Lam. Encycl. 4: 748. 1798. "Cette plante est dans l'herbier du Muséum. Je la crois d'Amérique Septentrionale." The type, labeled in Lamarck's hand "panicum laxiflorum lam. dict.," is in the Lamarck Herbarium. It consists of two culms, each with a loose terminal panicle, one leafless, the other with a single blade glabrous on both surfaces; the spikelets are $2.2 \mathrm{~mm}$. long, papillose-pilose, the fruit covered by the second glume and sterile lemma. These characters indicate not the species that has been called by this name in America, but the one of more restricted southern range.

Panicum pyriforme Nash, Bull. Torrey Club 26: 579. 1899. "Type collected by the writer in clay soil, at Orange Bend, a Lake Co., Florida, March 12-31, 1894, no. 239." The type, in Nash's herbarium, consists of a clump of three culms, 15 to $45 \mathrm{~cm}$. high.

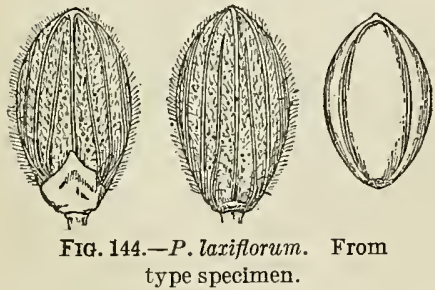
type specimen.

The description states that the blades are glabrous on the margin, but the type, as well as duplicate types in the National and Columbia University herbaria and in Hitchcock's herbarium, has several sparingly ciliate blades; the spikelets are said to be "about $2.5 \mathrm{~mm}$. long" but measure $2.2 \mathrm{~mm}$.

Panicum aureum Muhl.; Scribn. \& Merr. U. S. Dept. Agr. Div. Agrost. Circ. 27: 4. 1900. This is mentioned as a synonym of $P$. laxiflorum Lam. The type specimen is in the Muhlenberg Herbarium in folio "187, Panicum strigosum." It is labeled "117 P. aureum M 115."

\section{DESCRIPTION.}

Vernal form with slender culms 20 to $60 \mathrm{~cm}$. high, erect, or the lower nodes often geniculate, glabrous; nodes bearded with reflexed hairs; sheaths shorter than the internodes, conspicuously retrorsely pilose; blades mostly 10 to $18 \mathrm{~cm}$. long, 7 to 12 $\mathrm{mm}$. wide, acuminate, narrowed toward the base, glabrous on both surfaces and on

a The locality of Nash 239 as given on the label is "vicinity of Eustis." Orange Bend is a few miles northwest of Eustis. 
the margins, or sparsely ciliate; panicles long-exserted, but sometimes equaled by the long upper blades, 8 to $12 \mathrm{~cm}$. long, nearly as wide, lax, few-flowered, the branches flexuous, spreading, the lower often deflexed; spikelets 2.2 to $2.3 \mathrm{~mm}$. long, $1.2 \mathrm{~mm}$. wide, oblong-obovate, obtuse, first glume one-third to two-fifths as long as the spikelet; second glumeand sterile lemma equal and covering the fruit at maturity, papillose-pilose; fruit $1.8 \mathrm{~mm}$. long, $1.2 \mathrm{~mm}$.wide, obovate-elliptic, minutely umbonate.

Autumnal form branching at the base, forming soft, spreading tufts, the sheaths overlapping and the blades but little or not at all reduced, much exceeding the secondary panicles; spikelets more turgid and obtuse than the primary ones.

A specimen collected by Lester F. and Rosamond Ward at Palatka, Fla., in 1891, and another from Dr. Chapman, collected in Florida, without locality or date, have pilose blades like those of $P$. xalapense; the spikelets are 2.2 to $2.3 \mathrm{~mm}$. long, and the fruit is covered by the equal second glume and sterile lemma.

DISTRIBUTION.

Rich or damp woods, Georgia to Florida and Alabama.

Georgia: Stone Mountain, Eggert 42; Ocmulgee River Swamp, below Macon, Small in 1895.

Florida: Monticello, Combs 327; Lake City, Nash 2156, Hitch-

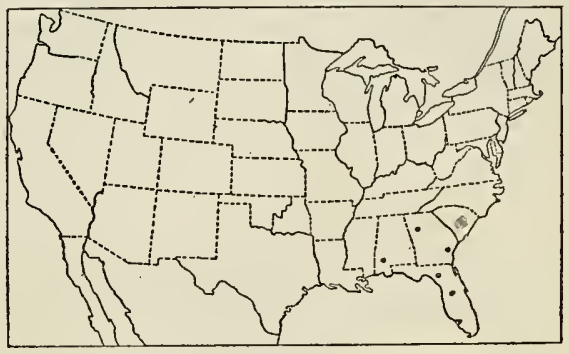

FIg. 145.-Distribution of $P$. laxiflorum.

cock 1009; Gainesville, Chase 4217, Combs 743; Mabel, Curtiss 6635 in part; $a$ Grasmere, Combs 1064; Spruce Creek, Curtiss in 1885; Manatee, Tracy 7383; Palmetto, Tracy 6707; Eustis, Nash 239, 2034; Orange Bend, Chase 4101; Dunnellon, Combs 909, Titusville, Chase 4023; Ormond, Hitchcock 111.

Alabama: Springhill, Mohr in 1895.

\section{Panicum xalapense H. B. K.}

Panicum xalapense H. B. K. Nov. Gen. \& Sp. 1: 103. 1816. "Crescit in regno Mexicano prope Xalapa et montem Macultepec." The type, in the Bonpland Herbarium, is labeled, "In regno Mexicano prope xalapa, regione temperata."

Panicum pumilum Bosc; Nees, Agrost. Bras. 228. 1829, not Lam. 1798. "(Herb. Willd.) Habitat in America boreali:". This is mentioned as a synonym under P. laxiflorum Lam. The specimen referred to, in the Willdenow Herbarium, is the vernal form.

Panicum rariflorum Rupr. Bull. Acad. Roy. Belg. 9²: 240. 1842, not Lam. 1798. "(Coll. H. Gal[eotti] No. 5733). Nous avons trouvé cette nouvelle espèce * * * pres de Xalapa." This is a nomen nudum. The type, in the Brussels Herbarium, is . a poor specimen, but undoubtedly belongs to this species.

Panicum ruprechti Fourn. Mex. Pl. 2: 21. 1886, not Fenzl, 1854. This name is based on the type of $P$.rariflorum Rupr., "(GaL[Еоттr] n. 5733)." It was earlier listed without description by Hemsley, b based on "Panicum rariflorum Rupr. * * * non Lam.," that is, a nomen nudum based on a nomen nudum.

Panicum caricifolium Scribn.; Ashe, Journ. Elisha Mitchell Soc. 15:c 57. 1898. This is given as a synonym of $P$. laxiflorum Lam. "As distributed by Kearney

$a$ Curtiss included $P$. xalapense also under this number. U. S. National Herbarium no. 388470 is a sheet of Curtiss 6635 , with a tuft of each species.

$b$ Biol. Centr. Amer. Bot. 3 : 495. 1885.

c The title page, vol. 15, pt. 1 (pp. 1-75) is incorrectly numbered 4 (IV). 
(Washington, D. C., May, 1897)." The Kearney specimen referred to could not be found in Ashe's herbarium, but other specimens there under this name are $P$. xalapense, as are specimens in the National Herbarium bearing the name "Panicum caricifolium" in Scribner's writing.

This is the species described as $P$. laxiflorum by American authors.

\section{DESCRIPTION.}

Vernal form similar to $P$. laxiflorum in texture and habit; culms and blades on the average shorter, the blades pilose on one or both surfaces or nearly glabrous, usually

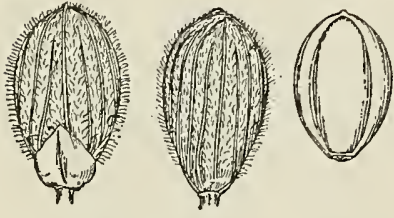

Fig. 146.-P. xalapense. From type specimen. short-ciliate, the uppermost more or less convolute at base around the culm; panicles hardly so fewflowered; spikelets 1.9 to $2 \mathrm{~mm}$. long, $1.1 \mathrm{~mm}$. wide, oblong-obovate, obtuse, the first glume one-fourth to one-third as long as the spikelet; second glume and sterile lemma pilose, less prominently papillose, the glume shorter than the fruit, the latter $1.5 \mathrm{~mm}$. long and $1 \mathrm{~mm}$. wide, oval, minutely umbonate.

Autumnal form as in P. laxiforum, but forming usually denser tufts with shorter leaves.

This species is conspicuously retrorsely pilose on the sheaths. Canby's no. 106, Stone Mountain, Ga., in the Gray Herbarium, is exceptional in having almost glabrous sheaths.

\section{DISTRIBUTION.}

Woods, Maryland, Illinois, and Missouri to Florida, Texas, and Mexico; also in Santo Domingo.

Indiana: Clarke County, Deam 6883.

ILuINoIs: Jackson County, French in 1905.

Missouri: Campbell, Bush 749 in part; Swan, Bush 4638; Jefferson County, Eggert 127; Pacific, Kellogg 19.

Maryland: Cabin John, Chase 5412, Chase in Kneucker Gram Exs. 549; west District Line, Hitchcock 343; Great Falls, Chase 2316, 2320.

VIRGINIA: Richmond, DeChalmot; Smyth County, Small in 1892; Princess Anne County, Kearney 1033, 1104, 1179, 1308, 1467, Pollard \& Maxon in 1900.

North Carolina: Biltmore, Biltmore Herb. 2993a; Madison County, Biltmore Herb. 2993c; Raleigh, Ashe; Chapel Hill, Ashe, Chase 3057; Wilmington, Chase 3111, 3117, 3118.

South Carolina: Orangeburg,

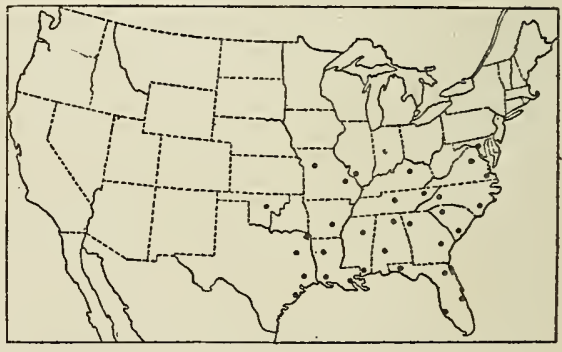

FIG. 147.-Distribution of P. xalapense. Hitchcock. 1391, 1415, 1424; Clemson College, House 2177.

Georgia: Thomson, Bartlett 1453; Rome, Curtiss 6791; Warm Springs, Tracy 8867; Augusta, Cuthbert 1119, Kearney 212; Union, Harper 1085; Clarke County, Harper 77; Dublin, Harper 2140; Stone Mountain, Chase 4517, Eggert 86, Harper 183, Hitchcock 1361, Small in 1893, Wilson 14.

Florida: Jacksonville, Curtiss 6602; Lake City, Combs \& Rolfs 141; Tallahassee, Combs 390, Kearney 75; Sanford, Hitchcock 773; Titusville, Chase 4009; Dade County, Curtiss 5537, Eaton 589, 831, Hitchcock 659, 673, Tracy 8849; Manatee County, Tracy 6694; Sarasota Key, Tracy 7202; Alva, Hitchcock Lee Co. 
Pl. 480; Tampa, Hitchcock 927, 935; Myers, Hitchcock 906; without locality, Rugel 392.

Kentucky: Harlan County, Kearney 53.

Tenneśsee: Knoxville, Ruth 68; Nashville, Gattinger in 1880; Wolf Creek, Kearney in 1894; Cocke County, Kearney 970.

Alabama: Auburn, Earle \& Baker in 1897; Tracy 3759; Tuskegee, Carver 55; Scottsboro, Chase 4506.

Mississipri: Meridian, Tracy 3267; Dekalb, Tracy 3255, 3256; Fairport, Tracy 3211; Acona, Tracy 2058; Starkville, Tracy 1410, 1753; Enterprise, Tracy 3267, 3287; Jackson, Hitchcock 1310; Biloxi, Hitchcock 1073, Tracy 2032, 4574, 4588, 6358. Arkansas: Fulton, Bush 1440; Texarkana, Bush 2488.

Louisiana: Calhoun, Ball 62, Hitchcock 1260; Coushatta, Ball 122; Shreveport, Cocks 3511, Hitchcock 1239; Lake Charles, Hitchcock 110, 1124; Opelousas, Langlois 36; New Orleans, Drummond 456, 457.

Texas: Waller County, Hitchcock 1182, Thurow in 1898 and 1906; Dallas, Reverchon 93, Bush 651; Houston, Bebb 1236; Denison, Bebb 1457; Columbia, Bush 1273; Heiler 4085, 4209; Galveston, Plank 91; Palestine, Plank 51; Nealley in 1884.

OkLaнoma: Wister, Hitchcock in 1903; Poteau, Hitchcock in 1903 (both in Hitchcock Herb.).

Mexıco: Jalapa, Pringle 8083, C. L. Smith 1752; Hidalgo, Pringle 13250; Orizaba, Nelson 201; Chinantla, Liebmann 328; Valley of Córdoba, Bourgeau 2162; Galeotti 5733 (Brussels Herb.), Schiede \& Depper "acuminatum c;" Seler 2160 (both in Berlin Herb.). Schaffiner 145 \&95C

Santo Domingo: Near Jarabaco, Eggers 2129.

- 87a. Panicum xalapense strictirameum subsp. nov.

DESCRIPTION.

Differing from $P$.xalapensc in having ovoid, more compact panicles with ascending branches, somewhat smaller spikelets, $1.7 \mathrm{~mm}$. long, shorter, narrower blades than common in the species, and shorter culms.

Autumnal form in smaller, shorter tufts.

Type U. S. National Herbarium no. 558449, collected April 28, 1906, Jackson, Miss., by A, S. Hitchcock (no.1311). This specimen has short, appressed blades, the uppermost 2.5 to $4 \mathrm{~cm}$. long, and longexserted panicles 2 to $3 \mathrm{~cm}$. long. This form was abundant on wooded hills in the outskirts of Jack-

FIG. 148.-P. xalapense strictirameum. From type specimen. son, where $P$. xalapense also grew, but from which it differed conspicuously in the form of the panicle. Most of the other specimens referred to this subspecies are less characteristic, but are smaller, with smaller blades than the species usually has, though occasional specimens of $P$.xalapense have the smaller blades of the subspecies.

\section{DISTRIBUTION.}

Dry woods, South Carolina to Louisiana.

South CArolina: Lancaster, House 2551.

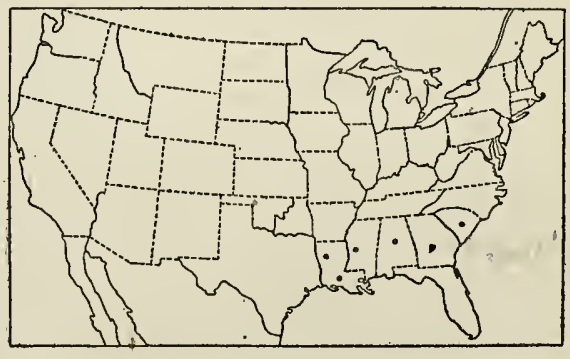

FIG. 149.-Distribution of $P$. xalapense strictirameum.

Ala baMa: Auburn, Hitcheock 1333.

Mississippi: Jackson, Hitchcock 1311; Madison, Tracy 1478.

Louisiana: Calhoun, Hitchcock 1290; West Feliciana, Cocks 3510.

$$
41616^{\circ}-\operatorname{voL} 15-10-11
$$




\section{Panicum ciliatum Ell.}

Panicum ciliatum Ell. Bot. S. C. \& Ga. 1: 126. 1816. No locality is cited. The type, in the Elliott Herbarium, consists of two short culms with short-exserted, immature panicles.

Panicum leucoblepharis Trin. Clav. Agrost. 234. 1822. Trinius's full citation is as follows: "1177. Gr. miliaceum americanum, majus, panicula minore. Pluk. Phytogr. p. 176. Tab. 92. f. 7. Mant. p. 95. (excl. Syn. Sloan. ut ipse Sloaneus monet). Citatur a Gronowio (Virg. p. 12.) ad Pan. paniculatum floribus muticis; sed quid illud? Figura bene convenit cum Panico quodam herb. notsr. [nostr.] ex Amer. bor. (Pan. leucoblepharis $m$.) praeter cilia foliorum elegantissima, rigidiuscula.-Synon. Recchii ap. Pluk. admodum dubium." Plukenet cites "Nov. Hispan. Terent. apud Recc. 373 " after the phrase name cited by Trinius. The figure, which is not identifiable, represents blades with cordate bases and no ciliæ. A specimen in the Trinius Herbarium is labeled: "ab Enslino in Am. bor. 1. dt. cl. Trattinick." This is typical P. ciliatum Ell. Trinius $a$ further describes this species, citing the Enslin specimen. Since the Plukenet figure can not certainly be identified, the Enslin specimen has been chosen as the type.

Panicum ciliatifolium Kunth, Rév. Gram. 1: 36. 1829. Based on P. ciliatum Ell. without description or explanation as to reason for change of name.

Panicum ciliatifolium Desv. Opusc. 88. 1831. "Habitat in America boreali." The type could not be found in the Desvaux Herbarium, but the description leaves no doubt as to the identity of the species. Desvaux cites P. ciliatum Ell. with a query. He uses the name ciliatifolium apparently without reference to its previous use by Kunth for the same species.

\section{DESCRIPTION.}

Vernal form with culms 5 to $30 \mathrm{~cm}$. high, erect or spreading, sparsely pilose toward the summit, the nodes glabrous; sheaths ciliate on the margin, otherwise glabrous, usually overlapping; blades 3 to $6 \mathrm{~cm}$. long, 3 to $8 \mathrm{~mm}$. wide, the uppermost often much smaller, lanceolate, ciliate on the margin with stiff hairs 2 to $3 \mathrm{~mm}$. long, arising from papillæ, panicles 3 to $4 \mathrm{~cm}$. long, about as wide, with more numerous spikelets than those of $P$.xalapense, the branches spreading, flexuous, the axis pilose; spikelets
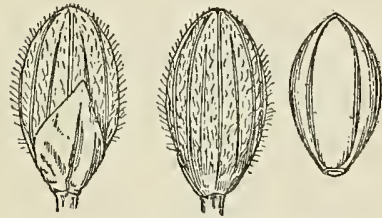

FIG. 150.-P. ciliatum. From type specimen. 1.8 to $2 \mathrm{~mm}$. long, $1 \mathrm{~mm}$. wide, obovate-elliptic; first glume half the length of the spikelet, subacute; second glume and sterile lemma equal, not exceeding the fruit, villous; fruit 1.7 to $1.8 \mathrm{~mm}$. long, $0.9 \mathrm{~mm}$. wide, elliptic, the apex minutely umbonate.

Autumnal form in flat, soft mats, similar to that of $P$.xalapense.

A specimen of Nash 807 from Eustis, Fla., in Hitchcock's herbarium, which is an autumnal form of this species, consists of two small tufts, of which one has glabrous spikelets, the other pubescent spikelets; the plants are otherwise identical; the spikelets are of the same size and the fruits of the glabrous ones are umbonate as in the pubescent ones. So far as examined, other specimens of this number have pubescent spikelets. Two specimens, Chase 3131 from Wilmington, N. C., and Hitchcock 1062 from Biloxi, Miss., with pubescent spikelets only $1.6 \mathrm{~mm}$. long are intermediate between $P$. ciliatum and $P$. polycaulon and might perhaps be considered as a form of $P$. polycaulon with pubescent spikelets. 


\section{DISTRIBUTION.}

Low pine lands and hammocks, North Carolina to Florida and Louisiana.

North Carolina: Onslow County, Chase 3184; Roanoke Island, Chase 3214, 3226; New Hanover County, Chase 4583, Hitchcock 1430, 1451, 1490, Kearney 250.

South Carolina: Orangeburg, Hitchcock 342, 1371.

Florida: Baldwin, Combs 57, Hitchcock 991, 993, 1000; Lake City, Combs 100, 137, Hitchcock 1019, 1036; Madison, Combs 288; Eustis, Nash 807.

ALABAMA: Flomaton, Hitchcock 1040; Mobile, Kearney 24.

MississipPi: Jackson County, Kear-

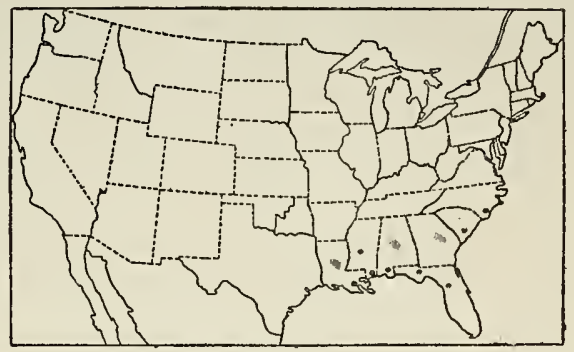

Fig. 151.-Distribution of $P$. ciliatum. ney 283, Tracy 162; Biloxi, Chase 4360, Kearney 326 in part; Avondale, Tracy 4582.

Louisiana: New Orleans, Drummond (Gray Herb.).

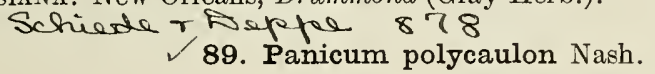

Panicum polycaulon Nash, Bull. Torrey Club 24:200. 1897. "Type specimen collected by the writer on August 20, 1895, in the flatwoods at Tampa, Florida, No. 2420a." The type, in Nash's herbarium, consists of a spreading tuft of numerous culms, 10 to $17 \mathrm{~cm}$. high, the overmature panicles nearly devoid of spikelets, and the first glume half the length of the spikelets, which are $1.6 \mathrm{~mm}$. Jong.

\section{DESCRIPTION.}

Vernal form similar to that of $P$. ciliatum, culms rarely over $20 \mathrm{~cm}$. high, glabrous, but pilose in the long-exserted panicle; sheaths sparingly ciliate; blades on the average narrower than those of $P$. ciliatum; spikelets 1.5 to $1.6 \mathrm{~mm}$. long (exceptionally as much as $2 \mathrm{~mm}$. long), $0.8 \mathrm{~mm}$. wide, obovate, blunt, glabrous; first glume one-third to half the length of the spikelet, subacute; second glume and sterile lemma strongly nerved; fruit $1.4 \mathrm{~mm}$. long, $0.8 \mathrm{~mm}$. wide, elliptic, subacute, not umbonate.

Autumnal form in flat, soft mats, similar to those of $P$. xalapense, but smaller.

The type specimens of $P$. ciliaium and $P$. polycaulon differ in the spikelet characters, the former having pubescent spikelets $2 \mathrm{~mm}$. long and the latter having gla-

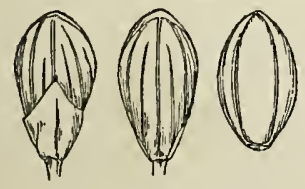

FIG. 152.-P. polycaulon. From type specimen. brous, more obovate, turgid spikelets $1.6 \mathrm{~mm}$. long. Our numerous specimens, however, do not show these constant differences. Occasional specimens have glabrous spikelets as much as $2 \mathrm{~mm}$. long. A comparatively few specimens have pubescent spikelets that are of the smaller size. We have not found any distinct differences in habit that can be coördinated with the spikelet characters. The range of the two forms is somewhat different, $P$. ciliatum extending from North Carolina to northern Florida, and $P$. polycaulon throughout Florida and southward into Cuba. It will be observed that the ranges of the two overlap in northern Florida and it is here that the intermediate specimens are found. A specimen from Tampa, Florida, Hitchcock 933, has blades nearly destitute of ciliæ. The following specimens have spikelets nearly or quite $2 \mathrm{~mm}$. long: FLoRIDA: Kalamazoo, Hitchcock 763; Lakeland, Hitchcock 836; Dunedin, Tracy 6698. MrssissIPPI: Mississippi City, Hitchcock 1101. 


\section{DISTRIBUTION.}

Flatwoods and hammocks, Florida and along the Gulf coast to Mississippi; also in Cuba.

Florida: Live Oak, Tracy 6727; Washington County, Combs 649 in part; Apalachicola, Biltmore ITerb. 6022a, Kearney 96; Orange County, Baker 68, Combs \& Baker 1086, Curtiss 6627; Orange Bend, Chase 4104; Titusville, Chase 3967; Dunedin, Tracy 6698, 6723; Kalamazoo, Hitchcock 762; Sanford, Hitchcock 771, 772, 827; Manatee, Hitchcock 950, 974; Lakeland, Hitchcock 843; Tampa, Combs 1338, Hitchcock 933, 943; Hog Island, Tracy 6710 in part; Lemon Bay, Tracy 7188 in part; Sneeds Island, Tracy 6692; Santa Rosa Island, Tracy 8411 ; Myers, Hitchcock 868, 903, 9231, Lee Co. Pl. 482; Miami, Chase

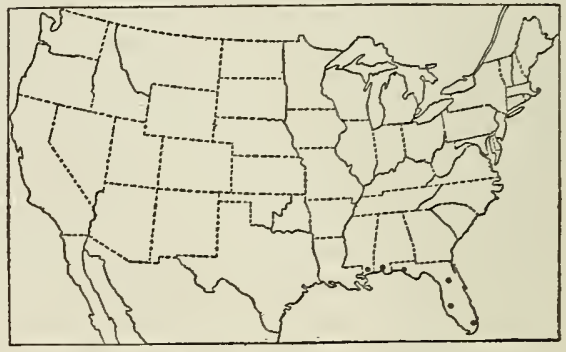

FIG. 153.-Distribution of $P$. polycaulon.

3885, Hitchcock 112, 665, 711, 721; Homestead, Hitchcock 6891.

Alabama: Fort Morgan, Tracy 7208.

MississipPI: Horn Island, Tracy 6470; Petit Bois Island, Tracy 4606; Ocean Springs, Skehan in 1895; Biloxi, Chase 4364.

CuBA: Herradura, Hitchcock 115; without locality, Wright 3875 in part; Isle of Pines, Palmer \& Riley 990.

Porto Rico: Near Piedra Blanca, Sintenis 5724, 5908

W.I: Eggare 2045

- 90. Panicum strigosum Muhl.

Panicum strigosum Muhl. in Ell. Bot. S. C. \& Ga. 1: 126. 1816. Elliott cites no locality. The type, in the Elliott Herbarium, is a single immature plant, the panicle only short-exserted. The accompanying label reads "Panicum strigosum Muhl. Hab. in humidis. Car: \& Georg: Flor: Ma-Jun:."

Panicum laxiflorum pubescens Vasey, Contr. Nat. Herb. 3: 30. 1892. No locality nor specimen is cited. Only two specimens bearing this name in Vasey's writing can be found in the National Herbarium. One of these, Curtiss North American Plants No. H, Duval County, Florida, agrees well with Vasey's description; the other, a specimen of $P$. xalapense, does not agree with the description. The first is therefore chosen as the type.

Panicum longipedunculatum Scribn. Tenn. Agr. Exp. Sta. Bull. 7: 53. pl. 16. f. 61. 1894. "Damp woods, White Cliff Springs [Tennessee], July 1890; Tullohoma, July, 1892. A large form of this species is represented by No. $3597^{*}$ A. H. Curtiss N. Am.

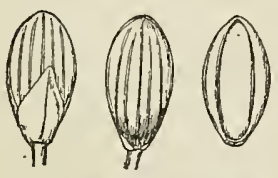

Fig. 154.-P. strigosum. From type specimen. Pl." The first specimen cited, which is evidently the plant figured and which is chosen as the type, is in Hitchcock's herbarium. It consists of two tufts with slender culms 15 to $40 \mathrm{~cm}$. high, more sparsely pilose than usual.

\section{DESCRIPTION.}

Vernal form similar to that of $P$. ciliatum, but having sparsely pilose culms and sheaths, bearded nodes, and blades on the average a little wider and more or less pilose on both surfaces; panicles larger, with pilose axis and branches, bearing more numerous, smaller, glabrous spikelets, the latter 1.3 to $1.5 \mathrm{~mm}$. long, $0.7 \mathrm{~mm}$. wide, obovate, less turgid than in other species 
of this group; first glume one-third to half the length of the spikelet; second glume and sterile lemma equal, faintly nerved; fruit $1.3 \mathrm{~mm}$. long, 0.6 to $0.7 \mathrm{~mm}$. wide, elliptic, subacute, not umbonate.

Autumnal form a dense mat with panicles scarcely rising above the leaves.

This species is variable as to pubescence. Some of the specimens from Cuba and Guatemala show only a few scattered hairs upon the surface of some of the blades, but these are conspicuously ciliate on the margin.

DISTRIBUTION.

Sandy woods, Virginia and Tennessee to Florida and Louisiana; also in Mexico, Guatemala, and Cuba.

Virginia: Norfolk County, Kearney 1761.

North Carolina: Roanoke Island, Chase 3244; Onslow County, Chase 3171; Wilmington, Hitchcock 1450, Kearney 282.

South Carolina: Aiken, Ravenel.

Florida: Jacksonville, Curtiss $3597^{*}$, 4031; Washington County, Combs 567, 584.

Tennessee: White Cliff Springs, Scribner in 1890 (Hitcheock Herb.).

Alabama: Cullman County, Eggert 21; Gateswood, Tracy 8422 ; Flomaton, Hitchcock 1043.

Mississippi: Saratoga, Tracy 8402.

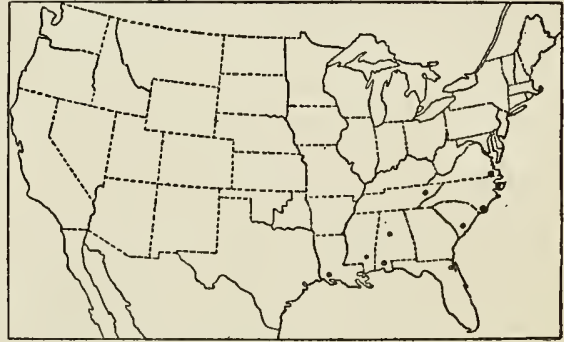

FIG. 155.-Distribution of $P$. strigosum.

Louisiana: Lake Charles, Hitcheock 1162.

Mexico: Minatitlan, J. G. Smith 555 (Hitchcock Herb.).

Guatemala: Secanquím, Pittier 257; Cuesta de Peixhá, Pittier 1800.

Cuba: El Guama, Palmer \& Riley 213; without locality, Wright-3875 in part.

Angustifolia.-Plants mostly dull grayish-green, cespitose; vernal culms erect or ascending from a spreading base, mostly 30 or $40 \mathrm{~cm}$., rarely as much as 100 $\mathrm{cm}$. high, appressed-villous at base or sometimes above, or rarely smooth even at base; ligules ciliate, less than $1 \mathrm{~mm}$. long; blades narrow, ascending, usually firm and rigid, more or less striate with prominent nerves, and sometimes longitudinally wrinkled besides, often ciliate at the base; spikelets attenuate at base, rather strongly 7-nerved, usually pubescent, the hairs arising from bullate papillæ; first glume narrow and sheathing at base. Autumnal culms repeatedly branching, forming bushy crowns, these remaining erect or becoming decumbent or widely spreading; blades much reduced, often involute; a distinct rosette of basal leaves formed in the fall. Species of the Atlantic Coastal Plain.

Nodes bearded; plants grayish-villous; autumnal blades flat.

Spikelets $2 \mathrm{~mm}$. long

\section{P. chrysopsi- difolium.}

Spikelets 2.5 to $2.8 \mathrm{~mm}$. long

93. P. consanguineum.

Nodes not bearded; plants villous only at base, or nearly gla-

brous; autumnal blades involute or flat.

Autumnal blades flat; lower panicle branches spreading or deflexed............................. 94. P. angustifolium. 
Autumnal blades involute; lower panicle branches more or less ascending.

Spikelets 3.3 to $3.5 \mathrm{~mm}$. long, pointed........... 95. P. fusiforme.

Spikelets less than $3 \mathrm{~mm}$. long, not pointed, or obscurely so.

Plants glabrous or nearly so; autumnal culms erect.

Spikelets subsecund along the suberect panicle branches.................. 98. P. neuranthum.

Spikelets not subsecund; panicle loose and open....................... 97. P. ovinum.

Plants pubescent, at least on the lower half.

Spikelets about $2.4 \mathrm{~mm}$, rarely only $2.1 \mathrm{~mm}$. long; vernal blades 7 to $12 \mathrm{~cm}$. long; autumnal blades not falcate....... 96. P. arenicoloides.

Spikelets not over $2 \mathrm{~mm}$. long; vernal blades 4 to $6 \mathrm{~cm}$. long, autumnal blades much crowded, falcate................ 91. P. aciculare.

$\checkmark$ 91. Panicum aciculare Desv.

Panicum aciculare Desv.; Poir. in Lam. Encycl. Suppl. 4:274. 1816. "Cette plante croît dans les Indes orientales. (V.s. in herb. Desv.)" Poiret cites "P. aciculare Desv. Herb." The type is in the Paris Herbarium. It is from the Desvaux Herbarium and is labeled in Desvaux's handwriting "Panicum aciculare Desv. in Enc. Suppl. 4. p. 274. habitat in india orientali." It is the autumnal form and is evidently the specimen described. The locality is certainly an error, as no such plant is known from the East Indies, and the specimen is without doubt from the southeastern United States. $a$

Panicum setaceum Muhl. Descr. Gram. 99. 1817. "Habitat in Georgia." The type, in the Muhlenberg Herbarium, is in a folio marked: "151 Panicum pungens M. 97 Elliott, 358." Panicum pungens in the herbarium stands in the same relation to the other species as does $P$. setaceum in Muhlenberg's book. $b$ In the herbarium folio 151 is the first of the Panicums. In the book $P$. setaceum is the first species described under this genus. Likewise the sequence in the two places is essentially the same. The specimen, which is the autumnal form, agrees with Muhlenberg's description of $P$. setaceum.

Panicum subuniflorum Bosc; Spreng. Syst. Veg. 1:312. 1825. "Carolin." In the Delessert Herbarium is a specimen from "Carolina" collected by Bosc. In the Willdenow Herbarium is another fragmentary specimen labeled $P$. subuniflorum Bosc, but without locality or collector. The latter may be the type.

Panicum arenicolum[cola] Ashe, Journ. Elisha Mitchell Soc. 15: 56. 1898. "Type material collected by the writer at Chapel Hill, N. C. June 1898." The type could not be found in Ashe's herbarium. In Hitchcock's herbarium is a specimen labeled "Panicum arenaecolum Ashe" collected in the vicinity of Chapel Hill, North Carolina, by W. W. Ashe, and sent by him to Professor Scribner. The date of collection is not given. This specimen, which is probably a duplicate type, consists of two vernat culms, somewhat appressed-pubescent below; the stiffly ascending blades are glabrous except the lowermost, which is sparsely pubescent beneath.

Panicum filiram[e]um Ashe, Journ. Elisha Mitchell Soc. 16: 88. 1900. "Sandy woods, eastern North Carolina. Type material collected in New Hanover County,

a Several cases of erroneous localities occur in Desvaux's herbarium. See Panicum illinonense Desv. under P. fasciculatum.

$b^{b}$ Compare U. S. Dept. Agr. Div. Agrost. Circ. 27: 2. 1900. 
N. C., in June 1899." The type, in Ashe's herbarium, consists of two single vernal plants, with slender, villous culms, sheaths less villous, blades nearly glabrous on one plant, sparsely long-pilose on the other, the panicles overmature.

Panicum pungens Muhl.; Scribn. \& Merr. U. S. Dept. Agr. Div. Agrost. Circ. $27: 2$. 1900, not Poir. 1816. This is mentioned as a herbarium name of $P$. setaceum Muhl., of which it is a typonym.

This is the species described in Britton's Manual $a$ and in Small's Flora $b$ under the name Panicum neuranthum Griseb.

\section{DESCRIPTION.}

Vernal culms numerous in a tuft, ascending from a spreading base, appressedpubescent below, glabrate above, 20 to $50 \mathrm{~cm}$. or, in shaded situations, $60 \mathrm{~cm}$. or more high, the nodes more or less pubescent but not bearded; lower sheaths villous, the upper glabrous except the ciliate margin; blades stiff, spreading or ascending, narrowed to an involute point, glabrous or the lower sparsely pilose, somewhat papillosehispid on the margin at base, the middle culm blades 4 to $6 \mathrm{~cm}$. long, rarely longer, 2 to $5 \mathrm{~mm}$. wide, the uppermost shorter, usually only 1 to $2 \mathrm{~cm}$. long and 1 to $2 \mathrm{~mm}$.
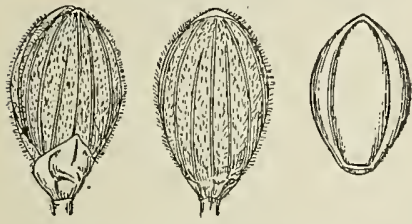

Fig. 156.-P. aciculare. From typespecimen in Florence Herbarium. wide; panicles open, 3 to $7 \mathrm{~cm}$. long, the flexuous branches spreading at maturity; spikelets 1.9 to 2 $\mathrm{mm}$. long, $1.1 \mathrm{~mm}$. wide, obovate, blunt, basal attenuation short; first glume about one-fourth the length of the spikelet, obtuse or pointed; second glume and sterile lemma equal, papillosepubescent; fruit $1.6 \mathrm{~mm}$. long, $1 \mathrm{~mm}$. wide, ovalelliptic, glabrous at the apex.

Autumnal form consisting of numerous bushybranched culms 10 to $30 \mathrm{~cm}$. long, spreading and forming dense cushions, the short blades involute, sharp-pointed and usually arcuate, mostly 1 to $3 \mathrm{~cm}$. long; spikelets more turgid than in the vernal form.

This species is abundant in the coast region and can be distinguished from all the other species of this group within its range by the small spikelets, and the awl-like blades of the autumnal state.

Chase's no. $3097 \frac{1}{2}$ is referred here though it is unusually glabrous.

\section{DISTRIBUTION.}

Sandy pine woods of the Coastal Plain from New Jersey to northern Florida and eastern Texas.

New Jersey: Cape May, Stone in 1909.

Virginia: Vicinity of Cape Henry, Chase 2357, 2936, 3682, 5413, 5414, Hitchcock 345, 347, Kearney 1375, 1566, 2038, Mackenzie 1664, Williams 3099.

North Carolina: Lake Mattamuskeet, Chase 3205; Raleigh, Chase 3084; Wilmington, Ashe in 1899, Chase 3123, 3130, 3157, 4578, 4586, Hitchcock 344, 1447, 1473, Kearney 247, 284 in part; Roanoke Island, Ashe in Curtiss Dist. 645I, Chase 3215, 3216, 3217; Ocracoke Island, Kearney 2272; Edenton, Kearney 1871; Wilsons Mills, Chase 3094, 309712, 3103, 3105; Jacksonville, Chase 3167; Wards Mill, Chase 3185.

South Carolina: Orangeburg, Hitchcock 17, 346, 1375, 1404; Aiken, Ravenel in 1882; Fripps Island, Cuthbert 1166; Isle of Palms, Chase 4525.

Georgra: Augusta, Kearney 215; Thomson, Bartlett 1444, 1455; Albany, Tracy 3640; Thomasville, Tracy 3638, 3641; Jessup, Biltmore Herb. 11866. 
Florida: Baldwin, Hitchcock 989; Lake City, Combs 183; Madison, Combs 216; Monticello, Combs 301, 329; Tallahassee, Combs 372, 380; Quincy, Combs 408; Washington County, Combs 554, 567a; Leon County, Curtiss E; Chattahoochee, Tracy 3639; Marianna, Tracy 3637 ; Milton, Chase 4302; Eustis, Nash 1243; Pasco County, Curtiss 6639.

Alabama: Tuskegee, Carver 96; Gateswood, Tracy 8420; Mobile, Kearney 21 in part.

MississipPI: Starkville, Chase 4444; vicinity of Biloxi, Chase 4359, Hitchcock 1082, Kearney $284 \frac{1}{2}, 306$ in part, Tracy 1417 , 3634 .

Louisiana: Covington, Langlois

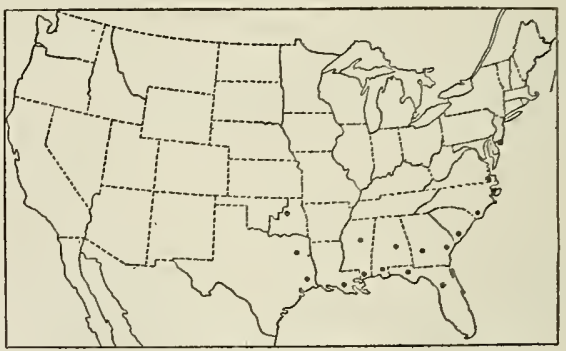

FIG. 157.-Distribution of $P$. aciculare.

48b in 1884; Calcasieu, Cocks 2194; Lake Charles, Hitchcock 1127, 11391 , 1140, Tracy 3650 .

Texas: Waller County, Hitchcock 1225, Thurow 1 in 1900.

Окцанома: Sapulpa, Bush 1388 in 1895 (Mo. Bot. Gard. Herb.).

Cof tis is Cencher 241

92. Panicum chrysopsidifolium Nash.

Panicum chrysopsidifolium Nash in Small, Fl. Southeast. U. S. 100. 1903. On page 1327 , in the list of new genera and species, the following citation is given: "Type, Curtiss, N. Am. Pl., ńo. D, in Herb. N Y. B. G." The type, in the herbarium of the New York Botanical Garden, is labeled "Hammock land, Leon Co. Fla., May 12, 1886," and consists of a clump of four vernal culms 30 to $55 \mathrm{~cm}$. high with mature, shortexserted panicles.

\section{DESCRIPTION.}

Vernal form with ascending or spreading, rather slender culms, 30 to $45 \mathrm{~cm}$. high, purplish, grayish-villous, especially below, the nodes bearded; sheaths much shorter than the internodes, villous like the culm, densely so at the summit; blades 5 to 10 $\mathrm{cm}$. long, 3 to $5 \mathrm{~mm}$. wide, tapering from base to apex, conspicuously pointed, villous on both surfaces; panicles finally long-exserted, 4 to $6 \mathrm{~cm}$. long, about three-fourths

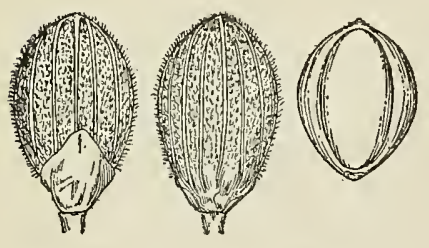

FIG. 158.-P. chrysopsidifolium. From type specimen. as wide, the flexuous branches ascending or spreading; spikelets $2 \mathrm{~mm}$. long, 1.2 to $1.3 \mathrm{~mm}$. wide, obovate, blunt and turgid; first glume one-third the length of the spikelet, subacute or obtuse; second glume and sterile lemma subequal, scarcely covering the fruit at maturity, villous, the bullate papillæ prominent; fruit $1.7 \mathrm{~mm}$. long, $1.2 \mathrm{~mm}$. wide, broadly elliptic, minutely puberulent at the apex. Autumnal form spreading and forming mats, the culms slender, often zigzag toward the tip; blades numerous, flat, becoming papery with age, mostly 1 to $3 \mathrm{~cm}$. long, $1.5 \mathrm{~mm}$. wide; spikelets more turgid than usual in the primary panicle.

Panicum chrysopsidifolium has been confused with $P$. neuranthum Griseb., because both species were distributed by Wright under the same number (Wright 3453). This number in the Grisebach Herbarium is the type of $P$. neuranthum. The same number in several other herbaria consists of the autumnal form of $P$. chrysopsidifolium. $a$

$a$ For further discussion of Wright's Cuba grasses, see Hitchcock, Contr. Nat. Herb. 12: 183.1909. 
The specimen referred to by Grisebach, $a$ under $P$. neuranthum as, "forma ascendens, ramosa, foliis planis, spiculis ut in $\alpha$ " is $P$. chrysopsidifolium.

This species can be distinguished from $P$. consanguineum by the smaller spikelets, and from $P$. aciculare by the bearded nodes and by the lax culms and flat blades of the autumnal form.

\section{DISTRIBUTION.}

- Sandy pine woods of the Coastal Plain, Florida to Louisiana; also in Cuba and Porto Rico.

Florida: Leon County, Curtiss D; Orange County, Baker 45; Sanford, Hitchcock 775 .

Louisiana: Lake Charles, Chase 4405.

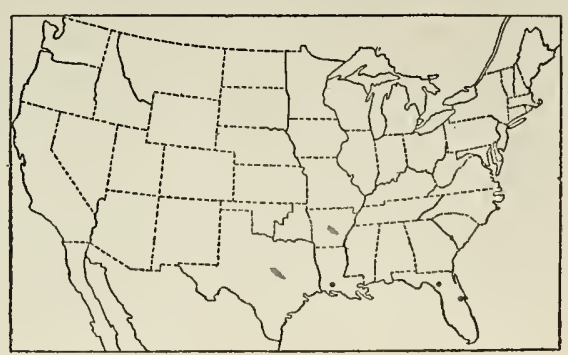

FIG. 159.-Distribution of P. chrysopsidifolium.

Cuba: Consolacion del Sur, Palmer \& Riley 481; Herradura, Hitchcock 116; eastern Cuba, Wright 3453 in part; Isle of Pines, Palmer \& Riley 982.

Ponto Rico: Santurce, Heller 982; Las Marias ad Tabomeo, Sintenis 5985.

\section{- 93. Panicum consanguineum Kunth.}

Panicum villosum Ell. Bot. S. C. \& Ga. 1: 124. 1816, not Lam. 1791. No locality is cited. The type, in the Elliott Herbarium, consists of a single culm lacking the base, bearing four leaves and an immature, scarcely exserted panicle. The accompanying label reads: "Panicum villosum mihi. Hab. in umbrosis. Flor. Ap. Ma."

Panicum consanguineum Kunth, Rév. Gram. 1: 36. 1829. Based on P. villosum Ell., the name presumably changed because of P. villosum Lam.

Panicum commutatum consanguineum Beal, Grasses N. Amer. 2: 141. 1896. Based on $P$. consanguineum Kunth.

Panicum georgianum Ashe, Journ. Elisha Mitchell Soc. 15: 36. 1898. "Georgia: Small; Darden [Darien] Junction, McIntosh Co., June 27, 1895." The type specimen, which is in the Biltmore Herbarium and which is marked "P. georgianum W. W. Ashe," in Ashe's writing, is the autumnal form.
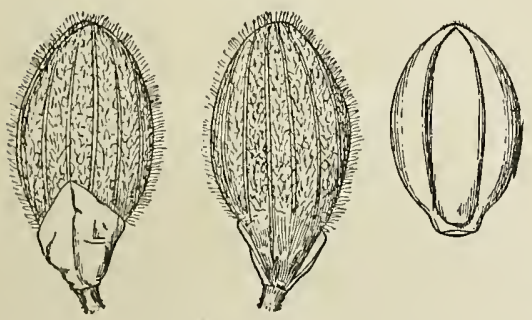

FIG.160.-P.consanguineum. From type specimen of $P$. villosum Ell.

Panicum cahoonianum Ashe, Journ. Elisha Mitchell Soc. 15: $b$ 113.1899. Based on $P$.georgianum Ashe, the name changed because of Panicum georgicum Spreng. 1825.

\section{DESCRIPTTON.}

Vernal form with culms ascending or spreading, often geniculate at base, 20 to $55 \mathrm{~cm}$. high, rather stout, densely feltyvillous below, less so above, nodes bearded; sheaths villous, the upper often sparsely so; blades erect or ascending, 7 to $11 \mathrm{~cm}$. long, 5 to $8 \mathrm{~mm}$. wide, (the lowermost shorter and broader), tapering slightly toward the base, more or less involute-pointed, villous on both surfaces or nearly glabrous above, the longitudinal

a Cat. Pl. Cub. 232. 1866.

$b$ The title page, vol. 15, pt. 2. (pp. 76-114) is incorrectly numbered 14. (XIV). 
wrinkling conspicuous in the lower blades; panicles 4 to $8 \mathrm{~cm}$. long, one-half to twothirds as wide, the lower branches usually narrowly ascending; spikelets 2.6 to 2.8 $\mathrm{mm}$. long, 1.6 to $1.8 \mathrm{~mm}$. wide, obovate, blunt, turgid; first glume one-third the length of the spikelet or less; second glume and sterile lemma equal, scarcely covering the fruit at maturity, densely papillose-villous, the bullate papillæ prominent; fruit $2 \mathrm{~mm}$. long, 1.5 to $1.7 \mathrm{~mm}$. wide, minutely puberulent at the apex.

Autumnal form spreading or decumbent, the numerous branches somewhat flabellately fascicled, the blades mostly 3 to $4 \mathrm{~cm}$. long, 2 to $3 \mathrm{~mm}$. wide, flat, thin, and papery.

The vernal form of this species may be distinguished from $P$. angustifolium by the greater amount of pubescence, the bearded nodes, and the ascending panicle-branches, and the autumnal form by the widely spreading habit and shorter blades.

\section{DISTRIBUTION.}

Sandy pine woods of the Coastal Plain from North Carolina to northern Florida and west to eastern Texas.

VirgInia: Virginia Beach, Hitchcock in 1905.

North Carolina: Wilmington, Hitchcock 1449, 1471; Wards Mill, Onslow County, Chase 3174; Wilsons Mills, Chase 3095; Roanoke Island, Chase 3230.

South Carolina: Orangeburg, Hitchcock 1373, 1382.

Georgia: Macon, Small in 1895; Darien Junction, Small in 1895.

Florida: Baldwin, Hitchcock 986, 999; Washington County, Combs 570, 651; Marianna, Tracy 3633; Milton, Chase 4299; without locality, Rugel 142.

Alabama: Gateswood, Tracy 8427. MississipPI: Vicinity of Biloxi, Chase 4351, Hitchcock 1069,

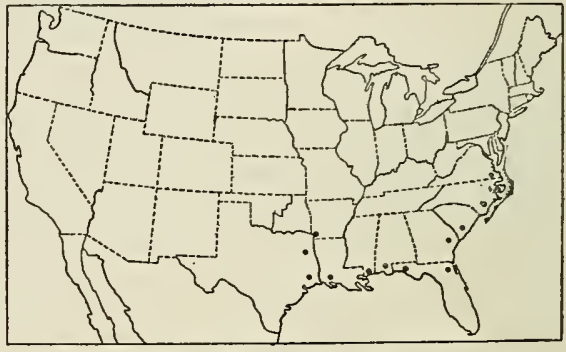

FIG. 161.-Distribution of $P$. consanguineum.

1070, 1083, Kearney 218 in part, 284 in part, Tracy 1884, 2873, 3661, 4614.

Arkansas: Texarkana, Heller 4238.

Louisiana: Lake Charles, Hitchcock 1139, 1155, Langlois in 1884.

Texas: Beaumont, Reverchon 4156; Waller County, Thurow 23 in 1906.

\section{Panicum angustifolium Ell.}

? Panicum ramulosum Michx. Fl. Bor. Amer. 1: 50. 1803. "Hab. in sylvis Carolinae." The type specimen, in the Michaux Herbarium, labeled "in pratis caespitosis Carolinae," belongs to a species of the Angustifolia, apparently P. angustifolium, but on account of the fragmentary condition of the type, which is devoid of spikelets, and the insufficiency of Michaux's description the identity of this specimen can not be determined with certainty.

Panicum angustifolium Ell. Bot. S. C. \& Ga. 1: 129. 1816. No locality is cited. The type, in the Elliott Herbarium, consists of a single culm, lacking the base, bearing three leaves and a scarcely exserted, immature panicle; the culm is glabrous, the sheaths are sparingly pilose, densely ciliate on the margin toward the summit; blades $18 \mathrm{~cm}$. long, involute toward the apex, long ciliate on the margin for half to twothirds their length, otherwise glabrous. The accompanying label reads: "Panicum angustifolium. Hab: in aridis. Flor. Ma.?" 
Panicum curtisii Steud. Syn. Pl. Glum. 1: 66. 1854. "M. A. Curtis sub: P. nervosum. Mühlbrg. var. legit in Carolina." The type in the Paris Herbarium, labeled by Steudel "Panicum curtisii Steud. Panicum nervosum Muhlb. var.? M. A. Curtis. Carolina australis, Commun. Lenormand," is a somewhat fragmentary specimen, but appears to be $P$. angustifolium.

\section{DESCRIPTION.}

Vernal form with erect or nearly erect culms 30 to $55 \mathrm{~cm}$. high, the lowermost internodes gray crisp villous, the middle and upper glabrous; nodes glabrous or the lower villous, not bearded; lower sheaths more or less appressed-villous, the upper glabrous, except the usually ciliate margin; blades 8 to 12 , rarely 15 , $\mathrm{cm}$. long, 4 to $8 \mathrm{~mm}$. wide (lowermost blades shorter and broader and longitudinally wrinkled), stiffly ascending, the upper more appressed, long-acuminate, scarcely narrowed at base; panicles longexserted, 4 to $10 \mathrm{~cm}$. long, nearly as wide, loosely flowered, the branches at anthesis
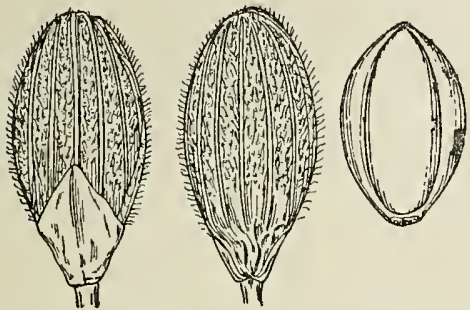

FIG. 162.-P. angustifolium. From type specimen. widely spreading, the lower 3 to $4 \mathrm{~cm}$. long, often reflexed; spikelets 2.5 to $2.8 \mathrm{~mm}$. long, 1.4 to $1.6 \mathrm{~mm}$. wide, elliptic-obovate, turgid; first glume about one-third the length of the spikelet, pointed or obtuse; second glume and sterile lemma equal, covering the fruit at maturity, not beaked beyond it, papillose-villous; fruit $2 \mathrm{~mm}$. long, 1.3 to $1.5 \mathrm{~mm}$. wide, broadly elliptic, minutely puberulent at the obscurely umbonate apex.

Autumnal culms stiffly ascending or somewhat topheavy-reclining, not spreading nor mat-like; blades very numerous, flat, ap-

pressed, rather thin and papery, panicles reduced (the later ones often to two or three spikelets), overtopped by the leaves; spikelets commonly more turgid and blunt than those of the primary panicles.

The flat, papery blades of the autumnal form as seen in the spring still attached to the plants bearing the vernal culm are very characteristic of this species and of the two others of this group with flat autumnal blades $(P$. consanguineum and $P$. chrysopsidifolium).

\section{DISTRIBUTION.}

Sandy pine woods along the Coastal Plain from Pennsylvania to northern Florida and westward to eastern Texas.

Pennsylvania: "Bank of Schuylkill below Reading, 1849, Thos. C. Porter" (Acad. Phil. Herb.).

Delaware: Frankford, Commons in 1875 .

Virginia: Vicinity of Cape Henry, Chase 5415, Hitchcock 348, Kearney 1369, 1416, Williams 3100; Dismal Swamp, Chase 3677.

North Carolina: Roanoke Island, Chase 3249 , 3250; vicinity of Wilmington, Chase 3138, 3163, 4585, Hitchcock 1466 $\frac{1}{2}, 1475$; Onslow County, Chase 3169; Chapel Hill, Chase 3063; Ral-

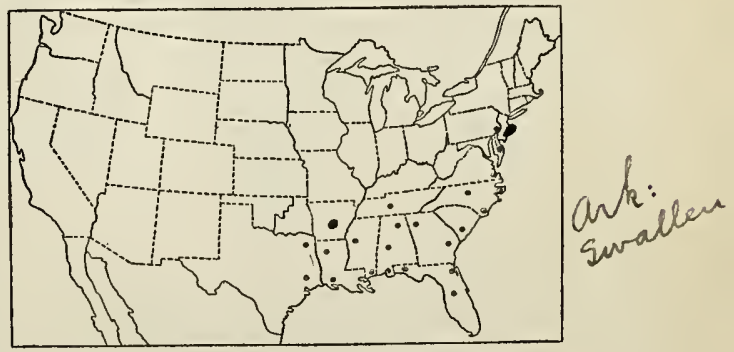

FIG. 163.-Distribution of $P$. angustifolium. eigh, Chase 3082; Caraleigh Junction, Chase 3087.

South Carolina: Fripps Island, Cuthbert 1165; Orangeburg, Hitchcock 349, 1408; Aiken, Ravenel in 1882. 
Georgia: Augusta, Kearney 206; Albany, Tracy 3635 in part; Lookout Mountain, Ruth 56; Stone Mountain, Hitchcock 1362; Bullock County, Harper 828; Thomson, Bartlett 1462.

Florida: Jacksonville, Curtiss 3587 in part, 6803; Baldwin, Hitchcock 984; Tallahassee, Combs 374, 376; Apalachicola, Biltmore Herb. 4278; Chattahoochee, Tracy 3636; Gainesville, Chase 4229, 4267; Milton, Chase 4297, 4301; Lakeland, Hitchcock 835.

Tennessee: Knoxville, Scribner in 1892 (Univ. Tenn. Herb.).

Alabama: Etowah County, Eggert 10; Pisgah, Chase 4479; Auburn, Hitchcock 1332, 1340, Tracy 3746, 3750, 3758 in part; Tuskegee, Carver 86; Flomaton, Hitchcock 1039; Mobile, Kearney 28 in part, Langlois 48.

Mississippi: Jackson, Hitchcock 1298; vicinity of Biloxi, Hitchcock 1087, 1091, 1105, 1115, Kearney 306 in part, Tracy 1730, 1883, 1888, 4578, 4579, 4615, 4616 in part.

Louisiana: Calhoun, Hitchcock 1261, 1264, 1269; Coushatta, Ball 121; Lake Charles, Hitchcock 1151, Tracy 3651, 3657; Calcasieu River, Langlois in 1884.

Texas: Waller, Hitchcock 1193, 1209, 1221; Beaumont, Reverchon 4159; Houston, Bebb 1262, Hall 833;.Big Sandy, Reverchon 4193; without locality, Wright

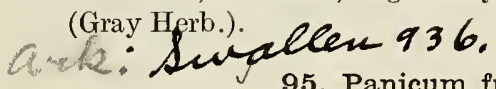

\section{Panicum fusiforme Hitchc.}

Panicum neuranthum ramosum Griseb. Cat. Pl. Cub. 232. 1866, not P. ramosum L. 1767. "Cuba occ. (Wr[ight] 3454)." The type, in the Grisebach Herbarium, was collected by Charles Wright in western Cuba in 1863, and is numbered " $900=3454$." It is the autumnal form. This species was also distributed by Wright under nos. 3453 and 3461 in part. $a$

Panicum fusiforme Hitchc. Contr. Nat. Herb. 12: 222. 1909. Based on P. neuranthum ramosum Griseb., not $P$. ramosum $\mathrm{L}$.

\section{DESCRIPTION.}

Vernal form similar to that of $P$. angustifolium; culms 30 to $70 \mathrm{~cm}$. high, the basal and lower blades narrower and at least the lowermost softly pubescent beneath, the longitudinal wrinkles obscure, the leaves more or less clustered toward the base of the

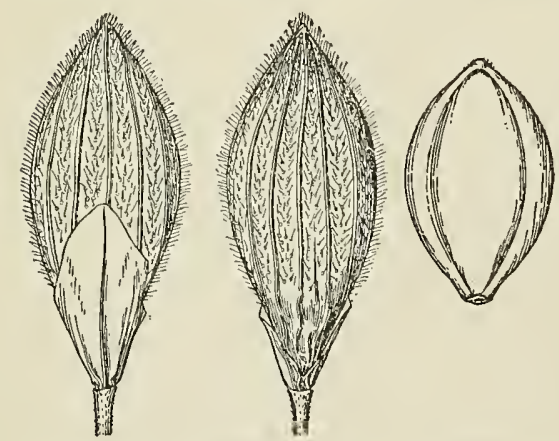

FIG. 164.-P. fusiforme. From type specimen of $P$. neuranthum ramosum Griseb. culms, the panicles thus long-exserted; spikelets 3.3 to $3.5 \mathrm{~mm}$. long, 1.4 to 1.5 $\mathrm{mm}$. wide, elliptic, long-attenuate at base; first glume two-fifths the length of the spikelet, usually obtuse, second glume and sterile lemma exceeding the fruit and somewhat beaked beyond it at maturity, the pubescence as in $P$. angustifolium; fruit $2.5 \mathrm{~mm}$. long, 1.4 to $1.5 \mathrm{~mm}$.wide, broadly elliptic, obscurely puberulent at the subacute apex.

Autumnal culms erect or reclining, under favorable conditions formingdense, bushy clusters 30 to $60 \mathrm{~cm}$. in height; blades soon involute, 3 to $5 \mathrm{~cm}$. long; spikelets more turgid than those of the primary panicles, 3.5 to $3.8 \mathrm{~mm}$. long, more pointed; fruit more turgid.

Panicum fusiforme can be distinguished from $P$. angustifolium in the vernal state by the larger and more pointed spikelets and the soft pubescence on the lower surface of 
the narrower lower blades; in the autumnal state by the involute blades and distinctly longer spikelets. In the autumnal state this species resembles $P$. arenicoloides, but has larger spikelets.

\section{DISTRIBUTION.}

Sandy pine woods, southern Georgia to Florida and Mississippi; also in Cuba.

Georgia: Albany, Tracy 3614, 3635 in part.

Florida: Lake City, Combs 136; De Funiak Springs, Combs 456; Monticello, Combs 298; Madison, Combs 231; Pensacola, Combs 516; Gainesville, Chase 4248, Combs 731; Sanford, Hitchcock 786, 791; Titusville, Chase 3991, 4021 ; Eustis, Nash 1226, 1856; Orange Bend, Chase 4105; Lake Harris, Chase 4119; Orange County, Combs 1037; Ormond, Hitchcock 114; Lafayette County, Combs 853, 899; Lakeland, Hitchcock 834, 837, 850; Wiwauma, Hitchcock 980; Tampa, Combs 1340, 1343; Seminole, Tracy 7163; Bartow, Combs 1241; Braidentown,

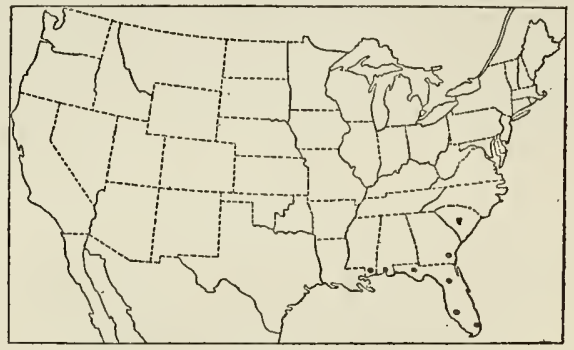

FIG. 165.-Distribution of $P$. fusiforme. Hitchcock 964; Manatee County, Tracy 6708, 6710 in part, 6713 in part, 6713a; Perico Island, Tracy 7371; Myers, Chase 4179, 4194, Hitchcock 877, 899, 912, 923; Miami, Chase 3855, Hitchcock 627.

Alabama: Flomaton, Hitchcock 1054.

Mississippi: Ocean Springs, Tracy in 1892.

CuвA: Herradura, Caldwell \& Baker 7139, Hitchcock 117, Tracy 9074; western Cuba, Wright 3453 in part, 3454 in part; Isle of Pines, Curtiss 406.

\section{$\checkmark$ 96. Panicum arenicoloides Ashe.}

Panicum arenicoloides Ashe, Journ. Elisha Mitchell Soc. 16:89. 1900. "Shady sandy woods along the coast of North Carolina. Type material collected by me near Wilmington, N. C., June 6, 1899." The type, in Ashe's herbarium, consists of three vernal culms with involute blades and mature panicles; the spikelets are $2.4 \mathrm{~mm}$. long.

Panicum orthophyllum Ashe, Journ. Elisha Mitchell Soc. 16:90. 1900. "Shady slopes of sand hills, New Hanover County, N. C., June, 1899." The type, in Ashe's
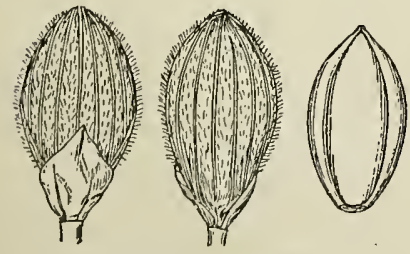

FIG. 166.-P. arenicoloides. From type specimen. herbarium, consists of a small tuft of vernal culms beginning to branch, about $60 \mathrm{~cm}$. high, the lower nodes geniculate. The primary panicles are mostly devoid of spikelets, the secondary nearly mature; the spikelets are $2.2 \mathrm{~mm}$. long.

\section{DESCRIPTION.}

Vernal form intermediate in appearance between that of $P$. angustifolium and $P$. aciculare, grayish green, slender, mostly 30 to $50 \mathrm{~cm}$. high; lower sheaths and blades softly villous; blades 7 to $12 \mathrm{~cm}$.

$\mathrm{rm}$, long (the lower shorter), 3 to 4 , rarely $5 \mathrm{~mm}$. wide, tapering from the base to a more or less involute apex; panicles 4 to $6 \mathrm{~cm}$. long, two-thirds to three-fourths as wide, the lower branches ascending; spikelets 2.1 to $2.5 \mathrm{~mm}$. Iong, 1.2 to $1.3 \mathrm{~mm}$. wide, obovate, obtuse; first glume one-third the length of the spikelet, truncate or pointed; second glume and sterile lemma scarcely covering the fruit at maturity, papillose- 
pubescent; fruit 1.8 to $1.9 \mathrm{~mm}$. long, 1.1 to 1.2 wide, obscurely puberulent at the apex.

Autumnal form bushy-branching, erect or topheavy, the blades involute; spikelets more turgid, the attenuate base in exceptional specimens elongated, lengthening the spikelet to as much as $2.8 \mathrm{~mm}$.

The vernal form of this species can be distinguished from $P$. aciculare by the larger spikelets and longer blades, from $P$. angustifolium by the smaller spikelets and the ascending branches of the panicle; the autumnal form is distinguished by the involute blades, longer than those of $P$. aciculare.

The following specimens have spikelets with lengthened bases: FLORIDA: Eustis, Nash 598, 1436; Lake City, Chase 4281; Gainesville, Chase 4211. Mississippr: Biloxi, Tracy 3632. An exceptional specimen, with beaked spikelets $2.9 \mathrm{~mm}$. long, Chase 4161, Myers, Florida, is doubtfully referred here.

\section{DISTRIBUTION .}

Sandy pine woods, mostly near the coast, from North Carolina to Florida, Arkansas, and Texas; also in Guatemala.

Norti Carolina: Near Wilmington, Chase 3120, 3143, 3156, 4581, Hitchcock 350; Raleigh, Chase $3082 \frac{1}{2}$.

South Carolina: St. Helena

Island, Cuthbert in 1899; Orangeburg, Hitchcock 352; Isle of Palms, Hitchcock 351.

Georgia: Millen, Harper 757.

Florida: Duval County, Curtiss $3583^{*}$ in part, $3587^{*}$ in part, 4028; Lake City, Chase 4291, Combs 164, Hitchcock 1012; Monticello, Combs 300; Leon County, Curtiss B; Citrus County, Combs 1022; Mary Esther, Tracy 9144; Gaines-

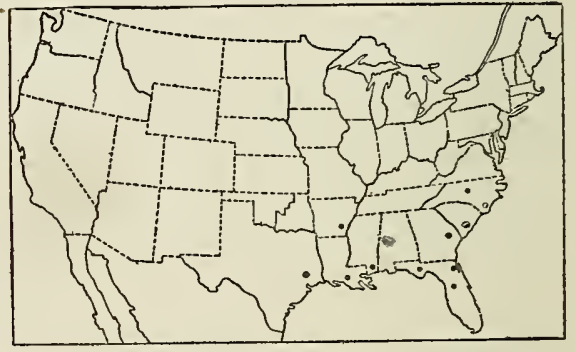

FIG. 167.-Distribution of $P$. arenicoloides. ville, Chase 4249; Ormond, Hitchcock 108.

Mississippi: Biloxi, Chase 4340, Hitchcock 1077, Kearney 215 in part.

Arkansas: Fulton, Bush 2522.

Louisiana: Breton Island, Tracy 459, 459a; Lake Charles, Chase 4423; Tangipohoa, Cocks 3322.

Texas: Houston, Eggert in 1899 (Mo. Bot. Gard. Herb.). Guatemala: Between Gualán and Copán, Pittier 1805b.

\section{- 97. Panicum ovinum Scribn. \& Smith.}

$P$. redivivum Trin.; Steud. Nom. Bot. ed. 2. 2:262. 1841. This is a nomen nudum, and appears as P. redivivum "Trin. mpt. Mexico." The type, in the Berlin Herbarium, was collected by Schiede at Hacienda de la Laguna, Mexico.

Panicum ovinum Scribn. \& Smith, U. S. Dept. Agr. Div. Agrost. Circ. 16 : 3. 1899. "Type collected by F. W. Thurow, Waller County, Texas, May 25, 1898." The type specimen, in the National Herbarium, the vernal form, is glabrous except the ciliate basal portion of some of the lowermost blades.

\section{DESCRIPTION.}

Vernal form with culms usually few in a cluster, erect or nearly so, glabrous, 30 to $50 \mathrm{~cm}$. high; sheaths glabrous or the lowermost appressed pubescent; blades erect or ascending, stiff, glabrous, the lower somewhat ciliate on the margin at base, the lower- 
most ovate or lanceolate, as much as $1 \mathrm{~cm}$. wide, those of the mid-culm, 10 to $15 \mathrm{~cm}$. long, 3 to $6 \mathrm{~mm}$. wide, the uppermost shorter and narrower; panicles usually short-
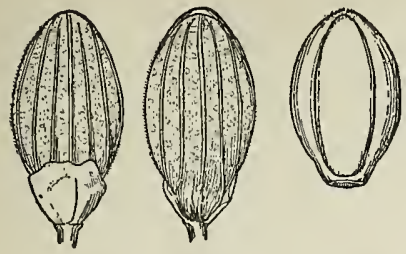

FIG. 168.-P. ovinum. From type specimen. exserted, 5 to $9 \mathrm{~cm}$. long, three-fourths as wide or less, loosely flowered, the lower branches ascending; spikelets 2.1 to $2.2 \mathrm{~mm}$. long, 1.2 to $1.3 \mathrm{~mm}$. wide, obovate-elliptic, obtuse, basal attenuation short; first glume about one-fourth the length of the spikelet, usually truncate; second glume and sterile lemma scarcely equaling the fruit at maturity, papillose-pubescent, sometimes minutely so; fruit $1.8 \mathrm{~mm}$. long, $1.1 \mathrm{~mm}$. wide, oval, puberulent at the apex.

Autumnal form erect or nearly so, the blades becoming loosely involute, not much shorter than the vernal blades; spikelets more turgid, sometimes slightly shorter than those of the primary panicle.

Panicum ovinum in its vernal form differs from $P$. aciculare in being nearly smooth, and in having broader spikelets and larger, less exserted panicles, the uppermost blades being proportionately longer.

\section{DISTRIBUTION.}

Dry or moist open ground, Mississippi to Arkansas and eastern Texas; also in Mexico. In Texas this species occurs upon the open prairie, on dry ground, and also in swales.

Mississippi: Ocean Springs, Tracy 4616 in part; Biloxi, Hitchcock $1077 \frac{1}{2}$.

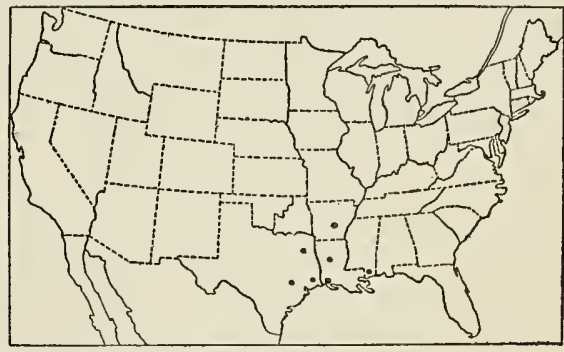

FIG. 169.-Distribution of $P$. ovinum.

Arkansas: Jefferson County, Eggert in 1898 (Mo. Bot. Gard. Herb.).

Louisiana: Shreveport, Hitchcock 1250; Lake Charles, Hitchcock 1131, 1141, 1150.

Texas: Dallas, Reverchon 1087; Waller County, Hitchcock 1172, 1192, 1210, 1222 ,

Thurow in 1898 and 1906; Montgomery County, Thurow in 1905; Grand Saline, Reverchon 4137; Hempstead, Hall 834 (Gray Herb.); without locality, Nealley in 1884 and 1887, Reverchon 92 in 1879.

Mexico: Hacienda de la Laguna, near Jalapa, Schiede (Berlin Herb.).

\section{$\sqrt{98 .}$ Panicum neuranthum Griseb.}

Panicum neuranthum Griseb. Cat. Pl. Cub. 232. 1866. "Cuba or. (Wr[ight] 3453); occ., in savanis pr. Hanabana (Wr[ight] a. 1865: forma ascendens, ramosa, foliis planis, spiculis ut in $\alpha$ )." The type specimen, in the Grisebach Herbarium, was collected by Charles Wright in eastern Cuba in 1860 and is numbered " $103=3453$." This is the autumnal form. Another specimen, the second one cited above, was collected in 1865 and is labeled " $\alpha$ forma ascendens ramosa." This specimen is $P$. chrysopsidifolium. $a$

\section{DESCRIPTION}

Vernal form with numerous cespitose, stiff, erect, glabrous culms, 30 to $60 \mathrm{~cm}$. high; sheaths glabrous or ciliate on the margin and usually with a few long hairs at the summit, or the lowermost sparsely ascending-pubescent; blades erect or ascending,

$a$ See Hitchcock, Contr. Nat. Herb. 12: 183. 1909, for a discussion of Wright's Cuba grasses. 
a $\longrightarrow$

glabrous or with a few cilire toward the base, the short basal blades few or wanting, those of the middle culm usually 10 to $15 \mathrm{~cm}$. (sometimes only 5 to $6 \mathrm{~cm}$.) long, 3 to 5 $\mathrm{mm}$. wide; panicles finally long-exserted, 5 to $9 \mathrm{~cm}$. long, narrow, the flexuous branches narrowly ascending, rarely loosely spreading, the branchlets appressed, the short-

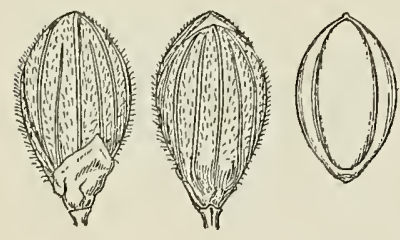

FIG. 170.-P. neuranthum. From type specimen. pediceled spikelets more or less secund along the branches; spikelets $2 \mathrm{~mm}$. long, $1.2 \mathrm{~mm}$. wide, broadly obovate, blunt, the attenuation at base short; first glume about one-third the length of the spikelet, truncate or pointed; second glume and sterile lemma scarcely equaling the fruit at maturity, finely papillose-pubescent; fruit $1.8 \mathrm{~mm}$. long, 1.1 $\mathrm{mm}$. wide, elliptic, puberulent at the subacute apex.

Autumnal form with erect, usually slender culms nearly as tall as the vernal form; blades involute but not stiff, not conspicuously shorter than the vernal blades, 4 to $10 \mathrm{~cm}$. long; spikelets more turgid, the fruit often slightly exceeding the second glume.

Most nearly related to $P$. ovinum, from which the vernal form may be distinguished by the narrower, fewer-flowered panicles with subsecund, slightly smaller spikelets, by the usually taller culms, and by the absence of the comparatively broad basal blades which distinguish the latter; the autumnal form is much taller, with longer, less crowded blades. From $P$. aciculare this is distinguished by absence of pubescence, much longer blades, subsecund spikelets, and an erect autumnal form.

\section{DISTRIBUTION.}

Savannas and open ground, southern Florida, and along the coast to Mississippi; also in the Bahamas and Cuba.

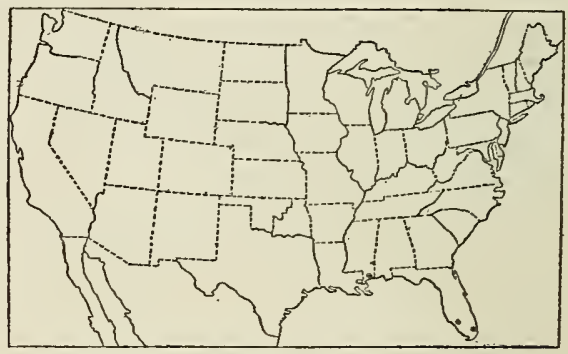

FIG. 171.-Distribution of $P$. neuranthum.

Florida: Miami, Hitchcock, 109, 705, 710; Alligator Harbor, Tracy 7176; Sanibel Island, Simpson 298; Clearwater, Tracy 7166; Braidentown, Tracy 6711; without locality, Rugel 290.

Mississippi: Petit Bois Island, Tracy 4567; Horn Island, Tracy 2859.

Bahamas: New Providence, Britton \& Brace 599 (Field Mus. Herb.).

CuBA: Eastern Cuba, Wright 3453 in part.

Bicknelliana.-Culms few to several in a tuft, glabrous or nearly so; sheaths glabrous or with a few hairs; ligules nearly obsolete; blades somewhat elongated, stiffly ascending or spreading, ciliate at base; panicles few-flowered, with 7-nerved, long-peduncled spikelets 2.5 to $3 \mathrm{~mm}$. long. Autumnal form sparingly branching from the upper or middle nodes.

This group of two species is intermediate in habit between the Depauperata and Dichotoma; the blades are elongated as in the former but the vernal culms and the mode of branching are more like those of the latter.

Spikelets 2.5 to $2.8 \mathrm{~mm}$. long, blades not over $9 \mathrm{~mm}$. wide... 99. P. bicknellii. Spikelets $3 \mathrm{~mm}$. long, blades as much as $12 \mathrm{~mm}$. wide.......100. P. calliphyllum. 


\section{$\checkmark$ 99. Panicum bicknellii Nash.}

Panicum bicknellii Nash, Bull. Torrey Club 24: 193. 1897. "The type specimens were collected by Mr. Eugene P. Bicknell * * * in Bronx Park [N. Y.] on July 21, 1895." The type, in Nash's herbarium, is the early branching form of the plant. The spikelets are sparsely pubescent.

Panicum nemopanthum Ashe, Journ. Elisha Mitchell Soc. 15:42. 1898. "Type material collected by the writer April, 1895, in the Penitentiary woods, Raleigh, N. C." The type could not be found in Ashe's herbarium, but a specimen from the type material labeled in Ashe's handwriting is in the National Herbarium. This is a single vernal culm with an immature, partly included panicle; the spikelets are nearly or quite glabrous.

Panicum bushii Nash, Bull. Torrey Club 26: 568. 1899. "Collected by B. F. Bush, in dry ground, in McDonald Co., Missouri, July 24, 1893 no. 413." The type in the Columbia University Herbarium consists of a small tuft of branching culms, the primary panicles devoid of spikelets; most of the primary nodes sparsely pilose, most of the secondary ones glabrous; the spikelets glabrous.

Although the types of $P$. nemopanthum and of $P$. bushii have glabrous spikelets,

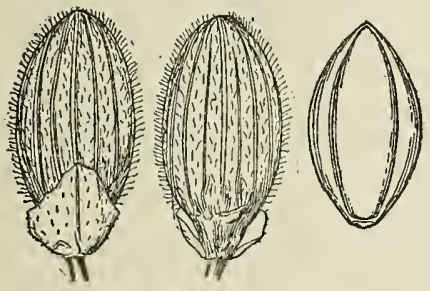

FIG. 172.-P. bicknellii. From type specimen. later collections of the species in the Penitentiary woods, Raleigh (Ashe \& Chase 3092) and from B. F. Bush have pubescent spikelets. These two types are exceptional specimens.

\section{DESCRIPTION.}

Vernal form bluish green; culms erect or ascending, 30 to $50 \mathrm{~cm}$. high, glabrous, or the lowermost portion puberulent, nodes sparsely bearded or glabrous; sheaths glabrous or the lower sparsely villous especially above the nodes; blades stiffly ascending, or somewhat spreading,

elongated, 8 to $15 \mathrm{~cm}$. long, 3 to $8 \mathrm{~mm}$. wide, the uppermost usually longest, narrowed toward the base, there usually ciliate with a few stiff hairs; panicles ovoid, 5 to $8 \mathrm{~cm}$. long, about two-thirds as wide, the branches ascending, bearing few long-pediceled spikelets, these 2.3 to $2.8 \mathrm{~mm}$. long, 1.1 to $1.2 \mathrm{~mm}$. wide, oblong-elliptic, sparsely pubescent or rarelyglabrous; first glume about one-third the length of the spikelet, subacute; second glume and sterile lemma equal, covering the fruit at maturity; fruit $2 \mathrm{~mm}$. long, $1.1 \mathrm{~mm}$. wide, elliptic, subacute.

Autumnal form erect, branching from the middle nodes, forming a loose, bushy crown of stiffly ascending blades not much reduced and overtopping the narrow, few-flowered panicles.

The long upper blades in this species are noticeable. Vernal specimens sometimes resemble $P$. werneri.

One specimen, Bush 3246, has pilose sheaths and scattered long hairs on the blades. Frucle $4530 a$. Aearbam, mich. eane tartir.

Dry, eterile or rocky woods, Connecticut to Georgia and Missouri.

Connecticut: Norwich, Graves 15 in 1899.

New York: Bronx Park, Bicknell

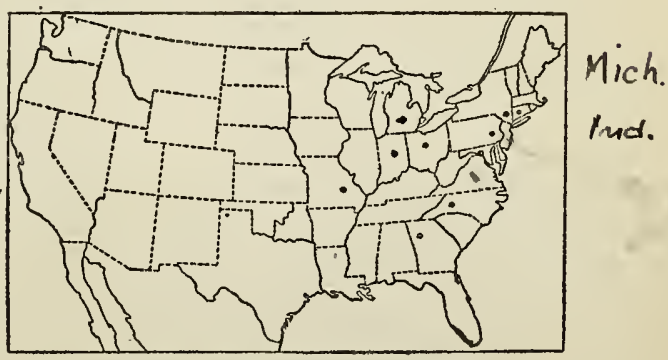

FIG. 173.-Distribution of $P$. bicknellii. in 1895; Cedarhurst, Bicknell in 1903; Rockville Center, Bicknell in 1906; Woodmere, Bicknell in 1904; Rockport, Bicknell 1905.

$41616^{\circ}-\operatorname{vor} 15-10-12$ 
Pennsylvania: Chambersburg, Porter in 1896, 1897, and 1898; Westchester, Windle in 1904.

Онго: Vinton, Kellerman 6887.

Missouri: McDonald County, Bush 413; Eagle Rock, Bush 3246.

Maryland: Plummers Island, Hitchcock 118, Steele in 1897; Great Falls, Chase 3783; West Chevy Chase, Chase 2477 $\frac{1}{2}, 5416$.

District of Columbia: Hitchcock 353.

North Carolina: Raleigh, Ashe in 1895, Ashe \& Chase 3092.

Georgia: Stone Mountain, Hitchcock 201.

\section{Panicum calliphyllum Ashe.}

Panicum calliphyllum Ashe, Journ. Elisha Mitchell Soc. 15: 31. 1898. "Type material collected by the writer at Watkins, Lake Seneca, N. Y., Aug. 1898." The type could not be found in Ashe's herbarium. In the National Herbarium is a specimen collected by Ashe "Near Ithaca, N. Y.," which Mr. Ashe has stated orally is from

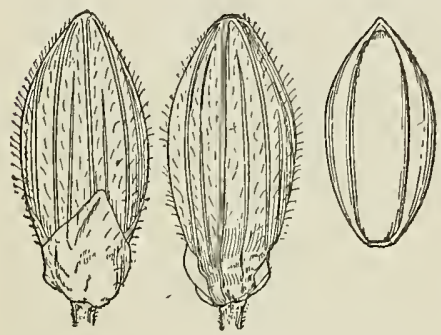

Fig. 174.-P. calliphyllum. From type specimen. the published locality and is a duplicate type. This specimen consists of two vernal culms, lacking basal leaves.

\section{DESCRIPTION}

Vernal form yellowish green; culms erect, 35 to $50 \mathrm{~cm}$. high, glabrous, the nodes sparsely villous; sheaths glabrous, or the lowermost sparingly pubescent, ciliate on the margin; blades ascending, flat, 8 to $12 \mathrm{~cm}$. long, 9 to $12 \mathrm{~mm}$. wide, glabrous, ciliate at the rounded base; panicles fewflowered, 7 to $9 \mathrm{~cm}$. long, half as wide or less, with a few ascending branches; spikelets mostly longpediceled, 2.9 to $3 \mathrm{~mm}$. long, $1.2 \mathrm{~mm}$. wide, elliptic, sparsely pubescent; first glume about one-third the length of the spikelet; second glume and sterile lemma equaling the fruit at maturity; fruit $2.3 \mathrm{~mm}$. long, $1.1 \mathrm{~mm}$. wide, elliptic, subacute.

Autumnal form sparingly branching from the middle nodes, the branches about as long as the internodes, erect; blades not greatly reduced; panicles narrow, partly included.

This little known species has been referred $a$ to $P$. xanthophysum, to small specimens of which the above-mentioned duplicate type bears some superficial resemblance. The species is closely related to $P$. bicknellii. But three specimens have been seen, on none of which is the habitat given.

\section{DISTRIBUTION.}

Massachusetts, New York, and Ohio. Massachusetts: Medford, Perkins in 1881 (N. E. Bot. Club Herb.).

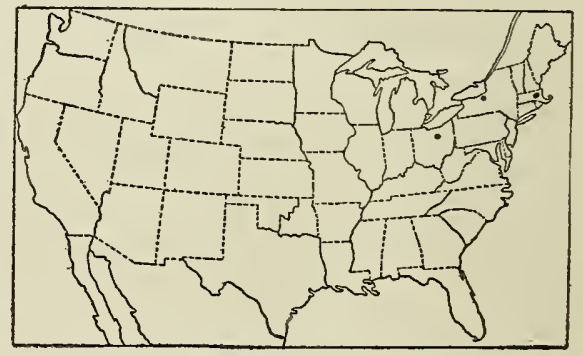

FIG. 175.-Distribution of $P$. calliphyllum.

New York: Near Ithaca, Ashe in 1898.

Онго: Painesville, Hacker in 1901.

a Merrill, Bull. Torrey Club 27 : 595. 1900. 
Nudicaulia.-The following species does not seem to be closely allied with any other, and hence is placed tentatively in a group by itself. So far as the technical characters are concerned it might be placed in the group Dichotoma, but it differs from any of the species of that group in the narrow, enveloping base of the blades, and the nearly naked culms. When the autumnal form is known the affinity of the species may be shown.

\section{o 101. Panicum nudicaule Vasey.}

Panicum nudicaule Vasey, U.S. Dept. Agr. Div. Bot. Bull. 8: 31. 1S89. "Swamps, Santa Rosa County, Fla. (A. H. Curtiss.)" The type, in the National Herbarium,
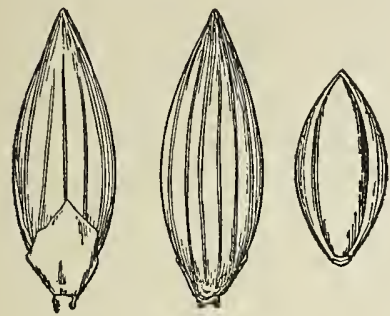

FIG. 176. -P. nudicaule. From type specimen. is the vernal form. It was collected in "Swamps, Santa Rosa County, N. W. Florida," in May [1886] by A. H. Curtiss (no. $3583^{*}$ ).

\section{DESCRIPTION .}

Vernal culms erect from a somewhat spreading base, 40 to $60 \mathrm{~cm}$. high, glabrous, the lower internodes short, the two upper much elongated, thus producing the effect of a long, nearly leafless stem; nodes glabrous, only the upper two visible; sheaths glabrous or the overlapping basal ones sometimes sparsely pubescent; ligules ciliate, less than $0.5 \mathrm{~mm}$. long; blades erect, rather thick, 4 to $10 \mathrm{~cm}$. or some of the lower as much as $13 \mathrm{~cm}$. long, 5 to $8 \mathrm{~mm}$. wide (the uppermost more or less reduced), nearly linear, abruptly pointed, slightly narrowed and somewhat enveloping the culm at base, glabrous; panicles long-exserted, 4 to $7 \mathrm{~cm}$. long, hardly as wide, fewflowered, the branches ascending; spikelets 2.7 to $2.9 \mathrm{~mm}$. long, 1 to $1.2 \mathrm{~mm}$. wide, narrowly ovate, acuminate, glabrous; first glume one-fourth to one-third as long as the spikelet, usually pointed; second glume and sterile lemma 7nerved, exceeding the fruit and pointed beyond it; fruit $2 \mathrm{~mm}$. long, $1 \mathrm{~mm}$. wide, elliptic, acute.

Autumnal form unknown.

\section{DISTRIBUTION.}

Swamps, western Florida and southern Alabama.

\section{FlORIDA: Blackwater River}

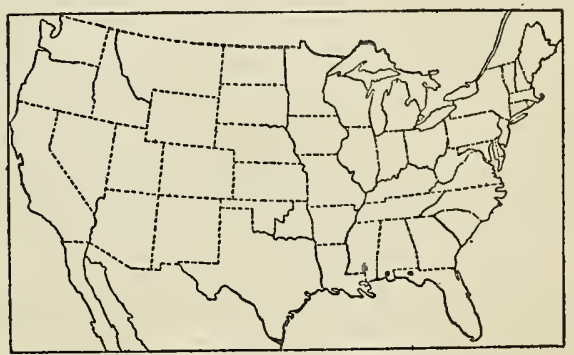

FIG. 177.-Distribution of $P$. nudicaule.

Swamp, Santa Rosa County, Curtiss, B, 3583*.

Alabama: Gateswood, Tracy 8431, 8432.

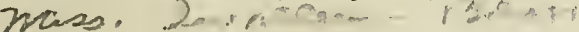

Dichotoma.-Culms few to many in a tuft, glabrous, or the nodes only pubescent; sheaths glabrous, or the lower sometimes pubescent, never conspicuously hirsute; ligules ciliate, $0.7 \mathrm{~mm}$. long or less; blades lanceolate, rarely as much as $1 \mathrm{~cm}$. wide, mostly glabrous; panicles usually open; spikelets elliptical, not turgid (except in P. roanokense and $P$. caerulescens), 1.5 to 2.5 $\mathrm{mm}$. long; second glume and sterile lemma 5 to 7 -nerved. Autumnal form usually freely branching, erect, reclining, or prostrate, secondary leaves and panicles much reduced. 
Nodes, at least the lower, bearded.

Spikelets 1.5 to $1.6 \mathrm{~mm}$. long, glabrous (occasional individuals with pubescent spikelets)..............102. P. microcarpon.

Spikelets $2 \mathrm{~mm}$. or more long.

Spikelets glabrous, $2 \mathrm{~mm}$. long; autumnal form topheavy-reclining......................... Parbulatum. Spikelets pubescent.

Blades all velvety; autumnal form sparingly branched........................105. P. annulum.

Blades glabrous, or only the lower pubescent or velvety; autumnal form freely branching. Spikelets $2 \mathrm{~mm}$. long; autumnal form profusely branching.

Fruits slightly exposed at maturity; upper sheaths viscid-spotted; autumnal form erect or reclining. .103. P. nitidum.

Fruits covered at maturity; sheaths not viscid-spotted; autumnal form decumbent, with flabellate fascicled branches; Mexican.....104. P.multirameum.

Spikelets $2.2 \mathrm{~mm}$. or more long; autumnal form less profusely branching.

Sheaths and upper nodes glabrous...... 107.

Lower sheaths and all nodes pubescent. . 106.

Nodes not bearded.

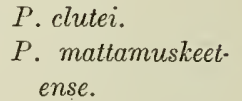

Spikelets pubescent.

Culms erect, never becoming vine-like.

Primary blades spreading; panicles purplish; fruit exposed at summit.................107. P. clutei.

Primary blades erect; panicles green; fruit covered (wood forms with spreading blades may be distinguished from $P$. dichotomum by pubescent spikelets, $2.2 \mathrm{~mm}$. long)....108. P. boreale.

Culms soon prostrate, vine-like; branches divaricate.

Plants bright green, culms lax; spikelets not over $2.1 \mathrm{~mm}$. long....................114. P. lucidum.

Plants grayish green, culms stiff; spikelets 2.5 mm. long........................... P. sphagnicola.

Spikelets glabrous.

Culms soon prostrate.

Plants bright green, culms lax; spikelets not over $2.1 \mathrm{~mm}$. long...................... 114 .

Plants grayish green, culms stiff; spikelets 2.5 $\mathrm{mm}$. long..........................

P. lucidum.

P. sphagnicola.

Culms erect, or the autumnal form topheavy, never prostrate.

Spikelets not over $1.6 \mathrm{~mm}$. long; panicles narrow; plants glaucous bluish green.........113. P. caerulescens.

Spikelets $2 \mathrm{~mm}$. or more long; panicles open.

Blades erect, firm; spikelets turgid, strongly nerved; plants grayish olive green....112. P. roanokense. Blades spreading; spikelets not turgid. 
Spikelets $2.2 \mathrm{~mm}$. or more long, pointed; sheaths bearing pale glandular spots......................111. P.yadkinense.

Spikelets not over $2 \mathrm{~mm}$. long, not pointed.

Autumnal form erect, branched like a little tree; primary blades rarely over $5 \mathrm{~mm}$. wide; second glume shorter than fruit and sterile lemma...... 109. P. dichotomum.

Autumnal form topheavy-reclining; primary blades 6 to $10 \mathrm{~mm}$. wide; second glume equaling fruit and sterile lemma.......110. P. barbulatum.

\section{$\sqrt{ }$ 102. Panicum microcarpon Muhl.}

Panicum microcarpon Muhl.; Ell. Bot. S. C. \& Ga. 1: 127. 1816. No locality is cited. The type, in the Elliott Herbarium, consists of a single culm, lacking the base, with five leaves and an immature panicle, slightly included at the base. The accompanying label reads: "Panicum microcarpon. barbulat: var.? Hab. Georg: Dr. Baldwin." As shown by his description and the above-mentioned type, Elliott misunderstood Muhlenberg's application of this name and attached it to a different species, though giving Muhlenberg as author. Muhlenberg's later publication of the name $a$ for a different species $b$ is thus invalidated.

Panicum nitidum ramulosum Torr. Fl. North. \& Mid. U. S. 146. 1824. "Near Quaker-Bridge, New-Jersey." The type, in the Torrey Herbarium, is a sparingly branched, vernal culm, with nearly mature terminal panicle. The label reads: "Panicum nitidum $\beta$ var. [ $\beta$ is ramulosum] collected in swamps in the pine barrens of New Jersey, near Quaker Bridge, June, 1818."

?Panicum nitidum barbatım Torr. Fl. North. \& Mid. U. S. 146. 1824. "In woods and meadows." The type could not be found in the Torrey Herbarium. The description seems to apply to the vernal form of $P$. microcarpon, or possibly to $P$. barbulatum.

This species is the one described by Muhlenberg $c$ under the name of $P$. discolor Spreng., as shown by a specimen so labeled in the Muhlenberg Herbarium. Panicum heterophyllum Schreb. is here cited as a synonym, erroneously, as Schreber did not publish this name. P. heterophyllum Muhl. $d$ is a nomen nudum.

Panicum microcarpon Muhl. is the species described as $P$. barbulatum by American authors, which proves to be not $P$. barbulatum Michx.

\section{DESCRIPTION.}

Vernal form cespitose; culms erect, or sometimes geniculate at base, 30 or usually 60 to $100 \mathrm{~cm}$. high, the nodes densely bearded with reflexed hairs; sheaths glabrous, or the lowermost pubescent, often mottled with white spots between the nerves, ciliate on the margin; blades thin, spreading, the upper often reflexed, 10 to $12 \mathrm{~cm}$. long, 8 to $15 \mathrm{~mm}$. wide, narrowed toward the base, glabrous, more or less papilloseciliate at base; panicles finally long-exserted, many-flowered, ovate in outline, 8 to $12 \mathrm{~cm}$. long, the branches ascending; spikelets $1.6 \mathrm{~mm}$. long, $0.7 \mathrm{~mm}$. wide, elliptic,

a Descr. Gram. 111. 1817.

$b$ See $P$. microcarpon Muhl. under $P$. polyanthes, page 255.

c Descr. Gram. 114. 1817.

d Trans. Amer. Phil. Soc. 3:160. 1793. 
glabrous, or rarely minutely pubescent; first glume one-fourth the length of the spikelet or less; second glume a little shorter than the sterile lemma and slightly exposing the fruit at maturity; fruit 1.3 to $1.4 \mathrm{~mm}$. long, $0.7 \mathrm{~mm}$. wide, elliptic, slightly pointed.

Autumnal form much branched from all the nodes, reclining from the weight of
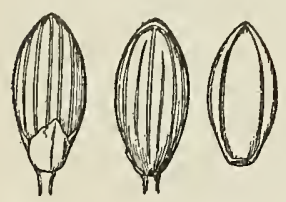

FIG. 178.-P. microcarpon. From type specimen in Elliott Herbarium. the dense mass of branches; blades reduced, flat, mostly 2 to $4 \mathrm{~cm}$. long; the ciliz of the sheaths and the hairs at the base of the blades relatively more conspicuous; panicles much reduced and loosely flowered; the tufted basal blades often large, sometimes as much as $8 \mathrm{~cm}$. long and $15 \mathrm{~mm}$. wide.

The following specimens have pubescent spikelets, but differ in no other respect from the typical form: MassaChusetts: Bartlett 844; Connecticut: Bissell 5570; New Jersey: Heritage 4; Pennsylvania: Smith 102; Illinors: Schneck in 1880; Dela ware: Canby 15; District of ColumBIa: Pollard 408, Vasey in 1884; North Carolina: Biltmore Herb. 803a, Chase 3204; Georgia: Ruth 57; Florida: Curtiss, P. Q.; Alabama: Carver 40, Hitchcock 1343; Mississippi: Tracy 1733, 3388, a 3623; Arkansas: Heller 4237. The last specimen is also exceptional in being pubescent throughout.

Curtiss's no. 6648, McClenny, Florida, with glabrous spikelets as much as $1.8 \mathrm{~mm}$. long, seems to be intermediate between $P$. microcarpon and $P$. nitidum.

\section{DISTRIB UTION}

Wet woods and swampy places, Massachusetts to Illinois, and south to northern Florida and eastern Texas.

Massachusetts: Milton, Bartlett 844.

Connecticut: New Haven, Bissell 5566; Groton, Bissell 5569; Stratford, Bissell 5571; Milford, Bissell 5570.

'Rhode Island: Providence, Collins in 1891 (Gray Herb.).

New York: Eastern New York, Austin (Mo. Bot. Gard. Herb.).

New Jersey: South Amboy, Mackenzie 1484, 2161; Morris Plains, Mackenzie 1605;

Haworth, Mackenzie 2476;

Wildwood, Chase 3516, Heritage 4, 4'; Clifton, Nash in 1892.

Pennsylvania: Lancaster County, Heller 4770 in part, 4787, Small in 1889; Philadelphia, Smith 102.

Oнго: Albion, Asheroft in 1897; Jackson, Kellerman 6778.

Indiana: Brazil, Somes 232.

Illinors: Peoria, Brendel; Mount Carmel, Schneck in 1880.

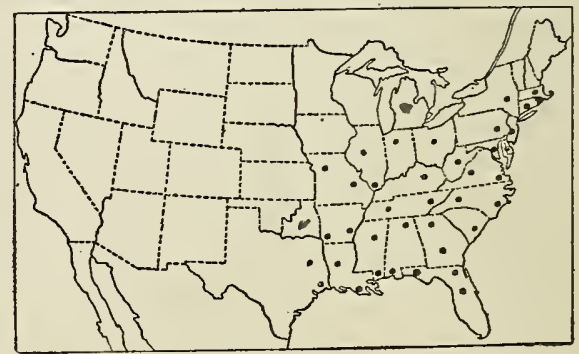

FIG. 179.-Distribution of P. microcarpon.

Missouri: Butler County, Eggert 236; Campbell, Bush 747 in part; Dunklin County, Eggert 287.

Delaware: Milton, Commons 346, 347; Centerville, Commons 285; Townsend, Canby 15.

Maryland: Chesapeake Beach, Chase 3253, 3262; Hitchcock 1606, 1611; Beltsville, Chase 3767, 3831; Riverdale, Chase 2367, 2370.

District of Columbia: Ball 704, Chase 5419, in Kneucker Gram. Exs. 550, Hitchcock 370, 596, Merrill 197, Pollard 362, 406, 408, Vasey in 1884.

a Tracy's no. 3388 was erroneously cited under Panicum subbarbulatum Scribn. \& Merr. U. S. Dept. Agr. Div. Agrost. Circ. 29: 9. 1901. 
VIRGinia: Vicinity of Norfolk, Kearney 1307, Mackenzie 1686, Noyes 93; Dismal Swamp, Chase 3668; Smyth County, Small in 1892.

West Virginia: Baileysville, Morris 1193; Peeryville, Morris 1139.

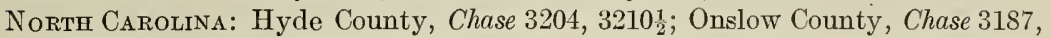
3190; Chapel Hill, Chase 3061 $\frac{1}{2}$; Rowan County, Small in 1894; Biltmore, Biltmore Herb. 803a.

South Carolina: Orangeburg, Hitchcock 1393, 1411, 1419.

Geongia: Clarke County, Harper 74; Stone Mountain, Eggert 89; Thomson, Bartlett 1081, 1457; Whitfield County, Harper 281, Wilson 125, 137; Gwinnett County, Small in 1893; Lookout Mountain, Ruth 57, 64; Augusta, Cuthbert 1161; Warm Springs, Tracy 8865; Leslie, Harper 1105; Rabun County, Small in 1893 .

Florida: Tallahassee, Combs 391, Kearney 88, Nash 2522; Lake City, Combs 173; Madison, Combs 255, 256; Orange County, Combs 1140.

Kentucky: Harlan County, Kearncy 50.

Tennessee: Polk County, Kearney 326 in part; Cocke County, Kearney 967; Carroll County, Eggert 78.

Alabama: Mobile, Mohr in 1892; Jackson County, Chase 4482; Tuskegee, Carver 16, 40; Cullman County, Eggert 15; Auburn, Hitchcock 1343.

Mississippi: Biloxi, Tracy 1733, 3623, 3624, 3761, 4609 in part, 7018; Wahalak, Tracy 3224; Coopolis, Tracy 4595; Fairport, Tracy 3207; Centerville, Tracy 3618; Macon, Tracy 3225; Saratoga, Tracy 8417; Starkville, Phares 3623; Morrisonville, Tracy 3388.

Arkansas: Little Rock, Coville in 1887; nòrthwest Arkansas, Harvey 4, Texarkana, Heller 4237.

Louisiana: Plaquemines Parish, Langlois 40a, 40b; Lake Charles, Chase 4426, Hitchcock 1149; Calhoun, Ball 51.

Texas: Big Sandy, Reverchon 4194; Texarkana, Heller 4088; Rockland, Nealley 36; Waller County, Thurow 18.

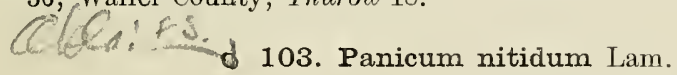

Panicum nitidum Lam. Tabl. Encycl. 1 : 172. 1791. "E Carolina. com. D. fraser." The type, ${ }^{a}$ in the Lamarck Herbarium, consists of a panicle and the uppermost joint of the culm.with its leaf, the blade reflexed, the node sparsely clothed with reflexed hairs. This specimen does not belong to any of the species to which the name $P$. nitidum has been applied by American authors.

Panicum nodiflorum Lam. Encycl. 4: 744. 1798. Lamarck states as to the origin of his specimen, "J'en possède un exemplaire recueilli par M. Fraser dans la Caroline. Le citoyen Michaux l'a trouvée dans la Basse-Caroline." The type, in the Lamarck Herbarium, is a fragment of an autumnal culm with two nodes, at each of which is a fascicle of branchlets with reduced leaves but devoid of spikelets. It is from "Caroline."

Panicum dichotomum nitidum Wood, Class-book ed. 3. 786. 1861. This is presumably based on $P$. nitidum Lam., though no synonym nor locality is cited. The short description seems to apply best to $P$. lindhcimeri Nash.

Panicum subbarbulatum Scribn. \& Merr. U. S. Dept. Agr. Div. Agrost. Circ. 29 : 9. 1901. Based on "(Panicum barbulatum of Ell. Sk. Bot. S. C. and Ga. 1: 127. 1817, not Michx. Fl. Bor. Am. 1: 49. 1803.)" "The type of the species in the herbarium of Elliott" consists of three vernal culms lacking the base.

$a$ For a full discussion see Hitchcock, Contr. Nat. Herb. 12 : 148. 1908. 


\section{DESCRIPTION .}

Vernal form cespitose; culms erect or sornewhat spreading at base, rather stout, usually 30 to $60 \mathrm{~cm}$. high, or sometimes as much as 1 meter high, the nodes bearded with reflexed hairs; sheaths glabrous, or the lower pubescent, ciliate on the margin, more or less mottled or glandular, especially the upper at anthesis; blades firm, glabrous, sometimes sparsely ciliate at the base, 5 to $12 \mathrm{~cm}$. long, 5 to $10 \mathrm{~mm}$. wide, the lower ascending, the upper usually reflexed; panicles ovoid, 5 to $8 \mathrm{~cm}$. long,

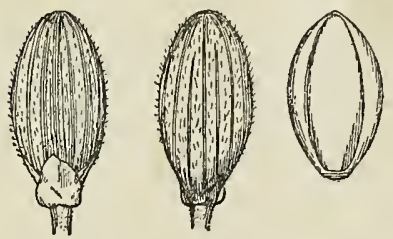

FIG. 180.-P. nitidum. From type specimen. nearly as wide, rather densely flowered, the axis and ascending branches viscid-spotted; spikelets elliptic, $2 \mathrm{~mm}$. long, $1 \mathrm{~mm}$. wide; first glume less than one-third the length of the spikelet, pointed; second glume and sterile lemma subequal, the slightly shorter glume scarcely covering the fruit at maturity; fruit elliptic $1.7 \mathrm{~mm}$. long, $1 \mathrm{~mm}$. wide, subobtuse.

Autumnal form erect or more or less reclining from the weight of the foliage, the branchlets and foliage forming large clusters from the nodes of the vernal culm; reduced blades numerous, 1 to $3 \mathrm{~cm}$. long, 1 to $3 \mathrm{~mm}$. wide, flat or soon becoming involute; panicles mostly reduced to a few long-pediceled spikelets.

This species has been confused with Panicum microcarpon, from which it is distinguished by the pubescent spikelets, $2 \mathrm{~mm}$. long, and by the erect autumnal form with involute blades. The viscid spots on the sheaths are often conspicuous.

Two specimens, Hitchcock 1420 and 1421, while showing all the other characters of this species have glabrous spikelets, but they are fully $2 \mathrm{~mm}$. long.

\section{DISTRIBUTION.}

Low moist or marshy ground from Virginia to Florida and along the coast to Texas; also in the Bahamas.

Missouri: Carter County, Eggert 288.

Virginia: Virginia Beach, Hitchcock 119.

North Carolina: Scranton, Chase 3200.

South Carolina: Orangeburg, Hitchcock 4, 15, 1376, 1389, 1392, 1420,1421, 1422, 1423.

Georgia: Thomson, Bartlett 1173, 1456.

Florida: Milton, Chase 4307, 4321; Madison County, Combs 266; Citrus County, Combs 979, 1008; Lake County, Chase 4091, Hitchcock 814, Nash 376; Sanford, Chase 4132, Hitchcock 774; Titusville, Chase 3990, 4005, 4017; Myers, Hitchcock 898, 908, Lee Co. P1. 478, 479; Miami, Hitchcock 718, Tracy 8850; Homestead, Hitchcock

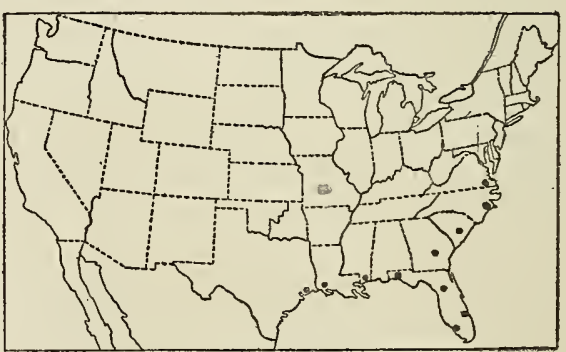

FIG. 181.-Distribution of $P$. nitidum. 687; Captiva Island, Tracy 7199; Sumter County, Curtiss 3600A in parta; Duval County, Curtiss 3600A in part; Sanibel Island, Tracy 7170; Braidentown, Hitchcock 961.

Mississippi: Biloxi, Hitchcock 1081, Tracy 2031, 4591, 4609 in part; Macon, Tracy 3228.

$a$ The specimen of this number in the Gray Herbarium consists of $P$. nitidum and P. equilaterale. 
Louistana: Lake Charles, Hitchcock 1128, 1143, 1148, 1153, 1154.

Texas: Hempstead, Hall 834 in part.

Baнnмas: Great Bahama, Britton \& Millspaugh 2518, 2736, Brace 3697 (all in Field Mus. Herb.).

\section{Panicum multirameum Scribn.}

Panicum multirameum Scribn. U. S. Dept. Agr. Div. Agrost. Circ. 19: 2. 1900. "Gravelly hills near Jalapa, State of Vera Cruz, altitude 1,250 m. (4000 feet). C. G. Pringle 7882, 1889. Orizaba, State of Vera Cruz, February 17, Jared G. Smith, No. 593, 1892." The type, Pringle 7882, in Hitchcock's herbarium, is the autumnal form with decumbent culms and numerous ascending branches, with a few vernal culnins still attached.

\section{DESCRIPTION.}

Vernal culms erect or soon decumbent, 30 to $60 \mathrm{~cm}$. high, nodes villous-bearded; sheaths strongly ciliate on the margin, especially at the summit, the upper glabrous, the lowermost more or less villous; blades rather thick, 3 to $6 \mathrm{~cm}$. long, 3 to $6 \mathrm{~mm}$. wide, glabrous, or rarely puberulent, somewhat ciliate around the base, obscurely

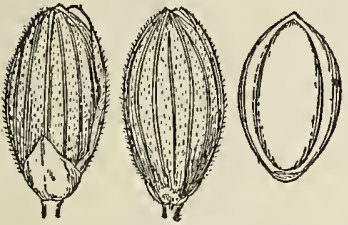

FIG.182.-P.multirameum. From type specimen. white-margined; panicles ovoid, 3 to $6 \mathrm{~cm}$. long, about three-fourths as wide, the branches ascending; spikelets $2 \mathrm{~mm}$. long, $1 \mathrm{~mm}$. wide, elliptic, finely pubescent; first glume one-third the length of the spikelet; second glume and sterile lemma equal and just covering the fruit at maturity; fruit $1.7 \mathrm{~mm}$. long, $0.9 \mathrm{~mm}$. wide, rather abruptly subacute.

Autumnal form decumbent, rooting at thelower nodes, flabellately branching before the maturity of the primary panicle, the branchlets in close, appressed clusters at the ends of the secondary branches; blades reduced, flat or somewhat rolled, appressed; panicles reduced to a few spreading branches or long-pediceled spikelets.

None of the -specimens examined shows a basal rosette of leaves. In technical characters this species is allied to $P$. nitidum but differs in the decumbent, flabellately-branched autumnal form.

\section{DISTRIBUTION.}

Dry hills and gravelly banks, southern Mexico.

Mexico: Jalapa, Pringle 7882, 8339,a 9209, 9210; Orizaba, J. G. Smith 593, Bourgeau 2383 in part (all in Hitchcock's herbarium except Pringle 8339); Botteri 703 in part (Gray Herb.).

Guatemala: Coban, Tuerckheim 56 in part (Gray Herb.).

\section{$\checkmark$ 105. Panicum annulum Ashe.}

Panicum annulum Ashe, Journ. Elisha Mitchell Soc. 15:58. 1898. "Dry rocky woods. Maryland to North Carolina and Georgia. Near Washington, D. C. Ward 1892 ," is the first specimen cited, and is taken as the type. This is in the National Herbarium and consists of three vernal culms with mature panicles. The year of collection is 1882 instead of 1892.

Panicum bogueanum Ashe, Journ. Elisha Mitchell Soc. 16: 85. 1900. Based on "P. annulum Ashe, not P. annulatum A. Rich." 1851.

$a$ Three species were distributed under this number: National Herbarium no. 381990 is $P$. multirameum; $P$. sphaerocarpon is mixed with this species in the specimen of this number in Hitchcock's herbarium; National Herbarium no. 823271 is $P$. olivaceum. 


\section{DESCRIPTION}

Vernal form usually purplish, in small clumps or solitary; culms 35 to $60 \mathrm{~cm}$. high, the nodes densely bearded; sheaths shorter than the internodes, velvety-pubescent
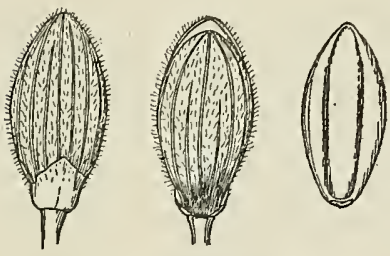

FIG. 183.-P. annulum. From type specimen. or the upper nearly glabrous; blades 6 to $12 \mathrm{~cm}$. long, 7 to $13 \mathrm{~mm}$. wide, densely velvety-pubescent on both surfaces, the margin ciliate toward the base; panicles 6 to $8 \mathrm{~cm}$. long, about three-fourths as wide, rather numerously flowered, the flexuous branches ascending or later spreading; spikelets $2 \mathrm{~mm}$. long, $0.9 \mathrm{~mm}$. wide, elliptic, blunt; first glume one-fourth to one-third the length of the spikelet, obtuse; second glume and sterile lemma pubescent, the glume slighty shorter; fruit 1.8 to $1.9 \mathrm{~mm}$. long, 0.9 $\mathrm{mm}$. wide, elliptic.

Autumnal form erect, bearing in late summer a few short, erect branches at the upper nodes; soon dying to the ground.

\section{DISTRIBUTION.}

Dry woods, New Jersey to Georgia, and west to Mississippi; also in Missouri; rare.

New Jersey: Milburn, Mackenzie 2138.

Pennsyluania: Chester County, Pennell 999, Windle 7; Delaware County, Pennell $621,642,727,1184$.

Missouri: Hunter, Eggert in 1893 (Mo. Bot. Gard. Herb.).

Maryland: West Chevy Chase, Chase 2947, 3809, 5420 .

District of Columbia: Woodley Park, Ward in 1882.

Virginia: Great Falls, Chase 3708.

North Carolina: Chapel Hill, Ashe in 1898.

Georgia: Augusta, Cuthber: 431.

Alabama: Mobile, Mohr in 1897;

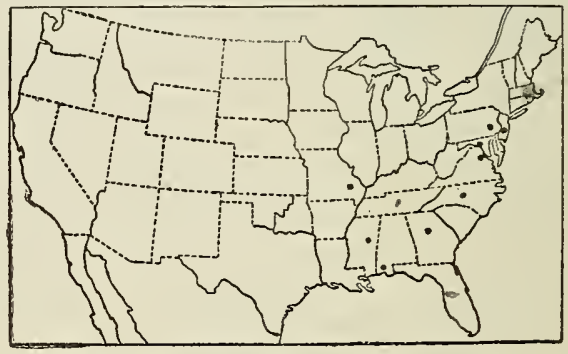

FIG. 184.-Distribution of $P$, annulum. Auburn, Earle \& Baker 1544 (Ala. Polyt. Inst. Herb.).

MississipPI: Starkville, Tracy in 1888.

\section{$\sqrt{ }$ 106. Panicum mattamuskeetense Ashe.}

Panicum mattamuske[e]tense Ashe, Journ. Elisha Mitchell Soc. 15:45. 1898. "Roadsides, ditch banks, and wet open woods around Lake Mattamuskeet, N. C. * * * Collected by the writer, and Mr. Gilbert Pearson in June, 1898." The type could not be found in Ashe's herbarium. In the National Herbarium is a specimen labeled "Panicum Mattamusketense Ashe, Lake Mattamuskeet" in Ashe's handwriting, collected "June 10-July 6, 1898," by "W. W. Ashe," evidently a duplicate type. This is a single vernal culm nearly $80 \mathrm{~cm}$. high, with a mature panicle, and agrees in all respects with the description except that the spikelets are described as glabrous, while those of the specimen are pubescent. The two lower sheaths and lowest blade are velvety pilose; the spikelets are $2.3 \mathrm{~mm}$. long. A second duplicate type in Biltmore Herbarium is a better and more characteristic specimen.

Panicum flexuosum Muhl.; Scribn. \& Merr. U. S. Dept. Agr. Div. Agrost. Circ. 27: 3. 1900, not Retz. 1791. This herbarium name of Muhlenberg is listed and 
referred to $P$. mattamuskeetense Ashe. The species was described by Muhlenberg $a$ immediately after Panicum discolor Spreng., under the heading, "Co-species vel varietas major." The type, in the Muhlenberg Herbarium, is somewhat fragmentary, consisting of a single culm broken into three pieces, but is evidently the same as $P$. mattamuskeetense.

\section{DESCRIPTION.}

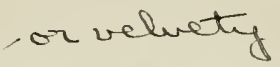

Vernal form in clumps of few to several culms, olivaceous, usually strongly tinged with deep purple; culms stout, erect or subgeniculate at base, the nodes bearded or the upper puberulent only; sheaths less than half the length of the internodes, pilose on the margin, a puberulent ring at the summit, the auricles pilose, the lower sheaths velvety-pilose, the upper glabrous $x$ ligule dense, $0.7 \mathrm{~mm}$. long; blades horizontally spreading, 8 to $12 \mathrm{~cm}$. long, 8 to $12 \mathrm{~mm}$. wide (basal blades much shorter), acuminate, narrowed toward the base, the lower velvety, the upper glabrous, on both surfaces; panicles long-exserted at maturity, 8 to $10 \mathrm{~mm}$., rarely $12 \mathrm{~mm}$. long, about three-

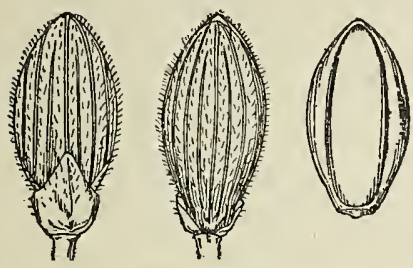

Fig. 185.-P. mattamuskeetense. From duplicate type specimen in National Herbarium. fourths as wide, many-flowered, the flexuous branches spreading, short spikelet-bearing branchlets in the axils; spikelets 2.3 to $2.5 \mathrm{~mm}$. long (rarely $2.7 \mathrm{~mm}$. long), $1.1 \mathrm{~mm}$. wide, elliptic, pointed before maturity, pubescent; first glume about onethird the length of the spikelet, subacute; second glume and sterile lemma subequal, barely covering the fruit at maturity; fruit $2 \mathrm{~mm}$. long, $1 \mathrm{~mm}$. wide, elliptic.

Autumnal form erect or becoming somewhat decumbent, branching rather sparingly from the middle nodes after the maturity of the primary panicles, the branches rather appressed, the reduced crowded blades ascending.

The spikelets at maturity are more turgid, shorter, and more obtuse than when immature, the swelling of the ripened fruit shortening the spikelet in length. In Chase 3744 the spikelets are $2.7 \mathrm{~mm}$. long, while in Chase 3791 from the same place three weeks later the mature spikelets are but $2.4 \mathrm{~mm}$. long, and in Chase 3793 , of the same date as the latter, they are but $2.1 \mathrm{~mm}$. long; the fruits, however, are of the same size, $2 \mathrm{~mm}$. long, the difference in length being due to a varying length of the second glume and sterile lemma.

\section{DISTRIBUTION .}

Low moist ground, New York to North Carolina.

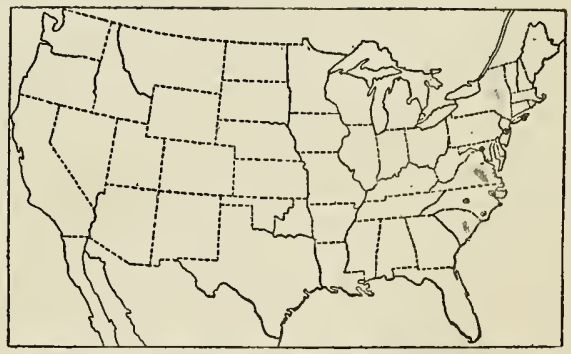

FIG. 186.-Distribution of $P$. mattamuskeetense.

New York: Hempstead, Bicknell in 1903; Woodmere, Bicknell in 1902; Hewletts, Bicknell in 1905; Far Rockaway, Bicknell in 1902.

New Jersey: Anglesea, Brown in 1897 (Phila. Acad. Herb.).

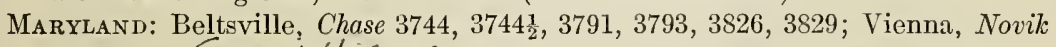
182. Suow tire C 12230,12237

North Carolina: Lake Mattamuskeet, Ashe in 1898; Wilsons Mills, Chase 3099; Wilmington, Hitchcock 354, 1455; Roanoke Island, Chase 3232. 


\section{- 107. Panicum clutei Nash.}

Panicum clutei Nash, Bull. Torrey Club 26: 569. 1899. "Pine-barrens of southern New Jersey. Collected by Mr. W. N. Clute * * * on a trip from Tuckerton to Atsion, July 3-6, 1899." The type, in Nash's herbarium, consists of three stout culms with mature panicles. The lowermost nodes are sparsely bearded, the upper glabrous, the lowermost sheaths sparsely soft-pilose as in the type of $P$. mattamuskeetense. The blades are puberulent or pilose on the auricles and the dense ligule is $0.5 \mathrm{~mm}$. long.

\section{DESCRIPTION.}

Vernal form similar in color, size, and habit to $P$. mattamuskeetense, but more nearly glabrous, only the lowermost nodes, sheaths, and blades velvety, the puberulent ring at the summit of the sheath less dense or wanting; paniclessimilar, on the average
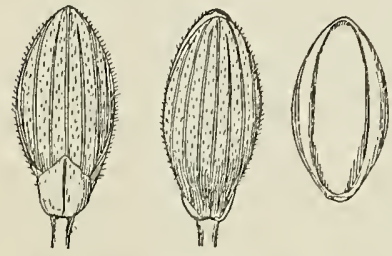

Fig. 187.-P. clutei. From type specimen. smaller; spikelets 2.2 to $2.3 \mathrm{~mm}$. long, $1 \mathrm{~mm}$. wide, indistinguishable from the smaller spikelets of $P$. mattamuskeetense; fruit the same size and shape.

Autumnal form stiffly erect, branching from the lower and middle nodes before the maturity of the primary panicles, the earlier branches nearly equaling the primary culms, the later branches shorter, somewhat crowded, the reduced blades spreading.

This form isıbut doubtfully distinguished from $P$. mattamuskeetense. The division is here made on the nearly glabrous character of $P$. clutei, and spikelets not over $2.3 \mathrm{~mm}$. long, but a few of the specimens are about as referable to one species as to the other. One specimen, Chase 3590 , has the smaller panicles and more numerous branches of $P$. clutei, but the two or three lower sheaths and blades are velvety, while Chase 3793 has spikelets but $2.1 \mathrm{~mm}$. long and upper nodes puberulent only, but is densely velvety below. The latter specimen is referred to $P$. mattamuskeetense because, its vernal form (Chase $3744 \frac{1}{2}$ ) is more like the type of $P$. mattamuskeetense than like that of $P$. clutei. One specimen, Chase 3242 , has glabrous spikelets.

\section{DISTRIBUTION.}

Low moist ground and cranberry bogs, Massachusetts to North Carolina.

Massachusetts: Framingham, Smith 732; West Falmouth, Churchill in 1894 (Hitchcock Herb.).

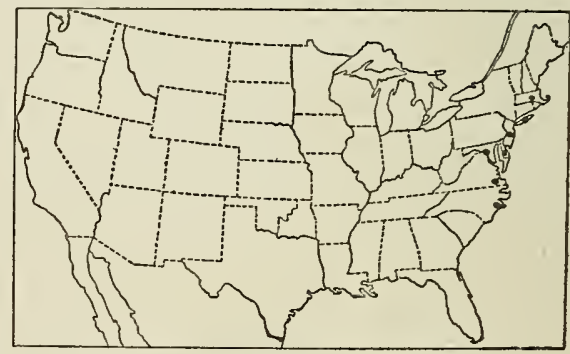

FIG. 188,-Distribution of $P$. clutei.

NeW York: Riverhead, Young in 1874 (Field Mus. Herb.).

New Jersey: Burlington County, Clute in 1899; Toms River, Bicknell in 1900;

Manchester, Chickering in 1877; Atsion, Chase 3545, 3553; Forked River, Chase 3590; Tuckerton, Chase 3598.

Delaware: Ellendale, Commons 345.

District of Columbia: Kenilworth Swamp, Steele in 1899.

Virginia: Bedford County, Curtiss in 1871 (Gray Herb.).

North Carolina: Roanoke Island, Chase 3242. 


\section{$\checkmark$ 108. Panicum boreale Nash.}

Panicum boreale Nash, Bull. Torrey Club 22: 421. 1895. "Moist soil, Newfoundland and Ontario to New York, Vermont and Minnesota. This plant was first noted by the writer in 1893 in the Catskill Mts., near Cairo, N. Y." The type in Nash's herbarium consists of several vernal culms with nearly mature panicles; the lower sheaths sparsely papillose-pubescent at least toward the summit, the lower and middle nodes bear a few reflexed hairs. The label reads: "Panicum boreale Nash., n. sp. Moist soil, Cairo, Greene Co., N. Y. Alt. $1400 \mathrm{ft}$. Coll: Geo. V. Nash, June 28, 1893."

\section{DESCRIPTION.}

Vernal form cespitose, the culms erect, or in shaded places sometimes decumbent at base, usually 30 to $50 \mathrm{~cm}$. high, the nodes glabrous or sometimes with a few hairs; sheaths often overlapping, ciliate on the margin, glabrous, or the lower sparsely pubescent; blades erect, or in laxer forms spreading, sparsely ciliate at the rounded base, otherwise glabrous, 6 to $12 \mathrm{~cm}$. long, 7 to $12 \mathrm{~mm}$. wide; panicles loosely rather fewflowered, 5 to $10 \mathrm{~cm}$. long, hardly as wide, the branches ascending or spreading;

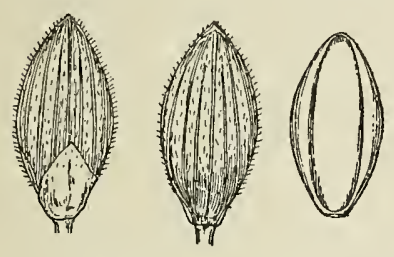

FIG. 189.-P. boreale: From type specimen. spikelets 2 to $2.2 \mathrm{~mm}$. long, $1 \mathrm{~mm}$. wide, elliptic, subacute, pubescent; first glume one-third as long as the spikelet or less; second glume and sterile lemma subequal, the glume scarcely as long as the fruit at maturity; fruit $1.9 \mathrm{~mm}$. long, $1 \mathrm{~mm}$. wide, elliptic, subacute.

Autumnal form erect, sparingly branched from all the nodes in late summer, the branches erect, the leaves and panicles not greatly reduced.

A weak form with geniculate base and lax spreading blades occurs in Maine, and is represented by Fernald 512 and 516, and Chase 3355. One specimen, Chase 3437 , is unusual in having blades that are puberulent beneath. Two specimens from northern Indiana, $B e b b$ 2030 and 2831, and a specimen from Wisconsin, Cheney 2100, have stouter culms and more compact and more numerously flowered panicles. A specimen from Detroit, Mich., Farwell 1425, is referred to this species doubtfully because of the pubescence on the back of the joint between the blade and the sheath and because of the sparse papillose-pubescence on the under surface of the blades and on some of the sheaths. It resembles $P$. mattamuskeetense in habit, but the nodes are glabrous and it is far out of the range of that species. A specimen from Rockville Center, Long Island, Bicknell in 1903, is doubtfully referred here.

\section{DISTRIBUTION.}

Moist open ground or woods, Newfoundland to New Jersey and west to northern Indiana and Minnesota.

Newfoundland: Exploits River, Robinson \& Schrenk 222.

Nova Scotia: Windsor, Macoun 29349; without locality, Burgess 16.

New Brunswick: Fredericton, Fowler in 1892; Miramichi, Fowler in 1892.

Quebec: Montmorenci Falls, Macoun 69204 (Gray Herb.).

MaIne: Dover, Fernald 239, 514; Orono, Fernald 513, 516, 517; Holden, Knight 60, 61; North Berwick. Parlin 1029, 1187; Brownsville, Parlin 1701, 1738, 1744; Canton, Parlin 2013, 2034; St. Francis, Fernald 505, Knight 58; Farm, ington, Fernald 512; Hartford, Parlin 1423; Cumberland, Chamberlain 336793; Cape Elizabeth, Chase 3458; Chesterville, Chase 3277, 3355, 3437, 3443; Mount Desert Island, Redfield in 1893. 
New Hampshire: Jaffrey, Hitchcock 120, Robinson 338, 338a; White Mountains, Hitchcock 121.

Vermont: Brattleboro, Jones 33.

Massachusetts: Framingham, Smith 733; South Hadley, Cook in 1887.

Connecticut: Southington, Bissell 5582; Griswold, Graves 77; Waterford, Graves 82.

New York: Cairo, Nash in 1893; Fulton Chain, Peck 2, 2a, 3.

Ontario: A Imonte, Fowler in 1898; Algonquin Park, Macoun 22022 .

New Jersey: Budds Lake, Mackenzie 2093; Cranberry Lake, Mackenzie 2109.

Оніо: Wauseon, Kellerman in 1899 (Ohio State Univ.).

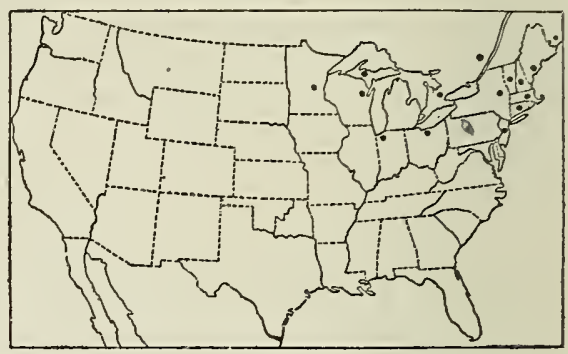

FIG. 190.-Distribution of $P$. boreale.

Indiana: Gibson, Bebb 2935, Hill 97 in 1908; Griffith, Hill 50 in 1909.

Michigan: Keweenaw County, Farwell 643; shore of Lake Superior, Wood in 1884. Wisconsin: Tomahawk, Cheney 2100; Newbold, Cheney 1700; Granite Heights, Cheney 3088.

Minnesota: Hennepin County, Sandberg in 1890 (Univ. Minn. Herb.).

$$
\checkmark \text { 109. Panicum dichotomum L. Fonde phame }
$$

Panicum dichotomum L. Sp. P1. 58. 1753. "Habitat in Virginia." Since Linnæus gives no description of his own, but quotes the diagnosis from Gronovius's Flora Virginica, ${ }^{a}$ the type of this species is Clayton no. 458 which is the specimen cited by Gronovius, $b$ and upon which his diagnosis is based. This specimen, preserved in the Gronovius Herbarium, is the autumnal form answering well to Gronovius's characterization, "vix pedale, in arbusculae formam excrescens." The specimen in the Linnæan Herbarium $c$ collected by Kalm is $P$ microcarpon $222,342,18 / 8$

Panicum angustifolium I.eC. in Torr. Cat. PI. N. Y. 91. 1819, not Ell. 1816. No specimen nor locality is cited. A vernal specimen in the Torrey Herbarium penciled "angustifolius (nitid. var)" but without data may be the type.

Panicum tremulum Spreng. Neu. Entd. 2: 103. 1821. "Panicum n. 39. Mühlenb. gram. p. 127.* In Nova Caesarea." [The * indicates a new species.] No locality is cited by Mublenberg, and this number does not now exist in the Muhlenberg Herbarium. In the Sprengel Herbarium is a specimen consisting of a vernal culm with mature panicle, which bears a label "Panicum tremulum Spr. Hb. Spr. Torrey." A second label reads "Panicum tremulum* Mühlenb. gram. p. 127." Though no locality is given this specimen is doubtless the basis of the locality cited by Sprengel, and may be considered his type, since he gives a description and had not seen Muhlenberg's plant.

Panicum dichotomum viride Vasey, U. S. Dept. Agr. Div. Bot. Bull. 8: 30. 1889. No locality nor specimen is cited. The diagnosis reads "Smooth all over, leaves light green and narrower." In the National Herbarium are four specimens marked "var.

a Fl. Virg. 2 : 133. 1743.

$b$ See Hitchcock, Contr. Nat. Herb. $12: 127.1908$, for an account of the grasses of Gronovius's Flora Virginica.

$c$ See Hitchcock, Contr. Nat. Herb. $12: 114.1908$, for an account of the American grasses in the Linnæan Herbarium. 
viride Vasey" in Vasey's handwriting. Of these a vernal specimen collected by L. F. Ward, Woodley Park, Washington, D. C., 1881, is chosen as the type, since it is entirely without pubescence, while the other specimens marked "var. viride" by Vasey have pubescent spikelets or nodes, or are fragmentary.

Panicum dichotomum divaricatum Vasey, U. S. Dept. Agr. Div. Bot. Bull. 8: 30 . 1889. No specimen nor locality is cited. There are in the National Herbarium two specimens of the autumnal form of $P$. dichotomum marked "var. divaricatum" by Vasey. Of these, S. M. Tracy 127, Lake, Mississippi, is chosen as the type, since the other specimen is nearly devoid of spikelets. Certain other specimens marked by Vasey do not correspond to the description.

Panicum nitidum pauciflorum Britton, Trans. N. Y. Acad. 9:14. 1889. Based on "P. dichotomum var. pauciflorum Vasey in Columbia College Herbarium." The type is labeled "Panicum, Shady moist grounds, July" and consists of several sparingly branched culms of $P$. dichotomum with small panicles. Vasey's herbarium name had not been published.

Panicum nitidum viride Britton, Trans. N. Y. Acad. 9 : 14. 1889. Based on P. dichotomum viride Vasey.

Panicum dichotomum commune Wats. \& Coulter in A. Gray, Man. ed. 6. 633. 1890. No specimen nor locality is cited. The name as published is "(a) commune" and was probably meant to designate the common vernal form. No specimen marked "var. commune" could be found in the Gray Herbarium.

Panicum ramulosum viride Porter, Bull. Torrey Club 20: 194. 1893. Presumably based on $P$. dichotomum viride Vasey, since "(Vasey)" is given after the varietal name.

\section{DESCRIPTION.}

Vernal form often purplish; culms 30 to $50 \mathrm{~cm}$. high, erect, from a knotted crown, the nodes naked or the lower with a few spreading hairs; sheaths less than half the length of the internodes, sometimes ciliate on the margin, otherwise glabrous, or the lowermost rarely sparingly pubescent; blades spreading, 5 to $11 \mathrm{~cm}$. long, 4 to $8 \mathrm{~mm}$. wide, acuminate, slightly narrowed toward the base, glabrous on both surfaces, sometimes with a few long hairs on the margin at the base, the basal blades lanceolateovate, long-ciliate on the margin near the base; pani-
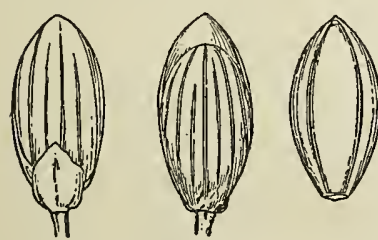

FIG.191.-P.dichotomum. From type specimen in Gronovius Herbarium. cles long-exserted, 4 to $9 \mathrm{~cm}$. long, the axis and spreading branches flexuous, spikelet-bearing toward the ends; spikelets $2 \mathrm{~mm}$. long, $0.9 \mathrm{~mm}$. wide, elliptic, glabrous or rarely pubescent; first glume one-third the length of the spikelet, subacute; second glume and sterile lemma rather faintly nerved, the glume shorter than the fruit at maturity; fruit $1.8 \mathrm{~mm}$. long, $0.9 \mathrm{~mm}$. wide, elliptic.

Autumnal culms much branched at the middle nodes, the lower portion usually erect and devoid of blades, thus giving the plants the appearance of diminutive trees as described by Gronovius and Linnæus; blades much reduced and very numerous, often involute.

This common and widely distributed species can be distinguished by its lack of pubescence, its smooth spikelets, $2 \mathrm{~mm}$. long, and its erect autumnal form.

A few specimens, such as Hitchcock 1292, Pollard 323, and Ward in 1881, from Washington, D. C., which show all the other characters of $P$. dichotomum have pubescent spikelets. 
DISTRIBUTION.

Dry or sterile woods, New Brunswick to Michigan and south to northern Florida and eastern Texas.

New Brunswick: Bass River, Fowler.

Maine: Mount Agamenticus, Parlin 1266, Ricker 1309.

New Hampshire: Walpole, Fernald 406.

Vermonr: West Rutland; Eggleston 1759.

MassachuseTts: Framingham, Smith 736. - lucidurm?

Connecticut: Greens Farms, Pollard 16; Bridgeport, Eames in 1895; Oxford, Harger in Kneucker. Gram. Exs. 245.

New York: Long Island, Bicknell in 1905; Oxford, Coville in 1884; Washington County, Burnham 13.

Ontario: Galt, Herriot 13.

New Jersey: Morris County, Mackenzie 1405, 2280; Cranberry Lake, Mackenzie 2106.

Pennsylvania: Easton, Porter in 1895, 1897, and 1898; Lancaster County, Heller 4769, 4783; York County, Rose \& Painter 8134; Mountainville, Pretz 1936.

OHIo: Berlin Heights, Moseley in 1895; Lancaster, Kellerman 6768; Sugar Grove, Kellerman 6891.

Indiana: Dune Park, Chase 1919, Umbach 1789; Miller, Chase 1543; Lafayette, Dorner 83.

IllinoIs: Cobden, Waite in 1885.

Michigan: Port Huron, Dodge in 1899 and 1909; Grand Beach Springs, Hill 84 in 1908.

Missouri: St. Francois County, Eggert 246.

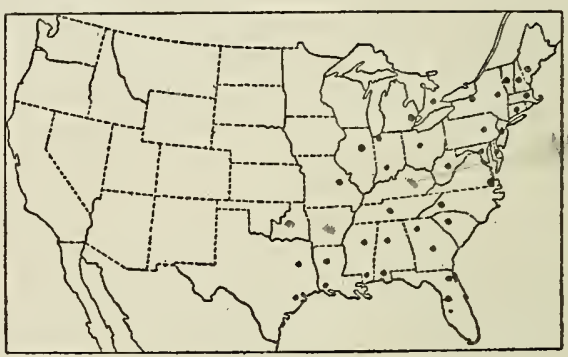

FIG. 192.-Distribution of $P$. dichotomum.

Delaware: Wilmington, Commons 297; Centerville, Commons 294, 295.

Maryland: Riverdale, Chase 2379, House 949; High Island, Pollard 324; Great Falls, Chase 2315.

District of Columbia: Hitcheock 122, 357, Kearney 5, 25, Williams 6, 8, 9 .

Virginia: Four-Mile Run, Hitchcock 358, Norfolk County, Kearney 300 in part, 1374, Noyes 73, 75, 97; Dismal Swamp, Chase 3657.

West Virginia: Wyoming County, Morris 1193a; Fayette County, Morse in 1903.

North Carolina: Chimney Rock Mountain, Biltmore Herb. 800c; Biltmore, Biltmore Herb. 800a in part; Blowing Rock Mountain, Small \& Heller 480; Chapel Hill, Chase 3048, 3056 2 .

South Carolina: Aiken, Kearney 234; Pickens County, Anderson 1201; Orangeburg, Hitchcock 1400, 1403; Graniteville, Cuthbert 962.

Georgia: Clark County, Harper 95; Albany, Tracy 3616, 3649; Rowe, Canby 219; Stone Mountain, Eggert 441 , 46, Hitchcock 1352; Pigeon Mountain, Wilson 179; Alcovey Mountain, Small in 1893.

Florida: Duval County, Curtiss 3600A in part, Kearney 147; Waldo, Combs 687 in part; Orange Bend, Chase 4100.

Tennessee: Knoxville, Scribner in 1890; Polk County, Chambliss 39, 77, Kearney 329.

Alabama: Auburn, Tracy 3757, Hitchcock 1330; Flomaton, Tracy 3625 in part; . Cullman County, Eggert 20. 
Missrssippi: Starkville, Tracy 1755; Enterprise, Tracy 3273; Meridian, Tracy 3253; Fairport, Tracy 3204, 3209; Nicholson, Kearney 367, 384; Biloxi, Tracy 2028, 2050.

Loursiana: Calhoun, Hitchcock 1262, 1292; Shreveport, Hitchcock 1240, 1246, 1251; 1 2 5 2; Calcasieu, Langlois 42 in 1884.

Texas: Hardin County, Nealley in 1892 ; Beaumont, Reverchon 4155, 4158. Qlola, FS.

\section{$\sqrt{ }$ 110. Panicum barbulatum Michx.}

Panicum barbulatum Michx. Fl. Bor. Amer. 1: 49. 1803. "Hab. in Carolina." In the Michaux Herbarium $a$ is a sheet upon which are three specimens and two labels. One label reads "Panicum barbulatum Hab. in Canada $\mathrm{P}$. capillari affine. Ad ripas amnis: Rivierre a Jacques Cartier dicti legi," the other "Rivierre a Jacques Cartier Route a Queb. P. barbulatum." The two larger plants are the vernal form of the species described below, and do not belong to the species to which the name $P$. barbulatum has been heretofore applied in our Manuals. $b$ The third plant upon this sheet is a small specimen of $P$. lindheimeri Nash. The only Carolina specimen from Michaux labeled $P$. barbulatum is one in the Drake de Castillo Herbarium sent out by Richard. This is labeled "Caroline," but since the specimen, which is P. ashei, has glabrous nodes, and hence does not agree with Michaux's description, it is rejected and the above specimens with bearded nodes from Canada are chosen as the type.

Panicum dichotomum barbulatum Wood, Class-book ed. 3. 786. 1861. This is presumably based on P. barbulatum Michx., though no synonymy is cited. The description given applies to $P$. microcarpon.

Panicum pubescens barbulatum Britton, Cat. Pl. N. J. 280. 1889. Presumably based on $P$. barbulatum Michx., no synonymy nor description being given.

Panicum nitidum barbulatum Chapm. Fl. South. U. S. ed. 3.586. 1897. Based on $P$. barbulatum Michx., though the description applies to $P$. microcarpon.

Panicum gravius Hitchc. \& Chase, Rhodora 8: 205. 1906. "Type Chase 3620; forming top-heavy tufts, in sandy, rather dry woods, on the old Commons farm, between Centreville and Mt. Cuba, Delaware, July 30, 1906; collected by Agnes Chase. Deposited in National Herbarium."

The name barbulatum is misspelled "barbatum" by Persoon, $c$ and "barbatulum"

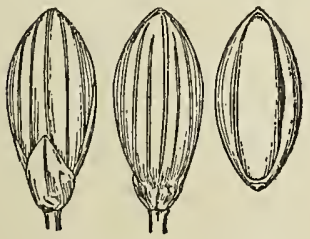

FIG. 193.-P. barbulatum. From type specimen. by Roemer and Schultes, $d$ the latter spelling being given by SteudeI $c$ under $P$. boscii (page 253), $P$. deustum (page 255 ), and $P$. sphaerocarpon (page 263).

\section{DESCRIPTION.}

Vernal form in large tufts; culms slender, 50 to $80 \mathrm{~cm}$. high, erect, or spreading at the summit, lower nodes usually bearded; sheaths glabrous except a puberulent ring at the summit, the lower usually softly pubescent; blades spreading, 6 to $10 \mathrm{~cm}$. long, 6 to $10 \mathrm{~mm}$. wide (the lower shorter), acuminate, rounded at the base, glabrous, the lower rarely puberulent; panicles long-exserted, 6 to $11 \mathrm{~cm}$. long, as wide or wider, the slender, flexuous branches fascicled, the lower spreading or drooping at maturity, spikelet-bearing at

$a$ See Hitchcock, Contr. Nat. Herb. 12 : 143. 1908, for an account of the American grasses in the Michaux Herbarium.

$b$ See $P$. microcarpon, page 181 .

c Syn. Pl. $1: 84.1805$.

$d$ Syst. Veg. $2: 447.1817$.

$e$ Nom. Bot. ed. $2.2: 253,255,263.1841$.

$$
41616^{\circ} \text { - vou } 15-10-13
$$


the ends; spikelets oval, $2 \mathrm{~mm}$. long, $1 \mathrm{~mm}$. wide, glabrous; first glume one-fourth to one-third as long as the spikelet, acute; second glume and sterile lemma equal, covering the fruit at maturity; fruit elliptic, $1.8 \mathrm{~mm}$. long, $1 \mathrm{~mm}$. wide, obscurely apiculate.

Autumnal form diffusely branched, forming very large, topheavy reclining bunches, the slender branchlets recurved, the numerous flat blades horizontally spreading.

Closely allied to $P$. dichotomum $\mathrm{L}$., from which it differs in the vernal form in having usually wider blades and bearded lower nodes and fruit covered by the equal second glume and sterile lemma; the autumnal form is distinguished by the large topheavy reclining tufts.

\section{DISTRIBUTION.}

Sterile or rocky woods, Massachusetts to Michigan and south to Georgia and eastern Texas.

Massachusetts: Malden, Frohoch in 1879 (N. E. Bot. Club Herb.).

Connecticut: Southington, Andrews 18, Bissell 5577; Groton, Graves 12.

New York: St. Albans, Bicknell in 1905.

New Jersey: South Amboy, Mackenzie 1548.

Pennsylvania: Easton, Porter in 1895; Lancaster County, Heller 4776.

Онго: Vinton, Kellerman 6886.

Indiana: Dune Park, Hill 129 in 1906; Clarke County, Deam 6577; Brown County, Deam 6467a.

Michigan: Port Huron, Dodge in 1899; Park Lake, Wheeler 17 (both in Hitchcock Herb.).

Missouri: Eagle Rock, Bush 148; Monteer, Bush 2877, 3529, 4733; Swan, Bush 3369, 3456A, 4473; Pleasant Grove, Bush 313, 720; Howell County, Bush 51; Chadwick, Bush 4458.

Dela ware: Wilmington, Canby 10 in 1891; Centerville, Chase 3620, Commons 296.

Maryland: Riverdale, Chase 3643; Lanham, Chase 3484; Chesapeake Junction, Hitchcock 1641, 2411; Beltsville, Chase 3747, 3758; High Island, Pollard 323.

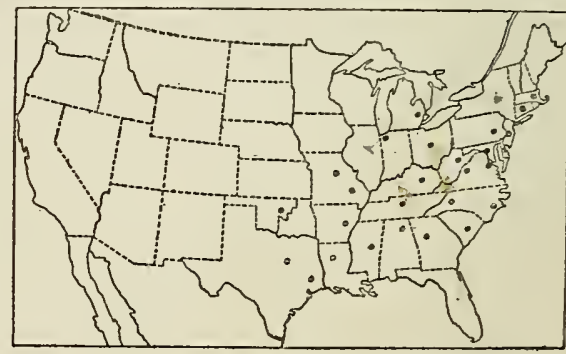

FIG. 194.-Distribution of P. barbulatum.

District of Columbia: Hitcheock 123, 125, Kearney in 1897.

VIrginia: Smyth County, Small in 1892; Arlington, Hitchcock 124; Clifton Forge, Tidestrom 22.

West Virginia: Fayette County, Kellerman 6903.

North Carolina: Biltmore, Biltmore Herb. 800a in part; Caraleigh Junction, Chase 3090; Wards Mill, Chase 3188.

South Carolina: Orangeburg, Hitchcock 360, 1416.

Georgra: Stone Mountain, Chase 4519, Hitchcock 359, 1350.

Kentucky: Harlan County, Kearney 35 in part, 57 in part.

Tennessee: Nashville, Gattinger in 1884 (Univ. Tenn. Herb.).

Alabama: Pisgah, Chase 4469; Scottsboro, Chase 4502.

Mississippi: Saratoga, Tracy 8403.

Arkansas: Benton County, Plank 9, 10a, 41; Fulton, Bush 2532.

Louisiana: Shreveport, Cochere $350 \mathrm{z}$

Texas: Houston, Plank 93; Mineola, Reverchon 4147.

OKLaнoma: Poteau, Hitcheock in 1903 (Hitchcock Herb.).

$$
1252 \text { is P. direhotomum }
$$




\section{Panicum yadkinense Ashe.}

? Panicum dumus Desv. Opusc. 88. 1831. "Habitat in America calidiori." The type, in the Desvaux Herbarium, is a fragment of a branch of some species in this group. The immature, glabrous spikelets, $2.3 \mathrm{~mm}$. long, the second glume and sterile lemma pointed beyond the fertile lemma, suggest $P$. yadkinense, though it may be $P$. barbulatum, the pointed spikelets being due to immaturity and withering.

Panicum maculatum Ashe, Journ. Elisha Mitchell Soc. 15:44. 1898, not Aubl. 1775. "Collected by the writer at Raleigh, N. C., May, 1895." The type of this could not be found in Ashe's herbarium. In the National Herbarium is a specimen labeled in Ashe's handwriting, "Panicum maculatum, Raleigh, May, 1895" which is probably a duplicate type. This plant belongs to the species here described though it does not agree in all respects with the original description of Panicum maculatum. The spikelets are there said to be $\frac{7}{8}$ lines long, and "about the size of those of $P$. barbulatum" [P. microcarpon of this monograph], and the species is said to be distinguished from $P$. dichotomum by the smaller spikelets. The specimen from Raleigh has spikelets larger than those of $P$. dichotomum, being about $2.5 \mathrm{~mm}$. long. Since this specimen belongs to the species as understood by Ashe, it is probable that the description of the spikelets was based upon an admixture of $P$. microcarpon, as the two species are frequently found growing together.

Panicum yadkinense Ashe, Journ. Elisha Mitchell Soc. 16: 85. 1900. Based on "P. maculatum Ashe, not P. maculatum Aubl."

\section{DESCRIPTION.}

Vernal form similar to that of $P$. dichotomum but culms taller and stouter, sometimes 1 meter high; sheaths usually bearing pale, glandular spots; blades 9 to $13 \mathrm{~cm}$. long, 8 to $11 \mathrm{~mm}$. wide, panicle about 10 to $12 \mathrm{~cm}$. long, about three-fourths as wide, the long lower branches ascending; spikelets 2.3 to $2.5 \mathrm{~mm}$. long, $1 \mathrm{~mm}$. wide, elliptic to subfusiform, pointed, glabrous; first glume about one-third the length of the spikelet, usually blunt; second glume and sterile lemma rather faintly nerved, equal, exceeding the fruit and forming a slight point beyond it; fruit $1.9 \mathrm{~mm}$. long, $0.9 \mathrm{~mm}$. wide, elliptic, subobtuse.

Autumnal form erect or leaning, loosely branching from the middle nodes, the blades smaller but not conspicuously reduced.

This species differs from $P$. dichotomum in the vernal form in its larger size and longer, acute spikelets, and in the autumnal form in the com-
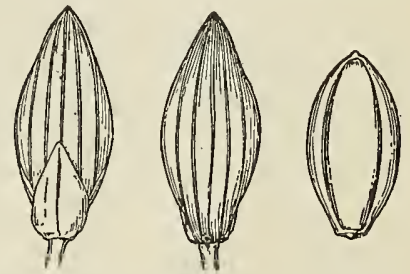

Fig. 195.-P. yadkinense. From duplicate type specimen of $P$. maculatum Ashe in National Herbarium.

paratively few branches, which do not form a bushy crown. Occasionally the branches are rather numerous, though not closely fascicled and bushy, for example, Harper 1349, and Porter from Pennsylvania in 1895. The following two specimens, Chase 3072 and Hitchcock 1416, are referred to this species, though the spikelets are scarcely over $2 \mathrm{~mm}$. long; that is, the second glume and sterile lemma do not extend into a point as in typical spikelets.

DISTRIBUTION.

Moist woods and thickets, Pennsylvania to Georgia, west to southern Illinois and Louisiana.

Pennsylvania: Easton, Portcr in 1895.

Illinors: Makanda, Gleason in 1903; Johnson County, Schneck in 1902 (Hitchcock Herb.). 
Dela ware: Wilmington, Chase 3616.

Maryland: Little Falls, Vasey in 1884; Cabin John, Chase 2853, 3772; West Chevy Chase, Chase 2946, Hitchcock 361.

District of Colvmbia: House 911, Kearney 28 in part.

Virginia: Arlington, Chase 2964.

North Carolina: Raleigh, Ashe in 1895, Chapel Hill, Chase 3059, 3061, 3072; Jacksonville, Chase 3192.

South Carolina: Orangeburg, Hitchcock 6, 1416 $\frac{1}{2}$.

Georgia: Dublin, Harper 1349.

Tennessee: Sumner County, Gat-

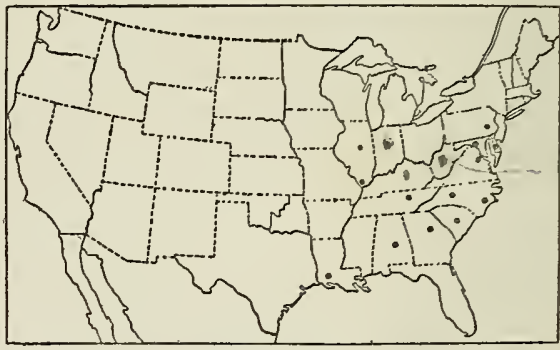

FIG. 196.-Distribution of $P$. yadkinense. tinger in 1883 (Univ. Tenn. Herb.).

Alabama: Tensaw, Tracy 8029.

Louisiana: Lake Charles, Hitchcock 1164.

Mexices. Puebla, nicabar.

\section{o 112. Panicum roanokense Ashe.}

Panicum roanokense Ashe, Journ. Elisha Mitchell Soc. 15: 44. 1898. "Type material collected by writer in dry soil, Roanoke Island, N. C. June, 1898. Also collected at Rose Bay and Mackleyville, N. C., the same month." The type could not be found in Ashe's herbarium. In the Biltmore Herbarium is a specimen from Manteo, Roanoke Island, N. C., collected by Ashe, June 10, 1898, and labeled by him Panicum roanokense Ashe. This is a duplicate type or possibly the type. It consists of two vernal culms with mature primary panicles.

Panicum curtivaginum Ashe, Journ. Elisha Mitchell Soc. 16: 85. 1900. "Collected at Petit Bois Island, Mississippi, May 8, 1898 by S. M. Tracy." An unnounted specimen of the collection cited was found in a cover marked "P. curtivaginatum sp. nov." in Ashe's herbarium. No name was written on the Tracy label, which bears the number 4584. As this was the only specimen of this collection found in Ashe's herbarium it is taken as the type. It consists of a tuft of three slender vernal culms with over-mature panicles. The autumnal form is not represented, but in a specimen
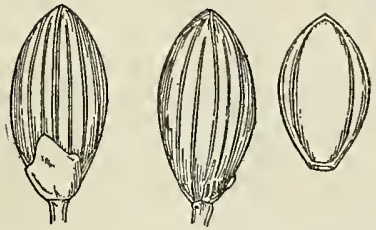

FIG. 197.-P. roanokense. From specimen collected by Ashe at Rose Bay. of Tracy 4584 in the National Herbarium the autumnal culms of the previous year are attached to the tuft. The spikelets are described as "quite $1.5 \mathrm{~mm}$." long, but they measure $2 \mathrm{~mm}$.

\section{DESCRIPTION}

Vernal form cespitose, somewhat glaucous olive green; culms erect or ascending, 50 to $100 \mathrm{~cm}$. high; sheaths half as long as the internodes or less, gla,brous, or the lowermost sometimes sparsely pubescent; blades at first stiffly erect, later ascending or spreading, 6 to $9 \mathrm{~cm}$. long, 3 to $8 \mathrm{~mm}$. wide, tapering to both ends, glabrous or with a few hairs around the base; panicles 4 to $8 \mathrm{~cm}$. long, scarcely as wide, the branches spreading; spikelets $2 \mathrm{~mm}$. long, $1 \mathrm{~mm}$. wide, ellipsoid-obovoid, very turgid, glabrous; first glume about one-third the length of the spikelet; second glume and sterile lemma strongly nerved, subequal, the glume rather conspicuously purple-tinged at base, scarcely covering the fruit at maturity; fruit $1.6 \mathrm{~mm}$. long, $0.9 \mathrm{~mm}$. wide, ellipsoid.

Autumnal form erect or decumbent, branching at the middle and upper nodes, the branches numerous but not in tufts, the primary internodes elongating and becoming 
arched about the time the branches appear; the reduced blades more or less involute, not exceeding the 1.5 to $4 \mathrm{~cm}$. long panicles; basal blades firm, erect, often as much as 5 or $6 \mathrm{~cm}$. long.

The plant is glabrous throughout with exceptions mentioned; the glaucous olive green color and very turgid spikelets, purple-stained at base, are characteristic.

Harper's number 458, from Sumter County, Georgia, is doubtfully referred to this

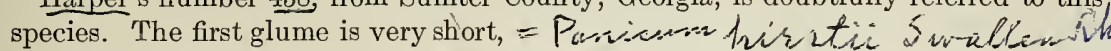
the panicle narrow with few, appressed branches, and the blades are long and narrow.

\section{DISTRIBUTION.}

Open swampy woods or wet peaty meadows, southeastern Virginia to Florida and west to eastern Texas.

\section{Oel.}

Virginia: Near Norfolk, Kearney 1514, 2026.

North Carolina: Rose Bay, Ashe

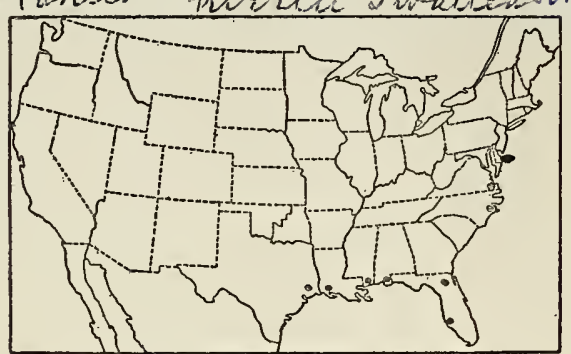

FIG. 198.-Distribution of $P$. roanokense.

in 1898; Lake Mattamuskeet, Chase 3203; Roanoke Island, Chase 3240, 3247; Wards Mill, Chase 3178.

Florida: Baldwin, Combs 60, Hitchcock 987, 998; Mabel, Curtiss 6636; Tampa, Hitchcock 938 $\frac{1}{2}, 939$.

Alabama: Flomaton, Tracy 3625 in part.

Mississippi: Petit Bois Island, Tracy 4584, Ocean Springs, Tracy 4592.

Louisiana: Lake Charles, Hitchcock 1144.

Texas: Waller, Hitchcock 1174.

\section{$\checkmark$ 113. Panicum caerulescens Hack.}

Panicum caerulescens Hack.; Hitchc. Contr. Nat. Herb. 12: 219. 1909. "The type is Hitchcock 706. In glade among Spartina, etc., stretching up through the tall grass, Miami, Florida, April 3, 1906, U. S. National Herbarium no. 558380." This specimen consists of two tufts, some of the culms beginning to branch and with overmature primary panicles, and some freely branching.

\section{DESCRIPTION.}

Vernal form similar to that of $P$. roanokense; culms more slender, rarely over $75 \mathrm{~cm}$. high; blades ascending or spreading, commonly purplish beneath, 5 to $8 \mathrm{~cm}$. long, 4 to $7 \mathrm{~mm}$. wide, the margins nearly parallel for two-thirds their length; panicles usually short-exserted, 3 to $7 \mathrm{~cm}$. long, half as wide or less, the branches narrowly ascending;

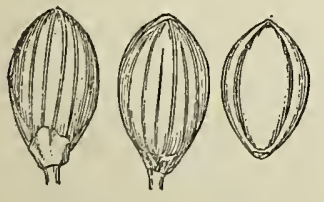

Fig. 199.-P. cacrulescens. From type specimen. spikelets 1.5 to $1.6 \mathrm{~mm}$. long, $0.9 \mathrm{~mm}$. wide, obovoid, blunt, very turgid, glabrous; first glume about one-third the length of the spikelets; second glume and sterile lemma subequal, the glume scarcely as long as the fruit at maturity; fruit $1.4 \mathrm{~mm}$. long, $0.8 \mathrm{~mm}$. wide, ellipsoid.

Autumnal form erect or leaning, sometimes decumbent at base, producing short, densely fascicled branches at the middle and upper nodes, these tufts scarcely as long as the primary internodes, the reduced blades ascending, more or less involute, the reduced panicles with a few long-pediceled spikelets.

This species is distinguished from $P$. roanokense by the narrow panicles and smaller spikelets and by the tufted branches of the autumnal form. 


\section{DISTRIBUTION.}

In marshes and swampy woods, southeastern New Jersey to Florida, west to Mississippi; also in the Bahamas and Cuba.

New Jersey: Cape May, Stone in 1909.

Vrrginia: Lynn Haven, Chase 5417, Hitchcock 356.

Florida: Levy County, Combs 803; Titusville, Chase 3992; Miami, Hitchcock 706, 715; Homestead, Hitchcock 690; Braidentown, Hitchcock 965; Myers, Hitchcock 897, 904, 915.

Alabama: Fort Morgan, Tracy 8401.

Mississippi: Horn Island, Tracy in 1903.

Bahamas: New Providence, Britton \& Brace 597, 599, Millspaugh 2182, Northrup 248; Great Bahamas, Brace 3524, Britton \& Millspaugh 2506, 2668; Andros, Brace 7015 (all in

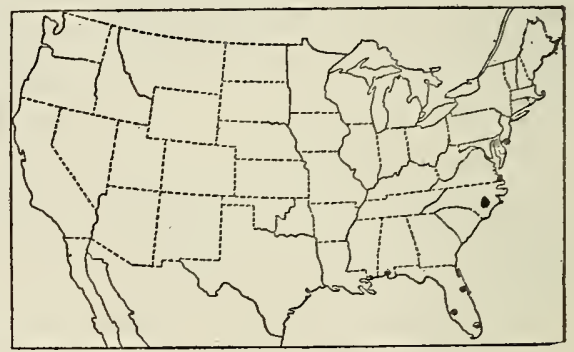

Fig. 200.-Distribution of $P$. caerulescens.

Field Mus. Herb.); New Providence, Eggers 4305 (Hackel Herb.), Eggers 4312 (Krug \& Urban Herb.).

Cuba: Without locality, Wright 3463 in part.

\section{Panicum lucidum Ashe. face teha se}

Panicum lucidum Ashe, Journ. Elisha Mitchell Soc. 15:47. 1898. "Collected in June 1898 by the writer in deep, shady swamps bordering Lake Mattamuskeet, N. C." There is no specimen in Ashe's herbarium from the type locality, but there is a specimen of the vernal form in the National Herbarium collected by Ashe in 1898 at Lake Mattamuskeet. This specimen is either the type or a duplicate type. The label is in Ashe's handwriting.

Panicum taxodiorum Ashe, Journ. Elisha Mitchell Soc. 16:91. 1900. "Type: K. K. McKenzie's no. 460. Hummocks in cypress swamps. Lake Charles, La., September 1890." The type, in Ashe's herbarium, is a specimen passing from the vernal to the autumnal form and showing the early branching condition.

\section{DESCRIPTION.}

Vernal form at first erect and resembling that of $P$. dichotomum, but the weak culms soon becoming decumbent, sometimes rooting at the lower nodes; sheaths glabrous, usually ciliate on the margin; blades thin, bright green, shining, glabrous, at first

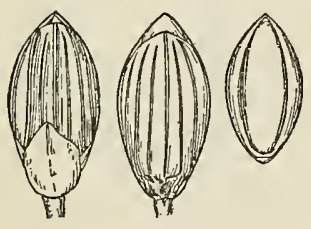

FIg. 201.-P. lucidum. From type specimen in National Herbarium. erect, but soon widely spreading, 4 to $7 \mathrm{~cm}$. long, 4 to $6 \mathrm{~mm}$. wide; panicles resembling those of $P$. dichotomum but fewer-flowered; spikelets 2 to $2.1 \mathrm{~mm}$. long, $1 \mathrm{~mm}$. wide, elliptic, glabrous (rarely obscurely pubescent); first glume about two-fifths the length of the spikelet, pointed; second glume and sterile lemma more strongly nerved than in $P$. dichotomum, both shorter than the fruit at maturity; fruit $1.7 \mathrm{~mm}$. long, $0.9 \mathrm{~mm}$. wide, slightly pointed.

Autumnal form repeatedly branching, forming large clumps or mats of slender, weak, vine-like culms, the branches elongated and diverging at a wide angle, not fascicled, the blades 2 to $4 \mathrm{~cm}$. long, waxy, flat and spreading; panicles much reduced, with few long-pediceled spikelets; basal blades linear-oblong, as much as $10 \mathrm{~cm}$. long.

Under a lens the oblong epidermal cells are visible between the nerves in the blades, especially on the lower surface, giving a minutely bullate surface characteristic of this species and of no other in this group. 


\section{DISTRIBUTION.}

Wet woods and sphagnum swamps, along the Coastal Plain from New York to Florida and wiest to eastern Texas.

NEw YoRk: Woodmere, Bicknell in 1902; Hempstead, Bicknell in 1903.

New Jersey: Speedwell, Stone 7; Wildwood, Pollard in 1897; Tuckerton, Chase 3599; Forked River, Chase 3593; Atsion, Chase 3550, 3554; South Amboy,

\section{Pe Mackenzie 2167.}

INDIANA: Dúné Park, Umbach 4962.

Delaware: Ogletown, Canby 11.

Maryland: Beltsville, Chase 3743; Lanham, Chase 3475.

District of Columbia: Chase 5418, Greene in 1908, Kearney in 1897, Pollard 403, Scribner in 1894, Steele in 1899.

Virginia: Fort Myer, Williams in 1898; Lynn Haven, Hitchcock 364.

North Carolina: Wilmington, Chase 3112, 3159, Hitchcock 365, 367, 368, 369, 1442, 1470, Kearney 260; Jacksonville, Chase 3197 ; Lake Mattamuskeet, Ashe in 1898; Rowan County, Small in 1894; Biltmore, Biltmore Herb. $5066 \mathrm{~b}$, Hitchcock 362 .

South Carolina: Aiken, Kearney 288 in part, Orangeburg, Hitchcock 363, 366.

Georgia: Clarke County, Harper 88; Randolph County, Harper 1760; Thomson, Bartlett 1136; Augusta, Cuthbert 529.

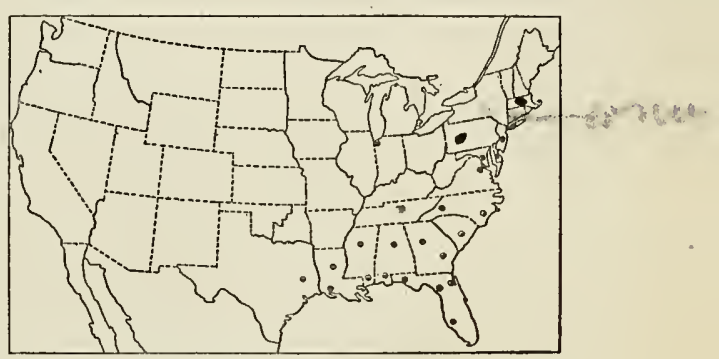

FIG. 202.-Distribution of P. lucidum.

Florida: Jacksonville, Curtiss 6601; eastern Florida, Palmer 632 in 1874; Lake City, Hitchcock 1026; Argyle, Curtiss 6403; Apalachicola, Biltmore Herb. 800b; Milton, Chase 4320; Washington County, Combs 615; Waldo, Combs 687 in part; Homosassa, Combs 934; Eustis, Chase 4068, Nash 337, 500; Bartow, Dere Combs 1218; Myers, Hitchcock 919, Lee Co. Pl. 481.

Átabain: Auburn, Pollard \& Maxon 54, Tracy 3749; Flomaton, Hitchcock 1059; Mobile, Kearney 45.

Mississippi: Taylorville, Tracy 8405; Magee, Trc cy 8504; Waynesboro, Kearney 167; Ocean Springs, Tracy 95.

Louisiana: Oberlin, Ball 202; Lake Charles, Mackenzie 460.

Texas: Colmesneil, Nealley 35 in 1892.

In the herbarium of the Philadelphia Academy is a specimen said to be from Brazil which appears to be $P$. lucidum.

\section{O 115. Panicum sphagnicola Nash.}

Panicum sphagnicolum[cola] Nash, Bull. Torrey Club 22:422. 1895. "The late and much branched state was collected by the writer this summer in a sphagnum bog at Lake City, Florida, and will be distributed as No. 2500." The type, in Nash's herbarium, consists of several culms 45 to $55 \mathrm{~cm}$. high, with long internodes and divaricate branches; the primary panicle is devoid of spikelets, the secondary panicles are small and few-flowered. There are three sheets of this collection in Nash's herbarium, none of which is marked type. The foregoing refers to the largest specimen. 


\section{DESCRIPTION.}

Vernal form grayish olive green, cespitose; culms slender, strongly flattened, erect, or reclining, 50 to $100 \mathrm{~cm}$. high; sheaths glabrous or the lowermost sparsely papillosepilose, soon becoming divaricate and enveloping the internodes only at base; blades at first erect, later widely spreading, glabrous, 5 to $8 \mathrm{~cm}$. long, 3 to $7 \mathrm{~mm}$. wide; panicles
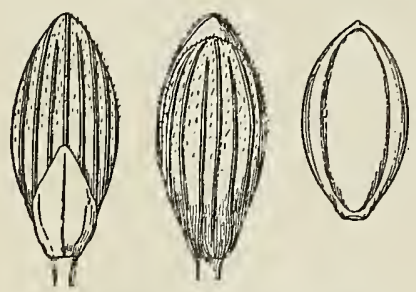

Fıa. 203.-P. sphagnicola. From type specimen. narrow, 5 to $6 \mathrm{~cm}$. long, the branches ascending or somewhat spreading, not spikelet-bearing at the base; spikelets $2.5 \mathrm{~mm}$. long, $1.1 \mathrm{~mm}$. wide, elliptic; first glume nearly half the length of the spikelet, subacute; second glume and sterile lemma strongly nerved, minutely pubescent toward the summit or glabrous, the glume shorter than the fruit; fruit $2 \mathrm{~mm}$. long, 1 to $1.1 \mathrm{~mm}$. wide, elliptic, subobtuse.

Autumnal form decumbent or finally prostratespreading, divaricately branching from all the nodes, the branches slender and elongated, sometimes rooting at the nodes; sheaths divaricately spreading from the stem, usually nearly as long as the blades; blades flat, reduced in length but not much in width, mostly 1 to $2 \mathrm{~cm}$. long, or on the ultimate branchlets only $5 \mathrm{~mm}$. long and $1 \mathrm{~mm}$. wide; panicles rather few, reduced to a few short-pediceled spikelets; basal blades 4 to $8 \mathrm{~cm}$. long, about $1 \mathrm{~cm}$. wide, sometimes sparsely pilose at base.

This species is readily distinguished in the autumnal form by its slender, widelyspreading branches and divaricate sheaths. At this stage the primary sheath may subtend two branches, each with its conspicuous prophyllum, 5 to $15 \mathrm{~mm}$. long, ciliate on the keels and bearing a tuft of hairs at the acuminate tip. The leaf of the second branch is much reduced and inclosed in the base of the primary sheath. Panicum lucidum, the only other species with a like autumnal habit, is much more slender, more leafy, and bright green and shining, and has smaller long-pediceled spikelets.

\section{DISTRIB UTION.}

Edges of cypress swamps, in sphagnum bogs, and in similar moist, shady places, southern Georgia and Florida.

Georgia: Darien, Biltmore Herb. 5066 e (Biltmore Herb.).

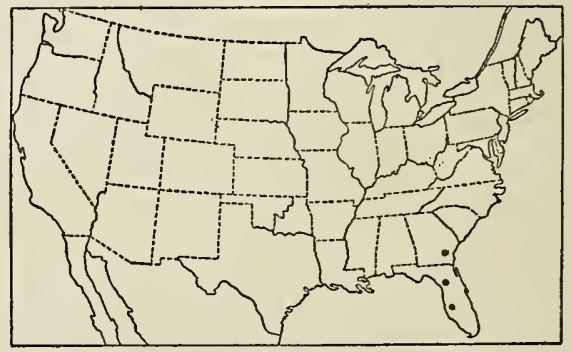

FIG. 204.-Distribution of P. sphagnicola.

Florida: Lake City, Bitting 18, Combs 73, Hitchcock 1006, Nash 2500; Sanford, Chase 4039; Levy County, Combs 838; eastern Florida, Palmer 633 in 1874 (Gray Herb.).

Spreta.-Culms tufted, rather stiff, mostly glabrous or nearly so; ligules densely hairy, 3 to $5 \mathrm{~mm}$. long; blades not over $8 \mathrm{~mm}$. wide; spikelets 1 to $1.6 \mathrm{~mm}$. long, pubescent or rarely glabrous, second glume and sterile lemma 5 to 7 nerved. Autumnal form with more or less tufted branchlets and much reduced leaves and panicles.

Panicle narrow, one-fourth to one-third as wide as long.....116. P. spretum.

Panicle open, two-thirds as wide as long, or more.

Spikelets $1.5 \mathrm{~mm}$. long . . . . . . . . . . . . . . . . . . 
Spikelets $1.3 \mathrm{~mm}$. long or less.

Culms and sheaths glabrous..................119. P. longiligula-

tum.

Culms and sheaths appressed-pubescent.

Spikelets 1.2 to $1.3 \mathrm{~mm}$. long...............118. P. leucothrix.

Spikelets not over $1 \mathrm{~mm}$. long. ..............120. P. wrightianum.

$\checkmark$ 116. Panicum spretum Schult.

wowt bettare

Panicum spretum Schult. Mant. 2 : 248. 1824. Based on "Mühlenb. Descr. ub. p. 125. n. 37. (sine nomine)." Muhlenberg's description is copied, but slightly rearranged, and the locality "N. Anglica" also copied. The type specimen, in the Muhlenberg Herbarium, is a vernal culm labeled "No. 2. Panicum an capillare? In moist ground. Mon. 184. M. 116a." On the folio "N. Angl." is written after this number.

Panicum nitidum densiflorum Rand \& Redfield, Fl. Mt. Desert 174. 1894. "Shore of Ripples Pond (Rand)." The type, in Rand's herbarium, collected July 28, 1892, has a narrow many-flowered panicle with pubescent spikelets like the abovementioned plant in the Muhlenberg Herbarium.

Panicum eatoni Nash, Bull. Torrey Club 25: 84. 1898. Collected by "Alvah A. Eaton ** * at Seabrook, N. H." The type, in Nash's herbarium, consists of two vernal culms with spikelets measuring 1.5 to $1.6 \mathrm{~mm}$. long.

Panicum octonodum Smith, U. S. Dept. Agr. Div. Agrost. Bull. 17 : 73.f. 369. June 30, 1899. "Texas." This species was republished $a$ with more complete description as "Panicum octonodum Scribn. \& Smith, sp. nov.," with the following citation: "Waller County, Texas. Collected by F. W. Thurow, May 5, 1898." The type, in the National Herbarium, is a wholly glabrous vernal plant with glabrous spikelets $1.5 \mathrm{~mm}$. long.

Panicum paucipilum Nash, Bull. Torrey Club 26:573. 1899. "Type collected by Mr. E. P. Bicknell, at Wildwood, New Jersey, May 30 and 31, 1897." The type, in Nash's herbarium, consists of four vernal culms, beginning to branch at the middle nodes, the sheaths sparsely ciliate toward the summit, the spikelets pubescent, 1.4 to $1.5 \cdot \mathrm{mm}$. long. Panicum paucipilum was described as differing from $P$. eatoni in having "much smaller spikelets with the first scale glabrous."

Panicum nitidum octonodum Scribn. \& Merr. U. S. Dept. Agr. Div. Agrost. Bull. 24: 34. 1901. Based on P. octonodum Smith.

Panicum spretum has been referred to Panicum nitidum Lam. and was discussed by Scribner $b$ in an article on that species. Scribner, however, based his identification of the latter upon a tracing made by A. H. Baldwin of a specimen in the Michaux Herbarium. The type of $P$. nitidum Lam. $c$ is in the Lamarck Herbarium and is different from $P$. spretum. The plant from which Baldwin's tracing was made is $P$. angustifolium or a closely allied species. $d$

\section{DESCRIPTION}

Vernal culms tufted, 30 to $90 \mathrm{~cm}$. high, erect or slightly decumbent at base, sometimes sending out rootlets from the lower nodes, glabrous, the nodes swollen; sheaths loose, shorter than the internodes, usually ciliate on the margin toward the summit, otherwise glabrous, or the lower sometimes slightly pubescent; ligules 2 to $3 \mathrm{~mm}$. long; blades firm, ascending or often reflexed, 7 to $10 \mathrm{~cm}$. long, 4 to $8 \mathrm{~mm}$. wide, sparingly

$a$ U. S. Dept. Agr. Div. Agrost. Circ. 16:5. July 1, 1899.

$b$ U. S. Dept. Agr. Div. Agrost. Bull. 24 : 31.1901.

c See p. 183.

$d$ See Hitchcock, Contr. Nat. Herb. 12 : 148. 1908. 
long-ciliate at the rounded base, otherwise glabrous; panicles 8 to $12 \mathrm{~cm}$. long, onefourth to one-third as wide, rather densely flowered, the branches ascending or appressed, short spikelet-bearing branchlets in the axils; spikelets 1.4 to $1.6 \mathrm{~mm}$. (usually $1.5 \mathrm{~mm}$.) long, 0.7 to $0.9 \mathrm{~mm}$. wide, elliptic, obscurely pointed; first glume one-fourth to one-third the length of the spikelet, obtuse or subacute; second glume and sterile lemma equaling the fruit at maturity, pubescent or rarely glabrous; fruit $1.3 \mathrm{~mm}$. long, 0.7 to $0.8 \mathrm{~mm}$. wide, elliptic, slightly pointed.

Autumnal form more or less reclining, branching after the maturity of the primary panicle, the earlier branches elongated, ascending but not appressed, bearing exserted
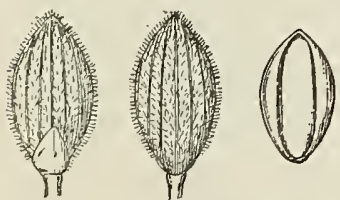

F1r. 205.-P. spretum. From type specimen in Muhlenberg Herbarium. panicles, the subsequent branchlets in short fascicles, the blades much reduced, sometimes minutely pubescent, overtopping the small ultimate panicles; winter rosette appearing rather early, the blades glabrous or nearly so.

Specimens with spikelets $1.4 \mathrm{~mm}$, or even $1.3 \mathrm{~mm}$. long, occur. The type of $P$. paucipilum Nash is such a specimen, as are Chase 2333 and Hitchcock 553. In the herbarium of the Philadelphia Academy are a number of such specimens, some with spikelets only $1.3 \mathrm{~mm}$. long. But since no other character can be correlated with the smaller spikelets, and since specimens with spikelets $1.5 \mathrm{~mm}$. long are much more numerous, we are unable to separate specifically the extremes of this species.

It does not seem advisable to recognize as a subspecies the form with glabrous spikelets. Besides the Texas plants, in which the spikelets are glabrous, similar specimens have been collected in Delaware, namely, Canby 4, Commons 340, and Hitchcock 553. The Commons specimen consists of two plants, one with glabrous and one with pubescent spikelets, but otherwise alike.

\section{DISTRIBUTION.}

Wet and usually sandy soil, mostly near the coast, Maine to Texas; also in northern Indiana.

Maine: York County, Fernald 510.

New Hampshire: East Kingston, Eaton in 1898 (Biltmore Herb.).

Massachusetrs: Essex County, Conant in 1881; Dedham, Bartlett 807.

Connecticut: Waterford, Graves 80, 87; East Lyme, Graves 157.

Rhode Island: Kingston, Piper in 1907.

New York: Riverhead, Bicknell in 1905, Peck 4.

New Jersey: Atsion, Chase 3551, 3569; Bear Swamp, Stone 2; Wildwood, Bicknell in 1897.

Pennsyluania: Westchester, Windle 2 (Hitchcock Herb.).

Indiana: Dune Park, Hill 128 in 1906, Umbach 1799; Miller,

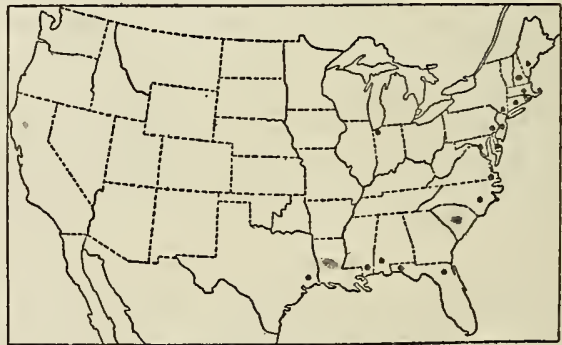

FIG. 206.-Distribution of $P$. spretum. Pepoon in 1898; Michigan City, Hill 162 in 1906.

Delaware: Cape Henlopen, Commons 340; Townsend, Canby in 1891; Milton, Commons 348; Lewes, Hitchcock 553.

Maryland: College Park, Novik in 1907.

Virginia: Cape Henry, Chase 2333, 5421; Lynn Haven, Hitchcock 378, 379.

North Carolina: Wilsons Mills, Chase 3093. 


\section{DIS'TRIBU'TION.}

Dry sandy or sterile woods or open ground, Maine to northern Florida, and west to southern California.

Maine: North Berwick, Parlin 1607 (Gray Herb.).

New Hampshire: Summers Falls, Eggleston in 1893 (Biltmore Herb.).

Vermont: Willoughby, E. \& C. E. Faxon in 1896.

MassachuserTs: Framingham, Smith 734.

Connecticut: Southington, Andrews 14, Bissell 5583; East Lyme, Graves 158; Franklin, Graves 76.

New York: Bergen, Hill 1831 in 1907; Long Point, Bicknell in 1906; Mineola, Bicknell in 1906; Mambasset Neck, Bicknell in 1908; Long Island, Bicknell in 1902 and 1905.

Ontario: Niagara Falls, Macoun 26338; Ottawa, Macoun 65370; Port Colborne, Macoun 26316; Sarnia, Dodge 49.

New Jersey: Clifton, Nash in 1892; Forked River, Chase 3589; Atsion, Chase 3528, 3572, Commons 68, 70; Wildwood, Heritage in 1897; South Amboy, Mackenzie 2156, 2160, 2164, 2168, 2349.

Pennsylvania: Ridley, Smith 157.

OHio: Ashtabula County, Kellerman in 1888 (Ohio State Univ. Herb.).

Indiana: Miller, Umbach 2353.

Illinois: Chicago, Nelson in 1899; Beach, Umbach 2242; Urbana, Seymour in 1880; St. Clair County, Eggert 237; Jackson County, French in 1871 in part.

Michigan: Port Huron, Dodge in 1909.

Wisconsin: Witches Gulch, Cheney 3872 .

Minnesota: Sandy Beach, MacMillan \& Sheldon 1703 (Univ. Minn. Herb.).

Missouri: Allenton, Kellogg 1, 4, 5; Cliff Cave, Kellogg 10; St. Louis, Hitchcock 552.

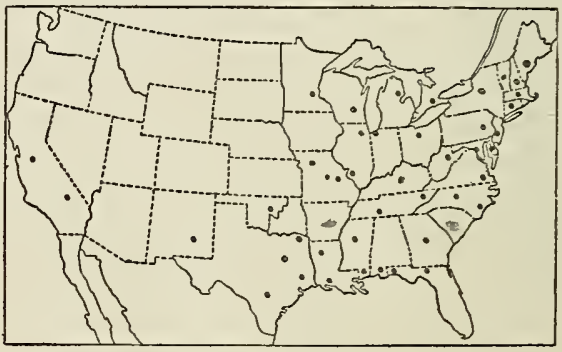

FIG. 208.-Distribution of $P$. lindheimeri.

Dela ware: Wilmington, Canby 13, Commons 55, 64, 67, 71, 291, 363; Ogletown, Commons 66; Millsboro, Commons 42; Newport, Canby 3.

Maryland: Chesapeake Beach, Chase 3255, 3259, Hitchcock 1603; Lanham, Chase 3464, 347312; Owings, Hitchcock 1622; Chevy Chase, Chase 2887; Beltsville, Chase 3729.

District of Columbia: Chase 2985, 5422, Hitchcock 380, Kearney 18, 26, Ward in 1879.

Virginia: Alexandria County, Chase 5423, in Kneucker Gram. Exs. 552; Norfolk, Kearney 309; Portsmouth, Chase 3686, Noyes 92.

West Virginia: Summers County, Morris 984.

North Carolina: Jacksonville, Chase 3198; Wilsons Mills, Chase 3108; West Durham, Chase 3047; Magnetic City, Wetherby 18, 51; Biltmore, Boynton 5. Georgia: Americus, Tracy 3889 in part; Stone Mountain, Hitchcock 381.

Florida: Chattahoochee, Tracy 3615.

Tennessee: Ducktown, Chambliss 27; Coffee County, Eggert 34.

Alabama: Mobile, Kearney 32.

Mississippi: Enterprise, Tracy 3285; Meridian, Tracy 3265; Starkville, Chase 4449; Biloxi, Tracy 6736. 
Louisiana: Calhoun, Ball 53; Hitchcock 1278, 1287; Shreveport, Cocks 3508; Mandeville, Langlois 42; Abbeville, Langlois 38; Lake Charles, Chase 4400, Hitchcock 1136, 1138, 1156, 1165.

Texas: Waller County, Hitchcock 1202, 1203, 1215; Thurow 3, 4, 12, 13, 14, 16, 19, 20, 24, 26, 27, 28, 29, 33; Columbia, Bush 178; Weatherford, Tracy 7944, 7947; La Grange, Plank 97; Huntsville, Plank 63; Gladewater, Reverchon 2357; Ennis, Smith in 1897; Kerrville, Heller 1752, 1888; Houston, Bebb 1276; Denison, Bebb 1428; New Braunfels, Lindheimer 565; Fort Smith to the Rio Grande, Bigelow; without locality, Nealley in 1884 and 1888.

Orlahoma: Poteau, Hitchcock 55l; without locality, Palmer 384 in 1868.

New Mexico: Without locality, Wright 2088, 2085 (the latter in Gray Herb.).

California: Three Rivers, Coville \& Funston 1286; Sacramento, Michener 142.

\section{$\sqrt{ }$ 118. Panicum leucothrix Nash.}

Panicum leucothrix Nash, Bull. Torrey Club 24: 41. 1897. "Type collected by the writer in the low pine land at Eustis, Lake County, Florida, in the latter part of July, 1894, no. 1338." The type, in Nash's herbarium, consists of somewhat branching primary culms, decumbent at base. The description reads: "Spikelets obovate, about $0.65 \mathrm{~mm}$. long, $0.4 \mathrm{~mm}$. wide." This is evidently an error, as the spikelets of the type measure $1.2 \mathrm{~mm}$. as do also those of Nash 334 and 467 cited with the description.

Panicum parvispiculum Nash, Bull. Torrey Club 24:347. 1897. "Type collected by Dr. John K. Small at Darien Junction, McIntosh Co., Ga., June 25-27, 1895." The type, in Nash's herbarium, consists of a tuft of mature vernal culms, beginning to branch. The culms and sheaths are appressed-pubescent, though less copiously so than is the type of $P$. leucothrix, and the panicles are larger. In the description the spikelets are given as $1.5 \mathrm{~mm}$. long, but those of the type measure $1.3 \mathrm{~mm}$.

\section{DESCRIPTION.}

Vernal plants light olive green, often purplish tinged; culms tufted, 25 to $45 \mathrm{~cm}$. high, erect or ascending, appressed papillose pilose, the nodes scarcely swollen, pubescent; sheaths shorter than the internodes, papillose-pubescent, the hairs less appressed than those of the culm, rarely nearly glabrous, the margins ciliate, densely so at the summit; ligules $3 \mathrm{~mm}$. long; blades rather firm, ascending or spreading, 3 to
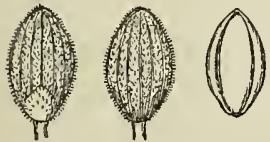

FIG. 209.-P. leucothrix.

From type specimen.

$7 \mathrm{~cm}$. long, 3 to $7 \mathrm{~mm}$. wide, rounded and papillose-ciliate at the base, glabrous or rarely sparsely villous on the upper surface, velvety puberulent beneath; panicles long-exserted, 3 to $8 \mathrm{~cm}$. long, about three-fourths as wide, rather densely flowered, the axis appressed-pubescent, with tufts of long hairs in the axils, the branches ascending; spikelets 1.2 to $1.3 \mathrm{~mm}$. long, $0.7 \mathrm{~mm}$. wide, obovate-elliptic, densely papillose-pubescent; first glume about one-fourth the length of the spikelet, obtuse; second glume and sterile lemma equaling the fruit but not exceeding it; fruit $1.1 \mathrm{~mm}$. long, $0.6 \mathrm{~mm}$. wide, elliptic, slightly pointed.

Autumnal form ascending, usually decumbent at base, at first sending out from the lower and middle nodes long branches similar to the vernal culms, later producing appressed, more or less fascicled branchlets, the flat or somewhat involute blades not greatly reduced.

The less copious pubescence and larger panicles of the type of $P$. parvispiculum prove not to be correlated. A specimen of Nash 467 cited in the description of $P$. leucothrix has one panicle $8 \mathrm{~cm}$. long as in the type of $P$. parvispiculum, and six small 
ones like those in the type of $P$. leucothrix. The New Jersey specimens, Chase 3536 , 3556 , and 3578, as also Hitchcock 1163 and 1398, though small plants with small panicles, are as little pubescent as is the type of $P$. parvispiculum or even less so.

\section{DISTRIBUTION.}

Low pine lands, New Jersey to Florida and Mississippi; also in Cuba.

New JerSey: Atsion, Chase 3536, 3556; Forked River, Chase 3578.

North Carolina: Wilmington, Hitchcock 377.

South Carolina: Orangeburg, Hitchcock 14, 376, 1372, 1398.

Georgia: Darien Junction, Small in 1895; Alapaha, Curtiss 6817 in part.

Florida: Jacksonville, Combs 6, Kearney 146; Washington County, Combs 672, 673; Chipley, Combs 551, 572, 617; Eustis, Hitchcock 800, 805, Nash 334, 467, 1338, 2075; Seminole,

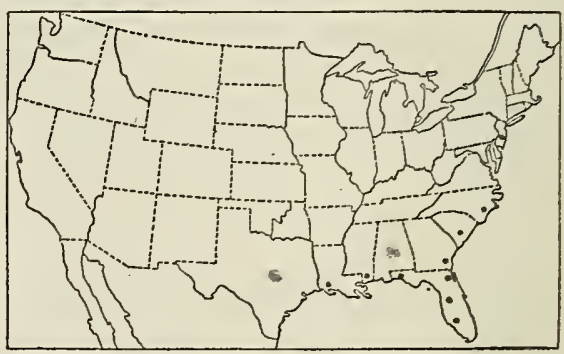

FIG. 210.-Distribution of P. leucothrix. Tracy 7193 in part; $a$ Warrenton, Tracy 8410.

Mississippi: Ocean Springs, Tracy 43.

Louisiana: St. Tammany Parish, Cocks 286; Lake Charles, Hitchcock 1163. CuBA: Herradura, Hitchcock 554; without locality, Wright 3460 in part.

\section{Panicum longiligulatum Nash.}

Panicum longiligulatum Nash, Bull. Torrey Club 26: 574. 1899. "Collected by Dr. Geo. Vasey, at A palachicola, Florida, in 1892." The type, in Nash's herbarium, consists of two vernal culms with three autumnal culms of the preceding year attached.

Elliott $b$ described this species under P. "nitidum? La Marck" as shown by the specimen so labeled in the Elliott Herbarium.

\section{DESCRIPTION.}

Vernal culms usually stout, 30 to $70 \mathrm{~cm}$. high, erect, or ascending at base, glabrous; sheaths glabrous, usually much shorter than the internodes; ligules 2 to $3 \mathrm{~mm}$. long; blades rather thick and firm, 4 to $8 \mathrm{~cm}$. long, 4 to $8 \mathrm{~mm}$. wide, glabrous on the upper surface, puberulent beneath, gradually narrowed to the sharp point, the lower ascending, the upper spreading or often reflexed; panicles ovoid, 3 to $8 \mathrm{~cm}$. long, two-thirds

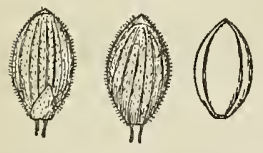

FIG. 211.-P. longiligulatum. From type specimen. to three-fourths as wide, rather densely flowered, the slender branches usually stiffly ascending, short spikelet-bearing branchlets in the axils; spikelets 1.1 to $1.2 \mathrm{~mm}$. long, $0.7 \mathrm{~mm}$. wide, elliptic, pubescent; first glume one-fourth as long as the spikelet; second glume slightly shorter than the fruit and sterile lemma; fruit $1 \mathrm{~mm}$. long, $0.7 \mathrm{~mm}$. wide, elliptic.

Autumnal culms more or less reclining, the branches spreading, usually somewhat recurved, with crowded branchlets and spreading, subinvolute, reduced blades about equaling the reduced panicles of few long-pediceled spikelets; winter rosette prominent, blades glabrous.

Smaller, more slender specimens of this species resemble less pubescent specimens of $P$. leucothrix; these may be distinguished from that species by the glabrous culms and sheaths and slightly smaller spikelets with fruit exposed at the summit.

a Panicum longiligulatum and $P$. lindheimeri were also distributed under this number.

¿ Bot. S. C. \& Ga. 1: 128. 1816. 


\section{DISTRIBUTION.}

Low pine barrens and swamps of the Coastal Plain, North Carolina to Florida and Louisiana.

North Carourna: Roanoke Island, Chase 3213, 3228, 3233; Wards Mill, Chase 3175, 3179; Wilmington, Chase 3136, 3145, 3150, Hitchcock 372.

South Carourna: Orangeburg, Hitchcock 16; Hartsville, Coker in 1908.

Georgia: Charlton County, Harper 1575; Sumter County, Harper 459; Bullock, Harper 839; Stone Mountain, Hitchcock 375.

Florida: Jacksonville, Curtiss 4033; Baldwin, Hitchcock 988, 1005; Chipley, Combs 569; Lake City, Combs 115; Milton, Chase 4308; Apalachicola, Chapman; Bay Head, Combs 652; Santa Rosa, Combs 488, Tracy 8398, 8423; Warrington, Tracy 8413; Braidentown,

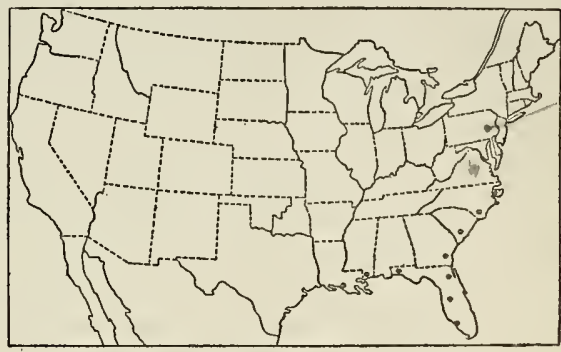

FIG. 212.-Distribution of $P$. longiligulatum.

Hitchcock 957, 958; Seminole, Tracy 7193 in part; Myers, Chase 4141, 4172, 4188, Hitchcock 875, 881, Lee Co. P1. 473.

Mrssissippr: Biloxi, Chase 4366, Hitchcock 1068; Ocean Springs, Kearney 288 in part, 300 in part; Petit Bois Island, Tracy in 1898.

Louisiana: Abita Springs, Cocks 422.

\section{$\checkmark$ 120. Panicum wrightianum Scribn.}

Panicum strictum Bosc; Roem. \& Schult. Syst. Veg. 2 : 447. 1817, not R. Br. 1810. This is described in a note under $P$. barbulatum Michx., from a specimen collected by Bosc in "America sept." and received from him under this name. The type, in the Munich Herbarium, is marked "Panicum strictum Bosc. Carolina, comm. Bosc." Two duplicates of it are in the Willdenow Herbarium, one bearing a new name bestowed by Panzer, but we can not find that this name has been published.

Panicum minutulum Desv. Opusc. 87. 183\%, not Gaud. 1826. The type, in the Desvaux Herbarium, consists of two plants beginning to branch. I t it a

Panicum wrightianum Scribn. U. S. Dept. Agr. Div. Agrost. Bull. 11 : 44. f. 4. 1898. "Cuba (No. 3463, C. Wright, 1865)." The type, in the National Herbarium, is the early autumnal form and is the large plant figured with the original description.

Trinius described $a$ this species under the name "Panicum nodiflorum La M.," citing $P$. strictum Bosc as a synonym. The specimen in the Trinius Ferbarium is marked "Carolina, Bosc. sub nom. $P$. strictum Bosc."

\section{DESCRIPTION.}

Vernal culms weak and slender, ascending from a decumbent

FIG. 213.-P. wrightianum. From type specimen. base, or rarely at first erect, 15 to $40 \mathrm{~cm}$., or rarely $60 \mathrm{~cm}$. high, minutely puberulent; sheaths striate, shorter than the internodes, glabrous, except the summit and ciliate margin, or puberulent; ligules 2 to $3 \mathrm{~mm}$. long; blades spreading, 2 to $4 \mathrm{~cm}$. long, 3 to 5 or rarely 6 $\mathrm{mm}$. wide, glabrous or puberulent beneath and minutely pilose above; panicles oblong-ovate, 3 to $6 \mathrm{~cm}$. long, one-third to half as wide, the branches ascending, the minute spikelets long-pediceled; spikelets 0.95 to $1 \mathrm{~mm}$. long, $0.5 \mathrm{~mm}$. wide,

$a$ Gram. Pan. 241. 1826.

$$
\begin{aligned}
& \text { Y Parr, demimatisurre Terke, Bull. N.y. Slate } \\
& \text { Murs. 116. Bat. Wol. 10: 27, 1007.. "Suffoere } \\
& \text { n. } x
\end{aligned}
$$


ellipsoid, turgid, subacute, pubescent; first glume about one-fourth as long as the spikelet; second glume shorter than the fruit and sterile lemma; fruit $0.8 \mathrm{~mm}$. long, $0.5 \mathrm{~mm}$. wide, subacute.

Autumnal form decumbent-spreading, the culms sending out from the lower and middle nodes numerous ascending branches, becoming somewhat bushy branched, the flat or subinvolute blades and secondary panicles not much reduced.

\section{DISTRIBUTION.}

Along the margins of streams and ponds in sandy or mucky soil, southern New Jersey to Florida and west to Texas; also in Cuba.

New Jersey: Bennett, Stone in 1909.

North Carolina: Wilsons Mills, Chase 3096; Wilmington, Chase 3135, Hitchcock 373, 374, Kearney 246.

Georg1a: Hawkinsville, Biltmore Herb. 7080a (Biltmore Herb.).

Florida: Live Oak, Curtiss 6652; Madison County, Combs 290; De Funiak Springs, Combs 441, 477, Curtiss 5912; Monticello, Combs 347, 354; Washington County, Combs 552, 664; Pensacola, Combs 524; Grasmere, Combs 1068, 1087; Marianna, Tracy 3644.

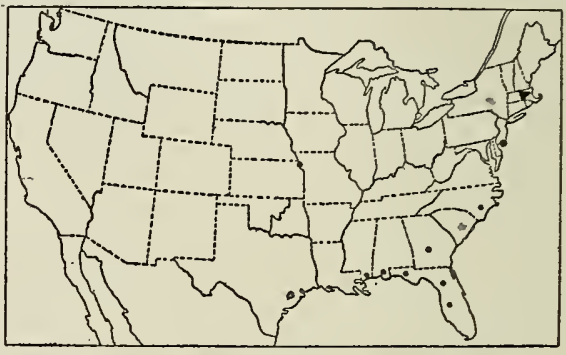

Frg. 214.-Distribution of $P$. wrightianum.

Alabama: Mobile, Kearney 49 in part.

Mississipp1: Biloxi, Kearney 307; Horn Island, Tracy 2861; Petit Bois Island, Tracy 4611.

Texas: Without locality, Wright (Gray Herb.).

Сuвa: Without locality, Wright 3463 in part.

Lanuginosa.-Plants more or less pubescent throughout, usually conspicuously so; ligules densely hairy, 2 to $5 \mathrm{~mm}$. long; blades not over $1 \mathrm{~cm}$. wide, usually narrower; spikelets 1.3 to $3 \mathrm{~mm}$. long, pubescent, the second glume and sterile lemma 5 to 7 or in the larger spikelets 7 to 9 -nerved. Autumnal form usually freely branching, secondary leaves and panicles much reduced.

These species were usually referred by the earlier American authors to $P$. pubescens Lam. or Michx.

Spikelets not over $2 \mathrm{~mm}$. long.

Plants grayish, velvety-pubescent.

Spikelets 1.4 to $1.5 \mathrm{~mm}$. long; autumnal blades involute-pointed (see also $P$. albemarlense)....128. P. auburne. Spikelets 1.8 to $2 \mathrm{~mm}$. long; autumnal blades flat.

Plants dark or olive green when dry; spikelets 1.9 to $2 \mathrm{~mm}$. long.

Freely branching from lower nodes, decumbent; vernal blades puberulent on both surfaces....................130. P. olivaceum.

Sparingly branching from middle nodes, erect; vernal blades sparingly pilose on upper surface.................129. P. thurowii.

Plants light or yellow green when dry.

Autumnal form prostrate, branching from base and lower nodes, forming close mats; blades not ciliate; around hot springs....................... 135. P. thermale. 
Autumnal form ascending or spreading, branching from middle and upper nodes; the reduced, fascicled blades strongly ciliate.

Culms 40 to $70 \mathrm{~cm}$. high, autumnal culms usually 40 to $50 \mathrm{~cm}$. long; southeastern U. S..............126. P. lanuginosum.

Culms 20 to $40 \mathrm{~cm}$. high, autumnal culms usually 20 to $30 \mathrm{~cm}$. long, the early branches zigzag; West Indies....................127. P. acuminatum.

Plants pubescent, often villous, but not velvety.

Culms conspicuously pilose with long, horizontally spreading hairs; branching before expansion of primary panicles........................131. P. praecocius.

Culms variously pubescent, if pilose the hairs not long and horizontally spreading.

Vernal blades glabrous or nearly so on the upper surface, firm in texture.

Autumnal culms branching from the lower nodes, forming a spreading bunch 10 to $15 \mathrm{~cm}$. high; Pacific slope.........133. P. occidentale.

Autumnal culms branching from the middle nodes, forming widely spreading mats; Atlantic slope (see also form of $P$. huachucae silvicola)................125. P. tennesseense.

Vernal blades pubescent on upper surface, sometimes pilose near base and margins only.

Spikelets 1.3 to $1.5 \mathrm{~mm}$. long; vernal blades long-pilose on upper surface.

Autumnal form widely decumbentspreading, forming a mat; vernal culms soon geniculate-spreading; plants olivaceous.............. 122. P. albemarlense.

Autumnal form erect or leaning, never forming a mat; plants yellowishgreen.

Axis of panicle pilose, panicle branches tangled, the lower drooping $. \ldots . . . . . .123$. P. implicatum.

Axis of panicle puberulent only, panicle branches not tangled,

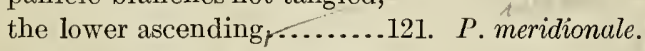

Spikelets 1.6 to $2 \mathrm{~mm}$. long; vernal blades pilose or pubescent.

Upper surface of blades pilose; spikelets 1.8 to $2 \mathrm{~mm}$. long; autumnal form decumbent-spreading.

Spikelets pointed; culms weak and lax....................... P. languidum.

Spikelets obtuse; culms not weak and lax. 
Culms leafy below, branching

from base and lower nodes;

Maine to Minn..........132. P. subvillosum.

Culms evenly leafy, branch-

ing from upper nodes;

Pacific slope............134. P. pacificum.

Upper surface of blades appressedpubescent or pilose toward the base only; spikelets 1.6 to 1.8 $\mathrm{mm}$. long; autumnal form not decumbent-spreading.

8 Blades stiff, erect............... oBlades lax, spreading..............124a. P. huachucae silvicola.

Spikelets $2.2 \mathrm{~mm}$. or more long.

Spikelets 2.2 to $2.4 \mathrm{~mm}$. long.

Pubescence on culms horizontally spreading; autum-

nal form freely branching..................137. P. villosissimum.

Pubescence on culms appressed or ascending; autum-

nal form rather sparingly branching.

Upper internodes shortened, the leaves approximate, blades often equaling the panicle;

pubescence sparse and stiff. ............ 140. P. scoparioides.

Upper internodes not shortened, the copious

pubescence silky.....................138. P. pseudopubescens.

Spikelets 2.7 to $2.9 \mathrm{~mm}$. long.

Culms stiff; blades conspicuously ciliate; southern

Atlantic coast..........................139. P. ovale.

Culms weak; blades not ciliate; Pacific coast........141. P. shastense.

\section{$\checkmark$ 121. Panicum meridionale Ashe.}

Panicum meridionale Ashe, Journ. Elisha Mitchell Soc. 15: 59. 1898. "North Carolina, Chapel Hill in June, 1898; and Jonas Ridge, Burke Co., June, 1893. * * * Dry rocky woods." The type could not be found in Ashe's herbarium. In the National Herbarium are two specimens, one from Chapel Hill and one from Burke County, collected by Ashe and labeled in his writing as this species. The first specimen is a tuft of very slender vernal culms, each bearing but three distant leaves, with panicles 2 to $3 \mathrm{~cm}$. long. This specimen does not agree so well with the description as the Burke County plant, which is therefore chosen to represent the type. In this the culms are numerous, less delicate, erect, 10 to $15 \mathrm{~cm}$. high. The spikelets are described as glabrous, but in both specimens they are minutely pubescent.

Panicum filiculme Ashe, Journ. Elisha Mitchell Soc. 15: 59. 1898, not Hack. 1895. "Dry soil, middle North Carolina to Georgia in the Piedmont plateau region. * * * North Carolina: Ashe; Chapel Hill, 1898. Georgia: Small; Stone Mt., Aug. 1895." The type could not be found in Ashe's herbarium. In the National Herbarium is a specimen from Stone Mountain, Georgia, collected by Ashe, which answers to the description. The culms are erect, slender, 12 to $20 \mathrm{~cm}$. high, with small panicles about $2 \mathrm{~cm}$. long. The culms are the early autumnal form with a few erect fascicles of secondary branches. This specimen differs somewhat in aspect from the type of $P$. meridionale, but they are forms of the same species.

? Panicum microphyllum Ashe, Journ. Elisha Mitchell Soc. 15: 61. 1898. "Collected by the writer June, 1898, at Chapel Hill, N. C., in moist sunny woods." The 
type could not be found in Ashe's herbarium, nor any specimens so named by him. The description seems to apply to the autumnal form of $P$. meridionale, though the culms and sheaths described as "glabrous or pubescent," seems to indicate that some material of $P$. tenue or other species of the Ensifolia was mixed with it.

Panicum unciphyllum meridionale Scribn. \& Merr. Rhodora 3: 123. 1901. Based on P. meridionale Ashe.

\section{DESCRIPTION.}

Vernal form tufted; culms 15 to $40 \mathrm{~cm}$. high, pilose below, the upper portion and the axis of the panicle appressed-pubescent, or the latter often nearly glabrous; lower sheaths pilose, upper minutely appressed-pubescent; ligules 3 to $4 \mathrm{~mm}$. long; blades 1.5 to $4 \mathrm{~cm}$. long, 2 to $4 \mathrm{~mm}$. wide, long-pilose on the upper surface, the hairs erect, less dense than in $P$. implicatum; panicles 1.5 to $4 \mathrm{~cm}$. long, nearly or quite as wide, ovate or rhombic, the branches ascending; spikelets 1.3 to $1.4 \mathrm{~mm}$. long, $0.8 \mathrm{~mm}$. wide, obovate, obtuse, minutely papillose-pubescent; first glume one-fourth to one-third the length of the spikelet, acute or subacute; second glume and sterile lemma equal, as long as the fruit at maturity; fruit $1.2 \mathrm{~mm}$. long, $0.8 \mathrm{~mm}$.
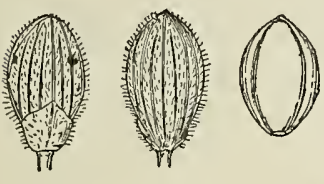

Frg.215.-P. meridionale. From type specimen. wide; broadly elliptic, obscurely pointed.

Autumnal form erect or nearly so, with fascicled branchlets from all the nodes; leaves and panicles not greatly reduced, the latter included late in the season; winter leaves lanceolate, long-pilose toward the base, the rosette formed rather late.

This species resembles $P$. implicatum in the vernal form but is more slender and less pilose. The axis of the panicle in $P$. implicatum is pilose, while in $P$. meridionale it is typically glabrous or somewhat puberulent but not pilose.

A late autumnal specimen, Chase 1472, Irondale, Chicago, Ill., is referred here, doubtfully, because of the scanty pubescence, but the presence of papillæ suggests that the hairs have been worn off; the spikelets are $1.4 \mathrm{~mm}$. long.

Exceptional specimens pilose in the panicle closely approach slender specimens of P. implicatum. This form is represented by Wheler 24 and 28.

\section{DISTRIBUTION .}

Sandy or sterile woods and clearings, Rhode Island to Wisconsin and south to Alabama.

Connecticut: Waterford, Graves 171, 172; South Glastonbury, Wilson 1258.

Rhode Istand: Kingston, Collins in 1908.

NEw YoRk: Lawrence, Bicknell in 1902 and 1906; Valley Stream, Bicknell in 1905; Hempstead, Bicknell in 1908; Hewlett, Bicknell in 1906; Woodmere, Bicknell in 1902.

New Jersey: Oradell, Mackenzie 2477; Atsion, Chase 35341 ; South Amboy, Mackenzie 2710.

Pennsyluania: Refton, Heller 4790.

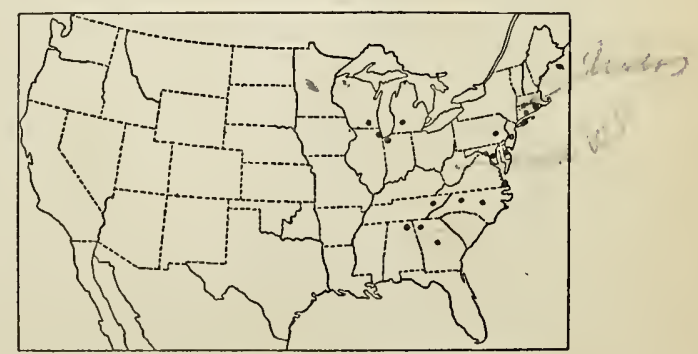

FIG. 216.-Distribution of $P$. meridionale.

Indiana: Lake County, Bebb 2815, 2936, 2947; Dune Park, Hill 98 in 1905, Umbach 1087, 1800.

Illinors: Chicago, Hill 145 in 1906. 
Michigan: Port Huron, Dodge in 1909; Twin Lakes, Wheeler 24, 28; Magician Lake, Umbach 2155.

Wisconsin: Lacrosse, in 1899, name of collector not given (Univ. Vt. Herb.). Dela ware: Deakynes Landing, Commons 286.

Maryland: Between Chesapeake Beach and Chesapeake Junction, Hitchcock 1629, 1636; Lanham, Chase 3466, Hitchcock 2395; Patuxent, House 957.

District of Columbia: Chase 2428, Hitchcock 384, Pollard 353, Ward in 1878.

Virginia: Portsmouth, Chase 3683; Dismal Swamp, Tyler in 1905.

Nortm Carolina: Highlands, J. D. Smith in 1882, Wilsons Mills, Chase 3100.

Georgia: Blue Ridge, Ruth in 1900; Rabun County, House 2258; Stone Mountain, Hitchcock 385.

Tennessee: Ducktown, Chambliss 24, 25.

Alabama: Pisgah, Chase 4478.

\section{Panicum albemarlense Ashe.}

Panicum velutinum Bosc; Spreng. Syst. Veg. 1: 315. 1825, not Meyer, 1818. This herbarium name is given as a synonym under $P$. lanuginosum Ell. and credited to "W. herb." The specimen, in the Willdenow Herbarium, is the vernal form of P. albemarlense.

Panicum albemarlense Ashe, Journ. Elisha Mitchell Soc. 16: 84. 1900. "Common in well drained open woods in Beaufort and Hyde counties, N. C., where the type material was collected by me May 26, 1899, near Scranton" The type specimen has been arbitrarily chosen from unmounted material in Ashe's herbarium in a cover marked on the outside "P. albemarlense," and on a sheet upon which is written "Panicum ? very common in N. E. Beaufort County, also in Hyde, in open woods well drained." There is nothing to indicate in which place the specimens were collected, except the published statement cited above. All the specimens are of the vernal form.

\section{DESCRIPTION .}

Vernal form olivaceous; culms cespitose, 25 to $45 \mathrm{~cm}$. high, slender, at first erect or ascending, soon becoming geniculate at the lower nodes and more or less spreading; culms, sheaths, and blades grayish-villous, the blades 4.5 to $7 \mathrm{~cm}$. long, 3 to $6 \mathrm{~mm}$. wide, ascending, the upper surface puberulent as well as long-villous; panicles 3 to
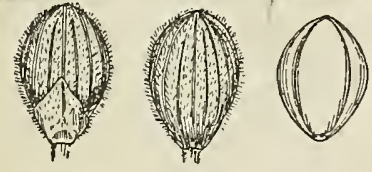

Fig. 217.-P. albemarlense. From type specimen. $5 \mathrm{~cm}$. long, about as wide, more densely flowered than $P$. meridionale, axis puberulent, branches ascending; spikelets $1.4 \mathrm{~mm}$. long, $0.9 \mathrm{~mm}$. wide, blunt and turgid, pilose; first glume about two-fifths the length of the spikelet; second glume and sterile lemma subequal, the glume scarcely equaling the fruit at maturity; fruit $1.25 \mathrm{~mm}$. long, $0.9 \mathrm{~mm}$. wide, obtuse.

Autumnal form widely decumbent-spreading or ascending, freely branching at all but the uppermost nodes, the branches narrowly ascending, the reduced, flat blades mostly exceeding the panicles.

Allied to $P$. meridionale, from which it differs mostly in the usually stouter, spreading culms, which often form large mats in the autumn, and in the softer, denser pubescence which gives the entire plant a grayish tone.

Two specimens from Wilsons Mills, N. C., Chase $3100 \frac{1}{2}$ and 3106 are doubtfully referred here. The spikelets are $1.6 \mathrm{~mm}$. long, and the whole plants suggest a very slender vernal form of $P$. aciculare. 
DISTRIBUTION .

Low sandy woods or open ground of the Coastal Plain, Connecticut to Michigan and south to North Carolina.

Massachusetts: Nantucket Island, Bicknell in 1899 and 1906.

Connecticut: Waterford, Graves in 1898.

New York: Garden City, Bicknell in 1906; Woodmere, Bicknell in 1902; Valley Stream, Bicknell in 1904; Hempstead, Bicknell in 1906.

New Jersey: Grenloch, Heritage in 1897 (Phila. Acad. Herb.).

Pennsyltania: Wo o d b o u rne, Jahn in 1904 (Phila. Acad. Herb.).

Indiana: Dune Park, Hill 53 in 1907.

Michigan: Cass County, Pepoon in 1904.

Maryland: Chesapeake Beach, Hitchcock 1612; Chesapeake

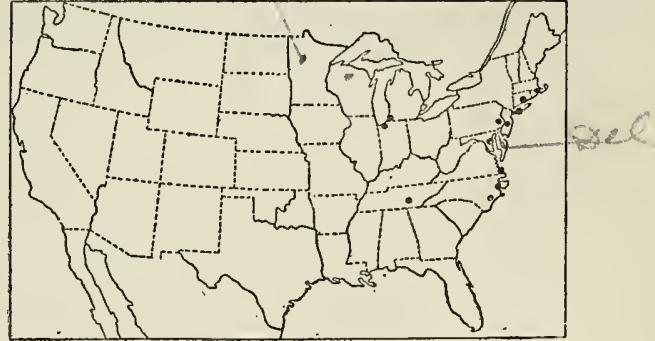

FIG. 218.-Distribution of $P$. albemarlense. Junction, Hitchcock 2409; Beltsville, Chase 3745, 3757, 3762, 3825; Pindell, Hitchcock 1628.

District of Columbia: Hitchcock 126, Kearney 27.

Virginia: Cape Henry, Chase 2339.

North Carolina: Washington, Ashe in 1899; Scranton, Chase 3201; Beaufort and Hyde counties, Ashe.

Tennessee: Tullahoma, Biltmore Herb. 9953c (Biltmore Herb.).

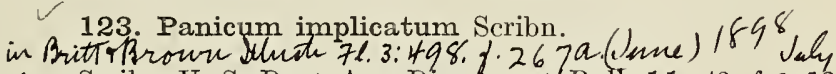

Panicum implicatum Scribn $\mathrm{n}$ U. S. Dept. Agr. Div. Agrost. Bull. 11: 43. f. 2. 1898. "Low marshy ground, Cape Elizabeth, Maine. Collected by F. Lamson-Scribner, July 26, 1895." The type, in Hitchcock's herbarium, consists of several plants in the early branching state, 45 to $50 \mathrm{~cm}$. high, with mature primary panicles $5.5 \mathrm{~cm}$. long and smaller secondary ones. There is a duplicate type in the National Herbarium.

Panicum unciphyllum implicatum Scribn. \& Merr. Rhodora 3: 123. 1901. Based on Panicum implicatum Scribn.

\section{DESCRIPTION.}

Vernal form with tufted, slender culms 20 to $55 \mathrm{~cm}$. high, erect or ascending, papillose-pilose, with spreading hairs; sheaths shorter than the internodes, papillosepilose; ligules 4 to $5 \mathrm{~mm}$. long; blades firm, erect or ascending, 3 to $6 \mathrm{~cm}$. long, 3 to 6

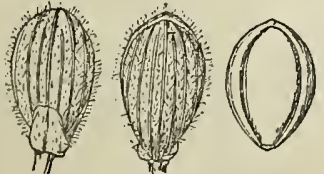

FIG.219.-P.implicatum. From type specimen. $\mathrm{mm}$. wide, rarely longer or wider, more or less involuteacuminate, the upper surface pilose with erect hairs 3 to $4 \mathrm{~mm}$. long, the lower surface papillose-pubescent with subappressed hairs; primary panicles long-exserted, pyramidal in outline, 3 to $6 \mathrm{~cm}$. long, about as wide, the axis long-pilose, the branches flexuous, in typical specimens tangled and the lower drooping; spikelets $1.5 \mathrm{~mm}$. long, $0.9 \mathrm{~mm}$. wide, obovate, obtuse, papillose-pilose; first glume about one-fourth the length of the spikelet, obtuse; second glume and sterile lemma equaling the fruit at maturity; fruit $1.3 \mathrm{~mm}$. long, $0.9 \mathrm{~mm}$. wide, broadly elliptic, obtuse, very minutely umbonate.

Autumnal form erect or spreading, rather loosely branching from the lower and middle nodes, the primary culms becoming more or less geniculate below; leaves and panicles reduced; winter leaves lanceolate-cvate, pilose above; the rosette appearing late. 
The type specimens of $P$. meridionale and $P$. implicatum as well as the greater number of the specimens referred to each respectively seem specifically distinct, $P$. implicatum being distinguished by the implicate panicle, with pilose axis and drooping branches, and less delicate culms than those of $P$. meridionale; but in occasional specimens these distinctions do not hold good. These intermediate specimens are referred to $P$. meridionale or to $P$. implicatum according to their apparent affinity to the type of the one or the other respectively. More robust specimens of $P$. implicatum approach P. huachucae. One specimen, Dodge 38, Port Huron, Michigan, has the characteristic habit of $P$. implicatum, but the axes of the implicate panicles are not pilose.

\section{DISTRIBUTION.}

Wet meadows, bogs, and sandy soil, cedar and hemlock swamps, Nova Scotia to New York and west to Michigan and Iowa.

Nova Scotia: Digby, Howe \& Lang 190 (Gray Herb.).

New Brunswick: St. Andrews, Fowler in 1900.

Quebec: Lake Memphremagog, Churchill in 1902 (Gray Herb.).

Maine: Cape Elizabeth, Chase 3454, 3459, Scribner in 1895; East Auburn, Merrill 2, 7, 8, 9, 16; Manchester, Scribner 14, 15; Cumberland, Ricker 1277; North Berwick, Parlin 1188, 1198; Farmington, Fernald 500; Foxcroft, Fernald 502; Orono, Fernald 504; Fayette, Chase 3392; Chesterville, Chase 3436; Canton, Parlin 2000.

New Hampshine: Jaffrey, Hitchcock 127; White Mountains, Hitchcock 130.

F. Vermont: Barnet, $\wedge^{\text {Blanchard in }}$ 1888; Burlington, Hitchcock 132.

Massachusetts: Cambridge, Blankinship in 1896.

Connecticut: Southington, $A n$ drews 20, Bissell 5590, 5622, 12002; Waterford, Graves 165; Griswold, Graves 78.

Rhode Island: Button woods, Bailey in 1890 (Brown Univ. Herb.).

New York: Preston, Coville in

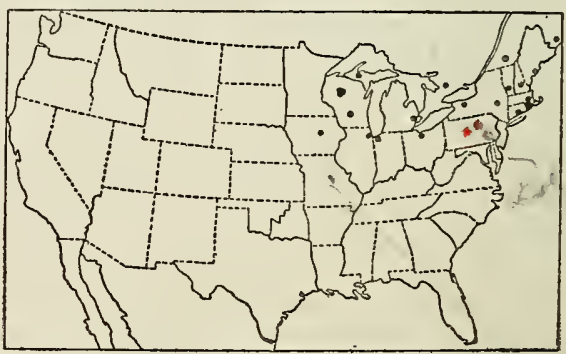

FIG. 220.-Distribution of P. implicatum. 1884; Washington County, Burnham 25; Utica, Haberer in 1900; Verona, Haberer in 1900; Sylvan Beach, House 1231; Chautauqua, Hill 184 in 1907; Jamaica, Bicknell in 1904; Valley Stream, Bicknell in 1905; Rosedale, Bicknell in 1904.

OnTario: Algonquin Park, Macoun 22024.

Онго: Sandusky, Morris A55; Hawks, Kellerman 6885.

Indiana: Miller, Chase 1546; Dune Park, Hill 99 in 1905, 185 in 1907; Porter County, Hill 163 in 1906.

Illinors: Oregon, Waite in 1885; Manito, Wilcox 57; Chicago, Nelson 66.

Michigan: Port Huron, Dodge in 1909; Keweenaw County, Farwell 597b, 643a; Port Alger, Wheeler in 1895.

Wisconsin: Sauk County, Eggert in 1903 (Mo. Bot. Gard. Herb.). Iowa: Iowa City, Shimek 10; without locality, Ball 817.

\section{$\checkmark \quad$ 124. Panicum huachucae Ashe.}

Panicum nitidum pilosum Torr. Fl. North. \& Mid. U. S. 146. 1824, not P. pilosum Swartz, 1788. "In dry woods, \&c. New-York." The type, in the Torrey Herbarium, consists of four vernal culms with immature panicles. 
Panicum huachucae Ashe, Journ. Elisha Mitchell Soc. 15: 51. 1898. "Based on: Lemmon: $P$. dichotomum var. nitidum, subvar. barbulatum; Huachuca Mountains, Arizona, 1882." Such a specimen could not be found in Ashe's herbarium, but in the National Herbarium is a specimen so labeled which agrees with the description and which is doubtless the type, since Mr. Ashe visited the National Herbarium in the summer of 1898 and took notes on species of Panicum. This specimen consists of several slender culms beginning to branch and with overmature panicles.

Panicum lanuginosum huachucae Hitchc. Rhodora 8: 208. 1906. Based on Panicum huachucae Ashe.

This species has been referred by some recent American authors $a$ to Panicum unciphyllum Trin. ${ }^{b}$

\section{DESCRIPTION.}

Vernal form cespitose, usually stiffly upright, light olivaceous, often purplish, harsh to the touch from the copious, spreading, papillose pubescence of culms and leaves; culms 20 to $60 \mathrm{~cm}$. high; nodes bearded with spreading hairs; sheaths shorter than the internodes; ligules 3 to $4 \mathrm{~mm}$. long; blades firm, stiffly erect or ascending, 4 to $8 \mathrm{~cm}$. long, 6 to $8 \mathrm{~mm}$. wide, the veins inconspicuous, the upper surface copiously short-pilose, especially toward the base, the lower surface densely pubescent; panicle rather shortexserted until maturity, 4 to $6 \mathrm{~cm}$. long, nearly as wide, rather densely flowered, the axis and often the branches pilose, the flexuous, fascicled branches ascending or spreading, short spikeletbearing branchlets at base of the fascicles; spikelets 1.6 to $1.8 \mathrm{~mm}$. long, $1 \mathrm{~mm}$. wide, obovate, obtuse, turgid, papillose-pubescent; first glume

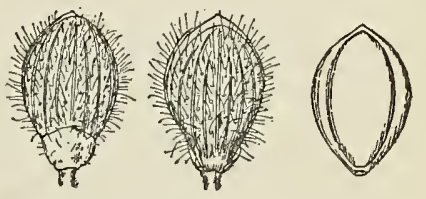

Fig. 221.-P.huachucae. From type specimen in National Herbarium. about one-third the length of the spikelet; second glume and sterile lemma subequal, scarcely covering the fruit at maturity; fruit 1.5 to $1.6 \mathrm{~mm}$. long, $1 \mathrm{~mm}$. wide, elliptic, obscurely apiculate.

Autumnal form stiffly erect or ascending, the culms and sheaths sometimes papillose only, the branches fascicled, the reduced, crowded leaves ascending, the blades 2 to $3 \mathrm{~cm}$. long, much exceeding the reduced panicles.

This species is variable as to amount of pubescence and as to the stiffness of the leaves, and it intergrades with the following subspecies. A specimen collected by Havard at EI Paso, Texas, is referred here, though it is an unusual form with wider blades and spreading habit suggesting $P$. lindheimeri.

\section{DISTRIBUTION.}

Prairies and open ground, Maine to South Dakota and south to North Carolina and southern California.

MaIne: North Berwick, Parlin 1186, 1189.

Vermont: Burlington, Hitchcock 133.

Massachusetts: Wellesley, Smith 737.

Connecticut: Southington, Andrews 70; New London, Graves 4.

New York: Vaughns, Burnham in 1897; Pavilion, Hill 182 in 1907; Westfield, Hill 171 in 1907; Jamaica, Bicknell in 1905; Hempstead, Bicknell in 1903; Woodmere, Bicknell in 1907.

Ontario: Galt, Herriot 14; Niagara, Macoun 26337; Belleville, Macoun 29369; Long Point, Herriot 44.

New Jensey: Netcong, Mackenzie 2075.

a Scribner and Merrill, Rhodora 3: 121. 1901; Nash in Britton, Man. 1040.1901. $\checkmark$ See synonymy under $P$. tenue Muhl., page $259^{\circ}$. 
Pennsylvania: Easton, Porter in 1893.

Онго: Big Darby, Morris 9; Lancaster, Kellerman 6769; Steubenville, Kellerman 6785; Mount Gilead, Kellerman 6873; Vinton, Kellerman 6893.

Indiana: Clark Junction, Bebb 520, Umbach 1816; Gibson, Hill 98 in 1908.

IllinoIs: Waukegan, Gleason \& Shobe 324; Chicago, Hill 130 in 1905, Somes 210; Beach, Umbach 2237, 2244; Williamsfield, V. H. Chase 1858; Waucanda, Hill 217 in 1898.

Michigan: Detroit, Farwell 643b, 1382 in part; Howard Terrace, Wheeler in 1899.

Wisconsin: Northwest Wisconsin, Wood in 1889; Doherty Lake, Cheney 1107; Drummond, Cheney 4104; Madeline Island, Cheney 5638 .

Minnesota: Nicollet, Ballard in 1892; Spring Lake, Ballard 544; Minneapolis, Sandberg 316; Center City, Sandberg 666; Thompson, Sandberg 385.

South DAкотA: Black Hills, Rydberg 1099.

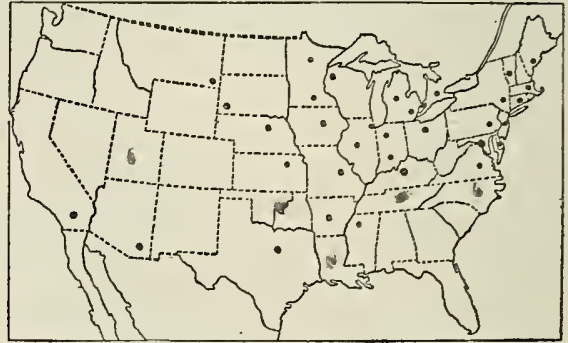

FIG. 222.-Distribution of $P$. huachucae.

Iowa: Mount Pleasant, Mills in 1894; Fayette County, Fink 562.

Nebraska: Ewing, Bates 1003; Thomas County, Rydberg 1368.

Missouri: Allenton, Kellogg 16.

Kansas: Manhattan, Hitchcock 2528, Kellerman in 1888.

Dela ware: Wilmington, Canby in 1898.

District of Columbia: Sudworth in 1889.

Virginia: Ashland, De Chalmot.

Kentucky: Harlan County, Kearney 58 in part; Lexington, Short 9 (Gray Herb.).

Mississippi: Agency, Tracy 3190.

Arkansas: Fulton, Bush 2332 (Mo. Bot. Gard. Herb.).

Texas: El Paso, Havard in 1881.

Montana: Without locality, Williams in 1887.

Arizona: Huachuca Mountains, Lemmon 2907.

California: San Bernardino Mountains, Abrams 2737 (Gray Herb.).

The Montana specimen, though from beyond the known range of this species, is fairly typical.

\section{$\checkmark$ 124a. Panicum huachucae silvicola Hitchc. \& Chase.}

Panicum dichotomum fasciculatum Torr. Fl. North. \& Mid. U. S. 145. 1824, not P. fasciculatum Swartz, 1788. "In sandy fields, New-Jersey." The type, in Columbia University Herbarium, is a late autumnal specimen with tufts of short branches at the nodes.

Panicum nitidum ciliatum Torr. Fl. North. \& Mid. U. S. 146. 1824, not P. ciliatum EIl. 1816. "In the pine-barrens of New-Jersey." The type, in Columbia University Herbarium, is a single vernal culm.

Panicum huachucae silvicola Hitchc. \& Chase in Robinson, Rhodora 10: 64. 1908.

"Type, District of Columbia, Chase, no. 2400, in National Herbarium." The specimen is a small clump of vernal culms beginning to branch and with mature primary panicles.

This is the form described by Scribner and Merrill $a$ under the name $P$. lanuginosum Ell. 


\section{DESCRIPTION.}

Vernal form taller and more slender, brighter green and less densely pubescent than in P. huachucae; culms 30 to $75 \mathrm{~cm}$. high, suberect or ascending, papillose-pilose with spreading hairs; nodes bearded with reflexed hairs, usually a glabrous ring below; sheaths papillose-pilose; blades thin, lax and spreading, 5 to $10 \mathrm{~cm}$. long, 6 to $12 \mathrm{~mm}$. wide, the veins inconspicuous; upper surface sparsely short-pilose or with copious long hairs toward the base; lower surface pubescent and with a satiny luster; panicles exserted, 5 to $8 \mathrm{~cm}$. rarely $10 \mathrm{~cm}$. long, nearly as wide, rather densely flowered, the axis pilose, the flexuous, fascicled branches spreading, with short spikelet-bearing branchlets at the base of the fascicles; spikelets 1.6 to $1.8 \mathrm{~mm}$. long, 0.8 to $1 \mathrm{~mm}$. wide, elliptic-obovate, at maturity subobtuse, pubescent.with spreading hairs; first glume one-fourth to one-third the length of the spikelet, obtuse or subacute; second glume and sterile lemma subequal, slightly shorter than the fruit at maturity; fruit $1.5 \mathrm{~mm}$. long, 0.8 to $0.9 \mathrm{~mm}$. wide, elliptic, subacute.

Autumnal form more or less decumbent, the numerous fascicled branches shorter than the primary internodes, at least late in the season, the reduced spreading leaves sometimes nearly glabrous above except for a few long hairs near the base.

The following specimens represent an extreme form

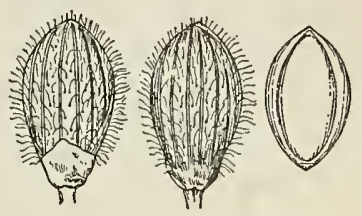

FIG.223.- $P$. huachucae silvicola. From type specimen. with the upper surface of the blades nearly or quite glabrous, thus approaching $P$. tennesseense. They differ from that species in the thin, lax blades, with no marked white margin and without conspicuous veins. MAINE: Westbrook, Ricker 666; Orono, Fernald 503; Massachusetts: Framingham, Smith 739; Connecticut: Franklin, Graves 166; Rhode Island: Providence, Battey in 1886; New York: Ithaca, Ashe in 1898; New Jersey: Bear Swamp, Stone 3; Pennsylvania: Easton, Porter in 1898; Germantown, Stone 5, 9; Iowa: Appanoose County, Fitzpatrick 38; District of Columbia: Kearney 33, Steele in 1900; North Carolina: Chapel Hill, Chase 3049, 3062, 3067; Tennessee: Polk County, Kearney 328; Texas: Ennis, Smith in 1897; OкLанома: Chelsea, Bush 1210.

\section{DISTRIBUTION.}

Open woods and clearings, Maine to northern Florida, west to Michigan, Nebraska, and Arizona.

MaIne: Falmouth, Chamberlain 513; Brewer, Knight 51; South Berwick, Parlin 1181; Southport, Fernald 509.

New Hampshire: Langdon, Fernald in 1899.

Vermont: Burlington, Jones in 1898; Brandon, Knowlton in 1832.

Massachusetts: Salem, Sears in 1883; Wellesley, Smith 735.

Connecticut: Southington, Andrews 36, 64, 66; Groton, Graves 8; Waterford, Graves 156.

Rhode Island: Providence, Battey in 1886.

New York: Sylvan Beach, Maxon 550; Oneida, Haberer in 1900, House 1136; Washington County, Burnham 14, 23; Gansevoort, Peck in 1897; Jamaica, Bicknell in 1904; Port Washington, Bicknell in 1908.

Ontario: Galt, Herriot 53, 61, 93; Windsor, Macoun 26334.

New Jersey: Clifton, Nash in 1892; South Amboy, Mackenzie 2159, 2169; Wildwood, Chase 3508; Forked River, Chase 3580; Berkeley Heights, Mackenzic 2249; Milburn, Mackenzie 2137; Cranberry Lake, Mackenzic 2197.

Pennsylvania: Refton, Heller 4791; Mount Hope, Heller 4785; McCalls Ferry, Rose \& Painter 8133; Easton, Porter in 1895. 
Onıо: Columbus, Morris 48; Painesville, Werner in 1885; Berea, Ashcroft in 1897; Erie County, Moseley in 1902; Big Darby, Kellerman 6758; Vinton, Kellerman 6890,6895 .

Indiana: Lafayette, Dorner 84, 91, 93; Steuben County, Deam in 1903; Brazil, Somes 230 .

IllinoIs: Downers Grove, Umbach 1820; Athens, Hall in 1861; Peoria, Brendel; Glasford, Wilcox 42; Princeville, V. II. Chase 81; Williamsfield, V. H. Chase 1851; Oregon, Waite in 1885; Mahomet, Gleason 1033; Makanda, Gleason 1028, 1030; Grand Tower, Gleason 1031.

Michigan: Port Huron, Dodge in 1909; Detroit, Farwell 597d, 1382 in part; Grand Beach Springs, Hill 83 and 85 in 1908.

Iowa: Ames, Ball 42, 157; Lebanon, Ball \& Sample 35; Decatur County, Fitzpatrick 37; Fort Dodge, Somes 207.

Nebraska: Pishelville, Clements 2983.

Missouri: Courtney, Bush 734, 1713, 2996, 3968; Monteer, Bush, 746, 759, 760; Sibley, Bush 4002, 4803; Dodson, Bush 4024; Vale, Bush 3915; Pleasant Grove, Bush 309; St. Louis, Eggert 124, 235, Hitchcock 599; Jefferson County, Eggert 244, 289.

Kansas: Cherokee County, Hitchcock Pl. Kan. 882; Manhattan, Hitchcock 2523.

Dela ware: Centerville, Commons 289, 290, 292, 293, 360, 364; Wilmington, Commons 362 .

Maryland: Chesapeake Beach, Chase 3254; Owings, Hitchcock $1621,1624,1630$.

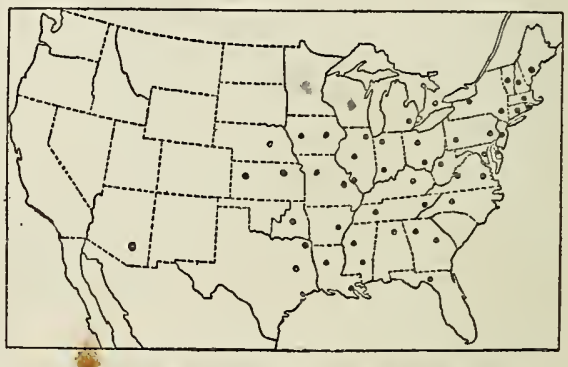

FIG. 224.-Distribution of $P$. huachucae silvicola.

District of Columbia: Chase 2400, Kearney 22, Vasey in 1882, Ward in 1881.

Virgrnia: Alexandria County, Chase in Kneucker Gram. Exs. 551, Hitchcock 382, 383, Ward in 1879; Clifton Forge, Tidestrom 48.

West Virginia: Fairmont, Hitchcock 136; Morgantown, Hitchcock 137.

North Carolina: Chapel Hill, Ashe, Chase 3065, 3069.

Georgra: Americus, Tracy 3889 in part; Augusta, Kearney 218 in part; Stone Mountain, Hitchcock $1357 \frac{1}{2}$.

Florida: Gainesville, Combs 751.

Tennessee: Sherwood, Eggert 30, 245; Ducktown, Chambliss 23; Chester County, Bain 197.

Alabama: Sand Mountain, Biltmore Herb. 14879b (Biltmore Herb.).

MrssissipPi: Jackson, Hitchcock 1306; Fairport, Tracy 3208; Macon, Tracy 3223; Starkville, Tracy 1751; Agency, Tracy 3198.

Arkansas: Prescott, Bush 251; Benton County, Plank 49.

Louisrana: New Orleans, Drummond 454; Shreveport, Hitchcock 1255; West Feliciana, Cocks 3509 .

Texas: Waller County, Hitchcock 1214, Thurow 22; Gillespie County, Jermy 57; without locality, Reverchon 1075; Texarkana, Heller 4084.

OkLahoma: Chelsea, Bush 1210 (Mo. Bot. Gard. Herb.).

Arizona: Tueson, Toumey 781.

\section{$\sqrt{\text { 125. Panicum tennesseense Ashe. }}$}

Panicum tennesseense Ashe, Journ. Elisha Mitchell Soc. 15: 52. 1898. "Based on No. 7087 Biltmore Herbarium: Cedar glades, La Vergne Co., Tennessee." The type specimen, in the Biltmore Herbarium, is the autumnal form, collected August 7, 1897. 


\section{DESCRIPTION.}

Vernal form suberect or stiffly spreading, bluish green, often purplish; culms 25 to $60 \mathrm{~cm}$. high, slender, papillose-pilose, or the upper portion glabrous; sheaths spreading-pubescent, rarely nearly glabrous; ligules dense, 4 to $5 \mathrm{~mm}$. long; blades firm with a thin white cartilaginous margin, ascending or suberect, 6 to $9 \mathrm{~cm}$. long, 5 to 8 $\mathrm{mm}$., rarely $10 \mathrm{~mm}$., wide (the upper smaller), often sparsely ciliate at base, the veins usually conspicuous, the upper surface glabrous or with a few long, scattered hairs toward the base, the lower surface appressed-pubescent or nearly glabrous; panicle

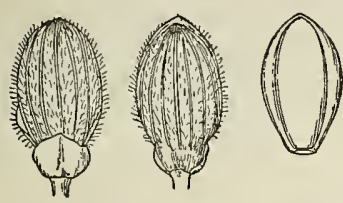

FIG. 225.-P.tennesseense. From type specimen. 4 to $7 \mathrm{~cm}$. long, nearly as wide, rather densely flowered, the lower branches ascending; spikelets 1.6 to $1.7 \mathrm{~mm}$. long, 0.8 to $1 \mathrm{~mm}$. wide, obovate-obtuse, turgid, pubescent; first glume about one-fourth the length of the spikelet; second glume shorter than the sterile lemma, leaving the summit of the fruit exposed at maturity; fruit $1.4 \mathrm{~mm}$. long, $0.8 \mathrm{~mm}$. wide, elliptic, obtuse.

Autumnal form widely spreading or decumbent, with numerous fascicled, somewhat flabellate, branches, often forming prostrate mats; leaves much reduced, the blades usually ciliate at base; winter rosette formed early.

This species resembles $P$. lindheimeri and $P$. huachucae silvicola. From the former it differs in the larger spikelets, pilose sheaths, and more or less white-margined blades, which are often pubescent beneath, from the latter, in the firmer blades, glabrous above, and from both in the prostrate, mat-like autumnal form. Two vernal specimens from Connecticut, Graves 13 and 75 in 1899, are referred here doubtfully because of the looser panicle and rather numerous hairs on the upper surface of the blades. Two specimens with spikelets about $2 \mathrm{~mm}$. long are referred doubtfully to $P$. tennesseense, one from Jefferson County, Missouri (Eggert 242) and one from Sapulpa, Oklahoma (Bush 711).

\section{DISTRIBUTION.}

Open rather moist ground and borders of woods, Maine to Minnesota, and south to Georgia, Mississippi, and Arkansas; also in Colorado and Utah.

Maine: Dover, G. B. Fernald 507; St. Francis, Fernald 166a; Fort Fairfield, Fernald 166; Cape Elizabeth, Chase 3457; Chesterville, Chase 3301; Fayette, Chase 3399; Hartford, Parlin 2017.

New Hampshire: Nashua, Robinson 789 (Gray Herb.).

Vermont: Westmore, Eggleston 2181 (Gray Herb.).

Massachusetts: Framingham, Smith 741, 743.

Connecticut: Hartford, Driggs 3; Preston, Graves 11; Branford, Bissell 5611.

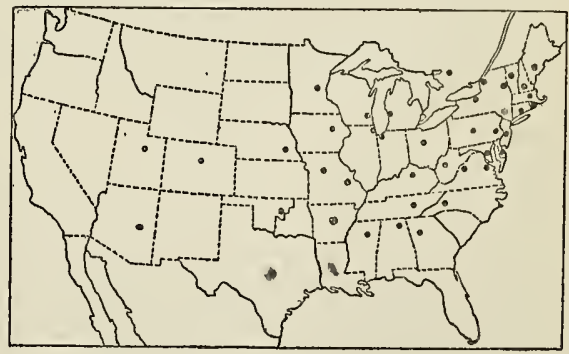

FIG. 226.-Distribution of $P$. tennesscense.

Rhode Island: Providence, Collins in 1891 (Gray Herb.).

NEW York: Thousand Islands, Ball 816, Robinson \& Maxon 86; Ithaca, Coville in 1885; Apalachin, Fenno 13, 17; Ausable Chasm, Jones in 1898; Jamaica, Bicknell in 1905; Valley Stream, Bicknell, in 1905; Rosedale, Bicknell in 1904; Rockville Center, Bicknell in 1902; Edgemere, Bicknell in 1902; Hewlett, Bicknell in 1905.

Ontario: Algonquin Park, Macoun 72965. 
New Jersey: Wildwood, Chase 3503; South Amboy, Mackenzie 1459; Netcong, Mackenzie 2076.

Pennsylvania: Easton, Porter in 1892, 1895, and 1898; Lancaster County, Heller 4774, 4778; Germantown, Stone 8, 13; Safe Harbor, Small in 1889; Sayre, Barbour in Kneucker Gram. Exs. 485 a; Rockdale, Pretz 2022.

Он1о: Berea, Ashcroft in 1897.

Ind1AnA: Clark Junction, Bebb 2881; Indiana Harbor, Chase 1904; Anderson, Deam 2065.

ILlinols: Zion City, Hill 141 in 1905.

Mrchlgan: Grand Beach Springs, Hill 86 in 1908; Petoskey, Hill 162 in 1878 (Hitchcock Herb.).

Wrsconsin: Racine, Wadmond 3424b; Webster, Cheney 3409; Stevens Point, Cheney 3471.

Mrnnesota: Milaca, Sheldon 2743.

Iowa: Fort Dodge, Somes 153.

Nebraska: Minden, Hapeman in 1907.

Missourr: Williamsville, Eggert 243; Swan, Bush 4532; Monteer, Bush 4684; Vale, Bush 3914.

Delaware: Wilmington, Chase 3617, Commons 365.

Maryland: Chesapeake Beach, Chase 3260; Potomac Valley a few miles above Washington, Chase 2463, 2849, 2874, 3274, 3275, 5424, 5425, Hitchcock 138, Kearney in 1897.

District of Columbia: Ball in 1902, Kearney 29a, Hitchcock 505, Pollard 523. Virginia: Fairfax County, Hitchcock 139; Clifton Forge, Tidestrom 5.

West Vrrgrnia: Quinnemont, Pollard \& Maxon 22.

North Carolina: Asheville, Boynton 2; Hendersonville, Biltmore Herb. 5184b; Biltmore, Biltmore Herb. 698b; Macon County, Boynton 9.

Georg1a: Stone Mountain, Hitchcock 1358.

Kentucky: Lexington, Peter in 1833 (Ky. State Univ. Herb.).

Tennessee: Knox County, Kearney in 1893.

Alabama: Pisgah, Chase 4477; Scottsboro, Chase 4499.

Mississipp1: Panola County, Eggert 296.

Arkansas: Texarkana, Heller 4160.

Oklahoma: Sapulpa, Bush 712.

Colorado: South Boulder, Jones $61 \dot{9}$.

UTAH: Springdale, Jones 6069.

Arizona: Santa Catalina Mountains, Thornber 308 (Jones Herb.).

\section{$\checkmark$ 126. Panicum lanuginosum Ell.}

Panicum lanuginosum Ell. Bot. S. C. \& Ga. 1: 123. 1816. "Grows in Georgia. Sent to me by Dr. Baldwin." The type, in the Elliott Herbarium, consists of a single culm lacking the base, with four leaves and primary panicle included at base; the spikelets, which are immature, are $1.8 \mathrm{~mm}$. long, and $0.8 \mathrm{~mm}$. wide. The accompanying label reads: "Panicum Lanuginosum. Hab. Georg: Dr. Baldwin."

Panicum dichotomum lanuginosum Wood, Class-book ed. 3. 786. 1861. Presumably based on $P$. lanuginosum Ell., no synonymy nor locality being cited.

Panicum orangensis[e] Ashe, Journ. Elisha Mitchell Soc. 15: 113. 1899. "I have collected the plant at two stations, both in Orange County, N. C." "Collected in June, 1898." No specimen bearing this name could be found in Ashe's herbarium. There is, however, a cover containing specimens collected at Chapel Hill, Orange County, North Carolina, June 29, 1898. On this cover are notes which indicate that Ashe considered the species allied to $P$. lanuginosum. The description of $P$. orangense 
agrees with these specimens except that the spikelets are said to be glabrous. But this statement is probably an error of observation or of description, since the author adds, "Related to Panicum lanuginosum Ell., and separated from it by having a longer, softer pubescence and its leaves not being ciliate." Since the spikelets of $P$. lanuginosum as described by Ashe (P. huachucae silvicola) are pubescent, this difference would probably have been noted in the contrast of the two species. A portion of the specimen mentioned above has been deposited in the National Herbarium and has been chosen as the type of $P$. orangense Ashe. It is the early autumnal form.

Panicum ciliosum Nash, Bull. Torrey Club 26: 568. 1899. "Type collected by S. M. Tracy, at Biloxi, Mississippi, September 1, 1898, no. 4580." The type, in Nash's herbarium, is the early autumnal form with a simple culm and primary panicle attached, and without the winter rosette. The specimen of Tracy 4580 in the National Herbarium has a winter rosette, the blades 4 to $6 \mathrm{~cm}$. long. In the description the ligule is said to be "about $0.5 \mathrm{~mm}$. long" but in the type it measures $3 \mathrm{~mm}$. long.

\section{DESCRIPTION.}

Vernal form grayish olive green, velvety to the touch; culms tufted, usually in large clumps, 40 to $70 \mathrm{~cm}$. long, slender, lax, spreading, densely villous with fine, soft hairs arising from small papillæ; nodes villous, often a glabrous ring below; sheaths shorter than the internodes, soft-villous like the culm, or the upper puberulent only, ciliate on the margin; ligules 3 to $4 \mathrm{~mm}$. long; blades thickish but not stiff, ascending or spreading, somewhat incurved or spoon-shaped, 5 to $10 \mathrm{~cm}$. long, 5 to 10 mm. wide (the uppermost much smaller), acuminate, narrowed toward the rounded base, the margins sometimes papillose-ciliate, the upper surface clothed with short, soft hairs with long soft hairs intermixed, especially toward the margins and base, the lower surface densely velvety-pubescent; panicles exserted, 6 to $12 \mathrm{~cm}$. long, about as wide, loosely flowered, the axis pubescent, the slender flexuous branches spreading or ascending, the lower often drooping; spikelets 1.8 to $1.9 \mathrm{~mm}$. long, $1 \mathrm{~mm}$. wide, obovate-elliptic, subobtuse, pubescent; first glume one-third the length of the spike-
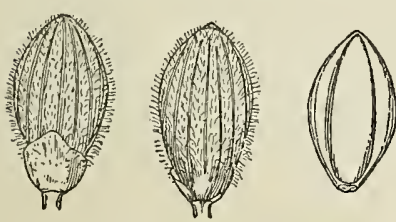

FIG. 227. $-P$. lanuginosum. From type specimen. let, obtuse or obscurely pointed; second glume and sterile lemma equal, slightly shorter than the fruit at maturity; fruit $1.6 \mathrm{~mm}$. long, $0.9 \mathrm{~mm}$. wide, elliptic, subacute.

Autumnal form widely spreading or decumbent, freely branching from the middle nodes, the branches repeatedly branching and much exceeding the internodes, the ultimate branchlets forming flabellate fascicles; leaves and panicles much reduced, the flat blades almost always ciliate and exceeding the panicles; winter rosette not appearing until late, the blades 4 to $5 \mathrm{~cm}$. long, usually ciliate, otherwise minutely velvety or nearly glabrous.

The plant bears some resemblance in color and pubescence to $P$. scoparium, but is smaller and much more slender. The vernal form also resembles $P$. huachucae silvicola but is larger and more velvety and is gray-green in color rather than bright green.

It may be that the form described by Nash as $P$. ciliosum is a distinct species. It differs in having blades glabrous on the upper surface or with a few long hairs only, but not velvety, and winter rosettes of large blades. The typical form has been found only in Tracy's garden, at Biloxi, in cultivated soil. Other Biloxi specimens lack the large rosettes, probably because not growing in cultivated soil. The following specimens, because of the lack of velvety pubescence on the upper surface of the blades, may be referred to this form: Mississippi: Biloxi, Chase 4331, Hitchcock 1079, Tracy 1735, 2867, 3620, 3622, 3645, 4580, 4605; Ocean Springs, Tracy 6469. Louisiana: Lake Charles, Hitchcock 1152, Chase 4401. 
DISTRIBUTION.

Moist sandy woods, mostly near the coast, New Jersey to Florida and Texas.

New JERSEY: Wildwood, Chase 3488, 3505, Heritage 6.

Delaware: Milton, Commons 342; Lewes, Hitchcock 387.

Maryland: Between Chesapeake Beach and Chesapeake Junction, Hitchcock $1613,1638$.

Virginia: Dismal Swamp, Chase 3663, Tyler in 1905; Norfolk County, Kearney 1559; Virginia Beach, Kearney 2043; Cape Henry, Chase 5426.

North Carolina: Chapel Hill, Ashe in 1898, Chase 3068, 3076; Raleigh, Chase 3086; Wilsons Mills, Chase

3107; Lake Mattamuskeet, Chase 3208; Scranton, Chase $3201 \frac{1}{2}$; Roanoke Island, Chase 3221; Wilmington, Chase 4584, Hitchcock 388, 1468.

South Carolina: Orangeburg, Hitchcock 389, 390, 1395; Isle of Palms, Hitchcock 386, Chase 4532; St. Helena Island, Cuthbert in 1899.

Georgra: Stone Mountain, J. $D$. Smith 48 in 1883; Millen, Cur-

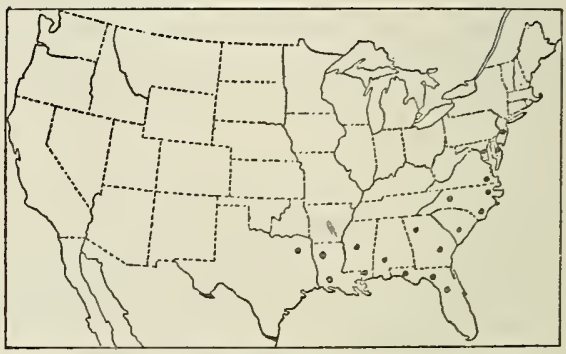

FIG. 228.-Distribution of $P$. ianuginosum. tiss 6827; Coney, Harper 1399; Burke County, Harper 765; Thomson, Bartlett $1443,1460$.

Florida: Lake City, Bitting 8, 13, Chase 4277, 4292, Combs 174, 194, Hitchcock 1032; Milton, Chase 4305, Curtiss R; Madison County, Combs 215, 294; Gainesville, Chase 4242, Combs 732; Eustis, Nash 375; Orange Bend, Chase 4113; St. Andrews, Tracy 9138.

Alabama: Fort Morgan, Tracy 8399.

Mrssissippi: Biloxi, Chase 4331, Hitchcock 1079, Tracy 1735, 2867, 3620, 3622, 3645, 4580, 4605; Ocean Springs, Tracy 6469; Cat Island, Tracy \& Lloyd 441; Horn Island, Tracy 2856; Jackson, Hitchcock 1297; Saratoga, Tracy 8416.

Louisiana: Shreveport, Hitchcock 1238, 1258; Cameron, Cocks 2191; Calcasieu, Cocks 2193; Breton Island, Tracy \& Lloyd 467; Alexandria, Ball 544; Lake Charles, Chase 4401, Hitchcock 1129, 1135, 1147, 1152.

Texas: Silver Lake, Reverchon 1884.

\section{$\checkmark$ 127. Panicum acuminatum Swartz.}

Panicum acuminatum Swartz, Prodr. Veg. Ind. Occ. 23. 1788. "Jamaica." In his Flora $a$ Swartz states concerning this species, "Incolit campos arenosos Jamaicae montosae." The type specimen, in the Swartz Herbarium, consists of three plants of the prostrate autumnal form.

Panicum dichotomum acuminatum Swartz; Griseb. Fl. Brit. W. Ind. 553. 1864. Based on $P$. acuminatum Swartz. In the Grisebach Herbarium is a plant of this species labeled by Grisebach, collected in Jamaica by March.

Panicum comophyllum Nash, Bull. Torrey Club 30:380. 1903. "Type collected in rich soil at Santurce [Porto Rico], January 9, 1899, by Heller, no. 12." The type, in the herbarium of the New York Botanical Garden, is a specimen in the early branching state.

$a$ Fl. Ind. Occ. 1: 152. 1797. 


\section{DESCRIPTION.}

Vernal culms leafy, ascending from a geniculate base, 20 to $70 \mathrm{~cm}$. high, densely villous with soft, spreading hairs, rarely glabrate above, the nodes more or less bearded; sheaths velvety papillose villous or the upper glabrate; ligule 2 to $3 \mathrm{~mm}$. long; blades ascending or spreading, 4 to $8 \mathrm{~cm}$. long, 6 to $13 \mathrm{~mm}$. wide, lanceolate, slightly cordate at base, sharply acuminate, usually ciliate, the lower surface velvety papillose puberulent, the upper surface from appressed papillose pubescent to long-villous, or nearly glabrous except for long hairs near the base or margin; panicles 3 to $10 \mathrm{~cm}$. long, about as wide, the axis usually villous, the branches flexuous, the lower spreading or even reflexed; spikelets 1.8 to $1.9 \mathrm{~mm}$. long, $0.9 \mathrm{~mm}$. wide, obovate, turgid, abruptly subacute, pilose; first glume about one-third the length of the spikelet, subacute; second glume and sterile lemma

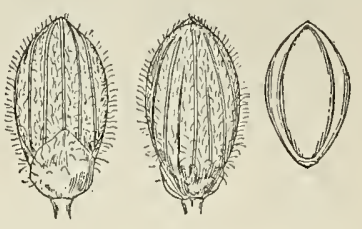

FIG. 229.-P. acuminatum. From type specimen. barely equaling the fruit at maturity; fruit 1.3 to $1.4 \mathrm{~mm}$. long, $0.9 \mathrm{~mm}$. wide, elliptic, abruptly acute.

Autumnal form appearing early, the primary culms branching at all but the uppermost nodes before the maturity of the primary panicles, these branches often exceeding the culm, more or less zigzag, repeatedly branching, the ultimate branchlets in dense, short, flabellate fascicles, the reduced blades flat or involute-pointed, the long hairs on the margins and upper surface usually conspicuous.

\section{DISTRIBUTION .}

Sandy pine woods, the West Indies; also in the United States of Colombia.

CubA: Herradura, Hitchcock 140, Tracy 9078; Pinar del Rio, Palmer \& Riley 447; Wright 3874; Isle of Pines, Curtiss 307, 328, Palmer \& Riley 989, 1083, A. A. Taylor in 1901 .

JAMAICA: Swartz, Hart 736.

Santo Domingo: Poiteau (Paris Herb.).

Porto Rico: Santurce, Heller in 1903, Maricao, Sintenis 355; Fajardo, Sintenis 1224 in part; Lares, Sintenis 5908.

Colombia: Near Jamundí, Pittier 932, 982a.

\section{Panicum auburne Ashe.}

Panicum auburne Ashe, N. C. Agr. Exp. Sta. Bull. 175: 115. 1900. "Auburn, Ala., May 7, 1898. Collected by Professors F. S. Earle and C. Baker, of the Alabama Biological Survey, at Auburn, Ala., May 7, 1898. No. 1527." The type specimen,

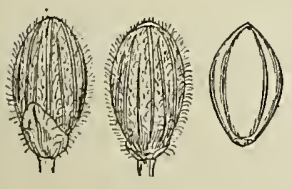

FIG. 230.-P. auburne. From type specimen. in Ashe's herbarium, consists of several immature vernal culms with portions of the dead autumnal culms of the preceding year attached.

\section{DESCRJPTION.}

Vernal form grayish velvety-villous throughout; culms tufted, 20 to $50 \mathrm{~cm}$. high, geniculate at base, widely spreading, soon becoming branched and decumbent, rather slender, densely papillose silky villous below, velvety with copious silky hairs intermixed above; sheaths usually about half the length of the internodes, villous like the culms; ligules 3 to $4 \mathrm{~mm}$. long; blades rather thin, ascending, 3 to 7 $\mathrm{cm}$. long, 3 to $5 \mathrm{~mm}$. wide, acuminate, slightly narrowed toward the base, the upper 
surface velvety with copious long, silky hairs intermixed, especially toward the base, the lower surface silky-villous or velvety, the nerves somewhat conspicuous; paniclesshortexserted, 3 to $5 \mathrm{~cm}$. long, about as wide, the axis velvety, with long, silky hairs intermixed, the flexuous branches ascending or spreading; spikelets 1.3 to $1.4 \mathrm{~mm}$. long, 0.8 to $0.9 \mathrm{~mm}$. wide, obovate, very turgid, densely papillose-pubescent; first glume one-third to half the length of the spikelet, acute; second glume and sterile lemma equal and covering the fruit at maturity; fruit 1.1 to $1.2 \mathrm{~mm}$. long, $0.8 \mathrm{~mm}$. wide, obovate-elliptic, minutely pointed.

Autumnal form early becoming diffusely branched at all the nodes, prostratespreading, forming large mats, the branches curved upward at the ends; earlierbranches longer than the primary internodes, the ultimate branchlets in short fascicles with involute-pointed blades 1 to $2 \mathrm{~cm}$. long, the numerous turgid little spikelets clustered at their bases; winter rosette appearing rather late, the lanceolate blades silky-villous like those of the primary culm.

The vernal form resembles that of $P$. lanuginosum but is smaller, more slender and more silky-villous, with smaller, more turgid spikelets; the prostrate autumnal form with upturned branch tips is characteristic.

\section{DISTRIBUTION.}

Sandy pine and oak woods of the Coastal Plain from Virginia to Florida,

nd: Oume and west to Louisiana.
ante. Hiel Virginia: Cape Henry, Chase 2341; 1913 Virginia Beach, Mackenzie 1733, Williams 3097, 3105; Dismal Swamp, Chase 3680.

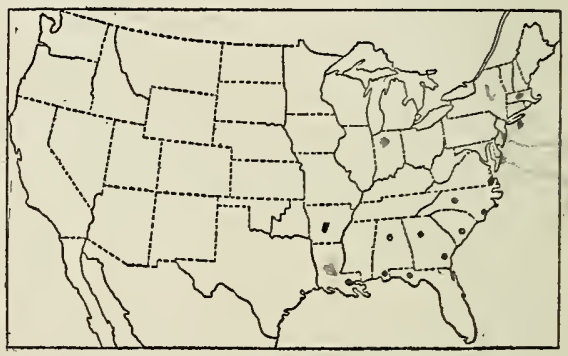

FIG. 231.-Distribution of $P$. auburne.

North Carolina: Wilmington, Chase 3132, 4579, Hitchcock 1482; Cumberland County, Stevens 6425.

South Carolina: Orangeburg, Hitchcock 10.

Georgia: Bainbridge, Curtiss 6811; Thomson, Bartlett 1172.

Florida: De Funiak Springs, Combs 440.

Alabama: Gateswood, Tracy 8430 in part; Auburn, Earle \& Baker 1527.

Louisiana: Shreveport, Cocks 3506.

\section{Panicum thurowii Scribn. \& Smith.}

Panicum thurowii Scribn. \& Smith, U. S. Dept. Agr. Div. Agrost. Circ. 16: 5.1899. "Named for Mr. F. W. Thurow, by whom it was collected in Waller County, Texas,
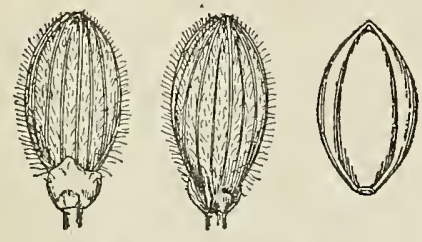

FIG. 232.-P. thurowii. From type specimen. June 5, 1898, No. 9." The type, in the National Herbarium, consists of one simple culm and one beginning to branch, about $40 \mathrm{~cm}$. high, with short-exserted, nearly mature panicles.

\section{DESCRIPTION.}

Vernal form bluish green, but drying olive; culms tufted, 35 to $70 \mathrm{~cm}$. high, erect or ascending, villous, the nodes bearded with spreading hairs, usually a glabrous ring below; sheaths long, the lower often overlapping, the upper shorter than the internodes, sparsely or rather densely villous; ligules $4 \mathrm{~mm}$. long; blades rather stiff, ascending or spreading, 7 to $12 \mathrm{~cm}$. long, or the uppermost only 2 to $3 \mathrm{~cm}$. long, 6 to $10 \mathrm{~mm}$. 
wide, acuminate, often somewhat involute toward the apex, narrowed toward the rounded base, the upper surface sparingly pilose toward the base and margins, the lower surface densely velvety-villous; panicles short-exserted, 7 to $11 \mathrm{~cm}$. long, nearly as wide, rather densely flowered, the axis sparingly villous near the base, the branches spreading; spikelets $2 \mathrm{~mm}$. long, $1 \mathrm{~mm}$. wide, elliptic, somewhat obovate at maturity, obtuse, pubescent with soft, spreading hairs; first glume one-fifth the length of the spikelet, obtuse or obscurely pointed; second glume and sterile lemma equal, scarcely equaling the fruit at maturity, obtuse or slightly pointed; fruit 1.7 $\mathrm{mm}$. long, $1 \mathrm{~mm}$. wide, elliptic, subacute.

Autumnal form erect, after the maturity of the primary panicle bearing at the middle nodes a few appressed or ascending fascicled branches scarcely longer than the primary internodes, the reduced blades flat or somewhat involute at the tips, ciliate.

\section{DISTRIBUTION.}

Prairies and dry open woods, Alabama to Texas.

Alabama: In the vicinity of Mobile, Mohr in 1895 and 1897.

Louisiana: Without locality, Hale (Gray Herb.).

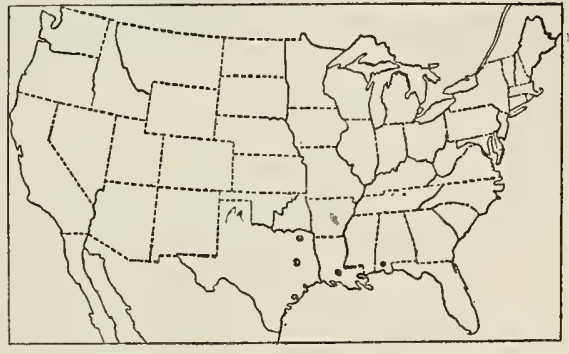

FIG. 233.-Distribution of $P$. thurowii.

Texas: Waller County, Hilchcock 1171, 1195, 1226, Thurow 9, 11; Montgomery County, Thurow in 1905; Hockley, Thurow in 1893 and 1906; Swan, Reverchon 4163; Houston, Ravenel in 1869; Del Rio, Plank 41; without locality, Nealley in 1884 and 1887.

\section{$\checkmark$ 130. Panicum olivaceum sp. nov.}

\section{DESCRIPTION .}

Vernal culms olive green, erect or somewhat spreading at base, 20 to $40 \mathrm{~cm}$. high, velvety-villous with short hairs, the nodes bearded; sheaths villous like the culm, mostly shorter than the internodes; ligules 3 to $4 \mathrm{~mm}$. long; blades rather stiffly erect or ascending or some of the lower spreading, 4 to $7 \mathrm{~cm}$. long, 5 to $8 \mathrm{~mm}$. wide (the uppermost erect, 1 to $3 \mathrm{~cm}$. long), puberulent on both surfaces, also more or less short-villous above, and often with longer villous hairs toward the base; panicles 3 to

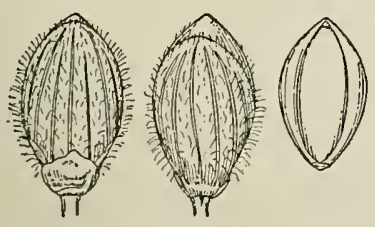

I'IG. 234.-P. olivaceum. From type specimen. $7 \mathrm{~cm}$. long, ovate, the flexuous branches spreading, short spikelet-bearing branchlets in the axils; spikelets 1.9 to $2 \mathrm{~mm}$. long, $1 \mathrm{~mm}$. wide, obovate, subacute, papillose-pilose; first glume one-fourth to onethird the length of the spikelet, usually pointed; second glume scarcely equaling the fruit and sterile lemma; fruit $1.6 \mathrm{~mm}$. long, $1 \mathrm{~mm}$. wide, subacute.

Autumnal form upright or becoming decumbentspreading, freely branching from the lower and middle nodes before the maturity of the primary panicle, the reduced branches appressed; or in the decumbent culms curved upward; blades reduced, flat, 1 to $2 \mathrm{~cm}$. long, 2 to $4 \mathrm{~mm}$. wide, usually conspicuously ciliate.

Type U. S. National Herbarium no. 823209, collected February, 1888, at Coban, Department of Alta Vera Paz, Guatemala, altitude 1,400 meters, by H. von Tuerck-

$$
41616^{\circ} \text { - VOL } 15--10-15
$$


heim (no. 428). It consists of four plants with mature primary panicles and freely branching culms.

This species is closely allied to $P$. acuminatum, differing in the olivaceous color, the less velvety pubescence, the stiff, appressed blades, and the larger spikelets. The autumnal form is bushy, the branches evenly distributed, not gathered into distinct fascicles as in $P$. acuminatum.

\section{DISTRIBUTION.}

Gravelly banks and cultivated fields, Mexico to Costa Rica; also in Venezuela. .

Mexico: Jalapa, Pringle 8339 in parta (Nat. Herb. no. 823271); Orizaba, Bourgeau 2383 in part, Bolteri 99, 101 (both in Brit. Mus. Herb.), 1987 (Paris Herb.); Minatitlan, J. G. Smith 571 (Hitchcock Herb.).

Guatemala: Coban, Tuerckheim 428 in 1879, 428 in 1888; Seler 3235 (Berlin Herb.).

Costa Rica: San Pedro de la Calabaza, Tonduz 10745 in part (Nat. Herb. no. 385918); Tablazo, Tonduz 7944.

Venezuela: Tovar, Fendler $1638 \beta$.

Colombia: Popayán, Lehmann 974 (Gray Herb.), farmundi, Tittier

$\checkmark$ 131. Panicum praecocius Hitchc. \& Chase.

Panicum praecocius Hitchc. \& Chase, Rhodora 8: 206. 1906. "Type V. H. Chase 649; dry bank, near Wady Petra, Stark County, Illinois, June 30, 1900, collected by Virginius H. Chase." The type, in the National Herbarium, is a clump of branching culms, with mature secondary panicles, the primary ones being devoid of spikelets.

\section{DESCRIPTION.}

Vernal culms tufted, 15 to $25 \mathrm{~cm}$. high, early branching and elongating, sometimes to 30 or $45 \mathrm{~cm}$., at first erect, soon becoming geniculate and spreading, very slender, wiry, abundantly papillose-pilose with weak spreading hairs 3 to $4 \mathrm{~mm}$. long; sheaths, even the lowest, much shorter than the very long internodes, those of the branches usually but 1 to $2 \mathrm{~cm}$. long, pilose like the culm, more prominently papillose; ligules 3 to $4 \mathrm{~mm}$. long; blades rather firm, erect or ascending, 5 to $9 \mathrm{~cm}$. long, 4 to $6 \mathrm{~mm}$. wide, the margins parallel about two-thirds their length, acuminate, long-pilose on

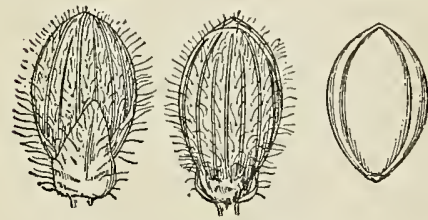

FiG. 235.-P. praecocius. From type specimen. both surfaces, the hairs of the upper surface 4 to $5 \mathrm{~mm}$. long, erect from the plane of the blade, the under surface prominently papillose; panicles at first usually overtopped by the upper leaf, but at or past maturity exserted, 4 to $6 \mathrm{~cm}$. long, about as wide, loosely flowered, the axis pilose, the branches flexuous, spreading or ascending; spikelets 1.8 to $1.9 \mathrm{~mm}$. long, $1 \mathrm{~mm}$. wide, obovate, turgid, obtuse, pilose; first glume one-third to half the length of the spikelet, triangular; second glume and sterile lemma subequal, the glume slightly shorter than the fruit at maturity; fruit $1.6 \mathrm{~mm}$. long, $1 \mathrm{~mm}$. wide, broad-elliptic.

Autumnal form ascending from a geniculate base, or in prairie sod erect, forming close bunches 10 to $20 \mathrm{~cm}$. high, the upper portion of the primary culms early deciduous, the branches appressed, the scarcely reduced blades erect or narrowly ascending, much exceeding the reduced panicles; winter rosette appearing late, the blades 2 to $3 \mathrm{~cm}$. long, long-pilose.

This species scarcely has a simple state, the branches appearing often before the first panicle is expanded.

$a$ See footnote under $P$. multirameum, page 185. 


\section{DISTRIBUTION.}

Dry prairies and clearings, Michigan and Indiana to Minnesota and Texas.

Indiana: Hessville, Hill 49 in 1909.

Illinois: Joliet, Hill 37 in 1907; Wady Petra, V. H. Chase 472, 649, 1212, 1214, 1218, 1492, 1515; Marshall County, V. H. Chase 1791; Williamsfield, V. H. Chase 1850; Havana, Gleason 1034.

Michigan: Port Huron, Dodge in 1909.

Wisconsin: Lauderdale, Bebb 2057.

Minnesota: Itaska Lake, Sandberg 1016.

Iowa: Fort Dodge, Somes 25; Armstrong, Cratty in 1890; Iowa City, Somes 246.

Nebraska: Broken Bow, Webber 4.

Missouri: Monteer, Bush 748, 749

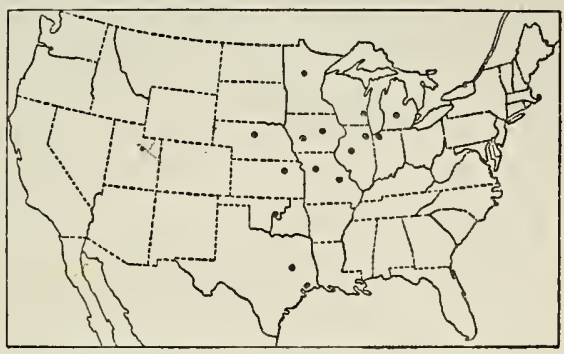

FIG. 236.-Distribution of $P$. praecocius. in part; McDonald County, Bush 87; Howell County, Bush 54; Lees Summit, Bush 3090, 3935.

KaNsas: Manhattan, Carleton in 1892, Hitchcock 2500, 2524, 3853, Kellerman 20; Belleville, Hitchcock 3544.

Texas: Waller County, Thurow 5, and in 1906; Weatherford, Tracy 7943 in part. OKLAнома: Stillwater, Hitchcock in 1903 (Hitcheock Herb.).

\section{$\checkmark$ 132. Panicum subvillosum Ashe.}

Panicum subvillosum Ashe, Elisha Mitchell Soc. 16: 86. 1900. "Collected by the writer at Carlton, Minnesota, in August, in the simple state. Type material preserved in my herbarium." The type specimen, in Ashe's herbarium, consists of three tufts of several culms each, 15 to $30 \mathrm{~cm}$. high, with leaves clustered at the base and long-exserted mature panicles.

Panicum unciphyllum forma pilosum Scribn. \& Merr. Rhodora 3: 124. 1901, not Panicum pilosum Swartz, 1788. "Dry woods, Orono, Maine, 501 M. L. Fernald, July 7, 1891." The type, in the National Herbarium, consists of a tuft of nine slender culms 15 to $35 \mathrm{~cm}$. high, with long-exserted nearly mature panicles.

\section{DESCRIPTION.}

Vernal culms tufted, 10 to $45 \mathrm{~cm}$. high, slender, ascending or spreading, pilose with ascending hairs, usually faintly papillose, the lower internodes short, thus making the
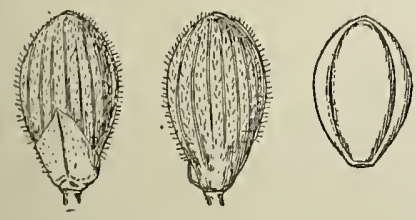

Frg. 237.-P. subvillosum. From type specimen. plant more leafy below, the nodes short-bearded; sheaths sparsely pilose with ascending hairs, the lower overlapping, the upper much shorter than the long internodes; ligules $3 \mathrm{~mm}$. long; blades rather firm, ascending, 4 to $6 \mathrm{~cm}$. long, 4 to $6 \mathrm{~mm}$. wide, rarely wider, acuminate, slightly narrowed toward the base, both surfaces pilose, the hairs on the upper surface 3 to $5 \mathrm{~mm}$. long, shorter on the lower; panicles long-exserted, ovate to oblong in outline, 3 to $5 \mathrm{~cm}$. long, two-thirds to three-fourths as wide, rather densely flowered, the axis pubescent or toward the base pilose, the lower branches ascending; spikelets 1.8 to $1.9 \mathrm{~mm}$. long, $0.9 \mathrm{~mm}$. wide, elliptic, obtuse, pubcscent; first glume nearly or quite half the length of the spikelet, acuminate; 
second glume scarcely equaling the fruit at maturity; fruit $1.5 \mathrm{~mm}$. long, $0.8 \mathrm{~mm}$. wide, elliptic, obtuse.

Autumnal form widely spreading, sparingly branching from the lower nodes, the leaves and panicles not greatly reduced, the panicles overtopped by the leaves, these less copiously pilose.

This species may be distinguished from $P$. implicatum and $P$. meridionale by the larger spikelets, the long-exserted panicles, the aggregation of the leaves toward the base of the vernal culms, and the sparingly branched, almost prostrate autumnal form. In its most characteristic form the panicle branches are strictly ascending at maturity and spikelet-bearing near the ends only, thus forming a compact panicle with a long naked base.

\section{DISTRIBUTION.}

Dry woods and sandy ground, Nova Scotia to Connecticut, and west to Minnesota and northern Indiana.

Nova Scotia: Bedford, Macoun 29368.

New Brunswick: Kent County, Fowler in 1875.

Quebec: Montmorenci Falls, Macoun 69205 (Gray Herb.).

Ma1ne: Chesterville, Chase 3278, 3320; Fayette, Chase 3391; Cape Elizabeth, Chase 3453; Stacy ville, Knight 56; North Yarmouth, Chamberlain 837; Hartford, Parlin 2016; Cumberland, Chamber-

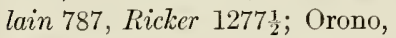
Fernald 501; Ogunquit, Parlin 1581; Canton, Parlin 2001.

New HaMpshure: Wiers, Carter in 1902 (Hitchcock Herb.).

Vermont: Rutland, Eggleston 1758.

Massachusetts: Ipswich, Oakes (Gray Herb.).

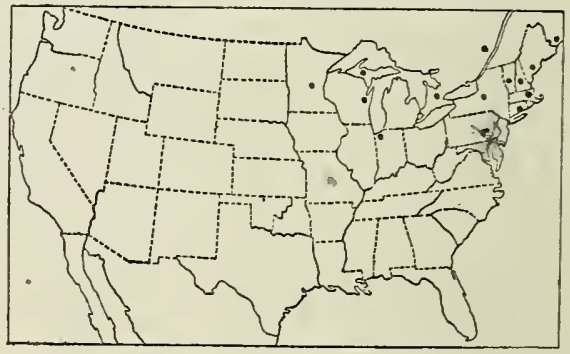

FIG. 238.-Distribution of $P$. subvillosum.

Connecticut: Tolland, Bissell 12001.

New York: Verona, Haberer in 1900; Hempstead, Bicknell in 1903; Valley Stream, Bicknell in 1905; Rosedale, Bicknell in 1904.

I Ontar1o: Galt, Herriot in 1898; Algonquin Park, Macoun 22023.

TIndiana: Clark Junction, Bebb 2832, $2833 \frac{1}{2}$.

Michigan: Keweenaw County, Farwell 642.

Wisconsin: Conover, Cheney 678; Tomahawk Lake, Cheney 1082.

Minnesota: Carlton, Ashe in 1899.

mo: noel, Bueh $5741,5741 \mathrm{~A}$

- 133. Panicum occidentale Scribn.

Panicum occidentale Scribn. Rep. Mo. Bot. Gard. 10:48. 1899. Based on "P. pubescens [Lam. misapplied by] Presl, not Lam. nor Michx." While the type must be the specimen in Presl's herbarium, Scribner's conclusions were based on a duplicate in the Bernhardi Herbarium at the Missouri Botanical Garden, labeled in Presl's handwriting "Panicum pubescens Michx." The type specimen collected by Haenke, which is the basis of Presl's $a$ identification, is in the Bohemian Museum at Prague and consists of three culms with mature primary panicles, and with secondary panicles on short branches from the lower nodes, that is, vernal culms showing the commencement of the autumnal form. One label reads "Panicum pubescens Michx.;" another bears the locality "Archipel," which refers to the vicinity of Nootka Sound, Vancouver Island, the locality as published by Presl, "Hab. in Nootka-Sund." 


\section{DESCRIPTION.}

Vernal form tufted, yellowish green; culms slender, 15 to $40 \mathrm{~cm}$. high, rarely higher, spreading, the lower internodes usually short, as in P. subvillosum, producing a leafy base as in that species, sparsely papillose-pubescent, the upper more or less elongated, glabrate, the nodes pubescent; sheaths rather sparsely papillose-pubescent,
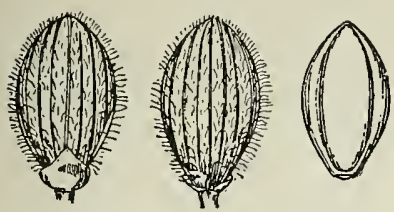

Fig. 239.-P. occidentale. From type specimen at Prague. rarely almost glabrous; ligules 3 to $4 \mathrm{~mm}$. long; blades firm, erect or ascending, 4 to $8 \mathrm{~cm}$. long, 5 to $7 \mathrm{~mm}$. wide, acuminate, rounded at the base, the upper surface with a few long hairs toward the base and margin, otherwise glabrous, the under surface appressed-pubescent; panicles long-exserted, 4 to 7 cm. long, about two-thirds as wide, rather loosely flowered, the flexuous branches ascending or spreading; spikelets $1.8 \mathrm{~mm}$. long, $1 \mathrm{~mm}$. wide, ellipticobovate, subacute, pubescent; first glume one-fourth the length of the spikelet or less, obtuse or pointed; second glume and sterile lemma as long as the fruit at maturity; fruit $1.6 \mathrm{~mm}$. long, $0.9 \mathrm{~mm}$. wide, elliptic, subacute.

Autumnal form branching from the lower nodes, forming a spreading bunch or tussock 10 to $15 \mathrm{~cm}$. high; leaves and panicles reduced; winter rosette appearing late, the blades narrowly lanceolate, glabrous or pilose at base.

This species is less pubescent than any other in this group.

\section{DISTRIBUTION.}

Peat bogs and moist sandy ground, British Columbia and Idaho to southern California.

IDAно: Lake Coeur d'Alene, Sandberg, Heller \& MacDougal in 1892; Priest Lake, Piper 3778.

Washington: Montesano, Heller 3978; Chelan County, Whited in 1901; Lake Chelan, Elmer 489, Lake \& Hull 118; Bingen, Suksdorf 5162, 5174; Granville, Conard 378, Yakima County, Cotton 736, 792.

British Columbia: Lake Osoyoos, Macoun 77229; Vancouver Island, Canby 352 (Gray Herb.).

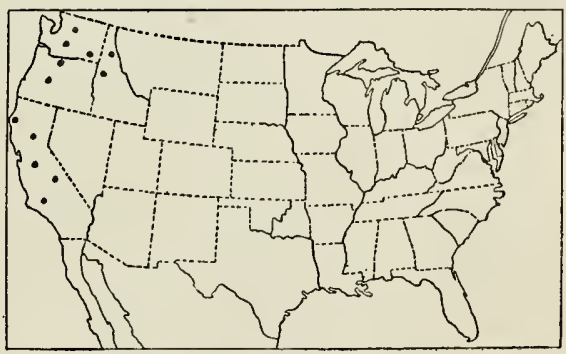

FIG. 240.-Distribution of $P$. occidentale.

Oregon: Mount Scott, Sheldon in 1902; Columbia River, Sheldon 8706.

California: Crescent City, Davy 5971; Mendocino, Davy 6092, McMurphy, 425; New York Falls, Hansen 1723; Yosemite Valley, Brewer 1646; Merced River, Torrey 587; San Diego, Orcutt 540; without locality, Bridges 366, Hartweg 2024.

134. Panicum pacificum sp. nov.

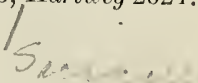

\section{DESCRIPTION.}

Vernal form light green; culms tufted, 25 to $50 \mathrm{~cm}$. high, ascending or spreading, leafy (culm leaves 5 or 6 ), papillose-pilose with spreading hairs, the nodes shortly spreading-pilose; sheaths papillose-pilose, the papillæ prominent; ligules 3 to $4 \mathrm{~mm}$. long; blades erect or ascending 5 to $10 \mathrm{~cm}$. long, 5 to $8 \mathrm{~mm}$. wide, acuminate, narrowed toward the rounded base, the upper surface papillose-pilose, typically with short hairs intermixed, but these often wanting and the long hairs sometimes sparse, 
the lower surface appressed papillose pubescent; panicles usually rather shortexserted, 5 to $10 \mathrm{~cm}$. long, about three-fourths as wide, the flexuous branches ascending; spikelets 1.8 to $2 \mathrm{~mm}$. long, 1 to $1.1 \mathrm{~mm}$. wide, obovate, obtuse, turgid, papillosepubescent; first glume one-fourth to one-third the length of the spikelet, truncate; second glume and sterile lemma equaling the fruit at maturity; fruit $1.6 \mathrm{~mm}$. long, $1 \mathrm{~mm}$. wide, elliptic-obovate, obtuse or obscurely pointed.

Autumnal form prostrate-spreading, repeatedly branching from the middle and upper nodes after the maturity of the primary panicle, the reduced blades less pilose

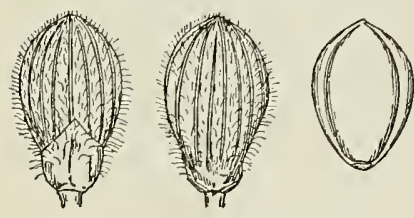

FIG. 241.-P. pacificum. From type specimen. than the vernal ones, exceeding the reduced panicles; winter rosette appearing rather early, blades only sparsely pubescent.

Type U. S. National Herbarium no. 592751, collected August 3, 1908, in moist places in woods, one-fourth mile east of hotel, Castle Crag, Shasta County, California, by A. S. Hitchcock (no. 3070). The specimen is a tuft of several branching culms.

This species is distinguished from $P$. occidentale by the more copious pubescence throughout, the more leafy culms, and in the autumnal form by the branching habit; from $P$. thermale by the taller, late-branching culms, longer, narrower blades, and pilose, not velvety, pubescence, also by the branching habit. It most nearly resembles $P$. huachucae, laxer forms resembling its subspecies silvicola, and like these it is variable in amount of pubescence. The spreading habit and larger spikelets, together with a distinct range, make it impossible to include this western form under $P$. huachucae.

\section{DISTRIBUTION.}

Sandy shores and slopes, and moist crevices in rocks, ascending to 1,650 meters, British Columbia and Idaho to southern California.

Iрано: Salmon River, Henderson 3569; Lake Coeur d'Alene, Hitchcock 2171, 2190, Leiberg 1312; Lochsa River, Piper 4056; Sawtooth National Forest, Tidestrom 2636.

Washington: Falcon Valley, Suksdorf 124; Wenatchee, Whited 1249; Kittitas County, Sandberg \& Leiberg 425; Spekane, Kreager 160; Lake Calispell, Kreager 325; Lake Chelan, Gorman 635; Klickitat County, Suksdorf 6292.

British Columbia: Vancouver Island, Canby 252, Rosendahl \& Brand 107, Waldron 1921.

Oregon: Grants Pass, Piper 6493; Belknap Springs, Gorman 1834; without locality, Hall 671 (Gray Herb.).

Nevada: Ruby Valley, Watson 1350.

Arizona: Lowell, W. F. Parish 263.

California. Castle Crag, Hitchcock 3070, 3071, 3073, 3077; Red-

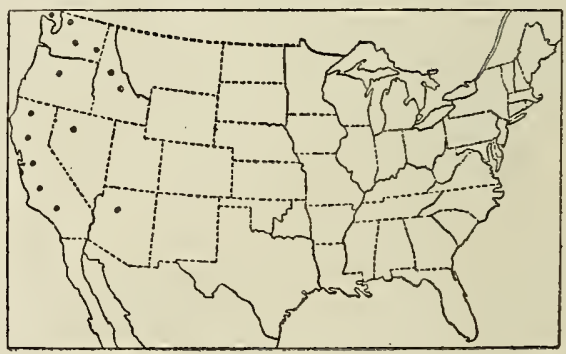

FIg. 242.-Distribution of $P$. pacificum. ding, Heller 7856; Yosemite Valley, Bolander 4840, Hall \& Babcock 3317, 3362, Hitchcock 3214, 3219, 3232, 3233, 3234; Crow Point, Hansen 1444; Clinton Bar, Hansen 1381; Pine Grove, Hansen 626; North Fork, Griffiths 4438, 4476, 4617; Madera, Griffuhs 6586; San Jacinto Mountains, Hall 2244; Pine Ridge, Hall_\& Chandler 239; Santa Cruz, Jones 2294; Point Reyes, Davy 6745, 6780; Requa, Davy \& Blasdale 5894; San Bernardino Mountains, S. B. \& W. F. Parish 1663; without locality, Bolander 564, Hartweg 2024 (Gray Herb.). 


\section{Panicum thermale Boland.}

Panicum thermale Boland. Proc. Calif. Acad. 2: 181. 1862. "On hot rocks and in hot water flowing from the Geyser springs and Geyser mountains, in the northern part of Sonoma County," California. The type, in the Gray Herbarium, is the early branching form. It is marked "I call this: Panicum thermale till I shall know better. It grows in the Geysers Sonoma Co. and on hot rocks."

\section{DESCRIPTION.}

Vernal culms grayish green, densely tufted, velvety-villous, 10 to $30 \mathrm{~cm}$. high, ascending or spreading, the nodes with a dense ring of short hairs; sheaths often overlapping, velvety-villous; ligules $3 \mathrm{~mm}$. long; blades thick, ascending or spreading, 3 to $8 \mathrm{~cm}$. (mostly about $5 \mathrm{~cm}$.) long, 5 to $12 \mathrm{~mm}$. wide, acuminate, rounded or subcordate at base, both surfaces densely velvety-villous; panicles exserted or in high alpine specimens partly included, 3 to $6 \mathrm{~cm}$. long, about as wide, densely flowered, the axis villous, the flexuous branches spreading, often drooping; spikelets 1.9 to 2
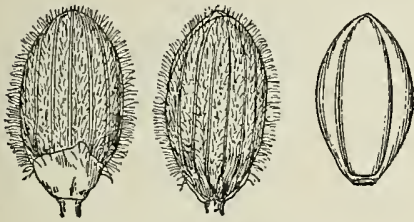

Fig. 243.-P. thermale. From type specimen. $\mathrm{mm}$. long, $1 \mathrm{~mm}$. wide, obovate-oblong, obtuse, turgid, papillose-pilose; first glume about onethird the length of the spikelet, obtuse or abruptly pointed; second glume and sterile lemma subequal, the glume shorter than the fruit at maturity; fruit $1.7 \mathrm{~mm}$. long, $1 \mathrm{~mm}$. wide, elliptic, subobtuse.

Autumnal form widely spreading, the branches appearing even before the primary panicles are exserted, repeatedly branching, the whole forning a dense cushion, the blades and panicles of the ultimate branchlets reduced; winter rosette appearing early, the blades ovate-lanceolate, usually less pubescent than those of the culms.

In the original description Dr. Bolander states: "The whole plant is like velvet to the feel. There are, however, some specimens which are rather smooth." This smoother form is represented by part of Merrill 157, one tuft of which has lower blades nearly glabrous, but sheaths and upper blades nearly as velvety as in the type, while other specimens of this collection are fully as villous. The Bolander type collection represents about the average of the species. Some of the specimens cited below are longer villous than the type and some few are smoother.

A specimen from Banff, Alberta, McCalla 2318, "on tufa and old bogs in warm sulphur stream; alt. 4,500 ft.," has short, early-branching culms, broad leaves and small panicles like $P$. thermale, but the pubescence is of sparser long hairs, somewhat harsh and prominently papillose as in $P$. pacificum.

\section{DISTRIBUTION.}

Wet saline soil in the immediate vicinity of .geysers and hot springs ascending to 2,500 meters, Alberta to Wyoming and California.

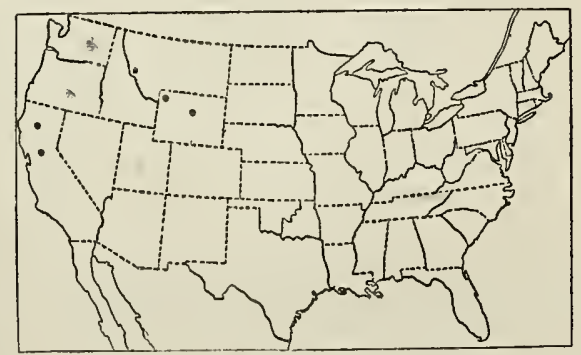

FIG. 244.-Distribution of $P$. thermale.

Alberta: Banff, McCalla 2318.

Montana: Lo Lo Hot Springs, Williams \& Griffith 306.

Wrouing: Yellowstone National Park, Chase 5252; Hitchcock 1902, 2061, 2086, Mearns 3061, 4050, 4166, 4203, 4789, 4870, 4983, 5064, 5110, 5134, Merrill 157, 
164, 165, A. Nelson 6174, A. Nelson \& E. Nelson 6037, Rydberg \& Bessey 3545, 3547, Tweedy 580; Bighorn County, Tweedy 94.

California: Sonoma County, Bolander 3941; خjapa County, Brewer 861; Lassen Peak, Bolander 2169.

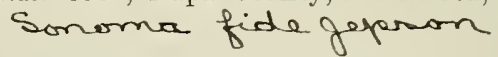

- 136. Panicum languidum nom. nov.

Panicum unciphyllum forma prostratum Scribn. \& Merr. Phodora 3: 124. 1901, not P. prostratum Lam. 1791. "South Berwick, Maine, M. L. Fernald, September 26, 1897." The type, in the National Herbarium, is a lax, decumbent, autumnal sperimen with geniculate nodes, numerous loose branches with immature panicles, and pointed spikelets $2 \mathrm{~mm}$. long.

DESCRIPTION.

Vernal form tufted; culms 25 to $40 \mathrm{~cm}$. high, weak, slender, ascending or spreading, pilose; sheaths shorter than the internodes, papillose-pilose; ligules about $3 \mathrm{~mm}$. long; blades thin, lax, ascending or spreading, 4 to $7 \mathrm{~cm}$. long, 4 to $9 \mathrm{~mm}$. wide, acumi-

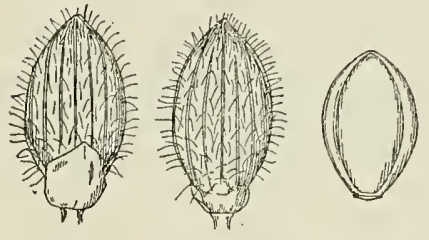

Fig. 245. $-P$. languidum. From type specimen of $P$. unciplyllum forma prostratum Scribn. \& Merr. nate, slightly narrowed to the rounded base, sparsely pilose on the upper surface, minutely appressed-pubescent beneath, usually with long hairs intermixed; panicles rather lony-exserted, 3 to $6 \mathrm{~cm}$. long, two-thirds to three-fourths as wide, loosely flowered, the very flexuous branches finally spreading or drooping, the spikelets on long, mostly divaricate, flexuous pedicels, the axis and branches sparsely long-pilose; spikelets $2 \mathrm{~mm}$. long, $1 \mathrm{~mm}$. wide, elliptic, acute, pilose; first glume about one-third the length of the spikelet, obtuse or acute; second glume and sterile lemma exceeding the fruit and slightly pointed beyond it; fruit $1.5 \mathrm{~mm}$. long, $1 \mathrm{~mm}$. wide, obtuse.

Autumnal form decumbent, with geniculate, sometimes rooting nodes, branching from all the nodes, the early branches nearly equaling the primary culm, repeatedly branching, forming a large, loose straggling clump, the ultimate blades and panicles scarcely reduced.

Type U. S. National Herbarium no. 592750 collected September 26, 1897, South Berwick, Maine, by M. L. Fernald, being the type of $P$. unciphyllum forma prostratum.

This species somewhat resembles $P$. villosissimum, though much less copiously pilose. It may be distinguished from that species and from $P$. huachucae silvicola by the pointed spikelets $2 \mathrm{~mm}$. long, the second glume and sterile lemma produced in a minute point beyond the fruit.

\section{DISTRIBUTION.}

Dry or sandy open woods, Maine, Massachusetts and eastern New York; apparently rare.

MaIne: South Berwick, Fernald in 1897, Parlin 938 (Gray

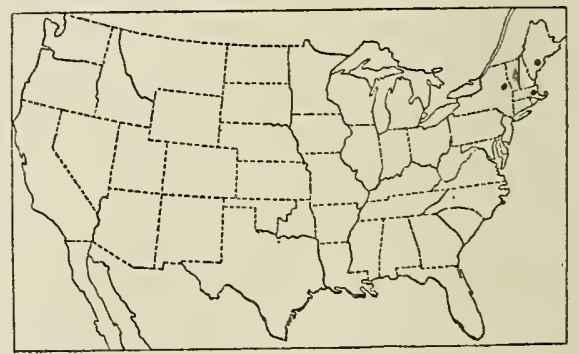

Fìg. 246.-Distribution of P. languidum.

Herb.); Island Falls, Fernald in 1897; Mount Desert Island, Fernald in 1892 in part (the last two in N. E. Bot. Club Herb.).

Massachusetts: Ashburnham, Harris in 1896.

New York: Platte Clove, Catskills, Williamson in 1903 (Phila. Acad. Ferb.).

Vermont: Wartland, Reiggles 4-9 


\section{Panicum villosissimum Nash.}

Panicum tectum Willd.; Spreng. Syst. Veg. $1: 313.1825$. This is given as a synonym under $P$. dichotomum. The type specimen, in the Willdenow Herbarium, is the autumnal form. It is labeled "Panicum tectum panicula divaricata. * * * Hab. a America boreali." A second specimen so named in the Willdenow Herbarium was sent by Muhlenberg and is $P$. xalapense.

Panicum dichotomum villosum Vasey, U. S. Dept. Agr. Div. Bot. Bull. 8: 31. 1889, not $P$. villosum Ell. 1816. The author cites "P. villosum Ell.?" but since on the same page he gives this name unquestioned as a synonym of $P$. consanguineum Kunth, Elliott's species can not be taken as the basis of Vasey's variety. No locality nor specimen is cited. A freely branching early autumnal specimen in the National Herbarium marked "dichotomum var. villosum" in Vasey's writing, and agreeing well with his description, is chosen as the type. This was collected "near Pierce's Mill, Rock Creek, D. C., July 1, 1883," by Dr. Vasey.

Panicum nitidum pubescens Scribn. in Kearney, Bull. Torrey Club 20:479. 1893. This is listed without description as the name of two numbers, 58 and 141, of Kearney's collection of plants in Harlan and Bell Counties, Kentucky. "Panicum laxiflorum pubescens Chapm." is cited but as the latter name had not at that time been published by Chapman, $P$. nitidum pubescens must be considered a nomen nudum. The specimens of his 58 and 141 in the National Herbarium, and distributed by Kearney, comprise $P$. villosissimum and $P$. huachucae, but the majority are the former.

Panicum laxiflorum pubescens Chapm.; Kearney, Bull. Torrey Club 20: 479. 1893, not Vasey 1892. This is given as a synonym of $P$. nitidum pubescens Scribn., but is later described by Chapman $a$ and based on $P$. pubescens Lam.

Panicum villosissimum Nash, Bull. Torrey Club 23:149. 1896. "Collected by Dr. John K. Small in the Ocmulgee River swamp, below Macon [Georgia], May 18-24, 1895." The type, in Nash's herbarium, consists of several vernal culms with branches appearing, but secondary panicles not expanded. The spikelets are $2.3 \mathrm{~mm}$. long.

Panicum atlanticum Nash, Bull. Torrey Club 24:346. 1897. "Type specimens collected by the writer on dry somewhat shaded knolls in the grounds of the New York Botanical Garden." The type, in Nash's herbarium, consists of a small clump and of two single specimens, the culms beginning to branch, primary panicles mature, secondary panicles immature. The spikelets are $2.2 \mathrm{~mm}$. long. This differs from the type of $P$. villosissimum only in the somewhat stiffer culms and slightly smaller spikelets.

Panicum haemacarpon Ashe, Journ. Elisha Mitchell Soc. i5: 55. 1898. "District of Columbia: Kearney; 1897. Ashe: North Carolina; Chapel Hill, 1898. Iowa: Carver; Jewell Junction, 1895, No. 258." The first specimen cited is chosen as the type. This is in Ashe's herbarium and consists of a tuft of three simple culms with nearly mature panicles and two autumnal culms of the previous year.

Panicum xanthospermum Scribn. \& Mohr, Contr. Nat. Herb. 6 : 348. 1901. "Type specimen collected by Dr. Charles Mohr in open sandy soil, Greenville, Butler County, Ala., May 8, 1898." This specimen, which is in the National Herbarium, consists of a tuft with two simple culms 18 and $20 \mathrm{~cm}$. high, and the burned bases of others, evidently a second growth after a fire. Except in its smaller size it compares well with the type of $P$. allanticum. The spikelets, which are immature, are $2.2 \mathrm{~mm}$. long. By selecting the shorter culms it could be matched from many typical clumps of $P$. villosissimum.

This species was described by Scribner $b$ as Panicum pubescens Lam., as indicated by a note upon a sheet, then in his possession, of a duplicate type of $P$. villosissimum.

$a$ Fl. South. U. S. ed. 3. 586. 1897.

b Tenn. Agr. Exp. Sta. Bull. 7 : 52. pl. 15.f. 58. 1894. 


\section{DESCRIPTION.}

Vernal plants light olive green; culms densely tufted, 25 to $45 \mathrm{~cm}$. high, slender, erect or ascending, papillose-pilose with spreading hairs $3 \mathrm{~mm}$. long; sheaths shorter than the internodes, pilose like the culm; ligules 4 to $5 \mathrm{~mm}$. long; blades rather firm, ascending or sometimes spreading, 6 to $10 \mathrm{~cm}$. long, 5 to $10 \mathrm{~mm}$. wide, often subinvolute toward the acuminate apex, little narrowed toward the base, pilose on both surfaces, the hairs of the upper surface appressed, longer and less copious; panicles short-exserted, 4 to $8 \mathrm{~cm}$. long, usually as wide, loosely flowered, the spikelets longpediceled, the axis sparsely pilose, the branches rather stiffly ascending or spreading; spikelets 2.2 to $2.3 \mathrm{~mm}$. long, $1.1 \mathrm{~mm}$. wide, oblong-elliptic, obtuse or obscurely

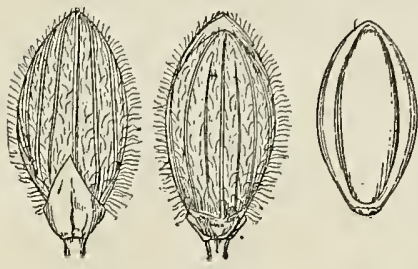

FIg. 247.-P. villosissimum. From type specimen. pointed, papillose-pubescent with spreading hairs; first glume sometimes glabrous, one-third to nearly half the length of the spikelet, acute; second glume and sterile lemrna subequal, the glume slightly shorter than the fruit ac maturity; fruit $1.9 \mathrm{~mm}$. long, $1 \mathrm{~mm}$. wide, elliptic, subacute.

Autumnal form at first decumbent, often with geniculate nodes and arched internodes, the first branches appearing at about the maturity of the primary panicle, late in the season prostrate, the leaves of the fascicled branchlets appressed, giving a combed-out appearance, a character conspicuous in the field but less so in the herbarium; blades not greatly reduced, often with only a few hairs on the upper surface, overtopping the much reduced panicles; winter rosette appearing rather early, blades long, bluish green, densely pilose.

This is fairly uniform as a whole for a species of so wide a range, but exceptional specimens with spikelets only $2 \mathrm{~mm}$. long occur, such as Andrews, Southington, Conn., in 1902; Chase 2378, 3762; Dodge 60, 83; Herriot 86; Hitchcock 1635; Smith, Framingham, Mass., in 1898. In these the habit and other characteristics are those of the typical form. Another rarer variation with blades nearly or quite glabrous on the upper surface is found, as Ashe, Manteo, N. C., Chase 3121, Commons 52.

\section{DISTRIBUTION.}

Dry sandy or sterile soil, open woods and hillsides, Massachusetts to Minnesota, south to Florida and Texas.

Massachusetts: Framingham, Smith in 1898.

Connectrcut: Franklin, Graves 14; Southington, Andrews in 1902.

New York: Bronx Park, Nash in 1897; Long Island, Bicknell in 1902 and 1904.

Ontario: Galt, Herriot 86; Squirrel Island, Dodge 60, 83.

New Jersey: South Amboy, Mackenzie 1381; Wildwood Junction, Chase 3522.

Pennsyluania: Westchester, Windle 12f. (Hitchcock Herb.)

Онго: Sandusky, Morris 135.

Indiana: Clark, Bebb 2833, 2834; Miller, Chase 1545, 1563; Umbach 2646 and in 1897.

IlurNors: Madison County, Eggert 293; Starved Rock, Chase 1606.

Michigan: Carleton, Wheeler in 1890 (Mich. Agr. Col. Herb.).

Wriseonsin: Juneau County, Mearns 25. = J

Mrnnesota: Minneapolis, Sandberg 316 in part (Hitchcock Herb.).

Missourr: Monteer, Bush 732, 750, 4788; Chadwick, Bush 14; Eagle Rock, Bush 141; Pleasant Grove, Bush 333; Carter County, Eggert 291; Jefferson County, Eggert 292; Noel, Bush 5023.

Delaware: Rehoboth, Commons 56 in part; Greenbank, Commons 38; Frankford, Commons 52; Lewes, Hitchcock 161. 
Maryland: Between Chesapeake Beach and Chesapeake Junction, Hitchcock 1608, 1619, 1623, 1627, 1631, 1635, 1643, 1644, 2415; Riverdale, Chase 2378;

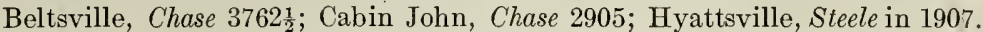

District of Columbia: Hitchcock 393, 2403, Kearney 29, Vasey 125, Ward in 1879, Williams 5.

Virginia: Four-Mile Run, Chase in Kneucker Gram. Exs. 555, Hitchcock 391, Pollard 337; Norfolk, Kearney 302; Dismal Swamp, Chase 3653, 3675, Tyler in 1905; Munden, Mackenzie 1710.

North Carolina: Manteo, Ashe in 1898; Raleigh, Chase 3081; Chapel Hill, Chase 3055, 3056, 3058, 3071, 3075; Wilmington, Chase 3121, 3141, 3155, Hitchcock 394; Biltmore, Boynton 4; Magnetic City, Wetherby 64; Jacksonville, Chase 3191; Lenoir, Hitchcock 395.

South Carolina: Orangeburg, Hitchcock 392, 1384; Clemson College, House 2158. Georgia: Lookout Mountain, Ruth 19; Stone Mountain, Hitchcock 396; Rabun County, House 2269; Lagrange, Tracy 8869; Warm Springs, Tracy 8859; Macon, Small in 1895; Thomson, Bartlett 1414, 1497; Augusta, Cuthbert 387, 1120.

Florida: Chipley, Combs 613; Chattahoochee, Tracy 3653, 3658; Leon County, Curtiss $\mathrm{F}$ in 1886 in part.

Kentucky: Harlan County, Kearney 58 in part, 141.

Tennessee: Cocke County, Kearney 971; Knoxville, Ruth 72 in part.

Ala bama: Auburn, Tracy 3751, 3753, 3754, 3758; Pisgah, Chase 4472; Gateswood, Tracy 8426 in part; Tuskegee, Carver 19; Mobile, Kearney 34 in part; Flomaton, Hitchcock 1046; Greenville, Mohr in 1898.

MississipPI: Starkville, Kearney 24 in part; Taylorville, Tracy 8415; Jackson, Hitchcock 1299; Enterprise; Tracy 3272; Biloxi, Kearney 337; Ocean Springs, Tracy 161; Míssissippi City, Hitchcock 1109.

Arkansas: Benton County, Plank 42, 100.

Louisiana: Calhoun, Hitchcock 1259, 1275, 1289; Shreveport, Hitchcock 1256.

Texas: Waller County, Thurow 25; Weatherford, Tracy 7943 in part; Angelina County, Reverchon 4136; Denison, Bebb 2661.

Ozlaномa: Sapulpa, Bush 1220.

\section{$\checkmark$ 138. Panicum pseudopubescens Nash.}

Panicum pseudopubescens Nash, Bull. Torrey Club 26: 577. 1899. "Type collected at Auburn, Lee Co., Alabama, May 7, 1898, by Messrs. F. S. Earle and C. F. Baker, No. 1537." The type, in Nash's Herbarium, is a clump of"a few vernal, mostly immature culms. Some of the blades are nearly naked along the middle of the upper surface. Other specimens cited by Nash under this species, Earle \& Baker 1522, $1524,1526,1529$, have narrower blades than the type, 'with the upper surface often nearly glabrous; these represent the more usual form of the species.

This species was described by Elliott $a$ as $P$. pubescens Lam., as shown by the specimen so labeled in his herbarium. The culm of this is appressed-pubescent, not "very glabrous," as stated in the description.

The species described in Gray's Manual $b$ under P. ovale Ell. is $P$. pseudopubescens. 


\section{DESCRIPTION.}

Vernal form similar to that of $P$. villosissimum; culms somewhat stiffer, the pubescence more silky, appressed on the culms, ascending on the sheaths; ligules 2 to $3 \mathrm{~mm}$. long; blades somewhat firmer, the pubescence on the upper surface short like that on the lower and sparse or wanting down the center or occasionally glabrous on the

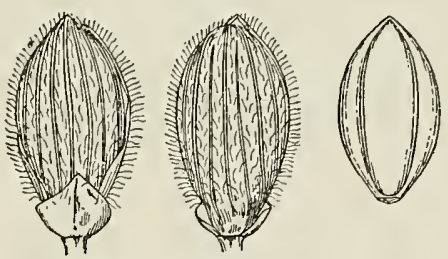

Fig. 249.-P. pseudopubescens. From type specimen. upper surface; panicles averaging larger, the spikelets not so long-pediceled; spikelets 2.25 to $2.4 \mathrm{~mm}$. long, $1.1 \mathrm{~mm}$. wide, obovate-elliptic, obtuse, or slightly pointed, pubescence as in $P$. villosissimum; second glume slightly shorter than the fruit at maturity; fruit $1.9 \mathrm{~mm}$. long, $1 \mathrm{~mm}$. wide, elliptic, subacute.

Autumnal form usually stiffly spreading, sometimes prostrate, culms sparingly branching from the lower and middle nodes after the maturity of the primary panicle, less freely branching than $P$. villosissimum; the upper surface of the reduced blades usually glabrous except along the margins and at the base; winter leaves as in $P$. villosissimum.

This species is very closely allied to $P$. villosissimum and occasional specimens are about as close to one type as to the other. In these cases the ascending, more silky pubescence of the culms and less pubescent or glabrous upper surface of the blades, together with the stiffer habit, have been used to distinguish $P$. pseudopubescens.

\section{DISTRIBUTION.}

Sandy, open woods, Connecticut to Illinois, south to Florida and Mississippi; also in Mexico.

Connecticut: South Britain, Harger 6031 (Bissell Herb.).

New Jersey: Atsion, Chase 3566; Camden, Smith; Wildwood Junction, Chase 3520.

Oнго: Cedar Point, Claassen (Gray Herb.).

Indiana: Miller, Chase 1542, Umbach in 1898; Clark, Umbach 1685; Clark Junction, Bebb 514, 2882; Dune Park, V. H. Chase 291, Hill 100 and 101 in 1905, Umbach 1080.

IllinoIs: Starved Rock, Chase

Sir:
umeauco., Gates 2535, 2539, 2575.

1605; Hanover, Gleas
umeauCo., Gates 2535, 2539, 2575.

learne 25. Mrchigan: Saginaw Bay, Morris aus. Cloudlo 240 in part; Twin Lakes, Wheeler in 1900 .

Maryland: Caroline County, Norton in 1907. Smare Hili C $12 \sim 9$

District of Columbia: Steele in

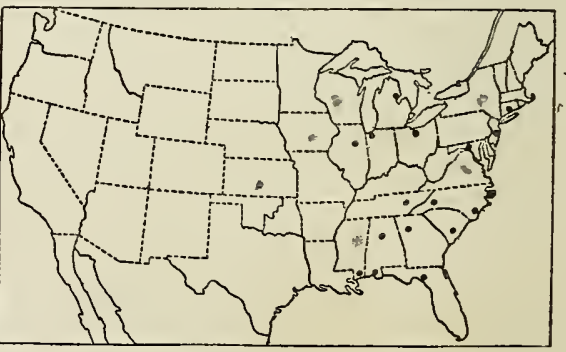

FIG. 250.-Distribution of P.pseudopubescens. 1899.

North Carolina: Roanoke Island, Ashe in Curtiss Pl. So. U. S. 6452, Chase 3218, 3222; Wilmington, Chase 3109, 3115, 3147, 3160, Hitchcock 1437, 1474, 1476, 1484, 1485; Biltmore, Boynton in 1906.

South Carolina: Orangeburg, Hitchcock 398, 1380, 1383, 1394, 1401, 1402; Fripps Island, Cuthbert 1164.

Georgia: Stone Mountain, Hitchcock 397, 1356, 1357.

Florida: Lake City, Hitchcock $1013 \frac{1}{2}$.

Tennessee: Ducktown, Chambliss 26. 
Alabama: Auburn, Earle \& Baker 1522, 1537, Hitchcock 1331, 1336; Gateswood, Tracy 8426 in part; Flomaton, Hitchoock 1048.

Mrssissippi: Biloxi, Hitchcock 1080; Mississippi City, Hitchcock 1090, 1096, 1112, Kearney 301 in part.

Mexico: San Luis Potosí, Schaffner 146.

๑ 139. Panicum ovale Ell.

Panicum ovale Ell. Bot. S. C. \& Ga. 1 : 123. 1816. "Grows in Carolina and Georgia. Sent from St. Mary's, Georgia, by Dr. Baldwin." The type, in the Elliott Herbarium, consists of the upper portion of a vernal culm with two leaves and an immature panicle included at base, the culm and sheaths densely pilose with ascending hairs, the blades long pilose along the margin. The ticket attached to this specimen reads: "Panicum Ovale. Hab. St. Mary's Georg. Dr. Baldwin." Another vernal culm with immature panicle mounted on the same sheet belongs to $P$. commutatum. To the culm is attached a slip marked " 64 " but with no data. Since Dr. Baldwin's is the only specimen cited, the one with the Baldwin label must be considered the type, though Elliott's description seems to show he had the two confused.

Panicum ciliiferum Nash, Bull. Torrey Club 24:195. 1897. "Type collected by the writer in the 'high pine land' at Eustis, Iake Co., Florida, March 12-31, 1894, no. 147." The type, in Nash's herbarium, is the vernal form with an old autumnal culm attached. The spikelets are $2.8 \mathrm{~mm}$. long. In a note following the description Nash states that after having examined a specimen named $P$. ovalc by Elliott he considers $P$. ciliiferum as distinct. The specimen referred to is in the Torrey Herbarium, and is labeled Panicum ovale Elliott, "From Elliott." This is a puberulent narrowleaved form of $P$. commutatum, and is the form described in Small's Flora $a$ as $P$. ovale.

Panicum erythrocarpon Ashe, Journ. Elisha Mitchell Soc. 16:90. 1900. "The type material was collected by the writer on the sand hills of New Hanover county, N. C., May 19, 1899." The type, in Ashe's herbarium, is the vernal form, labeled, "Shady slopes on the sand hills one mile north of Wilmington [New Hanover County], N. C."

DESCRIPTION.

Vernal plants light olive green; culms densely tufted, 20 to $50 \mathrm{~cm}$. high, erect or ascending, rather stout, long-pilose below with ascending or appressed hairs, often nearly glabrous above, usually leafy at the base, the nodes densely bearded with short spreading hairs; sheaths shorter than the internodes or the lower overlapping, ascending-pilose, the upper less densely so, rarely nearly glabrous; ligules composed of a ring of hairs about $1 \mathrm{~mm}$. long with a second sparse ring 2 to $3 \mathrm{~mm}$. long above it; blades firm, ascending, 6 to $10 \mathrm{~cm}$. long, 5 to $10 \mathrm{~mm}$. wide (the uppermost much smaller), sharply acuminate, rounded at base, the upper surface usually nearly glabrous except for long hairs on or near the margin and base thus giving the blades the appearance of being strongly ciliate, these hairs occasionally wanting except at the base, the lower surface appressed-pubescent; panicles

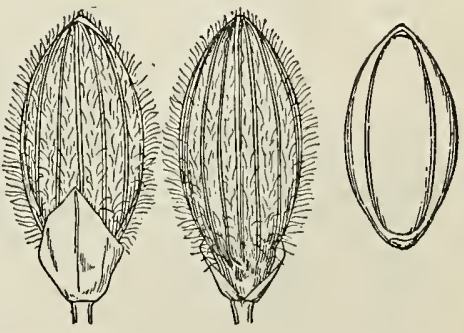

FIG. 251-P, ovale. From type specimen. usually short-exserted, 5 to $9 \mathrm{~cm}$. long, about as wide when fully expanded, the lower branches finally spreading, rarely drooping; spikelets 2.7 to $2.9 \mathrm{~mm}$. long, 1.3 $\mathrm{mm}$. wide, oblong-elliptic, obtuse, pilose, sometimes rather sparsely so; first glume one-third to nearly half the length of the spikelet, usually pointed; second glume 
slightly shorter than the fruit and sterile lemma at maturity; fruit $2.2 \mathrm{~mm}$. long, $1.2 \mathrm{~mm}$. wide, elliptic, obtuse.

Autumnal form spreading-decumbent, the stiff culms rather loosely branching from the middle and upper nodes, the ultimate branchlets crowded at the ends of the primary branches, the reduced blades erect; winter leaves very firm, conspicuously ciliate; short culms with tufted branches sometimes formed during the winter, the green bushy crown persistent at the base of the tall vernal culms.

Curtiss's no. 4877 is referred here although the specimens resemble $P$. commonsianum, and the ligule is only $1 \mathrm{~mm}$. long, as in that species; the spikelets, however, are those of $P$. ovale.

\section{DISTRIBUTION.}

Dry sandy woods, North Carolina to Florida, also in Texas.

North Carolina: Near Wilmington, Ashe in 1899, Chase 4589.

South Carolina: Isle of Palms, Hitchcock 107; Aiken, Ravenel.

Florida: Duval County, Curtiss $3583^{*}$ in part; Jacksonville, Curtiss 4877, 5866, 5813; Lake City, Combs 138, 145, Hitchcock 550, 1013; Madison, Combs 225; Chattahoochee, Tracy 3617; Gainesville, Chase 4250, 4261; Old Town, Combs 888; Eustis, Curtiss 6616, Nash 75, 103, 147, 1118, 1518, 1857; Lake Harris, Chase 4118; Tavares, Hitchcock 820; Grasmere, Combs 1080; Sanford, Hitchcock 785, 787; Titusville, Hitchcock $761 \frac{1}{2}$; Ormond, Hitcheock 160; Dunedin, Tracy

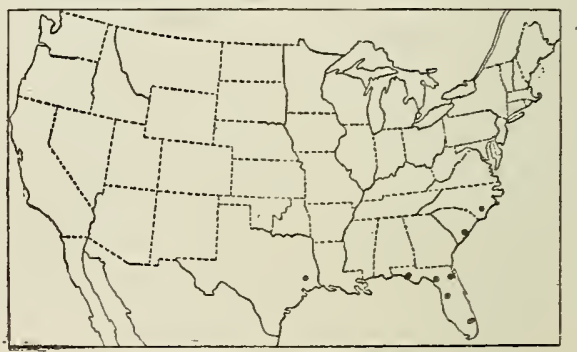

FrG. 252.-Distribution of $P$. ovale. 6725; Braidentown, Hitchcock 968; Lakeland, Hitchcock 833, 846, 847, 851; Myers, Chase 4174, Hitchcock 900, 914, Lee Co. Pl. 474; Miami, Chase 3866, 3947, Hitchcock 634, 661, 668, 677, 719, Pollard \& Collins 223; Homestead, Hitchoock 688.

Texas: Waller County, Thurow 17 in 1906.

\section{- 140. Panicum scoparioides Ashe.}

Panicum scoparioides Ashe, Journ. Elisha Mitchell Soc. 15: 53. 1898. "Based on No. 283, ex. Herb. A. Commons. Dry soil. Centreville, Del. June 1873. Distributed sub nom. P. Scribnerianum Nash." This specimen could not be found in Ashe's

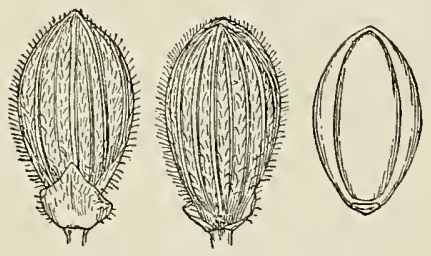

FIG. 253.-P. scoparioides. From type specimen in National Herbarium. herbarium, but a specimen bearing the above name and data is in the National Herbarium and is doubtless the type. $a$ This consists of four vernal culms with immature panicles partly included in the uppermost sheaths.

\section{DESCRIPTION.}

Vernal plants light green; culms few to several in a tuft, 30 to $50 \mathrm{~cm}$. high, slender,erect or ascending, sparsely papillose-hispid with ascending hairs or nearly glabrous, the upper internodes shortened; nodes sometimes sparsely bearded; sheaths papillose-hispid to nearly glabrous, the lower distant, the upper approximate, sometimes overlapping; ligules 2 to $3 \mathrm{~mm}$. long; blades firm, ascending, 7 to $10 \mathrm{~cm}$. long, 6 to $10 \mathrm{~mm}$. wide, tapering to the 
rounded base, acuminate, appressed-pubescent beneath, sparsely hispid on the upper surface, usually a few long hairs at the base; panicles short-exserted, usually included at the base until maturity, rather densely flowered, 4 to $7 \mathrm{~cm}$. long, about two-thirds as wide, the branches ascending; spikelets 2.2 to $2.3 \mathrm{~mm}$. long, $1.2 \mathrm{~mm}$. wide, obovate, obtuse or minutely pointed; first glume about one-fourth as long as the spikelet, subacute; second glume and sterile lemma papillose-pubescent, strongly nerved, subequal, as long as the fruit, the margins at the summit usually inrolled, the midnerve produced into an apiculus; fruit $1.9 \mathrm{~mm}$. long, $1.1 \mathrm{~mm}$. wide, elliptic.

Autumnal form erect or spreading, culms sparingly branching from the upper and middle nodes after the maturity of the primary panicle, the stiff, reduced blades involute-pointed, much exceeding the panicles.

This species is less pubescent than any other in this group except $P$. occidentale. The smoother specimens somewhat resemble $P$. borcale.

\section{DISTR1BUtion.}

Dry sandy or gravelly soil, Vermont to Delaware; also in Minnesota; apparently rare.

VERMONT: Hartland, Jones 30.

ConNeCTicut: Southington, Bissell 385, 5581, 8084; East Lyme, Graves in 1903 (Hitchcock Herb.).

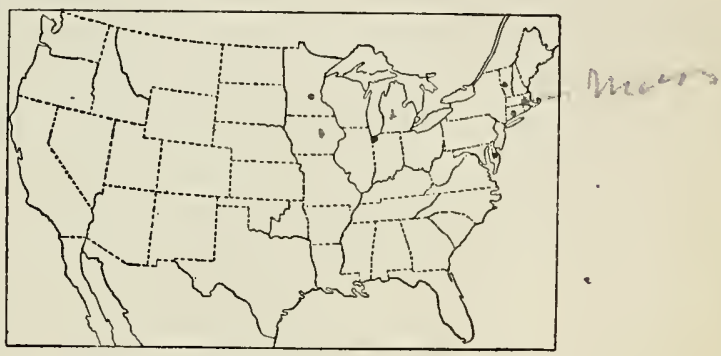

FIG. 254.-Distribution of $P$. scoparioides.

Indiana: Gary, Umbach 3686.

Minnesota: Hennepin County, Sandberg in 1890; Ramsey County, Oestlund in 1884 in part.

DelaWARE: Centerville, Commons 283, 359.

\section{Mich: Grand. Rapindse, Cola. \\ o 141. Panicum shastense Scrib. \& Merr.}

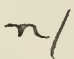

Panicum shastense Scribn. \& Merr. U. S. Dept. Agr. Div. Agrost. Circ. 35: 3. 1901. "Type specimens collected in a moist meadow at the edge of pine forests at Castle Crag, near Mt. Shasta, California, by Louis A. Greata, June, 1899." The type, in the National Herbarium, consists of three vernal

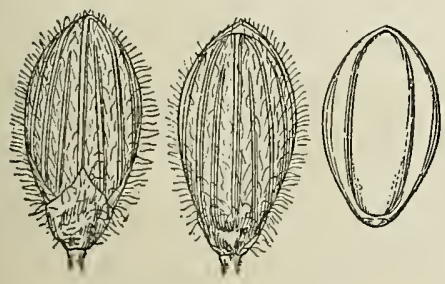

FIG. 255.-P. shastense. From type specimen. culms, 25 to $30 \mathrm{~cm}$. high, with short-exserted, nearly mature panicles.

\section{DESCRIPTION}

Vernal form pale green; culms tufted, 30 to 50 $\mathrm{cm}$. high, slender, ascending from a more or less geniculate base, papillose-pilose with ascending hairs; nodes short-bearded; sheaths papillosepilose, the hairs spreading; hairs of the ligule rather sparse, 2 to $3 \mathrm{~mm}$. long; blades ascending, 6 to $8 \mathrm{~cm}$. long, 6 to $8 \mathrm{~mm}$. wide, acuminate, scarcely narrowed toward the base, papillose-pilose on the under surface and with scattered long hairs on the upper; panicles short-exserted, 6 to $8 \mathrm{~cm}$. long, about two-thirds as wide, the axis pilose, the flexuous branches ascending; spikelets 2.4 to $2.6 \mathrm{~mm}$. long, 1.2 to $1.4 \mathrm{~mm}$. wide, obovate-oblong, obtuse, papillose-pubescent; first glume one-fourth to one-third as long as the spikelet, pointed; second glume scarcely equaling the fruit and sterile lemma; fruit $2.1 \mathrm{~mm}$. long, $1.3 \mathrm{~mm}$. wide, elliptic. 
Autumnal form spreading, with geniculate nodes and elongated, arched internodes, rather sparingly branching from the middle nodes, the primary branches elongated, the ultimate branchlets shorter than the internodes.

\section{DISTRIBUTION.}

Known only from Castle Crag, Shasta County, California, where it is found in meadows.

California: Castle Crag, Greata in 1899, Hitchcock 3072.

Columbiana.-Culms stiff, pubescent with appressed or ascending villous hairs, or crisp-puberulent, the sheaths pubescent like the culms or nearly glabrous; ligules usually less than $1 \mathrm{~mm}$. long, rarely $1.5 \mathrm{~mm}$. long; blades firm, thick, stiffly ascending, not over $7 \mathrm{~mm}$. wide; spikelets pubescent, 1.3 to $3.2 \mathrm{~mm}$. long, 5 to 9-nerved. Autumnal form freely branching, the branches and stiff blades mostlyappressed. With the exception of $P$. tsugetorum, confined to dunes and dry sands of the Coastal Plain, Massachusetts to Florida.

The species of this group form a lineal series from $P$. malacon with spikelets 3.2 $\mathrm{mm}$. long to $P$. columbianum thinium with spikelets only 1.3 $\mathrm{mm}$. long. With the exception of $P$. malacon and P. witmingtonense, there are con-

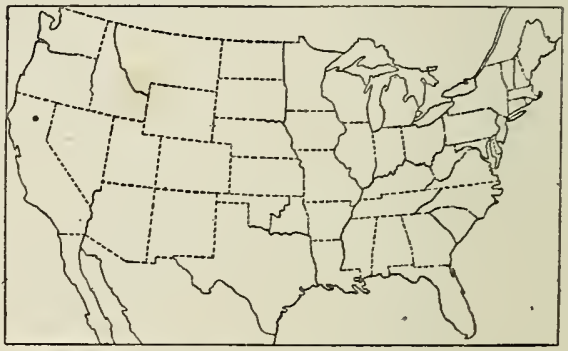

FIG. 256.-Distribution of $P$. shastense. necting forms between the successive species in this series, especially between $P$. commonsian um and $P$. addisonii, and between $P$. tsugetorum and $P$. columbianum. These intermediate specimens are, however, comparatively rare. On the other hand, $P$. oricola and hairy forms of $P$. tsugetorum make a clear cut division between the Lanuginosa and Columbiana impossible.

Spikelets 2 to $3.2 \mathrm{~mm}$. long, mostly elliptic.

Winter blades elongated, 5 to $10 \mathrm{~cm}$. long; spikelets 2

$\mathrm{mm}$. long; plants blue green...................145. P. witmingtonense.

Winter blades 1 to $3 \mathrm{~cm}$. long.

Spikelets $3.2 \mathrm{~mm}$. long; first glume conspicuously distant ................................ 142. Palacon.

Spikelets not over $2.5 \mathrm{~mm}$. long; first glume not distant.

Spikeletsabout $2.4 \mathrm{~mm}$. (2.2 to $2.4 \mathrm{~mm}$.) long; panicle open, branches stiffly spreading ..143. P. commonsianum. Spikelets 2 to $2.1 \mathrm{~mm}$. long; panicle rather dense, branches ascending.....................144. P. addisonii.

Spikelets not over $1.9 \mathrm{~mm}$. long, obovate, turgid.

Culms crisp-puberulent or appressed-pubescent with crimped hairs; plants bluish or grayish green; panicles about 3 to $7 \mathrm{~cm}$. long.

Spikelets 1.8 to $1.9 \mathrm{~mm}$. long.................... P. tsugetorum.

Spikelets 1.5 to $1.6 \mathrm{~mm}$. long.................... 147. P. columbianum.

Culms appressed or ascending-pilose; spikelets not over

$1.5 \mathrm{~mm}$. long, rounded and turgid; plants oliva-

ceous; panicles rarely more than $3 \mathrm{~cm}$. long.

Spikelets $1.5 \mathrm{~mm}$. long; culms rather stout; autumnal

form branching from all the nodes..........148, P. oricola. 
Spikelets 1.3 to $1.4 \mathrm{~mm}$. long; culms very slender; autumnal form with branches mostly aggregated toward the summit.................147a. P. columbian um thinium.

\section{Panicum malacon Nash.}

Panicum malacon Nash, Bull. Torrey Club 24:197. 1897. "Collected by the writer in the 'high pine land' at Eustis, Lake County, Florida, May 1-15, 1894, no. 628." The type, in Nash's herbarium, is the early branching form, the numerous branches appressed, the blades densely puberulent on both surfaces.

Panicum strictifolium Nash, Bull. Torrey Club 26:579. 1899. "Collected by the writer in the high pine land at Eustis, Lake Co., Florida, May 3, 1894, no. 603. Most nearly related to $P$. malacon, but distinguished by the less copious pubescence which is much finer and softer, and by the glabrous upper surface of the blades." The type, in Nash's herbarium, is the early branching form, the primary panicles destitute of spikelets and the secondary panicles immature. This is less densely pubescent than is Nash 628, but the pubescence is not softer. The type of $P$. malacon
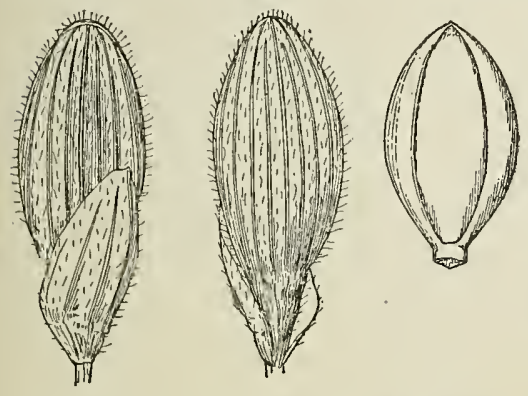

Fig. 257.-P. malacon. From type specimen. is more copiously pubescent than are most specimens of this species. The spikelets of the two types are identical except that those of Nash 603 are immature, while those of no. 628 are mature.

\section{DESCRIPTION.}

Vernal form erect or stiffly spreading, purplish olive green; culms 30 to $50 \mathrm{~cm}$. high, pubescent with ascending hairs, the nodes short-pubescent; sheaths pubescent like the culms, sometimes sparsely so; blades stiffly ascending or somewhat spreading, 4 to $12 \mathrm{~cm}$. long, 3 to $5 \mathrm{~mm}$. wide, rarely wider, sharply acuminate, scarcely narrowed toward the base, puberulent beneath, puberulent or glabrous above, often villous at or near the margin or base with long hairs; panicles 4 to $7 \mathrm{~cm}$. long, three-fourths to nearly as wide, few-flowered, branches few, stiffly ascending, the spikelets on long, stiff pedicels; spikelets 3 to $3.2 \mathrm{~mm}$. long, 1.4 to $1.5 \mathrm{~mm}$. wide, obovate (oblong before maturity), pubescent; first glume distant, half as long as the spikelet or more, subacute, 5 to 7 -nerved; second glume scarcely equaling the fruit and sterile lemma; fruit short-stipitate, $2.5 \mathrm{~mm}$. long, $1.4 \mathrm{~mm}$. wide, elliptic, acute.

Autumnal form more or less decumbent-spreading, branching from the lower and middle nodes, the branches appressed and later rather sparingly producing appressed fascicled branchlets, the reduced blades stiff, erect, and involutepointed.

\section{DISTRIB UTION.}

Dry pine woods, the so-called "high pine land," Florida.

Florida: East Pass, Tracy 9140; Lake City, Combs 167; Old Town, Comus 855; Grasmere, Combs 1036, 1161; Gainesville, Chase 4251; Eustis, Chase 4072,

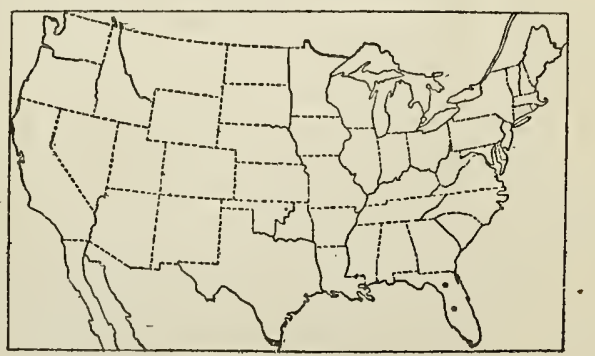

FIG. 258.-Distribution of $P$. malacon.

4077, Thitcheock 801, 813, Nash 36, 63, 132, 603, 628; Clearwater, Tracy 6700;

Dunedin, Tracy 6725; Lakeland, Hitchcock 845.

$41616^{\circ}-$ vol $15-10-16$ 


\section{Panicum commonsianum Ashe.}

Panicum commonsianum Ashe, Journ. Elisha Mitchell Soc. 15: 55. 1898. "Based on no. 341, Commons. Collected in drifting sands along the coast, Cape May, N. J., June, 1898." The type, in Ashe's herbarium, "Ex. Herb. A. Commons," consists of five tufts of vernal culms with mature primary panicles.

\section{DESCRIPTION.}

Vernal plants grayish olive, drying brownish; culms usually in dense tufts 20 to 50 $\mathrm{cm}$. high, stiffly ascending or spreading, papillose-strigose to appressed-pilose, the hairs at the nodes more spreading; sheaths shorter than the internodes, strigose to appressedpilose like the culms but less densely so; ligules $1 \mathrm{~mm}$. long or less; blades firm,

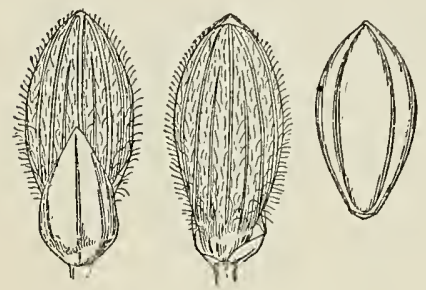

Fig.259.-P.commonsianum. From type specimen. stiffly ascending, 5 to 8 (rarely 9 ) $\mathrm{cm}$. long, 4 to 7 $\mathrm{mm}$. wide, broadest near the rounded base, the serrulate, cartilaginous margin involute toward the acuminate apex, glabrous on the upper surface or with a few long hairs toward the base or margin, strigose on the lower surface or glabrous; panicles long-exserted, 4 to $8 \mathrm{~cm}$. long, about as wide, loosely flowered, the axis and branches strigose to nearly glabrous, the branches stiffly spreading, spikelet-bearing toward the ends; spikelets 2.2 to $2.4 \mathrm{~mm}$. long, $1.2 \mathrm{~mm}$. wide, elliptic, subacute, pubescent; first glume about half as long as the spikelet, sometimes longer, usually pointed, 3-nerved; second glume slightly shorter than the fruit and sterile lemma at maturity; fruit $2 \mathrm{~mm}$. long, $1 \mathrm{~mm}$. wide, elliptic, subacute.

Autumnal culms branching from the middle and upper nodes, after the maturity of the primary panicles becoming spreading or prostrate, the larger clumps forming mats in the sand, the reduced secondary subinvolute blades rather crowded, stiffly ascending, overtopping the panicles; winter blades lanceolate, commonly more hairy than those of the culm.

This species is variable as to pubescence.

DISTRIBUTION.

Dunes and sandy woods near the coast, Connecticut to northern Florida.

Connecticut: North Haven, $A n$ drews in 1901; South Windsor, Bissell 12000.

New York: Lake Roukonkoma,

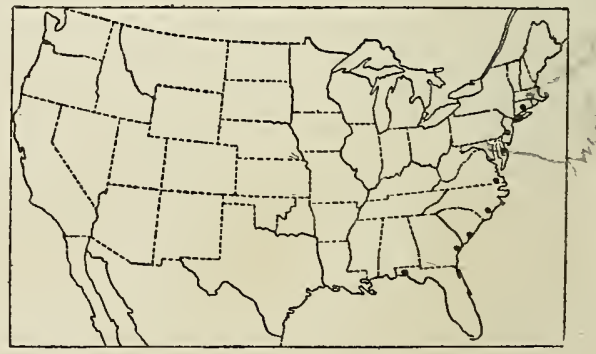

FIG. 260.-Distribution of $P$. commonsianum.

Bicknell; Rockville Center, Bicknell in 1906; Valley Stream, Bicknell in 1905;

Hempstead, Bicknell in 1903.

New Jersey: South Amboy, Mackenzie 1485, 2155, 2165; East Plains, Stone

4, 6; Lakehurst, Mackenzie 2067; Toms River, Bicknell in 1900, Chase 3575;

Forked River, Chase 3584, 3596; Atsion, Chase 3531, 3541, 3544, 3570; Cape

May, Canby 4 in 1902, Commons 43, 341; Wildwood, Chase $3517 \frac{1}{2}$.

DeLAWARE: Lewes, Hitchcock 408 ,

Md-Snow ifill $+C 12233,12234.12232$ 
Virginia: Region of Cape Henry, Chase 2349, 5428, Hitchcock 407, Kearney 1393, 1454, 1776, 2114, Pollard \& Maxon in 1900.

North Carolina: Wilmington, Chase 3161, 4601, Hitchcock 326, 336.

South Carolina: Isle of Palms, Chase 4544.

Georgia: Augusta, Kearney 209.

Florida: East Pass, Tracy 9141.

\section{$\checkmark$ 144. Panicum addisonii Nash.}

Panicum addisonii Nash, Bull. Torrey Club 25:83. 1898. "Collected by Mr. E. P. Bicknell in sandy soil at Wildwood, N. J., May 30 and 31, 1897." The type specimen, in Nash's herbarium, is the early branching form with culms 15 to $30 \mathrm{~cm}$. high, mature primary panicles, and spikelets 2 to $2.1 \mathrm{~mm}$. long.

Panicum owenae Bicknell, Bull. Torrey Club 35: 185. 1908. "Type collected September 20, 1907, on the sandy commons west of the town [Nantucket], deposited in herb. N. Y. Bot. Garden." The type specimen is the autumnal form, the primary panicles destitute of spikelets, the secondary panicles among the crowded autumnal leaves. The blades are nearly smooth except for scattered long hairs near the margin. The vernal form collected by Bicknell at the type locality June 20, 1908, is more pubescent:

\section{DESCRIPTION.}

Vernal form similar to that of $P$. commonsianum and often closely resembling that species; culms more slender, rarely as much as $40 \mathrm{~cm}$. high, appressed or ascendingpilose at least below, puberulent above; sheaths sparsely ascending-pilose; blades stiffly ascending, 4 to $7 \mathrm{~cm}$. long, 3 to $6 \mathrm{~mm}$. wide, involute-pointed, glabrous on the upper surface, sometimes with a few long hairs near the margin, pubescent or glabrous beneath; panicles long-exserted, 2 to $6 \mathrm{~cm}$. long, two-thirds to three-fourths as wide, the stiff branches ascending, the panicle thus appearing more densely flowered; spikelets 2 to 2.1 $\mathrm{mm}$. long, $1.1 \mathrm{~mm}$. wide, obovate, blunt, papillosepubescent, or the papillæ obscure; first glume onethird to half as long as the spikelet, usually pointed; second glume and sterile lemma barely equaling the fruit at maturity; fruit $1.7 \mathrm{~mm}$. long, $1 \mathrm{~mm}$. wide, elliptic, subobtuse.

Autumnal form more or less spreading, rather freely branching from all the nodes, the branches appressed or narrowly ascending, the later branch-

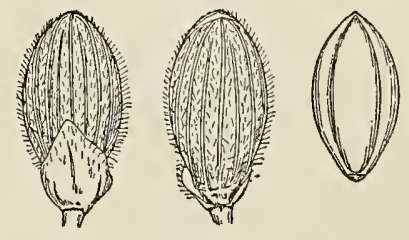

FIG. 261.-P. addisonii. From type specimen. lets somewhat fascicled, the stiff blades not greatly reduced, overtopping the numerous reduced panicles.

This species very closely approaches forms of $P$. commonsianum, the smaller, broader spikelets with shorter first glume affording about the only constant difference, though it is $P$. commonsianum rather than $P$. addisonii which varies much. The type of $P$. owenae and a specimen collected by Steele, Suitland, Maryland, in 1899, both late autumnal forms, have fascicled primary branches from the lower nodes. Usually only the secondary branchlets are fascicled. Two southern specimens, Chase 4580 and Hitchcock 557, have laxer culms and more spreading branches. 
DISTRIBUTION.

Sand barrens, Massachusetts to South Carolina.

Massachusetts: Andover, Blake in 1882; Nantucket, Bicknell in 1907 and 1908.

Connecticut: East Lyme, Graves in 1903 (Bissell Herb.).

New York: Hempstead, Bicknell in 1903 and 1906.

New Jersey: Wildwood, Bicknell in 1897, Chase 3517; Wildwood Junction, Chase 3523; Toms River, Bicknell in 1900; Forked River, Chase 3583,3595; Atsion, Chase 3538; Lakehurst, Chase 3574; Somers Point, Canby 5 in 1902; Tuckerton, Chase 3603.

Maryland: Chesapeake Beach, Hitchcock 1617; Suitland, Steele in 1899.

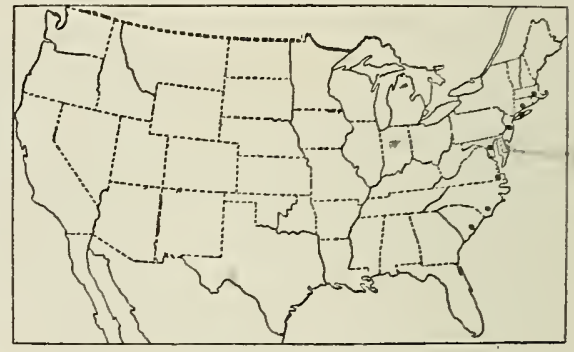

FIG. 262.-Distribution of $P$. addisonii.

Virginia: Virginia Beach, Hitchcock 556 (Hitchcock Herb.).

North Carolina: Wilmington, Chase 3166, 4580; Hitchcock 335, 399.

South Carolina: Orangeburg, Hitchcock 557.

\section{Panicum wilmingtonense Ashe.}

Panicum wilmingtonense Ashe, Journ. Elisha Mitchell Soc. 16: 86. 1900. "The type material collected in May, 1899, on the sand hills near Wilmington, N. C., is preserved in my herbarium." The type, in Ashe's herbarium, is labeled, "Shady slopes on the sand hills one mile to north of Wilmington, May 17, 1899. IT. IT. Ashe, Collector." The plants are the vernal form with some autumnal culms of the preceding season attached.

Panicum alabamense Ashe, N. C. Agr. Exp. Sta. Bull. 175: 116. 1900, not Trin. 1854. "Auburn, Ala., May 7, 1898. Number 1530, Alabama Biological Survey." The type, in Ashe's herbarium, is a tuft of young vernal culms, the panicles only
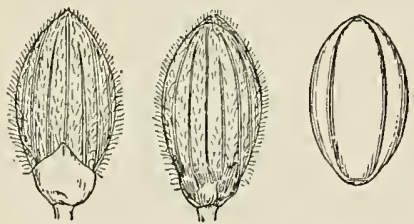

FIG. 263.-P. wilmingtonense. From type specimen. partly exserted. Mounted on the sheet with this is a specimen of $P$.lucidum. Ashe's description refers to the latter only in so far as the spikelets are said to be glabrous.

\section{DESCRIPTION.}

Vernal form bluish green; culms solitary in small tufts; slender, erect from an ascending base 20 to $40 \mathrm{~cm}$. high, pilose with soft, ascending hairs, the nodes pubescent with short, reflexed hairs; sheaths pubescent like the culms, densely villous-ciliate at the summit; blades rather stiff, ascending, 4 to $9 \mathrm{~cm}$. long, 3 to $7 \mathrm{~mm}$. wide, glabrous on the upper surface, softly pubescent to nearly glabrous beneath, strongly ciliate on margin near base, the thick cartilaginous margin white at least when dry; panicles 5 to $8 \mathrm{~cm}$. long, the branches ascending; spikelets $2 \mathrm{~mm}$. long, $1 \mathrm{~mm}$. wide, elliptic, subacute, first glume onefourth to one-third as long as the spikelet; second glume and sterile lemma pubescent, the glume slightly shorter than the fruit at maturity; fruit $1.7 \mathrm{~mm}$. long, $1 \mathrm{~mm}$. wide, elliptic, obtuse.

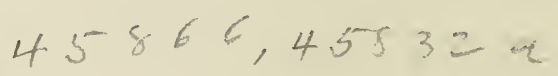


Autumnal form spreading, branching from the middle and upper nodes, the branches rather crowded, the reduced involute-pointed blades exceeding the ultimate panicles; blades of the winter rosette as much as $7 \mathrm{~cm}$. (rarely 12 cm.) long.

\section{DISTRIBUTION.}

Sandy woods, North Carolina and Alabama; rare.

North Carolina: Wilmington, Ashe in 1899, Hitchcock 316; Jacksonville, Chase 3195.

Alabama: Auburn, Alabama Bio-

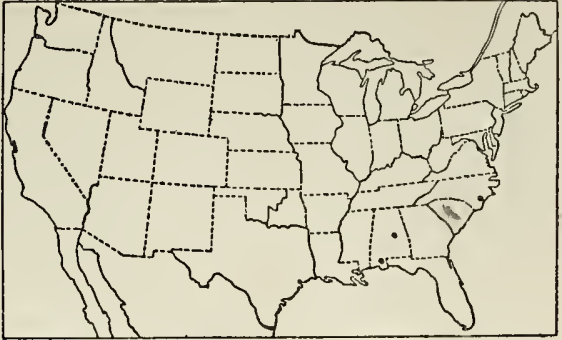

FIG. 264.-Distribution of $P$. wilmingtonense.

logical Survey, Earle \& Baker 1530 in part, Hitchcock 1325; Gateswood, Tracy 8429.

\section{Panicum tsugetorum Nash.}

Panicum tsugetorum Nash, Bull. Torrey Club 25: 86. 1898. "Type material collected by the writer in the Hemlock Grove, New York Botanical Garden, on dry soil, June 22, 1896, no. 287." The type, in Nash's herbarium, consists of a clump of 8 vernal culms 20 to $37 \mathrm{~cm}$. high, decumbent at base and bearing scarcely mature panicles. The culms are less stiff and the blades thinner than usual in this species, as the plants grew in the shade.

Panicum lanuginosum siccanum Hitchc. \& Chase, Rhodora 8: 207. 1906. "Type Chase 1602. Dry, hot sand of sandstone cliff. Starved Rock, Ill." This specimen, in the National Herbarium, is the early autumnal form, and represents an extremely hairy form of $P$.tsugetorum. The culms and sheaths are ascending-pilose and the blades are sparsely long-pilose on the upper surface.

\section{DESCRIPTION.}

Vernal plants usually pale bluish green; culms 30 to $50 \mathrm{~cm}$. high, spreading or ascending, the lower nodes often geniculate, densely appressed-pubescent with short, crisp hairs, long hairs more or less copiously intermixed with these on the lower internodes or sometimes nearly to the summit; sheaths commonly not much shorter than the internodes, pubescent like the culm but less densely so, ascending-ciliate on the

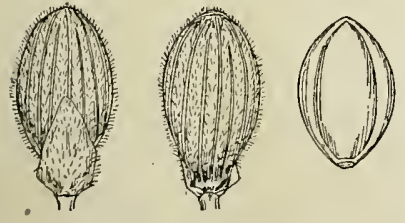

FIG. 265.-P.tsugetorum. From type specimen. margin; ligules 1 to $1.5 \mathrm{~mm}$. long; blades thickish, firm, with a thin white cartilaginous margin, ascending, 4 to $7 \mathrm{~cm}$. long, 4 to $7 \mathrm{~mm}$. wide, rounded at the base, acuminate, glabrous or with a few long hairs near the base on the upper surface, appressedpuberulent beneath; panicles 3 to $7 \mathrm{~cm}$. long, nearly as wide, the axis and spreading, flexuous branches appressed crisp puberulent; spikelets 1.8 to $1.9 \mathrm{~mm}$. long, $1 \mathrm{~mm}$. wide, obovate-obtuse, rather turgid, short-pubescent; first glume one-third to two-fifths as long as the spikelet, acute; second glume and sterile lemma barely equaling the fruit at maturity; fruit $1.5 \mathrm{~mm}$. long, $1 \mathrm{~mm}$. wide, broadly elliptic, obtuse.

Autumnal form decumbent-spreading, branching from the lower and middle nodes often before the maturity of the primary panicles, the branches ascending, the ultimate branchlets appressed, the blades not greatly reduced nor crowded; winter rosette appearing rather early, the blades often conspicuously long-pilose. 
In this species the blades are typically glabrous on the upper surface and the culms and sheaths are appressed-pubescent with short, crisp hairs, longer hairs intermixed on the lower internodes only, but numerous specimens have blades sparsely longpilose on the upper surface and culms and sheaths ascending-pilose almost to the summit. This form is represented by the following specimens: Massachusetrs: Smith 740; Ontario: Macoun 26236; New Jersey: Chase 3579, 3608; Indiana: Chase 1552; Illinors: Chase 1602 (type of P. lanuginosum siccanum Hitchc. \& Chase), 1604, 16051; Hill 124 and 129 in 1905; Michigan: Morris A240. Hill 124 and Chase 3608 are so strongly pilose as to resemble $P$. implicatum.

Two collections from Chesapeake Beach, Chase 3269 and 3270 , seem to be intermediate between $P$. tsugetorum and $P$. columbianum, having the habit and pubescence of the former but spikelets only $1.7 \mathrm{~mm}$. long.

\section{DISTRIBUTION.}

Sandy woods, Maine to Illinois, Virginia and Tennessee.

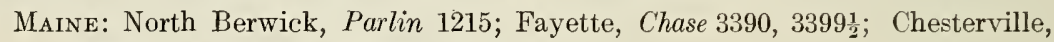
Chase 3321, 3363; Ogunquit, Parlin 1577.

Vermont: Salisbury, Brainerd in 1903 (Gray Herb.).

Massachusetts: Framingham, Smith 740.

Connecticut: South Manchester, Hitchcock 134; Southington, Andreu's 62, 74, Bissell 5594, 5595, 5616.

Rhode Island: Gloucester, Collins in 1908.

New York: Thousand Islands, Bicknell in 1905; Sylvan Beach, House 1287; Ausable Point, Eggleston 2843; Washington County, Burnham 19; Albany, Peck 6; Oneida Lake, Coville in 1887; Bronx Park, Nash 287; Woodmere, Bicknell in 1902 and 1906; Jamaica, Bicknell in 1904; Hempstead, Bicknell in 1903; Norwood, Bicknell in 1903; Rosedale, Bicknell in 1904; Valley Stream, Bicknell in 1904; Cedarhurst, Bicknell in 1902.

Ontario: Tilsonburg, Macoun 26236.

New Jersey: South Amboy, Mac-

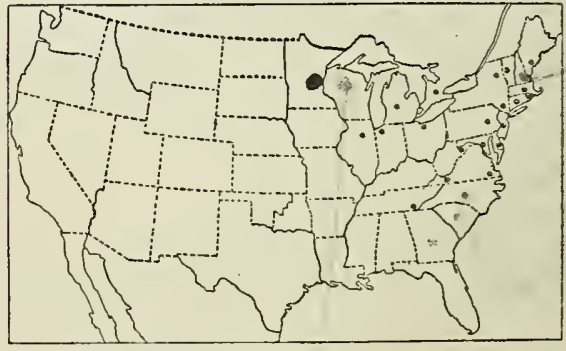

FIG. 266.-Distribution of $P$. tsugetorum. kenzie 1379, 2220; Tuckerton, Chase 3601, 3608, 3612; Atsion, Chase 3532, 3543, 3564; Forked River, Chase 3579; Wildwood Junction, Chase 3524.

Pennsylvania: Tannersville, Smith 2.

Онго: Defiance County, Fullmer in 1898 (Ohio State Univ. Herb.).

Indiana: Dune Park, Chase 1921; Miller, Chase 1544, 1552; Gibson, Bebb 2939 $\frac{1}{2}$, Steuben County, Deam in 1904.

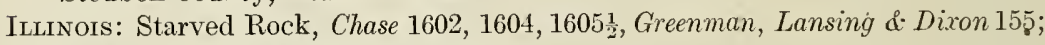
Oregon, Hill 124 and 129 in 1905.

Michigan: Port Huron, Dodge in 1909; Twin Lakes, Wheeler 22; Port Austin, Morris A240 in part.

Delaware: Point Lookout, Canby 9.

Maryland: Beltsville, Chase 3752; Riverdale, Chase 3642.

District of Columbia: House 907, Scribner in 1894, Ward in 1878.

Virginia: Patrick County, Heller 1312; Ocean View, Kearney 1447; Lee County, Small in 1892 (Gray Herb.).

West Virginia: Harpers Ferry, Hitchcock 135.

Tennessee: Lookout Mountain, Ruth in 1899 (Hitchcock Herb.). 
147. Panicum columbianum Scribn.

Panicum heterophyllum Bosc; Nees, Agrost. Bras. 227. 1829, not Spreng. 1822. Based on "Panicum heterophyllum Bosc, Herb. Willd." The type specimen, in the Willdenow Herbarium, labeled in Bosc's hand, is the vernal form.

Panicum columbianum Scribn. U. S. Dept. Agr. Div. Agrost. Bull. 7 : 78. f. 60. 1897. "Dry sandy fields, meadows and open woodlands, New England and southward to the Carolinas, and westward to Tennessee and Alabama, mostly near the coast; also in California." The type, the specimen from which figure 60 is drawn, is in Hitchcock's herbarium. It is labeled as follows in Scribner's writing: "Panicum columbianum Scribn. (Type) Brookland, D. C., July 14, 1894. Coll. F. L.-S." The specimen consists of three branching culms, 25 to $38 \mathrm{~cm}$. high, the primary panicles destitute of spikelets. A duplicate type is in the National Herbarium.

Panicum psammophilum Nash, Bull. Torrey Club 26:576. November, 1899, not Welw. July, 1899. "New Jersey: * * * Toms River, July 25-31, 1898, W. $N$. Clute, no. 175 (type)." This specimen, in the herbarium of the New York Botanical Garden, consists of five branching culms, 15 to $40 \mathrm{~cm}$. high, the primary panicles destitute of spikelets. The lower internodes are appressed-pilose, but otherwise the specimen is very similar to Scribner's type.

This species has been erroneously referred to Panicum unciphyllum Trin. ${ }^{a}$ The specimen sent as a portion of the type from the Trinius Herbarium is $P$. columbianum, but a subsequent examination of Trinius's plants showed that there were two groups of specimens lying loose upon a single sheet, one group being the type of $P$. unciphyllum (P. tenue Muhl.), the other group being $P$. columbianum. A plant of the latter had been sent with a copy of the label of the former.

\section{DESCRIPTION.}

Vernal plants light grayish green, often purplish; culms tufted, 15 to $50 \mathrm{~cm}$., rarely $60 \mathrm{~cm}$., high, stiffly ascending, densely crisp-puberulent with long, ascending, crimped hairs commonly intermixed toward the base, but much less copiously than in $P$. tsugetorum; sheaths shorter than the internodes, less pubescent than the culms, sometimes puberulent between the nerves only; ligules less than $1 \mathrm{~mm}$. long; blades firm, ascending or erect, 3 to $6 \mathrm{~cm}$. long (seldom over $5 \mathrm{~cm}$. long), 3 to $5 \mathrm{~mm}$. wide, broadest at the rounded base, the serrulate, often white, cartilaginous margin usually involute toward the acuminate apex, typically glabrous on the upper surface but sometimes sparsely pilose toward the base, densely appressed-puberulent to glabrous beneath; panicles 2.5 to $4 \mathrm{~cm}$. (rarely $5 \mathrm{~cm}$.) long, about three-fourths as wide, the lower branches

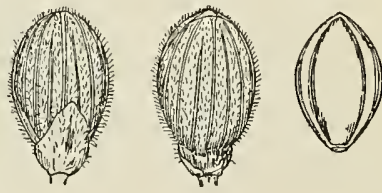

Fig. 267.-P. columbianum. From type specimen. ascending, the axis and branches puberulent to nearly glabrous; spikelets 1.5 to 1.6 $\mathrm{mm}$. long, $1 \mathrm{~mm}$. wide, obovate, obtuse, turgid, densely short-pubescent; first glume one-third to scarcely half as long as the spikelet, acute or subacute; second glume and sterile lemma subequal, scarcely covering the fruit at maturity; fruit $1.3 \mathrm{~mm}$. long, $0.9 \mathrm{~mm}$. wide, broadly elliptic, obtuse.

Autumnal culms branching from the middle and upper nodes at the maturity of the primary panicles, becoming widely spreading or decumbent at base, the early branches sometimes nearly equaling the primary culm, the ultimate branchlets in short, appressed fascicles, the crowded blades usually equaling or exceeding the reduced panicles; winter blades thickish, lanceolate, often sparsely pilose or ciliate.

Specimens of this species and the preceding often closely resemble each other, since both vary much in pubescence and somewhat in habit. Panicum columbianum 
is typically smaller, more slender and stiffer than $P$. tsugetorum, and the culms are densely crisp-puberulent with little of the pilose character of the latter. Occasional specimens, like Bissell 5596, Chase 38 $\$ 2$, and Graves 10, are larger, laxer plants with appressed-pilose culms and are referred to $P$. columbianum because the spikelets are not over $1.6 \mathrm{~mm}$. long.

DISTRIBUTION.

Sandy woods or open ground, Maine to Virginia. ${ }^{a}$

Malne: North Berwick, Parlin 1196; York Harbor, Bicknell in 1896.

New Hampshire: Laconia, Carter in 1902 (Hitchcock Herb.).

Massachusetts: Wellesley, Smith 738; Framingham, Smith 742, 744.

Connecticut: Griswold, Graves 10;

Waterford, Graves. 83, 84;

Southington, Andrews in 1902, Bissell 5596.

New York: Van Cortlandt Park, Bicknell in 1891; Rockville Center, Bicknell in 1903 and 1906; Cedarhurst, Bicknell in 1903; Hempstead, Bicknell in 1903; Jamaica, Bicknell in 1905.

New Jersey: Tuckerton, Chase 3606,3613 ; Atsion, Chase 3533 ,

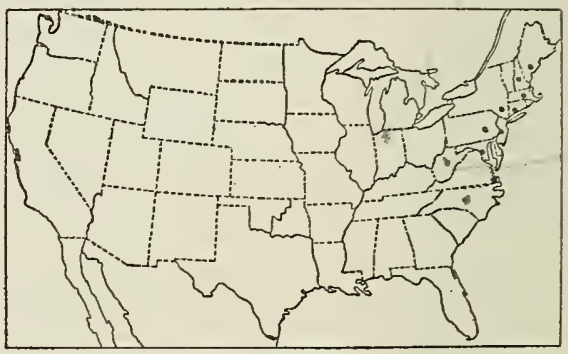

FIG. 26S.-Distribution of $P$. columbianum.

3539; Wildwood, Chase 3519; Toms River, Clute 175; Mount Arlington, Mackenzie 1399; Lakehurst, Mackenzie 2068; Chadwick, Mackenzie 2404; South Amboy, Mackenzie 2247; Sussex County, Mackenzie 2105.

Pennsylvania: Stroudsburg, Porter in 1898.

Maryland: Patuxent River, Hitchcock 1632; Chesapeake Junction, Hitchcock 2407, 2413; Beltsville, Chase 3794, 3832; West Chevy Chase, Chase 5427.

District of Columbia: Chase 5429, 5430, Hitcheock 2418, Scribner in 1894, Williams in 1896.

ViRGinia: Norfolk, Vasey in 1884 (Gray Herb.).

NC. 147a. Panicum columbianum thinium Hitchc. \& Chase.

Panicum unciphyllum thinium Hitche. \& Chase, Rhodora 8: 209. 1906. "Type Chase $35 \%$ in National Herbarium. In mats, sandy, open ground, Tom's River, N. J., July 28, 1906; collected by Agnes Chase". The type consists of a tuft of many autumnal culms 12 to $20 \mathrm{~cm}$. high, the spikelets $1.3 \mathrm{~mm}$. long.

Panicum columbianum thinium Hitchc. \& Chase in

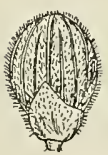

Fig. 269.-P. columbianum thinium. From type specimen.
Robinson, Rhodora 10:64. 1908. Based on P. unciphyllum thinium Hitchc. \& Chase.

\section{DESCRIPTION.}

Vernal culms shorter and more slender than in $P$. columbianum, not over $30 \mathrm{~cm}$. high, usually about $20 \mathrm{~cm}$. high, densely tufted, the appressed pubescence longer, stiffer, and arising from minute papillæ; sheaths sparsely ascending pilose; blades rarely over $3 \mathrm{~cm}$. long, sparsely pilose with long hairs on the upper surface at least near the margin

$a$ The extended range given with the original description was based on misidentification of various small specimens of $P$. lindheimeri, as shown by such specimens labeled by Scribner "Panicum columbianum" in the National Herbarium and in Hitchcock's herbarium. 
and base, the long hairs sometimes mixed with appressed pubescence beneath; panicles 1.5 to $4 \mathrm{~cm}$. long, about as wide; spikelets 1.3 to $1.4 \mathrm{~mm}$. long, rounded obovate, very turgid, pubescent; second glume shorter than the fruit at maturity; fruit $1.1 \mathrm{~mm}$. long, $0.8 \mathrm{~mm}$. wide, obtuse.

Autumnal form widely spreading, the branches appearing earlier than in the species, shorter and usually more crowded and somewhat aggregated toward the summit.

A few specimens intermediate between the species and subspecies occur, as Kearney 10, District of Columbia, which has the habit and pubescence of the subspecies but spikelets $1.5 \mathrm{~mm}$. long; Chase 3559, Atsion, New Jersey, and Commons 58, Rehoboth, Delaware, which have the stouter culms and crisped pubescence of the species but spikelets $1.4 \mathrm{~mm}$. long. Short specimens with much crowded branches resemble $P$. oricola, from which they may be distinguished by the smaller spikelets and less dense pubescence.

\section{DISTRIBUTION.}

Dry sands, Massachusetts to Virginia.

MASSACHUSETTS: Nantucket, Bicknell in 1899 and 1904.

New Jersey: Mantoloking, Lyon in 1902; Atsion, Chase 3534, 3560 , Saunders \& Clute 2 ; Toms

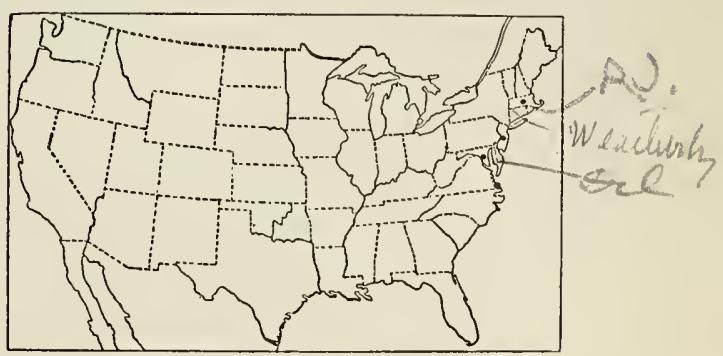

Fig. 270.-Distribution of $P$. columbianum thinium.

River, Chose 3577; Forked River, Chase 3588; Tuckerton, Chase 3605.

Maryland: Hyattsville, Chase 3806.

Virginia: Lynn Haven, Hitchcock 406.

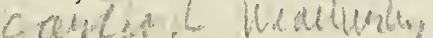

148. Panicum oricola Hitchc. \& Chase.

Panicum oricola Hitchc. \& Chase, Rhodora 8: 208. 1906. "Type Hitchcock 47 in National Herbarium. Prostrate clumps on bare sand on low mounds between marsh and sand dune. Lewes, Del., June 18, 1905, collected by A. S. Hitchcock." This specimen is the early autumnal form.

\section{LESCRIPTION.}

Vernal form grayish, often purplish; culms densely tufted, 10 to $30 \mathrm{~cm}$. high, spreading, densely appressed or ascending pilose, the hairs on the nodes spreading; sheaths usually more than half the length of the internodes, appressed-pilose; ligules
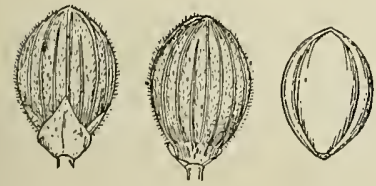

FIG. 271.-P. oricola. From type specimen.

1 to $1.5 \mathrm{~mm}$. long; blades firm, erect or ascending, 2 to $5 \mathrm{~cm}$. long, 2 to $4 \mathrm{~mm}$. wide, broadest near the base, acuminate, the upper surface pilose with hairs 3 to 5 $\mathrm{mm}$. long, the lower surface appressed-pubescent with longer hairs intermixed; panicles short-exserted, or rarely long-exserted early in the season, 1.8 to $3 \mathrm{~cm}$. long, rarely longer, about two-thirds as wide, rather densely flowered, the axis appressed-pubescent, the flexuous branches ascending or spreading; spikelets $1.5 \mathrm{~mm}$. long, $1 \mathrm{~mm}$. wide, broadly obovate, turgid, obtuse, pubescent with short spreading hairs; first glume one-third to half the length of the spikelet, abruptly pointed; second glume and sterile lemma barely equaling the fruit at maturity; fruit $1.3 \mathrm{~mm}$. long, $0.9 \mathrm{~mm}$. wide, broadly elliptic, very turgid. 
Autumnal form prostrate, forming mats, with short, fascicled branches at all the nodes, the branches appearing before the maturity of the primary panicles; leaves and panicles not greatly reduced, the latter overtopped by the blades, which are less pilose than earlier ones; winter blades sparsely pilose above.

This species is more copiously pubescent than any other in this group and in this character resembles species of the Lanuginosa, but its affinity seems to be rather with the Columbiana.

\section{DISTRIBUTION.}

Sand barrens along the coast, Massachusetts to Virginia.

MassachusetTs: Nantucket, Bartlett 1368, 1379, Bicknell in 1906, Hitchcock 558; Plymouth, Oakes; Quanquisset, Bartlett 1327.

Connecticut: Groton, Bissell 9306 (Bissell Herb.).

New York: Northville, Young in 1871; West Rockaway, Bicknell in 1903; Lawrence, Bicknell in 1906; Hempstead, Bicknell in 1903; Woodmere, Bicknell in 1902; Rockville Center, Bicknell in 1906; Valley Stream, Bicknell in 1905.

New Jersey: A bseçum, Commons

45; Tuckerton, Chase 3609;

East Plains, Stone 8; Atlantic

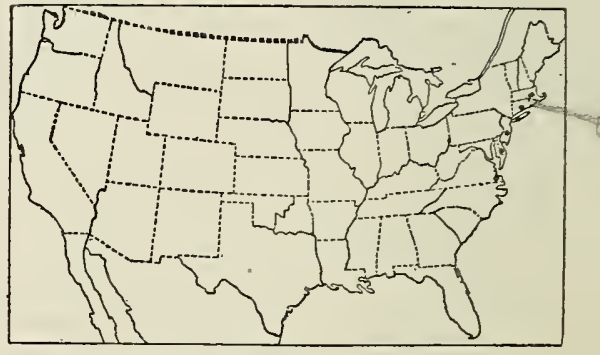

Fig. 272.-Distribution of $P$. oricola.

City, Parker; Hammonton, Canby in 1902; South Amboy, Mackenzie 1355; Atsion, Chase 3562; Toms River, Chase 3576; Forked River, Chase 3581.

Delaware: Rehoboth, Commons 59, 60; Lewes, Hitchcock 47.

Virginia: Ocean View, Coville 13, 14, Kearney 1461; Cape Henry, Chase 5431.

Sphaerocarpa.-Culms usually few in a tuft, rather stout, glabrous; ligules obsolete or nearly so; blades mostly thick and firm, cordate and ciliate at base, margins strongly cartilaginous; spikelets obovoid-spherical at maturity, oval when young, 1 to $1.8 \mathrm{~mm}$. long, puberulent; second glume and sterile lemma 5 to 7-nerved; panicle branches mostly viscid. Autumnal form remaining simple or but sparingly branching, the thick, white-margined blades of the winter rosette conspicuous.

Culms spreading; blades obscureiy nerved; panicle nearly as broad as long.

Ligules obsolete or wanting; blades lanceolate.........149. P.sphaerocarpon.

Ligules evident, 0.3 to $1 \mathrm{~mm}$. long; margins of blades parallel for at least two-thirds their length.......149a. P. sphaerocarpon

Culms erect or ascending; blades rather strongly nerved; inflatum. panicle never more than two-thirds as broad as long, usually less.

Spikelets 1.5 to $1.6 \mathrm{~mm}$. long; blades lanceolate, the upper not reduced....................... 150 . P. polyanthes.

Spikelets 1 to $1.2 \mathrm{~mm}$. long; blades tapering from base to apex, the upper much smaller than the lower......151. P. erectifolium. 


\section{Panicum sphaerocarpon Ell.}

Panicum sphaerocarpon Ell. Bot. S. C. \& Ga. 1: 125. 1816. "Grows in Georgia. Dr. Baldwin." The type, in the Elliott Herbarium, consists of a single plant with a mature, long-exserted panicle. The accompanying label reads: "Panicum sphaerocarpon Hab. Georg. Dr. Baldwin."

Panicum kalmii Swartz, Adnot. Bot. 6. 1829. "Hab. in America boreali (Pennsylvania?): Prof. Kalm." The type, labeled "Panicum Kalmii Swartz in Adnot. Bot. p. 6," in the Swartz Herbarium, is a single vernal plant.

Panicum heterophyllum Swartz, Adnot. Bot. 6. 1829, not Spreng. 1822. This is mentioned as a synonym of $P$. kalmii Swartz.

Panicum dichotomum sphaerocarpum Wood, Class-book ed. 3. 786. 1861. Presumably based on $P$. sphaerocarpon Ell., though the description hardly applies to this species.

Panicum nitidum crassifolium Gray; Doell in Mart. Fl. Bras. $2^{2}: 247.1877$. This is described from a "specimen in New-Jersey lectum, n. 30." Doell's plant is evidently one of the specimens distributed by Gray in Gramineae and Cyperaceae 1: no. 30. 1834, under the above name. The specimen in the Gray Herbarium bears the data "Hab.-Pine barrens of New-Jersey." This was not described by Gray. It represents the slender form of $P$. sphaerocarpon.

Panicum microcarpum sphaerocarpon Vasey, Grasses U. S. 12. 1883. Based on "P. sphaerocarpon, Ell."

Panicum vicarium Fourn. Mex. Pl. 2: 20. 1886. Fournier cites only one specimen, "Cordova (SchaffN. n. 285)." The type is in the Paris Herbarium. This name was earlier listed by Hemsley ${ }^{a}$ without description.

\section{DESCRIPTION.}

Vernal plants light green, in tufts of few to several culms, 20 to $55 \mathrm{~cm}$. high, radiatespreading, occasionally nearly erect, the nodes appressed-pubescent; sheaths nearly as long as or longer than the comparatively short internodes, loose toward the summit, ciliate on the margin, otherwise glabrous, sometimes with viscid tubercles between the nerves; ligules nearly or quite obsolete; blades thick and firm with usually incon-
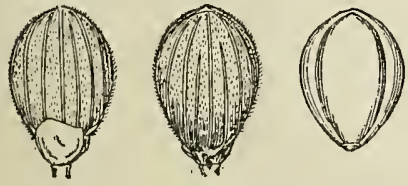

FiG. 273.-P. sphaerocarpon. From type specimen. spicuous nerves, ascending, 6 to $10 \mathrm{~cm}$. long, 7 to 14 $\mathrm{mm}$. wide (rarely longer or wider), the upper and lower smaller, acuminate, slightly narrowed to the subcordate base, rough on the upper surface, smooth below, the cartilaginous, scabrous margins stiffly ciliate toward the base; panicles long-exserted, 5 to $10 \mathrm{~cm}$. long, nearly as wide, rather loosely flowered, the axis and ascending branches with viscid spots; spikelets 1.6 to $1.8 \mathrm{~mm}$. long, 1 to 1.3 $\mathrm{mm}$. wide (in exceptional specimens only $1.5 \mathrm{~mm}$. long), obovoid-spherical at maturity (oval when young), puberulent; first glume about one-fourth the length of the spikelet, obtuse second glume and sterile lemma equaling the fruit at maturity; fruit 1.4 to $1.5 \mathrm{~mm}$. long, 1 to $1.2 \mathrm{~mm}$. wide, obovoid-spherical.

Autumnal form prostrate-spreading, sparingly branching late in the season from the base or lower and middle nodes, the branches short, mostly simple, the blades and panicles not greatly reduced; winter rosettes of many thick, ovate or ovatelanceolate, white-margined leaves, appearing early.

Numerous specimens occur which are intermediate between this species and the following subspecies. These more slender plants with usually narrower blades and slightly smaller spikelets are the form named Panicum nilidum var. crassifolium by 
Gray a as shown by the specimen from "Pine barrens of New-Jersey," in the Boott set of the Gramineae and Cyperaceae now in the Gray Herbarium. This varietal name was never published by Gray and $P$. nitidum was included under $P$. dichotomum in Gray's Manual from the first to the fifth editions. In the sixth edition the name $P$. nitidum was applied to $P$. sphaerocarpon Ell., (which was cited as synonym) as shown by the description and by specimens in the Gray Herbarium. The intermediate specimens, of which the following are representative, are included in those cited below: Ball 69, Bebb 1259, Chase 3089, 3256, 3489, 3611, Hitchcock 1216, 1607, Mackenzie 2166, Plank 49, Tracy 13, 4607.

\section{DISTRIBUTION,}

Sandy soil, Vermont to northern Florida, west to Illinois and Texas, and south through Mexico to Venezuela.

Vermont: Putney, Blanchard 9 (Gray Herb.).

Massachusetts: Boston, Swan in 1886; Framingham, Smith 748.

Connecticut: Southington, Andrews 8, 73; Waterford, Graves 85; Berlin, Bissell 5585; Portland, Wilson 1435.

Rhode Island: Providence, Olney in 1868 (Brown Univ. Herb.).

New York: Niagara County, Townsend 1; Long Island, Bicknell in 1905.

New Jersey: Berkeley Heights, Mackenzie 2250; Tuckerton, Chase 3611; Wildwood, Chase 3489, 3509; Cape May, Pollard in 1897; South Amboy, Mackenzie 2166.

Pennsyluania: Easton, Porter in 1893 and 1897; Stroudsburg, Porter in 1898; Germantown, Stone 6; Newtown, Smith 160.

Онго: Portsmouth, Kellerman in 1899 (Ohio State Univ. Herb.).

Indiana: Dune Park, Chase 1850, V. H. Chase 242.

ILLinoIs: Jackson, French in 1906.

Michigan: Detroit, Farwell 1388;

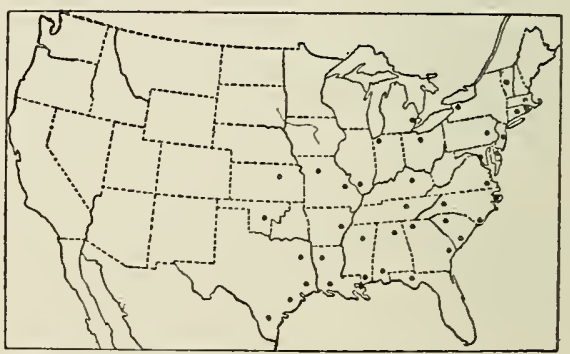

FIG. 274.-Distribution of P. sphaerocarpon. Grand Beach Springs, Hill 88 and 90 in 1908; Magician Lake, Umbach 2153.

Missouri: St. Louis, Eggert 254; Cliff Cave, Kellogg 9, 11; Swan, Bush 675; Eagle Rock, Bush 145.

Kansas: Cherokee County, Hitchcock Pl. Kans. 883.

Delaware: Centerville, Commons 284, 298; Milton, Commons 350; Rehoboth, Commons 49, 50; Lewes, Hitchcock 561 .

Maryland: Chesapeake Beach, Chase 3256, Hitchcock 1605, 1607, 1615, 1616, 2408; between Chesapeake Beach and Chesapeake Junction, Hitchcock, $1626,1639$.

District of Columbia: Ball 65, Chase 2401, 2412, Kearney 12, Pollard 398, Vasey 34, 111, Ward in 1878, Williams 1, 2.

Virginia: Alexandria, House 1058, Chase in Kneucker Gram. Exs. 553; FourMile Run, Chase 5432, 5433; Norfolk County, Chase 2332, Kearney 301 in part, 1560; Munden, Mackenzie 1663; Virginia Beach, Williams 3098.

North Carolina: Roanoke Island, Chase 3212, 3237; Lake Mattamuskeet, Chase 3206; Wilmington, Chase 4591, Hitchcock 1426; Chapel Hill, Chase 3074; Caraleigh Junction, Chase 3089; Biltmore, Biltmore Herb. 4292b. 
South Carolina: Orangeburg, Hitchcock 1381; Pacolet, House 2492; Clemson College, House 2413; Aiken, Kearney 243, Ravenel.

Georgia: Augusta, Cuthbert 1157, 1158; Kearney 217; Lookout Mountain, Ruth 1, 6, 75; Union, Harper 1087; Millen, Curtiss 6828; Thomson, Bartlett 1459.

Florida: Monticello, Combs 306; St. Andrews Bay, Tracy 9137.

Kentucky: Bell County, Kearney 594.

Tennessee: Cocke County, Kearney 968.

Alabama: Pisgah, Chase 4470; Valley Head, Ruth 21; Tuskegee, Carver 28, 67; Cullman County, Eggert 13, 23; Anniston, Tracy 7402; Mobile, Kearney 25; Springhill, Langlois 43.

MississiPPI: Starkville, Tracy 47; Jackson, Hitchcock 1307; Enterprise, Tracy 3296 in part; Biloxi, Hitchcock 1078, 1084, Kearney 320, Tracy 4576, 4597; Ocean Springs, Tracy 13; Mississippi City, Hitchcock 1095, 1099, 1102; Moss Point, Tracy 4604; Cat Island, Tracy 433; Petit Bois Island, Tracy 4607.

Arkansas: Little Rock, Coville in 1887; Miller County, Eggert 115; Benton County, Plank 49, 99.

Louisiana: Calhoun, Ball 69; Hitchcock 1284; Shreveport, Hitchcock 1241; Breton Island, Tracy \& Lloyd 468; Lake Charles, Hitchcock 1126, 1132, 1134, 1136, 1137.

Texas: Waller County, Hitchcock 1181, 1190, 1213, 1216, Thurow 2, 4, 10, 30; Houston, Bebb 1259; Hall 832; Denison, Bebb 1434; Terrell, Warburton 12; Columbia, Bush 177; Weatlierford, Tracy 7946; Victoria, Plank 4; Milano, Griffiths 6551; Galveston, Plank 34.

OкLанома: Sapulpa, Bush 1218; Stillwater, Hitchcock 562.

Mexico: San Luis Potosí, Schaffner 1037; Jalapa, Pringle 7883 (Hitchcock Herb.) 8344; Chinantla, Liebmann 327; Orizaba, Botteri; Schiede \& Deppe "acuminatum b" (Berlin Herb.), Schaffner 138 (Paris Herb.); Córdoba, Schaffner 285 (Paris Herb.).

Guatemala: Coban, Tuerckheim 56 in part; crater of Pacaya Volcano, Keller$\operatorname{man} 6236$.

Costa RICA: Abejonal, Tonduz 7878; San Pedro de la Calabaza, Tonduz 10745 in part; Copey, Tonduz 11866.

Venezuela: Fendler 1638.

\section{9a. Panicum sphaerocarpon inflatum (Scribn. \& Smith) Hitchc.}

Panicum inflatum Scribn. \& Smith, U. S. Dept. Agr. Div. Agrost. Circ. 16: 5. 1899. "Type No. 4622, S. M. Tracy, collected at Biloxi, Miss., October, 1898." The type, in the National Herbarium, is a branching plant, decumbent and rooting at the lower nodes, the loose sheaths prominently tuberculate, the loosely flowered panicles inature.

Panicum mississippiense Ashe, Journ. Elisha Mitchell Soc. 16: 91. 1900. "Collected by me on the banks of the Mississippi River below New Orleans in October. I also refer here S. M. Tracy's No. 6777, collected on Horne Island, Miss., in July, 1899."” The type specimen could not be found in Ashe's Herbarium. According to Tracy the number of the second specimen mentioned is a misprint for 6471. This specimen is in Ashe's herbarium. The culms are in the early branching state, slender and widely spreading, the branches elongated.

\section{DESCRIPTION.}

Vernal form similar to that of the species, more ascending, not radiate-spreading; culms on the average taller, more slender; sheaths rather looser, more commonly and prominently viscid-tuberculate; ligules 0.3 to $1 \mathrm{~mm}$. long; blades narrower, 5 to 10 
mm. wide, the margins nearly parallel for two-thirds their length, with fewer ciliæe at the base; panicles more loosely flowered; spikelets slightly smaller, 1.4 to $1.5 \mathrm{~mm}$. long, $1 \mathrm{~mm}$. wide.

Autumnal form decumbent, rather freely branching from the middle nodes before the maturity of the primary panicles, these early branches long and again branching more freely than in the species, the ultimate blades and panicles not greatly reduced.

This subspecies is distinguished by the ligules, slightly smaller spikelets, and nar-
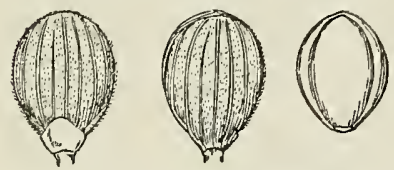

FIG. 275.-P. sphacrocarpon inflatum. From type specimen. rower, parallel-margined blades, taken in combination, and in autumnal specimens by the more freely branching habit. The specimens cited below all show this combination of characters, but about half as many specimens occur which are intermediate between this and the species. These bear a general resemblance to the subspecies, having spikelets about $1.5 \mathrm{~mm}$. long, and narrower, but not always parallel-margined blades, but with no ligule or the merest trace of one. Because of the large proportion of these intermediate specimens $P$. inflatum Scribn. \& Smith is here reduced to a subspecies of $P$. sphaerocarpon:

\section{DISTRIBUTION}

Moist sandy ground, Maryland to Florida, and west along the Gulf to Texas, thence north to Missouri.

Missouri: Monteer, Bush 747 in part, 753.

Maryland: Owings, Hitchcock 1618; Chesapeake Junction, Hitchcock 2412.

North Carolina: Wilmington, Chase $3134,3158$.

South Carolina: Orangeburg, Hitchcock 26.

Georgia: Savannah, Kearney 188, 194; Americus, Tracy 3642; Thomasville, Tracy 3656 .

Florida: Lake City, Combs 182; Quincy, Combs 403, 406; St. Vincent, Tracy 6458.

Alabama: Selma, Kearney 7 ; Fort Morgan, Tracy 8400.

Mississippi: Biloxi, Tracy 4593,

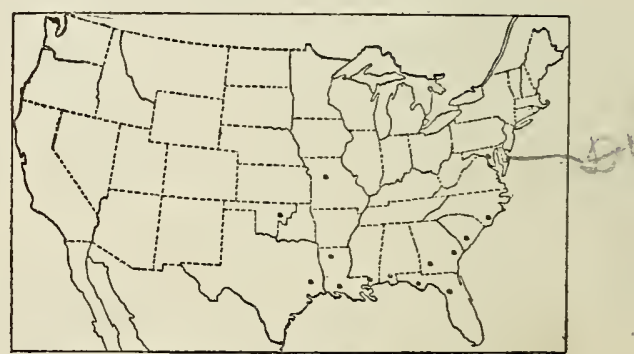

FIG. 276.-Distribution of $P$, sphaerocarpon inflatum. 4622; Centerville, Tracy 3619; Horn Island, Tracy 2862, 6471.

Louisiana: Calhoun, Hitchcock 1285; Alexandria, Ball 441, 536; Calcasieu, Cocks 3007; Lake Charles, Chase 4429.

Texas: Without locality, Nealley in 1890.

OKLaHoma: Poteau, Hitchcock in 1903 (Hitchcock Herb.).

\section{Panicum polyanthes Schult.}

Panicum multiflorum Ell. Bot. S. C. \& Ga. 1: 122. 1816, not Poir. 1816. Elliott gives no exact locality, but his specimen was presumably from the vicinity of Charleston as he merely states, "Grows in shaded, dry soils." The type, in the Elliott Herbarium, consists of a single culm, lacking base, bearing three leaves and an immature panicle, slightly included at base. The accompanying label reads: "Panicum multiflorum mihi, Hab. in umbrosis. Flor. May-Jun." 
Panicum microcarpon Muhl. Descr. Gram. 111. 1817, not Muhl.; Ell. 1816.a "Semina e Virg. et Cherokee et Delaware." The type in the Muhlenberg Herbarium consists of the upper portion of a culm with two leaves and a short-exserted panicle. The attached label reads: "40, c Jul. 12. e Cherokee."

Panicum polyanthes Schult. Mant. 2: 257. 1824. Based on P. multiflorum Ell. not Poir. That Poiret's use of the name was earlier is given on the authority of Sprengel. $b$

Panicum microcarpon isophyllum Scribn. Tenn. Agr. Exp. Sta. Bull. 7: 51. f. 54. 1894. No specimen is cited but in the Scribner Herbarium is a sheet to which is attached a note from Dr. Chapman suggesting the name "isophyllum" and upon which are four small specimens of $P$. polyanthes one of which is recognized as the plant figured with the original description. The specimens were collected by E. E. Gayle, Alleghany Springs, Blount Co., Tennessee, August, 1890.

\section{DESCRIPTION.}

Vernal plants light green, in tufts of few to several culms, 30 to $90 \mathrm{~cm}$. high, stout, erect, the nodes glabrous or nearly so; sheaths long, usually overlapping, finely ciliate on the margin, otherwise glabrous; ligules obsolete or wanting; blades rather thin, prominently nerved, ascending, 12 to $23 \mathrm{~cm}$. long, 15 to $25 \mathrm{~mm}$. wide, the upper seldom reduced, long-acuminate, scarcely narrowed toward the cordate base, rough or smooth on the upper surface, smooth below, the cartilaginous, scabrous margin ciliate toward the base; panicles exserted, 8 to $25 \mathrm{~cm}$. long, one-fourth to half as wide, densely flowered, the lower branches narrowly ascending, often distant, the upper fascicled, spikelet-bearing to the base; spikelets 1.5 to $1.6 \mathrm{~mm}$. long, 1 to $1.1 \mathrm{~mm}$. wide, obovoid-spherical at maturity, minutely puberulent; first glume one-third to two-fifths the length of the spikelet, obtuse or obscurely pointed; second glume and sterile lemma equaling the fruit at maturity; fruit obovoidspherical.

Autumnal form remaining erect and simple or producing from the lower or middle nodes simple

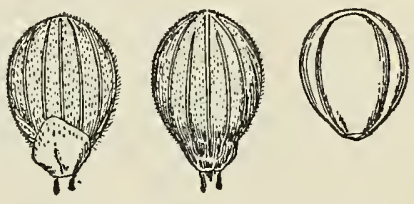

Fig. 277.-P. polyanthes. From type specimen of $P$. multifiorum Ell. branches with smaller blades and panicles; winter rosettes like those of $P$. sphaerocarpon, but the leaves larger.

This species is distinguished from $P$. sphaerocarpon by its erect habit, taller, more leafy culms, wider blades and narrow panicles. Specimens not infrequently occur in which, from a twisting of the internodes, the blades are all or mostly on one side. This is especially true of small, late culms. It was to such a specimen the name P. microcarpon isophyllum was given.

\section{DISTRIBUTION.}

Damp ground, woods and openings, New Jersey to Oklahoma, south to Georgia and Texas.

New Jersey: South Amboy, Mackenzie 1380.

Pennsyluania: Lancaster County, Heller 4772, Porter in 1898.

Оніо: Lancaster, Kellerman 6767.

Indiana: Clarke County, Deam 5392; Batesville, Deam 6815.

Ilurnors: Cobden, Earle in 1886; Jackson County, French in 1905.

Missouri: St. Louis, Eggert 250; Pleasant Grove, Bush 232.

$a$ See discussion under P. microcarpon Muhl.; Ell., page 181.

$b$ Neu. Entd. 2 : 190. 1821. 
Delaware: Wilmington, Commons 307; Townsend, Canby in 1896; Ogletown, Commons 47; Stanton, Commons 306.

Maryland: Chesapeake Beach, Hitchcock 1609; Chesapeake Junction, Hitchcock 2399; Riverdale, Chase 2368; Hyattsville, Chase 3803, House 450; West Chevy Chase, Chase 3273.

District of Columbia: Ball 21, 705, Chase in Kneucker Gram. Exs. 554, Hitchcock 2404, Kearney 13, 20, Merrill 199, Pollard 401, Vasey 110, Ward in 1880.

Virginia: Four-Mile Pun, Steele in 1897; Munden, Mackenzie 1745; Ocean View, Kearney 1476; Suffolk, Heller 968; Norfolk, Hitchcock 410.

West Virginia: Baileysville, Morris 1186.

North Carolina: Weșt Raleigh, Coit 1300; Chapel Hill, Ashe; Caldwell County, Small \& Heller 463; Hickory, Small \& Heller in 1891.

South Carolina : Abbeville, Maier 264 (Gray Herb.).

Georgia: Lookout Mountain, Ruth 5, 7, 15, 69; Stone Mountain, Small in 1893; Clarke County, Harper 104; Cobb County, Wilson 8; Thomson, Bartlett 1071, $1498,1500$.

Kentucky: Harlan County, Kearney 52.

Tennessee: Robertson County,

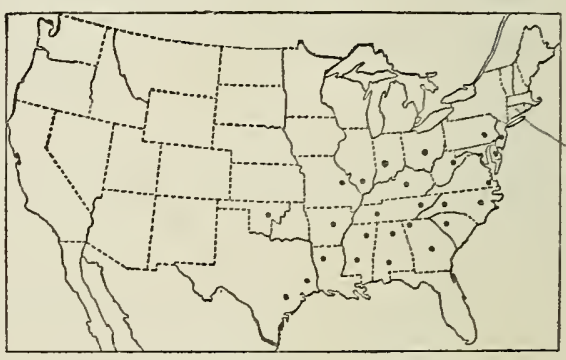

FIG. 278.-Distribution of $P$. polyanthes. Eggert 95; Cocke County, Kearney 974; Chester County, Bain 191; White Cliff Springs, Scribner in 1890.

Alabama: Cullman County, Eggert 14; Pisgah, Chase 4485; Nesheka, Carver 18.

Mrssissippr: Taylorville, Tracy 8418; Heidelberg, Tracy 3316; Centerville, Tracy 3631; Macon, Tracy 3238; Starkville, Kearney 57 in part; without locality, Tracy 3760.

Arkansas: Greene County, Eggert 240; Prescott, Bush 255.

Louisiana: Calhoun, Hitchcock 1270.

Texas: Palestine, Plank 89; Burnet, Plank 9; without locality, Nealley in 1884 and 1886 .

Окцанома: Poteau, Hitchcock in 1903 (Hitchcock Herb.).

\section{Panicum erectifolium Nash.}

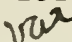

Panicum sphaerocarpon floridanum Vasey, U. S. Dept. Agr. Div. Bot. Bull. 8: 33. 1889 , not $P$. floridanum Tfin. 1835. "Florida." In the National Herbarium are three specimens from Florida marked in Dr. Vasey's writing "Panicum sphaerocarpon Ell. var. Floridanum." Of these Curtiss 3599, from "Moist pine barrens, Mosquito Inlet, Florida, May, 1879," has been chosen as the type, since with the other two no locality within the State is given. This specimen consists of two plants 45 and $50 \mathrm{~cm}$. high, with mature panicles of densely puberulent spikelets.

Panicum erectifolium Nash, Bull. Torrey Club 23:148. 1896. Based on $\dot{P}$. sphaerocarpon floridanum Vasey, not $P$. floridanum Trin.

Panicum floridanum Chapm. Fl. South. U. S. ed. 3. 585. 1897, not Trin. 1835. "In and around shallow ponds, near the coast of Trest Florida." The type, in the Chapman Herbarium at Biltmore, is from Apalachicola. Chapman presumably intended to base his name upon $P$. sphaerocarpon floridanum Vasey, but cites " $(P$. microcarpon, var., Vasey. P. sphaerocarpum, Flora.)" 


\section{DESCRIPTION.}

Vernal plants dull green, sometimes bluish, in tufts of few to several culms, 30 to 70 $\mathrm{cm}$. high, erect or ascending, usually stout, glabrous, including the nodes; sheaths, except the uppermost, short, rather loose, usually crowded and overlapping at base, ciliate on the margin, otherwise glabrous; ligules about $0.3 \mathrm{~mm}$. long; blades thick and firm with inconspicuous veins, ascending or erect, 7 to $13 \mathrm{~cm}$. long, 6 to 12 $\mathrm{mm}$. wide, the crowded lower ones usually much larger than the others, these successively smaller upward, tapering from the cordate base to the acuminate apex, smooth on both surfaces, margins scabrous, stiffly ciliate toward the base; panicles

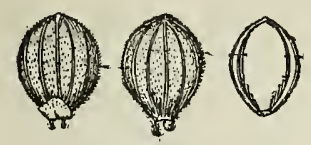

FIG. 279.-P . erectifolium. From type specimen. exserted, 6 to $12 \mathrm{~cm}$. long, half to two-thirds as wide, densely flowered, the lower branches usually narrowly ascending; spikelets 1 to $1.2 \mathrm{~mm}$. long, 0.8 to $1 \mathrm{~mm}$. wide, broadly ovate or subspherical, densely puberulent; first glume one-fifth to one-fourth the length of the spikelet; obtuse, second glume and sterile lemma equaling the fruit at maturity; fruit oval, very obscurely umbonate.

Autumnal form remaining erect and simple or late in the season producing branches from the third or fourth node, the branches nearly as long as the primary culm, rarely again branching; winter rosettes appearing late, the blades 3 to $10 \mathrm{~cm}$. long.

This species shows an unusual variation in the size of the blades and also the number of leaves to the culm. There are usually 5 to 7 , but sometimes as many as 10 leaves, and in a few specimens no blades are over $5 \mathrm{~cm}$. long. The specimens of Combs 553 are small autumnal plants more freely branching than usual.

\section{DISTRIB UTION.}

Moist pine barrens, swamps, and borders of ponds, North Carolina to Florida and Louisiana; also in Cuba.

North Carounna: Wilmington, Chase 3137, Hitchcock 411; without locality, Mc Carthy in 1885.

Georgia: Allapaha, Curtiss 6817 in part; Huntington, Harper 1394; Charlton County, Harper 1485 .

Florida: Jacksonville, Curtiss 4812 (Hitchcock Herb.); Baldwin, Combs 58; Lake City, Combs 114; De Funiak Springs, Combs 467; Washington County, Combs 553, 662; Ellzey, Combs 814; Mosquito Inlet, Curtiss 3599; Grasmere,

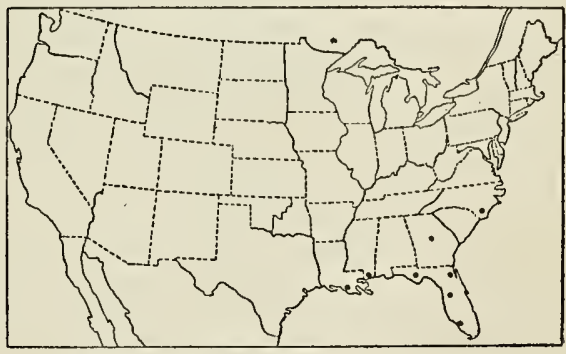

FIG. 280.-Distribution of $P$. crectifolium.

Combs 1117; Eustis, Nash 1012; Manatee River, Rugel 229; Orange Glade, Eaton 578; Myers, Chase 4154, Hitchcock 874, Lee Co. Pl. 469.

Mississippi: Beauvois, Tracy 4596.

Louisiana: St. Tammany Parish, Cocks 292 (Hitchcock Herb.).

Cuba: Vuelta Abajo, Wright 3462.

$41616^{\circ}$ - voL $15-10-17$ 
Ensifolia.-Plants low and slender, usually glabrous and less than $50 \mathrm{~cm}$. high; sheaths glabrous or puberulent (sparsely pilose in $P$. curtifolium); ligules nearly obsolete (about $1 \mathrm{~mm}$. long in $P$. curtifolium); panicles small, rarely more than $5 \mathrm{~cm}$. long; spikelets glabrous or pubescent, 1 to $1.7 \mathrm{~mm}$. long, 5 to 7-nerved. Autumnal form sparingly to freely branching, or in $P$. vernale a distinct autumnal form wanting.

Ligules about $1 \mathrm{~mm}$. long; sheaths or some of them sparsely spreading-pilose. 159. P. curtifolium.

Ligules obsolete or nearly so; pubescence if present not spreading.

Blades prominently white-margined, firm; spikelets densely puberulent.

Blades puberulent beneath, often above; sheaths and sometimes lower internodes ascending pubescent ............................152. P. tenue.

Blades glabrous; sheaths glabrous or minutely ciliate only.

Uppermost culm blades much reduced; culms branching from lower nodes only, the branches repeatedly branching...........153. P.albomarginatum.

Uppermost culm blades about as long as the others; culms bearing short branches from the upper and middle nodes ............ 154. P. trifolium.

Blades not white-margined or very obscurely so (or if white margin is evident spikelets only $1.1 \mathrm{~mm}$. long); spikelets glabrous or puberulent.

Culms branching only at base; plants soft, light green. 158. P. vernale.

Culms branching at the nodes; plants firm or at least not soft.

Spikelets glabrous.

Spikelets 1.1 to $1.2 \mathrm{~mm}$. long; blades rarely as much as $5 \mathrm{~cm}$. long.............160. P. chamaelonche.

Spikelets 1.2 to $1.5 \mathrm{~mm}$. long.

Blades elongated, at least some of them 8 to $10 \mathrm{~cm}$. long.................161. P. glabrifolium.

Blades not over $3 \mathrm{~cm}$. long...........157. P. ensifolium. Spikelets puberulent.

Spikelets $1.1 \mathrm{~mm}$. long; winter blades bluish green, not glossy................156. P. concinnius. Spikelets 1.3 to $1.5 \mathrm{~mm}$. long.

Blades involute, falcate, with long stiff hairs on margin near base; plants stiff and wiry.................162. P. breve.

Blades not involute, or at tip only, not falcate.

Plants bright green; winter blades conspicuous, glossy green......155. P. flavovirens.

Plants olive; winter blades not conspicuous nor glossy..........157. P. ensifolium. 


\section{Panicum tenue Muhl.}

Panicum tenue Muhl. Descr. Gram. 118. 1817. No locality is given. "P. deustum Brickell et Enslin," an unpublished name, is cited as synonym. The type, in the Muhlenberg Herbarium, consists of three plants with attached label bearing the name "Panicum deustum;" these are from 10 to $30 \mathrm{~cm}$. high, the panicles immature, the sheaths sparsely appressed-pilose, the blades puberulent on the lower surface and with conspicuous white margins.

Panicum deustum Brickell \& Enslin; Muhl. Descr. Gram. 119. 1817, not Thunb. 1794. This herbarium name is given as a synonym of $P$. tenue, of which it is a typonym.

Panicum liton Schult. Mant. 2 : 250.1824. Based on P. tenue Muhl., Muhlenberg's description, slightly rearranged, being copied, "Nomina mutanda, ob tenue Roxb. et deustum Thunb. antiquiora." Panicum tenue Roxb. 1813, a is a nomen nudum, the description not being published until $1820 .^{b}$

Panicum unciphyllum Trin. Gram. Pan. 242. 1826. Trinius states in regard to his specimen, "V. spp. Am. Bor. (Tratrinick)." The type, in the Trinius Herbarium, is the vernal form, with sparsely appressed-villous culms and sheaths and puberulent blades. As stated under $P$. columbianum, Trinius's species was misunderstood because the specimen sent from St. Petersburg as a part of the type proved on a subsequent examination of Trinius's herbarium to be not the type but a specimen of $P$. columbianum which was on the same sheet with the type specimen. The label accompanying the latter reads, "Panicum unciphyllum m. Pan. heterophyllum Muhl. (teste Nees) an Pluckn. Tav. 92 f. 8, ex herb. Enslini, spmna Am. bor. Trattinick."

Panicum macrum Kunth, Rév. Gram. 1: 40. 1829. Based on P. tenue Mühl., the name presumably changed because of $P$. tenue Roxb.

Panicum parvulum Muhl.; Scribn. \& Merr. U. S. Dept. Agr. Div. Agrost. Circ. 27: 4. 1900, not Trin. 1834. This name, found in Muhlenberg's herbarium, is given as a synonym of $P$. tenuc.

\section{UESCRIPTION.}

Vernal form olive green; culms in rather small tufts, 20 to $55 \mathrm{~cm}$. high, slender, erect from a more or less geniculate base, glabrous, or the lower internodes sparsely appressed-pubescent, the nodes glabrous, appressed-pubescent, or appressed-pilose; sheaths usually much shorter than the internodes, puberulent between the nerves to sparsely appressed-pilose, or the upper glabrous; ligules 0.3 to $0.5 \mathrm{~mm}$. long, dense; blades distant, ascending or speading, 2 to $5 \mathrm{~cm}$. long, 3 to $4 \mathrm{~mm}$. wide, rather thick and with a cartilaginous, often white, margin, involute-pointed, usually densely puberulent beneath, glabrous on the upper surface or puberulent toward the base; panicles long-exserted, 3 to $5 \mathrm{~cm}$. long, about as wide, pyramidal, open, rather fewflowered, the flexuous branches spreading; spikelets 1.6 to $1.7 \mathrm{~mm}$. long, elliptic, subobtuse, densely puberulent; first glume one-fifth as long as the spikelet or less, obtuse; second glume shorter than the fruit and sterile lemma; fruit 1.4 to $1.5 \mathrm{~mm}$. long, elliptic, subobtuse.

Autumnal culms erect or leaning, sparingly branching from the middle nodes, the

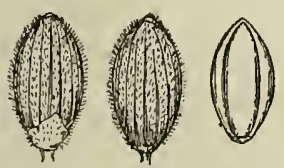

Fig. 281.-P. tenue. From type specimen.

branches in small fascicles, shorter than the primary internodes, the blades not much reduced; winter rosette collspicuous, the thick, cartilaginous-margined, involute-pointed blades 3 to $5 \mathrm{~cm}$. long, 4 to $7 \mathrm{~mm}$. wide, persistent (but usually dead) during the succeeding year.

This species seems to be intermediate between $P$. albomarginatum and $P$. ensifolium, differing from the first in being pubescent and in having taller, more slender culms, sparingly branched. From $P$. ensifolium it may be distinguished by the larger, 
more pubescent spikelets, the thicker, involute-pointed blades and the large basal rosette of firm leaves. In Hitchcock 1438, from Wilmington, N. C., referred here, the pubescence is so copious as to suggest $P$. leucothrix, but the nearly obsolete ligule and the size of the spikelets place it, though somewhat doubtfully, in P.tenue. Hitchcock'sno. 1467 is an unusually robust specimen with panicles as much as $9 \mathrm{~cm}$. long.

\section{DISTRIBUTION.}

Moist sandy woods, eastern North Carolina and northern Florida.

North Carolina: Parmele, Ashe in 1899; Manteo, Ashe in 1898;

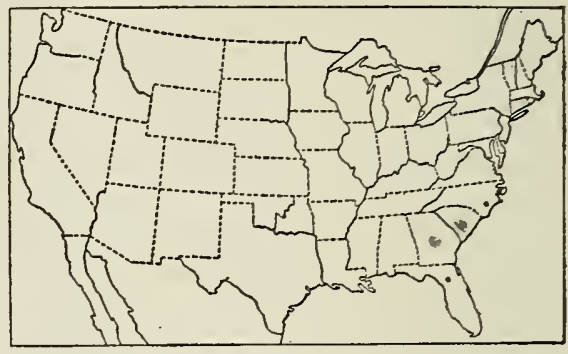

FIG. 282.-Distribution of $P$. tenue.

Wards Mill, Chase 3170, 3172, 3183; Wilmington, Ashe in 1899, Hitchcock 332, 1467.

Florida: Lake City, Bitting 20.

\section{Panicum albomarginatum Nash.}

Panicum albomarginatum Nash, Bull. Torrey Club 24: 40. 1897. "Collected by the writer in low pine land at Eustis, Lake County, Florida, early in June, 1894, no. 925." The type, in Nash's herbarium, consists of two large tufts in the early branching state, the culms 15 to $28 \mathrm{~cm}$. high, the primary panicles devoid of spikelets.

\section{DESCRIPTION}

Vernal plants usually grayish green, often purplish; culms densely tufted, 15 to $40 \mathrm{~cm}$. high (rarely taller), slender but firm, ascending or spreading, glabrous including the nodes; leaves crowded at the base, distant above, sheaths sometimes pubescent on the margin and at the summit, otherwise glabrous, or the lowermost sometimes obscurely pubescent; ligules $0.3 \mathrm{~mm}$. long, dense; bladespfirm, those of the midculm 4 to $6 \mathrm{~cm}$. long, 4 to $6 \mathrm{~mm}$. wide, rounded at the base, thick and with a prominent white, finely serrulate, cartilaginous margin, ascending or spreading, glabrous, the crowded basal blades as much as $11 \mathrm{~cm}$. long, and the uppermost blade usually much

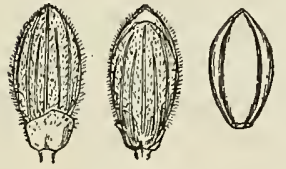

FiG. 283.-P. albomarginatum. From type specinien. reduced; panicles finally long-exserted, 3 to $6 \mathrm{~cm}$. long, nearly as wide, rather densely flowered, the flexuous branches ascending or spreading; spikelets 1.4 to $1.5 \mathrm{~mm}$. long, 0.7 $\mathrm{mm}$. wide, obovate-elliptic, subobtuse, turgid at maturity, densely puberulent; first glume one-fifth to one-fourth as long as the spikelet, obtuse or subacute; second glume and sterile lemma scarcely equaling the fruit at maturity; fruit $1.25 \mathrm{~mm}$. long, $0.65 \mathrm{~mm}$. wide, elliptic, subacute.

Autumnal form spreading, the primary culms branching fron the base and lower nodes, these early branches much longer than the primary interuodes and repeatedly branching, forming bushy tufts, the ultimate branchlets and reduced blades appressed; winter blades stiffly erect or spreading, very smooth and firm.

This species is distinguished by the long crowded basal and distant upper blades, the uppermost usually less than half as long as those of the midculm; and by the autumnal form in which the primary culms branch from the basal and lower, never from the upper, nodes.

The specimens collected by Hitchcock in Cuba (no. 555) are robust plants and differ from typical $P$. albomarginatum in having a ligule $1 \mathrm{~mm}$. long. 
DISTRIBUTION.

Low sandy soil of the Coastal Plain, from southeastern Virginia to Florida and west to Louisiana; also in Guatemala and Cuba.

Virginia: Dismal Swamp, Chase 3658.

North Carolina: Parmele, Ashe in 1899; Wilmington, Fitchcock 1428, 1429, 1434, 1440, Kearney 268.

South Carolina: Orangeburg, Hitchcock 1369, Aiken, Ravenel.

Florida: Baldwin, Hitchcock 990; Iake City, Combs 112, Hitchcock 1021, 1022;

Bay Head, Combs 650; Old

Town, Combs 854; Perdido Bay, Tracy 8409; Titusville, Chase 3966, Hitchcock 761; Sanford, Hitchcock 768, 823, 826; Eustis, Chase 4043, Hitchcock 817, Nash 925; Orange County, Baker 119; Lemon Bay, Tracy 7189; Miami, Hitchcock 639, $666,667,670,679,714,720$; Homestead, Hitchcock 692; Tampa, Hitchcock 945; Lakeland, Hitcheock 838, 839, 848;

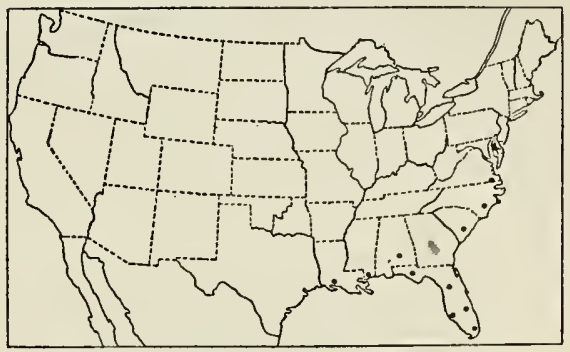

FIg. 284.-Distribution of P. albomarginatum. Braidentown, Hitchcock 949, 963, Tracy 6733; Manatee, Rugel 184; Myers, Chase 4151, Hitchcock 870, 876, 880, 882, 884, 886 .

Alaba.ma: Tuskegee, Carver 97.

Mississippi: Biloxi, Tracy 4605 in part (Gray Herb.).

Louisiana: Calcasieu River, Langlois 42 in 1884.

Guatemala: Between Gualán and Copán, Pittier 1805a.

CuBA: Herradura, Hitchcock 555; Pinar del Rio, Wright 3463 in part (Sauvalle Herb.); Isle of Pines, Taylor 32.

\section{$\checkmark$ 154. Panicum trifolium Nash.}

Panicum trifolium Nash, Bull. Torrey Club 26: 580. 1899. "Type collected by Dr. John K. Small, in the Ocmulgee River Swamp, below Macon, Georgia, May 18-24, 1895." The type, in Nash's herbarium, consists of two tufts of slender vernal culms, 25 to $40 \mathrm{~cm}$. high, with leafy bases and elongated internodes, the rather short-exserted panicles immature.

\section{DESCRIPTION .}

Vernal form similar to that of $P$. albomarginatum, but the culms in smaller tufts, taller, 20 to $50 \mathrm{~cm}$. high, more slender, erect; leaves less conspicuously crowded at the base, not so stiff, and proportionately not so much longer than those of the mid-

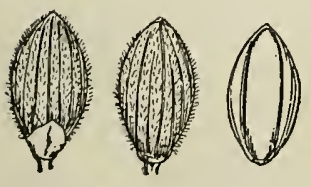

FIG.285.-P. trifolium. From type specimen. culm; sheaths much shorter than the elongated internodes; blades 3 to $5 \mathrm{~cm}$. long, 4 to $5 \mathrm{~mm}$. wide, rather less thick and firm than those of $P$. albomarginatum, the uppermost blade not reduced; panicles usually short-exserted, 3 to $5 \mathrm{~cm}$. long, about as wide, loosely flowered; spikelets as in $P$. albomarginatum but hardly as wide or as turgid, and the fruit rather less exposed at maturity.

Autumnal form erect or leaning, sparingly branching from the middle and upper nodes, the branches usually shorter than the primary internodes.

This species is very closely allied to the preceding and some vernal specimens are but doubtfully separated from it. Autumnal specimens may be distinguished by the small fascicles of short branches scattered along the slender primary culm. 
Occasional specimens, such as Chase 4112, 4166, and 4304, are brighter green than usual, with less pronounced white margins to the blades and resemble $P$. flavovirens, but in these the primary culms bear short branches from the middle and upper nodes.

\section{DISTRIBUTION .}

Low, mostly moist sandy woods, North Carolina and Tennessee to Florida and Louisiana. N.J. Cape May Co. Loug

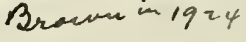

North Carolina: Scranton, Chase 3199; Roanoke Island, Chase 3225, 3238, 3239, 3248; Chapel Hill, Ashe, Chase 3060; east of Wilmington, Chase 3133, 4576.

South Carolina: Orangeburg, Hitchcock 1387; without locality, Ravenel.

Georgia: Below Macon, Small in 1d Sucow kie 8864 ; Augusta, Cuthber Tracy 1159.

Florida: Baldwin, IItchcock 997; Milton, Chase 4304; Apalachicola, Biltmore Herb. 697a; Lake City, Hitchcock 1023, 1038; Madison, Combs 263; Sanford, Hitchcock 779; Grasmere,

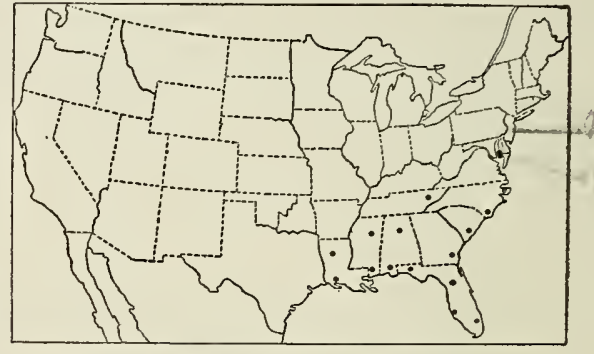

FIG. 286.-Distribution of P. trifolium. Combs 1063; Orange Bend, Chase 4112; Tampa, Hitchcock 938, 940; Braidentown, Hitchcock 953, 962; Dunedin,-Tracy 7029; Myers, Chase 4166, Hitchcock 890, 920, 921; Miami, Chase 3946, Hitchcock 712.

Tennessef: White Cliff Springs, Scribner in 1890 (Hitchcock Herb.).

Alabama: Auburn, Earle \& Baker 1535 in part; Cullman, Eggert 24; Flomaton, Hitchcock 1042, 1050, 1053.

Mississippi: Jackson, Hitchcock 1305; Biloxi, Chase 4358, Hitchcock 1063, 1072, 1088, Tracy 2865, 4612; Mississippi City, Hitchcock 1089, 1100, 1111, Avondale, Tracy 4583, 4603; Saundersville, Tracy 3334; Horn Island, Tracy 4601.

Louisiana: Calhoun, Hitchcock 1267, 1277; Lake Charles, Hitchcock 1130, 1146.

\section{Panicum flavovirens Nash.}

Panicum favovirens Nash, Bull. Torrey Club 26: 572. 1899. "Type collected by the writer in Lake Co., Florida, June 16-30, 1895, no. 2061; growing in swampy woods along the edge of road leading to the ford near the J. T. \& K. W. R. R. bridge across the Wekiva river." The type, in Nash's herbarium, is a late vernal form, the primary panicles mostly destitute of spikelets. One of the specimens has a tuft of the long, rather thin, bright green, glossy basal leaves that distinguish this species. The other specimen lacks this prominent tuft of basal leaves and in habit resembles

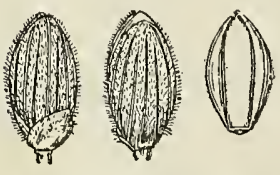

FIG.287.-P. flavovirens. From type specimen. the type of $P$.albomarginatum Nash, but the blades are not firm and leathery nor white-nargined, and the panicles are few-flowered, with flexuous branches.

\section{DESCRIP'TION.}

Vernal form bright glossy green; culms densely tufted, very slender, ascending or spreading, 15 to $30 \mathrm{~cm}$. high, glabrous, more or less striate-angled, the lower leaves somewhat crowded with overlapping sheaths, the upper distant; sheaths often minutely ciliate on the margin, especially at the summit, otherwise glabrous or the lowermost obscurely pubescent; blades ascending or spreading, 2 to $5 \mathrm{~cm}$. long, 3 to 
$4 \mathrm{~mm}$. wide, narrowed toward the rounded base, glabrous, or minutely puberulent beneath, thin, the cartilaginous margin inconspicuous or wanting; panicles open, loosely few-flowered, the flexuous branches spreading or the lower somewhat reflexed; spikelets 1.3 to $1.4 \mathrm{~mm}$. long, $0.7 \mathrm{~mm}$. wide, elliptic, subacute, pubescent; first glume one-fourth to one-third as long as the spikelet, subacute; second glume hardly equaling the fruit and sterile lemma; fruit $1.25 \mathrm{~mm}$. long, $0.6 \mathrm{~mm}$. wide, elliptic.

Autumnal form spreading, the slender culms mostly decumbent or prostrate, branching from the lower and middle nodes, these early branches usually as long as the primary culms and loosely branching toward the summit, the short branchlets somewhat fascicled, the flat, reduced blades spreading, the ultimate panicles reduced but exserted; winter rosettes appearing early, usually conspicuous and persisting green during the following season as a dense tuft of sterile shoots with somewhat developed internodes, the blades thin, bright glossy green, as much as $7 \mathrm{~cm}$. long, 3 to $5 \mathrm{~mm}$. wide.

This species is allied to $P$. albomarginatum and $P$. trifolium, from both of which it is distinguished by the thin bright-green glossy blades, which are scarcely or not at all white-margined. The mode of branching is like that of $P$. albomarginatum, but looser, the thin blades spreading, the small panicles exserted.

\section{DISTRIBUTION.}

Moist shady or mucky soil, North Carolina to Florida and Mississippi.

North Carolina: Wilmington, Hitchcock 337.

South Carolina: Orangeburg, Hitchcock 25.

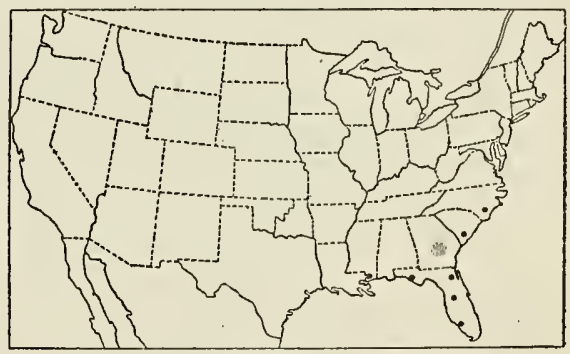

FIG. 288.-Distribution of $P$. flavovirens.

Florida: Jacksonville, Combs 34; Lake City, Combs 98 in part; Pensacola, Combs

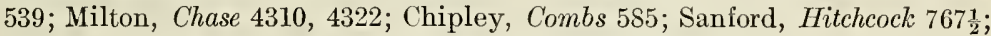
Eustis, Chase 4059, Nash 2061; Grasmere, Combs 1088; Tampa, Combs 1394; Lemon Bay, Tracy 7188 in part; Myers, Hitchcock $901 \frac{1}{2}, 905$.

Mississippr: Biloxi, Tracy 2027.

\section{() 156. Panicum concinnius nom. nov.}

Panicum gracilicaule Nash in Small, Fl. Southeast. U. S. 98. 1903, not Rendle, 1899. On page 1327 in the list of new genera and species, the following citation is given: "Type, Sand Mt., Jackson Co., Ala., Harbison, no. 2415, 1900, in Herb. N. Y. B. G." This specimen, in the herbarium of the New York

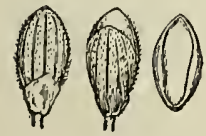

FIG.289.-P.concinnius. From type specimen of $P$. gracilicaule Nash. Botanical Garden, from the Biltmore Herbarium, is the vernal form, the panicles immature.

\section{DESCRIPTION .}

Vernal form bright green; culms tufted, very slender, erect, glabrous, 12 to $50 \mathrm{~cm}$. high, nodes minutely puberulent; sheaths, except the lower, much shorter than the internodes and less than half as long as the blades, puberulent on the margin, otherwise glabrous; ligules about $0.5 \mathrm{~mm}$. long; blades 5 to $7 \mathrm{~cm}$. long, 5 to $6 \mathrm{~mm}$. wide, erect or spreading, the margins nearly parallel for most of their length, rounded at base, glabrous or obscurely puberulent beneath, rather strongly nerved, faintly whitemargined; panicles finally long-exserted, rather few-flowered, 3 to $6 \mathrm{~cm}$. long, about two-thirds as wide, the branches ascending; spikelets $1.1 \mathrm{~mm}$. long, $0.7 \mathrm{~mm}$. wide, obovate, obtuse, pubescent; first glume about one-fifth the length of the spikelet; sec- 
ond glume and sterile lemma slightly shorter than the fruit at maturity; fruit $1 \mathrm{~mm}$. long, elliptic, acute.

Autumnal form radiate-spreading, late in the season bearing a few branches with somewhat reduced blades and small exserted panicles; winter rosette appearing early, the numerous, rather firm blades bluish green, about the size of those of the vernal culms.

\section{DISTRIBUTION.}

Moist sandy ground, northern Georgia and Alabama; apparently rare.

Georgia: Thomson, Bartlett 1461.

Alabama: "Sandy soil along a creek, Sand Mt., June 5, 1900," Harbison 2415; "Bank along roadside above Bryants Creek, south of Pisgah, Oct. 14, 1907,"

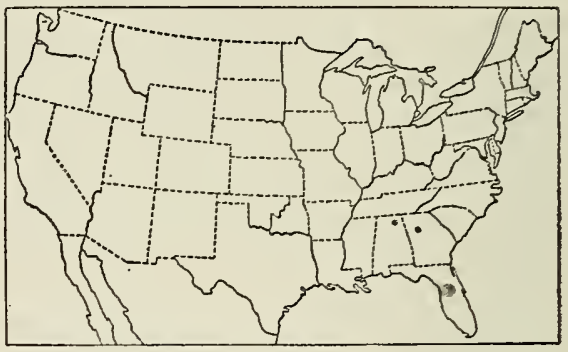

Fig. 290.-Distribution of $P$. concinnius.

Chase 4475; "In moist spot in woods, south of Pisgah, Oct. 14, 1907," Chase 4476; "Culms widely spreading, crevices of mossy rocks, north bank of Bryants Creek, south of Pisgah, Oct. 14, 1907," Chase 4483.

The last-mentioned specimen, Chase 4483, was collected at the type locality of the species, as indicated by Mr. Harbison in a letter.

\section{Panicum ensifolium Baldw.}

Panicum ensifolium Baldw.; Ell. Bot. S. C. \& Ga. 1:126. 1816. "Grows in damp soils, * * * Georgia. Dr. Baldwin." The type, in the Elliott Herbarium, is a slender plant $33 \mathrm{~cm}$. high, with a tuft of four acuminate basal leaves, the blades 2.5 to $3.5 \mathrm{~cm}$. long, four culm leaves, the upper minutely puberulent throughout on the under surface, the lower toward the tip only, and a long-exserted panicle, with puberulent spikelets $1.5 \mathrm{~mm}$. long. The accompanying label reads: "Panicum ensifolium Bald. Hab: in humidis Georg: Dr. Baldwin." The basal blades of the type specimen and of a second specimen from "Baldw. Georg." in the herbarium of the Philadelphia Academy are firm and sharp-pointed, though to a much less degree than in $P$. tenue and $P$. albomarginatum.

Panicum nitidum ensifolium Vasey, U. S. Dept. Agr. Div. Bot. Bull. 8: 29. 1889. Based on Panicum ensifolium Baldw., though the description applies to P. vernale.

Panicum brittoni[i] Nash, Bull. Torrey Club 24: 194. 1897. "In moist sand in the 'pine barrens' at Forked River, N. J. Collected by Dr. Britton during an excursion of the Torrey Botanical Club to the region May 29-June 2, 1896." The type, in Nash's herbarium, consists of a tuft of slender, simple, vernal culms 10 to $19 \mathrm{~cm}$. high, the blades glabrous or minutely puberulent on the under surface, the minutely pubescent spikelets 1.3 to $1.4 \mathrm{~mm}$. long.

Panicum cuthbertii Ashe, Journ. Elisha Mitchell Soc. 15: 48. 1898. "South Carolina: Cuthbert; St. Helena Island." This specimen could not be found in Ashe's herbarium, but a piece of the type bearing the above data, sent by Mr. Ashe, is in the National Herbarium. It consists of a single vernal culm lacking the base, with two nodes, the blades broken off, but the sheaths present, the panicle short-exserted, the immature, pubescent spikelets $1.4 \mathrm{~mm}$. long. Ashe states that "it is separated from $P$. ensifolium by the strict habit and large basal leaves of the latter," but $P$. ensifolium as understood by Ashe is $P$. albomarginatum, as shown by his description ${ }^{a}$ and by his giving $P$. albonarginatum Nash as a synonym of $P$. ensifolium. 
Panicum glabrissimum Ashe, Journ. Elisha Mitchell Soc. $15: 62.1898$. "The type material was collected by me June, 1898, at Manteo, Dare Co., N. C." The type could not be found in Ashe's herbarium. In the Mohr Herbarium is a specimen labeled in Ashe's writing "Panicum glabrissimum Ashe" and bearing the cited data. This is a tuft of three vernal culms and agrees with the description, except that the spikelets are said to be glabrous, while these are pubescent. The specimen in the National Herbarium from the same station and sent by Ashe as part of the type collection is $P$. tenue, and fails in several particulars to agree with the description. While neither of these specimens is the type itself, the one which most nearly agrees with the description is taken to represent the type.

Panicum shallotte Ashe, Journ. Elisha Mitchell Soc. 16:84. 1900. Based on "P. glabrissimum Ashe, not P. glaberrimum Steud.'

Panicum parvipaniculatum Ashe, Journ. Elisha Mitchell Soc. 16: 87. 1900. "Collected May 20, in Onslow county, N. C. Type material is preserved in my herbarium." No specimen so labeled could be found in Ashe's herbarium, but a cover marked in Ashe's hand " $P$. parvipaniculatum" was found which contained eight sheets of unmounted material, of which two sheets (one within the fold of the other) were accompanied by a label with the following data in Ashe's writing: "Panicum gray spikelets? Peaty-soiled thickets sandy flatwoods and ditch banks, 10-18 miles east of Jacksonville, Onslow county, N. C. May 20, 1899." Since these were the only specimens with locality and date according with those published, the specimens on the sheet with the label were chosen as the type, one tuft being deposited in the National Herbarium. These specimens agree with the description except that the species is said to be "perfectly glabrous except the ligule" while the blades are puberulent beneath and some of them on the upper surface also; that the ligule is given as "about $2 \mathrm{~mm}$. long," while it is almost obsolete (0.1 to $0.2 \mathrm{~mm}$. long); and that the spikelets are given as "barely $1 \mathrm{~mm}$. long," while they measure 1.3 to 1.4 $\mathrm{mm}$. long. This type differs from those of $P$. ensifolium and $P$. brittonii in having glabrous spikelets.

DESCRIPTION.

Vernal plants grayish olive green; culms cespitose, slender, erect or reclining, glabrous, 20 to $40 \mathrm{~cm}$. high; sheaths glabrous, usually much shorter than the internodes; blades distant, often reflexed, 1 to $3 \mathrm{~cm}$. long, 1.5 to $3 \mathrm{~mm}$. wide, glabrous on the upper surface or puberulent toward the base, puberulent beneath, at least toward the tip; panicles finally long-exserted, 1.5 to $4 \mathrm{~cm}$. long, nearly as wide, the flexuous branches spreading or the lower reflexed; spikelets 1.3 to $1.5 \mathrm{~mm}$. long,

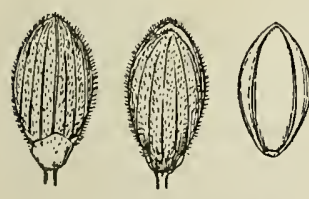

FIG. 201.-P. ensifolium.

From type specimen. elliptic, subacute, glabrous or puberulent; first glume onefourth as long as the spikelet or less, acute or obtuse; second glume slightly shorter than the fruit and sterile lemma; fruit $1.2 \mathrm{~mm}$. long, elliptic, subacute.

Autumnal culms spreading or reclining, sparingly branching from the middle nodes, the branches mostly remaining simple; winter blades glabrous, usually short, 1.5 to $3 \mathrm{~cm}$. long, 2 to $4 \$ \mathrm{~m}$. wide.

In this species the pubescence of the spikelets seems to be very inconstant. The type of $P$. briltonii and Chase 3557 have pubescent spikelets, while Chase 3535 and specimens collected by Clute in 1899 and by Bicknell in 1900, also in New Jersey, have glabrous spikelets; of the North Carolina specimens Hitchcock 1425, Chase $3096 \frac{1}{2}, 3176,3177,3227$, and 3234 have pubescent spikelets.

Combs's no. 74, Lake City, Florida, and Tracy 44, Ocean Springs, Mississippi, two very slender autumnal specimens, the first with puberulent, the latter with glabrous, spikelets, are doubtfully referred here. 
DISTRIBUTION.

Wet places, mostly sphagnum bogs or swamps, New Jersey to Georgia; also in Mississippi.

New Jersey: Forked River, Britton in 1896; Penn Place, Clute in 1899; Toms River, Bicknell in 1900; Atsion, Chase $3535,3557$.

Maryland: Beltsville, Chase 3739.

North Carolina: Roanoke Island, Chase 3227, 3234; West Raleigh, Stanton, 1272; Wilsons Mills, Chase 3096 $\frac{1}{2}$, 3097; Onslow County, Ashe in 1899, Chase 3176, 3177, 3196; Wilmington, Hitchcock 1425, $1436 \frac{1}{2}, 1439$.

South Carolina: St. Helena Is-

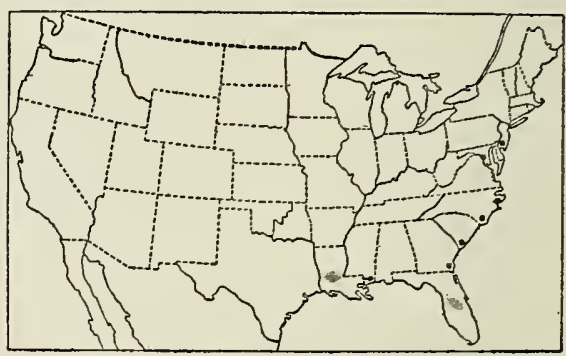

FIG. 292.-Distribution of $P$. ensifolium.

land, Cuthbert in 1887; Orangeburg, Hitchcock 1370, 1379, 1405.

Georgia: Bulloch County, Harper 829; Augusta, Cuthbert 1160; without locality, Baldwin.

Mississippi: Biloxi, Hitchcock 1067.

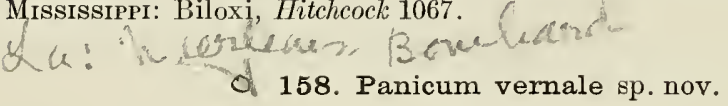

DESCRIPTION.

Vernal plants light green, soft in texture; culms densely cespitose, 15 to $30 \mathrm{~cm}$, rarely to $40 \mathrm{~cm}$. high, very slender, ascending or spreading, glabrous, the nodes glabrous; leaves clustered at the base, the thin, rather soft blades 2 to $7 \mathrm{~cm}$. long, 3 to $5 \mathrm{~mm}$. wide, those of the culm remote, the glabrous sheaths one-fourth to one-third as long as the elongated internodes; ligules almost obsolete; blades 0.7 to $2.5 \mathrm{~cm}$. long, 2 to 3 $\mathrm{mm}$. wide, glabrous or puberulent on the lower surface, occasionally also on the upper surface, at first erect, becoming spreading or reflexed; panicles finally long-exserted,

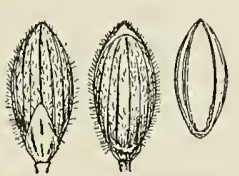

Fig. 293.-P.vernale. From type specimen. 1.5 to $3 \mathrm{~cm}$. long, nearly as wide, rather few-flowered, the flexuous branches spreading; spikelets 1.4 to $1.5 \mathrm{~mm}$. long, $0.8 \mathrm{~mm}$. wide, obovate-elliptic, subacute, pubescent; first glume about onefourth as long as the spikelet, subacute; second glume and sterile lemma scarcely as long as the fruit at maturity; fruit 1.2 $\mathrm{mm}$. long, 0.7 to $0.8 \mathrm{~mm}$. wide.

Autumnal form like the vernal form in appearance, branching from the base, these culms simple and soon dying to the ground, rarely late in the season producing a few short fascicled branchlets at the nodes, the scarcely reduced flat blades spreading; winter leaves numerous, soft, persistent during the vernal stage, linear, rather abruptly narrowed at the apex, not long-acuminate.

Type U. S. National Herbarium no. 558416, collected in a "sphagnum bog, Lake City, Florida, April 16, 1906," by A. S. Hitchcock (no. 1020).

This species has been confused with $P$. ensifolium Baldw., ${ }^{a}$ from which it is distinguished by the more densely cespitose liabit and light green, soft foliage, the very numerous basal blades as much as $7 \mathrm{~cm}$. long, flat, linear, not long-acuminate.

a Panicum nitidum ensifolium as described in Chapman's Flora (Fl. South. U. S. ed. 3.586 .1897 ) is $P$. vernale. 
All the specimens cited below were collected in the spring. Since localities, like Lake City, Eustis, and Miami, Florida, where this species was found in March and April, were visited in September without its being found, it would seem that the plants usually die to the ground in early summer and that the secondary branches appear only rarely. In Hitchcock 931 and $958 \frac{1}{2}$ a few sparingly branched dead culms are attached, being the only branching culms seen.

Two collections, Hitchcock 809 and Nash 424, have blades pubescent on the upper surface, while Hitchcock 941 and 1092 have some blades that are pubescent and some that are glabrous on the upper surface. Hitcheock's nos. 1066 and 1092 have glabrous spikelets.

\section{DISTRIBUTION.}

Moist places, especially sphagnum bogs, Florida to Mississippi.

Florida: Baldwin, Hitcheock 1004; Lake City, Bitting 19, Hitchcock 1020; Apalachicola, Chapman; Eustis, Nash 273 in part,

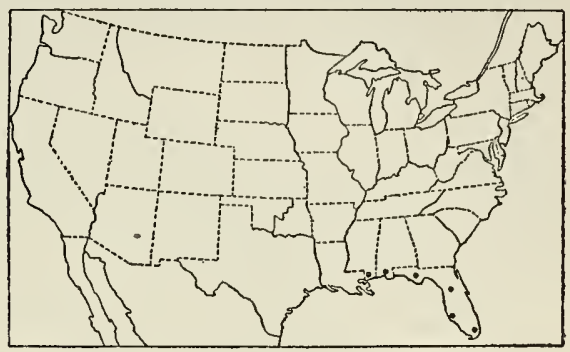

FIG. 294.-Distribution of $P$. vernale. 424, Hitchcock 795, 798, 809; Dunedin, Tracy 6699; Braidentown, Hitchcock

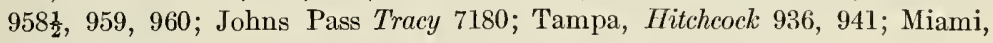
Hitchcock 931, 942.

Alabama: Flomaton, Hitchcock 1041.

Mississıpp1: Biloxi, Hitchcock 1066; Mississippi City, Hitchcock 1092.

\section{- 159. Panicum curtifolium Nash.}

Panicum curtifolium Nash, Bull. Torrey Club 26: 569. 1899. "Collected by S. M. Tracy at Ocean Springs, Mississippi, May 2, 1898, no. 4598." The type, in Nash's herbarium, consists of a tuft with two slender vernal culms about $30 \mathrm{~cm}$. long, beginning to branch at the middle nodes. The blades are glabrous above except at the base and glabrous or sparsely pubescent beneath. In a duplicate type in the National Herbarium several blades have a few scattered hairs on the upper surface.

Panicum earlei Nash, Bull. Torrey Club 26: 571. 1899. "Type collected at Auburn, Lee Co., Alabama, on May 7, 1898, by Messrs. F. S. Earle and C. F. Baker, no. 1532." The type, in Nash's herbarium, consists of a tuft of early vernal culms' 8 to $15 \mathrm{~cm}$. high, with immature panicles. The blades are sparsely pilose on the upper surface.

Panicum austro-montanum Ashe, Journ. Elisha Mitchell Soc. 16: 85. 1900. "Along mountain streams of Northern Alabama and the adjacent parts of Tennessee. Type material is preserved in my herbarium." The type specimen could not be found in Ashe's herbarium. In the National Herbarium is a specimen from Sand Mountain, Alabama, June, 1899, sent by the Biltmore Herbarium, which was compared by E. D. Merrill in 1900 and said by him to be identical with the type of P. austromontanum. It is also the same as a specimen from western North Carolina sent by Ashe as representing $P$. austro-montanum, and furthermore agrees with the original description except that the spikelets are $1 \mathrm{~mm}$. long, instead of $0.7 \mathrm{~mm}$. long. The Biltmore specimen agrees with the types of $P$. curtifolium and $P$. earlei.

\section{DESCRIPTION.}

Vernal form in dense colonies, the culms not crowded in the clump; culms 10 to $30 \mathrm{~cm}$. high, slender, weak, angled, erect or spreading, glabrous or sometimes with a few scattered hairs, the nodes sparsely bearded; sheaths much shorter "than the elongated internodes, striate-angled, sparsely spreading-pilose, ciliate, especially at 
the summit; ligules about $1 \mathrm{~mm}$. long, the hairs soft, rather sparse; blades spreading or reflexed, 1.5 to $3 \mathrm{~cm}$. long, 2 to $5 \mathrm{~mm}$. wide, thin and soft, sparsely pilose on both surfaces or glabrous above except for long soft hairs near the base; panicles

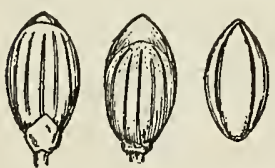

FIG. 295. $-P$. curtifolium. From type specimen. short-exserted at least till after maturity, 2 to $3 \mathrm{~cm}$. long, nearly as wide, the branches ascending; spikelets $1.4 \mathrm{~mm}$. long, $0.7 \mathrm{~mm}$. wide, elliptic-obovate, obtuse, glabrous, or minutely pubescent; first glume about one-fifth as long as the spikelet; second glume and sterile lemma both shorter than the fruit at maturity; fruit $1.25 \mathrm{~mm}$. long, $0.7 \mathrm{~mm}$. wide, elliptic.

Autumnal form weakly spreading, the culms branching from the middle nodes after the maturity of the primary panicles, the branches exceeding the internodes; ultimate branchlets in small fascicles toward the summit of the branches, the reduced blades spreading and the small panicles mostly exserted; winter rosette appearing early, the soft blades mostly 2 to $3 \mathrm{~cm}$., but sometimes as much as 5 cm. long.

This species is the only one of this group with spreading pilose pubescence and manifest ligules.

\section{DISTRIBUTION.}

Boggy soil and shady, moist places, sometimes forming a rather dense carpet, South Carolina and Tennessee to Florida and Mississippi.

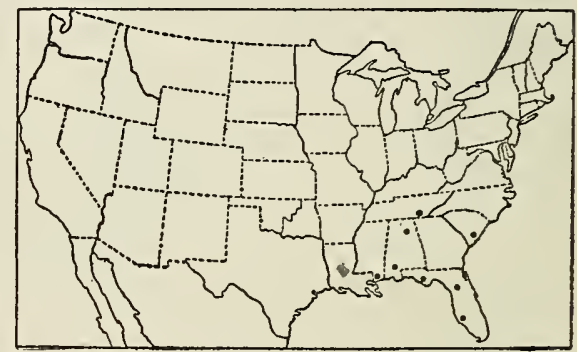

Fig. 296.-Distribution of $P$. curtifolium.

South Carolina: Aiken, Ravenel; Hartsville, Coker in 1909.

Florida: Pensacola, Combs 525; Eustis, Holm 24, Nash 1507; Myers, Hitchcock 867; without locality, Chapman.

Tennessee: Lookout Mountain, Biltmore Herb. 10715b (Biltmore Herb.).

Alabama: Sand Mountain, Biltmore Herb. in 1899; Auburn, Earle \& Baker 1532, Hitchcock 1337, Tracy 3748 in part, 3752; Flomaton, Hitchcock 1058; Tuskegee, Carver 27, 41; Gateswood, Tracy 8421.

MississipPI: Ocean Springs, Tracy 4598, 4599; Mississippi City, Hitchcock 1094.

\section{$\checkmark$ 160. Panicum chamaelonche Trin.}

Panicum chamaelonche Trin. Gram. Pan. 242. 1826. Trinius states concerning the origin of his specimen, "V. spp. Am. bor. (Tratrinick, ex. coll. Enslini)." The type, in the Trinius Herbarium, is the early branching form.

Panicum nitidum minor [us] Vasey, Contr. Nat. Herb. $3: 30.1892$. "Florida." The type, in the National Herbarium, was collected by William C. Canby at St. Augustine, Florida, April, 1869, and is labeled "nitidum var. minor" in Dr. Vasey's writing. This consists of several small tufts of vernal culms.

Panicum baldwinii Nutt.; Kearney, U. S. Dept. Agr. Div. Agrost. Bull. 1: 21. 1895. The citation is as follows: "Panicum baldwinii Nutt. in Herb. Phila. Acad. (Panicum nitidum minor Vasey Contr. U. S. Nat. Herb. 3: No. 1, 30, 1892.)" No description is given. Since Nuttall's herbarium name is taken up, this name should be considered a nomen nudum, and not based on the synonym cited.

Panicum baldwinii Nutt.; Chapm. Fl. South. U. S. ed. 3. 586. 1897. Based on "Panicum baldwinii Nutt. (in Herb.)" and described. The type, in the Nuttall Herbarium, labeled "Panicum Baldwinii, Florida, Bald." is a tuft of vernal culms beginning to branch, with mature and over-mature panicles. 
The species described as $P$. ramulosum Michx. by Chapman $a$ is $P$. chamaelonche as shown by the description, by a specimen in the Chapman Herbarium at the New York Botanical Garden labeled "Panicum ramulosum Michx. (nitidum S. Fl.!) b Southern Florida," and by the fact that Chapman $c$ cites " $P$. ramulosum Flora" [Southern U. S.] as a synonym under $P$. baldwinii Nutt.

Scribner $d$ describes and illustrates this species as $P$. baldwinii "Nutt. in herb." and gives as synonym, " $P$. dichotomum var. nitidum Chapman, Southern Flora, first edition." Chapman does not make the combination as stated by Scribner, but refers $P$. nitidum Ell. to $P$. dichotomum as a form. Chapman's plant as stated above is $P$. chamaelonche, but $P$. nitidum of Elliott's herbarium is $P$. longiligulatum Nash.

DESCRIPTION.

Vernal form densely tufted; culms 10 to 20 or even $30 \mathrm{~cm}$. high, ascending, glabrous, the nodes glabrous; sheaths, except the basal ones, half as long as the internodes or less, at least the upper rather loose, glabrous or occasionally with a few ciliæe on the margin; ligules $0.2 \mathrm{~mm}$. long; blades firm, ascending or spreading, 1.5 to $4 \mathrm{~cm}$., rarely $5 \mathrm{~cm}$. long, 2 to $3 \mathrm{~mm}$. wide, more" or less involute-pointed, glabrous on both surfaces, often with a few long, stiff hairs on the margin near the base; panicles finally longexserted, 2.5 to $5 \mathrm{~cm}$. long, nearly as wide, the flexuous branchlets and pedicels spreading at nearly right angles; spikelets 1.1 to $1.2 \mathrm{~mm}$. long, $0.6 \mathrm{~mm}$. wide, obovate, obtuse, turgid, glabrous; first glume one-fourth to one-third as long as the spikelet, obtuse; second glume slightly shorter than

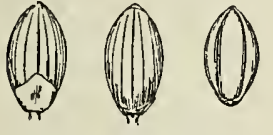

FIG. 297.- $P$. chamaelonche. From type specimen. the fruit and sterile lemma; fruit 0.9 to $1 \mathrm{~mm}$. long, 0.6 mm. wide, elliptic, subobtuse.

Autumnal form freely branching from the base and lower nodes, the early branches often as long as the primary culms, repeatedly branching, forming dense cushions, as much as 50 $\mathrm{cm}$. across, the longer culms upturned at the ends; ultimate branchlets more or less fascicled, the scarcely reduced blades drying involute, overtopping the small panicles; winter rosettes usually persisting green during the vernal state, the rather firm blades 2 to $5 \mathrm{~cm}$. long.

The plants are usually purple throughout in both vernal and autumnal state. Occasional specimens, such as Hitchcock 873, are yellow green, and look strikingly different in the field. Hitchcock's no. 1436, Chase 4570, and Tracy 6732 have unusually large blades, as much as 6 $\mathrm{cm}$. long and $5 \mathrm{~mm}$. wide. The specimens of Hitchcock 952 are 30 to $40 \mathrm{~cm}$. high, with large panicles and rather long lower blades and appear to be intermediate between this and $P$. glabrifolium.

\section{DISTRIBUTION.}

Open sandy soil, mostly in the low

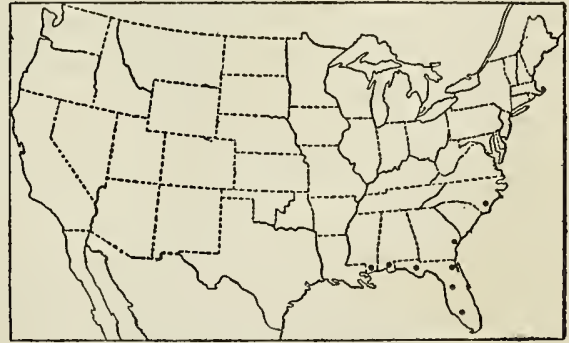

FIG. 298.-Distribution of $P$. chamaclonche. pine land or "flatwoods," North Carolina to Florida and Mississippi.

Nortil Carolina: Vicinity of Wilmington, Chase 3125, 4570, Hitchcock 338, 339, 1427, 1435, 1436, 1483, 1488; Wards Mill, Chase 3182.

Georgia: Savannah, Kcarney 177.

$a$ F1. South. U. S. ed. 2. 667. 1889.

$b$ This is included as a form under $P$. dichotomum L. in Chapm. Fl. South. U. S. 576. 1860.

c Fl. South. U. S. ed. 3. 586. 1897.

$d$ U. S. Dept. Agr. Div. Agrost. Bull. 11 : 43. f. 3. 1898. 
FlORIDA: Jacksonville, Curtiss 21, 3602*, 5588, Kearney 145; Baldwin, Hitchcock 985; Lake City, Combs 127, Hitchcock 1027, 1037; Carabelle, Kearney 92; Dunedin, Tracy 6726; St. Augustine, Canby in 1869; Indian River, Palmer 634 in 1874 in part; Melbourne, Curtiss 5804; Titusville, Chase 3965, Hitchcock 759; Jensen, Hitchcock 729; Sanford, Chase 4032, 4036, 4037, Hitchcock 769, 778, 781, 828; Eustis, Chase 4053, Hitchcock 794, 806, 807, 818, Nash 51, 71, 335, 778, 1238; Oakland, Curtiss 6628; Lemon Bay, Tracy 7191, 7200; Tampa, Combs 1344, Hitchcock 928, 934, 944; Braidentown, Hitchcock 951, 952, 954, 973, Tracy 6732; Manatee, Hitchcock 975, Rugel 377; Myers, Chase 4153, 4156, 4171, Hitchcock 865, 866, 873, 885, 887, 895, 916, 924, Lee Co. Pl. 472; Sneeds Island, Tracy 6451, 6464, 6693; Perdido, Tracy 8407.

Alabama: Fort Morgan, Tracy 7207.

MrssissipPr: Avondale, Tracy 4610; Mississippi City, Hitchcock 1114.

In the herbarium of the Philadelphia Academy is a specimen said to be from Surinam which appears to be $P$. chamaelonche.

\section{Panicum glabrifolium Nash.}

Panicum glabrifolium Nash, Bull. Torrey Club 24:196. 1897. "Collected by the writer in the 'flatwoods' 'at Tampa, Florida, on August 20, 1895, no. 2415a." The type, in Nash's herbarium, is the early branching state. The spikelets are $1.25 \mathrm{~mm}$.

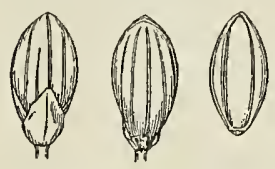

FIG. 299.-P. glabrifolium. From type specimen. long. The statement in the original description, "the spikelets slightly exceeding . $5 \mathrm{~mm}$. in length" is doubtless a typographical error.

\section{DESCRIPTION}

Vernal form similar to that of $P$. chamaelonche, in smaller tufts; culms stouter, more or less flattened, 15 to $50 \mathrm{~cm}$. high, erect or sometimes subgeniculate at base; blades firm, erect, or narrowly ascending 4 to $12 \mathrm{~cm}$. long, or the lower occasionally as much as $20 \mathrm{~cm}$. long, 2 to $4 \mathrm{~mm}$. wide, usually involute at least toward the apex, glabrous; panicles 4 to $9 \mathrm{~cm}$. long, two-thirds to three-fourths as wide, the branches ascending, the ultimate branchlets and spikelets more or less secund along the lower side of the branches; spikelets 1.2 to $1.4 \mathrm{~mm}$. long, obovate, obtuse, turgid, glabrous; first glume about one-third as long as the spikelet; second glume shorter than the fruit and sterile lemma; fruit 1.1 to $1.2 \mathrm{~mm}$. long, elliptic.

Autumnal culms wiry, elongated, and spreading, with geniculate nodes and long internodes; freely branching from the middle and upper nodes, the blades long and narrow, overtopping the somewhat reduced panicles; winter leaves less numerous than in $P$. chamaelonche, as much as 10 to $15 \mathrm{~cm}$. long, stiffly ascending.

In the vernal form this species is distinguished from $P$. chamaclonche by the taller, stouter culms, more involute blades, larger panicles, and slightly larger spikelets. The autumnal form is distinguished by the different branching habit. There are, however, intermediate specimens that appear to connect the two species, such as Hitchcock 893, from Myers, which has the tall culms, elongated lower blades and large panicles of $P$. glabrifolium but the smaller spikelets of $P$. chamaelonche.

\section{DISTRIBUTION.}

Low sandy w oods, peninsular Florida. Florida: Crystal, Combs 1024; Braidentown, Combs 1313,

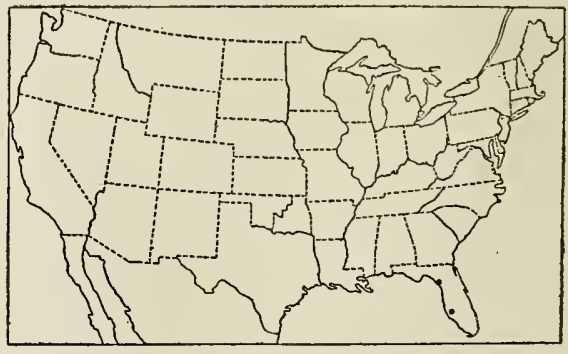

FIG. 300.-Distribution of P. glabrifolium.

1316, Hitchcock 966; Tracy 6715; Manatee, Hitchcock 978, Simpson in 1889; Cedar Key, Combs 780; Bartow, Combs 1187. 
162. Panicum breve sp. nov.

DESCRIPTION.

Vernal form purplish, culms in dense tufts, 5 to $17 \mathrm{~cm}$. high, erect, stiff and wiry, glabrous or appressed-pubescent below; sheaths crowded at the base as in species of Festuca, those of the culms usually longer than the internodes, ciliate on the margin,

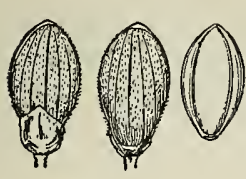

Fig.301.-P. breve. From type specimen. otherwise glabrous; ligules dense, about $0.3 \mathrm{~mm}$. long; blades firm, erect or ascending, 3 to $6 \mathrm{~cm}$., sometimes $8 \mathrm{~cm}$. long, about $1.5 \mathrm{~mm}$. wide when flattened out, strongly involute, more or less falcate, sometimes strongly so, a few long, stiff hairs on the margin toward the base, otherwise glabrous; panicle short-exserted, 1.5 to $4 \mathrm{~cm}$. long, nearly as wide, loosely flowered, the flexuous branches spreading; spikelets 1.3 to $1.4 \mathrm{~mm}$. long, obovate, obtuse, turgid, puberulent; first glume one-third to half as long as the spikelet; second glume and sterile lemma barely equaling the fruit at maturity; fruit $1.2 \mathrm{~mm}$. long, elliptic.

Autumnal form erect, branching from the middle nodes, the fascicled branches strict, the reduced wiry blades overtopping the panicles.

Type U. S. National Herbarium no. 558435, collected April 5, 1906, in "low pine woods between scrub hills, among palmetto," Jensen, Florida, by A. S. Hitchcock (no. 734).

This species is most closely related to $P$. glabrifolium, from which it is distinguished by its short, compact habit, by the strongly involute blades bearing long, stiff hairs near the base, and by the pubescent spikelets.

\section{DISTRIBUTION.}

Low pine woods and hammocks, east coast of southern Florida.

Florida: Indian River, Palmer 634 in 1874 in part; Jensen, Hitchcock 734; Fort Lauderdale, small \& Carter in

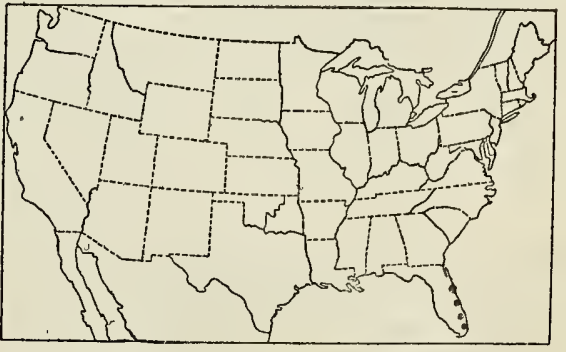

Fig. 302.-Distribution of $P$. breve.

1903; "About Boca Ratone Lake, below Delray," Small \& Carter in 1903 (Biltmore Herb.).

Lancearia.-Plants olive green, often purplish; vernal culms usually wiry, minutely crisp-puberulent or glabrous; sheaths glabrous or puberulent, at least at the summit; ligules nearly obsolete; blades glabrous or puberulent, usually strongly ciliate, at least near the base; spikelets unsymmetrically pyriform, that is, more swollen on the face than on the back; first glume thin and shining, broad at the summit, obtuse or truncate; second glume and sterile lemma strongly 7 to 9-nerved, puberulent or glabrous. Species of the Atlantic Coastal Plain.

Spikelets 1.5 to $1.6 \mathrm{~mm}$. long 163. portoricensel Spikelets $2 \mathrm{~mm}$. or more long.

Blades, or some of them, at least $8 \mathrm{~mm}$. wide; glabrous on

the upper surface; fruit papillose-roughened.......166. P. webberianum.

Blades not over $6 \mathrm{~mm}$. wide (or if wider, puberulent on

the upper surface); fruit smooth and shining.

Spikelets 2.4 to $2.6 \mathrm{~mm}$. long; blades narrowed totoward the base.......................... 167. P. patentifolium. 
Spikelets not over $2.1 \mathrm{~mm}$. long.

Blades firm, glabrous above; culms stiffly ascending............................. P. lancearium.

Blades lax, softly puberulent on both surfaces;

gev, culms decumbent......................165. P. patulum.

\section{$\checkmark$ 163. Panicum pauciciliatum Ashe.}

Panicum pauciciliatum Ashe, Elisha Mitchell Soc. 16:87. 1900. "Collected by me May 20, 1899, growing in dry sand near Wilmington, $\mathbb{N}$. C." The type, in Ashe's herbarium, consists of six single culms, beginning to branch, 25 to $30 \mathrm{~cm}$. high, with somewhat geniculate nodes, and short-exserted, hardly mature panicles.

\section{DESCRIPTION.}

Vernal culms cespitose, erect or geniculate at base, slender, stiff and wiry, 15 to 30 $\mathrm{cm}$. high, the internodes commonly reddish purple, crisp-puberulent to nearly glabrous; sheaths much shorter than the internodes, striate, glabrous or crisp-puberulent, usually ciliate; blades firm, 2 to $5 \mathrm{~cm}$. long, 3 to $6 \mathrm{~mm}$. wide, ascending or spreading, glabrous to puberulent, ciliate near the base; panicles 2 to $4 \mathrm{~cm}$., rarely 6 or $7 \mathrm{~cm}$., long, two-thirds as wide, the flexuous branches spreading or the lower reflexed, the pedicels and ultimate branchlets often directed toward the under side; spikelets 1.5 to $1.6 \mathrm{~mm}$.

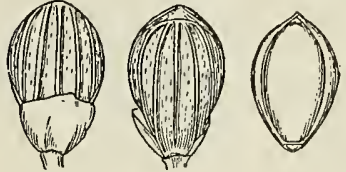

Fig. 303.-P. pauciciliatum. From type specimen. long, $1 \mathrm{~mm}$. wide; first glume one-third to half as long as the spikelet, obtuse or truncate; second glume and sterile lemma puberulent, the glume shorter than the fruit and sterile lemma; fruit $1.4 \mathrm{~mm}$. long, $1 \mathrm{~mm}$. wide, elliptic-obovoid, obscurely pointed.

Autumnal culms ascending from a decumbent base, branching from all but the uppermost node before the maturity of the primary panicles, the primary internodes often elongating, the terminal joint with its panicle together with the internode, below it often falling early, thus giving the appearance of short culms branehing at all the nodes characteristic of this species; early branches about equaling these shortened primary culms, repeatedly branching, the ultimate branchlets in fascicles toward the ends, the reduced blades spreading, involute-pointed; winter rosette appearing late, not conspicuous.

This species often closely resembles P. lancearium, butthe differences, though small, are fairly constant, though Chase 3126 and Ennis in 1899 have spikelets 1.7 to $1.8 \mathrm{~mm}$. long. Chase 3139, Wilmington, N. C., with ligules $0.3 \mathrm{~mm}$. long and scarcely pyriform spikelets, is doubtfully referred here.

\section{DISTRIBUTION.}

Sandy woods of the Coastal Plain, mostly in moist places, North Carolina to Florida and along the Gulf to Texas; also in Cuba and Porto Rico.

North Carolin : Roanoke Island, Chase 3246; Wilmington, Ashe in 1899, Chase 3126, 3127, 3128,

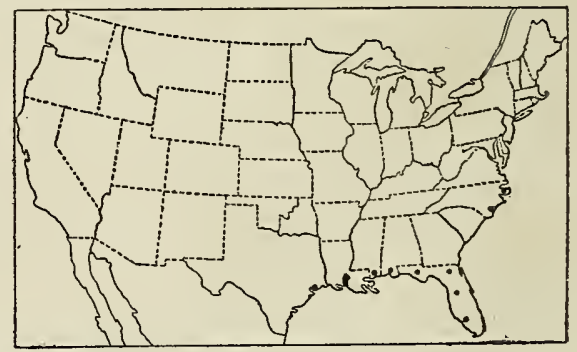

FiG. 304.-Distribution of $P$. pauciciliatum. 3162, 4567, Hitchcock 414, 416, 1432, 1477, 1479, 1487.

Florida: Baldwin, Hitchcock 992; A palachicola, Chapman; Orange County, Baker 41, 70, 71, 72, Combs 1085, Meislahn 169; Eustis, Chase 4045, Hitchcock 793, 
797, 803, 804, 808, 819, Nash 15, 63 in part, 1337, 2076; Sumter County, Curtiss F, 3600A in part; Jensen, Hitchcock 733, 737, 750; Santa Rosa Island, Tracy 6446, 6447; Perdido, Tracy 8406; Myers, Chase 4173, Hitchcock 889.

Alabama: Fort Morgan, Tracy 8397.

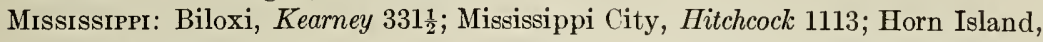
Tracy 2863,8412 .

Texas: Narcoossee, Ennis in 1899.

CuBA: Without locality, Wright 3876.

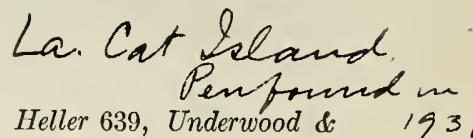

PoRto Rico: Santurce, Heller 982b, 6442; Vega Baja, Heller 639, Underwood \& Griggs 955 .

\section{Panicum lancearium Trin.}

Panicum lancearium Trin. Gram. Pan. 223. 1826. Trinius here gives a full description and states that his specimen was collected in North America by Enslin and communicated by Trattinick: "V. spp. Am. bor. (Tratrinick ex hbio Enslini)." Trinius had previously mentioned the name $a$ as a probable synonym of a Plukenet species. The type, in the Trinius Herbarium, is the vernal form, with glabrous spikelets $2 \mathrm{~mm}$. long. It is labeled "Plukn. Tb. 92. f. 6.? In Am. bor. ab Enslino 1. dt. cl. Trattinick."

Panicum nashianum Scribn. U. S. Dept. Agr. Div. Agrost. Bull. 7 : 79. f. 61. 1897. Two specimens are cited, "4029 Curtiss (1893), and 466 Nash (1894).-Low pine barrens, often in moist ground, near the coast, Virginia to Mississippi." The type (Nash 466 , since the species is named for the collector) is in the National Herbarium. It consists of a clump of numerous culms 15 to $30 \mathrm{~cm}$. high with mature and immature panicles, the spikelets minutely pubescent. The accompanying label gives the following data: "Dry sandy soil. Grows in dense clumps $1 \mathrm{ft}$. across. Collected in vicinity of Eustis, Lake county, Florida, by Geo. V. Nash, April 15-30, 1894." The Curtiss specimen cited by Scribner has glabrous spikelets.

\section{DESCRIPTION.}

Vernal culms cespitose, usually purplish, wiry, stiffly ascending from a more or less geniculate base, 20 to $50 \mathrm{~cm}$. high, minutely grayish crisp-puberulent; sheaths puberulent, at least near the margin, much shorter than the internodes; blades ascending or spreading, firm, 2 to $6 \mathrm{~cm}$. long, 3 to $7 \mathrm{~mm}$. wide, puberulent or nearly glabrous beneath, usually glabrous on the upper surface, strongly ciliate toward the base, or sometimes nearly to the apex; panicles 3 to $6 \mathrm{~cm}$. long, two-thirds as wide, rather few-flowered, the
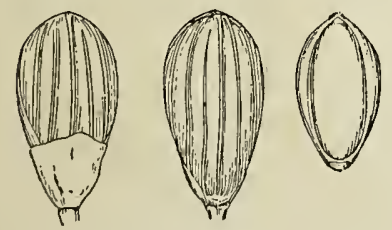

FIG. 305.-P. lancearium. From type specimen. flexuous branches spreading, or the lower reflexed; spikelets 2 to $2.1 \mathrm{~mm}$. long, 1 to $1.2 \mathrm{~mm}$. wide; first glume one-third to half as long as the spikelet, obtuse or truncate; second glume and sterile lemma puberulent or sometimes glabrous, the glume slightly shorter than the fruit and sterile lemma; fruit 1.6 to $1.7 \mathrm{~mm}$. long, $1 \mathrm{~mm}$. wide, obovate-elliptic, minutely puberulent at the apex.

Autumnal culms geniculate-spreading, ascending at the ends, the stiff internodes occasionally elongated, branching from the middle nodes, the branches much longer than the internodes, late in the season bearing fascicles of short branchlets toward the summit, the reduced flat or involute-pointed blades spreading, the ultimate panicles reduced to a few spikelets, partly inclosed in the sheaths.

à Clav. Agrost. 234. 1822.

$41616^{\circ}-$ vol $15-10-18$ 
Occasional unusually large specimens, such as Curtiss 6626, Hitchcock 678, and Tracy 7051, resemble $P$. webberianum, but may be distinguished by the smaller spikelets, with smooth and shining fruits.

The following specimens approach $P$. patulum in habit or in having papillose, more rounded spikelets, but the blades are not pubescent on the upper surface, or but one or two are pubescent, the others being glabrous: Chase 3211, 4543, 4568, 4569, Harper 1689, Hitchcock 1016, Wright 3460.

DISTRIBUTION .

Low sandy woods of the Coastal Plain, from southeastern Virginia to Florida and Mississippi; also in Cuba.

Vrrginia: Cape Henry, Chase 2345; Norfolk, Vasey in 1884; Dismal Swamp, Chase 3656.

Norti Carolina: Roanoke Island, Chase 3211, 3224; Wards Mill, Chase 3181; Jacksonville, Ashe in 1899, Chase 3193, 3194; vicinity of Wilmington, Chase 3113, 3129, 4568, 4569, Hitchcock 1431, 1466, 1486.

South Carolina: Isle of Palms, Ball 792, Chase 4536, 4542, 4543, 4545.

Georgia: Savannah, Kearney 178; Tifton, Harper 1689.

Florida: Duval County, Curtiss 3600 A in part; Jacksonville, Curtiss 4029 (Hitchcock Herb.); Baldwin, Hitchcock 994, 1003; Lake City, Combs 75, 104; Hitchcock 1016, 1025, 1028, 1033; Titusville, Chase 3970, 4004, 4015, Hitchcock 764, 766; Sanford, Hitchcock 770, 784, 821, 824, 825; Eustis, Nash 301, 466; Pensacola, Tracy 8425; Clearwater, Tracy 7051 in part; Waldo Combs 686; Indian River, Palmer 631 in 1874; Gainesville, Chase 4239, Combs 744, 752; Lakeland, Hitchcock 844, 849; Tampa, Hitchcock 929, 932, 937; Oakland, Curtiss

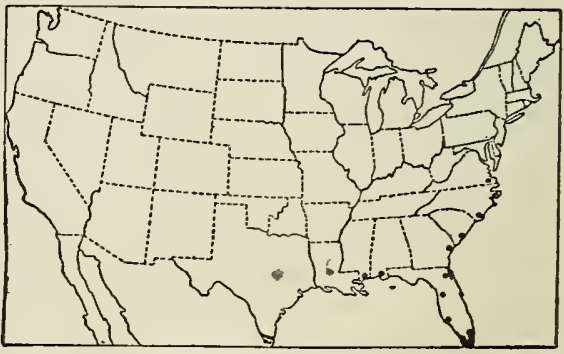

Fig. 306.-Distribution of $P$. lancearium. 6626; Madison, Combs 238; Crystal, Combs 1025; Bartow, Combs 1240; Manatee, Hitchcock 956, 977, Rugel 376; Santa Rosa Island, Tracy 6466; Pine Island, Tracy 7205; Sneeds Island, Tracy 6452; Perico Island, Tracy 6730; Palma Sola, Tracy 6714; Perdido, Tracy 8409; Sarasota, Tracy 7203; Seminole, Tracy 7194, 7195; Mary Esther, Tracy 7175, 9143; Myers, Chase 4149, .4175, Hitchcock 864, 869, 888, 911, 913; Miami, Hitchcock 664, 678, 713; without locality, Rugel 291.

Alabama: Flomaton, Hitchcock 1039 $\frac{1}{2}$; Fort Morgan, Tracy 7209.

Mississippr: Avondale, Tracy 4581 in part; Biloxi, Kearney 330 in part, Tracy 2869, 6465; Mississippi City, Hitchcock 1093, 1298; Ocean Springs, Skehan in 1895.

Cuba: San Juan de Buenavista, Wright 3460 (Gray Herb.).

Santo Domingo: Jurcta heim 3321. $\checkmark$ 165. Panicum patulum (Scribn. \& Merr.) Hitchc.

Panicum nashianum patulum Scribn. \& Merr. U. S. Dept. Agr. Div. Agrost. Circ. 27: 9. 1900. "Type specimen: 1296 Robert Combs, Braidentown, Manatee County, Fla., September 3, 1898." The type, in the National Herbarium, consists of a clump of numerous prostrate culms, 18 to $32 \mathrm{~cm}$. long, with mature primary panicles and numerous branches with secondary panicles.

Panicum patulum Hitchc. Rhodora 8: 209. 1906. Based on $P$. nashianum patulum Scribn. \& Merr. 
DESCRIPTION.

Vernal form densely cespitose, grayish olive green; culms geniculate-decumbent, ascending at the ends, as much as $50 \mathrm{~cm}$. long, the internodes and sheaths densely velvety puberulent, the latter usually ciliate on the margin, at least toward the summit; blades rather lax, spreading, 4 to $8 \mathrm{~cm}$. Iong, 4 to $8 \mathrm{~mm}$. wide, tapering toward both ends, velvety-puberulent beneath, softly pubescent on the upper surface, sometimes
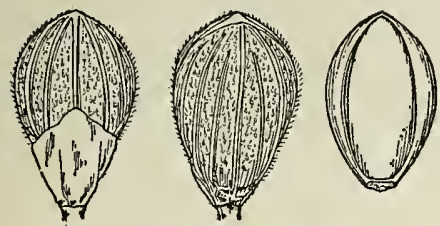

FIG. 307.-P. patulum. From type specimen. obscurely so, ciliate at least half their length; panicles as in $P$. lancearium, the spikelets more globular-pyriform than in that species, $1.3 \mathrm{~mm}$. wide and nearly as thick, second glume and sterile lemma densely papillose-pubescent; fruit 1.8 $\mathrm{mm}$. long, 1.1 to $1.2 \mathrm{~mm}$. wide; otherwise as in $P$. lancearium.

Autumnal form more freely branching than in $P$. lancearium, often forming large mats, the decumbent culms producing ascending branches from all the nodes at about the maturity of the primary panicles, these repeatedly branching, the ultimate branchlets crowded, but about evenly so throughout, not in fascicles at the summit only, the spreading blades much reduced; winter rosettes appearing early, the blades often 7 or $8 \mathrm{~cm}$. long, glabrous or nearly so on the upper surface.

This species is usually readily distinguished from $P$. lancearium by the decumbent habit and lax blades pubescent on both surfaces, but the blades are sometimes only obscurely pubescent above.

DISTRIBUTION.

Low moist woods of the Coastal Plain, southeastern Virginia to Florida and Louisiana.

Virginia: Cape Henry, Chase 5434; Dismal Swamp, Chase 3674.

North Carolina: Wilmington, Chase 3110, 4577.

South Carolina: Isle of Palms, Chase 4538, Hitchcock 413.

Georgta: Thomasville, Small in 1895 (Biltmore Herb.).

Florida: Jacksonville, Combs 3, Kearney 140; Lake City, Chase 4282, Combs 132 in part; Milton, Chase 4312; Old Town, Combs 858, 859; Gainesville, Chase 4209; Grasmere, Combs 1169; Titusville, Chase 4026, Hitchcock 765; Eustis, Chase 4050, 4062, 4086; Nash 50, 151, 1117; Clearwater, Tracy 6701; Tampa, Hitchcock 946; Miami,

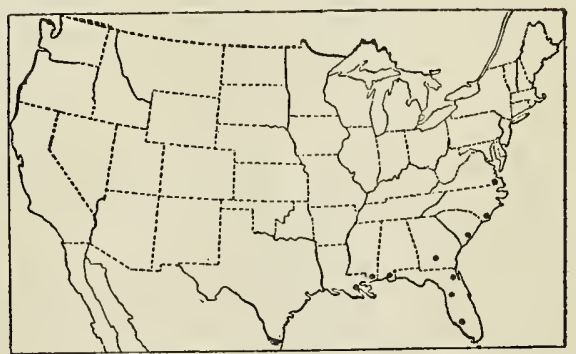

FIG. 308.-Distribution of $P$. patulum.

Hitchcock 654, Tracy 8853; Levy County, Combs 783, 835; Palma Sola, Tracy 6729; Sneeds Island, Tracy 6703; Myers, Chase 4183, Hitchcock 922; Seminole, Tracy 7198.

Alabama: Mobile, Hitchcock in 1904 (Hitcheock Herb.).

Mississippi: Biloxi, Chase 4357, 4371, Kearney 331, Tracy 4586, 4587; Horn Island, Tracy 3976.

Louislana: New Orleans, Drummond 452. 


\section{Panicum webberianum Nash.}

Panicum webberianum Nash, Bull. Torrey Club 23: 149. 1896. "Collected by the writer on the edge of a clay pit in the low pine land at Eustis, Lake Co., Florida, May 16-31, 1894, No. 781." The type, in Nash's herbarium, consists of two small tufts of vernal culms 35 to $45 \mathrm{~cm}$. high, with blades as much as $1 \mathrm{~cm}$. wide, and mature primary panicles, the spilielets $2.5 \mathrm{~mm}$. long.

Panicum onslowense Ashe, Journ. Elisha Mitchell Soc. 16: 88. 1900. "Type material was collected near Ward's Mill," Onslow County, N. C. The type, in Ashe's herbarium, is the vernal form with immature panicles, the culms glabrous or minutely puberulent, the lower blades as much as $1 \mathrm{~cm}$. wide, the immature spikelets $2.4 \mathrm{~mm}$. long. Other specimens in Ashe's herbarium and some distributed as $P$. onslowense and bearing the same data as the type are $P$.lancearium.

\section{DESCRIPTION.}

Vernal form commonly purplish; culms few to several in a tuft, rather stout, erect or ascending, 20 to $50 \mathrm{~cm}$. high, minutely puberulent or glabrous; leaves somewhat crowded below, distant above; sheaths minutely puberulent at the summit, often ciliate on the margin, otherwise glabrous or nearly so; blades firm, ascending, especially the lower somewhat incurved or spoon-shaped, 3 to $9 \mathrm{~cm}$. long, 4 to $12 \mathrm{~mm}$. wide, usually ciliate at base and sometimes along the margin, rounded or subcordate at base, acute but not long-acuminate; panicles finally long-exserted, 4 to $10 \mathrm{~cm}$. long, twothirds as wide, the numerous flexuous branches spreading or the lower even reflexed, the branchlets and pedicels usually rather short, thus giving to the main branches a somewhat racemose appearance; spikelets 2.3 to $2.5 \mathrm{~mm}$. long (in exceptional speci-
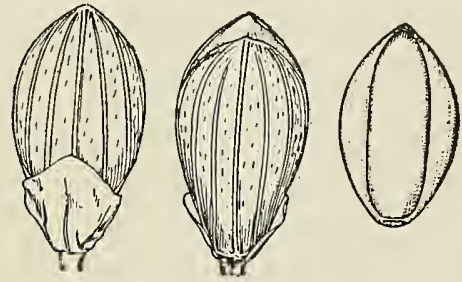

IG. 309.-P. webberianum. From type specimen. mens only 2.1 to $2.2 \mathrm{~mm}$. long), 1.2 to $1.3 \mathrm{~mm}$. wide, obovoid to pyriform, commonly green, conspicuously purple-stained at the base; first glume one-third to two-fifths as long as the spikelet; second glume and sterile lemma minutely pubescent or glabrous, the glumeslightly shorter than the fruit and sterile lemma; fruit 1.9 to $2 \mathrm{~mm}$. long, $1.2 \mathrm{~mm}$. wide, elliptic, under a lens minutely papillose-roughened, puberulent at the tip.

Autumnal form spreading or decumbent, flabellately branching at the middle and upper nodes, the branches appressed and rather evenly distributed, sometimes somewhat fascicled; winter blades 3 to $8 \mathrm{~cm}$. long, 5 to $10 \mathrm{~mm}$. wide, strongly stained with purple, forming a flat rosette.

As a whole this species is readily distinguished from $P$. lancearium by its stouter, taller culms, much larger blades, and in typical specimens by the larger spikelets, but a few specimens occur in which only the lower blades are much larger than in $P$. lancearium, and rather numerous specimens in which the spikelets are only 2.1 to $2.2 \mathrm{~mm}$. long. The minutely papillose-roughened fruit proves constant for all the specimens here referred to $P$. webberianum, but this character is evident only under a strong lens.

\section{DISTRIBUTION.}

Low pine land, North Carolina to Florida.

North Carolina: Onslow County, Ashe in 1899; Wilmington, Chase $4569 \frac{1}{2}$, Hitchcock 1433, 1472. 
Georgia: Brunswick, Ruth in 1893 (Ohio State Univ. Herb.).

Florida: Jacksonville, Curtiss 4637 (Hitchcock Herb.), J. D. Smith 570; Lake City, Hitchcock 1024; Apalachicola, Biltmore Herb. 6204a; Seville, Curtiss 6610; Titusville, Chase 3964; Hitchcock 766 $\frac{1}{2}$; Grasmere, Combs 1164; Eustis, Chase 4051 $\frac{1}{2}$, Hitchcock 792, 811, Nash 781; Sanford, Hitchcock 782; Tampa, Hitchcock $930 \frac{1}{2}$; Wimauma, Hitchcock 979; Arcadia, Hitchcock 855; Kalamazoo, Hitchcock $765 \frac{1}{2}$; Lakeland, Hitchcock 8381, 840 ; Braidentown, Hitchcock 955,

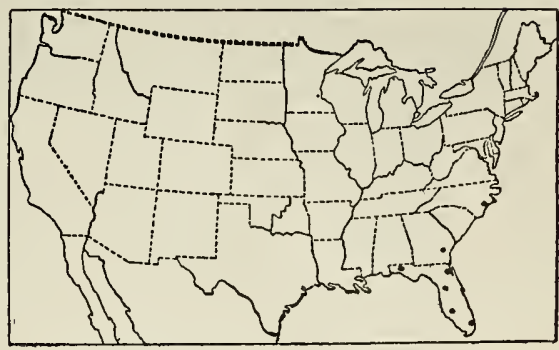

FIG. 310.-Distribution of $P$. webberianum. 972, Tracy 6716; Johns Pass, Tracy 7186; Jensen, Hitchcock 735, 748; Myers, Chase 4163, Hitchcock 910, 918, Lee Co. Pl. 470; Miami, Hitchcock 630; without locality, Rugel 443.

\section{$\checkmark$ 167. Panicum patentifolium Nash.}

Panicum patentifolium Nash, Bull. Torrey Club 26:574. 1899. "Type collected by the writer at Eustis, Lake Co., Florida, March 12-31, 1894, no. 72, in dry sand in a scrub hammock." The type, in Nash's herbarium, is the vernal form with two autumnal culms of the preceding year attached; all the blades are narrow, even the basal ones not over $4 \mathrm{~mm}$. wide.

\section{DESCRIPTION.}

Vernal form often purplish throughout; culms several to many in a tuft, slender and wiry, widely decumbent-ascending, 25 to $55 \mathrm{~cm}$. high, minutely puberulent or nearly glabrous; sheaths much shorter than the elongated internodes, a puberulent ring at the summit, otherwise glabrous or nearly so; blades stiffly spreading, 2.5 to $8 \mathrm{~cm}$. long, 2 to $5 \mathrm{~mm}$. wide, glabrous, acuminate, narrowed and sometimes ciliate toward the base; panicles commonly rather short-exserted, 3 to $7 \mathrm{~cm}$. long, about half as wide, the
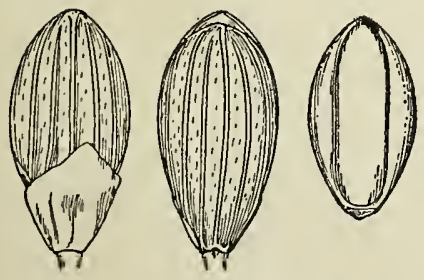

FIG. 311.-P. patentifolium. From type specimen.

branches few, ascending; spikelets 2.4 to $2.6 \mathrm{~mm}$. long, $1.3 \mathrm{~mm}$. wide, obovate, turgid; first glume one-third to half as long as the spikelet, obtuse or subacute; second glume and sterile lemma puberulent or nearly glabrous, the glume slightly shorter than the fruit and sterile lemma; fruit $2 \mathrm{~mm}$. long, $1.2 \mathrm{~mm}$. wide, elliptic, smooth and shining, minutely puberulent at the apex.

Autumnal form decumbent or spreading, branching from the middle and upper nodes, the branches appressed and somewhat elongated, the secondary branchlets shorter and more or less fascicled, not greatly reduced; winter rosettes appearing late, inconspicuous, the narrow blades ascending.

This species differs from $P$. webberianum in the more slender culms, narrower, spreading culm blades, absence of the large basal blades, and less turgid spikelets in which the fruit is smooth and shining. 
DISTRIBUTION.

Dry sand, especially in "scrub," Georgia to Florida and Mississippi.

GeORgIa: Dock Junction, Ricker 963 in part.

Florida: St. Augustine, Ricker 945; Gainesville, Chase 4245; Cedar Key, Combs 777, 778; Eustis, Chase 4051, 4058, 4088, Hitchcock 796, 802, Nash 52, 72; Titusville, Chase 4028, 4029, Hitchcock 767; Ormond, Hitchcock 563; Clearwater, Tracy 6702; Jensen, Hitchcock 730; Braidentown, Combs 1288, 1333, Hitchcock 969, 970, 971; East Pass, Tracy 6350; Mary Esther, Tracy 9139; Tampa, Hitcheock 930; Arcadia, Hitchcock 856; Sebastian, Hitchcock

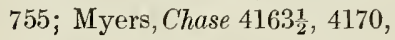
Hitchcock $915 \frac{1}{2}$.

Alabama: Fort Morgan, Tracy

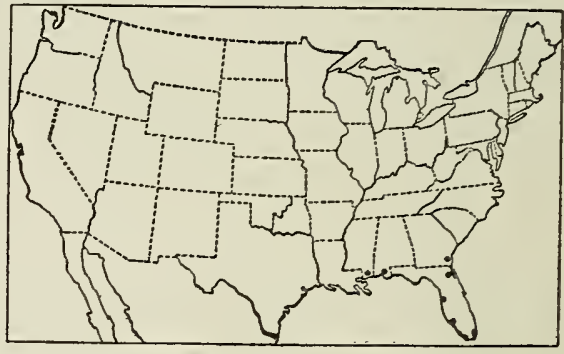

FIG. 312.-Distribution of P. patentifolium. 7174.

MississipPI: Biloxi, Kearney 330 in part.

Oligosanthia.-Culms rather stout, usually erect; sheaths more or less hirsute, villous, or sometimes glabrous; ligules inconspicuous except in $P$. ravenelii; blades firm, not over $2 \mathrm{~cm}$. wide, usually narrower; spikelets about 3 to $4 \mathrm{~mm}$. long, obovate, turgid, usually papillose-hirsute, strongly 7 to 9-nerved. Autumnal form with branches more or less crowded toward the summit.

Norles bearded; blades velvety-pubescent beneath.

Plants lax, soit-velvety throughout; spikelets not over

$3 \mathrm{~mm}$. long............................. malacophyllum.

Plants stiff, pubescence harsh; spikelets about $4 \mathrm{~mm}$.

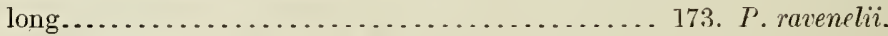

Norles not bearded (or but obscurely so in P. wilcoxianum);

blades not velvety.

Panicle narrow, branches erect, or spreading only at anthesis; blades erect.

Spikelets not over $3 \mathrm{~mm}$. long; blades not over $6 \mathrm{~mm}$. wide

168. P. wilcoxianum.

Spikelets 3.7 to $4 \mathrm{~mm}$. long; blades 8 to $20 \mathrm{~mm}$. wide.

Blades papillose-hispid.

174. P. leibergii.

Blades glabrous on both surfaces........... 175. P. xanthophysum.

Panicle about as wide as long.

Spikelets narrowly obovate, subacute; plants olivaceous, appressed-pubescent.............. 172. P.oligosanthes.

Spikelets broadly obovate, turgid, blunt; plants green, pubescence, if present, not appressed.

Blades erect, not over $6 \mathrm{~mm}$. wide; plants copiously hirsute throughout.............. 168. P. wilcoxianum.

Blades ascending or spreading, rarely less than $8 \mathrm{~mm}$. wide, usually wider; plants not hirsute throughout. 
Spikelets 3.2 to $3.3 \mathrm{~mm}$. long; blades firm; sheaths or some of them more or less hispid ..................... 171. P. scribnerianum.

Spikelets not over $3 \mathrm{~mm}$. long; blades rather thin; sheaths or some of them glabrous or sparsely hispid............... 170. P. helleri.

\section{$\sqrt{ }$ 168. Panicum wilcoxianum Vasey.}

Panicum wilcoxianum Vasey, U. S. Dept. Agr. Div. Bot. Bull. 8: 32. 1889. "Nebraska (Dr. T. E. Wilcox)." The type, in the National Herbarium, consists of several vernal culms beginning to branch, 13 to $17 \mathrm{~cm}$. high, with scarcely mature primary panicles. On the sheet is written in Vasey's hand, "Panicum Wilcoxianum, Vasey n. sp., Niobrara Ft., Nebraska. Dr. T. E. Wilcox, 1888."

\section{DESCRIPTION.}

Vernal form dull green; culms usually in dense tufts, erect, 10 to $25 \mathrm{~cm}$. high, copiously papillose-hirsute, as are the rather loose, usually overlapping sheaths; ligules about $1 \mathrm{~mm}$. long; blades firm, erect or ascending, 5 to $8 \mathrm{~cm}$. long, 3 to $6 \mathrm{~mm}$. wide,

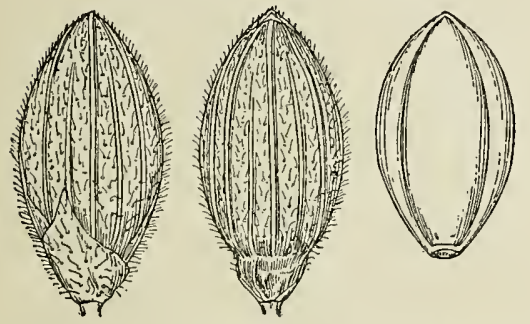

Fig. 313.-P. wilcoxianum. From type specimen. broadest toward the base (this scarcely wider than the wide sheath), commonly involute-acuminate, long-hirsute on both surfaces; panicles finally exserted, often equaled or exceeded by the upper blades, 2 to $5 \mathrm{~cm}$. long, about half as wide, or sometimes more expanded at anthesis, rather densely flowered; spikelets 2.7 to $3 \mathrm{~mm}$. long, $1.5 \mathrm{~mm}$. wide, obovate-elliptic, papillose-pubescent; first glume about one-third as long as the spikelet, pointed or obtuse; second glume slightly shorter than the fruit and sterile lemma; fruit 2.4 to $2.5 \mathrm{~mm}$. long, 1.3 to $1.4 \mathrm{~mm}$. wide, elliptic.

Autumnal form branching from all the nodes, forming bushy tuits with rigid, erect blades much overtopping the reduced panicles; branches appearing early, usually before the maturity of the primary panicles; secondary spikelets usually more turgid than those of the primary panicles.

\section{DISTRIBUTION.}

Prairies, Manitoba to North Dakota

\section{and soyth to Iowa and Kansas. 3 \\ MINNESOTA: Winona, Holzinger 28 in part (Biltmore Herb.).}

Manitoba: Sewell, Macoun 13227.

North Dakota: Towner, Lunell in 1908.

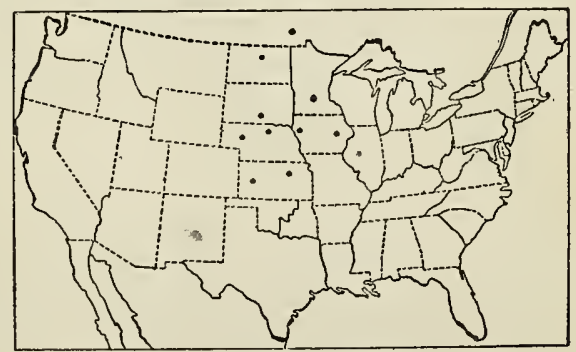

Fig. 314.-Distribution of $P$. wilcoxianum.

South Dakota: Brookings, Williams in 1891, E. N. Wilcox 14; Roberts County, S. D. Agr. Col. \& Exp. Sta. 4167; Rosebud, Wallace in 1896; Jamesville, Bruce 80.

Iowa: Missouri Valley, Pammel 3198; Gilbert Station, Carver in 1894. 
Nebraska: Niobrara Fort, T. E. Wilcox in 1888; Johnstown, Bates 1084; Thedford, Rydberg 1308; Weigand, Clements 2683.

Kansas: Manhattan, Hitchcock 2505, Pl. Kan. 879; Courtland, Hitchcock in 1892. Colorado: Without locality, American Plains Flora, Hall 231 in 1863 (Mo. Bot. Gard. Herb.).

\section{Panicum malacophyllum Nash.}

Panicum scoparium minor[us] Scribn. Tenn. Agr. Exp. Sta. Bull. 7: 48. 1894. "Middle Tennessee (Gattinger)." The type, in the herbarium of the University of Tennessee, consists of four branching culms with a primary panicle from which the spikelets have fallen and numerous secondary panicles with pilose branchlets and spikelets. On the accompanying label, which reads "Panicum scoparium Lam. Cedar Glades, Lavergne, Tennessee. Autumnal form 7 VII. '81. Legit Dr. A. Gattinger," is written in Scribner's hand "var. minor," and this is the only Gattinger and the only Tennessee specimen so marked by him. No specimen of $P$. scribnerianuma can be found which was referred by Scribner to his $P$. scoparium var. minor, while a specimen collected by Coville, Mountain Park, Arkansas, in 1887, corresponding to the above Gattinger specimen (that is $P$. malacophyllum Nash), is marked by him "Panicum scoparium Lam. var. minor Scribn." The description applies to the species represented by the Gattinger specimen except as to the panicle and spikelets: "Panicle branches and spikelets nearly smooth, or (subvar. pilosum) densely pilese hairy." Only the Gattinger specimen is cited and this, marked by Scribner as noted above, has pilose spikelets and panicle branches. No specimen can be found marked with the subvarietal name. Were it not that Scribner wrote "var. minor" on two specimens of $P$. malacophyllum Nash and on nothing else, the Gattinger citation might possibly be taken to refer to "subvar. pilosum." It would appear that the author $b$ confused $P$. scribnerianum and $P$. malacophyllum; that his description, drawn up from the material in his herbarium, was made to cover both, but more especially the common form, but that, having no Tennessee specimens of the common form he cited a specimen of the form he did have from Tennessee. The author's remark that "this is the most widely distributed and best known form of the species" bears out this conclusion.

Panicum malacophyllum Nash, Bull. Torrey Club 24: 198. 1897. "Type collected

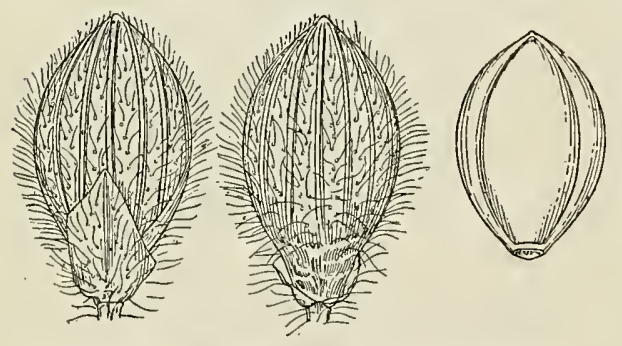

FIG. 315.-P. malacophyllum. From type specimen. by Mr. B. F. Bush on May 19, 1895, at Sapulpa, Indian Territory, No. 1228." The type, in Nash's herbarium, consists of two early autumnal culms 28 and $35 \mathrm{~cm}$. high, with mature primary panicles.

\section{DESCRIPTION.}

Vernal form velvety or velvetypilose throughout; culms slender, few to several in tufts, 25 to $70 \mathrm{~cm}$. high, more or less geniculate at base with arched internodes, ascending or spreading, papillose-pilose with soft, reflexed hairs, the nodes retrorsely bearded;

$a$ See discussion on the type of $P$. scribnerianum.

$b$ An examination of the specimens of this group in Scribner's herbarium shows that at that time his idea of true $P$. scoparium Lam. was $P$. ravenelii, on a sheet of which he had written "Certainly $P$. scoparium Ell., a form which suggests close relationship with $P$. Walteri Poir. ( $P$. latifolium Mx.)." Accepting Elliott's interpretation of Lamarck's species Scribner names this form var. genuinum; his var. pauciflorum (based on $P$. pauciflorum Ell.) is $P$. oligosanthes Schult.; his specimens of $P$. scribnerianum, ten in all (none of them from Tennessee), are all marked in Scribner's writing $P$. scoparium Lam., without particular comment, and none as stated above is marked "var. minor." 
sheaths loose, shorter than the internodes, usually less copiously pilose than the culm; ligules 1 to $1.5 \mathrm{~mm}$. long; blades spreading or ascending, 7 to $10 \mathrm{~cm}$. long, 6 to $12 \mathrm{~mm}$. wide, tapering to the rounded base, acuminate, rather thin, velvety on both surfaces, ciliate at least toward the base; panicles usually short-exserted, 3 to $7 \mathrm{~cm}$. long, at first narrow, the lower branches finally spreading, with short, spikelet-bearing branchlets in the axils; spikelets 2.9 to $3 \mathrm{~mm}$. long, 1.5 to $1.7 \mathrm{~mm}$. wide, elliptic-obovate, obscurely pointed, turgid at maturity, papillose-pilose; first glume about one-third as long as the spikelet; second glume and sterile lemma equaling the fruit at maturity; fruit $2.2 \mathrm{~mm}$. long, $1.5 \mathrm{~mm}$. wide, elliptic.

Autumnal form spreading, freely branching from the middle and upper nodes before the maturity of the primary panicle, at length forming bushy, topheavy clumps with reduced blades and numerous secondary panicles.

\section{DISTRIBUT1ON.}

Sandy woods, Tennessee and Missouri to Oklahoma and Texas.

Missour1: Warrenburg, Stigall 8.

Tennessee: Nashville, Gattinger in 1880; Lavergne, Gattinger in 1881 and 1882.

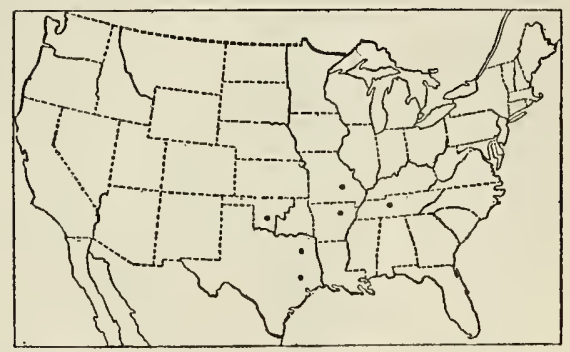

FIG. 316,-Distribution of $P$. malacophyllum.

Arkansas: Mountain Park, Coville in 1887; Prescott, Bush 263.

Texas: Dallas, Bush 642, Reverchon 1831; Weatherford, Traey 7942; Denison, Bebb 2670 (Hitchcock Herb.).

Oкlahoma: On the False Washita, Palmer 383 in 1868; Wister, Hitchook 578.

\section{- 170. Panicum helleri Nash.}

Ponicum helleri Nash, Bull. Torrey Club 26:572. 1899. "Collected at Kerrville, Kerr Co., Texas, by A. A. Heller, May 14-21, 1894, No. 1759. Differs from P. pernervosum in the pubescent culm and sheaths, the broader blades of a different shape and the narrow spikelets which are usually sparsely pubescent." The type,in Nash's herbarium, is a tuft of five vernal culms 24 to $39 \mathrm{~cm}$. high, the lower nodes subgeniculate; panicles immature, scarcely exserted, the upper spikelets well developed but not mature, $3 \mathrm{~mm}$. long, $1.5 \mathrm{~mm}$. wide, bearing a few scattered hairs; papillæ on the sheaths not prominent; lower internodes sparsely ascending-pilose, the upper short-pubescent, as frequently found in P. scribnerianum. The blades are 6 to $12 \mathrm{~mm}$. wide, while those of the type of $P$. pernervosum are 5 to $7 \mathrm{~mm}$. wide, but both are of the same shape, broadest in the middle instead of near the base, as in $P$. scribnerianum.

Panicum pernervosum Nash, Bull. Torrey Club 26: 576. 1899. "Type collected by Elihu Hall in woods at Houston, Texas, April 16, 1872, No. 830." The type, in the herbarium of the New York Botanical Garden, consists of two vernal plants with culms 27 and $34 \mathrm{~cm}$. high, and an extra piece of culm with a panicle. The culms are glabrous, the sheaths ciliate on the margin, otherwise glabrous, except one which has a few hairs near the summit. The panicles are mature and the spikelets more turgid than in the type of $P$. helleri, being $3 \mathrm{~mm}$. long and $1.7 \mathrm{~mm}$. wide. A few of them bear a few scattered hairs.

\section{DESCRIPTION.}

Vernal form in clumps of few to several culms, usually somewhat bluish light green; culms 25 to $60 \mathrm{~cm}$. high, slender, ascending or spreading, the lower internodes appressed-pilose, the upper often glabrous; sheaths sparsely papillose-hispid to glabrous, the papillæ often without hairs as in $P$. scribnerianum, ciliate on the margin; ligules 
about $1 \mathrm{~mm}$. long; blades ascending or spreading, measuring about the same as those of $P$. scribnerianum, but broadest about the middle, rather thin, glabrous on both surfaces or pubescent beneath, ciliate toward the base; panicles finally rather longexserted, 6 to $12 \mathrm{~cm}$. long, about three-fourths as wide, more open and loosely flowered than in P. scribnerianum; spikelets 2.9 to $3 \mathrm{~mm}$. long, 1.6 to $1.7 \mathrm{~mm}$. wide, obovate, turgid, blunt, glabrous, or with few scattered hairs; first glume about one-third the length of the spikelet, acute; second glume and sterile lemma subequal, slightly exposing the fruit at maturity, strongly nerved; fruit 2.4 to $2.5 \mathrm{~mm}$. long, 1.5 to 1.6 $\mathrm{mm}$. wide, oval, obscurely apiculate.

Autumnal form branching at all but the lowest nodes, forming loose sprawling tufts, the branches some what divaricate, with sheaths more commonly pubescent than those

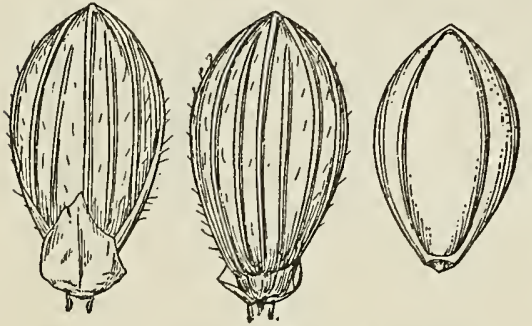

FIG. 317,-P. helleri. From type specimen. of the primary culm, the blades widely spreading, not much reduced, the longpediceled spikelets rather conspicuous among the foliage.

This species is closely related to $P$. scribnerianum, and many specimens are but doubtfully differentiated. As here distinguished, the smaller spikelets, thinner blades tapering to both ends, and the lax habit, taken in combination, have been used to separate $P$. helleri. As in $P$. scribnerianum little weight can be given to pubescence or lack of it, hispid and glabrous sheaths being found on the same plant, as in Bush 803 and Hitchcock 1173, though P. helleri is more commonly nearly glabrous than is $P$. scribnerianum. Reverchon's no. 2857 is probably referable to this species, but the pubescence of culms, sheaths, and lower surface of blades and the long hairs mixed with the short ligule show affinity to $P$. oligosanthes. The spikelets are $3 \mathrm{~mm}$. long, too immature to show turgidity.

A few specimens are intermediate in the size of the spikelets. In Harvey 17 and Hitchcock 1173 the spikelets are 3.1 to $3.2 \mathrm{~mm}$. long; and Hitchcock 1223, with spikelets $3.3 \mathrm{~mm}$. long, is referred here since the specimen shows the sprawling habit of $P$. helleri.

\section{DISTRIBUTION.}

Open woods and prairies, Missouri and Oklahoma to Louisiana and New Mexico.

Missouri: Sheffield, Bush 803, 3903; Levasy, Bush 1685; Courtney, Bush 1710, 3893.

Arkansas: Fulton, Bush 2529; northern Arkansas, Harvey 17.

Loulsiana: Cameron, Tracy 8419.

Texas: Dallas, Bush 705, Reverchon 1074 in part, 2444; Dallas County, Reverchon 2342, 2344, 2345; Denison, Bebb 1430; Weatherford, Tracy 7949 ; Corsicana, Reverchon 2855 in part; Grand Saline, Reverchon 4138; Terrell, Warburton 2; Waller, Hitchcock 1173, 1179, 1186, 1212; Waller County, Thurow in 1898; Houston, Bebb 1278, Hall 830, Nealley in 1887; Gal-

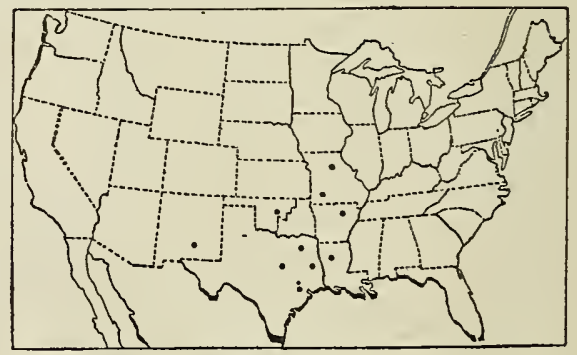

FIG. 318.-Distribution of $P$. helleri. veston, Plank 82; Virginia Point, Bray 33; Kerrville, Heller 1759, Smith in 1897; Burnet, Plank 3; Velasco, Smith in 1897; Victoria, Tracy 8870; Kingsville, Tracy 8885; without locality, Buckley in 1881.

OzLaнoma: On the False Washita, Palmer 382 in 1868.

New Mexico: Mogollon Mountains, Metcalfe 354. 


\section{Panicum scribnerianum Nash.}

Panicum macrocarpon Torr. Fl. North. \& Mid. U. S. 143. 1823, not LeConte 1819. "НАв. On the banks of the Connecticut River, near Deerfield, Massachusetts. Sent to me by Dr. Cooley." The type, in herbarium of Columbia University, is a single culm 'with terminal panicle. It is labeled in Torrey's hand "Panicum macrocarpon*," followed by a brief diagnosis, and "Near Deerfield, Mass. Dr. Cooley." On the same sheet was mounted the specimen of $P$. latifolium, which is taken as the type of $P$. macrocarpon LeConte. ${ }^{a}$ Torrey makes no mention of $P$. macrocarpon LeConte, published a few years earlier in his Catalogue of the Plants of New York.

Panicum scribnerianum Nash, Bull. Torrey Club 22:421. 1895. This is proposed as a new name without description, the following citations being given: "Panicum scoparium S. Wats. in A. Gray, Man. Ed. 6, 632. 1890. Not Lam. Panicum scoparium var. minor Scribn. Bull. Univ. Tenn. 7 : 48. 1894. Not P. capillare var. minor Muhl. 1817." The author does not state upon which of these two the new name is based, but since it "is proposed in honor of Prof. F. L. Scribner, who was the first to indicate its difference from P. scoparium Lam.," it seems evident that the intention is to raise Scribner's variety to specific rank, changing the name because of $P$. capillare var. minor Muhl. But examination of Scribner's type $b$ shows that it is not the species described as $P$. scoparium in Gray's Manual and as $P$. scribnerianum by Nash in the Illustrated Flora, $c$ Britton's Manual,d and Small's Flora.e Owing to the confusion and uncertainty arising from Scribner's citing a specimen which disagrees in part with his description, it seems best to take the first citation given by Nash as the basis of $P$. scribnerianum, excluding the reference to $P$. scoparium var. minor.

Panicum scoparium S. Wats.; Nash, Bull. Torrey Club 22 : 421. 1895. As synonym under P. scribnerianum Nash. The name is cited by Nash as "S. Wats. in A. Gray Man. Ed. 6, 632. 1890. Not Lam.," but Watson did not publish this name, since misapplication of a name does not constitute publication. The description of " $P$. scoparium Lam." [misapplied] in Gray's Manual, ed. 6, is identical with that of "P. pauciflorum Ell.?" of previous editions back to the first. In the first edition $f$ the range is given as "N. Pennsylvania (Carey) and W. New York to Michigan." The Carey specimen, in the Gray Herbarium, is a single branching plant with hispid sheaths, a primary panicle, destitute of spikelets, and two secondary panicles with scarcely mature spikelets. The accompanying label reads: "Panicum n. sp.? pauciflorum Ell.? Wysox. Penna. J. Carey, July 1836." This specimen we take as the type of $P$. scribnerianum.

\section{DESCRIPTION.}

Vernal form in clumps of few to many culms, 20 to $50 \mathrm{~cm}$. high, erect or ascending, often geniculate at base, glabrous or harshly puberulent or sometimes ascending papillose-pilose; sheaths rather loase, conspicuously striate, ciliate on the margin, ascending-pubescent between the nerves and papillose-hispid with spreading or ascending hairs to nearly glabrous, the papillæ often without hairs; ligules about 1 $\mathrm{mm}$. long; blades ascending or erect, 5 to $10 \mathrm{~cm}$. long, 6 to $12 \mathrm{~mm}$. wide, usually firm, acuminate, rounded and ciliate at base, glabrous on the upper surface, appressedpubescent to glabrous beneath; panicles short-exserted, 4 to $8 \mathrm{~cm}$. long, rarely longer, two-thirds to three-fourths as wide, the flexuous branches ascending; spikelets 3.2 to $3.3 \mathrm{~mm}$. long, $2 \mathrm{~mm}$. wide, obovate, turgid, blunt, sparsely pubescent to nearly

$a$ See note under $P$. latifolium L., page 314 .

$b$ See notes on $P$. scoparium minus Scribn. under $P$. malacophyllum Nash, page 280.

$c$ Britt. \& Brown, Illust. Fl. 1: 118. 1896.

$d$ Man. 87. 1901.

e Fl. Southeast U. S. 103.1903.

f A. Gray, Man. 613. 1848. 
glabrous; first glume about one-third the length of the spikelet, acute; second glume and sterile lemma subequal, barely or scarcely equaling the fruit at maturity, strongly nerved; fruit 2.8 to $2.9 \mathrm{~mm}$. long, 1.8 to $1.9 \mathrm{~mm}$. wide, broadly elliptic, minutely apiculate.

Autumnal form branching from the middle and upper nodes at about the maturity of the primary panicle; the branches longer than the internodes, and late in the season
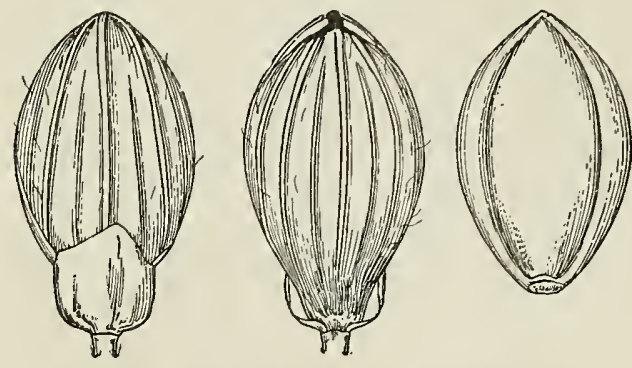

FIG. 319.-P. scribnerianum. From type specimen. producing crowded branchlets with ascending, not greatly reduced, blades and small, partially included, panicles from their upper nodes.

This species is very variable in the matter of pubescence. An unusually hispid Washington specimen, Elmer 763, was considered worthy of varietal rank by Scribner and Merrill and bears a herbarium name, but Moffatt 1863, Miller, Indiana, is quite and others nearly as hispid, while other Pacific coast specimens are not more hispid than eastern specimens. Glabrous and hispid sheaths are commonly found on the same specimen in this species. A few Mississippi specimens with blades softly pubescent beneath and spikelets 3.2 to $3.6 \mathrm{~mm}$. long, suggest an approach to $P$. ravenelii Scribn. \& Merr. These are: Jackson, Hitchcock 1295, 1296; Starkville, Tracy 42, 1752.

\section{DISTRIBUTION.}

Sandy soil or dry prairies, Maine, Ontario, and westward to the Pacific; south to Maryland and Arizona.

Maine: South Berwick, Parlin in Harvey, Maine Weeds 1245.

New Hampshire: Walpole, Fernald 280 (Gray Herb.).

Vermont: Westminster, Robinson in 1898.

Massachusetrs: Wellesley, Smith 731; Ipswich, Oales; Essex County, Conant in 1881.

Connecricut: Oxford, Harger in Kneucker Gram. Exs. 425; Rocky Hill, Wilson 1256; Farmington, Bissell 5563; Southington, Andrews 51.

Rhode Island: Providence, Collins in 1887 (Brown Univ. Herb.).

New York: Ithaca, Ashe.

Ontario: Sarnia, Macoun 26328; Sandwich, Macoun 26329.

New Jersey: Glenlock, Heritage in 1897; Morris Plains, Mackenzie 1611; Passaic County, Nash in 1893.

Pennsylvania: Safe Harbor, Porter in 1864; Germantown, Stone 4 in 1889; Easton, Porter in 1895, 1896, and 1898.

Онго: Erie County, Mertz 147; Cedar Point, York 6789; Bowling Green, Kellerman 6894 .

Indiana: Miller, Moffatt 1863, Umbach in 1897; Elston, Dorner 88.

Illinors: Hanover, Gleason \& Gates 2598; Beach, Umbach 2365; Chicago, Chase in 1896; Joliet, Skeels 250; Romeo, Umbach 1704; Starved Rock, Chase 1607, Greenman, Lansing \& Dixon 156; Wady Petra, V. H. Chase 922; Marshall County, V. H. Chase 1792; Galva, V. H. Chase 1749; Peoria, McDonald 32.

Michigan: Grand Rapids, Crozier; without locality, Wheeler 97.

Minnesota: Fort Snelling, Mearns 771; Spring Grove, Rosendahl 260; Minneapolis, Sheldon in 1895. 
North Dakota: Norfolk, Griffiths 871.

South Dakota: Lead City, Rydberg 1098; Rosebud, Wallace 12.

Iowa: Ames, Ball 178; Iowa City, Somes 167, 229.

Nebraska: Weeping Water, Williams 3009; Thedford, Rydberg 1279, 1493; Fort Niobrara, T. E. Wilcox in 1890; Mullen, Rydberg 1604.

Missouri: Wayne County, Eggert 234; Carter County, Eggert 297; St. Louis, Eggert 249; Washington County, Eggert 295; Monteer, Bush 722, 733 in part, 4653; Independence, Bush 729, 740; Watson, Bush 737; Dodson, Bush 1659; Arlington, Kellogg in 1903; Allenton, Kellogg in 1903; Swan, Bush 4568; Westport, Bush 4021; Vale, Bush 3933.

Kansas: Osborne City, Shear 85; Manhattan, Hitchcock 2383, 2502, 2511, 2519, 2525, 3854, Pl. Kan. 571, 571a, 921.

Delaware: Centerville, Commons 281, 282, Chase 3618.

Maryland: Glen Echo, House 831; High Island, Ward in 1879; Great Falls, Chase 2865.

District of Columbia: Chase 3808 , Steele in 1901, Ward in 1881 and 1883.

Tennessee: Knoxville, Kuth 74 in 1898.

Arkansas: Benton County, Plank $48 \mathrm{a}, 93$.

Texas: Denison, Bebb 2715(Hitchcock Herb.); without locality, Johnson in 1886.

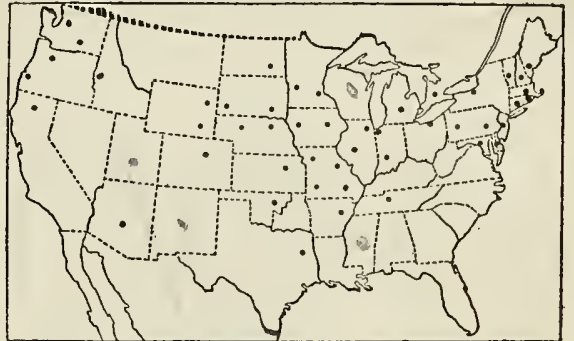

Fig. 320.-Distribution of $P$. scribnerianum.

OкLAномa: Limestone Gap, Butler 19; Sapulpa, Bush 1216, 1222; I'lora, Bebb 2167; Walker, Bebb 1459.

Wyoming: Cambria Canyon, A. Nelson 2524; Inyankara Creek, Williams 2577; Devils Tower, Griffiths 548; Whalen Canyon, A. Nelson 516.

Idaho: Nez Perces County, Sandberg, Heller \& MacDougal in 1892.

Washington: Wawawai, Elmer 763; Klickitat County, Suksdorf in 1882 and 1883; Ophir, Elmer 509; Thurston County, Heller 4058; Roy, Hunter 604a; Walla Walla, Wilkes Expl. Exped. 946.

British Columbia: Chilliwack Valley, Macoun 26333, 77230; Lake Osoyoos, Macoun 77231; Vancouver Island, Macoun 29297.

Oregon: Cascades, Kellogg \& Harford 1085; Cache Bar, Sheldon 8331; Coos County, Hitchcock 2836; Sauvies Island, Howell 63; Snake River at mouth of Cache Creek, Sheldon 8194; without locality, Hall. Pl. Oreg. 672.

Colorado: Fort Collins, Baker 36.

Arizona: Willow Spring, Palmer 561 in 1890; White Mountains, Griffiths 5401. CaIIfornia : Castle Crag, Hitchcock 3074.

\section{$\checkmark$ 172. Panicum oligosanthes Schult.}

Panicum pauciflorum Ell. Bot. S. C. \& Ga. 1: 120. 1816, not R. Br. 1810. "In Georgia, not very rare." The type, in the Elliott Herbarium, is a single culm beginning to branch, with five leaves and an exserted panicle $6 \mathrm{~cm}$. long and $6.5 \mathrm{~cm}$. wide. The accompanying label reads: "Panicum pauciflorum E. Hab: in humidis umbrosisque. Flor. Ap: Ma."

Panicum oligosanthes a Schult. Mant. 2: 256. 1824. Based on $P$. pauciflorum Ell., the name being changed because of $P$. pauciflorum $\mathrm{R}$. Br.

"This name is incorrectly formed: the word should be oliganthum, but since the incorrect form has been sanctioned by usage it seems wiser not now to correct it, especially sinec to do so would invalidate $P$. oliganthum Schlecht. 1854. 
Panicum scoparium angustifoliuma Vasey, U. S. Dept. Agr. Div. Bot. Bull. 8 : 32. 1889. "South Carolina (Dr. Ravenel)" is the first specimen cited. This, which is taken as the type, is in the National Herbarium, and consists of several culms in the early branching state, with mature terminal panicles.

Panicum scoparium pauciflorum Scribn. Tenn. Agr. Exp. Sta. Bull. 7 : 48. 1894. Based on $P$. pauciflorum Ell.

DESCRIPTION.

Vernal form olivaceous, in loose tufts of few to several culms 35 to $80 \mathrm{~cm}$. high, erect, often purplish, appressed-pubescent, especially below; sheaths shorter than the internodes or the lower longer, the papillose pubescence ascending; hairs of the ligule 1 to $2 \mathrm{~mm}$. long, with longer ones intermixed; blades stiffly spreading or ascending, 6 to $14 \mathrm{~cm}$. long, 5 to 8 (rarely 10 ) $\mathrm{mm}$. wide, sharply acuminate, narrowed toward the base, glabrous on the upper surface or rarely with a few long hairs, harshly puberulent beneath, stiffly ciliate near the base; panicles finally long-exserted, 6 to $12 \mathrm{~cm}$. long, about as wide, loosely flowered, branches usually stiffly ascending or spreading; spike-

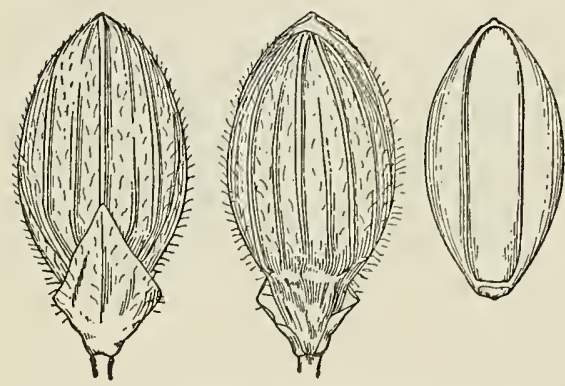

FIG. 321.- P. oligosanthes. From type specimen of P. pauciflorum Ell. lets long-pediceled, 3.5 to $4 \mathrm{~mm}$. long, 1.7 to $1.9 \mathrm{~mm}$. wide (smaller in exceptional specimens), oblong-obovate, subacute, sparsely hirsute; first glume less than half the length of the spikelet, acute; second glume slightly shorter than the fruit and sterile lemma; fruit 2.8 to $3 \mathrm{~mm}$. long, 1.5 to $1.6 \mathrm{~mm}$. wide, elliptic.

Autumnal form erect or spreading, sometimes topheavy-prostrate, branching sparingly from the lower, freely from the upper, nodes, late in the season the short branchlets aggregated at the summit of the branches, the crowded, reduced blades widely spreading, the panicles more or less included and reduced to a few spikelets, these commonly more turgid and blunt than those of the primary panicle.

In this species the spikelets vary more in size than usual in this group. The following specimens have spikelets only 3.2 to $3.3 \mathrm{~mm}$. long: Bebb 1426, Bush 1225, Hitchcock 1194, Kearney 1386, Reverchon 1840, 4142, and Thurow in 1899. The shape of the spikelets as well as the other characters of these specimens are those of $P$. oligosanthes. A few specimens, however, appear to be intermediate between this and $P$. scribnerianum, having the narrow blades, appressed pubescence, and open, few-flowered panicles of $P$. oligosanthes, but very turgid, blunt spikelets, which, however, measure 3.5 to $3.7 \mathrm{~mm}$. long. These are: Tracy 1754 ; Bebb 1389 and 2703, Denison, Texas; and Hitchcock in 1903, Wister, Oklahoma (the last two in Hitchcock Herb.).

DISTRIBUTION.

Sandy, usually moist woods, New Jersey to Illinois, south to Florida and Texas, mostly near the coast.

New Jersey: Atsion, Commons 54.

IndiANa: Dune Park, Hill 201 in 1898.

IllıNois: [Wabash County?] Schneck in 1879.

$a$ This is not based on $P$. angustifolium Ell. Vasey gives the latter species on page 29 of the same paper. 
Delaware: Seaford, Commons in 1882; Greenbank, Commons in 1883; Lewes, Hitchcock 419, 582.

District of Columbia: Steele in 1899.

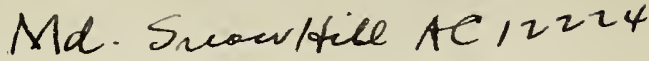

Virginia: Fort Monroe, Vasey in 1878 and 1883; Cape Henry, Chase 2912, 5435,

Kearney 1400; Virginia Beach, Hitcheock 581, Kearney 1386, Williams 3110.

North Carolina: Wilmington, Hitchcock 418, 1457, 1459, 1460.

South Carouina: Aiken, Hitcheock 580, Ravenel in 1867, Scribner in 1894; Sumter,

Hitchcock 579; Orangeburg,

Hitchcock 20, 1410.

Georgia: Augusta, Cuthbert 1121, 1167, Kearney 216; Clarke County, Harper 146; Stone Mountain, Hitchcock 417.

Florida: Jacksonville, Curtiss 5864; Lake City, Chase 4276, 4283, Combs 163, Hitchcock 1014; Tallahassee, Combs 382; Gainesville, Chase 4207, 4260, Combs 742.

Alabama: Flomaton, Hitchcock 1055.

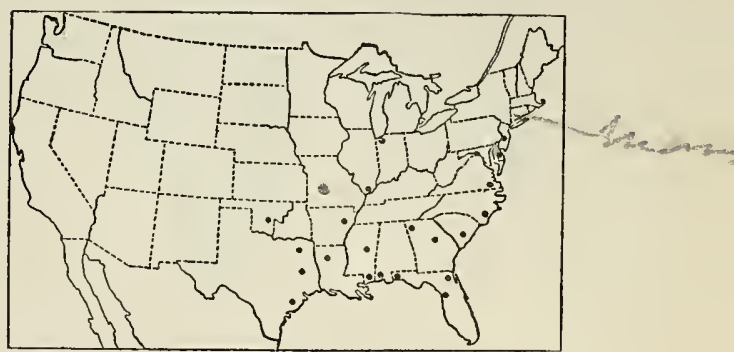

FIG. 322.-Distribution of $P$. oligosanthes.

Mississippi: Columbus, Tracy in 1896; Starkville, Tracy 1754; Waynesboro, Kearney 191; Biloxi, Tracy 3647; Mississippi City, Hitchcock 1106.

Arkansas: Benton County, Plank 73.

Louistana: Calhoun, Ball 64, Hitchcock 1263, 12741, 1293.

Texas: Dallas County, Reverchon 1841; Denison, Bebb 1389, 1426; Grand Saline, Reverchon 4142; Silver Lake, Reverchon 1840; Waller, Hitchcock 1194, Thurow in 1898 and 1899; Houston, Bebb 1245, Nealley in 1887; without locality, Wright (Gray Herb.).

Oкцанома: Sapulpa, Bush 1225.

$\checkmark$ 173. Panicum ravenelii Scribn. \& Merr.

Panicum scoparium major[us] Vasey, U. S. Dept. Agr. Div. Bot. Bull. 8 : 32.1889 The author states, "We have only seen this from South Carolina (Dr. Ravenel)." The type, in the National Herbarium, consists of three immature vernal culms.

Panicum scoparium genuinum Scribn. Tenn. Agr. Exp. Sta. Bull. 7: 48. 1894. "P. scoparium Lam., Ell." is cited, and, as it is evident that Scribner is designating Elliott's as the genuine $P$. scoparium, Elliott's specimen is considered the type.

Panicum ravenelii Scribn. \& Merr. U. S. Dept. Agr. Div. Agrost. Bull. 24 : 36.1901. Published as a new name for "Panicum scoparium of Ell. Sk. Bot. S. C. and Ga. 1 : 119. 1817. Not Lam. Encycl. 4: 744. 1797." The type, in the Elliott Herbarium, is a single vernal culm with an immature panicle. No locality is cited by Elliott, and none is given on the label; the specimen is presumably from South Carolina.

This species was referred to Panicum scoparium by Elliott, as stated above, and also by Chapman. ${ }^{a}$

\section{DESCRIPTION .}

Vernal form in loose tufts, grayish olive green; culms 30 to $70 \mathrm{~cm}$. high, erect or ascending, densely papillose-hirsute with ascending hairs, the nodes short-bearded; sheaths shorter than the long lower internodes, about equaling the short upper ones or overlapping, papillose-hirsute like the culm; ligules 3 to $4 \mathrm{~mm}$. long; blades thick, ascending or spreading, 8 to $15 \mathrm{~cm}$. long, 1 to $2 \mathrm{~cm}$. wide, sharply acuminate, rounded 
at the base, glabrous on the upper surface, densely velvety-hirsute beneath, usually short-ciliate nearly to the apex; panicles short-exserted or included at the base, 7 to
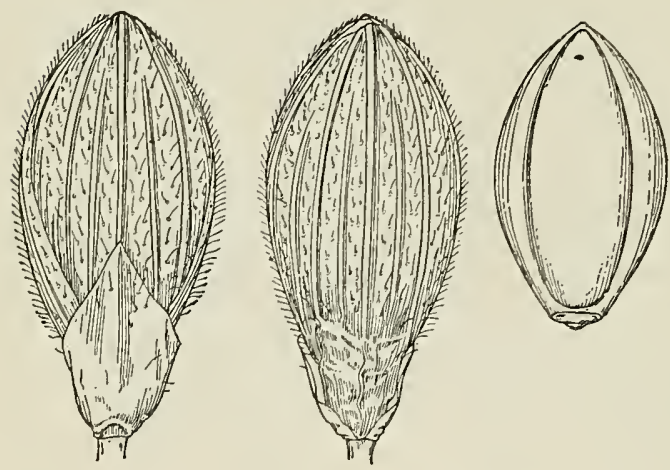

FIG. 323.-P. ravenclii. From type specimen.

$12 \mathrm{~cm}$. long, as wide or wider, loosely flowered, the branches finally spreading; spikelets 4 to $4.3 \mathrm{~mm}$. long, 2 to $2.2 \mathrm{~mm}$. wide, cbovate, turgid and blunt, sparsely papillose-pubescent; first glume one-third to twofifths the length of the spikelet, acute; second glume and sterile lemma subequal,scarcely equaling the fruit at maturity, strongly nerved; fruit $3.2 \mathrm{~mm}$. long, $2 \mathrm{~mm}$. wide, elliptic, minutely apiculate.

Autumnal form more or less spreading, branching from the middle and upper nodes, the short kranchlets crowded at the summit late in the season, the reduced blades ascending, overtopping the small panicles.

\section{DISTRIBUTION .}

Sandy or gravelly woods or open ground, Maryland to Missouri, Florida, and Texas. Missouri: Swan, Bush in 1899.

Delaware: New Castle County, Canby (Field Mus. Herb.).

Maryland: Great Falls, Chase 3780; Riverdale, Chase 3796.

District of Columbia: Steele in 1898 and 1900; Ward in 1881.

Virginia: Danville, Small \& Heller in 1891 (Biltmore Herb.).

North Carolina: Wilmington, Hitchcock 420, 1463, 1489; Raleigh, Chase 3088; Chapel Hill, Ashe.

South Carolina: Aiken, Ravenel; Orangeburg, Hitchcock 1390; Keowee, House 2200.

Georgia: Cobb County, Wilson 31, 47; Thomson, Bartlett 1502.

Florida: Apalachicola, Biltmore Herb. 2994a; Mc iticello, Combs 305; Chipley, Combs 602 in part; Lake City, Chase 4279, Hitchcock 1010.

Tennessee: Henderson, Bain in 1893 (Univ. Tenn. Herb.).

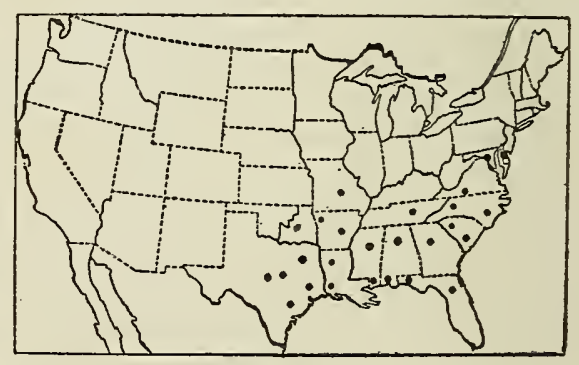

Frg. 324.-Distribution of $P$. ravenelii.

Alabama: Mobile County, Mohr 153; Flomaton, Hitchcock 1047; Auburn, Hitchcock 1334; Tuskegee, Carver 13.

MississipPI: Starkville, Tracy in 1888; Jackson, Hitchcock 1294; Mississippi City, Hitchcock 1107.

Arkansas: Little Rock, Coville in 1887; Fulton, Bush 2526; Benton County, Plank 56, 143; northwestern Arkansas, Harvey 31.

Louisiana: Calhoun, Hitchcock 1288; Shreveport, Hitchcock 1245.

Texas: Big Sandy, Reverchon 2390; Harvester, Thurow in 1898; Waller, Hitchcock 1187; without locality, Nealley in 1885; Wright 280 (Gray Herb.). 


\section{$\checkmark$ 174. Panicum leibergii (Vasey) Scribn. is peft. Aqpirc $19 \mathrm{w}$. \\ Ayunt. Pull F:}

Panicum scoparium liebergii Vasey, U. S. Dept. Agr. Div. Bot. Bull. 8: 32. 1889. "P. liebergii Scribn.)" is given as synonym, and "Plymouth County, Iowa (John Lieberg)" [error for Leiberg] is cited. The type, consisting of two vernal culms, is in Hitchcock's herbarium. The accompanying label reads: "Panicum Leibergii, Scribn. 1884. Plymouth Co., Iowa. 1878. Legit John Leiberg," the specific pliz.is 18 name, author, and date being in Scribner's writing. On the sheet is written in Vasey's hand, "P. scoparium var. Leibergii V."

Panicum scribnerianum leibergii Scribn. U. S. Dept. Agr. Div. Agrost. Bull. 6 : 32. 1897. No synonym is cited and "South Dakota: Brookings (Wilcox 16)" is the only specimen mentioned. This name must however be considered a new combina tion based on $P$. scoparium leibergii Vasey. The Wilcox specimen agrees with that of Leiberg.

Panicum liebergii Scribn. in Britt. \& Brown, Illust. Fl. 3: 497. 1898. Based on "Panicum scoparium Lam. var. Liebergii Vasey." This name was first mentioned as a synonym under $P$. scoparium liebergii Vasey. ${ }^{a}$

\section{DESCRIPTION.}

Vernal form dull green, in clumps of few to several slender culms, 25 to $75 \mathrm{~cm}$. high, erect from a more or less geniculate base, pilose to merely scabrous; sheaths shorter than the internodes, papillose-hispid with spreading hairs; ligules almost obsolete; blades ascending or erect, rather thin, 6 to $15 \mathrm{~cm}$. long, 7 to $15 \mathrm{~mm}$. wide, narrowed toward the rounded base, acuminate, papillose-hispid on both surfaces, often sparsely so above, papillose-ciliate from one-third to half their length; panicles finally long-exserted, 8 to $15 \mathrm{~cm}$. long, less than half as wide, the flexuous branches narrowly ascending or somewhat spreading at anthesis; spikelets 3.7 to 4
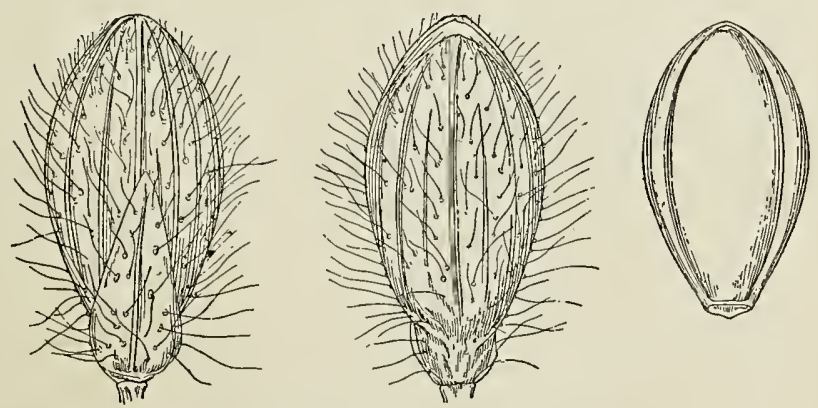

FIG. 325.-P. leibergii. From type speeimen.

$\mathrm{mm}$. long, 1.8 to $2 \mathrm{~mm}$. wide, oblong-obovate, turgid, strongly papillose-hispid with spreading hairs; first glume more than half the length of the spikelet, pointed, second glume and sterile lemma subequal, covering the fruit at maturity or the lemma slightly exceeding it; fruit $3 \mathrm{~mm}$. long, 1.7 to $1.8 \mathrm{~mm}$. wide, obovate-oval.

Autumnal form more or less leaning, sparingly branching from the middle and lower nodes late in summer, the branches mostly simple, erect, the blades scarcely reduced, usually exceeding the short-exserted panicles.

$a$ U. S. Dept. Agr. Div. Bot. Bull. 8: 32. 1889.

$41616^{\circ}$ - VoL $15-10-19$ 
DISTRIBUTION.

Prairies, New York to Manitoba, south to Ohio and Kansas.

New York: Head of Seneca Lake (Gray Herb.).

Ontario: Squirrel Island, Lake St. Clair, Dodge 17, 20, 62, 84.

Оніо: Erie County, Moseley in 1897.

Indiana: Lafayette, Dorner 35.

IllinoIs: Naperville, Umbach 1669; Emington, Wilcox 129; Joliet, Skeels 334;

Wady Petra, V. H. Chase 461, 1455; Knox County, V. H. Chase 1701; Peoria, McDonald 17; Champaign, Waite in 1888.

Michigan: Hansens Island, Lake St. Clair, Dodge in 1899 (Hitchcock Herb.).

Wisconsin: Racine, Wadmond 46; Elkhart Lake, Hill 91 in 1906.

Minnesota: Acton, Frost in 1892; St. Cloud, Campbell in 1887; Montevideo, Moyer in 1894; Spring Grove, Rosendahl 504, 538.

Manitoba: Macgregor, Macoun 73004 ; Carberry, Macoun 73003.

North Dakota: Fargo, Bolley 1865; Merrifield, Brannon 10; Leeds, Lunell in 1902.

South Dakota: Brookings, $E . N$. Wilcox 16, Williams 2228; Lake Hendricks, Williams in 1891; Simpson Park, Griffiths 836.

IowA: Plymouth County, Leiberg in 1878; Armstrong, Cratty in 1900; Ames, Ball \& Sample 16; Iowa City, Somes 236; De-

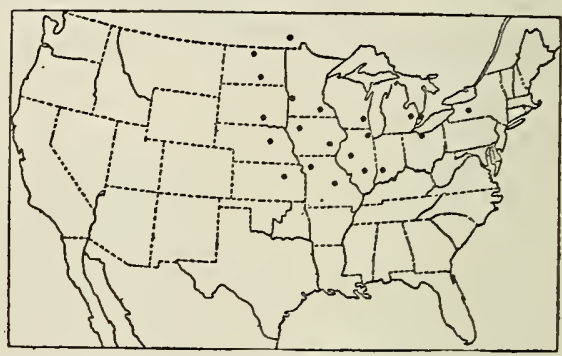

FIG. 326.-Distribution of P. leibergii. catur County, Fitzpatrick \& Fitzpatrick 36; New Albin, Pammel 932; Johnson County, Shimek 69.

Nebraska: Ponca, Clements 2523.

Missouri: Lees Summit, Mackenzie 297; Monteer, Bush 379, 730, 744, 2760; Dodson, Bush 1652; Levasy, Bush 1684.

Kansas: Manhattan; Hitchcock 2504, 2518, Pl. Kan. 571b.

This species is listed in the Botany of Stevens's Report $a$ as P. clandestinum, as shown by the specimen, without definite locality, in the National Herbarium.

\section{$\checkmark$ 175. Panicum xanthophysum A. Gray.}

Panicum xanthophysum A. Gray, Gram. \& Cyp. 1: no. 28. 1834. This was published in the set of exsiccatae, a printed description in Latin accompanying no. 28, the locality being given as "Pine Plains, near Oneida Lake, New-York." In the Gray Herbarium is a specimen, on the sheet of which is written in Dr. Gray's hand "Oneida Lake, Wood Creek barrens, P. xanthophysum Gray!" This specimen, which we consider the type, is a single culm with an overmature primary panicle, and a small secondary panicle. Dr. Gray apparently neglected to retain for himself a numbered set of this distribution of Gramineæ. The specimen of no. 28 in the Boott set in Gray Herbarium, and the other specimens of this number which we have seen agree with the above specimen. The species was later described by Grayb in English in a paper on "New or rare Plants of the State of New York."

Panicum xanthophysum forma amplifolium Scribn. in Brainerd, Jones \& Eggleston, Fl. Vt. 104. 1900. "Dry sandy soil, Burlington, Vt. L. R. Jones, collector, August 31, 1893." The type, in the National Herbarium, consists of two specimens with overlapping sheaths and blades 1.5 to $2 \mathrm{~cm}$. wide. 


\section{DESCRIPTION.}

Vernal form yellowish green, in loose tufts of few to many culms, 20 to $55 \mathrm{~cm}$. high, erect or ascending, more or less scabrous; sheaths loose, about as long as the internodes or longer, sparsely papillose-pilose and ciliate at least toward the summit, rarely nearly glabrous; ligules $1 \mathrm{~mm}$. long; blades erect or nearly so, rather thin, prominently nerved, 10 to $15 \mathrm{~cm}$. long, rarely longer, 1 to $2 \mathrm{~cm}$. wide, acuminate, slightly narrowed to the rounded papillose-ciliate base, otherwise glabrous, the uppermost blade not reduced, sometimes the largest; panicles finally long-exserted, 5 to $12 \mathrm{~cm}$. long, very narrow, sometimes appearing almost racemose, few-flowered, the stiff branches erect or nearly
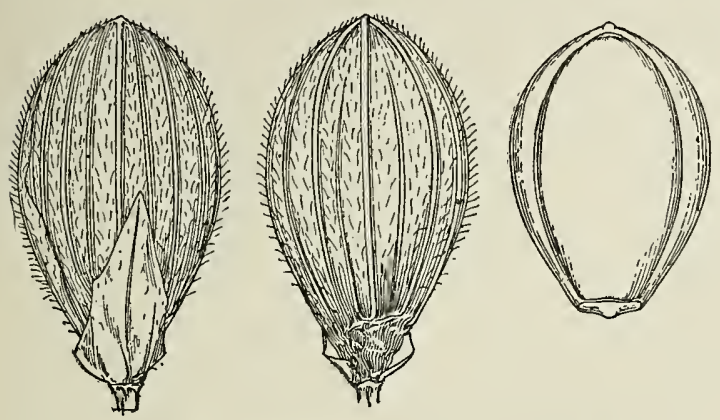

FIG. 327.- $P$, xanthophysum. From type specimen. so; spikelets 3.7 to $4 \mathrm{~mm}$. long, 2 to $2.1 \mathrm{~mm}$. wide, obovate, turgid and bluntat maturity, pubescent; first glume about half as long as the spikelet, pointed; second glume scarcely equaling the fruit and sterile lemma at maturity; fruit 2.9 to $3 \mathrm{~mm}$. long, $2 \mathrm{~mm}$. wide, obovate-oval, minutely umbonate.

Autumnal form erect or ascending, branching from the second and third nodes,

the branches erect, mostly simple, the blades not reduced, usually equaling the shortexserted panicles, the large, erect blades making the plant appear leafy in the middle.

The spikelets of the primary panicles sometimes perfect their grains. As stamens and stigmas are both frequently exserted, the fruitful spikelets in this species are not always cleistogamous as is commonly the case in Dichanthelium.

Three Minnesota specimens, Campbell 66, Ostland 1 and 2 in 1884, and an Ontario specimen, Macoun in 1865, seem to be intermediate between this species and $P$. leibergii. The first of these has the glabrous blades and strict panicles of $P$. xanthophysum, but the blades are only 5 to $7 \mathrm{~mm}$. wide. The Ostland specimens represent vernal and autumnal forms; both have blades that are ciliate for half their length or more but otherwise glabrous; the panicles are looser as in $P$. leibergii and the pubescence of the spikelets, which are too immature to indicate amount of turgidity, is papillosespreading as in that species; the autumnal specimen has broader blades and would be referred to $P$. xanthophysum unhesitatingly but for the intermediate vernal specimen.

\section{DISTRIBUTION.}

Sandy or gravelly soil, Q uebec to Minnesota, south to Pennsylvania.

Quebec: Sorel, Pringle in 1879.

Marne: Buckfield, Allen in 1877; Orono, Fernald 345; Madison, Fernald 521;

South Berwick, Fernald 519; York, Fernald 520; Bangor, Knight in 1904;

Cumberland, Knowlton \& Chamberlain 500; East Auburn, Merrill 11; Chesterville, Chase 3295,3300 .

New Hampshire: Laconia, Carter 101d.

Vermont: Burlington, Jones in 1893; Peacham, Blanchard in 1889; Vernon, Grout in 1895.

Massachusetts: Ashburnham, Harris in 1896 (N. E. Bot. Club Herb.).

Connecticut: Stafford, Graves in 1903 (Gray Herb.). 
New York: Oneida Lake, Gray; Lake George, Vasey in 1882; Schenectady, Wibbe in 1885; Danby, Coville in 1885; Cairo, Nash in 1893; Tripoli, Burnham in 1897.

Ontario: Belleville, Macoun in 1865; Galt, Herriot in 1898 and 1901; Algonquin Park, Macoun 22025.

Pennsyluania: Tannersville, Brown in 1901; without locality, McMinn.

Michigan: Keweenaw, Farwell 764; Alma, Davis in 1893.

Wisconsin: Rainbow Rapids, Cheney 1346; Mason, Cheney 4786; Webster, Cheney 3426.

Minnesota: Ramsey County, Ostland 1 and 2 in 1884; Lake Kilpatrick, Ballard in 1893; St. Cloud, Campbell 66.

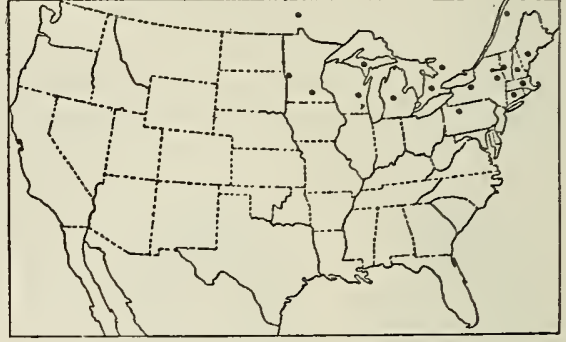

FIG. 328.-Distribution of $P$. xanthophysum.

Manitoba: Lake Winnepeg Valley, Bourgeau in 1857 (Gray Herb.).

Saskatchawan: Bourgeau in 1858 (Gray Herb.).

Pedicellata.-Clums slender, more or less hirsute; ligules of short hairs; blades not over $6 \mathrm{~mm}$. wide, ciliate; spikelets 3.5 to $4 \mathrm{~mm}$. long, attenuate at base, papillose, 7 to 9 -nerved. Autumnal form freely branching, the branches appearing before the maturity of the primary panicle; no distinct winter rosette formed.

This group of two species appears to be intermediate between the subgenus Dichanthelium and true Panicum. The plants bear a general resemblance to Oligosanthia but in the absence of a winter rosette and in the branching habit, especially of $P$. nodatum, they show a departure from Dichanthelium.

Culms erect or leaning; blades thin, 5 to $9 \mathrm{~cm}$. long, narrowed toward the base.............................176. P. pedicellatum. Culms decumbent; blades thick, not over $5 \mathrm{~cm}$. long, not narrowed toward the base.........................177. P. nodatum.

- 176. Panicum pedicellatum Vasey.

Panicum pedicellatum Vasey, U. S. Dept. Agr. Div. Bot. Bull. 8: 28. 1889. "Texas, J. Reverchon." The type specimen, in the National Herbarium, Reverchon Texas
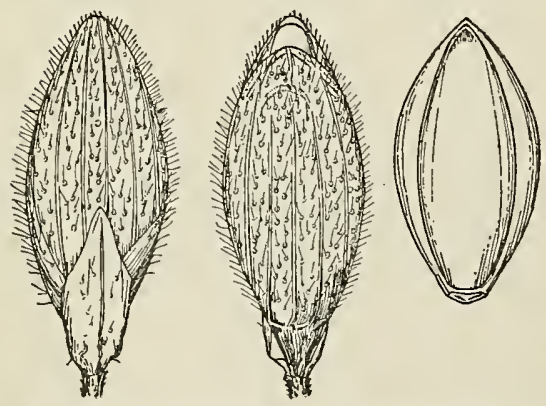

Fig. 329.-P. pedicellatum. From type specimen.
Plants 1620, bearing the data "Rocky woods, Kimble Co. June," consists of two branching plants.

\section{DESCRIPTION.}

Vernal form in tufts of few to several erect or ascending culms from a short, knotted rootstock; culms slender, 20 to $50 \mathrm{~cm}$. high, usually ascending-hirsute at least below, a few spreading hairs on the nodes; sheaths papillose, sparingly hirsute, ciliate on the margin; ligules dense, about $1 \mathrm{~mm}$. long; blades ascending or spreading, 5 to $9 \mathrm{~cm}$. long, 3 to 6 $\mathrm{mm}$. wide, the margin toward the narrowed base sparsely ciliate with long hairs, both surfaces glabrous or sometimes minutely hispid; panicles 3 to $6 \mathrm{~cm}$. long, 
about three-fourths as wide, the branches few, spreading or ascending; spikelets 3.5 to $3.7 \mathrm{~mm}$. long, $1.4 \mathrm{~mm}$. wide, elliptic, prominently papillose-hispid; first glume nearly or quite half the length of the spikelet, narrow, acute; second glume shorter than the fruit and sterile lemma at maturity; fruit $3 \mathrm{~mm}$. long, $1.3 \mathrm{~mm}$. wide, elliptic, subacute.

Autumnal form erect or leaning, branching from all but the uppermost nodes before the maturity of the primary panicle, the branches slightly divaricate, the blades and panicles not greatly reduced.

\section{DISTRIBUTION.}

Dry woods and prairie, Texas.

Texas: Kimble County, Reverchon 1620; Kerrville, Heller 1726, 1736,1766, Smith in 1897 ; Austin, Hall $834 a$ in part; Comanche Spring, Lindheimer 1265 in Mo. Bot. Gard. distr; "in

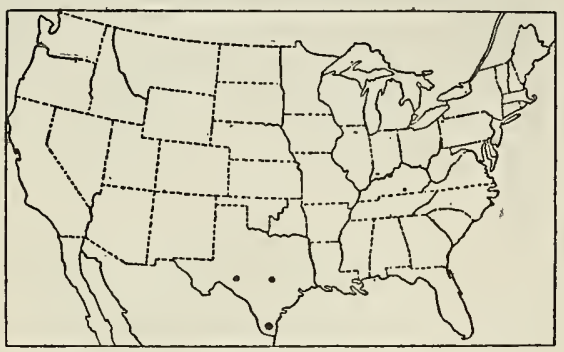

FIG. 330.-Distribution of $P$. pedicellatum: the Sabines bottom," Lindheimer 158 (last two in Gray Herb.).

\section{$\checkmark$ 177. Panicum nodatum sp. nov.}

\section{DESCRIPTION.}

Vernal form in tufts from a knotted crown; culms ascending or spreading, slender but hard and wiry, 25 to $35 \mathrm{~cm}$. high, finely papillose, crisp-puberulent; sheaths shorter than the internodes, papillose-hispid between the strong nerves; ligules dense, scarcely $1 \mathrm{~mm}$. long; blades firm, ascending, 3 to $5 \mathrm{~cm}$. long, 3 to $6 \mathrm{~mm}$. wide, broadest at the rounded base, abruptly acute, puberulent on both surfaces, papillose-ciliate
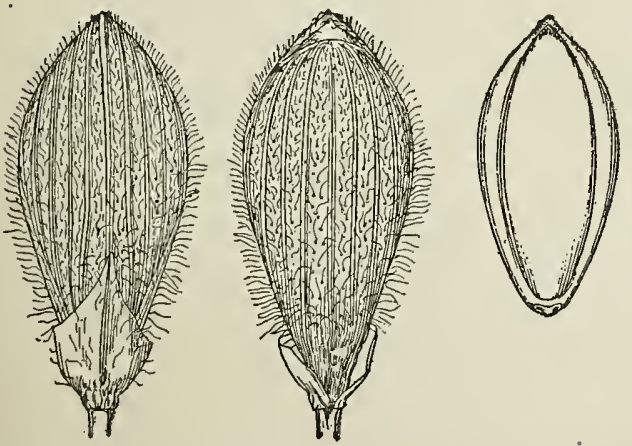

FIG. 331.-P, nodatum. From type specimen. with stiff hairs 2 to $3 \mathrm{~mm}$. long; panicles 4 to $5 \mathrm{~cm}$. long, half to two-thirds as wide, few-flowered, the few branches ascending; spikelets $4 \mathrm{~mm}$. long, $1.7 \mathrm{~mm}$. wide, pyriform, papillose-pubescent; first glume about one-third the length of the spikelet, acuminate; second glume slightly shorter than the fruit and sterile lemma; fruit 3 $\mathrm{mm}$. long, $1.4 \mathrm{~mm}$. wide, obovateelliptic, minutely white-puberulent at the apex.

Autumnal form widely geniculate-decumbent, early branching from all but the uppermost node, the branches somewhat divaricate, equaling or exceeding the main culm, with numerous swollen nodes, the internodes 2 to $3 \mathrm{~cm}$. long, the whole forming a loose tuft, the blades and panicles not reduced.

Type U. S. National Herbarium no. 592749, collected August 7, 1904, Sarita, Texas, by A. S. Hitcheock (no. 3865).

$a$ This in the Gray Herbarium is numbered 835.

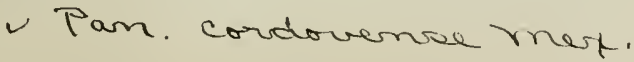


This species differs from $P$. pedicellatum in its stiffer, short-jointed culms, shorter, puberulent, prominently ciliate blades, and pyriform spikelets with a shorter first glume.

\section{DISTRIBUTION.}

Oak woods in sand dunes, southern Texas and northern Mexico; apparently rare.

Texas: Sarita, Hitchcock 3865.

Mexico: Matamoros, Berlandier 988, 2418 (last two in Gray Herb.).

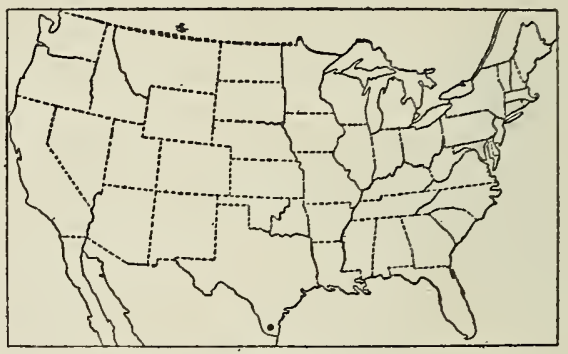

Fic. 332,-Distribution of $P$. nodatum.

Ssoparia.--Vernal culms tall; blades flat, elongated, not over $1.5 \mathrm{~cm}$. wide; ligules short; spikelets pointed, 7 to 9 -nerved.

Pubescence soft-villous or velvety; spikelets abruptly pointed.

Vernal culms erect or ascending; plants velvety through-

out; spikelets about $2.5 \mathrm{~mm}$. long..............178. P. scoparium.

Vernal culms decumbent at base; the upper sheaths more

or less glabrate; spikelets less than $2 \mathrm{~mm}$. long.....179. P. viscidellum.

Pubescence when present not velvety.

Spikelets elliptic; fruit $2 \mathrm{~mm}$. long................. P. aculeatum.

Spikelets ovate; that is, broadest below the middle; fruit

$2 \mathrm{~mm}$. long or less.

Sheaths or some of them hispid, rarely glabrous; au-

tumnal form with crowded branchlets.........181. P. scabriusculum.

Sheaths glabrous; autumnal form sparingly branching.182. P. cryptanthum.

\section{$\checkmark$ 178. Panicum scoparium Lam.}

Panicum scoparium Lam. Encycl. 4: 744. 1798. "Cette plante a été recueillie dans la basse Caroline par le citoyen Michaux." The type specimen, in the Lamarck Herbarium, is a part of a vernal culm with a single leaf and over-mature panicle. The accompanying label reads, "Panicum scoparium Lam. dict. donné par le C. Michaux."

Panicum pubescens Lam. Encycl. 4: 748. 1798. The author refers to two specimens as follows: "J'ai vu de cette espèce un individu nain dans l'herbier de Vaillant; il l'avoit reçue de Sherard en 1721. Le citoyen Michaux l'a trouvée dans la BasseCaroline." The first mentioned specimen is in the Paris Herbarium. It is some species of Brachiaria allied to Panicum villosum Lam. as described by Hooker. ${ }^{a}$ The other specimen referred to is in the Michaux Herbarium and consists of two freely branching autumnal culms of $P$. scoparium. The accompanying label reads "Panicum pubescens Lam. Hab. in pratis sylvestribus Carolinae." Since Lamarck's description applies to the Michaux ${ }^{b}$ rather than to the Sherard specimen we may consider the Michaux plant the type.

Panicum viscidum Ell. Bot. S. C. \& Ga. 1: 123. pl. 7.f. 3.c 1816. No specimen nor definite locality is cited. The type in the Elliott Herbarium is labeled: "Panicum viscidum mihi. Hab: in humidis." It consists of a single culm lacking the base, bearing several short branches and an over-mature primary panicle.

Panicum pauciflorum Bosc; Spreng. Syst. Veg. 1: 313. 1825. This, together with

- P. scoparium Michx., is placed as a synonym under $P$. pubescens Lam. We have seen no authentic specimen. 
Panicum laxiflorum pubescens Chapm. Fl. South. U. S. ed. 3. 586. 1897, not Vasey 1892. Based on Panicum pubescens Lam., though the description applies to $P$. strigosum Muhl., the species referred by Chapman to this variety.

\section{DESCRIPTION.}

Vernal plants grayish olive green, velvety-pubescent throughout except as noted; culms 80 to $130 \mathrm{~cm}$. high, stout, erect or ascending, usually geniculate at base, the nodes villous with reflexed hairs, a glabrous, viscid ring below; sheaths about half as long as the long internodes, the velvety pubescence wanting on the back toward the summit, the surface here viscid when fresh; ligules $1 \mathrm{~mm}$. long; blades rather thick, ascending or spreading, often reflexed late in the season, 12 to $20 \mathrm{~cm}$. long, 10 to $18 \mathrm{~mm}$. wide, long-acuminate, slightly narrowed to the rounded base, the uppermost leaf often much reduced; panicles finally long-exserted, 8 to $15 \mathrm{~cm}$. long, nearly as wide, manyflowered, the axis, branches, and pedicels with viscid blotches, the branches ascending or spreading, spikelet-bearing to the base; spikelets 2.4 to $2.6 \mathrm{~mm}$. long, 1.4 to 1.5 $\mathrm{mm}$. wide, obovate, turgid at maturity, abruptly pointed, papillose-pubescent with
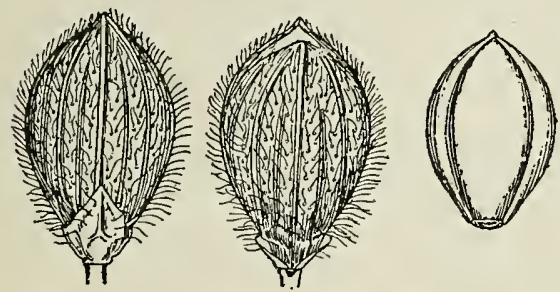

Fig. 333.-P. scoparium. From type specimen of P. viscidum Ell. spreading hairs; first glume one-fifth to one-fourth the length of the spikelet, acute to truncate; second glume and sterile lemma strongly nerved, the glume obtuse, shorter than the fruit at maturity, the lemma abruptly pointed and equaling it; fruit $2 \mathrm{~mm}$. long, 1.4 $\mathrm{mm}$. wide, obovate-elliptic, apiculate.

Autumnal form leaning or spreading, branching from the middle nodes after the maturity of the primary panicle, the branches usually longer than the primary internodes, repeatedly branching, often more or less scorpioid, the ultimate branchlets in flabellate fascicles, the sheaths often swollen toward the summit, contracted at the throat, the blades much reduced, overtopping the small, partially included panicles.

A well-marked and constant species, easily recognized by its velvety pubescence, the glabrous, viscid ring below the nodes, and the viscid upper portion of the sheath. The viscidity disappears in drying, but the glandular surface is evident.

\section{DISTRIBUTION}

Wet or damp soil, Massachusetts to Florida, west to Oklahoma and Texas; also in Cuba.

Massachusetrs: Cape Cod, Cheney in 1903 (N. E. Bot. Club Herb.).

New Jersey: Avon, Mackenzie 1854; Tuckerton, Chase 3600; Wildwood, Chase 3486.

Pennsylvania: Tinicum, Smith 159; without locality, McMinn.

Delaware: Millsboro, Commons 28; Ellendale, Commons 32.

Maryland: Eastern Shore, Canby; Anne Arundel County, J. D. Smith in 1879; Chesapeake Junction, Hitchcock 1637.

Drstrict of Columbia: Kearney in 1897, Merrill 233, Sheldon in 1881, Steele in 1896 and 1897, Topping in 1895, Vasey in 1881, Ward in 1878 and 1879.

Vrrainia: In the vicinity of Cape Henry, Chase 5438, Coville 17, Hitchcock 593, Kearney 308, 1477, Mackenzie 1688, Noyes 88, 89; Dismal Swamp, McCarthy in 1883.

North Carolina: Wilmington, Biltmore Herb.4290; Hickory, Small \& Heller in 1891; Heiligs Mill, Small \& Heller 204; West Raleigh, Coit 1304. 
South Carolina: Orangeburg, Mitchcock 437.

Georgia: Savannah, Kearney 183; McGuires Mill, Small in 1893; Clarke County, Harper 110, 150; Cobb County, Harper 210;-Americus, Tracy in 1897; Dekalb County, Eggert 82; Stone Mountain, Hitchcock 215; Thomson, Bartlett 1170.

Florida: Jacksonville, Kearney 156; Lake City, Nash 2204; Apalachicola, Bittmore IIerb. 4290a; without locality, Chapman.

Kentucky: Warren County, Price in 1896 (Mo. Bot. Gard. Herb.).

Tennessee: Chester County, Bain in 1892.

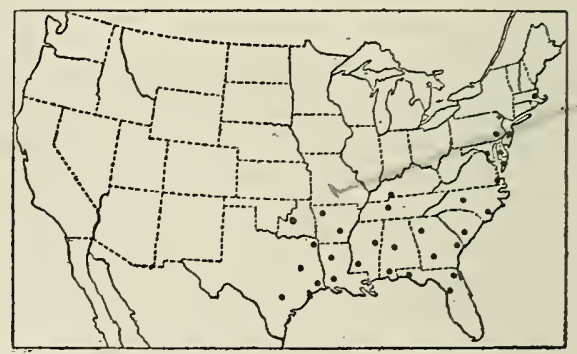

FIG. 334.-Distribution of P. scoparium.

Alabama: Auburn, Pollard \& Maxon 2, 67, Tracy 3978; Cullman, Eggert 12, 60, Mohr in 1895; Selma, Kearney 3; Tuskegee, Carver 52, 87; Mobile, Hitchcock 594, Kearney 67, Tracy 7048.

MississipPI: Starkville, Tracy in 1896; Taylorville, Tracy 8591; Pachuta, Tracy 3306.

Arkansas: Miller County, Eggert 116, Heller 4236; northwest Arkansas, Harvey 30. Louisiana: Arcadia, Ball 77; Ruston, Cocks 3324.

Texas: Waller County, Thurow in 1898; Texarkana, Plank 25; Hempstead, Hall 829; Fort Smith to the Rio Grande, Bigelow; without locality, Nealley in 1885, Drummond 381; Vincent 41b (Mo. Bot. Gard. Herb.).

Oklahoma: Choctaw Agency, Bigelow.

CubA: Road to Pinal Mayarí, Wright 3467 (Gray Herb.).

\section{$\checkmark$ 179. Panicum viscidellum Scribn.}

Panicum viscidellum Scribn. U. S. Dept. Agr. Div. Agrost. Circ. 19:2. 1900. "Gravelly banks near Jalapa, State of Vera Cruz, altitude 1,250 m. (4,000 feet). C. G. Pringle, No. 8089. 1899." A second specimen, Liebmann 323, is cited but the first is taken as the type. The Pringle specimen, which is in the National Herbarium, is in the early branching state. The culm appears to be decumbent or creeping, sending up erect branches.

\section{DESCRIPTION.}

Vernal culms ascending from a decumbent, widely spreading or creeping base, rooting at the lower nodes, softly villous or nearly glabrous, the nodes more or less short-bearded; sheaths shorter than the internodes, villous or, especially the upper-
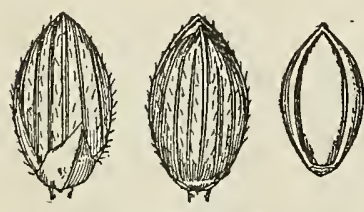

FIG. 335.-P. viscidellum. From type specimen. most, glabrate; ligules ciliate, 2 to $4 \mathrm{~mm}$. long; blades spreading, rather thick, more or less velvety-pubescent or villous on both surfaces, the uppermost 5 to $13 \mathrm{~cm}$. long, 9 to $13 \mathrm{~mm}$. wide, linear-lanceolate, subcordate, the lower lancelate, more cordate, shorter and wider; panicles 4 to $11 \mathrm{~cm}$. long, half to two-thirds as wide, usually densely flowered, the numerous branches spikelet-bearing from the base; spikelets 1.8 to $1.9 \mathrm{~mm}$. long, $1 \mathrm{~mm}$. wide, elliptic, acute, sparsely pubescent; first glume about one-third as long as the spikelet, pointed; second glume and sterile lemma slightly exceeding the fruit at maturity; fruit $1.5 \mathrm{~mm}$. long, $0.8 \mathrm{~mm}$. wide, elliptic, abruptly pointed. 
Autumnal form branching from the middle and upper nodes, the branches erect or ascending from the decumbent primary culm, the densely villous sheaths often overlapping on the shortened internodes, the blades more or less ovate-lanceolate and strongly cordate-clasping, velvety pubescent, the panicles similar to the primary ones but smaller.

The autumnal form is not well developed in any of the specimens examined. Judging from the habit of the plant it appears to belong to the subgenus Dichanthelium but more material is necessary to determine this with certainty. The characters of the vernal form would place it in the group Lanuginosa, but the method of branching is different from that of any of the species there segregated. The specimens often resemble $P$. scoparium, and the species is therefore placed in this group, though somewhat doubtfully because of the manifest ligules and the branching habit.

\section{DISTRIBUTION.}

Gravelly banks, fields and open forests, Mexico to Colombia; also in the Isle of Pines.

Mexico: Jalapa, Pringle 8089, C. L. Smith 1617; Zacualpan, Purpus 2160; Mirador, Liebmann 323; San Cristobal, Bourgeau 3132 (Paris Herb.); Jicaltepec, Liebmann 324 (Paris Herb.); Orizaba, Botteri 705 (Gray Herb.); Schaffner 284 (Paris Herb.).

Guatemala: Sierra del Mico, Kellerman 6231, 6249.

Nicaragua: U. S. Pacific Expl. Exped. Wright.

Costa Rica: Aserrí, Tonduz 1244; El General, Pittier 3358 (Instit. Costaric. Herb.).

Cuba: Isle of Pines, Palmer \& Riley 1065.

Colombia: Near Jamundí, Pittier 940; Popayán, Lehmann 985 (Gray Herb.).

\section{$\checkmark$ 180. Panicum aculeatum Hitchc. \& Chase.}

Panicum aculeatum Hitchc. \& Chase, Rhodora 8: 209. 1906. "Type Chase 2520 in National Herbarium. In large clumps by small slough, border of woods, Takoma Park, D. C., July 27, 1904; collected by Agnes Chase." The type is a vernal specimen beginning to branch, with a mature primary panicle.

\section{DESCRIPTION.}

Vernal plants in large clumps; culms slender, $70 \mathrm{~cm}$. to 1 meter high, ascending, scabrous, harshly pubescent below; sheaths papillose-hispid with stiff, sharp-pointed

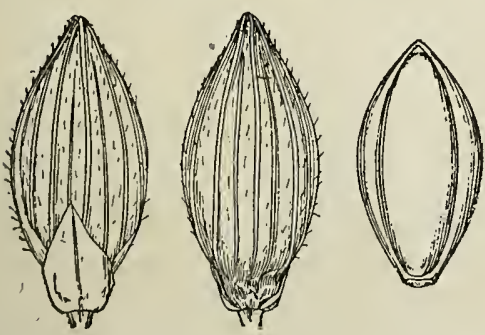

FIG. 336.-P. aculeatum. From type specimen. hairs, a puberulent ring at the summit, the uppermost usually glabrous; ligules minute, membranaceous, ciliate; blades firm, stiffly ascending or spreading, 12 to $20 \mathrm{~cm}$. long, 9 to $13 \mathrm{~mm}$. wide, acuminate, involute-pointed, scarcely narrowed to the rounded base, very scabrous on the upper surface and toward the apex beneath; panicles 8 to $12 \mathrm{~cm}$. long, about as wide, few-flowered, the slender, flexuous, fascicled branches ascending or spreading, naked at the base, scabrous, sometimes with a few viscid spots; spikelets $3 \mathrm{~mm}$. long, elliptic, minutely pubescent; first glume one-fourth to one-third as long as the spikelet, acute; second glume and sterile lemma abruptly acute, slightly exceeding the fruit; fruit elliptic, $2.7 \mathrm{~mm}$. long, $1.3 \mathrm{~mm}$. wide, minutely umbonate. 
Autumnal form branching from the middle nodes, the branches more or less divaricate, not much crowded, the blades not greatly reduced, the ultimate panicles wholly or partially included in the sheaths.

This species is allied to $P$. scabriusculum, but the panicles are smaller, more open, fewer-flowered, the axis and branches scarcely viscid, the spikelets larger and the glumes only slightly exceeding the fruit. Vernal plants bear a superficial resemblance to $P$. clandestinum.

\section{DISTRIBUTION.}

Swampy woods, Long Island, New York, District of Columbia, and North Carolina; rare.

New YoRk: Rockville Center,

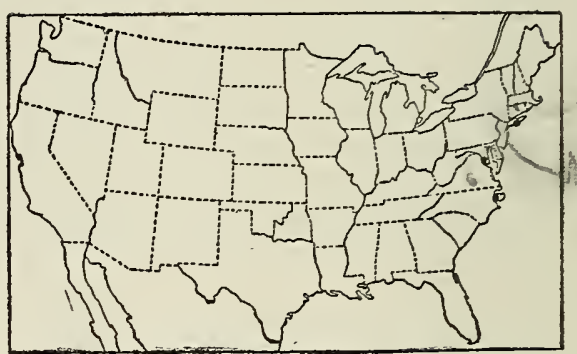

Fig. 337.-Distrlbution of $P$. aculeatum. Bicknell in 1903; Hempstead, Bicknell in 1906.

7 District of Columbia: Chase 2520, 5439, House 1041 (Hitchcock Herb.).

North Carolina: Lake Mattamuskeet, Chase 3210.

Panicum scabriusculum Ell. Bot. S. C. \& Ga. 1: 121. 1816. "Sent to me from Savannah by Dr. Baldwin." The type, in the Elliott Herbarium, consists of the upper part of a culm with one leaf and a large over-mature panicle. The accompanying label reads: "Panicum scabriusculum. Hab: Georg: Dr. Baldwin."

Panicum lanuginosum Bosc; Spreng. Syst. Veg. 1: 319. 1825, not Ell. 1816. "Georgia." The type is in the Willdenow Herbarium.

Panicum eriophorum Schult.; ${ }^{a}$ Kunth, Enum. Pl. 1: 128. 1833 . Based on $P$. lanuginosum Bosc, the description of which is copied.

Panicum nealleyi Vasey, Bull. Torrey Club 13: 25. 1886. "Collected in Texas by Mr. G. C. Nealley." The type, in the National Herbarium, is a vernal specimen. It was collected in Texas, May, 1885, the exact locality not being given.

Panicum dichotomum elatum Vasey, U. S. Dept. Agr. Div. Bot. Bull. 8 : 31.1889. No locality nor specimen is mentioned by Vasey. The only specimen in the National Herbarium bearing this name in Vasey's writing is one of $P$. scabriusculum in the early branching state. This specimen agrees with Vasey's description and is taken as the type. It was collected by Charles Mohr in Mobile County, Alabama, June 18, 1888.

\section{DESCRIPTION.}

Vernal form grayish olive green; culms erect, 1 to 1.5 meters high, scabrous at least below the nodes, sometimes puberulent, the nodes glabrous or puberulent; sheaths shorter than the internodes, glabrous to more or less hispid at least toward the summit, often mottled or white-spotted, commonly swollen at the base and contracted toward the summit; ligules short-membranaceous, usually with a ring of hairs above; blades stiffly ascending or spreading, often reflexed, 15 to $25 \mathrm{~cm}$. long, 9 to 12 or rarely $15 \mathrm{~mm}$. wide, glabrous or scabrous, often more or less pubescent beneath, gradually tapering to an involute point, slightly narrowed toward the base; panicles finally exserted, 10 to $20 \mathrm{~cm}$. long, half to two-thirds as wide, rarely wider, many-flowered, the

a Kunth cites "Schult. Mant. 3. 591" as place of publication, but neither the second nor third volume of Schultes's Mantissa contains a page 591, nor is this name in either volume. 
axis glabrous or pubescent, often viscid, the flexuous branches ascending, spikeletbearing from near the base; spikelets 2.3 to $2.6 \mathrm{~mm}$. long, 1.1 to $1.3 \mathrm{~mm}$. wide, ovate, pointed, glabrous or obscurely puberulent; first glume less than one-sixth as long as
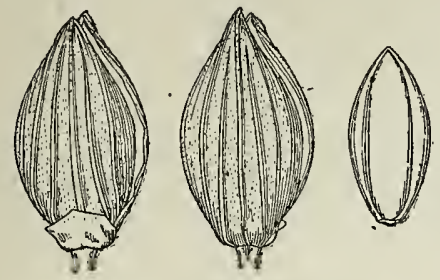

FIG. 338.-P. scabriusculum. From type specimen. the spikelet; second glume and sterile lemma strongly nerved, exceeding the fruit and forming an abrupt point beyond it; fruit $1.8 \mathrm{~mm}$. long, $1 \mathrm{~mm}$. wide, elliptic.

Autumnal form erect, branching from the middle and upper nodes, the branches appressed, somewhat longer than the internodes, finally bearing fascicled branchlets and forming dense oblong masses along the upper part of the primary culm, the sheaths, especially the later ones, densely papillose-hirsute, the flat, reduced blades ovate-lanceolate, reduced in length much more than in width, the panicles partly or entirely inclosed in the sheaths.

This species is very variable in the amount of pubescence; even on the same plant are often found glabrous and hispid sheaths or glabrous and pubescent blades. Otherwise it is an unusually uniform species.

\section{DISTRIBUTION.}

Moist ground, especially along ditches, streams, and swamps, near the coast, southeast Virginia to Florida and eastern Texas.

New JeRsey: Atlantic Gity, Long in 1909 (Phila. Acad. Herb.).

Virginia: Norfolk County, Kearney 1798; Dismal Swamp, Tyler in 1905.

North Carolina: Roanoke Island, Chase 3235; Wilsons Mills, Chase 3101; Wilmington, Chase 4600, Hitchcock 595, Kearney 270.

South Carolina: Orangeburg, Hitchcock 438, 1378; Aiken, Ravenel.

Georgia: Bullock County, Harper 881; Leslie, Harper 410.

Frorida: Jacksonville, Curtiss Q, 4878; Duval County, Curtiss 3610; Baldwin, Combs 67;

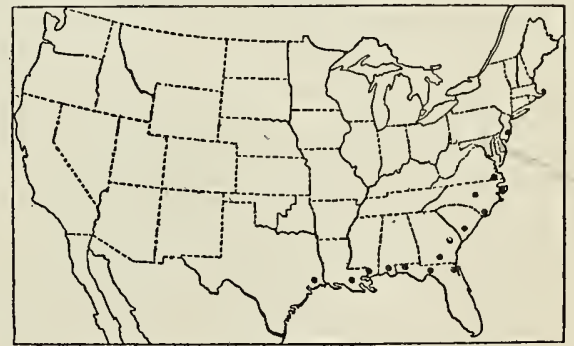

FIG. 339.-Distribution of P. scabriusculum. Washington, Combs 616; without locality, Chapman.

Alabama: Flomaton, Hitchcock 1052, Tracy 3643; Mobile, Kearney 27, 39; Mobile County, Mohr in 1888.

MississipPi: Beauvoir, Tracy 4617; Biloxi, Tracy 4569.

Louisiana: New Orleans, Drummond (Gray Herb.).

Texas: Nona, Nealley 38 in 1892; without locality, Nealley in 1885, Wright (Gray Herb.).

\section{Panicum cryptanthum Ashe.}

Panicum cryptanthum Ashe, N. C. Agr. Exp. Sta. Bull.175: 115. 1900. "Collected by the writer in swamps at Wilson's Mill, N. C., in July 1897." The type, in Ashe's herbarium, is a specimen arbitrarily chosen from among four bearing the label, "Wilson's Mill, N. C. July 15, 1897. W. W. Ashe collector," and with the additional data, "In a small swamp on north side of railroad about one mile west of the station." The name does not appear upon any of the sheets, but these plants agree with the 
description and are from the locality as published. These specimens all are the autumnal form, with the reduced panicles partially inclosed in the sheaths.

An earlier Panicum cryptanthum "Nuttall. Gen." is a nomen nudum. It is men-

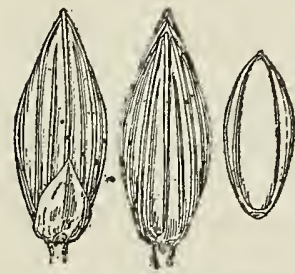

FIG. 340.-P. cryptanthum. From type specimen. tioned without description under Panicum cynodon Reichardt by Hillebrand $a$ as a name in Kew Herbarium.

\section{DESCRIPTION.}

Vernal form cespitose; culms erect, 80 to $100 \mathrm{~cm}$. high, glabrous except the usually bearded nodes; sheaths glabrous or the lowermost sparsely hirsute, the upper somewhat inflated, all more or less ciliate on the margins and pilose at the summit; ligules membranaceous, erose, scarcely $0.5 \mathrm{~mm}$. long; blades stiff, ascending or spreading, acuminate, involute-pointed, glabrous, sparingly ciliate at base, 10 to $15 \mathrm{~cm}$. long, 7 to $9 \mathrm{~mm}$. wide; panicles short-exserted, 6 to $10 \mathrm{~cm}$. long, nearly as wide, the axis and ascending branches viscid-spotted; spikelets 2.2 to $2.4 \mathrm{~mm}$. long, $1 \mathrm{~mm}$. wide, lanceolate-elliptic, pointed; first glume one-fourth to one-third as long as the spikelet; second glume and sterile lemma equal, longer than the fruit and pointed beyond it, glabrous or sparsely pilose; fruit $1.5 \mathrm{~mm}$. long, $0.9 \mathrm{~mm}$. wide, elliptic.

Autumnal form erect, glabrate on the nodes, sparingly branching from the middle and upper nodes, the branches stiffly ascending at an angle of 30 to 45 degrees; blades flat, stiffly ascending, 2 to $5 \mathrm{~cm}$. long, 3 to $5 \mathrm{~mm}$. wide, involute-pointed; panicles reduced to a narrow cluster partially hidden in the sheaths.

The habit of this species suggests a small P. scabriusculum.

\section{DISTRIBUTION.}

Low swampy ground, North Carolina to northern Florida, also in Texas; rare. Jolsorn New JeRsey: Atlantic Gity, Long in 1909 (Phila. Acad. Herb.).

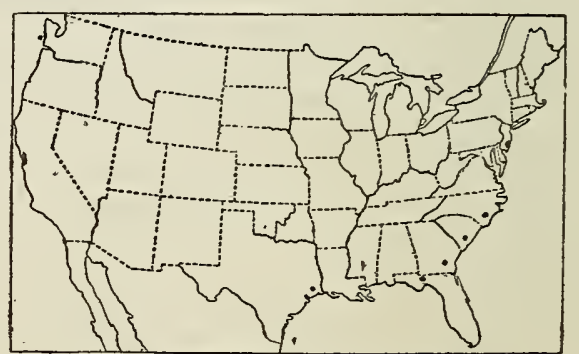

FIG. 341.-Distribution of P. cryptanthum.

North Carolina: Wilsons Mills, Ashe in 1897; Wilmington, Hitchcock 371, 1469.

South Caroliva: Orangeburg, Hitchcock 1377.

Georgia: Belair, Eggert in 1899 (Mo. Bot. Gard. Herb.).

Florida: De Funiak Springs, Combs 444.

TexAs: Kountzê, Nealley 37 in 1892.

Commutata.-Culms rather stout; glabrous or puberulent; ligules obsolete or nearly so; blades usually $1 \mathrm{~cm}$. or more wide (often narrower in $P$. ashei and $P$. equilaterale), cordate and more or less ciliate at base; spikelets 2.4 to $3.2 \mathrm{~mm}$. long, elliptic, not very turgid, pubescent, 7 to 9-nerved. Autumnal form usually not very freely branching.

Plants glaucous, glabrous; basal blades conspicuously ciliate;

vernal culms usually solitary . ................. 185. P. mutabile.

Plants not glaucous.

Blades nearly linear, that is with parallel margins; first glume about half as long as the spikelet.

Primary panicles long-exserted; sheaths mottled with white ............................188. P. albomaculatum. 
Primary panicles short-exserted; sheaths not mottled.................................187. P. equilaterale.

Blades lanceolate.

Culms crisp-puberulent; blades usually rigid, symmetrical, rarely over $10 \mathrm{~mm}$. wide; spikelets about $2.5 \mathrm{~mm}$. long.....................183. P. ashei.

Culms glabrous or softly puberulent; blades firm or lax; spikelets 2.7 to $3.2 \mathrm{~mm}$. long.

Culms erect, or autumnal form leaning; blades symmetrical, broadly cordate............184. . P. commutatum.

Culms decumbent; blades usually unsymmetrical and falcate, narrowed to the scarcely cordate base........................186. P.joorii.

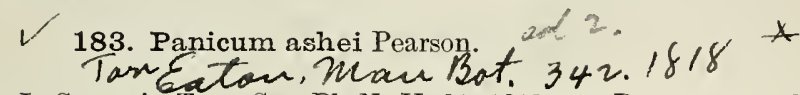

Panicum umbrosum LeConte, in Torr. Cat. PI. N. Y. 91. 1819, not Retz. 1786. On page 19 of this work the locality is given as, "In woods, Bloomingdale, N. Y." The type, in the Torrey Herbarium, consists of two vernal culms. On the same sheet is mounted a piece of a culm of $P$. dichotomum. On the label is written "Panicum umbrosum mihi" in LeConte's hand, to which is added in Torrey's hand, "(Le Conte)." The description as given by LeConte does not apply to this specimen in all respects. The culm and flowers are said to be glabrous, which is true of the specimen of $P$. dichotomum, but the other characters apply better to the two culms of P. ashei.

Panicum ashei Pearson; Ashe, Journ. Elisha Mitchell Soc. 15:35. 1898. "P.commutatum Schultes var. minor Vasey, Contrib. from U. S. Nat. Herb., vol. 3, No. I: 32 (1892). Not $P$. capillare var. minus Muhl. (1817)." It would appear from this citation that $P$. ashe $i$ was intended as a change of name, but "sp. nov." follows the author's name, preceding the above citation, and a description is given. Hence the synonym $a$ may be regarded as an error and the first specimen cited, "New York: Ashe; Ithaca, July 1898," may be taken as the type. This specimen could not be found in Ashe's herbarium, but there is a duplicate in the National Herbarium sent by Ashe, and labeled in his writing "Panicum Ashei, G. Pearson, Dry woods, Ithaca, N. Y. W. W. Ashe, July 1898." This consists of two vernal plants beginning to branch, with mature primary panicles; the culms and blades are less rigid than usual for this species. In the description the culms and sheaths are said to be glabrous, but in this specimen the culms and sheaths are crisp-puberulent.

\section{DESCRIPTION.}

Vernal plants usually conspicuously purplish, in loose clumps of few to several culm from a knotted crown; culms 25 to $50 \mathrm{~cm}$. high, erect, stiff and wiry, densely crisppuberulent, including the nodes; sheaths shorter than the internodes, less densely puberulent, short-ciliate; ligules obsolete; blades usually thick and firm, spreading or ascending, 4 to $8 \mathrm{~cm}$. long, 5 to $10 \mathrm{~mm}$. wide (the lower gradually smaller), acuminate, ciliate at the subcordate base and sometimes along the very scabrous margin, glabrous on both surfaces; panicles finally long-exserted, 5 to $8 \mathrm{~cm}$. long, hardly as wide, loosely flowered, the branches usually in distant fascicles, ascending or spreading; spikelets 2.4 to $2.7 \mathrm{~mm}$. long, 1.2 to $1.3 \mathrm{~mm}$. wide, oblong-elliptic, obtuse or obscurely pointed, short-pubescent; first glume about one-third the length of the spikelet, subacute; second glume and sterile lemma subequal, slightly exposing the fruit at maturity, obtuse or withering to a point; fruit $2.1 \mathrm{~mm}$. long, $1.1 \mathrm{~mm}$. wide, elliptic, minutely umbonate.

$a$ See synonymy under $P$. commutalum, page 304 .
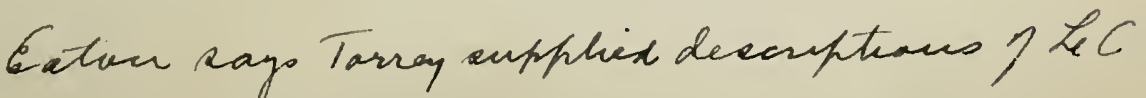
Autumnal form erect or topheavy-reclining, the culms bearing divergent branches from the middle and upper nodes or from the upper only, the terminal joint of the primary culm commonly falling, the sheaths crowded or overlapping, the blades rigid and widely spreading, little reduced except those of late autumn; winter rosette

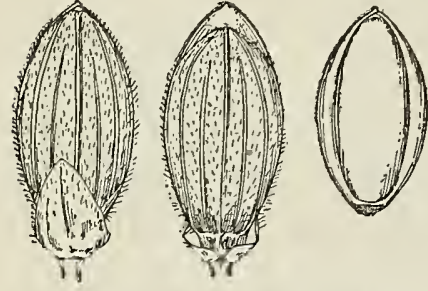

Fig. 342.-P. ashei. From duplicate type specimen in National Herbarium. appearing early, the blades thick and firm, usually prominently ciliate nearly to the apex.

This unusually uniform species is distinguished from $P$. commutatum by the rigid habit, thicker, narrower blades, crisp-puberulent culms and sheaths, and by the more freely branching, often topheavy autumnal form. Occasional specimens, such as Bissell 5580 and Andrews 63 have spikelets only 2.1 to $2.3 \mathrm{~mm}$. long.

There is a form represented by several specimens which appears to be intermediate between $P$. ashei and P. barbulatum. The plants grow in large clumps of numerous stiff culms, with narrow blades ciliate at the base, and with spikelets about $2 \mathrm{~mm}$. long. These specimens are as follows. New York: Lawence, Bicknell in 1892; New Jersey: Tuckerton, Chase 3601 $\frac{1}{2}$; District of Columbia: Hitchcock 503; South Carolina: Orangeburg, Hitchcock 1406, 1407.

\section{IISTRIBUTION.}

Dry, especially rocky woods, Massachusetts to northern Florida, west to Michigan, Missouri, and Mississippi.

Massachusetts: Malden, Fernald in 1891 in part; West Quincy, Churchill in 1894 (both in Hitchcock Herb.).

Connecticut: Montville, Graves 88; New London, Andrews 63; North Stonington, Bissell 5580.

Rhone Island: Providence, Olney.

New York: Ithaca, Ashe in 1898; Northville, Bicknell in 1903 and 1904, Young 4; Rockdale Center, Bicknell in 1906; Rosedale, Bicknell in 1904.

New Jersey: South Amboy, Mackenzie 2163; Sussex County, Mackenzie 2195; Wildwood, Chase 3502; Wildwood Junction, Chase 3521; Atsion, Chase 3542; Egg Harbor, Martindale in 1876; Oradell, Mackenzie 2480.

Pennsyluania: Easton, Porter in 1895, 1897, and 1898; Chambersburg, Porter in 1898; Lancaster County, Heller 4770 in part, 4780 .

Онго: Niles, Ingraham in 1892; Painesville, Hacker 6878; Sugar Grove, Kellerman 6892.

Indiana: Clarke County, Deam $6467,6905$.

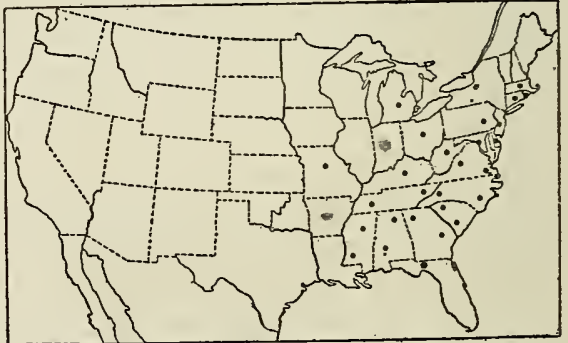

FIG. 343,-Distribution of $P$. ashci.

Michigan: Muskegan, Wheeler 19.

Missouri: Swan, Bush 17, 2911, 3456, 4487; Pleasant Grove, Bush 289, 312; Monteer, Bush 4714; Chadwick, Bush 4412.

Delaware: Wilmington, Commons 61; Milton, Commons 349, 356, 357; Greenbank, Commons 37; Ellendale, Commons 308; Frankford, Commons 53.

Maryland: Patuxent, House 961, Hitchcock 1640; Beltsville, Chase 3787; Hyattsville, Steele in 1903; Woodside, Chase 2830; West Chevy Chase, Chase 2477; Plummers Island, Hitchcock 564; Chesapeake Junction, Hitchcock 2410. 
District of Columbia: Chase in Kneucker Gram. Exs. 556, Hitchcock 422, 425, 568, Kearney in 1897, Ward 2, 7, 9, Williams 3, 4, 10.

Virginia: Great Falls, Chase 3704, Four-Mile Run, Pollard 180; Norfolk, Kearney 299, 1029; Portsmouth, Noyes 103; Virginia Beach, Pollard \& Maxon in 1900; Munden, Mackenzie 1708; Dismal Swamp, Chase 3679, Tyler in 1905; Clifton Forge, Tidestrom 4.

West Virginia: Summers County, Morris 977; Tibbs Run, Sheldon 566; Fayette County, Kellerman 6901.

North Carolina: Roanoke Island, Chase 3220; Wilmington, Hitchcock 424, 1461; Chapel Hill, Ashe, Chase 3051, 3064; Magnetic City, Wetherby 58; Lenoir, Hitchcock 565.

South Carolina: Orangeburg, Hitchcock 1388; Pelzer, House 2430; Clemson College, House 2105; Aiken, Hitchcock 566.

Georgia: Augusta, Cuthbert 427, 1163, Kearney 207; Stone Mountain, Eggert 44, Hitchcock 423, 567, 1353; Thomson, Bartlett 1458, 1504.

Florida: Chattahoochee, Tracy 3629 (Field Mus. Herb.).

Kentucky: Harlan County, Kearney 34 in part, 54 in part.

Tennessee: Polk County, Chambliss 14, 88, Kearney 324; Knoxville, Smith in 1895, Scribner in 1891; Nashville, Gattinger in 1882.

Alabama: Pisgah, Chase 4473; Scottsboro, Chase 4498; Auburn, Hitchcock 1323, 1327, Tracy 3747, 3756; Tuskegee, Ball in 1901.

Mississippi: Enterprise, Tracy 3275; Meridian, Tracy 3268.

Quel:

184. Panicum commutatum Schult.

Panicum nitidum majus Pursh, Fl. Amer. Sept. 1: 67. 1814. No specimen nor locality is cited. Among the Pursh plants in Kew Herbarium is a sheet upon which are mounted a specimen of $P$. commutatum and one of $P$. yadkinense. Above the first is a label reading "Panicum nitidum Mx.," and above the latter one reading "Panicum nitidum major." Since Pursh's description of the variety is "omnibus partibus multo majus," it would appear that the labels have been transposed, and that the specimen of $P$. commutatum should be taken as the type of variety majus.

Panicum nervosum Muhl.; Ell. Bot. S. C. \& Ga. 1: 122. 1816, not Lam. 1797. Elliott states that the species "grows in dry shaded soils," but no definite locality is given. The type specimen, in the Elliott Herbarium, consists of portions of two culms, the panicle of one destitute of spikelets. The culms are glabrous, the sheaths glabrous or minutely puberulent between the nerves, densely puberulent on the back at the summit, blades papillose-ciliate at base, otherwise glabrous. The accompanying label reads: "Panicum nervosum Muhl. Hab. Car. et Geor:" This species was also described as $P$. nervosum by Muhlenberg, ${ }^{a}$ but there is no specimen to represent this in the Muhlenberg Herbarium. In this description the ligule is said to be "barbaeform," and the species "P. aquaticob affine." This throws some doubt on the identity of Muhlenberg's specimen with the type of $P$. nervosum Muhl.; Ell. in Elliott's Herbarium. But the statement that the leaves are lanceolate and ciliate at base, and that the panicle branches are numerous and spreading shows that the species has no close affinity to his $P$. aquaticum, as suggested by Muhlenberg. Since no specimen can be found by which to interpret Muhlenberg's description, it is here assumed that his type is the same as Elliott's and that the statement concerning the ligule is an error.

Panicum commutatum Schult. Mant. 2: 242. 1824. Based on "P. nervosum Mühlenb. Descr. ub. p. 117" [error for 116], the name presumably changed because of 
P. nervosum Lam. 1797. Muhlenberg's description, including "ligula barbiformis," is copied. It is evident that Schultes had not seen a specimen of this. $a$

Panicum enslini Trin. Gram. Pan. 230. 1826. "Am.[erica] bor.[ealis] (TrattrnICK, e collect. Enslini)." The type, in the Trinius Herbarium, is the vernal form. The accompanying label in Trinius's hand reads "Panicum Enslini m. (An Pan. tenue Muhl. quaerit Nees ab Es.) ab Enslino in Am. bor. 1. dt. sine nom. cl. Trattinick Wiennae 1820." There is a duplicate specimen in the Vienna Herbarium. Judging from a small portion of the type sent to the National Herbarium from the Trinius Herbarium $^{b}$ this was thought to be the same as $P$. equilaterale, but from subsequent study of the somewhat fragmentary entire specimen and of the duplicate it appears to be a narrow-leaved form of $P$. commutatum.

Panicum polyneuron Steud. Syn. Pl. Glum. 1: 91. 1854. Based on "P. nervosum Mühlbrg. Gram. p. 116, Torr. Fl. N. Am. I. 143." The description, however, is a translation of that given in Torrey's Flora $c$ for $P$. nervosum and applies to the species described as $P$. macrocarpon LeConte, $d$ which proves to be the true $P$. latifolium $\mathrm{L}$. On the type sheet of $P$. macrocarpon LeConte, in Columbia University Herbarium, is written in Torrey's hand "(P. nervosum Muhl. T.)." [T. probably stands for Torrey, that is, $P$. nervosum Muhl. according to Torrey.]

Panicum commutatum minor[us] Vasey, U. S. Dept. Agr. Div. Bot. Bull. 8: 34 . 1888. "Southern States." The only specimen marked with this name in Vasey's writing is found in Nash's herbarium, having been obtained through exchange of duplicates with Dr. Vasey. This is a small, immature, vernal specimen with glabrous culms, collected by Ravenel at Aiken, S. C., in 1867, and is labeled in Vasey's hand "P. commutatum var. minor Vasey."

Panicum commutatum latifolium Scribn. in Kearney, Bull. Torrey Club 20: 476. 1893. This is described in a single line in a footnote to notes on plants collected on Pine Mountain, southeastern Kentucky, in August, 1893, as follows: "Leaves very broad, panicle large, the widely spreading branches few-flowered." On page 479 this name is listed as Kearney no. 299. In the Scribner Herbarium is a specimen of $P$. commutatum with unusually wide blades and large panicles, which is probably.the plant referred to, although there are no data with the specimen.e The sheet is marked $P$. latifolium Ell., through which is drawn a line and below in Scribner's hand is written "Panicum commutatum Schultes."

Panicum commelinaefolium Ashe, Journ. Elisha Mitchell Soc. 15: 29. 1898, not Rudge, 1805. "Based on material collected by Dr. J. K. Small near Stone Mt., Ga., Aug. 1-6, 1895." The type, in the Biltmore Herbarium, consists of several late ver. nal culms beginning to branch, with short internodes and short-exserted panicles. The culms, sheaths, and both surfaces of the blades are puberulent, the blades 1.7 to $2.5 \mathrm{~cm}$. wide, the spikelets $2.8 \mathrm{~mm}$. long.

Panicum currani Ashe, Journ. Elisha Mitchell Soc. 15: 113. 1899. Based on $P$. commelinaefolium Ashe, not Kunth.

Panicum subsimplex Ashe, N. C. Agr. Exp. Sta. Bull. 175: 115. 1900. "Collected by Mr. A. Commons in dry rocky woods near Wilmington, Del., in August." The type, in Ashe's herbarium, consists of autumnal culms, with broadly elliptic, somewhat falcate blades 1.5 to $2.5 \mathrm{~cm}$. wide, and small, few-flowered panicles, overtopped by the upper blades.

$a$ Schultes seems not to have had Elliott's Botany of South Carolina and Georgia, since where he refers to this work (Mant. 2: 256-257) he does so on the authority of Nuttall's Genera Plantarum.

$b$ See Hitchcock, Bot. Gaz. $41: 65.1906$.

c Fl. North. \& Mid. U. S. 143. 1823.

$d$ LeConte in Torr. Cat. Pl. N. Y. 91. 1819.

$e$ Other Kearney specimens in the Scribner Herbarium are often marked with collector's name and number only, without other data 


\section{DESCRIPTION.}

Vernal plants commonly purple-tinged; culms in clumps of few to many, 40 to 75 $\mathrm{cm}$. high, rather stout, erect, glabrous or sometimes softly (not crisp) puberulent; nodes puberulent; sheaths shorter than the long internodes, ciliate on the margin and with a densely puberulent ring at the summit, otherwise glabrous or puberulent between the nerves; ligules nearly obsolete; blades usually firm, spreading or ascending, 5 to $12 \mathrm{~cm}$. long, 12 to $25 \mathrm{~mm}$. wide, the lower and upper smaller than those of the midculm, rather abruptly tapering to an acuminate apex and slightly narrowed to the cordate-clasping base, glabrous on both surfaces or puberulent beneath or sometimes also above, the margin ciliate at the base; panicles usually long-exsèrted, 6 to $12 \mathrm{~cm}$. long, as wide or wider, loosely flowered, the axis glabrous or nearly so, the flexuous branches spreading; spikelets 2.6 to $2.8 \mathrm{~mm}$. long, $1.3 \mathrm{~mm}$. wide, oblongelliptic, obtuse, softly pubescent; first glume about one-fourth the length of the spikelet, triangular, acute or obtuse; second glume and sterile lemma barely covering the fruit at maturity; fruit 2.2 to $2.3 \mathrm{~mm}$. long, $1.2 \mathrm{~mm}$. wide, elliptic, minutely umbonate.

Autumnal form erect or leaning, branching from the middle nodes, the portion of the primary culm above the uppermost branch commonly falling away, leaving the branch, with its shortened internodes, crowded, rather loose sheaths, scarcely or not at all reduced blades, and hardly exserted panicle, as the apparent termination of the primary culm; secondary branchlets crowded toward the summit, the reduced blades

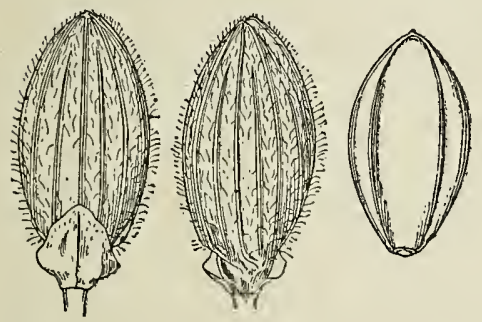

Fig. 344.-P. commutatum. From type specimen of $P$. nervosum Muhl. in Elliott Herbarium. exceeding the partly included, much reduced panicles; winter rosette appearing rather early, the blades firm, ovate.

This species is typically almost glabrous, with stiff culms and firm blades, but puberulence occurs rather commonly and is not found to be associated with any other character. The type of $P$.currani is puberulent throughout and has somewhat broader blades than common in P. commutatum, but these characters are too variable to allow of separating this form as a species. In some specimens the culms only are puberulent, in others the sheaths or the lower surface of the blades only. The puberulence can not be coördinated with the wide blades. Some puberulent specimens have ordinarily wide blades and other specimens with wide blades are glabrous.

Early autumnal specimens in which the upper branch has replaced the terminal portion of the main culm sometimes appear very different from vernal specimens, owing to a somewhat unsymmetrical broadening of the middle of the crowded upper blades. The type of $P$. subsimplex is such a specimen. A plant collected by Scribner at White Cliff Springs, Tenn. (in Hitchcock's herbarium), shows several culms of typical $P$. commutatum, the terminal portions widely divaricate, but not yet fallen, and the upright branches with the unsymmetrically broadened blades as in the type of $P$. subsimplex.

A few southwestern specimens such as Hitchcock 1104, 1253, Langlois 39, and 41 in part, Nealley in 1887 and Tracy 4577, differ in appearance from P.commutatum, having rather slender culms and narrower blades and seem to approach $P$. joorii, but the spikelets are not over $2.8 \mathrm{~mm}$. long.

Most of the Florida specimens are taller and more robust and have blades sometimes as much as $20 \mathrm{~cm}$. long and spikelets 3 to $3.2 \mathrm{~mm}$. long. This form can not be satisfactorily separated even as a subspecies, though extreme specimens differ sufficiently

$$
41616^{\circ} \text { - voL } 15-10-20
$$


to be recognizable. The following specimens represent this variation: Chase 4205 , Combs 89, 156, 886, 926, 1038, Curtiss 3583* in part, Hitchcock 757, 1008, Nash 1119, Tracy 3629 .

\section{DISTRIBUTION .}

Woods and copses, Massachusetts to Illinois, south to Florida and Texas.

Massachusetts: Wellesley, Rich in 1899.

Pennsylvania: Lancaster County, Heller 4768; Ohiopyle, Ricker 1153.

Онго: Vinton, Kellerman 6881.

Indiana: Clarke County, Deam 6595.

ILLINOIS: Without locality, Schneck in 1879.

Michigan: Agricultural College, Wheeler in 1890 (Mich. Agr. Col. Herb.).

Missouri: Butler County, Eggert 257 in 1893; Carter County, Eggert 290; Monteer, Bush 755, 4685; Malden, Bush 731; Campbell, Bush 748; Pleasant

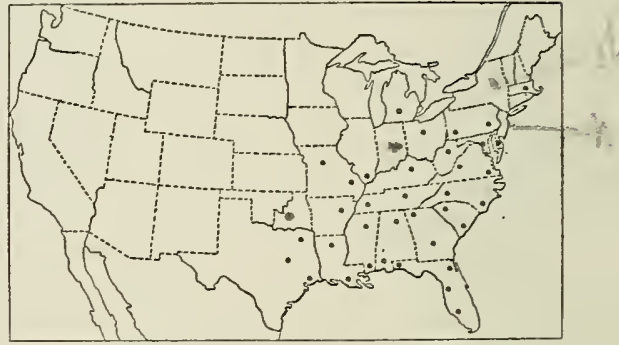

Fig. 345.-Distribution of $P$. commutatum. Grove, Bush 238, 287, 308, 322; Grandin, Bush 2736.

Delaware: Frankfort, Commons 48; Mount Cuba, Chase 3621, Commons 309.

Maryland: Great Falls, Chase 5436, Ward in 1882; Riverdale, Chase 2381.

District of Columbia: Chase in Kneucker Gram. Exs. 557, Hitchcock 426, 569, Kearney 31, Merrill 204, Scribner in 1894, Steele in 1899, Vasey in 1874, 1881, 1883, and 1884, Ward in 1879.

Virginia: Near Norfolk, Kearney 1317, 1414, 1463, Noyes 69, 74, Pollard \& Maxon in 1900; Dismal Swamp, Chase 3654, 3678; Smyth County, Small 2, 8, and 14, in 1892.

West Virginia: Fayette County, Kellerman 6902.

North Carolina: Jacksonville, Chase 3168; Wilmington, Chase 3114, Hitchcock 1458; Chapel Hill, Ashe in 1898, Chase 3052; Biltmore, Biltmore Herb. 802b, Hitchcock 570, 571; Lenoir, Hitchcock 428; Magnetic City, Wetherby 59; Columbus, Townsend in 1897; Rowan County, Small \& Helier 201.

South Carolina: Orangeburg, Hitchcock 1413, 1414; Clemson College, House 2106, 2179, 2387.

Georgia: Chickamauga, Ruth 11; Stone Mountain, Eggert 43, 45, Hitchcock 427, 1348; Augusta, Cuthbert in 1900; Athens, Harper 60; Rabun County, House

2305; Cobb County, Harper 221; Albany, Tracy 3630; Warm Springs, Tracy 8866; Brooks County, Harper 1623.

Florida: Duval County, Curtiss $3583^{*}$ in part, 4027, 4636 (last two in Hitchcock Herb.), Fredholm 455; Lake City, Combs 89, 139, 156, Hitchcock 572, 1008; Chattahoochee, Tracy 3629 in part; Apalachicola, Biltmore Herb. 802a; Madison, Combs 251; Monticello, Combs 330; Chipley, Combs 589, 601; Old Town, Combs 886; Homosassa, Combs 926; Titusville, Hitchcock 757; Clarcona, Meislahn 168a, 189; Grasmere, Baker 42, Combs 1038, 1098; Eustis, Nash 45 in part, 78, 240 in part, 302, 1119, 1675; Gainesville, Chase 4205; Manatee, Tracy 7382; Manavista, Tracy 6695.

Kentucky: Harlan County, Kearney 34 in part, 172. 
Tennessee: Hiwassee Gorge, Kearney 327; Wolf Creek, Kearney 972, 973, and in 1894; Knoxville, Ruth 61; Lavergne, Biltmore Herb. 2984a; Kingston Springs, Gattinger in 1882; Jackson, Bain in 1893; Greenhill, Gattinger in 1881.

Alabama: Scottsboro, Chase 4504; Auburn, Earle \& Baker 1531, Hitchcock 1319, 1328, 1339; Tuskegee, Carver 60, 88, 93, 94; Blount County, Eggert 22; Etowah County, Eggert 7; Flomaton, Hitchcock 1049; Mobile, Mohr.

Mississippi: Starkville, Tracy in 1888; Enterprise, Tracy 3296 in part; Biloxi, Tracy 4577 in part, Tracy in Pollard Distr. 1416; Ocean Springs, Earle in 1895; Petit Bois Island, Tracy 4577 in part; Bayou Gravelin, Tracy 4573; Mississippi City, Hitchcock 1104, 1108.

Arkansas: Fulton, Bush 234, 1450.

Louisiana: Calhoun, Ball 66, Hitchcock 1268, 1274, 1286, 1291; Shreveport, Hitchcock 1253; Alexandria, Ball 625; Plaquemines Parish, Langlois 39.

Texas: Houston, Bebb 1242, Hall 831, Nealley 18, Ravenel 46; Texarkana, Heller 4083; Columbia, Bush 1224; Grand Saline, Revcrchon 4143; Palestine, Qblank 55.

185. Panicum mutabile Scribn. \& Smith.

Panicum mutabile Scribn. \& Smith; Nash in Small, Fl. Southeast. U. S. 103. 1903. On page 1327 is the following citation: "Type, Biloxi, Miss., Tracy no. 3074, 1896 in Herb. Nash." The type, in Nash's herbarium, is the early branching form, the blades from the basal shoots large, 10 to $15 \mathrm{~cm}$. long, 13 to $24 \mathrm{~mm}$. wide, prominently ciliate almost to the apex, the culm blades ciliate toward the base only.

\section{DESCRIPTION.}

Vernal plants blue green, glaucous; culms solitary or few in a tuft, erect, 30 to $70 \mathrm{~cm}$. high, glabrous or rarely minutely pubescent; sheaths much shorter than the internodes, glabrous except the usually sparsely ciliate margin; ligules very short, membranaceous-fimbriate; blades horizontally spreading, 6 to $15 \mathrm{~cm}$. long, 8 to 20 $\mathrm{mm}$. wide, tapering to both ends, rather thin, glabrous on both surfaces, ciliate on the

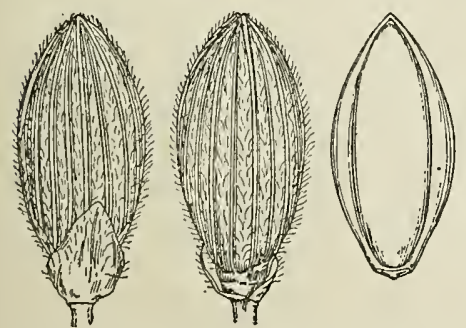

FIG.346.-P.mutabile. From typespecimen. margin toward the cordate base or the lower ciliate nearly to the apex; panicles 7 to $15 \mathrm{~cm}$. long, about as wide, very loosely few-flowered; spikelets 2.9 to $3 \mathrm{~mm}$. long, $1.2 \mathrm{~mm}$. wide, elliptic, minutely pointed, pubescent; first glume about one-third as long as the spikelet, subacute; second glume and sterile lemma equaling or slightly exceeding the fruit; fruit $2.6 \mathrm{~mm}$. long, $1.1 \mathrm{~mm}$. wide, elliptic, subacute.

Autumnal form erect or reclining, sparingly branching from the middle and upper nodes, the branches longer than the internodes, finally producing toward the ends fascicles of shortened branchlets with somewhat reduced leaves.

This species differs from $P$. commutatum in the glaucous blue green color, the more slender culms, solitary or few in a tuft, the glabrous sheaths, the narrower blades and the conspicuously ciliate basal blades. In herbarium specimens the glaucous color may be seen best on the culm below the nodes. 
DISTRIBUTION.

Sandy pine woods or hammocks, southeast Virginia to northern Florida and west to Mississippi.

Virginia: Cape Henry, Chase 5437, Hitchcock 429.

North Carolina: Wards Mill, Chase 3189; Wilmington, Chase 3154, Hitchcock 573, 1465.

Georgia: Stone Mountain, Hitchcock 430; Clarke County, Harper 147; Coffee County, Harper 1435; Thomson, Bartlett 1508.

Florida: Lake City, Chase 4290, Hitchcock 1015, 1035; Madison, Combs 224; Monticello, Combs 299, 307; Bay Head, Combs 653; Gainesville, Combs 740 .

Alabava: Gateswood, Tracy 8424.

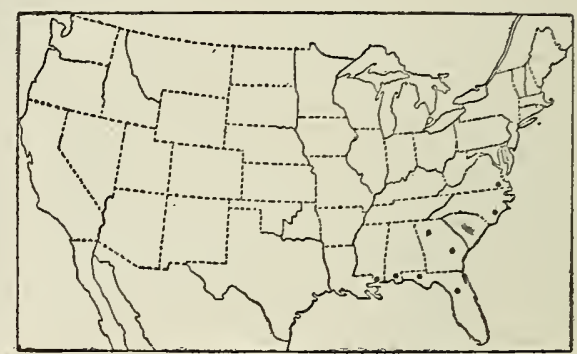

Fig. 347.-Distribution of $P$. mutabile.

Mississippi: Biloxi, Kearney 336, Tracy 3646; Mississippi City, Hitchcock 1103; Bayou Gravelin, Tracy 4573 (Field Mus. Herb.).

186. Panicum joorii Vasey.

Panicum leiophyllum Fourn. Mex. Pl. 2 : 20. 1886, not Nees, 1829. The only specimen cited is "In valle Cordovensi, januario (Bourg[Eav] absque n.)." This name was earlier listed by Hemsley $a$ without description. The type, in the Paris Herbarium, consists of several primary culms beginning to branch, the culms puberulent, the largest blades about $8 \mathrm{~cm}$. long and $12 \mathrm{~mm}$. wide.

Panicum joorii Vasey, U. S. Dept. Agr. Div. Bot. Bull. 8: 31. 1889. "Louisiana (Dr. J. F. Joor)." The type, in the National Herbarium, is a clump of several autumnal culms, branching at all the nodes, the primary summits mostly fallen and replaced by branches bearing fascicled branchlets, the primary blades as much as $16 \mathrm{~cm}$. long and $18 \mathrm{~mm}$. wide, more or less falcate. The accompanying label reads: "Panicum Joorii, Creek bank, in dense tufts! near Baton Rouge, La. Oct. 1, '85. No. 39 Legit J. F. Joor, M. D."

Panicum manatense Nash, Bull. Torrey Club 24:42. 1897. "Collected by the writer on August 21, 1895, near a sulphur well in a wet hammock northeast of Palmetto, Manatee County, Florida, no. 2428a." The type, in Nash's herbarium, is a clump of early autumnal culms branching from all the nodes, the largest primary blades being scarcely $8 \mathrm{~cm}$. long and $15 \mathrm{~mm}$. wide, somewhat falcate.

\section{DESCRIPTION .}

Vernal form rather pale grayish green; culms in clumps of few to many, 20 to $55 \mathrm{~cm}$. high, slender, spreading or ascending from a decumbent base, glabrous or rarely puberulent, at least the lower internodes purplish red; sheaths shorter than the internodes, ciliate, otherwise glabrous or rarely puberulent between the nerves; ligules nearly obsolete; blades ascending or spreading, 6 to $15 \mathrm{~cm}$., rarely $18 \mathrm{~cm}$. long, 7 to $18 \mathrm{~mm}$. wide, thin but firm, often subfalcate, acuminate, narrowed toward the rounded base, usually ciliate at base, otherwise glabrous; panicles short-exserted, 5 to $9 \mathrm{~cm}$. long, about two-thirds as wide, loosely flowered, the branches ascending or spreading; spikelets 3 to $3.1 \mathrm{~mm}$. long, 1.2 to $1.3 \mathrm{~mm}$. wide, elliptic, abruptly short-pointed, pubescent; first glume one-third to two-fifths as long as the spikelet, acute; second glume and

a Biol. Centr. Amer. Bot. 3 : 490. 1885. 
sterile lemma more or less pustulate-papillose between the nerves, the glume slightly shorter than the usually involute-pointed sterile lemma; fruit $2.4 \mathrm{~mm}$. long, $1.2 \mathrm{~mm}$. wide, elliptic, minutely umbonate.

Autumnal form widely spreading, bearing more or less divaricate branches from all the nodes, these primary branches longer than the internodes and branching from all or from their upper nodes, the ultimate branchlets in short, dense fascicles, the
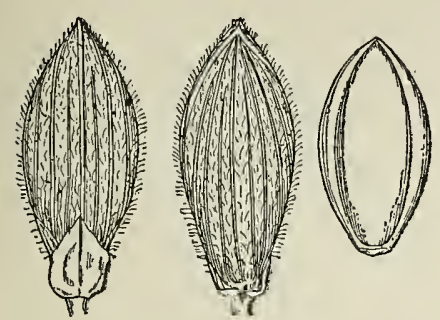

FIG.348.-P.joorii. From type specimen. reduced blades ascending, exceeding the numerous, small, partly included panicles; winter rosette a crown of a few short, leafy, basal shoots, with evident internodes.

The type of $P$. joorii is an exceptional specimen, having unusually large blades. The only other collection seen which entirely matches the type is Chase 4274 (Lake City, Florida), in which the blades are even a little longer than in Joor's no.39. Harper's no. 1106 (Georgia) and Tracy 120 and 3318 (Mississippi) are much like the type.

The type of $P$. manatense represents the usual form in its early autumnal state. As a whole this species has glabrous culms, sheaths, and blades, but occasional specimens more or less puberulent are found, such as Combs 860, Heller 4120, and Hitchcock Lee Co. Pl. 477.

Three specimens with spikelets only 2.2 to $2.5 \mathrm{~mm}$. long, and with more or less pubescence on culms and sheaths are doubtfully referred here: FloridA: Orange Bend, Chase 4094. Louisiana: Burnside, Combs 1427; Plaquemines Parish, Langlois 39.

\section{DISTRIBUTION.}

Low or swampy woods, southeastern Virginia to Florida, west to Texas and Arkansas; also in Mexico.

Virginia: Princess Anne County, Mackenzie 1794.

South Carolina: Isle of Palms, Chase 4550.

Georgia: Burke County, Harper 767; Leslie, Harper 1106; Albany, Tracy 3655; Thomson, Bartlett 1501.

Florida: Lake City, Chase 4274, Combs 144, Hitchcock 1011; Madison, Combs 270; Chattahoochee, Curtiss in 1884; Quincy, Combs 412; Tallahassee, Combs 373; Old Town, Combs 860; Titusville, Chase 4019, Hitchcock 756, 760; Eustis, Nash 240 in part; Orange Bend, Chase 4099; Eldorado, Chase 4126; Gainesville Chase 4219, 4256; Dunnellon, Combs 921; Mary Esther, Tracy 9142; Bartow, Combs 1237; Tampa, Combs 1393, 1400, Hitchcock 947; Manatee,

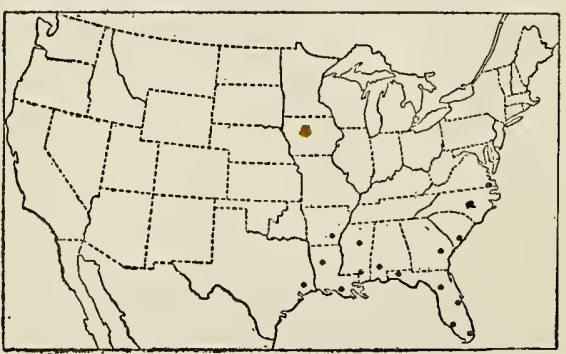

FIG. 349.-Distribution of $P$. joorii.

Hitchcock 976, Rugel 351, 378; Myers, Chase 4181, Hitchcock 909, Lee Co. PI. 471; Alva, Hitchcock Lee Co. Pl. 477; Miami, Chase 3907, 3948, Eaton 169, Hitchcock 576, 636, 652, 660, 674 .

Alabama: Chehaw, Hitchcock 577.

Mississippi: Starkville, Chase 4468; Tracy 29 in 1889; Morrisville, Tracy 3387; Bludlebury, Tracy 3318; Lake, Tracy 120 in 1888; Meridian, Tracy 3266.

Arkansas: Lafayette County, Heller 4120. 
Loursiana: Rayville, Ball 25; Lake Charles, Chase 4430, 4437, Hitchcock 1142; Plaquemines Parish, Langlois 41 in part.

Texas: Waller, Hitchcock 1207, 1208, Thurow in 1898; Houston, Hall 828 (Gray Herb.).

Mexıco: Córdoba, Bourgeau in 1866 (Paris Herb.). Berlarndier 401, 496; Lielmamon 329; Vincernt 110 .

\section{$\checkmark$ 187. Panicum equilaterale Scribn.}

Panicum equilaterale Scribn. U. S. Dept. Agr. Div. Agrost. Bull. 11: 42. pl. 2. 1898. Two specimens are cited as follows: "In pine lands [Eustis], Florida (No.' 1120, George V. Nash, June, 1894); scrubby hammock lands [Eustis], Florida (No. 1674, George V. Nash, August, 1894)." The plate cited above is drawn from Scribner's specimen of Nash 1674, now in Hitchcock's herbarium, which specimen is therefore the type. It consists of two culms 53 and $65 \mathrm{~cm}$. high, one simple, the other producing short fascicled branches at the upper two nodes. The blades are 10 to $17 \mathrm{~cm}$. long.

Panicum epilifolium Nash, Bull. Torrey Club 26: 571. 1899. "The type collected by the writer in a scrub hammock at Eustis, Lake Co., Florida, March 12-31, 1894, no. 45." The type, in Nash's herbarium, is the vernal form, with scarcely mature panicles. The longest blade is but $7.5 \mathrm{~cm}$. long, but a duplicate specimen in the National Herbarium has blades as much as $10 \mathrm{~cm}$. long. Two species were distributed under Nash's no. 45, the other being $P$. commutatum.

\section{DESCRIPTION.}

Vernal plants glossy, grayish green, in clumps of several to many culms, these 25 to 70 $\mathrm{cm}$. high, stiff and erect, glabrous or nearly so, including the nodes; sheaths much shorter than the elongated internodes, or the upper two approximate, glabrous except for the densely short-ciliate margin; ligules nearly obsolete; blades firm, widely spreading or ascending, 6 to $17 \mathrm{~cm}$. long, 6 to $14 \mathrm{~mm}$. wide, very scabrous (the margins nearly parallel), often ciliate at the rounded or subcordate base, acuminate, glabrous on both
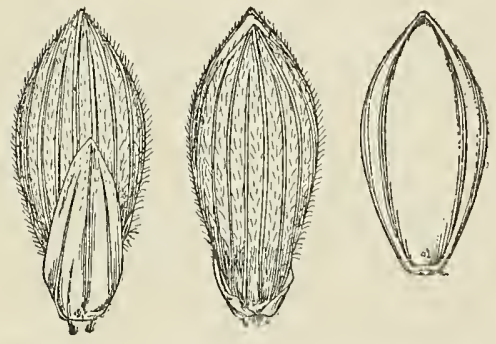

Fig.350.-P.equilaterale. From typespecimen. surfaces, often drying conduplicate; panicles usually short-exserted, loosely flowered, 5 to $10 \mathrm{~cm}$. long, two-thirds to three-fourths as wide, the branches ascending; spikelet 3.2 $\mathrm{mm}$. long, $1.3 \mathrm{~mm}$. wide, obovate-elliptic, obscurely pointed, pubescent; first glume half the length of the spikelet or more, rather remote, triangular, acute; second glume and sterile lemma subequal, barely covering the fruit at maturity; fruit 2.6 to $2.7 \mathrm{~mm}$. long, $1.25 \mathrm{~mm}$. wide, elliptic, minutely umbonate.

Autumnal form erect or leaning, branching from the upper and middle nodes after the maturity of the primary panicle, these primary branches often longer than the internodes and producing short, fascicled, appressed branchlets with reduced spreading blades from their uppermost nodes, the numerous small panicles partly included; winter rosette appearing late, the blades lanceolate, firm, sometimes ciliate.

This species is distinguished from $P$. commutatum by its almost linear blades, which vary much in size but are characteristically parallel-margined, and by its branching from the uppermost nodes of both the primary culm and the branches; and from $P$. manatense, which branches in the same way, by the erect habit and rather distant first glume half as long as the spikelet. 


\section{DISTRIBUTION.}

In pine lands, hammocks, and sandy woods, South Carolina to southern Florida.

South Carolina: Isle of Palms, Ball 791, Chase 4537, 4549, Hitchcock 421.

Florida: Duval County, Curtiss $3600 \mathrm{~A}$ in part (Gray Herb.); St. Augustine, Ricker 943; Cedar Key, Combs 793; Apalachicola, Chapman; Pensacola, Tracy 8428; Grasmere, Combs 1053; Gainesville, Chase 4241, 4258, Combs 737; Homossassa, Combs 9261: Crystal, Combs 1023; Clarcona, Pieters 116; Orange County, Baker 69; Eustis, Chase 4063, 4122, Nash 45 in part, 1120, 1674; Clear-

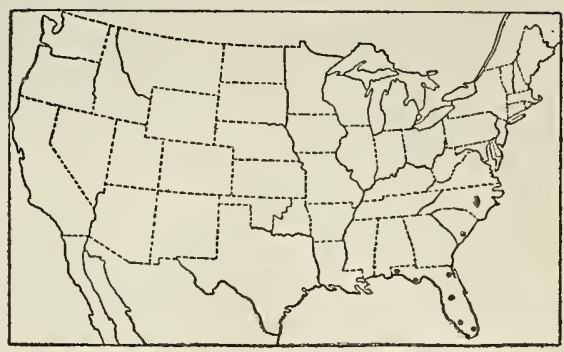

FIG. 351.-Distribution of $P$. equilaterale. water, Tracy 7167; Palma Sola, Tracy 6713 in part; Sneeds Island, Tracy 6460, 7050, 7051 in part: Miami, Chase 3908, Hitchcock 574, 633, 653, 655; Ormond, Hitchcock 575 .

\section{$\checkmark$ 188. Panicum albomaculatum Scribn.}

Panicum albomaculatum Scribn. U. S. Dept. Agr. Div. Agrost. Circ. 19: 2. 1900. "Dry rocky hills, Patzcuaro, State of Michoacan [Mexico], October 10. C. G. Pringle, No. 5203, 1892." The type, in Hitchcock's herbarium, consists of a tuft of primary culms with mature panicles, the culms beginning to branch from the lower nodes.

\section{DESCRIPTION .}

Vernal culms tufted, 50 to $100 \mathrm{~cm}$. high, arising from a knotty crown, erect, slender but stiff, minutely puberulent between the striæ, at least below the glabrous nodes; sheaths long, the lower overlapping, minutely puberulent, more or less mottled with white spots, densely short-ciliate on the margin; ligules about $0.2 \mathrm{~mm}$. long; blades
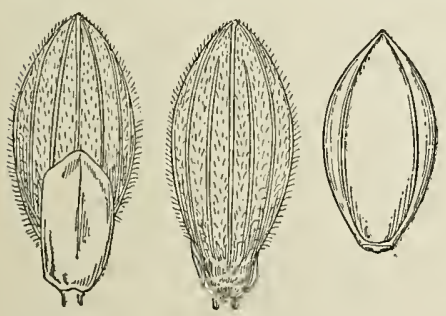

FIG. 352.-P. albomaculatum. From type specimen. firm, spreading or ascending, reflexed when old, 8 to $17 \mathrm{~cm}$. long, 9 to $15 \mathrm{~mm}$. wide, linearlanceolate, acuminate, rounded and ciliate at the base, roughish on the upper surface and with a narrow line of appressed pubescence along the very scabrous margins, glabrous or obscurely pubescent beneath; panicles longexserted, ovate in outline, 10 to $16 \mathrm{~cm}$. long, two-thirds to three-fourths as wide, loosely flowered, the axis and ascending branches glabrous; spikelets $2.8 \mathrm{~mm}$. long, $1.2 \mathrm{~mm}$. wide, obovate elliptic, obtuse, sparsely pubescent; first glume nearly or quite half the length of the spikelet, obtuse, or subacute; second glume and sterile lemma equaling the fruit at maturity; fruit $2.2 \mathrm{~mm}$. long, $1.2 \mathrm{~mm}$. wide, elliptic, subacute.

Autumnal form not known.

Probably most nearly related to $P$. equilaterale Scribn. 
DISTRIBUTION.

Known only from type locality.

Mexico: Patzcuaro, State of Michoacan, Pringle 5203.

Latifolia.-Culms rather stout, usually more than $50 \mathrm{~cm}$. high; ligules not over $1 \mathrm{~mm}$.

long; blades ample, usually more than $1.5 \mathrm{~cm}$. wide, cordate; spikelets 2.7 to 4.5 $\mathrm{mm}$. long, rather turgid, pubescent, 7 to 9 -nerved. Autumnal form not very freely branching.

Sheaths strongly papillose-hispid, at least the lower and those

of the branches.............................. 189. P.clandestinum.

Sheaths glabrous or softly villous.

Nodes glabrous; spikelets 3.4 to $3.7 \mathrm{~mm}$. long ........... 190. P. latifolium.

Nodes bearded; spikelets 4 to $4.5 \mathrm{~mm}$. long.

Blades glabrous or nearly so on both surfaces..........191. P. boscii.

Blades velvety beneath.......................191a. P. boscii molle.

\section{$\checkmark$ 189. Panicum clandestinum L.}

Panicum clandestinum L. Sp. P1. 58. 1753. "Habitat in Jamaica, Pensylvania. Kalm." In the Linnæan Herbarium is a specimen marked "clandestinum $\mathrm{K}$ " [Kalm] in Linnæus's writing, which is taken as the type since it is the only specimen so marked by Linnæus, and since it agrees with his description. The Jamaica locality is evidently based upon the Sloane phrase name and figure cited as synonym. This figure represents Hackelochloa granularis (L.) Kuntze, a species to which Linnæus's description does not at all apply, for which reason the Jamaica locality is rejected. The Kalm specimen is the autumnal form, the secondary panicles inclosed in the sheaths, which are crowded at the summit.

Milium clandestinum Moench, Meth. Pl. 204. 1794. Based on Panicum clandestinum L.

Panicum latifolium clandestinum Pursh, Fl. Amer. Sept. 1: 68. 1814. Based on P. clandestinum "Willd. sp. pl. 1. p. 351." In Willdenow's Species Plantarum the original Linnæan diagnosis, citations, and description are given, with reference to "Sp. Pl. 86." $a$

Panicam pedunculatum Torr. Fl. North. \& Mid. U. S. 141. 1823. "On the Island of New-York." The type, in Columbia University Herbarium, is a vernal specimen $80 \mathrm{~cm}$. high, beginning to branch, with an over-mature, long-exserted, primary panicle, the spikelets $2.8 \mathrm{~mm}$. long. The accompanying label, in Torrey's hand, reads "Panicum pedunculatum"" [followed by a brief diagnosis] "In wet meadows, among thickets. Aug."

Panicum clandestinum pedunculatum Torr. Fl. N. Y. 2: 426. 1843. Based on P. pedunculatum Torr.

Panicum decoloratum Nash, Bull. Torrey Club 26: 570. 1899. "Collected by Mr. E. P. Bicknell on a sandy railroad bank at Tullytown, Pennsylvania, May 30, 1899." The type, in Nash's herbarium, consists of four vernal specimens with partially included, immature panicles. The lower sheaths are papillose-hispid, less densely so than common in $P$. clandestinum, the upper glabrous. The immature spikelets are $2.7 \mathrm{~mm}$. long.

\section{DESCRIPTION.}

Vernal form in large, dense clumps, sometimes with strong rootstocks, 5 to $10 \mathrm{~cm}$. long; culms stout, $70 \mathrm{~cm}$. to 1.5 meters high, erect, scabrous to papillose-hispid, at least below the nodes; sheaths as long as the internodes or overlapping until after the 
branches appear, loose, strongly papillose-hispid to nearly glabrous, a puberulent ring at the summit; ligules $0.5 \mathrm{~mm}$. long; blades spreading or finally reflexed, 10 to 20 $\mathrm{cm}$. long, 1.2 to $3 \mathrm{~cm}$. wide, slightly tapering to the cordate-clasping base, acuminate, scabrous on both surfaces, at least toward the end, usually ciliate at the base; panicles finally rather long-exserted, 8 to $15 \mathrm{~cm}$. long, about three-fourths as wide, many-

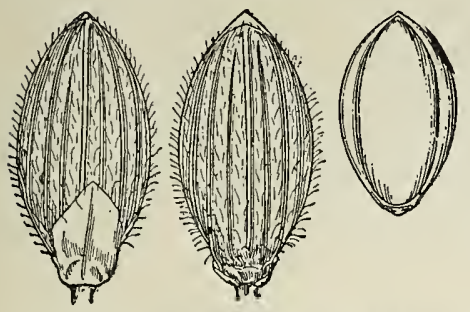

FIG.353.-P. clandestinum. From typespecimen of $P$. pedunculatum Torr. flowered, the flexuous branches in distant fascicles, short spikelet-bearing branchlets in the axils; spikelets 2.7 to $3 \mathrm{~mm}$. long, 1.4 to $1.5 \mathrm{~mm}$. wide, obovate-oblong, sparsely pubescent; first glume one-third the length of the spikelet, subacute or obtuse; second glume slightly shorter than the fruit and sterile lemma; fruit elliptic 2.1 to $2.3 \mathrm{~mm}$. long, 1.2 to $1.3 \mathrm{~mm}$. wide.

Autumnal form erect or leaning, sparingly branching, often before the maturity of the primary panicle, from the middle and upper nodes, the branches leafy, the swollen, bristly sheaths overlapping on the shortened internodes and inclosing wholly or partially the secondary panicles; spikelets more turgid than those of the primary panicles.

Occasional specimens, such as the type of $P$. decoloratum, and Eggert 114 and 253, Merrill 198, and one specimen of Small \& Heller, Blowing Rock Mountain, Tenn., in 1891 (a second being the ordinary form) are bristly only on the lower sheaths, the upper glabrous or only scabrous. This lack of pubescence is not found to be correlated with smaller spikelets nor with scarcely-exserted panicles. In Andrews 11 the spikelets are exceptionally small, only $2.5 \mathrm{~mm}$. long, but the sheaths and culms are bristly, and the developed panicle is long-exserted and an immature one scarcely exserted.

DISTRIBUTION.

Moist, mostly sandy ground, Maine to Kansas, south to Florida and Texas.

MaIne: Foxcroft, Fernald 292, 518; Farmington, Chamberlain \& Knowlton in 1902.

New Hampsinire: Gilford, Carter 111 (Hitchcock Herb.).

VERMONT: Burlington, Flynn in 1900 (Hitchcock Herb.).

MassachusetTs: South Hadley, Cook in 1887.

Connectrcut: Pine Meadow, Bissell 5544; Southington, Andrews 11, Bissell 5546; South Manchester, Hitchcock. 583; South Glastonbury, Wilson 17; Greens Farms, Pollard 92; Oxford, Harger in Kneucker Gram. Exs. 424.

RHOde Island: Without locality, Congdon (Hitchcock Herb.).

New York: Oneida County, Haberer 1257.

New Jersey: Clifton, Nash in 1891; Stockholm, Van Sickle in 1895; Woodbury, Smith 112; South Amboy, Mackenzie 1360; Wildwood, Chase 3513.

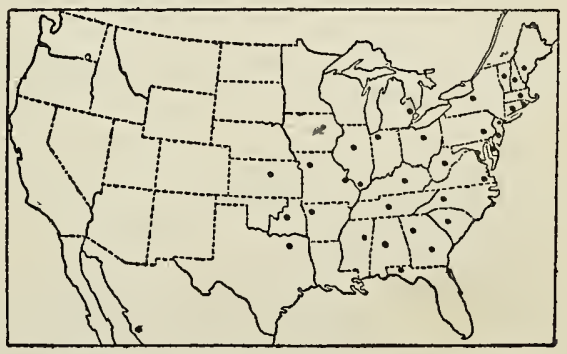

FIG. 354.-Distribution of $P$. clandestinum.

Pennsylvania: Easton, Porter in 1895 and 1897; Refton, Heller in 1901; Mount Hope, Heller 4781; Tullytown, Bicknell in 1899.

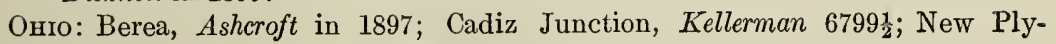
mouth, Kellerman 6883; Vinton, Kellerman 6888. 
Indiana: Michigan City, Ifill 158 in 1906; Brazil, Somes 231.

Illino1s: Peoria, Brendel, McDonald in 1903; without locality, Wolf in 1882.

Michigan: Port Huron, Dodge in 1904 and 1909.

Missouri: St. Louis, Eggert 114, 253, Kellogg 18; Sibley, Bush 4003; Independence, Bush 733 in part; Courtney, Bush 3977; Allenton, Kellogg in 1901; Monteer, Bush 4651, 4865.

Kansas: Pottawatomie County, Norton 878.

Delaware: Wilmington, Commons 27, 302; Centerville, Commons 300.

Maryland: High Island, Ward in 1878; West Chevy Chase, Chase 3272, Hitchcock 432; Riverdale, Chase 2366.

District of Columbia: Ball 702, Hitcheock 431, Kearney 21, 32, Merrill 198, Pollard 365, Scribner in 1894, Sudworth in 1890, Vasey in 1874 and 1887, Ward in 1880, Williams 7.

Virginia: Portsmouth, Noyes 68.

West Virginia: Aurora, Steele in 1898; Morgantown, Hitchcock 584; Fayette County, Kellerman 6900.

North Carolina: Biltmore, Biltmore Herb. 804, 804b; Blowing Rock Mountain, Small \& Heller in 1891; Heiligs Mill, Small \& Heller 348; Magnetic City, Wetherby 32; Chapel Hill, Ashe, Chase 3078.

South Carolina: Clemson College, House 2132.

Georgia: Gwinnett County, Small in 1893: Stone Mountain, Hitchcock 585; Clarke County, Harper 70.

FLORIDA: Without locality, Chapman.

Kentucky: Poor Fork, Kearney 229.

Tennessee: Wolf Creek, Kearney in 1897, Ruth 60; Ducktown, Chambliss 18, 78; Hiwassee Gorge, Kearney 330; Blowing Rock Mountain, Small \& Heller in 1891.

Alabama: Without locality, Buckley (Mo. Bot. Gard. Herb.).

Mississippi: Starkville, Chase 4463.

Arkansas: Northwest Arkansas, Harvey 32.

Texas: Dallas, Reverchon in 1875 (Gray Herb.).

Окцанома: Supulpa, Bush 718 (Mo. Bot. Gard. Herb.).

\section{Panicum latifolium L.}

Panicum latifolium L. Sp. Pl. 58. 1753. "Habitat in America." The type, in the Linnæan Herbarium, is a portion of a vernal culm with two leaves and a shortexserted but well-developed primary panicle. $a$

Milium latifolium Moench, Meth. Pl.204. 1794. Bassed on Pqniçum latifolizm L.

Panicum macrocarpon LeConte in Torr. Cat. Pl. N. Y. 91. 1819. No locality nor specimen is cited. In the Torrey Herbarium is a specimen with the following label

$a$ For a full discussion of the reasons for considering this specimen to be the type, see Hitchcock, Contr. Nat. Herb. 12: 118. 1908. The reasons are briefly: In the Linnæan Herbarium are two sheets upon which Linnæus has written the name. One of these, which is Panicum zizanioides H. B. K., was received from Browne after the preparation of the manuscript of the Species Plantarum. The second sheet includes two vernal specimens, Panicum macrocarpon LeConte, and $P$. clandestinum L. The first of these is taken as the type as it corresponds better to the description. The sheet marked "17 K latifolium," meaning that the specimens were received from Kalm and the species is no. 17, P. latifolium, in the Species Plantarum. Appended to the original description, Linnæus cites two synonyms, one from Morison, which is probably $P$. boscii Poir., and one from Sloane, which is $P$. sloanei Griseb. . The Sloane specimen is considered by some authors to be the type of $P$. latifolium, but the Sloane synonym is erroneously cited. 
in Torrey's writing: "Panicum macrocarpon Elliott' LeConte." Torrey's note on this specimen would seem to have been written before the publication of the species as above, as he seems to think LeConte credits the name to Elliott. No data are given on the label or sheet. No other specimen could be found in the herbarium that could be connected with LeConte's name. If LeConte had a herbarium and if it be in existence, its whereabouts is unknown. The above specimen, which is taken as the type of $P$. macrocarpon, is a single plant with simple culm and immature unexpanded panicle.

Panicum schnecki Ashe, N. C. Agr. Exp. Sta. Bull. 175: 116. 1900. "River bottoms, southern Indiana and Illinois, June." The type, in Ashe's herbarium, consists of two culms, one sterile and one with an immature, scarcely-exserted panicle. On the accompanying label with the printed heading "Herbarium of W. W. Ashe" is written in Ashe's hand "Panicum Schnecki W. W. Ashe," but no data whatever are given.

This is the species described by Torrey ${ }^{a}$ as P. nervosum Muhl. Panicum macrocarpon LeConte, though published in his Catalogue seems to have been unknown to Torrey. $b$

\section{DESCRIPTION.}

Vernal plants in clumps of few to several culms from a knotted crown; culms rather stout, $45 \mathrm{~cm}$. to 1 meter high, erect, glabrous, or the lower internodes sometimes sparsely pubescent, the nodes glabrous, rarely with a few hairs; sheaths shorter than the internodes, ciliate on the margin, a pubescent ring at the juncture with the blade, otherwise glabrous, or the lower sparsely downy; ligules nearly obsolete; blades rather
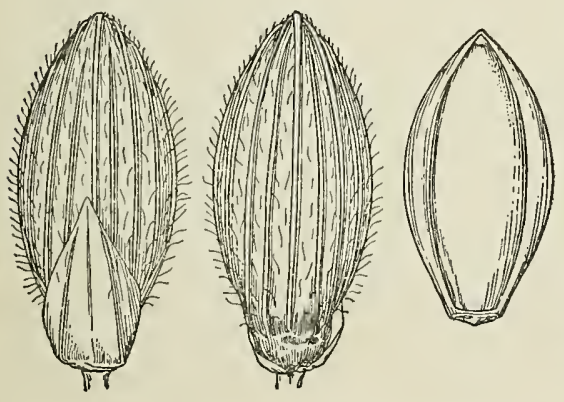

FIG. 355. $-P$. latifolium. From type specimen of $P$. macrocarpon LeConte. thin, ascending or spreading 8 to 18 $\mathrm{cm}$. long, 1.5 to $4 \mathrm{~cm}$. wide, the lower smaller, acuminate, cordate-clasping at the base, glabrous, rarely sparsely pubescent on one or both surfaces, shortciliate at least toward the base; panicles usually short-exserted or sometimes finally long-exserted, 7 to $15 \mathrm{~cm}$. long, about two-thirds as wide, the long, fewflowered, nearly simple branches stifly ascending; spikelets rather short-pediceled, commonly more or less clustered in twos or threes, 3.4 to $3.7 \mathrm{~mm}$. long, 1.8 to $2 \mathrm{~mm}$. wide, oval-obovate, turgid, sparsely pubescent; first glume onethird to half the length of the spikelet, pointed; second glume and sterile lemma scarcely covering the fruit at maturity; fruit $3 \mathrm{~mm}$. long, 1.6 to $1.8 \mathrm{~mm}$. wide, elliptic, minutely pubescent on the obscurely apiculate apex.

Autumnal form more or less spreading, branching from the middle nodes, the upper leaves of the branches crowded and spreading, not much reduced, the small panicles partly included.

In this species the culms, nodes, and leaves are typically glabrous, but occasional specimens show more or less pubescence. The following represent this variation: Dorner 89, Shear in 1899, Ward in 1880, Wetherby 53.

$a$ Fl. North. \& Mid. U. S. 143. 1823.

$b$ See $P$. macrocarpon Torr. under P. scribnerianum, page 283. 


\section{DISTRIBUTION.}

Rocky or sandy woods, Maine to Minnesota, south to North Carolina and Kansas.

Marne: Orono, Fernald 346; Basin Mills, Knight 53; North Berwick, Parlin 1191; Fayette, Chase 3367; East Auburn, Merrill 1243.

New Hampshire: Surry, Fernald 276 (Gray Herb.).

Vermont: Manchester, Day 216; Barnet, Blanchard in 1883.

MassachusetTs: South Hadley, Cook in 1887.

Connecticut: Southington, Andrews 44, Bissell 5548, 5549, 5550; Old Lyme, Graves 164; Montville, Graves 163; Waterford, Graves in 1898; Stratford, Eames in 1894; Oxford, Harger in Kneucker Gram. Exs. 423.

Rhode Island: Providence, Olney.

New York: Ithaca, Ashe, Coville in 1885, Dudley in 1885; Oxford, Coville in 1884; Apalachin, Fenno 3, 5, 10, 11, 12; Cairo, Nash in 1893; Long Island, Bicknell in 1903 and 1905.

OnTaRIo: Galt, Herriot in 1898 and 1901; Queenstown Heights, Macoun 26326, 26327; Tilsonburg, Macoun 26325.

New Jersey: Clifton, Nash in 1892; Phillipsburg, Porter in 1892 and 1895; Mount Arlington, Mackenzie 1414.

Pennsylvania: Easton, Porter in 1895, 1897, and 1898; Germantown, Stone in 1889; Westchester, Windle in 1904; McCalls Ferry, Rose \& Painter 8135.

Онго: Niles, Ingraham in 1891; Lancaster, Kellerman 6766; Cadiz Junction, Kellerman 6799.

Indiana: Miller, Chase 1541, Umbach 1791 and in 1898; Pine, Umbach in 1896; Wells County, Deam in 1903; Lafayette, Dorner 82.

ILLINoIs: Beverly Hills, Bebb 882,

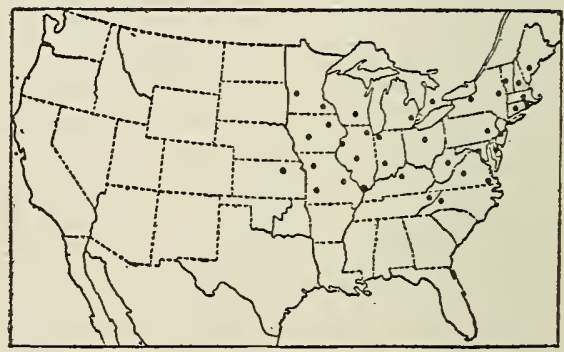

FIG. 356.-Distribution of $P$. latijolium.

Chase 1824; Savanna, Chase 1887; Glasford, Wilcox 22, 41; Mossville, Chase 889; Antioch, Gleason \& Shobe 268; Peoria, Brendel, McDonald 33; Urbana, Waite in 1886; St. Clair County, Eggert 239; Wabash County, Schreck in 1879 and 1905 .

Mrchigan: Detroit, Farïoll 1378; Port Huron, Dodge in 1909.

Wisconsin: Newbold, Cheney 1545; Milwaukee, Chase 1947.

Minnesota: Lindstrom, Taylor in 1892; Spring Grove, Rosendahl 487; Houston, Mearns 791.

Iowa: Fayette County, Fink 593; Ames, Ball 40, 155, Ball \& Sample 6; Iowa City, Shimek in 1894; Mount Pleasant, Mills in 1894.

Mrssouri: McDonald County, Bush 91; Independence, Bush in 1884; Swan, Bush 8; Monteer, Bush 190; Courtney, Bush 1732, 3981; Sibley, Bush 4001, 4807; Jefferson Barracks, Kellogg 17; Midway, E. J. Palmer 1405.

Kansas: Manhattan, Kellerman (Hitchcock Herb.).

Delaware: Centerville, Commons 301 in part.

Maryland: Garrett County, J. D. Smith in 1879.

District of Columbia: Shear in 1899, Ward in 1880.

Virginia: Norfolk, Pollard \& Maxon in 1900; Munden, Mackenzie 1709; Fairfax County, Hitchcock 587; Carroll County, Small in 1892; Peaks of Otter, Palmer 10.

West Virginia: Aurora, Steele in 1898; Marlinton, Kellerman 6899. 
North Carolina: Magnetic City, Wetherby 53; Blowing Rock Mountain, Small \& Heller 394; Biltmore, Hitchcock 588; Linville, Hitchcock 589; Grandfather Mountain, Hitchcock 433.

Kentucky: Lexington, Short 5 (Gray Herb.).

Tennessee: Roan Mountain, Hitchcock 586.

\section{Panicum boscii Poir.}

Panicum boscii Poir. in Lam. Encycl. Suppl. 4: 278. 1816. "Cette plante a été recueillie à la Caroline par M. Bosc. (V.s. in herb. Desfont.)." The type, in the Desfontaines Herbarium, consists of three early autumnal culms, the blades nearly glabrous, the spikelets $4.1 \mathrm{~mm}$. long. The accompanying label reads "Panicum boscii poir. enc. Suppl. (scr. Poiret.) Amer. Sept. à Bosc."

Panicum waltheri Poir. in Lam. Encycl. Suppl. 4: 282. 1816, not P. walteri Pursh, 1814. Based on "Panicum latifolium Mich. Flor. bor. Amer. 1. pag. 49.-Non Linn. * * (V.s. in Herb. Mich.)." The specimen in the Michaux Herbarium under the name of $P$. latifolium, and labeled "in pratis sylvestris Virginix Carolinæ," is a somewhat pubescent autumnal specimen of $P$. boscii. Scribner $a$ uses this name (as P. walteri Poir.) for P. boscii.

Panicum latifolium australis[e] Vasey, U. S. Dept. Agr. Div. Bot. Bull. 8 : 34.1889. "Alabama to Texas." The type, in the National Herbarium, consists of two vernal culms, the sheaths and blades glabrous or nearly so, the spikelets $4.3 \mathrm{~mm}$. long. The specimen was collected by Dr. Charles Mohr, at Thomasville, Clark County, Ala., April 16, 1888.

Panicum porterianum Nash, Bull. Torrey Club 22: 420. 1895. The author proposes a new name for "Panicum latifolium Walt. Fl. Car. 73. 1788. Not Linnæus, 1753. Panicum Walteri Poir. in Lam. Encycl. Suppl. 4: 282. 1816. Not Pursh, 1814. Panicum latifolium var. molle Vasey, Bull. Bot. Div., U. S. Dept. of Agric. 8: 33. [error for 34] 1889." No description is given. In Walter's Flora Linnæus's diagnosis of $P$. latifolium is copied with no additional description, and there is no specimen in Walter's herbarium $b$ labeled $P$. latifolium by Walter. A fragmentary panicle and two leaves, doubtfully referable to P. commutatum Schult., labeled "Panicum 469," possibly may be the specimen to which Walter applied the name. In the absence of an authentic specimen, and because $P$. latifolium Walt. must be considered a misapplication of $P$. latifolium L., $P$. porterianum is here regarded as based upon the next name cited, $P$. walteri Poir. Since the name was given in honor of Dr. Porter, doubtless because of his distinguishing this form from what he understood to be $P$. latifolium L., $c$ it is more fitting also that the name $P$. porterianum be based on the name which he applied to this form, that is, $P$. watteri Poir.

This species has been described as P. latifolium L. by many American authors.

\section{DESCRIPTION.}

Vernal form resembling that of $P$. latifolium, usually in larger clumps; culms 40 to to $70 \mathrm{~cm}$. high, erect or ascending, glabrous or minutely puberulent, rarely somewhat papillose, the nodes retrorsely bearded; sheaths much shorter than the internodes, ciliate, a pubescent ring at the juncture with the blade, otherwise glabrous or sparsely downy-pilose; ligules about $1 \mathrm{~mm}$. long; blades spreading, 7 to $12 \mathrm{~cm}$. long, 1.5 to 3 $\mathrm{cm}$. wide, more or less tapering toward the sparsely ciliate, cordate base, acuminate, glabrous on both surfaces or puberulent on the lower and sparsely pubescent on the

a Mem. Torrey Club. 5 : 32. 1894.

$b$ For an account of the grasses in Walter's herbarium see Hitchcock, Rep. Mo. Bot. Gard. 16: 36. 1905.

c Bull. Torrey Club 20: 194. 1893. 
upper surface; panicles 6 to $12 \mathrm{~cm}$. long, as wide or wider, the main axis and the flexuous spreading or ascending branches puberulent; spikelets 4 to $4.5 \mathrm{~mm}$. long, 2 to $2.2 \mathrm{~mm}$. wide, oblong-obovate, less turgid than in $P$. latifolium, papillosepubescent; first glume one-third to two-fifths the length of the spikelet, pointed; second glume slightly shorter than the fruit and sterile lemma at maturity; fruit 3.2 to $3.5 \mathrm{~mm}$. long, 1.5 to $1.6 \mathrm{~mm}$. wide, elliptic, minutely pubescent, and usually black at the tip.

Autumnal form as in $P$. latifolium, rather more freely branching, sometimes topheavy reclining; spikelets more turgid than those of the primary panicles.

As in $P$. commutatum, what appear to be simple, very leafy, autumnal culms are commonly formed by the replacing of the fallen primary summit by the uppermost

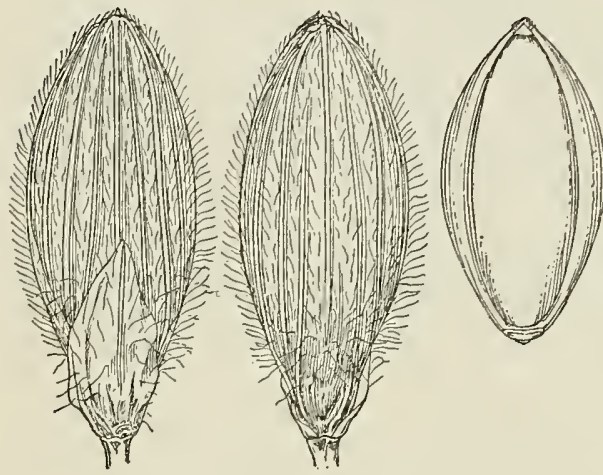

FIG. 357.-P. boscii. From type specimen. branch. These culms are often recurved, the blades all turned into the plane of the branch, or even all to one side, from a twisting of the internodes, and more or less unsymmetrically expanded in the middle, the whole producing a very different aspect from that of the vernal form.

This species is closely related to $P$. latifolium and is often difficult to distinguish from pubescent specimens of that species.

The form distinguished by Vasey as $P$. latifolium australe can not be satisfactorily separated. The longer spikelets and blades narrowed to the base, or rather expanded in the middle, are not correlated. Specimens with large spikelets are mostily oi southern range, but those with blades strongly tapering to the base occur throughout, Andrevs 40, Connecticut, being a pronounced case. The following specimens represent this variation: Chase 4491, Combs 334, 337, 399, 683, Commons 361, Hall 828, Harper 1812, Mohr in 1888, Nash 2329. In most of the Alabama and Floricla specimens the longer spikelets and tapering blades are correlated and might be given subspecific rank but for the more numerous intermediate specimens. The larger spikelets and tapering blades also occur in $P$. boscii molle.

The following specimens are intermediate in character between $P$. boscii and $P$. boscii molle, having blades more or less downy, or glabrous and downy blades on the same plant: Bush 303, 310, 3348, Chase 4501, Harper 1366, Tracy 3 in 1888.

\section{DISTRIBUTION.}

Woods, Massachusetts to Oklahoma, south to northern Florida and Texas.

Massachusetts: Monson, Herb. Western High School of Washington (Biltmore Herb.).

Connecricut: Southington, Andrews 40, Bissell 5552; Ledyard, Graves in 1897.

New Jersey: Byram Station, Fisher in 1897; Milburn, Mackenzie 2144.

Pennsylvania: Lancaster County, Heller 4771; Upper Darby, Smith 154.

Онго: Painesville, Werner in 1886; Cincinnati, Lloyd 3597.

Indiana: Clarke County, Deam 5386, 6586.

latifolium IllinoIs: Marshall County, V. H. Chase 1489; Jackson County, French in 1905;

Tunnel Hill, Ridgway in 1902; Wabash County, Schneck in 1896.

Missouri: Allenton, Kellogg 15; Pleasant Grove, Bush 303, 310, 323; Doniphan, Bush 276; Swan, Bush 26, 4534; Monteer, Bush 4652, 4908. 
Delaware: Wilmington, Commons in 1897; Centerville, Commons 361.

Maryland: Chesapeake Beach, Hitchcock 1604; Riverdale, Chase 2374; Plummers Island, Hitchcock 590.

District of Columbia: Ball 14, Kearney in 1897, Scribner in 1894, Sudworth in 1890, Vasey in 1884, Ward in 1876 and 1878.

Virginia: Rosslyn, Dewey 235; Glencarlyn, Dewey 280; Marion, Small in 1892; Ocean View, Kearney 1469; Virginia Beach, Kearney 1411.

North Carolina: Asheville, Canby 220; Biltmore, Hitchcock 591; Columbus, Townsend in 1897; West Raleigh, Coit 1293; Chapel Hill, Chase 3073; Spray, De Chalmot; without locality, Vasey in 1878.

South Carolina: Aiken, Ravenel; Clemson College, House 2136; Orangeburg, Hitchcock 19, 1412.

Georgia: Stone Mountain, Hitchcock 222, Eggert 40; Clyo, Harper 1812; Dublin, Harper 1366; Thomson, Bartlett 1505; Tallulah Falls, Cuthbert in 1899.

Frorida: Chipola River, Curtiss K.; Tallahassee, Nash 2329; Monticello, Combs 334, 337; Quincy, Combs 399; Chipley, Combs 683.

Kentucky: Pine Mountain, Kearney 258; without locality, Short.

Tennessee: Franklin County, Eggert 26 in 1897; Hiwassee

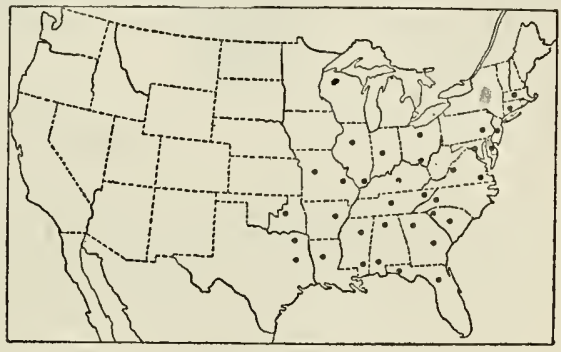

FIG. 358.-Distribution of $P$. boscii. Gorge, Kearney 325; White Cliff Springs, Scribner in 1890; Knox County, Kearney in 1894.

Alabalia: Northern Alabama, Vasey in 1878; Scottsboro, Chase 4501; Pisgah to Tennessee River, Chase 4491; Auburn, Hitchcock 1320; Montgomery, Carver 64; Dadeville, Pollard \& Maxon 136; Talladega Springs, Pollard \& Maxon 247; Thomasville, Mohr in 1888.

Mississippr: Meridian, Tracy 3252; Starkville, Tracy 3 in 1888; Jackson, Hitchcock 1300 .

Arkansas: Benton County, Plank 7.

Louisiana: Calhoun, Hitchcock 1272; Shreveport, Hitchcock 1244.

Texas: Monterey, Reverchon 4144 b; Houston, Hall 828 in part; without locality, Nealley in 1889.

Oklahoma: Without locality, Butler 43 (Mo. Bot. Gard. Herb.).

191a. Panicum boscii molle (Vasey) Hitehc. \& Chase.

$$
\text { ; Wand, Fl. Washinglou 135.1881. }
$$

Panicum latifolium molle Vasey'U. S. Dept. Agr. Div. Bot. Bull. 8: 34. 1889. "Virginia to Louisiana." The type, in the National Herbarium, consists of two vernal plants, with softly villousculms and sheaths, bearded nodes, and nearly mature primary panicles. The accompanying label in Vasey's hand reads: "Panicum latifolium var. molle Vasey, a state downy all over, Washington, D. C., a L. F. Ward."

Panicum walteri molle Porter, Bull. Torrey Club 20: 194. 1893. Presumably based on P. latifolium molle Vasey, since "(Vasey)" is given as authority, though Vasey's combination is not cited.

$a$ "Washington, D. C.," was commonly given as locality for the surrounding region, and the specimens may have been collected on the Virginia side of the Potomac as indicated in the range given. 
Panicum pubifolium Nash, Bull. Torrey Club 26:577. 1899. "P. latifolium var. molle Vasey, Contr. U. S. Nat. Herb. 3: 33. 1892. Not P. molle Sw. 1788," is cited and a description follows. As no type is cited this is evidently primarily a change of name, based on $P$. latifolium molle Vasey.
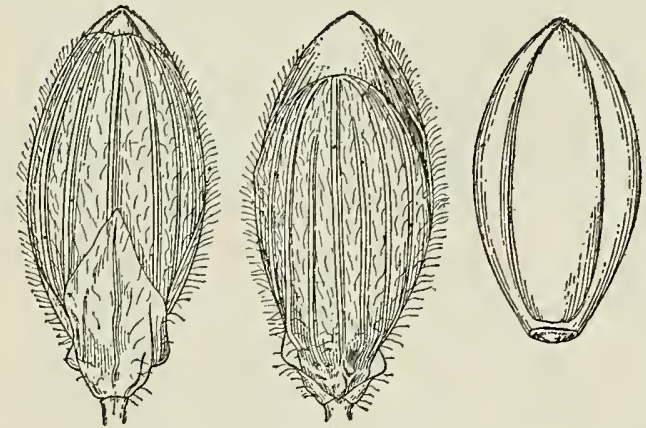

ITIG. 359.-P. boscii molle. From type specimen.

Panicum boscii molle Hitchc. \& Chase in Robinson, Phodora 10: 64. 1908. Based on "P. latifolium var. molle Vasey."

\section{DESCRIPTION.}

Closely resembling $P$. boscii and often scarcely to be distinguished from it; culms on the average not so tall, downy-villous; sheaths rather sparsely villous; blades velvety on the under surface, sparsely appressed-pubescent on the upper; panicle axis and branches puberulent and somewhat pilose; spikelets rather more strongly pubescent than in the species.

The Florida specimens, together with Biltmore Herbarium 5185b, Dewey 73 and Steele in 1896, have spikelets mostly larger than $4.5 \mathrm{~mm}$. long, and correspond with the variation of the species which includes $P$. latifolium australe Vasey.

\section{DISTRIBUTION.}

Woods, Connecticut to Illinois and Arkansas, south to Florida and Louisiana.

Connecticut: Norwalk, Bissell 5551.

New YoRk: Long Island, Bicknell in 1903, 1904, and 1905.

New Jersey: Great Notch, Nash in 1893.

Pennsylvania: Germantown, Stone in 1889; Easton, Porter in 1891, 1895, and 1898; Westchester, Windle in 1904; Haines Station, Heller 4779 .

Oнго: Cincinnati, James.

Ilumois: Union County, French in 1872.

Missour1: Monteer, Bush 754; Noel, Bush 5060.

Delaware: Newark, Hitchcock 592.

District of Columbia: Ball 703, Hitchcock 435, Merrill 202, 203, Pieters in 1896, Pollard 412,

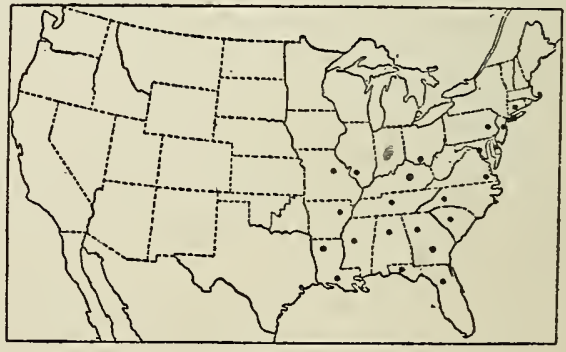

FIG. 360.-Distribution of P. boscii molle.

Seaman in 1873, Steele in 1896, Vasey in 1873 and 1884, Ward in 1881 and 1882.

Virainia: Glencarlyn, Dewey 73, 92; Four-Mile Run, Hitchcock 434, 436; Belfield, Meynke in 1904; Portsmouth, Noyes 104.

North.Carolina: Asheville, McCarthy in 1888; Biltmore, Biltmore Herb. 5185a, 5185 b; Chapel Hill, Chase 3054.

South Carolina: Newry, House 2211.

Georg1A: Stone Mountain, Hitchcock 1344; Gwinnett County, Small in 1893; Cobb County, Wilson 27; A thens, Harper 15; Warm Springs, Tracy 8868; Augusta, Cuthbert 392, 1162.

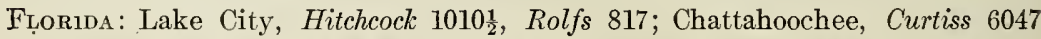
(Hitchcock Herb.); Madison, Combs 295; Gainesville, Chase 4208, Combs 738. 
Kentucky: Irvine, Biltmore Herb. $9959 f$ (Biltmore Herb.).

Tennessee: Knoxville, Ruth 70, Scribner in 1892; Madison County, Bain 189.

Alabama: Auburn, Hitchcock 1321.

MississipPI: Fairport, Tracy 3205; Jackson, Hitchcock 1301; Starkville, Tracy in Pollard Dist. Miss. Pl. 1409.

Arkansas: Benton County, Plank 16, 46.

Louisiana: Covington, Langlois 41 in part; Calhoun, Hitchcock 1283.

\section{MISCELLANEOUS SPECIES.}

\section{- 192. Panicum obtusum H. B. K.}

Panicum obtusum H. B. K. Nov. Gen. \& Sp. 1: 98. 181\%. "Crescit in planitie montana regni Mexicani prope Guanaxuato et Burras, in humidis, alt. 1080 hexap." The type specimen, in the Bonpland Herbarium, is labeled: "Panicum obtusum Kunth, Synops. 174, in planitie montana Regni Mexicani, prope Guanaxuato, 1080 hex. No. 4204."

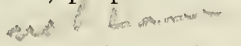

Panicum polygonoides C. Muell. Bot. Zeit. 19: 323. 1861.^"America septentrionalis, ubi forsan in Texas legit T. Drummond (Coll. No. 371)." The type specimen, bearing the published data, is in the Berlin Herbarium.

Panicum repente Buckl. Prel. Rep. Geol. Agr. Surv. Tex. App. 3. 1866. No specimen nor locality within Texas is cited. The type specimen could not be found in the herbarium of the Philadelphia Academy, where the Buckley collections are deposited. The description amply identifies the species.

Brachiaria obtusa Nash in Britton, Man. 77. 1901. Based on Panicum obtusum H. B. K. In this species the spikelets are placed with the back of the fruit to the axis (that is the first glume turned from the axis) as characteristic of true Panicum,

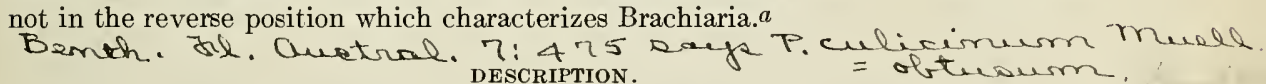

Plants perennial, usually tufted from a more or less knotted rootstock, and producing widely creeping stolons, sometimes 2 or more meters long, with long internodes, and geniculate, swollen, conspicuously villous nodes, these often with a knob-like cluster of hairy scales at the base of the extravaginal, erect branches, these clusters being produced sometimes when the branch is not developed; culms wiry, compressed, 20 to $80 \mathrm{~cm}$. high, simple, usually decumbent at base, glabrous, the nodes glabrous; sheaths shorter than the internodes, glabrous, or the lower and those of the stolons sometimes villous; ligules membranaceous, about $1 \mathrm{~mm}$. long; blades 3 to $20 \mathrm{~cm}$. long, 2 to $7 \mathrm{~mm}$. wide, erect, firm, usually involute-setaceous toward the tip, glabrous on both surfaces or sometimes with a few long hairs on the upper surface at the base; panicle usually short-exserted, 3 to $12 \mathrm{~cm}$. long, about 1 $\mathrm{cm}$. wide, the few, appressed, raceme-like branches densely flowered; spikelets short-pediceled along

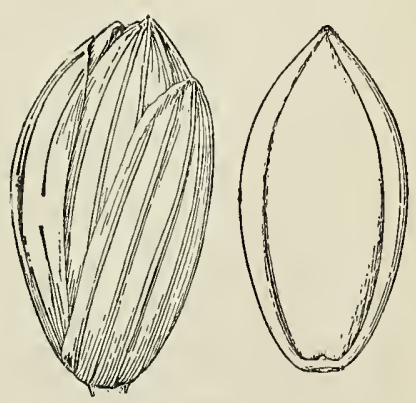

FIG. 361.-P. ohtusum. From type specimen. one side of a slightly flattened rachis, 3 to $3.8 \mathrm{~mm}$. long, 1.5 to $1.8 \mathrm{~mm}$. wide, and about $2 \mathrm{~mm}$. thick, obovoid, blunt, glabrous, usually brownish; first glume nearly

$a$ The genus Brachiaria Ledeb. (Fl. Ross. 4: 469. 1853) is based upon Panicum eruciformis Sibth., in which the spikelets are placed with the back of the fruit turned from the rachis.

$41616^{\circ}-$ VOL $15-10-21$ 
as long as the spikelet, 5-nerved; second glume and sterile lemma subequal, 7 to 9-nerved, the lemma subtending a rather firm palea and a staminate flower; fruit 3 to $3.5 \mathrm{~mm}$. long, 1.5 to $1.7 \mathrm{~mm}$. wide, subacute, smooth and shining, but very obscurely pubescent at the apex.

The Brazilian species, $P$. repandum Nees, is the only known species related to P. obtusum.

\section{DISTRIBUTION}

Sandy or gravelly soil, mostly along the banks of rivers, arroyos, and irrigation ditches, western Missouri and Colorado to Texas and Arizona and southward to southern Mexico.

Missouri: Kansas City, Bush 1832, 3107 (Gray Herb.).

Kansas: Stanton County, Hitchcock Pl. Kan. 572.

Texas: Dallas, Hall 827, Reverchon 1079 and in 1879; Kerrville, Heller 1741, Smith in 1897; Waller County, Thurow in 1898 and 1906; Llano, Plank in 1892; Amarillo, Ball 1139; Fort Worth, Ward in 1877; Abilene, Tracy 7935; Bexar County, Jermy 6; San Antonio, Plank in 1893; El Paso, Jones 4168; Fort Davis, Havard in 1881; Kingsville, Piper in 1906; Texline, Griffiths 5612; without locality, Buckley in 1881; Nealley in 1887.

Oklahoma: On the False Washita, Palmer 370 in 1868.

Colorado: Rocky Ford, Griffiths 3309; Canyon City, Shear 975; Trinidad, Shear in 1900; Las Animas County, Chase 5406.

New Mexico: Cabra Spring, Pease in 1878; McCarty, Munson \& Hopkins in 1889; Socorro, Plank 76, Vasey in 1881; Gray, Skehan 94, 97; Cimarron Canyon Griffiths 5542; Roswell, Earle 301; Las Cruces, Wooton 1068; Silver City, Metcalfe 749; Mesilla, Wooton 64; Mesilla Park, Hitchcock 3830; D e ming, Hitchcock 3763; Grant County, Blumer 205, Smith in 1897; White Water, Mearns 2308; without locality, Vasey in 1881, Wright 2092.

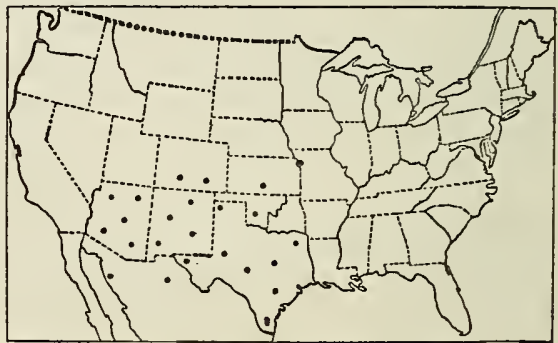

FIG. 362.-Distribution of P. obtusum.

Arizona: Moki Reservation, Hough 80; Beaver Creek, MacDougal 569, Rusby 864, 8921; Toumey in 1891; Santa Rita Mountains, Griffiths 3405, 6959, 7288, Griffiths \& Thornber in 1902; St. Johns, Griffiths 5196; Holbrook, Zuck in 1896; Tucson, Griffiths 1514, 1546; Benson, Griffiths 2006, Hitchcock 3737; Pearce, Griffiths 1935; Sulphur Spring Valley, Forbes 1645; Patagonia, Hitchcock 3646, 3661; Fort Huachuca, Wilcox in 1894; San Pedro River, Mearns 1130; Bisbee, Mearns 925; San Bernardino Ranch, Mearns 773; near Monument 88 (Mexican Boundary), Mearns 1845.

Mexico: La Ventura, Nelson 3908; Saltillo, Palmer 394 in 1898; Chihuahua, Nelson 6352, Pringle 476; Nogales, Griffiths 6800; Durango, Palmer 175 in 1896; Conception del Oro, Palmer 266 in 1904; San Luis Potosí, Palmer 590 in 1898, Parry \& Palmer 960, Schaffner 148; Faral, Schumann 1714.

\section{d 193. Panicum hemitomon Schult.}

Panicum walteri Ell. Bot. S. C. \& Ga. 1: 115. 1816, not Pursh, 1814. "Grows in damp soils. On Charleston neck, common. Macleod's pond, $6 \frac{1}{2}$ miles from Sุavannah, on the Ogechee road." The type, in the Elliott Herbarium, consists of the upper portions of two culms, one sterile, the other with an immature panicle. Attached to this specimen is a label which reads: "Panicum Walteri mihi. Hab. in humidis 


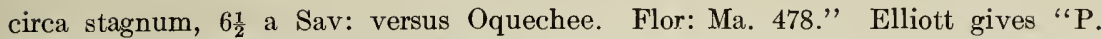
dimidiatum, Walt. p. 72 " as a synonym.

Panicum walteri Muhl. Descr. Gram. 108. 1817, not Pursh, 1814. No locality nor specimen is cited, but after the description the author adds " $P$. dimidiatum Walter secundum Elliott." The specimen in the Muhlenberg Herbarium is labeled "Panicum dimidiatum Walter, Ell. 478," and is evidently a duplicate of Elliott's specimen.

Panicum hemitomon Schult. Mant. 2 : 227. 1824. Based on Panicum walteri Muhl.

Panicum carolinianum Spreng. Syst. Veg. 1:310. 1825. Sprengel's name appears to be based on $P$. walteri Ell. as he cites after the brief description, "Carol. austr. (P. Walteri Ell.)."

Panicum carinatum Torr. in Curtis, Bost. Journ. Nat. Hist. 1: 137. 1835, not Presl, 1830. "Hab. swamps," [around Wilmington, N. C.]. Curtis's specimen, labeled "Panicum carinatum n. sp. Tor. mss. North Carolina. Mr. M. A. Curtis," is in the Torrey Herbarium. This is taken as the type since Torrey evidently intended this as a new species, although "P. Walteri Ell." is cited as a synonym.

Panicum digitarioides Carpenter; Curtis, Amer. Journ. Sci. II. 7: 410. 1849, not Rasp. 1833. This is mentioned as a synonym under $P$. carinatum Torr., Curtis doubtless taking the name from specimens distributed by Carpenter under this name. Such a specimen, collected by "W. M. Carpenter, prairie ponds, Opelousas \& Attackopay La.," is in the Gray Herbarium. The species is later described by Steudel $a$ under this name, his description being a translation of that of Curtis.

Panicum curtisii Chapm. Fl. South. U. S. 573. 1860, not Steud. 1854. This is proposed as a new name for "P. Walteri, Ell., not of Poiret nor Pursh. P. carinatum, Torr., in Curtis's Plants, Wilmington, not of Presl."

Brachiaria digitarioides Nash, in Britton, Man. 77. 1901. Based on Panicum digitarioides Carpenter.

DESCRIPTION.

Plants aquatic or semiaquatic, with extensively creeping rootstalks often producing numerous sterile shoots with overlapping, sometimes densely hirsute sheaths, and blades 10 to $25 \mathrm{~cm}$. long and 8 to $12 \mathrm{~mm}$. wide, strigose on one or both surfaces; fertile culms erect, 0.5 to 1.5 meters or more high, stout, usually hard, rarely rather soft and flaccid about the water line, glabrous; submerged sheaths rather loose and papery, often nodulose, aerial sheaths shorter than the internodes, close, glabrous or ciliate

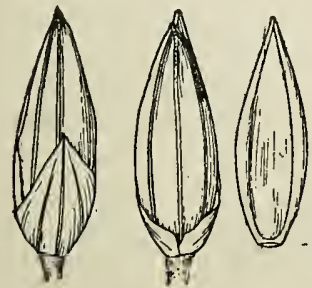

FIG. 363.-P. hemitomon. From type specimen of $P$. walteri Muhl. in the Muhlenberg Herbarium. on the margin, rarely hirsute toward the summit like those of the sterile shoots, or the lower hirsute throughout; ligules lacerate-ciliate, about $1 \mathrm{~mm}$. long; blades ascending or spreading, 10 to $25 \mathrm{~cm}$. long, 7 to $15 \mathrm{~mm}$. wide, acuminate, rounded at base, firm, usually scabrous on the upper surface, smooth below; panicles short-exserted, 15 to $30 \mathrm{~cm}$. long, very narrow, the branches erect or ascending, solitary or 2 or 3 in a fascicle, the lower distant, gradually approximate upward, 2 to $10 \mathrm{~cm}$. long, bearing short, appressed branchlets or subsessile spikelets along the triquetrous, scabrous rachis; spikelets 2.4 to $2.7 \mathrm{~mm}$. long, 0.8 to $1 \mathrm{~mm}$. wide, lanceolate, acute, often slightly laterally compressed (that is the glumes so keeled that the spikelet lies on its side); first glume clasping, about half the length of spikelet, acute, 3-nerved; second glume strongly keeled, somewhat boat-shaped, acute, 3 to 5nerved, slightly shorter than the 5-nerved sterile lemma, the latter inclosing a membranaceous, scabrous-nerved palea of nearly equal length; fruit 2.3 to $2.5 \mathrm{~mm}$. long, 0.7 $\mathrm{mm}$. wide, slightly boat-shaped, elliptic, acute, smooth and shining, not rigid, the margins of the lemma inrolled toward the base only, the apex of the palea scarcely inclosed.

In this species the spikelets rarely perfect their grains. $P$. hemitomon departs somewhat from the typical species of Panicum in that the fruit is less rigid and the tip of

$a$ Syn. Pl, Glum, 1: 75, 1854.

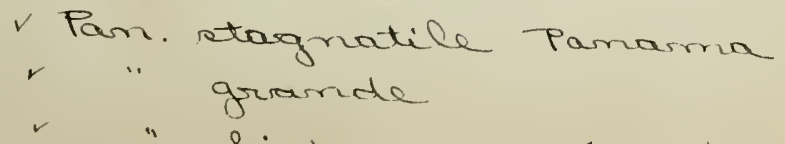


the palea is not entirely inclosed by the fertile lemma. In these characters and in its inflorescence and aquatic habit it approaches Hymenachne.

In some parts of Florida this species, known as "maiden cane," becomes a troublesome weed in cultivated soil on account of the creeping rootstocks. In this situation it very rarely produces flowering culms.

\section{DISTRIBUTION.}

In moist soil, along river banks and ditches, borders of lakes and ponds, often in water, Delaware to Florida and west to Texas.

Delaware: Millsboro, Commons 23 in 1884.

North Carolina: Burgaw, Hyams; Wilmington, Kearney 269.

South Carolina: Society Hill, Curtis (Gray Herb.).

Georgia: Sumter County, Harper 1007.

Florida: Jacksonville, Curtiss 3585, 4811, Kearney 157; Baldwin, Combs 69; Lake City, Combs 87, 206; Madison, Combs 287; De Funiak Springs, Combs 443; Econfina, Combs 680; Eustis, Nash 745; Lake Harris, Chase 4121; Homosassa, Combs 960; Ellzey, Combs 832; Bronson, Combs 836; Waldo, Combs 711; Braidentown, Combs 1270 , 1323; Palma Sola, Tracy 6731; Tampa, Garber in 1876; Bartow, Combs 1195; Hastings, Tracy 8847; Jensen, Hitchcock

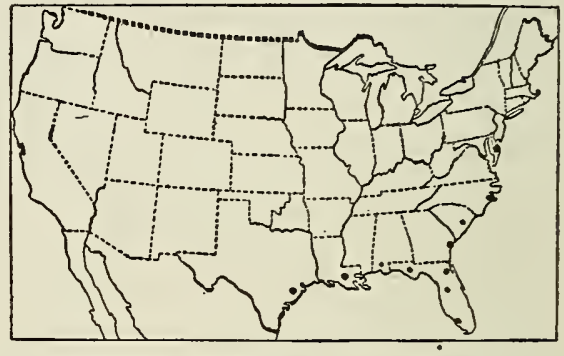

FIG. 364.-Distribution of $P$. hemitomon.

744; Myers, Hitchcock 863; Orange Glade, Eaton 574; Miami, Hitchcock 696; without locality, Rugel 347.

Alabama: Mobile, Mohr in 1882.

Louisiana: Pointe a la Hache, Langlois 46 in 1879; New Orleans, Drummond 461.

Texas: Big Sandy, Reverchon 2341; Hempstead, Hall 820; Waller, Thurow in 1898; Kounze, Nealley 40 in 1892; without locality, Drummond 367.

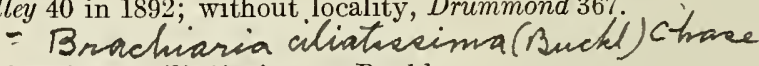

\section{$\checkmark$ 194. Panicum ciliatissimum Buckl.}

Panicum ciliatissimum Buckl. Prel. Rep. Geol. Agr. Surv. Tex. App. 4. 1866. "Northern Texas." The type is in the herbarium of the Philadelphia Academy. No locality is given on the label other than "Texas."

\section{DESCRIPTION.}

Plants perennial, producing long, leafy stolons, with short internodes, rooting at the swollen nodes, the sheaths mostly longer than the internodes but usually not inclosing them, the blades short, firm, and divaricately spreading; flowering culms usu-
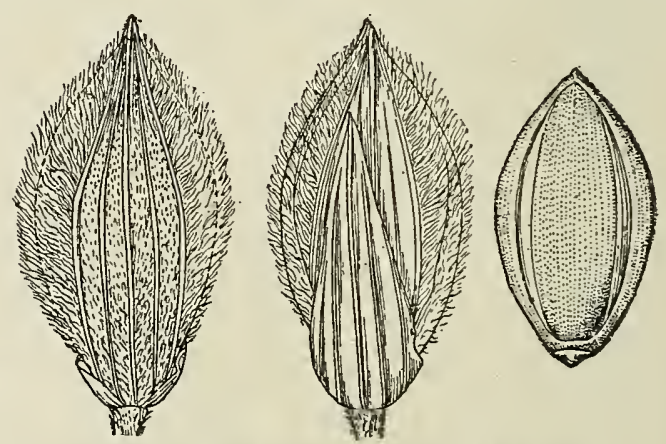

FIG. 365.-P. ciliatissimum. From type specimen.

ally sparingly branching, erect or ascending, 15 to $40 \mathrm{~cm}$. high, glabrous, the nodes bearded; sheaths sparsely, or sometimes rather densely, pilose, mostly shorter 
than the internodes; ligules densely hairy, less than $1 \mathrm{~mm}$. long; blades 3 to $7 \mathrm{~cm}$. long, 3 to $5 \mathrm{~mm}$. wide, tapering from near the rounded base to a sharp point, flat, puberulent or glabrous, usually ciliate along the lower portion of the thick, white margin; panicles finally long-exserted, 3 to $6 \mathrm{~cm}$. long, rarely over $1 \mathrm{~cm}$. wide, the few, erect branches bearing approximate, short-pediceled spikelets, placed with the back of the fruit turned from the rachis, that is the first glume toward the rachis; spikelets $4 \mathrm{~mm}$. long, about $1.8 \mathrm{~mm}$. wide, pointed; first glume three-fourths the length of the spikelet or more, cuneate, 5-nerved, glabrous, or with a few silky hairs at the very base; second glume and sterile lemma subequal, exceeding the fruit, 5-nerved, the internerves densely silky pubescent, or in the lemma sometimes nearly glabrous, the portion from the lateral nerves to the margins densely clothed with white and glistening silky hairs, the sterile palea about two-thirds as long as its lemma; fruit $3 \mathrm{~mm}$. long, about $1.6 \mathrm{~mm}$. wide, ellipsoid, apiculate, transversely rugose.

This species is somewhat doubtfully retained in Panicum. The racemose inflorescence and the reversed position of the silky, pointed spikelets show relationship with Eriochloa, in which, however, the first glume is nearly obsolete. It is most nearly allied to Panicum cimicinum (I.) Retz., an East Indian species.

\section{DISTRIB UTION.}

Open sandy ground, Arkansas and Texas.

Arkansas: Benton County, Plank 8.

Texas: Austin, Hall 824 ; Abilene, Tracy 7955; San Diego, Smith in 1897; Pena, Nealley 31 in

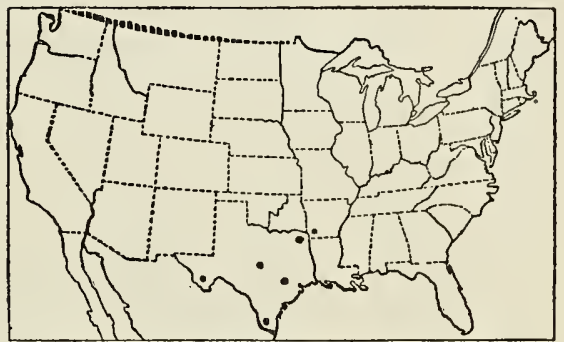

FIG. 366.--Distribution of P. ciliatissimum.

1891; Elsordo, Griffiths 6441, 6445; Torrecillas, Griffiths 6432; Encinal, Griffiths 6381; western Texas, Buckley; without locality Nealley in 1887, 1889, and 1892, Reverchon in 1885.

\section{$\checkmark$ 195. Panicum zizanioides H. B. K. \}}

Panicum oryzoides Swartz, Prodr. Veg. Ind. Occ. 23. 1788, not Ard. 1764. "Jamaica." The type is in the Swartz Herbarium.

Panicum zizanioides H. B. K. Nov. Gen. \& Sp. 1: 100. 181\%. "Crescit in calidissimis regni Novogranatensis, in ripa fuminis Magdalenx, inter Borjorque et Los Paxarales de Sogamozo." The specimen of this in the Bonplond Herbarium is not from the published locality, but "in calidissimis regni Mexicani prope Queretaro." A specimen from Humboldt in the Willdenow Herbarium is from "Amer. merid," and may be the type.

? Panicum balbisianum Schult. Mant. 2:254. 1824. Based on "Panicum aturense Herb. Balbis n. 2578." "In S. Domingo. D. Bertero" is also cited. We have not seen either of these specimens, but the description appears to apply to $P$. zizanioides to which Doell $a$ refers this name.

Panicum grandiflorum Trin.; Nees, Agrost. Bras. 143. 1829. This is given as a synonym of $P$. zizanioides and credited to "Herb. Trinii." No specimen so named was found in the Trinius Herbarium.

Panicum pseudoryzoides Steud. Syn. Pl. Glum. 1: 75. 1854. The only specimen cited is "P. oryzoides Salzm. * * * Bahia." A specimen of this was examined in the De Candolle Herbarium.

$a$ Mart. Fl. Bras. 2² : 228. 1877.

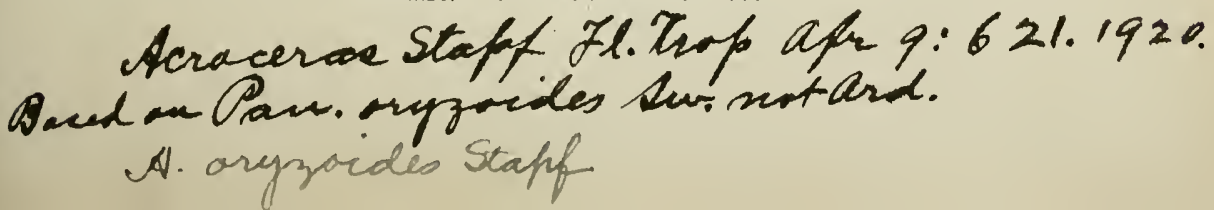


The name $P$. latifolium $\mathrm{L}$. has been applied to this species by some authors but the type of the former belongs to a very different species. $a$

\section{DESCRIPTION.}

Plants perennial, decumbent at base, rooting and rather sparingly branching at the lower nodes; culms spreading or ascending, 0.5 to 1 meter long beyond the decumbent base, rather robust, more or less angled, glabrous, rarely with a few appressed hairs below the glabrous nodes; sheaths densely short-ciliate, otherwise glabrous or papillose-hirsute toward the summit; ligule nearly obsolete; blades 4 to $15 \mathrm{~cm}$. Iong, 8 to $30 \mathrm{~mm}$. wide, cordate-clasping, acuminate, glabrous or rarely with a few appressed hairs; panicles short-exserted, 10 to $25 \mathrm{~cm}$. long, composed of a few ascend-
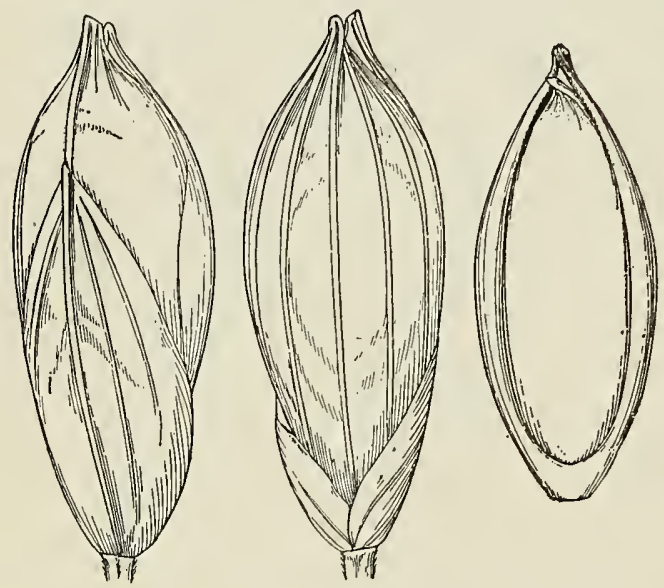

FIG. 367.-P. zizanioides. From specimen in Bonpland , Herbarium. ing or appressed, stiff, slender branches 3 to $10 \mathrm{~cm}$. long, bearing throughout their length short, appressed branchlets with more or less secund spikelets, mostly two on each branchlet, one nearly sessile, the other on a pedicel about as long as the spikelet, the branchlets angled, scabrous; spikelets 5.5 to $6 \mathrm{~mm}$. long, 2 to $2.5 \mathrm{~mm}$. wide, and as thick or thicker, obovoid, abruptly short-pointed, glabrous; first glume about two-thirds the length of thespikelet, acute, 3 to 5-nerved, second glume and sterile lemma equal, abruptly contracted into a short, keeled tip, 5-nerved, the lateral nerves of the lemma usually obsolete below the summit, the sterile palea about two-thirds as long as its lemma; fruit 4.7 to $5 \mathrm{~mm}$. long, 1.8 to $2 \mathrm{~mm}$. wide, becoming dark brown at maturity, smooth and shining, the lemma somewhat boat-shaped and with a short erose, laterally compressed crest at the apex, the apex of the palea similarly compressed and bent outward.

Closely related to P. zizanioides is Panicum paucispicatum Morong $b$ from Paraguay, which is distinguished from this by the smaller panicles, pubescent spikelets, and a more pronounced crest to the fertile lemma.

\section{DISTRIB UTION.}

Woods and copses, Mexico, West Indies, and south to Paraguay.

Mexico: Ocuilopa, Nelson 3023; Trapiche de la Concepcion, Liebmann 394; San Juan Bautista, Rovirosa 624.

Guatemala: Dept. Alta Vera Paz, Tuerckheim 7699, 7700, 8785, 8796.

Costa Rica: La Florida, Pittier 11276; Talamanca, Tonduz 8566; San Rafael, Pittier 2598.

$a$ For a further discussion see Hitchcock, Contr. Nat. Herb. 12: 118. 1908. One of the sheets upon which Linnæus has written the name "latifolium" is P. zizanioides. But this was received from Browne in Jamaica after the publication of the first edition of Linnæus's Species Plantarum and hence could not be the type of P. latifolium.

b Ann. N. Y. Acad. Sci. 7 : 262. 1893. 
CuBA: Laguna Castillano, Baker 4334; Sancti Spiritus, León 903; without locality, Wright 3466.

Jamaica: Gordon Town, Hart 726; Port Antonio, Maxon 2109.

Colombia: Santa Marta, Smith 169.

Venezuela: Tovar, Fendler 1634 (Gray Herb.).

TоваGо: Eggers 5810.

Trinidad: Broadway 2563, Botanic Gardens Herb. 2286, 3188.

British Guiana: Jenman 6001.

Dutch Guiana: Surinam, Hostmann (Gray Herb.).

BraziL: Santarem, Spruce 706; San Gabriel da Cachoeira, Spruce 2344; Organ Mountains, Wilkes Expl. Exped. 8; Rio Janeiro, Widgren in 1844; without locality, Riedel 960.

Paraguay: Morong 536, 1001.

EcUadoR: Recreo, Eggers 15422 (Field Mus. Herb.).

\section{Panicum gymnocarpon Ell.}

Panicum gymnocarpon Ell. Bot. S. C. \& Ga. 1: 117. 1816. "Collected near Savannah, by Dr. Baldwin." The type, in the Elliott Herbarium, consists of the upper part of a culm, being a panicle and the uppermost leaf.

Panicum monachnoides Desv. Opusc. 86. 1831. "Habitat in Brasilio." The type is in the Desvaux Herbarium. The locality given is doubtless an error as is the case with many of Desvaux's specimens.

Panicum drummondii Nees; Steud. Syn. Pl. Glum. 1:63. 1854. "Drum[m]ond legit in N. Orleans." In the Berlin Herbarium is a specimen labeled "Panicum Drummondii N. ab E. in Herb. Lindh. New Orleans n. 574," which is probably the type.

Phanopyrum gymnocarpum Nash in Small, Fl. Southeast. U. S. 104. 1903. Based on Panicum gymnocarpon Ell. Rafinesque ${ }^{a}$ proposed Phanopyrum as a section of

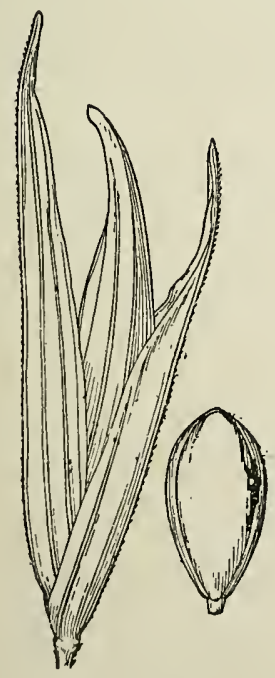

FIG. 368,-P. gymnocarpon. From type specimen. Panicum, including the single species $P$. gymnocarpon. This section was raised to generic rank by Nash, $b$ the distinguishing characters being the acuminate equal glumes and the short fertile lemma. This species departs somewhat from the usual characters of the genus Panicum, but the divergence does not seem sufficient to, justify segregating the single species as the type of a separate genus.

\section{DESCRIPTION.}

Plants perennial, with a succulent, decumbent or creeping base, sometimes as much as 2 meters long, rooting at the nodes, glabrous throughout; culms erect or ascending, 60 to $100 \mathrm{~cm}$. high, rather thick and succulent, nodes often dark colored; sheaths shorter than the in ternodes, sometimes ciliate near the summit, ligules membranaceous, about $1 \mathrm{~mm}$. long, decurrent down the margin of the sheath; blades linearlanceolate, 20 to $35 \mathrm{~cm}$. long, or the upper and lower shorter, usually 15 to $25 \mathrm{~mm}$. wide, flat, scarcely narrowed at the cordate, sparingly ciliate base, narrowed from about the middle to the acute apex, margins very scabrous; panicles finally exserted, 20 to $40 \mathrm{~cm}$. long, about three-fourths as wide, consisting of several to many racemes, solitary or fascicled along a main axis, the racemes stiffly ascending, or somewhat spreading, the middle 8 to $12 \mathrm{~cm}$. or occasionally as much as $18 \mathrm{~cm}$. long, usually spikelet-bearing from base, the spikelets short-pediceled on short, appressed branchlets, thus appearing in

a Bull. Bot. Seringe 220. 1830.

b Sinall, Fl. Southeast. U. S. 104. 1903.

$$
\begin{aligned}
& \text { 197. Parr. Rirturn Sarr. Porto Rixe, } \\
& \text { Jienidad o S. Arn. }
\end{aligned}
$$


somewhat scattered clusters; spikelets 6 to $7 \mathrm{~mm}$. long, about $1.2 \mathrm{~mm}$. wide, and, by the spreading of the glumes, about twice as thick, strongly nerved; first glume nearly as long as the sterile lemma, acuminate-pointed, the second glume exceeding the sterile lemma, both much exceeding the fruit and at maturity spreading and exposing it, acuminate-pointed, the summit of the lemma arcuate, the sterile palea obsolete; fruit $2 \mathrm{~mm}$. long, $1 \mathrm{~mm}$. wide, obovate, stipitate, smooth and shining.

\section{DISTRIBUTION.}

Ditches and muddy banks of streams and lakes, Georgia and Florida to Texas.

Georgia: Americus, Harper 522.

Florida: Burnside, Combs 1426; without locality, Chapman, Rugel 599, Simpson in 1890.

Alabama: Mobile, Mohr in 1887. Mrssissippr: Saratoga, Tracy 8396.

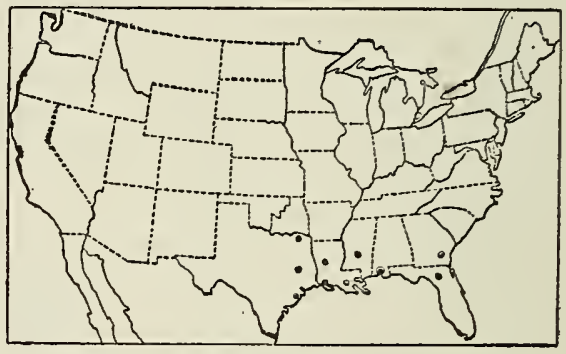

FIG. 369.-Distribution of P.gymnocarpon.

Louisiana: Plaquemines Parish, Langlois 47, 151; Chalmette, Tracy 7400; Alexandria, Hale; Natchitoches, Ball 157; Lake Charles, Chase 4407.

Texas: Harrisburg, Joor in 1875; Mineola, Reverchon 2235; Columbia, Bush 1498; Hempstead, Plank 9; Waller County, Thurow 17, and in 1889.

\section{$\checkmark$ 26A. Panicum decolorans H. B. K.}

Panicum decolorans H. B. K. Nov. Gen. \& Sp. 1: 100. 181\$. "Crescit in temperatis, apricis regni Mexicani prope Queretaro, alt. 995 hexap." The type specimen from the Bonpland Herbarium in the Paris Herbarium, bearing the published data, consists of

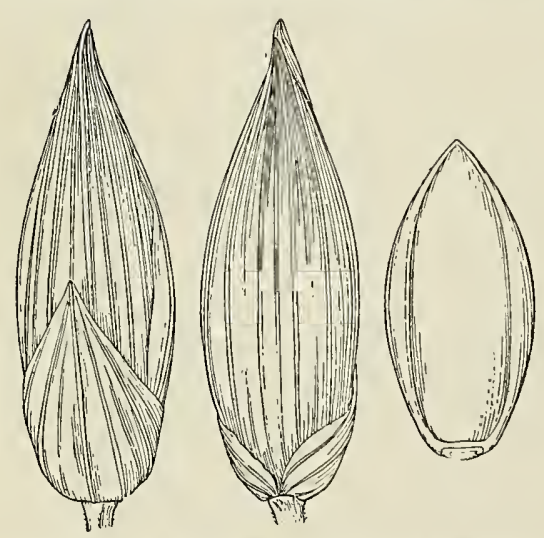

FIG. 370,-P. decolorans. From type specimen. two pieces of a culm with flat blades, one with a narrow terminal panicle about 18 $\mathrm{cm}$. long. The spikelets are 5 to 5.2 $\mathrm{mm}$. long.

Plants tinged with purple, branching from the base; culms ascending or erect, usually from a geniculate base, simple or bearing simple, usually sterile branches from the lower one or two nodes, strongly striate or almost grooved, glabrous to sparsely papillose-hispidulous, the nodes appressed-pubescent or glabrous; sheaths short, but sometimes overlapping on the shortened lower internodes, glabrous to sparsely papillose-hispid, ciliate; ligules membranaceous-fimbriate, hardly $1 \mathrm{~mm}$. long; blades 8 to $15 \mathrm{~cm}$. long, 7 to $10 \mathrm{~mm}$. wide, flat, glabrous on both surfaces or with a few scattered papillæ, these with or without short, stiff hairs; panicles finally exserted, 10 to $18 \mathrm{~cm}$. long, usually not more than one-third, but sometimes as much as two-thirds as wide, the rather long branches usually narrowly ascending, the short-pediceled spikelets somewhat crowded on approximate, short, appressed branchlets; spikelets 4.5 to $5.2 \mathrm{~mm}$. long, $1.6 \mathrm{~mm}$. wide, pointed; first glume less than half the length of the spikelet, acute; second glume and sterile lemma subequal, exceeding the fruit and pointed beyond it; fruit 2.8 to $3.2 \mathrm{~mm}$. long, $1.5 \mathrm{~mm}$. wide. 
examined. The culms and blades are minutely pubescent, the latter $8 \mathrm{~cm}$. long and $12 \mathrm{~mm}$. wide. The spikelets are glabrous and $3 \mathrm{~mm}$. long, the first glume or,tuse, 3-nerved, nearly as long as the spikelet, the second glume 5-nerved, the sterile lemma 2-nerved, the central nerve being suppressed.

Panicum densum Muhl. Descr. Gram. 122. 1817. No locality is given. The type is not in the Muhlenberg Herbarium. The description suggests one of the Lanuginosa.

Panicum dichotomum curvatum Torr. Fl. North. \& Mid. U.S. 145. 1824. No locality is given. There is no specimen thus marked in the Torrey Herbarium. The reference to tall culms and curved branches suggests $P$. yadkinense Ashe.

Panicum dichotomum gracile Torr. Fl. North. \& Mid. U. S. 145. 1824. "Common in swamps, New-York." The type is not in the Torrey Herbarium and the form can not be certainly identified, but the description, "culm tall, slender; leaves membranaceous. Common in swamps," suggests the vernal form of $P$. lucidum Ashe.

Panicum dichotomum spathaceum Wood, Bot. \& Flor. 393. 187\&. No locality nor specimen is mentioned and the form can not be identified.

Panicum disciferum Fourn. Mex. Pl. 2: 19. 1886. "San Luis de Potosi (V1RL[ET] n, 1292)." We have been unable to find the type of this. The name was mentioned earlier, without description, by Hemsley. $a$ The description of the inflorescence as

S/ consisting of six appressed spikes suggest that this may not be a true Panicum.

Panicum discolor Spreng. Mant. Fl. Hal. 31. 1807. The only specimen mentioned is "E Pensylvania." We have not been able to locate the type and the species can not be identified from the description, though it belongs to the subgenus Dichanthelium.

Panicum elliottii Spreng.; Steud. Nom. Bot. ed. 2. 2 : 256. 1841, not Trin. 1829. This is given as a synonym of $P$. pubescens. As the latter name is given without an author, Sprengel's name can be fixed upon no definite species and is hence a nomen nudum. No type has been seen.

Panicum firmandum Steud. Syn. Pl. Glum. 1 : 418. 1854. "Carolina sptr." This was received from M. A. Curtis under the name of $P$. microcarpon Muhl. We have not seen the type. The description applies well to $P$. sphaerocarpon except that the spikelets are said to be glabrous while in the latter species they are finely puberulent.

Panicum flexuosum Raf.; Desv. Journ. de Bot. 4 : 273. 1814, not Retz. 1791. The description is as follows: "feuilles lancéolées, élatées, ciliees à la base; panicule pubescente; pedoncules flexueux; glume ciliee. Dans le nouveau Jersey."

Panicum gracilescens Desv.; Poir. in Lam. Encycl. Suppl. 4: 279. 1816. "Cette plante croît à la Caroline (V. s. in herb. Desv.)." The type could not be found in the Desvaux Herbarium and the species can not be identified. Desvaux gives a later description, $b$ which disagrees in some respects with that of Poiret.

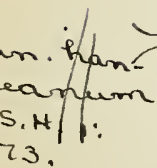

Panicum hirsutum Vahl; Griseb. Fl. Brit. W. Ind. 548. 1864, not Swartz, 1797. This is mentioned as a synonym under $P$.diffusum Swartz. We have not seen the type but the specific name and the statement by Grisebach that the sheaths of $P$. diffusum may be glabrous or pilose, suggest that $P$. hirsutum Vahl may be $P$. ghiesbreghtii Fourn.

Panicum iowense Ashe, N. C. Agr. Exp. Sta. Bull. 175 : 115. 1900. "Dry prairies, eastern Iowa to Kansas, June and July." There is no specimen in Ashe's herbarium bearing this name nor that can with any degree of certainty be connected with the description. There is a specimen of $P$. praecocius collected on dry prairies at Armstrong, Iowa, July, 1890, by R. I. Cratty, which is marked in pencil by Ashe, "Panicum prairie." The description applies fairly well to this specimen except that the height is given as "1-2 cm." [error for 1 to $2 \mathrm{dm}$.?], the panicle as "small, 1-2 cm. long," and the length of the spikelets as "1.1-1.4 mm." [the spikelets are 1.8 to 1.9 $\mathrm{mm}$. long]. The description is too meagre to distinguish this species from $P$. huachucae which is found in the range given, and to which the description of panicles and spikelets better applies. A specimen of $P$. praecocius, Carver 258, Jewell Junction, Iowa, in the Iowa Agricultural College Herbarium, is marked in Ashe's writing "Panicum haemocarpon Ashe sp. nov. affine P. villosissimum Nash." This adds to the evidence against taking the Cratty specimen as the type of $P$. iowense. 
Panicum muhlenbergianum Schult. Mant. 2: 230. 1824. Based on "Panicum n. 27 (sine nomine) Muhlenb. Descr. ub. p. 118." The type is not in the Muhlenberg Herbarium, and there is no evidence that Schultes saw the plant, the description of which he copies from Muhlenberg. The latter gives the locality as "Habitat in Georgia." The description applies well to $P$. barbulatum Michx.

Panicum nitidum glabrum Torr. Fl. North. \& Mid. U. S. 146. 1824. No locality is mentioned, and the type can not be found in the Torrey Herbarium. The description suggests $P$. commutatum Schult.

Panicum nitidum gracile Torr. Fl. North. \& Mid, U. S. 146. 1824. The only locality mentioned is "near New-York." The type can not be found in the Torrey Herbarium. The description applies fairly well to the vernal form of $P$. dichotomum $\mathrm{L}$.

Panicum nitidum major[us] Vasey, Contr. Nat. Herb. 3: 30. 1892. No specimen nor locality is cited and no type can be found in the National Herbarium. Vasey says, "Here could be placed several variable forms."

Panicum ornatum Desv.; Hamilt. Prodr. Pl. Ind. Occ. 11. 1825. "Herb. Prof. acumiDesv. Porto Rico." This is further described by Desvaux. ${ }^{a}$ We have been unable to find the type of this species. It is doubtful if the type came from Porto Rico, as the description does not appear to apply to any of the West Indian species.

Panicum pensylvanicum Spreng. Bot. Gart. Halle, Erst. Nacht. 30. 1801. "Pensylvanien." No type nor authentic specimen of this could be found. The species can not be recognized from the description given. A later description $b$ differs in several essentials and may apply to $P$. anceps. Willdenow $c$ refers $P$. pensylianicum "Spreng. cat. hort. halens." to P. rostratum Muhl. (P. anceps).

Panicum portoricense Desv.; Hamilt. Prodr. Pl. Ind. Occ. 11. 1825. "Herb. Prof. Desv. Porto Rico." A further description is given later by Desvaux, d where the locality is given as "Antillis." We have been unable to find the type of this. The description appears to apply to a species of the subgenus Dichanthelium.

Panicum pumilum Raf. Med. Repos. N. Y. 5: 353. 1808. This is a nomen nudum with no mention of locality nor specimens.

Panicum rafinesquianum Schult. Mant. 2: 257. 1824. Based on P. flexuosum Raf.

Panicum reflexopilum Steud. Syn. Pl. Glum. 1: 84. 1854. "Oaxaca." We havenot seen the type. The description applies well to $P$. viscidellum Scribn.

Panicum sessilicaule Desv.; Hamilt. Prodr. Pl. Ind. Occ. 11. 1825. This is mentioned in a note under P. cayennense Lam. and later described by Desvaux, $e^{e}$ who gives the locality as "Habitat in Carolina?" and states that the plant is only a variety of $P$. cayennense. It probably did not come from Carolina. We have not seen the type.

Panicum speciosum Walt. FI. Carol. 73. 1788. No special locality is given, but the general locality is the valley of the lower Santee River, South Carolina. There is no specimen of this in Walter's herbarium. It can not be identified.

Panicum striatum Muhl.; Hemsl. Biol. Centr. Amer. Bot. 3: 492. 1885. This is given as a synonym of $P$. neuranthum Griseb. The name appears here and also later in Fournier's work, $f$ from which Hemsley quotes as "Panicum striatum Muhl. not Lam." We know of no P. striatum of Muhlenberg.

Panicum vilfiforme Wood, Class-book. 785. 1861. "Wet meadows, E. Tenn.!" We have not been able to locate the type of this, and it can not be identified from the description. It appears to be a species of the group Agrostoidia.

Panicum virletii Fourn. Mex. Pl. 2 : 29. 1886. "San Luis de Potosi (VIrL. n. 1305, 1371)." This name was earlier listed without description by Hemsley.g Neither of the specimens cited could be found. The only description given is "Differt a $P$. diffuso gluma inferiore mediam spiculam superante." The specimens cited by Fournier under $P$. diffusum are mostly $P$. ghiesbreghtii Fourn.

$a$ Opusc. 88 [90]. 1831.

$b$ Spreng. Mant. F1. Hal. 1 : 31.1807.

c Enum. Pl. 1032. 1809.

d Opusc. 89. 1831. nota caturn valid 


\section{IIST OF NEW SUBGENERA AND SPECIES AND NEW NAMES.}

Dichanthelium Hitchc \& Chase, qubgen nov (type $P$ dichotomum $\mathrm{L}$ )

Lasiacis (Griseb.) Hitchc..................................... ${ }^{16}$

Lasiacis sect. Panicum Griseb.

Lasiacis divaricata (L.) Hitchc............................ 16

Panicum divaricatum $\mathrm{L}$.

Panicum amarulum Hitchc. \& Chase, sp. nov..................... 96

Panicum breve Hitchc. \& Chase, sp. nov....................... 271

Panicum bulbosum sciaphilum (Rupr.) Hitchc. \& Chase................. 83 Panicum sciaphilum Rupr.

Panicum concinnius Hitchc. \& Chase......................... 263

Panicum gracilicaule Nash, 1903, not Rendle, 1899.

Panicum cupreum Hitchc. \& Chase.............................. $\quad 120$

Panicum hians purpurascens Scribn., not $P$. purpurascens H. B. K.

Panicum firmulum Hitchc. \& Chase, sp. nov....................... ${ }_{27} 27$

Panicum languidum Hitchc. \& Chase............................... ${ }_{2} 232$

Panicum unciphyllum forma prostratum Scribn. \& Merr., not P. prostratum Lam.

Panicum lepidulum Hitchc. \& Chase, sp. nov.................... $\quad 75$

Panicum longum Hitchc. \& Chase................................ . 111 Panicum pilosum macranthum Scribn., not $P$. macranthum Trin.

Panicum nodatum Hitchc. \& Chase, sp. nov........................ 293

Panicum olivaceum Hitchc. \& Chase, sp. nov....................... 225

Panicum pacificum Hitchc. \& Chase, sp. nov...................... 229

Panicum paludivagum Hitchc. \& Chase, sp. nov.................... $\quad 32$

Panicum pampinosum Hitchc. \& Chase, sp. nov..................... 66

Panicum parcum Hitchc. \& Chase, sp. nov......................... 68

Panicum plenum Hitchc. \& Chase, sp. nov....................... 80

Panicum rhizomatum Hitchc. \& Chase, sp. nov .................... . 109

Panicum rotundum Hitchc. \& Chase, sp. nov ....................... 139

Panicum sphaerocarpon inflatum (Scribn. \& Smith) Hitche............ 253

Panicum inflatum Scribn. \& Smith.

Panicum stramineum Hitchc. \& Chase, sp. nov................... 67

Panicum vernale Hitchc. \& Chase, sp. nov...................... 266

Panicum xalapense strictirameum Hitchc. \& Chase, subsp. nov......... 161

Paurochaetium Hitchc. \& Chase, subgen. nov.(type P.distantiflorum Rich.). 22 


\section{INDEX TO NUMBERED SPECIMENS.}

The following list includes the numbered specimens distributed in the more important collections of Panicum. Two or more species when here listed under one number were distributed under this number by the collector.

ANDrews, I.
8. sphaerocarpon.
11. clandestinum.
14. lindheimeri.
18. barbulatum.
20. implicatum.
23. verrucosum.
36. huachucae silvicola.
40. boscii.
44. latifolium.
49. linearifolium.
51. scribnerianum.
58. depauperatum.
62. tsugetorum.
63. ashei.
64. huachucae silvicola.
66. huachucae silvicola.
70. huachucae.
73. sphaerocarpon.
74. tsugetorum.

BAKER, C. F.
36. scribnerianum.
48. 'barbinode.
131. agrostoides.
676. barbipulvinatum.

2053. barbinode.

2078. parvifolium.

4334. zizanioides.

4837. stenodes.

BAKER, C. H.
18. condensum.
31. verrucosum.
40. rhizomatum.
41. pauciciliatum.
42. commutatum.
45. chrysopsidifolium.
68. polycaulon.
69. equilaterale.
70. pauciciliatum.
71. pauciciliatum.
72. pauciciliatum.
119. albomarginatum.

BALL, C. R.

8. anceps.

14. boscii.

20. agrostoides.

21. dichotomiflorum. polyanthes.

25. joorii.

30. perlongum.

34. dichotomiflorum.

39. dichotomiflorum.

40. latifolium.

42. huachucae silvicola.

46. anceps.

51. microcarpon.

53. lindheimeri.

60. hians.

62. xalapense.

64. oligosanthes.

65. sphaerocarpon.

66. commutatum.

67. dichotomiflorum.

69. sphaerocarpon.

70. stipitatum.

77. scoparium.

83. agrostoides.

111. agrostoides.

120. capillare.

121. angustifolium.

122. xalapense.

123. hians.

124. agrostoides.

125. anceps.

135. dichotomiflorum.

137. rhizomatum.

139. dichotomiflorum.

145. perlongum.

149. capillare.

155. latifolium.

156. agrostoides.

157. gymnocarpon. huachucae silvicola.

164. dichotomiflorum. 
BALL, C. R.-Continued.

166. anceps.

169. agrostoides.

178. scribnerianum.

190. hians.

192. virgatum.

202. lucidum.

204. verrucosum.

215. dichotomiforum.

220. brachyanthum.

225. agrostoides.

228. anceps.

229. dichotomiflorum.

441. sphaerocarpon inflatum.

535. hians.

536. sphaerocarpon inflatum.

544. lanuginosum.

625. commutatum.

702. clandestinum.

703. boscii molle.

704. microcarpon.

705. polyanthes.

720. capillare.

791. equilaterale.

792. lancearium.

816. tennesseense.

817. implicatum.

966. capillare.

1139. obtusum.

Bartlett, H. H.

807. spretum.

844. microcarpon.

903. anceps.

1024. philadelphicum.

1066. agrostoides.

1071. polyanthes.

1081. microcarpon

1103. verrucosum.

1136. lucidum.

1170. scoparium.

1172. auburne.

1173. nitidum.

1327. oricola.

1368. oricola.

1379. oricola.

1414. villosissimum.

1443. lanuginosum.

1444. aciculare.

1453. xalapense.

1455. aciculare.

1456. nitidum.

1457. microcarpon.

1458. ashei.
Bartlett, H. H.-Continued.

1459. sphaerocarpon.

1460. lanuginosum.

1461. concinnius.

1462. angustifolium.

1497. villosissimum.

1498. polyanthes.

1500. polyanthes.

1501. joorii.

1502. ravenelii.

1504. ashei.

1505. boscii.

1508. mutabile.

Beвb, R.

513. depauperatum.

514. pseudopubescens.

520. huachucae.

882. latifolium.

1236. xalapense.

1242. commutatum.

1245. oligosanthes.

1259. sphaerocarpon.

1262. angustifolium.

1276. lindheimeri.

1278. helleri.

1299. capillare.

1321. reverchoni.

1426. oligosanthes.

1428. lindheimeri.

1430. helleri.

1434. sphaerocarpon.

1457. xalapense.

1459. scribnerianum.

2057. praecocius.

2167. scribnerianum

2661. villosissimum.

2663. depauperatum.

2670. malacophyllum.

2703. oligosanthes.

2715. scribnerianum.

2815. meridionale.

2832. subvillosum.

2833. villosissimum.

$2833 \frac{1}{2}$. subvillosum.

2834. villosissimum.

2881. tennesseense.

2882. pseudopubescens.

2917. capillare.

2928. flexile.

2935. boreale.

2936. meridionale.

29391. tsugetorum.

2947. meridionale. 


\section{Biltmore Herbarium.}

696a. anceps.

697a. trifolium.

698b. tennesseense.

$700 \mathrm{a}$. virgatum.

$700 \mathrm{~b}$. virgatum.

$700 \mathrm{c}$. virgatum.

700e. virgatum cubense.

702a. dichotomiflorum.

797. depauperatum.

797a. depauperatum.

797c. depauperatum.

800a. barbulatum.

dichotomum.

$800 \mathrm{~b}$. lucidum.

$800 \mathrm{c}$. dichotomum.

802a. cómmutatum.

802 b. commutatum.

803a. microcarpon.

804. clandestinum.

804b. clandestinum.

808a. stipitatum.

2984a. commutatum.

2993a. xalapense.

2993c. xalapense.

2994a. ravenelii.

3627. longifolium.

4278. angustifolium.

4290. scoparium.

4290a. scoparium.

4292b. sphaerocarpon.

$5066 \mathrm{~b}$. lucidum.

5066e. sphagnicola.

5184b. tennesseense.

5185a. boscii molle.

5185b. boscii molle.

$5839 \mathrm{~b}$. anceps.

6022a. polycaulon.

6028. spretum in part.

6204a. webberianum.

7079a. linearifolium.

7080a. wrightianum.

8342. werneri.

9953c. albemarlense.

9959f. boscii molle.

10715b. curtifolium.

11866. aciculare.

14879b. huachucae silvicola.

Bissell, C. H.

385. scoparioides.

5529. agrostoides.

5533. depauperatum.

5541. linearifolium.
Bissell, C. H.-Continued.

5542. linearifolium.

5544. clandestinum.

5546. clandestinum.

5548. latifolium.

5549 . latifolium.

5550. latifolium.

5551. boscii molle.

5552 . boscii.

5563. scribnerianum.

5566. microcarpon.

5569. microcarpon.

5570. microcarpon.

5571. microcarpon.

5577. barbulatum.

5580. ashei.

5581. scoparioides.

5582. boreale.

5583. lindheimeri.

5585. sphaerocarpon.

5590. implicatum.

5594. tsugetorum.

5595. tsugetorum.

5596. columbianum.

5611. tennesseense.

5616. tsugetorum.

5622. implicatum.

8084. scoparioides.

9306. oricola.

11596. longifolium.

12000. commonsianum.

12001. subvillosum.

12002. implicatum.

BоTTER1, M.

99. olivaceum.

101. olivaceum.

160. plenum.

648. virgatum.

688. laxum.

705. viscidellum.

1987. olivaceum.

Bourgeau, E.

235. bulbosum.

529. elephantipes.

1455. pulchellum.

1662. polygonatum in part.

2162. xalapense.

2383. multirameum.

olivaceum.

2751. ghiesbreghtii.

2794. bulbosum.

3132. viscidellum.

3192. glutinosum. 
Brace, L. J. K.

3467. bartowense.

3524. caerulescens.

3697. nitidum.

3742. dichotomiflorum.

4158. exiguiflorum.

4164. exiguiflorum.

4380. exiguiflorum.

7015. caerulescens.

7019. tenerum.

7132. tenerum.

Broadway, W. E.

2370. stoloniferum.

2371. frondescens.

2372. parvifolium.

2563. zizanioides.

2629. hirsutum.

BURCHELL, W. J.

A101-2. rotundum.

4146. millegrana.

4315-2. millegrana.

4653. millegrana.

7062. trichanthum.

8350. cayennense.

8706. trichoides.

8791. trichanthum.

Bush, B. F.

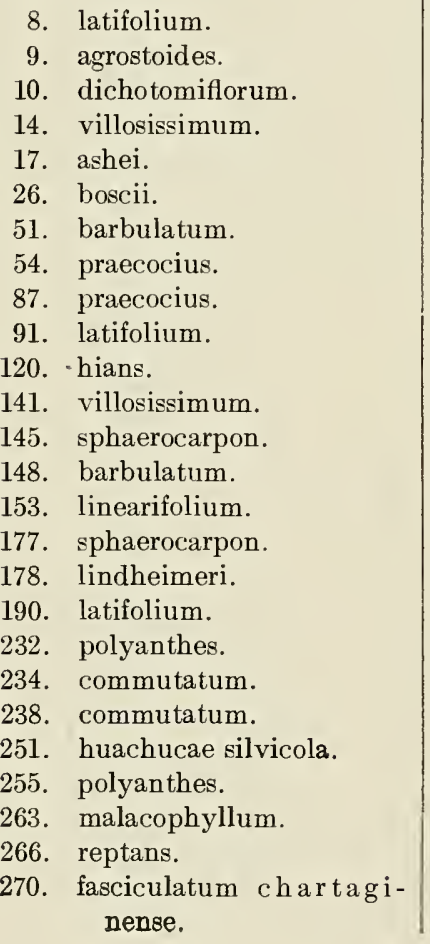

Bush, B. F.-Continued.

276. boscii.

287. commutatum.

289. ashei.

302. agrostoides.

303. boscii.

308. commutatum.

309. huachucae silvicola.

310. boscii.

312. ashei.

313. barbulatum.

320. linearifolium.

322 . commutatum.

323. boscii.

333. villosissimum.

379. leibergii.

384. flexile.

413. bicknellii.

642. malacophyllum.

651. xalapense.

674. reverchoni.

675. sphaerocarpon.

705. helleri.

virgatum.

707. hians.

708. hians.

709. hians.

711. tennesseense.

712. tennesseense.

718. clandestinum.

720. barbulatum.

722. scribnerianum.

729. scribnerianum.

730. leibergii.

731. commutatum. linearifolium.

732. villosissimum.

733. clandestinum. scribnerianum.

734. huachucae silvicola.

737. scribnerianum.

738. brachyanthum.

740. scribnerianum.

742. linearifolium.

744. leibergii.

746. huachucae silvicola.

747. microcarpon. sphaerocarpon inflatum.

748. commutatum. praecocius.

749. praecocius. xalapense.

750. villosissimum.

753. sphaerocarpon inflatum. 
Bush, B. F.-Continued.

754. boscii molle.

755. commutatum.

759. huachucae silvicola.

760. huachucae silvicola.

803. helleri.

848. flexile.

906. flexile.

979. brachyanthum.

1023. agrostoides.

1107. linearifolium.

1156. filipes.

1157. fasciculatum chartaginense.

1198. texanum.

1210. huachucae silvicola.

1216. scribnerianum.

1218. sphaerocarpon.

1220. villosissimum.

1222. scribnerianum.

1224. commutatum.

1225. oligosanthes.

1273. xalapense.

1296. reptans.

1298. anceps.

1388. aciculare.

1398. agrostoides.

1440. xalapense.

1450. commutatum.

1498. gymnocarpon.

1555. linearifolium.

1652. leibergii.

1659. scribnerianum.

1684. leibergii.

1685. helleri.

1710. helleri.

1713. huachucae silvicola.

1732. latifolium.

1832. obtusum.

2332. huachucae.

2350. depauperatum.

2488. xalapense.

2522. arenicoloides.

2526. ravenelii.

2529. helleri.

2532. barbulatum.

2736. commutatum.

2760. leibergii.

2877. barbulatum.

2881a. linearifolium.

2911. ashei.

2913. werneri.

2926. werneri.
Bush, B. F.--Continued.

2996. huachucae silvicola.

3089. perlongum.

3090. praecocius.

3107. obtusum.

3246. bicknellii.

3295. flexile.

3318. capillare.

3369. barbulatum.

3456. ashei.

3456a. barbulatum.

3529. barbulatum.

3658. stipitatum.

3893. helleri.

3903. helleri.

3914. tennesseense.

3915. huachucae silvicola.

3933. scribnerianum.

3935. praecocius.

3936. depauperatum.

3968. huachucae silvicola.

3977. clandestinum.

3981. latifolium.

4001. latifolium.

4002. huachucae silvicola.

4003. clandestinum.

4021. scribnerianum.

4024. huachucae silvicola.

4038. virgatum.

4411. linearifolium.

441la. linearifolium.

4412. ashei.

4458. barbulatum.

4473. barbulatum.

4487. ashei.

4532. tennesseense.

4533. linearifolium.

4534. boscii.

4549. linearifolium.

4568. scribnerianum.

4638. xalapense.

4651. clandestinum.

4652. boscii.

4653. scribnerianum.

4654. depauperatum.

4684. tennesseense.

4685. commutatum.

4712. ashei.

4714. ashei.

4733. barbulatum.

4734. linearifolium.

4788. villosissimum.

4803. huachucae silvicola. 
Bush, B. F.-Continued.

4807. latifolium.

4824. gattingeri.

4865. clandestinum.

4908. boscii.

5023. villosissimum.

5060. boscii molle.

5105 . virgatum.

5114. anceps.

5115. agrostoides.

5116. gattingeri.

5119. philadelphicum.

5120. philadelphicum.

5203. philadelphicum.

5234. agrostoides.

5259. flexile.

Chamberlain, E. B.

298. depauperatum.

336 . boreale.

513. huachucae silvicola.

552. virgatum.

787. subvillosum.

793. boreale.

837. subvillosum.

Chase, A.

867. depauperatum.

889. latifolium.

918. verrucosum.

1178. virgatum.

1472. meridionale.

1474. flexile.

1479. flexile.

1480. capillare.

1540. depauperatum.

1541. latifolium.

1542. pseudopubescens.

1543. dichotomum.

1544. tsugetorum.

1545. villosissimum.

1546. implicatum.

1552. tsugetorum.

1563. villosissimum.

1602. tsugetorum.

1604. tsugetorum.

1605. pseudopubescens.

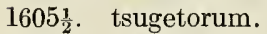

1606. villosissimum.

1607. scribnerianum.

1633. miliaceum.

1636. virgatum.

1729. flexile.

1824. latifolium.

1850. sphaerocarpon.

1887. latifolium.
Chase, A.-Continued.

1904. tennesseense.

1919. dichotomum.

1921. tsugetorum.

1947. latifolium.

2006. flexile.

2008. capillare.

2284. depauperatum.

2303. linearifolium.

2315. dichotomum.

2316. xalapense.

2320. xalapense.

2332. sphaerocarpon.

2333. spretum.

2339. albemarlense.

2341. auburne.

2345. lancearium.

2349. commonsianum.

2357. aciculare.

2366. clandestinum.

2367. microcarpon.

2368. polyanthes.

2370. microcarpon.

2374. boscii.

2378. villosissimum.

2379. dichotomum.

2381. commutatum.

2400. huachucae silvicola.

2401. sphaerocarpon.

2402. depauperatum.

2412. sphaerocarpon.

2428. meridionale.

2463. tennesseense.

2477. ashei.

$2477 \frac{1}{2}$. bicknellii.

2520. aculeatum.

2528. virgatum.

2585. anceps.

2599. philadelphicum.

2628. gattingeri.

2673. condensum.

2679. stipitatum.

2830. ashei.

2849. tennesseense.

2853. yadkinense.

2864. depauperatum.

2865. scribnerianum.

2874. tennesseense.

2887. lindheimeri.

2905. villosissimum.

2912. oligosanthes.

2936. aciculare.

2946. yadkinense.

2947. annulum. 
Chase, A.-Continued.

2964. yadkinense.

2985. lindheimeri.

2996. anceps.

3047. lindheimeri.

3048. dichotomum.

3049. huachucae silvicola.

3051. ashei.

3052. commutatum.

3053. depauperatum.

3054. boscii molle.

3055. villosissimum.

3056. villosissimum.

3056 $\frac{1}{2}$. dichotomum.

3057. xalapense.

3058. villosissimum.

3059. yadkinense.

3060. trifolium.

3061. yadkinense.

$3061 \frac{1}{2}$. microcarpon.

3062. huachucae silvicola.

3063. angustifolium.

3064 . ashei.

3065. huachucae silvicola.

3067 . huachucae silvicola.

3068. lanuginosum.

3069. huachucae silvicola.

3071. villosissimum.

3072. yadkinense.

3073. boscii.

3074. sphaerocarpon.

3075. villosissimum.

3076. lanuginosum.

3078. clandestinum.

3081. villosissimum.

3082. angustifolium.

$3082 \frac{1}{2}$. arenicoloides.

3084. aciculare.

3086. lanuginosum.

3087. angustifolium.

3088. ravenelii.

3089. sphaerocarpon.

3090. barbulatum.

3092. bicknellii.

3093. spretum.

3094. aciculare.

3095. consanguineum.

3096. wrightianum.

3096ㄹ. ensifolium.

3097. ensifolium.

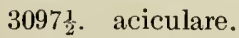

3098. hians.

3099. mattamuskeetense.

3100. meridionale.
Chase, A.-Continued.

$3100 \frac{1}{2}$. albermarlense.

3101. scabriusculum.

3103. aciculare.

3105. aciculare.

3106. albemarlense.

3107. lanuginosum.

3108. lindheimeri.

3109. pseudopubescens.

3110. patulum.

3111: xalapense.

3112. lucidum.

3113. lancearium.

3114. commutatum.

3115. pseudopubescens.

3117. xalapense.

3118. xalapense.

3120. arenicoloides.

3121. villosissimum.

3123. aciculare.

3125. chamaelonche.

3126. pauciciliatum.

3127. pauciciliatum.

3128. pauciciliatum.

3129. lancearium.

3130. aciculare.

3131. ciliatum.

3132. auburne.

3133. trifolium.

3134. sphaerocarpon inflatum.

3135. wrightianum.

3136. longiligulatum.

3137. erectifolium.

3138. angustifolium.

3139. pauciciliatum.

3141. villosissimum.

3143. arenicoloides.

3144. virgatum cubense.

3145. longiligulatum.

3147. pseudopubescens.

3150. longiligulatum.

3154. mutabile.

3155. villosissimum.

3156. arenicoloides.

3157. aciculare.

3158. sphaerocarpon inflatum.

3159. lucidum.

3160. pseudopubescens.

3161. commonsianum.

3162. pauciciliatum.

3163. angustifolium. •

3166. addisonii.

3167. aciculare. 
Chase, A.-Continued.

3168. commutatum.

3169. angustifolium.

3170. tenue.

3171. strigosum.

3172. tenue.

3174. consanguineum.

3175. longiligulatum.

3176. ensifolium.

3177. ensifolium.

3178. roanokense.

3179. longiligulatum.

3181. lancearium.

3182. chamaelonche.

3183. tenue.

3184. ciliatum.

3185. aciculare.

3187. microcarpon.

3188. barbulatum.

3189. mutabile.

3190. microcarpon.

3191. villosissimum.

3192. yadkinense.

3193. lancearium.

3194. lancearium.

3195. wilmingtonense.

3196. ensifolium.

3197. lucidum.

3198. lindheimeri.

3199. trifolium.

3200. nitidum.

3201. albemarlense.

$3201 \frac{1}{2}$. lanuginosum.

3203. roanokense.

3204. microcarpon.

3205. aciculare.

3206. sphaerocarpon.

3208. lanuginosum.

3210. aculeatum.

$3210 \frac{1}{2}$. microcarpon.

3211. lancearium.

3212. sphaerocarpon.

3213. longiligulatum.

3214. ciliatum.

3215. aciculare.

3216. aciculare.

3217. aciculare.

3218. pseudopubescens.

3220. ashei.

3221. lanuginosum.

3222. pseudopubescens.

3224 . lancearium.

3225. trifolium.

3226. ciliatum.
Chase, A.-Continued.

3227. ensifolium.

3228. longifolium.

3230 . consanguineum.

3232. mattamuskeetense.

3233. longiligulatum.

3234. ensifolium.

3235. scabriusculum.

3237. sphaerocarpon.

3238. trifolium.

3239. trifolium.

3240. roanokense.

3242. clutei.

3244. strigosum.

3246. pauciciliatum.

3247. roanokense.

3248. trifolium.

3249. angustifolium.

3250. angustifolium.

3253. microcarpon.

3254 . huachucae silvicola.

3255. lindheimeri.

3256. sphaerocarpon.

3259. lindheimeri.

3260 . tennesseense.

3262. microcarpon.

3269 . tsugetorum.

3270 . tsugetorum.

3272. clandestinum.

3273 . polyanthes.

3274. tennesseense.

3275 . tennesseense.

3277 . boreale.

3278. subvillosum.

3283. depauperatum.

3295. xanthophysum.

3299. werneri.

3300. xanthophysum.

3301. tennesseense.

3316. depauperatum.

3320. subvillosum.

3321. tsugetorum.

3326. linearifolium.

3355. boreale. .

3363. tsugetorum.

3367. latifolium.

3379. depauperatum.

3382. werneri.

3390 . tsugetorum.

3391. subvillosum.

3392. implicatum.

3393. linearifolium.

3399 . tennesseense.

$3399 \frac{1}{2}$. tsugetorum. 
Chase, A.-Continued. 3436. implicatum.

3437 . boreale.

3443 . boreale.

3453. subvillosum.

3454. implicatum.

3457. tennesseense.

3458 . boreale.

3459. implicatum.

3464. lindheimeri.

3466. meridionale.

3469 . agrostoides.

$3473 \frac{1}{2}$. lindheimeri.

3475. lucidum.

3484 . barbulatum.

3486. scoparium.

3488. lanuginosum.

3489. sphaerocarpon.

3502. ashei.

3503. tennesseense.

3505. lanuginosum.

3508. huachucae silvicola.

3509. sphaerocarpon.

3513. clandestinum.

3516. microcarpon.

3517. addisonii.

$3517 \frac{1}{2}$. commonsianum.

3519. columbianum.

3520. pseudopubescens.

3521. ashei.

3522. villosissimum.

3523. addisonii.

3524. tsugetorum.

3528 . lindheimeri.

3529. agrostoides.

3530 . longifolium.

3531. commonsianum.

3532. tsugetorum.

3533. columbianum.

3534. columbianum thinium.

$3534 \frac{1}{2}$. meridionale.

3535. ensifolium.

3536. leucothrix.

3538. addisonii.

3539. columbianum.

3541. commonsianum.

3542. ashei.

3543 . tsugetorum.

3544. commonsianum.

3545 . clutei.

3546. verrucosum.

3550. lucidum.

3551. spretum.

3553. clutei.
Chase, A.-Con tinued.

3554. lucidum.

3556. leucothrix.

3557. ensifolium.

3559. columbianum thinium.

3560 . columbianum thinium.

3562 . oricola.

3564. tsugetorum.

3566. pseudopubescens.

3569. spretum.

3570 . commonsianum.

3572. lindheimeri.

3573. virgatum cubense.

3574. addisonii.

3575. commonsianum.

3576 . oricola.

3577. columbianum thinium.

3578. leucothrix

3579. tsugetorum.

3580. huachucae silvicola

3581. oricola.

3583. addisonii

3584. commonsianum.

3588. columbianum thinium.

3589. lindheimeri.

3590. clutei.

3593. lucidum.

3595. addisonii.

3596. commonsianum.

3598. clutei.

3599. lucidum.

3600 . scoparium.

3601. tsugetorum.

$3601 \frac{1}{2}$. ashei.

3603 . addisonii.

3605. columbianum thinium.

3606. columbianum.

3608 . tsugetorum.

3609 . oricola.

3611. sphaerocarpon.

3612. tsugetorum.

3613. columbianum.

3616. yadkinense.

3617. tennesseense.

3618. scribnerianum

3620 . barbulatum.

3621. commutatum.

3623 . virgatum.

3631. anceps.

3642 . tsugetorum.

3643. barbulatum.

3653. villosissimum.

3654. commutatum.

3656 . lancearium. 
Chase, A.-Continued.

3657. dichotomum.

3658. albomarginatum.

3660 . verrucosum.

3662. longifolium.

3663. lanuginosum.

3668. microcarpon.

3674. patulum.

3675. villosissimum.

3676 . virgatum.

3677. angustifolium.

3678. commutatum.

3679. ashei.

3680. auburne.

3682. aciculare.

3683. meridionale.

3686. lindheimeri.

3687. philadelphicum.

3704. ashei.

3708. annulum.

3729. lindheimeri.

3739. ensifolium.

3743. lucidum.

3744. mattamuskeetense.

$3744 \frac{1}{2}$. mattamuskeetense.

3745. albemarlense.

3747. barbulatum.

3752. tsugetorum.

3757. albemarlense.

3758. barbulatum.

3762. albemarlense.

$3762 \frac{1}{2}$. villosissimum.

3767. microcarpon.

3772. yadkinense.

3780. ravenelii.

3783. bicknellii.

3787. ashei.

3791. mattamuskeetense.

3793. mattamuskeetense.

3794. columbianum.

3796. ravenelii.

3803. polyanthes.

3806. columbianum thinium.

3808. scribnerianum.

3809. annulum.

3825. albemarlense.

3826. mattamuskeetense.

3829. mattamuskeetense.

3831. microcarpon.

3832. columbianum.

3850. bartowense.

3851. adspersum.

3855. fusiforme.

3859. virgatum cubense.
Chase, A.-Continued.

3860. virgatum cubense.

3866 . ovale.

3885. polycaulon.

3889. hians.

3899. amarulum.

3900 . virgatum.

3907. joorii.

3908. equilaterale.

3915. amarulum.

3926. chapmani.

3935. amarulum.

3946. trifolium.

3947. ovale.

3948. joorii.

3953. amarulum.

3964. webberianum.

3965. chamaelonche.

3966. albomarginatum.

3967. polycaulon.

3970. lancearium.

3984. rhizomatum.

3986. verrucosum.

3990. nitidum.

3991. fusiforme.

3992. caerulesscens.

4004. lancearium.

4005. nitidum.

4007. bartowense.

4009. xalapense.

4014. condensum.

4015. lancearium.

4017. nitidum.

4019. joorii.

4021. fusiforme.

4023. laxiflorum.

4026. patulum.

4028. patentifolium.

4029. patentifolium.

4032. chamaelonche.

4036. chamaelonche.

4037. chamaelonche.

4039. sphagnicola.

4043. albomarginatum.

4045. pauciciliatum.

4050. patulum.

4051. patentifolium.

$4051 \frac{1}{2}$. webberianum.

4053. chamaelonche.

4058. patentifolium.

4059. flavovirens.

4062. patulum.

4063. equilaterale.

4066. verrucosum. 
Chase, A.-Continued.

4068. lucidum.

4072. malacon.

4077. malacon.

4086. patulum.

4088. patentifolium.

4091. nitidum.

4094. joorii.

4095. anceps.

4099. joorii.

4100. dichotomum.

4101. laxiflorum.

4104. polycaulon.

4105. fusiforme.

4112. trifolium.

4113. lanuginosum.

4118. ovale.

4119. fusiforme.

4121. hemitomon.

4122. equilaterale.

4126. joorii.

4132. nitidum.

4141. longiligulatum.

4149. lancearium.

4151. albomarginatum

4153. chamaelonche.

4154. erectifolium.

4156. chamaelonche.

4161. arenicoloides.

4163. webberianum.

4163․ patentifolium.

4166. trifolium.

4170. patentifolium.

4171. chamaelonche.

4172. longiligulatum.

4173. pauciciliatum.

4174. ovale.

4175. lancearium.

4179. fusiforme.

4181. joorii.

4183. patulum.

4187. tenerum.

4188. longiligulatum.

4191. rhizomatum.

4194. fusiforme.

4201. anceps.

$4201 \frac{1}{2}$. rhizomatum.

4202. verrucosum.

4205. commutatum.

4207. oligosanthes.

4208. boscii molle.

4209. patulum.

4211. arenicoloides.

4217. laxiflorum.
Chase, A.-Continued.

4219. joorii.

4220. rhizomatum.

4225. longifolium.

4229. angustifolium.

4234. dichotomiflorum.

4239. lancearium.

4241. equilaterale.

4242. lanuginosum.

4245. patentifolium.

4248. fusiforme.

4249. arenicoloides.

4250 . ovale.

4251. malacon.

4256. joorii.

4258. equilaterale.

4260 . oligosanthes.

4261. ovale.

4267. angustifolium.

4271. rhizomatum.

4274. joorii.

4276. oligosanthes.

4277. lanuginosum.

4279. ravenelii.

4281. arenicoloides.

4282. patulum.

4283. oligosanthes.

4284. anceps.

4286. agrostoides.

4287. agrostoides.

4290. mutabile.

4291. arenicoloides.

4292. lanuginosum.

4297. angustifolium.

4299. consanguineum.

4301. angustifolium.

4302. aciculare.

4304. trifolium.

4305. lanuginosum.

4307. nitidum.

4308. longiligulatum.

4310. flavovirens.

4312. patulum.

4314. verrucosur

4318. longifolium

4320. lucidum.

4321. nitidum.

4322. flavovirens.

4331. lanuginosum.

4340. arenicoloides.

4346. longifolium.

4351. consanguineum.

4357. patulum.

4358. trifolium. 
Chase, A.-Continued.

4359. aciculare.

4360. ciliatum.

4364. polycaulon.

4366. longiligulatum.

4371. patulum.

4377. repens.

4389. brachyanthum.

4392. dichotomiflorum.

4393. anceps.

4397. agrostoides.

4400. lindheimeri.

4401. lanuginosum.

4405. chrysopsidifolium.

4407. gymnocarpon.

4410. agrostoides.

4423. arenicoloides.

4424. verrucosum.

4426. microcarpon.

4429. sphaerocarpon inflatum.

4430. oorii.

4434. combsii.

4437. joorii.

4444. aciculare.

4445. agrostoides.

4449. lindheimeri.

4453. flexile.

4459. virgatum.

4460 . virgatum.

4461. capillare.

4463. clandestinum.

4464. anceps.

4468. joorii.

4469. barbulatum.

4470. sphaerocarpon.

4472. villosissimum.

4473. ashei.

4475. concinnius.

4476. concinnius.

4477. tennesseense.

4478. meridionale,

4479. angustifolium.

4482. microcarpon.

4483. concinnius.

4485. polyanthes.

4491. boscii.

4492. flexile.

4495. capillare.

4497. stipitatum.

4498. ashei.

4499. tennesseense.

4501. boscii.

4502. barbulatum.

4504. commutatum.
Chase; A.-Continued.

4506. xalapense.

4517. xalapense.

4519. barbulatum.

4525. aciculare.

4527. condensum.

4532. lanuginosum.

4536. lancearium.

4537. equilaterale.

4538. patulum.

4542. lancearium.

4543. lancearium.

4544. commonsianum.

4545. lancearium.

4549. equilaterale.

4550. joorii.

4554. anceps.

4555. amarum.

4560. rhizomatum.

4564. longifolium.

4567. pauciciliatum.

4568. lancearium.

4569. lancearium.

$4569 \frac{1}{2}$. webberianum.

4570. chamaelonche.

4576. trifolium.

4577. patulum.

4578. aciculare.

4579. auburne.

4580. addisonii.

4581. arenicoloides.

4583. ciliatum.

4584. lanuginosum.

4585. angustifolium.

4586. aciculare.

4589 . ovale.

4591. sphaerocarpon.

4600. scabriusculum.

4601. commonsianum.

4746. barbipulvinatum.

4886. barbipulvinatum.

5251. barbipulvinatum.

5252. thermale.

5253. barbipulvinatum.

5292. barbipulvinatum.

5307. barbipulvinatum.

5345. barbipulvinatum.

5406. obtusum.

5411. linearifolium.

5412. xalapense.

5413. aciculare.

5414. aciculare.

5415. angustifolium.

5416. bicknelli. 
Chase, A.-Continued.

5417. caerulescens.

5418. lucidum.

5419. ' microcarpon.

5420. annulum.

5421. spretum.

5422. lindheimeri.

5423. lindheimeri.

5424. tennesseense.

5425. tennesseense.

5426. lanuginosum.

5427. columbianum.

5428. commonsianum.

5429. columbianum.

5430. columbianum.

5431. oricola.

5432. sphaerocarpon.

5433. sphaerocarpon.

5434. patulum.

5435. oligosanthes.

5436. commutatum.

5437. mutabile.

5438. scoparium.

5439. aculeatum.

5440 . verrucosum.

5441. philadelphicum.

5442. capillare.

5443. gattingeri.

5444. flexile.

5445. anceps.

5519. urvilleanum.

5766. urvilleanum.

Chase, V. H.

73. virgatum.

81. huachucae silvicola.

124. gattingeri.

125. capillare.

183. capillare.

242. sphaerocarpon.

291. pseudopubescens.

460. perlongum.

461. leibergii.

472. praecocius.

649. praecocius.

774. capillare.

783. gattingeri.

818. virgatum.

922. scribnerianum.

1158. perlongum.

1212. praecocius.

1214. praecocius.

1218. praecocius.

1455. leibergii.

1489. boscii.
| Chase, V. H.-Continued.

1492. praecocius.

1515. praecocius.

1701. leibergii.

1731. perlongum.

1749. scribnerianum.

1791. praecocius.

1792. scribnerianum.

1850. praecocius.

1851. huachucae silvicola.

1858. huachucae.

Cheney, L. S.

678. subvillosum.

1082. subvillosum.

1107. huachucae.

1216. depauperatum.

1345. werneri.

1346. xanthophysum.

1545. latifolium.

1700. boreale.

2100 . boreale.

2911. philadelphicum.

3088. boreale.

3409. tennesseense.

3426. xanthophysum.

3471. tennesseense.

3868 . virgatum.

3872. lindheimeri.

4104. huachucae.

4786. xanthophysum.

5638. huachucae.

Cocks, R. S.

286. leucothrix.

292. erectifolium.

422. longiligulatum.

2186. repens.

2191. lanuginosum.

2193. lanuginosum.

2194. aciculare.

3001. anceps.

3007. sphaerocarpon inflatum.

3008. stipitatum.

3322. arenicoloides.

3324. scoparium.

3506. auburne.

3508. lindheimeri.

3509. huachucae silvicola.

3510. xalapense strictirameum.

3511. xalapense strictirameum. Cомвs, R.

3. patulum.

6. leucothrix.

8. virgatum.

14. virgatum. 
Combs, R.-Continued.

26. hians.

34. flavovirens.

57. ciliatum.

58. erectifolium.

60. roanokense.

61. tenerum.

63. virgatum.

66. virgatum.

67. scabriusculum

69. hemitomon.

73. sphagnicola.

74. ensifolium.

75. lancearium.

87. hemitomon.

89. commutatum.

94. dichotomiflorum.

98. flavovirens in part.

100. ciliatum.

104. lancearium.

112. albomarginatum.

114. erectifolium.

115. longiligulatum.

117. hians.

119. virgatum.

120. rhizomatum.

125. hians.

127. chamaelonche.

132. patulum in part.

136. fusiforme.

137. ciliatum.

138. ovale.

139. commutatum.

141. xalapense.

144. joorii.

145. ovale.

156. commutatum.

164. arenicoloides.

167. malacon.

172. hians.

173. microcarpon.

174. lanuginosum.

182. sphaerocarpon inflatum.

183. aciculare.

187. hians.

192. rhizomatum.

194. lanuginosum.

206. hemitomon.

215. lanuginosum.

216. aciculare.

224. mutabile.

225. ovale.

231. fusiforme.

235. virgatum.
Сомвs, R.-Continued.

238. lancearium.

251. commutatum.

255. microcarpon.

256. microcarpon.

259. rhizomatum.

262. hians.

263. trifolium.

266. nitidum.

267. virgatum.

270. joorii.

282. anceps.

287. hemitomon.

288. ciliatum.

290. wrightianum.

294. lanuginosum.

295. boscii molle.

298. fusiforme.

299. mutabile.

300. arenicoloides.

301. aciculare.

305. ravenelii.

306. sphaerocarpon.

307. mutabile.

320 . anceps.

327. laxiflorum.

329. aciculare.

330. commutatum.

334. boscii.

337. boscii.

347. wrightianum.

348. virgatum.

354. wrightianum.

372. aciculare.

373. joorii.

374. angustifolium.

376. angustifolium.

380. aciculare.

381. anceps.

382. oligosanthes.

390. xalapense.

391. microcarpon.

399. boscii.

403. sphaerocarpon inflatum.

406. sphaerocarpon inflatum.

408. aciculare

412. joorii.

415. anceps.

427. hians.

434. hians.

437. virgatum.

440. auburne.

441. wrightianum.

443. hemitomon. 
Сомвs, R.-Continued.

444. cryptanthum.

456. fusiforme.

458. virgatum.

467. erectifolium.

470. anceps.

473. virgatum.

475. virgatum.

476. tenerum.

477. wrightianum.

487. tenerum.

488. longiligulatum.

496. rhizomatum.

516. fusiforme.

524. wrightianum.

525. curtifolium.

526. hians.

530. tenerum.

537. virgatum.

539. flavovirens.

551. leucothrix.

552. wrightianum.

553. erectifolium.

554. aciculare.

560 . anceps.

567. strigosum.

567a. aciculare.

569 . longiligulatum.

570. consanguineum.

571. longifolium.

572. leucothrix.

574. tenerum.

576. longifolium.

579. virgatum.

583. combsii.

584. strigosum.

585. flavovirens.

586. anceps.

587. hians.

589. commutatum.

597. virgatum.

601. commutatum.

602. ravenelii in part.

613. villosissimum.

615. lucidum.

616. scabriusculum.

617. leucothrix.

619. tenerum.

633. rhizomatum.

644. longifolium.

645. virgatum.

646. virgatum.

647. virgatum.

648. rhizomatum.
Coмвs, R.-Continued.

649. polycaulon in part.

650. albomarginatum.

651. consanguineum.

652. longiligulatum.

653. mutabile.

654. virgatum.

662. erectifolium.

664. wrightianum.

665. capillare.

672. leucothrix.

673. leucothrix.

680. hemitomon.

683. boscii.

686. lancearium.

687. dichotomum. lucidum.

695. virgatum.

700. rhizomatum.

703. virgatum.

711. hemitomon.

712. hians.

717. anceps.

722. virgatum.

731. fusiforme.

732. lanuginosum.

737. equilaterale.

738. boscii molle.

740. mutabile.

742. oligosanthes.

743. laxiflorum.

744. lancearium.

751. huachucae silvicola.

752. lancearium.

760. paludivagum.

774. virgatum cubense.

777. patentifolium.

778. patentifolium.

780. glabrifolium.

783. patulum.

793. equilaterale.

803. caerulescens.

804. agrostoides.

814. erectifolium.

820. rhizomatum.

831. hians.

832. hemitomon.

835. patulum.

836. hemitomon.

838. sphagnicola.

853. fusiforme.

854. albomarginatum.

855. malacon.

858. patulum. 
Сомвs, R.-Continued.

859. patulum.

860. joorii.

878. anceps.

879. agrostoides.

884. rhizomatum.

886. commutatum.

887. virgatum.

888. ovale.

899. fusiforme.

909. laxiflorum.

915. agrostoides.

919. rhizomatum.

921. joorii.

926. commutatum.

$926 \frac{1}{2}$. equilaterale.

930. virgatum cubense.

934. lucidum.

935. anceps.

957. condensum.

960 . hemitomon.

961. agrostoides.

9641. condensum.

971. bartowense.

972. anceps.

973. condensum.

979. nitidum.

990. dichotomiflorum.

1008. nitidum.

1010. longifolium.

1011. condensum.

1012. agrostoides.

1021. anceps.

1022. arenicoloides.

1023. equilaterale.

1024. glabrifolium.

1025. lancearium.

1036. malacon.

1037. fusiforme.

1038. commutatum.

1049. verrucosum.

1051. rhizomatum.

1052. paludivagum.

1053. equilaterale.

1063. trifolium.

1064. laxiflorum.

1068. wrightianum.

1073. anceps.

1080. ovale.

1085. pauciciliatum.

1086. polycaulon.

1087. wrightianum.

1088. flavovirens.

1098. commutatum.
Сомвs, R.-Continued.

1112. tenerum.

1116. verrucosum.

1117. erectifolium.

1120. agrostoides.

1125. rhizomatum.

1140. microcarpon.

1144. condensum.

1154. longifolium.

1161. malacon.

1164. webberianum.

1168. longifolium.

1169. patulum.

1170. maximum.

$1180 \frac{1}{2}$. longifolium.

1187. glabrifolium.

1192. rhizomatum.

1195. hemitomon.

1198. agrostoides.

1204. agrostoides.

1206 . anceps.

1207. agrostoides.

$1217 \mathrm{a}$. rhizomatum.

1218. lucidum.

1220. bartowense.

1234. verrucosum.

1235. longifolium.

1237. joorii.

1240. lancearium.

1241. fusiforme.

1246. hians.

1249. virgatum.

1251. dichotomiflorum.

1252. rhizomatum.

1253. paludivagum.

1261. hians.

1264. rhizomatum.

1265. barbinode.

1266. tenerum.

1269. verrucosum.

1270. hemitomon.

1280. virgatum.

1288. patentifolium.

1294. verrucosum.

1297. virgatum.

1303. rhizomatum.

1310. maximum.

1311. barbinode.

1313. glabrifolium.

1316. glabrifolium.

1323. hemitomon.

1325. hians.

1333. patentifolium.

1338. polycaulon. 
Combs, R.-Continued.

1340. fusiforme.

1343. fusiforme.

1344. chamaelonche.

1393. joorii.

1394. flavovirens.

1395. rhizomatum.

1398. anceps.

1400. joorii.

1419. dichotomiflorum.

1426. gymnocarpon.

1427. joorii.

1431. reptans.

1435. capillare.

1436. dichotomiflorum.

Commons, A.

23. hemitomon.

25. stipitatum.

27. clandestinum.

28. scoparium.

29. depauperatum.

30. capillare.

32. scoparium.

37. ashei.

38. villosissimum.

42. lindheimeri.

43. commonsianum.

45. oricola.

47. polyanthes.

48. commutatum.

49. sphaerocarpon.

50. sphaerocarpon.

52. villosissimum.

53. ashei.

54. oligosanthes.

55. lindheimeri.

56. villosissimum in part.

57. miliaceum.

58. columbianum thinium.

59. oricola.

60. oricola.

61. ashei.

64. lindheimeri.

66. lindheimeri.

67. lindheimeri.

68. lindheimeri.

70. lindheimeri.

71. lindheimeri.

224. longifolium.

225 . anceps.

228. amarum.

229 . dichotomiflorum.

230. dichotomiflorum.
Соmmons, A.-Continued.

231. verrucosum.

281. scribnerianum.

282. scribnerianum.

283. scoparioides.

284. sphaerocarpon.

285. microcarpon.

286. meridionale.

289. huachucae silvicola.

290. huachucae silvicola.

291. lindheimeri.

292. huachucae silvicola.

293. huachucae silvicola.

294. dichotomum.

295. dichotomum.

296. barbulatum.

297. dichotomum.

298. sphaerocarpon.

300. clandestinum.

301. latifolium in part.

302. clandestinum.

303. anceps.

304. longifolium.

305. stipitatum.

306. polyanthes.

307. polyanthes.

308. ashei.

309. commutatum.

340 . spretum.

341. commonsianum.

342. lanuginosum.

343. longifolium.

344. longifolium.

345. clutei.

346. microcarpon.

347. microcarpon.

348. spretum.

349. ashei.

350. sphaerocarpon.

356. ashei.

357. ashei.

358. werneri.

359. scoparioides.

360 . huachucae silvicola.

361. boscii.

362. huachucae silvicola.

363. lindheimeri.

364. huachucae silvicola.

365. tennesseense.

Costa Rrca.a

412. barbinode.

1183. polygonatum.

1244. viscidellun.

a Herbarium Instituto físico-geográfico. Collectors Biolley, Cooper, Pittier, Tonduz. 
Costa Rica-Continued.

2035. fasciculatum.

2479. polygonatum.

2598. zizanioides.

2633. ghiesbreghtii.

2995. maximum.

3071. laxum.

3107. polygonatum.

3117. laxum.

3123. trichoides.

3358. viscidellum.

3583. stenodes.

3619 . virgatum.

3631. parvifolium.

3640. costaricense.

3651. trichoides.

3661. costaricense.

3673. costaricense.

3679. rudgei.

3685. cayennense.

3687. costaricense.

4042. polygonatum.

4092. polygonatum.

4458. trichoides.

4459. pulchellum.

4460. pulchellum in part.

4626. costaricense.

4860. costaricense.

4864. laxum.

4865. trichoides.

4871. laxum.

4875. rudgei.

4881. pulchellum.

7360. pulchellum.

7463. pilosum.

7467. hirsutum.

7471. fasciculatum.

7878. sphaerocarpon.

7944. olivaceum.

8557. polygonatum.

8566. zizaniodes.

8600 . trichanthum.

8670. trichanthum.

8818. virgultorum.

8829 . virgultorum.

9050. maximum.

9080. parviglume.

9114. maximum.

9495. pilosum.

9727. fasciculatum.

9754. trichoides.

10379. trichoides.

10576. rudgei.

10588. rudgei.
Costa Rica-Continued.

10589. stenodes.

10594. parvifolium.

10615. millegrana.

10745. sphaerocarpon.

olivaceum.

11017. glutinosum.

11276. zizanioides.

11393. barbinode.

11396. polygonatum.

11866. sphaerocarpon.

12002. glutinosum.

12064. rudgei.

13749. fasciculatum.

16081. trichoides.

16123. laxum.

Curtiss, A. H.

B. arenicoloides.

nudicaule.

D. chrysopsidifolium.

F. pauciciliatum. villosissimum.

K. boscii.

Q. scabriusculum.

R. lanuginosum.

21. chamaelonche.

113. adspersum.

115. barbinode.

124. maximum.

174. condensum.

175. geminatum.

177. dichotomiflorum.

267. cayennense.

305. pilosum.

307. acuminatum.

328. acuminatum.

384. diffusum.

406. fusiforme.

464. laxum.

494. diffusum.

536. reptans.

598. trichanthum.

691. reptans.

714. trichoides.

748. adspersum.

3578. amarulum.

3579 . rhizomatum.

tenerum.

$3583^{*}$. commutatum. arenicoloides. ovale. nudicaule.

3585. hemitomon.

3587. angustifolium, 
Curtiss, A. H.-Continued.

3587*. arenicoloides.

3589 . fasciculatum.

3594. hians.

$3597^{*}$. strigosum.

$3597^{* *}$. maximum.

3599. erectifolium.

$3600 \mathrm{~A}$. dichotomum. equilaterale.

lancearium.

nitidum.

pauciciliatum.

3601. geminatum.

$3602 *$ chamaelonche.

$3606^{* *}$. adspersum.

3607. chapmani.

3608. verrucosum.

3609 . virgatum.

3610. scabriusculum.

4027. commutatum.

4028. arenicoloides.

4029. lancearium.

4031. strigosum.

4033. longiligulatum.

4035. tenerum.

4036. verrucosum.

4636. commutatum.

4637. webberianum.

4811. hemitomon.

4812. erectifolium.

4877. ovale.

4878. scabriusculum.

5083. tenerum.

5084. virgatum.

5252. verrucosum.

5289. rhizomatum.

5298. condensum.

5302. agrostoides.

5386. bartowense.

5431. adspersum.

5457. chapmani.

5527. amarulum.

5534. hians.

5537. xalapense.

5576. condensum.

5576A. condensum.

5576B. longifolium.

5576C. tenerum.

5588. chamaelonche.

5747. rhizomatum.

5804. chamaelonche.

5808. verrucosum.

5813. ovale.

5864. oligosanthes.

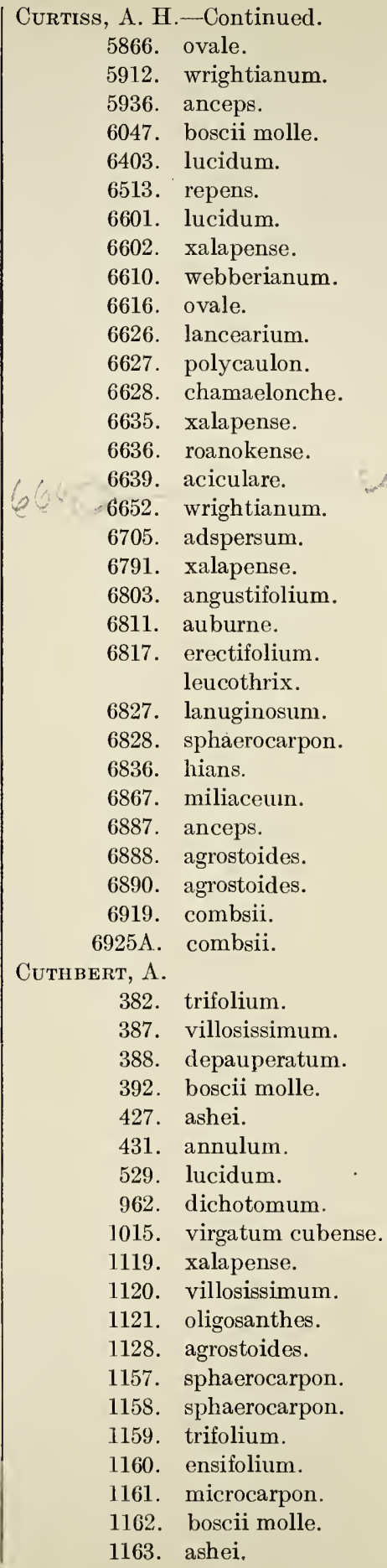


Cuthrert, A.-Continued.

1164. pseudopubescens.

1165. angustifolium.

1166. aciculare.

1167. oligosanthes.

DAVY, J. B.

5894. pacificum.

5971. occidentale.

6092. occidentale.

6745. pacificum.

6780. pacificum.

Deam, C. C.

424. trichanthum.

2065. tennesseense.

2638. virgatum.

3218. linearifolium.

5386. boscii.

5392. polyanthes.

6041. trichoides.

6143. molle.

6267. fasciculatum.

6268. maximum.

6467. ashei.

6595. commutatum.

6753. perlongum.

6883. xalapense.

Dewey, L. H.

53. anceps.

73. boscii molle.

92. boscii molle.

134. virgatum.

235. boscii.

280. boscii.

408. verrucosum.

Dodge, C. K.

17. leibergii.

20. leibergii.

38. implicatum.

49. lindheimeri.

60. villosissimum.

62. leibergii.

78. depauperatum.

83. villosissimum.

84. leibergii.

124. flexile.

128. flexile.

130. flexile.

Dorner, H. B.

12. virgatum.

23. dichotomiflorum.

35. leibergii.

82. latifolium.

83. dichotomum.

84. huachucae silvicola.

85. virgatum.
Dorner, H. B.-Continued.

86. dichotomiflorum.

87. gattingeri.

88. scribnerianum.

91. huachucae silvicola.

93. huachucae silvicola.

DRUMmond, T.

286. filipes.

367. hemitomon.

381. scoparium.

384. filipes.

394. filipes.

452. patulum.

454. huachucae silvicola.

456. xalapense.

457. xalapense.

461. hemitomon.

Duss, Père.

536. diffusum.

537. fasciculatum.

538. fasciculatum.

539. barbinode.

1288. maximum.

1290. reptans.

1293. geminatum.

1321. trichoides.

2681. trichoides.

2689. barbinode.

2690. geminatum.

2691. fasciculatum.

3177. utowanaeum.

3178. dichotomiflorum.

3179. laxum.

3180. adspersum.

3184. ghiesbreghtii.

3186. maximum.

3529. reptans.

3584. geminatum.

3917. hirsutum.

3919. condensum.

4154. pilosum.

Earle, F. S., and Baker, C. F.

1522. pseudopubescens.

1527. auburne.

1530. wilmingtonense in part.

1531. commutatum.

1532. curtifolium.

1535. trifolium in part.

1537. pseudopubescens.

1544. annulum.

2455. reptans.

Eaton, A. A.

164. agrostoides.

bartowense.

165. agrostoides. 
EAton, A. A.-Continued.

169. joorii.

242. agrostoides.

341. anceps.

467. bartowense.

574. hemitomon.

578. erectifolium.

589. xalapense.

831. xalapense.

Eggers, H. F. A.

165. laxum.

293. reptans.

1226. maximum.

1328. barbinode.

1329. laxum.

2129. xalapense.

3978. exiguiflorum.

4305. caerulescens.

4312. caerulescens.

4405. dichotomiflorum.

4512. dichotomiflorum.

4870. barbinode.

4875. fasciculatum.

5350. trichanthum.

5406. ghiesbreghtii.

5534. pilosum.

5810. zizanioides.

5987. trichoides.

14149. stoloniferum.

14345. megiston.

14481. trichoides.

14585. laxum.

15417. trichoides.

15418. fasciculatum.

15419. ghiesbreghtii.

15422. zizanioides.

15834. fasciculatum.

EGGERT, H.

7. commutatum.

10. angustifolium.

12. scoparium.

13. sphaerocarpon.

14. polyanthes.

15. microcarpon.

20. dichotomum.

21. strigosum.

22. commutatum.

23. sphaerocarpon.

24. trifolium.

26. boscii.

30. huachucae silvicola.

34. lindheimeri.

39. depauperatum.
EgGert, H.-Continued.

40. boscii.

42. Iaxiflorum.

43. commutatum

44. ashei.

$44 \frac{1}{2}$. dichotomum.

45. commutatum.

46. dichotomum.

58. philadelphicum.

59. verrucosum.

60. scoparium.

78. microcarpon.

82. scoparium.

86. xalapense.

89. microcarpon.

95. polyanthes.

110. dichotomiflorum.

114. clandestinum.

115. sphaerocarpon.

116. scoparium.

117. hians.

124. huachucae silvicola.

125. agrostoides.

126. virgatum.

127. xalapense.

233. depauperatum.

234. scribnerianum.

235. huachucae silvicola.

236. microcarpon.

237. lindheimeri.

239. latifolium.

240. polyanthes.

241. flexile.

242. tennesseense.

243. tennesseense.

244. huachucae silvicola.

245. huachucae silvicola.

246. dichotomum.

249. scribnerianum.

250. polyanthes.

253. clandestinum.

254. sphaerocarpon.

257. commutatum.

287. microcarpon.

288. nitidum.

289. huachucae silvicola.

290. commutatum.

291. villosissimum.

292. villosissimum.

293. villosissimum.

295. scribnerianum.

296. tennesseense.

297. scribnerianum. 
Eggleston, W. W.

1757. werneri.

1758. subvillosum.

1759. dichotomum.

2181. tennesseense.

2843. tsugetorum.

Farwell, O. A.

597. linearifolium.

597b. implicatum.

597d. huachucae silvicola.

642. subvillosum.

643 . boreale.

643a. implicatum.

643b. huachucae.

755. perlongum.

764. xanthophysum.

893. flexile.

1378. latifolium.

1382. huachucae. huachucae silvicola.

1388. sphaerocarpon.

1414. miliaceum.

Fendler, A.

368. pilosum.

946. polygonatum.

1634. zizanioides.

1638. sphaerocarpon.

1638 $\beta$. olivaceum.

1641. millegrana.

1643. trichanthum.

2499. trichoides.

Fernald, M. L.

166. tennesseense.

166a. tennesseense.

239. boreale

271. virgatum.

276. latifolium.

280. scribnerianum.

292. clandestinum.

345. xanthophysum.

346. latifolium.

361. philadelphicum.

406. dichotomum.

500. implicatum.

501. subvillosum.

502. implicatum.

503. huachucae silvicola.

504. implicatum.

505 . boreale.

506. werneri.

508. boreale.

509. huachucae silvicola.

510 . spretum.

512. boreale.
Fernald, M. L.-Continued.

513. boreale.

514. boreale.

516. boreale.

517. boreale.

518. clandestinum.

519. xanthophysum.

520. xanthophysum.

521. xanthophysum.

2802. philadelphicum.

Gardner, G.

1178. rudgei.

1179. megiston.

1183. laxum.

1876. molle.

2353. molle.

2357. fasciculatum.

2361. molle.

3517. laxum.

Graves, C. B.

4. huachucae.

7. werneri.

8. huachucae silvicola.

10. columbianum.

11. tennesseense.

12. barbulatum.

14. villosissimum.

15. bicknellii.

16. werneri.

17. werneri.

76. lindheimeri.

77. boreale.

78. implicatum.

80. spretum.

82. boreale.

83. columbianum.

84. columbianum.

85. sphaerocarpon.

87. spretum.

88. ashei.

156. huachucae silvicola.

157. spretum.

158. lindheimeri.

163. latifolium.

164. latifolium.

165. implicatum.

166. huachucae silvicola.

167. philadelphicum.

171. meridionale.

172. meridionale.

236. stipitatum.

244. virgatum cubense.

248. longifolium.

256. longifolium. 


\section{GRIFrithS, D.}

7. barbipulvinatum.

15. capillare.

22. virgatum.

53. virgatum.

82. virgatum.

120. capillare.

132. virgatum.

206. virgatum.

207. capillare.

242. virgatum.

278. barbipulvinatum.

295. virgatum.

371. virgatum.

395. virgatum.

399. barbipulvinatum.

548. scribnerianum.

684. barbipulvinatum.

751. virgatum.

836. leibergii.

863. perlongum.

871. scribnerianum.

1514. obtusum.

1520. hirticaule.

1545. fasciculatum chartaginense.

1546. obtusum.

1596. arizonicum.

1616. fasciculatum chartaginense.

1654. fasciculatum chartaginense.

1810. arizonicum.

1813. hallii.

1913. arizonicum.

1918. hirticaule.

1935. obtusum.

1938. hirticaule."

2006. obtusum.

3309. obtusum.

3313. barbipulvinatum.

3356. arizonicum.

3358. hirticaule.

3362. fasciculatum chartaginense.

3388. hallii.

3405. obtusum.

3427. plenum.

4438. pacificum.

4476. pacificum.

4617. pacificum.

4811. bulbosum sciaphilum.

5047. virgatum.

51.96. obtusum.
| Griffiths, D.-Continued.

5401. scribnerianum.

5463. virgatum.

5504. hallii.

5542. obtusum.

5551. barbipulvinatum.

5600 . hallii.

5612. obtusum.

5664. virgatum.

5735. havardii.

5852. barbipulvinatum.

5981. arizonicum.

6123. hirticaule.

6151. arizonicum.

6168. arizonicum.

6288. hallii.

6306. geminatum.

6323. filipes.

6380. ramisetum.

6381. ciliatissimum.

6387. filipes.

6432. ciliatissimum.

6441. ciliatissimum.

6445. ciliatissimum.

6446. firmulum.

6508. fasciculatum.

6551. sphaerocarpon.

6586. pacificum.

6737. arizonicum.

6747. arizonicum.

6758. hirticaule.

6759. arizonicum.

6785 . bulbosum sciaphilum.

6799. hirticaule.

6800. obtusum.

6857. fasciculatum.

6891. arizonicum.

6892. hirticaule.

6894. arizonicum.

6929. arizonicum.

6938. arizonicum.

6939. arizonicum.

69391. pampinosum.

6959. obtusum.

6990. arizonicum.

7005. hirticaule.

7017. arizonicum.

7063. lepidulum.

7083. bulbosum.

7143. arizonicum.

7146. hirticaule.

7148. arizonicum.

7194, hirticaule. 
Griffiths, D.-Continued.

7288. obtusum.

7297. fasciculatum chartaginense.

7299. fasciculatum chartagi nense.

7317. hirticaule.

7357. hallii.

7399. arizonicum in part.

7400. plenum.

7401. plenum.

7408. hallii.

HaLl, E.

231. wilcoxianum.

671. pacificum.

672. scribnerianum.

815. hians.

816. hallii in part.

817. dichotomiflorum.

819. agrostoides.

820. hemitomon.

823. geminatum.

824. ciliatissimum.

825. fasciculatum chartaginense.

827. obtusum.

828. joorii.

boscii.

829. scoparium.

830. helleri.

831. commutatum.

832. sphaerocarpon.

833. angustifolium.

834. ovinum. pedicellatum. nitidum.

Hansen, G.

599. capillare.

626. pacificum.

1381. pacificum.

1444. pacificum.

1723. occidentale.

HARPER, R. M.

15. boscii molle.

60. commutatum.

70. clandestinum.

74. microcarpon.

77. xalapense.

88. lucidum.

95. dichotomum.

104. polyanthes.

110. scoparium.

146. oligosanthes.

147. mutabile.
Harper, R. M.-Continued.

150. scoparium.

183. xalapense.

184. philadelphicum.

210. scoparium.

221. commutatum.

281. microcarpon.

369 . anceps.

382. dichotomiflorum.

410. scabriusculum.

429. virgatum.

459. longiligulatum.

522. gymnocarpon.

631. virgatum.

638. verrucosum.

742. amarum.

757. arenicoloides.

765. lanuginosum.

767. joorii.

828. angustifolium.

829. ensifolium.

838. hians.

839. longiligulatum.

881. scabriusculum.

1007. hemitomon.

1037. virgatum.

1045. tenerum.

1081. combsii.

1085. xalapense.

1087. sphaerocarpon.

1105. microcarpon.

1106. joorii.

1220. virgatum.

1239. agrostoides.

1349. yadkinense.

1366. boscii.

1394. erectifolium.

1399. lanuginosum.

1435. mutabile.

1485. erectifolium.

1575. longiligulatum.

1623. commutatum.

1679. combsii.

1689. lancearium.

1730. agrostoides.

1760. lucidum.

1812. boscii.

2014. combsii.

2140. xalapense.

HART, J

73. polygonatum.

78. fasciculatum.

87. trichanthum.

726. zizanioldes. 
HART, J.-Continued.

732. pilosum.

736. acuminatum.

785. fasciculatum.

792. glutinosum.

797. maximum.

806. geminatum.

838. reptans.

840. fasciculatum.

2177. laxum.

2289. laxum.

3293. pilosum.

Heller, A. A.

100. barbinode.

135. fasciculatum.

157. trichoides.

377. maximum.

387. trichoides.

497. reptans.

522. laxum.

531. trichoides.

639. pauciciliatum.

701. flexile.

968. polyanthes.

982. chrysopsidifolium.

982b. pauciciliatum.

1312. tsugetorum.

1316. parvifolium.

1378. laxum.

1490. filipes.

1603. reverchoni.

1726. pedicellatum.

1736. pedicellatum.

1741. obtusum.

1752. lindheimeri.

1759. helleri.

1766. pedicellatum.

1883. filipes.

dichotomiflorum.

1888. lindheimeri.

1898. plenum.

3978. occidentale.

4058. scribnerianum.

4082. anceps.

4083. commutatum.

4084. huachucae silvicola.

4085. xalapense.

4088. microcarpon.

4103. hians.

4120. joorii.

4145. hians.

4160. tennesseense.

4209. xalapense.

4210. dichotomiflorum.
Heller, A. A.-Continued.

4221. brachyanthum.

4235. agrostoides.

4236. scoparium.

4237. microcarpon.

4238. consanguineum.

4246. dichotomiflorum.

4528. fasciculatum.

4768. commutatum.

4769. dichotomum.

4770. ashei.

microcarpon.

4771. boscii.

4772. polyanthes.

4774. tennesseense.

4775. depauperatum.

4776. barbulatum.

4777. flexile.

4778. tennesseense.

4779. boscii molle.

4780. ashei.

4781. clandestinum.

4783. dichotomum.

4785. huachucae silvicola.

4786. flexile.

4787. microcarpon.

4789. philadelphicum.

4790. meridionale.

4791. huachucae silvicola.

6094. trichoides.

6226. fasciculatum.

6293. barbinode.

6302. fasciculatum.

6442. pauciciliatum.

7856. pacificum.

HILL, E. J.

37 in 1907. praecocius.

49 in 1909 . praecocius.

50 in 1909. boreale.

53 in 1907. albemarlense.

83 in 1908. huachucae silvicola.

84 in 1908. dichotomum.

85 in 1908. huachucae silvicola.

86 in 1908. tennesseense.

88 in 1908. sphaerocarpon.

90 in 1908. sphaerocarpon.

91 in 1906. leibergii.

97 in 1908. boreale.

98 in 1905. meridionale.

98 in 1908. huachucae.

99 in 1905. implicatum.

100 in 1905. pseudopubescens. 
HILL, E. J.-Continued.

101 in 1905. pseudopubescens.

124 in 1905. tsugetorum.

128 in 1906. spretum.

129 in 1905. tsugetorum.

129 in 1906 . barbulatum.

130 in 1905. huachucae.

141 in 1905 . tennesseense.

145 in 1906 . meridionale.

158 in 1906 . clandestinum.

162 in 1878. tennesseense.

162 in 1906. spretum.

163 in 1906. implicatum.

171 in 1907. huachucae.

177 in 1898 . verrucosum.

182 in 1907. huachucae.

$183 \frac{1}{2}$ in 1907. lindheimeri.

184 in 1907. implicatum.

185 in 1907. implicatum.

201 in 1898. oligosanthes.

217 in 1898. huachucae.

Нiтснсоск, A. S.
4. nitidum.
6. yadkinense.
7. philadelphicum.
10. auburne.
14. leucothrix.
15. nitidum.
16. longiligulatum.
17. aciculare.
19. boscii.
20. oligosanthes.
25. flavovirens.
26. sphaerocarpon inflatum.
47. oricola.
102. ashei.
104. rhizomatum.
107. ovale.
108. arenicoloides.
109. neuranthum.
110. xalapense.
111. laxiflorum.
112. polycaulon.
114. fusiforme.
115. polycaulon.
116. chrysopsidifolium.
117. fusiforme.
118. bicknellii.
119. nitidum.
120. boreale.
121. boreale.
122. dichotomum.
123. barbulatum.
124. barbulatum.

Hiтснсоск, A. S.-Continued.

125. barbulatum.

126. albemarlense.

127. implicatum.

129. agrostoides.

130. implicatum.

132. implicatum.

133. huachucae.

134. tsugetorum.

135. tsugetorum.

136. huachucae silvicola.

137. huachucae silvicola.

138. tennesseense.

139. tennesseense.

140. acuminatum.

141. utowanaeum.

142. geminatum.

143. geminatum.

144. distantiflorum.

145. reptans.

146. reptans.

150. dichotomiflorum.

151. dichotomiflorum.

152. elephantipes.

153. virgatum cubense.

154. tenerum.

155. stenodes.

156. maximum.

157. maximum.

160. ovale.

161. villosissimum.

162. fasciculatum chartagi nense.

163. texanum.

164. verrucosum.

165. philadelphicum.

166. philadelphicum.

167. gattingeri.

168. amarulum.

169. amarum.

170. virgatum.

171. virgatum.

172. condensum.

174. condensum.

175. rhizomatum

177. laxum.

178. laxum.

179. exiguiflorum.

180. millegrana.

181. parvifolium.

201. bicknellii.

215. scoparium.

216. verrucosum.

217. dichotomiflorum. 
Нiтснсоск, A. S.-Continued.

218. capillarioides.

219. hallii.

220. filipes.

221. hallii.

222. boscii.

225. stipitatum.

226. virgatum.

227. amarum.

228. anceps.

229. anceps.

230. anceps

310. rhizomatum.

316. wilmingtonense.

326. commonsianum.

332 . tenue.

335. addisonii.

336. commonsianum

337. flavovirens.

338. chamaelonche.

339. chamaelonche.

340. depauperatum.

341. depauperatum.

342. ciliatum.

343. xalapense.

344. aciculare.

345. aciculare.

346. aciculare.

347. aciculare.

348. angustifolium.

349. angustifolium.

350. arenicoloides.

351. arenicoloides.

352. arenicoloides.

353. bicknellii.

354. mattamuskeetense.

356 . caerulescens.

357. dichotomum.

359. barbulatum.

360 . barbulatum.

361. yadkinense.

362. lucidum.

363. lucidum.

364. lucidum.

365. lucidum.

366. lucidum.

367. lucidum.

368. lucidum.

369. lucidum.

370. microcarpon.

371. cryptanthum.

372. longiligulatum.

373. wrightianum.

374. wrightianum.
Hiтснсоск, A. S.-Continued.

375. longiligulatum.

376. leucothrix.

377. leucothrix.

378. spretum.

379. spretum.

380. lindheimeri.

381. lindheimeri.

384. meridionale.

385. meridionale.

386. lanuginosum.

387. lanuginosum.

389. lanuginosum.

390. lanuginosum.

391. villosissimum.

392. villosissimum.

393. villosissimum.

394. villosissimum.

395. villosissimum.

396. villosissimum.

397. pseudopubescens.

398. pseudopubescens.

399. addisonii.

406. columbianum thinium.

407. commonsianum.

408. commonsianum.

410. polyanthes.

411. erectifolium.

413. patulum.

414. pauciciliatum.

416. pauciciliatum.

417. oligosanthes.

418. oligosanthes.

419. oligosanthes.

420. ravenelii.

421. equilaterale.

422. ashei.

423. ashei.

424. ashei.

425. ashei.

426. commutatum.

427. commutatum.

428. commutatum.

429. mutabile.

430. mutabile.

431. clandestinum.

432. clandestinum.

433. latifolium.

434. boscii molle.

435. boscii molle.

436. boscii molle.

437. scoparium.

438. scabriusculum.

439. philadelphicum. 
Н Нтснсоск, A. S.-Continued.

440. amarulum.

441. amarum.

442. virgatum.

444. condensum.

445. agrostoides.

446. longifolium.

447. longifolium.

448. anceps.

449. anceps.

450. rhizomatum.

451. hians.

503. ashei.

505. tennesseense.

550 . ovale.

551. lindheimeri.

552. lindheimeri.

553. spretum.

554. leucothrix.

555. albomarginatum.

556. addisonii.

557. addisonii.

558. oricola.

562. sphaerocarpon.

563. patentifolium.

564. ashei.

565. ashei.

566. ashei.

567. ashei.

568. ashei.

569. commutatum.

570. commutatum.

571. commutatum.

572. commutatum.

573. mutabile.

574. equilaterale.

575. equilaterale.

576. joorii.

577. joorii.

578. malacophyllum.

579. oligosanthes.

580. oligosanthes.

581. oligosanthes.

582. oligosanthes.

583. clandestinum.

584. clandestinum.

585. clandestinum.

586. latifolium.

587. latifolium.

588. latifolium.

589. latifolium.

590. boscii.

591. boscii.

592. boscii molle.
Нгтснсоск, A. S.-Continued.

593. scoparium.

594. scoparium.

595. scabriusculum.

596. microcarpon.

597. linearifolium.

598. linearifolium.

599. huachucae silvicola.

613. geminatum.

627. fusiforme.

$627 \frac{1}{2}$. virgatum.

630. webberianum.

633. equilaterale.

634 . ovale.

636. joorii.

639. albomarginatum.

648. bartowense.

652. joorii.

653. equilaterale.

654. patulum.

655. equilaterale.

658. bartowense.

659. xalapense.

660 . joorii.

661. ovale.

664. lancearium.

665. polycaulon.

666. albomarginatum.

667. albomarginatum.

668. ovale.

670. albomarginatum.

673. xalapense.

674. joorii.

677. ovale.

678. lancearium.

679. albomarginatum.

687. nitidum.

688. ovale.

$689 \frac{1}{2}$. polycaulon.

690. caerulescens.

692. albomarginatum.

695. condensum.

696. hemitomon.

697. bartowense.

699. condensum.

705. neuranthum

706. caerulescens.

710. neuranthum.

711. polycaulon.

712. trifolium.

713. lancearium.

714. albomarginatum.

715. caerulescens.

718. nitidum. 
Нгтснсоск, A. S.-Continued.

719. ovale.

720. albomarginatum.

721. polycaulon.

728. virgatum.

729. chamaelonche.

730. patentifolium.

733. pauciciliatum.

734. breve.

735. webberianum.

737. pauciciliatum.

743. virgatum cubense.

744. hemitomon.

747. condensum.

748. webberianum.

750. pauciciliatum.

755. patentifolium.

756. joorii.

757. commutatum.

759. chamaelonche.

760. joorii.

761. albomarginatum.

$761 \frac{1}{2}$. ovale.

762. polycaulon.

763. polycaulon.

764. lancearium.

765. patulum.

$765 \frac{1}{2}$. webberianum.

766. lancearium.

$766 \frac{1}{2}$. webberianum.

767. patentifolium.

$767 \frac{1}{2}$. flavovirens.

768. albomarginatum.

769. chamaelonche.

770. lancearium.

771. polycaulon.

772. polycaulon.

773. xalapense.

774. nitidum.

775. chrysopsidifolium.

778. chamaelonche.

779. trifolium.

781. chamaelonche.

782. webberianum.

784. lancearium.

785. ovale.

786. fusiforme.

787. ovale.

791. fusiforme.

792. webberianum.

793. pauciciliatum.

794. chamaelonche.

795 . vernale.

796. patentifolium.
Hiтchсоск, A. S.-Continued.

797. pauciciliatum.

798. vernale.

800 . leucothrix.

801. malacon.

802. patentifolium.

803. pauciciliatum.

804. pauciciliatum.

805. leucothrix.

806. chamaelonche.

807. chamaelonche.

808. pauciciliatum.

809 . vernale.

811. webberianum.

813. malacon.

814. nitidum.

817. albomarginatum.

818. chamaelonche.

819. pauciciliatum.

820 . ovale.

821. lancearium.

823. albomarginatum.

824. lancearium.

825. lancearium.

826. albomarginatum.

827. polycaulon.

828. chamaelonche.

833. ovale.

834. fusiforme.

835. angustifolium.

836. polycaulon.

837. fusiforme.

838. albomarginatum.

838 $\frac{1}{2}$. webberianum.

839. albomarginatum.

840. webberianum.

843. polycaulon.

844. lancearium.

845. malacon.

846. ovale.

847. ovale.

848. albomarginatum.

849. lancearium.

850. fusiforme.

851. ovale.

855. webberianum.

856. patentifolium.

863. hemitomon.

864. lancearium.

865. chamaelonche.

866. chamaelonche.

867. curtifolium.

868. polycaulon.

869. lancearium. 
Hiтchсоск, A. S.-Continued.

870. albomarginatum.

872. hians.

873. chamaelonche.

874. erectifolium.

875. longiligulatum.

876. albomarginatum.

877. fusiforme.

880. albomarginatum.

881. longiligulatum.

882. albomarginatum.

884. albomarginatum.

885. chamaelonche.

886. albomarginatum.

887. chamaelonche.

888. lancearium.

889. pauciciliatum.

890. trifolium.

893. glabrifolium.

895. chamaelonche.

897. caerulescens.

898. nitidum.

899. fusiforme.

900 . ovale.

$901 \frac{1}{2}$. flavovirens.

903. polycaulon.

904. caerulescens.

905. flavovirens.

906. xalapense.

908. nitidum.

909. joorii.

910. webberianum.

911. lancearium.

912. fusiforme.

913. lancearium.

914. ovale.

915. caerulescens.

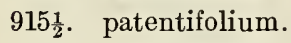

916. chamaelonche.

918. webberianum.

919. lucidum.

920. trifolium.

921. trifolium.

922. patulum.

923. fusiforme.

923슬. polycaulon.

924. chamaelonche.

927. xalapense.

928. chamaelonche.

929. lancearium.

930. patentifolium.

$930 \frac{1}{2}$. webberianum.

931. vernale.

932. lancearium.
Hiтchсоск, A. S.-Continued.

933. polycaulon.

934. chamaelonche.

935. xalapense.

936. vernale.

937. lancearium.

938. trifolium.

938 $\frac{1}{2}$. roanokense.

939. roanokense.

940. trifolium.

941. vernale.

942. vernale.

943. polycaulon.

944. chamaelonche.

945. albomarginatum.

946. patulum.

947. joorii.

949. albomarginatum.

950. polycaulon.

951. chamaelonche.

952. chamaelonche.

953. trifolium.

954. chamaelonche.

955. webberianum.

956. lancearium.

957. longiligulatum.

958. longiligulatum.

$958 \frac{1}{2}$. vernale.

959. vernale.

960 . vernale.

961. nitidum.

962. trifolium.

963. albomarginatum.

964. fusiforme.

965. caerulescens.

966. glabrifolium.

968. ovale.

969. patentifolium.

970. patentifolium.

971. patentifolium.

972. webberianum.

973. chamaelonche.

974. polycaulon.

975. chamaelonche.

976. joorii.

977. lancearium.

978. glabrifolium.

979. webberianum.

980. fusiforme.

984. angustifolium.

985. chamaelonche.

986. consanguineum.

987. roanokense.

988. longiligulatum. 
Нrтснсоск, A. S.-Continued.

989. aciculare.

990. albomarginatum.

991. ciliatum.

992. pauciciliatum.

993. ciliatum.

994. lancearium.

997. trifolium.

998. roanokense.

999. consanguineum.

1000. ciliatum.

1003. lancearium.

1004. vernale.

1005. longiligulatum.

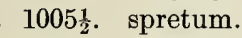

1006. sphagnicola.

1008. commutatum.

1009. laxiflorum.

1010. ravenelii.

1010 $\frac{1}{2}$ boscii molle.

1011. joorii.

1012. arenicoloides.

1013. ovale.

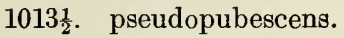

1014. oligosanthes.

1015. mutabile.

1016. lancearium.

1019. ciliatum.

1020. vernale.

1021. albomarginatum.

1022. albomarginatum.

1023. trifolium.

1024. webberianum.

1025. lancearium.

1026. lucidum.

1027. chamaelonche.

1028. lancearium.

1032. lanuginosum.

1033. lancearium.

1035. mutabile.

1036. ciliatum.

1037. chamaelonche.

1038. trifolium.

1039. angustifolium.

1039 $\frac{1}{2}$. lancearium.

1040. ciliatum.

1041. vernale.

1042. trifolium.

1043. strigosum.

1046. villosissimum.

1047. ravenelii.

1048. pseudopubescens.

1049. commutatum.

1050. trifolium.
Hiтcнсоск, A. S.-Continued.

1052. scabriusculum.

1053. trifolium.

1054. fusiforme.

1055. oligosanthes.

1058. curtifolium.

1059. lucidum.

1062. ciliatum.

1063. trifolium.

1066. vernale.

1067. ensifolium.

1068. longiligulatum.

1069. consanguineum.

1070. consanguineum.

1072. trifolium.

1073. xalapense.

1077. arenicoloides.

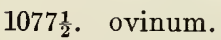

1078. sphaerocarpon.

1079. lanuginosum.

1080. pseudopubescens.

1081. nitidum.

1082. aciculare.

1083. consanguineum.

1084. sphaerocarpon.

1087. angustifolium.

1088. trifolium.

1089. trifolium.

1090. pseudopubescens.

1091. angustifolium.

1092. vernale.

1093. lancearium.

1094. curtifolium.

1095. sphaerocarpon.

1096. pseudopubescens.

1099. sphaerocarpon.

1100. trifolium.

1101. polycaulon.

1102. sphaerocarpon.

1103. mutabile.

1104. commutatum.

1105. angustifolium.

1106. oligosanthes.

1107. ravenelii.

1108. commutatum.

1109. villosissimum.

1111. trifolium.

1112. pseudopubescens.

1113. pauciciliatum.

1114. chamaelonche.

1115: angustifolium.

1124. xalapense.

1126. sphaerocarpon.

1127. aciculare. 
Hiтснсоск, A. S.-Continued. 1128. nitidum.

1129. lanuginosum.

1130. trifolium.

1131. ovinum.

1132. sphaerocarpon.

1133. hians.

1134. sphaerocarpon.

1135. lanuginosum.

1136. lindheimeri.

1137. sphaerocarpon.

1138. lindheimeri.

1139. consanguineum.

1139 $\frac{1}{2}$. aciculare.

1140. aciculare.

1141. ovinum.

1142. joorii.

1143. nitidum.

1144. roanokense.

1146. trifolium.

1147. lanuginosum.

1148. nitidum.

1149. microcarpon.

1150. ovinum.

1151. angustifolium.

1152. lanuginosum.

1153. nitidum.

1154. nitidum.

1155. consanguineum.

1156. lindheimeri.

1162. strigosum.

1163. leucothrix.

1164. yadkinense.

1165. lindheimeri.

1171. thurowii.

1172. ovinum.

1173. helleri.

1174. roanokense.

1175. spretum.

1179. helleri.

1181. sphaerocarpon.

1182. xalapense.

1184. hians.

1186. helleri.

1187. ravenelii.

1190. sphaerocarpon.

1192. ovinum.

1193. angustifolium.

1194. oligosanthes.

1195. thurowii.

1202. lindheimeri.

1203. lindheimeri.

1207. joorii.

1208. joorii.
Hiтснсоск, A. S.-Continued.

1209. angustifolium.

1210. ovinum.

1212. helleri.

1213. sphaerocarpon.

1214. huachucae silvicola.

1215. lindheimeri.

1216. sphaerocarpon.

1221. angustifolium.

1222. ovinum.

1225. aciculare.

1226. thurowii.

1238. lanuginosum.

1239. xalapense.

1240. dichotomum.

1241. sphaerocarpon.

1244. boscii.

1245. ravenelii.

1246. dichotomum.

1249. depauperatum.

1250. ovinum.

1251. dichotomum.

1252. barbulatum.

1253. commutatum.

1255. huachucae silvicola.

1256. villosissimum.

1258. lanuginosum.

1259. villosissimum.

1260. xalapense.

1261. angustifolium.

1262. dichotomum.

1263. oligosanthes.

1264. angustifolium.

1267. trifolium.

1268. commutatum.

1269. angustifolium.

1270. polyanthes.

1272. boscii.

1274. commutatum.

$1274 \frac{1}{2}$. oligosanthes.

1275. villosissimum.

1277. trifolium.

1278. lindheimeri.

1282. hians.

1283. boscii molle.

1284. sphaerocarpon.

1285. sphaerocarpon inflatum.

1286. commutatum.

1287. lindheimeri.

1288. ravenelii.

1289. villosissimum.

1290. xalapense strictirameum.

1291. commutatum.

1292. dichotomum. 
Hiтchсоск, A. S.-Continued. 1293. oligosanthes.

1294. ravenelii.

1295. scribnerianum.

1296. scribnerianum.

1297. lanuginosum.

1298. angustifolium.

1299. villosissimum.

1300. boscii.

1301. boscii molle.

1303. depauperatum.

1305. trifolium.

1306. huachucae silvicola.

1307. sphaerocarpon.

1310. xalapense.

1311. xalapense strictirameum.

1319. commutatum.

1320. boscii.

1321. boscii molle.

1323. ashei.

1325. wilmingtonense.

1327. ashei.

1328. commutatum.

1330. dichotomum.

1331. pseudopubescens.

1332. angustifolium.

1333. xalapense strictirameum.

1334. ravenelii.

1336. pseudopubescens.

1337. curtifolium.

1339. commutatum.

1340. angustifolium.

1343. microcarpon.

1344. boscii molle.

1348. commutatum.

1350. barbulatum.

1352. dichotomum.

1353. ashei.

1354. depauperatum.

1356. pseudopubescens.

1357. pseudopubescens.

1357 2 . huachucae silvicola.

1358. tennesseense.

1360. depauperatum.

1361. xalapense.

1362. angustifolium.

1369. albomarginatum.

1370. ensifolium.

1371. ciliatum.

1372. leucothrix.

1373. consanguineum.

1375. aciculare.

1376. nitidum.

1377. cryptanthum.
Hiтснсоск, A. S.-Continued.

1378. scabriusculum.

1379. ensifolium.

1380. pseudopubescens.

1381. sphaerocarpon.

1382. consanguineum.

1383. pseudopubescens.

1384. villosissimum.

1387. trifolium.

1388. ashei.

1389. nitidum.

1390. ravenelii.

1391. xalapense.

1392. nitidum.

1393. microcarpon.

1394. pseudopubescens.

1395. lanuginosum.

1398. leucothrix.

1400. dichotomum.

1401. pseudopubescens.

1402. pseudopubescens.

1403. dichotomum.

1404. aciculare.

1405. ensifolium.

1406. ashei.

1407. ashei.

1408. angustifolium.

1410. oligosanthes.

1411. microcarpon.

1412. boscii.

1413. commutatum.

1414. commutatum.

1415. xalapense.

1416. barbulatum.

$1416 \frac{1}{2}$. yadkinense.

1419. microcarpon.

1420. nitidum.

1421. nitidum.

1422. nitidum.

1423. nitidum.

1424. xalapense.

1425. ensifolium.

1426. sphaerocarpon.

1427. chamaelonche.

1428. albomarginatum.

1429. albomarginatum.

1430. ciliatum.

1431. lancearium.

1432. pauciciliatum.

1433. webberianum.

1434. albomarginatum.

1435. chamaelonche.

1436. chamaelonche.

1436 $\frac{1}{2}$. ensifolium. 
Нгтснсоск, А. S.-Continued.

1437. pseudopubescens.

1438. tenue.

1439. ensifolium.

1440. albomarginatum.

1442. lucidum.

1447. aciculare.

1449. consanguineum.

1450. strigosum.

1451. ciliatum.

1455. mattamuskeetense.

1457. oligosanthes.

1458. commutatum.

1459. oligosanthes.

1460. oligosanthes.

1461. ashei.

1463. ravenelii.

1465. mutabile.

1466. lancearium.

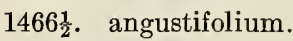

1467. tenue.

1468. lanuginosum.

1469. cryptanthum.

1470. lucidum.

1471. consanguineum.

1472. webberianum.

1473. aciculare.

1474. pseudopubescens.

1475. angustifolium.

1476. pseudopubescens.

1477. pauciciliatum.

1479. pauciciliatum.

1482. auburne.

1483. chamaelonche.

1484. pseudopubescens.

1485. pseudopubescens.

1486. lancearium.

1487. pauciciliatum.

1488. chamaelonche.

1489. ravenelii.

1490. ciliatum.

1603. lindheimeri.

1604. boscii.

1605. sphaerocarpon.

1606. microcarpon.

1607. sphaerocarpon.

1608. villosissimum.

1609. polyanthes.

1611. microcarpon.

1612. albemarlense.

1613. lanuginosum.

1615. sphaerocarpon.

1616. sphaerocarpon.

1617. addisonii.
Нıтснсоск, A. S.-Continued.

1618. sphaerocarpon inflatum.

1619. villosissimum.

1621. huachucae silvicola.

1622. lindheimeri.

1623. villosissimum.

1624. huachucae silvicola.

1626. sphaerocarpon.

1627. villosissimum.

1628. albemarlense.

1629. meridionale.

1630. huachucae silvicola.

1631. villosissimum.

1632. columbianum.

1635. villosissimum.

1636. meridionale.

1637. scoparium.

1638. lanuginosum.

1639. sphaerocarpon.

1640. ashei.

1641. barbulatum.

1643. villosissimum.

1644. villosissimum.

1902. thermale.

2061. thermale.

2086. thermale.

2114. barbipulvinatum.

2171. pacificum.

2190. pacificum.

2204. barbipulvinatum.

2205. barbipulvinatum.

2275. barbipulvinatum.

2374. barbipulvinatum.

2380. capillare.

2383. scribnerianum.

2391. virgatum.

2395. meridionale.

2398. agrostoides.

2399. polyanthes.

2403. villosissimum.

2404. polyanthes.

2407. columbianum.

2408. sphaerocarpon.

2409. albemarlense.

2410. ashei.

2411. barbulatum.

2412. sphaerocarpon inflatum.

2413. columbianum.

2414. depauperatum.

2415. villosissimum.

2418. columbianum.

2500. praecocius.

2501. perlongum.

2502. scribnerianum. 
Нгтснсоск, A. S.-Continued.

2504. leibergii.

2505. wilcoxianum.

2506. linearifolium.

2509. perlongum.

2511. scribnerianum.

2518. leibergii.

2519. scribnerianum.

2523. huachucae silvicola.

2524. praecocius.

2525. scribnerianum.

2528. huachucae.

2789. barbipulvinatum.

2798. barbipulvinatum.

2836. scribnerianum.

3069. barbipulvinatum.

3070. pacificum.

3071. pacificum.

3072. shastense.

3073. pacificun?.

3074. scribnerianum.

3077. pacificum.

3214. pacificum.

3219. pacificum.

3232. pacificum.

3233. pacificum.

3234. pacificum.

3481. hirticaule.

3482. arizonicum.

3494. hirticaule.

3495. fasciculatum chartaginense.

3509. hirticaule.

3526. hirticaule.

3541. hirticaule.

3542. arizonicum.

3544. praecocius.

3547. hirticaule.

3553. liirticaule.

3561. fasciculatum chartaginense.

3562. arizonicum.

3573. hirticaule.

3598. fasciculatum.

3604. hirticaule.

3631. hirticaule.

3637. arizonicum.

3646. obtusum.

3658. hirticaule.

3661. obtusum.

3675. hirticaule.

3694. plenum.

3695. arizonicum.

3706. hallii.
Нгтснсоск, A. S.-Continued.

3716. bulbosum sciaphilum.

3730. hirticaule.

3737. obtusum.

3760. barbipulvinatum.

3762. hallii.

3763. obtusum.

3783. hallii.

3784. bulbosum sciaphilum.

3819. barbipulvinatum.

3830. obtusum.

3838. dichotomiflorum.

3840 . virgatum.

3842. capillare.

3851. capillare.

3853. praecocius.

3854. scribnerianum.

3865. nodatum.

3866. firmulum.

4932. capillare.

5050. barbipulvinatum.

5083. barbipulvinatum.

5099. capillare.

5111. capillare.

5712. decolorans.

5822. decolorans.

Нiтchсоск, A. S., Lee Co. Pl.

147. adspersum.

148. adspersum.

159. adspersum.

469. erectifolium.

470. webberianum.

471. joorii.

472. chamaelonche.

473. longiligulatum.

474. ovale.

477. joorii.

478. nitidum.

479. nitidum.

480. xalapense.

481. lucidum.

482. polycaulon.

483. bartowense.

484. fasciculatum.

485. adspersum.

487. chapmani.

488. hians.

489. hians.

490. rhizomatum.

491. virgatum.

492. tenerum.

611. adspersum.

618. adspersum.

620. adspersum.

650. adspersum. 
Нiтchсоск, A. S., Pl. Kan.

570a. virgatum.

571. scribnerianum.

571a. scribnerianum.

571b. leibergii.

572. obtusum.

876. anceps.

877. agrostoides.

879. wilcoxianum.

880. linearifolium.

882. huachucae silvicola.

883. sphaerocarpon.

921. scribnerianum.

House, H. D.

257. anceps.

358. virgatum.

413. philadelphicum

450. polyanthes.

831. scribnerianum.

907. tsugetorum.

911. yadkinense.

947. depauperatum.

949. dichotomum.

957. meridionale.

961. ashei.

1041. aculeatum.

1058. sphaerocarpon.

1136. huachucae silvicola.

1231. implicatum.

1287. tsugetorum.

1443. stipitatum.

2105. ashei.

2106. commutatum.

2132. clandestinum.

2136. boscii.

2158. villosissimum.

2161. depauperatum.

2177. xalapense.

2179. commutatum.

2200. ravenelii.

2211. boscii molle.

2258. meridionale.

2269. villosissimum.

2305. commutatum.

2387. commutatum.

2413. sphaerocarpon.

2430. ashei.

2492. sphaerocarpon.

2551. xalapense strictirameum.

2575. virgatum cubense.

2668. virgatum cubense.

\section{Jenman, G.}

3969. geminatum.

4081. stoloniferum.

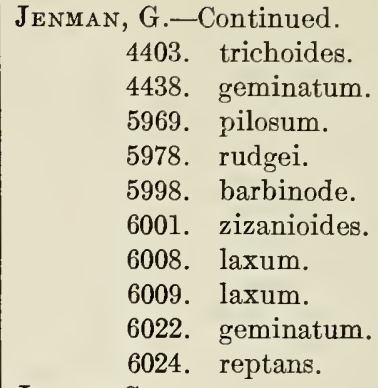

Jenman, G.-Continued.

4403. trichoides.

4438. geminatum.

5969. pilosum.

5978. rudgei.

5998. barbinode.

6001. zizanioides.

6008. laxum.

6009. laxum.

6022. geminatum.

6024. reptans.

JERMY, G.

6. obtusum.

22. fasciculatum chartaginense.

39. reverchoni.

57. huachucae silvicola.

203. fasciculatum chartaginense.

219. virgatum.

233. reverchoni.

234. reverchoni.

787. virgatum.

JoNES, M. E.

619. tennesseense.

2294. pacificum.

4019. bulbosum sciaphilum.

4168. obtusum.

4212. hirticaule.

6035. barbipulvinatum.

6069. tennesseense.

KEARNEY, T. H.

3. scoparium.

5. dichotomum.

7. sphaerocarpon inflatum.

9. dichotomiflorum.

10. columbianum thinium.

12. sphaerocarpon.

13. polyanthes.

16. anceps.

17. repens.

18. dichotomiflorum.

lindheimeri.

20. anceps.

polyanthes.

virgatum.

21. aciculare.

clandestinum.

22. huachucae silvicola.

24. ciliatum.

villosissimum.

25. sphaerocarpon.

26. lindheimeri. 
KeARney, T. H.-Continued.

27. albemarlense. scabriusculum.

28. angustifolium. yadkinense.

29. villosissimum.

29a. tennesseense.

30. hians.

31. commutatum.

32. clandestinum. lindheimeri.

33. huachucae silvicola.

34. ashei.

commutatum.

villosissimum.

35. barbulatum in part.

39. scabriusculum.

45. lucidum.

49. wrightianum in part.

50. microcarpon. tenerum.

52. polyanthes.

53. xalapense.

54. ashei in part.

57. barbulatum. polyanthes.

58. huachucae. villosissimum.

61. rhizomatum.

67. scoparium.

72. flexile.

74. agrostoides.

75. xalapense.

80. capillare.

82. virgatum.

87. anceps.

88. flexile. microcarpon.

92. chamaelonche.

96. polycaulon.

108. rhizomatum.

116. longifolium.

120. verrucosum.

121. hians.

138. rhizomatum.

139. tenerum.

140. patulum.

141. villosissimum.

145. chamaelonche.

146. leucothrix.

147. dichotomum.

151. philadelphicum.

156. scoparium.
Kearney, T. H.-Continued.

157. hemitomon.

158. virgatum.

167. lucidum.

168. virgatum.

172. commutatum.

173. hians.

176. adspersum.

177. chamelonche.

178. lancearium.

181. rhizomatum.

183. scoparium.

187. hians.

188. sphaerocarpon inflatum.

191. oligosanthes.

194. sphaerocarpon inflatum.

206. angustifolium.

207. ashei.

208. dichotomiflorum.

209. commonsianum.

212. xalapense.

215. aciculare. arenicoloides.

216. oligosanthes.

217. sphaerocarpon.

218. consanguineum. huachucae silvicola.

220. longifolium.

229. clandestinum.

234. dichotomum.

235. rhizomatum.

243. sphaerocarpon.

246. wrightianum.

247. aciculare.

250. ciliatum.

258. boscii.

260. lucidum.

267a. virgatum.

$267 \mathrm{~b}$. virgatum cubense.

268. albomarginatum.

269. hemitomon.

270. scabriusculum.

274. anceps.

282. strigosum.

283. ciliatum.

284. aciculare. consanguineum.

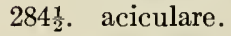

288. lucidum.

longiligulatum.

292. amarulum.

293. tenerum.

298. virgatum. 
Kearney, T. H.-Continued.

299. ashei.

300. dichotomum. longiligulatum.

301. pseudopubescens. sphaerocarpon.

302. villosissimum.

306. aciculare. angustifolium.

307. wrightianum.

308. scoparium.

309. lindheimeri.

312. flexile.

320. sphaerocarpon.

324. ashei.

325. boscii.

326. ciliatum.

microcarpon.

327. commutatum.

328. huachucae silvicola.

329. dichotomum.

330. clandestinum. lancearium. patentifolium.

331. patulum.

$331 \frac{1}{2}$. pauciciliatum.

336. mutabile. verrucosum.

337. villosissimum.

342. repens.

358. rhizomatum.

363. hians.

367. dichotomum.

369. virgatum.

372. agrostoides. anceps. dichotomiflorum.

374. dichotomiflorum.

376. anceps.

378. gattingeri.

379 . verrucosum.

380. longifolium.

380a. stipitatum.

384. dichotomum.

594. sphaerocarpon.

960. flexile.

961. philadelphicum.

962. gattingeri.

963. gattingeri.

965. anceps.

966. dichotomiflorum.

967. microcarpon.

968. sphaerocarpon.
Krarney, T. H.-Continued.

969. stipitatum.

970. xalapense.

971. villosissimum.

972. commutatum.

973. commutatum.

974. polyanthes.

1029. ashei.

1033. xalapense.

1104. xalapense.

1179. xalapense.

1307. microcarpon.

1308. xalapense.

1317. commutatum.

1369. angustifolium.

1374. dichotomum.

1375. aciculare.

1386. oligosanthes.

1393. commonsianum.

1400. oligosanthes.

1411. boscii.

1414. commutatum.

1416. angustifolium.

1447. tsugetorum.

1454. commonsianum.

1461. oricola.

1463. commutatum.

1467. xalapense.

1469. boscii.

1476. polyanthes.

1477. scoparium.

1514. roanokense.

1559. lanuginosum.

1560. sphaerocarpon.

1566. aciculare.

1748. anceps.

1761. strigosum.

1775. amarulum.

1776. commonsianum.

1798. scabriusculum.

1871. aciculare.

1899. virgatum cubense.

2018. virgatum.

2021. amarulum.

2025. longifolium.

2026. roanokense.

2038. aciculare.

2043. lanuginosum.

2053. verrucosum.

2063. amarulum.

2064. amarum.

2114. commonsianum.

2242. longifolium. 
Kearney, T. H.-Continued. 2249. stipitatum.

2272. aciculare.

2317. amarum.

Kellerman, W. A.

20. praecocius.

4725. maximum.

5114. polygonatum.

5119. pilosum.

6231. viscidellum.

6236. sphaerocarpon.

6246. pulchellum.

6249. viscidellum.

6250. geminatum.

6253. paludivagum.

6254. paludivagum.

6263. trichoides.

6267. maximum.

6272. trichanthum.

6758. huachucae silvicola.

6765. capillare.

6766. latifolium.

6767. polyanthes.

6768. dichotomum.

6769. huachucae.

6778. microcarpon.

6785. huachucae.

6799. latifolium.

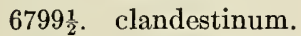

6800. stipitatum:

6873. huachucae.

6881. commutatum.

6883. clandestinum.

6885. implicatum.

6886. barbulatum.

6887. bicknellii.

6888. clandestinum.

6890. huachucae silvicola.

6891. dichotomum.

6892. ashei.

6893. huachucae.

6894. scribnerianum.

6895. huachucae silvicola.

6899. latifolium.

6900. clandestinum.

6901. ashei.

6902. commutatum.

6903. barbulatum.

Kneucker, A., Gram. Exs.

189. capillare.

245. dichotomum.

302. virgatum.

366. molle.
Kneucker, A., Gram. Exs.-Continued.

423. latifolium.

424. clandestinum.

425. scribnerianum.

485. tennesseense.

546. dichotomiflorum.

547. perlongum.

548. depauperatum.

549. xalapense.

550. microcarpon.

551. huachucae silvicola.

552. lindheimeri.

553. sphaerocarpon.

554. polyanthes.

555. villosissimum.

556. ashei.

557. commutatum.

LeiberG, J. B.

714. barbipulvinatum.

834. barbipulvinatum.

1312. pacificum.

5732. virgatum.

5783. barbipulvinatum.

5816. bulbosum sciaphilum.

5916. hallii.

LEMMON, J. G.

353. arizonicum.

2907. huachucae.

2908. bulbosum sciaphilum.

2912. bulbosum.

2914. bulbosum.

2916. bulbosum.

2922. bulbosum sciaphilum.

3062. arizonicum.

3152. bulbosum sciaphilum.

3154. virgatum.

León, Brother.

190. diffusum.

276. reptans.

283. barbinode.

291. adspersum.

292. reptans.

296. repens.

297. reptans.

305. diffusum.

$305 \mathrm{~b}$. distantiflorum.

335. elephantipes.

427. maximum.

557. trichanthum.

563. repens.

566. reptans.

567. distantiflorum.

568. barbinode. 
León, Brother-Continued. 570. adspersum.

573. fasciculatum.

576. reptans.

813. fasciculatum.

902. exiguiflorum.

903. zizanioides.

906. reptans.

907. laxum.

908. pilosum.

909. laxum.

910. reptans.

910b. reptans.

910c. reptans.

911. exiguiflorum.

912. distantiflorum.

913. exiguiflorum.

914. laxum.

916. fasciculatum.

917. distantiflorum.

918. geminatum.

919. dichotomiflorum.

920. geminatum.

921. maximum.

922. ghiesbreghtii.

922b. ghiesbreghtii.

923. diffusum.

$923 \mathrm{~b}$. diffusum.

923c. diffusum.

924. adspersum.

925. adspersum.

957. maximum.

Liebmann, F. M.

275. millegrana.

277. fasciculatum.

279. fasciculatum.

317. trichoides.

320. trichanthum.

323. viscidellum.

324. viscidellum.

327. sphaerocarpon.

328. xalapense.

394. zizanioides.

405. frondescens.

411. pilosum.

412. laxum.

419. laxum.

425. maximum in part.

428. glutinosum.

432. trichanthum.

441. bulbosum.

442. bulbosum.

450. gouini.
LINDHEIMER, F.

158. pedicellatum.

565. lindheimeri.

728. condensum.

733. virgatum.

1265. pedicellatum.

MACKenZIE, K. K.

297. leibergii.

301. agrostoides.

460. lucidum.

1339. linearifolium.

1355. oricola.

1360. clandestinum.

1379. tsugetorum.

1380. polyanthes.

1381. villosissimum.

1398. linearifolium.

1399. columbianum.

1405. dichotomum.

1414. latifolium.

1452. depauperatum.

1459. tennesseense.

1484. microcarpon.

1485. commonsianum.

1548. barbulatum.

1605. microcarpon.

1611. scribnerianum.

1663. sphaerocarpon.

1664. aciculare.

1671. verrucosum.

1686. microcarpon.

1688. scoparium.

1708. ashei.

1709. latifolium.

1710. villosissimum.

1725. amarulum.

1733. auburne.

1736. amarum.

1745. polyanthes.

1794. joorii.

1854. scoparium.

1893. stipitatum.

2067. commonsianum.

2068. columbianum.

2075. huachucae.

2076. tennesseense.

2093. boreale.

2105. columbianum.

2106. dichotomum.

2109. boreale.

2137. huachucae silvicola.

2138. annulum.

2144. boscii. 
Mackenzie, K. K.-Continued.

2155. commonsianum.

2156. lindheimeri.

2159. huachucae silvicola.

2160. lindheimeri.

2161. microcarpon.

2163. ashei.

2164. lindheimeri.

2165. commonsianum.

2166. sphaerocarpon.

2167. lucidum.

2168. lindheimeri.

2169. huachucae silvicola.

2170. meridionale.

2195. ashei.

2197. huachucae silvicola.

2220. tsugetorum.

2247. columbianum.

2249. huachucae silvicola.

2250. sphaerocarpon.

2251. werneri.

2280. dichotomum.

2349. lindheimeri.

2355. agrostoides.

2366. philadelphicum.

2404. columbianum.

2476. microcarpon.

2477. meridionale.

2480. ashei.

Macoun, J. AND J. M.

135. agrostoides.

7444. philadelphicum.

13003. virgatum.

13225. capillare.

13227. wilcoxianum.

13231. virgatum.

21957. werneri.

22022. boreale.

22023. subvillosum.

22024. implicatum.

22025. xanthophysum.

26236. tsugetorum.

26316. lindheimeri.

26317. capillare.

26322. depauperatum.

26324. virgatum.

26325. latifolium.

26326. latifolium.

26327. latifolium.

26328. scribnerianum.

26329. scribnerianum.

26330. flexile.

26331. flexile.
Macoun, J. and J. M.-Continued.

26332. flexile.

26333. scribnerianum.

26334. huachucae silvicola.

26337. huachucae.

26338. lindheimeri.

29297. scribnerianum.

29303. virgatum.

29304. virgatum.

29348. agrostoides.

29349. boreale.

29368. subvillosum.

29369. huachucae.

65370. lindheimeri.

69204. boreale.

69205. subvillosum.

72965. tennesseense.

73003. leibergii.

73004. leibergii.

77229. occidentale.

77230. scribnerianum.

77231. scribnerianum.

Maxon, W. R.

550. huachucae silvicola.

1659. fasciculatum.

2109. zizanioides.

2361. fasciculatum.

2816. glutinosum.

3153. pulchellum.

3476. barbinode.

Mearns, E. A. $\vee$

25. villosissimum.

738. hirticaule.

743. barbipulvinatum.

755. barbipulvinatum.

756. capillare.

758. virgatum.

767. hirticaule.

769. virgatum.

771. scribnerianum.

773. obtusum.

788. barbipulvinatum.

791. latifolium.

793. virgatum.

925. obtusum.

1072. arizonicum.

1130. obtusum.

1845. obtusum.

1905. hirticaule.

1932. bulbosum sciaphilum.

2093. hirticaule.

2294. hirticaule.

2308. obtusum. 
Mearns, E. A.-Continued.

2501. bulbosum.

3061. thermale.

4050. thermale.

4166. thermale.

4203. thermale.

4789. thermale.

4870. thermale.

4983. thermale.

5064. thermale.

5110. thermale.

5134. thermale.

MerRILL, E. D.

2. implicatum.

7. implicatum.

8. implicatum.

9. implicatum.

11. xanthophysum.

16. implicatum.

43. barbipulvinatum.

152. barbipulvinatum.

157. thermale.

164. thermale.

165. thermale.

197. microcarpon.

198. clandestinum.

199. polyanthes.

202. boscii molle.

203. boscii molle.

204. commutatum.

233. scoparium.

1243. latifolium.

Metcalfe, O. B.

6. plenum.

80. bulbosum. plenum.

354. helleri.

357. bulbosum sciaphilum.

434. barbipulvinatum.

738. plenum.

739. plenum.

749. obtusum.

768. arizonicum.

807. hallii.

1294. arizonicum.

1422. bulbosum.

1442. hirticaule.

Millspaugh, C. F.

126. dichotomiflorum.

324 . barbinode.

454. maximum.

702. utowanaeum.

726. reptans.
Millspaugh, C. F.-Continued.

727. barbinode.

1859. pilosum.

2182. caerulescens.

Morong, T.

317. trichanthum.

405a. glutinosum.

441. polygonatum.

519. parvifolium.

534. laxum.

536. zizanioides.

537. laxum.

543. dichotomiflorum.

779a. barbinode.

813. megiston.

977. laxum.

1001. zizanioides.

1002. dichotomiflorum. elephantipes.

1072. megiston.

1571. trichanthum.

1574. laxum.

Morris, E. L.

9. huachucae.

48. huachucae silvicola.

53. virgatum.

55. implicatum.

124. virgatum.

135. villosissimum.

171. capillare.

226. capillare.

240. pseudopubescens. tsugetorum.

252. capillare.

287. dichotomiflorum.

294. virgatum.

977. ashei.

984. lindheimeri.

1139. microcarpon.

1186. polyanthes.

1193. microcarpon.

1193a. dichotomum.

1283. philadelphicum.

NASH, G. V.

15. pauciciliatum.

36. malacon.

45. equilaterale. commutatum.

50. patulum.

51. chamaelonche.

52. patentifolium.

63. malacon.

pauciciliatum. 
Nash, G. V.-Continued.

71. chamaelonche.

72. patentifolium.

75. ovale.

78. commutatum.

103. ovale.

132. malacon.

147. ovale.

151. patulum.

213. hians.

239. laxiflorum.

240. commutatum. joorii.

273. vernale in part.

287. tsugetorum.

301. lancearium.

302. commutatum.

334. leucothrix.

335. chamaelonche.

337. lucidum.

372. dichotomiflorum.

375. lanuginosum.

376. nitidum.

424. vernale.

466. lancearium.

467. leucothrix.

500 . lucidum.

598. arenicoloides.

603. malacon.

628. malacon.

745. hemitomon.

746. paludivagum.

778. chamaelonche.

780 . verrucosum.

781. webberianum.

807. ciliatum.

874. dichotomiflorum.

925. albomarginatum.

1012. erectifolium.

1117. patulum.

1118. ovale.

1119. commutatum.

1120. equilaterale.

1226. fusiforme.

1238. chamaelonche.

1243. aciculare.

1337. pauciciliatum.

1338. leucothrix.

1436. arenicoloides.

1507. curtifolium.

1518. ovale.

1674. equilaterale.

1675. commutatum.

1694. agrostoides.
Nash, G. V.-Continued

1713. rhizomatum.

1730. maximum.

1856. fusiforme.

1857. ovale.

2034. laxiflorum.

2075. leucothrix.

2076. pauciciliatum.

2156. laxiflorum.

2204. scoparium.

2249. tenerum.

2258. rhizomatum.

2329. boscii.

2500. sphagnicola.

2522. microcarpon.

2529. anceps.

Nelson, A.

516. scribnerianum.

2524. scribnerianum.

3626 . virgatum.

6037. thermale.

6174. thermale.

8346. barbipulvinatum.

8360 . virgatum.

Nelson, E.

330. virgatum.

476. virgatum.

481. barbipulvinatum.

4984. barbipulvinatum.

Nelson, E. W.

201. xalapense.

1374. bulbosum.

1622. reptans.

2874. fasciculatum.

2958. fasciculatum.

2975. virgatum.

3023. zizanioides.

3056. pilosum.

3357. glutinosum.

3781. biglandulare.

3908. obtusum.

4257. trichoides.

6187. bulbosum.

6297. hirticaule.

6298. bulbosum sciaphilum.

6301. bulbosum.

6352. obtusum.

6355. hirticaule.

Palmer, E.

$1 \mathrm{~b}$ in 1885 . arizonicum.

hirticaule.

1c in 1885 . sonorum.

14 in 1897. hirticaule. 
Palmer, E.-Continued.

15 in 1869 . geminatum.

19 in 1897. fasciculatum.

143 in 1897. hirticaule.

145 in 1897. hirticaule.

149 in 1897. molle.

152 in 1904. fasciculatum chartaginense.

158 in 1887. fasciculatum.

159 in 1887. arizonicum.

159 in 1887. fasciculatum chartaginense.

168a in 1887. stramineum.

175 in 1896 . obtusum.

206 in 1887. stramineum.

207 in 1886 . bulbosum.

virgatum.

207 in 1887. fasciculatum.

207a in 1886. bulbosum.

208 in 1887. hirticaule.

241 in 1897. fasciculatum.

249 in 1897. hirticaule.

250 in 1897. arizonicum.

251 in 1897. hirticaule.

266 in 1904 . obtusum.

287 in 1895. trichoides.

289 in 1894. geminatum.

340 in 1906. bulbosum.

346 in 1887. hirticaule.

348 in 1906. bulbosum s c i a philum.

349 in 1906. bulbosum s c i a philum.

370 in 1868. obtusum.

375 in 1868. dichotomiflorum.

376 in 1868. virgatum.

' 380 in 1868. anceps.

381 in 1868. hians.

382 in 1868. helleri.

383 in 1868. malacophyllum.

384 in 1868. lindheimeri.

394 in 1898. obtusum.

412 in 1907. fasciculatum chartaginense.

429 in 1886. paludivagum.

467 in 1896 . bulbosum sciaphilum.

469 in 1906. bulbosum.

bulbosum sciaphilum.

510 in 1886 . virgatum.

525 in 1896 . lepidulum.

525a in 1896. bulbosum.
Palmer, E.-Continued.

533 in 1906. lepidulum.

554 in 1906. bulbosum scia. philum.

554 in 1907. hallii.

561 in 1890. scribnerianum.

590 in 1898. obtusum.

631 in 1874 . lancearium.

632 in 1874. lucidum.

633 in 1874. sphagnicola.

634 in 1874. breve.

chamaelonche.

690 in 1887 . geminatum.

690 in 1890. hirticaule.

694 in 1890. fasciculatum.

695 in 1890 . hirticaule.

741 in 1896. plenum.

750 in 1890 . hirticaule.

947 in 1889. sonorum.

1078 in 1890 . barbinode.

1083 in 1890 . trichoides.

1151 in 1879 . trichanthum.

1257 in 1891 . trichanthum.

1338 in 1880. hallii.

1538 in 1891. stramineum.

1539 in 1891 . sonorum.

1544 in 1891. hirticaule.

1545 in 1891. hirticaule.

1554 in 1891. hirticaule.

sonorum.

1557 in 1891 . fasciculatum.

1558 in 1891 . laxum.

1659 in 1891. parcum.

1660 in 1891. molle.

1758 in 1891. trichoides.

2649 in 1892 . barbipulvinatum.

2709 in 1892 . barbipulvinatum.

Palmer, IV., and Riley, J. H.

178. maximum.

213. strigosum.

377. maximum.

447. acuminatum.

481. chrysopsidifolium.

542. maximum.

545. maximum.

746. adspersum.

771. adspersum.

802. diffusum.

816. maximum.

982. chrysopsidifolium.

989 . acuminatum.

990. polycaulon.

1065. viscidellum. 
Palmer, W., and Rlley, J. H.-Cont'd. 1069. laxum.

1083. acuminatum.

1086. cayennense.

1134. virgatum cubense.

Parish, S. B.

263. pacificum.

887. urvilleanum.

1081. barbipulvinatum.

1663. pacificum.

Paruin, J. C.

751. agrostoides.

938. languidum.

1029. boreale.

1181. huachucae silvicola.

1186. huachucae.

1187. boreale.

1188. implicatum.

1189. huachucae.

1190. werneri.

1191. latifolium.

1196. columbianum.

1198. implicatum.

1215. tsugetorum.

1266. dichotomum.

1423. boreale.

1502. werneri.

1577. tsugetorum.

1581. subvillosum.

1607. lindheimeri.

1701. boreale.

1738. boreale.

1744. boreale.

1776. philadelphicum.

1806. werneri.

1957. depauperatum.

1971. linearifolium.

2000. implicatum.

2001. subvillosum.

2013. boreale.

2016. subvillosum.

2017. tennesseense.

2034. boreale.

Pitrier, H.

101. paludivagum.

257. strigosum.

361. laxum.

364. stoloniferum.

521. laxum.

553. laxum.

665. laxum.

932. acuminatum.

940. viscidellum.
Pittier, H.-Continued.

971. trichoides.

982a. acuminatum.

1617. maximum.

1621. trichoides.

1800. strigosum.

1805a. albomarginatum.

1805b. arenicoloides.

1960. maximum.

Pollard, C. L.

16. dichotomum.

92. clandestinum.

180. ashei.

323. barbulatum.

324. dichotomum.

337. villosissimum.

338. depauperatum.

353. meridionale.

362. microcarpon.

365. clandestinum.

398. sphaerocarpon.

401. polyanthes.

403. lucidum.

406. microcarpon.

408. microcarpon.

412. boscii molle.

523. tennesseense.

595. virgatum.

682. dichotomiflorum.

1106. rhizomatum.

1152. repens.

1201. virgatum cubense.

1228. anceps.

Pringle, C. G.

7. plenum.

26. barbinode.

73. reptans.

74. fasciculatum.

124. fasciculatum.

376. hallii.

377. bulbosum.

379. fasciculatum chartaginense.

380. fasciculatum chartaginense.

465. arizonicum.

476. obtusum.

487. arizonicum.

497. lepidulum.

1124. havardii.

1415 , vaseyanum.

1406. bulbosum sciaphilum.

2377. ramisetum. 
Pringle, C. G.--Continued.

3336. paludivagum.

3449. cupreum.

3817. schmitzii.

3828. trichoides.

5203. albomaculatum.

5207. bulbosum.

5569. gouini.

5573. hirsutum.

6322. elephantipes.

6418 . bulbosum.

7882. multirameum.

7883. sphaerocarpon.

8083. xalapense.

8089. viscidellum.

8195. longum.

8323. ramisetum.

8339. multirameum. olivaceum.

8344. sphaerocarpon.

9209. multirameum.

9210. multirameum.

9556. paludivagum.

9575. bulbosum.

9577. elephantipes.

13250. xalapense.

Purpus, C. A.

2156. glutinosum.

2159. laxum.

2160. laxum. viscidellum.

2902. trichoides.

2903. glutinosum.

2908. bulbosum.

3774. maximum.

Reverchon, J.

22. virgatum.

32. virgatum.

88. geminatum.

92. ovinum.

93. xalapense.

99. hians.

103. agrostoides.

106. anceps.

1074. helleri in part.

1075. huachucae silvicola.

1078. geminatum.

1079. obtusum.

1083A. agrostoides.

1086. fasciculatum chartaginense.

1087. ovinum.

1096. reverchoni.

1226. texanum.
Reverchon, J.-Continued.

1620. pedicellatum.

1622. virgatum.

1682. hallii.

1831. malacophyllum.

1840. oligosanthes.

1841. oligosanthes.

1842. philadelphicum.

1884. lanuginosum.

2222. agrostoides.

2223. brachyanthum.

2224. brachyanthum.

2228. texanum.

2235. gymnocarpon.

2341. hemitomon.

2342. helleri.

2344. helleri.

2345. helleri.

2357. lindheimeri.

2368. condensum.

2390. ravenelii.

2444. helleri.

2844. virgatum.

2855. helleri.

3526. filipes.

4136. villosissimum.

4137. ovinum.

4138. helleri.

4142. oligosanthes.

4143. commutatum.

4144b. boscii.

4147. barbulatum.

4155. dichotomum.

4156. consanguineum.

4158. dichotomum.

4159. angustifolium.

4163. thurowii.

4193. angustifolium.

4194. microcarpon.

Ricker, P. L.

666. huachucae silvicola.

908. tenerum.

933. rhizomatum.

936. virgatum cubense.

943. equilaterale.

945. patentifolium.

952. adspersum.

962. rhizomatum.

963. patentifolium in part.

975. capillare.

1153. commutatum.

1277. implicatum.

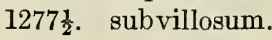

1309. dichotomum. 
Ricksecker, A. E.

66. adspersum.

77. reptans.

200. maximum.

212. geminatum.

300. barbinode.

317. fasciculatum.

384. adspersum.

413. maximum.

Riedel, L.

52. laxum.

53. maximum.

958. parvifolium.

959. dichotomiflorum.

1239. megiston.

1360. trichanthum.

Rose, J. N.

1834. fasciculatum.

1878. stramineum.

1883. stramineum.

1884. fasciculatum.

1889. stramineum.

1999. bulbosum.

2053. bulbosum sciaphilum.

2280. arizonicum.

2609. bulbosum.

3281. stramineum.

3351. hirticaule.

3361. bulbosum.

Rovirosa, J. N.

427. laxum.

434. trichoides.

497. frondescens. .

532. megiston.

598. trichoides.

599. pilosum.

624. zizanioides.

RUGEL, F.

123. geminatum.

142. consanguineum.

184. albomarginatum.

229. erectifolium.

231. hians.

290. neuranthum.

291. lancearium.

347. hemitomon.

351. joorii.

376. lancearium.

377. chamaelonche.

378. joorii.

392. xalapense.

394. chapmani.

443. webberianum.
Rugel, F.-Continued.

444. amarulum.

595. virgatum.

598. verrucosum.

599. gymnocarpon.

Rusby, H. H.

22. laxum.

199. polygonatum in part.

210. laxum.

pilosum.

212. pilosum.

217. pulchellum.

228. laxum.

229. frondescens.

233. millegrana.

236. laxum.

244. glutinosum.

444. pampinosum.

445. virgatum.

445b. bulbosum.

445c. bulbosum sciaphilum in part.

864. obtusum.

866. bulbosum sciaphilum.

8921. obtusum.

Rusby, H. H., and Squires, R. W.

79. pilosum.

347. pilosum.

355. megiston.

362 . rudgei.

Ruth, A.

1. sphaerocarpon.

5. polyanthes.

6. sphaerocarpon.

7. polyanthes.

11. commutatum.

15. polyanthes.

19. villosissimum.

21. sphaerocarpon.

56. angustifolium.

57. microcarpon.

59. capillare. gattingeri.

60. clandestinum.

61. commutatum.

63. depauperatum.

64. microcarpon.

65. agrostoides.

66. flexile.

68. xalapense.

69. polyanthes.

70. boscii molle.

71. dichotomiflorum. 
Ruth, A.-Continued.

72. villosissimum in part.

75. sphaerocarpon.

76. virgatum.

Rydberg, P. A.

1096. barbipulvinatum.

1097. virgatum.

1098. scribnerianum.

1099. huachucae.

1100. perlongum.

1279. scribnerianum.

1308. wilcoxianum.

1368. huachucae.

1493. scribnerianum.

1538. barbipulvinatum.

1561. virgatum.

1604. scribnerianum.

1788. barbipulvinatum.

2011. barbipulvinatum.

2351. barbipulvinatum.

2505. barbipulvinatum.

2508. virgatum.

2512. virgatum.

2516. virgatum.

SchaffNer, S. W.

138. sphaerocarpon.

146. pseudopubescens.

148. obtusum.

284. viscidellum.

285. sphaerocarpon.

1037. sphaerocarpon.

Shear, C. L.

85. scribnerianum.

152. barbipulvinatum.

223. virgatum.

264. barbipulvinatum.

436. barbipulvinatum.

606. virgatum.

755. barbipulvinatum.

756. virgatum.

767. virgatum.

819. virgatum.

965. barbipulvinatum.

975. obtusum.

980. virgatum.

Sintenis, P.

51. maximum.

160. trichoides.

355 . acuminatum.

357. glutinosum.

360. laxum.

847. reptans.

938. elephantipes.

1216. parvifolium.
Sintenis, P.-Continued.

1224. acuminatum in part.

1254. laxum.

1901. fasciculatum.

1957. adspersum.

2468. maximum.

2471. trichanthum.

2609. glutinosum.

3365. utowanaeum.

3366. maximum.

3367. geminatum.

3368. reptans.

3416. utowanaeum.

3463. utowanaeum.

3647. fasciculatum.

4983. ghiesbreghtii.

5719. parvifolium.

5724. polycaulon.

5908. acuminatum.

5985. chrysopsidifolium.

Small, J. K., and Heller, A. A.

201. commutatum.

204. scoparium.

205. hians.

279. depauperatum.

348. clandestinum.

394. latifolium.

463. polyanthes.

480. dichotomum.

Sмrтн, H. H.

151. geminatum.

167. trichoides.

169. zizanioides.

173. reptans.

202. laxum.

203. pilosum.

204. laxum.

206. polygonatum.

211. barbinode.

589. pulchellum.

1409. maximum.

2146. millegrana.

2151. trichanthum.

2153. max́imum.

2190. polygonatum.

Somes, M. P.

25. praecocius.

153. tennesseense.

167. scribnerianum.

189. virgatum.

207. huachucae silvicola.

210. huachucae.

219. virgatum.

229. scribnerianum. 
Somes, M. P.-Continued.

230. huachucae silvicola.

231. clandestinum.

232. microcarpon.

236. leibergii.

245. perlongum.

246. praecocius.

Spruce, R.

93. rudgei.

466. trichoides.

603. millegrana.

632. parvifolium.

706. zizanioides.

1289. stenodes.

2207. parvifolium.

2344. zizanioides.

Suksdorf, W. N.

124. pacificum.

2330. hirticaule.

5162. occidentale.

5174. occidentale.

6292. pacificum.

Thinge, C.

195. fasciculatum.

532. virgatum.

781. polygonatum.

5578. polygonatum.

5584. fasciculatum.

5587. laxum.

pilosum.

polygonatum.

trichanthum.

Tidestrom, I.

4. ashei.

5. tennesseense.

22. barbipulvinatum.

48. huachucae silvicola.

2482. barbipulvinatum.

2636. pacificum.

Tracy, S. M.

3. boscii.

13. sphaerocarpon.

26. tenerum.

29. joorii.

38. repens.

42. scribnerianum.

43. leucothrix.

44. ensifolium.

47. sphaerocarpon.

77. dichotomiflorum.

91. spretum.

95. lucidum.

120. joorii.

161. villosissimum.
TracY, S. M.-Continued.

162. ciliatum.

192. barbipulvinatum.

433. sphaerocarpon.

434. urvilleanum.

459. arenicoloides.

459a. arenicoloides.

912. virgatum.

1410. xalapense.

1416. commutatum.

1417. aciculare.

1418. hians.

1478. xalapense strictirameum.

1535. anceps.

1730. angustifolium.

1733. microcarpon.

1735. lanuginosum.

1751. huachucae silvicola.

1752. scribnerianum.

1753. xalapense.

1754. oligosanthes.

1755. dichotomum.

1837. reptans.

1883. angustifolium.

1884. consanguineum.

1888. angustifolium.

2027. flavovirens.

2028. dichotomum.

2031. nitidum.

2032. xalapense.

2036. agrostoides.

2050. dichotomum.

2058. xalapense.

2854. amarum.

2856. lanuginosum.

2859. neuranthum.

2861. wrightianum.

2862. sphaerocarpon inflatum.

2863. pauciciliatum.

2865. trifolium.

2867. lanuginosum.

2869. lancearium.

2873. consanguineum.

3190. huachucae.

3198. huachucae silvicola.

3204. dichotomum.

3205. boscii molle.

3207. microcarpon.

3208. huachucae silvicola.

3209. dichotomum.

3211. xalapense.

3223 . huachucae silvicola.

3224. microcarpon.

3225. microcarpon. 
Tracy, S. M.-Continued.

3228. nitidum.

3238. polyanthes.

3252. boscii.

3253. dichotomum.

3255. xalapense.

3256. xalapense.

3265. lindheimeri.

3266. joorii.

3267. xalapense.

3268. ashei.

3272. villosissimum.

3273. dichotomum.

3275. ashei.

3285. lindheimeri.

3287. xalapense.

3296. commutatum.

sphaerocarpon.

3306. scoparium.

3316. polyanthes.

3318. joorii.

3334. trifolium.

3387. joorii.

3388. microcarpon.

3388a. microcarpon.

3603. rhizomatum.

3604 . virgatum.

3614. fusiforme.

3615. lindheimeri.

3616. dichotomum.

3617. ovale.

3618. microcarpon.

3619. sphaerocarpon inflatum.

3620 . lanuginosum.

3622. lanuginosum.

3623. microcarpon.

3624. microcarpon.

3625. dichotomum.

roanokense.

3626. rhizomatum.

3627. longifolium.

3629. ashei.

commutatum.

3630. commutatum.

3631. polyanthes.

3633. consanguineum.

3634. aciculare.

3635. angustifolium.

fusiforme.

3636. angustifolium.

3637. aciculare.

3638. aciculare.

3639. aciculare.
TracY, S. M.-Continued.
3640. aciculare.

3641. aciculare.

3642. sphaerocarpon inflatum.

3643. scabriusculum.

3644. wrightianum.

3645. lanuginosum.

3646. mutabile.

3647. oligosanthes.

3649. dichotomum.

3650 . aciculare.

3651. angustifolium.

3653. villosissimum.

3655. joorii.

3656. sphaerocarpon inflatum.

3657. angustifolium.

3658. villosissimum.

3660 . virgatum.

3661. consanguineum.

3746. angustifolium.

3747. ashei.

3748. curtifolium in part.

3749. lucidum.

3750. angustifolium.

3751. villosissimum.

3752. curtifolium.

3753. villosissimum.

3754. villosissimum.

3756. ashei.

3757. dichotomum.

3758. angustifolium.

villosissimum.

3759. xalapense.

3760. polyanthes.

3761. microcarpon.

3762 . virgatum.

virgatum cubense.

3763. virgatum.

3858. longifolium.

3859. longifolium.

3860. longifolium.

3861 . repens.

3889. lindheimeri.

huachucae silvicola.

3976. patulum.

3978. scoparium.

4562. verrucosum.

4563. longifolium.

4564. rhizomatum.

4565. virgatum.

4566. gouini.

4567. neuranthum.

4568. combsii in part. 
Tracy, S. M.-Continued.

4569. scabriusculum.

4573. commutatum. mutabile.

4574. xalapense.

4576. sphaerocarpon.

4577. commutatum in part.

4578. angustifolium.

4579. angustifolium.

4580. lanuginosum.

4581. lancearium in part.

4582. ciliatum.

4583. trifolium.

4584. roanokense.

4585. spretum.

4586. patulum.

4587. patulum.

4588. xalapense.

4591. nitidum.

4592. roanokense.

4593. sphaerocarpon inflatum.

4594. spretum.

4595. microcarpon.

4596. erectifolium.

4597. sphaerocarpon.

4598. curtifolium.

4599. curtifolium.

4601. trifolium.

4603. trifolium.

4604. sphaerocarpon.

4605. lanuginosum.

albomarginatum.

4606. polycaulon.

4607. sphaerocarpon.

4609. nitidum.

microcarpon.

4610. chamaelonche.

4611. wrightianum.

4612. trifolium.

4614. consanguineum.

4615. angustifolium.

4616. angustifolium. ovinum.

4617. scabriusculum.

4618. dichotomiflorum.

4619. rhizomatum.

4620. anceps.

4621. rhizomatum.

4622. sphaerocarpon inflatum.

6350. patentifolium.

6358. xalapense.

6444. condensum.

6446. pauciciliatum.
Tracy, S. M.-Continued.

6447. pauciciliatum.

6451. chamaelonche.

6452. lancearium.

6455. fasciculatum.

6458. sphaerocarpon inflatum.

6460 . equilaterale.

6464. chamaelonche.

6465. lancearium.

6466. lancearium.

6469. lanuginosum.

6470. polycaulon.

6471. sphaerocarpon inflatum.

6507. dichotomiflorum.

6507a. longifolium.

6508. amarulum.

6691. bartowense.

6692. polycaulon.

6693. chamaelonche.

6694. xalapense.

6695. commutatum.

6698. polycaulon.

6699 . vernale.

6700. malacon.

6701. patulum.

6702. patentifolium.

6703. patulum.

6707. laxiflorum.

6708. fusiforme.

6710. fusiforme.

polycaulon.

6711. neuranthum.

6713. fusiforme.

equilaterale.

67i3a. fusiforme.

6714. lancearium.

6715. glabrifolium.

6716. webberianum.

6723. polycaulon.

6725. malacon.

6726. chamaelonche.

6727. polycaulon.

6729. patulum.

6730. lancearium.

6731. hemitomon.

6732. chamaelonche.

6733. albomarginatum.

6736. lindheimeri.

7008. hians.

7018. microcarpon.

7029. trifolium.

7048. scoparium.

7050 . equilaterale. 
Tracy, S. M.-Continued.

7051. equilaterale. lancearium.

7093. rhizomatum.

7105. rhizomatum.

7163. fusiforme.

7166. neuranthum.

7167. equilaterale.

7170. nitidum.

7174. patentifolium.

7175. lancearium.

7176. neuranthum.

7180. vernale.

7186. webberianum.

7188. flavovirens.

polycaulon.

7189. albomarginatum.

7191. chamaelonche.

7193. leucothrix.

longiligulatum.

7194. lancearium.

7195. lancearium.

7198. patulum.

7199. nitidum.

7200. chamaelonche.

7202. xalapense.

7203. lancearium.

7205. lancearium.

7207. chamaelonche.

7208. polycaulon.

7209. lancearium.

7371. fusiforme.

7381. geminatum.

7382. commutatum.

7383. laxifiorum.

7387. reptans.

7392. geminatum.

7400. gymnocarpon.

7402. sphaerocarpon.

7405. rhizomatum.

7409. capillare.

7412. paludivagum.

7651. agrostoides.

7738. bartowense.

7740. bartowense.

7745. hians.

7748. texanum.

7753. gouini.

7763. barbinode.

7935. obtusum.

7939. reverchoni.

7940. reverchoni.

7941. hallii.

7942. malacon,
Tracy, S. M.-Continued.

7943. praecocius.

villosissimum.

7944. lindheimeri.

7945. hallii.

7946. sphaerocarpon.

7947. lindheimeri.

7948. reverchoni.

7949. helleri.

7950. hallii.

7952. hallii.

7953. hallii.

7954. hallii.

7955. ciliatissimum.

7958. ramisetum.

8029. yadkinense.

8200. hallii.

8224. plenum.

8229. ramisetum.

8289. fasciculatum chartaginense.

8290. texanum.

8295. barbipulvinatum.

8396. gymnocarpon.

8397. pauciciliatum.

8398. longiligulatum.

8399. lanuginosum.

8400. sphaerocarpon inflatum.

8401. caerulescens.

8402. strigosum.

8403. barbulatum.

8405. lucidum.

8406. pauciciliatum.

8407. chamaelonche.

8408. combsii.

8409. lancearium.

8410. leucothrix.

8411. polycaulon.

8412. pauciciliatum.

8413. longiligulatum.

8414. anceps.

8415. villosissimum.

8416. lanuginosum

8417. microcarpon

8418. polyanthes.

8419. helleri.

8420. aciculare.

8421. curtifolium.

8422. strigosum.

8423. longiligulatum.

8424. mutabile.

8425. lancearium.

8426. pseudopubescens. villosissimum. 
Tracx, S. M.-Continued.

8427. consanguineum.

8428. equilaterale.

8429. wilmingtonense.

8430. auburne in part.

8431. nudicaule.

8432. nudicaule.

8433. spretum.

8504. lucidum.

8591. scoparium.

8847. hemitomon.

8849. xalapense.

8850. nitidum.

8853. patulum.

8859. villosissimum.

8864. trifolium.

8865. microcarpon.

8866. commutatum.

8867. xalapense.

8868. boscii molle.

8869. villosissimum.

8870. helleri.

8879. ramisetum.

8885. helleri.

8908. filipes.

9054. laxum.

9055. dichotomiflorum.

9060. parvifolium.

9062. laxum.

9063. pilosum.

9068. ghiesbreghtii.

9072. laxum.

9073. cayennense.

9074. fusiforme.

9075. exiguiflorum.

9078. acuminatum.

9079. parvifolium,

9080. tenerum.

9082. diffusum.

9089. utowanaeum.

9091. fasciculatum.

9098. millegrana.

9099. laxum.

9102. adspersum.

9103. reptans.

9109. adspersum.

9111. diffusum.

9114. laxum.

9116. ghiesbreghtii.

9137. sphaerocarpon.

9138. lanuginosum.

9139. patentifolium.

9140. malacon.
Tracy, S. M.-Continued.

9141. commonsianum.

9142. joorii.

9143. lancearium.

9144. arenicoloides.

9338. hallii.

9342. dichotomiflorum.

Tuerokheim, H. von.

56. multirameum. sphaerocarpon.

428. olivaceum.

657. millegrana.

1254. laxum.

II. 1956. biglandulare.

7699. zizanioides.

7700 . zizanioides.

7702. pulchellum.

7797. polygonatum.

7798. trichanthum.

7799. barbinode.

7801. trichoides.

8617. barbinode.

8783. millegrana.

8784. millegrana.

8785. zizanioides.

8790. paludivagum.

8794. pulchellum.

8795. polygonatum.

8796. zizanioides.

8797. pilosum.

8803. laxum.

UMBACH, L. M.

1080. pseudopubescens

1087. meridionale.

1657. depauperatum.

1669. leibergii.

1670. perlongum.

1685. pseudopubescens.

1704. scribnerianum.

1789. dichotomum.

1791. latifolium.

1799. spretum.

1800. meridionale.

1816. huachucae.

1820. huachucae silvicola.

1922. virgatum.

2153. sphaerocarpon.

2155. meridionale.

2237. huachucae.

2242. lindheimeri.

2244. huachucac.

2353. lindheimeri.

2363. miliaceum. 
UмBACH, L. M.-Continued.

2365. scribnerianum.

2543. flexile.

2646. villosissimum.

3686. scoparioides.

4962. lucidum.

Wetherby, A. G.

18. lindheimeri.

19. dichotomiflorum.

21. gattingeri.

32. clandestinum.

51. lindheimeri.

53. latifolium.

58. ashei.

59. commutatum.

64. villosissimum.

Wilcox, T. E.
13. virgatum.
15. virgatum.
22. latifolium.
27. dichotomiflorum.
41. latifolium.
54. virgatum.
100. virgatum.

Williams, T. A.

1. sphaerocarpon.

2. sphaerocarpon.

3 . ashei.

4. ashei.

5. villosissimum.

6. dichotomum.

7. clandestinum.

8. dichotomum.

9. dichotomum.

10. ashei. philadelphicum.

12. philadelphicum.

2184. capillare.

2228. leibergii.

2577. scribnerianum.

2847. barbipulvinatum.

3009. scribnerianum.

3061. virgatum.

3089. amarum.

3090. amarulum.

3097. auburne.

3098. sphaerocarpon.

3099. aciculare.

3100. augustifolium.

3105. auburne.

3110. oligosanthes.
Wilson, P.

8. polyanthes.

14. xalapense.

27. boscii molle.

31. ravenelii.

47. ravenelii.

125. microcarpon.

137. microcarpon.

179. dichotomum.

188. trichoides.

283. trichoides.

511. diffusum.

512. adspersum.

593. fasciculatum.

1248. dichotomiflorum.

1249. capillare.

1405. diffusum.

Wooton, E. O.

64. obtusum.

303. barbipulvinatum.

368. bulbosum.

1068. obtusum.

1071. barbipulvinatum.

2001. virgatum.

2014. pampinosum.

2017. plenum.

2936. virgatum.

2948. barbipulvinatum.

Wright, C.

280. ravenelii.

753. trichanthum.

757. glutinosum.

758. ghiesbreghtii.

759. laxum.

761. geminatum.

786. plenum.

792. reverchoni.

797. fasciculatum chartaglnense.

1317. dichotomiflorum.

2084. pampinosum.

2085. lindheimeri.

2086. bulbosum sciaphilum.

2088. lindheimeri.

2092. obtusum.

3450 . exiguiflorum.

3451. pilosum.

3452. utowanaeum.

3453. chrysopsidifolium.

fusiforme.

neuranthum? 
Wright, C.-Continued.

3454. fusiforme in part.

3455. millegrana.

3456. dichotomiflorum.

3458. parvifolium.

3460. lancearium. leucothrix.

3462. erectifolium. millegrana.

3463. albomarginatum.

3463. caerulescens. wrightianum.

3466. zizanioides.

3467. scoparium.

3751. laxum.

3852. diffusum.

3855. millegrana.

3857. reptans.
Wright, C.-Continued.

3860 . dichotomiflorum. diffusum.

3861. dichotomiflorum.

3862. condensum in part.

3863. laxum in part.

3865 . cayennense.

3869. adspersum.

3870. tenerum in part.

3871. stenodes.

3872. megiston.

3873. virgatum cubense.

3874. acuminatum.

3875. polycaulon. strigosum.

3876. pauciciliatum.

3877. diffusum. 



\section{INDEX.}

[Page number of princlpal entries in bold-face type. Synonyms in italics.]

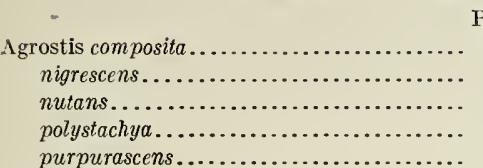

grostoidia.

Aira incompleta........................ 118

American Code of Botanical Nomenclature. 5, 14, 15

Angustifolia.

Ashe, W. IV., herbarium of.

Axonopus...

Barbey, William, herbarium of............

Beauvois, limitation of genus Panicum by...

Berlin, herbaria at.....................

Bernhardi Herbarium

Bicknelliana

Biltmore Herbarium

Boissier Herbarium

Borpland, types of.

Bosc, collections of.

Brachiaria

digitarioides...

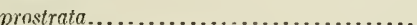

British Museum, herbaria at.............

Broom-corn millet.

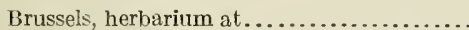

Buckley, collections of.

Capillaria .

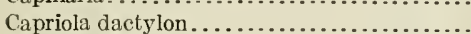

Cavanilles, types of. .

Cenchrus alopecuroides.

Chaetochloa glauca.

italica

verticillata.

viridis.

Chapman, types of

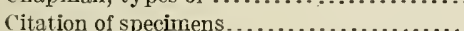

Coleataenia.

Colorado grass.

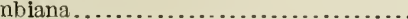

Columbia University Herbarium ...........

Commutata

Copenhagen, herbarium at.............

Cosson Herbarium...................

De Candolle Herbarium

Delessert IJerbarium . . . . . . . . . . . . . . .

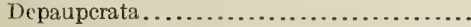

I)

Desvaux, duplicate types of.

$1 y$ pes of.

Dichanthelium.

Dichotoma.

Dichotomiflora

Diffusa
100

115

107

100

102

99

118
15

165

2

18

3
Digitaria affinis ............

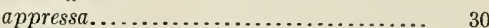

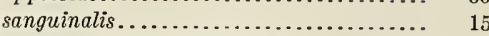

Distribution, maps illustrating........... 10 geographical, of genus Panicum in North America.

Doell, types of .

Doubtful species........................

Drake de Castillo, herbarium of.............. 4

Eatonia purpurascens.................. $\quad 87$

Echinochloa colona...................... 31

crusgalli....................... 11, 12,13

Echinolaena.......................... $\quad 16$

Elliott Herbarium...................... 2

Engelmann Herbarium................... 2

Ensifolia . . . . . . . . . . . . . . . . . . . . . 258

Eriochloa pulchella ...................... 123

Fasciculata........................... 35

Festuca obtusa........................ 118

Field Museum Herbarium................ 1

Florence, herbarium at.................. 3

Fournier, types of ...................... 3,4

Franqueville Herbarium................ 4

Fries, South American collections of ........ . 4

Galeotti, Mexican collections of............. 3

Gastridium lendigerum.................. 11

Gattinger Herbarium.................... 2

Geminata.......................... $\quad 30$

Genera excluded from Panicum............ 16

Geneva, herbaria at....................

Geographical distribution of the genus Panieum in North $A$ merica................. 8

Göttingen, herbaria at................. 3

Gray Herbarium...................... 1

Grisebach Herbarium................... 3

Gronovius Herbarium.................

Grouping of species..................... 17

Guinea grass........................... $\quad 79$

Hackel, Edıard, herbarium of............ 2

Hackelochloa granularis................ $\quad 312$

Haenke, collections of................... 4

Halle, herbaria at..................... 3

Herharia, Anterican, examined............. 1

European, examined .................. 2

Herbarium, Ashe's.................... 2

Barbey's........................... 3

Berlin, Königlicher Botanischer Garten. 2 Bernhardi......................... 2

Biltmore........................ 1

Boissier........................... 3

Bonpland...................... 4

Herbarium, British Museum of Natural His-

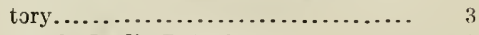
Brussels, Jardin Botanique............. $\quad 3$ Columbia University ................. 1 
Herbarium, Copenhagen, Botanical Garden of the University...................

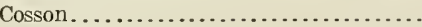

De Candolle.........................

Delessert...........................

Desfontaines.........................

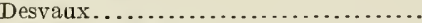

Drake de Castillo.....................

Elliott............................

Engelmann

Field Museum......................

Florence, Orto Botanico...............

Fournier..........................

Franqueville.

Gattinger..........................

Gencva, Conservatoire et Jardin Botanique....................... Institut de Botanique de l'U niversité. Göttingen, Botanischer Garten der Universität...

Gray

Griscbach

Gronovius.

Hackel

Halle.

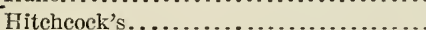

Jussieu.

Kew.

Lamarck.

London, British Museum of Natura History..................... Kew

Madrid, Jardin Botanico..............

Michaux..........................

Missouri Botanical Garden.............

Mohr

Muhlenberg.

Munich, Königliches Botanisches $\mathrm{Nu}$ seum

Nash's.

New York Botanical Garden............

Padua, Orto Botanico.

Paris, Bonpland

Cosson...

Desvaux..........................

Drake de Castillo

Fournier...

Jussieu .

Lamarek........................

Michaux........................

Richard........................

Steudel.......................

Parry...

Philadelphia Academy ...............

Prague, Botanischer Garten.

Museum des Königreichs Böhmen... Presl.

Richard. .

St. Petersburg, Académie Impériale des Sciences.

Botanical Garden

Scribner

Short.

Sloane.

Steudel.
Page.

Herbarium, Stockholm, Naturhistoriska Riksinuseinin

Swartz.........................................

Torrev...........................

Trinius............................

United States National............... 2

Van Huerck..................... 2

Vienna, Kaiserliches und Königliches

Naturhistorisches Hofmuseum.......

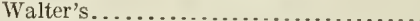

Willdenow

History and limitation of the genus Panicum. of Panicum after 1753. .

Hitcheock, A. S., herbarium of............ 2

Hog millet.......................... 69

Holcus sorghum...................... 11 spicatus......................... 15

Hymenachne....................... 16

Ichnanthus glaber...................... 88

Jussieu Herbarium....................

Karwinsky, Mexican collections of.........

Kew, herbarium at..................... 3

Lagasca, duplicate types of ................ 3

types of...........................

Lamarck, duplicate types of ............... 3

Herbarium...................... 4

Lancearia............................ 271

Lanuginosa.......................... 208

Lasiacis............................ 16

divaricati........................ 16

Latifolia............................ $\quad 312$

Laxa .............................. 110

Laxiflora............................ 158

Liebmann, Mexican collections of.......... 3

Lindman, South A merican collections of.... 4

Linnæan Herbarium .................. 3

London, herbaria at.................. 3

Madrid, herbarium at.................. $\quad 3$

Maps, illustrating distribution........... 10

Martius, collections of ................. 3

Maxima........................... 78

Mez, Carl, work of ..................... 3

Michaux Herbarium .................... .

Milium, Linnæus's limitation of the genus .. 13

pre-Linnæan use of the name ......... 11

Tournefort's limitation of the genus..... 11

capillare.........................

clandestinum...................... 312

confertum....................... 13

efiusum........................ $13,14,15$

esculentum........................ 69

latifolium......................... 311

microspermum..................... 131

panicum......................... 15,69

Millet............................. 11

broom-corn ...................... 69

fox-tail . . . . . . . . . . . . . . . 13

hog............................... 69

pearl ............................ 15

Missouri Botanical Garden Herbarium..... 2

Mohr Herbarium........................

Mueller, F., Mexican collections of......... $\quad$ t

Muhlenberg Herbarium................. . 2

Munich, herbarium at.................. 3

Nash, G. V., herbarium of............... 1

Nees von Esenbeck, types of............. . 3 
New York Botanical Garden Herbarium....

Nomenclature, American code of botanical. 5,14,15

Nudicaulia.

Nuttall, collections of................. 1

Oligosanthia........................ 278

Oplismenus compositus.................. 12

Otachyrium.......................... 16

Padua, herbarium at.................... 3

Panicularia elongota ..................... 118 melicaria......................... 118

Panicum aciculare .... 166, 169,173, 174, 175, 176, 212 aculeatum..................... $\quad \mathbf{2 9 7}$ acuminatum............... 151,152,222,226 acutifolium........................ 129 addisonii.......................... 240, 243 adscendens.......................... 134 adspersum ...................... 18,43,44 affine............................ 30 agrostidiforme..................... 100,115 agrostis............................ 115 agrostoides ............ 100,101,102,103,104 elongatum....................... 104 alabamcnse........................ 244 albemarlense....................... 212 albomaculatum................... $\quad 311$ albomarginatum...... 259,260, 261,262,263, 264 alopecuroides....................... 12 altissimum ....................... 82,141 amaroides......................... 94,95 amarulum......................... $\quad 96$ amarum...................... 94, 95, 96 minus ambitiosum....................... $\quad 329$ americanum .................... 12,14,15 amplectans........................ $\quad 49$ anceps............. 100, 105, 107, 109, 110,331 angustum...................... 107 densiflorum .................... 107,108 pubescens....................... 105, 109 strictum ...................... 97 angustifolium ..................... 17, $128,170,171,172,173,174,190,201$ annulatum........................ 185 annulum.......................... 185 apiculatum....................... 113 appressum......................... $\quad 31$

aquaticum ......................... 48, 303 arborescens............................ 13

arenarium......................... 85,88

arenicola......................... 166

arenicoloides....................... 173

arizonicum .................. 18,42,44,45 laeviglume...................... 45 majus........................... 45 tenue.......................... 45

arundinariae...................... 329

ascendens.......................... 134

ashei ................. 154, 193, 300, 301, 302 aspcrimum..................... 69

atlanticum......................... 233

aturense H. B. K................... 16

aturensc Balb..................... 325

auburne.......................... $\quad 223$

aurclianum.......................... 36

aureum.......................... 158

austro-montanum.................... 267

avenaceum

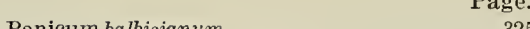
baldwinii ........................ 268,269 barbinode ................. 17, 18,33, 34, 35 barbipulvinatum .................61,62 barbulatùm ..... $6,7,181,183,193,195,207,331$ bartowense ..................... 52,53 beckmanniaeforme.................. $\quad 30$ bergii.............................. 78 beyrichii.......................... 136 bicknellii ....................... 177,178 biglandulare ................ 120,123, 124 bobarti........................... 60 bogueanum ....................... 185 boreale ....................... 189, 239 boscii .................... 193,314,317, 318 molle ................... 318,319, 320

bourgaci......................... 112 brachiatum...................... 48,49

brachyanthum................... 128

brachyclados....................... 122

brasitiense .......................... 134

breve.......................... 271

brevifolium ................. 13,62,129,329

brittonii......................... 264,265

brizaeforme....................... 30

brizoides........................... 31

buchingeri....................... 329

bulbosum .................. $58,81,82,83$ avenaceum..................... 82

minus......................... 83

sciaphilum................... 83

s. var. violaceum.................. 82

bushii............................ 177

caerulescens...................... 197

caespititium........................ 72

caespitosum....................... 36, 43

cahoonianum...................... 169

calliphyllum...................... 178

campestre........................ 57

capillaceum......................... 129

capillaceum strictius.................. 129

capillare....... 13,55,56,57,59,60, 63,70, 129 agreste........................ 60

brevifolium ...................... 62

campestre...................... $\quad 57$

flexile........................... 55

gattingcri....................... 57

geniculatum..................... 57

glabrum........................ 64

miliaceum...................... 67

minimum.................... 58

minus...................... 55, 283, 301

sylvaticum.....................

vulgare....................... $\quad 60$

capillarioides ...................... 72

caricifolium ....................... 159, 160

caricoides......................... 99

carinatum....................... 323

carnosum.......................... $\quad 30$

carolinianum....................... 323

cartilagincum........................ 329

cayennense.................... 70, 140, 331

divaricatum..................... 140

patulum........................ 70

chamaelonche................ 268, 269, 270

chapmani ........................ 21

chartaginense................... 40,41,44 
Panicum chloroticum................ $\begin{array}{r}\text { Page } \\ 48,50,5\end{array}$ agreste........................... 48, 49 pingue......................... 49 sylvestre................... 48,49,51 chrysopsidifolium........... 168, 169,171,175 ciliatifolium......................... 162 ciliatissimum....................... $\quad 324$ ciliatum................. 162, 163, 164, 216 cilivferum......................... 237 ciliosum.......................... 220 cimicinum ......................... 325 clandestinum........... 13,290, 298, 312, 314 pedunculatum................... 312 clutei............................. 188 colonum............................ 34 coloratum......................... 87,88 columbianum.......... $240,246,247,248,259$ thinium..................... 240,248 combsii......................... 106 commelinaefolium.................... 304 commonsianum............. 238, 240, 242, 243 commutatum............ 6, 154, 237, 301, 302, $303,304,305,307,310,317,318,329,331$ consanguineum................. 169 latifolium....................... 304

minus........................... 301, 301

comophyllum...................... 222

compositum.......................... 12

conchatum.................... 124,329

concinnius........................ 263

condensum ...................... 101,102

confertum........................ 86

confusum.......................... 82

consanguineum................ 169, 171, 233

contractum....................... 102

cordifolium....................... $\quad 329$

cordovense......................... 329

costaricense....................... 134

crusgalli........................... 12,14

cryptanthum..................... 299, 300

ctenodes........................... 121

majus.......................... 122

cupreum..................... 110,118,120

currani......................... 304,305

curtifolium....................... 258,267

curtisii........................ 171,323

curtivaginum.......................... 196

cuthbertii.......................... 264

cynodon......................... 300

dactylon.......................... 13,11,15

dasytrichum ......................... 139

debile............................ 118, 127

decipiens............................. 118

decolorans.................... 66, 328, 329

decoloratum........................ 312,313

delawarense........................ 156

densiflorum........................ 113

densum........................... 330

depauperatum........... 151,152,154,155, 157

involutum..................... 152

laxum.......................... 152

deustum.......................... 193, 259

diandrum........................ 115

dichotomiflorum...........48,49,52,53,54

dichotomum................... 13, 142,190,

$191,194,195,198,233,252,269,301,331$ acuminatum
Panicum dichotomum barbulatum........... 193

commune..................... 191

curvatum...................... 330

divaricatum..................... 191

elatum........................ 298

fasciculatum...................... 216

gracile.......................... 330

lanuginosum................... 220

nitidum......................... 183

spathaceum..................... 330

sphacrocarpon.................... 251

villosum........................ 233

viride ......................... 190, 191

diffusum ..........6, 55, $72,73,71,77,330,331$

digitarioides........................ 323

dimidiatum ....................... 12, 323

disciferum.......................... 3330

discolor....................... 181, 187, 330

dispersum....................... 136

dissectum........................... 12,15

dissitiflorum........................ 44,45

distans............................. 113

distantiflorum. . . . . . . . . . . . . . . 22, 28. 24

distichum......................... 113

lancifolium...................... 114

divaricatum........................ 16,118

drummondii...................... $\quad 327$

dubium............................ $\quad 112$

dumus............................. 195

carlei............................. 267

eatoni............................. 201

elatius............................. 111

elephantipes.................... 18,48, 33.88

clliottii.............................. 49,330

elongatum........................ 88,104

ramosius.................... 100, 101

ensifolium. . ............... 259,264, 265, 266

enslini.......................... 304

cpilifolium........................... 310

equilaterale............ 181,300,304,310, 311

equinum.......................... 33

equisctum.......................... 141

erectifolinm......................... $\mathbf{2 5 6}$

eriөphorum........................ 298

cruciformis......................... 321

crythrocarpon ....................... 237

exiguiflorum.................... 117,118

expansum Fourn................... 131, 136

expansum Trin . . . . . . . . . . . . . . ..... 136

fasciculatum ............ 18,35,39,41, 166,216

chartaginense................40,41,44

dissitiflorum.................... 45

flavesccns........................ 39

fuscum......................... 39

genuinum....................... $\quad 39$

reticulatum...................... 41

fastigiatum......................... $\quad 38$

filiculme........................... 210

filiforme........................... 12

filipes . ................... $73,74,75,76$

filirameun.......................... 166

firmandum..................... $\quad 330$

firmulum........................ $\quad \mathbf{2 7}$

fistulosum ........................ 53

flabellatum........................... 64

flavescens............................ 38, 39

flavovirens $. . . \ldots \ldots \ldots \ldots \ldots \ldots \ldots \ldots . \quad \mathbf{2 6 2}$ 
Page.

Panicum flexile. $6,55,58,59,61$

fiexuosum.

floribundum. 186,330

fioridanum

francavillanum

frondescens.

121,122

funstoni........................... 203

fuscatum........................... 38

fusco-rubens......................... $\quad 38$

fuscum........................... 38

fasciculatum..................... 38

majus...........................44,45

reticulatum...................... 41

fusiforme......................... 172

gattingeri......................... 57

geminatum.................. 17, 18,30, 33

generic description of ................ 18

geniculatum ...................... 48, 49

georgianum......................... 169

gcorgicum......................... 169

germanicum....................... 15

ghiesbreghtii ............... 73, $76,330,331$

giganteum........................ 74,88

glabcrimum..................... 88, 265

glabrifolium ................. 269,270, 271

glabrissimum...................... 265

glaucum.......................... 12,14

glomeratum......................... 31

glutinosum....................... 19, 138

gongylodes........................ $\quad 82$

gouini. ........................... 86, 88

pumilum...................... 86

gracilcscens........................ $\quad 330$

gracilicaule........................ 263

grandiflorum...................... 325

gravius............................ 193

grossarium........................ 36, 43

guadaloupcnse...................... 33

guayaquilense....................... 131

gymnocarpon.................... $\mathbf{3 2 7}$

hacmacarpon.................... 233,330

hallii......................... $74,75,76$

halophilum....................... 86

havardii................................

hclleri........................... 281,282

hemitomon...................... 822,323

hetcrophyllum................ 181,247,251

hians ................. 98, 110, 117, 118, 120 purpurascens................... 120

hirsutum Swartz.................. 77

hirsutum Lam....................... 135

hirsutum Willd...................... 139

hirsutum Vahl....................... $\quad 330$

hirticaulc ....................... $1,67,68$

hirtivagirum........................ 76

history and limitations of ............ 11

history of, after $1753 \ldots \ldots \ldots \ldots \ldots \ldots . \quad 15$

huachucae...... $7,214,215,21 \overline{7}, 230,233,238,330$ silvicola ....... $\mathbf{7 , \mathbf { 2 1 6 } , 2 1 9 , 2 2 0 , 2 2 1 , 2 3 0 , 2 3 2}$

hydropilitum ........................ 112

hygrophilum....................... 49

ichnanthoides....................... 88

illinoniensc.......................38, 166

implicatum ............. 211,213, 214, 228, 246

inflatum...................... 253,254

insularum ........................ 36

involutum......................... 151
Page.

Panicum iowense........................ $\quad 330$

italicum .................... 1i, 12,14,15

jejunum......................... 118

joorii ..................... 305, 308, 309

jumentorum....................... 78

junceum.......................... 151

kalmii............................. 251

kegelii.......................... 122

kunthii........................... 88

laevc............................ 78

lancearium . ............... 272,273,275,276

languidum....................... $\quad 232$

lanuginosum ........ 212,216,220, 221, 224, 298

huachucae........................ 215

siccanum..................... 245,246

lasianthum ....................... 136

latifolium... 6, 13,280, 283, 304, 311, 317, 318, 326 australe .................. 317, 318, 320 clandestinum.................... 312 molle..................... 317,319,320

laxiflorum .................. 158, 159, 160 pubescens................. 164,233, 295

laxum...... 100,110,112,113, 114, 115, 118, 297 pubescens.................... 115,116 variegatum ...................... 117

leibgrgii ........................ $\mathbf{2 8 9 , 2 9 1}$

lciophyllum....................... 308

lepidulum.......................... $7_{5}$

lepricurii........................... 121

lcptomerum........................ 115

leptostachyum...................... 123

leucoblepharis...................... 162

leucothrix................. $205,206,260,329$

lindenii......................... 138

lindbeimeri ....... 183, 193,203, 206, 215, 219,248

linearifolium............ 151, 152, 155. 156, 157

Linnæan species of .................. 12

liton.............................. $\quad 259$

littorale ........................... 85

longifolium ................... 105, 106, 107

longiligulatum................... 206,269

longipedunculatum................... 164

longum....................... 110,111

lucidum................. I\$8, 200,244,330

macranthum ...................... 93,111

macrocarpon............... 283,304,314,315

macrum........................... 259

maculatum........................ 195

malacon........................... 240, 241

malacophyllum................... 280,283

manatense.................... 308, 309, 310

mattamuskeetense........... 186, 187, 188, 189

maximum ..................... 78, 79,83

bulbosum..................... 82

gongylodes...................... $\quad 82$

megastachyum....................... 132

megiston........................ 23, 141

melicarium....................... 48, 118

meridionale........... 210, 211, 212, 214, 228

microcarpon Muhl. in Elliott.......... 6 ,

$181,182,184,190,193,195,255,330$

microcarpon Mulıl.................. 255

isophyllum.................... 255

sphaerocarpon.................. 251

microphyllum..................... 210

microspermum..................... 131

miliaceum......... 11, 12, 13, 14, 15.17, 4S,67,69

miliare........................ 50 
Panicum milium millegrana... 135, 136,137 minimum......................... 58 minus............................... 55 minutiflorum...................... 117 minutulum...................... 207 mississippiense.................... 253 molle................... 34, 35, 42, 45, 320 monachnoides...................... 327 muhlenbergianum................... 330 muhlenbergii..................... 151, 152 multiculmum..................... 41 multiflorum................... 48,254,255 multirameum................... 185, 226 munitum.......................... 111

mutabile....................... $\quad 807$

muticum.......................... 34

nashianum........................ 273

patulum....................... 274

nealleyi............................ 298

nemopanthum..................... 177

nervosum.................. 6,303, 304, 315 neuranthum............167, 168, 169,175, 331 ramosum...................... 172

nigrescens....................... 115

nigricans.......................... 38

nitidum...................... 182,

$183,184,185,201,203,206,252,269,303$

barbatum ..................... 181

barbulaium.................... 6, 193

ciliatum........................ 216

crassifolium....................... 251

densiflorum...................... 201

ensifolium...................... 264,266

glabrum....................... 331

gracile........................ 331

majus........................ 303, 331

minus........................ 268

octonodon....................... 201

pauciflorum..................... 191

pilosum........................ 214

pubescens........................ 233

ramulosum...................... 181

viride.......................... 191

nodatum...................... 292,293

nodiflorum....................... 183,207

nodosum......................... 82

notatum........................ \$5

nudicaule....................... 179

numidianum...................... 34

nutans............................ 107

oaxacense....................... 141

oblongiflorum........................ 118

oblongum......................... 125

obtusiftorum....................... 138

obtusum........................ 321,322

occidentale .................... 228, 230, 239

octonodon.......................... 201

oliganthum......................... 285

oligosanthes............ 6,280,282,285, 286

olivaceum...................... 185, 225

olyraefolium......................... 121

onslovense........................ 276

optismenoides......................... 135

orangense........................ 220,221

oricola......................... 240, 249

ornatum............................ 331

orthophyllum..................... 173 ovale ............ 235,237, 238 ovalifolium........................ 13, 129 ovinum.................... 174, 175, 176 owenae.............................. 243 pacificum...................... 229. 231 paludivagum.................. 17, 18, 31, 32 paludosum........................ 53 pammeli.......................... 154 pampinosum..................... $\quad 66$ paniculatum......................... 39 paraguayense....................... 34 parcum.......................... $\quad 68$ parvifolium....................... 134 parviglume...................... 124, 126 parvipaniculatum................... 265 parvispiculum.................... 205,206 parvulum......................... 259 paspalodes...................... 30,31,33 patens............................. 13 patentifolium..................... 277 patulum.......................... $\quad \mathbf{2 7 4}$ pauciciliatum..................... 272 pauciflorum............. 280,283, 285, 286, 294 paucipilum........................ 201,202 paucispicatum..................... 326 pedicellatum.................... 292, 294 pedunculare.......................... 70 pedunculatum....................... $\quad 312$ pensylvanicum...................... 331 perlongum ........................ 158 pernervosum....................... 281 petiverii........................... $\quad 42$ philadelphieum............ 55,56,58, 59,61 pictigluma......................... 34 pilisparsum........................ 113 pilosum.............. 110,113, 118,214, 227 epilosum....................... 115

genuinum..................... 136 leiogonum...................... 136 macranthum..................... 111 polygonatum.................... 112 plenum.......................... $\quad 80$ polyanthes.................. 181,254, 255 polyeaulon. . ..................... 162, 163 polygamum....................... 78

gongylodes..................... 82

hirticaule......................... 64

polygonatum.................. 110,112, 118

polygonoides........................ 321 polyneuron........................ 5,6,304 porphyrium........................ 58 porterianum....................... 317 portoricense......................... 331 potamicum........................ 112 potamium........................ 112 praecocius..................... $\mathbf{2 2 6 , 3 3 0}$ praticola........................... 79 pre-Linnæan use of the name ......... 11 preslei............................. 132 probandum........................ 136 procerrimum........................ 141 proliferum .................. 49,50,53,54,100

chloroticum...................... 50

geniculatum.................... 49

pilosum......................... 49

strictum....................... 49 
Panicum prostratum .................... $\begin{aligned} & \text { Page. } \\ & \text { pilosum } 232\end{aligned}$ pruinosum.............................. 87 psammophitum.................... 247 pseudanceps......................... 105 pseudopubescens .................. 235, 236 pseudoryzoides...................... $\quad 325$ puberulum....................... 136 pubescens......... 208, 228, 233, 235, 294, 295, 330 barbulatum...................... 193 pubifolium........................ 320 pulchellum...................... 123, 124 pumilum......................... 159, 331 punctatum........................ 31,33 pungens.......................... 166,167 purpurascens H. B. K............... 120 purpurascens Raddi.................. 33, 34 pyriforme.......................... 158 rafinesquianum...................... 331 ramisetum .................. 5, 25, 27,28 ramosum .....................4 41,44, 172 ramuliflorum...................... 115 ramulosum....................... 170,269 viride........................ 191 rariflorum........................ 159 ravenelii .................. 278,280,284,287 rectum.......................... 151 redivivum.......................... 174 reflexopilum...................... 331 repandum........................ 322 repens ........................ 85, 87 confertum...................... 86 repente........................... 321 reptans ........................ 17, $\mathbf{3 6 , 4 3}$ reticulatum....................... 38, 40,41 retrof ractum ....................... 49 reverchoni......................... 25,26 rhigiophyllum .................... 139,140 rhizomatum.................. 105, 109,110 rigens............................. 140 rigidulum........................ 100 roanokense ...................... 196, 197 rostratum........................... 107, 331 rotundum....................... 133,139 rudgei ................... 70,71, 133,139, 140 brasiliense...................... 139

rugosum......................... 127 rugulosum....................... 135, 136 glabrescens..................... 136 hirtiglume................... 136 pubcscens....................... 136 subvelutinum.................. 137 ruprcchti.......................... 159 sanguinale......................... 12,15 scaberrimum....................... 78 seabriusculum ................. 298, 300 schifineri........................ 124 schmitzii....................... 125, 329 schnecki......................... 315 sciaphilum........................ 83 scoparioides ....................... $\quad 238$ scoparium Lam...... . 221, 280, 283, 287, 294, 297 scoparium Rudgc................... 139, 140 angustifolium.................... 286 genuinum................... 280,287 licbergii.
Panicum scoparium pauciflorum.................... 280,28i scribnerianum .... 238, 280, 281, 282, 283, 286, 315 leibergii......................... 289

sellowii......................... 136, 137 tongevaginatum................... 136 sessiticaule............................ 331 staceum...................... 166,167 shallolte........................... 265

shastense......................... $\quad 239$ sintenisii............................. 24 sloanei........................... $\quad 314$ soboliferum........................ 58 sonorum........................ sparsiflorum...................... $\quad 128$ speciosum....................... 331 sphaerocarpon. $185,193, \mathbf{2 5 1}, 252,254,255,256,330$ floridanum................... 256 inflatum.................... 253

sphagnicola....................... 6, 199 spithamaeum....................... $\quad 38$ sprengelii............................. 152 spretum......................... 201 stenodes.......................... 97,98 stipitatum.................... 100, 101,104 stramineum.......................... 68 striatum........................... 331 strictifolium........................ 241 strictum...................... 151, 207 strigosum.................... 158, 161,295 Stoloniferum.................... 121, 122 majus......................... 122 subbarbulatum..................... 182, 183 subsimplex....................... 304,305 subspicatum...................... 5, 25 subuniflorum...................... 166 subvillosum. ...................... 227,229 taxodiorum......................... 198 tectum........................... 233 tenerum ........................ 97,98 tennesseense............... 203,217, 218,219 tenue....... 211, 215, 247, 259, 260,264, 265, 304 tenuiculmum..................... 24,115 texanum.......................... 18,46 thermale...................... 8,230, 231

thomasianum..................... 43 thurowii........................ $\mathbf{2 2 1}$

torrcyi........................... 58

Tournefort's limitation of the genus...... 13

tremulum........................ 190

trichanthum..................... 131

trichidiachne...................... 124

trichocondylum..................... $\quad 79$

trichogonum ..................... $\quad 112$ trichoides.....................60, 129,131 trichophorum..................... 113 tricolor............................. 117

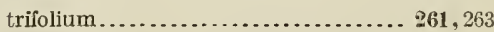
truncatum.......................... 30 tsugetorum.............. 240, 245, 246, 248

tubercutatum....................... 141

tuerekheimii........................ 16 type species of........................ 13, 14 umbraculum....................... 127 umbrosum....................... 122, 301 


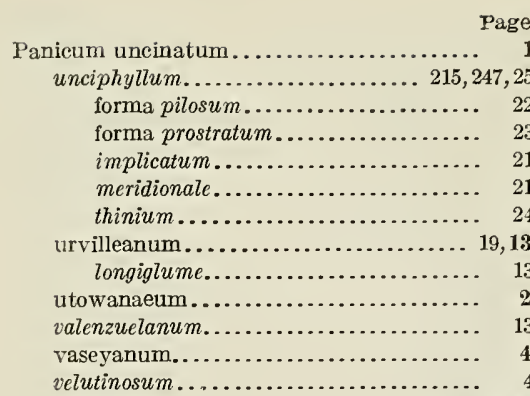

42,212

vernale...................... 258,264, 266

verrucosum...................... 118,127

vicarium............................ 251

vilfiformc......................... 331

villosissimum............... 232, 233, 236, 330

villosum Ell ...................... 169, 233

villosum Lam...................... 294

virgatum ........ 8, 13,87, 88, 92, 93, 94, 100, 329

breviramosum................... 92 confertum..................... 88, 89

cubense........................ 92

diffusum....................... 88

elongatum...................... 88

macranthum.................... 93

obtusum........................ 92

virgultorum ..................... 125, 329

virletii........................... 331

viscidellum................... 116,296, 331

viscidum.......................... 294

walteri................... 280,317,322, 323

mollc............................ 319

waltheri.......................... 317

webberianium............... 274,276,277

werneri................... 155,156, 157,177

wilcoxianum.................... $\quad \mathbf{2 7 9}$

wilmingtonense.................. 240,244

wrightianum...................... 207

xalapense.... 154,159, 160,161,162,163,164,233

strictirameum.................. 161

xanthophysum................ 178,290, 291

forma amplifolium............... 290 xanthospermum.................... 233 yadkinense.................. 195, 303, 330 zizanioides.................... 314,325,326

Para grass. ........................... 34

Paris, herbaria at........................ 4

Parry Herbarium...................... 2

Parviglumia.......................... 124

Paspalum........................... 17, 18

Paspalum appressum.................... 30,31

dissectum........................ 12

paniculatum...................... 39

Paurochaetium.................... 17, 18, 22

Pedicellata............................ 292

Pennisetum americanum............... 11, 12

Phanopyrum.......................... 18

gymnocarpum...................... 327

Philadelphia Academy Herbarium........ 1

Polret, types of........................ . 3,4

Polypogon monspeliensis................ $\quad 11$

Prague, herbaria at. .
Pre-Linnæan use of the name Milium .......

Pre-Linnæan use of the name Panicum....

Presl, C. B. and J. S., types of..............

Ptychophyllum.......................

Pursh, types of.

Raddi, specimens from...................

Rafinesque, types of.....................

Richard, types of.

Rudge, specimens from..................

Sacciolepis.

striata.

St. Petersburg, herbaria at...............

Salzmann, Brazilian collections of...........

Schaffner, Mexican collections of............

Scoparia

Scribner, herbarium of .

Setaria disticha...........................

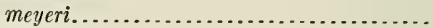

pilosa.

polygonata.........................

schraderi..............................

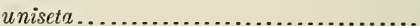

Short Herbarium

Sloane Herbarium

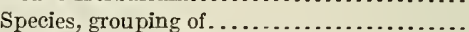

miscellaneous........................

subspecies and forms.................

Specimens, citation of ...................

Spelling of names........................

Sphaerocarpa............................

Spikelets, text figures of .................

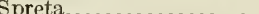

Stcinchisma.......................... 18,118

hians........................... 118

Stenotaphrum dimidiatum................ 12

Steudel, types of....................... 4

Stockholm, herbaria at................. 4

Stolonifera............................. 120

Streptostachys.......................... 16

Subspecies, species, and forms............ 7

Swartz Herbarium ..................... 4

Swartz, duplicate types of .................. 3

Synonymy.............................

Syntherisma filiformis .................. 12

sanguinalis......................... 12

Tenera................................ 97

Terminology ............................ 10

Text figures of spikelets................. 10

Torrey Herbarium....................... 1

Tournefort, limitation of the genus Milium... 11

limitation of the genus Panicum........ 11

Trichoidia.......................... 129

Trinius Herbarium. . . . . . . . . . . . . . . . . .

Type specimens......................... 4

Typonyms............................ i

United States National Herbarium .......... 1,2

Urvilleana............................ 132

Valota............................... 18

Van Huerck, herbarium of................ 2

Verrucosa............................ 126

Vienna, herbarium at................... $\quad 4$

Virgata............................. $\$ 4$

Walter's herbarium..................... 3

Willdenow Herbarium................... 2

Wood, Alphonso, types of............... 2 



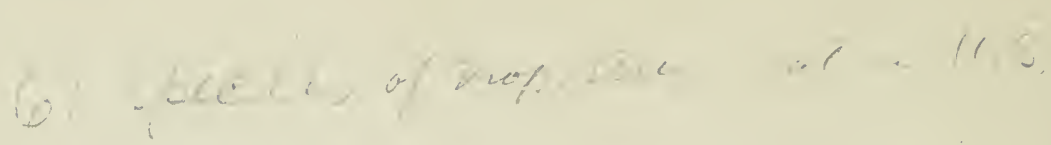




\section{CONTRIBUTIONS}

FROM THE

\section{United States National Herbarium \\ Volume 17, PARt 6}

TROPICAL NORTH AMERICAN SPECIES OF PANICUM

By A. S. HITCHCOCK and AGNES CHASE 
BULLETIN OF THE UNITED STATES NATIONAL MUSEUM. Issued JuLy 24, 1915.

II 


\section{PREFACE.}

The accompanying paper by A. S. Hitchcock, Systematic Agrostologist of the United States Department of Agriculture, and Agnes Chase, Assistant Agrostologist, is supplemental to a revision of the genus Panicum published by the same authors in volume 15 of the Contributions under the title of "The North American Species of Panicum." As stated in the preface to that paper, it was impossible at that time to offer a satisfactory treatment of the tropical species. Since then much additional material, including collections made by the authors, has been accumulated. The present paper includes the results of the study of these collections and presents a fairly detailed account of the genus in tropical North America.

There are included 116 species and 3 subspecies. Of these, 9 species are described as new; 5 are South American species which were unknown within the limits of the area covered; 1 is a species recently described; and 4 are species that were included in the list of synonyms or of dubious species but are now considered valid. In all 19 species are added, making the total for the genus Panicum in North America 216. Each species is accompanied by an outline map graphically representing the geographical distribution within the Tropics of North America.

Frederick V. Coville, Curator of the United States National Herbarium. 



\section{CONTENTS.}

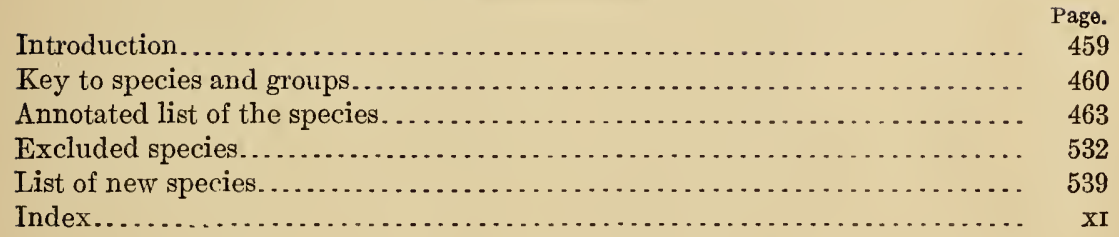





\section{ILLUSTRATIONS.}

TEXT FIGURES.

FIs. 11. Distribution of Panicum distantiflorum ....................... Page.

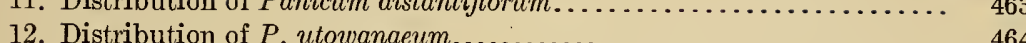

13. Distribution of $P$. chapmani.............................. 464

14. Distribution of $P$. ramisetum............................ 464

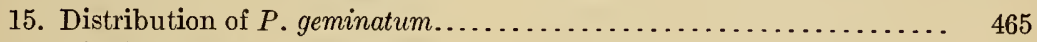

16. Distribution of $P$. paludivagum....................... 466

17. Distribution of $P$. barbinode .......................... 467

18. Distribution of $P$. reptans............................. 468

19. Distribution of $P$. fasciculatum.......................... 469

20. Distribution of $P$. fasciculatum reticulatum................ 470

21. Distribution of $P$. molle................................ 471

22. Distribution of $P$. adspersum........................... 471

23. Distribution of $P$. arizonicum............................ 472

24. Distribution of $P$. texanum............................. 472

25. Distribution of $P$. vaseyanum......................... 473

26. Distribution of $P$. dichotomiflorum...................... 473

27. Distribution of $P$. bartowense......................... 474

28. P. aquaticum....................................... 474

29. Distribution of $P$. aquaticum............................. 475

30. P. sucosum............................................ 475

31. Distribution of $P$. sucosum................................. 476

32. Distribution of $P$. elephantipes............................ 476

33. Distribution of $P$. capillare............................ 477

34. Distribution of $P$. hirticaule............................ 477

35. Distribution of $P$. pampinosum........................ 478

36. Distribution of $P$. decolorans............................ 478

37. Distribution of $P$. stramineum........................... 478

38. Distribution of $P$. sonorum......................... 479

39. Distribution of $P$. parcum........................... 479

40. Distribution of $P$. cayennense........................... 479

41. Distribution of $P$. capillarioides........................ 480

42. Distribution of $P$. diffusum......................... 480

43. Distribution of $P$. hallii............................. 481

44. Distribution of $P$. lepidulum.......................... 481

45. Distribution of $P$. ghiesbreghtii........................ 482

46. Distribution of $P$. hirsutum.......................... 483

47. Distribution of $P$. maximum.......................... 483

48. Distribution of $P$. plenum............................... 484

49. Distribution of $P$. bulbosum......................... 485

50. Distribution of $P$. bulbosum sciaphilum.................. 485

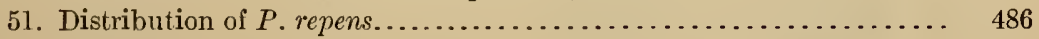

52. Distribution of $P$.gonini............................. 487 
Fig. 53. Distribution of $P$. virgatum .

54. Distribution of $P$. virgatum cubense....................... 487

55. P. ichnanthoides..................................... 488

56. Distribution of $P$. ichnanthoides........................... 488

57. P. altum ......................................... 489

58. Distribution of $P$. altum ............................... 489

59. Distribution of $P$. havardii............................. 489

60. Distribution of $P$. amarulum........................... 489

61. Distribution of $P$. tenerum .......................... 490

62. P. stenodoides....................................... 490

63. Distribution of $P$. stenodoides............................. 491

64. P. caricoides.......................................... 491

65. Distribution of $P$. caricoides.............................. 491

66. Distribution of $P$. stenodes............................... 492

67. Distribution of $P$. condensum............................ 492

68. Distribution of $P$. longum................................ 493

69. Distribution of $P$. polygonatum........................ 494

70. P. milleflorum...................................... 494

71. Distribution of $P$. milleflorum.......................... 495

72. Distribution of $P$. pilosum.................................. 495

73. P. boliviense.......................................... 496

74. Distribution of $P$. boliviense............................ 496

75. Distribution of $P$. laxum.............................. 497

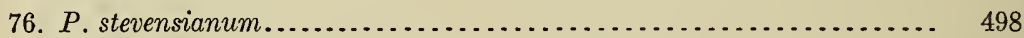

77. Distribution of $P$. stevensianum.......................... 498

78. Distribution of $P$. exiguiflorum.......................... 499

79. Distribution of $P$. hians............................... 499

80. Distribution of $P$. cupreum............................. 499

81. Distribution of $P$. stoloniferum....................... 500

82. Distribution of $P$. frondescens.......................... 500

83. Distribution of $P$. pulchellum......................... 501

84. Distribution of $P$. biglandulare ............................ 501

85. Distribution of $P$. virgultorum ........................ 502

86. Distribution of $P$. schmitzii........................... 502

87. P. schiffneri........................................ 503

88. Distribution of $P$. schiffneri........................ 503

89. Distribution of $P$. parviglume......................... 504

90. Distribution of $P$. trichoides. . . . . . . . . . . . . . . . . . . . 505

91. Distribution of $P$. trichanthum........................ 506

92. Distribution of $P$. parvifolium........................ 507

93. P. cyanescens.......................................... 507

94. Distribution of $P$. cyanescens.......................... 508

95. P. pyrularium..................................... 508

96. Distribution of $P$. pyrularium.......................... 508

97. Distribution of $P$. haenkeanum ........................ 509

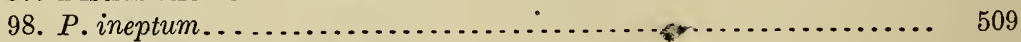

99. Distribution of $P$. ineptum ........................... 509

100. Distribution of $P$. millegrana .......................... 510

101. Distribution of $P$. glutinosum ..................... 510

102. Distribution of $P$. rudgei................................. 511

103. Distribution of $P$. megiston ........................... 511

104. Distribution of $P$. xalapense......................... 513 


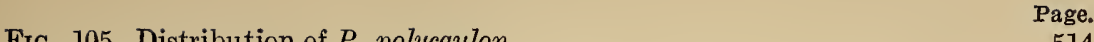

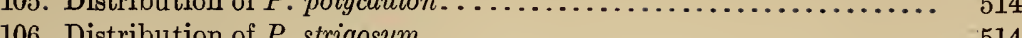

107. Distribution of $P$ aciculare ................................. 514

108. Distribution of $P$. aciculare............................ 515

108. Distribution of $P$. chrysopsidifolium.................... 515

110. Distribution of $P$. fusiforme......................... 515

110. Distribution of $P$. arenicoloides..................... 516

111. Distribution of $P$. ovinum......................... 516

112. Distribution of $P$. neuranthum..................... 516

113. Distribution of $P$. nitidum . . . . . . . . . . . . . . . . . 517

114. Distribution of $P$. multirameum. . . . . . . . . . . . . . . . 517

115. Distribution of $P$. yadkinense........................ 517

116. Distribution of $P$. roanokense. . . . . . . . . . . . . . . . . 518

117. Distribution of $P$. caerulescens. . . . . . . . . . . . . . . . . . 518

118. Distribution of $P$. leucothrix. . . . . . . . . . . . . . . . . 518

119. Distribution of $P$. wrightianum ....................... 519

120. Distribution of $P$. tennessense........................ 519

121. Distribution of $P$. acuminatum..................... 520

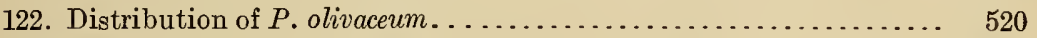

123. Distribution of $P$. villosissimum....................... 521

124. Distribution of $P$. pseudopubescens.................... 521

125. Distribution of $P$. sphaerocarpon . . . . . . . . . . . . . . . 521

126. Distribution of $P$. erectifolium . . . . . . . . . . . . . . . . . 522

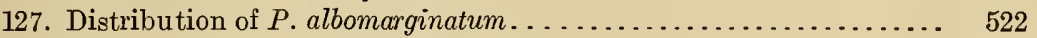

128. Distribution of $P$. portoricense......................... 523

129. Distribution of $P$. lancearium......................... 523

130. Distribution of $P$. nodatum ........................... 523

131. Distribution of $P$. scoparium . . . . . . . . . . . . . . . . . 524

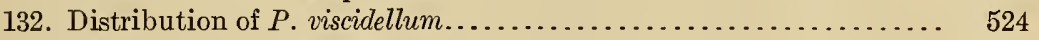

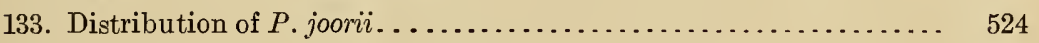

134. Distribution of $P$. albomaculatum........................ 525

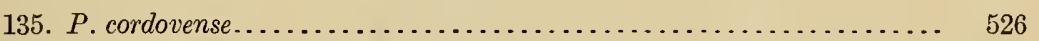

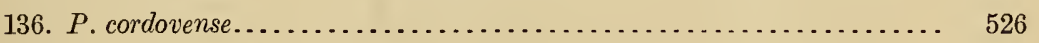

137. Distribution of $P$. cordovense. . . . ................... 526

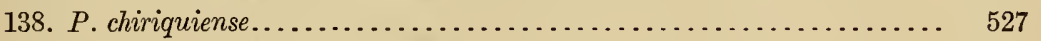

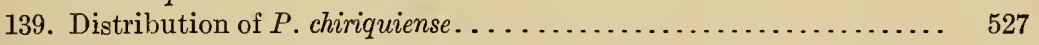

140. Distribution of $P$. obtusum. ......................... 528

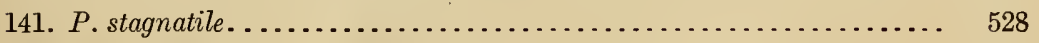

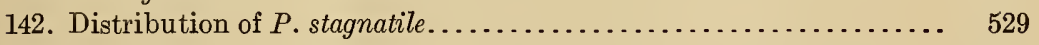

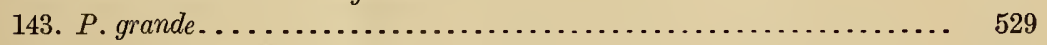

144. Distribution of $P$. grande.......................... 530

145. P. tuerckheimii..................................... 530

146. Distribution of $P$. tuerckheimii....................... 530

147. Distribution of $P$. zizanioides.......................... 531

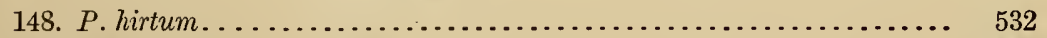

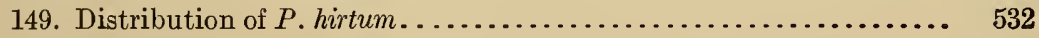





\title{
TROPICAL NORTH AMERICAN SPECIES OF PANICUM.
}

\author{
By A. '́. Hitcheock and Agnes Ch ise.
}

\section{INTRODUCTION.}

In a preceding paper ${ }^{1}$ our knowledge of the North American species of Panicum was presented in a revision of the genus, based upon material in the United States National Herbarium. Since the publication of that paper a large amount of additional material from tropical North America has been accumulated. Mr. Hitchcock visited Mexico in 1910, Central America and Panama in 1911, and Jamaica and Trinidad in 1912. Mrs. Chase visited Sonora in 1910 and Porto Rico in 1913. The collections of Mr. H. Pittier in Panama, of Brother León of the Colegio de la Salle, Habana, in Cuba, and of several other collectors in tropical North America, besides specimens from various islands of the West Indies received through Dr. I. Urban, serve to augment the amount of material studied. As a result of these further studies in the genus the range of nearly all the tropical species described in the revision can be presented in much greater detail. Several South American species hitherto unknown from North America and several new species have been discovered, while a few doubtful species and a few referred to synonymy have by field work and further study been established as valid.

While the present paper is supplementary to the revision, it is designed to be of use for the region covered without necessarily referring to the main work. For this reason keys are given for all the tropical species, though descriptions are given of additional species only. A study in their native habitat of species before known from herbarium specimens alone, has necessitated in some cases a revision of the description of habit or of duration, or exceptions have been found to characters given as common for groups. Such notes are given without other description and are to be understood as additions to or corrections of the descriptions given in the revision. Following the reference to the original publication of each species is a reference 
to the description in the revision, if the species is there described. No synonymy is given except such as is additional to that cited in the previous work.

The distribution here given is based upon all the material at present in the National Herbarium, including that already cited. As in the earlier paper all specimens cited are in the United States National Herbarium, unless otherwise stated. Specimens from other herbaria are cited when such specimens add to the known range. Through the courtesy of Dr. I. Urban the grasses of the Krug and Urban Herbarium in the Berlin Museum were submitted for study. Many additional specimens are cited from this herbarium, such specimens being indicated by the abbreviation "K. U. Herb." The range within the region covered is graphically presented by maps. For the sake of comparison these maps indicate also the distribution in the southern border of the United States of such species as extend into this region. Trinidad and Tobago, though they are continental islands and their flora is essentially South American, are included in the West Indies because they are so included by Grisebach ${ }^{1}$ and by. Urban. $^{2}$ In order to connect Panama and Trinidad the detailed distribution includes Venezuela and Colombia.

\section{KEY TO SPECIES AND GROUPS.}

Axis of branchlets produced beyond the base of the uppermost spikelet as a point or bristle 1 to $6 \mathrm{~mm}$. long.................. Subgenus Pacrochaetium, p. 463. Axis of branchlets not produced into a bristle. (In P.geminatum and $P$. paludivagum the somewhat flattened axis pointed but not bristle-form.)

Basal leaves usually distinctly different from those of the culm, forming a winter rosette; culms at first simple, the spikelets of the primary panicle not perfecting seed, later usually becoming much branched, the small secondary panicles with cleistogamous, fruitful spikelets.

Subgenus Dichanthelium, p. 512.

Basal leaves similar to culm leaves, not forming a winter rosette; spikelets all fertile.

Plants annual.

Spikelets plano-gibbous, the second glume swollen, bristly and burlike at maturity; first glume nearly as long as the minute spikelet.

Spikelets not plano-gibbous nor burlike.

116. P. hirtum.

Panicles consisting of several more or less secund spikelike racemes; fruit transversely rugose; glumes and sterile lemma usually reticulate-veined................ See Fasciculata, p. 467. Panicles more or less diffuse (small and narrow in $P$. vaseyanum).

Blades ovate-lanceolate or elliptical, one-fifth to one-fourth as broad as long; plants low; spikelets minute, not over $1.5 \mathrm{~mm}$. long.

Spikelets pyriform, attenuate at base, glabrous.

71. P. pyrularium.

Spikelets elliptic, pubescent..........67. P. trichoides. 
Blades linear, many times as long as broad; spikelets $1.7 \mathrm{~mm}$. or more long.

First glume not over one-fourth the length of the spikelet, truncate or triangular-tipped.

See Dichotomiflora, p. 473.

First glume usually as much as half the length of the spike-

Plants perennial. let, acute or acuminate....... See CaPILLARIA, p. 476.

Spikelets short-pediceled along one side of the panicle branches, forming more or less spikelike racemes.

First glume nearly as long as the obtuse spikelets; plants with long wiry stolons with woolly nodes............... 111. P. obtusum.

First glume much shorter than the spikelet.

Spikelets more or less hispid.

Sterile lemma glandless; second glume inflated-gibbous.

Sterile lemma bearing a pair of crateriform glands.

73. P. ineptum.

Spikelets glabrous.

See Stolonifera, p. 500 .

Blades lanceolate or ovate-lanceolate; glumes strongly carinate.

See Stolonifera, p. 500.

Blades linear, often elongated; glumes not carinate or but slightly so.

Fruit transversely rugose.............. See Geminata, p. 465.

Fruit not rugose.

Second glume shorter than the spikelet; fertile lemma subindurate, inrolled only at base, scabrous at the acute apex.

112. P. stagnatile.

Second glume as long as the spikelet; fertile lemma indurate, inrolled to the summit................ See LAXA, p. 492.

Spikelets in open or sometimes in contracted or congested panicles, but not in 1-sided spikelike racemes.

Fruit transversely rugose.................... See Maxima, p. 483.

Fruit not transversely rugose (minutely papillose-roughened in $P$. millegrana).

Culms more or less succulent; plants glabrous or nearly so throughout, aquatic or subaquatic.

First glume not over one-fifth the length of the spikelet.

See Dichotomiflora, p. 473.

First glume one-third to half the length of the spikelet.

Fruit indurate, the margins of the lemma inrolled; culms erect; panicle contracted.................. 48. P. condensum.

Fruit subindurate, the margins of the lemma inrolled only at

base; culms decumbent at base; panicles open.

Spikelets $1.8 \mathrm{~mm}$. long; second glume shorter than the fruit; secondary panicle branches secund..... 112. P. stagnatile.

Spikelets $2.5 \mathrm{~mm}$. long; second glume exceeding the fruit; panicle branches not secund............. 113. $P$. grande.

Culms not succulent.

First glume hyaline, inconspicuous; spikelets acuminate; lower

blades with long petiole-like bases........ 114. P. tuerckheimii.

First glume evident.

First glume very small, not over one-fourth the length of the small obovate, blunt, glabrous spikelets.

See Parviglumia, p. 502. 
First glume usually more than one-third the length of the spikelet,

if shorter the spikelets not small and blunt.

Sterile palea enlarged and indurate at maturity, expanding the spikelet; blades scarcely wider than their sheaths.

See LAXA, p. 492.

Sterile palea if present not enlarged and indurate.

First glume short, blunt; spikelets pointed; base of culm usually decumbent and rooting.

See Dichotomiflora, p. 473.

First glume usually more than one-third the length of the spikelet.

Plants forming conspicuous hard creeping scaly rootstocks.

Plants not forming creeping scaly rootstocks.

See Virgata, p. 486.

Fruit crested at the apex; spikelets 5.5 to $6 \mathrm{~mm}$. long.

Fruit not crested.

115. P. zizanioides.

Panicles narrow and few-flowered; culms erect and wiry; blades drying involute... See Tenera, p. 490.

Panicles open or contracted, many-flowered.

Panicles 40 to $60 \mathrm{~cm}$. long, the numerous elongated branches in verticils........ 77. P. megiston.

Panicles mostly much less than $40 \mathrm{~cm}$. long; branches not verticillate.

Spikelets short-pediceled along the nearly simple panicle branches......... 48. $P$. condensum.

Spikelets long-pediceled; panicle open at maturity.

Primary panicles open, the secondary reduced, narrow, partly inclosed in the sheaths.

First glume three-fourths as long as the elliptical spikelets; fruit apiculate.

See Cordovensia, p. 525.

First glume one-third as long as the pyriform spikelets; fruit not apiculate.

104. P. nodatum.

Primary and secondary panicles alike, or the secondary wanting.

First glume not pointed, two-thirds the length of the spikelet or more; spikelets blunt.

Panicles not over $6 \mathrm{~cm}$. long; plants somewhat glaucous, relatively small.

See Parvifolia, p. 506.

Panicles 10 to $20 \mathrm{~cm}$. long, very diffuse; plants tall, not glaucous.

Spikelets viscid, $3 \mathrm{~mm}$. long.

75. P. glutinosum.

Spikelets not viscid, 2 to $2.3 \mathrm{~mm}$. long.

74. P. millegrana.

First glume pointed, usually less than twothirds as long as the pointed spikelets.

Spikelets more or less pubescent.

Culms slender, straggling; spikelets not turgid; glumes and sterile lemma hirsute along the margins.

72. P. haenkeanum. 
Culms stout, erect or nearly so; spikelets turgid, sparsely hirsute.

Spikelets glabrous.

76. P. rudgei.

Culms straggling; spikelets minute.

68. P. trichanthum.

Culms erect or stiffly ascending; blades linear, usually elongated.

Sheaths glabrous; culms 1.5 to 2 meters high...... 40. P. ichnanthoides.

Sheathshirsute, or if glabrous the culms less than 1 meter high.

See Diffusa, J. 480.

\section{ANNOTATED IIST OF THE SPECIES.}

Subgenus PAUROCHAETIUM Hitchc. \& Chase.

Blades less than $10 \mathrm{~cm}$. long, not narrowed toward the base; spikelets about $2.5 \mathrm{~mm}$. long..................... 4. P. ramisetum.

Blades elongated, usually more than $15 \mathrm{~cm}$. long, narrowed toward the base.

First glume rounded or truncate; second glume about as long as fruit............................... 3. P. chapmani.

First glume acute; second glume about two-thirds as long as fruit.

Spikelets $1.5 \mathrm{~mm}$. long; blades involute............ 1. P. distantiflorum. Spikelets $2 \mathrm{~mm}$. long; blades flat................ 2. P. utowanaeum.

\section{Panicum distantiflorum A. Rich.}

Panicum distantiflorum A. Rich. in Sagra, Hist. Cuba 11: 304. 1850; Contr. U. S. Nat. Herb. 15: 23. 1910.

\section{DISTRIBUTION.}

Limestone hills at low altitudes, Bahamas to Cuba and Haiti; Curaçao. The type specimen from Cuba.

BaнAмas: Inagua, Hitchcock in 1890, Nash \& Taylor 893 (both Field Mus. Herb.).

CuвA: Playa de Cojimar, Hitchcock 144, León 912. Near Habana, León 305 b, 567,2382. Santiago, León 917. Silla de Cayo, Shafer 2512. Guanoroca, Wright 284. Hanábana, Wright 285. Playa de Marianao, León in 1909. Without locality, Wright 3452.

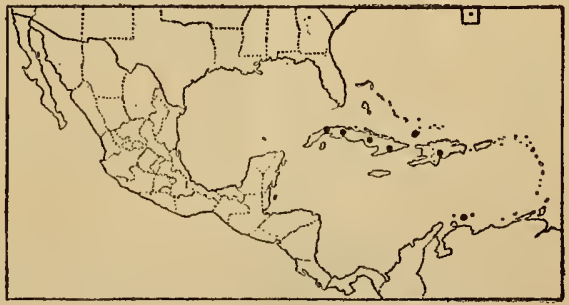

Fig. 11.-Distribution of $P$. distantiflorum.

Santo Domingo: Naranjo, Fuertes 1284. Los Charcos, Fuertes 1427.

Curaçao: Britton \& Shafer 3088. Bonaire, Suringar in 1885. (K. U. Herb.) ${ }^{1}$

${ }^{1}$ Krug \& Urban Herbarium. 


\section{Panicum utowanaeum Scribn.}

Panicum utowanaeum Scribn. in Millsp. Field Mus. Bot. 2: 25. 1900; Contr. U. S. Nat. Herb. 15: 24. 1910.

\section{DISTRIBUTION .}

Open rocky soil, mostly near the coast, Cuba, Porto Rico, Guadeloupe, and Venezuela. The type specimen from Porto Rico.

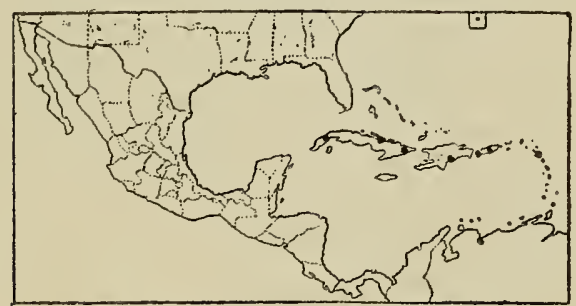

FIG. 12,-Distribution of $P$. utowanaeum.

LeE Ward Islands: Guadeloupe, Duss 3177.

Venezuela: Near Puerto Caballo, Pittier 6434.

\section{Panicum chapmani Vasey.}

Panicum chapmani Vasey, Bull. Torrey Club 11: 61. 1884; Contr. U. S. Nat. Herb. 15: 24. 1910.

\section{DISTRIBUTION.}

Coral sand and shell mounds, southern Florida and the Bahamas. The type specimen from Florida.

Baнamas: New Providence, Britton \& Brace 401. Rose Island, Britton \& Millspaugh 2137. Great Exuma, Britton Herb.)

4. Panicum ramisetum Scribn.

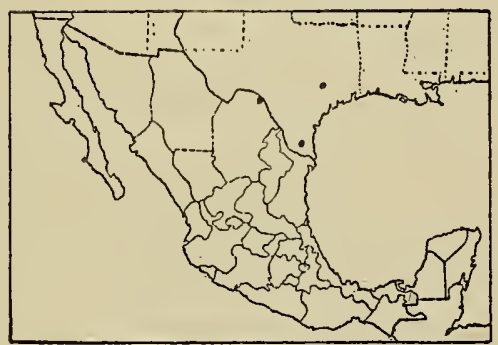

FIG. 14.-Distribution of $P$. ramisetum.

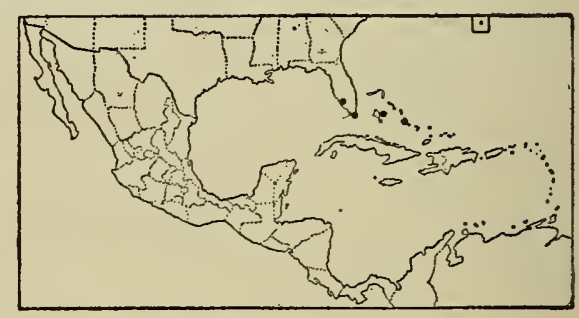

FIG. 13.-Distribution of $P$. chapmani.

\& Millspaugh $\cdot 3076$. (All in Field Mus. icum ramisetum Scribn. U. S. Dept. Agr. Div. Agrost. Circ. 27: 9. 1900; Contr. U. S. Nat. Herb. 15: 25. 1910.

\section{DISTRIBUTION.}

Sandy plains and prairies, southern Texas and northern Mexico. The type specimen from Texas.

CoAнuila: Near Díaz, ${ }^{1}$ Pringle 8323.

1 The "Guía Postal de la República Mexicana" has been followed in the accenting of Mexican geographical names.

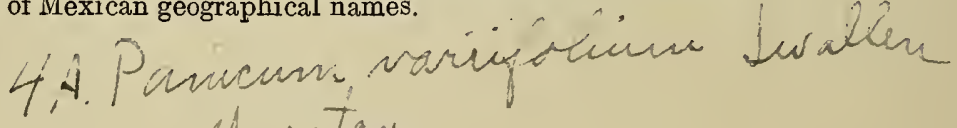
Uncatas. 


\section{TRUE PANICUM.}

\section{GEMINATA.}

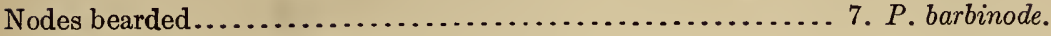

Nodes glabrous.

Spikelets $3 \mathrm{~mm}$. long; glumes and sterile lemma papery..... 6. P. paludivagum. Spikelets not over $2.4 \mathrm{~mm}$. long; glumes and sterile lemma not papery .............................. 5. P. ginatum.

\section{Panicum geminatum Forsk.}

Panicum geminatum Forsk. Fl. Aegypt. Arab. 18. 1775; Contr. U. S. Nat. Herb. 15: 30.1910.

This species is described by Presl ${ }^{1}$ under the name Panicum brizoides L. (as well as under $P$. brizaeforme Presl). The Haenke specimen from Mexico is in the herbarium of the National Museum at Prague.

DISTRIBUTION.

Moist ground, ditches and swamps, mostly near the coast, tropical regions of both hemispheres, in America extending north into southern Florida and Texas. Originally described from Rosetta, Egypt.

Lower California: El Taste, Brandegee in 1893. San José del Cabo, Brandegee $14,36$.

Sonora: Yaqui River, Palmer 15 in 1869. Guaymas, Palmer 690 in 1887. Sierra de Alamos, Rose, Standley \& Russell 12996.

Srinaloa: Mazatlán, Rose, Standley \& Russell 14109.

Tamaulipas: Tampico, Hitchcock 5796, Palmer 259 in 1910.

Colrma: Manzanillo, Hitchcock 7032.

VERACRUZ: Veracruz, Hitchicock 6586.

Guerrero: Acapulco, Palmer 289 in 1894.

Yucatán: Izamal, Gaumer 1027.

Guatemala: San José, Kellerman 6250.

SAlvador: Lake Ilopango, Hitchcock 8920 .

Costa Rica: Bebedero, Jiménez 734.

Panama: Corozal, Pittier 2168, 2170. Pedro Miguel, Hitchcock 7956, Pittier 2509. Empire, Pittier 3714. Gatun,

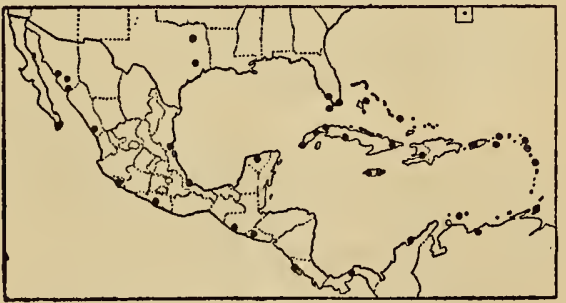

FIG. 15.-Distribution of $P$. geminatum. Hitchcock 7980.

Bahamas: Nassau, Curtiss 175. Fortune Island, Eggers 3992 (K. U. Herb.).

CuBA: Habana, León 769, 918. Corrientes Bay, Britton \& Cowell 9931. Santiagc de las Vegas, Hitchcock 143. Guanabacoa, León 920. Guantánamo, Britton 2281. Sancti Spiritus, Sergius 2789. Batabanó, Hitchcock 142. Hanábana, Wright 761. Palma Sola, Wright in 1860.

Jamaica: Gordon Town, Hart 806. Ferry River, Harris 11352. Appleton, Hitchcock 9653. Palisadoes near Kingston, Hitchcock 9752. Black River, IIitchcock 9579. Savanna-la-Mar, Hitchcock 9877.

\footnotetext{
${ }^{1}$ Presl, Rel. Haenk. 1: 302. 1830.
}

$82472^{\circ}-15-2$ 
HaItr: La Coupe, Buch 975. Port-au-Prince, Picarda 1430. (Both in K. U. Herb.)

Porto Rico: Guanica, Chase 6527, 6531, Sintenis 3367. Mayaguez, Chase 6288, 6318. Boqueron, Chase 6511. Coamo Springs, Chase 6552.

Danish West Indies: St. Croix, Ricksecker 212. St. Thomas, Eggers in 1882.

Leeward Islands: Antigua, Wullschlaegel 614. Guadeloupe, Duss 2690, 3584, L'Herminier.

WindWard Islands: Martinique, Duss 1293.

Trinidad: Icacos, Hitchcock 10158.

CURAÇAO: Aruba, Suringar in 1885.

Venezuela: Paparo, Pittier 6347.

Colombia: Santa Marta, Smith 151.

6. Panicum paludivagum Hitchc. \& Chase.

Panicum paludivagum Hitchc. \& Chase, Contr. U. S. Nat. Herb. 15: 32. 1910.

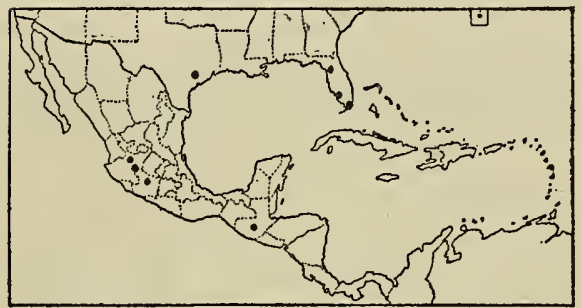

FIG. 16.-Distribution of $P$. paludivagum.

DISTRIBUTION.

Fresh-water lakes and rivers, the base submerged, Florida and Texas, Mexico, Central America to Uruguay. The type specimen from Florida.

JALISCO: Guadalajara, Palmer 429 in 1886, Hitchcock 7294 . Örozco, Hitchcock 7374.

Michoacín: Lake Pátzcuaro, Pringle 3336. Zamora Valley, Pringle 9556. Morelia, Arsène in 1909.

Guatemala: Amatitlán, Kellerman 6253, 6254, Pittier 101, Türckheim 8790.

\section{Panicum barbinode Trin.}

Panicum barbinode Trin. Mém. Acad. St. Pétersb. VI. Sci. Nat. 1: 256. 1834; Contr. U. S. Nat. Herb. 15: 33. 1910.

Commercially known as "Pará grass"; called "malajilla" in Porto Rico.

\section{DISTRIBUTION.}

Cultivated and waste ground, especially in moist places, tropical America, extending into southern Florida and Texas; introduced in the warmer parts of the Old World. The type specimen from Bahia, Brazil.

Lower California: San José del Cabo, Brandegee 46. La Paz, Palmer 131 in 1890. Colima: Paso del Río, Emrick 8. Manzanilla, Palmer 1078.

México: Cuantla, Holway 3045.

Veracruz: Veracruz, Amer. Gr. Nat. Herb. $4 .^{1}$

OAXaca: Tomellín, Hitchcock 6227.

Yucatán: Mérida, Collins 27.

Guatemala: Mazatenango, Maxon \& Hay 3476. Cubilquitz, Türckheim 7799, 8617. Escuintla, Hitchcock 9007.

SALVADOR: Without locality, Renson 214.

NiCARAGUA: Jinotepe, Hitchcock 8701. Chinandega, Baker 2053.

Costa Rica: Térraba, Pittier 412, 4090. Río Tuís, Tonduz 11393. Puntarenas, Hitchcock 8545. Taboga, Guanacaste, Jiménez 722. Turrialba, Tonduz 8401.

\footnotetext{
${ }^{1}$ American Grasses, exsiccatæ distributed from the U. S. National Herbarium,
} Smithsonian Institution. 
Panamá: El Boquete, Hitchcock 8266. Gatun Lake, Pittier 2559, Hitchcock $8031 \frac{1}{2}$. Pedro Miguel, Hitchcock 7931. Chepo, Pittier 4734. Culebra, Pittier 4807.

BaHamas: Nassau, Curtiss 115.

Cuba: Near Habana, León 568. Camaguey, Shafer 2881. Romelie, Eggers 4870. Cienfuegos, Pringle 26. Almendares River, León 283. Without locality, Wright 1545.

JAMaICA: Hope Gardens, Harris 11254, 10930. Mount Hybla, Harris 11565. Newcastle, Hitchcock 9339. Black River, Hitchcock 9580. Montego Bay, Hitchcock 9693.

Porto Rico: Bayamon, Hioram 360, Millspaugh 324, Heller 100. Aibonito, Goll 613, Playa de Fajardo, Chase 6657. Guanica, Chase 6528, Millspaugh 727. Yauco, Heller 6293. Los Mameyes, Eggers 1328. Vieques, Chase 6679. Mona, Hess 450 .

Danish West Indies: St. Croix, Ricksecker 300 .

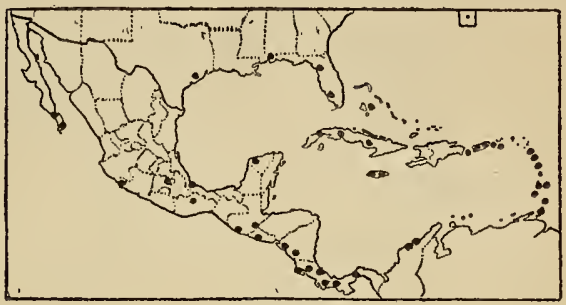

FIG. 17.-Distribution of $P$. barbinode.

LeEWARd Islands: Guadeloupe, Duss 2689, L'Herminier. Dominica, Eggers 1030 (K. U. Herb.).

Windward Islands: Martinique, Duss 539. Grenada, Buckmire 1423, Broadway in 1904 and in 1905. St. Vincent, Eggers 6834 (K. U. Herb.). Barbados, Eggers 7079 (K. U. Herb.).

Trinidad: Port of Spain, Hitchcock 9941, 10044.

Товаяо: Scarborough, Hitchcock 10204.

Curaçao: Santa Cruz, Britton \& Shafer 3012.

ColoмвIA: Cartagena, Hitchcock 9901. Santa Marta, Smith 211. Without locality, Lehmann 5744 .

\section{FASCICULATA.}

Spikelets 5 to $6 \mathrm{~mm}$. long.

Spikelets 2 to $4 \mathrm{~mm}$. long.

Spikelets strongly reticulate-veined, 2 to $3 \mathrm{~mm}$. long; glabrous.

Panicle branches long and spreading; blades pubescent or glabrous...............................

Panicle branches short, appressed; blades narrow, pubes-

9. P. fasciculatum. cent.................................. 9a. P. fasciculatum reticulatum.

Spikelets scarcely reticulate-veined or only near the apex.

Spikelets not over $2 \mathrm{~mm}$. long, glabrous.............. 8. P. reptans.

Spikelets over $3 \mathrm{~mm}$. long, pubescent.

Rachis scabrous but not bristly ...

13. P. texanum.

Rachis pilose with bristly hairs.

Plant more or less velvety; sheaths not papillose. 10. P. molle.

Plant not velvety; sheaths papillose ........... 12. P. arizonicum.

\section{Panicum reptans $\mathrm{L}$.}

Panicum reptans L. Syst. Nat. ed. 10. 2: 870. 1759; Contr. U. S. Nat. Herb. 15: 36. 1910

DISTRIBUTION .

Open ground at low altitudes especially near the coast, frequently a weed in waste places and cultivated soil, Gulf Coast of the United States and Atlantic slope of 
Mexico through the West Indies to northern South America; also introduced in the warm regions of the Eastern Hemisphere. The type specimen from Jamaica.

Tamaulipas: Tampico, Palmer 153 in 1910.

Veracruz: Baños del Carrizal, Purpus 6213.

OAxaca: Tomellín, Hitchcock 6231. Cuicatlán, Nelson 1622.

CubA: Habana, Curtiss 691, Hitchcock 146, León 3474. Habana Vedado, León 276, 292, 297, 566. Habana Vibora, León 906, 910c. El Caño, León 1980. Baracoa, Shafer 3955, Palmer, Pollard \& Palmer 19. Buenaventura, Wilson 9243, 9399. Río Almendares, Wilson 9187. Cojimar, Britton, Earle \& Gager 6295. Valley of Bacuranao River, León \& Wilson 2869. Cienfuegos, Pringle 73. Herradura, Tracy 9103. San Antonio, Hitchcock 145. Madruga, Curtiss 536. Arroyo Apolo, León 576. La Magdalena, Earle \& Baker 2455. Santiago de Cuba, León 910. Guayabal, León 910b. Guantánamo Bay, Britton 1933, 2245. Romelie, Eggers 5346. Without locality, Wright 762, 763, 3857.

JAMAICA: Prospect, Harris 11539. Black River, Hitchcock 9631. Montego Bay,

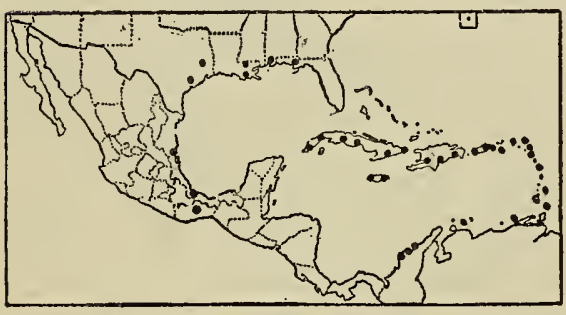

FIG. 18.-Distribution of $P$. reptans.

Hitchcock 9689. Hope, Harris 6845. Gordon Town, Hart 838. Haitr: Without locality, Picarda 1246 (K. U. Herb.).

Santo Domivgo: Rincón, Fuertes 1377, 1417. San Pedro de Macoris, Rose, Fitch \& Russell 4171.

Porto Rico: Guanica, Chase 6515, Millspaugh 726, Sintenis 3368. Bayamon, Chase 6395 . Joyuda, Chase 6305. Ponce, Heller 497, Chase 6326. Cabo Rojo, Sintenis 847. Coamo Springs, Goll 662. Fajardo, Chase 6664. Vieques, Chase 6700.

Danish West Indies: St. Croix, Ricksecker 77. St. Thomas, Eggers 293.

Leeward Islands: Antigua, Wullschlaegel 617. Guadeloupe, Duss 3529. St. Martin, Boldingh 3383 (K. U. Herb.).

Windward Islands: Martinique, Duss 1290. Grenada, Broadway 721. Bequia, Smith \& Smith 19, 370 (K. U. Herb.). Barbados, Eggers 7081 (K. U. Herb.). Bot. Sta. Herb. 538.

TоваGo: Scarborough, Hitchcock 10212.

CuraçaO: Santa Cruz, Britton \& Shafer 2987, 3002.

Venezuela: EI Valle, Island of Margarita, Miller \& Johnston 171.

CoLoмвia: Santa Marta, Smith 173, 2753. Cartagena, Hitchcock 9907. Puerto de Colombia, Hitchcock 9936.

\section{Panicum fasciculatum Swartz.}

Panicum fasciculatum Swartz, Prodr. Veg. Ind. Occ. 22. 1788; Contr. U. S. Nat. Herb. 15: 38. 1910.

Panicum chartaginense Swartz, Prodr. Veg. Ind. Occ. 22. 1788; Contr. U. S. Nat. Herb. 15: 40. 1910. "America meridionalis chartagena." A reconsideration of Swartz's type in the light of recent collections from the region whence it came leads to the conclusion that it is referable to Panicum fasciculatum rather than to the narrowpanicled form confined to the semiarid southwestern United States and Mexico, which was described by Torrey as $P$. reticulatum. 


\section{DISTRIBUTION.}

Moist open ground, often a weed in fields and waste places, southern Florida and Texas, through Mexico and the West Indies to central South America. The type specimen from Jamaica.

Sonora: Hermosillo, Hitchcock 3598. Imeris to Santa Ana, Griffiths 6857. Alanos, Palmer 694 in 1890. Guaymas, Palmer 158 and 207 in 1887.

Chrmuahua: Norogachi, Palmer la in 1885.

Sinaloa: Rosario, Rose 1834, 1884. Topolobampo, Palmer 241 in $1897 . \quad$ Culiacán, Palmer 1557 in 1891.

San Lyrs Potosí: Rascón, Purpus 5418. Cárdenas, Hitchcock 5728.

Querétaro: Querétaro, Hitchcock 5838.

Couma: Jala, Hitchcock 7011. Alzada, Hitchcock 7097, 7106. Without locality, Palmer 19 in 1897.

Veracruz: Misantla, Purpus 5979. Córdoba, Finck in 1893, Hitchcock 6448. Baños del Carrizal, Purpus 6218. Santa María Tlatetla, Liebmann 279.

Oaxaca: Tomellín, Rose, Painter \& Rose 10077, Hitchcock 6214. Totalcingo, Liebmann 277.

Chrapas: Vicinity of Topana, Nelson 2874. Between San Ricardo and Ocozucuantla, Nelson 2958.

Yucatán: Mérida, Schott 384.

Britrsh Honduras: Manatee Lagoon, Peck 317 (Gray Herb.).

Guatemala: Nenton, Seler 2704. Gualán, Deam 6267. Finca Trece Aguas, Goll 81. Chicarao, Heyde \& Lux 6404. Escuintla, Smith 2233.

Honduras: San Pedro Sula, Thieme 195, 5584. Highland Creek, Wilson 644.

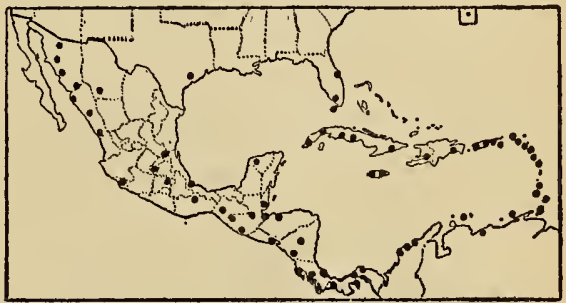

Fig. 19.-Distribution of $P$. fasciculatum.

Salvador: La Unión, Hitchcock 8778.

Nicaraqua: Jinotepe, Hitchcock 8670. Masaya, Hitchcock 8663. Without locality, Flint in 1868.

Costa Rica: Puerto Viejo, Biolley 7471. Nuestro Amo, Alajuela, Jiménez 525. Hacienda la Estrella, Tonduz 190. Puntarenas, Hitchcock 8552. Puerto de Río Grande, Pittier 2035. Nicoya, Tonduz 13749. Matina, Pittier 9727.

Panama: Laguna de Chiriquí, Hart 78. Taboga Island, Pittier 3626, Hitchcock 8076, 8079. Gatun, Hitchcock 9185. Toro Point, Hitchcock 8057. Culebra, Hitchcock 7908, 7932, Pittier 2117. David, Hitchcock 8358. Porto Bello, Pittier 2478. Puerto Obaldía, Pittier 4375. Empire, Pittier 3718. Las Cascadas, Pittier 3743. Chepo, Pittier 4695. La Sabana de Panama, Gervais 165.

Cuвa: Hoyo Colorado, Lebn 573. Herradura, Tracy 9091. Cienfuegos, Pringle 74, 124. San Antonio, Eggers 4875. Santiago de Cuba, León 813. Banao Hills, León 3966. Sancti Spiritus, León 916. Sierra de Anafe, León 1979. Santiago de las Vegas, Wilson 593 . Without locality, Wright 754.

JamaICA: Gordon Town, Hart 785, 840, Harris 11345, 11400. Bath, Maxon 2361. Hope Gardens, Maxon 1659, Harris 11252, 11255, Hitchcock 9312, Amer. Gr. Nat. Herb. 5. Flamstead, Harris 11470. Ferry River, Harris 11324, Hitchcock 9747. Montego Bay, Hitchcock 9682. Savanna-la-Mar, Hitchcock 9870. Above Constant Spring, Hitchcock 9259. Ewarton to Linstead, Hitcheock 9411. Without locality, Lloyd 1116, Wilson 322. 
Hartr: Labrante, Buch 48. Without locality, Picarda 409, Christ 2144. (All in K. U. Herb.).

Santo Domingo: San Pedro de Macoris, Rose, Fitch \& Russell 4440, 4174.

Porto RIco: Aibonito, Underwood \& Griggs 462. Monte Goyo, Sintenis 1901. Guanica, Sintenis 3647, Chase 6523. Rio Piedras, Barrett 63, Heller 135. Ponce, Heller 6226, 6302. Caguas, Goll 385. Guayama Road, Goll 588. Aguadilla, Heller 4528. Maricao, Chase 6197. Coamo Springs, Chase 6542. Bayamon, Chase 6376, Hioram 316. Mayaguez, Chase 6263. Sierra Luquillo, Hioram 357. Culebra, Britton \& Wheeler 137. Vieques, Chase 6693. Without locality, Fisher 59, Underwood \& Griggs 824.

Danish West Indies: St. Thomas, Eggers in 1880 and in 1882 . St. Croix, Ricksecker 317.

Leeward Islands: Guadeloupe, Duss 2691, L'Herminier. Montserrat, Shafer 584. St. Kitts, Britton \& Cowell 269 (K. U. Herb.). Dominica, Duss (K. U. Herb.).

Wrndward Islands: Martinique, Duss 537, 538, Hahn in 1867-70. Grenada, Broadway in 1905. St. Vincent, Smith \& Smith 565 (K. U. Herb.).

Trinidad: St. Joseph, Hitcheock 10014. Port of Spain, Hitchcock 9976. Without locality, Bot. Gard. Herb. ${ }^{1}$ 2283, 3192.

Toвago: Mount Marie, Broadway 3977. Rockley Vale, Broadway 4630. Scarborough, Hitchcock 10216.

Curaģa: Santa Catherina, Britton \& Shafer 3145. Bonaire, Suringar in 1885 (K. U. Herb.).

Venezuela: Paparo, Pittier 6336. Island of Margarita, Miller \& Johnston 180.

Colombia: Puerto de Colombia, Hitchcock 9934. Río Frío, State of Magdalena, Pittier 1610. Cartagena, Hitchcock 9911. Santa Marta, Smith 131, 208.

9a. Panicum fasciculatum reticulatum (Torr.) Beal.

Panicum reticulatum Torr. in Marcy, Expl. Red Riv. 299. 1852.

Panicum fasciculatum reticulatum Beal, Grasses N. Amer. 2: 117. 1896.

For further treatment see Contr. U. S. Nat. Herb. 15: 40. 1910 (where this is included under $P$. fasciculatum chartaginense (Swartz) Doell); see also discussion under $P$. fasciculatum.

\section{DISTRIBUTION .}

Prairies, fields, and waste grounds, Texas to Arizona and southern Mexico. The type specimen from Texas.

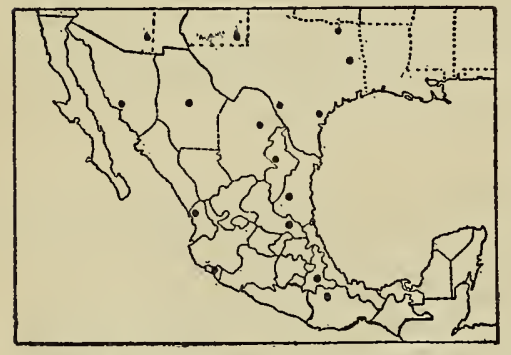

FIG. 20.-Distribution of $P$. fasciculatum reticulatum.
Sonora: Guaymas, Hitchcock 3561.

Chinuahua: Chihuahua, Pringle 379, 380.

Coahurla: Sabinas, Nelson 6818.

Nuevo León: Monterrey, Hitchcock 5535, 5541.

TAMa Ulmas: Victoria, Palmer 412 in 1907.

TEPIC: Acaponeta, Rose, Standley \& Russell 14265.

SaN Lurs Potosí: San Dieguito, Palmer 152 in 1904.

Colrma: Manzanillo, Hitchcock 7029.

Puebla: Tehuacán, Hitchcock 6050.

OAXACA: Ignacia Mejía, Hitchcock 6115. Tomellín, Hitchcock 6195.

\footnotetext{
${ }^{1}$ Herbarium of the Botanical Garden, Trinidad. Many specimens are without data other than the number.
} 


\section{Panicum molle Swartz.}

- Panicum molle Swartz, Prodr. Veg. Ind. Occ. 22. 1788; Contr. U. S. Nat. Herb. 15: 42. 1910.

\section{DISTRIB UTION.}

Open ground, often a weed in fields, Cuba, Jamaica, Mexico, and Central America to Argentina. The type from the West Indies, probably Jamaica. Since at the time the revision of Panicum ${ }^{1}$ was prepared we had no specimens of the species from the West Indies, we doubted the accuracy of the locality given by Swartz. This species proves, however, to be not uncommon in the vicinity of Kingston, Jamaica.

Sinaloa: Lodiego, Palmer 1660 in 1891.

Colma: Manzanillo, Amer. Gr. Nat. Herb. 7. Alzada, Hitchcock 7107. Colima, Palmer 149 in 1897.

VERACRUz: Without locality, Galeotti 5710.

Guerrero: Balsas, Hitchcock 6813.

OAXaca: Tomellín, Hitchcock 6205, 6229.

Guatemala: Agua Caliente, Deam 6143.

Salvador: San Salvador, Hitchcock 8860 .

Costa Rica: Puntarenas, Hitchcock 8585.

Panama: Point Chamé, Amer.Gr. Nat. Herb. 8. Taboga Island, Hitchcock 8067.

CuBA: Without locality, Reed.

Jamarca: Kingston, Alexander in 1849, Hitchcock in 1890. Gordon Town, Harris 11504, Hitchcock 9323. St. Andrew, Harris

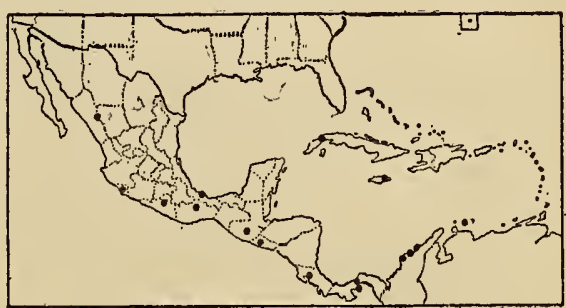

FIG. 21.-Distribution of $P$. molle.

11483. Healthshire Hills, Hitchcock 9758. Hope Gardens, Amer.Gr.Nat.Herb.9.

Curaģao: Santa Cruz, Britton \& Shafer 2986, 3004. Aruba, Suringar in 1885. (K. U. Herb.)

Colombia: Santa Marta, Smith 209. Cartagena, Hitchcock 9922. Puerto de Colombia, Hitchcock 9940.

11. Panicum adspersum Trin.

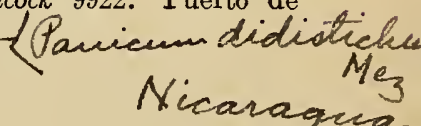

Panicum adspersum Trin. Gram. Pan. 146. 1826; Contr. U. S. Nat. Herb. 15: 43. 1910.

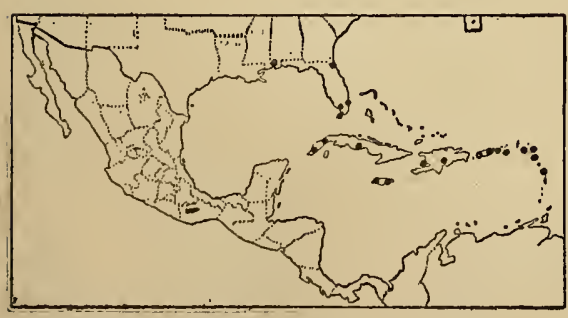

FIG. 22.-Distribution of P. adspcrsum.

\section{DISTRIBUTION.}

Moist open ground, Florida and the West Indies. The type specimen from Santo Domingo.

Bahamas: Nassau, Curtiss 113. Anguilla Isles, Wilson 8066.

Cuba: Habana Vedado, León 291, 1978. Habana, León 570, Curtiss 748. Santiago de las Vegas, Baker \& Wilson 512, Tracy 9109, Hitchcock 147, 148. Tris-

cornia, Hitchcock 159. Cabanas, Palmer \& Riley 746, 771. Herradura, Tracy 9102. Sancti Spiritus, León 925. Guines, Leon 924. Zaza del Sur, Sergius 2776. Without locality, Wright 3869. 
Jamaica: Black River, Hitchcock 9630. Hope Gardens, Amer. Gr. Nat. Herb. 10, 11, Harris 11247. Kingston, Hitchcock 9750. Alligator Pond, Hitchcock 9830.

Gordon Town, Harris 11343, 11512. Yallahs Valley, Harris 11498.

Hattr: Gonaïves, Buch 23.

Santo Domingo: Barahona, Fuertes 43.

Porto Rico: Between Coamo and Aibonito, Sintenis 1957, Chase 6333. Joyuda,

Chase 6302. Guanica, Chase 6514. Mayaguez, Chase 6286. Bayamon, Hioram 315. Vieques, Chase 6686.

Danish West Indies: St. Croix, Eggers in 1876, Ricksecker 66, 384.

Leeward Islands: Antigua, Wullschlaegel 615, 616. Guadeloupe, Duss 3180.

Saba, Boldingh 1583 (K. U. Herb.). St. Eustatius, Suringar in 1885 (K. U.

Herb.). St. Bartholomew, Goës (K. U. Herb.).

Windward Islands: Duss 537b (K. U. Herb.).

12. Panicum arizonicum Scribn. \& Merr.

Panicum arizonicum Scribn. \& Merr. U. S. Dept. Agr. Div. Agrost. Circ. 32: 2. 1901; Contr. U. S. Nat. Herb. 15: 44. 1910.

\section{DISTRIBUTION.}

Open sandy or stony ground, southwestern United States and northern Mexico. The type specimen from Arizona.

Lower California: Arroyo San Lazaro, Brandegee in 1902. San José del Cabo, Brandegee in 1890.

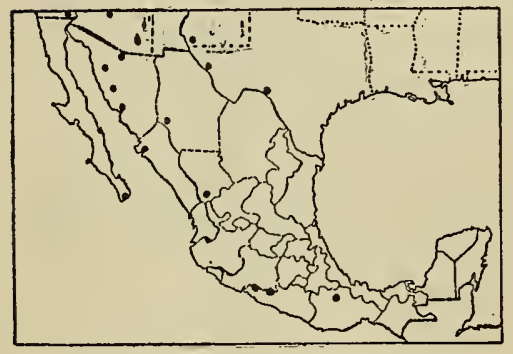

FIG. 23.-Distribution of $P$. arizonicum. Sonora: Nogales, Griffiths 6747, 6759, Hitchcock 3637. Lokuka Ranch to Altar, Griffiths 6891. Guaymas, Palmer 159 and 208 in 1887. Hitchcock 3562. Hermosillo, Hitchcock 3542.

Chinuahua: Norogachi, Palmer $1 B$ in 1885. Chihuahua, Pringle 487.

SinaloA: Topolobampo, Palmer 250 in 1897.

Durango: Without locality, Rose 2280.

Guerrero: Río Balsas, Orcutt 4195. Balsas, Hitchcock 6775.

OAxaca: Tomellín, Hitchcock 6192, Amer. Gr. Nat. Herb. 13.

\section{Panicum texanum Buckl.}

Panicum texanum Buckl. Prel. Rep. Geol. Agr. Surv. Tex. App. 3. 1866; Contr. U. S. Nat. Herb. 15: 46. 1910.

\section{DISTRIBUTION.}

Prairies and open ground, often a weed in fields, Texas and northern Mexico. The type specimen from Texas.

Nuevo León: Monterrey, Hitchcock 5540 .

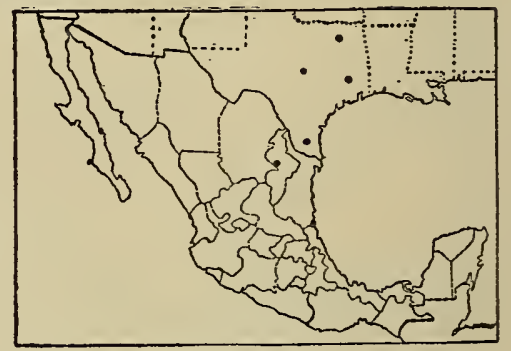

FIG. 24.-Distribution of $P$. texanum. 


\section{DICHOTOMIFLORA.}

Three species of this group, Panicum aquaticum, $P$. sucosum, and $P$. elephantipes, are found to be perennial.

Plants annual.

Panicles narrow, less than $1 \mathrm{~cm}$. wide

14. P. vaseyanum.

Panicles open, the branches ascending or spreading.

Sheaths glabrous......................... 15. P. dichotomiflorum.

Sheaths papillose-hispid.................... 16. P. bartowense.

Plants perennial.

Fruit not acuminate; panicles rarely over $18 \mathrm{~cm}$. long... 17. P. aquaticum.

Fruit acuminate; panicles as much as $40 \mathrm{~cm}$. long, rarely

less than $20 \mathrm{~cm}$.; culms succulent.

Spikelets about $3.5 \mathrm{~mm}$. long; fruit abruptly acuminate.............................. 18. P. sucosum.

Spikelets 4 to $5 \mathrm{~mm}$. long; fruit long-acuminate; culms very succulent.................. 19. P. elephantipes.

14. Panicum vaseyanum Scribn.

Panicum vaseyanum Scribn.; Beal, Grasses N. Amer. 2: 140. 1896; Contr. U. S. Nat. Herb. 15: 47. 1910.

\section{DISTRIBUTION.}

Moist open ground, around ponds and depressions in prairies, northern Mexico. The type specimen from Chihuahua.

Chrнuahua: Base of Sierra Madre, Pringle 1415. Miñaca, Hitchcock 7757.

Aguascalientes: Aguascalientes, Hitchcock 7491, Amer. Gr. Nat. Herb. 15.

JALISco: Guadalajara, Hitchcock 7315.

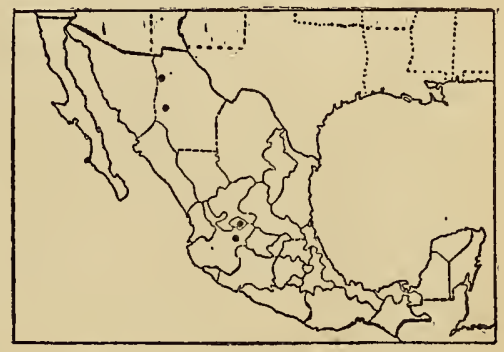

FIG. 25.-Distribution of $P$. vaseyanum.

\section{Panicum dichotomiflorum Michx.}

Panicum dichotomiflorum Michx. Fl. Bor. Amer. 1: 48. 1803; Contr. U. S. Nat. Herb. 15: 48.1910.

The South American Panicum chloroticum Nees, included in the Revision in $P$. dichotomiflorum, is a distinct species, or possibly a subspecies. It is not known from north of Brazil.

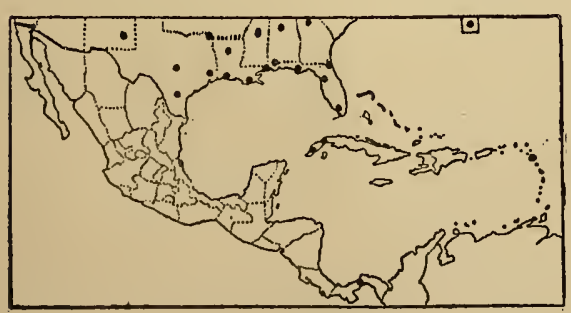

FIG. 26.-Distribution of $P$. dichotomiflorum.

\section{DISTRIBUTION.}

Moist ground along streams and a weed in waste places and in cultivated soil, Maine to Florida and California (rare in the West), and in the West Indies and Panama. The type specimen from the Alleghenies.

Panama: Near Chepo, Pittier 4614. Gatun, Hitchcock 7977.

Bermuda: Hamilton, Millspaugh 126.

Bamamas: Hog Island, Eggers 4405, 4512. Watlings, Geogr. Soc. Baltimore 489. Nassau, Curtiss 177. Cat Cay, Brace 3742. 
CubA: Herradura, Tracy 9055, 9342, Britton \& Earle 6566. Ariguanabo, León $1975 \frac{1}{2}$, 2774, 2775. Santiago de las Vegas, Hitchcock 151. Batabanó, Hitchcock 150. Leeward Islands: Guadeloupe, Duss 3178.

16. Panicum bartowense Scribn. \& Merr.

Panicum bartowense Scribn. \& Merr. U. S. Dept. Agr. Div. Agrost. Circ. 35: 3. 1901; Contr. U. S. Nat. Herb. 15: 52. 1910.

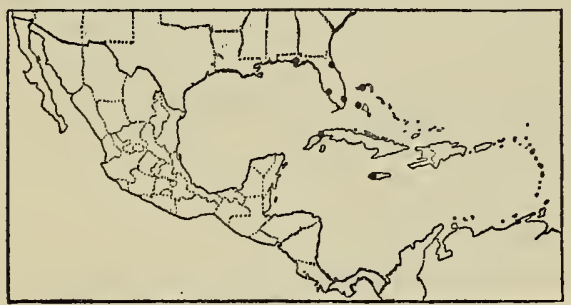

FIG. 27.-Distribution of $P$. bartowense.

\section{DISTRIB UTION.}

Low ground, often growing in shallow water, Florida, Bahamas, Cuba, and Jamaica. The type specimen from Bartow, Florida.

Baramas: Great Bahama, Britton \& Millspaugh 2706. North Bimini, Brace 3467 (Field Mus. Herb.).

CuBA: Batabanó, Hitchcock 149. Without locality, Wright 3860 .

JAMArCA: Black River, Amer. Gr. Nat. Herb. 18.

\section{Panicum aquaticum Poir.}

Panicum aquaticum Poir. in Lam. Encycl. Suppl. 4: 281. 1816. "Cette plantecrôt à Porto-Ricco; elle m'a été comuniquée par M. Ledru." The type is in the Cosson Herbarium. In the Revision ${ }^{1}$ this species was included in $P$. dichotomiflorum Michx. Subsequent field study has shown it to be a perennial.

Panicum chloroticum sylvestre Nees; Trin. Gram. Pan. 236. 1826; Contr. U. S. Nat. Herb. 15: 48. 1910.

Panicum hygrophilum Salzm.; Steud. Syn. Pl. Glum. 1: 71. 1854; Contr. U. S. Nat. Herb. 15: 49. 1910.

Panicum proliferum strictum Griseb. Cat. Pl. Cub. 232. 1866; Contr. U. S. Nat. Herb. 15: 49.1910.

\section{DESCRIPTION.}

Plants perennial, mostly aquatic, glabrous except as noted; culms usually decumbent at base, rooting at the nodes, erect branches often arising therefrom, the flowering culms erect, simple or sparingly branching, averaging lower and more slender than in $P$. dichotomiflorum; sheaths usually overlapping, rarely pilose at the junction with the blade; ligule a ring of hairs about $1 \mathrm{~mm}$. long; blades commonly elongated, as much as $25 \mathrm{~cm}$. long, but sometimes 5 to $10 \mathrm{~cm}$. long and abruptly pointed, 5 to $10 \mathrm{~mm}$. wide, linear, acute, occasionally sparsely pilose on the upper surface toward the base; panicles terminal and axillary, short-exserted or included at base, averaging smaller than those of $P$. dichotomiflorum, rarely as much as $20 \mathrm{~cm}$. long, less freely branching and fewer flowered, the branchlets and pedicels smooth or nearly so on the angles; spikelets 3 to $3.4 \mathrm{~mm}$. long, $1 \mathrm{~mm}$. wide, more gradually

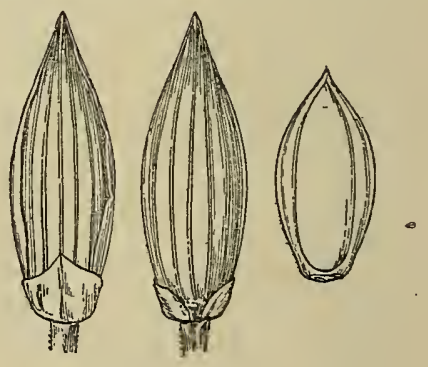

Fig. 28.-P. aquaticum. From type specimen. pointed than those of $P$. dichotomiflorum, the fruit slightly larger and more pointed than in that species.

Herbarium specimens lacking basal parts are difficult to distinguish from $P$. dichotomiflorum. 
DISTRIBUTION.

Wet places or in shallow water, margins of streams and ponds, mostly at low altitudes, Cuba, Porto Rico, and Mexico to Trinidad and Paraguay.

Colma: Alzada, Hitchcock 7067.

Guatemala: Puerto Barrios, Hitchcock 9147.

CuBA: Guanabacoa, León 919. Ariguanabo, León 1975, 1976. Habana, León 4155 . El Caño, León 1974. Laguna Jovero, Shafer 10912. Without locality, Wright 3456 in part, 3861.

Porto Rrco: Laguna del Tortuguero, Chase 6804. Lake Loisa,

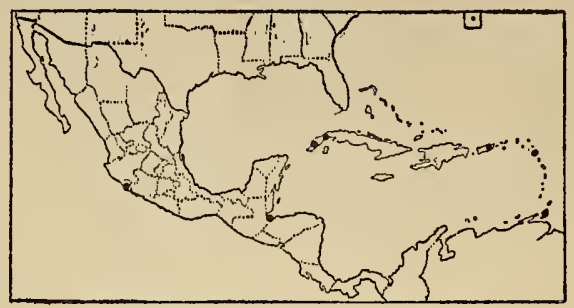

FIG. 29.-Distribution of $P$. aquaticum.

Chase 6778. Alto de Bandera, Chase 6471. Utuado, Britton \& Cowell 432.

Lenward Islands: Guadeloupe, Duss 3178 (K. U. Herb.).

Trinidad: Pitch Lake, Hitchcock 10099.

\section{Panicum sucosum sp. nov.}

\section{DESCRIPTION.}

Plants perennial, glabrous throughout except as noted; culms few to several in a tuft, 1 to 1.5 meters long, decumbent at base and rooting at the lower nodes, succulent; sheaths rather loose, about as long as the internodes; ligule a densely ciliate membrane about $1 \mathrm{~mm}$. long; blades flat or somewhat involute in drying, 15 to $30 \mathrm{~cm}$. long, 3 to $9 \mathrm{~mm}$. wide, linear, acuminate, scaberulous on both surfaces, sparsely pilose

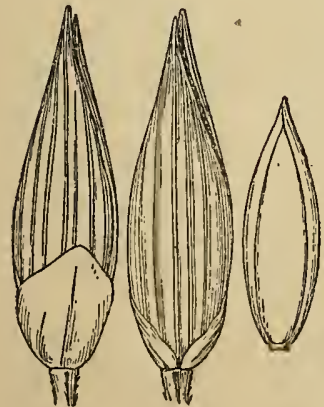

FIG. 30.-P. sucosum. From type specimen. above toward the base; panicle 15 to $30 \mathrm{~cm}$. long, about half as wide, the axis and branches somewhat scabrous, the branches solitary or in pairs, rather stiffly spreading or finally horizontal, as much as $15 \mathrm{~cm}$. long, naked at base for 1 or $2 \mathrm{~cm}$., the internodes of the rachis mostly 3 to $5 \mathrm{~cm}$. long, the branchlets appressed or ascending, mostly from the lower side; spikelets short-pediceled, somewhat appressed to the rachis, 3.3 to $3.7 \mathrm{~mm}$. long, about $1 \mathrm{~mm}$. wide, lanceolate, acuminate, glabrous; first glume one-fourth to nearly one-third the length of the spikelet, broadly triangular, usually subacute, 3-nerved; second glume and sterile lemma subequal, exceeding the fruit and pointed beyond it, 7 to 9 -nerved; fruit about $2.5 \mathrm{~mm}$. long, $0.7 \mathrm{~mm}$. wide, rather abruptly acuminate.

Type in the U. S. National Herbarium, no. 693325, collected in water of a pond at Orozco, near Guadalajara, Jalisco, Mexico, September 29, 1910, by A. S. Hitchcock (no. 7379).

This species, which in the Revision ${ }^{1}$ was included in $P$. elephantipes, differs from $P$. dichotomiflorum in being perennial and in having larger spikelets; from $P$. aquaticum in its larger panicle and more pointed spikelets and fruit; from $P$. elephantipes in having smaller, less succulent culms with narrower blades and in having less acuminate fruit. 


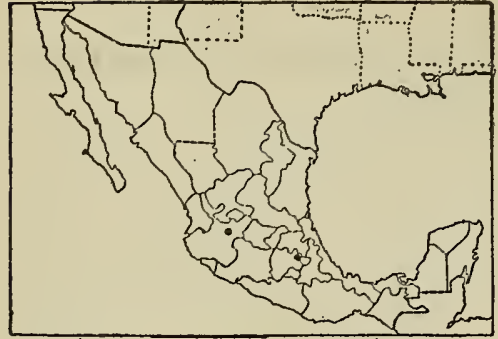

FIG. 31.-Distribution of $P$. sucosum.

\section{DISTRIBUTION.}

In water of ponds at high altitudes, southern Mexico.

Jalisco: Orozco, Hitchcock 7379.

México: Near Mexico City, Orcutt 4269, Pringle 6322, 9577, Bourgeau 529.

Republic of Mexico: Without locality, Schaffner 525

19. Panicum elephantipes Nees.

Panicum elephantipes Nees, Agrost. Bras. 165. 1829; Contr. U. S. Nat. Herb. 15: 53. 1910.

Field study has shown that this species is perennial.

DISTRIBUTION.

In ponds and shallow weter at low altitudes, West Indies and Guatemala, south to Argentina. The type specimen from Brazil.

Guatemala: Near mouth of Río Pol_ ochic, Alta Verapaz, Goll 35A.

CUBA: San Antonio, Hitchcock 152. Almendares River, León 335.

JAmaica: Middle Quarters, on Black River, Amer. Gr. Nat. Herb. 19. Savanna-Ia-Mar, Hitchcock 9878.

Porto Rico: Between Cataño and Bayamon, Chase 6407. Dorado, Chase 6415. Fajardo, Sintenis 938 .

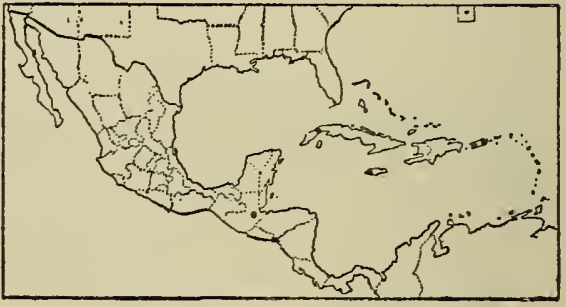

FIG. 32.-Distribution of $P$. elephantipes.

CAPILLARIA.

Panicles more or less drooping 25. P. sonorum.

Panicles erect.

Inflorescence elongated, composed of several approximate, implicate panicles............................

Inflorescence not composed of approximate nor implicate panicles.

Panicles more than half the length of the entire plant.. 20. P. capillare. Panicles not more than one-third the entire height of the plant.

First glume about one-third the length of the spikelets, subacute or blunt..............24. P. stramineum.

First glume usually more than half the length of the spikelet, acuminate.

Spikelets 4.5 to $6 \mathrm{~mm}$. long.

Spikelets $6 \mathrm{~mm}$. long, scattered.

Spikelets scarcely over $5 \mathrm{~mm}$. long, approximate................. 23. P. decolorans.

Spikelets not over $4 \mathrm{~mm}$. long.

First glume more than three-fourths the length of the spikelet; spikelets 4 $\mathrm{mm}$. long ....................... 27. P. cayennense. of the spikelet; spikelets not over 3.3 $\mathrm{mm}$. long. 


\section{Panicum capillare L.}

Panicum capillare L. Sp. Pl. 58. 1753; Contr. U. S. Nat. Herb. 15: 60. 1910.

\section{DISTRIBUTION.}

Open ground, common in eastern United States, introduced in Bermuda. The type specimen from Virginia.

Bermuda: North Shore Road, Brown \& Britton 21.

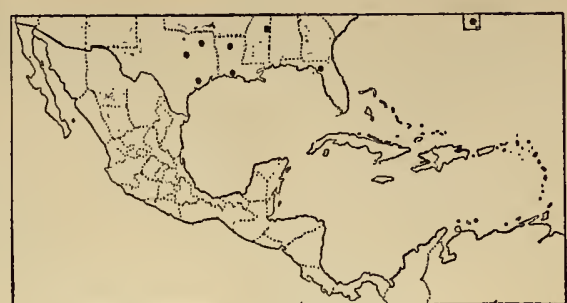

FIG. 33.-Distribution of $P$. capillare.

\section{Panicum hirticaule Presl.}

Panicum hirticaule Presl, Tel. Haenk. 1: 308. 1830; Contr. U. S. Nat. Herb. 15: 64. 1910.

\section{DISTRIBUTION.}

Rocky or sandy soil, southwestern United States and south through Mexico to South America; also in Haiti. The type specimen from Acapulco, Mexico.

Lower California: San José del Cabo, Brandegee 42. Purísima, Brandegee in 1889.

Sonora: Nogales, Hitchcock 3631, Griffiths 6758, 6799. Lokuka Ranch to Altar, Griffiths 6892. Llano, Hitchcock 3526. Johnstons Ranch, east of San Pedro River, Merton 1705. Guaymas, Hitchcock 3547, 3553, Palmer 208 and 346 in 1887. Alamos, Palmer 690, 695, and 750 in 1890. White Water, Mearns 2294.

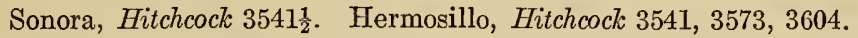

Chindahua: Southwestern Chihuahua, Palmer $1 \mathrm{~b}$ in 1885 . Between Casas Grandes and Sabinal, Nelson 6355. Sierra Madre, Nelson 6297.

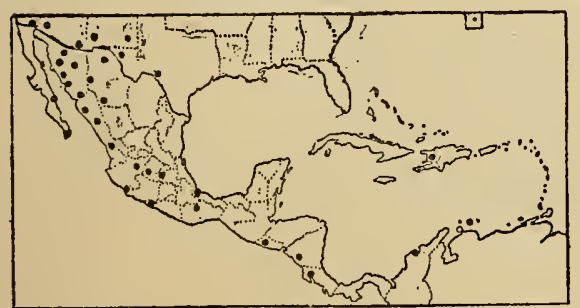

FIG. 34.-Distribution of $P$. hirticaule.

Sinaloa: Culiacán, Palmer 1544, 1545, and 1554 in 1891 . Topolobampo, Palmer 249 and 251 in 1897.

Tepic: Between Aguacate and Dolores, Rose 3351.

JALIsco: Guadalajara, Hitchcock 7357.

Guanajuato: Irapuato, Hitchcock 7424.

Querétaro: Querétaro, Hitchcock 5846.

Colmas: Alzada, Hitchcock 7089, 7096, 7104. Without locality, Palmer 14, 143, and 145 in 1897.

Veracruz: Baños del Carrizal, Purpus 6212.

Guerrero: Balsas, Hitchcock 6773, 6814, 6815. Río Balsas, Orcutt 4197.

OAxaca: Tomellín, Hitchcock 6248, Amer. Gr. Nat. Herb. 28.

Salvador: La Unión, Hitchcock 8794. West side of Lake Ilopango, Hitchcock 8924.

Nicaragua: Masaya, Hitchcock 8654. Without locality, Flint in 1868.

Costa Rica: $\Lambda$ tenas, Hitchcock 8517.

Hattr: Near the River Artibonite, Picarda 1654.

Curaça: Boldingh 5379 .

Colombia: Puerto de Colombia, Hitchcock 9927. 
22. Panicum pampinosum Hitchc. \& Chase.

Panicum pampinosum Hitchc. \& Chase, Contr. U. S. Nat. Herb. 15: 66. 1910. Culms 15 to $40 \mathrm{~cm}$. high, ascending from a decumbent base or widely spreading.

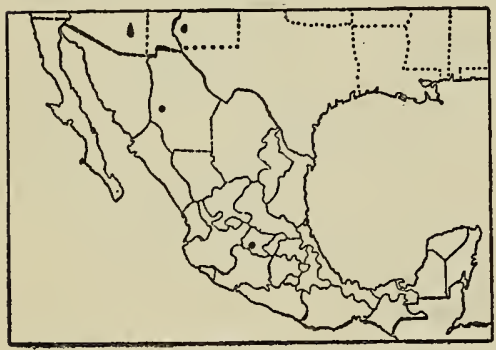

FIG. 35.-Distribution of $P$. pampinosum.

\section{DISTRIBUTION.}

Open ground and depressicns in mesas, southwestern United States to central Mexico. The type specimen from Arizona.

Chinuahua: Miñaca, Hitchcock 7751, 7756.

Guanajuato: Acámbaro, Hitchcock 6952.

23. Panicum decolorans H. B. $K$.

Panicum decolorans H. B. K. Nov. Gen. \& Sp. 1: 100. 1816; Contr. U. S. Nat. Herb. 15: 66. 328. 1910.

\section{DISTRIBUTION.}

Fields and waste ground, central Mexico. The type specimen from Querétaro.

San Luis Potosí: Cárdenas, Amer. Gr. Nat. Herb. 29.

QuerÉTaro: Querétaro, Basile 51, 52, Hitchcock 5822, 5864 .

Puebla: Tehuacán, Hitchcock 6057.

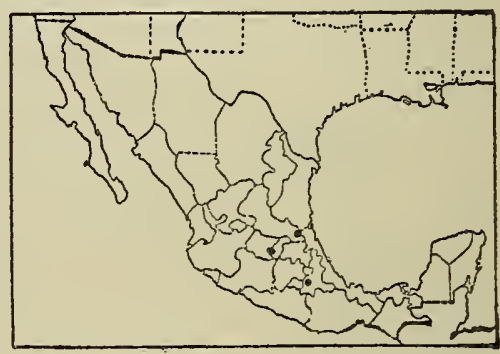

FIG. 36.-Distribution of $P$. decolorans.

24. Panicum stramineum Hitchc. \& Chase.

Panicum stramineum Hitchc. \& Chase, Contr. U. S. Nat. Herb. 15: 67. 1910.

This species was described as having glabrous (or sometimes ciliate) blades. Later collections show that the blades are sometimes sparsely papillose-pilose.

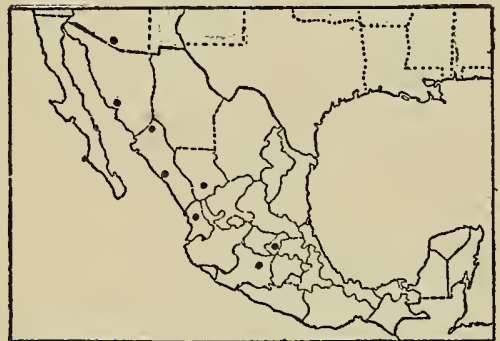

FIG. 37.-Distribution of $P$. stramineum.

\section{DISTRIBUTION.}

Rich bottom lands and damp soil, Arizona to Michoacán. The type specimen from Guaymas.

Sonora: Guaymas, Palmer 168a and 206 in 1887.

Sinaloa: Culiacán, Palmer 1538 in 1891. Between Rosario and Acaponeta, Rose 1878, 1883.

Durango: Durango, Hitchcock 7658.

TePIC: Between Concepción and Acaponeta, Rose 1889. Acaponeta, Rose 3281. Michoacán: Morelia, Arsène 60, 2985.

Guerrero: Lagunillas, Langlassé $263 .^{1}$

${ }^{1}$ In the Revision this specimen was doubtfully referred to $P$. filipes Scribn. (Contr. U. S. Nat. Herb. 15: 74. 1910). 
25. Panicum sonorum Beal.

Panicum sonorum Beal, Grasses N. Amer. 2: 130. 1896; Contr. U. S. Nat. Herb. 15: 67.1910.

\section{DISTRIBUTION.}

Rich bottom land, northwestern Mexico. The type specimen from Lerdo.

Sonora: Lerdo, Palmer 947 in 1889. Without locality, Palmer in 1885.

CHнHUAнUA: Southwestern Chihuahua, Palmer $1 \mathrm{c}$ in 1885.

SinaloA: Culiacán, Palmer 1539 and 1554 in 1891.

CHIAPAS: Between San Ricardo and Ocozucuantla, Nelson 2959.

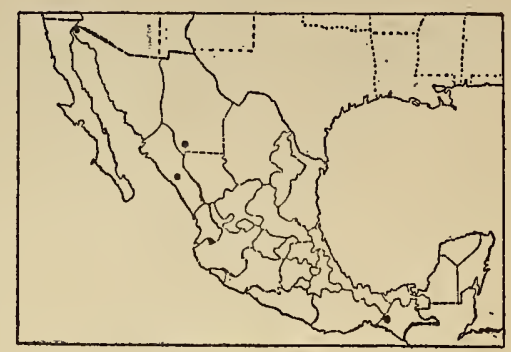

FIG. 38.-Distribution of $P$. sonorum.

26. Panicum parcum Hitchc. \& Chase.

Panicum parcum Hitchc. \& Chase, Contr. U. S. Nat. Herb. 15: 68. 1910.

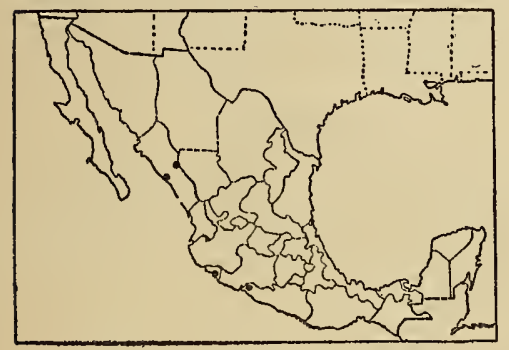

FIG. 39.-Distribulion of $P$. parcum.

\section{DISTRIBUTION.}

Open rocky soil, Sinaloa to Guerrero. The type specimen from Sinaloa.

Sinaloa: Lodiego, Palmer 1657. Copradía, Brandegee in 1904.

Colima: Alzada, Orcutt 4687, Hitchcock 7081.

Guerrero: Balsas, Hitchcock 6808, 6810, 6811, Amer. Gr. Nat. Herb. 30 .

\section{Panicum cayennense Lam.}

Panicum cayennense Lam. Tabl. Encycl. 1: 173. 1791; Contr. U. S. Nat. Herb. 15: 70. 1910.

DISTRIBUTION.

Open ground and pine woods, Cuba, Costa Rica to Brazil. The type from French Guiana.

Costa Rica: Buenos Aires, Tonduz 3685.

Panama: Dolega, Hitchcock 8335. David, Amer. Gr. Nat. Herb. 31.

Cuba: Isle of Pines, Curtiss .267, Taylor 34, Palmer \& Riley 1086. Herradura, Tracy 9073, Britton, Earle \& Gager 6520. Sierra de Cabra, Brillon, Earle \& Gager

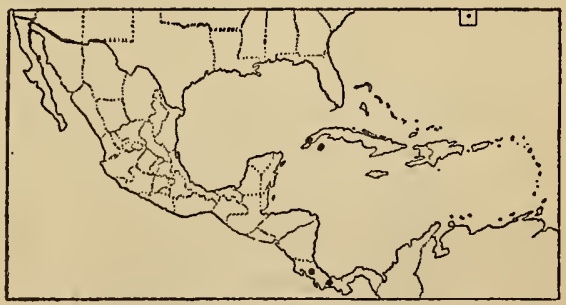

FIG. 40.-Distribution of $P$. cayennense. 7275. Laguna Jovero, Shafer 10910. Sumidero, León \& Shafer 13717. Pinar del Río, Wright 3865. 


\section{DIFFUSA.}

Second glume and sterile lemma elongated, at least three times as long as the fruit............................ 28. P. capillarioides.

Second glume and sterile lemma not elongated.

Culms as much as $1 \mathrm{~cm}$. thick; blades $2 \mathrm{~cm}$. or more wide.. $33 . P$. hirsutum.

Culms slender; blades not over $1 \mathrm{~cm}$. wide.

Blades 1 to $3 \mathrm{~mm}$. wide; plants spreading or ascending. 29. P. diffusum.

Blades mostly over $5 \mathrm{~mm}$. wide; plants erect.

Spikelets 4 to $4.2 \mathrm{~mm}$. long, the midnerves of glumes and sterile lemma scabrous toward the apex.......................... 31. P. lepidulum.

Spikelets usually less than $3.5 \mathrm{~mm}$. long.

Blades hirsute on both surfaces (sometimes glabrescent), not at all glaucous....... 32. P. ghiesbreghtii.

Blades glabrous on both surfaces or with a few hairs on either surface, glaucous above.. 30. $P$. hallii.

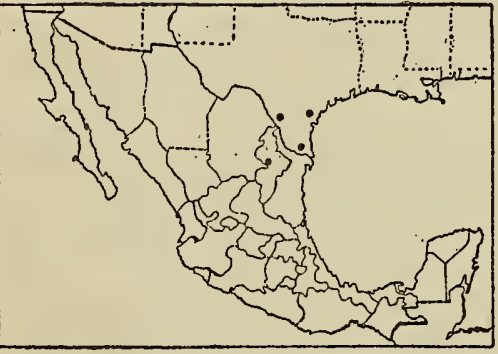

FIG. 41.-Distribution of $P$. capillarioides.

\section{Panicum capillarioides Vasey.}

Panicum capillarioides Vasey in Coulter, Contr. U. S. Nat. Herb. 1: 54. 1890; Contr. U. S. Nat. Herb. 15: 72. 1910.

\section{DISTRIBUTION.}

Prairies, southern Texas and northern Mexico. The type specimen from Texas.

Nuevo León: Monterrey, Hitchcock 5547.

\section{Panicum diffusum Swartz.}

Panicum diffusum Swartz, Prodr. Veg. Ind. Occ. 23. 1788; Contr. U. S. Nat. Herb. 15: 72.1910.

Panicum guadalupense Spreng.; Steud. Nom. Bot. ed. 2. 2: 257. 1841. This is a nomen nudum, ascribed to "Spr. hrb. Trin. mpt. Guadal." In the Krug \& Urban Herbarium is a specimen of Panicum diffusum, collected by "Bertero, S. Domingo," marked in Sprengel's hand "Panicum guadalupense."

\section{DISTRIBUTION.}

Banks, cliffs, and savannas, West Indies. The type specimen from Jamaica or Hispaniola.

Bahamas: New Providence, Britton \& Brace 424.

Cuba: Campo Florido, León 3449.

Vibora Habana, León 2532.

Monte la Noria, León 2559.

Bahía Honda, Wilson 9443.

Holguin, Shafer 1512. La

Gloria, Shafer 385 . Columbia,

León 305 in part, 923b. Ar-

royo Apolo, León 190, 923.

Province of Santa Clara, León

923c. Santiago de las Vegas,

Tracy 9111 , Van Hermann 1444,

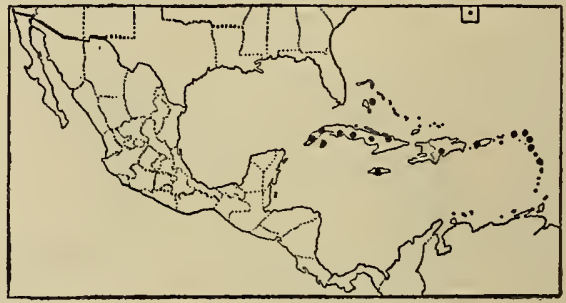

FIG. 42.-Distribution of $P$. diffusum.

Baker \& Wilson 511, Wilson 1405. Hanábana, Wright in 1865. Triscornia, Tracy 9082. Guanajay, Palmer \& Riley 802. Isle of Pines, Curtiss 384, 494. Without locality, Wright 1540, 3852, 3860 in part, 3877. 
JAMaICA: Ewarton to Linstead, Hitchcock 9463.

Santo Domingo: Without locality, Wright, Parry \& Brummel 627. Azua, Rose, Fitch \& Russell 4410.

Ponto Rico: Quebradillas, Chase 6567, 6577. Joyuda, Chase 6308.

Danish West Indies: St. Thomas, Eggers in 1882.

Leeward Islands: Antigua, Wullschlaegel 64. Guadeloupe, Duss 3177, 3181 (K. U. Herb.). St. Bartholomew, Goës (K. U. Herb.).

Windward Islands: Martinique, Duss 536, Hahn 1232.

\section{Panicum hallii Vasey.}

Panicum hallii Vasey, Bull. Torrey Club 11: 64. 1884; Contr. U. S. Nat. Herb. 15: 74. 1910.

- DISTRIBUTION.

Dry prairie, rocky and gravelly hills and canyons, and in irrigated fields, Texas to Arizona and south to central Mexico. The type specimen from Texas.

Chinuahua: Santa Eulalia Mountains, Pringle 376.

Durango: Without locality, Palmer - 525 in 1896.

Confunla: Monclova, Palmer 1338 in

1880. Saltillo, Hitchcock 5605.

Nuevo León: Monterrey, Hitchcock 5537.

Tamaulipas: Victoria, Palmer 554 in 1907.

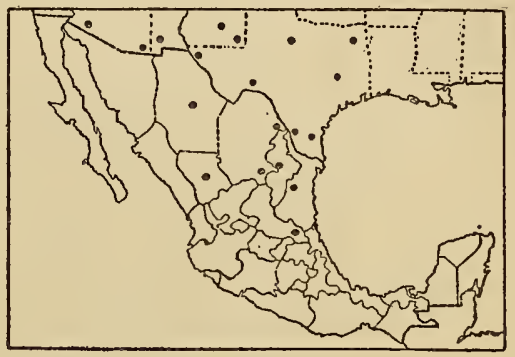

Fig. 43.-Distribution of P. hallii.

San Lurs Potosí: Las Canoas, Hitchcock 5756. Cárdenas, Hitchcock 5719⿺辶一

31. Panicum lepidulum Hitchc. \& Chase.

Panicum lepidulum Hitchc. \& Chase, Contr. U. S. Nat. Herb. 15: 75.1910.

DISTRIBUTION.

Rocky hills and moist banks, Mexico to Panama. The type specimen from Chihuahua.

Chimuahua: Chihuahua, Pringle 497.

Durango: Durango, Palmer 525 in 1896, Hitchcock 7591. Tobar, Palmer 533 in 1906.

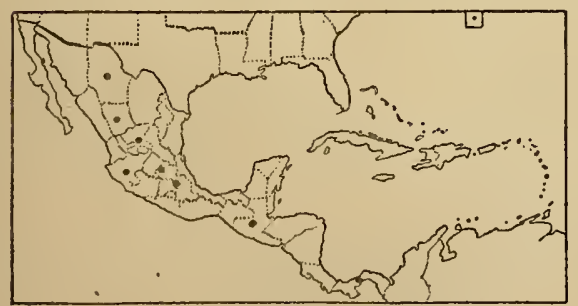

FIG. 44.-Distribution of P. lepidulum.

ZACATECAS: Zacatecas, Hitchcock 7510.

San Luis Potosí: Cárdenas, Hitchcock 5719.

JALISCO: San Nicolás, Hitchcock 7199. Zapotlán, Hitchcock 7238.

QuerÉta Ro: San Juan del Río, Rose, Painter \& Rose 9555.

MÉxico: Pedregal, Federal District, Amer. Gr. Nat. Herb. 35.

Pueblo: Tehuacán, Hitchcock 6063.

Guatemala: Guatemala City, Hitchcock 9014.

Panama: Sabano de Juan Corso, Pittier 4526.

$82472^{\circ}-15-3$ 
32. Panicum ghiesbreghtii Fourn.

Panicum ghiesbreghtii Fourn. Mex. PI. 2: 29. 1886; Contr. U. S. Nat. Herb. 15: 76. 1910.

\author{
DISTRIBUTION
}

Low moist ground, Mexico and West Indies to northern South America. The type specimen from Mexico.

JAL1sco: Zapotlín, Hitchcock 7117.

Veracruz: Córdoba, Hitchcock 6418, 6426. Jalapa, Hitchcock 6546. Orizaba, Bourgeau 2751, Hitchcock 6363, Amer. Gr. Nat. Herb. 36.

OAXaca: Oaxaca, Hitchcock 6143.

YuCATÁN: Izamal, Gaumer 2477.

SALVAdor: Acajutla, Hitchcock 8993.

Nicaragua: Corinto, Hitchcock 8755. San Juan del Sur, Hitchcock 8601. Jinotepe, Hitchcock 8687.

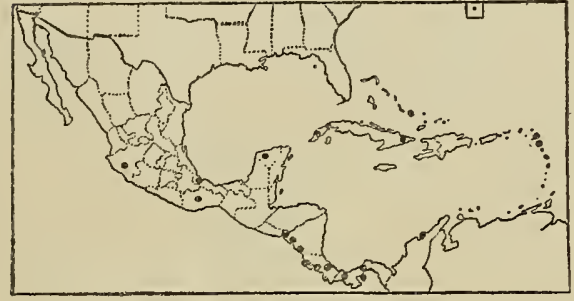

FIG. 45.-Distribution of $P$. ghiesbreghtii.

Costa Rica: San José, Hitchcock 8452. Guanacaste, Jiménez 730. Llano Grande de Puriscal, Jiménez 880. Nuestro Amo, Jiménez 530. Salinas Bay, Pittier 2633, Tonduz 2858.

Panava: South of David, Hitchcock 8377. Balboa, Hitchcock 7997, 8014. Taboga Island, Hitchcock 8065,8094 .

Bahamas: Crooked Island, Brace 4812. Cuba: La Soledad, Eggers 5406. Herradura, Tracy 9068. Santiago de las Vegas, Tracy 9116. La Perla, León 3783. El Calvario, León 922, 2674. Guayabal, León 922b. Without locality, Wright 758. Eastern Cuba, Wright. Santiago de Cuba, León 3747.

Porto Rico: Coamo Springs, Chase 6547. Cayey, Chase 6744. Tabucoa, Sintenis 4983.

Lemward Islands: Guadeloupe, Duss 3184. - Antigua, Wullschlaegel 620, 621. (K. U. Herb.).

Colombia: Santa Marta, Smith 165.

\title{
33. Panicum hirsutum Swartz.
}

Panicum hirsutum Swartz, Fl. Ind. Occ. 1: 173. 1797; Contr. U. S. Nat. Herb. 15: 77. 1910.

Panicum elatum Willd.; Steud. Nom. Bot. ed. 2. 2: 256. 1841. In the Willdenow Herbarium this unpublished name is written on a Humboldt collection from "America merid."

The sheaths, especially the lower, of this robust species are hirsute with spreading stiff hairs that cause mechanical irritation to the skin. The panicles are at first compact, with ascending branches, but become diffuse at maturity, the branches finally widely spreading. DISTRIBUTION.

Open moist soil, West Indies and central Mexico to northern South America. The type specimen from Jamaica.

Colima: Manzanillo, Hitchcock 7031.

OAxaca: San Antonio, Pringle 5573.

Costa RICA: Port Limon, Hitchcock 8435. Along Bananita River, Pittier 3634. Zent Farm, Pittier in 1904, Tonduz 266. Puerto Viejo, Biolley 7467. 
Panama: Between Bohío and Frijoles, Hitchcock 8397. Near Bohío, Hitchcock 8392. Tabernilla, Hitchcock 8382. Gorgona, Amer. Gr. Nat. Herb.37. Pedro Miguel, Hitchcock 7957. Puerto Obaldía, Pittier 4374. Culebra, Pittier 3441.

CubA: Matanzas, Wright in 1865. Guantínamo, León 3913.

LEeward Islands: Guadeloupe, Duss 3917.

WindwaRd Islands: Martinique, Duss 768 (K. U. Herb.).

Trinidad: St. Margaritas, Broadway 2629 . "Burke's pasture," Bot. Gard. Herb. 2295.

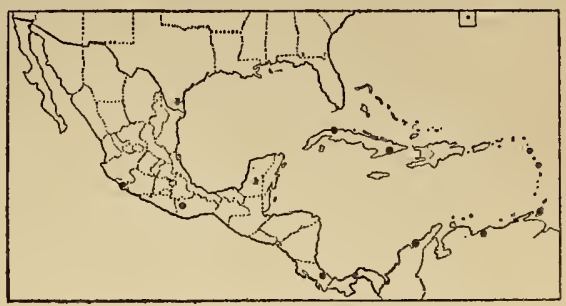

FIG. 46.-Distribution of $P$. hirsutum.

Venezuela: Río Grande del Tuy, Paparo, Pittier 6332. Bobures, Jahn 353, 355. Colombia: Santa Marta, Smith 164.

\section{MAXIMA.}

Culms with a cormlike base.

Blades mostly over $5 \mathrm{~mm}$. wide; culms more than 1 meter high.......................................... P. bulbosum.

Blades less than $5 \mathrm{~mm}$. wide; culms rarely as much as 1 meter high....................................... P. bulbosum

Culms from a creeping rootstock, not cormlike at base. sciaphilum.

Nodes hirsute; ligules 4 to $6 \mathrm{~mm}$. long; fruit strongly rugose....34. P. maximum.

Nodes glabrous; ligules $2 \mathrm{~mm}$. long; fruit very obscurely rugose.........................................

\section{Panicum maximum Jacq.}

Panicum maximum Jacq. Coll. Bot. 1: 76. 1786; Contr. U. S. Nat. Herb. 15: 78. 1910. DISTRIBUTION.

Open ground, at low altitudes, escaped from cultivation, southern Florida through Mexico and West Indies to South America, a native of Africa and now widespread in the warmer parts of the Old World. Type locality, Guadeloupe.

Sinaloa: Mazatlín, Rose, Standley \& Russell 14121.

Colma : Paso del Río, Emrick 3.

Veracruz: Córdoba, Fitchcock 6410, Finck 8, Kerber 48. Jalapa, Hitchcock 6621. Huitamalco, Liebmann 425

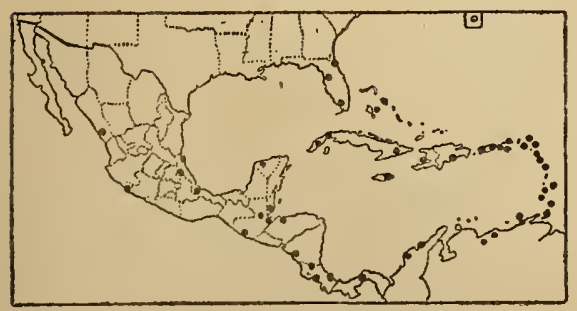

FIG. 47.-Distribution of $P$. maximum. in part. Veracruz, Hitchcock 6562. San Francisco, Smith 1409. Zacuapán, Purpus 3774.

YUCATÁn: Izamal, Gaumer 719.

Britisi Honduras: Manatee Lagoon, Peck 195 (Gray Herb.).

Guatemala: Escuintla, Smith 2705, 2706, Hitchcock 9001. Morales, Kellerman 6267. Gualán, Deam 6268. Finca Sepacuité, Alta Verapaz, Cook \& Griggs 579.

Honduras: Puerto Cortez, Kellerman 4725.

Salvador: San Salvador, Velasco 2. Izalco, Pittier 1960. Without locality, Renson 293. 
Nicaragua: Corinto, Hitchcock 8762.

Costa Rica: Zent Farm, Pitiier in 1904. Boca Banana, Tonduz 9114. San José, Pittier 9050. Nuestro Amo, Pittier 2034, 16662. Alajuelita, Tonduz 2995.

Panama: Taboga Island, Hitchcock 8080. Caña, Williams 779. Culebra, Pittier 2088, 4806, Amer. Gr. Nat. Herb. 38.

BerMudA: North Shore Road, Brown \& Britton 20, Harshberger in 1905.

Bahamas: Nassau, Curtiss 124. Eleuthera, Geogr. Soc. Baltimore 338.

Сuва: Herradura, Hitchcock 156. Guines, León 427, Liebmann 445. Santiago de las Vegas, Baker 32, Wilson 438, Hitchcock 157. Santiago de Cuba, León 915, Pollard \& Palmer 283. Guayabal, León 921. Marianao, León 957. Guanajay, Palmer \& Riley 816. San Diego de los Baños, Palmer \& Riley 542, 545. El Guama, Palmer \& Riley 178. Pinar del Río, Palmer \& Riley 377. Sierra de Anafe, León 2871.

Jamaica: Port Antonio, Fredholm 3319. Kingston, Hitchcock 9256, and in 1890. Gordon Town, Hart 797. Hope Gardens, Harris 11249.

Haitr: Gonaïves, Buch 468 (K. U. Herb.).

Santo Domingo: Azua, Rose, Fitch \& Russell 3949. San Pedro de Macoris, Rose, Fitch \& Russell 4172.

Porto Rico: Guanica, Sintenis 3366. Mayaguez, Sintenis 51, Chase 6256. Cayey, Sintenis 2468. Aibonito, Chase 6332. Sobrante, Eggers 1226. Martin Peña, Heller 377. Vieques, Chase 6669. Mona, Hess 449.

Danish West Indies: St. Croix, Ricksecker 200, 413. St. Thomas, Millspaugh 454, Eggers in 1887, Rose 3184.

LeeWARD Islands: Antigua, Wullschlaegel 623b, Rose, Fitch \& Russell 3452. Dominica, Jones 10. Guadeloupe, Duss 3186. St. Bartholomew, Goës (K. U. Herb.). Saba, Boldingh 1580, Suringar in 1885 (both in K. U. Herb.)

Windward Islands: Martinique, Duss 1288. Barbados, Dash 259. Grenada, Broadway in 1905. St. Vincent, Smith \& Smith 288 (K. U. Herb.).

Trinidad: Four Roads, Hitchcock 10049.

Toвago: Scarborough, Broadway 4081. Plymouth, Hitchcock 10239.

Venezuela: Caracas, Pittier 6163. Around Dos Caminos and Los Chorros, Pititier 5917. Río Grande del Tuy, Pittier 6327. Island of Margarita, Miller \& Johnston 177.

Colombia: Santa Marta, Smith 2153. Cartagena, Hitchcock 9917. Río Frío, Piltier 1617.

35. Panicum plenum Hitchc. \& Chase.

Panicum plenum Hitchc. \& Chase, Contr. U. S. Nat. Herb. 15: 80. 1910.

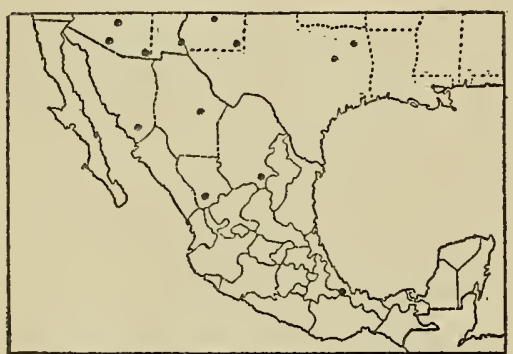

Fic. 48.-Distribution of $P$. plenum.

\section{DISTRIBUTION}

Moist places in rocky hills and canyons, southwestern United Stat3s to central Mexico. The type specimen from New Mexico.

Sonora: Las Cuevas, Hartman 170.

Chiнuahua: Santa Eulalia Plains, Wilkinson in 1885. Chihuahua, Hitchcock 7772.

Durango: Durango, Palmer 741 in 1896.

CoAmuila: Saltillo, Hitchcock 5609. Jaral, Schumann 1739.

Veracruz: Orizaba, Botteri 160. 
36. Panicum bulbosum H. B. K.

Panicum bulbosum H. B. K. Nov. Gen. \& Sp. 1: 99. 1816; Contr. U. S. Nat. Herb. 15: 81.1910.

\section{DISTRIBUTION.}

Moist places in canyons and valleys, southwestern United States to southern Mexico. The type specimen from central Mexico.

Chinuahua: Candelaria, Stearns 266. Chihuahua, Pringle 377. Colonia García, Nelson 6187, Townsend \& Barber 221. Sierra Madre, Nelson 6301. Mount Mohinora, Nelson 4901. Cañon de San Diego, Hartman 790.

Durango: Otínapa, Palmer 340 in 1906. Durango, Palmer 525a in 1896. Without locality, Palmer 741 in 1896.

Tepic: Between Aguacate and Dolores, Rose 3361. Between Pedro Paulo and San Blasito, Rose 1999.

San Luis Potosí: San Luis Potosí, Parry \& Palmer 958. Las Canoas, Hitchcock 5754.

JALISCo: Road between Mexquitic and Monte Escobedo, Rose 2609. Nevada de Colima, Hitchcock 7150. Río Blanco, Palmer 207 in 1886.

Michodcín: Morelia, Arsène in 1909.

México: Federal District, Orcutt 3518,

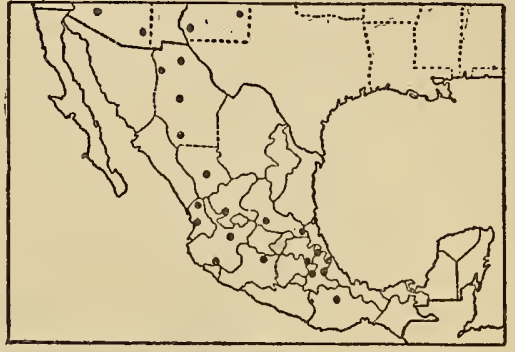

FIG. 49.-Distribution of $P$. bulbosum.

Hitchcock 5932, 5941, 7835, Amer. Gr. Nat. Herb. 39, Holway 12, Bourgeau 235, Rose \& Painter 9249, Pringle 9575, 6418. Valley of Toluca, Pringle 5207. Puebla: Chinantla, Liebmann 441, 442. Cerro de Baxtla, Purpus 2908. Esperanza, Seaton 317. Bords de l'Atoyac, Nicolas in 1909.

Veracruz: Borrego, Bourgeau 2754. Orizaba, Hitchcock 6384.

Oaxaca: Oaxaca, Nelson 1374. Cerro de San Felipe, Conzatti \& González 243.

36a. Panicum bulbosum sciaphilum (Rupr.) Hitchc. \& Chase.

Panicum bulbosum sciaphitum (Rupr.) Hitchc. \& Chase, Contr. U. S. Nat. Herb. 15: 83.1910.

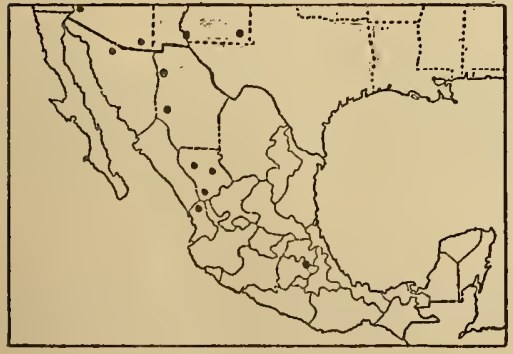

FIG. 50.-Distribution of $P$. bulbosum sciaphilum.
DISTRIB UTION.

Gravelly river banks, southwesternUnited States to central Mexico. The type specimen from central Mexico.

Sonora: Nogales to Cocospora Ranch, Griffiths $6785_{2}^{1}$.

Chinuahua: Cusihuiriachic, Pringle 1406. Sierra Madre, Nelson 6298. Sánchez, Hitchcock 7666.

Durango: Tejaméu, Palmer469 in 1906. Otínapa, Palmer 348,349 , and 554 in 1906. Santiago Papasquiaro, Palmer 467 in 1896. Iron Mountain, Hitchcock 7634 .

TePIC: Between Dolores and Santa Gertrudis, Rose 2053.

México: Barranca de Río Aqueducto, Rose \& Painter 8634. 


\section{VIRGATA.}

Perennials, mostly with stout rootstocks, one species, $P$. ichnanthoides found to be without rootstocks.

Creeping rootstocks wanting

40. P. ichnanthoides.

Creeping rootstocks present.

Spikelets not over $2.5 \mathrm{~mm}$. long; first glume less than half the length of the spikelet.

Panicles loosely flowered; first glume truncate, about one-fifth the length of the spikelet........... 37. P:repens.

Panicles rather densely flowered; first glume triangular, about one-third the length of the spikelet...... 38. P. gouini.

Spikelets 3 to $7 \mathrm{~mm}$. long (sometimes less than $3 \mathrm{~mm}$. in $P$. virgatum cubense); first glume more than half the length of the spikelet.

Culms decumbent or creeping at base.

Spikelets 3.2 to $4 \mathrm{~mm}$. long................ 41. P. altum.

Spikelets 6 to $8 \mathrm{~mm}$. long.................. 42. P. havardii.

Culms erect.

Panicles elongate, strongly contracted; seacoast plants............................

Panicles diffuse or only slightly contracted; plants sometimes of salt marshes but not littoral.

Panicles open, loosely-flowered; spikelets 3.5 to $5 \mathrm{~mm}$. long, beaked; first glume twothirds the length of the spikelet or more, acuminate-pointed............... 39. P. virgatum.

Panicles somewhat contracted; spikelets not over $3.2 \mathrm{~mm}$. long, not beaked; first glume about half the length of the spikelet, not acuminate

39a. P. virgatum

37. Panicum repens $\mathrm{L}$. cubense.

Panicum repens L. Sp. Pl. ed. 2. 87. 1762; Contr. U. S. Nat. Herb. 15: 85. 1910.

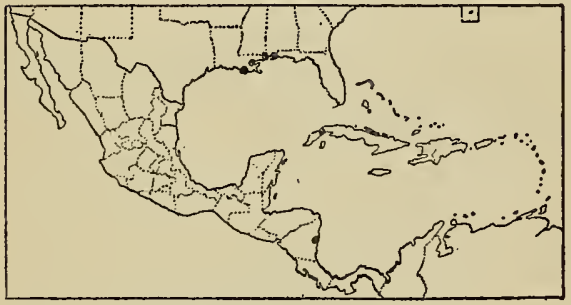

FIG. 51.-Distribution of $P$. repens.

\section{DISTRIBUTION.}

Sea beaches, warmer regions of both hemispheres; in America from Alam bama to Brazil. Originally described from the Old World.

Nicaragua: Without locality, Flint 8.

Cuba: Arroyo Apolo, León 296, 563. Habana, León in 1909. 
38. Panicum gouini Fourn.

Panicum gouini Fourn. Mex. P1. 2: 28. 1886; Contr. U. S. Nat. Herb. 15: 86. 1910. DISTRIBUTION.

Sea beaches along the Gulf of Mexico. The type specimen from Veracruz.

Veracruz: Veracruz, Pringle 5569, Amer. Gr. Nat. Herb. 40, Müller 2177. Antigua, Liebmann 450. Coatzacoalcos, Smith 913.

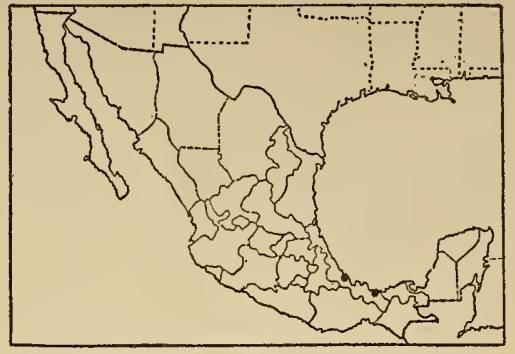

FIG. 52.-Distribution of $P$. gouini.

\section{Panicum virgatum L.}

Panicum virgatum L. Sp. P1. 59. 1753; Contr. U. S. Nat. Herb. 15: 87.1910.

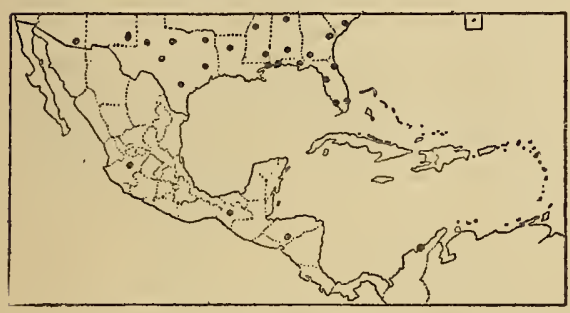

FIG. 53.-Distribution of $P$. virgatum.

Honduras: Santa Anna, Thieme 532.

Venezuela: Alto Apure, Jahn 198.

Colombia: Santa Marta, Smith 166.
DISTRIBUTION.

Prairies and open woods, eastern and central United States, south to northern South America. The type specimen from Virginia.

JAlisco: Río Blanco, Palmer 207 and 510 in 1886.

ChIAPAs: Between San Ricardo and Ocozucuantla, Nelson 2975.

\section{9a. Panicum virgatum cubense Griseb.}

Panicum virgatum cubense Griseb. Cat. Pl. Cub. 233. 1866; Contr. U. S. Nat. Herb. 15: 92.1910.

\section{DISTRIBUTION.}

Pine woods, A.tlantic Coastal Plain, Bermuda and Cuba. The type specimen from Cuba.

Bermuda: Stone in 1888 (Acad. Phil. Herb.).

CuBa: Batabanó, Hitchcock 153, Palmer \& Riley 1.134. Be-

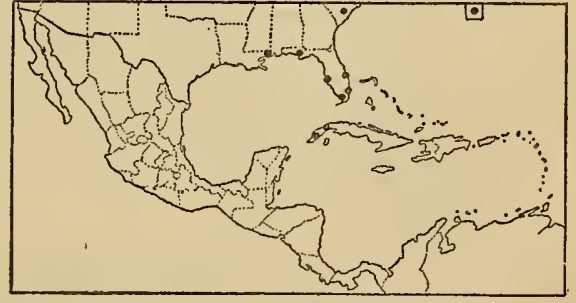

FIG. 54.-Distribution of $P$. virgalum cubense. tween Laguna Jovero and Laguna Herradura, Shafer 10927. Without locality, Wright 3873. 


\section{Panicum ichnanthoides Fourn.}

Panicum ichnanthoides Fourn. Mex. P1. 2: 30. 1886; Contr. U. S. Nat. Herb. 15: 88. 1910, as synonym under $P$. virgatum. The type specimen, Müller 2002, in the herbarium of the Botanical Garden in St. Petersburg, was collected at Orizaba.

Panicum buchingeri Fourn. Mex. Pl. 2: 30. 1886. "Orizaba (Thomas in herb. Buchinger)." Contr. U. S. Nat. Herb. 15: 329. 1910. We have been unable to find the type. From the description it is evident that the species is allied to $P$. virgatum L., while the locality would indicate $P$. ichnanthoides.

\section{DESCRTPTION.}

Plants in large clumps with knotted crowns, without creeping rootstocks; culms I.5 to 2 meters high, erect or decumbent at base, smooth, firm, and hard, more or less

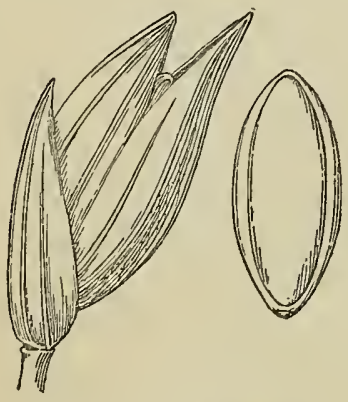

FrG. 55.-P. ichnanthoides. From type specimen. glaucous about the nodes; sheaths shorter than the internodes, pubescent on the overlapping margin toward the apex, otherwise glabrous; ligule about $3 \mathrm{~mm}$. long, membranaceous-ciliate; blades elongate, mostly 8 to $15 \mathrm{~mm}$. wide, flat except at the narrowed and usually inrolled base, scabrous on the margins, villous on the upper surface near the base, otherwise glabrous; panicle 20 to $40 \mathrm{~cm}$. long, one-fourth to one-third as wide, the long slender branches ascending; spikelets 3.5 to 4.2 $\mathrm{mm}$. long, about $1.5 \mathrm{~mm}$. wide, similar to those of $P$. virgatum.

This species is closely allied to $P$. virgatum $\mathrm{L}$., from which it differs in the absence of creeping rootstocks and in the narrow panicle. The patch of plants from which was collected Hitchcock's no. 6364 is probably that from which Botteri, Müller, and Thomas obtained their specimens. This patch lies along a trail leading up a prominent hill at the western edge of the city of Orizaba, a locality likely to be visited by all botanists collecting in that region.

\section{DISTRIBUTION.}

Open rocky hillsides, southern Mexico, British Honduras, and Nicaragua.

Puebla: Tehuacán, Endlich 1938.

Veracruz: Orizaba, Botteri 648, Hitchcock 6364, Müller 2002.

British Honduras: Manatee Lagoon, Peck 73 (Gray Herb.).

Nicaragua: Jinotepe, Hitchcock 8685.

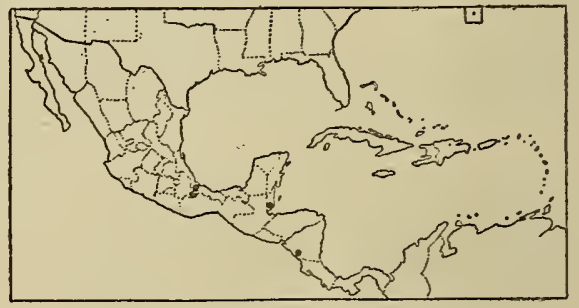

FIG. 56.-Distribution of $P$.ichnanthoides.

\section{Panicum altum sp. nov.}

\section{DESCRIPTION.}

Plants perennial, in tangled masses, the culms decumbent and straggling at base stout, reedlike, as much as $6 \mathrm{~mm}$. in diameter, ascending to a height of 2 to 4 meters, smooth and glaucous, simple or with extravaginal, mostly erect, sterile branches from the swollen nodes; sheaths smooth; ligule a short membrane less than $1 \mathrm{~mm}$. long, the ciliate fringe once or twice as long; blades flat, firm, not greatly elongated, mostly 30 to $45 \mathrm{~cm}$. long, 8 to $15 \mathrm{~mm}$. wide, smooth except the scabrous margins, panicles rather more densely flowered than in $P$. virgatum, 20 to $30 \mathrm{~cm}$. long, narrowly ovoid in out- 
line, open, the slender scabrous branches ascending and spreading, fascicled, some naked at base, with short branchlets intermixed; spikelets rather short-pediceled, 3.2 to $4 \mathrm{~mm}$. long, about $1.2 \mathrm{~mm}$. wide, turgid, glabrous, the glumes and sterile lemma strongly nerved, pointed, somewhat keeled, usually widely gaping, the first glume about two-thirds the length of the spikelet, the second glume and sterile lemma exceeding the fruit, subequal; fruit 2 to $2.2 \mathrm{~mm}$. Iong, $1 \mathrm{~mm}$. wide, elliptic.

Type in the U. S. National IIerbarium, no. 693326 , collected in moist sandy soil, near sea beach on Point Chamé, Province of Panama, September 18, 1911, by A. S. Hitchcock (no. 8167).

In the inflorescence this species closely resembles $P$. virgatum, but in habit it differs distinctly. It
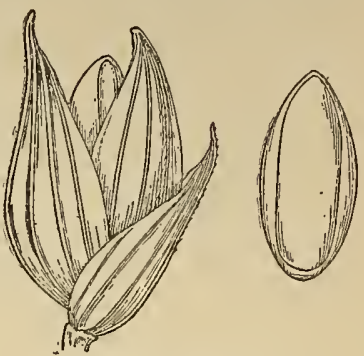

FIG. 57.-P. allum. From type specimen. grows in masses like large reeds such as Phragmites but is straggling and much tangled at base.

\section{DISTRIBUTION.}

Sandy marshes or flats near the seacoast, British Honduras to Trinidad.

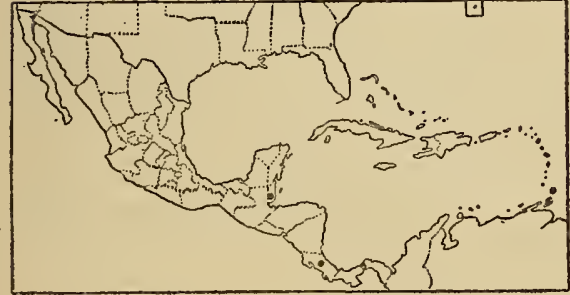

FIG. 58. - Distribution of $P$. allum

Britise Honduras: Manatee Lagoon, Peck 123 (Gray Herb.).

Costa Rica: Buenos Aires, Tonduz 3619. Panama: Point Chamé, Hitchicock 8167. Trinidad: Near Port of Spain, Iitchcock 10053. Icacos, Hitchcock 10154 . Three miles south of Cedros, Hitchcock 10159.

Toвago: Plymouth, Hitchcock 10233. Pigeon Point, Broaduay 3068.

\section{$41 t$ ten 42. Fanicum havardi vasey.}

Panicum havardii Tasey, Bull. Torrey Club 14: 95. 1887; Contr. U. S. Nat. Herb. 15: 93.1910.

\section{DISTRIBUTION.}

Arroyos and sand bills, southwestern United States and northern Mlexico. The type specimen from Texas.

Chinuariun: Paso del Norte (Juárez), Pringle 1124.

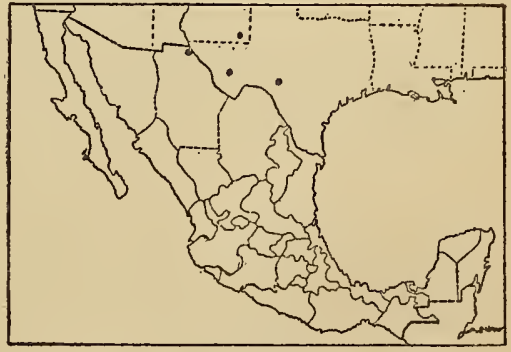

FIG. 59.-Distribution of $P$. havardii.

43. Panicum amarulum Hitchc. \& Chase.

Panicum amurulum Iitchc. \& Chase, Contr. U. S. Nat. Merb. 15: 96.1910.

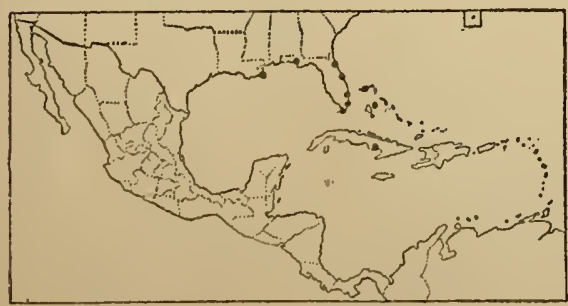

Fia. 60.-Distribution of $P$. amarulum.

\section{DISTRIBUTION.}

Sandy seashores and coast dunes, " southeastern United States, Bahamas, and Cuba. The type specimen from Virginia.

Bahamas: Great Bahama, Britton \& Millspaugh 2739. New Providence, Britton \& Brace 307, 493 (all Field Mus. Herb.).

Cuba: Camaguey, Shafer 2735. 
TENERA.

Second glume and sterile lemma exceeding the fruit; spikelets pointed........................................44. P. tenerum.

Second glume and sterile lemma not exceeding the fruit; spikelets rather blunt.

Pedicels bearing long stiff erect hairs at the summit.......46. P. caricoides. Pedicels not hairy.

Spikelets attenuate at base, about $2 \mathrm{~mm}$. long; leaves more or less pilose.........................45. P. stenodoides.

Spikelets not attenuate at base, about $1.5 \mathrm{~mm}$. long; leaves glabrous.............................47. P. stenodes.

\section{Panicum tenerum Beyr.}

Panicum tenerum Beyr. in Trin. Mém. Acad. St. Pétersb. VI. Sci. Nat. 1: 341.

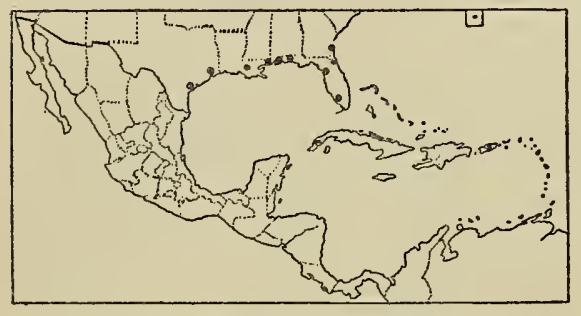

FIG. 61.-Distribution of P. tenerum. 1834; Contr. U. S. Nat. Herb. 15: 97. 1910.

\section{DISTRIBUTION.}

Margins of sandy swamps and pouds and in wet places in sandy woods, southeastern United States, Cuba, and Porto Rico. The type specimen from Georgia.

CuвA: Herradura, Hitchcock 154, Tracy 9080. Laguna Jovero, Shafer 10750. Laguna Los Indios, Shafer 10807. Pinar del Río, Wright 3870 in part.

Ponto Rico: Campo Alegre, Chase 6617.

\section{Panicum stenodoides Hubbard.}

Panicum stenodoides Hubbard, Proc. Amer. Acad. 49: 497. 1913. "Type (in the Gray Herb.) and only specimen seen, low pine ridge, Ycacos Lagoon, March 5, 1907, M. E. Peck, no. 681." A portion of the type in Hubbard's herbarium has been examined.

\section{DESCRIPTION.}

Plants perennial in dense tufts; culms erect, slender and wiry, glabrous or sparsely pilose below the glabrous nodes, 20 to $40 \mathrm{~cm}$. high, producing from the upper nodes slender leafless panicle-bearing branches; sheaths papillose or more or less papillose-pilose, the lowermost bladeless, glabrous, in age fibrous; ligule membranaceous, about 0.3 $\mathrm{mm}$. long; blades erect, flat at base, involute toward the apex, 3 to $8 \mathrm{~cm}$. long, 1 to $2 \mathrm{~mm}$. wide, more or less papillose or papillose-pilose, at least on the upper surface, sometimes glabrous; panicles short-exserted, usually exceeded by the uppermost blade, about $1 \mathrm{~cm}$. long, narrow, bearing 3 to 7 spikelets on appressed scabrous pedicels, rarely a few delicate hairs at the apex of the pedicels; spikelets 2 to 2.1 $\mathrm{mm}$. long, $0.9 \mathrm{~mm}$. wide, turgid, attenuate at base, glab-

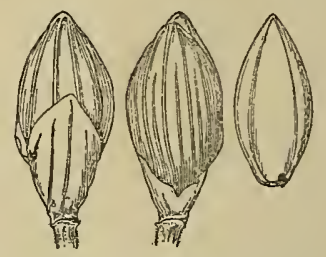

Frg. 62.-P.stenodoides. From type specimen. rous; first glume about half as long as the spikelet; second glume and sterile lemma subequal, barely covering the fruit, strongly nerved; fruit $1.7 \mathrm{~mm}$. long, $0.8 \mathrm{~mm}$. wide. 
This species resembles $P$. stenodes, but differs in having larger spikelets and papillose-pilose or at least papillose sheaths. The type specimen and Hitchcock's no. 8147 are conspicuously pilose on sheaths and blades, but the other specimens of this little-known species are papillose only or have a few hairs on the upper surface of the blades.

\section{DISTRIBUTION.}

Open grass land and moist savannas, Central America and northern South America.

British Honduras: Ycacos Lagoon, Peck 681 (Gray Herb.).

Costa Rica: Buenos Aires, Tonduz 3583.

Panama: Chorrera, Hitchcock 8147. Near Corozal, Hitchcock 9207.

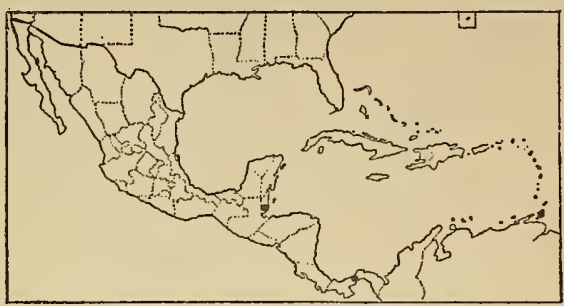

FIG. 63.-Distribution of $P$. stenodoides.

Trinidad: Piarco Savanna, south of Arouca, Hitchcock 10346.

\section{Panicum caricoides Nees.}

Panicum caricoides Nees; Trin. Gram. Pan. 149. 1826. Trinius received the type specimen from Nees, "V. spp. Brazil. (N. ab Esenb.)" Nees ${ }^{1}$ afterwards describes the species more fully and gives the original locality as "provincia Paraensi." The type specimen is in the Trinius Herbarium at the St. Petersburg Academy of Science. It is evidently a portion of the specimen at the Munich Herbarium. This specimen, which is the basis of Nees's later description, was collected in Pará by Martius,

Panicum junciforme Steud. Syn. P1. Glum. 1: 82. 1854. Given as a synonym of $P$. caricoides.

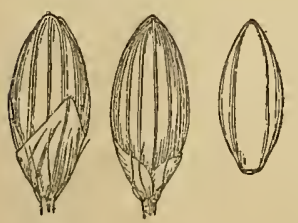

FIG. 64.- $P$. caricoides.

From type specimen.

\section{DESCRIPTION.}

Perennial, in tufts; culms erect, slender, glabrous, stiff and wiry, as much as $90 \mathrm{~cm}$. high; sheaths smooth; ligule membranaceous, lacerate, minute; blades appressed, narrower than the sheath, involute, glabrous, 1 to $5 \mathrm{~cm}$. long, the lower rarely longer; panicles terminal and axillary from the upper sheaths, short-exserted, 1 to $1.5 \mathrm{~cm}$. long, narrow, nearly simple, the later panicles smaller, in fascicles of 2 or

3 , at first partially inclosed by the somewhat inflated sheaths, the pedicles bearing long erect white hairs just below the rather crowded spikelets; spikelets 1.5 to 1.8 $\mathrm{mm}$. long, about $0.8 \mathrm{~mm}$. wide, turgid, glabrous; first glume about half as long as the spikelet, subacute; second glume and sterile lemma equal, covering the fruit, strongly nerved; fruit 1.4 to $\mathbf{1 . 5}$ $\mathrm{mm}$. long, $0.6 \mathrm{~mm}$. wide.

\section{DISTRIBUTION.}

Wet savannas, Trinidad to Brazil.

Trinidad: Aripo Savanna, Cumuto Station, Hitchcock 10069.

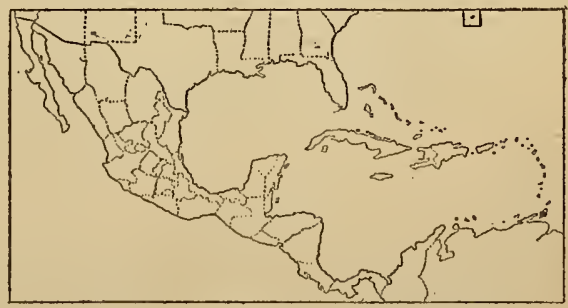

FIG. 65.-Distribution of $P$. caricoides.

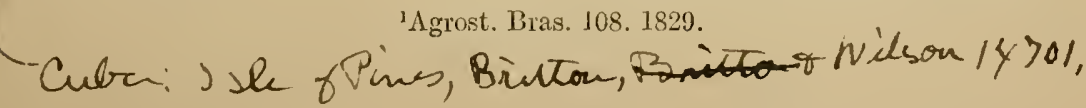




\section{Panicum stenodes Griseb.}

Panicum stenodes Griseb. Fl. Brit. W. Ind. 547. 1864; Contr. U. S. Nat. Herb. 15: 98. 1910.

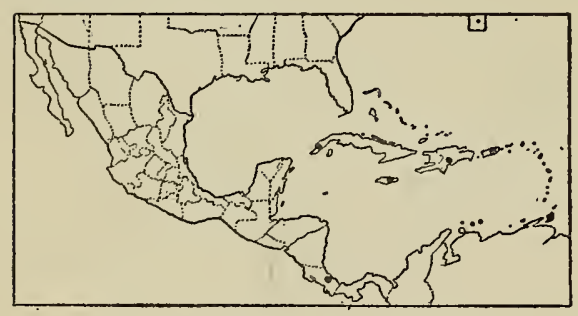

I'IG. 66.-Distribution of $P$. stenodes.

\section{DISTRIBUTION.}

Borders of ponds and wet savannas, West Indies and Costa Rica to Brazil. The type specimen from Jamaica.

Costa Rica: Buenos Aires, Pittier 10589, Tonduz 3583.

CuBA: Herradura, Hitchcock 155. Without locality, Wright 3871. JAMAICA: Bull Head Mountain, Amer. Gr. Nat. Herb. 46.

Santo D’omingo: Without locality, Wright, Parry \& Brummel 624.

Porto Rico: Trujillo Alto, Chase 6769.

Trinid 4 D: Cumuto Station, Hitchcock 10069. Piarco Savanna, Hitchcock 10347.

\section{AGROSTOIDIA.}

\section{Panicum condensum Nash.}

Panicum condensum Nash in Small, Fl. Southeast. U. S. 93. 1903; Contr. U. S. Nat. Herb. 15: 102. 1910.

\section{DISTRIBUTION.}

Swamps and borders of ponds and streams, Pennsylvania to Florida and Texas near the coast, south into Mexico and the West Indies. The type specimen from Florida.

Veracruz:Without locality,Gouin 10.

Bahamas: Nassau, Curtiss 174.

CuBA: Banks of Guanabo River, León 4141. Along Gibora carretera north of Holguin, Shafer 1438. Hanábana, Wright 184 in 1865. Without locality, Wright 3862 in part.

JAMAICA: Savanna-la-Mar, Hitch-

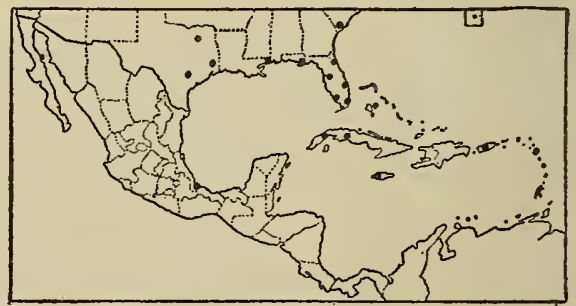

FIG. 67.-Distribution of $P$. condensum. cock 9884. Black River, Amer. Gr. Nat. Herb. 47.

Porto Rico: Santurce, Chase 6351. Campo Alegre, Laguna disl Tortuguero, Chase 6802.

Leeward Islands: Guadeloupe, Duss 3919.

\section{LAXA.}

All the species are perennial.

Spikelets not expanded at maturity by an enlarged sterile palea, pointed.

Nodes glabrous; spikelets $2.5 \mathrm{~mm}$. long. ................. 49. P. longum.

Nodes densely pubescent; spikelets not over $1.5 \mathrm{~mm}$. long.. 50. P. polygonatum. 
Spikelets expanded at maturity by the enlarged sterile palea, usually blunt.

Panicle branches not racemose; blades scarcely wider than their sheaths; sterile palea conspicuously enlarged.

Spikelets $3 \mathrm{~mm}$. long, congested; panicles dark purple.. 58. P. cupreum.

Spikelets not over $2.4 \mathrm{~mm}$. long; panicles green or pale.

Panicle branches spikelet-bearing or branchlet bearing along the upper half or toward the ends only ........................ 57. Pians.

Panicle branches branchlet-bearing throughout their length or nearly so................... 56. P. exiguiflorum.

Panicle branches subracemose, the spikelets secund; blades at least $5 \mathrm{~mm}$. wide; enlarged sterile palea not conspicuous.

Blades narrowed toward the base.................. 54. P. laxum.

Blades cordate or truncate at base.

Spikelets $2 \mathrm{~mm}$. long; panicle branches erect or nearly so . . ...................... 55. P. stevensianum.

Spikelets not over $1.6 \mathrm{~mm}$. long, usually less; panicle branches spreading or ascending.

Panicles one-third to half as wide as long; spikelets not conspicuously secund, somewhat irregularly disposed; blades cordateclasping..................... 53. P. boliviense.

Panicles rarely one-fourth as wide as long; spikelets conspicuously secund and regularly disposed.

CuIms as much as 2 meters long; panicles 25 to $30 \mathrm{~cm}$. long.............. 51. P. milleflorum. Culms not over 1 meter long; panicles 5 to $15 \mathrm{~cm}$. long.

49. Panicum longum Hitchc. \& Chase.

Panicum longum Hitchc. \& Chase, Contr. U. S. Nat. Herb. 15: 111. 1910.

DISTRIBUTION.

Swamps, State of Veracruz. The only collections known are from near Jalapa, Pringle 8195 (the type) and Schiede \& Deppe 674 (Haile Herb.).

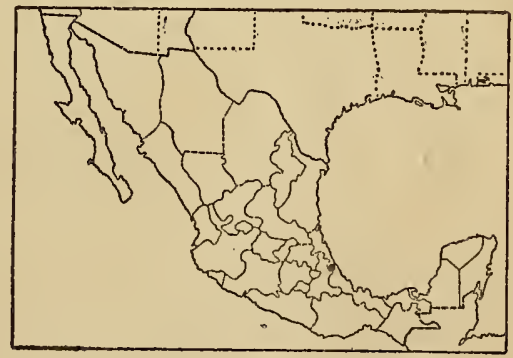

FIG. 68.-Distribution of P. longum.

50. Panicum polygonatum Schrad.

Panicum polygonalum Schrad. in Schult. Mant. 2: 256. 1824; Contr. U. S. Nat. Ĺerb. 15: 112. 1910.

\section{DISTRIBUTION.}

Swamps and moist soil, Mexico to Paraguay. The type specimen from Brazil.

Veracruz: Córdoba, Bourgeau 1662 in part. ' yas 0 , y

Guatemala: Sepacuité, Collins \& Goll 08, Cook \& Griggs 530. Cubilquitz, Tiurckheim 7797, 8795. Puerto Barrios, Kellerman 5114.

Honduras: San Pedro Sula, Thieme 781, 5578, 5587 in part. 
Costa PrcA: Boruca, Tonduz 4460. Puerto Limon, Ilitchcock 8421. Llano Grande de Puriscal, Jiménez 881. Macienda de Guácimo, Tonduz 27. San José, Pittier 1183. Echeverría, Pittier \& Tonduz 2479. Carrillo, Biolley 3107, Pittier 1182. Talamanca, Tonduz 8557. River Tómres, San Francisco, Jiménez 126. Tuís, Tonduz 11396.

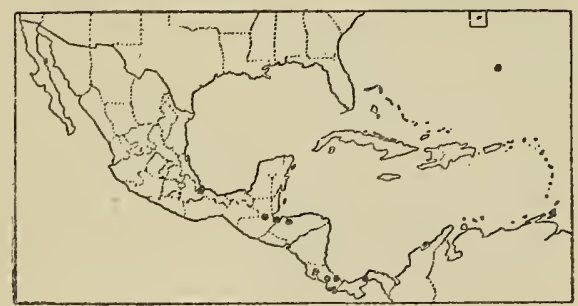

FIG. 69.-Distribution of $P$. polygonatum. Turrialba, Tonduz 4092, 8244. Buenos Aires, Tonduz 4042. Río Tuís, Tonduz 8187. Boca Zhorquín, Tonduz 8557. Quebrada de Tocorí, Tonduz 7542. Santo Domingo de Golfo Dulce, Tonduz 10099. Piedra del Convento, Pittier 3650 .

Panama: Boca del Toro, Hart 73. Mount Hope, Hitchcock 9172. Between Mindí and Colón, Hitchcock

7943. Between Bohío and Frijoles, Hitcheock 8395. Gorgona, Amer. Gr. Nat. Herb. 58.

Trinidad: Arima, Hitchcock 10297, 10306. Cumuto Station, Hitchcock 10077. Port of Spain, Hitchcock 9953. Tabaquite, Hitchcock 10132. Caparo, Broadway 2837.

Toвago: Mason Hall, Broadway 4476.

Colombia: Santa Marta, Smith 206, 2190, 2747.

51. Panicum milleflorum sp. nov.

\section{DESCRIPTION}

Plants perennial; culms ascending or erect from an elongated creeping base, rooting at the nodes, glabrous, 0.8 to 2 meters high, 4 to $5 \mathrm{~mm}$. thick, compressed, the nodes pubescent or glabrous, usually with one to several long erect panicle-bearing branches; sheaths about as long as the internocies, keeled toward the summit, ciliate on the margin and puberulent at the junction with the blade, otherwise glabrous or sparsely papllose-hispid; ligule wanting, the ligular region puberulent; blades flat, 20 to $40 \mathrm{~cm}$. long, 1 to $2 \mathrm{~cm}$. wide, rarely wider, long-acuminate, somewhat narrowed to the subcorclate base, glabrous or very sparsely hirsute, the margin scabrous; panicles 20 to 35 $\mathrm{cm}$. long, about $6 \mathrm{~cm}$. wide, in outline tapering to both ends, consisting of numerous ascending or spreading, often curving, slender spikelike branches, solitary or in fascicles along an elongated glabrous axis, the lower distant, the upper approximate, the scabrous-angled, often sparsely pilose rachises bearing throughout their length along their lower side evenly disposed short approximate densely flowered branchlets, those of the lower branches sometimes as much as $15 \mathrm{~mm}$. long, the others 1 or $2 \mathrm{~mm}$. long; spikelets subsessile, $1.3 \mathrm{~mm}$. long, about $0.5 \mathrm{~mm}$. wide, glabrous, the first glume about one-third the length of the spikelet, the second glume and sterile lemma equal, the lemma inflated boat

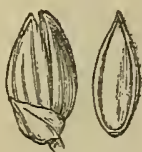

FIG. 70. $-P$. milleflorum. From type specimen. shaped with a large membranaceous palea; fruit $1.2 \mathrm{~mm}$. long, $0.4 \mathrm{~mm}$. wide, acute, the lemma boat-shaped.

Type in the U. S. National Herbarium, no. 693327, collected in water of swamp, Frijoles, Canal Zone, Panama, October 12, 1911, by A. S. Hitchcock (no. 8387).

This species differs from Panicum pilosum in its larger size, its strong decumbent rooting base, and its longer blades and panicles. It appears to be the same as Panicum distichum lancifolium Griseb. ${ }^{1}$ which was previously included ${ }^{2}$ under $P$. pilosum.

${ }^{3}$ Fl. Brit. W. Ind. 548. 1864.

${ }^{2}$ Contr. U. S. Nat. Herb. 15: 114. 1910. 
Grisebach's variety was based upon Crueger 84 from Trinidad. This has strongly appressed-hispid nodes and sparsely pilose panicle branches. Hitchcock's no. 8387, the type, has only moderately pubescent nodes and no hairs on the branches of the panicle. Hitchcock's no. 7942 has glabrous nodes, evidently, though sparsely, pilose blades, and strongly pilose panicle branches. The three collections appear, however, to belong to the same species. Frijoles, the type locality, is now covered by the water of Gatun Lake.

\section{TISTRIBUTION.}

Swamps, Panama to Trinidad.

Panama: Frijoles, Canal Zone, Hitchcock 8387. Between Mindí and Colón, Canal Zone, Hitchcock 7942.

Trinidad: Without locality, Crueger 84 .

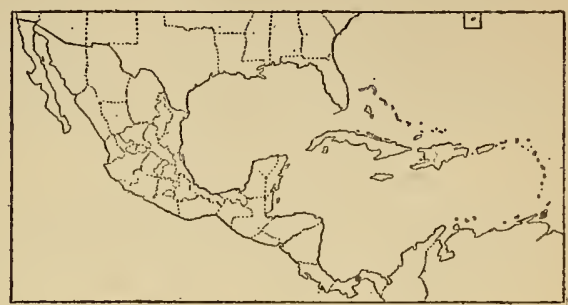

Fig. 71.-Distribution of $P$. milleflorum.

\section{Panicum pilosum Swartz.}

Panicum pilosum Swartz, Prodr. Veg. Ind. Occ. 22. 1788; Contr. U. S. Nat. Herb. 15: 113. 1910.

DISTRIBUTTON.

Moist ground, ditches, and swamps, Mexico and the West Indies to Paraguay. The type specimen from Jamaica.

Veracruz: Córdoba, Amer. Gr. Nat. Herb. 60. Mirador, Liebmann 411.

TABAsco: San Juan Bautista, Rovirosa 599.

Chtapas: Ocuilapa, Nelson 3056.

British Honduras: Manatee Lagoon, Peck 28 (Gray Herb.).

Guatemala: Finca Trece Aguas, Goll 11. Cubilquitz, Türckheim 8797. Puerto

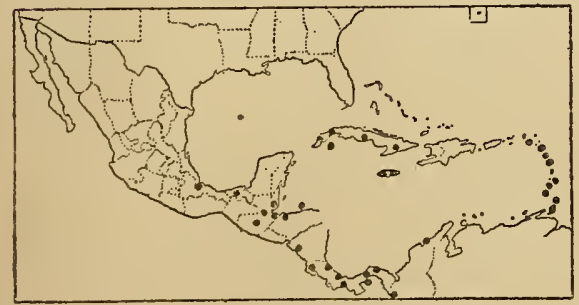

FIG. 72.-Distribution of $P$. pilosum. Barrios, Hitchcock 9159. Los Andes, Kellerman 5119.

Honduras: San Pedro Sula, Thieme 5587 in part. Bonacco Island, Gaumer in 1887.

Nicaragua: Wright, U. S. Pacific Expl. Exped. 1853-56.

Costa Rica: Río Hondo, Cook \& Doyle 499. Talamanca, Tonduz 9495. Puerto Viejo, Biolley 7463. Puntarenas, Hitchcock 8564.

Panama: Chagres, Fenaller 368. Chepo, Pittier 4536. Puerto Obaldía, Pittier 4371. Toro Point, Hitchcock 8044. Taboga Island, Hitchcock 8083. Balboa, Hitchock 8016. Gatun, Hitchcock 8029. Caña, Williams 776. David, Hitchcock 8347. Culebra, IItchcock 7897, 9208, Pittier 2082. Between Bohío and Frijoles, Hitchcock 8390. Between Pedro Miguel and Corozal, Hitchcock 7992. Chorrera, IIitchcock 8139. Porto Bello, Pittier 2481.

Cuвム: Dayaniguas, Wright 3451 in part. Sancti Spiritus, León 908. Herradura, Van IIermann 763, Tracy 9063. Isle of Pines, Curtiss 305, Taylor 36. Sumidero, Shafer 13505, 13533. Buenaventura, Wilson 9444. Banao Hills, León 3982. Near Marianao, León 1977. Without locality, Pöppig 1834. 
JamaICA: Troy, Hitchcock 9782. Pamble, Hitchcock 9517. Bull Head Mountain, Hitchcock 9548. Castleton Gardens, Hitchcock 9407. Ewarton to Linstead, Mitchcock 9423. Ipswich, Mitchcock 9626. Navy Island, Millspaugh 1859. Port Morant, Hitchcock in 1890. Portland, Harris 11524. Castleton, Harris 11280a. Gordon Town, Mart 732. Cedar Hurst, Harris 11547.

Leeward Islands: St. Kitts, Britton \& Cowell 287 (K. U. Herb.). Guadeloupe, Duss 4154. Dominica, Imray 151312, Jones 20.

Windward Islands: St. Vincent, Eggers 6562, 6633 (K. U. Herb.): Grenada, St. Georges, Broadway in 1904. Martinique, Duss 534, 4018 (both in K. U. Herb.). Barbados, Eggers 7195 (K. U. Herb.).

Trinidad: Piarco Savanna, Hitchcock 10358. Port of Spain, Hitchcock 9961, 10045, Hart 3293. Tabaquite, Hitchcock 10121. Cedros, Amer. Gr. Nat. Herb. 59. Arima, Hitchcock 10309.

Tовнgо: Brushfield, Eggers 5534. Scarborough, Hitchcock 10208. Castara, Broadway 4063. Center of island, Hitchcock 10265. Spey Side, Hitchcock 10242.

Colombia: Córdoba, Pittier 557. Santa Marta,-Smith 203.

\section{Panicum boliviense Hack.}

Pancium boliviense Hack. Repert. Nov. Sp. Fedde 11: 19. 1912. "Bolivia: Antahuacana, Espirito Santo in alveo arenoso fluminis * * * leg. Dr. O. Buchtien no. 2501." A portion of the type was sent by Prof. Hackel for deposit in the National Herbarium.

\section{DESCRIPTION,}

Plants perennial with long decumbent or creeping bases, rooting and branching at the lower nodes; flowering culms ascending, 0.5 to 1.5 meters high, glabrous, the nodes glabrous; sheaths short, glabrous below, usually hirsute toward the summit, especially at the junction with the blade, the margins ciliate; ligule a ciliate membrane about

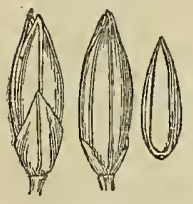

FIG. 73.-P. bolivicnse. From type specimen. $0.5 \mathrm{~mm}$. long; blades flat, 8 to $15 \mathrm{~cm}$. long, 1 to $2 \mathrm{~cm}$. wide, gradually narrowed from the cordate-clasping base to an acuminate apex, ciliate at base, otherwise glabrous, obscurely cross-nerved between the veins, the margins scabrous; panicle usually short-exserted, 10 to $25 \mathrm{~cm}$. long, one-third to half as wide, the solitary or fascicled branches increasingly approximate toward the summit of the slender angled scabrous axis, usually pilose in the axils, the lowermost branch solitary and remote, all but the uppermost compound, the branchlets somewhat spikelike, rather distant, usually along the lower side of the rachis, the axils pilose; spikelets subsessile, clustered, 1.5 to 1.6 $\mathrm{mm}$. long, about $0.7 \mathrm{~mm}$. wide, turgid, the first glume nearly half the length of spikelet, the second glume and sterile lemma equal, the sterile lemma somewhat inflated, subtending a membranaceous palea; fruit $1.4 \mathrm{~mm}$. long, $0.6 \mathrm{~mm}$. wide, subacute.

Several collections of this species were referred in the Revision ${ }^{1}$ to $P$. laxum as exceptionally robust specimens with cordate blades and turgid spikelets.

\section{DISTRIBUTION.}

Ditches, banks of streams, moist open or wooded ground, southern Mexico and Cuba to Paraguay.

Veracruz: Veracruz, Hitchcock 6582. Mirador, Liebmann 419. Córdoba, Finck 3, Hitchcock 6435, 6457. Zacuapán, Purpus 2159, 2160. Misantla, Purpus 5980. Jalapa, Hitchcock 6666.

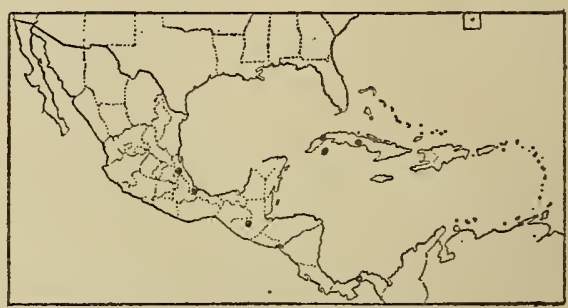

FIG. 74.-Distribution $0_{1} P$. boliviense. 
Guatemala: Cobán, Türckheim 1254.

Panama: Along ditch to Old Panama, Hitchcock 8400.

Cuвa: Sancti Spiritus, León 909. Isle of Pines, Curtiss 464. Baños San Vicente, Britton \& Gager 7452 .

\section{Panicum. laxum Swartz.}

Panicum laxum Swartz, Prodr. Veg. Ind. Occ. 23. 1788; Contr. U. S. Nat. Herb. 15: 115.1910.

\section{DISTRIBUTION.}

Ditches, banks, moist woods and wet savannas, Mexico and West Indies to Paraguay. The type specimen from Jamaica.

Sinaloa: Culiacán, Palmer 1558 in 1891.

Veracruz: Coatepec, Hitchcock 6665. Jalapa, Hitchcock 6624. Córdoba, Hitchcock 6421, 6433. Veracruz, Hitchcock 6583. Sanborn, Orcutt 3238. Mirador, Liebmann 412. Orizaba, Botteri 688.

Tabasco: Mayito, Rovirosa 427.

British Honduras: Manatee Lagoon, Peck 60 (Gray Herb.).

Guatemala: Puerto Barrios, Pittier 361, Hitchcock 9160. Cubilquitz, Türckheim 8803. Santa Rosa, Heyde \& Lux 3900. Cobán, Türckheim 3832.

Honduras: San Pedro Sula, Thieme 5587.

Salvador: Sonsonate, Hitchcock 8971.

Nicaragua: Corinto, Iritchcock 8748.

Costa Rrca: Buenos Aires, Tonduz 4864, 4868, 4871, Pittier 3657. Río Birrís, Pittier 3117. Turrialba, Tonduz 8267, Pittier 16123. Río Grande de Térraba, Tonảuz 3622. Boruca, Tonduz 4473. Carrillo, Biolley 3107. Port Limon, Hitchcock 8429. San José, Hitchcock 8455. Río Maravilla, Alajuela, Jiménez 141. Puntarenas, Hitchcock 8566. Río Bebedero, Jiménez 740. Río Tilirí, Tonduz 3071.

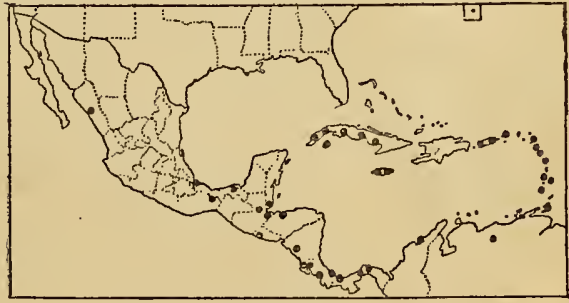

FIG. 75.-Distribution of $P$. laxum.

Panama: Gatun, Hitchcock 7968, 8027. Boca del Toro, Hart 86. Porto Bello, Pittier 2443. Culebra, Mitchcock 7900. David, Hitchcock 8346, 8350. Chepo, Pittier 4615. Vicinity of Olá, Pittier in 1911. Gamboa, Pittier 4789. Along Sambú River, Pittier 5234. Chorrera, Hitchcock 8134. Between Pedro Miguel and Corozal, Hitchcock 7993. Dolega, Hitchcock 8334.

Cuba: Sancti Spiritus, Lcón 907, Sergius 2781, Pöppig 6. Hanábana, Wright 189, 196, 197. Isle of Pines, Taylor 37, Palmer \& Rilcy 1069. Herradura, Caldwell \& Baker 7136, Tracy 9054, 9062, 9072, 9099, Hitchcock 177. Santiago de las Vegas, Hitchcock 178, Tracy 9114. Banao Hills, Lcón 39821. Guanabacoa, Lcón 914. Wajay, Earle \& Wilson 343. Zaza del Sur, Sergius 2780. Camaguey, Shafer 217. Sumidero, Shafer 13724. Los Palacios, Shafer 11793. La Gloria, Shafer 174. Without locality, Wright 759, 3451, 3863.

JAMarca: Bull Iread Mountain, Hitchcock 9539, 9545. Castleton Gardens, Hitchcock 9397. Ewarton to Linstead, Hitchcock 9461. Appleton, IItchcock 9658. Gordon Town, Hitchcock 9333. Troy, Hitchcock 9786. Castleton, Harris 11285. Below Flamstead, IIarris 11466.

Santo Domivgo: Jarabacoa, Eggers 2120. 
Porto Rico: Between Aibonito and Cayey, Chase 6341, Heller 522. Arecibo, Chase 6440. Sierra Luquillo, Hioram 368, Chase 6713. Adjuntas Road, Heller in 1902. Cataño, Heller 1378. Utuado, Britton \& Covell 394. Mayar guez, Chase 6155, 6185, Sintenis 360. Along Rio Coamo, Chase 6549. Trujillo Alto, Chase 6363, 6775. Jajome Alto, Chase 6753. Santurce, Chase 6354. Mount Morales, Britton \& Marỏle 1068. Fajardo, Sintenis 1254. Danish West Indies: St. Thomas, Eggers 874 (K. U. Herb.).

LEeWARD Islands: Antigua, Wullschlaegel 623. Guadeloupe, Duss 3179. Dominica, Jones 21, 25.

Windward Islands: Martinique, Duss 535, 716 (K. U. Herb.). Barbados, Dash 450. St. Lucia, Voyage of the Albatross in 1887-88. Grenada, Broadway 1870, $3712,4668$.

Trinidad: Port of Spain, Hitchcock 9984. Piarco Savanna, Hitchcock 10343, 10351, 10361. Brighton, Hitchcock 10098. Pitch Lake, Hitchcock 10091. Cumuto Station, Hitchcock 10068. Cedros, Hitchcock 10149, Bot. Gard. Herb. $2177,2289$.

Toвago: Center of island, Hitchcock 10272. Spey Side, Hitchcock 10245.

Venezuela: Llanos del Alto Apure, Jahn 201.

Colombia: Córdoba, Pittier 521, 553. Calí, Pittier 665. Santa Marta, Smith $202,204$.

\section{Panicum stevensianum sp. nov.}

DESCRIPTION.

Plants perennial, tufted, glabrous throughout; culms compressed, 30 to $60 \mathrm{~cm}$. long, spreading, prostrate, rooting at the nodes, the flowering ends and the branches ascend-

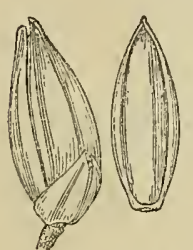

FIG. 76. $-P$. stevensianum. From type specimen. ing; sheaths loose, much shorter than the internodes, compressed, keeled, ciliate on the overlapping margin; ligule a delicate membrane about $0.5 \mathrm{~mm}$. long; blades flat, rather firm, more or less spreading, 4 to $10 \mathrm{~cm}$. long, 5 to $10 \mathrm{~mm}$. wide, tapering from a little above the sparsely ciliate, truncate-cordate base to an acuminate apex; panicles terminal on the culm and branches, short-exserted, 6 to $10 \mathrm{~cm}$. long, narrow, consisting of several appressed or ascending spikelike branches along an angled axis, the lower branches somewhat remote, 1.5 to $3 \mathrm{~cm}$. long, usually longer than the internodes, the upper approximate, all spikelet-bearing to the base, the shortpediceled spikelets in crowded clusters, not secund, along a slender scabrous rachis; spikelets about $2 \mathrm{mam}$. long and $0.8 \mathrm{~mm}$. wide, acute, somewhat inflated and gaping; first glume about one-fourth the length of the spikelet, subacute, 3-nerved; second glume and sterile lemma equal, pointed, slightly exceeding the fruit, 3 to 5 -nerved, the lemma inclosing a large palea and abortive perfect flower; fruit $1.9 \mathrm{~mm}$. long, 0.6 $\mathrm{mm}$. wide, minutely scabrous at the acute apex.

Type in the U. S. National Herbarium, no. 693323, collected "on wet sand around pool, forming a dense carpet, white sand region, Campo Alegre near Laguna del Tortuguero,". Porto Rico, November 25, 1913, by Agnes Chase (no. 6616).

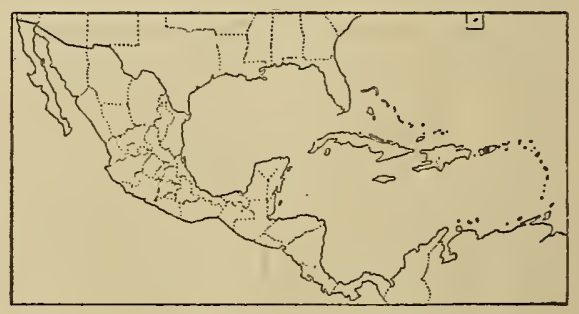

FIG. 77,-Distribution of $P$. stevensianum.

This species appears to be most nearly related to the South Ameiican P. milioides Nees, from which it differs in the short erect panicle branches, spikelet-bearing to the base. 
None of the specimens collected is mature. It may be that the large sterile palea becomes indurated at maturity as in $P$. hians and its close allies. The species is named in honor of Dr. F. L. Stevens of the University of Illinois, who, during the three years he was dean of the College of Agriculture and Mechanic Arts of Porto Rico, was an ardent student of the flora of the island and who contributed greatly to the success of a botanical trip made by one of the authors to Porto Rico in 1913.

Since this work went to press a second collection of this species has been received: Wilson 9558, Laguna de Castellano, Cuba.

\section{Panicum exiguiflorum Griseb.}

Panicum exiguiflorum Griseb. Cat. Pl. Cub. 234. 1866; Contr. U. S. Nat. Herb. 15: $117,1910$.

\section{DISTRIBUTION.}

Savannas and moist sandy woods, Bahamas and Cuba. The type specimen from Cuba.

Bahamas: Fortune Island, Hitchcock in 1890.

Cuba: Hanábana, Wright in 1865. Sancti Spiritus, Sergius 2566. Obispo Hill, León 902b. Zaza del Medio, León 902. Guanabacoa, Lcón 911, 913. Chirigote, Wright 3450 . Herradura, Hitchcock179, Tracy 9075. Isle of Pines, Taylor 35. Without locality, Wright 755, 3450, 3877.

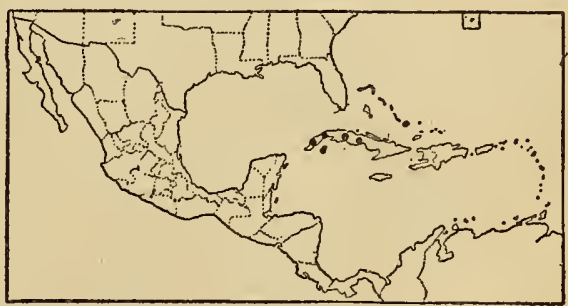

FIG. 78.-Distribution of $P$. exiguiflorum.

\section{5\%. Panicum hians Ell.}

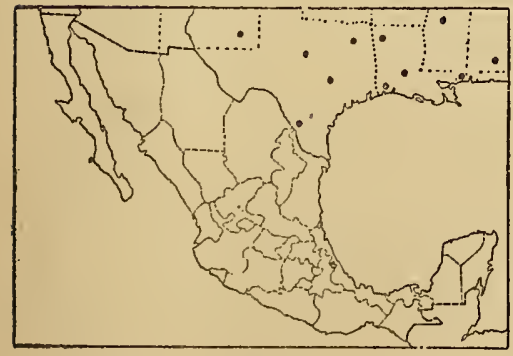

FIG. 79,-Distribution of $P$. hians.

Panicum hians Ell. Bot. S. C. \& Ga. 1: 118. 1816; Contr. U. S. Nat. Herb. 15: 118. 1910.

\section{DISTRIBUTION.}

Savannas and moist soil along ponds and streams, North Carolina to New Mexico and in Veracruz, Mexico. The type specimen from South Carolina.

Veracruz: Jalapa, Schiede. Without locality, Müller 2095.

53. Panicum cupreum Hitchc. \& Chase.

Panicum cupreum Hitchc. \& Chase, Contr. U. S. Nat. Herb. 15: 120. 1910.

\section{DISTRIBUTION .}

Only known from the type collection, in "wet hollows in prairies of Flor de Maria, State of Mexico," Pringle 3449.
Prebla :

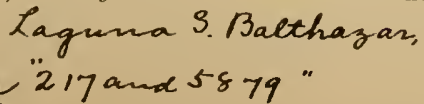
nicalas
217 and 5879"
Mrcharan: Horelea irsine 5657
Ipikclet tale, wat much crounded 


\section{STOLONIFERA.}

Spikelets hispid and with 2 crateriform glands on the sterile lemma; second glume and sterile lemma not boat-shaped.

Spikelets not over $2 \mathrm{~mm}$. long; blades not over $4 \mathrm{~cm}$. long.. 61. P. pulchellum.

Spikelets $3.6 \mathrm{~mm}$. long; blades 4 to $10 \mathrm{~cm}$. long......... 62. P. biglandulare. Spikelets glabrous, glandless; second glume and sterile lemma boat-shaped.

Blades not over $5 \mathrm{~cm}$., usually 2 or $3 \mathrm{~cm}$., long; second glume rather blunt and shorter than the sterile lemma.... 59. P. stoloniferum.

Blades 5 to $11 \mathrm{~cm}$. long; second glume acute, nearly equaling the sterile lemma.......................

60. P. frondescens.

\section{Panicum stoloniferum Poir.}

Panicum stoloniferum Poir. in Lam. Encycl. Suppl. 4: 274. 1816; Contr. U. S. Nat. Herb. 15: 121. 1910.

\section{DISTRIBUTION.}

Moist shady places, Guatemala to Brazil. The type specimen from Cayenne.

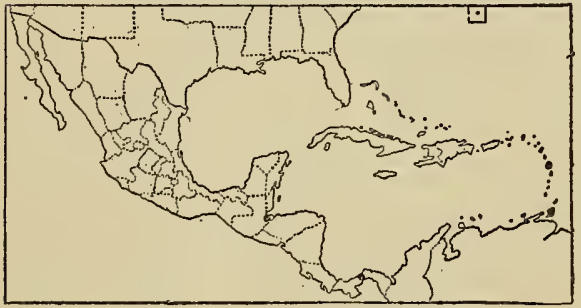

FIG. 81.-Distribution of $P$. stoloniferum.

Guatemala: Puerto Barrios, Pittier 364.

Panama: Frijoles, Amer. Gr. Nat. Herb. 62.

WindWARD IsLaNDS: Martinique, Duss 1291 (K. U. Herb.).

Trinidad: St. Anns Valley, Bot. Gard. Herb. 2293. Aqua Santa Arima, Broadway 2370. Without locality, Crueger 79.

60. Panicum frondescens Meyer.

Panicum frondescens Meyer, Prim. Fl. Esseq. 56. 1818; Contr. U. S. Nat. Herb. 15: 121. 1910.

Hymenachne frondescens Fourn. Mex. P1. 2: 36. 1886. Based·on Panicum frondescens Meyer.

A specimen in the Berlin Herbarium, Seler 5024, without locality other than Mexico and Central America, is exceptionally lax and is peculiar in having occasional spikelets with glands on the sterile lemma as in $P$. pulchellum and $P$. biglandulare. In most of the spikelets there are a few hairs along the margin of the sterile lemma. Further collections may show this to be a distinct species. In Pittier 6328, cited below, a few spikelets bear glands, but all are glabrous.

\section{DISTRIBUTION.}

Moist woods, Mexico to Brazil. The type specimen from British Guiana.

Veracruz: 'Papantla, Liebmann 405.

TABASCo: Sebastián, Rovirosa 497.

Guatemala: Dept. Petén, Walker 1138.

Costa Rica: Harienda de Zent, Tonduz 259.

Panama: Trinidad Basin, Pittier 4027.

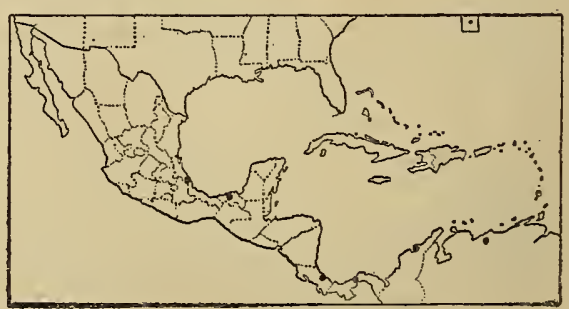

Fig. 82.-Distribution of $P$. frondescens. 
Windward Islands: Smith \& Smith 187 (K. U. Herb.).

Trinidad: Aqua Santa Arima, Broadway 2371. Blanchisseuse, Broadway 2390.

Without locality, Crueger 85.

Venezuela: Above Paparo, Pittier 6328.

Colombia: Santa Harta, Smith 2126, 2571.

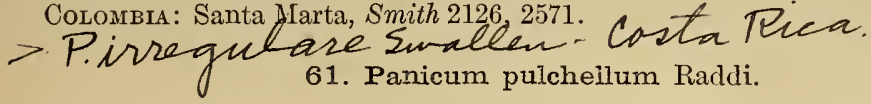

Panicum pulchellum Raddi, Agrost. Bras. 42. 1823; Contr. U. S. Nat. Herb. 15: 123. 1910.

Hymenachne leptostachya Fourn. Mex. Pl. 2: 36. 18s6. Based on Panicum leptostachyum Presl.

DISTRIBUTION.

Moist shady places, southern Mexico and the Windward Islands to Brazil. The type specimen from Rio de Janeiro.

Veracruz: Córdoba, Hitchcock 6444, Bourgeau 1455. Minatitlán, Smith 589.

British Honduras: Manatee Lagoon, Peck 279 (Gray Herb.).

Guatemala: Cuhilquitz, Türckheim 7702, 8794. Secanquím, Cook \& Griggs 284, Maxon \& Hay 3153. E1

Palmar, Kellerman 6246.

Costa Rica: San Francisco, Jiménez 162. San Mateo, Biolley 7001. Desamparados, Tonduz 1482. Boruca, Tonduz 4459, 4460. El General, Pittier 3362. Piedra del Convento, Pittier 3656. Cañas Gordas, Pittier 7360. Buenos Aires, Tonduz 4881.

Panama: Between Panama and

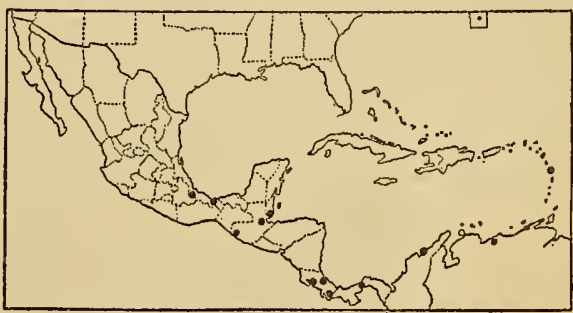

FIG. 83.-Distribution of $P$. pulchellum.

Corozal, Amer. Gr. Nat. Herb. 63. Culebra, Pittier 2226. Cerro Vaca, Pittier 5375.

Windward Islands: Martinique, Duss 767 (K. U. Herb.).

Venezuela: Cárdenas, Pittier 5975.

Colombia: Santa Marta, Smith 2127.

62. Panicum biglandulare Scribn. \& Smith.

Panicum biglandulare Scribn. \& Smith, U. S. Dept. Agr. Div. Agrost. Bull. 4: 13.

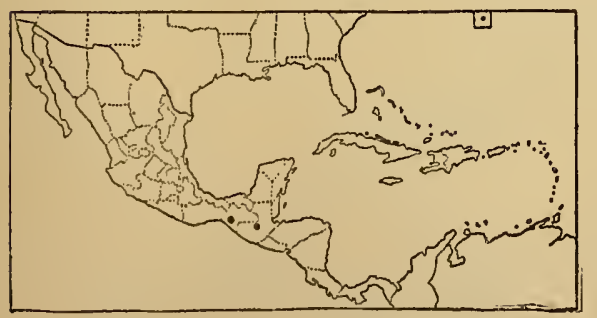

FIG. 84.-Distribution of $P$. biglandulare. pl. 4. 1897; Contr. U. S. Nat. Herb. 15: 123.1910.

\section{DISTRIBUTION}

Among bushes, southern Mexico and Guatemala. The type specimen from Chiapas.

Chiapas: Pinabete, Nelson 3781. Guatemala: Cobán, Türckheim II. 1342, II. 1956. 


\section{PARVIGLUMIA.}

Fruit glabrous.............................. 66. P. parviglume.

Fruit with scattered appressed silky hairs.

Culms creeping, with ascending flowering branches, not over

0.5 meter high; blades falcate................. 64. P. schmitzii.

Culms clambering, usually 1 to 3 meters long; blades not falcate.

Panicles 2.5 to $7 \mathrm{~cm}$. long; blades not over $1 \mathrm{~cm}$. wide, symmetrical at base..................6. 63 . P. virgultorum.

Panicles 10 to $15 \mathrm{~cm}$. long; blades 1.2 to $2.5 \mathrm{~cm}$. wide, unsymmetrical at base .................. 65. P. schiffneri.

Panicum virgultorum Hack. Oesterr. Bot. Zeitschr. 51: 369. 1901; Contr. U. S. Nat. Herb. 15: 125. 1910.

\section{DISTRIBUTION.}

Hedge rows, brushy banks, and cultivated fields, southern Mexico to Panama. The type specimen from Costa Rica.

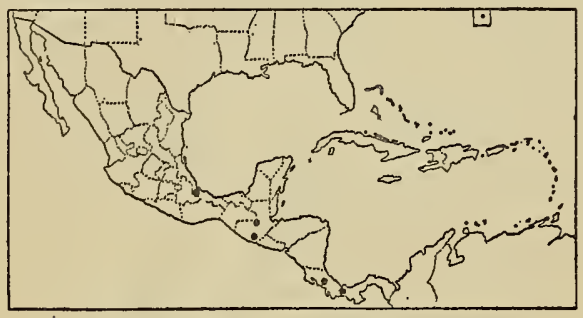

FIG. 85.-Distribution of $P$. virgultorum.

Veracruz: Jalapa, Hitchcock 6630. Córdoba, Hitchcock 6441. Orizaba, Amer. Gr. Nat. Herb. 64.

Guatemala: Guatemala City, Hitchcock 9074 . Chacula, Seler 2708. Cobán, Türckheim 3788.

Costa Rica: San José, Hitchcock 8490. Alajuelita, Tonduz 8818, 8829. Tres Ríos, Pittier \&

Tonduz 4326. San Francisco, Río Tórres, Jiménez 49. San Juan, Jiménez 919.

Panama: El Boquete, Hitchcock 8317.

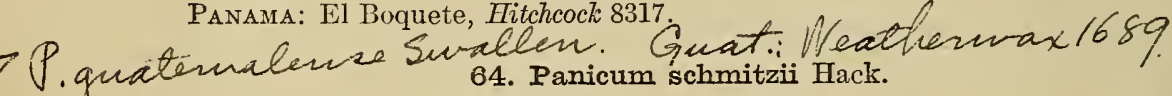

Panicum schmitzii Hack. Ann. Naturhist. Hofm. Wien 17: 254. 1902; Contr. U. S. Nat. Herb. 15: 125. 1910.

\section{DISTRIBUTION.}

Shaded rocky slopes, central and southern Mexico. The type specimen from Mexico.

San Luis Potosí: Las Canoas, Pringle 3817.

VERACRUZ: Córdoba, Hitchcock 6423, 6446. Orizaba, Amer. Gr. Nat. Herb. 65.

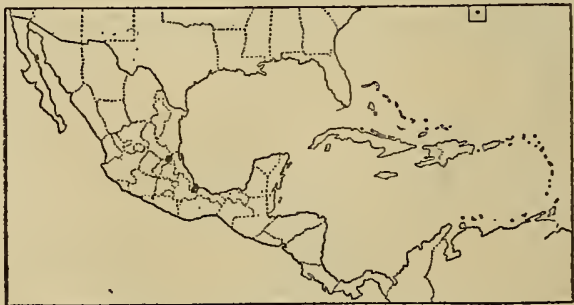

FrG. 86.-Distribution of $P$. schmitzii.

\section{Panicum schiffneri Hack.}

Panicum schiffneri Hack. Ergeb. Bot. Exped. Akad. Wiss. Südbras. 11. 1906; Denkschr. Kais. Akad. Wiss. Wien 79: 72. 1908. The type specimen, in Hackel's herbarium, was collected in southern Brazil by Wettstein and Schiffner in 1901. 
DESCRIPTION.

Plants perennial with long branching decumbent base, rooting at the nodes; culms straggling, ascending, 2 to 3 meters long, slender, more or less compressed, smooth or hirsute or roughened below the nodes, producing long divaricate branches; sheaths papillose-hispid especially toward the summit, sometimes glabrate below, densely pubescent at the junction with the blade; ligule membranaceous-ciliate, about 0.5 $\mathrm{mm}$. long; blades flat, rather firm, usually horizontally spreading, 10 to $15 \mathrm{~cm}$. long, 1.2 to $2.5 \mathrm{~cm}$. wide (rarely larger), narrowed to the usually unsymmetrical base, gradually tapering from below the middle to an acuminate apex, scabrous and sometimes sparsely hispid on the upper surface, pubescent above the ligule, scaberulous or puberulent beneath or sometimes sparsely hispid, especially along the midnerve, the fine white margin undulate, scabrous; panicle 10 to $15 \mathrm{~cm}$. long, usually about as wide, the few slender scabrous branches remote, pilose in the axils, the lower branches solitary or in pairs, widely spreading or reflexed, more than half as long as the very scabrous main axis, naked at the base,

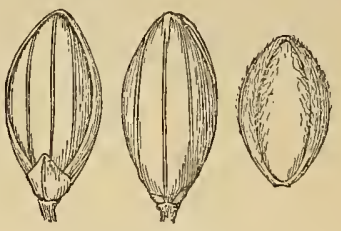

FIG. 87. $-P$. schiffneri. From type specimen.

the upper branches much shorter, ascending, the rather densely flowered short branchlets appressed along the upper half or two-thirds of the branches, the bract at the base of inflorescence usually well developed; spikelets short-pediceled, aggregated, scarcely $2 \mathrm{~mm}$. long, $1 \mathrm{~mm}$. wide, turgid, glabrous; first glume less than onefourth as long as the spikelet; second glume and sterile lemma equal, exceeding the fruit, obscurely nerved; fruit about $1.5 \mathrm{~mm}$. long, $0.9 \mathrm{~mm}$. wide, elliptical, sparsely covered with long appressed silky hairs.

This species resembles Panicum parviglume in habit and $P$. schmitzii and $P$. virgultorun in spikelet characters. It has longer, more straggling culms than has any other species of this group, and larger blades than any except $P$. parviglume.

\section{DISTRIBUTION.}

Wet shady banks and slopes, Porto Rico, Windward Islands, and southern Mexico to southern Brazil.

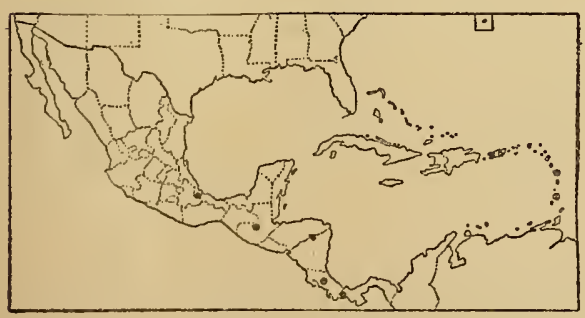

Fig. 88.-Distribution of $P$. schiffneri.

Veracruz: Córdoba, Amer. Gr. Nat. Herb. 66, distributed as P. parviglume.

Guatemala: Cobán, Turckheim II. 1326.

Costa Rica: San Francisco de Guadalupe, Jiménez in 1910.

Panama: El Boquete, Hitchcock 8278,8305 .

PoRto Rrco: Maricao, Chase 6198. Indiera Tria, Chase 6247. Vicinity of Cayey, Chase 6745. Alto de Bandera, Chase 6474.

Mrndward Isuands: Martinique, Hahn 616. St. Vincent, Eggers 6653, Swith \& Smith 1099 (K. U. Herb.).

\section{Panicum parviglume Hack.}

Panicum parviglume Hack. Oesterr. Bot. Zeitschr. 51: 429. 1901; Contr. U. S. Nat. Herb. 15: 126. 1910.

Panicum conchatum Fourn. Mex. P1. 2: 25. 1886. This was previously included among the doubtful species. ${ }^{1}$ A few spikelets from Schaffner's no. 204 (the type

${ }^{1}$ Contr. U. S. Nat. Herb. 15: 329. 1910. 
collection) in the Berlin Herbarium are in the National Herbarium. A restudy of these together with later collections show that they are referable to $P$. parviglume. Fournier's description is vague and inadequate and appears to have been based on more than one species, the vegetative characters as described being unlike those of any species in this group. Because of this uncertainty the name $P$. conchatum is not taken up to replace $P$. parviglume.

Panicum arundinariae Trin.; Fourn. Mex. Pl. 2:25. 1886. This name is also included among the doubtful species. ${ }^{1}$ Müller's no. 2018, one of the specimens cited by Fournier, is $P$. parviglume, while another, Schaffner 279, also cited, is Ponicum virgultorum. As in the preceding case, the description is inadequate, for which reason the name $P$. arundinariae is not taken up.

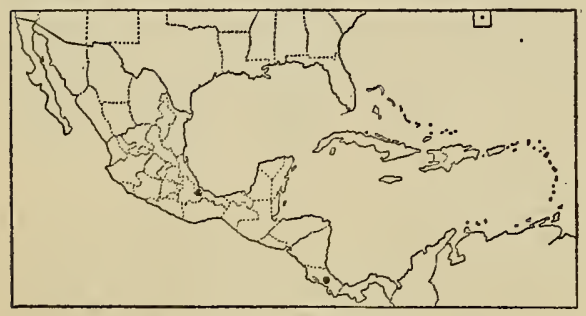

FIG. 89.-Distribution of $P$. parviglume.

\section{DISTRIBUTION.}

Banks and ditches, southern Mexico to Costa Rica. The type specimen from San José, Costa Rica.

Veracruz: Orizaba, Bourgeau 3197, Müller 2018. Borrego, Botteri 150, 152.

Costa Rica: Alajuelita, Jiménez 403. San Francisco de

Guadalupe, Tonduz \& Pittier 8448, Jiménez 113. San José, Hitchcock 8487.

\section{TRICHOIDIA.}

One of the two species of this group, Panicum trichanthum, is found to be a perennial.

Blades more than one-fourth as wide as long; spikelets pubescent; plants annual...........................6. 67. P. trichoides.

Blades less than one-eighth as wide as long; spikelets minutely bullate-rugose; plants perennial................ 68. P. trichanthum.

\section{Panicum trichoides Swartz.}

Panicum trichoides Swartz, Prodr. Veg. Ind. Occ. 24. 1788; Contr. U. S. Nat. Herb. 15: 129. 1910.

\section{DISTRIBUTION.}

Damp shady places, often a weed in fields and groves, tropical America. The type specimen from Jamaica.

SinaloA: Imala, Paimer 1758 in 1891.

Tepic: María Madre Islands, Nelson 4257.

JAlisco: Guadalajara, Amer. Gr. Nat. Herb. 70, Pringle 2618, 3828.

Colrma: Manzanillo, Palmer 1083 in 1890. Colima, Orcutt 4515. Alzada, Hitchcock 7110.

MichoACÁs: La Correa, Langlassé 380. Hacienda Coahuayula, Emrick 53.

Veracruz: Zacuapán, Purpus 2902. Minatitlán, Smith 601. Córdoba, Fincki in 1893. Sanborn, Orcutt 3241.

Guerrero: Acapulco, Palmer 287 in 1894.

OAXACA: Guatulco, Liebmann 317.

Tabasco: Mayito, Rovirosa 434. San Juan Bautista, Rovirosa 598.

Yucatán: Izamal, Gaumer 522. San Anselmo, Gaumer 895, 2027. 
British Honduras: Manatee Lagoon, Peck 314. Toledo, Peck 637 (both in Givey Herb.).

Guatemala: El Palmar, Kellerman 6263. Santa Rosa, Heyde \& Lux 4299 . Cubilquitz, Türckheim 7801. Morales, Deam 6041. Rinconcito, Heyde \& Lux 4299.

Honduras: Amapala, Hitchcock 8768. Puerto Sierra, Witson 89, 188.

Salvador: Sonsonate, Hitchcock 8981. San Salvador, Velasco 10. La Unión, Hitchcock 8791.

Nicaragua: Jinotepe, Hitchcock 8693. San Juan del Sur, Hitchcock 8604. Masaya, ITitchcock 8631.

Costa Rica: Hacienda de Zent, Tonduz 363, Pittier in 1904. Atenas, Hitchcock 8521. Puntarenas, Hitchcock 8555. Alajuela, Jiménez 145. San José, Tonduz 3133. Buenos Aires, Tonduz 4865, Pittier 3651. Matina, Pittier 9754. Nicoya, Cooper 10379, Tonduz 13754. Boruca, Pittier 4458. Hacienda de Chirripó, Pittier 16081. Carrillo, Biolley 3111.

Panama: Culebra, Fitchcock 7933, 8022. Alajuela, Pittier 2352. Puerto Obaldía, Pitiier 4284. Below Chepo,

Pittier 4696. Culebra, Pittier 2083. Tabernilla, Hitchcock: 8384. Taboga Island, Celestine 84.

Cuba: Habana, León in 1910, Curtiss 714. Monte Verde, Wright 1538. Sancti Spiritus, León 4105.

JAMAICA: Ramble, Hitchcock 9475. Cedar Hurst, Harris 11566. Castleton, Harris 11299, 11328.

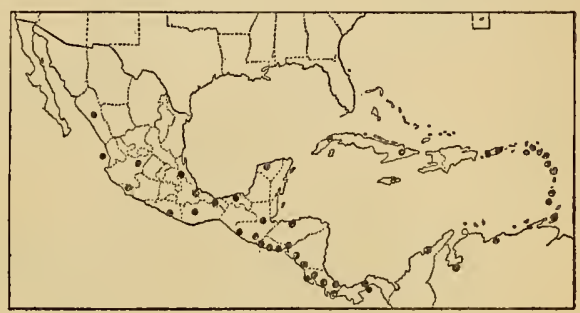

FIG. 90.-Distribution of $P$. trichoides.

Kingston, Hitchcock 9281. Port Antonio, Fredholm 3282. Gordon Town, Hitchcock 9332.

Porto Rico: Maricao, Chase 6191. Vega Baja, Chase 6417. Mayaguez, Chase 6167, Sintenis 160, Cowell 522, 583. Ponce, Heller 6094. Luquillo Mountains, Wilson 283. Martin Peña, Heller 387. Between Aibonito and Cayey, Heller 531. Mount Morales, Britton \& Cowell 444. Santurce, Heller 157. Rio Piedras, Barrett 61.

Leeward Islands: St. Kitts, Britton \& Cowell 295. Guadeloupe, Duss 2681. Dominica, Eggers in 1881. Montserrat, Shafer 337, 706. Saba, Suringar in 1885, Boldingh 2122 (K. U. Herb.).

Wrndward Islands: Martinique, Hahn 1047, Duss 1321. Grenada, Broadway in 1905, Eggers 5987. St. Vincent, Smith \& Smith 185 (K. U. Herb.).

Trinidad: Port of Spain, Hitchcock 9946.

Venezuela: Above Paparo, Pittier 6494. Tovar, Fendler 2499.

Coloubia: Santa Marta, Smith 167. Sevilla, Pittier 1621. Calí, Pittier 971.

\section{Panicum trichanthum Nees.}

Panicum trichanthum Nees, Agrost. Bras. 210. 1829; Contr. U. S. Nat. Herb. 15: 131. 1910.

The habit of this species as studied in the field indicates that it is a perennial. The culms are long and straggling with rootlets at the nodes and form a tangled mass among shrubs or vines.

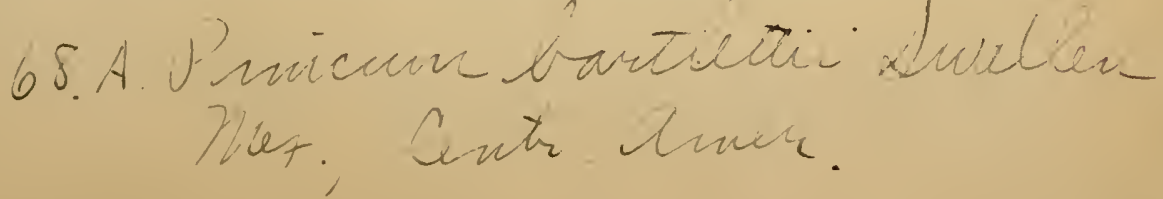




\section{DISTRIBUTION .}

Moist thickets and river banks, Mexico, and the West Indies to Paraguay. The type specimen from Mexico.

San Luis Potosí: San Luis Potosí to Tampico, Palmer 1151 in 1879.

Colmua : Palmer 1257 in 1891.

Veracruz: Motzorongo, Smith 585. Veracruz, Hitchcock 6584. Jicaltepec, Liebmann 320. Colipa, Liebmann 432. Without locality, Müller 2172.

CAmpeche: Near Champotón, Collins 37.

Brttish Monduras: Toledo, Peck 775 (Gray Herb.).

Guatemala: Gualán, Deam 424. Puerto Barrios, Hitchcock 9149. Morales,

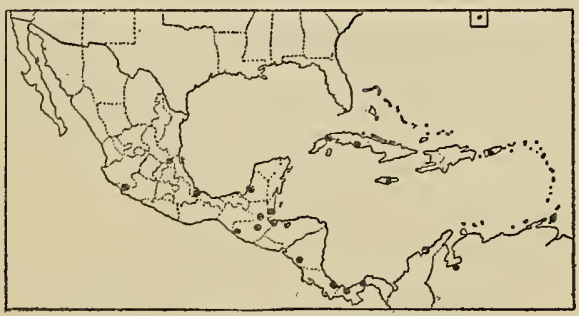

Fig. 91.-Distribution of $P$. trichanthum. Kellerman 6272. Finca Trece Aguas, Lewton 377. Cubilquitz, Türckheim 7798.

Honduras: San Pedro Sula, Thieme 5587.

Nicaragua: Jinotepe, Hitchicock 8669,8682 .

Costa Rica: Port Limon, Hitchcock 8434. Talamanca, Tonduz 8600,8670 .

Panama: Laguna de Chiriquí, Hart 87. Culebra, Hitchcock 7895 .

Frijoles, Maxon 4703. Panama, Hitchcock 9212. Tabernilla, Pittier 3824, Hiichcock 8383. Gamboa, Pittier 4798. Balboa, Hitchcock 8015.

Cuba: Trinidad, Wright 753. Vento, Curtiss 598, León 557. Romelie, Eggers 5350.

JAmaica: Port Antonio, Hitchcock in 1890.

Porto Rico: Cayey, Sintenis 2471, Chase 6748. Peñuelas, Chase 6487. Rio Piedras, Johnston 143.

Triniddad: Port of Spain, Hitchcock 9943. Cedros, Hitchcock 10146.

Venezuela: Tovar, Fendler 1443.

Colombia: Santa Marta, Smith 2151.

\section{PARVIFOLIA.}

Perennials, usually glaucous; culms more or less decumbent; panicles small, diffuse, the spikelets small, turgid or subglobose, glabrous, the first glume more than half the length of the spikelet.

Culms very slender, decumbent or creeping; blades 1 to $3 \mathrm{~cm}$.

long......................................... 69. parvifolium. Culms firm, erect or decumbent at base only; blades 3 to $8 \mathrm{~cm}$.

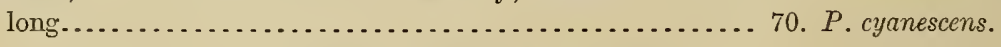

\section{Panicum parvifolium Lam.}

Panicum parvifolium Lam. Tabl. Encycl. 1: 173. 1791; Contr. U. S. Nat. Herb. 15: 134. 1910.

The blades in this species vary in shape from oblong or ovate-lanceolate to narrowly lanceolate, in surface from glabrous to densely appressed-hirsute, and in texture from thin to firm. One form, in aspect approaching $P$. cyanescens, has firm pubescent erect blades, as much as $5 \mathrm{~mm}$. wide and $4.5 \mathrm{~cm}$. long. This is represented by Broadway 2372 in part and Hitchcock 10065, both from Trinidad. Panicum brasiliense Spreng. is a pubescent form with oblong-lanceolate moderately firm blades. It does not appear possible to recognize this form as a distinct species. 
DISTRIBUTION.

Wet savannas and margins of ponds and streams, Costa Rica and the West Indies to Paraguay. The type specimen from tropical America.

Costa Rrca: Buenos Aires, Tonduz 3631, 3659, Pittier 10594.

Cuba: Los Almacigos, Wright 3458. Herradura, Baker 2078, Tracy 9060, 9079, Hitchcock 181, Britton, Earle \& Gager 6494. Pinar del Río, Britton \& Gager 7075. Guane, Shafer 10659. Laguna Los Indios, Shafer 10803.

Porto Rico: Lake Loisa, Chase 6786. Campo Alegre, Chase 6615, 6788. Aguada, Sintenis 5719. Guainabo, Chase 6630. Cataño, Sintenis 5719. Martin Peña, Chase 6358. Trujillo

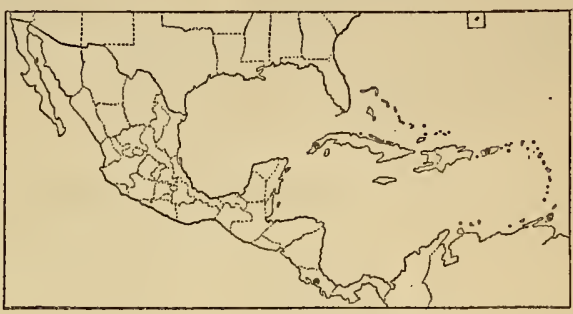

FIG. 92.-Distribution of $P$. parvifolium. Alto, Chase 6763. Vega Baja, Chase 6796, Hcller 1316.

Trinidad: Cumuto Station, Hitchcock 10065, Amer. Gr. Nat. Herb. 72. Pitch Lake, Hitchcock 10100. Arima, Broadway 2372. Without locality, Crueger, 224.

- 7o. Panicum cyanescens Nees.

Panicum cyanescens Nees Agrost. Bras. 220. 1829. "Habitat in Brasilia meridionali (Sellow)." The type is in the Berlin Herbarium.

Panicum firmifolium Trin.; Nees, 1oc. cit. A herbarium name given as a synonym of $P$. cyanescens.

\section{DESCRIPTION.}

Plants perennial, bluish or glaucous; culms tufded, erect or with a decumbent base rooting at the nodes, slender, smooth, leafy, 30 to $50 \mathrm{~cm}$. high, branching from the middle and upper nodes; sheaths striate, glabrous, rarely ciliate on the overlapping margin; ligule minute, membranaceous, sparsely ciliate with long hairs or sometimes naked; blades flat, rather firm, erect, spreading or reflexed, 3 to $8 \mathrm{~cm}$. long, 4 to $5 \mathrm{rhm}$. wide,

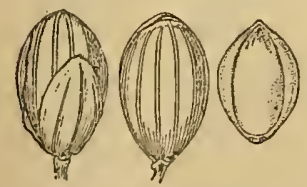

FIG. 93.-P. cyanescens. From type specimen. oblong-lanceolate, slightly narrowed to the base, acute, glabrous; panicles short-exserted, terminal and often from. the upper sheaths, 3 to $6 \mathrm{~cm}$. long, as wide or wider, open, the slender flexuous branches rather remote, stiffly ascending or spreading, naked below, branching and spikeletbearing toward the ends, the spikelets on slender divaricate pedicels; spikelets about $1.5 \mathrm{~mm}$. long, $0.9 \mathrm{~mm}$. wide, turgid or subglobose, obtuse, glabrous; first glume two-thirds to three-fourths as long as the spikelet; second glume and sterile lemma equal, covering the fruit, or at maturity the glume.wrinkled because of the turgidity of the fruit, exposing the summit; fruit $1.2 \mathrm{~mm}$. long, $0.8 \mathrm{~mm}$. wide, very turgid, subacute, the lemma and palea cellular-roughened as seen under a lens, bearing a few very obscure appressed hairs toward the summit.

This species resembles $P$. parvifolium, but differs in the less slender, more erect culms, longer blades, and stiffly ascending panicle branches, naked below. 


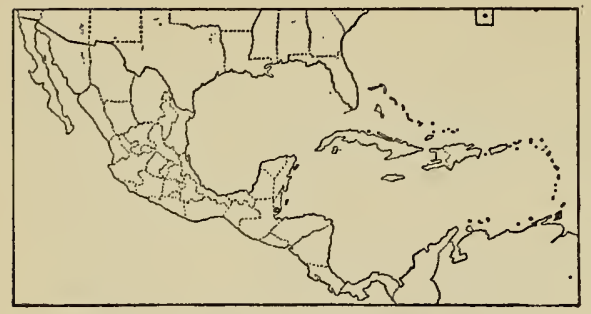

FIG. 94.-Distribution of $P$. cyanescens.
DISTRIBUTION.

Swamps and wet savannas, British Honduras and Trinidad to Brazil.

British Honduras: Manatee Lagoon, Peck 271 (Gray Herb.).

Trinidad: Piarco Savanna, Hitchcock 10349, 10354, 10364. Cumuto Station, Hitchcock 10067. Aripo Savanna, Broadway 2377.

\section{UNGROUPED SPECIES OF TRUE PANICUM.}

\section{Panicum pyrularium sp. nov.}

Plants annual; culms delicate, 10 to $13 \mathrm{~cm}$. high, at first erect and simple, finally decumbent and branching, often rooting at the nodes, more or less zigzag, sometimes elongating to 25 or $30 \mathrm{~cm}$.; nodes sparsely pilose or glabrous; sheaths shorter than the blades, glabrous or sparsely pilose; ligule membranaceous, about $0.5 \mathrm{~mm}$. long; blades thin, flat, spreading, 1 to $3 \mathrm{~cm}$. long, 2 to $7 \mathrm{~mm}$. wide (the lower sometimes smaller), narrowly elliptical, somewhat clasping at base, obtuse or acutish at the apex, scabrous on the margins, glabrous or sparsely pilose on both surfaces, sometimes glaucous; panicles terminating the culm and branches, loose and open, 2 to 5 $\mathrm{cm}$. long, about as wide, oval or pyramidal in outline, the delicate flexuous branches and branchlets spreading or reflexed, smooth, the capillary divaricate pedicels several times longer than the spikelets; spikelets $1.5 \mathrm{~mm}$. long, $0.6 \mathrm{~mm}$. wide, turgid, pyriform, long-attenuate at base, glabrous; first glume about half as long as the spikelet, acute; second glume and sterile lemma 5-nerved, not exceeding the fruit, the glume slightly shorter than the sterile lemma; fruit $1 \mathrm{~mm}$. long, $0.5 \mathrm{~mm}$. wide, turgid.

Type in the U. S. National Herbarium, no. 715639, collected

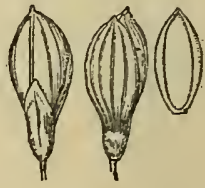

Fig. 95.-P. pyrularium. From type specimen. between Hato del Jobo and Cerro Vaca, eastern Chiriquí, Panama, altitude 700 to 1,000 meters, December 25 to 28, 1911, by H. Pittier (no. 5416).

Panicum pyrularium, one of the smallest and most delicate species in the genus, is not related to any North American species.

The South American Panicum polycomum Trin. is an allied species of more tufted habit, with much narrower blades, smaller panicles, and smaller pubescent spikelets not attenuate at base.

None of the labels with the specimens cited below indicates the habitat.

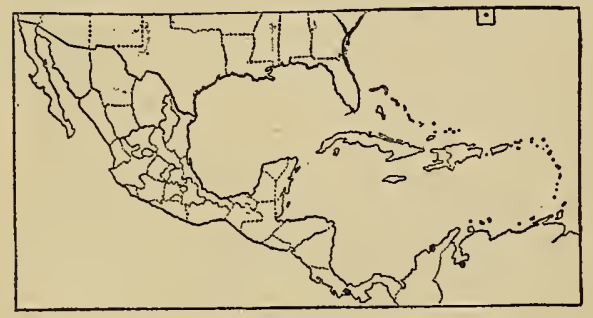

FIG. 96.-Distribution of $P$. pyrularium.

\section{DISTRIBUTION.}

Panama to Ven ezuela.

Panama: Between Hato del Jobo and Cerro Vaca, Chiriquí, Pittier 5416.

Venezuela: Tovar, Fendler 2502.

Colombia: Santa Marta, Smith 2570. Without locality, Triana 281 (2811?). 


\section{Panicum haenkeanum Presl.}

Panicum haenkeanum Presl, Rel. Haenk..1: 304. 1830. "Hab. in Mexico." The type specimen is in the herbarium of the National Museum at Prague. The only datum on the label is the word "Mexico."

Panicum costaricense Hack. Oesterr. Bot. Zeitschr. 51: 428. 1901; Contr. U. S. Nat. Herb. 15: 134. 1910.

For discussion of Panicum expansum Fourn., mentioned in the Revision under $P$. costaricense, see page 525 under $P$. cordovense.

Field study of this species shows that it is a perennial with straggling culms as much as 2 meters long, of ten rooting at the lower nodes.

\section{DISTRIBUTION.}

Moist wooded or grassy banks and slopes, Mexico to Panama.

Costa Rica: Térraba, Tonduz 3628, 3636, 3673. Boruca, Pittier 4626. Cordoncillal, Pittier 3640. Buenos Aires, Tonduz 3687, 4860, Pittier 3661 .

Panama: Culebra, Hitchcock 9168. Between Corozal and Ancon, Pittier 2169, 2636. San Felix, Pittier 5247. Between Panama and Corozal, Hitchcock 9206.

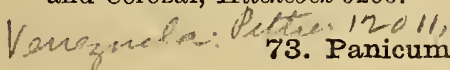

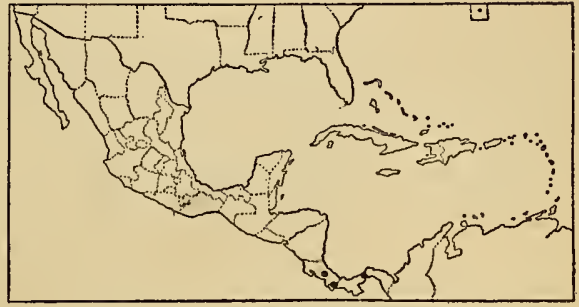

FIG. 97.-Distribution of $P$. haenkeanum.

\section{DESCRIPTION.}

Plants perennial (?); culms slender, apparently ascending, probably $50 \mathrm{~cm}$. or more long, slender, striate-fluted, glabrous or the upper internodes sparsely pilose,
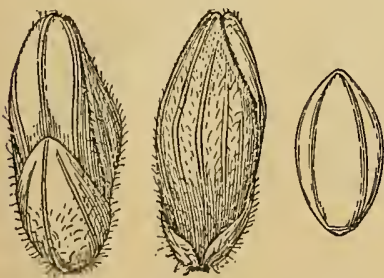

FIG. 98.-P.ineplum. From type specimen. producing nearly simple branches as much as 25 $\mathrm{cm}$. long; nodes retrorsely pubescent; sheaths loose, shorter than the internodes, pilose, the margins densely ciliate; ligule ciliate, about $0.5 \mathrm{~mm}$. long; blades spreading, flat, 3 to $7 \mathrm{~cm}$. long, 3 to $6 \mathrm{~mm}$. wide, tapering from the truncate base to an acuminate apex, softly pilose on both surfaces; panicles terminal, those of the branches short-exserted, 3 to $5 \mathrm{~cm}$. long, consisting of few to several short spreading densely flowered branches, remote along the slender pilose axis, the branches 4 to $6 \mathrm{~mm}$. long, bearing 1 to 8 subsessile spikelets, the rachis pilose; spikelets 2.5 to $2.7 \mathrm{~mm}$. long, $1.1 \mathrm{~mm}$. wide, blunt; first glume about half as long as the spikelet, 3-nerved, obtuse, pubescent; second glume and sterile lemma equal, inflated, much larger than the fruit, the glume gibbous in the middle, 7-nerved, pubescent, the sterile lemma 3-nerved, glabrous, inclosing a membranaceous palea; fruit $1.6 \mathrm{~mm}$. long, $0.9 \mathrm{~mm}$. wide, elliptical, smooth and shining, the lemma strongly convex.

Type in the herbarium of Krug \& Urban in the Berlin Botanical Mu-

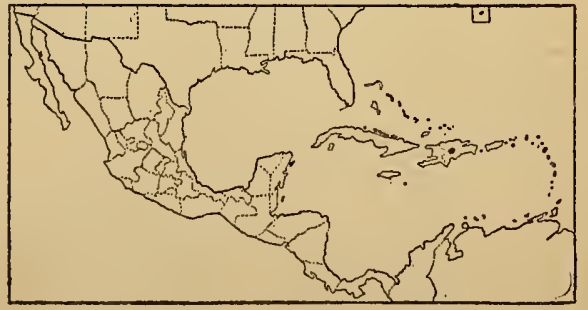

FIG. 99.-Distribution of $P$. ineptum. seum, the ticket reading "817 Panicum-_-S. Domingo, Bertero. Hb. Spr." A slip in Sprengel's hand bears the name "Panicum nemorosum Sw." [Ichnanthus nemorosus].

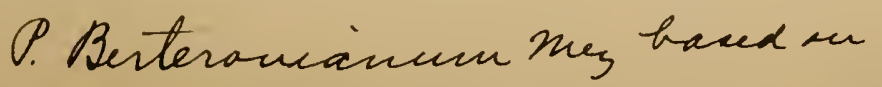


The type specimen, consists of a culm with four internodes, the base and summit wanting, bearing two flowering branches. No other collection of the species is known. It appears to be related to Panicum venesuelae Hack., from which it differs in the smaller panicle and in the smaller and pubescent instead of bristly hispid spikelets.

74. Panicum millegrana Poir.

Panicum millegrana Poir. in Lam. Encycl. Suppl. 4:278. 1816; Contr. U. S. Nat. Herb. $15: 135.1910$.

Panicum patentissimum Desv.; Poir. in Lam. Encycl. Suppl. 4: 283. 1816. "Cette plante crôit à Saint-Dominique \& à la Nouvelle-Espagne." The type from the herbarium of Desvaux in the Paris Ferbarium is a fragmentary specimen consisting of a panicle with immature glabrous spikelets together with a few broken leaves.

\section{DISTRIBUTION.}

Damp woods and shady banks, Mexico and the West Indies to Paraguay. The type specimen from tropical America, probably from Cayenne.

Veracruz: Córdoba, Amer. Gr. Nat. Herb. 73. Jalapa, Hitchcock 6605, Holway 3083. Mirador, Lielmann 275.

OAXACA: Without locality, Galeotti 5728.

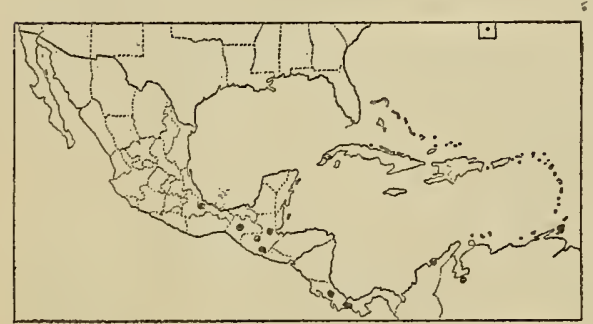

FIG. 100.-Distribution of $P$. millegrana.

Chiapas: Santa Rosa, Heyde \& Lux 3927.

Guatemala: Cubilquitz, Türckheim 8783, 8784. Cobán, Türckheim 657. Guatemala City, Hitchcock 9056 .

Costa Rica: El General, Pittier 10615.

Panama: El Boquete, Hitchcoch 8299.

CuBA: Herradura, Hitchcock 180, Tracy 9098. Ira Catalina,

Wright 3455. Pinar del Río, Wright 3855. Sumidero, Shafer 13562. Sierra de Cabra, Britton \& Gager 7201.

Trinidad: Pitch Lake, Hitchcock 10087. Port of Spain, Hitchcock 9979.

Venezuela: Tovar, Fendler 1641.

Colombia: Santa Marta, Smith 168, 2146.

\section{Panicum glutinosum. Swartz.}

Panicum glutinosum Swartz, Prodr. Veg. Ind. Occ. 24. 1788; Contr. U. S. Nat. Herb. 15: 138. 1910.

\section{DISTRIBUTION.}

Mountain woods, throughout tropical America. The type specimen from Jamaica.

Veracruz: Mirador, Liebmann 428, Ross 701. Orizaba, Bourgeau 3192, Botteri. Jalapa, Amer. Gr. Nat. Herb. 74. Zacuapán, Purpus 2156, 2903.

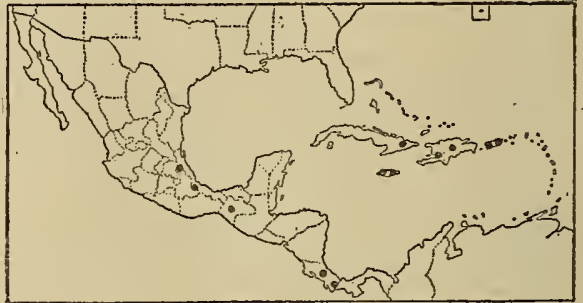

FIG. 101.-Distribution of $P$. glutinosum. 
Chiapas: Turubula, Nelson 3357.

Costa Rica: Helechales del General, Pittier 12002. Cañas Gordas, Pittier 11017. Cabagra, Tonduz 6547. Río Birrís, Pittier 3118.

Cuba: Loma Pelada, Wright 757. La Perla, León 3790. Banao Hills, León 399S. Gran Piedra, Shafer 9014. Without locality, Linden 2143.

JAMAICA: Gordon Town, Hart 792, Hitchcock 9321. Troy, Maxon 2816, Hitchcock 9785. Abbey Green, Hitchcock 9370. Cinchona, Hilchcock 9708, Harris 11264, 11440, 11508. Ewarton, Hitchcock 9451. Ipswich, Hitchcock 9627. Newport, Britton 3193. Road to Salt Hill, Harris 11395. Without locality, Wullschlaegel 11.63.

Haits: Kenskoff, Buch 956.

Santo Domingo: Picarda 620 (K. U. Herb.).

Porto Prco: Sierra de Yabucoa, Sintenis 2609, Mayaguez, Sintenis 357 . Alto de Bandera, Chase 6469. Maricao; Chase 6199, 6250.

Venezuela: Caracas, Pittier 5910.

76. Panicum rudgei Roem. \& Schult. ${ }^{1}$

Panicum rudgei Roem. \& Schult. Syst. Veg. 2: 444. 1817; Contr. U. S. Nat. Herb. 15: 139. 1910.

\section{DISTRIBUTION.}

Savannas, Jamaica and British Honduras to Brazil. The type specimen from British Guiana.

British Honduras: Monkey River, Peck 588 (Gray Herb.).

Costa RicA: Buenos Aires, Pittier 10576, Tonduz 3679, 4 S75.

Los Palmares, Pittier 10588.

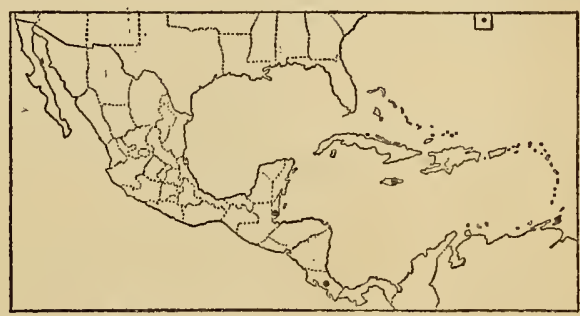

FIG. 102,-Distribution of $P$. rudgei.

Helechales del General, Pittier 12064.

JAMAICA: Bunkers Hill Savanna, Harris 11170.

Trinidad: Pitch Lake, Amer. Gr. Nat. Herb. 75. St. Joseph, Hitchcock 10181.

Without locality, Crueger.

77. Panicum megiston Schult.

Panicum megiston Schult. Mant. 2: 248. 1824; Conts. U. S. Nat. Herb. 15: 141. 1910.

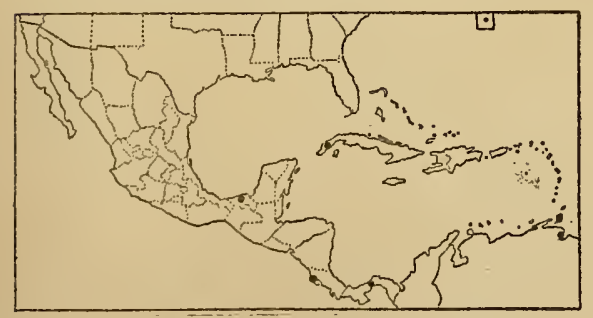

FIG. 103.-Distribution of $P$. megiston.

DISTRIBUTION.

Swamps, Mexico and Cuba to Paraguay. The type specimen from British Guiana.

TABASco: San Juan Bautista, Rovirosa 532 .

Costa Rica: Guanacaste, Jiménez 727.

Panama: Empire, Pittier 3726. Bolı́́o, Amer.Gr. Nat. Herb. 76.

Cuвa: Santa Cruz de los Piños, Wright 3872.

Trunidad: Caroní Savanna, Ilart 4197. Without locality, Crueger.

Venezuela: Santa Catalina, Rusby \& Squires 355.

1 The South American species described as Panicum rotundum Fitchc. \& Chase (Contr. U. S. Nat. Herb. 15: 139. 1910) proves to be the same as Panicum campestro Nees (Trin. Gram. Pan, 197. 1826). 
Panicum TRIgonum Retz., ${ }^{1}$ an East Indian perennial with low creeping and branching culms and spreading pilose blades 2 to $4 \mathrm{~cm}$. long, contracted panicles of sinort-pediceled lispidulous spikelets about $1.7 \mathrm{~mm}$. long, the second glume keeled, the fruit slightly compressed laterally, has been found "under the shade of a shrub," Port of Spain, Trinidad, Broadway 4891. (Cyrtacecum trigoncem G. Cas Subgenus DICHANTHEIIUM Hitche. \& Chase.

Foliage soft and lax, the flat blades prominently ciliate; plants branching from the base, finally forming rosettes or cushions......................... See Laxiflora, p. 513.

Foliage not soft and lax; plants branching from the culm nodes.

First glume nearly as long as the spikelet........... See Cordovinsia, p. 525.

First glume much shorter than the spikelet.

Spikelets glabrous; plants glabrous throughout; autumnal form erect, not bushy-branching. See Diснотома, p. 516. Spikelets pubescent.

Sheaths glabrous or minutely puberulent onl ; ligules minute or obsolete.

Spikelets attenuate at base, mostly prominently pustulose; blades narrow, stiff, strongly nerved, tapering from base to apex....... See ANGustrfolia, p. 514.

Spikelets not attenuate at base, not pustulose.

Spikelets subglobose or pyriform.

Blades spreading, rarely over 5 $\mathrm{cm}$. long and $5 \mathrm{~mm}$. wide, spikelets pyriform; autumnal form bushybranching ............. See Lancearia, p. 522.

Blades erect, 7 to $13 \mathrm{~cm}$. long,

7 to $14 \mathrm{~mm}$. wide; spike-

lets spheroid .......... See Sphaerocarpa, p. 521.

Spikelets not subglobose nor pyriform.

Spikelets $2.8 \mathrm{~mm}$. or more long. See Comnutata, p. 524.

Spikelets not over $2 \mathrm{~mm}$. long.

Blades with a cartilaginous white margin; spikelets not over $1.5 \mathrm{~mm}$. long .............. 101. P. albomarginatum.

Blades not white-margined;

Sheaths pubescent.

spikelets $2 \mathrm{~mm}$. long. See Dichотома, p. 516 .

Spikelets $4 \mathrm{~mm}$. long, pyriform....... 104. P. nodatum.

Spikelets not over $2.6 \mathrm{~mm}$. long.

- Spikelets attenuate at base, mostly prominently pustulose; blades narrow, stiff, strongly nerved, tapering from base to apex; autumnal form often bushybranched............... See Angustifolia, p. 514. 
Spikelets not attenuate at base.

Culms tall, usually $75 \mathrm{~cm}$. high or more; foliage velvety-

pubescent.............. See Scoparia, p. 523.

Culms not over $50 \mathrm{~cm}$. high.

Spikelets not over $1.3 \mathrm{~mm}$.

long; sheaths and culms appressed-pubescent ........... . See Spreta, p. 518.

Spikelets 1.7 to $2.4 \mathrm{~mm}$.

long; plants conspicuously pubescent, at

least on the sheaths. See Lanuginosa, p. 519.

\section{LAXIFLORA.}

Spikelets papillose-pilose; sheaths retrorsely pilose........... 78. P.xalapense. Spikelets glabrous; sheaths not retrorsely pilose.

Blades glabrous on the surface . . . . . . . . . . . . . . . . 79. Polycaulon.

Blades pilose on the surface.

80. P. strigosum.

78. Panicum xalapense H. B. K.

Panicum xalapense H. B. K. Nov. Gen. \& Sp. 1: 103. 1816; Contr. U. S. Nat. Herb. 15: 159. 1910.

\section{DISTRIBUTION.}

Moist banks and rich woods, southeastern United States to Guatemala; also Santo Domingo. The type specimen from Jalapa.

Hidalgo: Trinidad Iron Works, Pringle 13250.

Puebla: Chinantla, Liebmann 328.

Veracruz: Jalapa, Pringle 8083, Hitchcock 6587, Amer. Gr. Nat. Herb. 84, Smith 1752. Córdoba, Bourgeau 2162. Boca del Monte, Nelson 201, Seler 2160.

Guatemala: Cobán, Türckheime

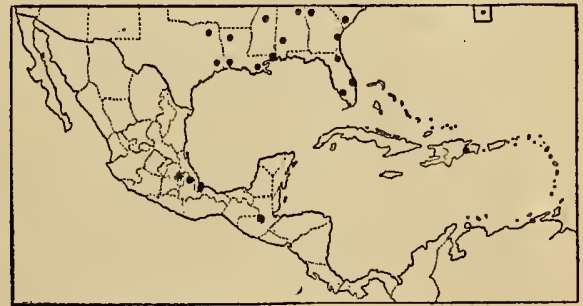

Fig. 104.-Distribution of $P$. xalapense. 3831 .

Santo Domingo: Constanza, Türckheim 3059. Río Yaqui near Jarabacoa, Eggers 2129.

\section{Panicum polycaulon Nash.}

Panicum dichotomum $\beta$ glabrescens Griseb. Fl. Brit. W. Ind. 553. 1864. "Pd. [Purdie], in mountain-savannahs [Jamaica]." The type specimen is in the Kew Herbarium.

Panicum polycaulon Nash, Bull. Torrey Club 24: 200. 1897; Contr. U. S. Nat. Herb. 15: 163.1910.

$$
82472^{\circ}-15-5
$$




\section{DISTRIB UTION.}

Open moíst woods and savannas, Florida and the Greater Antilles. The type specimen from Florida.

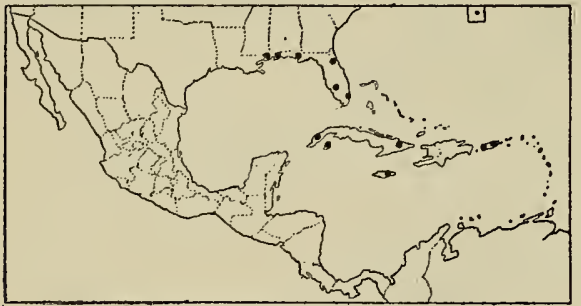

FIG. 105.-Distribution of $P$. polycaulon.
CuBA: Sierra Nipe near Woodfred, Shafer 3083. Herradura, Hitchcock 115. Isle of Pines, Palmer \& Riley 990. Without locality, Wright 3875 in part.

JAMAICA: Hills back of Barican, Hitchcock 9561. Bull Head Mountain, Hitchcock 9550 .

Porto Rico: Aguada, Sintenis 5724. Monte Mesa, Chase 6276.

Trujillo Alto, Chase 6767. Campo Alegre, Chase 6621.

\section{Panicum strigosum Muhl.}

Panicum strigosum Muhl. in Ell. Bot. S. C. \& Ga. 1: 126. 1816; Contr. U. S. Nat. . Herb. 15: 164. 1910.

\section{DISTRIBUTION .}

Sandy woods and open moist ground, southeastern United States to Colombia and in the Greater Antilles. Type specimen from South Carolina or Georgia.

Veracruz: Minatitlán, Smith 555.

Guatemala: Road from Gualán to

Copán, Pittier 1800 . Secanquím, Pittier 257.

Costa Rica: Between De Candelaria and San Cristobal, Jiménez 459.

CuBA: El Guama, Palmer \& Riley 213. Without locality, Wright 3875 in part.

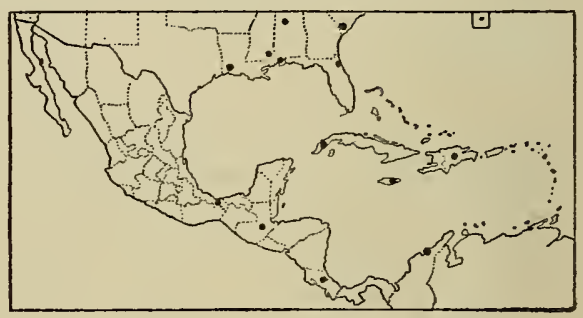

FIG. 106.-Distribution of $P$. strigosum.

JAMAICA: Bull Head Mountain, Hitchcock 9551.

Santo Domingo: Without locality, Eggers 2045 (K. U. Herb.).

Colombia: Santa Marta, Smith 163.

Pomana: ancou, e?, killip yov

ANGUSTIFOLIA.

Nodes bearded; plants grayish-villous; autumnal blades flat, rather soft. ........................... 82. P. chrysopsidifolium.

Nodes not bearded; plants villous only at base, or nearly glabrous; autumnal blades involute.

Spikelets 3 to $3.5 \mathrm{~mm}$. long, pointed.

83. P. fusiforme.

Spikelets less than $3 \mathrm{~mm}$.long, not pointed or obscurely so.

Plants glabrous or nearly so; autumnal culms erect.

Spikelets subsecund along the suberect panicle branches........................ 86. P. neuranthum.

Spikelets not subsecund; panicle loose and open. 85. P. ovinum. Plants pubescent, at least on the lower half.

Spikelets about $2.4 \mathrm{~mm}$., rarely only $2.1 \mathrm{~mm}$., long; vernal blades 7 to $12 \mathrm{~cm}$. long; autumnal blades not falcate............ 84. P. arenicoloides.

Spikelets not over $2 \mathrm{~mm}$. long; vernal blades 4 to $6 \mathrm{~cm}$. long; autumnal blades much crowded, falcate................. 81. P. aciculare. 


\section{Panicum aciculare Desv.}

Panicum aciculare Desv.; Poir. in Lam. Encycl. Suppl. 4: 274. 1816; Contr. U. S. Nat. Herb. 15: 166. 1910.

In the discussion of the type specimen it is stated that it probably came from the southeastern United States. As the species is now known to occur in Porto Rico, it becomes probable that this island is the type locality, since Desvaux described many species from there.

DISTRIBUTION.

Grassy slopes and sandy woods, southeastern United States, Cuba, and Porto Rico.

Cuba: Pinar del Río, Britton \& Gager 7064. Sierra Nipe, Shafer 2968. Laguna Jovero, Shafer 10733, 10873. Without locality, Wright 3454, 3461.

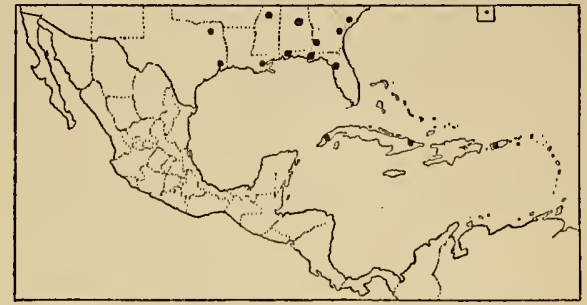

FIg. 107.-Distribution of $P$. aciculare.

Ponto Rico: Monte Mesa, Chase 6273. Campo Alegre, Chase 6624.

\section{Panicum chrysopsidifolium Nash.}

Panıcum chrysopsidifoliu $m$ Nash in Small, Fl. Southeast. U. S. 100. 1903; Contr. U. S. Nat. Herb. 15: 168. 1910.

\section{DISTRIBUTION.}

Sandy woods and open moist ground, Florida, Louisiana, and the Greater Antilles. The type specimen from Florida.

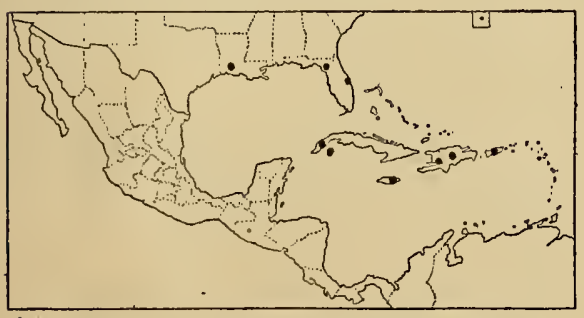

FIG. 108,-Distribution of $P$. chrysopsidifolium.
Cuba: Consolación del Sur, Palmer $\&$ Riley 481. Isle of Pines, Palmer \& Riley 982. Herradura, Hitchcock 116.

Jamaica: Pedro Morass, Harris 11163. Bull Head Mountain, Amer. Gr. Nat. Herb. 89.

Porto Rico: Las Marias, Sintenis 5985. Trujillo Alto, Chase 6766. Santurce, Heller 982.

HAITI: Without locality, Christ 1744 (K. U. Herb.).

Santo Domingo: Without locality, Bertero 818 (K. U. Herb.).

83. Panicum fusiforme Hitchc.

Panicum fusiforme Hitchc. Contr. U. S. Nat. Herb. 12: 222. 1909; 15: 172.1910. IISTIRIBUTION.

Sandy pine woods and open mo:st ground, Florida, Cuba, Jamaica, and British Honduras. The type specimen from Cuba.

British Honduras: Manatee Lagoon, Peck 453a (Gray Herb.).

Cuna: Herradura, Hitchcock 117, Caldwell \& Baker 7139, Tracy

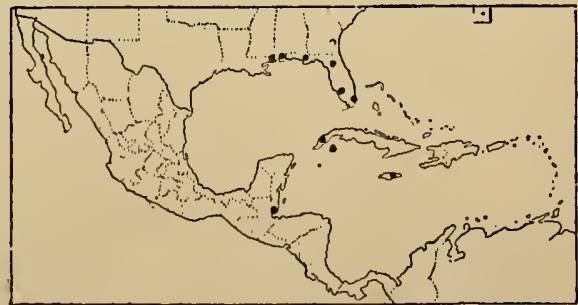

FIG. 109.-Distribution of $P$. fusiforme. 9074. Nueva Gerona, Curtiss 406. Western Cuba, Wright 3453, 3454.

JaMaICA: Bull Head Mountain, Mitchcock 9552. 
84. Panicum arenicoloides Ashe.

Panicum arenicoloides Ashe, Journ. Elisha Mitchell Soc. 16: 89. 1900; Contr. U. S. Nat. Herb. 15: 173. 1910.

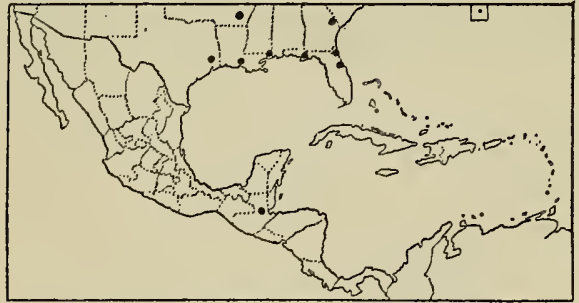

FIG. 110.-Distribution of $P$. arenicoloides.

\section{DISTRIBUTION.}

Sandy pine woods, southeastern United States; also in Guatemala. The type specimen from North Carolina. Anelom

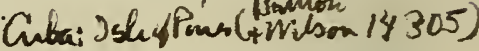

Guatemala: Cuesta de Peinha, between Gualán and Copán, Pittier 1805 b.

85. Panicum ovinum Scribn. \& Smith.

Panicum ovinum Scribn. \& Smith, U. S. Dept. Agr. Div. Agrost. Circ. 16: 3. 1899; Contr. U. S. Nat. Herb. 15: 174. 1910.

\section{DISTRIBUTION.}

Open prairie and meadows, Southern States and in Veracruz. The type specimen from Texas.

Veracruz: Hacienda de la Laguna, near Jalapa, Schiede (Berlin Herb.).

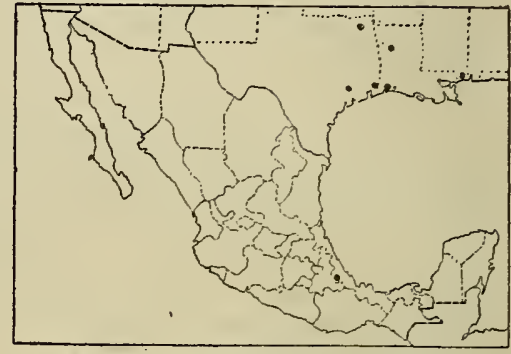

FIG. 111.-Distribution of $P$. orinum.

86. Panicum neuranthum Griseb.

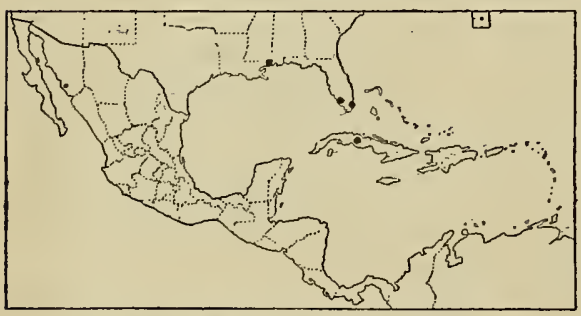

Fia. 112.-Distribution of $P$. neuranthum.

Panicum neuranthum Griseb. Cat. Pl. Cub. 232. 1866; Contr. U. S. Nat. Herb. 15: 175. 1910.

\section{DISTRIBUTION.}

Moist savannas, Florida and Cuba. The type specimen from Cuba.

Cuba: Hanábana, Wright 3453 in part. Without locality, Wright 3454a.

\section{DICHOTOMA.}

Nodes, at least the lower, bearded; spikelets pubescent.

Fruit slightly exposed at maturity; upper sheaths viscidspotted; autumnal form erect or reclining........ 87. P. nitidum.

Fruit covered at maturity; sheaths not viscid-spotted; autumnal form decumbent, with flabellate-fascicled branches. 88. P. multirameum.

Nodes not bearded; spikelets glabrous.

Spikelets not over $1.6 \mathrm{~mm}$. long; panicles narrow; plants glaucous bluish green...................... 91. P. caerulescens. 
Spikelets $2 \mathrm{~mm}$. or more long; panicles open.

Blades erect, firm; spikelets turgid, strongly nerved; plants grayish olive green; spikelets turgid, blunt............................. 90. P. roanokense.

Blades spreading; spikelets not turgid, $2.2 \mathrm{~mm}$. or more long, pointed; sheaths bearing pale glandular spots............................. 89. P. yadkinense.

\section{Panicum nitidum Lam.}

Panicum nitidum Lam. Tabl. Encycl. 1: 172. 1791; Contr. U. S. Nat. Herb. 15: 183. 1910.

DISTRIBUTION.

Moist ground and wooded swamps, southeastern United States, Bahamas, and Cuba. The type specimen from [South?] Carolina.

BaHamas: Great Bahama, Golden Grove, Britton \& Millspaugh 2736.

CuBA: Sierra Nipe, Shafer 2999, 3001.

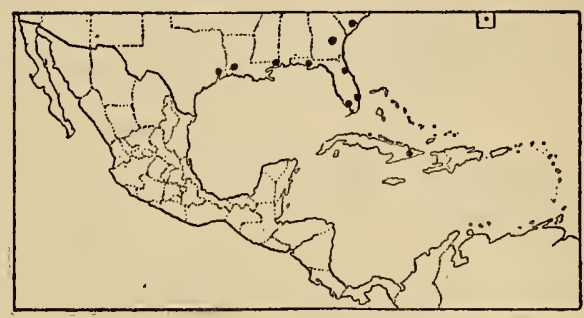

FIG. 113.-Distribution of $P$. nitidum.

\section{Panicum multirameum Scribn.}

Panicum multirameum Scribn. U. S. Dept. Agr. Div. Agrost. Circ. 19: 2. 1900; Contr. U. S. Nat. Herb. 15: 185. 1910.

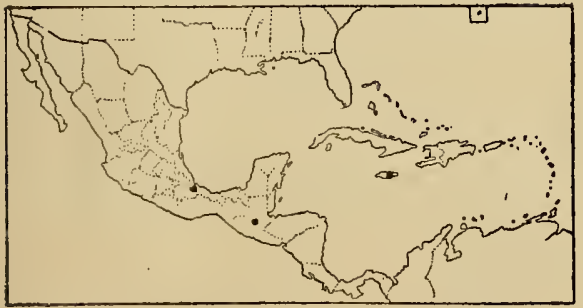

Fig. 114.-Distribution of $P$. multirameum.

Guatemala: Cobán, Türckheim II. 1322.

JAMAYCA: Bull Head Mountain, Hitchcock 9532.

89. Panicum yadkinense Ashe.

Panicum yadkinense Ashe, Journ. Elisha Mitchell Soc. 16: 85. 1900; Contr. U. S. Nat. Herb. 15: 195. 1910.

\section{DISTRIBUTION.}

Moist woods and thickets, southeastern United States to Mexico. The typo specimen from North Carolina.

Puebla: Without locality, Nicolas in 1909.

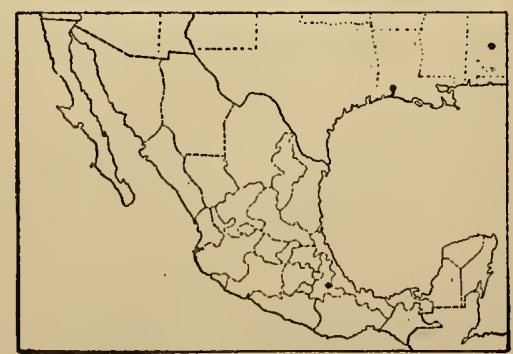

Fig. 115.-Distribution of $P$. yadkinense. 
90. Panicum roanokense Ashe.

Panicum roanokense Ashe, Journ. Elisha Mitchell Soc. 15: 44. 1898; Contr. U. S. Nat. Herb. 15: 196. 1910.

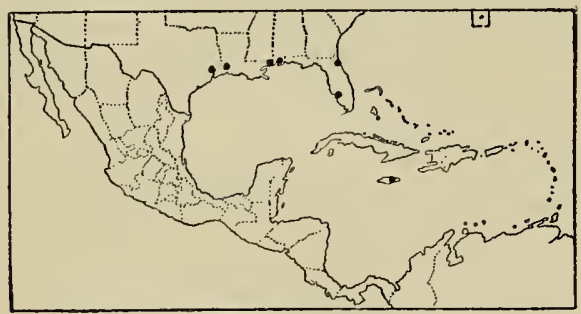

DISTRIBUTION.

Open swampy woods and wet meadows, Virginia to Texas; also in Jamaica. The type specimen from North Carolina.

JAMraICA: Bull Head Mountain, Hitchcock 9530.

FIG. 116.-Distribution of $P$. roanokense.

\section{Panicum caerulescens Hack.}

Panicum caerulescens Hack.; Hitchc. Contr. U. S. Nat. Herb. 12: 219. 1909; 15: 197. 1910.

DISTRIBUTION.

Marshes and swampy woods, New Jersey to Florida and Mississippi, Bahamas and Cuba. The type specimen from Florida.

Baнamas: Great Bahama, Brace 3524, Britton \& Millspaugh 2506, 2668. Andros, Brace 7015 (all in Field Mus. Herb.). New Providence, Britton \& Brace 597, 599, Millspaugh 2182, Northrup 248, Eggers 4305 (Hackel Herb.), Eggers 4312 (K. U. Пеrb.).

CuBA: Without locality, Wright 3463 in part.

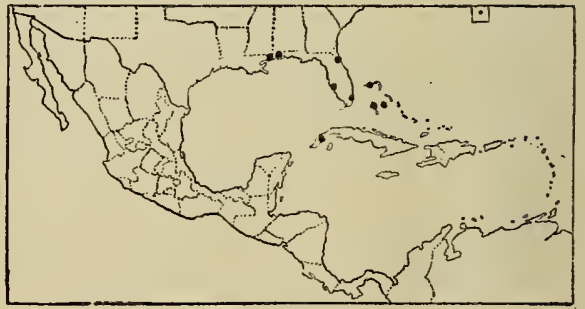

FIG. 117.-Distribution of $P$. caerulescens.

SPRETA.

Spikelets 1.2 to $1.3 \mathrm{~mm}$. long 92. P. leucothrix. Spikelets not over $1 \mathrm{~mm}$. long. 93. P. wrightianum.

\section{Panicum leucothrix Nash.}

Panicum leucothrix Nash, Bull. Torrey Club 24: 41. 1897; Contr. U. S. Nat. Herb. 15: 205. 1910.

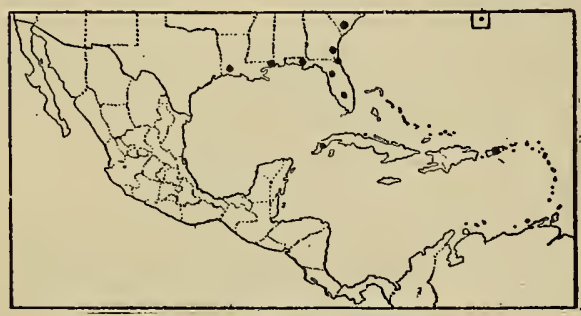

Fig. 118.-Distribution of $P$. leucothrix.
DISTRIBUTION.

Pine woods and moist open ground, New Jersey to Louisiana, Cuba, and Porto Rico. The type specimen from Florida.

Cuba: Herradura, Hitchcock 554, 560. Without locality, Wright 3460,3463 .

Porto Rico: Trujillo Alto, Chase 6770. 


\section{Panicum wrightianum Scribn.}

Panicum wrightianum Scribn. U. S. Dept. Agr. Div. Agrost. Bull. 11: 44. f. 4. 1898. Contr. U. S. Nat. Herb. 15: 207. 1910.

\section{DISTRIB UTION.}

Moist sandy soil, Massachusetts to Texas and Cuba. The type specimen from Cuba.

Cuba: Pinar del Río, Britton \& Gager 6952. Without locality, Wright 3463 in part.

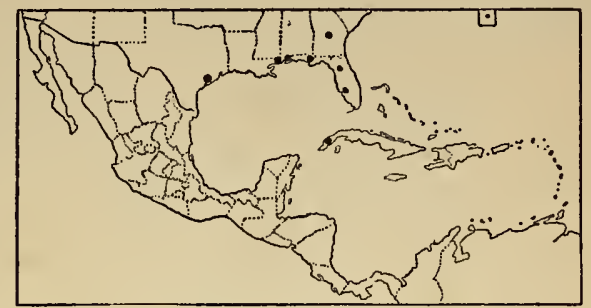

FIG. 119.-Distribution of $P$. wrightianum.

\section{LANUGINOSA.}

Spikelets $2.2 \mathrm{~mm}$. or more long.

Pubescence on culms horizontally spreading; autumnal form freely branching.................. 97. P. villosissimum.

Pubescence on culms appressed or ascending; autumnal form rather sparingly branching............. 98. P. pseudopubescens. Spikelets not over $2 \mathrm{~mm}$. long.

Plants not velvety; blades usually glabrous on the upper surface............................. 94. P. tennesseense.

Plants velvety; blades softly pubescent on both surfaces.

Plants light or yellow green when dry......... 95. P. acuminatum.

Plants dark or olive green when dry.......... 96. P. olivaceum.

94. Panicum tennesseense Ashe.

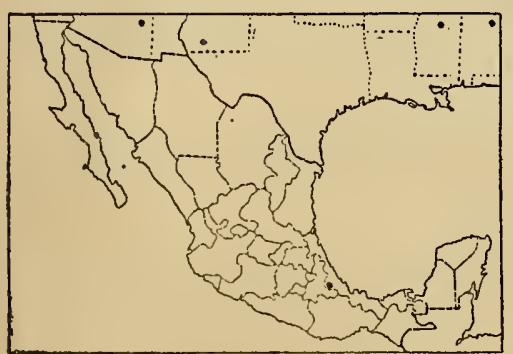

FIG. 120.-Distribution of P.tennesscense.

Panicum tennesseense Ashe, Journ. Elisha Mitchell Soc. 15: 52. 1898; Contr. U. S. Nat. Herb. 15: 218. 1910.

\section{DISTRIBUTION.}

Open ground, Atlantic States to Utah; also in southern Mexico. The type specimen from Tennessee.

Veracruz: Orizaba, Botteri 101. Jalapa, Hitchcock 6632.

\section{Panicum acuminatum Swartz.}

Panicum acuminatim Swartz, Prodr. Veg. Ind. Occ. 23. 1788; Contr. U. S. Nat. Herb. 15: 222. 1910.

Panicum ornatum Desv.; Hamilt. Prodr. Pl. Ind. Occ. 11. 1825. "Herb. Prof. Desv. Porto Rico."

In the Revision ${ }^{1}$ this was listed among the doubtful species. The inadequate description indicates the common $P$. acuminatum. 


\section{DISTRIBUTION.}

Sandy pine woods, moist banks and open ground, Greater Antilles; also Colombia. The type specimen from Jamaica.

Cuba: Isle of Pines, Palmer \& Riley 989, 1083, Curtiss 307, 328, Taylor 3873. Pinar del Río, Palmer \& Riley 447. Herradura, Britton, Earle \& Gager 6505, Hitchcock 140, Tracy 9078. Río Guao, Britton \& Cowell 9673. Cuchillas de San Sebastián, León \& Shafer 13719. Sumidero, León 3472, Shafer 13544. Without locality, Wright 3874.

JAMAICA: Clyde River, Harris 11444. Cinchona, Harris 11315, 11371, 11435, 11494, Hitchcock 9697, 9722. Hills back of Barican, Hitchcock 9564. Bull

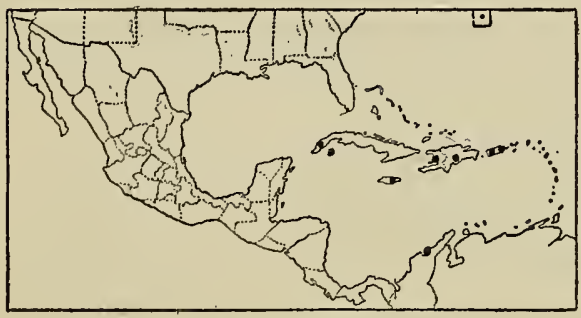

FIG. 121.-Distribution of P. acuminatum. Head Mountain, Hitchcock 9538. Gordon Town, Hart 736. Abbey Green, Amer. Gr. Nat. Herb. 133. Catherines Peak, Harris 11554, Hitchcock 9738. Below Sir Johns Peak, Harris 11597. Upper Clarendon, Harris 11109.

HaITI: Morne la Sette, Christ 1850.

Santo Domingo: Without locality, Eggers 2021, 2028, 2333 (all in K. U. Herb.).

Porto Rico: Santurce, Heller in 1903. Maricao, Sintenis 355. Bayamon, Chase 6378. Alto de Bandera, Chase 6475. Sierra de Luquillo, Chase 6719. Between Guainabo and Cataño, Chase 6647. Indiera Fria, Chase 6249. Trujillo Alto, Chase 6765. Jajome Alto, Chase 6752. Lares, Sintenis 5908. Fajardo, Sintenis 1224.

Colombia: La Esmeralda near Jamundí, Pittier 932, 982a. Santa Marta, Smith 2140.

96. Panicum olivaceum Hitchc. \& Chase.

Panicum olivaceum Hitchc. \& Chase, Contr. U. S. Nat. Herb. 15: 225. 1910.

DISTRIBUTION.

Clay slopes and open ground, Mexico to Venezuela. The type specimen from Guatemala.

Veracruz: Orizaba, Bourgeau 2383 in part, Botteri 99,100 , 101. Minatitlán, Smith 571. Jalapa, Hitchcock 6631, 6646, 6651, 6667, Amer. Gr. Nat. Herb. 134, Pringle 8339.

Guatemala: Cobán, Türckheim 428. Without locality, Seler 3235.

Costa Rica: San Pedro de la Calabaza, Tonduz 10745.

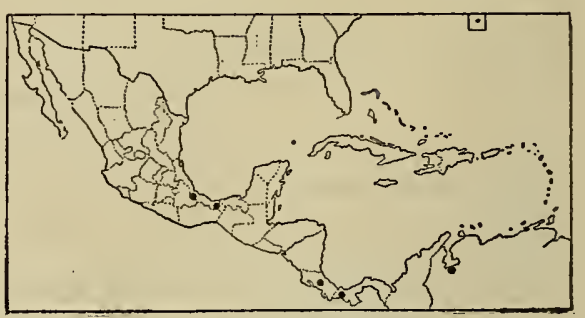

FIG. 122.-Distribution of $P$.olivaceum.

Panama: El Boquete, Maxon 5136, Hitchcock 8189, 8252, 8280.

Venezuela: Tovar, Fendler 1638b. Pico de Naiguatá, Pittier 6252.

Colombia: La Esmeralda, near Jamundí, Pittier 946. 
97. Panicum villosissimum Nash.

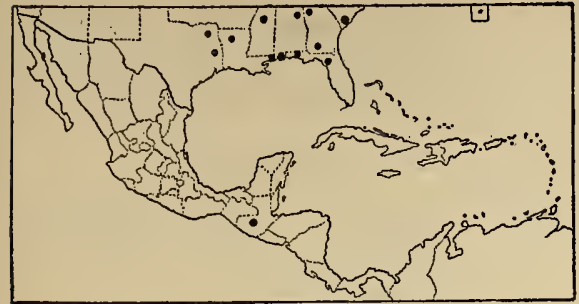

FIG. 123.-Distribution of $P$. villosissimum.

Panicum villosissimum Nash, Bull. Torrey Club 33: 149. 1896; Contr. U. S. Nat. Herb. 15: 233. 1910.

DISTRIBUTION.

Dry open woods, eastern United States; also in Guatemala. The type specimen from Georgia.

Guatemala: Guatemala City, Hitchcock 9106.

98. Panicum pseudopubescens Nash.

Panicum pseudopubescens Nash, Bull. Torrey Club 26: 577. 1899; Contr. U. S. Nat. Herb. 15: 235.1910.

\section{DISTRIB UTION.}

Sandy open woods eastern United States; also in San Luis Potosí. The type specimen from Alabama.

SaN LuIs Potosí: Without locality, Schaffner 146.

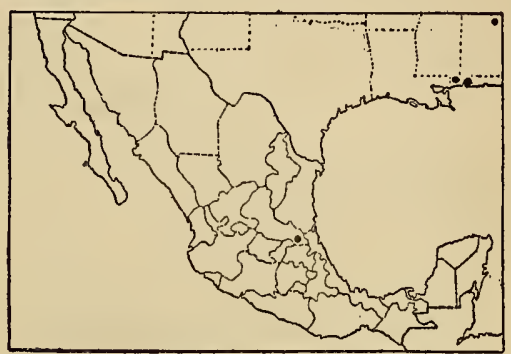

FIG. 124.-Distribution of $P$. pseudopubescens.

\section{SPHAEROCARPA.}

Culmsspreading; panicle nearly as broad as long; spikelets $\mathbf{1 . 6}$

to $1.8 \mathrm{~mm}$. long . . . . . . . . . . . . . . . . . . . . . . . 99. Phaerocarpon.

Culms erect or ascending; panicle never more than two-thirds

as broad as long; spikelets 1 to $1.2 \mathrm{~mm}$. long......... 100. P. erectifolium.

99. Panicum sphaerocarpon Ell.

Panicum sphaerocarpon Ell. Bot. S. C. \& Ga. 1: 125. 1816; Contr. U. S. Nat. Herb. 15: 251. 1910.

\section{DISTRIBUTION.}

Sandy soil and gravelly banks, eastern United States through Mexico to northern South America. The type specimen from Georgia.

SaN Iuis Potosí: Without locality, Schaffner 147.

Мгсносса́: Sierra de San Andrés, Ross 381.

Puebla: Chinantla, Liebmann 327. Teziutlán, Oreutt 3952.

Veracruz: Orizaba, Amer. Gr. Nat. Herb. 155, Botteri. Jalapa, Pringle 7883, 8344, Hitchcock 6607, 6633 .

British Honduras: Manatee Lagoon, Peck 61 (Gray Herb.).

Guatemala: Guatemala City, Hitchcock9105. Cobán, Türckheim 56, 3829. Volcano Pacaya, Kellerman 6236.

Costa Rrca : Copey, Tonduz11866.

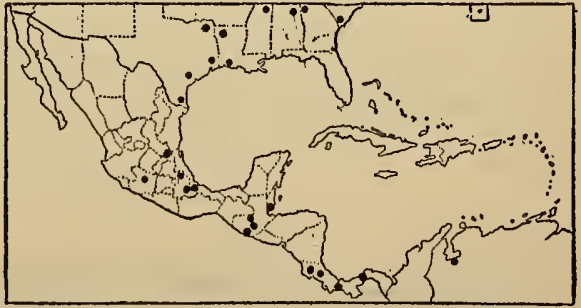

FrG. 125.-Distribution of $P$. sphaerocarpon.

San Pedro de la Calabaza, Tonduz 10745. Páramos del Abejonal, Tonduz 7878.

Panama: El Boquete, Hitchcock 8172. Dolega, Hitchcock 8343.

Venezuela: Without locality, Fendler 1638. 
100. Panicum erectifolium Nash.

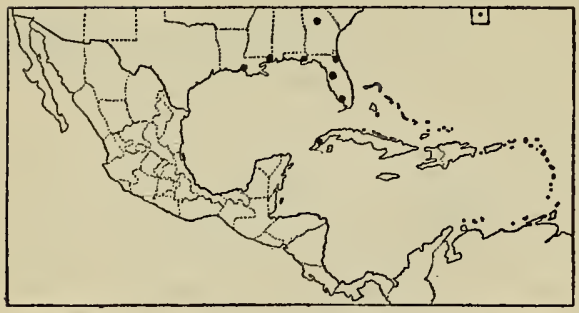

FIG. 126.-Distribution of $P$. erectifolium.

Panicum erectifolium Nash, Bull. Torrey Club 23: 148. 1896; Contr. U. S. Nat. Herb. 15: 256. 1910.

\section{DISTRIBUTION.}

Moist pine woods, southeastern United States and Cuba. Type specimen from Florida.

CubA: Vuelta Abaja, Wright 3462. Laguna Santa María, Britton \& Gager 7170.

\section{X ensifolia.}

101. Panicum albomarginatum Nash.

Panicum albomarginatum Nash, Bull. Torrey Club 24: 40. 1897; Contr. U. S. Nat. Herb. 15: 260. 1910.

\section{DISTRIBUTION.}

Moist sandy woods, southeastern United States, Cuba and Guatemala. Type specimen from Florida.

Guatemata: Gualán to Copán, Pittier 1805a.

Cuвa: Between Sumidero and Pinar del Río, León 3466. Herradura, Hitchcock 555 . Isle of Pines, Taylor 32.

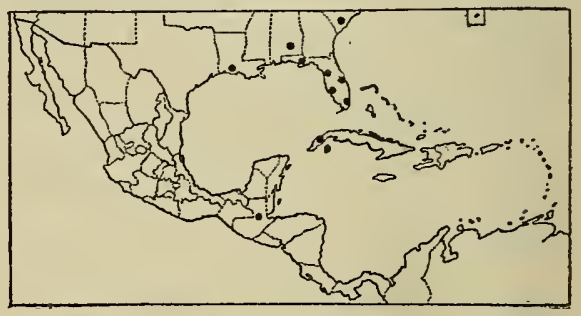

FIG. 127.-Distribution of $P$. albomarginatum.

\section{LANCEARIA.}

Spikelets 1.5 to $1.6 \mathrm{~mm}$. long . . . . . . . . . . . . . . . . . . . 102. Poricense. Spikelets $2 \mathrm{~mm}$. long................................. 103. P. lancearium.

\section{Panicum portoricense Desv.}

Panicum portoricense Desv.; Hamilt. Prodr. Pl. Ind. Occ. 11. 1825. "Herb. Prof. Desv. Porto Rico." We have been unable to find the type of this and in the Revision ${ }^{1}$ placed it among doubtful species. Recent study of the grasses of Porto Rico, however, leaves no doubt that Desvaux's description was drawn from a specimen in the autumnal phase of $P$. pauciciliatum Ashe, which is found to be common in the vicinity of San Juan Bay, the region most likely to have been visited by early botanists.

Panicum pauciciliatum Ashe, Journ. Elisha Mitchell Soc. 16: 87. 1900; Contr. U. S. Nat. Herb. 15: 272. 1910.

${ }^{1}$ Contr. U. S. Nat. Herb. 15: 331. 1910.

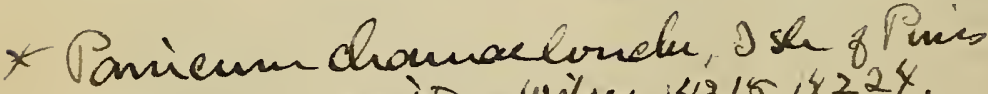
Britoren, Buition owilsar $142 / 8,1422 \%$. 


\section{DISTRIBUTION.}

Moist sandy woods, southeastern United States, Cuba and Porto Rico.

CuBA: Without locality, Wright 3876 .

Porto Rico: Martin Peña, Chase 6357. Between Cataño and Guainabo, Chase 6631. Lake Loisa, Chase 6783. Santurce, Heller 982b, 6442. Vega Baja, Heller 639, Underwood \& Griggs 955. Campo Alegre, Chase 6434.

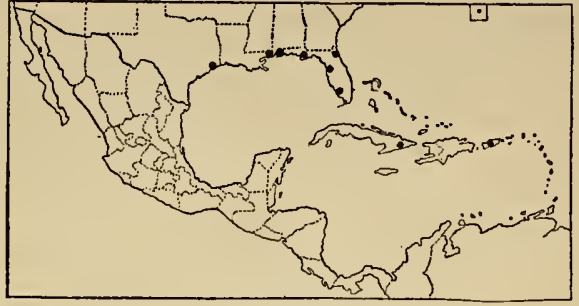

FiG. 128.-Distribution of $P$. portoriccnse.

103. Panicum lancearium Trin.

Panicum lancearium Trin. Gram. Pan. 223. 1826; Contr. U. S. Nat. Herb. 15: 273. 1910.

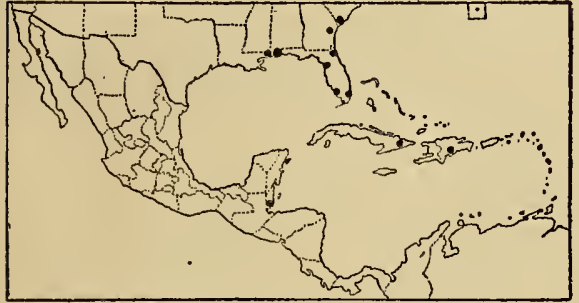

FIG. 129.-Distribution of P. lancearium.

Santo Domingo: Constanza, Türckheim 3321.
DISTRIBUTION.

Sandy pine woods, southeastern United States, British Honduras, Cuba, and Santo Domingo. The type specimen from North America, the exact locality not known.

British Honduras: Sibune River, Peck 425 (Gray Herb.). Cuba: San Juan de Buenavista, Wright 3460 (Gray Herb.).

\section{PEDICELLATA.}

104. Panicum nodatum Hitchc. \& Chase.

Panicum nodatum Hitchc. \& Chase, Contr. U. S. Nat. Herb. 15: 293. 1910.

\section{DISTRIBUTION .}

Oak woods and wooded sand dunes, along the coast of Texas and adjoining Mexico. The type specimen from Texas.

Mexico: Matamoros, Berlandier 988, 2418 (Gray Herb.).

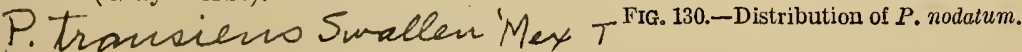
SCOPARIA.

Vernal culms erect or ascending; plants velvety throughout; spikelets about $2.5 \mathrm{~mm}$. long..................... 105. P. scoparium.

Vernal culms decumbent at base; upper sheaths more or less glabrate; spikelets less than $2 \mathrm{~mm}$. long.............. 106. P. viscidellum. 
105. Panicum scoparium Lam.

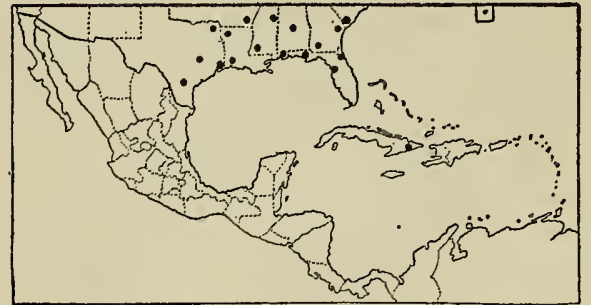

Fig. 131.-Distribution of $P$. scoparium.
Panicum scoparium Lam. Encycl. 4: 744. 1798; Contr. U. S. Nat. Herb. 15: 294. 1910 .

\section{DISTRIBUTION.}

Wet places, southeastern United States and Cuba. The type specimen from South Carolina.

Cuba: Road to Pinal Mayarí, Wright 3467. Sierra Nipe, Shafer 2997, 3018.

106. Panicum viscidellum Scribn.

Panicum viscidellum Scribn. U. S. Dept. Agr. Div. Agrost. Circ. 19:2. 1900; Contr. U. S. Nat. Herb. 15: 296. 1910.

\section{DISTRIBUTION .}

Open woods and slopes, Mexico to Colombia; also in Cuba. The type specimen from Jalapa.

Veracruz: Córdoba, Hitchcock 6425. Orizaba, Amer.Gr. Nat. Herb. 179. Jalapa, Hitchcock 6606, 6673, Smith 1617, Pringle 8089. Mirador, Liebmann 323. Zacuapán, Purpus 2160.

Guatemala: Cobán, Türckheim 3836,3829 in part. Sierra del Mico, Kellerman 6231, 6249.

Nicaragua: U. S. Pacific Expl. Exped. Wright.

Costa Rica: Asserí, Tonduz 1244. El General, Pittier 3358.

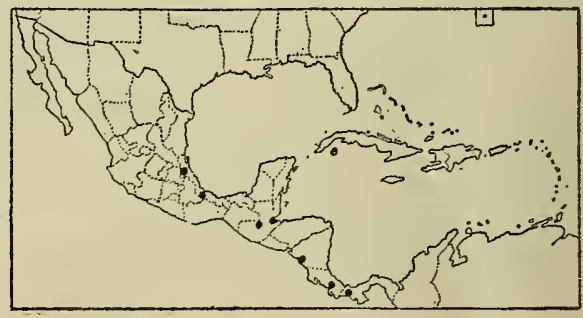

FIG. 132.-Distribution of $P$. viscidellum.

Panama: El Boquete, Hitchcock 8178, Pittier 3043.

CubA: Managua, Palmer \& Riley 1065.

Colombia: La Esmeralda, near Jamundí, Pittier 940.

\section{COMMUTATA.}

Blades unsymmetrical and falcate; culms decumbent; first glume about one-third as long as the spikelet........ 107. P. joorii.

Blades symmetrical, nearly linear; culms erect; first glume about half as long as the spikelet................ 108. P. albomaculatum. 107. Panicum joorii Vasey.

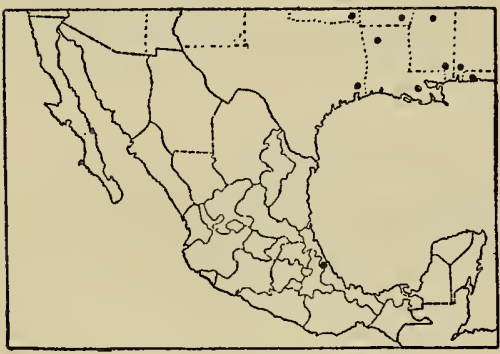

FIG. 133.-Distribution of $P$. joorii.
Panicum joorii Vasey, U. S. Dept. Agr. Div. Bot. Bull. 8: 31. 1889; Contr. U. S. Nat. Herb, 15: 308. 1910.

\section{DISTRIBUTION}

Damp woods, southeastern United States; also in southern Mexico. The type specimen from Louisiana.

Veracruz: Jalapa, Hitchcock 6650.

RePUblic of MeXICo: Without locality, Pringle 13290. 


\section{Panicum albomaculatum Scribn.}

Panicum albomaculatum Scribn. U. S. Dept. Agr. Div. Agrost. Circ. 19: 2. 1900; Contr. U. S. Nat. Herb. 15: 311. 1910.

Autumnal form leaning or ascending, with geniculate nodes, branching from the lower and middle nodes, the branches nearly as long as the primary culm, erect, simple or sparingly branching, the sheaths overlapping, the blades scarcely reduced, the panicles short-exserted; apparently no winter rosette developed.

One specimen, Hitchcock 6979 , has harshly pilose foliage, but in all other respects its characters are those of $P$. albomaculatum.

\section{DISTRIBUTION.}

Shady banks and wooded slopes, Mexico and Guatemala. The type specimen from Pátzcuaro.

JALIsco: Zapotlán, Hitchcock 7170, Amer. Gr. Nat. Herb. 193.

MichoacÁn: Pátzcuaro, Pringle 5203. Uruápan, Hitchcock 6979. Jorullo, Humboldt (Willd. Herb.).

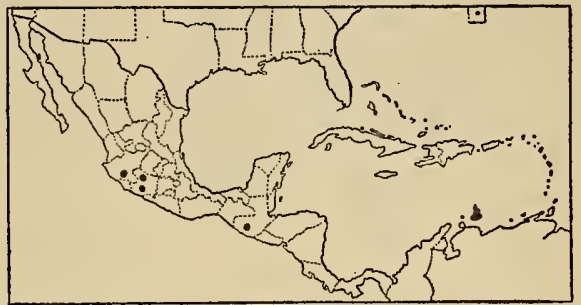

FIG. 134.-Distribution of $P$. albomaculatum.

Guatemala: Antigua, Hitchcock 9139.

\section{CORDOVENSIA.}

Plants perennial, straggling, the culms decumbent at base, rooting at the nodes; ligules membranaceous, minute; spikelets elliptical, the first glume two-thirds the length of the spikelet or more; fruit smooth and shining, apiculate.

This group, to which are apparently allied the South American Panicum phragmites Nces ( $P$. discolor Trin., not Spreng.) and $P$. ovuliferum Trin., appears to be intermediate between true Panicum and the subgenus Dichanthelium, having the sterile primary panicles and secondary panicles with fruitful, probably cleistogamous, spikelets, but not forming a winter rosette.

Plants glabrous or the leaves sparsely pilose ............ 109. P. cordovense. Plants velvety pubescent........................ 110. P. chiriquiense.

\section{Panicum cordovense Fourn.}

Panicum cordovense Fourn. Mex. P1. 2: 26. 1886. "Cordova (Schaffn. n. 293 in herb. FranQ.)." The type specimen in the herbarium of Drake de Castillo, now a part of the herbarium of the Jardin des Plantes, Paris, has glabrous spikelets (like that shown in Fig. 135). This in the Revision was listed among the doubtful species. ${ }^{1}$

Punicum expansum Fourn. Mex. P1. 2: 26. 1886 (following P. cordovense). "Huitamalco (Licbm. n. 426)." The type specimen, in the Copenhagen Herbarium, has a large immature primary panicle, the spikelets glabrous. In the Revision ${ }^{2}$ it was suggested that this unknown species was related to $P$. costaricense.

Ichnanthus apiculatus Scribn. U. S. Dept. Agr. Div. Agrost. Circ. 30: 1. 1901. "Type specimen from near Jalapa, State of Vera Cruz. C. G. Pringle, no. 9208." In the type specimen, in the United States National Herbarium, the spikelets are glabrous.

Panicum missionum Ekman, Ark. för Bot. 114: 19. pl. 3. f.1. 1912. "Bonpland, ad rivulum prope praedium 'Almacén finlandesa,' 26. 12.07. N. 632.", collected by E. L. Ekman, in the State of Misiones, Argentina. An immature specimen of the type collection is in the U. S. National Herbarium, received from Dr. Ekman. The 
photograph of the type specimen (plate 3, figure 1) shows the large open primary panicle, like that of the type of $P$. expansum, which is characteristic of the early phase of the species.

\section{DESCRIPTION.}

Plants perennial in tangled masses; culms slender, subcompressed, a line of pubescence down one side or glabrous, rarely sparsely pilose, straggling, widely creeping, rooting at the lower nodes, as much as 2 meters long, freely branching, the branches

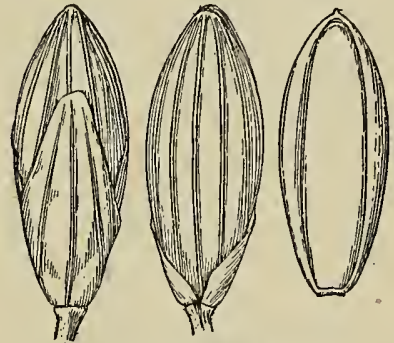

Fig. 135.-P. cordovense. From IItichcock 8328. usually divergent, becoming nearly as long as the primary culm; nodes puberulent or glabrate; sheaths much shorter than the usually elongate internodes, sparsely papillose-pilose or papillose only, densely ciliate on the margin, puberulent at the junction with the blade; ligule about $0.3 \mathrm{~mm}$. long; blades thin, flat, spreading, 5 to $10 \mathrm{~cm}$. (rarely as much as 15 $\mathrm{cm}$.) long, 5 to $10 \mathrm{~mm}$. wide, narrowly lanceolate, acuminate, rounded and usually ciliate at base, scaberulous on both surfaces at least on the midnerve, usually papillose-hispid above the ligule, sometimes sparsely so throughout; panicles of two kinds, the primary short-exserted or included at base, loose and open, 10 to $15 \mathrm{~cm}$. long, half to two-thirds as wide, the axis and branches slender, subflexuous, scaberulous, pubescent in the axils, the few branches solitary or in pairs, remote, simple or nearly so, finally spreading, few-flowered, the branchlets and shortpediceled, apparently unfruitful spikelets more or less appressed to the rachis, the secondary panicles terminal on the branches, reduced, narrow, few-flowered, partially inclosed in the sheath, the crowded apparently cleistogamous spikelets fruitful; spikelets 3 to $3.5 \mathrm{~mm}$. long, 1.2 to $1.4 \mathrm{~mm}$. wide, those of the primary panicles usually glabrous, those of the secondary panicles usually pustulose-villous, turgid; first glume about two-thirds as long as the spikelet, obtuse, 3 to 5-nerved, the second glume and sterile lemma equal, covering the fruit, 7-nerved, the middls internerves of the sterile lemma in the pubescent spikelets usually glab-
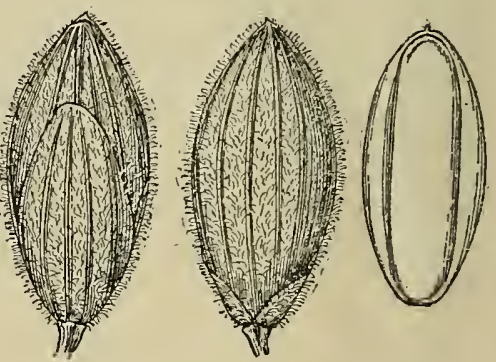

FIG. 136.-P. cordovense. From Hitchcock 8328 . rous, the midnerve sometimes indistinct; fruit 2.8 to $2.9 \mathrm{~mm}$. long, 1.1 to $1.2 \mathrm{~mm}$. wide, apiculate.

The spikelets shown in figures 135 and 136 are from the terminal and lateral panicles respectively of the same individual.

\section{DISTRIBUTION.}

Shady banks and in deep woods, southern Mexico to Argentina.

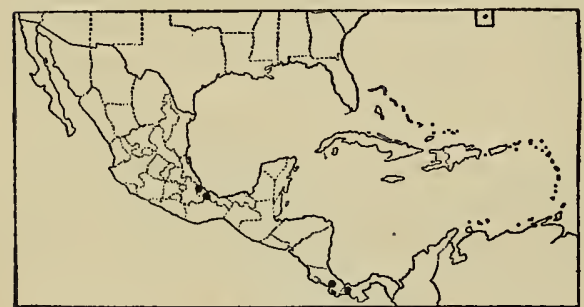

Fia. 137.-Distribution of $P$. cordovense.
Veracruz: Córdoba, Schaffner 293. Jalapa, Pringle 9208, Hitchcock 6611. Huitmalco, Liebmann 426.

Costa Rica: Piedra del Convento, Pittier 3655 .

Panama: Chiriquí Volcano, Hitchcock 8196. El Boquete, Hitchcock 8271, 8275, 8303, 8328 . 


\section{Panicum chiriquiense sp. nov.}

\section{DESCRIPTION.}

Plants perennial, olivaceous; culms straggling, creeping and rooting at the lower nodes, softly papillose-pilose, freely branching, the leafy fertile branches ascending, 20 to $30 \mathrm{~cm}$. high; nodes pilose; sheaths nearly as long as the internodes or the upper overlapping, softly papillose-pilose; ligule about $0.5 \mathrm{~mm}$. long; blades flat, somewhat spreading, 4 to $7 \mathrm{~cm}$. long, 7 to $10 \mathrm{~mm}$. wide, narrowly lanceolate, unsymmetrical at base and often somewhat falcate, acuminate, softly papillosevillous beneath, rather sparsely pilose on the upper surface; panicles short-exserted or included at base, 2.5 to $3.5 \mathrm{~cm}$. long, half to two-thirds as wide, the few branches ascending, the axis and few nearly simple branches slender, villous; spikelets short-pediceled, 2.6 to $2.8 \mathrm{~mm}$. long, about $1.1 \mathrm{~mm}$. wide, elliptical; first glume about threefourths as long as the spikelet, acute, 3-nerved, villous; second glume and sterile lemma equal, covering the fruit, the glume villous, minutely

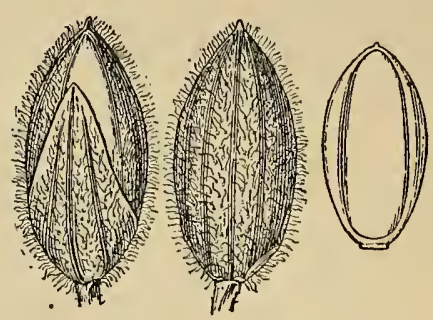

FIG. 138. $-P$. chiriquiense. From type specimen. apiculate, the lemma usually subindurate, smooth and shining in the two middle internerves, the midnerve suppressed or evident at the summit only, the lateral internerves villous; frtit $2.1 \mathrm{~mm}$. long, $1 \mathrm{~mm}$. wide, minutely apiculate.

Type in the U. S. National Herbarium, no. 725186, collected "in shade along trail, hillside jungle, foothills, vicinity of El Boquete, province of Chiriquí, Panama,

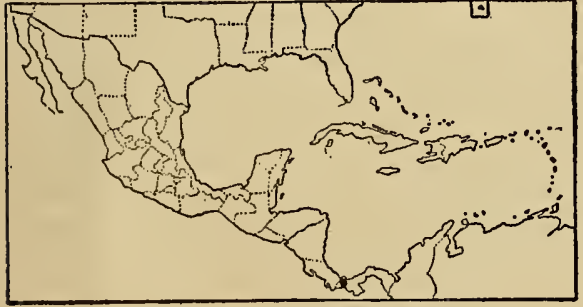

FIG. 139.-Disiribution of $F$. chiriquiense. altitude 1,000 to 1,300 meters, October 4, 1911," by A. S. Hitch cock (no. 8313).

Known only from the type collection. This species differs from $P$. cordovense in the villous foliage with shorter, unsymmetrical blades, the less elongate culms, and the smaller spikelets. In the specimens collected all the panicles are terminal on the branches. Whether or not the plants at an earlier season bear large panicles on a primary culm is not known. The character of the suppressed midnerve and smooth middle internerves, rare in $P$. cordovense, is usual and emphazised in $P$. chiriquiense. Only an occasional spikelet in panicles with the usual form has undifferentiated middle internerves.

\section{MISCELLANEOUS SPECIES.}

\section{Panicum obtusum H. B. K.}

Panicum obtusum II. B. K. Nov. Gen. \& Sp. 1: 98. 1816; Contr. U. S. Nat. Herb. 15: 321.1910.

\section{DISTRIBUTION.}

Moist sandy or gravelly soil, southwestern United States to central Mexico. The type specimen from Guanajuato.

Sonora: Nogales to Cocospora Ranch, Griffiths 6800.

Chinuarua: Between Casas Grandes and Sabinal, Nelson 6352. Chihuahua, Pringle 476. Miñaca, Hitchcock 7734. 
Durango: Durango, Palmer 175 in 1896, Hitchcock 7618. Torreón, Hitchcock 7563.

CoAHurla: Saltillo, Palmer 394 and 504 in 1898, Hitchcock 5582. La Ventura, Nelson 3908. Jaral, Schumann 1714.

Nuevo Lé́n: Monterrey, Hitchcock 5533.

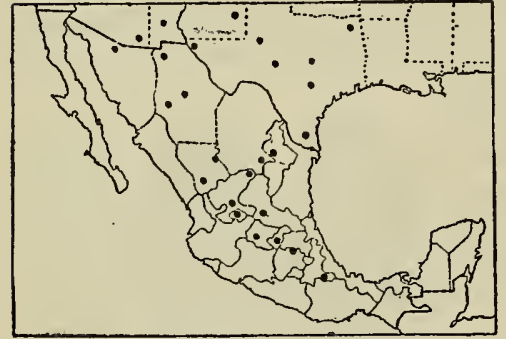

Fig. 140.-Distribution of $P$. obtusum.

Zacatecas: Concepción del Oro, Palmer 266 in 1904 . Zacatecas, Hitchcock 7525.

Aguascalientes: Aguascalientes, Rose \& Hay 6231, Hitchcock 7456.

San Luis Potosí: San Luis Potosí, Palmer 590 in 1898 , Parry \& Palmer 960 in 1878, Schaffner 148, Hitchcock 5657.

Guanajuato: Obregón, Hitchcock 5801. Irapuato, Hitchcock 7407.

Querétaro: San Juan del Río, Rose, Painter \& Rose 9552, 9594. Querétaro, Hitchcock 5813, 5863 .

Hidalgo: Tula, Rose, Painter \& Rose 8356. Ixmiquilpan, Rose, Painter \& Rose 9057.

Puebla: Tehuacán, Hitchcock 6060.

Republic of Mexico: Without locality, Hartweg 244.

112. Panicum stagnatile sp. nov.

DESCRIPTION.

Plants perennial, gregarious; culms erect from an ascending or decumbent base rooting at the nodes, somewhat lush, 1 to 2 meters high, about $5 \mathrm{~mm}$. thick, glabrous, simple or occasionally with sterile branches; nodes glabrous or the lower retrorsely appressed-pubescent; sheaths usually about as long as the internodes or the upper overlapping, ciliate on the margin, otherwise glabrous or pubescent on the sides at the junction with the blade; ligule membranaceous, less than $1 \mathrm{~mm}$. long; blades flat, 20 to $35 \mathrm{~cm}$. long, 1.5 to $3 \mathrm{~cm}$. wide, slightly narrowed to the rounded base, tapering from below the middle to an acuminate apex, sparingly pilose above the ligule, otherwise glabrous, the margins scabrous; panicle 20 to $40 \mathrm{~cm}$. long, about half as wide, fusiform in outline, the main axis and rachises strongly angled, scabrous, usually sparsely pilose in the lower axils, the numerous slender, compound branches rather stiffly ascending or spreading, solitary or irregularly fascicled, bearing from near the base and usually along the lower side rather stifly spreading slender secondary branchlets, the lower 1 to $2 \mathrm{~cm}$. long; spikelets loosely clustered, short-pediceled, glabrous, $1.8 \mathrm{~mm}$. long, about $0.6 \mathrm{~mm}$. wide, acute; first glume about one-third as long as the spikelet, acute, scabrous on the keeled midnerve, the second glume two-thirds as long as the spikelet, somewhat boat-

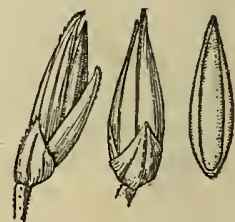

FIG.141.-P. stagnatile. From type specimen. shaped, scabrous on the keel, the sterile lemma slightly exceeding the fruit, boatshaped and scabrous on the midnerve at the apex; fruit $1.6 \mathrm{~mm}$. long, $0.4 \mathrm{~mm}$. wide, lanceolate, scabrous at the acute apex, the lemma and palea subindurate, the margins of the lemma inrolled only at the base.

Type in the U. S. National Herbarium, no. 693328, collected in water of swamp, Frijoles, Canal Zone, Panama, October 12, 1911, by A. S. Hitchcock (no. 8388).

This species is allied to $P$. rivulare Trin. but differs in the broader blades, less densely flowered panicle branches, and smaller spikelets. The numerous small spikelets and slender branchlets give the panicle a lacelike appearance. The type locality is now covered by the water of Gatun Lake. 
DISTRIBUTION.

Swamps, growing in the water, southern Mexico to Panama.

TABAsco: Between San Juan Bautista and San Sebastián, Rovirosa 625.

Guatemala: Puerto Barrios, Hitchcock 9153 .

Panama: Frijoles, Hitchcock 8388.

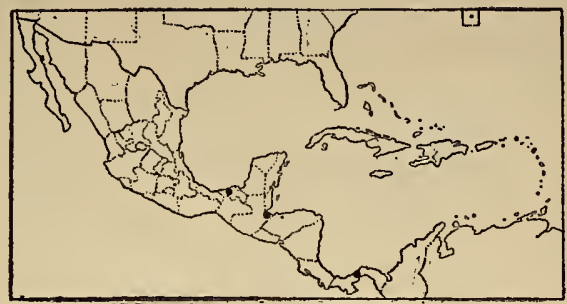

FIG. 142.-Distribution of $P$. stagnatile.

\section{Panicum grande sp. nov.}

Plants perennial, gregarious, producing extensively creeping or floating leafy stolons about $5 \mathrm{~mm}$. thick; culms 1.5 to 2 meters or more high, erect from a long decumbent base with papery sheaths and tufts of fibrous roots, 1 to $2 \mathrm{~cm}$. thick, simple or sparingly branching, succulent, the nodes densely appressed-hirsute; sheaths overlapping except toward the summit, glabrous, the junction with the blade in drying presenting a darkened triangle on each side; ligule membranaceous, about $2 \mathrm{~mm}$. long; blades flat, as much as 1 meter long and $6 \mathrm{~cm}$. wide (the upper and lower smaller), at base narrower than the sheath, gradually widening to about the middle, narrowing rather abruptly to the acuminate apex, glabrous, striate, somewhat plicate, the margins strongly serrulate; panicle as much as $60 \mathrm{~cm}$. long and $40 \mathrm{~cm}$. wide, the axis

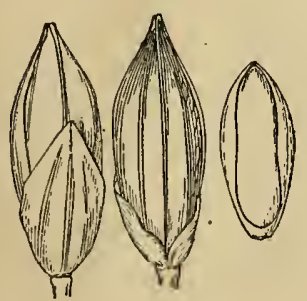

FIG. 143.-P. grande. From type specimen. and branches strongly several-angled, scaberulous, the prominent pulvilli minutely pubescent, the branches stifly spreading, naked at base, the lower in whorls, the short ultimate branchlets and the pedicels appressed along the rather loose secondary branchlets, the pedicels mostly 1 to $2 \mathrm{~mm}$. long; spikelets $2.5 \mathrm{~mm}$. long, $0.9 \mathrm{~mm}$. wide, nearly terete, pointed, glabrous; first glume slightly over half the length of the spikelet, the second glume and sterile lemma equal, exceeding the fruit, somewhat beaked beyond it; fruit $1.8 \mathrm{~mm}$. long, $0.7 \mathrm{~mm}$. wide, narrowly obovate, smooth and shining, the lemma and palea indurate but the lemma margins flat.

Type in U. S. National Herbarium, nos. 693329, 693330, 693331 (parts of the same individual), collected in the water of a swamp along the margin of Gatun Lake, Canal Zone, Panama, December 15, 1911, by A. S. Hitchcock (no. 9178).

This species grows in large masses in swamps, flowering in December. The broad blades give a lily-like aspect to "the plants earlier in the season. In Gatun Lake, Panama, plants were found growing in 10 feet of water.

Doell ${ }^{1}$ describes this species under the name Panicum multiflorum Poir., ${ }^{2}$ but the latter name applies to a different species. ${ }^{3}$ Panicum grande is allied to the South American $P$. grumosum Nees, $P$. rivulare Trin., and $P$. prionitis Nees, from all of which it differs in its aquatic habit and open panicle and in the more indurate fertile lemma and palea; from $P$. rivulare and $P$. prionitis in the equal second glume and fertile lemma.

\footnotetext{
${ }^{1}$ Mart. Fl. Bras. 22: 215. 1877.

${ }^{2}$ Encycl. 4: 282. 1816.

${ }^{3}$ See Contr. U. S. Nat. Herb. 15: 48. 1910.
} 


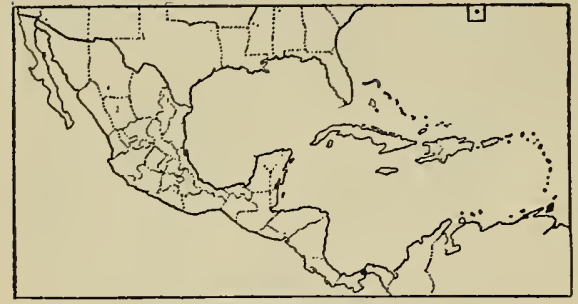

FIG. 144.-Distribution of $P$. grande.
DISTRIBUTION.

Lakes, ponds, and swamps, growing in the water, Panama to Pará.

Panama: Gatun, Hitchcock 9178. Along the Sambú River, Pittier 5546.

Trinidad: Mazanilla, Hitchcock 10376. Cedros, Hitchcock 10148. St. Joseph, Hitchcock 10022.

Venezuela: Bobures, Jahn 353.

\section{Panicum tuerckheimii Hack.}

Panicum tuerckheimï Hack. Oesterr. Bot. Zeitschr. 12: 60. 1906. Guatemala, Cubilgüitz [Cubilquitz] im Hochwald, $350 \mathrm{~m} \mathrm{~s} \mathrm{m.} \mathrm{leg} \mathrm{H.} \mathrm{v.} \mathrm{Türckheim(1903} \mathrm{sub} \mathrm{nr.} \mathrm{II.}$ 820)."

\section{DESCRIPTION.}

Plants perennial from a firm knotty base with strong roots; culms erect or ascending, simple, 30 to $50 \mathrm{~cm}$. high, compressed, glabrous, the nodes appressed-hirsute, few to several long erect leaves borne at the base; sheaths compressed-keeled, more or less hispidulous at the junction with the blade, otherwise glabrous, those of the basal leaves loose, overlapping, those of the culm about as long as the internodes; ligule membranaceous-ciliate, scarcely $0.5 \mathrm{~mm}$. long; blades thin, flat, 10 to $25 \mathrm{~cm}$. long, 2 to $2.5 \mathrm{~cm}$. wide, gradually tapering from about the middle to an acuminate apex, the uppermost rather abruptly narrowed to a somewhat rounded ciliate base, the lower and especially the basal blades gradually tapering into a narrow, more or less folded, petiole-like base, ciliate on the margins, puberu lent on the upper surface at the very base; panicle short exserted, 15 to $20 \mathrm{~cm}$. long, less than one-fourth as wide, the slender angled axis and branches glabrous, the branches remote, rather stiffly ascending, with short ascending remote branchlets, these spikelet-bearing from the base,

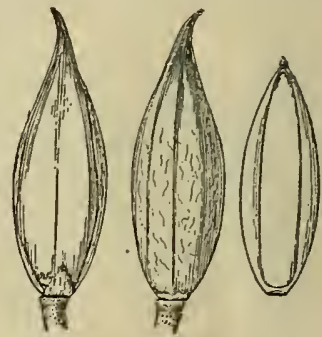

FIG. 145.-P. tuercl:heimii. From type specimen. more or less pilose in the axils, the lower branches about $10 \mathrm{~cm}$. long; spikelets rather short-pediceled, russet brown, 2.5 to $3 \mathrm{~mm}$. long, about $0.9 \mathrm{~mm}$. wide, acuminate, very sparsely appressed-pilose; first glume minute, hyaline; second glume and sterile lemma rather faintly nerved, subequal, or the acuminate tip of the glume exceeding the lemma; the sterile palea wanting; fruit $2.4 \mathrm{~mm}$. long, $0.8 \mathrm{~mm}$. wide,

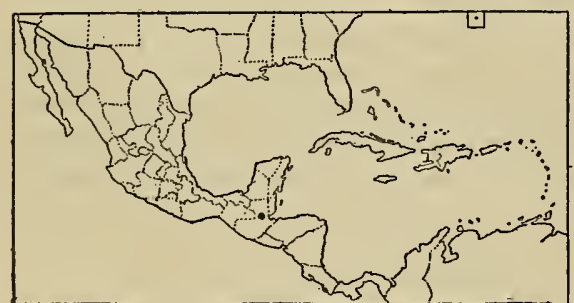

FIG. 146.-Distribution of $P$. tuerckheimii. the lemma and palea not greatly indurated, the lemma minutely pubescent at the pointed apex, the palea at the very tip not inclosed.

In the original description Professor Hackel states that the first glume is altogether wanting. This appeared to be the case and, failing to note the obscure organ, we excluded this species from the genus Panicum in the Revision. ${ }^{1}$ The first glume is present, but is so thin in texture and so closely appressed that the nerves and the base of the sterile lemma are obscurely visible through it.

This species, known only from the type collection, has no close allies. 
115. Panicum zizanioides H. B. K.

Panicum zizanioides H. B. K. Nov. Gen. \& Sp. 1: 100. 1816; Contr. U. S. Nat. Herb. 15: 325.1910.

\author{
DISTRIBUTION.
}

Moist usually shaded places, Mexico and the West Indies to Paraguay. The type locality, Colombia.

Veracruz: Córdoba, Hitchcock 6436.

OAXaca: Trapeche de la Concepción, Liebmann 394.

TABAsco: San Juan Bautista, Rovirosa 624.

Chisapas: Ocuilapa, Nelson 3023.

Guatenala: Cubilquitz, Türckheim 7699, 7700, 8785, 8796. Cobán, Türckheim 3828.

NiCARAGUA: Jinotepe, Hitchcock 8680.

Costa Rica: Hacienda de Zent, Tonduz 302. La Florida, Pittier 11276. Matina, Pittier 10307. Talamanca, Tonduz 8566. San Rafael, Pittier 2598.

Panama: David, Hitchcock 8351. Tabernilla, Hitchcock 8112, 8385. Gatun, Hitchcock 7974. Gamboa, Pittier 4790. Between Gamboa and Cruces, Pittier 3781. Along the Río Sirrí, Pittier 4026.

CubA: Sancti Spiritus, León 903. Laguna Castellano, Baker 4334, Wilson 9567. Puentes Grandes, León 2743. Sumidero, León 13635. Without locality, Wright 3466 .

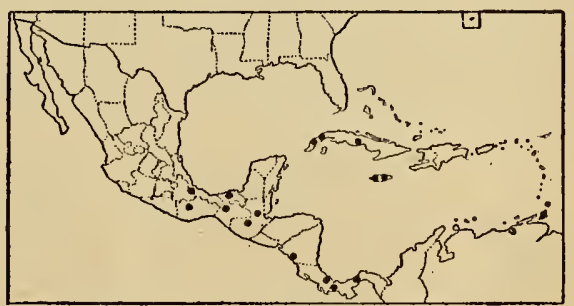

FIG. 147.-Distribution of $P$. zizanioides.

Jamaica: Gordon Town, Hart 726. Port Antonio, Maxon 2109. Ramble, Hitchcock 9513. Castleton Gardens, Hitchcock 9398. Above Constant Spring, Hitchcock 9278. Buff Bay, Hitchcock 9779. Ipswich, Hitchcock 9609. Ewarton to Linstead, Hitchcock 9419. St. Georges, Portland, Harris 11420. Temple Hall, Harris 11385. Troy, Hitchcock 9781. Montego Bay, Hitchcock 9684. Without locality, Alexander Prior in 1850, Wullschlaegel 1108.

Trinidad: Port of Spain, Hitchcock 9958. Mount Pleasant Estate, Bot. Gard. Herb. 2286. Toco, Broadway 2563. Without locality, Bot. Gard. Herb. 3188.

Tоваgо: Great Dog River, Eggers 5810. Roxburgh, Hitchcock 10258. Easterfield, Broadway 4556.

\title{
116. Panicum hirtum Lam.
}

Panicum hirtum Lam. Encycl. 4: 741. 1798. Lamarck states that "Cette plante croît à Cayenne, d'où elle a été envoyée par Jos. Martin." The type specimen in the Lamarck Herbarium is marked "Panicum hirtum Lam. dict. Cayenne. Martin."

DESCRIPTION.

Plants annual, at first simple and erect, later branching and decumbent, rooting at the lower nodes; culms slender, puberulent, the fertile branches 20 to $40 \mathrm{~cm}$. high; sheaths shorter than the internodes, loose, short-villous, densely ciliate on the margin; ligule a delicate toothed membrane less than $0.5 \mathrm{~mm}$. long; blades flat, thin, 2 to $6 \mathrm{~cm}$. long, 0.8 to $2 \mathrm{~cm}$. wide, ovate to lanceolate, cordate-clasping at base, rather abruptly acuminate, scabrous on the upper surface, sparsely hispid on boll surfaces, ciliate at the base; panicles exserted of included at base, 3 to $7 \mathrm{~cm}$. loug, half to two-thirds as 
wide, ovoid in outline, the main axis pilose, the numerous delicate but rather stiff brahches ascending at a uniform angle (in herbarium specimens the branches con-

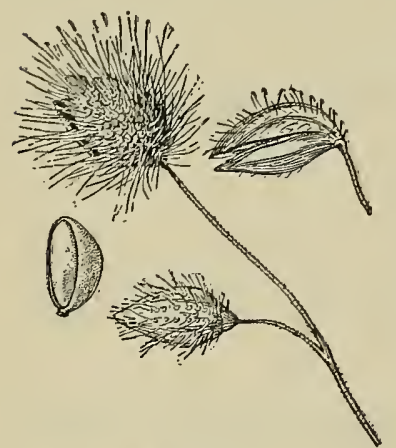

FIG. 148-P. hirtum. From type specimen. spicuously parallel), the numerous but not crowded spikelets recurved at right angles on capillary pedicels; spikelets $1.2 \mathrm{~mm}$. long, about $0.7 \mathrm{~mm}$. wide, strongly plano-convex, turgid; first glume nearly as long as the spikelet, 3-nerved, narrow, covering the middle internerves of the sterile lemma, thin in texture and so closely appressed as to be usually invisible, sparsely hispid; second glume inflated, gibbous, pointed, 5-nerved, papillose-hispid, at maturity subindurate, the hairs stiffening and as much as $1 \mathrm{~mm}$. long; sterile lemma equaling the second glume and inclosing a 2-keeled palea, 5-nerved, glabrous, the two middle internerves thin; fruit $1 \mathrm{~mm}$. long, $0.6 \mathrm{~mm}$. wide, very turgidly plano-convex, at first white, at maturity brown, sparsely sprinkled with minute globular hairs.

The spikelets of this unique species at maturity look like tiny burs or, as Lamarck says, like the "seeds of Daucus." The bristly second glume sometimes falls, leaving the turgid fruit, together with the first glume and sterile lemma, attached to the pedicel.

DISTRIBUTION.

Damp shady places, Trinidad to Brazil.

Trinidad: Arima, Hitchcock 10310. Piarco Savanna, Hitchcock 10363. St. Joseph, Hitchcock 10177. Port of Spain, Hitchcock 10320. Without locality, Bot. Gard. Herb. 3194.

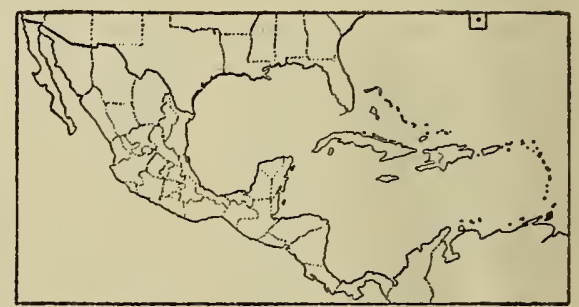

FIG. 149.-Distribution of $P$. hirtum.

\section{EXCLUDED SPECIES.}

The study of geners allied to Panicum and the examination of a large number of type specimens has resulted in the identification of most of the species of North America included now or in the past by some authors in Panicum. Besides the valid species and the names accounted for in synonymy within the genus Panicum there are a great many names that, according to our present conception of the genera of Paniceae, are referable to other genera. While the list is not complete it is so nearly complete as to enable us to account for almost all the names of North American species that have been referred to Panicum. The second name in the column merely indicates the genus to which the species belongs. In no case is any name in the following list a transfer of a species or a new combination. In many cases the name, if transferred to the genus indicated, would be untenable.

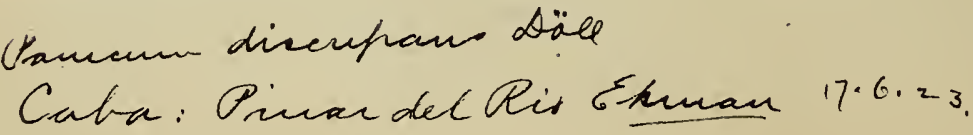


Panicum acutum Rasp. Reimarochloa. adscendens H. B. K. Syntherisma. adustum Nees. Syntherisma. africanum Trin: Oplismenus. Fin agglutinans Kunth. Lasiacis. alabamense Trin. Paspalum. alopecuroides L. Pennisetum. alopecuroideum L. Pennisetum. alopecuroideum Walt. Chaetochloa, alopecurus Lam. Pennisetum. alsinoides Griseb. Ichnanthus. $r$ americanum L. Pennisetum. amphistemon Wright. Scutachne. amplexicaule Rudge. Hymenachne. amplifolium Steud. Chaetochloa. Areffresela anomalum Walt. Chaetochloa. anthaenantia Kuntze. Anthaenantia. antillarum Poir. Pennisetum. aquaticum Bosc. Sacciolepis. aquaticum Muhl. Sacciolepis. arborescens Sieber. Lasiacis. arbusculum Sieber. Isachne. aristatum Macf. Echinochloa. arundinaceum Swartz. Isachne. aturense H. B. K. Homolepis. aureum Trin. Axonopus. auriculatum Willd. Hymenachne. autumnale Bosc. Leptoloma. badium Scribn. \& Merr. Syntherisma. bambusioides Desv. Lasiacis. barbatum Lam. Chaetochloa. berchtholdiae Doell. Chaetium. bermudianum Steud. Sacciolepis. berteronianum Schult. Chaetochloa. g chreut uf a
bifidum Bertol. Paspalum.

blepharophorum Presl. Homolepis. brachiatum Poir. Chaetochloa. Litosa brachyphyllum Steud. Syntherisma. brevifolium Kunth. Syntherisma. buckleyanum Vasey. Error in Index Kewensis for Paspalum. californicum Benth. Valota. campylostachyum Hack. Thrasya. caudatum Lam. Chaetochloa. caudatum Salzm. Sacciolepis. cenchroides Rich. Pennisetum. cenchroicles Ell. Cenchrus. cernuum Willd. Chaetochloa. chaetium Steud. Chaetium. chauvinii Steud. Lasiacis. chrysites Steud. Axonopus. chrysoblephare Steud. Axonopus. chrysodactylon Trin. Axonopus. cognatum Schult. Leptoloma. 
Panicum colonum L. Echinochloa. $\checkmark$

compactum Swartz. Lasiacis.

compositum Nees. Chaetochloa.

compressum Balb. Chaetochloa. Luef tew

ceresia Kuntze. Paspalum.

ciliatiflorum Wood. Anthaenantia. ciliatiflorum Wood. Anthaenantia.
cirrhosum Scribn. \& Merr. Ghaetochloa. J yetheng. we se Let.
confertum Desv. ? Isachne.

corrugatum Ell. Chaetochloa.

crinitum Willd. Pennisetum.

crusardeae Willd. Chaetochloa. Sulfé Le h

cruscorvi L. Echinochloa.

crusgalli L. Echinochloa.

aristatum Pursh. Echinochloa.

hispidum Ell. Echinochloa."

mite Pursh. Echinochloa.

muticum Ell. Echinochloa.

purpureum Pursh. Echinochloa.

sabulicola Trin. Echinochloa.

cruspavonis Nees. Echinochloa.

cubense Steud. Oplismenus.

cultratum Trin. Thrasya.

curvinerve Hack. Syntherisma.

dactylon L. Capriola.

decumbens Roem. \& Schult. Paspalum.

densispica Poir. Pennisetum.

digitarioides Rasp. Paspalum.

dispermum Lam. Isachne. $\checkmark$

dissectum L. Paspalum.

dissitiflorum Steud. Chaetochloa.

divaricatum Kunth. Lasiacis.

divaricatum $\mathbf{L}$. Lasiacis.

glabrum Kuntze. Lasiacis.

latifolium Fourn. Lasiacis.

puberulum Griseb. Lasiacis.

stenostach yum Griseb. Lasiacis.

divaricatum Michx. Festuca.

divergens Muhl. Leptoloma.

domingense Zucc. Syntherisma.

drummondii Vasey. Error in Index Kewensis for Paspalum.

duchaissingii Steud. Valota.

dumetorum A. Rich. Chaetochloa.

durum Griseb. Scutachne.

echinatum Willd. Echinolaena.

echinolaena Nees. Echinolaena.

eggersii Hack. Valota.

elliottianum Schult. Sacciolepis.

erianthum Poir. Anthaenantia.

falsum Steud. Valota.

fasciculatum Lam. Oplismenus. -

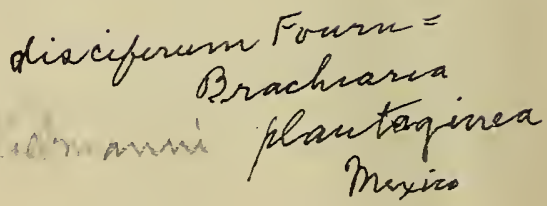

fasciculiflorum Steud. Oplismenus.

filiforme L. Syntherisma. 
Panicum fimbriatum Presl. Syntherisma. setigerum Fourn. Syntherisma.

firmum Kunth. Oryzopsis.

flavescens Sieb. Eriochloa.

floridanum Trin. Paspalum.

fluviatilis Nees. Sacciolepis.

fragile Kunth. Leptoloma.

francoi Steud. Oplismenus.

frumentaceum Roxb. Echinochloa.

frumentaceum Salisb. Holcus.

furcellatum S. Moore. Paspalum.

fuscescens Willd. Chaetochloa.

fusciflorum Steud. Leptocoryphium.

fuscum Sieber. Lasiacis.

gavanianum Steud. Valota.

geniculatum Lam. Chaetochloa.

georgicum Spreng. Eriochloa.

gibbum Ell. Sacciolepis.

glaberrimum Ell. Chaetochloa.

glabrum Gaud. Syntherisma.

mississippiense Gattinger. Syntherisma.

glandulosum Nees. Echinolaena.

glaucescens H. B. K. Isachne.

glaucescens Nees. Syntherisma.

glaucescens Salzm. Chaetochloa. Gewivid uh

glaucescens Willd. Isachne.

glaucum L. Pennisetum.

glaucum Rupr. Chaetochloa.

glaucum Steud. Chaetochloa.

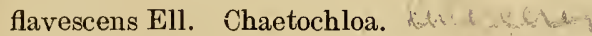

purpurascens Ell. Chaetochloa. and

glutinosum Lam. Lasiacis.

gracilentum Poir. Festuca.

gracillimum Scribn. Syntherisma.

grisebachii Nash. Lasiacis.

grossum Salisb. Echinochloa. $\downarrow$ -

hamiltonui Kunth. Syntherisma.

heteranthum Link. Echinolaena.

hirtellum L. Oplismenus.

hirtellum Walt. Echinochloa.

hirticalycinum Bosc. Anthaenantia.

hirticalycum Bosc. Echinochloa.

hirtum Willd. Isachne.

hispidum Muhl. Echinochloa. $r$

holciforme Steud. Echinochloa.

horizontale G. F. W. Meyer. Syntherisma.

horridum Salzm. Echinochloa.

humboldtianum Kuntze. Paspalum.

humifusum Kunth. Syntherisma.

hydrophilum Schult. Sacciolepis.

hymenachne Desv. Hymenachne.

ichnodes Griseb. Ichnanthus.

ignoratum Kunth. Anthaenantia. 
Panicum imberbe Poir. Chaetochloa. immersum Trin. Axonopus. inaequivalve Kuntze. Paspalum. incertum Bosc. Echinochloa. insulare G. F. W. Meyer. Valota. ischaemum Schreb. Syntherisma. isocalycinum Meyer. Homolepis. italicum L. Chaetochloa. jurgensenii Scribn. \& Merr. Chaetochloa. A 11$\}$ \& $1 \mathrm{al}$ lachnanthum Torr. Valota. laevigatum Lam. Chaetochloa. laevigatum Ell. Chaetochloa. laevigatum Muhl. Chaetochloa. lagascae Kuntze. Paspalum. lagopus Willd. Eriochrysis. lagotis Trin. Ichnanthus. lanatum Rottb. Valota. lanatum Swartz. Lasiacis. sorghoideum Hamilt. Lasiacis.

langei Fourn. Homolepis.

laterale Presl. Olyra.

leandri Trin. Brachiaria.

leucites Trin. Syntherisma.

leucocomum Scribn. Syntherisma.

leucophaeum H. B. K. Valota.

liebmannianum Fourn. Lasiacis. depauperatum Fourn. Lasiacis.

lindeni Fourn. Ichnanthus.

lineare L. Syntherisma.

lineare Krock. Syntherisma. mississippiense Gattinger. Syntherisma.

linkianum Kunth. Syntherisma. litorale Kuntze. Paspalum. loliaceum Lam. Oplismenus. loliiforme Hochst. Mesosetum. longiflorum Trin. Homolepis. longisetum Torr. Echinochloa.: longispicula Doell. Homolepis. lutescens Weigel. Chaetochloa. macrostachya Nees. Chaetochloa. maculatum Aubl. Lasiacis. pilosum Fourn. Lasiacis. malacophyllum Kuntze. Paspalum. martinicense Griseb. Lasiacis. mayarense Wright. Ichnanthus. melicarium Michx. Panicularia. melicarium Muhl. Sporobolus. melinis Trin. Melinis. mexicanum Scribn. \& Merr. Chaetochloa. michauxianum Schult.' Eriochloa. michauxii Poir. Eriochloa. minutiflorum Rasp. Melinis. molle Michx. Eriochloa. 
Panicum mollissimum Kunth. Syntherisma. monobotrys Trin. Paspalum.

monostachyum H. B. K. Paspalum.

montanum Poit. Ichnanthus.

multinerve Desv. Isachne.

muricatum Michx. Echinochloa.

myosurus Rich. Sacciolepis.

myurus Lam. Sacciolepis.

neesii Kunth. Syntherisma. nemorale Schrad. Ichnanthus. nemorosum Swartz. Ichnanthus. nemorosum Willd. Echinolaena. nudum Walt. Leptoloma. nuttallianum Steud. Oplismenus. oaxacense Steud. Lasiacis. obtectum Presl. Paspalum. occidentale Nieuwl. Chaetochloa. If wiculala onurus Willd. Chaetochloa. orinocense Willd. Lasiacis. oxyanthum Steud. Reimarochloa. pallens Swartz. Ichnanthus. palmeri Vasey. Ixophorus. palmifolium Poir. Chaetochloa. p w w paniculatum Kuntze. Paspalum. paniculiferum Steud. Chaetochloa. paractaenoides Trin. Chaetochloa. parciflorum Steud. Oplismenus. patentissimum Roem. \& Schult. Festuca. penicillatum Willd. Chaetochloa. génitubata petrosum Trin. Thrasya. phaeocarpum drummondianum Nees. Syntherisma. phaeothrix Scribn. Syntherisma. phleiforme Presl. Sacciolepis. pittieri Hack. Valota. plantagineum Link. Brachiaria. platyphyllum Munro. Brachiaria. plicatulum Kuntze. Paspalum. polyrrhizum Presl. Paspalum. polystachion Muhl. Chaetochloa. CEzzsagules polystachyum Presl. Hymenachne. praegnans Steud. Lasiacis. pringlei Vasey. Ixophorus. procerrimum Hack. Lasiacis. prorepens Steud. Oplismenus. pulchrum Willd. Axonopus. pungens Poir. Echinochloa. purpurascens H. B. K. Chaetochloa. radicosum Presl. Syntherisma. rariforum Lam. Orthoclada. rariflorum Presl. Chaetochloa. L6s, ${ }^{3}+1,+$ thet restitutum Steud. Chaetochloa. rhizophorum Fourn. Lasiacis. rigens Swartz. Isachne. 



\section{INDEX.}

[Synonyms in italic.

\begin{tabular}{|c|c|c|c|}
\hline \multicolumn{2}{|c|}{ Page. } & \multicolumn{2}{|c|}{ Page. } \\
\hline grostoidia. & 492 & Panicum conchatum. & 503 \\
\hline ngustifolia. & 514 & condensum. & 492 \\
\hline pillaria.... & 476 & cordovense. & 525 \\
\hline ommutata...... & 524 & costaricense........ & 509 \\
\hline ordovensia..... & 525 & cupreum.......... & 499 \\
\hline helium. & 512 & escens......... & 507 \\
\hline Dich & 516 & ns. & 478 \\
\hline miflora. & 473 & dichotomiflorum . . .................. & 473 \\
\hline .. & 480 & mum $\beta$ glabrescens............... & 513 \\
\hline n............... & 522 & m................... & 480 \\
\hline (................. & 467 & stantiflorum. . . . . . . . . . . . . . & 463 \\
\hline$\ldots \ldots \ldots \ldots \ldots \ldots \ldots \ldots \ldots$ & 465 & um lancifolium............ & 494 \\
\hline frondescens.............. & 500 & & 482 \\
\hline & 501 & & 476 \\
\hline piculatus.................... & 525 & 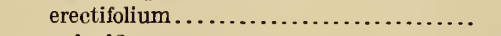 & 522 \\
\hline ( & 522 & iguiflorum........................ & 499 \\
\hline (n..................... & 519 & expansum.......................... 509, &, 525 \\
\hline (n................................. & 492 & 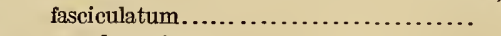 & 468 \\
\hline Lax & 513 & chartaginense.................. & 470 \\
\hline Mal & 466 & reticulatum......... & 470 \\
\hline ; & 483 & 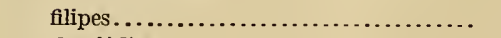 & 478 \\
\hline culare.......................... & 515 & 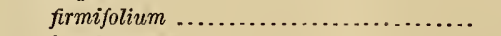 & 507 \\
\hline n....................... & 519 & ns......................... & 500 \\
\hline$\ldots \ldots \ldots \ldots \ldots$ & 471 & (n) & 515 \\
\hline & 525 & ............ & 465 \\
\hline 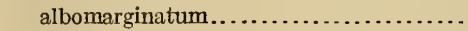 & 522 & tii........ & 482 \\
\hline & 488 & … & 510 \\
\hline 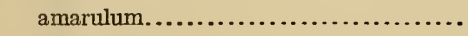 & 489 & in. & 487 \\
\hline $1 . \ldots \ldots \ldots \ldots \ldots \ldots \ldots \ldots \ldots \ldots \ldots \ldots \ldots \ldots$ & 474 & 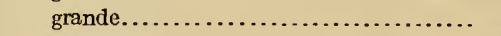 & 529 \\
\hline (............... & 516 & n......... & 529 \\
\hline & 472 & se......... & 480 \\
\hline & 504 & a......... & 509 \\
\hline (n. & 466 & .......... & 481 \\
\hline ............................ & 474 & $\ldots \ldots \ldots \ldots \ldots \ldots \ldots \ldots$, & 489 \\
\hline & 501 & n.......... & 499 \\
\hline 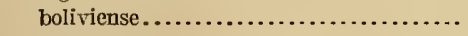 & 496 & (n.......................... & 482 \\
\hline ...................... & 506 & le......................... & 477 \\
\hline 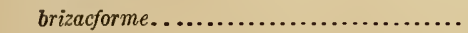 & 465 & & 531 \\
\hline & 405 & iilum...................... & 474 \\
\hline & 48 & oides...... & 488 \\
\hline ........................ & 48 & (n..., & 509 \\
\hline m........................ & 48 & 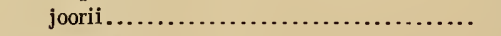 & 524 \\
\hline . & 518 & e............................... & 491 \\
\hline & 511 & ium .......................... & 523 \\
\hline & 477 & . & 497 \\
\hline$\cdots$ & 480 & n....................... & 481 \\
\hline ................. & 491 & 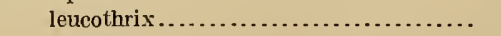 & 518 \\
\hline n........................ & 479 & 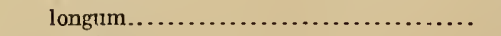 & 493 \\
\hline & 464 & m.............................. & 483 \\
\hline$n s e . \ldots \ldots \ldots \ldots \ldots \ldots \ldots \ldots \ldots$ & 468 & ston ............................... & 511 \\
\hline 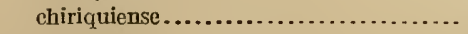 & 527 & 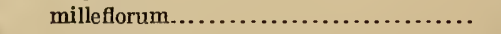 & 494 \\
\hline 101 & 473 & na......................... & 510 \\
\hline & 47 & $m \ldots \ldots \ldots \ldots \ldots$ & 525 \\
\hline chrysopsidifollum ................... & 515 & n................. & 471 \\
\hline
\end{tabular}




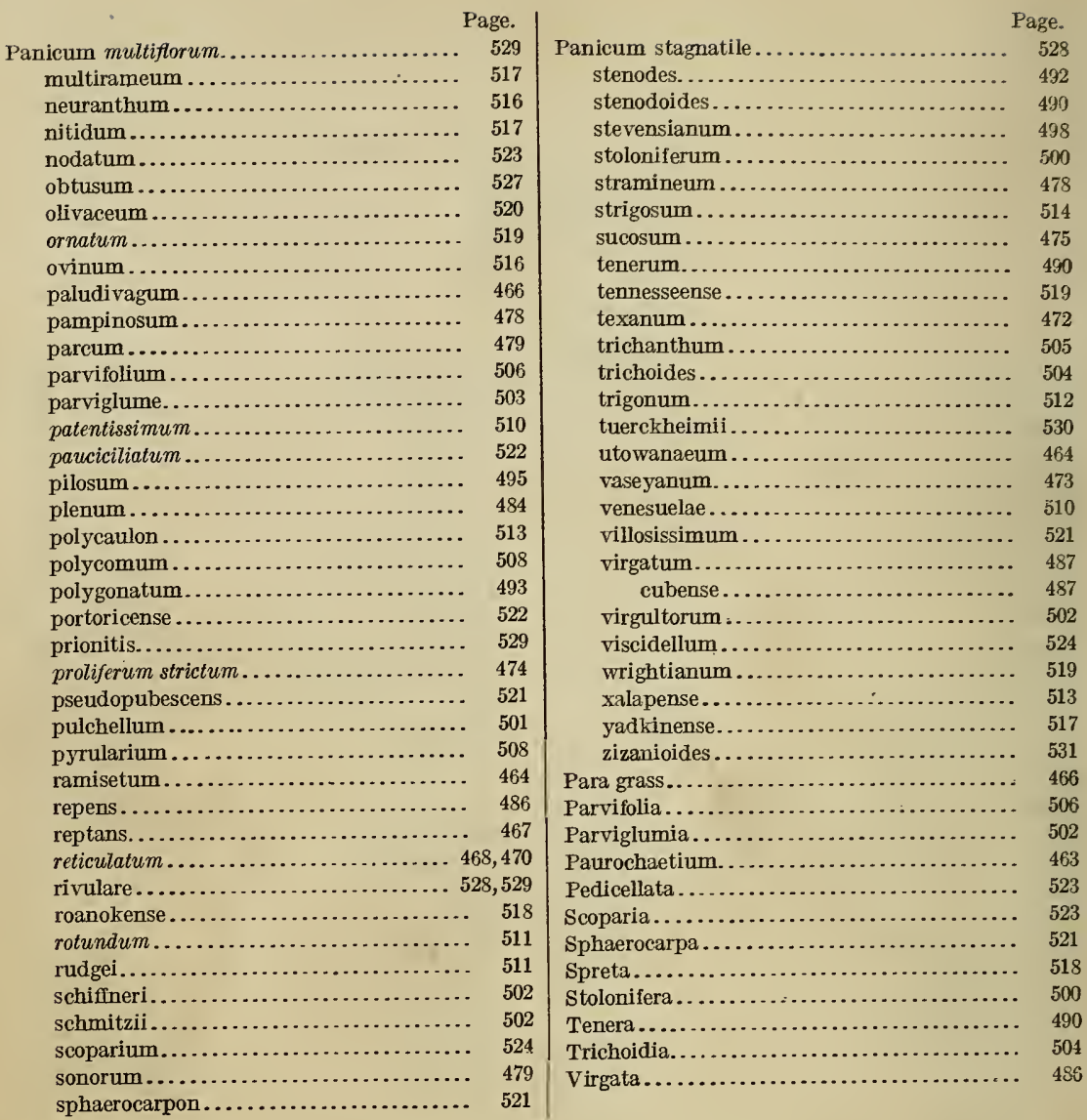




\section{.}





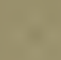




